Historic, archived document

Do not assume content reflects current scientific knowledge, policies, or practices. 
i 


\section{THE OUTLOOK FOR TIMBER IN THE UNITED STATES}

FOREST SERVICE - U.S. DEPARTMENT OF AGRICULTURE 
For sale by the Superintendent of Documents, U.S. Government Printing Office Washington, D.C. 20402 - Price $\$ 3.70$

Stock Number 0101-00375 


\section{Foreword}

This report on the Nation's timber supply and demand situation and outlook relates primarily to the 500 million acres of commercial timberland in the United States that are suitable for production of timber crops. Although limited primarily to timber, the report recognizes that these lands must also provide recreation, water, wildlife, and other similar products for the American people. Achieving a balance between rapidly rising demands for timber and these other goods and services is a challenge for American forestry that must be met.

The implications of comparisons of prospective timber supplies and demands presented in this report are clear-demands for lumber, plywood, woodpulp, and other products are increasing more rapidly than available timber supplies. This can only mean rising prices of timber and timber products.

Growing needs for raw materials for housing and other economic development in the United States might be met in part by greater use of substitutes for timber such as steel, aluminum, and plastics. But this alternative involves problems of high energy requirements, pollution impacts, balance of payments problems, and accelerated depletion of nonrenewable resources. Timber imports also might be expanded but this option is limited by rising demands for timber throughout the world.

The better alternative, in my view, is to improve the utilization of arailable timber supplies in the United States, and to increase timber growth and harvests in the longer run by accelerated tree planting, stand improvement, protection, and other forestry measures. This alternative will require substantial investments and balanced management of forest lands to assure adequate supplies of timber and other forest goods and services. But the opportunities are large and the prospective benefits to the Nation will be substantial.

Јонn R. McGuire, Chief, Forest Service. 



\section{Preface}

Orer the past sereral decades the Forest Service of the U.S. Department of Agriculture has periodically reviewed the timber supply and demand situation and outlook in the United States. The objectives of these reviews are expressed in the authorization for the nationwide Forest Survey, contained in Section 9 of the McSweeney-McNary Forest Research Act of 1928, which directs the Secretary of Agriculture to cooperate with States and other agencies

". . in making and keeping current a comprehensive survey of the present and prospective requirements for timber and other forest products in the United States, and of timber supplies, including a determination of the present and potential productivity of forest land therein, and of such other facts as may be necessary in the determination of rays and means to balance the timber budget of the United States..."

This report provides an analysis of the Nation's timber situation as of 1970 and the outlook under a number of economic and management alternatives. It represents the latest in a series of similar timber appraisals prepared by the Forest Service in the past. ${ }^{1}$

This new study includes statistical data as of 1970 on the current area and condition of the Nation's forest land, inrentories of standing timber, and timber growth and remorals by individual States. Information is also included on recent trends in forest land and timber resources, trends in utilization of the Nation's forests for timber and other purposes, and trends in consumption of wood products. Data are also presented on foreign sources of timber and foreign markets for U.S. products.

Projections of future demands for timber in the United States indicate market potentials under a range of economic and price assumptions. Projections of timber supplies point to prospective and potential arailability of wood products with alternative levels of forest management and utilization, and alternative price trends.

These projections of timber demand and supply potentials from domestic and foreign sources are compared to identify prospective developments in timber prices, the outlook for supply problems in the wood-using industries, and possible impacts of changes in forestry policies and programs.

Many changes are taking place in the use of American forests. Demands for timber products have been increasing rapidly, but perhaps even more striking has been the growth in demand for recreational uses of forest areas and for management of forest cover to improve the quantity and quality of water yields, to improve wildlife habitat, and to preserve scenic ralues.

More and more areas in both public and private ownerships are being used exclusively or in part for such nontimber purposes. A major expansion in multiple-use management of forest lands, particularly on public holdings, also has put new constraints on traditional timber production and harresting practices. The Nation's forests more than ever are being used for both commodities and services.

1 U.S. Department of Agriculture, Forest Service. The timber supply of the United States. USDA Forest Serv. Cir. 166, 24 p. 1909.

Timber depletion, lumber prices, lumber exports, and concentration of timber ownership. Rep. on Senate Resolut. 311, 66th Congr., 2d sess. 71 p. (The Capper Report.) 1920.

A national plan for American forestry. Senate Doc. 12, 73rd Congr., 1st sess 2v., 1677 p. (The Copeland Report.) 1933.

Forests and national prosperity. USDA Misc. Publ. 668, 99 p. (The Reappraisal Report.) 1948.

- Timber resources for America's future. USDA Forest Resource Rep. 14, 713 p. (The Timber Resources Review Report.) 1958.

Timber trends in the United States. USDA Forest Resource Rep. 17, 235 p. 1965.

A partial list of related reports concerned with the timber situation in the United States includes:

U.S. Department of Commerce and Labor, Bur. Corps. Summary of report of the Commissioner of Corporations on the lumber industry, Pt. I, Standing timber. $38 \mathrm{p}$. (The Bureau of Corporations Report.) 1911.

Part I, Standing timber (including summary) 301 p. 1913.

Part II, Concentration of timber ownership in important selected regions. 1914 .

- Part III, Land holdings of large timber owners (with ownership maps). 264 p. 1914.

U.S. Congress Joint Committee on Forestry. Forest lands of the United States. Senate Doc. 32, 77th Congr., 1st sess. 44 p. (The JCC Report.) 1941.

President's Materials Policy Commission. Resources for freedom, selected reports to the Commission, Vol. V. U.S. Government Printing Office, Washington, D.C. 1952.

Stanford Research Institute. America's demand for wood, 1929-1975. 404 p. Stanford, Calif. 1954.

Resources for the Future, Inc. Resources in America's future, patterns of requirements and availabilities, 19602000. 1017 p. Johns Hopkin Press, Baltimore, Md. 1962. Commission on Population Growth and the American Future. Population, resources, and the environment, Tol. II, Economic aspects of population change, Tol. III, Population, resources and the environment. 337 p. 1972. 
In this study an effort consequently has been made to view timber supply and demand in relation to use of forest resources for nontimber purposes. Only limited evaluations of demands for and supplies of these related uses of forest resources and users are currently available. Nevertheless, rising demands for nontimber purposes are important considerations in evaluating the current and prospective timber situation. Thus on National Forest lands, for example, future availability of timber has been estimated within the context of multiple-use plans which provide for balanced programs of development and use of all resources. Some allowances have been made for continuing transfers of timberproducing lands to other uses. On much of the forest land in farm and miscellaneous private ownerships it has been recognized that owners' objectives are primarily for purposes other than timber production and that timber harvests on such lands consequently may be limited.

In view of the many changes in both economic and environmental factors that have been occurring, a new look at timber supply and demand prospects is considered essential. This appraisal is designed to provide some of the basic input required for appraising the effectiveness of existing forestry programs, to indicate opportunities for economic development of timber resources, and to help evaluate the desirability of new or different action relating to timber production.

Specific recommendations for forestry programs -for forest development or for improving the economy of rural America, for example-lie beyond the scope of this study. This report is designed, rather, to identify and appraise changes occurring in the forest situation, and to provide some indication of the outlook for timber with and without changes in the way forests are managed and used.

Information on the Nation's timber situation and outlook is of far-reaching economic and environmental importance. Timber products make up nearly one-fifth of all industrial raw materials consumed in the United States. Processing of timber products supports thousands of establishments and millions of workers, many in rural areas and cities where timber is the principal support of the local economy.

Growing concern over prospective depletion of nonrenewable mineral resources, and the higher energy requirements and pollution impacts resulting from use of nontimber resources in lieu of wood products, also emphasize the growing importance of timber in the U.S. economy. Unlike most competitive products, wood is a renewable industrial raw material.

The analysis of resource supplies and demands presented in this report pertains only to the next few decades. For the longer run, well within the span of time it takes to grow trees, shortages of natural resources could become an increasingly serious issue. In appraising today's needs for forestry programs, some consideration therefore needs to be given to the probable situation beyond the period covered by this report. 


\section{Acknowledgments}

Many members of the Forest Service contributed to the collection of data and preparation of this report. The help of all those who participated in planning, compiling material, and reviewing the preliminary report is gratefully acknowledged.

Information on timber resources in Chapter I was compiled by Forest Survey staffs under the direction of Joe F. Christopher, Burton L. Essex, Carl E. Mayer, Joe P. McClure, Melvin E. Metcalf, Keith Hutchinson, Benjamin Spada, and .John H. Wikstrom. Charles Van Sickle, James W. Thorne, and David.J. Neebe prepared the original draft materials.

Projections and analyses of timber supply potentials in Chapter II was prepared for the East by Robert IV. Larson and Mark Goforth. John H. Wikstrom prepared the projections for the Rocky Mountains, and Donald R. Gedney and Daniel D. Oswald the projections for the Pacific Coast.

Additional principal contributors to the evaluation of timber management opportunities presented in Chapter III, included Robert $\mathrm{N}$. Stone, Thomas H. Ellis, T. A. McClay, Thomas J. Mills, Clark Row, Charles A. Wellner, Clarence Brown, David Tackle, and Walker P. Newman, plus a number of participants in the Regional Offices and Experiment Stations of the Forest Service who contributed information and judgments. Examples of local management opportunities were prepared largely by David A. Gansner, Joseph Barnard, and Samuel F. Gingrich for the Northeast; Joe P. McClure and Herbert A. Knight for the Southeast; Sam Guttenberg and $W_{\text {alter }} \mathrm{M}$. Anderson for the South; Allen L. Lundgren and Rolfe $\mathbf{A}$.
Leary for the North Central Region; and Donald F. Flora, Roger D. Fight, Donald R. Gedney, and Daniel D. Oswald for the Pacific Northwest-in all cases assisted by cooperating staff members at these field locations. Information on utilization opportunities prepared by Experiment Station staffs were compiled for the report by Dean N. Quinney.

Material on foreign timber resources presented in Chapter IV was prepared largely be S. Blair Hutchison and Thomas E. Hamilton.

Chapter $\mathrm{V}$ dealing with timber demand trends and projections was prepared under the direction of Dwight Hair, with contributions from Robert B. Phelps, James T. Micklewright, Thomas C. Marcin, Thomas G. Gill. William H. Reid, Maurice G. Wright, Charles W. Dane, Jerome F. Saeman, Clyde A. Fasick, Robert G. Knutson, A. Jeff Martin, Darid C. Baumgartner, and Gordon D. Lewis.

Much appreciation is also due reviewers of an earlier draft, including particularly John Fedkiw and members of forest industries, conservation organizations, and forestry schools, for example, who contributed numerous suggestions that are reflected in this final report. Contributions of William P. Everard for editorial services, Lewis G. Glover for drafting of charts, and Miss Dorothy M. Hawkins and Mrs. Milly Otwell for checking and preparation of manuscripts are also acknowledged.

The planning and general direction of this study and much of the final drafting was by H.R. Josephson, Director of the Division of Forest Economics and Marketing Research. 


\section{Contents}

HIGHLIGHTS

CHAPTER I. RECENT TRENDS IN FOREST LAND AND TIMBER RESOURCES

Forest land areas

Commercial timberland

Other forest lands................

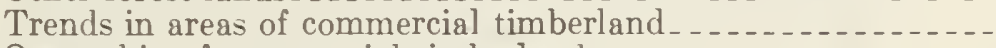

Ownership of commercial timberlands

Forest type groups_.............

Forest site productivity

Timber stocking . .

Stand-size classes

Timber growth

Recent trends in timber growth

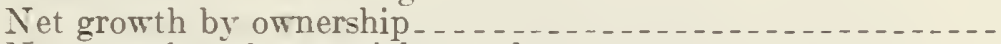

Net growth and potential growth per acre

Impacts of destructive agents

Volume of mortality.

Additional losses from destructive agents

Salrage of mortality $\ldots \ldots \ldots \ldots$

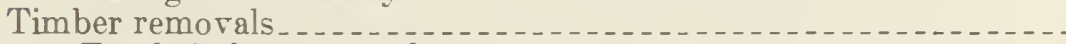

Total timber removals........

Roundwood timber harvests.

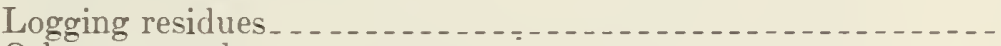

Other remorals . . . . . . .

Vet growth in relation to remorals.

Softmood growth-removal balances

Hardwood growth-removal balances

Timber inrentories

Total timber volumes..................................

Softwood inventories

Hardwood inventories

Ownership of timber inventories

Trends in timber inventories

Page

Plant residues............

Trends in utilization of plant byproducts

Primary plant residues._.

Secondary plant residues

Bark residues

CHAPTER II. PROJECTED TRENDS IN TIMBER SUPPLIES

WITH 1970 LEVEL OF \IANA GEMENT

1970 level of forest management defined

Forest fire control

Insect and disease control

Reforestation

Timber stand improvement

Assistance to forest landowners

Forestry research

Other forestry measures. 
CHAPTER II.-Continued Page

Forest area assumptions for projections _.

A base projection of timber supplies with 1970 levels of management

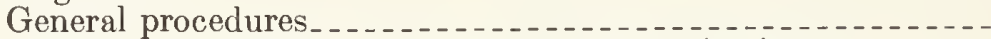

Timber harvesting assumptions for base projections

Summary of base projections of supplies for the United States.-. -

Trends in timber removals

Net growth and mortality

Supplies of roundwood products

Timber inventories. . . .

Projections of timber supplies in the South

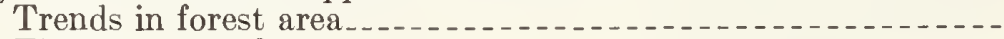

Timber removals.

Supplies of roundwood products

Removals in relation to net growth.....................

Trends in net growth per acre

Trends in timber inventories

Projections of timber supplies in the North

Trends in forest area

Timber removals and net growth

Supplies of roundwood products

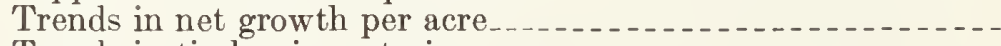

Trends in timber inventories..............................

Projections of timber supplies in the Rocky Mountains........

Trends in forest area

Timber removals $\ldots \ldots \ldots \ldots$

Supplies of roundwood

Net growth and mortality

Trends in timber inventories............................

Projections of timber supplies in the Pacific Coast section......

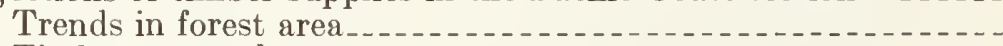

Timber removals

Supplies of roundwood products

Net growth in relation to removals

Trends in inventory volumes $\ldots$

Economic projections of supply with 1970 levels of management.--

Recent supply-price relationships for timber products......

Projected supplies from National Forests

Projected supplies from other lands....................

Projected supplies from all ownerships.

CHAPTER III. OPPORTUNITIES FOR INCREASING TIMBER SUPPLIES THROUGH INTENSIFIED MANAGEMEN'T AND UTILIZATION

General opportunities for management intensification

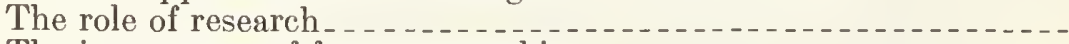

The importance of forest ownership_._.

Environmental factors relating to intensification of forest manage-

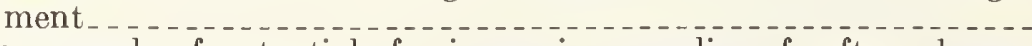

An example of potentials for increasing supplies of softwood sawtimber in the United States

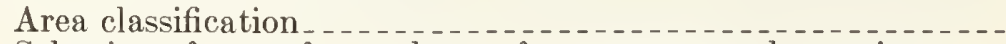

Selection of areas for analyses of management alternatives..--

Costs of intensified management.

Yields from intensified management $\ldots \ldots \ldots$

Values of increased yields.

Ranking opportunities _..............................

Increased yields from farm and miscellaneous private lands -

Increased yields from National Forest lands_.............

Sensitivity to price assumptions.

Possible succession of treatment programs 
CHAPTER III.-Continued

An example of potentials for increasing supplies of sof twood sawtimber in the United States.-Continued

Summary of potentials for intensification of management .... -

General comparison of alternatives studied . . . . . . . . . . .

Additional management opportunities

An example of opportunities for intensifying forest management in

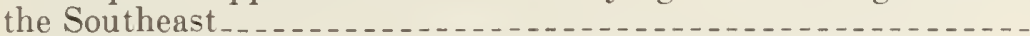

Identifylng areas suitable for intensified management

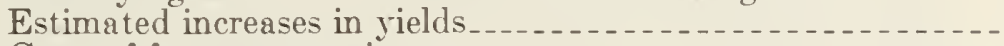

Costs of forestry practices.........

Values of increased harvests.

Areas suitable for treatment...........................

Rates of return on investments

An example of potentials for intensified forest management in the

Northeast region

Designation of management classes

Projecting stand development

Regional expansion of the oak-hickory pilot study

Maple-beech-birch pilot study

An example of potentials for intensified forest management in the

North Central region..................................

Selection of areas for analysis of treatments............

Yields, prices, and costs

Regional estimates of management opportunities at 1970 prices

Regional estimates of opportunities at higher prices..._....

Limitations of current study

An example of intensified management potentials in Washington,

Oregon, and California

Area classification

Management practices considered

Yield assumptions.

Cost assumptions

Price assumptions

Economic analysis

Intensification potentials with 1970 prices

Page

105

105

106

106

107

108

110

110

110

111

112

112

113

114

115

116

116

117

117

117

120

120

120

121

121

121

121

121

Management potentials with rising prices

122

122

123

123

Assumed improvements in utilization in base projections....

Additional opportunities for improved utilization

Projection alternatives

124

125

CHAPTER IV. AVAILABILITY OF WORLD TIMBER

RESOURCES

Trends in U.S. imports of timber products

Trends in U.S. exports of timber products

Trends in U.S. net imports of timber products

World timber demands

The situation in Europe

The situation in Japan

The situation in other countries and regions

World forest land and timber resources

Forest areas.

Timber volumes

Timber production.

Timber supply potential

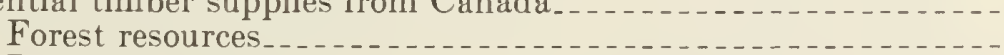

Production trends

Production potentials

Utilization trends

Exports to the United States 
CHAPTER IV.-Continued Page

Potential supplies of tropical woods__._.

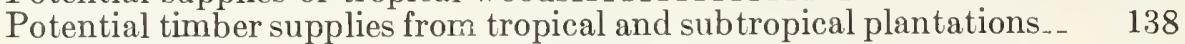

Potential timber supplies from the USSR

A summary of prospective trends in U.S. timber imports and exports_ 139

CHAPTER V. DEMAND FOR TIMBER PRODUC'TS _. . . . . . . _ _ 142

Basic assumptions_.................................... 143

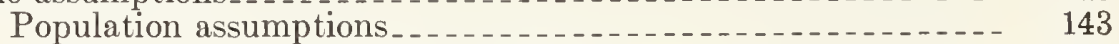

Gross national product assumptions

Technological and institutional assumptions

Price assumptions $\ldots \ldots \ldots 7$

Effects of price increases on timber demands_.......... 149

Demand for timber products in new housing ............... 150

Household formation.............................. 150

Housing replacements

Vacancies__._.

Total demand for new housing

Demand for new housing by type of unit_._.

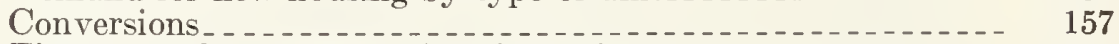

Timber products use per dwelling unit_._.............. 157

Projected demand for timber products in new housing

Demand for timber products in residential upkeep and improve-

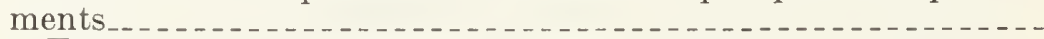

Expenditures for residential upkeep and improvements

Timber products use and projected demand

Demand for timber products in new nonresidential construction . . - -

Nonresidential construction expenditures _. . . . . . . . . . . . .

Timber products use in nonresidential construction.........

Timber products use per dollar of construction expenditure.--

Projected demand for timber products in new nonresidential construction.

Demand for timber products in railroad construction

Demand for timber products in manufacturing

Timber products use in manufacturing

Shipments of manufactured products

Timber products use per dollar of shipments

Projected demand for timber products in manufacturing ....-

Demand for timber products in shipping .

Demand for timber products in pallets

Demand for timber products in wooden containers.........

Demand for timber products in dunnage.................

Projected demand for timber products in shipping.........

Demand for timber products in miscellaneous uses.............

Summary of demand projections for lumber, plywood, and building

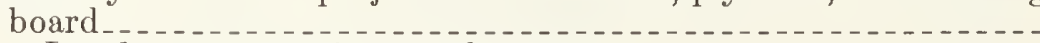

Lumber consumption and demand

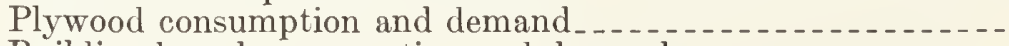

Building board consumption and demand

Demand for pulpwood .

Demand for paper and board.

Demand for fibrous material for paper and board manufacture -

Pulpwood consumption and demand ..................

Demand for miscellaneous timber products

Cooperage logs and bolts

Poles and piling

Fence posts

Other industrial wood

Demand for fuelwood

Log exports and imports

160 
CHAPTER V.-Continued Page

Summary of demand for timber . .

Improvements in utilization . . . .

Recent trends in roundwood consumption $\ldots \ldots \ldots$

Projected demand for roundwood

Projected demand by species groups _................. 207

Projected demand for sawtimber

Projected export demand......................... 208

Projected imports

Projected net imports_............................. 210

Projected demand for roundwood from U.S. forests_._._._. 211

Demand for industrial timber products in relation to other industrial

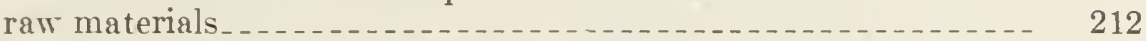

CHAPTER VI. TIMBER DEMAND_SUPPLY RELATIONSHIPS -- 214

Softwood demand-supply balances with 1970 levels of forest management

Sof twood sawtimber supply-demand balances with 1970 levels of management

Softwood sawtimber supplies with intensified management and

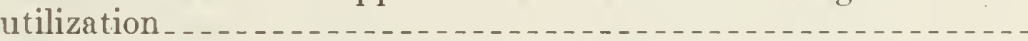

Hardwood demand-supply balances with 1970 levels of forest management

Hardwood sawtimber supply-demand balances with 1970 levels of

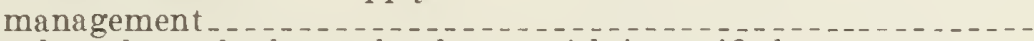

Hardwood supply-demand volumes with intensified management - -

Implications for timber industries . . . . . . .

Dependence on net imports of timber

Economic and environmental effects of rising timber prices......

Opportunities for intensified timber management and utilization APPENDIX I. FOREST STATISTICS, 1970

APPENDIX II. GLOSSAR Y OF 'TERMIS

APPENDIX III. TIMBER SUPPLY TABLES

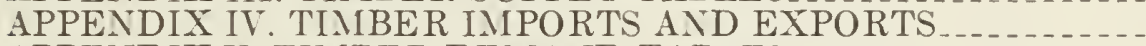
APPENDIX V. TIMBER DEMAND TABLES 



\section{Highlights}

This study relates primarily to the long-run outlook for timber supplies and demands in the United States under changing economic and environmental conditions. Timber arailability will have a direct bearing on the economic development of the Nation as well as availability of forest lands for nontimber and environmental purposes.

1. Demands for industrial timber products in the United States have been increasing steadily, with a 65-percent rise in use of these products during the past three decades.

Consumption of industrial wood products-such as lumber, woodpulp, plywood, etc.-increased 65 percent between 1942 and 1972 to an annual total of 125 million tons. In this period consumption of industrial roundwood (that is, all roundwood products except fuelwood) required to produce these wood products increased about 56 percent to 13.7 billion cubic feet in 1972 . The difference in these trends for roundwood and industrial wood products consumption reflected more complete use of the timber harrested, with a resulting reduction of unused wood residues.

In the 1942-72 period, lumber consumption rose 27 percent. Use of round pulpwood climbed 157 percent, and consumption of veneer and plywood over 438 percent. On the other hand, use of fuelwood and minor products such as poles and posts declined.

\section{Further substantial increases in future demands} for timber are expected.

Projections of potential future demands for timber vary widely with such factors as economic growth and relative prices of timber products. A "medium" projection of possible future demand was based on the assumptions: (1) that the population of the United States will increase nearly 40 percent between 1970 and 2000 to 281 million people; (2) that real gross national product will grow at an arerage of 4.0 percent annually, or about 240 percent by 2000; and (3) that recent trends in technology and institutional factors will continue.

With prices of timber products relative to other materials at 1970 levels, this medium projection of U.S. demand for roundwood rises from a 1970 level of 12.7 billion cubic feet to nearly 23 billion cubic feet by the year 2000. Potential demand for softwoods rises from 9.7 billion cubic feet in 1970 to 15.8 billion cubic feet by 2000. Demand for hardwoods is projected to rise from 3.0 billion cubic feet in 1970 to 7.0 billion cubic feet in 2000 .

With higher relative prices of timber products in the future-which timber demand-supply comparisons indicate can be expected-projected demands for roundwood are correspondingly lower. Thus, with rising relative prices of 1.5 percent per year above the 1970 trend level of lumber and somewhat smaller price increases for plywood, woodpulp, and other items, projected total timber demand by the year 2000 approximates 19 billion cubic feet. This latter projection includes increases in demand of 5 percent for saw logs between 1970 and 2000, 58 percent for veneer logs, and 130 percent for round pulpwood.

In terms of softwood sawtimber-of primary importance for lumber and plywood used in housing and many other markets-projected demand at 1970 prices rises from 47.6 billion board feet in 1970 to 73 billion board feet by 2000 . With the specified rising prices, however, projected demand reaches 55 billion board feet in 2000 - a rise of 16 percent.

Projected demand for hardwood sawtimber with rising prices increases from 12.3 billion board feet in 1970 to 19 billion board feet in 2000 a rise of 55 percent.

3. Timber growth in the United States has been increasing as a result of recent forestry programs.

The condition of timberlands in the United States has improved materially in recent decades, primarily because of expanding fire protection and some increase in tree planting and other forestry activities. As a result, net growth of both softwoods and hardwoods increased about onethird between 1952 and 1970 to a total of 10.7 billion cubic feet of softwoods and 7.9 billion cubic feet of hardwoods.

Roughly 60 percent of this total net growth of softwoods in 1970 , or about 40 billion board feet, consisted of softwood sawtimber suitable for lumber and plywood. Hardwood sawtimber growth totaled 20 billion board feet in 1970 .

Removals of softwood sawtimber as a result of timber harvesting and other factors exceeded net growth in 1970 by 18 percent. In the East removals were less than net growth but this was 
more then offset by an excess of removals over net growth in the West. Removals of hardwood sawtimber in 1970 , on the other hand, were 24 percent less than net growth.

4. Projected supplies of softwood sawtimber products potentially available from U.S. forests show limited increases with 1970 levels of management.

Potential supplies of softwood timber from the Nation's forests - assuming 1970 levels of management, timber cutting practices and policies similar to those in recent years and only minor reductions in areas of commercial timberland-are estimated to increase about 31 percent by 2000 , from 8.8 billion cubic feet in 1970 to about 11.5 billion cubic feet. This is a technical potential which may not be fully realized, however, because of factors of operability and owners' willingness to sell timber.

Thus in the case of softwood sawtimber-of particular importance for lumber, plywood and various other products-projections of economically available future supplies show limited changes from the 1970 level of output. Assuming relative prices of timber products remained at 1970 levels, for example, estimates of economically available supplies of softwood sawtimber are only slightly above the actual harvest of about 46.9 billion board feet in 1970. With increased prices of softwood lumber and plywood averaging 50 percent above 1970, projected supplies increase to over 53 billion board feet over the next decade, but then decline below the 1970 level.

5. Supplies of hardwood timber are increasing although industrial use is limited by problems of quality and availability.

The outlook for hardwoods is somewhat mixed in spite of the fact that removals of all sizes and species of hardwood timber in 1970 was some 25 percent less than total net growth.

Projections of available supplies of hardwood sawtimber over the next few decades-assuming 1970 levels of forest management and specified cutting rates-increase 66-percent, from an actual harvest of 12.3 billion board feet in 1970 to over 20 billion board feet by 2000 . This approximates the projection of demand associated with 1970 prices.

Projected supplies of hardwood products, in cubic feet, under these same assumptions materially exceed potential demands at 1970 prices.

While these projections imply little or no increase in hardwood prices, there are practical limitations on amounts of timber available for sale and industrial use at any given time. To many owners of hardwood timberland use of the forest for recreation or other nontimber objectives is of primary importance. Problems of quality also are of special significance. Much of the growth and available supply of hardwoods are in small tree sizes or species for which markets are llimited; whereas the larger sizes of preferred species are in short supply in most areas. Other factors that could produce a tighter supply situation and higher prices include possible substitution of hardwoods for softwoods in production of woodpulp and certain other timber items.

\section{The outlook for timber supplies differs widely by ownerships and by regions.}

Nationwide, private holdings account for the major part of the commercial timberlands, including 14 percent ir forest industry and 59 percent in farm and miscellaneous private holdings. National Forests include about 18 percent of the total commercial timberlands and other public holdings 9 percent.

Timber harvests in 1970 reflected this pattern of ownership, with 48 percent of the 12.2 billion cubic feet of total roundwood harvested from U.S. forests coming from farm and miscellaneous private holdings. Forests industry lands supplied 28 percent of the total, National Forests 17 percent, and other public lands 7 percent. In the projections of supply the major changes in these proportions include a drop for forest industries and a corresponding increase for farm and miscellaneous private owners.

Southern forests provided about 45 percent of the Nation's timber harvests in 1970, compared with 32 percent for the Pacific Coast, and 23 percent for other sections of the United States.

In the South progress in fire control and other forestry activities has improved the timber situation to the point where it appears that with 1970 levels of management, softwood timber harvests could be increased gradually on both National Forests and other lands by roughly 50 percent over the next few decades.

On the Pacific Coast, on the other hand, a marked decline in sof twood sawtimber supplies of about 18 percent is projected in the 1970-2000 period as a result of reduced availability of timber from forest industry lands.

Sustained harvests of timber from western National Forests and other public lands at levels close to 1970 estimates of allowable harvests appear possible for some decades, although only with timber prices significantly in excess of 1970 levels. Also, allowable harvests on National Forests can be expected to drop shortly after the projection period, if not before, unless forest management and utilization of timber on these lands is intensified.

7. Substantial increases in softwood timber prices appear necessary to balance potential timber demands with available timber supplies.

With forest management continuing at 1970 levels, projected supplies of softwood sawtimber might balance the medium projection of timber 
demand with relative prices of softwood lumber and plywood in 1980 possibly 20 to 25 percent abore the 1970 level, and possibly 50 to 60 percent higher in the rear 2000. Related equilibrium prices for paper and board by 2000 are estimated to a rerage roughly 15 to 20 percent above 1970 .

Stumpage prices associated with these increases in prices of timber products, according to historical relationships, by 2000 could be expected to arerage more than double the lerel of prices in 1970 .

Such prospective increases in prices for softwood lumber would be consistent with an arerage rise of 1.7 percent annually in lumber prices relative to the general price level orer the past century. Relative prices of lumber leveled off in the period 1950-67-rears marked by rapid improrements in productivity in logging and processing and by derelopment of new sources of timber in western National Forests and in British Columbia.

Relative prices of softwood plywood declined dramatically during this recent period with adoption of new technology and equipment. Relative prices of pulp, paper, and board were quite stable. Nerertheless, the timber supply outlook with 1970 levels of management and utilization indicates new supply problems and shif ts to higher price levels for all timber products.

8. Supply and price problems appear most critical for softwood lumber and plywood, but all forest industries will be affected.

Comparisons of projected timber demands and supplies indicate that problems of timber arailability are likely to be most critical for softwood sawtimber used for lumber and plywood in housing, other construction, and rarious other markets.

The outlook for the pulp and paper industry is better than for lumber and plywood, largely because of the wide rariety of species and qualities of timber that can be used for pulpwood, Howerer, the tightening supply-demand situation for softwoods, and new derelopments suck as installation of chipping headrigs, are leading to increased competition for arailable wood supplies and higher wood costs for all industries.

Producers of hardwood lumber and plywood who depend on the higher qualities and sizes of preferred species, such as white oak, walnut, maple, birch, and gum, also face serious supply problems and prospective increases in timber prices. On the other hand, substantial supplies of timber are prospectirely arailable for industries producing hardwood products such as pallets, construction timber, railroad ties, or hardwood pulps.

\section{Demands for nontimber products and services and for environmental protection are of growing importance in the timber situation.}

Use of forest land for timber production is being increasingly affected by public desires for recreation and other nontimber uses. Sizable areas of public forest lands have been withdrawn from timber use for wilderness and scenic areas, although many of these are of relatively low site productivity for timber. Extensive areas of both prirate and public forest lands hare been shifted to nontimber uses such as reservoirs, highways, airports, urban expansion, and recreational developments. Still other areas, particularly fertile bottomlands capable of producing quality hardwoods, hare been cleared for crops and pasture.

Until recently, reversion of abandoned agricultural lands to forests more than offset such losses. Between 1962 and 1970, however, areas classified as commercial timberland declined about 8.5 million acres to a total of 500 million acres. Some continuing net losses of commercial timberland, averaging possibly 5 million acres per decade, have been assumed in this analysis.

Lands remaining in the commercial timberland category also are increasingly called on to supply nontimber goods and services as well as timber harvests. These demands, as well as new concern over protection of the natural environment, are leading to numerous modifications in timber harvesting and other forestry practices, particularly on public lands. It seems clear that management of forests for combinations of products and uses, especially those in public ownership, will be increasingly essential.

Such constraints on land use and management on public lands and to some extent on private forests, together with unforeseen transfers of forest lands to nontimber uses, could reduce timber harvests below the projections developed in this report. Impacts on timber prices and supplies of wood products would be correspondingly intensified.

It is also possible that raw material shortages could in time seriously constrain growth of the Nation's economy or interfere with the achievement of social goals such as improvement of housing. In such case forest recreation and other nontimber uses could also suffer as a result of efforts to alleviate materials shortages. Thus, success in supplying nontimber ralues and products may be influenced deeply by the effectiveness with which industrial raw material needs can be met. For such reasons, essentially all users of forest land have an interest in the timber outlook. 
10. A partial alternative in meeting prospective timber supply problems is to increase timber imports from Canada and other wood surplus countries. Rising exports of timber products, however, have been offsetting a substantial part of the increase in timber imports.

About half a century ago the United States ceased to be self-sufficient in timber products and since then has depended increasingly on net imports from other countries. Imports of timber products reached a total of 2.9 billion cubic feet, roundwood equivalent, in 1972. This represented 19 percent of the total U.S. domestic and export demand for timber products.

Timber imports obtained largely from Canada made up about 19 percent of total U.S. supplies of lumber and 25 percent of total U.S. pulp and paper supplies in 1972. More than 60 percent of the hardwood plywood and veneer consumed in the United States was obtained from Southeast Asia and other tropical areas.

With rising prices of timber, imports from Canada and from tropical areas have been assumed to increase substantially over the next three decades, mainly in the form of softwood lumber, pulp and paper, and hardwood veneer and plywood. In time, however, rising world demands for timber and a general tightening of the world timber supply situation seem likely to limit such import potentials.

Exports of forest products also have increased substantially in recent years, in large part as a result of large Japanese purchases of logs and pulp chips, expanding world markets for kraft pulp and liner board, and continued exports of lumber. In 1972, about 9 percent of the total U.S. supply of timber products, or 1.3 billion cubic feet roundwood equivalent, was exported to various parts of the world. Along with prospective increases in timber imports in future years, some further increases in exports from the United States have been assumed.

Net imports in 1972 of 1.6 billion cubic feet made up nearly 11 percent of the total consumption of timber products in the United States. Net imports have been estimated to increase to around 2.8 billion cubic feet, roundwood equivalent, by 2000 , with prices of lumber, for example, rising 1.5 percent per year. But such dependence on other countries, while important, appears to offer only a partial means of meeting the growing demands for timber products in the United States.

11. Greater use of nonwood materials is a possible alternative, although this appears to have undesirable environmental and economic impacts.

The relative importance of timber products in the U.S. economy has changed greatly over time as other raw materials such as steel, concrete, and aluminum have replaced or supplemented wood in various uses. With increased prices and insufficient supplies of timber, such continuing substitution can be expected.

While there are no immediate threats of shortages of wood substitutes, continued geometric growth in materials use, such as experienced in the past and in prospect in coming decades, will require enormous quantities of materials and entail serious environmental problems. Most competing products such as steel, aluminum, and plastics are derived from depletable resourcesin contrast to timber which is renewable. Thus it is possible that the historical stability in relative prices of competing materials may be replaced by rising real costs of these materials.

Timber products can be produced with relatively low energy requirements for processing and low pollution impacts compared with most alternatives. Energy requirements for processing steel for framing exterior walls of houses, for example, amount to more than three times the energy required for processing lumber for the same use.

Production of competitive materials also ordinarily results in more serious air, water, or land pollution problems than in the case of wood products-both directly and indirectly through the generation of energy required for processing different materials. Wood products that are not recycled also have an important characteristic of being biodegradable.

If prices of timber products rise relative to prices of substitute materials, substitutes will, of course, be used. But in view of accelerating world use of raw materials, increased need for foreign exchange to finance imports of such materials, and higher energy requirements and pollution impacts than with use of timber products, greater dependence on substitutes for timber may not be a desirable alternative.

For such reasons long-run demands for wood, and related justifications of forestry programs, could increase considerably more than indicated by projections in this study.

\section{Better utilization of available supplies is a partial answer to problems of timber supply.}

Major progress has been made in recent years in the use of slabs, edgings, veneer cores, and other similar material from lumber and plywood operations for pulp, particleboard, and other products. In 1970 , nearly three-fourths of all such material produced at sawmills and other primary processing plants, plus some additional material from secondary manufacturing plants, was utilized in this way. Such byproducts comprised 35 percent of the 72 million cords of pulpwood used by U.S. pulpmills in 1972 .

Despite the progress made, unused plant residues still represent a sizable resource. In 1970, unused chippable material at primary manufacturing plants amounted to 0.4 billion cubic feet 
and all residues about 1 billion cubic feet (12.4 million cords). With prospective trends in timber prices and utilization practices, it has been assumed that most chippable residues and much of the fines will be utilized for pulp or particleboard within the next decade or so.

Large additional quantities of wood fiber, largely suitable for pulping, also are left in the woods each vear as logging residues because of high costs of recovery and problems such as bark removal on limbs and fragmented material. In 1970, these residues included some 1.6 billion cubic feet of material from sound trees, plus at least this much material from other sources such as limbs, rough and rotten trees, and dead trees (a total of roughly 40 million cords). Environmental requirements and rising timber values can be expected to lead to better clean up and utilization of timber on harvested areas. But accelerated efforts to improve utilization on logging areas-along with expanded efforts to grow more timber-appear essential if rising pulpwood demands in future decades are to be met.

More of the timber killed by insects, fire, and other destructive agents, although widely scattered for the most part, also might be salvaged with higher prices and improved forest access. Such losses in 1970 included 11 billion board feet of softwood sawtimber.

Improving efficiency of wood utilization in manufacturing plants also would help extend timber supplies. It has been assumed on the basis of past trends that modernization of sawmills, for example, through better production methods and installation of newly available equipment such as high-strain, thin-kerf saws will result in increased lumber recovery from available logs of possibly 2 to 4 percent per decade. But much larger increases in recovery rates should be possible with rising timber values and faster application of improved technology.

Better sorting of logs to help insure use for the most valuable end product-lumber, plywood, or pulp-similarly could stretch available supplies of sawtimber for lumber and plywood.

Development and use of improved structural particleboards and some substitution of hardwoods for softwoods could further extend softwood sawtimber supplies. Wood products also could be used more efficiently in construction by better design and construction methods.

13. Intensified forest management offers an important means of increasing timber supplies in the long run, while maintaining an acceptable forest environment.

Sizable increases in timber growth and future harvests could be achieved in U.S. forests by increased investments to expand tree planting, stand improvement, protection, and other forestry practices. Most forest areas are not fully stocked with desirable timber and are growing at a much lower rate than is possible under intensified management. Fire, insects, and other destructive agents also cause losses that in effect nullify about one-fifth of total timber growth.

Opportunities for increasing future timber supplies by intensified management exist in all sections of the country and all classes of ownership. In the South, for example, timber growth currently averages about 45 cubic feet per acre ammually, including only 104 board feet of sawtimber sized material. Large areas of plantations are yielding more than double this amount of growth. And there are millions of other acres where conversion from poor hardwood stands to pine stands, especially with use of genetically improved planting stock, would in time greatly increase available supplies of timber.

Similarly on the West Coast and other parts of the country there are large additional areas in Federal, State, industrial, and other private ownerships where timber supplies could be greatly increased by reforestation and by other practices such as precommercial thinnings and intermediate cutting in older age classes.

On nonindustrial private ownerships held by farmers and a wide variety of miscellaneous owners, timber growing efforts other than fire protection have been limited. Yet several million of these owners hold 59 percent of the timberlands in the United States that are considered suitable and available for timber production. Most of these owners are unwilling to invest in timber growing and many are reluctant to sell timber because of conflicts with other purposes.

Capturing a larger part of the very large potential for timber growing on these numerous holdings is technically sound and economically feasible, but will require substantial investments. On many ownerships public cost sharing and technical assistance appear necessary to achieve the increased growth that is estimated to be economically feasible to produce.

An initial analysis to illustrate management opportunities on National Forests and farm and miscellaneous private holdings indicated that increased investments of about $\$ 69$ million annually could increase annual harvests of softwood sawtimber about 1.6 billion board feet by 1980 and and as much as 13 billion board feet by 2020 . This analysis used as a criterion a minimum rate of return of 5 percent on additional investments, with prices of lumber and plywood assumed to average 30 percent above 1970 levels.

Additional promising opportunities for increased timber production also undoubtedly exist on other public and industrial ownerships, and in the use of genetically improved planting stock, fertilization, or other new technology.

Environmental inanagement to assure balanced production of nontimber uses and protection of the 
environment as well as timber crops will be essential, particularly on public forest lands and to an increasing degree on private lands as well.

14. A combination of efforts could help supply growing uemands for timber products while simultaneously providing for nontimber uses and protection of the environment.

In summary, if increased supplies of timber for a growing Nation are desired, a number of things could be done to increase and extend timber supplies, including:

- More complete utilization of logging residues, plant residues, and trees lost by mortality, and greater use of recycled fibers.

- Greater use of available equipment and manufacturing processes to increase output of lumber and other products from available log supplies.

- Better allocation of available timber to assure use for optimum end products.

- Some increase in dependence on imports of timber products.
- More intensive management of all classes of forestlands suitable for timber management, by road construction, commercial thinning and salvage, reforestation with genetically improved planting stock, timber stand improvement, use of fertilizers, and better protection against fire, insects and other destructive agents-while simultaneously managing lands to assure a balance with other uses and environmental protection.

- Continued development and application of new technology in timber growing, in processing of timber products, and in consumer use of wood products.

Substantial public and private investments will be necessary for such measures to increase timber supplies significantly and to improve utilization of available timber supplies. Such measures are both technically and economically feasible. They can be carried out while maintaining a balance with environmental uses of the forest. 
This chapter presents information on recent trends in the area and condition of commercial timberlands by classes of ownership; timber growth and mortality; the volume, quality, location, and ownership of standing timber; the output of roundwood timber products; and output and use of plant residues. ${ }^{1}$

This presentation is primarily concerned with national trends, although considerable information is also presented for the major sections of the country-North, South, Rocky Mountains, and Pacific Coast (fig. 1). Detailed regional and State statistics on forest land and timber resources as of 1970 are presented in Appendix I; these data have been updated from statistical information published by the Forest Service in Forest Survey reports for individual States.

\section{FOREST LAND AREAS}

Some 754 million acres, or one-third of the 2.3 billion acres of land in the United States, were classified as forest lands in 1970 (table 1). These vary from highly productive forest areas intensively managed for timber production to areas

1 For definitions of terms used in this report, see Glossary. incapable of yielding industrial wood because of adverse conditions of climate, soil, or elevation.

\section{Commercial Timberland}

Two-thirds of the Nation's forest land in 1970 , or about 500 million acres, was classed as commercial timberland -i.e., both available and suitable for growing continuous crops of saw logs or other industrial timber products (fig. 2). These areas also provide recreation, wildlife habitat, watershed protection, and some forage for livestock.

Areas classed as commercial timberland vary widely in timber producing potentials, but all are judged capable of growing at least 20 cubic feet of timber per year, and suitable now or prospectively for timber harvesting. Although landowner intentions have a major bearing on use of land for timber production, forest areas were excluded from the commercial category only when of low productivity or actually reserved or developed for nontimber uses.

Nearly three-quarters of the commercial timberland is located in the eastern half of the United States, about equally divided between the North and South sections (fig. 3). These forests cover 80 percent of the total land area in New England, and more than half of the area along the Atlantic

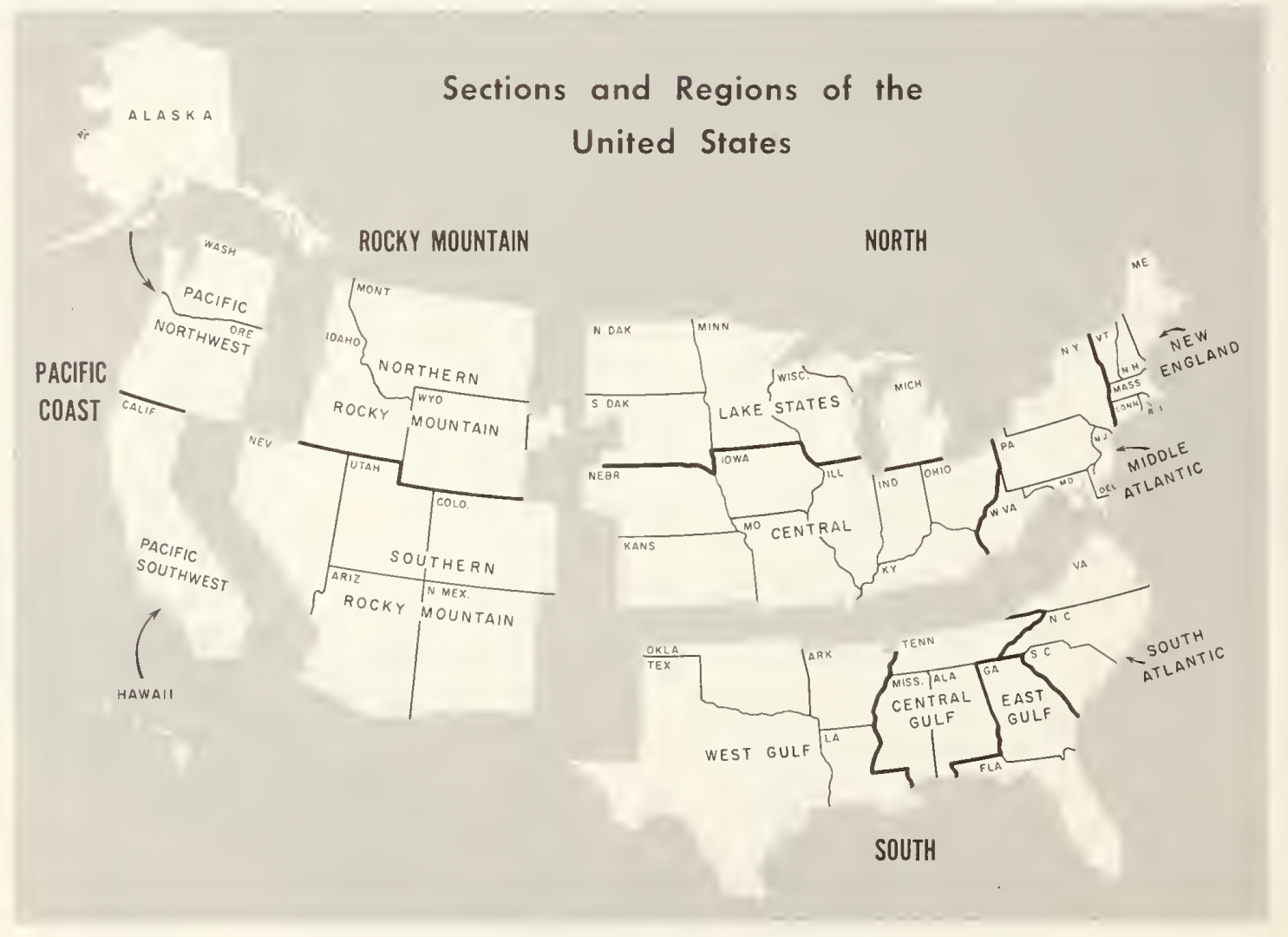

Figure 1 
TABLE 1.-Land area of the United States, by type of land and section, January 1, 1970

\begin{tabular}{|c|c|c|c|c|c|c|}
\hline \multirow{2}{*}{ Type of land } & \multicolumn{2}{|c|}{ Total United States } & \multirow{2}{*}{ North } & \multirow{2}{*}{ South } & \multirow{2}{*}{$\begin{array}{l}\text { Rocky } \\
\text { Mountains }\end{array}$} & \multirow{2}{*}{$\begin{array}{l}\text { Pacific } \\
\text { Coast }\end{array}$} \\
\hline & Area & Proportion & & & & \\
\hline Commercial timberland... & $\begin{array}{r}\text { Million acres } \\
499.7\end{array}$ & $\begin{array}{l}\text { Percent } \\
22.0\end{array}$ & $\begin{array}{r}\text { Million acres } \\
177.9\end{array}$ & $\begin{array}{r}\text { Million acres } \\
192.5\end{array}$ & $\begin{array}{r}\text { Million acres } \\
61.6\end{array}$ & $\begin{array}{r}\text { Million acres } \\
67.6\end{array}$ \\
\hline $\begin{array}{l}\text { Other forest land: } \\
\text { Productive-reserved_... } \\
\text { Deferred.-. } \\
\text { Unproductive.......... }\end{array}$ & $\begin{array}{r}17.2 \\
2.7 \\
233.9\end{array}$ & $\begin{array}{r}.8 \\
.1 \\
10.3\end{array}$ & 4.3 & $\begin{array}{l}1.7 \\
17.6\end{array}$ & $\begin{array}{r}7.9 \\
2.3 \\
66.5\end{array}$ & $\begin{array}{r}3.3 \\
145.6\end{array}$ \\
\hline Total .... & 253.9 & 11. 2 & 8. 6 & 19. 3 & 76.6 & 149. 3 \\
\hline $\begin{array}{l}\text { Total forest land. } \\
\text { Cropland } \\
\text { Other land. }\end{array}$ & $\begin{array}{r}753.5 \\
427.0 \\
1,089.5\end{array}$ & $\begin{array}{l}\text { 33. } 2 \\
18.8 \\
48.0\end{array}$ & $\begin{array}{l}186.5 \\
260.2 \\
181.4\end{array}$ & $\begin{array}{l}211.9 \\
103.7 \\
197.2\end{array}$ & $\begin{array}{r}138.2 \\
37.4 \\
379.7\end{array}$ & $\begin{array}{r}216.9 \\
25.7 \\
331.3\end{array}$ \\
\hline Total land area... & $2,270.1$ & 100. 0 & 628. 0 & 512.8 & 555.3 & 573. 9 \\
\hline
\end{tabular}

Land Area of the United States

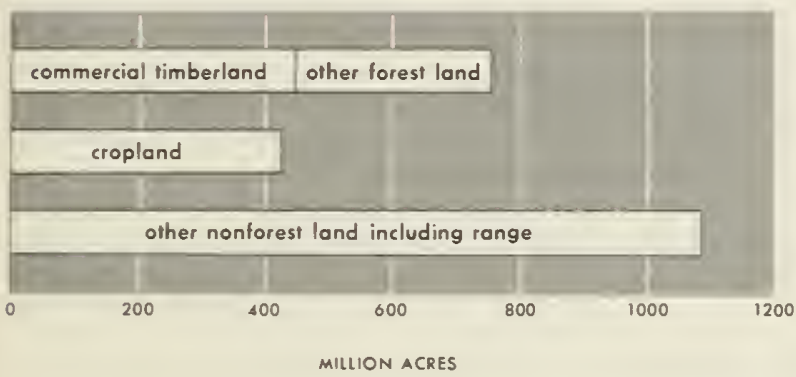

Figure 2

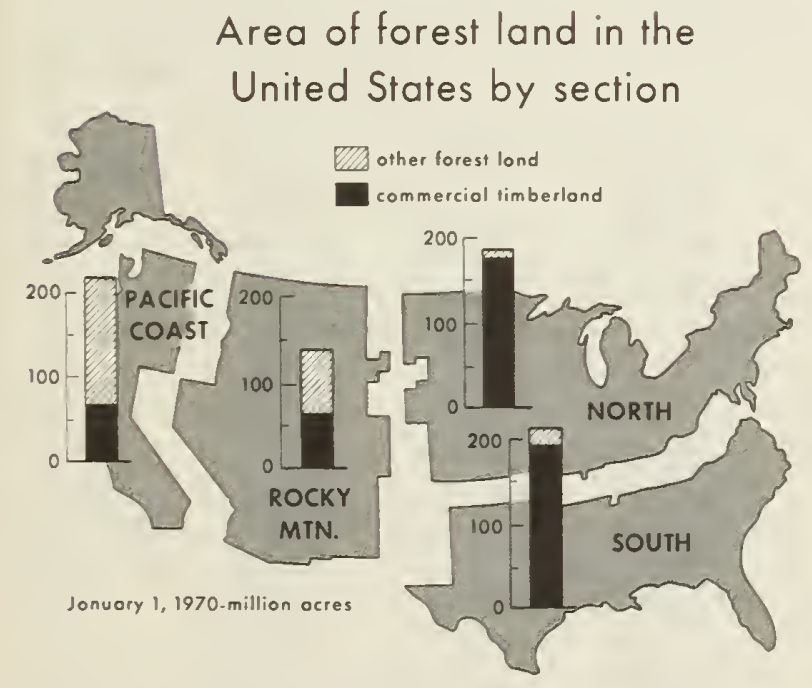

Figure 3

Coast. In the Central region, about 15 percent of the total land area is in the commerical timberland category.
The one-quarter of the Nation's commercial timberland located in the West is concentrated in the Pacific Coast States of Oregon, Washington, and California, and in the Rocky Mountain States of Montana, Idaho, and Colorado.

\section{Other Forest Lands}

Additional areas of productive timberland in public ownership on which timber harvesting is excluded have been classed as "reserved" areas. These totaled 17.2 million acres in 1970. Also, about 2.7 million acres of productive timberland in National Forests were classed as "deferred" in 1970 while under study for possible inclusion in the wilderness system.

The remaining one-third of the total forest land-some 234 million acres-includes lands of low productivity for timber, that is, generally of less than 20 cubic feet per acre per year of timber growth capacity. These areas largely support stands of pinyon-juniper, woodland-grass, chaparral, subalpine forests, or forests in the interior of Alaska.

As in the case of commercial timberlands, these other forests are of considerable importance for nontimber uses, such as recreation, watershed protection, wildlife habitat, and livestock production. The timber on these lands, as well as on "nontimber" lands, also supply limited quantities of roundwood products.

The interior of Alaska contains an estimated 106 million acres of forest land, or about 32 percent of Alaska's total land area. An estimated 22.5 million acres of these forests have a growth potential in excess of 20 cubic feet per acre. However, because of geographic and economic remoteness, none of the forest land in the interior of Alaska has been included in the statistics for commercial timberland, as in similar previous timber appraisals. 
The better stands of timber in the interior of Alaska include cottonwood along major streams and areas of spruce and white birch. For the most part timber growth is limited by permafrost, poor drainage, and short growing seasons. Because of a history of frequent forest fires, most interior forests are also relatively young and occur in a patchwork of mixed age classes and types. Quaking aspen and paper birch usually seed in promptly after fires, but both are short-lived species and in time are usually succeeded by spruce.

White spruce is the most important softwood species, accounting for 81 percent of the total sawtimber volume in interior forests and a major part of the volume of smaller pulpwood size timber. Total timber inventory volumes on the 22.5 million acres of the more productive forest lands was estimated at 14.3 billion cubic feet-roughly equivalent to 2.2 percent of timber inventories on commercial timberland in the United States.

Development of forest industries in interior Alaska has been limited by lack of access, low timber volumes per acre, small size of trees, low product values, and difficult logging conditions. Divided ownership among the Federal Government, State of Alaska, natives, and other private individuals may be a constraint in some areas. Environmental factors and ecological stability also will represent highly important factors in the development of forests in interior Alaska. In the coastal portion of Alaska much of the allowable harvest on commercial timberlands has been committed for the support of pulp and lumber production.

\section{Trends in Areas of Commercial Timberland}

The 500 million acres of land classed as commercial timberland in 1970 was 8.4 million acres less than estimated for 1962 (table 2). These and other data suggest that the long rise in commercial timberland areas resulting from agricultural land abandonment in the eastern United States has now been reversed.

Recent declines in commercial timberland were largely in the South and Rocky Mountains. Much of the reduction in the West, especially in the Rocky Mountains, reflected shifts of public lands in National Forests to reserved or deferred status in response to growing demands for public recreational uses. Some was the result of increased use of forest land for roads and urban expansion.

In the South, much clearing of commercial timberland for soybean and other crop production took place in recent years, particularly in hardwood forest areas of the Mississippi River floodplain. In addition, extensive areas of forested uplands were converted to pasture for the South's growing cattle industry. In all regions, sizable areas of forest land also have been taken over for suburban development, highways, reservoirs, and other nontimber uses.

The estimates of net changes in timberland area such as shown in table 2 do not measure directly impacts of land-use shifts on timber

\section{TABLE 2.-Area of commercial timberland, by region, 1952, 1962, and 1970}

[Thousand acres]

\begin{tabular}{|c|c|c|c|c|}
\hline Region & 19.52 & 1962 & 1970 & $\begin{array}{c}\text { Change } \\
1962-1970\end{array}$ \\
\hline 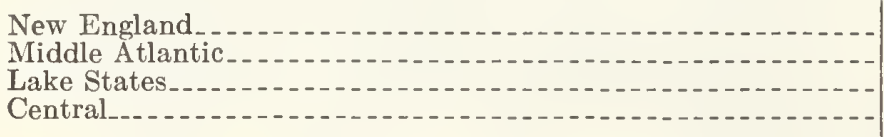 & $\begin{array}{l}30,935 \\
42,098 \\
52,604 \\
44,559\end{array}$ & $\begin{array}{l}31,878 \\
46,737 \\
51,530 \\
44,942\end{array}$ & $\begin{array}{l}32,367 \\
49,685 \\
50,841 \\
45,008\end{array}$ & $\begin{array}{r}+488 \\
+2,947 \\
-690 \\
+66\end{array}$ \\
\hline Total North $\ldots . . .$. & 170,198 & 175,089 & 177,901 & $+2,812$ \\
\hline $\begin{array}{l}\text { South Atlantic } \\
\text { East Gulf } \\
\text { Central Gulf } \\
\text { West Gulf. }\end{array}$ & $\begin{array}{l}46,962 \\
42,104 \\
49,497 \\
53,518\end{array}$ & $\begin{array}{l}47,911 \\
43,128 \\
53,361 \\
55,504\end{array}$ & $\begin{array}{l}48,463 \\
41,334 \\
51,454 \\
51,291\end{array}$ & $\begin{array}{r}+551 \\
-1,794 \\
-1,907 \\
-4,214\end{array}$ \\
\hline Total South & 192,082 & 199,905 & 192,542 & $-7 ; 364$ \\
\hline $\begin{array}{l}\text { Pacific Northwest } \\
\text { Pacific Southwest } \\
\text { Northern Rocky Mountain } \\
\text { Southern Rocky Mountain }\end{array}$ & $\begin{array}{l}50,589 \\
18,216 \\
38,337 \\
25,554\end{array}$ & $\begin{array}{l}50,407 \\
18,132 \\
38,792 \\
25,810\end{array}$ & $\begin{array}{l}49,713 \\
17,909 \\
36,669 \\
24,963\end{array}$ & $\begin{array}{r}-694 \\
-223 \\
-2,124 \\
-848\end{array}$ \\
\hline Total West & 132,696 & 133,141 & 129,254 & $-3,888$ \\
\hline All regions & 494,978 & 508,137 & 499,697 & $-8,440$ \\
\hline
\end{tabular}

Note: Data for 1952 and 1962 as published in early reports have been revised to insure comparability with 1970 definitions and local specifications of commercial timberland. 
resources. Agricultural acreage that is abandoned and reverts to forest usually remains understocked for many years, except for areas planted to trees. Timberlands shifted to other uses, on the other hand, generally contain timber inventories that are either reserved or largely destroyed as a part of changes in land use.

Net changes also are often much smaller than areas moring into and out of commercial status. Thus in Florida, for example, about 1.7 million acres of forested lands were shifted to agriculture, urban, and other uses during the 1959-70 period, while 0.7 million acres of farm land reverted to forest-a net loss of forest land of about a million acres.

\section{Ownership of Commercial Timberlands}

Largely as a result of historical policies which encouraged transfer of public domain lands to private ownership, about 73 percent of all commercial timberlands was prirately owned in 1970 . About 27 percent was in Federal, State, and other public holdings (table 3.)

Farm and miscellaneous private lands.-Commercial timberlands held by business and professional people, wage and salary workers, housewives, railroad, mining, and other corporations, and other nonfarm owners represent the largest class of forest ownership. In 1970, these owners held 165 million acres, or 33 percent of the total area of commercial timberland. Another 26 percent was classed as owned by farmers.

Many of the farm and miscellaneous private holdings include highly productice timber sites, and most are close to markets for timber products. These ownerships consequently have long been of major importance as a source of timber supplies for the wood-using industries. Nearly half of these timberlands were in the South in 1970 and most of the remainder in the North.

Since 1952 the combined area of farm and miscellaneous ownership has not shown much change (fig. 4 ; Appendix I, table 2). However, farm ownership dropped about 42.5 million acres between 1952 and 1970 , while miscellaneous private ownerships increased about the same amount. Farm abandonment and a decline in rural populations has typically been associated with sales of land to nonfarm or industrial owners.

Forest industry ownerships.-The 67 million acres of commercial timberland in forest industry holdings in 1970-about 14 percent of the totalincluded some of the Nation's most productive timber growing areas. About 52 percent of these industrial lands were in the South, and 26 percent in the North. Most of the remaining areas were on the Pacific Coast, generally including the more productive lower elevation lands.

In the 1952-70 period, areas of commercial timberland in forest industry ownerships increased 13 percent-close to 8 million acres. Much of the increase was in the South where wood-using companies have been actively acquiring forest lands. A substantial part of the added acreage was purchased from farm and miscellaneous owners.

Forest industries have also turned to leasing and long-term cutting contracts to supplement fee ownership. Thus in the South, an estimated 9 million acres of commercial timberlands in nonindustrial ownerships were managed by the forest industries in 1970.

National Forest lands.--Some 92 million acres of commercial timberlands, or 18 percent of the U.S. total, were in National Forests in 1970. These forests are located largely in the Rocky Mountain and Pacific Coast sections. Most are

TABLE 3.-Area of commercial timberland in the United States, by type of ownership and section, January 1, 1970

\begin{tabular}{|c|c|c|c|c|c|c|}
\hline \multirow{2}{*}{ Type of ownership } & \multicolumn{2}{|c|}{ Total United States } & \multirow{2}{*}{ North } & \multirow{2}{*}{ South } & \multirow{2}{*}{$\begin{array}{c}\text { Rocky } \\
\text { Mountains }\end{array}$} & \multirow{2}{*}{$\begin{array}{l}\text { Pacific } \\
\text { Coast }\end{array}$} \\
\hline & Area & Proportion & & & & \\
\hline $\begin{array}{l}\text { Federal: } \\
\text { National Forest } \\
\text { Bureau of Land Management... } \\
\text { Bureau of Indian Affairs..... } \\
\text { Other Federal. }\end{array}$ & $\begin{array}{r}\text { Thousand acres } \\
91,924 \\
4,762 \\
5,888 \\
4,534\end{array}$ & $\begin{array}{r}\text { Percent } \\
18 \\
1 \\
1 \\
1\end{array}$ & $\begin{array}{r}\text { Thousand acres } \\
10,458 \\
75 \\
815 \\
963\end{array}$ & $\begin{array}{r}\text { Thousand acres } \\
10,764 \\
11 \\
220 \\
3,282 \\
\end{array}$ & $\begin{array}{r}\text { Thousand acres } \\
39,787 \\
2,024 \\
2,809 \\
78\end{array}$ & $\begin{array}{r}\text { Thousand acres } \\
30,915 \\
2,652 \\
2,044 \\
211\end{array}$ \\
\hline Total Federal_. & 107,109 & 21 & 12,311 & 14,277 & 44,699 & 35,822 \\
\hline $\begin{array}{l}\text { State } \\
\text { County and municipal } \\
\text { Forest industry } \\
\text { Farm } \\
\text { Miscellaneous private }\end{array}$ & $\begin{array}{r}21,423 \\
7,589 \\
67,341 \\
131,135 \\
165,101\end{array}$ & $\begin{array}{r}4 \\
2 \\
14 \\
26 \\
33\end{array}$ & $\begin{array}{r}13,076 \\
6,525 \\
17,563 \\
51,017 \\
77,409\end{array}$ & $\begin{array}{r}2,321 \\
681 \\
35,325 \\
65,137 \\
74,801\end{array}$ & $\begin{array}{l}2,198 \\
71 \\
2,234 \\
8,379 \\
4,051\end{array}$ & $\begin{array}{r}3,828 \\
312 \\
12,219 \\
6,602 \\
8,840\end{array}$ \\
\hline All ownerships & 499,697 & 100 & 177,901 & 192,542 & 61,632 & 67,622 \\
\hline
\end{tabular}


Ownership of commercial timberlands, 1952-1970

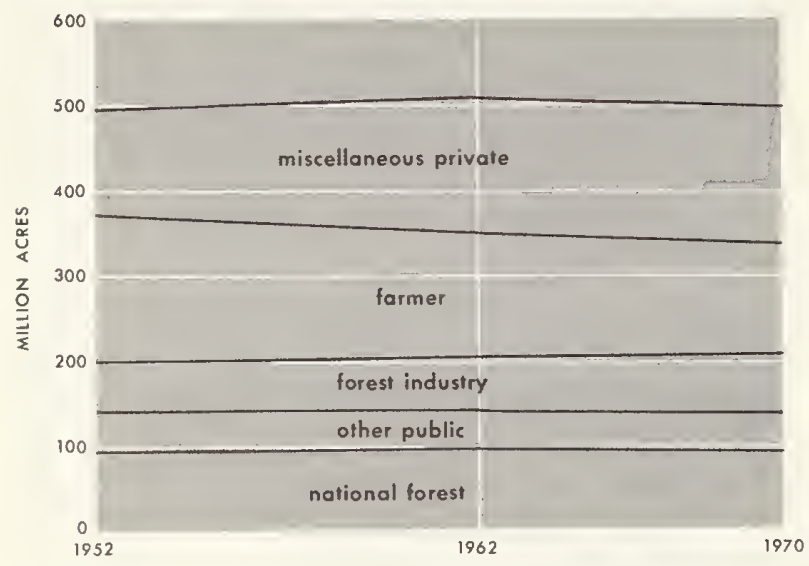

Figure 4

of relatively low site quality and located at higher elevations, but these forests nevertheless contain a substantial part of the Nation's timber inventory, as pointed out in a later section of this chapter.

Since 1962 areas in National Forests classed as commercial timberland have been reduced about 3 million acres. These reductions were mainly in the Rocky Mountain section, and mainly included lands selected for study as possible inclusions in the wilderness system. Since 1970 some additional areas also have been added to this deferred classification.

Some 5 million acres of the National Forest lands included in commercial timberland in 1970 were classed as "unregulated," and were not included in projecting available timber supplies. On these lands the amount and timing of future harvests are uncertain because of economic considerations or a lack of acceptable and economic logging systems.

Other public lands.-Federal lands other than National Forests made up 3 percent of all commercial timberlands in 1970. Lands in western Oregon administered by the Bureau of Land Management, and lands administered by the Bureau of Indian Affairs, were of particular importance in this group. State, county, and municipal forests made up 6 percent of the total. Many of these latter holdings were located in the Lake States, largely consisting of lands that were cutover and reverted through tax delinquency to public ownership during the depression years of the 1930's.

\section{Forest Type Groups}

Over half of all commercial timberlands in the United States in 1970 was occupied by eastern hardwood forest types ${ }^{2}$ (table 4 ). Softwood types made up 42 percent, western hardwoods 3 percent, and nonstocked areas 4 percent, of all commercial timberlands.

Eastern hardwood forests.-Oak-hickory stands, stretching from southern New England to Texas,

TABLE 4.-Area of commercial timberlands in the United States, by forest type groups, 1970

\begin{tabular}{|c|c|c|}
\hline Type group & $\begin{array}{l}\text { Total } \\
\text { area }\end{array}$ & $\begin{array}{l}\text { Propor- } \\
\text { tion of } \\
\text { total }\end{array}$ \\
\hline EASTERN TYPE GROUPS & & \\
\hline $\begin{array}{l}\text { Softwood types: } \\
\text { Loblolly-shortleaf pine } \\
\text { Longleaf-slash pine. } \\
\text { Spruce-fir } \\
\text { White-red-jack pine. }\end{array}$ & $\begin{array}{l}\begin{array}{c}\text { Thousand } \\
\text { acres }\end{array} \\
52,832 \\
18,315 \\
18,913 \\
12,168\end{array}$ & $\begin{array}{r}\text { Percent } \\
10.7 \\
3.7 \\
3.8 \\
2.5 \\
\end{array}$ \\
\hline Total & 102,228 & 20.7 \\
\hline $\begin{array}{l}\text { Hardwood types: } \\
\text { Oak-hickory } \\
\text { Oak-pine-_. } \\
\text { Oak-gum-cypress } \\
\text { Maple-beech-birch } \\
\text { EIm-ash-cottonwood } \\
\text { Aspen-birch }\end{array}$ & $\begin{array}{r}111,861 \\
35,028 \\
30,630 \\
31,140 \\
24,728 \\
20,484 \\
\end{array}$ & $\begin{aligned} & 22 . 6 \\
& \text { 7. } 1 \\
& 6 . 2 \\
& 6 . 3 \\
& 5 . 0 \\
& 4 . 1 \\
&\end{aligned}$ \\
\hline Total _. & 253,871 & 51.3 \\
\hline Nonstocked__._. & 14,343 & 2. 9 \\
\hline Total East $\ldots$ & 370,442 & 74.9 \\
\hline WESTERN TYPE GROUPS & & \\
\hline $\begin{array}{l}\text { Softwood types: } \\
\text { Douglas-fir } \\
\text { Ponderosa pine } \\
\text { Fir-spruce } \\
\text { Lodgepole pine } \\
\text { Hemlock-Sitka spruce } \\
\text { Larch } \\
\text { White pine } \\
\text { Redwood }\end{array}$ & $\begin{array}{r}30,788 \\
27,964 \\
17,830 \\
13,235 \\
10,819 \\
2,743 \\
829 \\
803\end{array}$ & $\begin{array}{l}\text { 6. } 2 \\
\text { 5. } 6 \\
\text { 3. } 6 \\
\text { 2. } 7 \\
\text { 2. } 2 \\
.5 \\
.2 \\
.2\end{array}$ \\
\hline $\begin{array}{l}\text { Total } \\
\text { Hardwood types } \\
\text { Nonstocked }\end{array}$ & $\begin{array}{r}105,011 \\
12,818 \\
6,379\end{array}$ & $\begin{array}{r}\text { 21. } 2 \\
2.6 \\
1.3\end{array}$ \\
\hline Total West_............ & 124,208 & 25.1 \\
\hline All groups & ${ }^{1} 494,650$ & 100. 0 \\
\hline
\end{tabular}

1 Not including 5 million acres of "unregulated" commercial timberlands on National Forests in the Rocky Mountain States.

${ }^{2}$ Forest types describe assocations of tree species, which in turn reflect factors of site, climate, and stand history. The forest type groups presented in this report are combinations of more than 80 local forest types traditionally used for forest management purposes. A map showing location of major forest types is for sale $(\$ 1.50)$ by the U.S. Geological Survey, Washington, D.C. 20242, as Sheet No. 182. 
represent the most widespread timber type group, accounting for about 23 percent of all commercial timberlands in 1970 (fig. 5). Much of this type group now occurs on abandoned farm lands and in mountain areas. Many stands include large proportions of less desirable species such as post oak, black oak, chestnut oak, and blackjack oak. Some local types, howerer, are comprised of yellow-poplar and other desirable species.

The oak-pine type, which covered 14 percent of the eastern hardwood area in 1970, was mainly concentrated in the South. This trpe largely includes residual bardwoods left after cutting the merchantable pine trees from mixed pine-hardwood forests. In the last few decades many oak-pine stands have been converted to pine stands by killing or cutting hardwoods, followed in many cases by planting pines.

Oak-gum-crpress forests include such valuable species as sweetgum, cherrybark oak, tupelo, and baldcypress, as well as poorer species. These types occupied about 12 percent of the hardwood forest area in the East in 1970. Nearly all of this type occurs in the Mississippi Delta and other southern river bottoms where sites are of high productivity.

Maple-beech-birch forests are found mainly on upland sites in the New England, Middle Atlantic, and Lake States regions. Elm-ashcottonwood types are largely concentrated in bottomlands in the Central and Lake States

Forest type groups in the United States, 1970

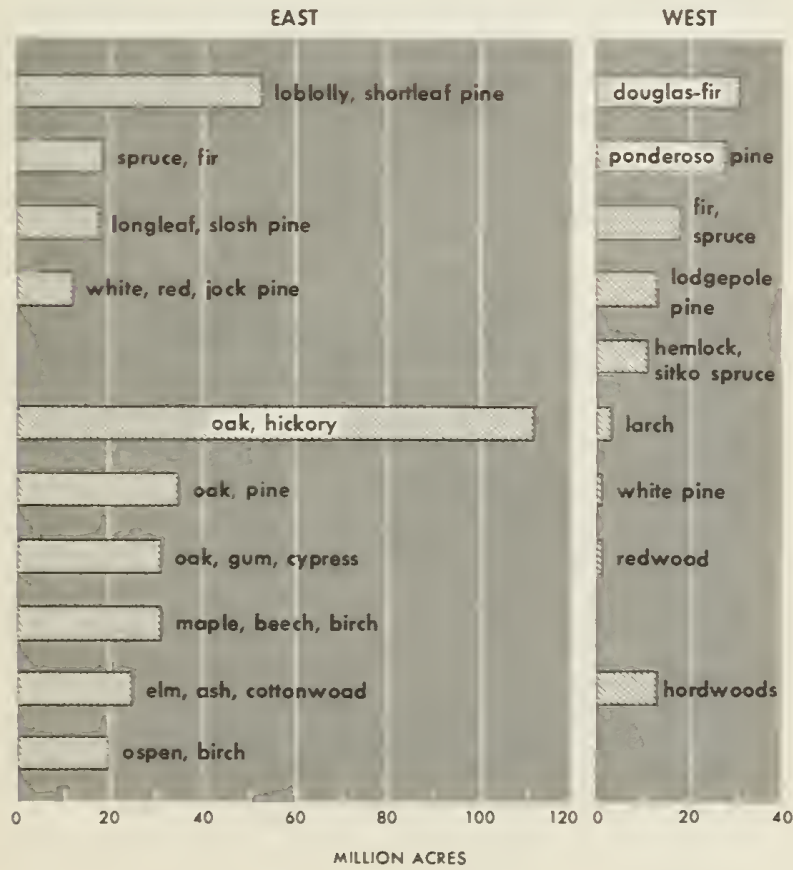

Figure 5 regions. Aspen-birch types are found chiefly in the Lake States region. This type is composed of relatively short-lived pioneer species that have taken over large areas following logging and fires.

Eastern softwood forests.-Southern pine type groups made up a little more than 14 percent of the Nation's commercial timberlands in 1970. These types are concentrated on the Coastal Plain and Piedniont extending from New Jersey to Texas. In 1970 harvests of southern pine made up more than one-fourth of the total timber harvest in the United States.

Spruce-fir and white-red-jack pine types in the Lake States and Northeast covered about 6 percent of all commercial timberlands in 1970 . As in the case of southern pines, these forests also support substantial local industries.

Western forests. - In the West about 85 percent of the commercial timberland supports softwood types. Douglas-fir and ponderosa pine types each make up about 6 percent of the total commercial timberland in the United States, and other western softwood type groups 9 percent. Most Douglas-fir areas occur on the Pacific Coast west of the Cascade Range where sites generally are highly productive. Douglas-fir also occurs in California and the Rocky Mountains, frequently on moderatly productive sites and mixed with other coniferous species.

The ponderosa pine type occupies a large acleage in eastern Oregon and Washington and in 1970 was also the most extensive commercial forest type in California and the Rocky Mountains.

Recent trends in forest types.- Shifts in land use patterns and natural succession have caused many important changes in forest type areas. Thus bottomland haldwood forests were reduced about 20 percent between 1962 and 1970 by clearing of forest land along the deltas of the Mississippi River and its tributaries for farm crops. For many years forests of the oak-gum-cypress group in this area have supplied a major share of the Nation's quality hardwood sawtimber.

Many changes have also been apparent in areas formerly supporting Douglas-fir. Red alder, other hardwoods, or western hemlock have taken over sizable areas after harvesting of the softwood stands. Western hardwood types thus increased almost 2 million acres between 1962 and 1970 . Industry may be able to increase utilization of alder and other hardroods, as in the case of aspen in the Lake States, but at present most alder stands offer little ralue compared to Douglas-fir.

\section{Forest Site Productivity}

Because of differences in such factors as soil fertility, moisture, slope, aspect, and eleration, there are considerable variations in timber-growing 
TABle 5.-Area of commercial timberland in the United States, by site productivity class and by section, 1970

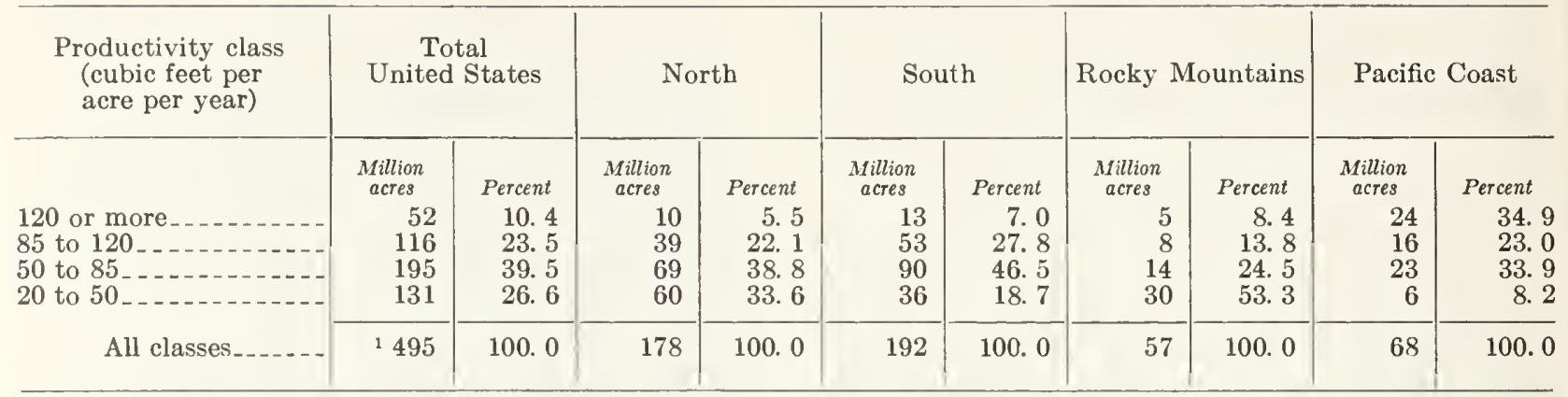

${ }^{1}$ Not including 5 million acres in National Forests in the Rocky Mountains classed as "unregulated" commercial timberlands.

potentials, and responses to cultural practices, on the Nation's commercial timberlands.

About 10 percent of all commercial timberlands were classed as site 120 or more, that is, capable of producing 120 cubic feet or more per acre per year in fully stocked natural stands (table 5). (Under intensive management more timber can be produced than indicated by such figures for natural stands.) Nearly half of this highly productive land is in the Pacific Coast section, largely supporting Douglas-fir, hemlock-Sitka spruce, and western hardwoods. Each of the other sections also contain some of this high-site land.

Nearly two-thirds of the total area of commercial timberland is in the 85 to 120 and the 50 to 85 cubic foot site classes. About half of this acreage is in the South.

The remaining area of 20 to 50 cubic foot growth potential makes up more than a quarter of all commercial timberlands. This class of land provides limited response to timber management activities but often yields important values for grazing, recreation, or other nontimber uses. These lowersite lands are mostly in eastern areas such as the Appalachians, and in the Rocky Mountains where this site class makes up about half of that section's commercial timberland.

A relatively large proportion of the better sites above 85 cubic feet are in forest industry ownerships. The National Forests and other public ownerships have relatively high proportions of the poorer sites of less than 50 cubic feet potential.

\section{Timber Stocking}

The potential yields indicated by site productivity classifications are generally not realized, even though practically all commercial timberlands in 1970 were occupied to some extent by some type of tree cover, and many forests were fully stocked or even overstocked in terms of all live trees.

Illustrative data for a number of sample hardwood forest areas indicated, however, that only a fifth of the land supported desirable trees of good form, vigor, and preferred species. Growing stock of acceptable trees, and trees classed as rough and rotten, made up the lemaining tree stocking. An estimated 90 percent of the land in these sample areas would require cultural treatments such as cull tree removal or thinnings to achieve a high level of output of merchantable timber and thus approach the yield potentials indicated by indexes of site productivity.

\section{Stand-Size Classes}

The distribution of forest areas by stand-size classes largely reflects the recency of timber harvesting and other factors such as fires or reversion of farm land to forest. Stand size is also indicative of prospective supplies of industrial timber, and a basic factor in the planning of timber management.

About 44 percent of all commercial timberlands supported sawtimber stands in 1970 (table 6). Poletimber stands made up 26 percent, and seedling and sapling stands 27 percent, with some 4 percent classed as nonstocked.

Sawtimber stands made up a sizable part of the total area in the South and in the North, even though most forests in these sections have been cutover one or more times. Most of these eastern sawtimber stands are relatively young and composed of trees in the lower part of the sawtimbersize range.

Much larger proportions of western forests supported sawtimber stands, including considerable old-growth areas that have never been cut. Stands on the Pacific Coast contain most of the large-size, high-quality sawtimber remaining in the United States.

Wide differences in timber volumes per acre are also illustrated by data in table 7 . Nearly half of all commercial timberlands supported less than 1,500 board feet per acre in 1970 . Only 23 percent had inventory volumes of more than 5,000 board feet per acre. 
a further 14 percent between 1962 and 1970 (table 8). This strong upward trend occurred in both softwoods and hardwoods, and for both sawtimber and all growing stock.

Net growth has been rising in all regions, although softwood sawtimber in the South and hardwood sawtimber in the North showed the ]argest increases (table 9). There is of course considerably more commercial timberland in the East than in the West, and eastern stands are essentially all young growth where mortality is relatively low. In the West, sizable areas still support old growth in which mortality nullifies much of the total growth.

About two-thirds of the total sawtimber growth of nearly 60 billion board feet in 1970 was on

TABLE 8.-Net annual growth of growing stock and sawtimber on commercial timberland, by softwoods and hardwoods, and by section, 1952, 1962, and $1970^{1}$

GROWING STOCK-BILLION CUBIC FEET

\begin{tabular}{|c|c|c|c|c|c|c|c|c|c|}
\hline \multirow{2}{*}{ Section } & \multicolumn{3}{|c|}{ All species } & \multicolumn{3}{|c|}{ Softwoods } & \multicolumn{3}{|c|}{ Hardwoods } \\
\hline & 1952 & 1962 & 1970 & 1952 & 1962 & 1970 & 1952 & 1962 & 1970 \\
\hline $\begin{array}{l}\text { North } \\
\text { South } \\
\text { Rocky Mountains } \\
\text { Pacific Coast } \ldots\end{array}$ & $\begin{array}{l}\text { 4. } 1 \\
\text { 6. } 3 \\
\text { 1. } 2 \\
\text { 2. } 3\end{array}$ & $\begin{array}{l}\text { 4. } 9 \\
\text { 7. } 5 \\
\text { 1. } 3 \\
\text { 2. } 7\end{array}$ & $\begin{array}{l}5.5 \\
8.6 \\
\text { 1. } 4 \\
\text { 3. } 1\end{array}$ & $\begin{array}{l}\text { 1. } 1 \\
\text { 3. } 6 \\
\text { 1. } 1 \\
\text { 2. } 0\end{array}$ & $\begin{array}{l}\text { 1. } 2 \\
\text { 4. } 5 \\
\text { 1. } 2 \\
2.3\end{array}$ & $\begin{array}{l}\text { 1. } 4 \\
\text { 5. } 4 \\
\text { 1. } 3 \\
\text { 2. } 6\end{array}$ & $\begin{array}{r}3.0 \\
2.7 \\
.1 \\
.3\end{array}$ & $\begin{array}{r}3.6 \\
3.0 \\
.1 \\
.4\end{array}$ & $\begin{array}{r}\text { 4. } 2 \\
\text { 3. } \\
.1 \\
.5\end{array}$ \\
\hline Total $\ldots$ & 13. 9 & 16. 4 & 18. 6 & 7. 8 & 9. 3 & 10. 7 & 6. 1 & 7. 1 & 7. 9 \\
\hline
\end{tabular}

SAWTIMBER-BILLION BOARD FEET

\begin{tabular}{|c|c|c|c|c|c|c|c|c|c|}
\hline $\begin{array}{l}\text { North } \\
\text { South } \\
\text { Rocky Mountains } \\
\text { Pacific Coast }\end{array}$ & $\begin{array}{r}9.4 \\
21.2 \\
4.3 \\
10.3\end{array}$ & $\begin{array}{r}11.5 \\
24.3 \\
4.6 \\
11.9\end{array}$ & $\begin{array}{r}\text { 13. } 7 \\
28.0 \\
5.1 \\
13.1\end{array}$ & $\begin{array}{r}2.4 \\
\text { 13. } 6 \\
\text { 4. } 2 \\
9.4\end{array}$ & $\begin{array}{r}2.8 \\
16.7 \\
4.5 \\
10.7\end{array}$ & $\begin{array}{r}\text { 3. } 6 \\
\text { 20. } 1 \\
\text { 4. } 9 \\
11.6\end{array}$ & $\begin{array}{r}\text { 7. } 0 \\
\text { 7. } 6 \\
.1 \\
.9\end{array}$ & $\begin{array}{l}\text { 8. } 6 \\
\text { 7. } 6 \\
.1 \\
1.2\end{array}$ & $\begin{array}{r}\text { 10. } 1 \\
\text { 7. } 9 \\
\text { 1. } 1 \\
\text { 1. } 5\end{array}$ \\
\hline Total $\ldots \ldots$ & 45. 1 & 52.3 & 59.9 & 29.5 & 34. 7 & 40. 3 & 15. 6 & 17. 6 & 19. 7 \\
\hline
\end{tabular}

1 Data may not add to totals because of truncating.

Note: Data for 1952 and 1962 differ from data published in earlier reports because of adjustments based on newer information from remeasured Forest Survey plots. Data for all years are "trend level" estimates.

TABLE 9.-Change in net annual growth of growing stock and sawtimber on commercial timberland, by softwoods and hardwoods, and by section, 1962 to 1970

GROWING STOCK

\begin{tabular}{|c|c|c|c|c|c|c|}
\hline Section & \multicolumn{2}{|c|}{ All species } & \multicolumn{2}{|c|}{ Softwoods } & \multicolumn{2}{|c|}{ Hardwoods } \\
\hline $\begin{array}{l}\text { North } \\
\text { South } \\
\text { Rocky Mountains } \\
\text { Pacific Coast... }\end{array}$ & $\begin{array}{r}\text { Million cu. ft } \\
+664 \\
+1,155 \\
+50 \\
+345\end{array}$ & $\begin{array}{r}\text { Percent } \\
+14 \\
+15 \\
+4 \\
+13\end{array}$ & $\begin{array}{r}\text { Million cu.ft } \\
+144 \\
+920 \\
+44 \\
+261\end{array}$ & $\begin{array}{r}\text { Percent } \\
+12 \\
+21 \\
+4 \\
+11\end{array}$ & $\begin{array}{r}\text { Million cu.ft. } \\
+519 \\
+235 \\
+6 \\
+84\end{array}$ & $\begin{array}{r}\text { Percent } \\
+14 \\
+8 \\
+8 \\
+22\end{array}$ \\
\hline Total_- & $+2,214$ & +14 & $+1,369$ & +15 & +844 & +12 \\
\hline
\end{tabular}

\section{SAWTIMBER}

\begin{tabular}{|c|c|c|c|c|c|c|}
\hline $\begin{array}{l}\text { North } \\
\text { South } \\
\text { Rocky Mountains } \\
\text { Pacific Coast.-. }\end{array}$ & $\begin{array}{r}\text { Million bd. ft. } \\
+2,218 \\
+3,735 \\
+451 \\
+1,243\end{array}$ & $\begin{array}{l}\text { Percent } \\
+19 \\
+15 \\
+10 \\
+10\end{array}$ & $\begin{array}{r}\text { Million bd. ft. } \\
+787 \\
+3,428 \\
+431 \\
+976\end{array}$ & $\begin{array}{l}\text { Percent } \\
+28 \\
+21 \\
+9 \\
+9\end{array}$ & $\begin{array}{r}\text { Million bd. ft. } \\
+1,431 \\
+307 \\
+38 \\
+267\end{array}$ & $\begin{array}{r}\text { Percent } \\
+17 \\
+4 \\
+35 \\
+22\end{array}$ \\
\hline Total & $+7,646$ & +15 & $+5,603$ & +16 & $+2,043$ & +12 \\
\hline
\end{tabular}


softwood species. Roughly half of the softwood growth was comprised of southern pines and 16 percent of Douglas-fir (Append. I, tables 23 and 24).

The one-third of the total growth that was on hardwoods included growth of both preferred species such as select red and white oaks, sweetgum, rellow-poplar, and ash, walnut and cherry (about two-fifths of total hardwood growth) and species of more limited demand by industry such as other oaks, hickory, beech, and cottonwood (about three-fifths of total hardwood growth).

\section{Net Growth by Ownership}

Around 48 percent of the total net growth of softwoods in 1970, and nearly three-fourths of hardwood net growth, was on lands in farm and miscellaneous private ownerships (Append. I, table 21). Another quarter of the total net growth of softwoods, and 12 perçent of hardwood growth, was on forest industry ownerships. The National Forests and other public lands accounted for about 28 percent of all softwood net growth, and 17 percent of hardwood growth.

\section{Net Growth and Potential Growth Per Acre}

Average net annual growth in 1970 raried widely by section and by ownership from 23 to 65 cubic feet per acre (table 10). Net growth of the sawtimber portion of total growing stock also raried from an average of 77 board feet per acre in the North to 194 board feet on the Pacific Coast (Append. I, tables 22 and 23).

The relatively large average growth per acre in 1970 in the Pacific Coast section, in spite of the presence of much old-growth timber, largely reflects a high proportion of land in high site productivity classes and high rates of growth in young stands on private lands logged over in the past. In the South the presence of good sites and much thrifty young growth resulting from protection and other forestry practices explain the relatively high growth figures.

Arerage net growth in the North reflected a high proportion of land in lower productirity classes, predominance of slow-growing hardwood stands, and the presence of considerable rough and rotten timber. Averages for the Rocky Mountains reflected the presence of much old growth, frequent stagnation of stands, relatively low sites, and restocking problems following fire or logging.

In spite of recent substantial increases, net growth of timber is still much less than potential yields in fully stocked natural stands (table 10 and fig. 7). Even higher yields are attainable in stands under intensive management with use of genetically improred trees, fertilization, and spacing control.

The relatively limited net growth of growing stock and sawtimber in 1970 in relation to potentials in part reflected partial stocking of trees on much of the forest area, mortality and growth losses from destructice agents, and the presence of brush and cull trees which limit regeneration and increment of growing stock trees. These and other factors such as restocking problems often make it difficult and costly to achiere "full" stocking.

In old-growth stands in the West, mortality offsets much of the total growth and contributes to the relatively low net annual growth per acre, particularly on western National Forests.

\section{TABLE 10.-Average net annual and potential growth per acre, by owner, class and section, $1970^{1}$}

[Cubic feet]

\begin{tabular}{|c|c|c|c|c|c|}
\hline Section & All owners & $\begin{array}{c}\text { National } \\
\text { Forest }\end{array}$ & Other public & $\begin{array}{c}\text { Forest } \\
\text { industry }\end{array}$ & $\begin{array}{l}\text { Farm and } \\
\text { miscellaneous } \\
\text { private }\end{array}$ \\
\hline $\begin{array}{l}\text { North: } \\
\quad \text { Current_..... } \\
\text { Potential... }\end{array}$ & $\begin{array}{l}31 \\
68\end{array}$ & $\begin{array}{l}38 \\
66\end{array}$ & $\begin{array}{l}33 \\
59\end{array}$ & $\begin{array}{l}40 \\
72\end{array}$ & $\begin{array}{l}29 \\
69\end{array}$ \\
\hline $\begin{array}{l}\text { South: } \\
\text { Current }\end{array}$ & & & & & \\
\hline Potential. & $\begin{array}{l}45 \\
76\end{array}$ & $\begin{array}{l}55 \\
70\end{array}$ & $\begin{array}{l}45 \\
71\end{array}$ & $\begin{array}{l}53 \\
81\end{array}$ & $\begin{array}{l}42 \\
75\end{array}$ \\
\hline $\begin{array}{l}\text { Rocky Hountains: } \\
\text { Current }\end{array}$ & 24 & 23 & 23 & 47 & 25 \\
\hline $\begin{array}{l}\text { Potential-_- } \\
\text { Pacific Coast: }\end{array}$ & 60 & 65 & 54 & 70 & 50 \\
\hline $\begin{array}{l}\text { Current } \\
\text { Potential }\end{array}$ & $\begin{array}{l}45 \\
95\end{array}$ & $\begin{array}{l}27 \\
88\end{array}$ & $\begin{array}{r}60 \\
100\end{array}$ & $\begin{array}{r}65 \\
107\end{array}$ & $\begin{array}{l}58 \\
96\end{array}$ \\
\hline $\begin{array}{l}\text { Total: } \\
\quad \text { Current_... } \\
\quad \text { Potential... }\end{array}$ & $\begin{array}{l}38 \\
74\end{array}$ & $\begin{array}{l}30 \\
73\end{array}$ & $\begin{array}{l}39 \\
68\end{array}$ & $\begin{array}{l}52 \\
83\end{array}$ & $\begin{array}{l}36 \\
72\end{array}$ \\
\hline
\end{tabular}

${ }^{1}$ Potential growth is defined as the average net growth attainable in fully stocked natural stands. Higher growth rates can be attained in intensively managed stands. 
Potential and current net growth per acre

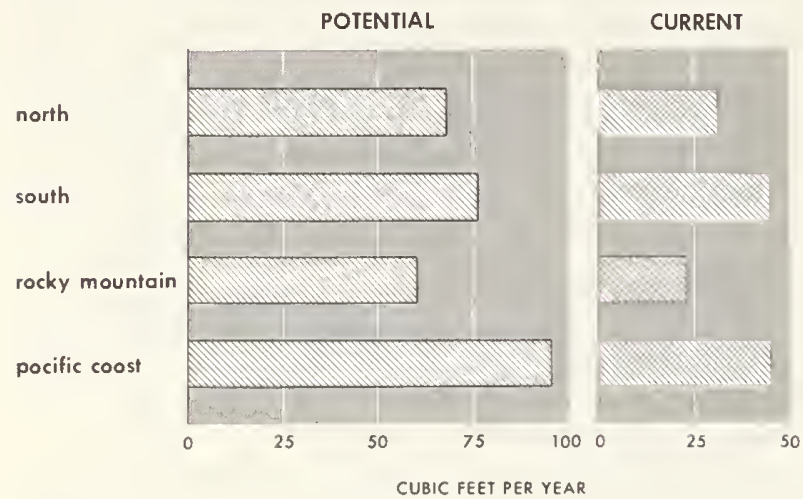

Figure 7

\section{IMPACTS OF DESTRUCTIVE AGENTS}

Fire, insects, disease, storms, and other destructive natural agents have significant impacts on net annual growth. Such impacts are partially accounted for by the statistics on mortality (that is, volumes of growing stock trees above 5.0 inches in diameter dying from natural causes during a given period).

\section{Volume of Mortality}

Annual mortality losses from natural causes were estimated at about 4.5 billion cubic feet of growing stock in 1970. Mortality of sawtimber amounted to an estimated 15.3 billion board feet (that is, roughly 2.6 billion cubic feet in the saw-log portion of sawtimber trees) (table 11). Mortality thus nullified about one-fifth of the total annual growth of both growing stock and sawtimber.

Softwood species accounted for the major part of mortality losses--that is, about three-fifths of growing stock mortality and three-quarters of sawtimber mortality.

Most softwood mortality in 1970 was in the West, chiefly in the Pacific Coast section (fig. 8). This distribution is related to the concentration of

Timber mortality by section, 1970

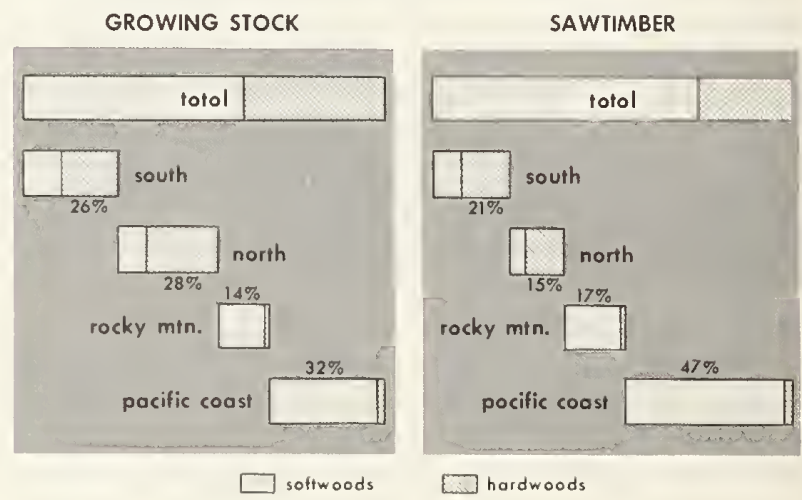

Figure 8

TABLE 11.-Mortality of growing stock and sawtimber on commercial timberland, by section and by softwoods and hardwoods, 1952, 1962, and $1970^{1}$

GROWING STOCK-BILLION CUBIC FEET

\begin{tabular}{|c|c|c|c|c|c|c|c|c|c|}
\hline \multirow{2}{*}{ Section } & \multicolumn{3}{|c|}{ All species } & \multicolumn{3}{|c|}{ Softwoods } & \multicolumn{3}{|c|}{ Hardwoods } \\
\hline & 1952 & 1962 & 1970 & 1952 & 1962 & 1970 & 1952 & 1962 & 1970 \\
\hline $\begin{array}{l}\text { North } \\
\text { South } \\
\text { Rocky Mountains } \\
\text { Pacific Coast_. }\end{array}$ & $\begin{array}{l}0.8 \\
\text { 1. } 0 \\
.6 \\
\text { 1. } 6\end{array}$ & $\begin{array}{r}1.0 \\
1.1 \\
.6 \\
1.5\end{array}$ & $\begin{array}{r}1.3 \\
1.2 \\
.6 \\
1.5\end{array}$ & $\begin{array}{r}0.2 \\
.3 \\
.6 \\
1.5\end{array}$ & $\begin{array}{r}0.3 \\
.4 \\
.6 \\
1.4\end{array}$ & $\begin{array}{r}0.4 \\
.5 \\
.6 \\
1.4\end{array}$ & $\begin{array}{r}0.6 \\
\quad .6 \\
\quad .1\end{array}$ & $\begin{array}{r}0.7 \\
.7 \\
(2)^{-} \\
\quad 1\end{array}$ & $\begin{array}{r}0.9 \\
\quad .7 \\
\quad .1\end{array}$ \\
\hline Total & 3. 9 & 4. 3 & 4. 5 & 2. 6 & 2. 7 & 2. 8 & 1. 3 & 1.5 & 1. 7 \\
\hline
\end{tabular}

SAWTIMBER-BILLION BOARD FEET

\begin{tabular}{|c|c|c|c|c|c|c|c|c|c|}
\hline $\begin{array}{l}\text { North. } \\
\text { South } \\
\text { Rocky Mountains } \\
\text { Pacific Coast_... }\end{array}$ & $\begin{array}{l}\text { 1. } 5 \\
2.6 \\
2.5 \\
8.4\end{array}$ & $\begin{array}{l}\text { 1. } 9 \\
\text { 3. } 0 \\
2.6 \\
\text { 7. } 8\end{array}$ & $\begin{array}{l}\text { 2. } 3 \\
\text { 3. } 2 \\
\text { 2. } 6 \\
\text { 7. } 1\end{array}$ & $\begin{array}{r}0.4 \\
.9 \\
2.5 \\
8.2\end{array}$ & $\begin{array}{l}0.5 \\
1.1 \\
2.5 \\
\text { 7. } 6\end{array}$ & $\begin{array}{l}0.7 \\
1.3 \\
2.5 \\
6.9\end{array}$ & $\begin{array}{r}\text { 1. } 1 \\
\text { 1. } 7 \\
.1 \\
.2\end{array}$ & $\begin{array}{r}1.4 \\
2.0 \\
.1 \\
.2\end{array}$ & $\begin{array}{r}1.7 \\
1.9 \\
.1 \\
.3\end{array}$ \\
\hline Total $\ldots \ldots$ & 15. 1 & 15. 3 & 15. 3 & 11. 9 & 11. 6 & 11.3 & 3. 1 & 3. 6 & 4. 0 \\
\hline
\end{tabular}

1 Data may not add to totals because of truncating.

2 Less than 0.1 billion.
Note: Data for 1952 and 1962 differ from data published in earlier reports because of adjustments based on newer information from remeasured Forest Survey plots. Data for all years are "trend level" estimates. 
timber volumes in the West, and the high proportion of overmature timber in old-growth stands. Much of the sawtimber lost included trees containing large proportions of high-quality material. But most mortality has occurred in inaccessible and unroaded areas, especially on the National Forests, where salrage has not been feasible.

In many important softrood types, bark beetles have been a major cause of mortality, especially in old-growth stands of ponderosa pine, Douglas-fir, and other western species. The mountain pine beetle, for example, lias killed billions of board feet of lodgepole and ponderosa pine sawtimber in recent years. Occasional outbreaks of bark beetles in the South, as in 1972 , have also caused significant mortality.

Foremost among diseases causing mortality in forest trees are dwarf mistletoes, root rots, white pine blister rust, fusiform rust, hypoxylon canker, oak wilt, and dutch elm disease.

So-called catastrophic losses from fire, insects, or blowdown, included with other forms of mortality in table 11 , represent the most spectacular losses, but on the average do not account for a large part of total mortality and growth losses.

\section{Additional Losses From Destructive Agents}

Destructive agents also cause additional losses of timber by killing trees under 5 inches in diameter, delaying regeneration by destroying seed crops and seedlings, inhibiting diameter and height growth, reducing quality and usable inventory volumes through decay or other defects, and inducing changes in stand composition from preferred to less desirable species.

The stunting of young trees by insects such as shoot and tip moths, or by diseases such as dwarf mistletoe, for example, frequently extends the time required to grow trees to merchantable size. Various defoliators such as the hemlock looper and spruce budworm often lower forest growth as well as kill trees.

In other cases insects, diseases, or wind cause deformities which limit usable vields of timber, as in the case of white pine reevil in eastern white pine stands. Crooking and forking of hardwoods caused by insects or disease reduce usable tree volumes. Tree borers cause significant degrade and losses of value in some species and areas.

Methods and data are not available to measure these varied impacts of destructive agents, but growth losses have been substantial and an important contributing cause of relatively low current growth rates. Some causes of mortality and growth losses, such as outright destruction of trees by fires, blowdown, or flooding, are highly visible and measurable. But reasons for many losses are not obvious. Insects and diseases also interact in diverse ways with each other and with other agents such as fire and manrelated activities.

\section{Salvage of Mortality}

An estimated 195 million cubic feet of dead softwood timber and 57 million cubic feet of dead hardwood timber was salvaged in 1970. This was equivalent to about 7 percent of the total estimated mortality of softwoods, and 3 percent of hardwood mortality. Much of the timber salvaged has been in concentrations of timber killed by destructive agents, as in the case of timber blown down in Mississippi by hurricane Camille in 1969, and salvage operations following major fires.

Efforts to reduce mortality include increased thinning operations. Chemicals to control insects and disease have also been widely used, but recent opposition to the use of hard pesticides and delays in control programs related to environmental considerations are having adverse effects on the effectiveness of control. New technology from research programs, and increased forest accessibility through expanding road systems, are helping reduce mortality and increase salrage opportunities.

\section{TIMBER REMOVALS}

Timber volumes removed from growing stock inventories on commercial timberland include: (a) harrests of roundwood products such as saw logs, veneer logs, and pulpwood; (b) logging residues; and (c) other removals from changes in land use such as clearing for agriculture or housing developments, and withdrawal of forest lands for parks or other nontimber uses.

\section{Total Timber Removals}

Timber removals in 1970 totaled about 14 billion cubic feet of growing stock, including 62.8 billion board feet of sawtimber (table 12). These rolumes were substantially above levels in the 1950 's and early 1960's when removals averaged about 12 billion cubic feet, including 50 billion board feet of sawtimber.

Softwoods made up some two-thirds of all growing stock removals, and three-quarters of all sawtimber removals, in 1970 . These removals were concentrated in the Pacific Coast and South.

About a third of all softwood removals in 1970 came from forest industry ownerships (Append. I, table 21), nearly 40 percent from farm and miscellaneous private ownerships, and about 30 percent from public lands.

\section{Roundwood Timber Harvests}

By far the largest portion of timber removals from growing stock consists of roundwood timber products (fig. 9). In 1970, 87 percent of all softwood removals, and 63 percent of all hardwood removals, were used in this way. These products 
TABLE 12.-Timber removals from growing stock and sawtimber, by softwoods and hardwoods and by section, 1952, 1962, and $1970^{1}$

GROWING STOCK-BILLION CUBIC FEET

\begin{tabular}{|c|c|c|c|c|c|c|c|c|c|}
\hline \multirow{2}{*}{ Section } & \multicolumn{3}{|c|}{ All species } & \multicolumn{3}{|c|}{ Softwoods } & \multicolumn{3}{|c|}{ Hardwoods } \\
\hline & 1952 & 1962 & 1970 & 1952 & 1962 & 1970 & 1952 & 1962 & 1970 \\
\hline $\begin{array}{l}\text { North } \\
\text { South } \\
\text { Rocky Mountains } \\
\text { Pacific Coast }\end{array}$ & $\begin{array}{r}2.1 \\
5.7 \\
.5 \\
3.5\end{array}$ & $\begin{array}{r}2.1 \\
5.4 \\
.7 \\
3.6\end{array}$ & $\begin{array}{r}2.4 \\
6.5 \\
.9 \\
4.2\end{array}$ & $\begin{array}{r}0.6 \\
3.1 \\
.5 \\
3.5\end{array}$ & $\begin{array}{l}0.6 \\
2.8 \\
.7 \\
3.5\end{array}$ & $\begin{array}{r}0.6 \\
4.0 \\
.9 \\
4.1\end{array}$ & $\begin{array}{l}1.5 \\
2.6 \\
(2) \\
(2)\end{array}$ & $\begin{array}{r}1.5 \\
2.6 \\
(2) \\
.1\end{array}$ & $\begin{array}{r}1.8 \\
2.5 \\
(2) \quad .1 \\
\end{array}$ \\
\hline Total & 11. 8 & 11.8 & 14. 0 & 7. 8 & 7.6 & 9. 6 & 4. 1 & 4. 2 & 4.4 \\
\hline
\end{tabular}

SAWTIMBER-BILLION BOARD FEET

\begin{tabular}{|c|c|c|c|c|c|c|c|c|c|}
\hline $\begin{array}{l}\text { North } \\
\text { South } \\
\text { Rocky Mountains } \\
\text { Pacific Coast }-\ldots\end{array}$ & $\begin{array}{r}6.7 \\
20.2 \\
3.2 \\
22.4\end{array}$ & $\begin{array}{r}6.5 \\
17.2 \\
4.3 \\
22.3\end{array}$ & $\begin{array}{r}9.0 \\
22.8 \\
5.4 \\
25.6\end{array}$ & $\begin{array}{r}1.9 \\
11.9 \\
3.2 \\
22.3\end{array}$ & $\begin{array}{r}1.5 \\
9.8 \\
4.3 \\
22.1\end{array}$ & $\begin{array}{r}2.1 \\
15.0 \\
5.4 \\
25.2\end{array}$ & $\begin{array}{r}4.8 \\
8.3 \\
\left({ }^{2}\right) \\
.1\end{array}$ & $\begin{array}{r}5.0 \\
7.3 \\
\left({ }^{2}\right) \\
\quad .2\end{array}$ & $\begin{array}{r}6.8 \\
7.8 \\
\left({ }^{2}\right) \\
.4\end{array}$ \\
\hline Total_. & 52.5 & 50.3 & 62.8 & 39.2 & 37. 7 & 47.7 & 13.3 & 12. 6 & 15.0 \\
\hline
\end{tabular}

1 Data may not add to totals because of truncating.

2 Less than 0.1 billion.

Note: Data for 1952 and 1962 differ from data published

amounted to 11.1 billion cubic feet of roundwood, including 54.7 billion board feet of sawtimber (table 13).

In addition to roundwood harvests from growing stock, significant quantities of roundwood-about 1 billion cubic feet in 1970-were produced from rough and rotten trees, dead trees, and other nongrowing stock sources such as trees growing on low site forest lands and in fence rows and shelterbelts.

Total harvests of roundwood timber products from all sources thus amounted to an estimated 1970 "trend level" of output of 12.2 billion cubic feet. Harvests of sawtimber amounted to 54.7 billion board feet, and all sawtimber size material including logs from nongrowing stock sources

Timber removals, 1970

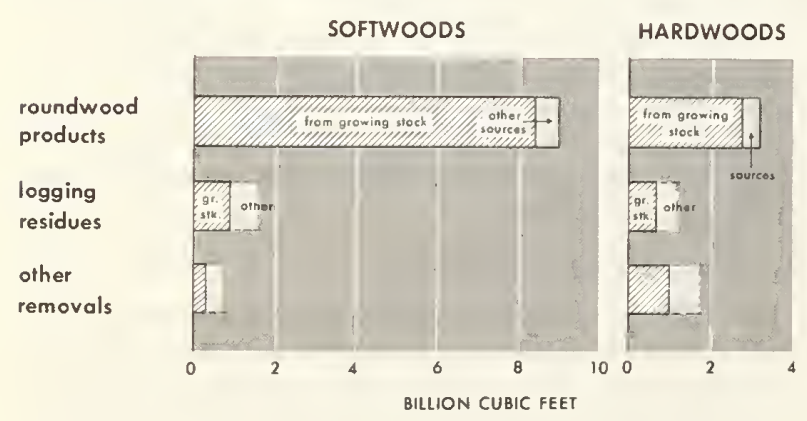

Figure 9 in earlier reports because of adjustments based on newer information from remeasured Forest Survey plots. Data for all years are "trend level" estimates.

amounted to an estimated 59 billion board feet (including 46.9 billion board feet of softwoods and 12.3 billion board feet of hardwoods).

Saw-log harvests.- Saw logs were the most important single product produced from U.S. forests in 1970 , with output amounting to 6.2 billion cubic feet (table 13). This harvest represented about 36.2 billion board feet of sawtimber plus about 3.0 billion board feet from other roundwood sources.

Western forests supplied more than half of the total saw logs produced in 1970, and more than one-third of all roundwood products (table 14). Although the West has maintained this relatively high proportion of total output for more than two decades, production on the Pacific Coast has been increasingly supplemented by production in the Rocky Mountain States.

All but 3 percent of the hardwood saw logs harvested in 1970 came from the eastern States, with the cut about equally divided between the North and South. Oaks made up a sizable part of the saw-log harvest in the East. In the South, yellow-poplar and gum were also important components of the timber harvested. In the North, maple, cottonwood, aspen, elm, and birch were the principal species cut. Production of alder for the furniture industry has also become of importance in the Pacific Northwest.

Saw-log production in the United States in 1970 was at about the same level as reported in 1952 , but materially higher than in 1962 (fig. 10). Recent 
increases in saw-log production have come about partly because of rising log exports. More small logs also are being used for a combination of lumber and pulp chips.

Veneer log harcests. - Veneer logs made up about 9 percent of the total roundwood harrested in 1970. Production has risen rapidly in recent decades as a result of rising use of softwood plywood. Harrests of domestic hardwood logs for plywood and reneer, on the other hand, have declined in the face of major increases in imports of hardwood plywood and veneer.

In the early years of softwood plywood manufacture, large high-quality logs were required but by 1970 a high proportion of the production of softwood plywood was in lower quality sheathing grades. MIoreorer, with new equipment such as high-speed lathes with retractable chucks sinall logs can now be profitably processed.

During the 1960's a spectacular expansion of the softwood plywood inclustry occurred in the South, and by 1972 this region supplied roughly 30 percent of the U.S. output of softwood plywood. Hardwood veneer logs also have come primarily from the South.

Pulpwood harvests.-Production of round pulpwood rose from 1.8 billion cubic feet in 1952 to 3.8 billion cubic feet in 1970 (fig. 10). In this latter year an additional 1.8 billion cubic feet of wood used in pulping or exported as pulp chips was obtained as byproducts from lumber and veneer manufacture in such forms as slabs, edgings, and veneer cores (table 13).

The South led the Nation in round pulpwood production in 1970, with more than two-thirds of the total harvest (table 14). The strength and rersatility of woodpulp from southern pine, plus historic advantages of low production costs and ready access to eastern and foreign markets have helped increase the South's dominance of the U.S. pulp and paper industry.

Southern pines and other softwoods made up 72 percent of the round pulpwood harvest in 1970 . Proportions of hardwoods in pulpwood harvests have risen steadily; however, from 15 percent in 1952 to 28 percent in 1970 . Equally significant has been a shift away from almost total dependence on soft-textured hardwood species such as aspen and gum, to the more plentiful oaks and other species such as hard maple, beech, hickory, and paper birch. These hard hardwoods comprised about one-third of the hardwoods cut for pulp in 1970.

Most of the round pulpwood produced has come from poletimber sized trees and upper stems of sawtimber trees. However, a substantial proportion-roughly one-third of the total cubic volume of roundwood used in 1970-or 9.5 billion board feet-came from sawtimber.
Trends in U.S. roundwood harvests 1950-72

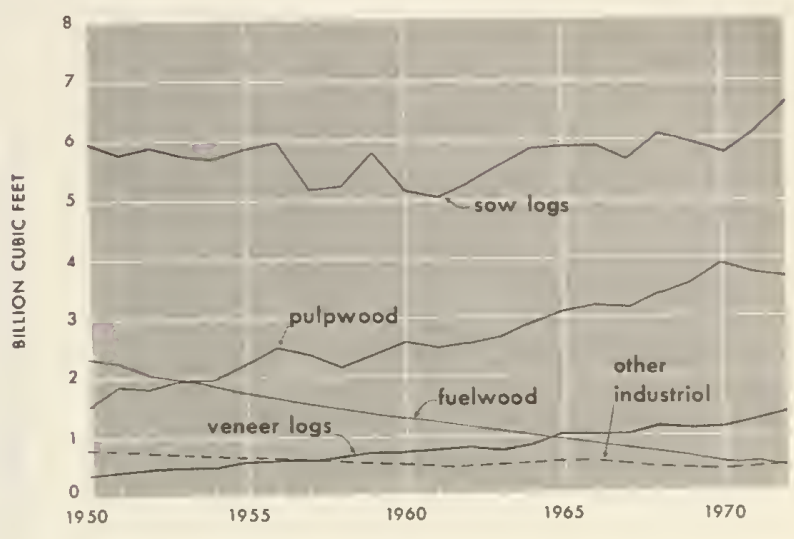

Figure 10

Miscellaneous products harvests.-Production of utility poles, fence posts, mine timbers, piling, cooperage, and other miscellaneous industrial products totaled an estimated 0.4 billion cubic feet of roundwood in 1970. This was somewhat below estimated harvests of these products in 1962, and about 40 percent below output in 1952 . The largest drop since 1952 has been in posts, mine timbers, and cooperage logs. An additional 0.2 billion cubic feet of plant byproducts also was used in the manufacture of charcoal and other minor products.

Harvests of round fuelwood in 1970 were estimated at 0.5 billion cubic feet. An additional 0.7 billion cubic feet of plant byproducts-sawdust, slabs, edgings, etc.-also were used for fuel. Nearly all of the round fuelwood was used for domestic heating and cooking, and nearly all of the plant byproducts for heat and power in wood processing plants. Fuelwood harrests hare dropped rapidly in recent decales as a result of the substitution of oil, gas, coal, and electricity in home cooking, heating, and industrial uses.

\section{Logging Residues}

Residues of trees left behind after logging operations constitute a fairly sizable part of removals of growing stock in 1970 -some 10 percent of all softwood removals and 15 percent of all hardwood removals. These residues include material from growing stock trees such as broken sections, upper stems, and logs missed in yarding.

Volumes of logging residues from growing stock in 1970 totalerl 1.6 billion cubic feet, or approximately 20 million cords, of solid wood fiber (table 15). About 58 percent of this volume was softwood, and 42 percent hardwood. More than half of the softwood residues were on recent logging operations on the Pacific Coast, and about onefourth in the South.

In addition to these residues from growing 


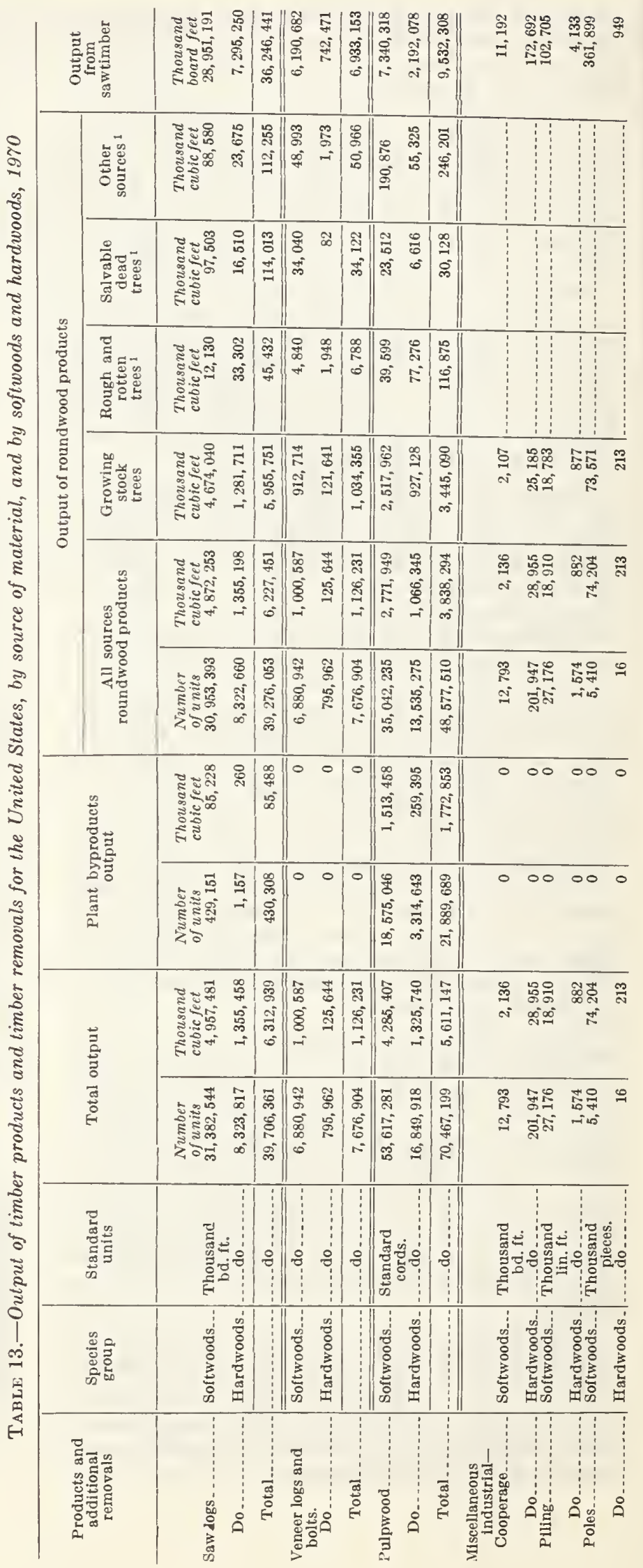




\begin{tabular}{|c|c|c|c|c|c|c|c|c|c|c|}
\hline 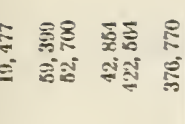 & 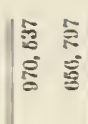 & 俤 & 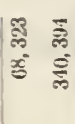 & 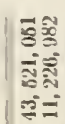 & 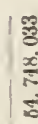 & 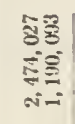 & 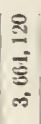 & 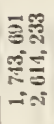 & (5) & 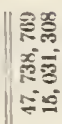 \\
\hline & 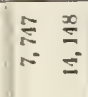 & 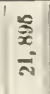 & 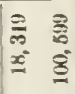 & 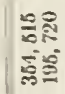 & 羿 & & & & & \\
\hline & 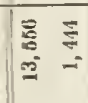 & $\begin{array}{l}\text { 옹 } \\
\text { s. } \\
\text { - }\end{array}$ & 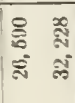 & 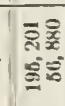 & 天气㐅े & & & & & \\
\hline & 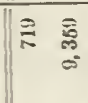 & $\left|\begin{array}{l}x \\
5 \\
5 \\
0 \\
0\end{array}\right|$ & $\stackrel{\bar{x}}{=}$ & 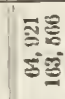 & $\frac{\infty}{x}$ & & & & & \\
\hline
\end{tabular}

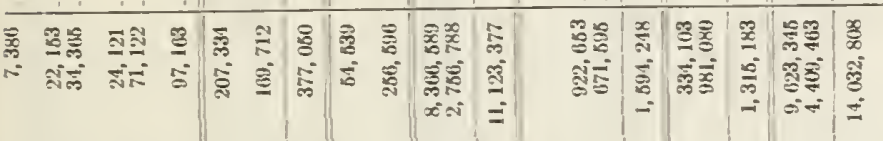

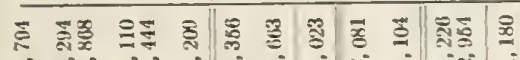

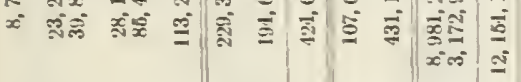

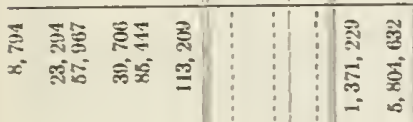

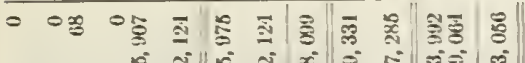

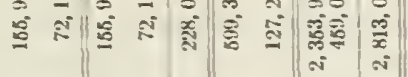

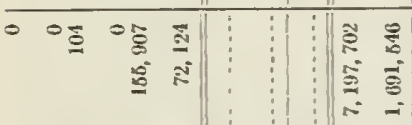

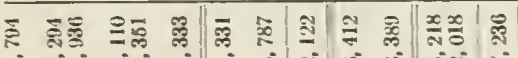

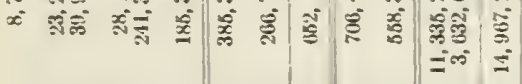

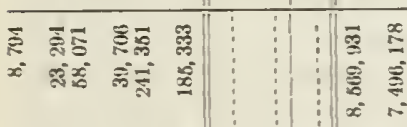

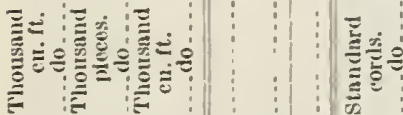

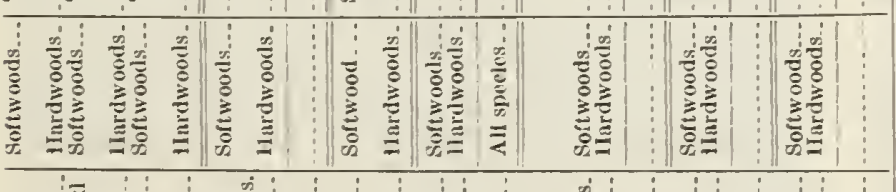

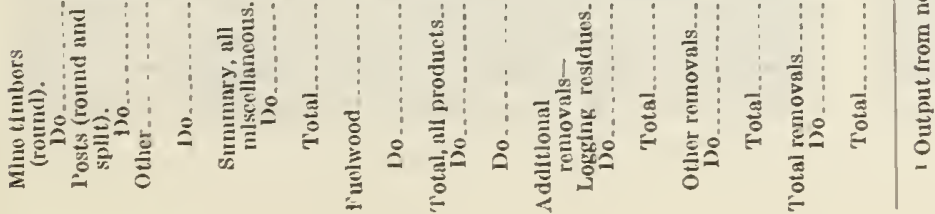


TABLE 14.-Roundwood harvests, by product and section, 1970

[Million cubic feet]

\begin{tabular}{|c|c|c|c|c|c|}
\hline Species group and product & Total & North & South & $\begin{array}{c}\text { Rocky } \\
\text { Mountain }\end{array}$ & $\begin{array}{l}\text { Pacific } \\
\text { Coast }\end{array}$ \\
\hline $\begin{array}{l}\text { Softwoods: } \\
\text { Saw logs } \\
\text { Veneer logs } \\
\text { Pulpwood_. } \\
\text { Miscellaneous industrial } \\
\text { Fuelwood }-\ldots\end{array}$ & $\begin{array}{r}4,872 \\
1,001 \\
2,772 \\
229 \\
107\end{array}$ & $\begin{array}{r}198 \\
2 \\
350 \\
26 \\
3\end{array}$ & $\begin{array}{r}1,330 \\
257 \\
1,992 \\
107 \\
59\end{array}$ & $\begin{array}{r}710 \\
73 \\
29 \\
21 \\
20\end{array}$ & $\begin{array}{r}2,634 \\
668 \\
401 \\
76 \\
25\end{array}$ \\
\hline Total $\ldots$ & 8,981 & 579 & 3,745 & 853 & 3,805 \\
\hline $\begin{array}{l}\text { Hardwoods: } \\
\text { Saw logs } \\
\text { Veneer logs } \\
\text { Pulpwood.-.. } \\
\text { Miscellaneous industrial } \\
\text { Fuelwood }\end{array}$ & $\begin{array}{r}1,355 \\
126 \\
1,066 \\
195 \\
431\end{array}$ & $\begin{array}{r}670 \\
31 \\
436 \\
125 \\
148\end{array}$ & $\begin{array}{r}642 \\
93 \\
597 \\
69 \\
267\end{array}$ & $\begin{array}{r}1 \\
\text { neg. } \\
\text { neg. } \\
1 \\
8\end{array}$ & $\begin{array}{r}42 \\
2 \\
33 \\
\text { neg. } \\
8\end{array}$ \\
\hline Total_._.... & 3,173 & 1,410 & 1,668 & 10 & 85 \\
\hline 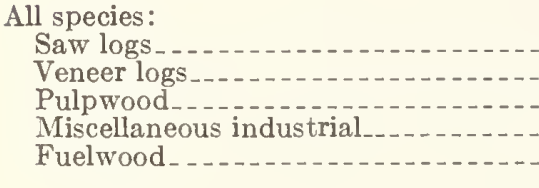 & $\begin{array}{r}6,227 \\
1,127 \\
3,838 \\
424 \\
538\end{array}$ & $\begin{array}{r}868 \\
33 \\
786 \\
151 \\
151\end{array}$ & $\begin{array}{r}1,972 \\
350 \\
2,589 \\
176 \\
326\end{array}$ & $\begin{array}{r}711 \\
73 \\
29 \\
21 \\
28\end{array}$ & $\begin{array}{r}2,676 \\
670 \\
435 \\
76 \\
33\end{array}$ \\
\hline Total & 12,154 & 1,989 & 5,413 & 863 & 3,890 \\
\hline
\end{tabular}

Note: Data may not add to totals because of rounding.

stock, substantial volumes of rough and rotten trees, dead trees, limbs, and material under 4 inches in diameter are typically left on the ground after logging. Recent studies in oldgrowth stands on the Pacific Coast indicated that residues from such nongrowing stock sources above 4 inches in diameter approximately equaled residues from growing stock trees. In hardwood stands of the East, hardwood limbs and rough or rotten trees similarly account for substantial volumes of unutilized wood fiber.

Since 1952, estimated volumes of logging residues from growing stock as a percent of total removals have declined only moderately. Rapid growth of the pulp industry has led to closer utilization of the softwood timber cut, especially in the South. On the other hand, a major decline in use of fuelwood has greatly reduoed post-logging use of low-grade material. Also, increased use of mechanized harvesting systems may have tended to raise volumes of logging residues in some areas.

Logging residues in the East especially are widely scattered and occur in relatively small quantities. Many residues are remote from manufacturing plants. Since most logging residues are of a size and form to make cutting into solid wood products uneconomic, potential uses are primarily for pulp and particleboard.
Environmental impacts of logging residues have become an important public issue in some areas, and public concern may supplement economic pressures to reduce residues. Recent action taken on National Forests, for example, to improve timber utilization includes modification of timber sale contracts to provide greater incentives for removal of low-value material.

\section{Other Removals}

Other removals largely include timber removed from growing stock inventories by land clearing for nontimber uses, or reservation of forests for parks, wilderness areas, or other purposes. These amounted to an estimated 1.3 billion cubic feet in 1970 - or 9 percent of all removals (table 15). These are trend figures designed to show an average situation for recent years.

Some portion of the timber on cleared areas is often utilized and such material is shown as part of roundwood production. However, in most land clearing for home building or agricultural use, for example, timber is typically piled and burned.

Most of the other removals in 1970 consisted of hardwoods, main y removed in land clearing operations in the South and in other land-use changes in the North. A major part of other removals for softwoods also occurred in the South. In the West most of the loss of timber 
TABLE 15.-Timber remorals from growing stock and sawtimber, by source and section, $1970^{1}$ GROWING STOCK-BILLION CUBIC FEET

\begin{tabular}{|c|c|c|c|c|c|c|c|c|c|}
\hline \multirow{2}{*}{ Section } & \multicolumn{3}{|c|}{ All species } & \multicolumn{3}{|c|}{ Soft roods } & \multicolumn{3}{|c|}{ Hardwoods } \\
\hline & $\begin{array}{l}\text { Round- } \\
\text { wood } \\
\text { products }\end{array}$ & $\begin{array}{l}\text { Logging } \\
\text { residue }\end{array}$ & $\begin{array}{l}\text { Other } \\
\text { removals }\end{array}$ & $\begin{array}{l}\text { Round- } \\
\text { wood } \\
\text { products }\end{array}$ & $\begin{array}{l}\text { Logging } \\
\text { residue }\end{array}$ & $\begin{array}{l}\text { Other } \\
\text { removals }\end{array}$ & $\begin{array}{l}\text { Round- } \\
\text { wood } \\
\text { products }\end{array}$ & $\begin{array}{l}\text { Logging } \\
\text { residue }\end{array}$ & $\begin{array}{l}\text { Other } \\
\text { removals }\end{array}$ \\
\hline \multirow{2}{*}{$\begin{array}{l}\text { North } \\
\text { South } \\
\text { Rocky IIountains. } \\
\text { Pacific Coast } \\
\text { Total United } \\
\text { States........ }\end{array}$} & $\begin{array}{r}1.7 \\
5.0 \\
.8 \\
3.5\end{array}$ & $\begin{array}{r}0.3 \\
.7 \\
.1 \\
.5\end{array}$ & $\begin{array}{r}0.4 \\
.8 \\
\left({ }^{2}\right) \\
.1\end{array}$ & $\begin{array}{r}0.5 \\
3.6 \\
.8 \\
3.5\end{array}$ & $\begin{array}{r}0.1 \\
.3 \\
.1 \\
.5\end{array}$ & $\begin{array}{r}0.1 \\
.2 \\
\left({ }^{2}\right) \\
.1\end{array}$ & $\begin{array}{r}\begin{array}{r}1.2 \\
1.4 \\
(2) \\
.1\end{array}\end{array}$ & $\begin{array}{l}0.2 \\
\left(^{2}\right) \\
\left({ }^{2}\right)\end{array}$ & $\begin{array}{rr} & 0.3 \\
& .6 \\
\left({ }^{2}\right) & \\
(2) & \end{array}$ \\
\hline & 11. 1 & 1. 6 & 1. 3 & 8.4 & .9 & .3 & 2. 8 & 7 & 1. 0 \\
\hline
\end{tabular}

SAWTIMBER-BILLION BOARD FEET

\begin{tabular}{|c|c|c|c|c|c|c|c|c|c|}
\hline $\begin{array}{l}\text { North } \\
\text { South } \\
\text { Rocky Mountains } \\
\text { Pacific Coast }\end{array}$ & $\begin{array}{r}7.4 \\
19.3 \\
5.0 \\
.23 .1\end{array}$ & $\begin{array}{l}0.5 \\
1.3 \\
.3 \\
1.6\end{array}$ & $\begin{array}{r}1.1 \\
2.3 \\
.1 \\
.9\end{array}$ & $\begin{array}{r}\text { 1. } 9 \\
\text { 13. } 9 \\
4.9 \\
22.8\end{array}$ & $\begin{array}{r}0.1 \\
.6 \\
.3 \\
1.5\end{array}$ & $\begin{array}{r}0.2 \\
.6 \\
.1 \\
.9\end{array}$ & $\begin{array}{r}5.5 \\
5.4 \\
(2) \\
.3\end{array}$ & $\begin{array}{l}0.4 \\
\left({ }^{2}\right) \\
(2)\end{array}$ & $\begin{array}{l}0.9 \\
\text { (2) } \\
\text { (2) } \\
\text { (2) }\end{array}$ \\
\hline $\begin{array}{l}\text { Total United } \\
\text { States }\end{array}$ & 54.7 & 3. 7 & 4.4 & 43. 5 & 2.5 & 1. 7 & 11. 2 & 1. 2 & 2. 6 \\
\hline
\end{tabular}

1 Data may not add to totals because of truncating.

2 Less than 0.1 billion.

Note: Data for 1952 and 1962 differ from data published

in other removals was attributable to shifts of forest land to roads, wilderness areas, and other nontimber uses.

\section{NET GROWTH IN RELATION TO REMOVALS}

Comparisons of net annual growth and remorals provide one measure of the present or prospectire timber situation in the United States. In 1970, there were large differences in these relationships, both among species groups and among sections of the country.

\section{Softwood Growth-Removal Balances}

In the past two decades net annual growth of softwoods in the eastern sections of the United States has been consider ably higher than removals (table 16). Thus in 1970 net growth of eastern softroods exceeded remorals by 2.2 billion cubic feet, or 48 percent. Growth of softwood sawtimber in the East exceeded removals by 6.6 billion board feet, or 39 percent (table 17).

These generally favorable growth-remoral balances indicate that eastern forests can support larger softwood timber harvests. Howerer, large areas are still understocked and a growth surplus will be needed for some time if inventories are to be built up to more desirable levels. Also, some part of the growth is on land held primarily for recreation or other nontimber purposes, and thus may not be available for industrial use. in earlier reports because of adjustments based on newer information from remeasured Forest Survey plots. Data for all years are "trend level" estimates.

In the West, net growth of softwood growing stock in 1970 was about 1.1 billion cubic feet, or 22 percent, less than removals (fig. 11). Net growth of softwood sawtimber was some 14 billion board feet, or 46 percent, less than removals.

These apparent imbalances in the West do not in themselves represent a serious problem, for a sizable part of the western timber harvest is drawn from old-growth stands where allowable harrests can exceed net growth for some time to come. The trend in net growth in the West is rising, but with 1970 levels of management prospective increases in net growth would not be sufficient to sustain 1970 levels of timber harrest indefinitely.

\section{Hardwood Growth-Removal Balances}

Net growth of eastern hardwoods in 1970 substantially exceeded removals, particularly in the North (tables 16 and 17). For the entire East, net growth of hardwoods was 3.1 billion cubic feet, or 72 percent, greater than removals.

For hardwood sawtimber, net growths was 3.4 billion board feet, or 23 percent, greater than removals. Although growth-removal balances for hardwoods were generally favorable, in areas where extensive clearing of bottomlands has occurred, as in the West Gulf region of the South, net growth of hardwoods in 1970 was less than remorals (Append. I, tables 25 and 26). 
TABLE 16.- Net annual growth and removals of growing stock, by species group and section ${ }^{1}$ [Billion cubic feet]

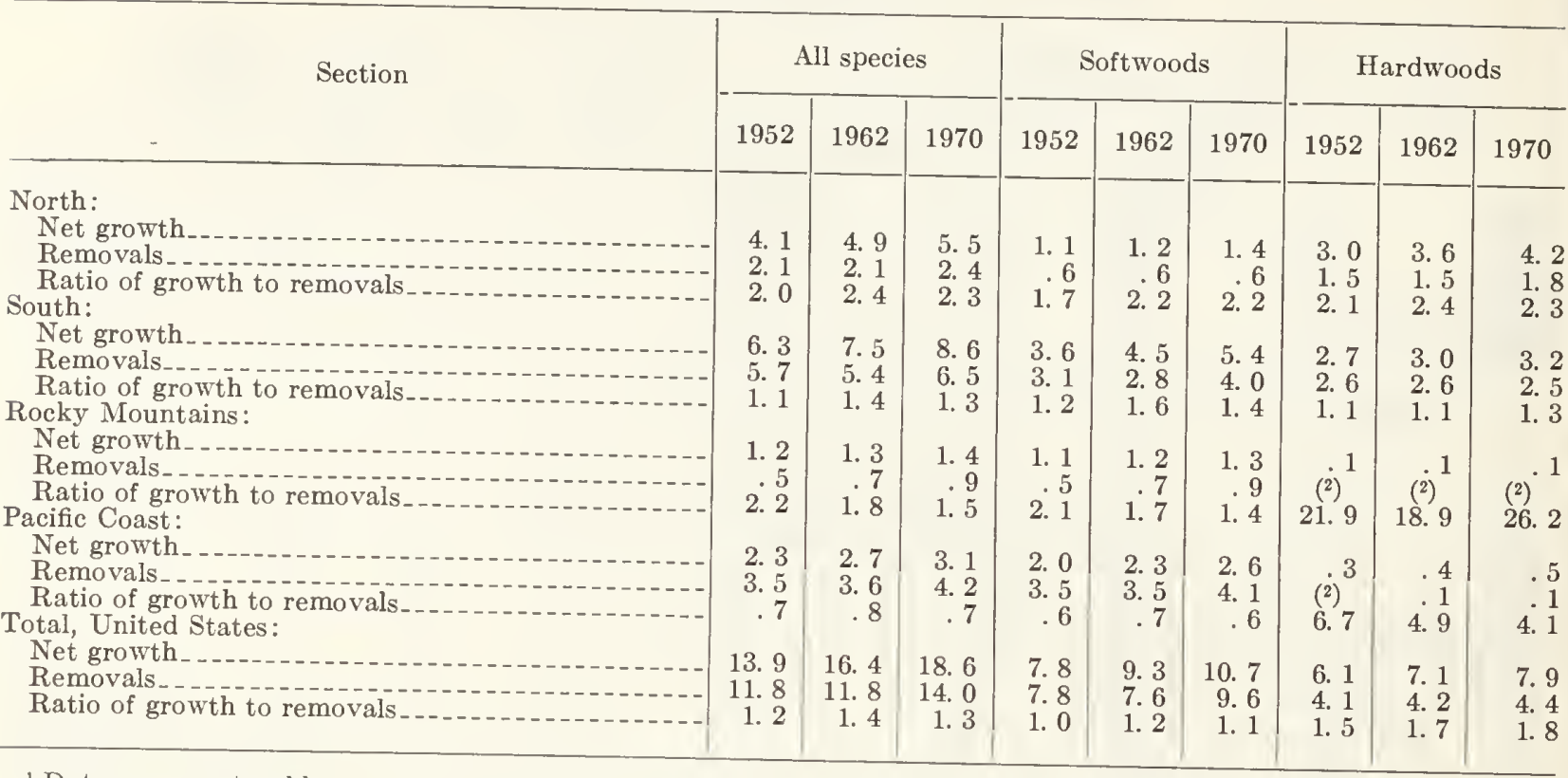

1 Data may not add to totals because of rounding.
2 Less than 0.1 billion.

Note: Data for 1952 and 1962 differ from data published in earlier reports because of adjustments based on newer information from remeasured Forest Survey plots. Data for all years are "trend level" estimates.

TABLE 17. - Net annual growth and removals of sawtimber, by species group and section ${ }^{1}$ [Billion board feet]

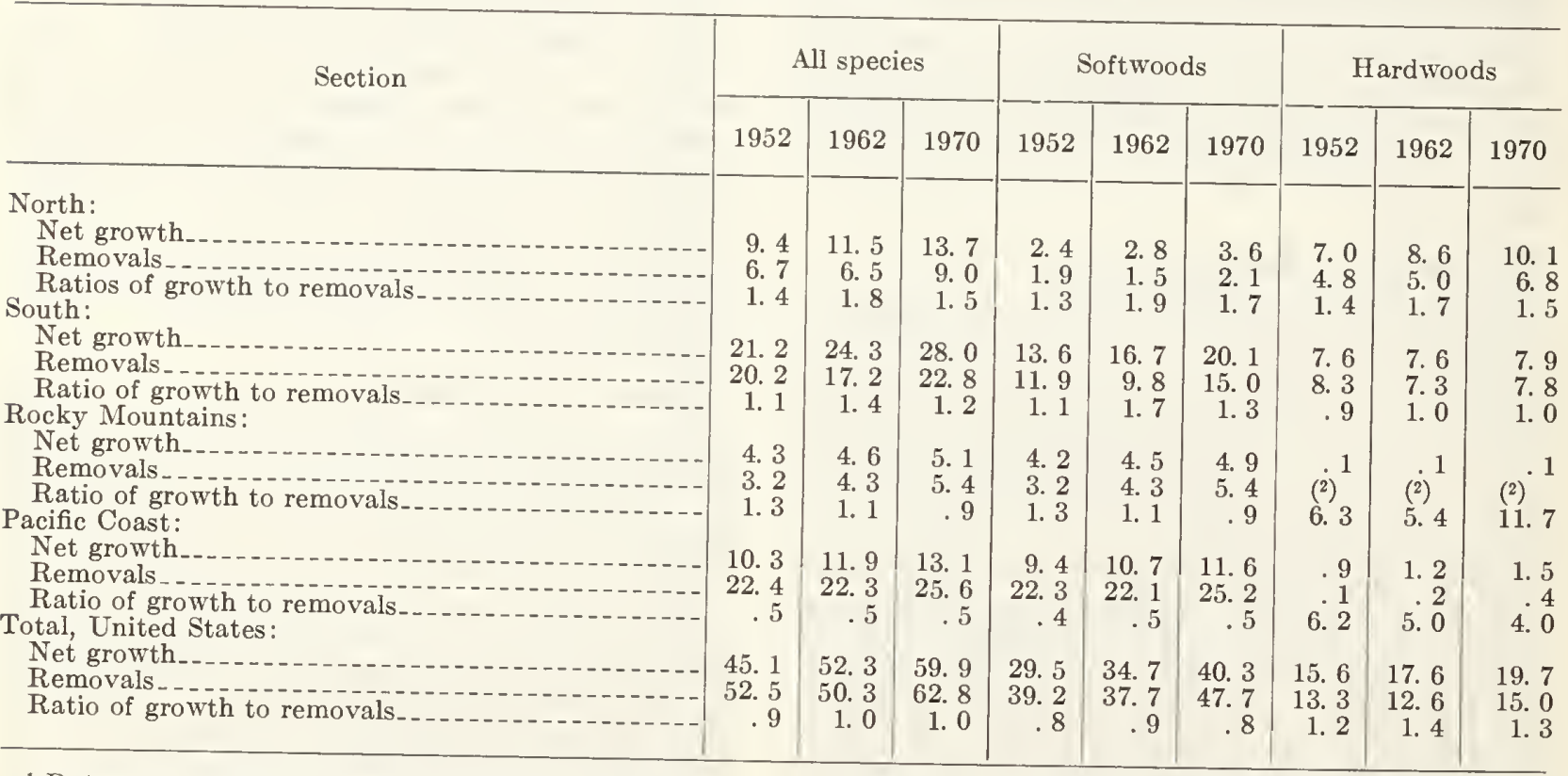

Data may not add to totals because of rounding.
2 Less than 0.1 billion.

Note: Data for 1952 and 1962 differ from data published in earlier reports because of adjustments based on newer information from remeasured Forest Survey plots. Data for all years are "trend level" estimates. 
Timber growth and removals, 1970

growth $\square$ removols

GROWING STOCK

eastern softwoods

eostern hardwoods

western soltwoods

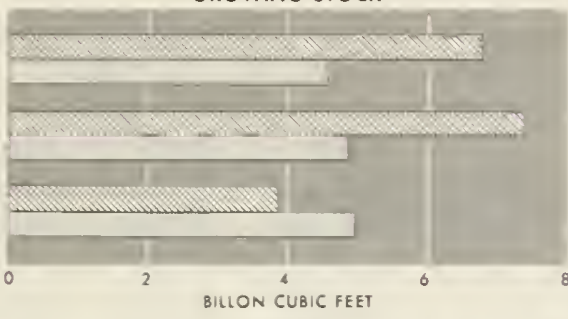

SAWTIMBER

eostern softwoods

eastern hordwoods

western softwoods

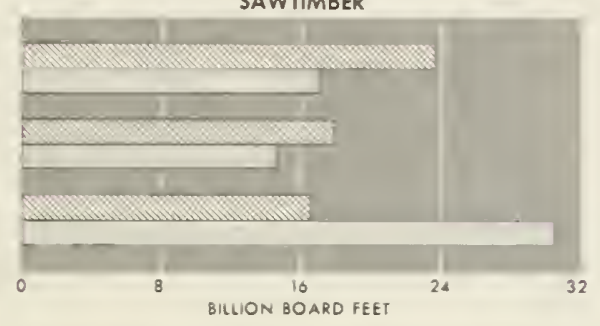

Figure 11

Utilization of hardwoods is highly oriented to preferred species such as walnut, sweetgum, and yellow birch (Append. I, table 24). Relatively heary cutting of large diameter trees has also led to a decline in quality of hardwood inventories, and a buildup of smaller diameter trees and nonpreferred species of hardwoods.

On the Pacific Coast hardwoods such as alder have occupied many areas following cutting of the softwood stands, and hardwood growth has been far above removals.

Net annual growth per acre in 1970 ranged from about 3 times remorals on National Forests in the East to 1.2 times on eastern farm and miscellaneous private ownerships (fig. 12). In the West, on the other hand, removals per acre ranged from 3 times growth on forest industry lands to a small excess of growth on farm and miscellaneous private holdings.

Timber removals per acre were relatively high on forest industry lands, as a result of high sites, heary stands of timber, and relatively high levels of forestry investments. Nationwide, removals of sawtimber on industry lands averaged about 5 percent of the inventory of standing timber, compared with somewhat more than 1 percent on public ownerships.

\section{TIMBER INVENTORIES}

During the next few decades most timber harvests must come from trees now standing on commercial timberlands. The volume, species composition, location, quality, and ownership of this standing timber is thus of major importance
Sawtimber growth and removals per acre, by ownerships, 1970
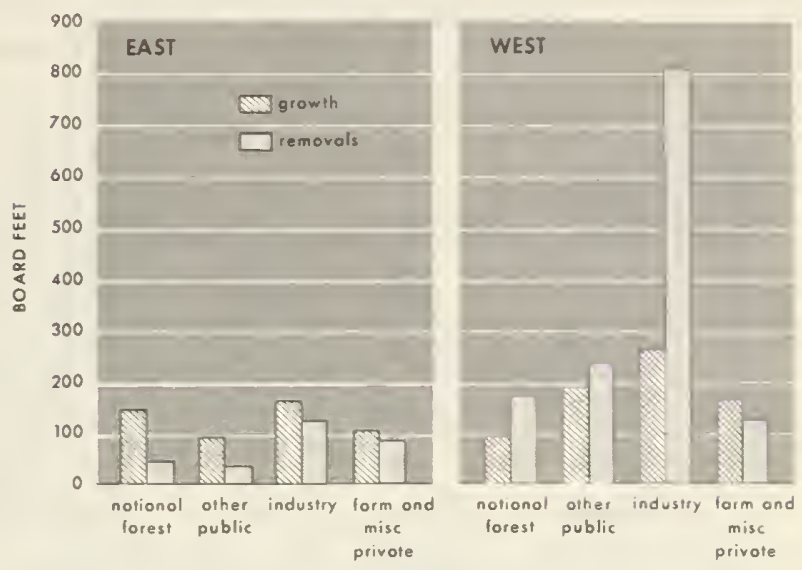

Figure 12

in appraising the present and prospective timber situation.

\section{Total Timber Volumes}

Commercial timberlands of the United States supported some 715 billion cubic feet of sound wood in 1970 (table 18 and Append. I, table 10). About 64 percent of this total volume was in sawtimber trees (trees large enough to contain at least one log suitable for the manufacture of lumber) (fig. 13). Another 27 percent was in poletimber trees (trees from 5 inches in diameter at breast height to sawtimber size and now or prospectively suitable for industrial roundwood). The remaining 9 percent of all sound wood rolumes was in rough and rotten trees and salvable dead trees. Some of this latter material is suitable for lumber and veneer but most of it is usable only for pulp and other products where log quality requirements are more flexible.

\section{Soltwood Inventories}

Softroods predominate in the Nation's timber inventory, accounting for about 64 percent of the total volume of all classes of timber, and 75 percent of the total sawtimber volume. These inventories of softwoods are mostly on the Pacific Coast (table 19). This distribution, in contrast to that for commercial timberland, which is mostly in the East, reflects the concentration of timber in western old-growth stands with relatively high volumes per acre.

About 27 percent of the Nation's softwood sawtimber inventory in 1970 was Douglas-fir-the Nation's most important sof twood species (table 20). Three-fifths of this Douglas-fir inventory was located in western Washington and western Oregon. Western hemlock, true firs, ponderosa 
TABLE 18.-Timber inventories on commercial timberlands, by class of material and species group, 1970

\begin{tabular}{|c|c|c|c|c|c|c|}
\hline \multirow{2}{*}{ Class of timber } & \multicolumn{2}{|c|}{ All species } & \multicolumn{3}{|c|}{ Softwoods } & \multirow{2}{*}{$\begin{array}{l}\text { Hard- } \\
\text { woods }\end{array}$} \\
\hline & Volume & $\begin{array}{l}\text { Pro- } \\
\text { portion }\end{array}$ & Total & Eastern & Western & \\
\hline $\begin{array}{l}\text { Sawtimber trees: } \\
\text { Saw-log portions } \\
\text { Upper stems.-- }\end{array}$ & $\begin{array}{c}\text { Million } \\
\text { cu. ft. } \\
1410,774 \\
44,602\end{array}$ & $\begin{array}{r}\text { Percent } \\
57.5 \\
6.2\end{array}$ & $\begin{array}{l}\text { Million } \\
\text { cu. ft. } \\
317,280 \\
23,753\end{array}$ & $\begin{array}{l}\text { Million } \\
\text { cu.ft. } \\
66,219 \\
10,039\end{array}$ & $\begin{array}{l}\text { Million } \\
\text { cu. ft. } \\
251,062 \\
13,714\end{array}$ & $\begin{array}{l}\text { Million } \\
\text { cu.ft. } \\
93,493 \\
20,849\end{array}$ \\
\hline $\begin{array}{l}\text { Total } \\
\text { Poletimber trees }\end{array}$ & $\begin{array}{l}455,376 \\
193,504\end{array}$ & $\begin{array}{l}63.7 \\
27.1\end{array}$ & $\begin{array}{r}341,033 \\
90,840\end{array}$ & $\begin{array}{l}76,258 \\
41,261\end{array}$ & $\begin{array}{r}264,776 \\
49,579\end{array}$ & $\begin{array}{l}114,342 \\
102,664\end{array}$ \\
\hline $\begin{array}{l}\text { Total growing stock } \\
\text { Salvable dead trees } \\
\text { Sound cull trees } \\
\text { Rotten cull trees. }\end{array}$ & $\begin{array}{r}648,879 \\
12,035 \\
33,921 \\
19,711\end{array}$ & $\begin{array}{r}90.8 \\
1.7 \\
4.7 \\
2.8\end{array}$ & $\begin{array}{r}431,874 \\
11,361 \\
6,910 \\
5,022\end{array}$ & $\begin{array}{r}117,519 \\
173 \\
3,773 \\
1,281\end{array}$ & $\begin{array}{r}314,355 \\
11,189 \\
3,138 \\
3,742\end{array}$ & $\begin{array}{r}217,005 \\
673 \\
27,010 \\
14,689\end{array}$ \\
\hline All classes_. - & ${ }^{2} 714,546$ & 100.0 & 455,168 & 122,746 & 332,423 & 259,378 \\
\hline
\end{tabular}

1 This portion is also expressed in board feet of sawtimber, i.e., $2,420,767$ miliion board feet, or an average of 5.9 board feet per cubic foot of the saw-log portion.

2 Additional timber volumes not inventoried by the Forest Survey, but providing some timber products, include

Timber inventories, 1970

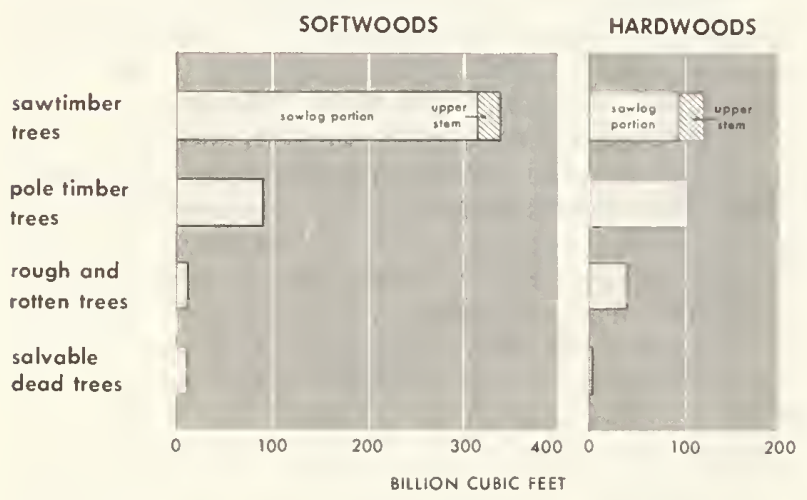

Figure 13

pine, and other western softwoods comprised another 54 percent of U.S. softwood inventories.

These western softwoods provided about threequarters of the timber used in the manufacture of softwood plywood in 1970, and two-thirds of the logs used for softwood lumber. This was of course related to the concentration of softwood inventories in the West and the predominance of relatively large-size high-quality trees (table 21). As old-growth stands are harvested, the geographical distribution of timber inventories and available harvests will of necessity conform more and more closely to areas of commercial timberlands.

Eastern softwoods, including mainly southern pines, made up 18 percent of the Nation's growing stock in 1970, and about 15 percent of softwood sawtimber volumes. wood in limbs and stumps, trees on noncommercial forest lands, and trees on other areas such as parks and fence rows.

Note: Data may not add to totals because of rounding.

Most southern pine timber in 1970 was relatively small, with four-fifths of the total inventory in trees less than 15 inches in diameter. Nonetheless, the South was the source of about a quarter of the softwood lumber and plywood, and three-fourths of the softwood pulpwood produced in 1970 . Inventories of fir, white and red pine, hemlock, cypress, and other eastern softwoods also were concentrated in the smaller sizes.

\section{Hardwood Inventories}

Hardwoods made up about 36 percent of all classes of standing timber in 1970, and about 25 percent of all sawtimber (table 18). More than half of all hardwood growing stock was in the North (table 19).

More than a third of hardwood sawtimber volumes in 1970 was in select species-that is, select white and red oaks, ${ }^{3}$ hard maple, yellow birch, sweetgum, yellow-poplar, ash, black walnut, and black cherry (table 20). These are the species preferred for cabinet work, paneling, furniture, and other uses where quality and/or surface appearance are important considerations.

Nearly two-thirds of the hardwood sawtimber inventory in 1970 was composed of upland oaks, hickory, beech, cottonwood, and various other species that have more limited potentials for highquality hardwood products. However, most of this timber is suitable for the manufacture of products

${ }^{3}$ Select white oaks include Quercus alba, Q. michauxii, Q. muehlenbergii, Q. durandii, Q. bicolor, and Q. macrocarpa. Select red oaks include $Q$. rubra, Q. falcata var. pagodaefolia, and $Q$. shumardii. 
TABLE 19.-Growing stock and sawtimber inventories on commercial timberlands, by section and softwoods and hardwoods, 1970

GROWING STOCK

\begin{tabular}{|c|c|c|c|c|c|c|}
\hline \multirow{2}{*}{ Section } & \multicolumn{2}{|c|}{ All species } & \multicolumn{2}{|c|}{ Softwoods } & \multicolumn{2}{|c|}{ Hardwoods } \\
\hline & Volume & $\begin{array}{c}\text { Pro- } \\
\text { portion }\end{array}$ & Volume & $\begin{array}{c}\text { Pro- } \\
\text { portion }\end{array}$ & Volume & $\begin{array}{l}\text { Pro- } \\
\text { portion }\end{array}$ \\
\hline $\begin{array}{l}\text { North } \\
\text { South } \\
\text { Rocky Mountains } \\
\text { Pacific Coast }\end{array}$ & $\begin{array}{r}\text { Billion cu. ft. } \\
155.7 \\
159.5 \\
92.2 \\
241.5\end{array}$ & $\begin{array}{l}\text { Percent } \\
24.0 \\
24.6 \\
14.2 \\
37.2\end{array}$ & $\begin{array}{r}\text { Billion cu. ft. } \\
39.1 \\
78.4 \\
87.7 \\
226.6\end{array}$ & $\begin{array}{r}\text { Percent } \\
9.0 \\
18.2 \\
20.3 \\
52.5\end{array}$ & $\begin{array}{r}\text { Billion cu. ft. } \\
116.6 \\
81.1 \\
4.5 \\
14.8\end{array}$ & $\begin{array}{r}\text { Percent } \\
\text { 53. } 7 \\
37.4 \\
2.1 \\
6.8\end{array}$ \\
\hline Total $\ldots$ & 648. 9 & 100.0 & 431. 9 & 100.0 & 217.0 & 100. 0 \\
\hline
\end{tabular}

SAWTIMBER

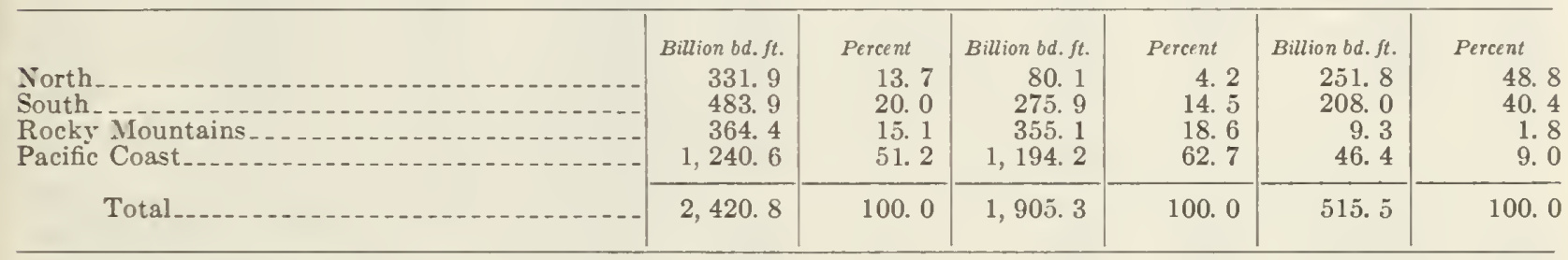

Note: Data may not add to totals because of rounding.

such as railroad ties, pallet lumber, and construction timber.

Only 12 percent of the hardwood growing stock volume in 1970 was in trees 19 inches and larger in diameter at breast height (table 21). This limited supply of larger timber further limits suitability of hardwood timber for products where quality is important.

About 40 percent of the total hardwood inventory was between 11 and 19 inches in diametertrees large enough for the manufacture of common grades of lumber and products such as ties and timbers. Trees 5 to 11 inches in diameter made up about half of the total hardwood inventory.

\section{Ownership of Timber Inventories}

The largest portion of the softwood timber inventory in 1970 was in National Forests, including some 46 percent of all softwood growing stock and 51 percent of all softwood sawtimber (table 22). Most of these timber volumes were in old-growth stands in the West, with a major part in areas still lacking access roads. Only 8 percent of all hardwood growing stock was in National Forests.

Farm and miscellaneous private ownerships contained the major part of the Nation's inventory of hardwoods-about 71 percent-and a substantial part of all sof twood inventories-about 26 percent. Nearly all of this timber is readily accessible from existing road systems and is relatively close to timber markets.
Forest industries in 1970 held about 17 percent of all softwood inventories, and a somewhat smaller proportion of hardwoods. Wood-using plants in the Fast thus must look to nonindustrial private ownerships for much of their timber supply, while many western firms must depend on National Forest and other public lands for much of their log requirements.

Public ownerships other than National Forests held roughly 10 percent of all timber inventories in 1970. These inventories were of particular importance in the Pacific Northwest and the Lake States.

\section{Trends in Timber Inventories}

Total inventories of softwoods in the United States increased about 1 percent between 1962 and 1970, while softwood sawtimber volumes dropped about 3 percent (table 23). Hardwood volumes increased by somewhat larger percentages for both sawtimber and total growing stock. These trends in inventories in part reflect significant success in efforts to protect and improve American forests.

Inventories rose substantially in the South and in the North for both softwood and hardwood volumes. Inventories decreased in the Pacific Coast and Rocky Mountain sections, as would be expected while old-growth stands are being harvested.

Inventories increased between 1952 and 1970 in all size classes except in the 30 -inch and larger 
TABLE 20.-Growing stock and sawtimber inventories on commercial timberlands, by species, 1970

\begin{tabular}{|c|c|c|c|c|}
\hline \multirow{2}{*}{ Species } & \multicolumn{2}{|c|}{ Growing stock } & \multicolumn{2}{|c|}{ Sawtimber } \\
\hline & Volume & Proportion & Volume & Proportion \\
\hline $\begin{array}{l}\text { Eastern softwoods: } \\
\text { Southern pines } \\
\text { Spruce and fir } \\
\text { White and red pines } \\
\text { Cypress } \\
\text { Other }{ }^{1}-\end{array}$ & $\begin{array}{r}\text { Million cu. ft. } \\
74,622 \\
17,322 \\
8,348 \\
5,034 \\
12,193\end{array}$ & $\begin{array}{r}\text { Percent } \\
11.5 \\
2.6 \\
1.3 \\
.8 \\
1.9\end{array}$ & $\begin{array}{r}\text { Million bd. ft. } \\
259,059 \\
23,486 \\
26,874 \\
19,111 \\
27,407\end{array}$ & $\begin{array}{r}\text { Percent } \begin{array}{r}\text { 10. } 7 \\
1.0 \\
\text { 1. } 1 \\
.8 \\
1.1\end{array}\end{array}$ \\
\hline Total $\ldots$ & 117,519 & 18. 1 & 355,937 & 14. 7 \\
\hline $\begin{array}{l}\text { Eastern hardwoods: } \\
\text { Select white and red oaks. } \\
\text { Other oaks, } \\
\text { Hickory } \\
\text { Hard maple } \\
\text { Ash, walnut, and black cherry } \\
\text { Sweetgum } \\
\text { Yellow-poplar } \\
\text { Yellow birch } \\
\text { Other }\end{array}$ & $\begin{array}{r}32,613 \\
38,796 \\
12,582 \\
11,732 \\
12,185 \\
10,527 \\
8,566 \\
3,249 \\
67,426\end{array}$ & $\begin{array}{l}\text { 5. } 0 \\
\text { 6. } 0 \\
\text { 2. } 0 \\
\text { 1. } 8 \\
\text { 1. } 9 \\
\text { 1. } 6 \\
\text { 1. } 3 \\
\text { 10. } 5 \\
\text { 10 }\end{array}$ & $\begin{array}{r}85,835 \\
99,069 \\
30,915 \\
25,758 \\
25,405 \\
26,318 \\
25,094 \\
7,323 \\
134,065\end{array}$ & $\begin{array}{l}\text { 3. } 5 \\
\text { 4. } 1 \\
\text { 1. } 3 \\
\text { 1. } 1 \\
\text { 1. } 1 \\
\text { 1. } 1 \\
\text { 1. } 0 \\
\text { 5. } \\
\text { 5. }\end{array}$ \\
\hline Total & 197,676 & 30.5 & 459,781 & 19. 0 \\
\hline Total eastern & 315,194 & 48. 6 & 815,718 & 33. 7 \\
\hline 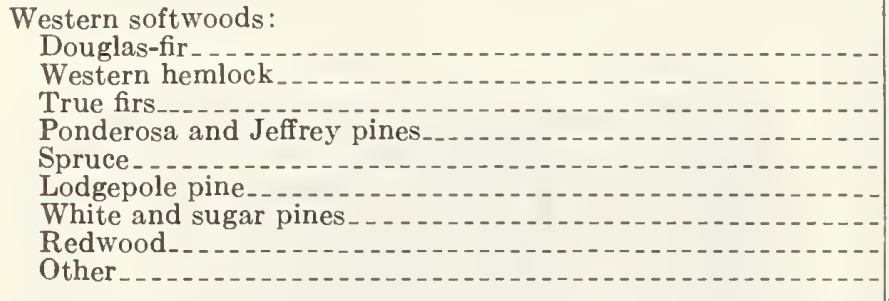 & $\begin{array}{r}96,861 \\
47,540 \\
45,326 \\
38,292 \\
26,296 \\
25,530 \\
8,337 \\
4,428 \\
21,745\end{array}$ & $\begin{array}{r}\text { 14. } 9 \\
\text { 7. } 3 \\
\text { 7. } 0 \\
\text { 5. } 9 \\
\text { 4. } 0 \\
\text { 3. } 9 \\
\text { 1. } 3 \\
\text { 3. } \\
\text { 3. }\end{array}$ & $\begin{array}{r}520,640 \\
251,012 \\
218,772 \\
189,897 \\
132,225 \\
65,273 \\
44,392 \\
23,627 \\
103,515\end{array}$ & $\begin{array}{r}21.5 \\
10.4 \\
9.0 \\
7.8 \\
5.5 \\
2.7 \\
1.8 \\
1.0 \\
4.3\end{array}$ \\
\hline $\begin{array}{r}\text { Total } \\
\text { Western hardwoods }\end{array}$ & $\begin{array}{r}314,355 \\
19,330\end{array}$ & $\begin{array}{r}\text { 48. } 4 \\
\text { 3. } 0\end{array}$ & $\begin{array}{r}1,549,352 \\
55,696\end{array}$ & $\begin{array}{r}\text { 64. } 0 \\
2.3\end{array}$ \\
\hline Total western & 333,685 & 51. 4 & $1,605,048$ & 66. 3 \\
\hline All species_. & 648,879 & 100. 0 & $2,420,767$ & 100.0 \\
\hline
\end{tabular}

${ }^{1}$ Includes 128 million cubic feet and 540 million board feet of ponderosa pine in eastern South Dakota and Nebraska.

classes of softwoods (fig. 14). Increases in stand volumes were especially large in the 5 - to 11 -inch diameters.

\section{PLANT RESIDUES}

Wood residues from primary processing at sawmills and other wood processing plants provide an important part of the fiber supply for the pulp industry and a significant potential for further expansion of wood-based industries.

\section{Trends in Utilization of Plant Byproducts}

In recent years the wood-using industries have made much progress in utilization of the roundwood delivered to sawmills, veneer mills, and other primary wood processing plants. In 1970, an estimated 2.8 bil]ion cubic feet of slabs, sawdust, veneer cores, and other similar material resulting from the manufacture of lumber and other wood products was used for pulp, particleboard, fuel, or other products (table 24). This represented about 74 percent of all such material produced.

Use of these plant byproducts by the pulp industry was of chief importance, almost 1.8 billion cubic feet (about 22 million cords) being used for pulp in 1970, including nearly 2 million cords of chip exports to Japan. Use of such material for pulping increased nearly 18-fold between 1952 and 1970 (fig. 15).

Volumes of plant byproducts used for other products such as particleboard, although small, also have increased substantially. Use of sawdust, slabs, etc. for industrial and domestic fuel, on the other hand, has declined sharply. 
TABLE 21.-Growing stock inventories, by species and diameter classes, 1970

[Million cubic feet]

\begin{tabular}{|c|c|c|c|c|c|c|c|}
\hline Species & $\begin{array}{c}\text { All } \\
\text { diameters }\end{array}$ & $\begin{array}{l}5.0 \text { to } \\
9.0 \\
\text { inches }\end{array}$ & $\begin{array}{l}9.0 \text { to } \\
11.0 \\
\text { inches }\end{array}$ & $\begin{array}{l}11.0 \text { to } \\
15.0 \\
\text { inches }\end{array}$ & $\begin{array}{l}15.0 \text { to } \\
19.0 \\
\text { inches }\end{array}$ & $\begin{array}{l}19.0 \text { to } \\
29.0 \\
\text { inches }\end{array}$ & $\begin{array}{c}29.0 \\
\text { inches } \\
\text { and larger }\end{array}$ \\
\hline $\begin{array}{l}\text { Eastern softwoods: } \\
\text { Southern pines } \\
\text { Spruce and fir } \\
\text { White and red pines } \\
\text { Cypress } \\
\text { Other }\end{array}$ & $\begin{array}{r}74,622 \\
17,322 \\
8,348 \\
5,034 \\
12,193\end{array}$ & $\begin{array}{r}20,988 \\
11,199 \\
2,394 \\
1,040 \\
5,640\end{array}$ & $\begin{array}{r}13,790 \\
2,962 \\
1,152 \\
718 \\
2,119\end{array}$ & $\begin{array}{r}23,154 \\
2,370 \\
2,192 \\
1,545 \\
2,582\end{array}$ & $\begin{array}{r}11,549 \\
637 \\
1,364 \\
914 \\
1,180\end{array}$ & $\begin{array}{r}5,006 \\
154 \\
1,133 \\
655 \\
625\end{array}$ & $\begin{array}{r}136 \\
114 \\
162 \\
46\end{array}$ \\
\hline Total___. & 117,519 & 41,261 & 20,741 & 31,843 & 15,644 & 7,573 & 458 \\
\hline $\begin{array}{l}\text { Eastern hardwoods: } \\
\text { Select white and red oaks } \\
\text { Other oaks } \\
\text { Hickory } \\
\text { Hard maple } \\
\text { Ash, walnut, and black cherry. } \\
\text { Yellow-poplar } \\
\text { Yellow birch } \\
\text { Other }\end{array}$ & $\begin{array}{r}32,613 \\
38,796 \\
12,582 \\
11,732 \\
12,185 \\
8,566 \\
3,249 \\
77,953\end{array}$ & $\begin{array}{r}8,358 \\
10,364 \\
3,699 \\
4,148 \\
4,033 \\
1,692 \\
1,038 \\
27,944\end{array}$ & $\begin{array}{r}5,148 \\
6,149 \\
2,143 \\
1,907 \\
2,201 \\
1,250 \\
538 \\
13,737\end{array}$ & $\begin{array}{r}9,232 \\
10,525 \\
3,548 \\
2,840 \\
3,353 \\
2,685 \\
835 \\
19,250\end{array}$ & $\begin{array}{r}5,490 \\
6,474 \\
1,914 \\
1,667 \\
1,683 \\
1,791 \\
476 \\
10,091\end{array}$ & $\begin{array}{l}3,888 \\
4,644 \\
1,176 \\
1,106 \\
861 \\
1,053 \\
332 \\
6,301\end{array}$ & $\begin{array}{r}498 \\
639 \\
103 \\
64 \\
54 \\
94 \\
30 \\
629\end{array}$ \\
\hline Total_.. & 197,676 & 61,276 & 33,073 & 52,267 & 29,587 & 19,362 & 2,111 \\
\hline 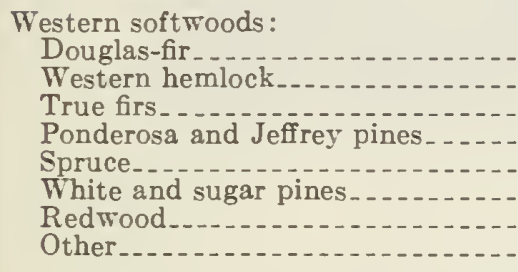 & $\begin{array}{r}96,861 \\
47,540 \\
45,326 \\
38,292 \\
26,296 \\
8,337 \\
4,428 \\
47,275\end{array}$ & $\begin{array}{r}8,160 \\
2,788 \\
5,865 \\
3,304 \\
2,422 \\
526 \\
96 \\
14,695\end{array}$ & $\begin{array}{r}5,544 \\
2,396 \\
3,536 \\
2,252 \\
1,656 \\
416 \\
109 \\
6,805\end{array}$ & $\begin{array}{r}12,406 \\
5,765 \\
6,999 \\
5,340 \\
3,964 \\
1,042 \\
315 \\
9,043\end{array}$ & $\begin{array}{r}12,176 \\
6,690 \\
6,342 \\
5,827 \\
4,114 \\
1,052 \\
417 \\
4,841\end{array}$ & $\begin{array}{r}22,985 \\
15,447 \\
11,437 \\
11,823 \\
6,933 \\
2,242 \\
1,079 \\
6,242\end{array}$ & $\begin{array}{r}35,589 \\
14,454 \\
11,147 \\
9,746 \\
7,206 \\
3,0 \Sigma 8 \\
2,412 \\
5,649\end{array}$ \\
\hline Total $\ldots$ & 314,355 & 37,858 & 22,715 & 44,874 & 41,460 & 78,187 & 89,261 \\
\hline Western hardwoods.--- & 19,330 & 5,559 & 2,755 & 4,562 & 2,840 & 2,829 & 783 \\
\hline All species_-_ & 648,879 & 145,955 & 79,284 & 133,546 & 89,531 & 107,951 & 92,613 \\
\hline
\end{tabular}

Note: Data may not add to totals because of rounding.

Closer utilization of the roundwood delivered to sawmills and other plants has been made possible by a number of technological and economic developments. Widespread installation of log debarkers and chippers at sawmills has permitted production of bark-free chips of high quality and relatively low cost compared with roundwood. Recent installation of chipping headrigs in sawmills has also helped increase chip output. New technology in pulping with continuous digesters has provided added opportunities for use of sawdust and other fine residues. Enactment of State laws controlling disposal of waste material by burning or dumping also has stimulated the search for uses of waste materials.

\section{Primary Plant Residues}

In spite of the rapid growth in use of the byproducts of primary manufacture of wood products, volumes of unused residues were still sizable in 1970. Almost one billion cubic feet (more than
12 million cords) of material was left unused at sawmills and other primary manufacturing plants (table 24).

About two-thirds of this unused material was softwoods (fig. 16). About 40 percent of this softwood volume (3.4 million cords) was chippable residues, that is, slabs, edgings, and other coarse material. Most of this volume was on the Pacific Coast, although there were also substantial volumes in the South and Rocky Mountains (Append. I, table 43). Coarse hardwood residues in the East totaled about 132 million cubic feet (1.7 million cords).

Unused sawdust and other fine residues amounted to 7.4 million cords in 1970 . Unused plant residues in 1970 were largely at some distance from markets or in areas where supply currently exceeded demand. Use of residues is increasing rapidly, however, and it seems likely that within the next decade or so most of the coarse softwuur 
TABLE 22.-Ownership of growing stock and sawtimber, by softwoods and hardwoods, January 1, 1970 GROWING STOCK

\begin{tabular}{|c|c|c|c|c|c|c|}
\hline \multirow[b]{2}{*}{ Type of ownership } & \multicolumn{2}{|c|}{ Total } & \multicolumn{2}{|c|}{ Softwcods } & \multicolumn{2}{|c|}{ Hardwoods } \\
\hline & Volume & $\begin{array}{c}\text { Pro- } \\
\text { portion }\end{array}$ & Volume & $\begin{array}{l}\text { Pro- } \\
\text { portion }\end{array}$ & Volume & $\begin{array}{l}\text { Pro- } \\
\text { portion }\end{array}$ \\
\hline $\begin{array}{l}\text { National Forest } \\
\text { Other public } \\
\text { Forest industry } \\
\text { Farm and miscellaneous private }\end{array}$ & $\begin{array}{l}\text { Billion } \\
\text { cu. ft. } \\
217 \\
68 \\
100 \\
264\end{array}$ & $\begin{array}{r}\text { Percent } \\
34 \\
10 \\
15 \\
41\end{array}$ & $\begin{array}{l}\text { Billion } \\
\text { cu.ft. } \\
200 \\
48 \\
73 \\
110\end{array}$ & $\begin{array}{r}\text { Percent } \\
46 \\
11 \\
17 \\
26\end{array}$ & $\begin{array}{r}\text { Billion } \\
\text { cu. ft. } \\
18 \\
20 \\
27 \\
153\end{array}$ & $\begin{array}{r}\text { Percent } \\
8 \\
9 \\
12 \\
71\end{array}$ \\
\hline All ownerships $\ldots$ & 649 & 100 & 432 & 100 & 217 & 100 \\
\hline \multicolumn{7}{|c|}{ SAWTIMBER } \\
\hline $\begin{array}{l}\text { National Forest } \\
\text { Other public } \\
\text { Forest industry } \\
\text { Farm and miscellaneous private }\end{array}$ & $\begin{array}{l}\text { Billion } \\
\text { od. ft. } \\
1,022 \\
263 \\
386 \\
751\end{array}$ & $\begin{array}{r}\text { Percent } \\
42 \\
11 \\
16 \\
31\end{array}$ & $\begin{array}{l}\text { Billion } \\
\text { bd. ft. } \\
982 \\
223 \\
318 \\
382\end{array}$ & $\begin{array}{r}\text { Percent } \\
51 \\
12 \\
17 \\
20\end{array}$ & $\begin{array}{l}\text { Billion } \\
\text { bd. ft. } \\
40 \\
40 \\
68 \\
368\end{array}$ & $\begin{array}{r}\text { Percent } \\
8 \\
8 \\
13 \\
71\end{array}$ \\
\hline All ownersbips $\ldots$ & 2,421 & 100 & 1,905 & 100 & 515 & 100 \\
\hline
\end{tabular}

Note: Data may not add to totals because of rounding.

TABLE 23.-Growing stock and sawtimber inventories on commercial timberland, by section and by softwoods and hardwoods, 1952, 1962, and $1970^{1}$

GROWING STOCK-BILLION CUBIC FEET

\begin{tabular}{|c|c|c|c|c|c|c|c|c|c|}
\hline \multirow{2}{*}{ Section } & \multicolumn{3}{|c|}{ All species } & \multicolumn{3}{|c|}{ Softwoods } & \multicolumn{3}{|c|}{ Hardwoods } \\
\hline & 1952 & 1962 & 1970 & 1952 & 1962 & 1970 & 1952 & 1962 & 1970 \\
\hline $\begin{array}{l}\text { North } \\
\text { South } \\
\text { Rocky Mountains } \\
\text { Pacific Coast_. } \ldots\end{array}$ & $\begin{array}{r}110.0 \\
130.7 \\
89.0 \\
253.5\end{array}$ & $\begin{array}{r}135.2 \\
145.0 \\
95.8 \\
247.9\end{array}$ & $\begin{array}{r}155.7 \\
159.5 \\
92.2 \\
241.5\end{array}$ & $\begin{array}{r}27.8 \\
55.1 \\
85.0 \\
243.1\end{array}$ & $\begin{array}{r}34.0 \\
66.8 \\
91.3 \\
235.2\end{array}$ & $\begin{array}{r}39.1 \\
78.4 \\
87.7 \\
226.6\end{array}$ & $\begin{array}{r}82.2 \\
75.6 \\
4.0 \\
10.4\end{array}$ & $\begin{array}{r}\text { 101. } 2 \\
78.3 \\
4.5 \\
127\end{array}$ & $\begin{array}{r}116.6 \\
81.1 \\
4.5 \\
14.8\end{array}$ \\
\hline United States_-_-_ & 583. 1 & 623.9 & 648.9 & 411. 0 & 427. 2 & 431. 9 & 172.1 & 196. 7 & 217. 0 \\
\hline
\end{tabular}

SAWTIMBER-BILLION BOARD FEET

\begin{tabular}{|c|c|c|c|c|c|c|c|c|c|}
\hline $\begin{array}{l}\text { North } \\
\text { South } \\
\text { Rocky Mountains } \\
\text { Pacific Coast_... }\end{array}$ & $\begin{array}{r}246.3 \\
391.1 \\
378.1 \\
1,396.5\end{array}$ & $\begin{array}{r}290.7 \\
434.9 \\
390.9 \\
1,313.8\end{array}$ & $\begin{array}{r}331.9 \\
483.8 \\
364.4 \\
1,240.6\end{array}$ & $\begin{array}{r}58.9 \\
185.6 \\
369.2 \\
1,365.2\end{array}$ & $\begin{array}{r}69.2 \\
230.4 \\
381.3 \\
1,274.6\end{array}$ & $\begin{array}{r}80.1 \\
275.9 \\
355.1 \\
1,194.2\end{array}$ & $\begin{array}{r}187.4 \\
205.5 \\
8.8 \\
31.3\end{array}$ & $\begin{array}{r}221.5 \\
204.5 \\
9.6 \\
39.2\end{array}$ & $\begin{array}{r}251.8 \\
208.0 \\
9.3 \\
46.4\end{array}$ \\
\hline United States....... & $2,412.0$ & $2,430.3$ & $2,420.8$ & $1,978.9$ & $1,955.5$ & $1,905.3$ & 433. 1 & 474. 8 & 515.5 \\
\hline
\end{tabular}

1 Data may not add to totals because of truncating.

Note: Data for 1952 and 1962 differ from data published in earlier reports because of adjustments based on newer information from remeasured Forest Survey plots. Data for all years are "trend level" estimates. 
Timber inventory, by diameter class, 1952 and 1970

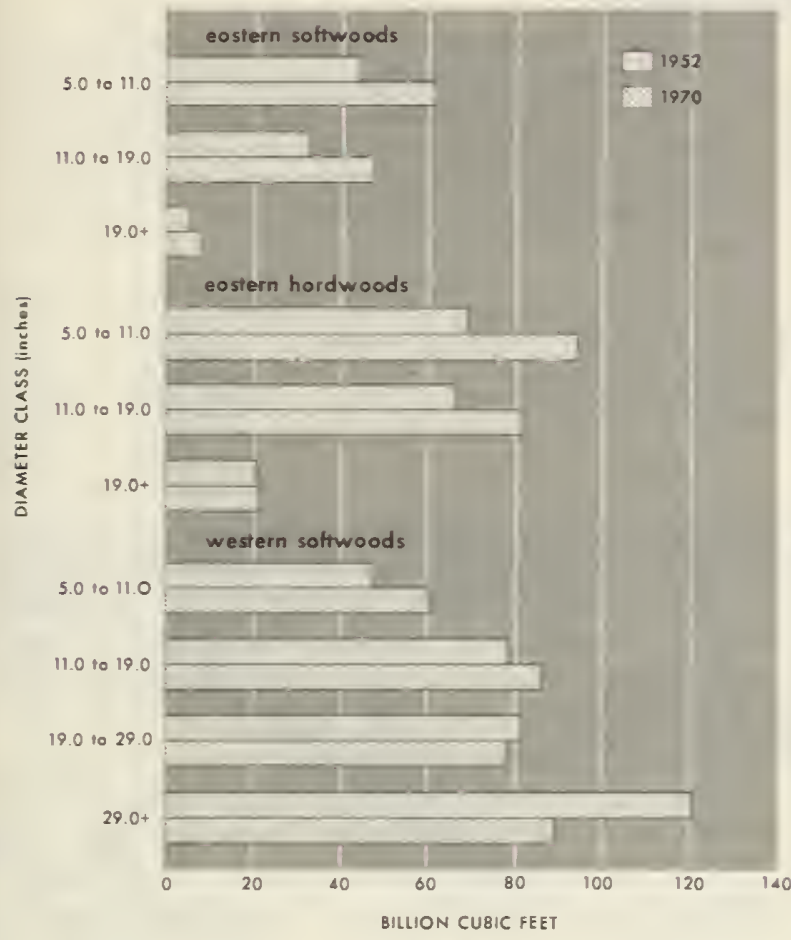

Figure 14

residues, and a substantial part of the fine residues, will be utilized for pulp and particleboard.

\section{Secondary Plant Residues}

In addition to unused residues at sawmills and other primary wood processing plants,
Disposal of plant residues, 1952-1970

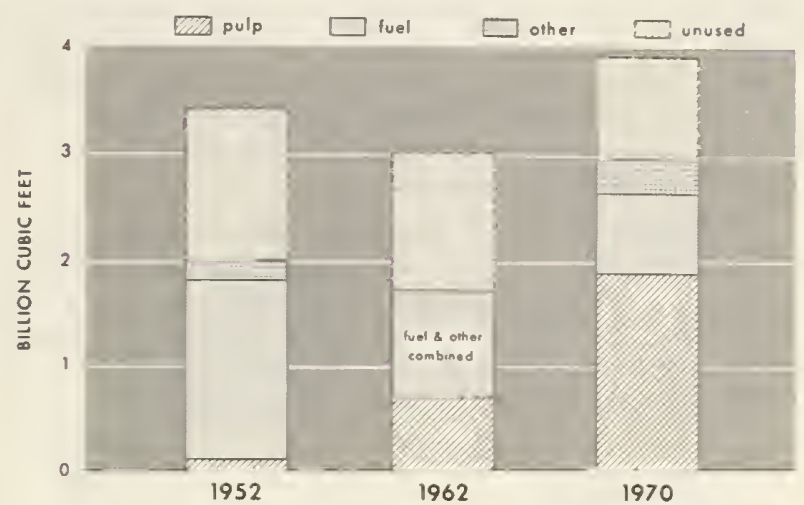

Figure 15

Wood residues at primary plants, 1970

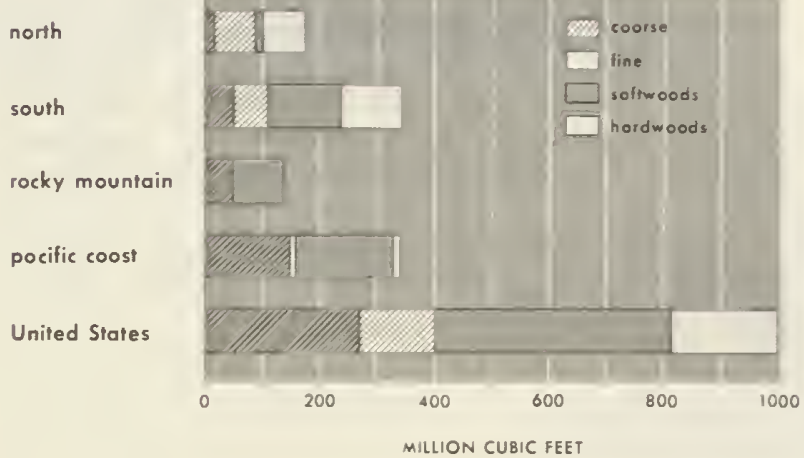

Figure 16

TABLE 24.-Residues at primary wood processing plants in the United States, by species group and use, 1970

[Million cubic feet]

\begin{tabular}{|c|c|c|c|c|c|c|}
\hline \multirow{2}{*}{ Item } & \multicolumn{2}{|c|}{ All species } & \multicolumn{2}{|c|}{ Softwoods } & \multicolumn{2}{|c|}{ Hardwoods } \\
\hline & Volume & Percent & Volume & Percent & Volume & Percent \\
\hline $\begin{array}{l}\text { Used for pulp } \\
\text { Used for fuel } \\
\text { Used for other products. }\end{array}$ & $\begin{array}{r}1,773 \\
726 \\
313\end{array}$ & $\begin{aligned} \text { 46. } 6 \\
\text { 19. } 1 \\
8.2\end{aligned}$ & $\begin{array}{r}1,514 \\
599 \\
241\end{array}$ & $\begin{aligned} 49.9 \\
19.7 \\
7.9\end{aligned}$ & $\begin{array}{r}259 \\
127 \\
72\end{array}$ & $\begin{array}{r}33.7 \\
16.5 \\
9.4\end{array}$ \\
\hline All uses_ _ & 2,813 & 73. 9 & 2,354 & 77.5 & 459 & 59. 6 \\
\hline $\begin{array}{l}\text { Unused: } \\
\text { Coarse....... } \\
\text { Fine....... }\end{array}$ & $\begin{array}{l}402 \\
591\end{array}$ & $\begin{array}{l}10.6 \\
15.5\end{array}$ & $\begin{array}{l}270 \\
412\end{array}$ & $\begin{array}{r}8.9 \\
13.6\end{array}$ & $\begin{array}{l}132 \\
179\end{array}$ & $\begin{array}{l}\text { 17. } 2 \\
\text { 23. } 2\end{array}$ \\
\hline Total unused & 993 & 26.1 & 682 & 22.5 & 311 & 40.4 \\
\hline Total residues...... & 2,806 & 100. 0 & 3,036 & 100.0 & 770 & 100.0 \\
\hline
\end{tabular}

Source: Forest Survey surveys of wood processing plants. 
sizable quantities of shavings, trimmings, and other residues are generated at secondary wood manufacturing establishments producing millwork, hardwood dimension and flooring, prefabricated structures, pallets, and a wide variety of other products. These secondary plants are mainly small and widely distributed, with many in eastern population centers.

Although statistics on amounts of byproducts generated and used at secondary manufacturing plants are not generally available, a study of establishments in the Midwest ${ }^{4}$ disclosed a total production of close to 241 million cubic feet of material which was disposed of as follows:

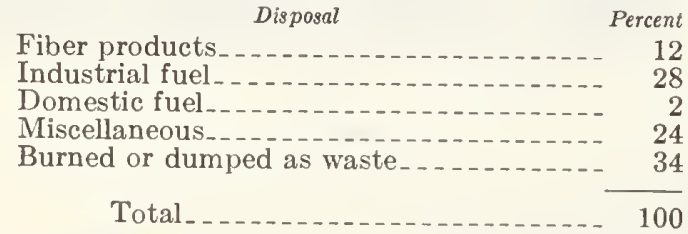

This limited sample suggests that total production of secondary plant byproducts in the United States in 1970 may have approximated 900 million cubic feet. Possibly 100 million cubic feet of this material was used for particleboard, or other products. These uses are expected to increase somewhat, although opportunities for expansion are apparently less promising than for primary

\footnotetext{
${ }^{4}$ Carpenter, Eugene M. Wood residues-a cost or a market potential? Woodworking and Furniture Digest 73(1), 3 p. June 1971.
}

plant residues in view of the character and scattered location of secondary residues.

\section{Bark Residues}

Volumes of bark accumulated at sawmills and other primary processing plants, based upon limited studies and informed judgment, amounted to roughly 2 billion cubic feet in 1970. Most of this sizable volume of material represented a waste disposal problem, as indicated by the following estimates:

Disposal Percent

Used for industrial fuel including charcoal

Used for domestic fuel or given away

Used for fiber products..........

Used for miscellaneous purposes........ 3

Burned or dumped.... 69

Total _...

Environmental considerations have added urgency to the search for economic uses for the large amounts of unused bark. Some progress has been made in developing markets for bark as soil amendments, mulches, livestock bedding, and charcoal. ${ }^{5}$ Rising costs for fossil fuels may also increase the attractiveness of bark, as well as other wood residues, as a source of energy. Some quantities of bark may also be incorporated in certain types of particleboard and other fiberboards.

${ }^{5}$ Mater, Jean. How to turn bark into dollars. Wood and Wood Products 74(1):31-32, 38. 1969. 
This chapter presents estimates of potential supplies of timber products from U.S. forests during the next half century under the assumption that forest management efforts will continue at approximately 1970 levels.

An initial set of basic projections of timber supply was first developed based on the further assumptions (1) that timber harvesting would be related to prospectively available growth of timber, or in the case of public lands to allowable harvests, and (2) that areas of commercial timberland will decline somewhat as a result of increasing use of forest lands for nontimber purposes.

A second set of projections is also included to indicate supplies of softwood sawtimber considered likely to be available for harvesting with different price levels. 'These economic supply projections were based in part upon the base projections of softwood sawtimber supplies that might be physically available and judgments as to timber operability, utilization potentials, and owners' willingness to sell timber at various price levels. It is recognized that higher prices for timber products should also lead to increased investments in timber growing but it is estimated that this would have only limited effects on available roundwood supplies during the projection period used in this study.

The projections of timber supplies in this and the following chapter should be regarded as conditional statements of roundwood supplies likely to be available in the future if the specified assumptions as to level of management, timber harvesting practices, area of available timberland, and other factors are actually realized. It is of course apparent that many alternative projections could be made depending on assumptions as to to these key variables.

Also, as in the case of demand projections, cyclical variations in availability of timber supplies could be significant, and differences between projections and actual supplies in the future could become progressively greater as the projection period lengthens. Factors such as environmental limitations, and impacts of nontimber uses on timber supplies, have been considered in this analysis but unforeseen changes in these factors could also have additional impacts on availability of timber for industrial use.

In the last chapter of this report the timber supply projections developed in this and the following chapter are compared with the projections of timber demands developed in Chapter $V$. This comparison is designed to provide an indication of prospective relationships between timber supplies and demands, related price implications, and changes in forestry programs that might be adopted to achieve various forestry goals.

Estimates of prospective timber supplies have been developed for a 50-year period-a very long period in the light of the many uncertainties associated with management and response of forests and forest users to changing conditionsbut a short period in the life of most commerical timber stands.

\section{LEVEL OF FOREST MANAGEMENT DEFINED}

The average amount of forest management actirities prevailing in the 1960 's has been assumed to represent the "1970 level of management." In most respects the general intensity of timber management in 1970, as indicated in this section, was not greatly different from the average of recent years. This management level is intended to provide a base level for judging the future outlook with and without intensification of timber growing and utilization.

Forest management includes a variety of activities-protection against fire, insects and disease, reforestation, stand improvement, thinnings, and harvesting practices to assure desirable regeneration. Related to these on-the-ground measures are additional activities in forestry research, technical assistance to landowners and operators, and general educational activities.

These management activities directly influence future timber supplies through their effect on such variables as rates of establishment of seedlings and related additions to forest growing stock, rates of diameter growth, tree mortality, and the amount and distribution of timber removals by diameter and tree classes.

Estimates for these variables in each forest region, and relationships to factors such as stand density and composition, were obtained from forest inventory plots taken mostly during the 1960 's. Thus the variables used in developing the projections of timber supplies shown later in this chapter largely reflect the timber culture, protection, and utilization levels and practices of this period.

\section{Forest Fire Control}

The most widespread forestry practice in the United States, and in many ways the most important and effective historically, is organized protection against wildfire.

Expenditures.-Direct expenditures of Federal and State forestry agencies, and private cooperators for organized programs of control of wildfires approximated $\$ 200$ million in 1970 (table 25 and fig. 17). In terms of constant 1967 dollars, direct expenditures for fire prevention and control increased about 30 percent between 1960 and 1970. Expenditures per acre in 1970 averaged about 22 cents per acre protected. Federal fire control organizations averaged about 16 cents per acre protected and State and private fire control organizations about 32 cents per acre. 
Forest area burned and fire control expenditures

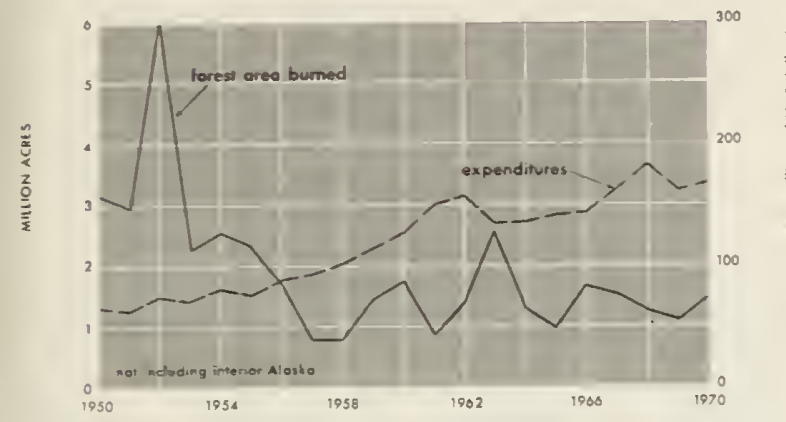

Figure 17

TABLE 25.-Reported expenditures for forest fire
protection, 1950- $\gamma 1^{1}$

[Million dollars]

\begin{tabular}{|c|c|c|c|c|c|}
\hline \multirow{2}{*}{ Year } & \multirow{2}{*}{$\begin{array}{c}\text { National } \\
\text { Forest }\end{array}$} & \multirow{2}{*}{$\begin{array}{c}\text { Other } \\
\text { Federal }\end{array}$} & \multirow{2}{*}{$\begin{array}{c}\text { State } \\
\text { and } \\
\text { private }\end{array}$} & \multicolumn{2}{|c|}{ Total } \\
\hline & & & & $\begin{array}{l}\text { Current } \\
\text { dollars }\end{array}$ & $\begin{array}{c}1967 \\
\text { dollars }\end{array}$ \\
\hline $1950 \ldots$ & 7 & 1 & 29 & 37 & 66 \\
\hline $1951 \ldots$ & 6 & 1 & 32 & 39 & 64 \\
\hline 1952 & 10 & 1 & 36 & 47 & 75 \\
\hline $1953 \ldots$ & 7 & 1 & 38 & 46 & 72 \\
\hline 1954 & 13 & 1 & 39 & 53 & 81 \\
\hline 1955 ... & 12 & 1 & 39 & j2 & 77 \\
\hline 1956. & 19 & 2 & 42 & 63 & 88 \\
\hline 19507 & 23 & 2 & 45 & 70 & 93 \\
\hline 1958 & 23 & 4 & 52 & 79 & 102 \\
\hline $1959 \ldots$ & 29 & 7 & 54 & 90 & 113 \\
\hline 1960 & 39 & 7 & 57 & 103 & 126 \\
\hline $1961 \ldots$ & 55 & 8 & 61 & 124 & 149 \\
\hline 1962 & 58 & 9 & 65 & 132 & 156 \\
\hline 1963 & 41 & 8 & 67 & 116 & 133 \\
\hline 1964 _ & 39 & 9 & 73 & 121 & 134 \\
\hline 1965 -.- & 43 & 10 & 77 & 130 & 140 \\
\hline 1966 & 42 & 9 & 86 & 137 & 142 \\
\hline $1967 \ldots$ & 54 & 17 & 91 & 162 & 162 \\
\hline 1968 & 75 & 19 & 96 & 190 & 181 \\
\hline $1969 \ldots$ & 53 & 25 & 101 & 179 & 159 \\
\hline $\begin{array}{l}1970 \ldots \\
1971^{3}--\end{array}$ & $\begin{array}{r}58 \\
113\end{array}$ & $\begin{array}{l}29 \\
39\end{array}$ & $\begin{array}{l}114 \\
125\end{array}$ & $\begin{array}{l}201 \\
277\end{array}$ & $\begin{array}{l}164 \\
213\end{array}$ \\
\hline & & & & & \\
\hline
\end{tabular}

${ }^{1}$ Includes funds appropriated for prevention, presuppression and suppression of forest fires. Does not include additional expenditures for hazard reduction such as slash burning and prescribed burning, and unreported expenditures by counties, private operators and others. Such expenditures were roughly estimated at $\$ 25$ million in 1960 and \$120 million in 1970.

${ }^{2}$ Cooperative forest fire prevention and control expenditures under Clarke-McNary Law, Section 2.

3 Preliminary.

Source: U.S. Department of Agriculture, Forest Service and cooperating agencies.
Additional unreported expenditures for hazard reduction, such as slash disposal and prescribed burning, ${ }^{1}$ plus other protection efforts not included in organized programs amounted to an estimated $\$ 120$ million in 1970 . Thus total direct and indirect outlays for fire control and hazard reduction in 1970 amounted to about $\$ 320$ million.

The area protected against wildfires by organized fire control programs has gradually risen to a total of about 973 million acres in the contiguous States, plus some 248 million acres in interior Alaska (table 26). Areas protected include nearly all the 496 million acres classed as commercial timberland, most of the 270 million acres of noncommercial forests, and approximately 170 million acres of nonforest watershed and intermingled nonforest land in the contiguous States. As of 1970, estimates of protection agencies indicated there were some 56 million acres of rural lands still not receiving organized fire protection.

Areas burned.-In contrast to the continuing rise in protection expenditures, there has been no pronounced trend in forest area burned by wildfires during the past 15 years. Areas burned during this period were of course only a fraction of fire losses in earlier decades.

Total areas reported burned in the contiguous States during the 1960's areraged about 3.9 million acres annually (table 26 and fig. 17). This included both forest and nonforest lands in areas such as southern California, and both protected and unprotected areas. Areas burned have fluctuated widely from year to year.

Commercial timberlands burned during the 1960's - of key importance for timber supply analysis-averaged about 1.3 million acres annually. About 6 percent of this burned area was National Forest land; the remaining 94 percent was private and other public land. Areas burned annually during the 1960 's areraged about 0.25 percent of the total area of commercial timberland, with rates rarying from 0.08 percent of the commercial timberland in National Forests to 0.35 percent on other ownerships.

In spite of increasing protection expenditures, the number of fires starting annually has continued to average about 120,000 per year. As in the case of area burned, rising expenditures for fire prevention and control have in effect been offset by greater risks stemming from improved access and greater public use of forest areas.

Future trends.-Comparison of the relatively stable trend in areas burned by wildfires in the 1960 's with the rising trend in control expenditures suggests that continuing increases in fire control expenditures may be necessary to prevent increases in area burned. Risks of fire continue

\footnotetext{
1 Cooper, Rnbert W. The pros and cons of prescribed burning in the South. Forest Farmer 31(2):10-12, 39-40. November 1971.
} 
TABLE 26.-Areas protected from forest fires, and areas burned, 1950-71

\begin{tabular}{|c|c|c|c|c|c|c|}
\hline \multirow{3}{*}{ Year } & \multirow{3}{*}{$\begin{array}{c}\text { Area } \\
\text { protected }{ }^{1}\end{array}$} & \multicolumn{5}{|c|}{ Area burned ${ }^{2}$} \\
\hline & & \multirow[b]{2}{*}{ Total } & \multicolumn{3}{|c|}{ Protected areas } & \multirow{2}{*}{$\begin{array}{l}\text { Unprotected } \\
\text { areas }\end{array}$} \\
\hline & & & Total & $\begin{array}{c}\text { Total } \\
\text { forest land }\end{array}$ & $\begin{array}{l}\text { Commercial } \\
\text { timberland }\end{array}$ & \\
\hline Average, $1950-59$ & Million acres & $\begin{array}{r}\text { Thousand acres } \\
8,377\end{array}$ & $\begin{array}{r}\text { Thousand acres } \\
2,930\end{array}$ & $\begin{array}{r}\text { Thousand acres } \\
2,375\end{array}$ & $\begin{array}{r}\text { Thousand acres } \\
\text { n.a. }\end{array}$ & $\begin{array}{l}\text { Thousand acres } \\
5,447\end{array}$ \\
\hline 1960 & $\begin{array}{l}633 \\
688 \\
644 \\
652 \\
863\end{array}$ & $\begin{array}{l}4,452 \\
3,036 \\
4,050 \\
7,105 \\
4,194\end{array}$ & $\begin{array}{l}2,505 \\
1,428 \\
1,887 \\
3,301 \\
1,861\end{array}$ & $\begin{array}{r}1,709 \\
847 \\
1,349 \\
2,562 \\
1,288\end{array}$ & $\begin{array}{r}\text { n.a. } \\
\text { n.a. } \\
1,254 \\
2,440 \\
1,127\end{array}$ & $\begin{array}{l}1,947 \\
1,608 \\
2,163 \\
3,804 \\
2,333\end{array}$ \\
\hline $\begin{array}{l}1965 \\
1966 \\
1968 \\
1969\end{array}$ & $\begin{array}{l}883 \\
880 \\
887 \\
890 \\
918\end{array}$ & $\begin{array}{l}2,645 \\
3,899 \\
4,571 \\
3,263 \\
2,582\end{array}$ & $\begin{array}{l}1,345 \\
2,498 \\
2,181 \\
1,869 \\
1,587\end{array}$ & $\begin{array}{r}960 \\
1,660 \\
1,510 \\
1,260 \\
1,099\end{array}$ & $\begin{array}{r}894 \\
1,413 \\
1,363 \\
1,069 \\
968\end{array}$ & $\begin{array}{l}1,300 \\
1,401 \\
2,390 \\
1,391 \\
995\end{array}$ \\
\hline $\begin{array}{l}1970 \\
1971^{3} \\
\text { Annual average, }\end{array}$ & $\begin{array}{l}916 \\
973\end{array}$ & $\begin{array}{l}3,165 \\
3,232\end{array}$ & $\begin{array}{l}2,146 \\
2,499\end{array}$ & $\begin{array}{l}1,449 \\
1,499\end{array}$ & $\begin{array}{l}1,131 \\
1,397\end{array}$ & $\begin{array}{r}1,019 \\
753\end{array}$ \\
\hline $1960-70 \ldots$ & 805 & 3,906 & 2,055 & 1,427 & 1,284 & 1,850 \\
\hline
\end{tabular}

${ }^{1}$ Areas under organized public and private programs. Includes some nonforest watershed and other intermingled nonforest areas. Excludes Interior Alaska with protected area in 1971 of 248 million acres.

2 Excludes areas burned in Interior Alaska; this averaged 0.5 million acres annually in the period 1960-70.

to increase as a result of greater accessibility of forest lands and rapidly increasing public use of forest areas. As an alternative, further development of technology through continuing research efforts and other measures such as increased prescribed burning and closer timber utilization could help offset increases in fire risks.

The level of area burned is related to the rates of mortality that were used in developing the timber supply projections presented below. In spite of increasing fire risks, it has been assumed for this analysis that improved technology will help avoid an increase in mortality rates with continuance of fire control expenditures at 1970 levels. If this is not achieved prospective timber supplies shown by the base level projections in this chapter could be somewhat overstated.

\section{Insect and Disease Control}

Expenditures for pest control during the period 1960-70 averaged about $\$ 12$ million annually (table 27). About 87 percent of these funds were provided by the Federal Government and 13 percent by cooperating States and/or private organizations.

The major part of the funds provided for pest control have been used to abate epidemic losses in western regions, for example, where attacks of
${ }^{3}$ Preliminary.

Source: U.S. Department of Agriculture, Forest Service, based on reports from State Foresters and other protection agencies.

TABLE 27. Expenditures for forest pest control, $1960-71$

[Million dollars]

\begin{tabular}{|c|c|c|c|c|c|}
\hline \multirow{2}{*}{ Year } & \multirow{2}{*}{$\begin{array}{l}\text { Na- } \\
\text { tional } \\
\text { Forest }\end{array}$} & \multirow{2}{*}{$\begin{array}{l}\text { Other } \\
\text { Federal }\end{array}$} & \multirow{2}{*}{$\begin{array}{c}\text { Private } \\
\text { and other } \\
\text { public }\end{array}$} & \multicolumn{2}{|c|}{$\begin{array}{c}\text { United States } \\
\text { total }\end{array}$} \\
\hline & & & & $\begin{array}{l}\text { Current } \\
\text { dollars }\end{array}$ & $\begin{array}{c}1967 \\
\text { dollars }\end{array}$ \\
\hline 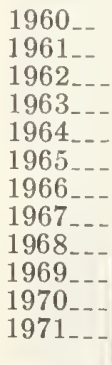 & $\begin{array}{r}6.2 \\
6.5 \\
8.0 \\
11.6 \\
8.9 \\
8.6 \\
9.9 \\
10.1 \\
10.0 \\
10.1 \\
7.7 \\
9.3\end{array}$ & $\begin{array}{r}0.4 \\
.4 \\
.7 \\
.8 \\
1.0 \\
1.2 \\
1.2 \\
1.2 \\
.8 \\
.9 \\
.7 \\
.7\end{array}$ & $\begin{array}{l}1.5 \\
1.5 \\
2.1 \\
3.4 \\
2.5 \\
2.2 \\
2.6 \\
2.8 \\
2.9 \\
2.9 \\
2.8 \\
3.7\end{array}$ & $\begin{array}{r}8.1 \\
8.4 \\
10.8 \\
15.8 \\
12.4 \\
12.0 \\
13.7 \\
14.1 \\
13.7 \\
13.9 \\
11.2 \\
13.7\end{array}$ & $\begin{array}{r}9.9 \\
10.1 \\
12.7 \\
18.2 \\
13.8 \\
12.9 \\
14.2 \\
14.1 \\
13.0 \\
12.4 \\
9.3 \\
10.5\end{array}$ \\
\hline
\end{tabular}

Source: U.S. Department of Agriculture, Forest Service and cooperating agencies.

bark beetles, spruce budworm, the Tussock moth, and other pests are often heavy in old-growth stands of that area. Major expenditures were 
also made in prior years for control of blister rust in western white pine stands but these efforts to control this important disease were not considered sufficiently effective and this program consequently was largely phased out during the 1960 's.

In the South recent expenditures for pest control have been mostly for locating and controlling bark beetles, the most damaging insect in this area. Some control programs are directed against other bark beetles, tipmoths, sawflies, pales weevil, leaf miners, and other insects. Attention is also being given to control of insects which damage cones and seeds, particularly in seed orchards. Diseases such as fusiform rust on loblolly and slash pine, brown spot, littleleaf disease, and fomes annosus also cause serious mortality. Control methods are a railable for fomes annosus, and tree breeding for genetic resistance offers a strong possibility for controlling fusiform rust in the future.

In the North efforts hare mainly been concentrated on control of such destructire agents as white pine blister rust, the gypsy moth, oak wilt, the spruce budworm, and jack-pine budworm.

\section{Reforestation}

Planting of forest trees increased sharply during the 1950 's from about one-half million acres to a peak of 2.1 million acres during the height of the Soil Bank Program in 1959 (table 28 and fig. 18). Planting declined sharply in the early 1960 's to about 1.3 million acres then trended upward again. The arerage area planted during the decade of the 1960's approximated 1.5 million acres-about 50 percent higher than the arerage for the 1950's.

Accurate data are not available on survival of trees planted but field estimates suggest an average surviral rate of around 85 percent in the South and 70 to 75 percent in the West and the North. Estimates of State Foresters indicate some continuing improvement in current survival rates. particularly where complete site preparation precedes planting or direct seeding.

In addition to these planting efforts, site preparation for natural regeneration covered an estimated 250,000 acres annually during the $1968-70$ period.

Planting by section and ownership.-Planting in the South has accounted for about 60 percent of the total area recently planted or direct seeded in the United States, or an average of about 0.9 million acres annually during the 1960's (table 28 and fig. 18). Areas planted in this region declined sharply in the early 1960's but has shown some upward trend in recent years. Planting in the North and Pacific Coast States each accounted for approximately one-fifth of recent plantings.

Planting on farm and miscellaneous private lands accounted for a major part of the total area planted or seeded during the 1950 's, particularly
Area planted and direct seeded, by ownership class

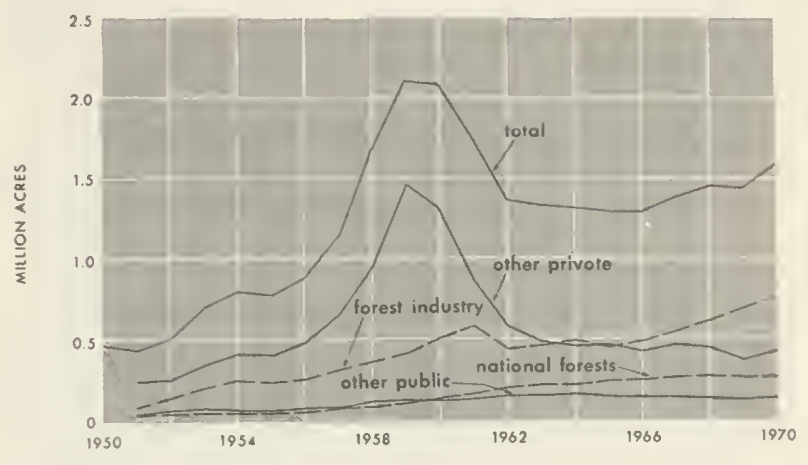

Area planted and direct seeded, by section

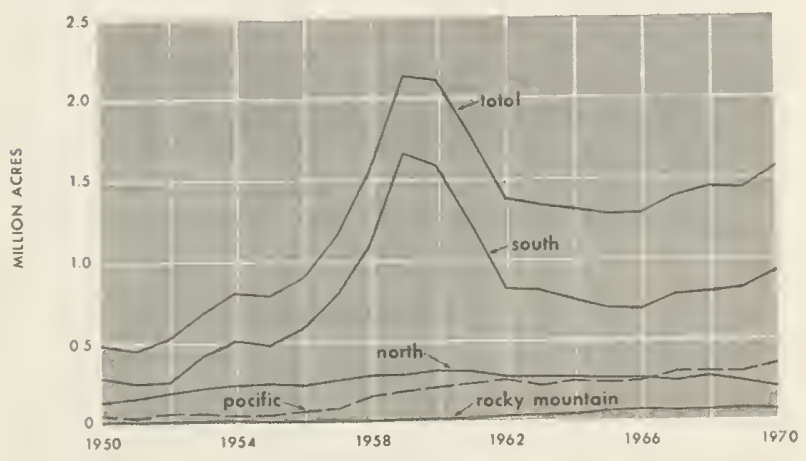

Figure 18

during the period of the Soil Bank program when payments were made for cropland retirement. In the 1960 's, however, planting on these ownerships declined sharply, while planting on forest industry lands climbed to over half the total reforestation program.

For the decade of the 1960's industrial and farm and miscellaneous private owners each averaged about 37 percent of the total planting effort. About 15 percent of the area planted in the 1960 's was in National Forests, and 9 percent in other public ownerships.

Artificial versus natural regeneration.-Planting and seeding of forest trees, although substantial, has covered a relatively small part of the area harvested annually. Forest owners still rely on natural regeneration to restore most stands after logging, and in a large part of the United States this is an effective and economic method of regenerating forest cover. Exact data are not available on the area of forest land harrested annually in the United States but this might amount to as much as 8 million acres per year, including both partial and complete harvesting of timber.

Only part of the 1.5 million acres planted annually during the 1960 's was on recently logged 
TABLE 28.-Areas planted and direct seeded by section and ownership class, 1950-71

[Thousand acres]

\begin{tabular}{|c|c|c|c|c|c|c|c|c|c|}
\hline \multirow{2}{*}{ Fiscal year } & \multirow{2}{*}{$\begin{array}{l}\text { Total } \\
\text { United } \\
\text { States }\end{array}$} & \multicolumn{4}{|c|}{ Section } & \multicolumn{4}{|c|}{ Ownership class } \\
\hline & & North & South & $\begin{array}{c}\text { Rocky } \\
\text { Mountains }\end{array}$ & Pacific & $\begin{array}{c}\text { National } \\
\text { Forest }\end{array}$ & $\begin{array}{l}\text { Other } \\
\text { public }\end{array}$ & $\begin{array}{l}\text { Forest } \\
\text { industry }\end{array}$ & $\begin{array}{l}\text { Farm and } \\
\text { miscellane- } \\
\text { ous private }\end{array}$ \\
\hline $\begin{array}{l}1950 \\
1951 \\
1952 \\
1953 \\
1954 \ldots\end{array}$ & $\begin{array}{l}488 \\
453 \\
520 \\
710 \\
808\end{array}$ & $\begin{array}{l}137 \\
164 \\
191 \\
212 \\
236\end{array}$ & $\begin{array}{l}285 \\
245 \\
250 \\
420 \\
506\end{array}$ & $\begin{array}{l}15 \\
15 \\
15 \\
17 \\
17\end{array}$ & $\begin{array}{l}52 \\
29 \\
63 \\
60 \\
49\end{array}$ & $\begin{array}{l}45 \\
46 \\
50 \\
53 \\
54\end{array}$ & $\begin{array}{l}54 \\
49 \\
67 \\
89 \\
70\end{array}$ & $\begin{array}{l}153 \\
106 \\
143 \\
217 \\
265\end{array}$ & $\begin{array}{l}237 \\
253 \\
260 \\
352 \\
419\end{array}$ \\
\hline $\begin{array}{l}1955-1956-10 \\
1957 \\
1958 \\
1959\end{array}$ & $\begin{array}{r}779 \\
886 \\
1,138 \\
1,533 \\
2,117\end{array}$ & $\begin{array}{l}242 \\
235 \\
258 \\
285 \\
283\end{array}$ & $\begin{array}{r}482 \\
574 \\
782 \\
1,080 \\
1,642\end{array}$ & $\begin{array}{r}5 \\
7 \\
7 \\
7 \\
13\end{array}$ & $\begin{array}{r}51 \\
70 \\
91 \\
161 \\
179\end{array}$ & $\begin{array}{r}56 \\
61 \\
85 \\
89 \\
112\end{array}$ & $\begin{array}{r}72 \\
84 \\
86 \\
119 \\
123\end{array}$ & $\begin{array}{l}239 \\
257 \\
311 \\
370 \\
417\end{array}$ & $\begin{array}{r}413 \\
484 \\
657 \\
955 \\
1,465\end{array}$ \\
\hline $\begin{array}{l}1960 \\
1961 \\
1962 \\
1963 \\
1964\end{array}$ & $\begin{array}{l}2,100 \\
1,761 \\
1,366 \\
1,325 \\
1,313\end{array}$ & $\begin{array}{l}308 \\
302 \\
270 \\
270 \\
269\end{array}$ & $\begin{array}{r}1,567 \\
1,205 \\
816 \\
798 \\
756\end{array}$ & $\begin{array}{l}14 \\
18 \\
27 \\
37 \\
42\end{array}$ & $\begin{array}{l}212 \\
235 \\
253 \\
221 \\
246\end{array}$ & $\begin{array}{l}134 \\
163 \\
198 \\
221 \\
208\end{array}$ & $\begin{array}{l}130 \\
140 \\
151 \\
151 \\
161\end{array}$ & $\begin{array}{l}521 \\
588 \\
443 \\
467 \\
485\end{array}$ & $\begin{array}{r}1,315 \\
870 \\
573 \\
486 \\
460\end{array}$ \\
\hline $\begin{array}{l}1965 \\
1966 \\
1967 \\
1968\end{array}$ & $\begin{array}{l}1,285 \\
1,281 \\
1,373 \\
1,439 \\
1,431\end{array}$ & $\begin{array}{l}268 \\
265 \\
245 \\
281 \\
250\end{array}$ & $\begin{array}{l}708 \\
696 \\
769 \\
795 \\
808\end{array}$ & $\begin{array}{l}64 \\
69 \\
65 \\
69 \\
73\end{array}$ & $\begin{array}{l}245 \\
251 \\
294 \\
294 \\
300\end{array}$ & $\begin{array}{l}233 \\
237 \\
257 \\
269 \\
257\end{array}$ & $\begin{array}{l}136 \\
144 \\
132 \\
128 \\
127\end{array}$ & $\begin{array}{l}455 \\
475 \\
527 \\
604 \\
681\end{array}$ & $\begin{array}{l}461 \\
425 \\
457 \\
437 \\
367\end{array}$ \\
\hline $\begin{array}{l}1970 \ldots+1 \\
1971\end{array}$ & $\begin{array}{l}1,577 \\
1,667\end{array}$ & $\begin{array}{l}225 \\
271\end{array}$ & $\begin{array}{r}925 \\
1,002 \\
\end{array}$ & $\begin{array}{l}70 \\
84\end{array}$ & $\begin{array}{l}357 \\
310\end{array}$ & $\begin{array}{l}261 \\
267\end{array}$ & $\begin{array}{l}131 \\
124\end{array}$ & $\begin{array}{l}763 \\
895\end{array}$ & $\begin{array}{l}422 \\
381 \\
\end{array}$ \\
\hline 1960-70 Average _ & 1,477 & 268 & 895 & 50 & 264 & 222 & 140 & 545 & 570 \\
\hline Percent of total_ & 100 & 18 & 61 & 3 & 18 & 15 & 9 & 37 & 39 \\
\hline
\end{tabular}

Note: Data may not add to totals because of rounding.

Source: U.S. Department of Agriculture, Forest Service, and cooperating agencies.

lands. In many areas planting of abandoned fields no longer used for crops or pastures made up a major part of the total planting effort. Thus in South Carolina roughly half of the area planted in the 1960's was estimated to be on former crop or pasture land. On the other hand, on National Forests and other ownerships in the West a major portion of the planting has been on recent cutovers, with some limited planting of old burns and cutovers and some replanting of areas difficult to regenerate.

The scale of current planting efforts may be further illustrated by comparison with the total area of commercial timberland. Thus for the decade of the 1960's, areas planted comprised about 8.3 percent of the commercial timberland owned by forest industries, 3.1 percent of nonindustrial private ownerships, 2.3 percent of National Forest lands, and 1.9 percent of other public holdings.

For many years practically all artifivial reforestation involved planting of seedlings raised in nurseries. In recent years, however, effective methods have been developed for direct seeding of species such as longleaf pine and Douglas-fir. Direct seeding consequently increased from 8 percent of the total area planted in 1960 to 15 percent in 1971, that is, about 243 thousand acres. Almost half of the direct seeding effort in 1971 was in the South, about 40 percent in the Pacific Coast States, and one-tenth in other sections. Three-fourths of the area direct seeded was on forest industry lands and the remainder on public ownerships.

Environmental constraints on use of persistent pesticides could result in some decline in future direct seeding programs unless more effective means of controlling rodents and other pests can be developed.

Reforestation costs. - Costs of planting and seeding approximately doubled during the 1960 's, according to data for the National Forests. Such increases in costs wele attributable to such factors as higher labor costs, the increasing need for site 
preparation, and a shift from easily planted areas to nore difficult planting sites. Further increases in costs are considered likely unless offset by in proved technology from research and development.

Planting costs vary widely by section and local area, depending on planting conditions and the need for site preparation or drainage operations. Assuming an arerage planting cost of $\$ 50$ an acre in 1971 and areas planted as indicated in table 28 would point to a total national investment for tree planting in that year of roughly $\$ 85$ million.

\section{Timber Stand Improvement}

Stand improrement practices include such measures as deadening inferior hardwoods and precommercial thinning of young stands. For the period 1968-70, estimates indicate about 1.4 million acres were treated annually-that is, only one-third of one percent of all commercial timberlands in the United States. ${ }^{2}$ This is estimated to be somewhat less than areas treated in the early sixties and late fifties.

TSI by section and ownership.-A major part of the reported stand improvement efforts have been concentrated in the South, particularly on lands operated by forest industries. Distribution of this reported TSI work is shown by the following tabulation of average areas treated annually in the period 1968-71:

By region

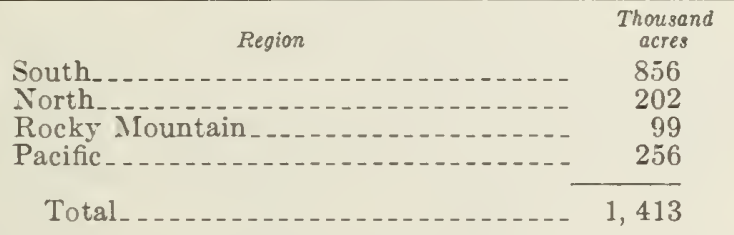

By ounership

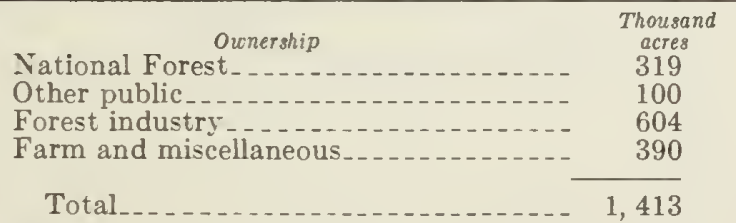

TSI costs.- Timber stand improrement costs per acre on National Forests approximately doubled between 1960 and 1970, due primarily to rising labor costs and more intensive treatment. Costs have raried considerably according to method and degree of stand treatment. Assuming an average of $\$ 18$ per acre in 1970 , total annual investments in timber stand improvement for all ornerships in the United States are estimated to hare approximated $\$ 25$ million.

${ }^{2}$ U.S. Department of Agriculture. USDA Forestry Planning Committee Annual Accomplishment Reports. Processed.
Additional cultural measures not classed as stand improvement include commercial thinnings or other intermediate cuts that produce merchantable material, improved harvesting practices, and prescribed burning. These measures are being increasingly adopted, especially on industrial and public holdings, but estimates of areas covered are not available.

\section{Fertilization}

Forest fertilization to date has been quite limited and there is still uncertainty about physical gains that might be realized, environmental impacts, and the costs and financial benefits of fertilization. However, experience to date is highly promising. Forest fertilization by 1969 amounted to an estimated 60,000 acres of forest land on the Pacific Coast treated with nitrogen fertilizers. In the South areas fertilized through 1970 totaled an estimated 180,000 acres. By 1971 forest industries were reported to be applying fertilizer to nearly 150,000 acres annually. Good response has been reported in the South from addition of nitrogen in older stands and phosphorous in poorly drained pine flatwoods of the Gulf and Atlantic Coastal Plain.

\section{Assistance to Forest Landowners}

Forestry accomplishments in on-the-ground measures, including planting, stand improvement, timber harvesting, improved utilization, and other practices can be attributed in considerable part to educational, technical assistance, and costsharing programs of public and private forestry agencies. Assumptions as to these programs consequently also influence supply projections.

Technical assistance provided forest landowners and operators by Federal and State agencies in 1971 cost $\$ 24.1$ million. In terms of constant dollars, this program more than doubled between 1950 and 1970 , as shown in figure 19 . Numbers of foresters providing service to forest landowners and timber operators steadily increased over the years to nearly 1,600 in 1970.

Cost-sharing assistance provided under the Agricultural Conservation Program of the Federal Government amounted to about $\$ 6$ million in 1970. As shown in figure 19, during the 1950's and 1960's cost-sharing assistance fluctuated widely from less than $\$ 3$ million annually during the earlier years to a peak of nearly $\$ 23$ million during the Soil Bank program of $1957-62$. In this period tree planting set new records (fig. 18). Most costsharing assistance has been for tree planting, with smaller expenditures for timber stand improvement and other practices.

\section{Forestry Research}

Supporting the action programs of forest management and protection described above is a program of public and private forestry research that 
Public expenditures to aid private forest land owners

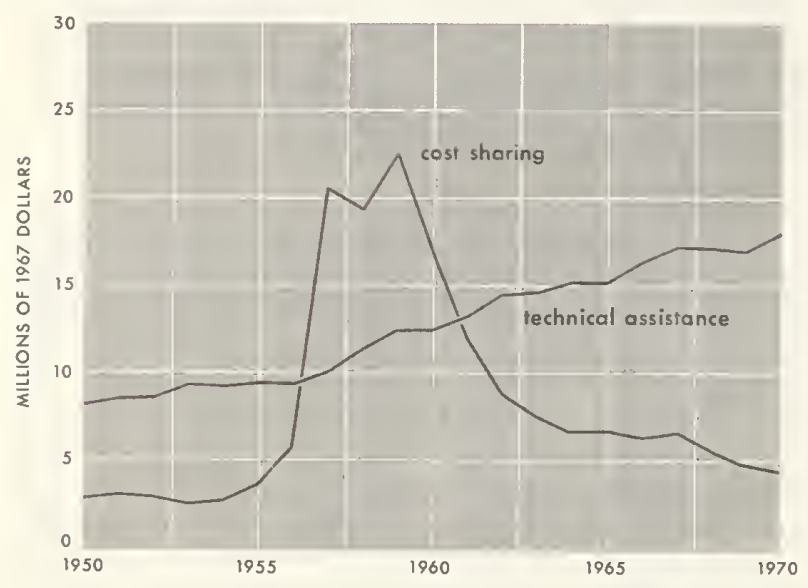

Figure 19

has steadily expanded in recent years. As shown in table 29, total expenditures for forestry research in 1970 amounted to an estimated \$208 million. In terms of constant dollars, research expenditures increased about 65 percent during the decade of the 1960 's.

\section{'TABLE 29.-Expenditures for forestry research, by agency, 1960-71}

[Million dollars]

\begin{tabular}{|c|c|c|c|c|c|}
\hline \multirow{2}{*}{ Year } & \multirow{2}{*}{$\begin{array}{c}\text { Forest } \\
\text { Service }^{1}\end{array}$} & \multirow{2}{*}{ State ${ }^{1}$} & \multirow{2}{*}{$\begin{array}{c}\text { Forest } \\
\text { industry }\end{array}$} & \multicolumn{2}{|c|}{ Total } \\
\hline & & & & $\begin{array}{l}\text { Current } \\
\text { dollars }\end{array}$ & $\begin{array}{c}1967 \\
\text { dollars }\end{array}$ \\
\hline $\begin{array}{l}1960 \\
1961 \ldots \\
1962 \\
1963 \\
1964 \\
1965 \\
1966 \\
1967 \\
1968 \\
1969 \\
1970- \\
1971 \ldots \\
\end{array}$ & $\begin{array}{l}16 \\
19 \\
19 \\
26 \\
28 \\
36 \\
31 \\
39 \\
40 \\
40 \\
49 \\
52\end{array}$ & $\begin{array}{r}2 \\
4 \\
3 \\
5 \\
4 \\
\text { n.a. } \\
8 \\
13 \\
12 \\
18 \\
16 \\
20\end{array}$ & $\begin{array}{r}66 \\
69 \\
75 \\
80 \\
83 \\
89 \\
101 \\
97 \\
115 \\
137 \\
143 \\
3170\end{array}$ & $\begin{array}{r}84 \\
92 \\
97 \\
111 \\
115 \\
3 \quad 135 \\
143 \\
149 \\
167 \\
195 \\
208 \\
3222\end{array}$ & $\begin{array}{l}103 \\
110 \\
114 \\
127 \\
124 \\
145 \\
148 \\
149 \\
159 \\
175 \\
170 \\
170\end{array}$ \\
\hline
\end{tabular}

1 Includes research on timber and nontimber uses of the forests and on utilization of timber products; other Federal and private university expenditures not included.

${ }^{2}$ Includes mainly research and development in the forest industries. Related research on equipment, adhesives, etc., in other industries not included.

3 Estimated.

Sources: National Science Foundation. Research and development in industry. Surveys of Science Resources Series, Annual; and U.S. Department of Agriculture, Forest Service and Cooperative State Research Service.
A major part of the public research effort is aimed at improving the technology of forest land management-for timber and for related resources such as water, range, wildlife, and recreation. Such research to date has led to substantial improvements in equipment and techniques relating, for example, to fire prevention, control, and prescribed burning. At least partial control of various insects and diseases is now being achieved as a result of past investigations. Studies of genetic improvement of forest planting stock has led to practical techniques of seed selection and other measures to obtain more productive plantations. Research on cultural measures and harvesting practices also is pointing the way to increased wood yields and incomes from forestry investments.

Continuation of the programs of forestry research at the 1970 level can be expected to result in continued improvements in available technology. In developing the projections of timber supply presented in this chapter some allowances were, therefore, made for improved technology, as in the case of forest fire control where it was assumed that rising hazards would be offset by better techniques of prevention and control.

However, all technological improvements that might result from on-going programs of research, such as genetic improvement for example, cannot be foreseen. 'To this extent the projections of prospective timber supplies in this analysis may be conservative.

Part of the public research and most of the private research conducted by the forest industries and by related industries which produce equipment and supplies for the forest industries is directed toward problems of timber utilization. This research relates, for example, to improvements in technology for production of logs and other roundwood, improvements in processing roundwood into lumber, pulp, and other products, and more efficient use of wood materials in manufactured products and in construction.

In the analysis of timber demands presented in Chapter $V$ of this report, estimates were made of possible impacts on timber demands of on-going research relating to use of timber products and competing materials. Estimates also were made of potential applications of improved technology that would extend timber supplies by closer utilization in the forest, and by increasing output of lumber, pulp, or other production per unit of roundwood used.

\section{Other Forestry Measures}

In addition to the forest protection, management and research activities described above, entailing expenditures of nearly $\$ 700$ million in 1970 , a number of other forestry and related activities also influence timber supply.

Thus road construction and maintenance require major expenditures both by public agencies 
and $b y$ the forest industries for logging operations and forest administration. Expenditures for roads on National Forests in 1970, for example, totaled about $\$ 180$ million (plus $\$ 112$ million of timber purchaser construction and maintenance). Substantial outlays for roads were also made on other Federal and State forest lands, on those portions of the Federal, State, and county highway systems that have local impacts on forestry activities, and on private forest holdings.

General administration of forestry operations of both public and pricate forest owners and forestry agencies inrolie additional expenditures that hare not been eraluated in this study.

Tax prorisions of the Federal and State Gorernments include certain financial benefits to owners of timber properties. Thus the Internal Rerenue Code generally permits treatment of income from the sale and cutting of timber as capital gains rather than as ordinary income and this is beliered to hare been a significant inducement to inrest in planting and other forestry practices.

Some 35 States hare enacted special forest tax laws to modify State and local property taxation of forest lands and timber in order to encourage improred forest management. However, most of these special laws have been of relatively limited application.

\section{FOREST AREA ASSUMPTIONS FOR PROJECTIONS}

Orer the past sereral decades additions to the area of commercial timberland in the United States exceeded losses, with a resulting rise in the area of commercial timberland to about 508 million acres around the year 1962 (table 30). Gains in forest areas were largely the result of natural or artificial reseeding of abandoned farm lands. Losses of forest land stemmed from a wide rariety of changes in land use, including withdrawals of land for parks and other recreation areas, urban derelopment, cropland expansion, highways, reserroirs, and other nontimber uses.

During the 1960's the upward trend in commercial timberland area was reversed. More and more private forest properties have been acquired and dereloped for second homes or other recreational uses. Public lands hare been withdrawn and other areas acquired from private owners for public recreation use. Throughout the country forest lands have been engulfed by urban sprawl. Extensive areas have also been cleared for agriculture, whereas additions to forest land from abandoned crop and pasture lands hare been declining.

It has been assumed in dereloping the supply projections shown in this chapter that the area of commercial timberland will continue to decline orer the $1970-2020$ period by roughly 5 million acres per decade-or a 5 percent reduction for the 50-year period (table 30). Rates of area reductions were assumed to differ somewhat by region and by ownership.

These projections of commercial timberland areas are intended only as reasonable possibilities of future changes. With different area assumptions, projections of timber supplies could be roughly adjusted by applying the same percentage change to both area and supply projections.

In the case of National Forests and other public lands, it is quite possible that some additional areas berond a 5 percent reduction as shown in table 31 may be remored from the timber supply base in the future. After the 1970 compilation was completed certain areas were selected for study as possible additions to the wilderness system, and some or all of these could be permanently reserved from cutting. These include some 11 million acres of the 56 million acres of roadless areas in the National Forests. Environmental

TABLE 30.-Area of commercial timberland in the United States, by section, 1952, 1962, and 1970, with projections to 2020

[Million acres]

\begin{tabular}{|c|c|c|c|c|c|c|c|}
\hline \multirow{2}{*}{ Section } & \multirow{2}{*}{1952} & \multirow{2}{*}{1962} & \multirow{2}{*}{1970} & \multicolumn{4}{|c|}{ Projections } \\
\hline & & & & 1980 & 1990 & 2000 & 2020 \\
\hline 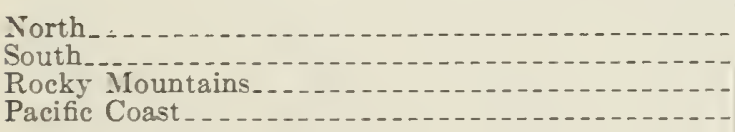 & $\begin{array}{r}170.2 \\
192.1 \\
63.9 \\
68.8\end{array}$ & $\begin{array}{r}175.1 \\
199.9 \\
64.6 \\
68.5\end{array}$ & $\begin{array}{l}177.9 \\
192.5 \\
161.6 \\
267.6\end{array}$ & $\begin{array}{r}176.3 \\
191.1 \\
60.5 \\
66.5\end{array}$ & $\begin{array}{r}174.7 \\
189.7 \\
59.3 \\
65.5\end{array}$ & $\begin{array}{r}173.1 \\
188.3 \\
58.3 \\
64.7\end{array}$ & $\begin{array}{r}169.8 \\
185.5 \\
56.0 \\
63.4\end{array}$ \\
\hline Total United States_. & 495. 0 & 508. 1 & 499. 7 & 494. 4 & 489. 2 & 484.4 & 474.7 \\
\hline
\end{tabular}

Includes 5 million acres of National Forest land in the Rocky Mountains not considered in projecting timber supplies. These include small patches and stringers of productive forest land isolated from markets, areas too unstable to harvest with current technology, and lands where nontimber uses predominate.

2 Includes 1.1 million acres in Hawaii not considered in projecting timber supplies. 
TABLE 31.-Area of commercial timberland, by owner class, 1952, 1962, and 1970, with projections to 2020 [Million acres]

\begin{tabular}{|c|c|c|c|c|c|c|c|}
\hline \multirow{2}{*}{ Owner class } & \multirow{2}{*}{1952} & \multirow{2}{*}{1962} & \multirow{2}{*}{1970} & \multicolumn{4}{|c|}{ Projections } \\
\hline & & & & 1980 & 1990 & 2000 & 2020 \\
\hline $\begin{array}{l}\text { National Forest } \\
\text { Other public } \\
\text { Forest industry } \\
\text { Farm and miscellaneous private }\end{array}$ & $\begin{array}{r}93.1 \\
46.1 \\
59.5 \\
296.2\end{array}$ & $\begin{array}{r}94.9 \\
44.4 \\
62.5 \\
306.4\end{array}$ & $\begin{array}{r}191.9 \\
44.2 \\
67.3 \\
2296.2\end{array}$ & $\begin{array}{r}91.2 \\
43.5 \\
68.4 \\
291.2\end{array}$ & $\begin{array}{r}90.3 \\
43.1 \\
69.5 \\
286.3\end{array}$ & $\begin{array}{r}89.2 \\
42.7 \\
70.7 \\
281.8\end{array}$ & $\begin{array}{r}87.4 \\
41.9 \\
72.9 \\
272.6\end{array}$ \\
\hline All owners & 495.0 & 508. 1 & 499. 7 & 494. 4 & 489.2 & 484. 4 & 474. 7 \\
\hline
\end{tabular}

1 Includes 5 million acres of National Forest land in the Rocky Mountains not considered in projecting timber supplies. These include small isolated patches and stringers of productive forest land areas too unstable to harvest with current technology, and lands where nontimber uses predominate.

statements also must be prepared before proceeding with development of the remaining unroaded areas. Legislation is pending, moreover, that would extend the wilderness system to eastern National Forests. In 1972 some half million acres of eastern National Forest land was identified for study of suitability as wilderness.

Commercial timberlands in other Federal, State, and local public ownerships, amounting to 44 million acres in 1970 , are also projected to decrease somewhat as a result of continuing withdrawals from timber harresting of areas important for nontimber uses.

The upward trend in area of commercial timberland owned by forest industries through acquisitions from other owners is projected to continue, with a modest increase over the 1970 figure of 67 million acres.

In this initial base projection by far the biggest acreage change is estimated for nonindustrial private owners. Forest areas available for timber production on these holdings were assumed to drop from an estimated 296 million acres in 1970 to 273 million acres by 2020 .

\section{A BASE PROJECTION OF TIMBER SUPPLIES WITH 1970 LEVELS OF MANAGEMENT}

This section presents a set of estimates of timber supplies that might be available in future decades if the same level and type of timber management as in 1970 continued, and timber harvesting were based upon biological relationships between growth and harvests, for example, as suggested by recent trends. A summary of these base projections for the United States is first presented, followed by a description of supply potentials in each of the four major sections of the United States.
${ }^{2}$ Includes 1.1 million acres in Hawaii not considered in projecting timber supplies. A large part of this area ( 0.495 million acres) is in "other public" ownership.

A later section of this chapter presents a set of alternative projections of economically available timber supplies with alternative price levels, related in part to these base projections and in part to other factors bearing on timber operability and availability.

\section{General Procedures}

Projections of timber supply were developed by a stand table method utilizing rates of radial growth, mortality, harvesting, and sapling ingrowth, together with growth constraint equations related to basal area and other factors, based upon data from remeasured Forest Survey plots. A computer program was developed to perform the calculations required to project variables by 2 -inch tree diameter classes, with specified adjustments for area changes and schedules of timber harvesting. ${ }^{3}$ The same procedure was used in reconciling data from successive surveys, and in updating to 1970 Forest Survey data collected over the previous 12 years or so. Growth rates and other inputs used in this procedure reflect the effects of management practices during the 10 - to 15 -year period prior to 1970 when Survey field measurements were taken. Each projection also was evaluated to assure that supply estimates represented reasonable biological possibilities.

\section{Timber Harvesting Assumptions for Base Projections}

In addition to the amount and kind of cultural measures and protection applied to the Nation's commercial timberland, both timber harvesting practices and the timing, amount, and composition of timber harvests in relation to growth and inventories will have major impacts on future roundwood supplies.

\footnotetext{
${ }^{3}$ Larson, Robert W., and Marcus H. Goforth. TRAS-A computer program for the projection of timber volume. U.S. Dept. Agric., Agric. Handb. 377, 24 p. June 1970.
} 
This initial base projection of roundwood timber supplies that might be biologically arailable over the 1970-2020 period was developed with the following assumptions:

Eastern forests.--In the East, total remorals of both softwood and hardwood growing stock in cubic feet, and sawtimber in board feet, were assumed to rise from the 1970 trend lerel to a balance with net growth in all sizes of timber by the year 2000 and thereafter. The estimates of growth-which in this initial assumption constrains arailable remorals and roundwood suppliesassume continuing biological relationships between variables such as radial growth and stand basal area similar to those prevailing in the 1950's and 1960 's as indicated by remeasured Forest Survey plots.

These assumptions do not mean that landowners would necessarily be willing and able to sell all of this "arailable" supply of roundwood, nor that plant capacity would actually be constructed to use all of this projected supply, but rather that these rolumes of remorals would be physically possible under the management, area, and harvesting assumptions specified. It is readily apparent that there are many possible alternative trends in future removals determined by such factors as owner objectires and timber prices and market conditions, as indicated in the final part of this chapter.

Western public lands.-On public lands in the West, it was assumed that the allowable cut of timber as estimated in 1970 would be continued through the projection period-eren though some reductions of allowable cuts might be required after the projection period, or even before, unless management is intensified above 1970 lerels. Extensive road construction by the public and by timber operators will be required to harrest the arailable timber on these public lands, much of which was still in unroaded areas in 1970.

The rate of timber harvesting of National Forests and other public lands could be modified by changes in management policy, and/or by intensified management as pointed out in Chapter III, but for this analysis existing policies as of 1970 were accepted in evaluating the timber supply outlook.

The harresting of timber on National Forests and certain other public lands is influenced significantly by requirements for multiple-use management of forest areas. Such management is designed not only to produce timber on a sustained basis but also to maintain the quality of waterflows, protect aesthetic ralues and wildlife habitat, and accommodate rapidly growing numbers of recreational visitors.

Harvesting timber in such a way as to achieve such multiple-use goals can be expected to be of increasing importance on public lands and extend to some degree to privately owned lands as well. Such increases in emphasis on environmental considerations reflect the growing ralues placed on forest resources by an expanding population with more arailable time, money, and mobility.

Although allowable harrests on public lands hare been set with allowances for nontimber uses, it is possible that further adjustments in timber management may be required.

Timber harresting has been especially challenged in the case of clearcutting, particularly on public lands, because of aesthetic and environmental impacts. From a timber growing standpoint, on the other hand, clearcutting is considered to be the most effective harresting alternative in many forest areas to avoid problems such as excessive blowdown of reserved trees and to obtain satisfactory regeneration of desirable species. Various studies have shown that eren-aged silviculture with some form of clearcutting farors regeneration of the more desirable species such as Douglas-fir in the Pacific Northwest, southern pine, or Appalachian hardwoods such as yellowpoplar, walnut, black cherry, and preferred oaks. Such management also makes possible concentration of logging activities and stand improrement operations, with resulting sarings in costs. Complete remoral of existing stands followed by planting also permits reforestation with genetically improved stock, and may be the only practical way to convert hardwoods to more productive softwood stands.

In spite of such biological and economic considerations, the need to balance enrironmental and commodity uses may require additional modifications of timber harresting and regeneration practices, particularly on National Forest and other public lands. ${ }^{4}$ Any substantial modifications of harresting or other management practices to give greater emphasis to nontimber uses than assumed in this study would likely require a reduction of the supply projections presented below.

Western private lands. - On private lands in the West estimates were made of the prospectire remorals of timber that could reasonably be expected with 1970 levels of management and operating practices. These estimated removals decline rather sharply in the projection period to a rough balance with growth and removals by the year 2020

Roundwood supplies.-The estimates of timber supplies presented in this section are in terms of roundwood products, including both products from growing stock and from nongrowing stock sources. Related information on logging residues and other removals are also included to show total remorals from inventories, as well as net growth,

\footnotetext{
1 See, for example: U.S. Department of Agriculture Forest Service. National Forest management in a quality environment-timber productivity. 66 p. 1971.
} 
mortality, and inventories. In estimating available supplies of roundwood, utilization standards were keyed primarily to practices of 1970 but with some allowance for increased use of logging residuals as a result of improvements in technology that appear likely with ongoing programs of research and development.

These supply projections are believed to represent reasonable biological possibilities with a continuation of recent trends in forest conditions and management. They are also designed to provide a partial basis for judging possible changes in roundwood supplies in response to alternative price trends, as indicated in the final section of this chapter, and in response to alternative management levels, as indicated in the following chapter.

\section{SUMMARY OF BASE PROJECTIONS OF SUPPLIES FOR THE UNITED STATES}

A summary of timber removals, net growth, mortality, roundwood supplies, and timber inventories in the 1952-70 period, and projections for

TABLE 32.-Timber removals, net growth, mortality, supplies of roundwood products, and inventories in the United States, 1952, 1962, and 1970, with projections (1970 level of management) ${ }^{1}$ to 2020

[Billion cubic feet]

\begin{tabular}{|c|c|c|c|c|c|c|c|}
\hline \multirow{2}{*}{ Item } & \multirow{2}{*}{1952} & \multirow{2}{*}{1962} & \multirow{2}{*}{1970} & \multicolumn{4}{|c|}{ Projections } \\
\hline & & & & 1980 & 1990 & 2000 & 2020 \\
\hline $\begin{array}{l}\text { SOFTWOODS } \\
\text { Removals from growing stock: } \\
\text { Roundwood products } \\
\text { Logging residues } \\
\text { Other removals }\end{array}$ & $\begin{array}{r}6.6 \\
.9 \\
.3\end{array}$ & $\begin{array}{r}6.5 \\
.8 \\
.3\end{array}$ & $\begin{array}{r}8.4 \\
.9 \\
.3\end{array}$ & $\begin{array}{r}9.5 \\
.9 \\
.4\end{array}$ & $\begin{array}{r}10.1 \\
.8 \\
.4\end{array}$ & $\begin{array}{r}10.9 \\
.8 \\
.4\end{array}$ & $\begin{array}{r}11 . \\
.7 \\
.4 \\
\end{array}$ \\
\hline Total $\ldots$ & 7. 8 & 7. 6 & 9.6 & 10.8 & 11. 3 & 12. 1 & 12.2 \\
\hline 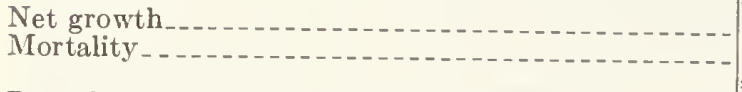 & $\begin{array}{r}7.8 \\
2.6 \\
\end{array}$ & $\begin{array}{l}9.3 \\
2.7\end{array}$ & $\begin{array}{r}10.7 \\
2.8\end{array}$ & $\begin{array}{r}11.3 \\
2.8\end{array}$ & $\begin{array}{r}11.6 \\
2.9\end{array}$ & $\begin{array}{r}11.6 \\
3.0\end{array}$ & $\begin{array}{r}11.9 \\
\text { 3. } 0 \\
\end{array}$ \\
\hline $\begin{array}{l}\text { Roundwood supplies: } \\
\text { From growing stock } \\
\text { From other sources }{ }^{2}\end{array}$ & $\begin{array}{r}6.6 \\
.8\end{array}$ & $\begin{array}{r}6.5 \\
.7\end{array}$ & $\begin{array}{r}8.4 \\
.6\end{array}$ & $\begin{array}{r}9.5 \\
.6\end{array}$ & $\begin{array}{r}10 . \\
.6\end{array}$ & $\begin{array}{r}10.9 \\
.6\end{array}$ & $\begin{array}{r}11 . \\
.5 \\
\end{array}$ \\
\hline Total & 7.4 & 7. 2 & 9.0 & 10. 1 & 10. 7 & 11.5 & 11.6 \\
\hline Inventory of growing stock & 411.0 & 427.2 & 431.9 & 436.4 & 442.1 & 442.7 & 437.8 \\
\hline 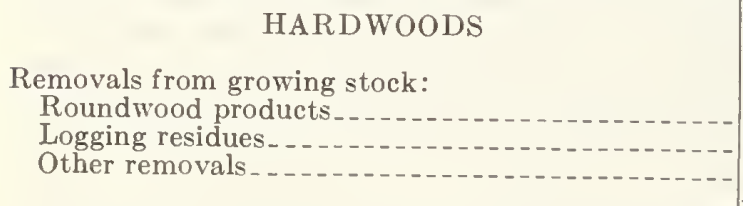 & $\begin{array}{r}2.6 \\
.8 \\
.7 \\
\end{array}$ & $\begin{array}{r}2.4 \\
.6 \\
1.2 \\
\end{array}$ & $\begin{array}{r}\text { 2. } 7 \\
\text { 1. } 0 \\
\end{array}$ & $\begin{array}{r}4.8 \\
.8 \\
.3\end{array}$ & $\begin{array}{r}5.9 \\
.9 \\
.3\end{array}$ & $\begin{array}{r}\text { 7. } 0 \\
.9 \\
.3\end{array}$ & $\begin{array}{r}\text { 7. } 0 \\
.7 \\
.3\end{array}$ \\
\hline Total $\ldots$ & 4. 1 & 4. 2 & 4. 4 & 5. 9 & 7. 1 & 8. 2 & 8. 0 \\
\hline $\begin{array}{l}\text { Net growth } \\
\text { Mortality }\end{array}$ & $\begin{array}{l}\text { 6. } 1 \\
1.3\end{array}$ & $\begin{array}{l}7.1 \\
1.5\end{array}$ & $\begin{array}{l}\text { 7. } 9 \\
\text { 1. } 7\end{array}$ & $\begin{array}{l}8.2 \\
2.0\end{array}$ & $\begin{array}{l}8.2 \\
2.1 \\
\end{array}$ & $\begin{array}{l}8.0 \\
2.2\end{array}$ & $\begin{array}{l}\text { 7. } 8 \\
\text { 2. } 1\end{array}$ \\
\hline $\begin{array}{l}\text { Roundwood supplies: } \\
\text { From growing stock } \\
\text { From other sources } 2\end{array}$ & $\begin{array}{r}2.6 \\
.8 \\
\end{array}$ & $\begin{array}{r}2.4 \\
.6 \\
\end{array}$ & $\begin{array}{r}2.7 \\
.5\end{array}$ & $\begin{array}{r}4.8 \\
.4\end{array}$ & $\begin{array}{r}5.9 \\
.4\end{array}$ & $\begin{array}{r}\text { 7. } 0 \\
.4\end{array}$ & $\begin{array}{r}\text { 7. } 0 \\
.4 \\
\end{array}$ \\
\hline Total & 3. 4 & 3. 0 & 3. 2 & 5. 2 & 6.3 & 7.4 & 7.4 \\
\hline Inventory of growing stock & 172. 1 & 196. 7 & 217.0 & 245.9 & 262.9 & 267.6 & 268.9 \\
\hline
\end{tabular}

1 Plus other area and harvesting assumptions specified in this chapter.

${ }^{2}$ Includes roundwood products from rough and rotten trees, dead trees, limbs, and trees on noncommercial and nonforest land.

Note: Estimates are for trend levels and consequently may differ from actual figures for the specified years. 
TABLE 33.-Sawtimber removals, net growth, mortality, supplies of roundwood products, and inventories in the United States, 1952, 1962, and 1970, with projections (1970 level of management) ${ }^{1}$ to 2020

[Billion board feet]

\begin{tabular}{|c|c|c|c|c|c|c|c|}
\hline \multirow{2}{*}{ Item } & \multirow{2}{*}{1952} & \multirow{2}{*}{1962} & \multirow{2}{*}{1970} & \multicolumn{4}{|c|}{ Projections } \\
\hline & & & & 1980 & 1990 & 2000 & 2020 \\
\hline SOFTWOODS & & & & & & & \\
\hline $\begin{array}{l}\text { Removals from sawtimber: } \\
\text { Round wood products } \\
\text { Logging residues. } \\
\text { Other removals. }\end{array}$ & $\begin{aligned} 35.3 \\
2.6 \\
1.3\end{aligned}$ & $\begin{array}{r}34.1 \\
2.3 \\
1.3\end{array}$ & $\begin{array}{r}43.5 \\
2.5 \\
1.7\end{array}$ & $\begin{array}{r}45.6 \\
2.3 \\
1.5\end{array}$ & $\begin{aligned} 47.6 \\
2.0 \\
1.6\end{aligned}$ & $\begin{aligned} 50.8 \\
1.8 \\
1.6\end{aligned}$ & $\begin{aligned} & 50 . 1 \\
& 1.5 \\
& 1.6\end{aligned}$ \\
\hline Total & 39.2 & 37.7 & 47. 7 & 49.4 & 51. 2 & 54. 2 & 53. 2 \\
\hline $\begin{array}{l}\text { Net growth } \\
\text { Mortality }\end{array}$ & $\begin{array}{l}29.5 \\
11.9\end{array}$ & $\begin{array}{l}34.7 \\
11.6\end{array}$ & $\begin{array}{l}40.3 \\
11.3\end{array}$ & $\begin{array}{l}43.3 \\
10.8\end{array}$ & $\begin{array}{l}45.7 \\
10.6\end{array}$ & $\begin{array}{l}47.2 \\
10.4\end{array}$ & $\begin{array}{l}48.4 \\
10.0\end{array}$ \\
\hline $\begin{array}{l}\text { Roundwood supplies: } \\
\text { From sawtimber..- } \\
\text { From other sources 2-. }\end{array}$ & $\begin{array}{r}35.3 \\
3.5\end{array}$ & $\begin{aligned} & 34 . 1 \\
& 3.4\end{aligned}$ & $\begin{array}{r}43.5 \\
3.4\end{array}$ & $\begin{array}{r}45.6 \\
3.2\end{array}$ & $\begin{array}{r}47.6 \\
3.3\end{array}$ & $\begin{array}{r}50.8 \\
3.4\end{array}$ & $\begin{array}{r}50.1 \\
3.8\end{array}$ \\
\hline Total_... & 38.8 & 37.5 & 46. 9 & 48.8 & 50.9 & 54.2 & 53.9 \\
\hline Inventory of sawtimber.... & $1,978.9$ & $1,955.5$ & $1,905.3$ & $1,823.0$ & $1,777.1$ & $1,724.6$ & $1,621.9$ \\
\hline HARDWOODS & & & & & & & \\
\hline $\begin{array}{l}\text { Removals from sawtimber: } \\
\text { Roundwood products } \\
\text { Logging residues } \\
\text { Other removals }\end{array}$ & $\begin{array}{r}11.3 \\
.9 \\
1.1\end{array}$ & $\begin{aligned} 10.0 \\
1.0 \\
1.6\end{aligned}$ & $\begin{array}{r}11.2 \\
1.2 \\
2.6\end{array}$ & $\begin{array}{r}14.4 \\
1.1 \\
.7\end{array}$ & $\begin{array}{r}17.1 \\
1.0 \\
.8\end{array}$ & $\begin{array}{r}19.5 \\
1.0 \\
.8\end{array}$ & $\begin{array}{r}19.4 \\
.8 \\
.7\end{array}$ \\
\hline Total ..... & 13.3 & 12. 6 & 15. 0 & 16. 2 & 18.9 & 21.3 & 20.9 \\
\hline $\begin{array}{l}\text { Net growth } \\
\text { Mortality }-1.2\end{array}$ & $\begin{array}{r}15.6 \\
3.1\end{array}$ & $\begin{array}{r}17.6 \\
3.6\end{array}$ & $\begin{array}{r}19.7 \\
4.0\end{array}$ & $\begin{aligned} 208 \\
4.3\end{aligned}$ & $\begin{array}{r}21.0 \\
4.6\end{array}$ & $\begin{array}{r}20.9 \\
4.7\end{array}$ & $\begin{array}{r}20.3 \\
4.7\end{array}$ \\
\hline $\begin{array}{l}\text { Roundwood supplies: } \\
\text { From sawtimber.-- } \\
\text { From other sources }{ }^{2}-\end{array}$ & $\begin{array}{r}11.3 \\
.8\end{array}$ & $\begin{array}{r}10.0 \\
.8\end{array}$ & $\begin{aligned} 11.2 \\
1.1\end{aligned}$ & $\begin{array}{r}14.4 \\
1.1\end{array}$ & $\begin{aligned} 17 . & 1 \\
1 . & 1\end{aligned}$ & $\begin{aligned} 19.5 \\
1.1\end{aligned}$ & $\begin{aligned} \text { 19. } 4 \\
1.1\end{aligned}$ \\
\hline Total $\ldots \ldots$ & 12.1 & 10. 8 & 12. 3 & 15.5 & 18. 2 & 20. 6 & 20.5 \\
\hline Inventory of sawtimber... & 433. 1 & 474.8 & 515.5 & 572.8 & 608.3 & 618.8 & 611.6 \\
\hline
\end{tabular}

1 Plus other area and harvesting assumptions specified in this chapter.

2 Includes roundwood products from rough and rotten trees, dead trees, trees on noncommercial or nonforest

1980-2020, are presented in table 32 in cubic feet, and in table 33 in board feet. ${ }^{5}$ These base projections reflect management levels of 1970 and related area and cutting assumptions specified earlier.

The estimates of removals, net growth, and inventories developed in this study refer to

${ }^{5}$ As indicated in table footnotes in Chapter I, data shown for 1952 and 1962 may differ from figures in previous publications because of revisions to insure comparability with 1970 definitions and specifications, or because of adjustments based on new information from Forest Survey plots. Figures also are "trend level" estimates and may" differ from actual figures for the specified years. land, and from trees of less than sawtimber size used as saw logs.

Note: Estimates are for trend levels and consequently may differ from actual figures for the specified years.

growing-stock trees, including sawtimber trees, on commercial timberland, excluding rough and rotten trees, salvable dead trees, and trees on other types of land. Estimates of roundrood supplies available to forest industries, on the other hand, include material from both growing stock and these other sources.

\section{Trends in Timber Removals}

Annual remorals of softwood growing stock increased about 23 percent between 1952 and 1970 to a total of 9.6 billion cubic feet (table 32 and fig. 20). Projections of available softwood removals 
Net growth and removals of growing stock in the United States

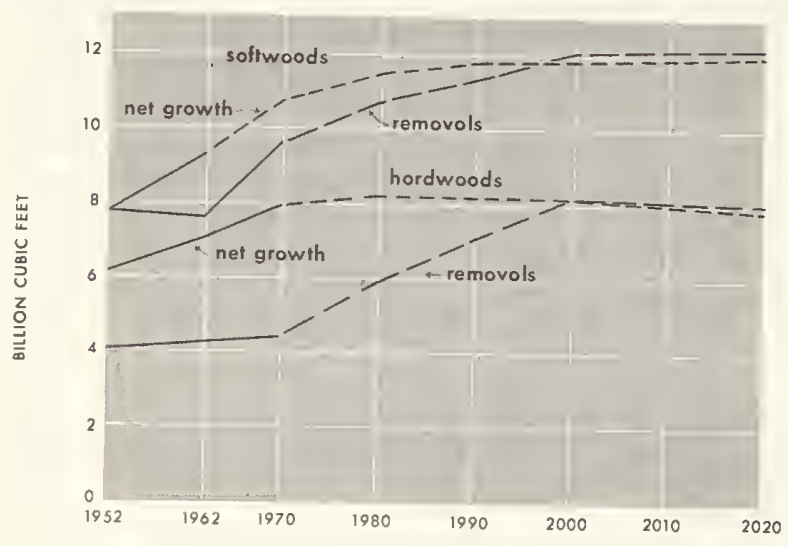

Figure 20

rise a further 26 percent by 2000 to 12.1 billion cubic feet. This increase in removals is associated with a slight increase in inventories of growing stock.

Recent removals of hardwood glowing stock rose slowly from 1952 to 1970 but available removals in the future are projected to increase at a much more rapid rate than softwoods, that is, from 4.4 billion cubic feet in 1970 to 8.2 billion cubic feet in 2000-an increase of 86 percent.

Sawtimber removals.-Removals of softwood sawtimber rose some 22 percent between 1952 and 1970 to about 47.7 billion board feet (table 33 and fig. 21). Projected removals increase a further 14 percent by 2000 to 54.2 billion board feet. The smaller increase in projected supplies of available softwood sawtimber in contrast to the projected increase for softwood growing stock remorals

Net growth and removals of sawtimber in the United States

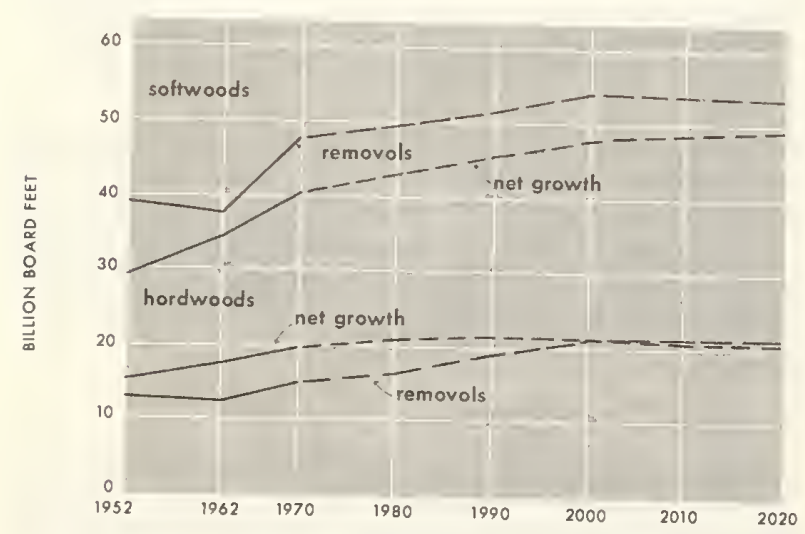

Figure 21 reflects prospective changes in the distribution of timber harvesting by size class resulting in part from continuing depletion of western old-growth timber. These increases in removals reflect the cutting and other assumptions outlined earlier and differ from projections related to price shown in a later section of this chapter.

Annual removals of hardwood sawtimber increased about 13 percent between 1952 and 1970 (table 33). As in the case of softwoods, the projection of a 42 percent increase in available removals of hardwood sawtimber is much less than the projected gain for growing stock.

Components of removals.-Roundwood products such as saw logs and pulpwood comprised some 87 percent of all softwood removals in 1970, but only 63 percent of total hardwood removals (table 34 ).

Logging residues made up 10 percent of the softwood removals and other removals for land clearing, withdrawals, etc., accounted for 3 percent. For hardwoods, on the other hand, logging residues made up 15 percent of the total and other removals 22 percent.

In the base projection assuming 1970 management lerels it was assumed that residues from logging operations, as a percent of total remorals, will decline in the years ahead for several reasons. Inprovements in equipment for handling, transporting, and converting timber, for example, along with expanding markets makes possible various improvements in timber utilization. Technological developments stemming from current research and development efforts are expected to continue, along with growth in markets for fiber products. Also, enrironmental considerations appear likely to require closer utilization of timber on areas harvested, particularly on public lands. A further factor fayoring closer utilization is the continuing increase in numbers of large integrated firms in the forest industries which have multiproduct options and facilities to utilize entire trees for optimum combinations of lumber, pulp, particleboard, or other products.

Logging residues from softwood growing stock consequently are projected to drop from about 9 percent of total removals in 1970 to 6 percent by the year 2000, with roundwood products output increasing correspondingly (table 34). Complete use of logging residues is not considered economically feasible even with higher prices because of the scattered location and poor quality of much of the material left after logging.

\section{Net Growth and Mortality}

Trends in net growth, which have a major bearing on the availability of timber removals, rose substantially in the $1952-70$ period, and projections indicate further moderate increases. Net growth of softwood growing stock increased 37 percent between 1952 and 1970 to 10.7 billion cubic feet, and is projected to increase a further 8 
TABLE 34.-Components of growing stock removals in the United States, 1952, 1962, and 1970, with projections to 2020

[Percent]

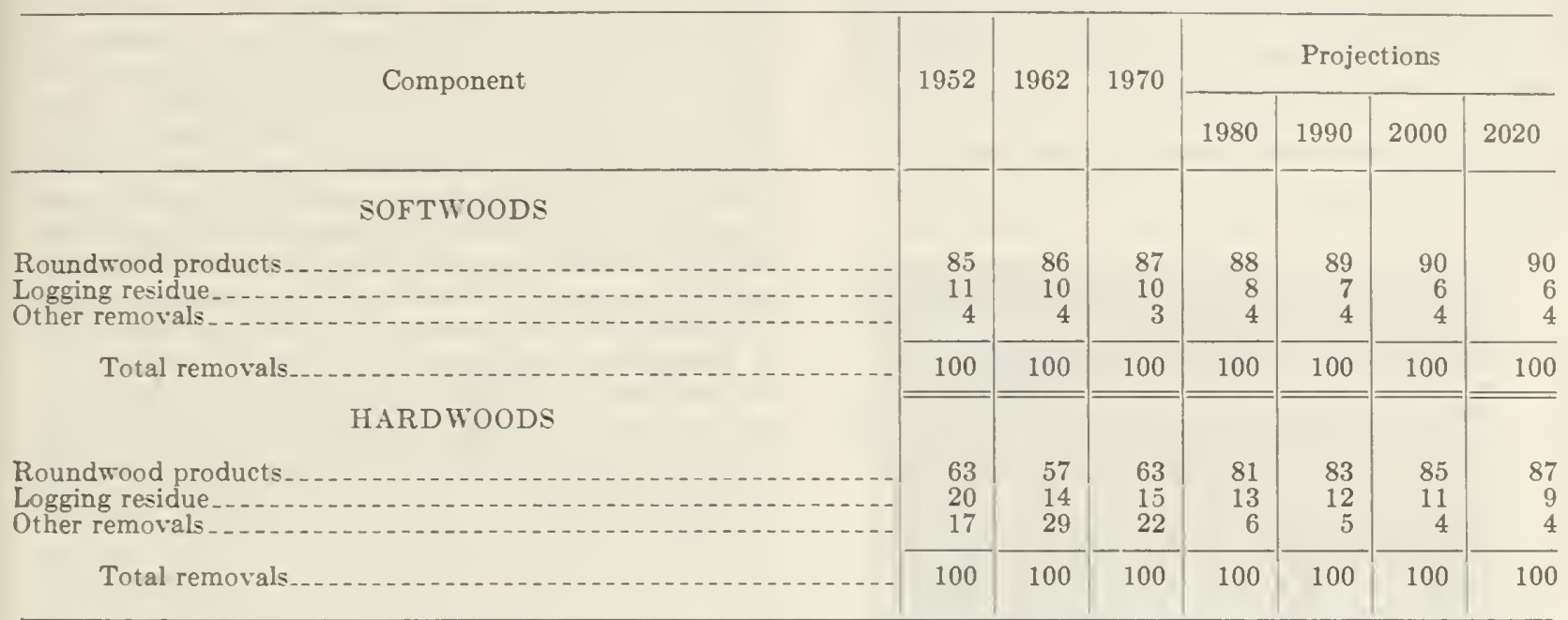

percent by 2000 (table 32 and fig. 20). Under the cutting assumptions outlined earlier, net growth continues to exceed remorals until reaching approximate balance in the year 1990 .

Net growth of hardwood growing stock increased in the $1952-70$ period to 7.9 billion cubic feet, a rise of 30 percent. Howerer, because of the heary stocking attained in most hardwood stands, projected net growth rises only 4 percent more by 1980. Net growth in cubic feet is projected to decline slightly thereafter as a result of heary stocking attained under the specific management assumptions of this section and assumed loss of forest land to other uses.

Estimates of mortality, under the assumption of 1970 levels of management, change relatively little during the projection period. Mortality is in considerable part a reflection of the inventory of old-growth timber held orer the projection period.

For softwoods, mortality is projected to rise slightly from 2.8 billion cubic feet in 1970 . Hardwood mortality also is estimated to rise with increasing stand density from 1.7 billion cubic feet in 1970 (table 32). Mortality of softwood sawtimber, amounting to 11.3 billion board feet in 1970 , is estimated to decline somewhat orer the projection period as old-growth timber stands are harrested.

Trees killed by destructive agents are for the most part widely scattered, and it is assumed that only a small portion of these losses will be salvaged for roundwood products unless management is substantially intensified.

\section{Supplies of Roundwood Products}

In addition to roundrood products cut from growing stock, some logs and bolts also are pro- duced from other sources, including salraged dead timber, sections of rough and rotten trees, and trees growing on noncommercial and nonforest lands. Estimated rolumes of roundwood products in board feet also include an increasing rolume of saw logs from trees having smaller diameters than specified in the standard definition of sawtimber. Increased harresting of such timber is anticipated as thinning operations expand and new chipping headrigs become more common in the sawmill industry.

Nongrowing stock sources provided 7 percent of the total output of softwood roundwood products in 1970 , and 16 percent of all hardwood products (table 32). Many of the trees arailable from these sources are relatively high-quality trees of species such as walnut growing along fence rows or in narrow strips of forests along streams.

In recent decades, volumes of softwood products from nongrowing stock sources has partially offset volumes of logging residues and other remorals, and consequently roundwood production has not differed greatly from growing stock removals (table 32). In the case of hardwoods, however, roundwood production has been much less than removals.

Under the particular assumptions of these base projections, estimates of arailable roundwood supplies in cubic feet of softwoods rise 28 percent between 1970 and 2000 , from 9.0 billion feet to 11.5 billion cubic feet. For hardwoods, projected volumes of available roundwood products that could be harvested under the assumptions of this section rise from 3.2 billion cubic feet in 1970 to 7.4 billion cubic feet by 2000 - a rise of 131 percent.

In the case of sawtimber size material measured in board feet, prospective increases in arailable 
roundwood supplies are much more moderate. For softwood products projected supplies rise from a log harvest of 46.9 billion board feet in 1970 to about 54 billion board feet by 2000 - an increase of 16 percent (table 33 and fig. 22). For hardwoods, the projected increase in available sawtimber size products over the projection period is 67 percent.

Supplies of softwood sawtimber products in the United States, by section

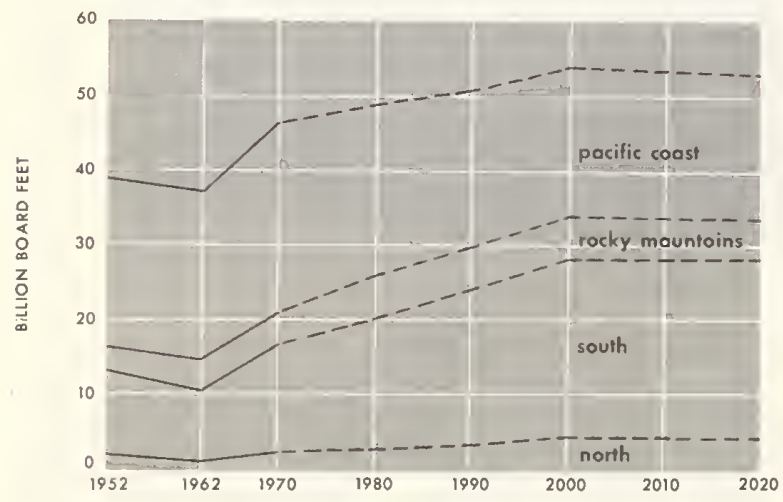

Figure 22
Problems of timber supply and price have been most critical for products derived from larger sizes of timber. Hence these projections in board feet of available roundwood are considered to be more significant than projections of supply in cubic feet, which include all sizes and species of timber and both low- and high-quality trees. Forest industries typically draw much more heavily on larger and better quality sawtimber trees than on other components of the total timber inventory. Thus of the total roundwood produced in 1970 , about 80 percent of the sof twood products, and 65 percent of the hardwood products, came from the saw-log portion of sawtimber trees.

Roundwood supplies by section.-In 1970 the South and the Pacific Coast each supplied about 42 percent of all softwood roundwood products, as shown in table 35 and the following tabulation of the distribution in percent of softwood roundwood produced by section:

\begin{tabular}{|c|c|c|c|c|c|c|c|}
\hline \multirow[b]{2}{*}{ Section } & \multirow[b]{2}{*}{1952} & \multirow[b]{2}{*}{1962} & \multirow[b]{2}{*}{1970} & \multicolumn{4}{|c|}{ Projections } \\
\hline & & & & 1980 & 1990 & 2000 & 2020 \\
\hline $\begin{array}{l}\text { North } \\
\text { South } \\
\text { Rocky Mountains } \\
\text { Pacific Coast.... }\end{array}$ & $\begin{array}{r}8 \\
41 \\
7 \\
44\end{array}$ & $\begin{array}{r}7 \\
37 \\
10 \\
46\end{array}$ & $\begin{array}{r}6 \\
42 \\
10 \\
42\end{array}$ & $\begin{array}{r}8 \\
46 \\
10 \\
36\end{array}$ & $\begin{array}{r}9 \\
49 \\
10 \\
32\end{array}$ & $\begin{array}{l}10 \\
50 \\
11 \\
29\end{array}$ & $\begin{array}{l}10 \\
50 \\
10 \\
30\end{array}$ \\
\hline Total United States..... & 100 & 100 & 100 & 100 & 100 & 100 & 100 \\
\hline
\end{tabular}

TABLE 35.-Supplies of roundwood products from U.S. forests, by section and species group, 1952, 1962, and 1970, with projections to 2020

[Million cubic feet]

Section and species group

\begin{tabular}{|c|c|c|c|c|c|c|}
\hline \multirow{2}{*}{1952} & \multirow{2}{*}{1962} & \multirow{2}{*}{1970} & \multicolumn{4}{|c|}{ Projections } \\
\hline & & & 1980 & 1990 & 2000 & 2020 \\
\hline $\begin{array}{r}603 \\
1,378\end{array}$ & $\begin{array}{r}513 \\
1,299\end{array}$ & $\begin{array}{r}579 \\
1,409\end{array}$ & $\begin{array}{r}803 \\
2,428\end{array}$ & $\begin{array}{r}942 \\
3,165\end{array}$ & $\begin{array}{l}1,109 \\
3,845\end{array}$ & $\begin{array}{l}1,113 \\
3,799\end{array}$ \\
\hline 1,981 & 1,812 & 1,988 & 3,231 & 4,107 & 4,954 & 4,912 \\
\hline $\begin{array}{l}3,048 \\
1,935\end{array}$ & $\begin{array}{l}2,677 \\
1,606\end{array}$ & $\begin{array}{l}3,745 \\
1,668\end{array}$ & $\begin{array}{l}4,622 \\
2,651\end{array}$ & $\begin{array}{l}5,217 \\
3,009\end{array}$ & $\begin{array}{l}5,768 \\
3,327\end{array}$ & $\begin{array}{l}5,788 \\
3,416\end{array}$ \\
\hline 4,983 & 4,283 & 5,413 & 7,273 & 8,226 & 9,095 & 9,204 \\
\hline $\begin{array}{r}495 \\
11\end{array}$ & $\begin{array}{r}684 \\
14\end{array}$ & $\begin{array}{r}852 \\
11\end{array}$ & $\begin{array}{r}1,044 \\
46\end{array}$ & $\begin{array}{r}1,139 \\
65\end{array}$ & $\begin{array}{r}1,275 \\
89\end{array}$ & $\begin{array}{r}1,231 \\
89\end{array}$ \\
\hline 506 & 698 & 863 & 1,090 & 1,204 & 1,364 & 1,320 \\
\hline $\begin{array}{r}3,239 \\
35\end{array}$ & $\begin{array}{r}3,324 \\
62\end{array}$ & $\begin{array}{r}3,805 \\
85\end{array}$ & $\begin{array}{r}3,642 \\
82\end{array}$ & $\begin{array}{r}3,376 \\
96\end{array}$ & $\begin{array}{r}3,332 \\
105\end{array}$ & $\begin{array}{r}3,491 \\
114\end{array}$ \\
\hline 3,274 & 3,386 & 3,890 & 3,724 & 3,472 & 3,437 & 3,605 \\
\hline $\begin{array}{l}7,387 \\
3,358 \\
\end{array}$ & $\begin{array}{l}7,199 \\
2,980\end{array}$ & $\begin{array}{l}8,981 \\
3,173\end{array}$ & $\begin{array}{r}10,111 \\
5,207\end{array}$ & $\begin{array}{r}10,675 \\
6,334\end{array}$ & $\begin{array}{r}11,484 \\
7,365\end{array}$ & $\begin{array}{r}11,622 \\
7,418\end{array}$ \\
\hline 10,745 & 10,179 & 12,154 & 15,318 & 17,009 & 18,849 & 19,040 \\
\hline
\end{tabular}


Dependence on the South as a source of softrrood roundwood supplies is estimated to continue to increase to half the Nation's total supply, whereas the share of U.S. production coming from the West is projected to decline rather sharply as remaining old-growth timber is harrested.

The South also prorided somerhat more than half of the hardwood products harrested in the United States in 1970 (table 35). Over the next few decades, howerer, prospectively arailable supplies of hardwoods increase more in the North than in other sections. In terms of cubic feet, the North consequently accounts for orer half the projected supply of hardwood products in 2000 .

The distribution of roundwood production in terms of board feet is quite different from output in cubic feet. Because of the larger a verage size of timber in the West, the Pacific Coast region produced 43 percent of the total board footage of roundwood products in 1970, whereas the South accourted for only 34 percent (table 36 and fig. 22). As in the case of cubic feet of products, howerer, projections show a reversal of this situation, with 42 percent of the projected total output in 2000 coming from the South, compared with 28 percent from the Pacific Coast.
Roundwood supplies by owner class.-Farm and miscellaneous private ownerships have long been the principal source of roundwood products. Thus of the 12.2 billion cubic feet of roundwood products harrested in 1970 , nearly half was derived from these farm and miscellaneous private holdings (table 37). About one-fourth of the total came from land owned by forest industries. Public lands also contributed about a quarter of the total, as shown by the following tabulation of percent of cubic feet of roundwood products derived from each owner class:

\begin{tabular}{|c|c|c|c|c|c|c|c|}
\hline \multirow[b]{2}{*}{ Owner class } & \multirow[b]{2}{*}{1952} & \multirow[b]{2}{*}{1962} & \multirow[b]{2}{*}{1970} & \multicolumn{4}{|c|}{ Projections } \\
\hline & & & & 1980 & 1990 & 2000 & 2020 \\
\hline $\begin{array}{l}\text { National Forest. } \\
\text { Other public }\end{array}$ & $\begin{array}{l}8 \\
5\end{array}$ & $\begin{array}{r}16 \\
7\end{array}$ & $\begin{array}{r}17 \\
7\end{array}$ & $\begin{array}{r}17 \\
7\end{array}$ & $\begin{array}{r}16 \\
8\end{array}$ & $\begin{array}{r}15 \\
9\end{array}$ & $\begin{array}{r}15 \\
9\end{array}$ \\
\hline Forest industry & 30 & 28 & 28 & 22 & 20 & 19 & 21 \\
\hline Farm and miscellaneous private.. & 57 & 49 & 48 & 54 & 56 & 57 & \\
\hline All owners & 100 & 100 & 100 & 100 & 100 & 100 & 100 \\
\hline
\end{tabular}

In terms of board feet, the distribution of roundwood harrested shows a heavier concentration of cutting on forest industry and National Forest lands (table 38 and fig. 23)-an indication of the relative concentration of larger diameter timber inventories in these holdings.

TABLE 36.-Supplies of sawtimber products from U.S. forests, by section and species group, 1952, 1962, and 1970 , with projections to 2020

[Million board feet]

\begin{tabular}{|c|c|c|c|c|c|c|c|}
\hline \multirow{2}{*}{ Section and species group } & \multirow{2}{*}{1952} & \multirow{2}{*}{1962} & \multirow{2}{*}{1970} & \multicolumn{4}{|c|}{ Projections } \\
\hline & & & & 1980 & 1990 & 2000 & 2020 \\
\hline $\begin{array}{l}\text { North: } \\
\text { Softwoods. } \\
\text { Hard woods. }\end{array}$ & $\begin{array}{l}1,898 \\
4,300\end{array}$ & $\begin{array}{l}1,488 \\
4,430\end{array}$ & $\begin{array}{l}2,115 \\
6,083\end{array}$ & $\begin{array}{l}2,390 \\
7,648\end{array}$ & $\begin{array}{l}3,014 \\
9,997\end{array}$ & $\begin{array}{r}3,793 \\
12,139\end{array}$ & $\begin{array}{r}3,793 \\
11,994\end{array}$ \\
\hline Total _. & 6,198 & 5,918 & 8,197 & 10,038 & 13,011 & 15,932 & 15,787 \\
\hline $\begin{array}{l}\text { South: } \\
\text { Softwoods_..... } \\
\text { Hardwoods.... }\end{array}$ & $\begin{array}{r}11,337 \\
7,690\end{array}$ & $\begin{array}{l}9,292 \\
6,139\end{array}$ & $\begin{array}{r}14,366 \\
5,914\end{array}$ & $\begin{array}{r}17,586 \\
7,368\end{array}$ & $\begin{array}{r}20,882 \\
7,602\end{array}$ & $\begin{array}{r}23,836 \\
7,752\end{array}$ & $\begin{array}{r}23,919 \\
7,830\end{array}$ \\
\hline Total & 19,027 & 15,431 & 20,280 & 24,954 & 28,484 & 31,588 & 31,749 \\
\hline $\begin{array}{l}\text { Rocky Mountains: } \\
\text { Softwoods...... } \\
\text { Hardwoods.....- }\end{array}$ & $\begin{array}{r}3,126 \\
15\end{array}$ & $\begin{array}{r}4,189 \\
19\end{array}$ & $\begin{array}{r}5,273 \\
13\end{array}$ & $\begin{array}{r}5,585 \\
108\end{array}$ & $\begin{array}{r}5,648 \\
148\end{array}$ & $\begin{array}{r}5,915 \\
195\end{array}$ & $\begin{array}{r}5,511 \\
191\end{array}$ \\
\hline Total & 3,141 & 4,208 & 5,286 & 5,693 & 5,796 & 6,110 & 5,702 \\
\hline $\begin{array}{l}\text { Pacific Coast: } \\
\text { Softwoods-_... } \\
\text { Hardwoods.... }\end{array}$ & $\begin{array}{r}22,439 \\
122\end{array}$ & $\begin{array}{r}22,540 \\
201\end{array}$ & $\begin{array}{r}25,182 \\
322\end{array}$ & $\begin{array}{r}23,264 \\
380\end{array}$ & $\begin{array}{r}21,323 \\
435\end{array}$ & $\begin{array}{r}20,647 \\
469\end{array}$ & 20, 722 \\
\hline Total _- & 22,561 & 22,741 & 25,504 & 23,644 & 21,758 & 21,116 & 21,225 \\
\hline $\begin{array}{l}\text { Total United States: } \\
\text { Softwoods-_...-..- } \\
\text { Hardwoods.-...-. }\end{array}$ & $\begin{array}{l}38,800 \\
12,127\end{array}$ & $\begin{array}{l}37,510 \\
10,788\end{array}$ & $\begin{array}{l}46,936 \\
12,331\end{array}$ & $\begin{array}{l}48,825 \\
15,505\end{array}$ & $\begin{array}{l}50,867 \\
18,182\end{array}$ & $\begin{array}{l}54,191 \\
20,556\end{array}$ & $\begin{array}{l}53,945 \\
20,518\end{array}$ \\
\hline Total ....... & 50,927 & 48,298 & 59,267 & 64,330 & 69,049 & 74,747 & 74,463 \\
\hline
\end{tabular}


TABLE 37.-Supplies of roundwood products from U.S. forests, by owner class and species group, 1952, 1962, and 1970, with projections to 2020

[Million cubic feet]

\begin{tabular}{|c|c|c|c|c|c|c|c|}
\hline \multirow{2}{*}{ Owner class and species group } & \multirow{2}{*}{1952} & \multirow{2}{*}{1962} & \multirow{2}{*}{1970} & \multicolumn{4}{|c|}{ Projections } \\
\hline & & & & 1980 & 1990 & 2000 & 2020 \\
\hline $\begin{array}{l}\text { National Forest: } \\
\text { Softwoods } \\
\text { Hardwoods }\end{array}$ & $\begin{array}{r}838 \\
60\end{array}$ & $\begin{array}{r}1,605 \\
79\end{array}$ & $\begin{array}{r}1,926 \\
90\end{array}$ & $\begin{array}{r}2,309 \\
210\end{array}$ & $\begin{array}{r}2,427 \\
287\end{array}$ & $\begin{array}{r}2,547 \\
370\end{array}$ & $\begin{array}{r}2,551 \\
378\end{array}$ \\
\hline Total__... & 898 & 1,684 & 2,016 & 2,519 & 2,714 & 2,917 & 2,929 \\
\hline $\begin{array}{l}\text { Other public: } \\
\text { Softwoods } \\
\text { Hardwoods...- }\end{array}$ & $\begin{array}{l}403 \\
125\end{array}$ & $\begin{array}{l}547 \\
125\end{array}$ & $\begin{array}{l}685 \\
149\end{array}$ & $\begin{array}{l}812 \\
318\end{array}$ & $\begin{array}{l}943 \\
433\end{array}$ & $\begin{array}{r}1,089 \\
548\end{array}$ & 1, 142 \\
\hline Total _. & 528 & 672 & 834 & 1,130 & 1,376 & 1,637 & 1,689 \\
\hline $\begin{array}{l}\text { Forest industry: } \\
\text { Softwoods_._._. } \\
\text { Hardwoods_._._- }\end{array}$ & $\begin{array}{r}2,700 \\
486\end{array}$ & $\begin{array}{r}2,237 \\
597\end{array}$ & $\begin{array}{r}2,918 \\
512\end{array}$ & $\begin{array}{r}2,759 \\
619\end{array}$ & $\begin{array}{r}2,635 \\
725\end{array}$ & $\begin{array}{r}2,805 \\
836\end{array}$ & $\begin{array}{r}2,993 \\
902\end{array}$ \\
\hline Total _. & 3,186 & 2,834 & 3,430 & 3,378 & 3,360 & 3,641 & 3,895 \\
\hline $\begin{array}{l}\text { Farm and miscellaneous private: } \\
\text { Softwoods } \\
\text { Hardwoods }\end{array}$ & $\begin{array}{l}3,445 \\
2,688\end{array}$ & $\begin{array}{l}2,810 \\
2,179\end{array}$ & $\begin{array}{l}3,451 \\
2,423\end{array}$ & $\begin{array}{l}4,230 \\
4,061\end{array}$ & $\begin{array}{l}4,670 \\
4,888\end{array}$ & $\begin{array}{l}5,043 \\
5,611\end{array}$ & $\begin{array}{l}4,936 \\
5,592\end{array}$ \\
\hline Total $\ldots \ldots \ldots$ & 6,133 & 4,989 & 5,874 & 8,291 & 9,558 & 10,654 & 10,528 \\
\hline 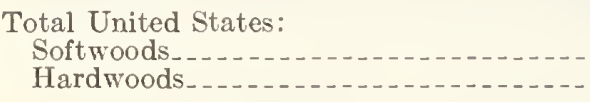 & $\begin{array}{l}7,387 \\
3,358\end{array}$ & $\begin{array}{l}7,199 \\
2,980\end{array}$ & $\begin{array}{l}8,981 \\
3,173\end{array}$ & $\begin{array}{r}10,111 \\
5,207\end{array}$ & $\begin{array}{r}10,675 \\
6,334\end{array}$ & $\begin{array}{r}11,484 \\
7,365\end{array}$ & $\begin{array}{r}11,622 \\
7,418\end{array}$ \\
\hline Total _- & 10,745 & 10,179 & 12,154 & 15,318 & 17,009 & 18,849 & 19,040 \\
\hline
\end{tabular}

The projections of this chapter indicate that relatively constant proportions of roundwood harvests will be maintained from National Forests and other public owners. The share of output from forest industry lands is projected to drop about 7 percentage points, with farm and miscellaneous owners sharing a corresponding increase.

\section{Timber Inventories}

Hardwood growing stock inventories increased substantially from 1952 through 1970 at an average annual rate of 1.45 percent for growing stock and 1.06 percent for sawtimber (tables 32 and 33 ).

Softwood growing stock inventories increased more slowly at an average of 0.28 percent annually. Softwood sawtimber inventories, on the other hand, decreased 0.21 percent annually as a result of relatively heavy cutting of this preferred raw material and the limited growth obtained in western old-growth stands.

Under the management and related assumptions adopted in this section, projected inventories of softwood growing stock remain roughly constant, while softwood sawtimber inventories drop about
15 percent. Hardwood inventories in both cubic feet and board feet continue to rise between 1970 and 2020 , although at a considerably slower rate than previously.

As indicated earlier, alternative projections related to different price assumptions are presented later in this chapter.

\section{PROJECTIONS OF TIMBER SUPPLIES IN THE SOUTH}

Harvesting of timber in the South increased sharply in the 1960's along with rising timber growth and inventories. Major construction of new pulping and capacity, the rise of a major softwood plywood industry, and expansion of a modernized lumber industry led to more than a 25 percent increase in output of industrial wood products. In 1970 the South accounted for 45 percent of the Nation's output of roundwood products and net growth of timber. The outlook for continued expansion of softwood timber supplies and the potentials for intensification of management emphasize the major importance of this region, particularly for softwoods. 
TABLE 38.-Supplies of sawtimber products from U.S. forests, by owner class and species group, 1952, 1962 , and 1970, with projections to 2020

[Million board feet]

\begin{tabular}{|c|c|c|c|c|c|c|c|}
\hline \multirow{2}{*}{ Owner class and species group } & \multirow{2}{*}{1952} & \multirow{2}{*}{1962} & \multirow{2}{*}{1970} & \multicolumn{4}{|c|}{ Projections } \\
\hline & & & & 1980 & 1990 & 2000 & 2020 \\
\hline $\begin{array}{l}\text { National Forest: } \\
\text { Softwoods } \\
\text { Hardwoods }\end{array}$ & $\begin{array}{r}5,564 \\
217\end{array}$ & $\begin{array}{r}10,402 \\
332\end{array}$ & $\begin{array}{r}12,548 \\
359\end{array}$ & $\begin{array}{r}14,163 \\
634\end{array}$ & $\begin{array}{r}14,672 \\
910\end{array}$ & $\begin{array}{r}15,228 \\
1,193\end{array}$ & $\begin{array}{r}14,812 \\
1,194\end{array}$ \\
\hline Total _- & 5,781 & 10,734 & 12,906 & 14,797 & 15,582 & 16,421 & 16,006 \\
\hline $\begin{array}{l}\text { Other public: } \\
\text { Sof twoods.-...-- } \\
\text { Hardwoods...-.- }\end{array}$ & $\begin{array}{r}2,323 \\
365\end{array}$ & $\begin{array}{r}3,348 \\
339 \\
\end{array}$ & $\begin{array}{r}4,236 \\
497\end{array}$ & $\begin{array}{r}4,594 \\
879\end{array}$ & $\begin{array}{l}5,140 \\
1,273\end{array}$ & $\begin{array}{l}5,790 \\
1,679 \\
\end{array}$ & $\begin{array}{l}5,907 \\
1,666\end{array}$ \\
\hline Total. & 2,688 & 3,687 & 4,733 & 5,473 & 6,413 & 7,469 & 7,573 \\
\hline $\begin{array}{l}\text { Forest industry: } \\
\text { Softwoods...... } \\
\text { Hardwoods.... }\end{array}$ & $\begin{array}{r}16,003 \\
1,572\end{array}$ & $\begin{array}{r}12,9 \times 4 \\
1,724\end{array}$ & $\begin{array}{r}16,352 \\
1,774\end{array}$ & $\begin{array}{r}14,001 \\
1,967\end{array}$ & $\begin{array}{r}12,896 \\
2,213\end{array}$ & $\begin{array}{r}13,321 \\
2,456\end{array}$ & $\begin{array}{r}13,865 \\
2,615\end{array}$ \\
\hline Total $\ldots$ & 17,575 & 14,688 & 18,126 & 15,968 & 15,109 & 15,777 & 16,480 \\
\hline $\begin{array}{l}\text { Farm and miscellaneous private: } \\
\text { Softwoods... } \\
\text { Hardwoods. }\end{array}$ & $\begin{array}{r}14,910 \\
9,973 \\
\end{array}$ & $\begin{array}{r}10,796 \\
8,393 \\
\end{array}$ & $\begin{array}{r}13,801 \\
9,701\end{array}$ & $\begin{array}{l}16,068 \\
12,025 \\
\end{array}$ & $\begin{array}{l}18,158 \\
13,786\end{array}$ & $\begin{array}{l}19,851 \\
15,228\end{array}$ & $\begin{array}{l}19,360 \\
15,043 \\
\end{array}$ \\
\hline Total... & 24,883 & 19,189 & 23,502 & 28,093 & 31,944 & 35,079 & 34,403 \\
\hline $\begin{array}{l}\text { Total United States: } \\
\text { Softwoods } \\
\text { Hardwoods................... }\end{array}$ & $\begin{array}{l}38,800 \\
12,127 \\
\end{array}$ & $\begin{array}{l}37,510 \\
10,788 \\
\end{array}$ & $\begin{array}{l}46,936 \\
12,331 \\
\end{array}$ & $\begin{array}{l}48,825 \\
15,505\end{array}$ & $\begin{array}{l}50,867 \\
18,182 \\
\end{array}$ & $\begin{array}{l}54,191 \\
20,556\end{array}$ & $\begin{array}{l}53,945 \\
20,518\end{array}$ \\
\hline Total _.. & 50.927 & 48,298 & 59,267 & 64,330 & 69,049 & 74,747 & 74,463 \\
\hline
\end{tabular}

Supplies of softwood sawtimber products in the United States, by owner class

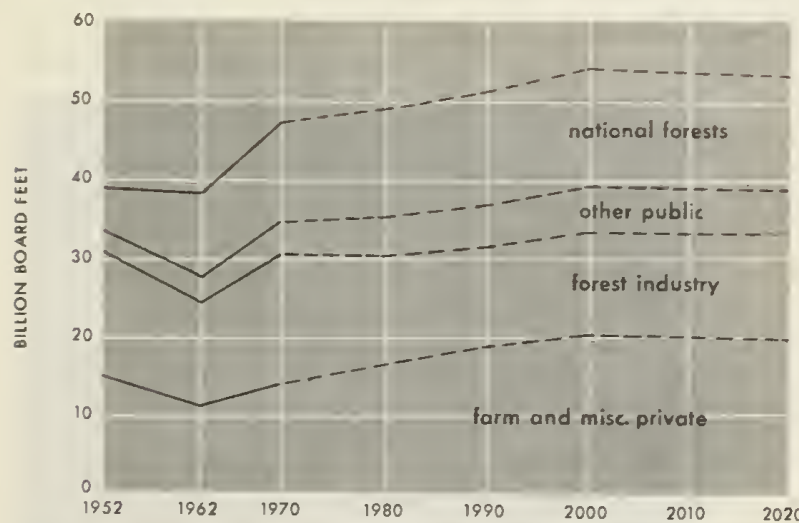

Figure 23

\section{Trends in Forest Area}

Recent trends in forest areas and changing land-use patterns in the South point to a smaller area of forest land available for timber production in the future.
Between 1952 and 1962, gains in commercial timberland exceeded losses by some 7.8 million acres, but during the 1962-70 period this trend was reversed, with a net loss of some 7.4 million acres (table 39). Half of the southern States showed decreases in commercial timberland in this recent period, most notably in the Delta States of Mississippi, Arkansas, and Louisiana. Large areas of forest land in these areas have been cleared for agriculture. Reservoirs have inundated sizable areas of choice hardwood lands capable of producing sweetgum, tupelo, and other sof ttextured hardwoods. In contrast, most lands reverting to forests have been eroded uplands.

While additional shifts from forest to nonforest uses can be expected, a large portion of the idle farm land left in the wake of rural-to-urban migration has now either reverted to trees or has been planted to pine. With a continuation of the trend toward a larger and more stable agricultural land base in the South, additional reversions of agricultural land to forest do not appear likely to be significant.

In these base projections it has therefore been assumed that commercial timberland will continue to decrease, although at a much slower rate than 
Table 39.-Area of commercial timberland in the South, by owner class, 1952, 1962, and 1970, with projections to 2020

[Million acres]

\begin{tabular}{|c|c|c|c|c|c|c|c|}
\hline \multirow{2}{*}{ Owner class } & \multirow{2}{*}{1952} & \multirow{2}{*}{1962} & \multirow{2}{*}{1970} & \multicolumn{4}{|c|}{ Projections } \\
\hline & & & & 1990 & 1990 & 2000 & 2020 \\
\hline $\begin{array}{l}\text { National Forest } \\
\text { Otber public } \\
\text { Forest industry } \\
\text { Farm and miscellaneous private. }\end{array}$ & $\begin{array}{r}10.4 \\
6.4 \\
32.1 \\
143.2\end{array}$ & $\begin{array}{r}10.7 \\
6.5 \\
34.1 \\
148.7\end{array}$ & $\begin{array}{r}10.8 \\
6.5 \\
35.3 \\
139.9\end{array}$ & $\begin{array}{r}10.7 \\
6.4 \\
36.0 \\
138.0\end{array}$ & $\begin{aligned} 10.6 \\
6.4 \\
36.6 \\
136.1\end{aligned}$ & $\begin{array}{r}\text { 10. } 4 \\
6.3 \\
37.3 \\
134.3\end{array}$ & $\begin{array}{r}10.2 \\
6.2 \\
38.6 \\
130.5\end{array}$ \\
\hline All owners_.. & 192. 1 & 199.9 & 192.5 & 191. 1 & 189. 7 & 188. 3 & 185.5 \\
\hline
\end{tabular}

in the 1960's. During the next 50 years projected areas of commercial timberland decline an average of about 140 thousand acres annually.

It is also estimated that a major part of the loss in commercial timberland will take place on farm and miscellaneous private ownerships-which make up the bulk of the commercial timberlands in this region. For the most part, these holdings of farmers and a wide variety of other owners are in small tracts and many are adjacent to areas likely to experience further urban or other development. In keeping with recent trends, the area in this owner class is assumed to decrease about 7 percent by 2020 .

On the other hand, the upward trend in forest area owned by forest industries is assumed to continue. Moderate declines are assumed in areas of commercial timberland in National Forests and other public ownerships, although in view of growing demands for nontimber uses, reductions could be greater than assumed in these projections.

\section{Timber Removals}

Removals of softwood growing stock in the South increased substantially in the period 195270 , while removals of hardwoods showed little change (table 40 and fig. 24).

Under the assumptions of 1970 management levels and a rise in removals to equal net growth by 2000 , projected softwood removals increase about 45 percent between 1970 and 2020 , compared to 44 percent for hardwoods. These estimates reflect a general emphasis on management of forests for softwoods rather than hardwoods. Many stands tend to revert to hardwoods following harvesting of pine, and hence without such management hardwoods would increase faster than softwoods.

Sawtimber removals.-Removals of softwood sawtimber are estimated to increase from 15 billion board feet in 1970 to 24 billion feet by 2000 (table 41 and fig. 25). This would represent a rise of 59 percent, compared to 47 percent for projected removals from softwood growing stock,
Net growth and removals of growing stock in the South

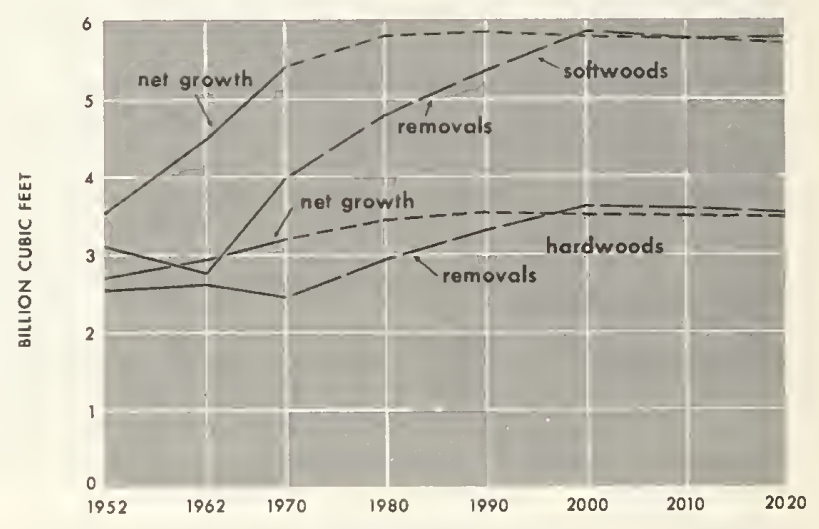

Figure 24

Net growth and removals of sawtimber in the South

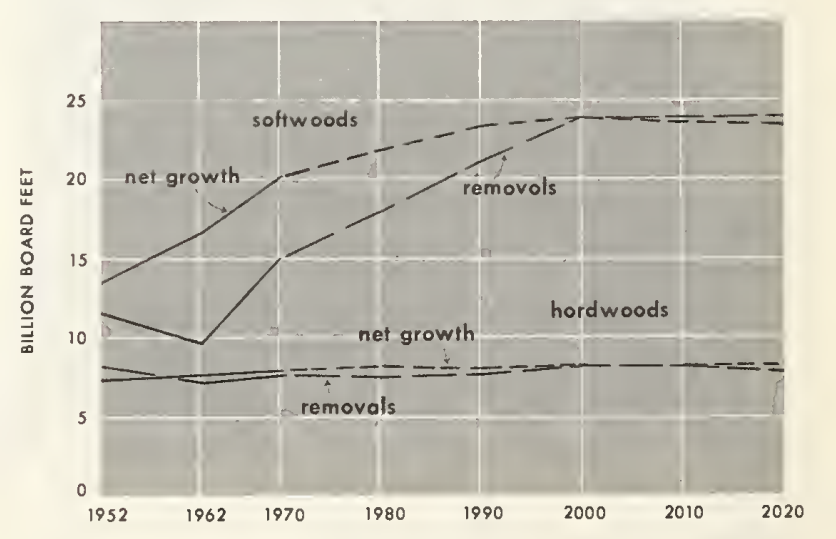

Figure 25

largely as a result of widespread development of sawtimber in both natural stands and plantations. 
TABLE 40.-Timber removals, net growth, mortality, supplies of roundwood products, and inventories in the South, 1952, 1962, and 1970, with projections (1970 level of management) ${ }^{1}$ to 2020

[Million cubic feet]

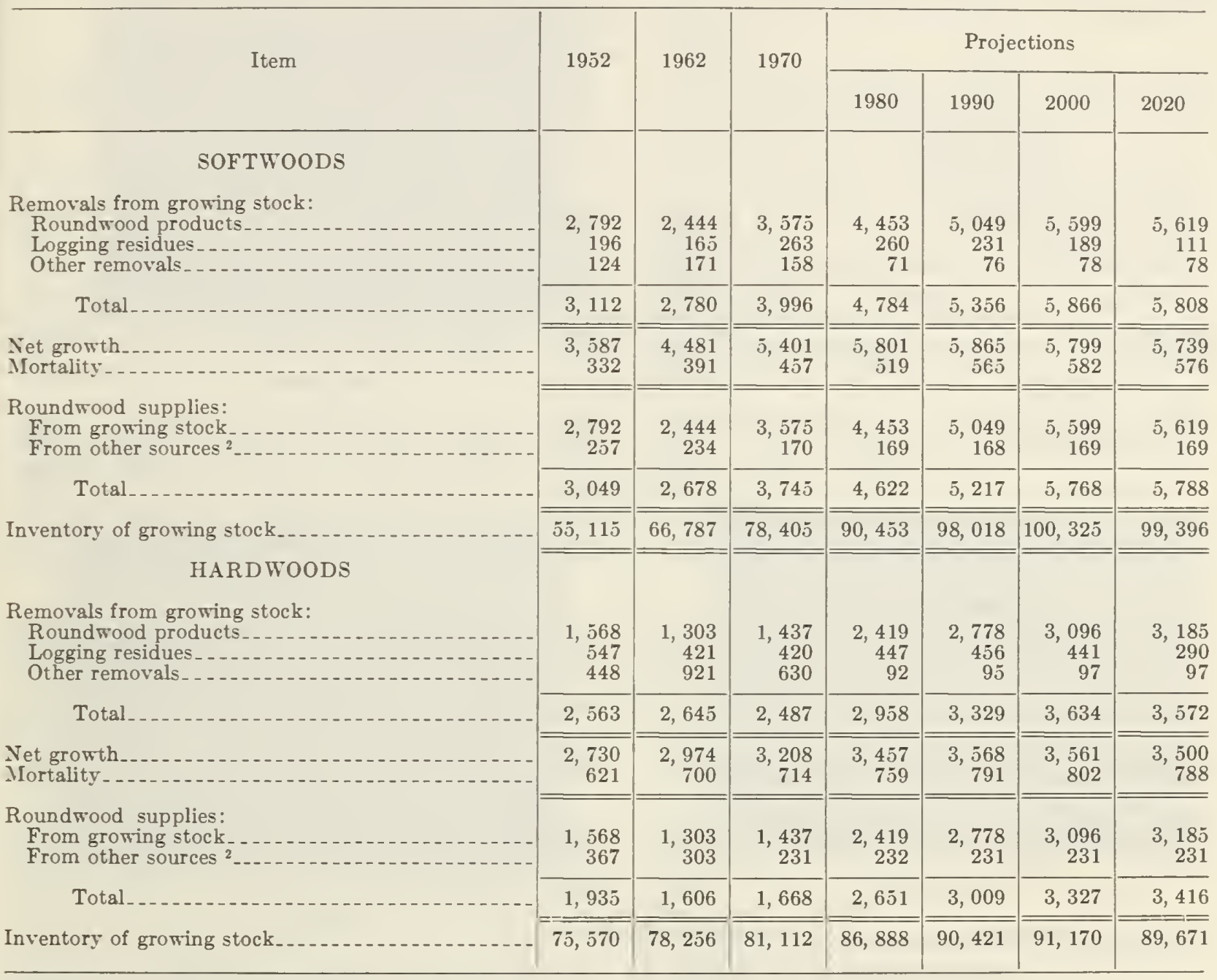

${ }^{1}$ Plus other area and harvesting assumptions specified in this chapter.

${ }^{2}$ Includes roundwood products from rough and rotten trees, dead trees, and trees on noncommercial and non-

On the other hand, very little change is projected in arailable removals of hardwood sawtimber, in spite of a sizable projected increase in growing stock remorals. This difference reflects the heary cutting of larger diameters and the concentration of future volumes in smaller size trees.

Removals by size of material.-About threefourths of the softwood timber remored in 1970 was derived from trees above 9.0 inches in diameter (fig. 26). Trees 5-9 inches in diameter provided the remaining one-fourth of these removals (table 42 ). forest land.

Note: Estimates are for trend levels and consequently may differ from actual figures for the specified years.

Material in the saw-log portion of softwood sawtimber trees-of key importance for lumber and plywood production-represented about 66 percent of the estimated total removals in 1970 . This proportion of saw-log material is estimated to remain roughly the same in the projection period with the cutting rates assumed in this section.

In the case of hardwoods, removals from the saw-log portion of sawtimber trees in 1970 represented only about half the total removals (fig. 27). The principal change in projected remorals is a sizable gain in volume and proportion of trees 
TABLE 41.-Sawtimber removals, net growth, mortality, supplies of roundwood products, and inventories in the South, 1952, 1962, and 1970, with projections (1970 level of management) ${ }^{1}$ to 2020

[Million board feet]

\begin{tabular}{|c|c|c|c|c|c|c|c|}
\hline \multirow{2}{*}{ Item } & \multirow{2}{*}{1952} & \multirow{2}{*}{1962} & \multirow{2}{*}{1970} & \multicolumn{4}{|c|}{ Projections } \\
\hline & & & & 1980 & 1990 & 2000 & 2020 \\
\hline SOFTWOODS & & & & & & & \\
\hline $\begin{array}{l}\text { Removals from sawtimber: } \\
\text { Roundwood products } \\
\text { Logging residues. } \\
\text { Other removals }\end{array}$ & $\begin{array}{r}10,879 \\
543 \\
459\end{array}$ & $\begin{array}{r}8,909 \\
371 \\
565\end{array}$ & $\begin{array}{r}13,868 \\
567 \\
611\end{array}$ & $\begin{array}{r}17,090 \\
541 \\
255\end{array}$ & $\begin{array}{r}20,384 \\
475 \\
278\end{array}$ & $\begin{array}{r}23,338 \\
351 \\
286\end{array}$ & $\begin{array}{r}23,421 \\
81 \\
286\end{array}$ \\
\hline Total_. & 11,881 & 9,845 & 15,046 & 17,886 & 21,137 & 23,975 & 23,788 \\
\hline $\begin{array}{l}\text { Net growth } \\
\text { Mortality }\end{array}$ & $\begin{array}{r}13,638 \\
883\end{array}$ & $\begin{array}{r}16,668 \\
1,053\end{array}$ & $\begin{array}{r}20,096 \\
1,266\end{array}$ & $\begin{array}{r}21,967 \\
1,563\end{array}$ & $\begin{array}{r}23,310 \\
1,724\end{array}$ & $\begin{array}{r}23,745 \\
1,783\end{array}$ & $\begin{array}{r}23,549 \\
1,766\end{array}$ \\
\hline $\begin{array}{l}\text { Roundwood supplies: } \\
\text { From sawtimber. } \\
\text { From other sources }{ }^{2}\end{array}$ & $\begin{array}{r}10,879 \\
457\end{array}$ & $\begin{array}{r}8,909 \\
383\end{array}$ & $\begin{array}{r}13,868 \\
498\end{array}$ & $\begin{array}{r}17,090 \\
497\end{array}$ & $\begin{array}{r}20,384 \\
498\end{array}$ & $\begin{array}{r}23,338 \\
498\end{array}$ & $\begin{array}{r}23,421 \\
498\end{array}$ \\
\hline Total_. & 11,336 & 9,292 & 14,366 & 17,587 & 20,882 & 23,836 & 23,919 \\
\hline Inventory of sawtimber... & 185,571 & 230,398 & 275,876 & 323,285 & 354,751 & 365,081 & 362,093 \\
\hline HARDWOODS & & & & & & & \\
\hline $\begin{array}{l}\text { Removals from sawtimber: } \\
\text { Roundwood products } \\
\text { Logging residues } \\
\text { Other removals }\end{array}$ & $\begin{array}{r}7,288 \\
433 \\
548\end{array}$ & $\begin{array}{r}5,743 \\
561 \\
1,042\end{array}$ & $\begin{array}{r}5,425 \\
692 \\
1,678\end{array}$ & $\begin{array}{r}6,877 \\
621 \\
228\end{array}$ & $\begin{array}{r}7,111 \\
573 \\
232\end{array}$ & $\begin{array}{r}7,261 \\
520 \\
233\end{array}$ & $\begin{array}{r}7,340 \\
315 \\
233\end{array}$ \\
\hline Total & 8,269 & 7,346 & 7,795 & 7,726 & 7,916 & 8,014 & 7,888 \\
\hline $\begin{array}{l}\text { Net growth } \\
\text { Mortality }\end{array}$ & $\begin{array}{l}7,592 \\
1,743\end{array}$ & $\begin{array}{l}7,625 \\
1,982\end{array}$ & $\begin{array}{l}7,932 \\
1,943\end{array}$ & $\begin{array}{l}8,025 \\
1,995\end{array}$ & $\begin{array}{l}7,971 \\
2,019\end{array}$ & $\begin{array}{l}7,852 \\
2,013\end{array}$ & $\begin{array}{l}7,723 \\
1,981\end{array}$ \\
\hline $\begin{array}{l}\text { Roundwood supplies: } \\
\text { From sawtimber-.-.- } \\
\text { From other sources.-. }\end{array}$ & $\begin{array}{r}7,288 \\
402\end{array}$ & $\begin{array}{r}5,743 \\
396\end{array}$ & $\begin{array}{r}5,425 \\
489\end{array}$ & $\begin{array}{r}6,877 \\
491\end{array}$ & 7, 111 & $\begin{array}{r}7,261 \\
491\end{array}$ & $\begin{array}{r}7,340 \\
490\end{array}$ \\
\hline Total.. & 7,690 & 6,139 & 5,914 & 7,368 & 7,602 & 7,752 & 7,830 \\
\hline Inventory of sawtimber... & 205,496 & 204,530 & 207,975 & 212,107 & 213,691 & 212,951 & 209,611 \\
\hline
\end{tabular}

1 Plus other area and harvesting assumptions specified in this chapter.

2 Includes roundwood products from rough and rotten trees, dead trees, and trees on noncommercial and nonforest land.

$5-11$ inches in diameter, with little change in volumes of available saw-log material (table 42 ).

\section{Supplies of Roundwood Products}

Of the total removals of growing stock in 1970 , 89 percent of the softwoods and 58 percent of the hardwoods were utilized as wood products (tables 40 and 43). About 7 percent of the softwood removals and 17 percent of the hardwood removals were left in the woods as logging residues. Other timber removals attributable to land clearing or other withdrawals of land and timber from the timber growing base accounted for 4 percent of
Note: Fstimates are for trend levels and consequently may differ from actual figures for the specified years.

all softwood removals in 1970 , and 25 percent of all hardwood removals.

Partially offsetting nonproduct removals are products coming from timber that does not qualify as growing stock, such as rough and rotten trees and trees from land not considered commercial timberland. In 1970, about 5 percent of the softwood roundwood produced and 14 percent of hardwood roundwood products came from these nongrowing stock sources (table 40).

The net result of these partially offsetting factors was that in 1970 total output of roundwood products of 3.7 billion cubic feet of softwood growing 
Net growth and removals of softwood growing slock in the South, by size of material

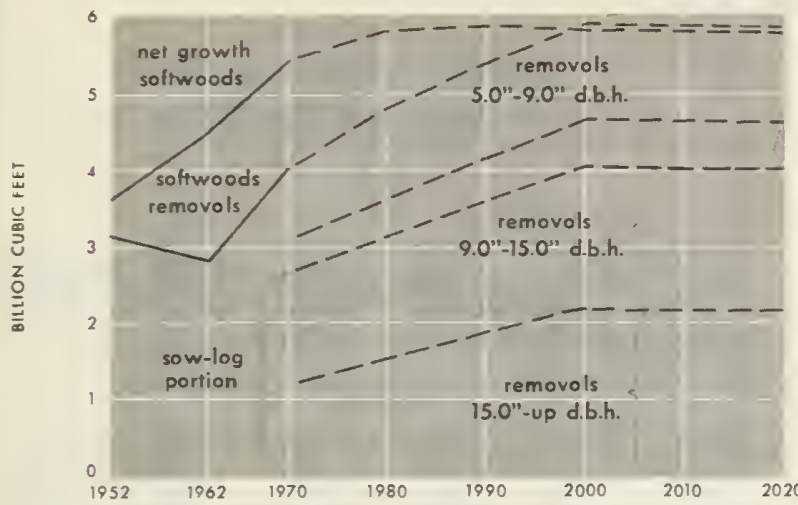

Figure 26

Net growth and removals of hardwood growing stock in the South, by size of material

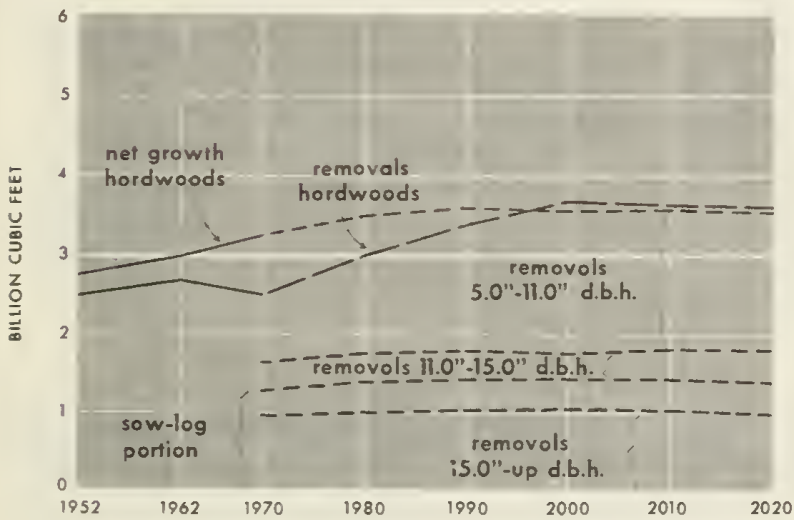

Figure 27

stock was 7 percent less than removals of 4.0 billion cubic feet. For hardwoods, however, total roundwood products, amounting to 1.7 billion cubic feet, were equivalent to only 67 percent of the 2.5 billion cubic feet of removals.

It has been assumed that with expanding markets and improved technology resulting from ongoing research and development, the proportion of total removals going into logging residues and other remorals will decline. The biggest change is projected for hardwoods where the proportion of removals going into timber products is projected to increase from 58 percent in 1970 to 89 percent by 2020.

Roundwood supplies by owner class.-Farm and miscellaneous private owners supplied more than two-thirds of the softwood timber products harvested in the South in 1970 (table 44 and fig. 28). These owners also supplied 76 percent of all hard- wood products harvested (table 44 and fig. 29). Proportions of total output in board feet were quite similar (table 45). In future decades this owner class is projected to supply larger volumes but a diminishing percentage of all roundwood products.

Though far less important in acreage than farm and miscellaneous private holdings, forest industry lands constituted the second leading source of timber products in the South, with 24 percent of the total output of roundwood in 1970 . The proportion of the total products obtained from these lands is projected to increase, particularly for softwoods.

National Forests and other public ownerships provided about 5 percent of all roundwood products harvested in the South in 1970, but because of a large excess of growth over removals these lands are projected to supply up to 10

Supplies of softwood sawtimber products in the South, by owner class

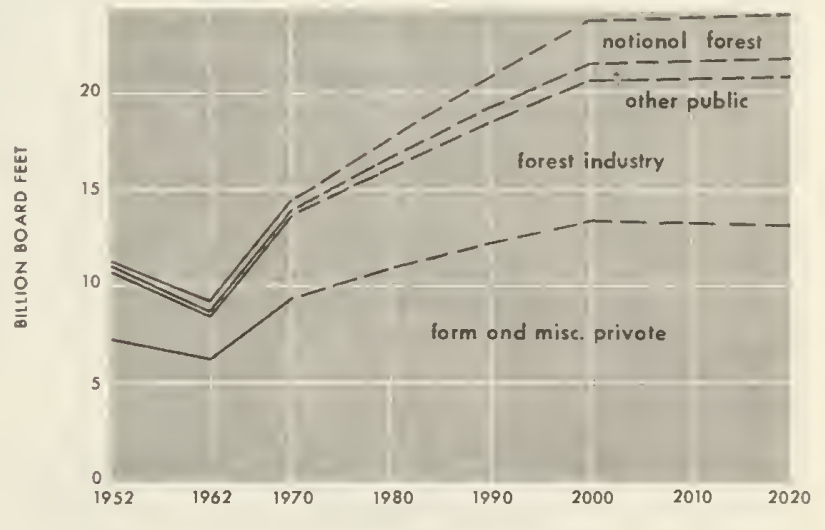

Figure 28

Supplies of hardwood sawtimber products in the South, by owner class

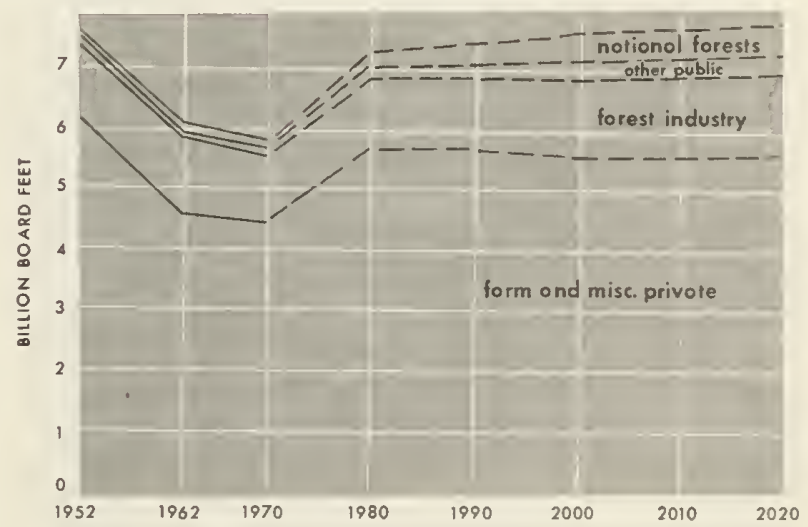

Figure 29 
TABLE 42.-Removals in the South, by size of material, 1970, with projections to 2020 [Million cubic feet]

\begin{tabular}{|c|c|c|c|c|c|c|}
\hline \multirow{2}{*}{ Item } & \multirow{2}{*}{1970} & \multicolumn{5}{|c|}{ Projections } \\
\hline & & 1980 & 1990 & 2000 & 2010 & 2020 \\
\hline SOFTWOODS & & & & & & \\
\hline $\begin{array}{l}\text { All growing stock } \\
\text { Sawtimber trees } \\
\text { Large sawtimber trees } 1 \text { (1) } \\
\text { Saw-log portion }\end{array}$ & $\begin{array}{l}3,996 \\
3,019 \\
1,159 \\
2,626\end{array}$ & $\begin{array}{l}4,784 \\
3,598 \\
1,506 \\
3,129\end{array}$ & $\begin{array}{l}5,356 \\
4,119 \\
1,835 \\
3,583\end{array}$ & $\begin{array}{l}5,866 \\
4,609 \\
2,135 \\
4,009\end{array}$ & $\begin{array}{l}5,836 \\
4,590 \\
2,127 \\
3,992\end{array}$ & $\begin{array}{l}5,808 \\
4,572 \\
2,120 \\
3,977\end{array}$ \\
\hline HARDWOODS & & & & & & \\
\hline $\begin{array}{l}\text { All growing stock } \\
\text { Sawtimber trees } \\
\text { Large sawtimber trees }{ }^{1} \\
\text { Saw-log portion }\end{array}$ & $\begin{array}{r}2,487 \\
1,609 \\
934 \\
1,279\end{array}$ & $\begin{array}{r}2,958 \\
1,722 \\
986 \\
1,368\end{array}$ & $\begin{array}{l}3,329 \\
1,767 \\
1,000 \\
1,404\end{array}$ & $\begin{array}{l}3,633 \\
1,787 \\
1,012 \\
1,420\end{array}$ & $\begin{array}{l}3,602 \\
1,774 \\
1,004 \\
1,409\end{array}$ & $\begin{array}{r}3,572 \\
1,759 \\
996 \\
1,398\end{array}$ \\
\hline
\end{tabular}

1 Trees more than 15.0 inches in diameter at breast height.

TABLE 43.-Components of removals of growing stock in the South, 1952, 1962, and 1970, with projections to 2020

[Percent]

\begin{tabular}{|c|c|c|c|c|c|c|c|}
\hline \multirow{2}{*}{ Component } & \multirow{2}{*}{1952} & \multirow{2}{*}{1962} & \multirow{2}{*}{1970} & \multicolumn{4}{|c|}{ Projections } \\
\hline & & & & 1980 & 1990 & 2000 & 2020 \\
\hline SOFTWOODS & & & & & & & \\
\hline $\begin{array}{l}\text { Roundwood products. } \\
\text { Logging residue } \\
\text { Other removals }\end{array}$ & $\begin{array}{r}90 \\
6 \\
4\end{array}$ & $\begin{array}{r}88 \\
6 \\
6\end{array}$ & $\begin{array}{r}89 \\
7 \\
4\end{array}$ & $\begin{array}{r}93 \\
5 \\
2\end{array}$ & $\begin{array}{r}94 \\
4 \\
2\end{array}$ & $\begin{array}{r}96 \\
3 \\
1\end{array}$ & $\begin{array}{r}97 \\
2 \\
1\end{array}$ \\
\hline Total removals & 100 & 100 & 100 & 100 & 100 & 100 & 100 \\
\hline HARDWOODS & & & & & & & \\
\hline $\begin{array}{l}\text { Roundwood products. } \\
\text { Logging residue } \\
\text { Other removals }\end{array}$ & $\begin{array}{l}61 \\
21 \\
18\end{array}$ & $\begin{array}{l}49 \\
16 \\
35\end{array}$ & $\begin{array}{l}58 \\
17 \\
25\end{array}$ & $\begin{array}{r}82 \\
15 \\
3\end{array}$ & $\begin{array}{r}83 \\
14 \\
3\end{array}$ & $\begin{array}{r}85 \\
12 \\
3\end{array}$ & $\begin{array}{r}89 \\
8 \\
3\end{array}$ \\
\hline Total removals. & 100 & 100 & 100 & 100 & 100 & 100 & 100 \\
\hline
\end{tabular}

percent of the total by 2020. On these publicly owned forests production of timber is only one of several management objectives. With the growing concern over the appearance and quality of the outdoor environment throughout the country, the public may call for further modifications in the management of these lands that would be inconsistent with the assumptions used in these projections. Also, a large proportion of the surplus growth on southern National Forests occurs in hardwood stands in the rugged southern Appalachians on sites of relatively low quality. Hence, projections of products output based on the assumption that removals will equal growth by 2000 , may be overstated.
Roundwood harvests per acre.-Production of roundwood varied widely by ownership in 1970 . Output from forest industry lands averaged 37 cubic feet per acre, compared to 28 cubic feet for farm and miscellaneous private holdings, and 12 cubic feet for National Forests (table 46).

Roundwood production for all owners combined is projected to increase from an average of 28 cubic feet per acre in 1970 to 50 cubic feet by 2020 under the assumption of 1970 management. Forest industry and National Forest lands are expected to support the largest available harvests per acre-approximately 56 cubic feet by 2020 , compared to 47 cubic feet for farm and miscellaneous private ownerships. 
TABLE 44.-Supplies of roundwood products in the South, by owner class and species group, 1952, 1962, and 1970, with projections to 2020

[Million cubic feet]

\begin{tabular}{|c|c|c|c|c|c|c|c|}
\hline \multirow{2}{*}{ Owner class and species group } & \multirow{2}{*}{1952} & \multirow{2}{*}{1962} & \multirow{2}{*}{1970} & \multicolumn{4}{|c|}{ Projections } \\
\hline & & & & 1980 & 1990 & 2000 & 2020 \\
\hline $\begin{array}{l}\text { National Forest: } \\
\text { Softwoods } \\
\text { Hardwoods }\end{array}$ & $\begin{array}{l}61 \\
17\end{array}$ & $\begin{array}{r}117 \\
21\end{array}$ & $\begin{array}{r}103 \\
24\end{array}$ & $\begin{array}{r}208 \\
76\end{array}$ & $\begin{array}{l}307 \\
120\end{array}$ & $\begin{array}{l}404 \\
165\end{array}$ & $\begin{array}{l}403 \\
169\end{array}$ \\
\hline Total. - & 78 & 138 & 127 & 284 & 427 & 569 & 572 \\
\hline $\begin{array}{l}\text { Other public: } \\
\text { Softwoods..... } \\
\text { Hardwoods... }\end{array}$ & $\begin{array}{l}92 \\
46\end{array}$ & $\begin{array}{l}73 \\
32\end{array}$ & $\begin{array}{l}87 \\
42\end{array}$ & $\begin{array}{r}127 \\
80\end{array}$ & $\begin{array}{l}167 \\
101\end{array}$ & $\begin{array}{l}202 \\
119\end{array}$ & $\begin{array}{l}201 \\
123\end{array}$ \\
\hline Total_... & 138 & 105 & 129 & 207 & 268 & 321 & 324 \\
\hline $\begin{array}{l}\text { Forest industry: } \\
\text { Softwoods } \\
\text { Hardwoods }\end{array}$ & $\begin{array}{l}829 \\
334\end{array}$ & $\begin{array}{l}595 \\
454\end{array}$ & $\begin{array}{l}980 \\
327\end{array}$ & $\begin{array}{l}1,194 \\
3855\end{array}$ & $\begin{array}{r}1,386 \\
441\end{array}$ & $\begin{array}{r}1,581 \\
493\end{array}$ & $\begin{array}{r}1,659 \\
533\end{array}$ \\
\hline Total_. & 1,163 & 1,049 & 1,307 & 1,579 & 1,827 & 2,074 & 2,192 \\
\hline $\begin{array}{l}\text { Farm and miscellaneous private: } \\
\text { Softwoods } \\
\text { Hardwoods }\end{array}$ & $\begin{array}{l}2,066 \\
1,538\end{array}$ & $\begin{array}{l}1,892 \\
1,100\end{array}$ & $\begin{array}{l}2,575 \\
1,275\end{array}$ & $\begin{array}{l}3,093 \\
2,110\end{array}$ & $\begin{array}{l}3,358 \\
2,346\end{array}$ & $\begin{array}{l}3,581 \\
2,550\end{array}$ & $\begin{array}{l}3,525 \\
2,591\end{array}$ \\
\hline Total ... & 3,604 & 2,992 & 3,850 & 5,203 & 5,704 & 6,131 & 6,116 \\
\hline $\begin{array}{l}\text { Total South: } \\
\text { Softwoods.-- } \\
\text { Hardwoods.- }\end{array}$ & $\begin{array}{l}3,048 \\
1,935\end{array}$ & $\begin{array}{l}2,677 \\
1,606\end{array}$ & $\begin{array}{l}3,745 \\
1,668\end{array}$ & $\begin{array}{l}4,622 \\
2,651\end{array}$ & $\begin{array}{l}5,217 \\
3,009\end{array}$ & $\begin{array}{l}5,768 \\
3,327\end{array}$ & $\begin{array}{l}5,788 \\
3,416\end{array}$ \\
\hline Total _. - & 4,983 & 4,283 & $\overline{5}, 413$ & 7,273 & 8,226 & 9,095 & 9,204 \\
\hline
\end{tabular}

\section{Removals in Relation to Net Growth}

Net growth of growing stock in the South has risen rapidly in recent decades to about 5.4 billion cubic feet of softwood growing stock in 1970, and 3.2 billion cubic feet of hardwoods (table 40 and fig. 24). Growth of sawtimber has shown similar marked increases (table 41 and fig. 25).

Net growth for all ownerships combined exceeded remorals in 1970 by 33 percent, a much wider margin than in 1952. A peaking of growth in excess of remorals in the early 1960's was a result of unusually low remorals combined with increasing growth on a rapidly expanding inventory base.

Under the cutting assumptions underlying these projections, growth of softwoods is estimated to increase about 7 percent by 2000, while arailable remorals rise by 47 percent (table 40 ). Hardwood net growth is projected to rise about 11 percent by 2000 , and a vailable remorals 46 percent.

\section{Trends in Net Growth Per Acre}

Net growth of timber per acre averaged about 45 cubic feet in 1970 - a substantial rise over the estimate of 33 cubic feet in 1952 (table 47).
Under the assumptions of these base projections average net growth per acre would reach a level of close to 50 cubic feet per acre of growing stock by 2000. Additional growth of rough and rotten trees that occupy considerable area would add to this projection.

It is also possible that growth will increase more than indicated even at 1970 levels of management as a result of wider use of genetically improved stock and other technological improvements. A factor on the other side is the possibility that growth and inventories on some properties may not be arailable because of nontimber objectives of forest owners.

On farm and miscellaneous private lands net annual growth per acre in 1970 was somewhat less than the average for all lands, whereas relatively high levels of growth per acre were attained on forest industry and National Forest lands.

The largest excess of growth orer removals in 1970 was on public lands, especially on National Forests (tables 46 and 47). On these lands, landmanagement objectives aimed at building up stands to produce sawtimber were reflected in net growth four times greater than timber remorals. 
TABle 45.-Supplies of sawtimber products in the South, by owner class and species group, 1952, 1962, and 1970 , with projections to 2020

[Million board feet]

\begin{tabular}{|c|c|c|c|c|c|c|c|}
\hline \multirow{2}{*}{ Owner class and species group } & \multirow{2}{*}{1952} & \multirow{2}{*}{1962} & \multirow{2}{*}{1970} & \multicolumn{4}{|c|}{ Projections } \\
\hline & & & & 1980 & 1990 & 2000 & 2020 \\
\hline $\begin{array}{l}\text { National Forest: } \\
\text { Softwoods_- } \\
\text { Hardwoods.-. }\end{array}$ & $\begin{array}{r}257 \\
99\end{array}$ & $\begin{array}{l}485 \\
144\end{array}$ & $\begin{array}{l}452 \\
119\end{array}$ & $\begin{array}{r}1,008 \\
248\end{array}$ & $\begin{array}{r}1,651 \\
383\end{array}$ & $\begin{array}{r}2,284 \\
517\end{array}$ & $\begin{array}{r}2,264 \\
520\end{array}$ \\
\hline Total .... & 355 & 629 & 571 & 1,256 & 2,034 & 2,801 & 2,784 \\
\hline 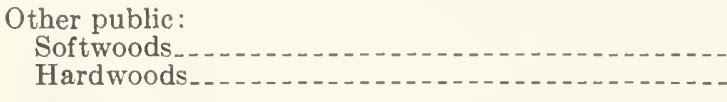 & $\begin{array}{l}336 \\
186\end{array}$ & $\begin{array}{l}261 \\
109\end{array}$ & $\begin{array}{l}311 \\
148\end{array}$ & $\begin{array}{l}513 \\
239\end{array}$ & $\begin{array}{l}722 \\
291\end{array}$ & $\begin{array}{l}922 \\
333\end{array}$ & $\begin{array}{l}918 \\
340\end{array}$ \\
\hline Total. . & 522 & 370 & 459 & 752 & 1,013 & 1,255 & 1,258 \\
\hline $\begin{array}{l}\text { Forest industry: } \\
\text { Softwoods } \\
\text { Hardwoods........- }\end{array}$ & $\begin{array}{l}3,504 \\
1,171\end{array}$ & $\begin{array}{l}2,363 \\
1,303\end{array}$ & $\begin{array}{l}4,263 \\
1,102\end{array}$ & $\begin{array}{l}5,158 \\
1,183\end{array}$ & $\begin{array}{l}6,301 \\
1,238\end{array}$ & $\begin{array}{l}7,339 \\
1,273\end{array}$ & $\begin{array}{l}7,662 \\
1,352\end{array}$ \\
\hline Total $\ldots$ & 4,675 & 3,666 & 5,365 & 6,341 & 7,539 & 8,612 & 9,014 \\
\hline $\begin{array}{l}\text { Farm and miscellaneous private: } \\
\text { Softwoods } \\
\text { Hardwoods. }\end{array}$ & $\begin{array}{l}7,240 \\
6,235\end{array}$ & $\begin{array}{l}6,183 \\
4,583\end{array}$ & $\begin{array}{l}9,340 \\
4,545\end{array}$ & $\begin{array}{r}10,907 \\
5,698\end{array}$ & $\begin{array}{r}12,208 \\
5,690\end{array}$ & $\begin{array}{r}13,291 \\
5,629\end{array}$ & $\begin{array}{r}13,075 \\
5,618\end{array}$ \\
\hline Total & 13,475 & 10,766 & 13,885 & 16,605 & 17,898 & 18,920 & 18,693 \\
\hline $\begin{array}{l}\text { Total South: } \\
\text { Softwoods_-- } \\
\text { Hardwoods.- }\end{array}$ & $\begin{array}{r}11,337 \\
7,690\end{array}$ & $\begin{array}{l}9,292 \\
6,139\end{array}$ & $\begin{array}{r}14,366 \\
5,914\end{array}$ & $\begin{array}{r}17,586 \\
7,368\end{array}$ & $\begin{array}{r}20,882 \\
7,602\end{array}$ & $\begin{array}{r}23,836 \\
7,752\end{array}$ & $\begin{array}{r}23,919 \\
7,830\end{array}$ \\
\hline Total & 19,027 & 15,431 & 20,280 & 24,954 & 28,484 & 31,588 & $31,74 \mathrm{c}$ \\
\hline
\end{tabular}

The heaviest cut in relation to net growth has been on private farm and miscellaneous lands, but in 1970 net growth exceeded removals by 22 percent even on these lands.

Growth by forest types.- Net annual growth per acre also varies widely by forest type, largely as a result of differences in site quality and stand composition. Thus pine stands averaged 61 cubic feet per acre of net growth in 1970, compared to 42 cubic feet for oak-pine, 34 cubic feet for oakhickory, and 38 cubic feet for the lowland oakgum-cypress type.

About 35 percent of the total forest area in the South, or 68 million acres, qualified as pine type in 1970. These stands include natural pine lands of the Coastal Plain, about 15 million acres of pine plantations, and a substantial area of upland sites where pine became established following cropland abandonment. After harvesting, many of these stands are likely to become oak-pine stands, and without timber stand improvement most of these oak-pine stands will probably revert in time to the oak-hickory type.

Most oak-hickory stands-amounting to nearly 56 million acres in 1970--are capable of supporting pine but in many areas the natural propensity to grow hardwoods is so strong, notably in the southern Appalachians and the Cumberland Plateau, that opportunities to grow pine are not favorable. Many of the oak-hickory seedling and sapling stands are residuals following the removal of pine.

With net growth substantially in excess of removals, a shift in stand size distribution from seedlings and saplings to poletimber and sawtimber can be expected. Hence the proportion of areas in seedlings and saplings is estimated to decline from 38 percent of the commercial timberland in 1970 to 19 percent in 2000 . With removals equal to net growth thereafter, a distribution of about 20 percent seedlings and saplings, 30 percent poletimber and 50 percent sawtimber probably could be maintained.

Growth rates.-Net annual growth rates increased from 4.8 percent of the growing stock inventory in 1952 to 5.4 percent in 1970 (table 48). Ingrowth of small trees into measurable size was of particular importance in this period. With a projected buildup of timber inventories in the future, net growth rates are estimated to decline to somewhat less than 5 percent by 2000 . 
TABLE 46.-Roundwood harvests per acre in the South, by owner class and species group, 1952, 1962, and 1970 , with projections to 2020

[Cubic feet]

\begin{tabular}{|c|c|c|c|c|c|c|c|}
\hline \multirow{2}{*}{ Owner class and species group } & \multirow{2}{*}{1952} & \multirow{2}{*}{1962} & \multirow{2}{*}{1970} & \multicolumn{4}{|c|}{ Projections } \\
\hline & & & & 1980 & 1990 & 2000 & 2020 \\
\hline $\begin{array}{l}\text { Yational Forests: } \\
\text { Softwoods-_. } \\
\text { Hardwoods }\end{array}$ & $\begin{array}{l}5.9 \\
\text { 1. } 6\end{array}$ & $\begin{array}{r}10.9 \\
2.0\end{array}$ & $\begin{array}{l}9.6 \\
\text { 2. } 2\end{array}$ & $\begin{array}{r}19.5 \\
7.1\end{array}$ & $\begin{array}{l}28.9 \\
11.4\end{array}$ & $\begin{array}{l}\text { 38. } 9 \\
\text { 15. } 8\end{array}$ & $\begin{array}{l}\text { 39. } 5 \\
16.6\end{array}$ \\
\hline Total. . & 7. 5 & 12. 9 & 11.8 & 26. 6 & 40. 3 & 54. 7 & 56.1 \\
\hline $\begin{array}{l}\text { Other public: } \\
\text { Soft woods..... } \\
\text { Hardwoods... }\end{array}$ & $\begin{array}{r}\text { 14. } 4 \\
7.2\end{array}$ & $\begin{array}{r}11.3 \\
4.9\end{array}$ & $\begin{array}{r}\text { 13. } 3 \\
6.5\end{array}$ & $\begin{array}{l}19.8 \\
12.5\end{array}$ & $\begin{array}{l}26.1 \\
15.8\end{array}$ & $\begin{array}{l}\text { 32. } 1 \\
\text { 18. } 9\end{array}$ & $\begin{array}{l}32.4 \\
19.8\end{array}$ \\
\hline Total & 21.6 & 16. 2 & 19. 8 & 32. 3 & 41. 9 & 51. 0 & 52. 2 \\
\hline $\begin{array}{l}\text { Forest industry: } \\
\text { Softwoods } \\
\text { Hardwoods......... }\end{array}$ & $\begin{array}{l}25.9 \\
10.4\end{array}$ & $\begin{array}{l}\text { 17. } 5 \\
\text { 13. } 3\end{array}$ & $\begin{array}{r}27.7 \\
9.3\end{array}$ & $\begin{array}{l}33.2 \\
\text { 10. } 7\end{array}$ & $\begin{array}{l}\text { 37. } 9 \\
\text { 12. } 0\end{array}$ & $\begin{array}{l}\text { 42. } 4 \\
\text { 13. } 2\end{array}$ & $\begin{array}{l}\text { 43. } 0 \\
\text { 13. } 8\end{array}$ \\
\hline Total & 36. 3 & 30.8 & 37.0 & 43. 9 & 49. 9 & 55.6 & 56.8 \\
\hline $\begin{array}{l}\text { Farm and miscellaneous private: } \\
\text { Softwoods } \\
\text { Hardwoods... }\end{array}$ & $\begin{array}{l}14.4 \\
10.7\end{array}$ & $\begin{array}{r}12.7 \\
7.4\end{array}$ & $\begin{array}{r}18.4 \\
9.1\end{array}$ & $\begin{array}{l}22.4 \\
15.3\end{array}$ & $\begin{array}{l}24.7 \\
17.2\end{array}$ & $\begin{array}{l}26.7 \\
\text { 19. } 0\end{array}$ & $\begin{array}{l}27.0 \\
19.9\end{array}$ \\
\hline Total & 25.1 & 20. 1 & 27.5 & 37. 7 & 41. 9 & 45. 7 & 46. 9 \\
\hline $\begin{array}{l}\text { All owners: } \\
\text { Softwoods } \\
\text { Hardwoods.... }\end{array}$ & $\begin{array}{l}15.9 \\
10.1 \\
\end{array}$ & $\begin{array}{r}13.4 \\
8.0 \\
\end{array}$ & $\begin{array}{r}19.4 \\
\text { \&. } 7\end{array}$ & $\begin{array}{l}\text { 24. } 2 \\
\text { 13. } 9\end{array}$ & $\begin{array}{l}27.5 \\
15.9\end{array}$ & $\begin{array}{l}30.6 \\
17.7\end{array}$ & $\begin{array}{l}\text { 31. } 2 \\
\text { 18. } 4\end{array}$ \\
\hline Total $\ldots$ & 26. 0 & 21.4 & 28. 1 & 38. 1 & 43. 4 & 48. 3 & 49. 6 \\
\hline
\end{tabular}

The relatively low percentage growth rates estimated for National Forest lands mainly reflect hearier volumes per acre. Another factor is the inclusion in natural forests of many mountain areas of relatively low site and high proportions of hardwoods which have significantly lower growth rates than softwoods.

\section{Trends in Timber Inventories}

As a result of the sizable increases in timber growth relative to remorals, timber inventory volumes increased from an arerage of 680 cubic feet per acre in 1952 to 829 cubic feet in 1970 (table 49). A further buildup of inventory rolumes averaging about 23 percent by 2000 is estimated under the assumptions of these base projections.

\section{PROJECTIONS OF TIMBER SUPPLIES IN THE NORTH}

The North is of major importance as a source of hardwood timber, accounting for 44 percent of the total U.S. output of hardwood roundwood products in 1970. Softwood products from this section made up only 6 percent of the Nation's total softwood harrest.

\section{Trends in Forest Area}

For a number of decades the area of commercial timberland in the North has been increasing as a result of widespread abandonment of crop and pasture lands and reversion to forests. A reversal of this long upward trend is anticipated, however, with a continuing decline in forest area throughout the projection period (table 50). The assumed area reductions are judged to be within the range of reasonable possibilities and are used as benchmarks in evaluating future timber supplies.

Most projected area changes have been assumed to occur in the category of farm and miscellaneous private ownerships. It is expected that urbanization, for example, especially along the Mid-Atlantic corridor, will continue to engulf extensive forested areas. Many areas adjoining lakes throughout the North and areas in the Appalachians are likewise expected to contribute very little to the timber supply.

\section{Timber Removals and Net Growth}

During the 1952-70 period both softwood and hardwood timber removals from growing stock 
TABLE 47.-Net growth of growing stock per acre in the South, by owner class and species group, 1952, 1962, and 1970, with projections to 2020

[Cubic feet]

\begin{tabular}{|c|c|c|c|c|c|c|c|}
\hline \multirow{2}{*}{ Owner class and species group } & \multirow{2}{*}{1952} & \multirow{2}{*}{1962} & \multirow{2}{*}{1970} & \multicolumn{4}{|c|}{ Projections } \\
\hline & & & & 1980 & 1990 & 2000 & 2020 \\
\hline $\begin{array}{l}\text { National Forests: } \\
\text { Softwoods }-1 .-1 . \\
\text { Hardwoods. }\end{array}$ & $\begin{array}{l}\text { 27. } 4 \\
\text { 11. } 9\end{array}$ & $\begin{array}{l}38.4 \\
16.5\end{array}$ & $\begin{array}{l}\text { 37. } 0 \\
\text { 17. } 6\end{array}$ & $\begin{array}{l}40.9 \\
18.6\end{array}$ & $\begin{array}{l}40.7 \\
18.4\end{array}$ & $\begin{array}{l}39.8 \\
18.0\end{array}$ & $\begin{array}{l}39.8 \\
18.0\end{array}$ \\
\hline Total $\ldots$ & 39. 3 & 54. 9 & 54.6 & 59.5 & 59.1 & 57.8 & 57.8 \\
\hline $\begin{array}{l}\text { Other public: } \\
\text { Sof twoods } \\
\text { Hardwoods.-- }\end{array}$ & $\begin{array}{l}19.2 \\
11.5\end{array}$ & $\begin{array}{l}20.8 \\
14.1\end{array}$ & $\begin{array}{l}27.9 \\
\text { 17. } 6\end{array}$ & $\begin{array}{l}31.3 \\
19.5\end{array}$ & $\begin{array}{r}32.7 \\
20.2 \\
\end{array}$ & $\begin{array}{l}32.6 \\
20.1\end{array}$ & $\begin{array}{l}32.5 \\
20.2\end{array}$ \\
\hline Total _- & 30. 7 & 34. 9 & 45. 5 & 50.8 & 52. 9 & 52. 7 & 52. 7 \\
\hline $\begin{array}{l}\text { Forest industry: } \\
\text { Softwoods_- } \\
\text { Hardwoods. }\end{array}$ & $\begin{array}{l}33.5 \\
11.1\end{array}$ & $\begin{array}{l}38.9 \\
12.6\end{array}$ & $\begin{array}{l}39.8 \\
13.3\end{array}$ & $\begin{array}{l}42.5 \\
14.2\end{array}$ & $\begin{array}{l}\text { 43. } 1 \\
14.7\end{array}$ & $\begin{array}{l}42.9 \\
14.7\end{array}$ & $\begin{array}{l}42.9 \\
14.7\end{array}$ \\
\hline Total_. . & 44. 6 & 51.5 & 53. 1 & 56. 7 & 57. 8 & 57. 6 & 57. 6 \\
\hline $\begin{array}{l}\text { Farm and miscellaneous private: } \\
\text { Softwoods. } \\
\text { Hardwoods. }\end{array}$ & $\begin{array}{l}\text { 14. } 7 \\
15.2\end{array}$ & $\begin{array}{l}\text { 17. } 6 \\
15.3\end{array}$ & $\begin{array}{l}24.4 \\
17.4\end{array}$ & $\begin{array}{l}26.3 \\
19.0\end{array}$ & $\begin{array}{l}26.8 \\
19.9\end{array}$ & $\begin{array}{l}26.6 \\
20.1\end{array}$ & $\begin{array}{l}26.6 \\
20.1\end{array}$ \\
\hline Total & 29. 9 & 32.9 & 41.8 & 45. 3 & 46.7 & 46. 7 & 46. 7 \\
\hline $\begin{array}{l}\text { All owners: } \\
\text { Softwoods.-..- } \\
\text { Hardwoods.-- }\end{array}$ & $\begin{array}{l}\text { 18. } 7 \\
\text { 14. } 2\end{array}$ & $\begin{array}{l}22.4 \\
14.9\end{array}$ & $\begin{array}{l}\text { 28. } 0 \\
\text { 16. } 7\end{array}$ & $\begin{array}{l}30.4 \\
18.1\end{array}$ & $\begin{array}{l}30.9 \\
18.8\end{array}$ & $\begin{array}{l}30.8 \\
18.9\end{array}$ & $\begin{array}{l}30.9 \\
18.9\end{array}$ \\
\hline Total_.. & 32. 9 & 37. 3 & 44. 7 & 48. 4 & 49. 7 & 49. 7 & 49. 8 \\
\hline
\end{tabular}

in the North averaged less than half the annual net growth (table 51 and fig. 30). Moreover, the margin of growth over removals increased during this period as a result of rapid increases in net growth. In 1970, growth of hardwoods was 2.3

Net growth and removals of growing stock in the North

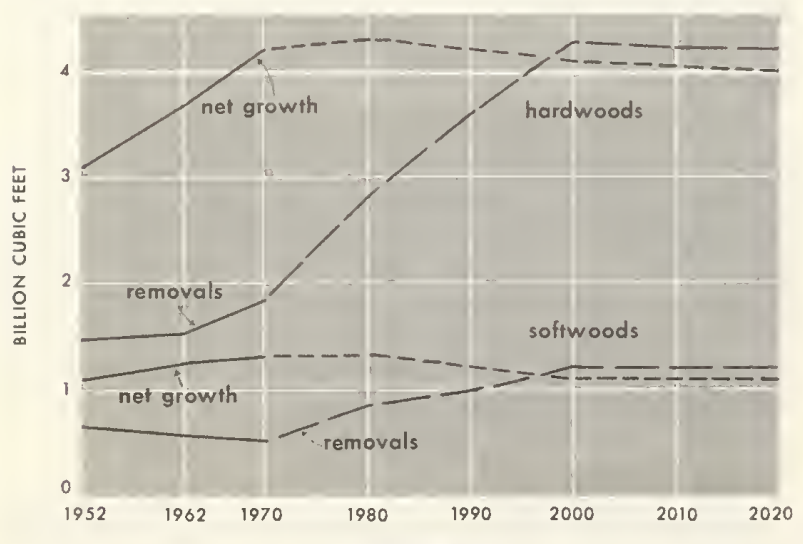

Figure 30 times removals, and growth of softwoods was 2.2 times greater than removals.

Rapid increases in net growth of sawtimber has similarly led to a substantial surplus of growth over removals of larger sizes of timber in recent years. Net growth of sof twood sawtimber in 1970 was 1.7 times annual removals (table 52 and fig. 31). Net growth of hardwood sawtimber was $\mathbf{1 . 5}$ times more than removals.

The substantial excess of net growth over removals in recent years represented a recovery of northern timber resources from an extremely low level of productivity, especially in terms of the sizes and quality of timber needed by forest industries. Past logging and repeated fires left vast areas poorly stocked, but with improved fire protection most forest areas are again growing timber. Also, large areas of former agricultural land which reverted to forest after abandonment are now contributing considerable "ingrowth" as trees pass 5.0 inches in diameter. In some areas ingrowth made up at least half of the total net annual growth in 1970 .

On public lands, net growth averaged about four times greater than timber removals in 1970 (Append. I, tables 21 and 22). This largely reflects 
TABLE 48.-Net growth rates of growing stock in the South, by owner class and species group, 1952, 1962, and 1970, with projections to 2020

[Percent of inventory]

\begin{tabular}{|c|c|c|c|c|c|c|c|}
\hline \multirow{2}{*}{ Окner class and species group } & \multirow{2}{*}{1952} & \multirow{2}{*}{1962} & \multirow{2}{*}{1970} & \multicolumn{4}{|c|}{ Projections } \\
\hline & & & & 1980 & 1990 & 2000 & 2020 \\
\hline $\begin{array}{l}\text { National Forests: } \\
\text { Softwoods_-_..-- } \\
\text { Hardwoods....-. }\end{array}$ & $\begin{array}{l}5.9 \\
\text { 3. } 3\end{array}$ & $\begin{array}{l}\text { 6. } 2 \\
\text { 3. } 6\end{array}$ & $\begin{array}{l}5.8 \\
3.6\end{array}$ & $\begin{array}{l}\text { 4. } 6 \\
\text { 3. } 0\end{array}$ & $\begin{array}{l}3.9 \\
2.7\end{array}$ & $\begin{array}{l}3.6 \\
2.5\end{array}$ & $\begin{array}{l}\text { 3. } 6 \\
2.5\end{array}$ \\
\hline Total $\ldots$ & 4. 8 & 5.1 & 4. 8 & 4. 0 & 3. 4 & 3. 2 & 3. 2 \\
\hline $\begin{array}{l}\text { Other public: } \\
\text { Soft woods--.-- } \\
\text { Hardwoods.-.- }\end{array}$ & $\begin{array}{l}5.9 \\
\text { 3. } 9\end{array}$ & $\begin{array}{l}\text { 5. } 6 \\
\text { 3. } 9\end{array}$ & $\begin{array}{l}5.8 \\
4.0\end{array}$ & $\begin{array}{l}5.2 \\
\text { 3. } 8\end{array}$ & $\begin{array}{l}\text { 4. } 8 \\
\text { 3. } 6\end{array}$ & $\begin{array}{l}4.5 \\
3.5\end{array}$ & $\begin{array}{l}\text { 4. } 6 \\
\text { 3. } 5\end{array}$ \\
\hline Total $\ldots$ & 5. 0 & 4. 7 & 4. 9 & 4. 6 & 4. 3 & 4. 1 & 4. 1 \\
\hline $\begin{array}{l}\text { Forest industry: } \\
\text { Softwoods } \\
\text { Hardwoods }\end{array}$ & $\begin{array}{r}6.8 \\
3.4 \\
\end{array}$ & $\begin{array}{l}6.7 \\
\text { 3. }\end{array}$ & $\begin{array}{l}6.8 \\
\text { 3. } 7\end{array}$ & $\begin{array}{l}\text { 6. } 3 \\
\text { 3. } 8\end{array}$ & $\begin{array}{l}5.8 \\
\text { 3. } 7\end{array}$ & $\begin{array}{l}5.6 \\
\text { 3. } 7\end{array}$ & $\begin{array}{l}\text { 5. } 6 \\
\text { 3. } 7\end{array}$ \\
\hline Total $\ldots$ & 5.4 & 5. 5 & 5. 7 & 5.4 & 5. 1 & 5. 0 & 5. 0 \\
\hline $\begin{array}{l}\text { Farm and miscellaneous private: } \\
\text { Softwoods } \\
\text { Hardwoods }\end{array}$ & $\begin{array}{l}\text { 6. } 5 \\
\text { 3. } 7\end{array}$ & $\begin{array}{l}\text { 6. } 9 \\
\text { 3. } 9\end{array}$ & $\begin{array}{l}\text { 7. } 2 \\
\text { 4. } 0\end{array}$ & $\begin{array}{l}\text { 6. } 9 \\
4.1\end{array}$ & $\begin{array}{l}6.6 \\
4.1\end{array}$ & $\begin{array}{l}6.4 \\
4.1\end{array}$ & $\begin{array}{l}\text { 6. } 4 \\
\text { 4. } 1\end{array}$ \\
\hline Total _. & 4. 7 & 5. 0 & 5. 4 & 5.4 & 5. 3 & 5. 2 & 5. 2 \\
\hline $\begin{array}{l}\text { All owners: } \\
\text { Softwoods } \\
\text { Hardwoods.....- }\end{array}$ & $\begin{array}{l}\text { 6. } 5 \\
\text { 3. } 6\end{array}$ & $\begin{array}{l}6.7 \\
3.8\end{array}$ & $\begin{array}{l}6.9 \\
4.0\end{array}$ & $\begin{array}{l}6.4 \\
4.0\end{array}$ & $\begin{array}{l}\text { 6. } 0 \\
\text { 3. } 9\end{array}$ & $\begin{array}{l}5.8 \\
3.9\end{array}$ & $\begin{array}{l}5.8 \\
\text { 3. } 9\end{array}$ \\
\hline Total $\ldots$ & 4. 8 & 5. 1 & 5.4 & 5. 2 & 5. 0 & 4. 9 & 4. 9 \\
\hline
\end{tabular}

Net growth and removals of sawtimber in the North

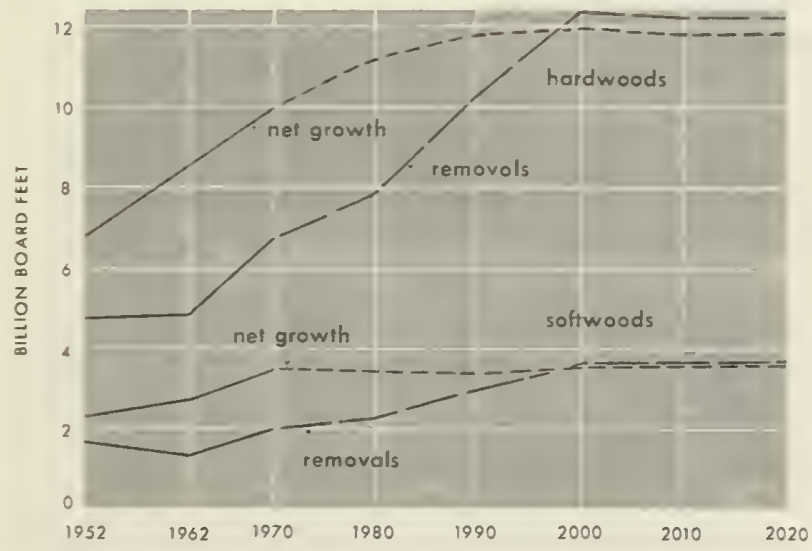

Figure 31

age classes on those areas and a policy of building up timber inventories to emphasize sawtimber harvests under relatively long rotations.

The heaviest cutting in relation to net growth has been on private lands. But on both forest industry and farm and miscellaneous holdings, removals of softwoods and hardwoods in 1970 amounted to about half the net annual growth.

Under the area and harvesting assumptions used in developing these particular projections, that is, with projected removals rising to equal net growth by the year 2000, net growth of softwood growing stock is estimated to decrease about 18 percent from the 1970 level, whereas available removals of softwoods are projected to rise by 88 percent.

Hardwood net growth in cubic feet is projected to increase somewhat then decline slightly by the year 2000 with rising stand density. Total removals, however, are projected to increase some 140 percent under the assumptions of these base projections. After 2000 growth and removals drop slightly because of the assumed drop in commercial timberland areas.

A breakdown of the data for growth and removals reveals significant differences by tree size class and quality. Growth takes place over the entire timber inventory, whereas removals are more heavily concentrated on selected species, such as maple, birch, walnut, or white oak, for 
TABLE 49.-Inventories of growing stock per acre in the South, by owner class and species group, 1952, 1962, and 1970, with projections to 2020

[Cubic feet]

\begin{tabular}{|c|c|c|c|c|c|c|c|}
\hline \multirow{2}{*}{ Owner class and species group } & \multirow{2}{*}{1952} & \multirow{2}{*}{1962} & \multirow{2}{*}{1970} & \multicolumn{4}{|c|}{ Projections } \\
\hline & & & & 1980 & 1990 & 2000 & 2020 \\
\hline $\begin{array}{l}\text { National Forests: } \\
\text { Softwoods } \\
\text { Hardwoods }\end{array}$ & $\begin{array}{l}466 \\
361\end{array}$ & $\begin{array}{l}623 \\
459\end{array}$ & $\begin{array}{l}643 \\
486\end{array}$ & $\begin{array}{l}885 \\
610\end{array}$ & $\begin{array}{r}1,038 \\
686\end{array}$ & $\begin{array}{r}1,092 \\
712\end{array}$ & $\begin{array}{r}1,092 \\
712\end{array}$ \\
\hline Total & 827 & 1,081 & 1,129 & 1,495 & 1,724 & 1,804 & 1,804 \\
\hline $\begin{array}{l}\text { Other public: } \\
\text { Softwoods } \\
\text { Hardwoods. }\end{array}$ & $\begin{array}{l}324 \\
296\end{array}$ & $\begin{array}{l}374 \\
364\end{array}$ & $\begin{array}{l}482 \\
439\end{array}$ & $\begin{array}{l}605 \\
510\end{array}$ & $\begin{array}{l}687 \\
556\end{array}$ & $\begin{array}{l}716 \\
573\end{array}$ & $\begin{array}{l}713 \\
575\end{array}$ \\
\hline Total_- & 620 & 738 & 921 & 1,115 & 1,243 & 1,289 & 1,288 \\
\hline $\begin{array}{l}\text { Forest industry: } \\
\text { Softwoods } \\
\text { Hardwoods }\end{array}$ & $\begin{array}{l}494 \\
326\end{array}$ & $\begin{array}{l}576 \\
359\end{array}$ & $\begin{array}{l}584 \\
356\end{array}$ & $\begin{array}{l}679 \\
378\end{array}$ & $\begin{array}{l}741 \\
392\end{array}$ & $\begin{array}{l}762 \\
397\end{array}$ & $\begin{array}{l}761 \\
397\end{array}$ \\
\hline Total _- - & 820 & 936 & 940 & 1,057 & 1,133 & 1,159 & 1,158 \\
\hline $\begin{array}{l}\text { Farm and miscellaneous private: } \\
\text { Softwoods } \\
\text { Hardwoods. }\end{array}$ & $\begin{array}{l}226 \\
415\end{array}$ & $\begin{array}{l}256 \\
395\end{array}$ & $\begin{array}{l}341 \\
432\end{array}$ & $\begin{array}{l}382 \\
460\end{array}$ & $\begin{array}{l}408 \\
479\end{array}$ & $\begin{array}{l}417 \\
486\end{array}$ & $\begin{array}{l}417 \\
487\end{array}$ \\
\hline Total _- & 641 & 651 & 773 & 842 & 887 & 904 & 904 \\
\hline $\begin{array}{l}\text { All owners: } \\
\text { Sof twoods_... } \\
\text { Hardwoods..- }\end{array}$ & $\begin{array}{l}287 \\
393\end{array}$ & $\begin{array}{l}334 \\
392\end{array}$ & $\begin{array}{l}407 \\
421\end{array}$ & $\begin{array}{l}473 \\
455\end{array}$ & $\begin{array}{l}517 \\
476\end{array}$ & $\begin{array}{l}533 \\
484\end{array}$ & $\begin{array}{l}536 \\
483\end{array}$ \\
\hline Total & 680 & 726 & 829 & 928 & 993 & 1,017 & 1,019 \\
\hline
\end{tabular}

Note: May not add to totals because of rounding.

TABLE 50.-Area of commercial timberland in the North, by owner class, 1952, 1962, and 1970, with projections to 2020

[Million acres]

\begin{tabular}{|c|c|c|c|c|c|c|c|}
\hline \multirow[b]{2}{*}{ Owner class } & \multirow[b]{2}{*}{1952} & \multirow[b]{2}{*}{1962} & \multirow[b]{2}{*}{1970} & \multicolumn{4}{|c|}{ Projections } \\
\hline & & & & 1980 & 1990 & 2000 & 2020 \\
\hline $\begin{array}{l}\text { National Forests } \\
\text { Other public } \\
\text { Forest industry } \\
\text { Farm and miscellaneous private-- }\end{array}$ & $\begin{array}{r}10.3 \\
22.0 \\
14.0 \\
123.8\end{array}$ & $\begin{array}{r}10.3 \\
21.5 \\
14.2 \\
129.1\end{array}$ & $\begin{array}{r}10.5 \\
21.5 \\
17.6 \\
128.4\end{array}$ & $\begin{array}{r}10.4 \\
21.2 \\
18.2 \\
126.5\end{array}$ & $\begin{array}{r}10.3 \\
21.0 \\
18.8 \\
124.6\end{array}$ & $\begin{array}{r}10.1 \\
20.8 \\
19.5 \\
122.7\end{array}$ & $\begin{array}{r}9.9 \\
20.4 \\
20.7 \\
118.8 \\
\end{array}$ \\
\hline Total_- & 170.2 & 175. 1 & 177. 9 & 176. 3 & 174. 7 & 173. 1 & 169. 8 \\
\hline
\end{tabular}

example. Cutting also tends to be concentrated in the better quality stands and more accessible areas. Supplies of saw logs and veneer logs thus may be short in many areas, whereas supplies of hardwood pulpwood are more than adequate for industry's needs.

Changes in timber harvesting practices and development of markets for timber that is cur- rently unmerchantable will, therefore, be necessary to achieve the trend in available removals shown by these projections.

\section{Supplies of Roundwood Products}

In 1970 , only 80 percent of the total softwood removals in the North, and 69 percent of all hardwood removals, consisted of roundwood 
TABLE 51.-Timber removals, net grouth, mortality, supplies of roundwood products, and inventories in the North, 1952, 1962, and 1970, with projections (1970 level of management) ${ }^{1}$ to 2020

[Million cubic feet]

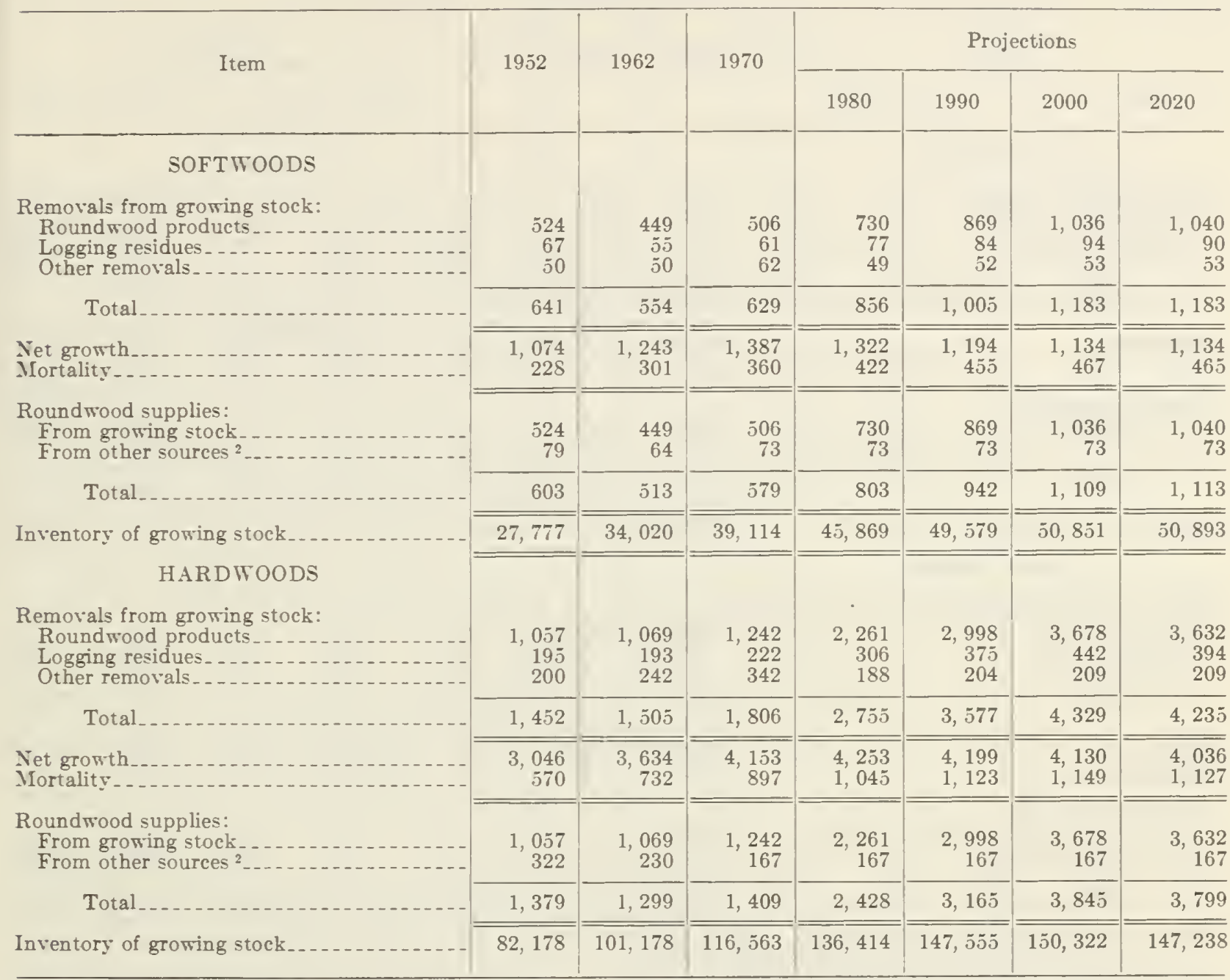

${ }_{1}^{1}$ Plus other area and harvesting assumptions specified in this chapter.

2 Includes roundwood products from rough and rotten trees, limbs, dead trees, and trees on noncommercial and nonforest land.

products (table 53). Some 10 percent of the softwood removals and 12 percent of the hardwood removals were left in the woods as logging residues-about the same proportion of economically unusable material as in earlier years. Other removals, including timber losses to urban and industrial development, strip mining, highways, etc., are estimated to have amounted to somewhat more than volumes of logging residues.

Residues and other removals are expected to decrease over the projection period because of better utilization of available material. Estimated proportions of removals used for products increase, therefore, in future decades to 88 percent of all
Note: Estimates are for trend levels and consequently may differ from actual figures for the specified years.

removals for softroods and 86 percent for hardwoods.

Under the assumptions of these base projections, prospectively available supplies of sof twood roundwood nearly double, from 0.6 billion cubic feet in 1970 to 1.1 billion cubic feet by 2000 (table 51). Projections for hardwoods increase nearly threefold, from 1.4 billion cubic feet to about 3.8 billion cubic feet. Somewhat smaller increases are projected for sawtimber products (table 52).

Roundwood supplies by owner class.-As in the case of forest areas, farm and miscellaneous private ornerships represent by far the major source of roundwood in the North (tables 54 and 55, and 
TABLE 52.-Sawtimber removals, net growth, mortality, supplies of roundwood products, and inventories in the North, 1952, 1962, and 1970, with projections (1970 level of management) ${ }^{1}$ to 2020

[Million board feet]

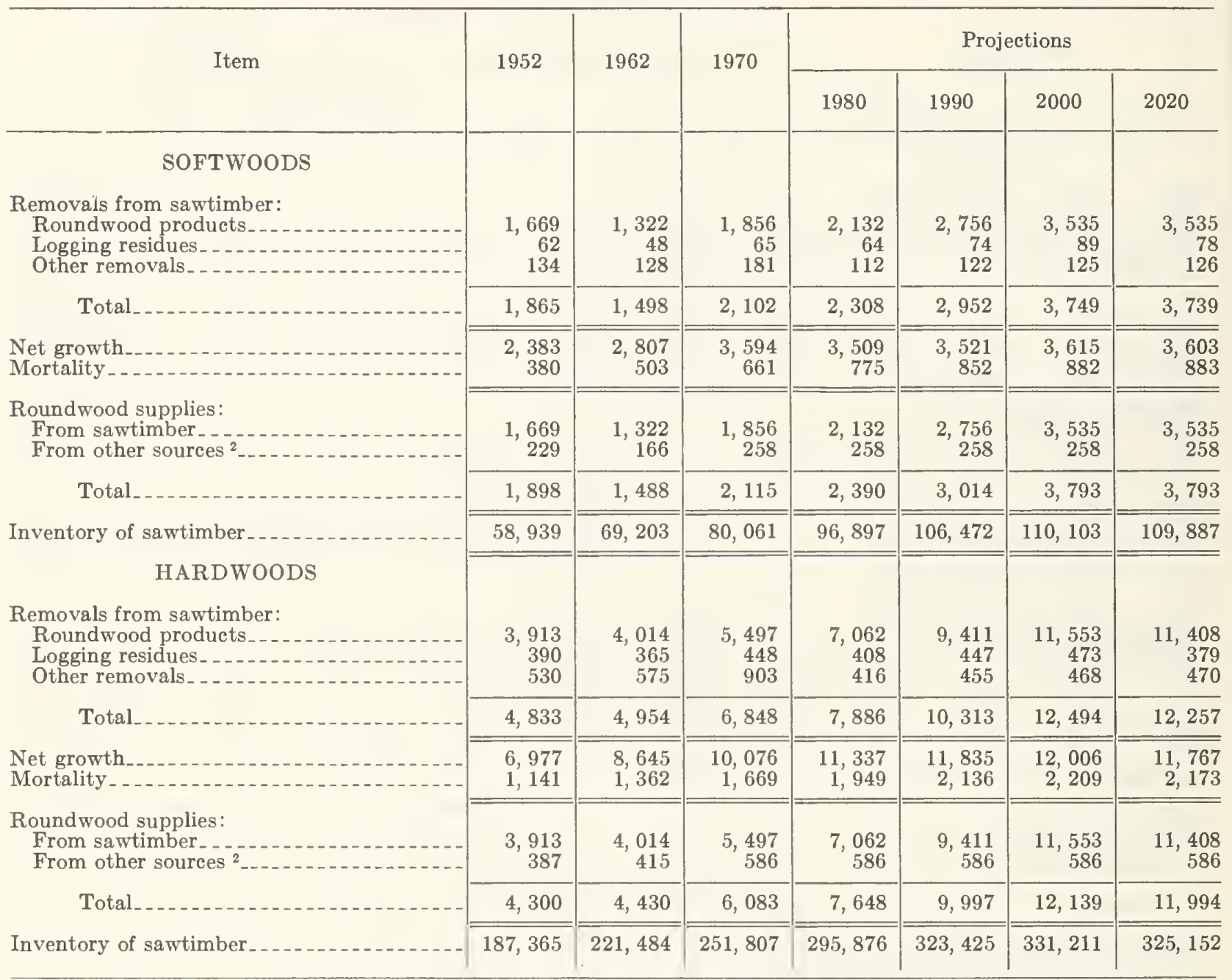

${ }^{1}$ Plus other area and harvesting assumptions specified in this chapter.

${ }^{2}$ Includes roundwood products from trees too small to qualify as sawtimber, rough and rotten trees, dead trees, and from trees on noncommercial and nonforest land.

figures 32 and 33). In 1970 these holdings supplied 73 percent of all roundwood products, while forest industry lands supplied 16 percent, and public lands 11 percent.

Roundwood production per acre.-Output of timber products per acre of commercial timberland in 1970 ranged from about 7 cubic feet on public lands other than National Forests, to 18 cubic feet on forest industry lands. Under the assumptions of this section, available harvests are projected to increase from an average cut of 11.2 cubic feet per acre in 1970 to about 29 cubic feet by 2000 (table 56).
Note: Estimates are for trend levels and consequently may differ from actual figures for the specified years.

\section{Trends in Net Growth Per Acre}

Average net growth per acre has risen 29 percent since 1952 to an average of about 31 cubic feet per acre (table 57). With the level of management and other conditions assumed in this section, average net growth of growing stock for all owners combined is expected to remain fairly constant at about 31 cubic feet per acre. Some additional growth would also occur on rough and rotten trees.

On public and industry lands some decrease in net growth is projected as a result of industry 
PROJECTED TIMBER SUPPLIES-1970 LEVEL OF MANAGEMENT

TABLE 53.-Components of growing stock removals in the North, 1952, 1962, and 1970, with projections to 2020

[Percent]

\begin{tabular}{|c|c|c|c|c|c|c|c|}
\hline \multirow{2}{*}{ Component } & \multirow{2}{*}{1952} & \multirow{2}{*}{1962} & \multirow{2}{*}{1970} & \multicolumn{4}{|c|}{ Projections } \\
\hline & & & & 1980 & 1990 & 2000 & 2020 \\
\hline SOFTWOODS & & & & & & & \\
\hline $\begin{array}{l}\text { Roundwood products } \\
\text { Logging residue } \\
\text { Other removals }\end{array}$ & $\begin{array}{r}82 \\
10 \\
8\end{array}$ & $\begin{array}{r}81 \\
10 \\
9\end{array}$ & $\begin{array}{l}80 \\
10 \\
10\end{array}$ & $\begin{array}{r}85 \\
9 \\
6\end{array}$ & $\begin{array}{r}87 \\
8 \\
5\end{array}$ & $\begin{array}{r}88 \\
8 \\
4\end{array}$ & $\begin{array}{r}88 \\
8 \\
4\end{array}$ \\
\hline Total removals & 100 & 100 & 100 & 100 & 100 & 100 & 100 \\
\hline HARDWOODS & & & & & & & \\
\hline $\begin{array}{l}\text { Roundwood products } \\
\text { Logging residue } \\
\text { Other removals }\end{array}$ & $\begin{array}{l}73 \\
13 \\
14\end{array}$ & $\begin{array}{l}71 \\
13 \\
16\end{array}$ & $\begin{array}{l}69 \\
12 \\
19\end{array}$ & $\begin{array}{r}82 \\
11 \\
7\end{array}$ & $\begin{array}{r}84 \\
10 \\
6\end{array}$ & $\begin{array}{r}85 \\
10 \\
5\end{array}$ & $\begin{array}{r}86 \\
9 \\
5\end{array}$ \\
\hline Total removals..... & 100 & 100 & 100 & 100 & 100 & 100 & 100 \\
\hline
\end{tabular}

TABLE 54.-Supplies of roundwood products in the North, by owner class and species group, 1952, 1962, and 1970, with projections to 2020

[Million cubic feet]

\begin{tabular}{|c|c|c|c|c|c|c|c|}
\hline \multirow{2}{*}{ Owner class and species group } & \multirow{2}{*}{1952} & \multirow{2}{*}{1962} & \multirow{2}{*}{1970} & \multicolumn{4}{|c|}{ Projections } \\
\hline & & & & 1980 & 1990 & 2000 & 2020 \\
\hline $\begin{array}{l}\text { National Forests: } \\
\text { Soft woods_..... } \\
\text { Hardwoods...- }\end{array}$ & $\begin{array}{l}22 \\
34\end{array}$ & $\begin{array}{l}26 \\
44\end{array}$ & $\begin{array}{l}30 \\
45\end{array}$ & $\begin{array}{l}57 \\
98\end{array}$ & $\begin{array}{r}81 \\
126\end{array}$ & $\begin{array}{l}104 \\
160\end{array}$ & $\begin{array}{l}102 \\
158\end{array}$ \\
\hline Total ... & 56 & 70 & 75 & 155 & 207 & 264 & 260 \\
\hline $\begin{array}{l}\text { Other public: } \\
\text { Softwoods. } \\
\text { Hardwoods. }\end{array}$ & $\begin{array}{l}39 \\
72\end{array}$ & $\begin{array}{l}41 \\
87\end{array}$ & $\begin{array}{l}50 \\
94\end{array}$ & $\begin{array}{r}92 \\
227\end{array}$ & $\begin{array}{l}130 \\
318\end{array}$ & $\begin{array}{l}168 \\
411\end{array}$ & $\begin{array}{l}165 \\
406\end{array}$ \\
\hline Total & 111 & 128 & 144 & 319 & 448 & 579 & 571 \\
\hline $\begin{array}{l}\text { Forest industry: } \\
\text { Softwoods.-. } \\
\text { Hardwoods. }\end{array}$ & $\begin{array}{l}138 \\
132 \\
\end{array}$ & $\begin{array}{l}123 \\
118\end{array}$ & $\begin{array}{l}168 \\
148\end{array}$ & $\begin{array}{l}213 \\
187\end{array}$ & $\begin{array}{l}260 \\
228\end{array}$ & $\begin{array}{l}324 \\
278\end{array}$ & $\begin{array}{l}344 \\
296\end{array}$ \\
\hline Total _.. & 270 & 241 & 316 & 400 & 488 & 602 & 640 \\
\hline $\begin{array}{l}\text { Farm and miscellaneous private: } \\
\text { Soft woods } \\
\text { Hardwoods. }\end{array}$ & $\begin{array}{r}404 \\
1,140\end{array}$ & $\begin{array}{r}324 \\
1,048\end{array}$ & $\begin{array}{r}332 \\
1,122\end{array}$ & $\begin{array}{r}441 \\
1,917\end{array}$ & $\begin{array}{r}471 \\
2,493\end{array}$ & $\begin{array}{r}514 \\
2,996\end{array}$ & $\begin{array}{r}502 \\
2,939 \\
\end{array}$ \\
\hline Total _. & 1,545 & 1,372 & 1,454 & 2,358 & 2,964 & 3,510 & 3,441 \\
\hline $\begin{array}{l}\text { Total North: } \\
\text { Softwoods--. } \\
\text { Hardwoods.-- }\end{array}$ & $\begin{array}{r}603 \\
1,379\end{array}$ & $\begin{array}{r}513 \\
1,299\end{array}$ & $\begin{array}{r}579 \\
1,410\end{array}$ & $\begin{array}{r}803 \\
2,428\end{array}$ & $\begin{array}{r}942 \\
3,165\end{array}$ & $\begin{array}{l}1,109 \\
3,845\end{array}$ & $\begin{array}{l}1,113 \\
3,799\end{array}$ \\
\hline Total & 1,982 & 1,812 & 1,989 & 3,231 & 4,107 & 4,954 & 4,912 \\
\hline
\end{tabular}


TABLE 55.-Supplies of sawtimber products in the North, by owner class and species group, 1952, 1962, and 1970, with projections to 2020

[Million board feet]

\begin{tabular}{|c|c|c|c|c|c|c|c|}
\hline \multirow{2}{*}{ Owner class and species group } & \multirow{2}{*}{1952} & \multirow{2}{*}{1962} & \multirow{2}{*}{1970} & \multicolumn{4}{|c|}{ Projections } \\
\hline & & & & 1980 & 1990 & 2000 & 2020 \\
\hline $\begin{array}{l}\text { National Forests: } \\
\text { Softwoods } \\
\text { Hardwoods.-.-- }\end{array}$ & $\begin{array}{r}82 \\
104\end{array}$ & $\begin{array}{r}99 \\
162\end{array}$ & $\begin{array}{l}118 \\
186\end{array}$ & $\begin{array}{l}169 \\
259\end{array}$ & $\begin{array}{l}275 \\
386\end{array}$ & $\begin{array}{l}393 \\
529\end{array}$ & $\begin{array}{l}387 \\
521\end{array}$ \\
\hline Total & 186 & 261 & 304 & 428 & 661 & 922 & 908 \\
\hline $\begin{array}{l}\text { Other public: } \\
\text { Softwoods.--- } \\
\text { Hardwoods.-- }\end{array}$ & $\begin{array}{r}99 \\
154\end{array}$ & $\begin{array}{l}103 \\
218\end{array}$ & $\begin{array}{l}170 \\
302\end{array}$ & $\begin{array}{l}293 \\
598\end{array}$ & $\begin{array}{l}468 \\
933\end{array}$ & $\begin{array}{r}659 \\
1,286\end{array}$ & $\begin{array}{r}649 \\
1,265\end{array}$ \\
\hline Total_- & 252 & 321 & 472 & 891 & 1,401 & 1,945 & 1,914 \\
\hline $\begin{array}{l}\text { Forest industry: } \\
\text { Softwoods } \\
\text { Hardwoods...- }\end{array}$ & $\begin{array}{l}428 \\
329\end{array}$ & $\begin{array}{l}344 \\
337\end{array}$ & $\begin{array}{l}611 \\
530\end{array}$ & $\begin{array}{l}567 \\
595\end{array}$ & $\begin{array}{l}743 \\
748\end{array}$ & $\begin{array}{l}965 \\
924\end{array}$ & $\begin{array}{r}1,023 \\
980\end{array}$ \\
\hline Total_. & 757 & 681 & 1,141 & 1,162 & 1,491 & 1,889 & 2,003 \\
\hline $\begin{array}{l}\text { Farm and miscellaneous private: } \\
\text { Softwoods } \\
\text { Hardwoods }\end{array}$ & $\begin{array}{l}1,289 \\
3,713\end{array}$ & $\begin{array}{r}942 \\
3,713\end{array}$ & $\begin{array}{l}1,216 \\
5,064\end{array}$ & $\begin{array}{l}1,361 \\
6,196\end{array}$ & $\begin{array}{l}1,529 \\
7,929\end{array}$ & $\begin{array}{l}1,776 \\
9,400\end{array}$ & $\begin{array}{l}1,734 \\
9,228\end{array}$ \\
\hline Total & 5,002 & 4,655 & 6,280 & 7,557 & 9,458 & 11,176 & 10,962 \\
\hline $\begin{array}{l}\text { Total North: } \\
\text { Softwoods--- } \\
\text { Hardwoods -- }\end{array}$ & $\begin{array}{l}1,898 \\
4,300\end{array}$ & $\begin{array}{l}1,488 \\
4,430\end{array}$ & $\begin{array}{l}2,115 \\
6,082\end{array}$ & $\begin{array}{l}2,390 \\
7,648\end{array}$ & $\begin{array}{l}3,014 \\
9,997\end{array}$ & $\begin{array}{r}3,793 \\
12,139\end{array}$ & $\begin{array}{r}3,793 \\
11,994\end{array}$ \\
\hline Total_- & 6,198 & 5,918 & 8,197 & 10,038 & 13,011 & 15,932 & 15,787 \\
\hline
\end{tabular}

Supplies of hardwood sawtimber products in the North, by owner class

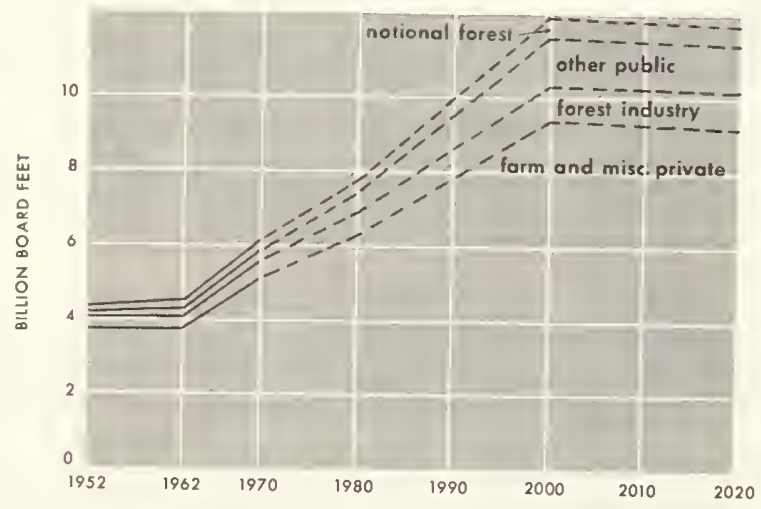

Figure 32

buildup and resulting constraints on net growth. On farm and miscellaneous private holdings, growth per acre is expected to increase somewhat with prospective improvements in stocking on these lands.
Supplies of softwood sawtimber products in the North, by owner class

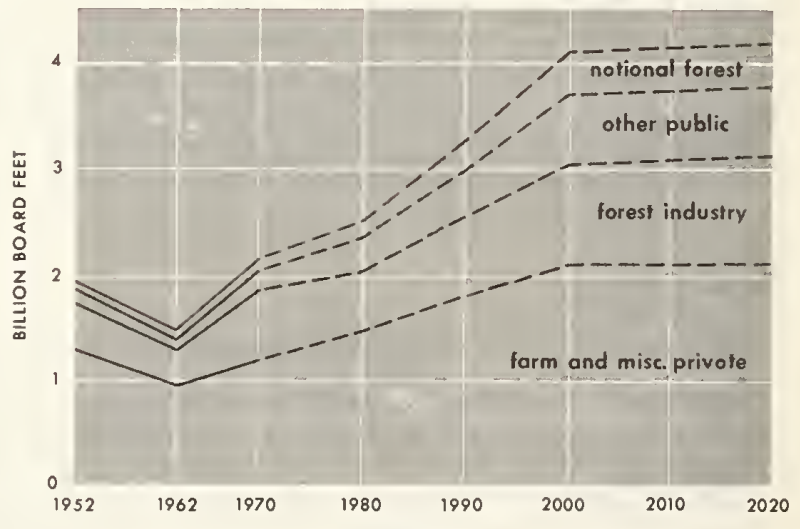

Figure 33

Projected net growth of timber by 2000, under the assumptions of this chapter, would still be less than half of the potential net growth that could be attained ultimately in natural stands fully stocked 
TABLE 56.-Supplies of roundwood products per acre in the North, by owner class and species group, 1952, 1962, and 1970, with projections to 2020

[Cubic feet]

\begin{tabular}{|c|c|c|c|c|c|c|c|}
\hline \multirow{2}{*}{ Owner class and species group } & \multirow{2}{*}{1952} & \multirow{2}{*}{1962} & \multirow{2}{*}{1970} & \multicolumn{4}{|c|}{ Projections } \\
\hline & & & & 1980 & 1990 & 2000 & 2020 \\
\hline $\begin{array}{l}\text { National Forests: } \\
\text { Softwoods....- } \\
\text { Hardwoods...- }\end{array}$ & $\begin{array}{l}2.1 \\
\text { 3. } 3 \\
\end{array}$ & $\begin{array}{l}2.5 \\
4.3 \\
\end{array}$ & $\begin{array}{l}2.8 \\
\text { 4. } 4\end{array}$ & $\begin{array}{l}5.5 \\
9.4\end{array}$ & $\begin{array}{r}7.9 \\
12.2\end{array}$ & $\begin{array}{l}\text { 10. } 3 \\
15.8\end{array}$ & $\begin{array}{l}10.3 \\
16.0\end{array}$ \\
\hline Total ... & 5.4 & 6.8 & 7. 2 & 14. 9 & 20.1 & 26.1 & 26. 3 \\
\hline $\begin{array}{l}\text { Other public: } \\
\text { Softwoods } \\
\text { Hardwoods.-.. }\end{array}$ & $\begin{array}{l}1.8 \\
3.3\end{array}$ & $\begin{array}{l}\text { 1. } 9 \\
\text { 4. } 1\end{array}$ & $\begin{array}{l}2.3 \\
4.4\end{array}$ & $\begin{array}{r}4.3 \\
10.7\end{array}$ & $\begin{array}{r}6.2 \\
15.1\end{array}$ & $\begin{array}{r}8.0 \\
19.8\end{array}$ & $\begin{array}{r}8.1 \\
19.9\end{array}$ \\
\hline Total & 5.1 & 6.0 & 6.7 & 15.0 & 21.3 & 27.8 & 28.0 \\
\hline $\begin{array}{l}\text { Forest industry: } \\
\text { Softwoods } \\
\text { Hardwoods.-. }\end{array}$ & $\begin{array}{l}9.8 \\
9.4\end{array}$ & $\begin{array}{l}8.7 \\
8.3\end{array}$ & $\begin{array}{l}9.6 \\
8.4\end{array}$ & $\begin{array}{l}11.7 \\
10.3\end{array}$ & $\begin{array}{l}13.8 \\
12.1\end{array}$ & $\begin{array}{l}\text { 16. } 6 \\
14.3 \\
\end{array}$ & $\begin{array}{l}16.6 \\
14.3\end{array}$ \\
\hline Total $\ldots$ & 19. 2 & 17. 0 & 18. 0 & 22.0 & 25.9 & 30.9 & 30.9 \\
\hline $\begin{array}{l}\text { Farm and miscellaneous private: } \\
\text { Softwoods } \\
\text { Hardwoods. }\end{array}$ & $\begin{array}{l}3.3 \\
9.2 \\
\end{array}$ & $\begin{array}{l}2.5 \\
8.1\end{array}$ & $\begin{array}{l}2.6 \\
8.7\end{array}$ & $\begin{array}{r}3.5 \\
15.1\end{array}$ & $\begin{array}{r}3.8 \\
20.0 \\
\end{array}$ & $\begin{array}{r}4.2 \\
24.4 \\
\end{array}$ & $\begin{array}{r}4.2 \\
24.8\end{array}$ \\
\hline Total $\ldots$ & 12.5 & 10.6 & 11.3 & 18. 6 & 23.8 & 28. 6 & 29. 0 \\
\hline $\begin{array}{l}\text { All owners: } \\
\text { Softwoods } \\
\text { Hardwoods.......... }\end{array}$ & $\begin{array}{l}3.5 \\
8.1\end{array}$ & $\begin{array}{l}2.9 \\
7.4\end{array}$ & $\begin{array}{l}\text { 3. } 3 \\
\text { 7. } 9\end{array}$ & $\begin{array}{r}4.5 \\
13.8\end{array}$ & $\begin{array}{r}5.4 \\
18.1 \\
\end{array}$ & $\begin{array}{r}6.4 \\
22.2 \\
\end{array}$ & $\begin{array}{r}6.5 \\
22.4\end{array}$ \\
\hline Total $\ldots . .$. & 11. 6 & 10. 3 & 11. 2 & 18. 3 & 23.5 & 28. 6 & 28. 9 \\
\hline
\end{tabular}

with growing-stock trees. This mainly reflects reductions in radial growth and increases in mortality resulting from increased stocking in younger stands, and the occupancy of much forest land by rough and rotten trees or nontimber cover.

Net annual growth rates as a percent of the growing stock inventory averaged about 3.6 percent in 1970. A moderate drop to an average of 2.6 percent by 2000 is estimated under the assumptions of this section, largely to the projected buildup of both softwood and hardwood inventories.

Many of the differences in growth and in stand conditions among ownership classes are the result of differences in forest types and levels of management. Thus larger inventories per acre and higher levels of growth on National Forests and forest industry lands reflect in part higher proportions of the more productive types such as maple-birch-beech and spruce-fir. Farm and miscellaneous private lands, on the other hand, include relatively large proportions of the oakhickory type which generally occupies the drier and less productive uplands.

Proportions of stand-size classes in 1970 also differed considerably by ownership. On public lands poletimber stands predominated, whereas sawtimber stands were more important on forest industry lands.

\section{Trends in Timber Inventories}

Because of the substantial surplus of net growth over removals in recent years, volumes of growing stock in the North increased about 42 percent between 1952 and 1970 to an average of 875 cubic feet per acre (table 58). Forest industry lands and National Forests supported the heaviest inventory volumes per acre in 1970, and such differentials are projected to continue. For all owners combined, the average inventory per acre under the assumptions of this chapter is projected to increase a further 33 percent by 2020 .

\section{PROJECTIONS OF TIMBER SUPPLIES IN THE ROCKY MOUNTAINS}

The Rocky Mountain section contained 14.2 percent of the Nation's timber inventory in 1970 , and accounted for 7.1 percent of the total national output of roundwood products. Some 4 percent of the Nation's lumber and wood products establishments were located in this area in 1967; these 
TABLE 57.-Net growth of growing stock per acre in the North, by owner class and species group, 1952, 1962, and 1970, with projections to 2020

[Cubic feet]

\begin{tabular}{|c|c|c|c|c|c|c|c|}
\hline \multirow{2}{*}{ Owner class and species group } & \multirow{2}{*}{1952} & \multirow{2}{*}{1962} & \multirow{2}{*}{1970} & \multicolumn{4}{|c|}{ Projections } \\
\hline & & & & 1980 & 1990 & 2000 & 2020 \\
\hline $\begin{array}{l}\text { National Forests: } \\
\text { Softwoods } \\
\text { Hardwoods. }\end{array}$ & $\begin{array}{r}9.2 \\
19.1\end{array}$ & $\begin{array}{l}\text { 10. } 2 \\
24.9\end{array}$ & $\begin{array}{l}11.1 \\
27.3\end{array}$ & $\begin{array}{l}10.9 \\
21.8\end{array}$ & $\begin{array}{l}10.7 \\
18.0\end{array}$ & $\begin{array}{l}10.3 \\
16.9\end{array}$ & $\begin{array}{l}10.3 \\
17.0\end{array}$ \\
\hline Total.... & 28. 3 & 35. 1 & 38.4 & 32.7 & 28. 7 & 27.2 & 27. 3 \\
\hline $\begin{array}{l}\text { Other public: } \\
\text { Softwoods-1. } \\
\text { Hardwoods }\end{array}$ & $\begin{array}{r}\text { 7. } 3 \\
\text { 17. } 6\end{array}$ & $\begin{array}{r}7.0 \\
19.0\end{array}$ & $\begin{array}{r}8.1 \\
25.3\end{array}$ & $\begin{array}{r}8.4 \\
24.5\end{array}$ & $\begin{array}{r}8.4 \\
22.4\end{array}$ & $\begin{array}{r}8.2 \\
21.1\end{array}$ & $\begin{array}{r}8.2 \\
21.1\end{array}$ \\
\hline Total _- & 24. 9 & 26. 0 & 33. 4 & 32. 9 & 30.8 & 29. 3 & 29. 3 \\
\hline $\begin{array}{l}\text { Forest industry: } \\
\text { Softwoods.--. } \\
\text { Hardwoods.-. }\end{array}$ & $\begin{array}{l}16.4 \\
16.8\end{array}$ & $\begin{array}{l}20.1 \\
19.4\end{array}$ & $\begin{array}{l}22.4 \\
18.1\end{array}$ & $\begin{array}{l}20.1 \\
17.3\end{array}$ & $\begin{array}{l}\text { 18. } 3 \\
16.4\end{array}$ & $\begin{array}{l}\text { 17. } 7 \\
15.9\end{array}$ & $\begin{array}{l}17.7 \\
15.9\end{array}$ \\
\hline Total $\ldots$ & 33. 2 & 39.5 & 40.5 & 37.4 & 34.7 & 33. 6 & 33. 6 \\
\hline $\begin{array}{l}\text { Farm and miscellaneous private: } \\
\text { Softwoods } \\
\text { Hardwoods }\end{array}$ & $\begin{array}{r}4.7 \\
18.0\end{array}$ & $\begin{array}{r}5.4 \\
20.9\end{array}$ & $\begin{array}{r}5.5 \\
23.4\end{array}$ & $\begin{array}{r}5.3 \\
25.2\end{array}$ & $\begin{array}{r}4.5 \\
26.0 \\
\end{array}$ & $\begin{array}{r}4.2 \\
26.2 \\
\end{array}$ & $\begin{array}{r}4.2 \\
26.2 \\
\end{array}$ \\
\hline Total & 22. 7 & 26. 3 & 28. 9 & 30.5 & 30.5 & 30.4 & 30.4 \\
\hline 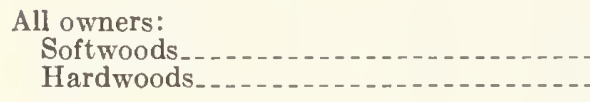 & $\begin{array}{r}6.3 \\
17.9\end{array}$ & $\begin{array}{r}7.1 \\
20.8\end{array}$ & $\begin{array}{r}7.8 \\
23.3\end{array}$ & $\begin{array}{r}7.5 \\
24.1\end{array}$ & $\begin{array}{r}6.8 \\
24.1\end{array}$ & $\begin{array}{r}6.5 \\
23.9\end{array}$ & $\begin{array}{r}6.7 \\
23.7\end{array}$ \\
\hline Total $\ldots$ & 24.2 & 27.9 & 31.1 & 31.6 & 30.9 & 30.4 & 30.4 \\
\hline
\end{tabular}

produced 6 percent of the value added in U.S. production of lumber and wood products.

\section{Trends in Forest Area}

Classification of forest lands in terms of commercial timberland is particularly difficult in this section because of the marginal nature of much of the forest land and timber resource and the increasing importance of nontimber and environmental management objectives that limit or preclude commercial timber production.

Forest areas in the Rocky Mountains that were classed as suitable and available for timber production in 1970 amounted to 61.6 million acres, or 3 million acres less than comparable figures in 1962 (table 59). About 0.7 million acres of National Forest land were withdrawn between 1962 and 1970 for additions to wilderness, and about 2.3 million acreas were placed in a "deferred" category pending further study of use potentials.

A further 5 percent decline in National Forest commercial timberland over the next several decades was assumed in developing projections of possible future supplies of timber. As pointed out earlier, it is of course possible that landuse and classification studies currently underway could lead to additional reductions in these area figures.

For other public owners a similar decline in commercial timberland has been projected. The small area under forest industry ownership, 2.2 million acres, was assumed to remain constant.

Commercial timberland in farm and miscellaneous ownerships remained almost constant in recent years at about $\mathbf{1 2 . 5}$ million acres. However, availability of these lands for commercial timber use is believed to have diminished because of growing use for nontimber purposes. Much of this forest acreage is of low productivity for timber production and much is held by owners whose management goals conflict with timber management. The acreage of farm and miscellaneous owners available for commercial timber use has therefore been projected to decline 25 percent below the figures shown for 1970 .

The total acreage of commercial timberland in the Rocky Mountains is therefore projected to decline about 9 percent by 2020 to a level of 56 million acres. This figure includes 5 million acres with marginal possibilities for timber production, as noted in the footnote of table 59 . 
TABLE 5S.-Inventory of growing stock per acre in the North, by owner class, 1952, 1962, and 1970, with

[Cubic feet]

\begin{tabular}{|c|c|c|c|c|c|c|c|}
\hline \multirow{2}{*}{ Owner class and species group } & \multirow{2}{*}{1952} & \multirow{2}{*}{1962} & \multirow{2}{*}{1970} & \multicolumn{4}{|c|}{ Projections } \\
\hline & & & & 1980 & 1990 & 2000 & 2020 \\
\hline $\begin{array}{l}\text { National Forests: } \\
\text { Softwoods.-. } \\
\text { Hardwoods.-. }\end{array}$ & $\begin{array}{l}189 \\
447\end{array}$ & $\begin{array}{l}258 \\
598\end{array}$ & $\begin{array}{l}296 \\
704\end{array}$ & $\begin{array}{l}363 \\
871\end{array}$ & $\begin{array}{l}403 \\
950\end{array}$ & $\begin{array}{l}417 \\
974\end{array}$ & $\begin{array}{l}417 \\
974 \\
\end{array}$ \\
\hline Total & 636 & 856 & 1,000 & 1,234 & 1,353 & 1, 391 & 1,391 \\
\hline $\begin{array}{l}\text { Other public: } \\
\text { Soft woods_-. } \\
\text { Hardwoods.-. }\end{array}$ & $\begin{array}{l}150 \\
402\end{array}$ & $\begin{array}{l}193 \\
545\end{array}$ & $\begin{array}{l}226 \\
648\end{array}$ & $\begin{array}{l}274 \\
814\end{array}$ & $\begin{array}{l}305 \\
906 \\
\end{array}$ & $\begin{array}{l}316 \\
936\end{array}$ & $\begin{array}{l}316 \\
936\end{array}$ \\
\hline Total & 552 & 738 & 874 & 1,088 & 1,211 & 1,252 & 1,252 \\
\hline $\begin{array}{l}\text { Forest industry: } \\
\text { Softwoods._... } \\
\text { Hardwoods...- }\end{array}$ & $\begin{array}{l}440 \\
494\end{array}$ & $\begin{array}{l}544 \\
590\end{array}$ & $\begin{array}{l}640 \\
571\end{array}$ & $\begin{array}{l}749 \\
643\end{array}$ & $\begin{array}{l}805 \\
686\end{array}$ & $\begin{array}{l}823 \\
701\end{array}$ & $\begin{array}{l}824 \\
701 \\
\end{array}$ \\
\hline Total_. & 934 & 1,134 & 1,211 & 1,392 & 1,491 & 1,524 & 1,525 \\
\hline $\begin{array}{l}\text { Farm and miscellaneous private: } \\
\text { Softwoods. } \\
\text { Hardwoods. }\end{array}$ & $\begin{array}{l}132 \\
499\end{array}$ & $\begin{array}{l}151 \\
580\end{array}$ & $\begin{array}{l}155 \\
664\end{array}$ & $\begin{array}{l}179 \\
778\end{array}$ & $\begin{array}{l}192 \\
850\end{array}$ & $\begin{array}{l}196 \\
875\end{array}$ & $\begin{array}{l}196 \\
875\end{array}$ \\
\hline Total. & 631 & 731 & 819 & 957 & 1,042 & 1,071 & 1,071 \\
\hline $\begin{array}{l}\text { All owners: } \\
\text { Softwoods._. - } \\
\text { Hardwoods... }\end{array}$ & $\begin{array}{l}163 \\
483\end{array}$ & $\begin{array}{l}194 \\
578\end{array}$ & $\begin{array}{l}220 \\
655\end{array}$ & $\begin{array}{l}260 \\
774\end{array}$ & $\begin{array}{l}284 \\
845\end{array}$ & $\begin{array}{l}294 \\
869\end{array}$ & $\begin{array}{l}300 \\
867\end{array}$ \\
\hline Total & 646 & 772 & 875 & 1,034 & 1,129 & 1,163 & 1,167 \\
\hline
\end{tabular}

TABLE 59.-Area of commercial timberland in the Rocky Mountains, by owner class, 1952, 1962, and 1970, with projections to 2020

[Millions acres]

\begin{tabular}{|c|c|c|c|c|c|c|c|}
\hline \multirow{2}{*}{ Owner class } & \multirow{2}{*}{1952} & \multirow{2}{*}{1962} & \multirow{2}{*}{1970} & \multicolumn{4}{|c|}{ Projections } \\
\hline & & & & 1980 & 1990 & 2000 & 2020 \\
\hline $\begin{array}{l}\text { National Forest } \\
\text { Other public } \\
\text { Forest industry } \\
\text { Farm and miscellaneous private }\end{array}$ & $\begin{array}{r}41.9 \\
7.2 \\
2.2 \\
12.5\end{array}$ & $\begin{array}{r}42.7 \\
7.2 \\
2.2 \\
12.5\end{array}$ & $\begin{array}{r}139.8 \\
7.2 \\
2.2 \\
12.4\end{array}$ & $\begin{array}{r}39.4 \\
7.1 \\
2.2 \\
11.8\end{array}$ & $\begin{array}{r}39.0 \\
7.0 \\
2.2 \\
11.1\end{array}$ & $\begin{aligned} 38.6 \\
7.0 \\
2.2 \\
10.5\end{aligned}$ & $\begin{array}{r}37.8 \\
6.8 \\
2.2 \\
9.2\end{array}$ \\
\hline Total_- & 63.9 & 64.6 & 61.6 & 60.5 & 59.3 & 58. 3 & 56. 0 \\
\hline
\end{tabular}

1 Includes 5 million acres of National Forest land not considered in projecting timber supplies. These include small patches and stringers of productive forest land isolated from markets, areas too unstable to harvest with current technology, and lands where nontimber uses predominate.

\section{Timber Removals}

Because of accessibility problems and low stumpage values, timber harvests in the Rocky Mountain area for many years were limited to large, high-quality timber such as white pine and ponderosa pine. A large portion of the tim- ber inventory was not economically available until after World War II, when improved transportation in the region and growing timber markets led to increased values for diverse species and smaller sized trees.

The extent of recent timber development is indicated by the substantial rise in timber re- 
TABLE 60.-Timber removals, net growth, mortality, supplies of roundwood products, and inventories in the Kocky Mountains, 1952, 1962, and 1970, with projections (1970 level of management) " to 2020

[Million cubic feet]

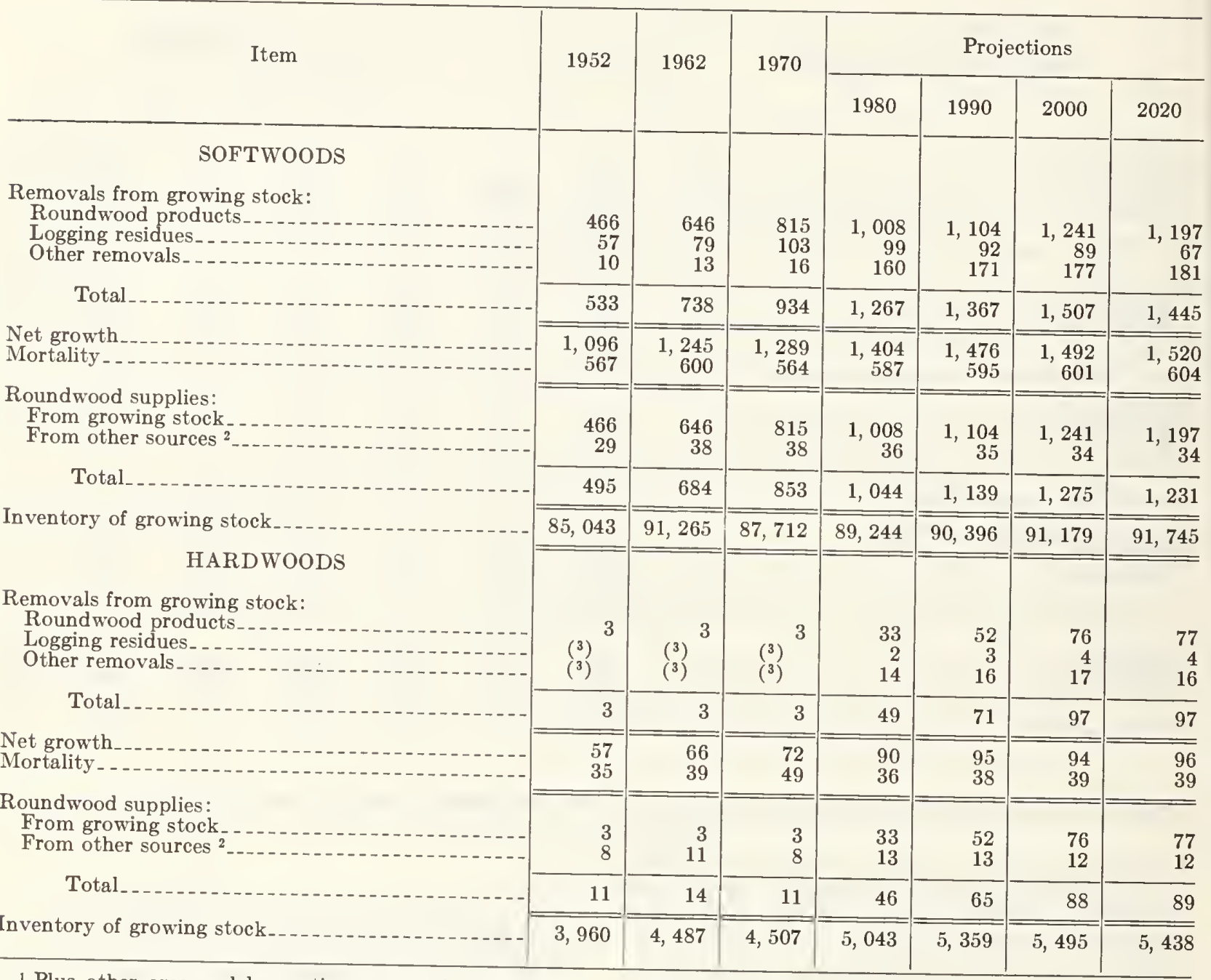

${ }^{1}$ Plus other area and harvesting assumptions specified in this chapter.

${ }^{2}$ Includes roundwood products from rough and rotten trees, dead trees, and trees on noncommercial and non-

movals between 1952 and 1970 (tables 60 and 61 and figs. 34 and 35). Acceptance of smaller tree sizes for roundwood products also is evidenced by a 75 percent increase in removals of trees 5.0 inches and larger; compared with a 68 percent increase for removals of sawtimber, that is, the saw-log portion of sound trees 9.0 inches and larger. Some of this expanded harvesting reflects cutting for pulpwood. Some is the result of using modern equipment for production of lumber from small timber.

Hardwoods play a very minor role in the Rocky Mountains. In 1970 they comprised 4.9 percent of the inventory and 0.3 percent of total removals forest land.

${ }^{3}$ Less than 0.5 million cubic feet.

Note: Estimates are for trend levels and consequently may differ from actual figures for the specified years.

(table 60). Only 4 percent of the net growth of hardwoods was removed in 1970.

Under the assumptions concerning trends in commercial timberland areas and continuance of forest management at 1970 levels, available removals in this base projection have been estimated to increase substantially in cubic feet, and to rise moderately for sawtimber.

These projections indicate the possibility of a 61 percent increase by 2000 in softwood growing stock removals above actual removals in 1970 , and a 22 percent increase in sawtimber removals. More than half of the projected increase in removals occurs before 1980, based on the assump- 
TABLE 61.-Sawtimber removals, net growth, mortality, supplies of roundwood products, and inventories in the Rocky Mountains, 1952, 1962, 1970, with projections (1970 level of management) ${ }^{1}$ to 2020

[Million board feet]

\begin{tabular}{|c|c|c|c|c|c|c|c|}
\hline \multirow[b]{2}{*}{ Item } & \multirow[b]{2}{*}{1952} & \multirow[b]{2}{*}{1962} & \multirow[b]{2}{*}{1970} & \multicolumn{4}{|c|}{ Projections } \\
\hline & & & & 1980 & 1990 & 2000 & 2020 \\
\hline \multicolumn{8}{|l|}{ SOFTWOODS } \\
\hline $\begin{array}{l}\text { Removals from sawtimber: } \\
\text { Roundwood products } \\
\text { Logging residues. } \\
\text { Other removals }\end{array}$ & $\begin{array}{r}2,940 \\
177 \\
60\end{array}$ & $\begin{array}{r}3,961 \\
240 \\
78\end{array}$ & $\begin{array}{r}4,948 \\
311 \\
97\end{array}$ & $\begin{array}{r}5,274 \\
275 \\
605\end{array}$ & $\begin{array}{r}5,349 \\
261 \\
633\end{array}$ & $\begin{array}{r}5,625 \\
259 \\
647\end{array}$ & $\begin{array}{r}5,222 \\
237 \\
660 \\
\end{array}$ \\
\hline Total & 3,177 & 4,279 & 5,356 & 6,154 & 6,243 & 6,531 & 6,119 \\
\hline $\begin{array}{l}\text { Yet growth.......... } \\
\text { Mortality. }\end{array}$ & $\begin{array}{l}4,153 \\
2,470 \\
\end{array}$ & $\begin{array}{l}4,523 \\
2,517\end{array}$ & $\begin{array}{l}4,936 \\
2,546\end{array}$ & $\begin{array}{l}5,646 \\
2,214\end{array}$ & $\begin{array}{l}6,034 \\
2,185 \\
\end{array}$ & $\begin{array}{l}6,178 \\
2,168 \\
\end{array}$ & $\begin{array}{l}6,328 \\
2,150 \\
\end{array}$ \\
\hline $\begin{array}{l}\text { Roundwood supplies: } \\
\text { From sawtimber-.... } \\
\text { From other sources }{ }^{2}-\ldots\end{array}$ & $\begin{array}{r}2,940 \\
186\end{array}$ & $\begin{array}{r}3,961 \\
228\end{array}$ & $\begin{array}{r}4,948 \\
326\end{array}$ & $\begin{array}{r}5,274 \\
311\end{array}$ & $\begin{array}{r}5,349 \\
300\end{array}$ & $\begin{array}{r}5,625 \\
289\end{array}$ & $\begin{array}{r}5,222 \\
289\end{array}$ \\
\hline Total & 3,126 & 4,189 & 5,274 & 5,585 & 5,649 & 5,914 & 5,511 \\
\hline Inventory of sawtimber & 369,173 & 381,344 & 355,107 & 345,984 & 342,424 & 340,949 & 339,635 \\
\hline \multicolumn{8}{|l|}{ HARDWOODS } \\
\hline 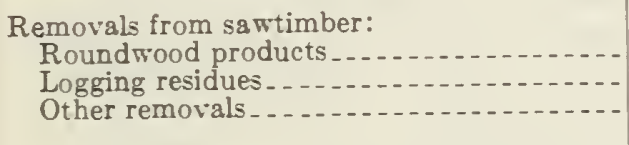 & $\begin{array}{r}14 \\
1 \\
1\end{array}$ & $\begin{array}{r}18 \\
1 \\
1\end{array}$ & $\begin{array}{r}11 \\
1 \\
1\end{array}$ & $\begin{array}{r}106 \\
4 \\
28\end{array}$ & $\begin{array}{r}146 \\
5 \\
30\end{array}$ & $\begin{array}{r}194 \\
6 \\
32\end{array}$ & $\begin{array}{r}189 \\
6 \\
32 \\
\end{array}$ \\
\hline Total..... & 16 & 20 & 13 & 138 & 181 & 232 & 227 \\
\hline $\begin{array}{l}\text { Net growth } \\
\text { Mortality }\end{array}$ & $\begin{array}{l}98 \\
71 \\
\end{array}$ & $\begin{array}{r}107 \\
73 \\
\end{array}$ & $\begin{array}{l}145 \\
102 \\
\end{array}$ & $\begin{array}{r}187 \\
63 \\
\end{array}$ & $\begin{array}{r}209 \\
63\end{array}$ & $\begin{array}{r}212 \\
68\end{array}$ & $\begin{array}{r}210 \\
63 \\
\end{array}$ \\
\hline $\begin{array}{l}\text { Roundwood supplies: } \\
\text { From sawtimber } \\
\text { From other sources }{ }^{2}\end{array}$ & $\begin{array}{r}14 \\
1\end{array}$ & $\begin{array}{r}18 \\
1\end{array}$ & $\begin{array}{r}11 \\
2\end{array}$ & $\begin{array}{r}106 \\
2\end{array}$ & $\begin{array}{r}146 \\
2\end{array}$ & $\begin{array}{r}194 \\
2\end{array}$ & $\begin{array}{r}189 \\
2\end{array}$ \\
\hline Total $\ldots$ & 15 & 19 & 13 & 108 & 148 & 196 & 191 \\
\hline Inventory of sawtimber.- & 8,904 & 9,580 & 9,302 & 9,955 & 10,310 & 10,386 & 9,970 \\
\hline
\end{tabular}

${ }_{1}^{1}$ Plus other area and harvesting assumptions specified in this chapter.

2 Includes roundwood products from rough and rotten trees, dead trees, and trees on noncommercial and non-

tion that National Forest removals could rise to equal the level of allowable cut estimated in 1970.

It is recognized that forest acreages could rary from assumptions as a result of changing land management objectives. Allowable cut levels could be revised downward as a result of increases in nontimber uses. And economic analyses indicate that actual timber harrests could equal allowable cuts only with significantly higher stumpage price lerels than existed in 1970.

Projections also indicate that substantial volumes of hardwoods, particularly aspen, could be made available under the assumptions of these forest land.

Note: Estimates are for trend levels and consequently may differ from actual figures for the specified years.

base projections, but substantial changes in hardwood values, plant capacity, and markets would be necessary before expanded use becomes feasible.

\section{Supplies of Roundwood}

Harrests of timber products for use by the timber industries made up an estimated 87 percent of all softwood growing stock remorals in 1970 (tables 60 and 62). Approximately 11 percent of the total volume removed from growing stock was left in the woods as logging residues. An estimated 2 percent--which probably was an underestimate of average annual withdrawals-represented re- 
Net growth and removals of growing stock in the Rocky Mountains

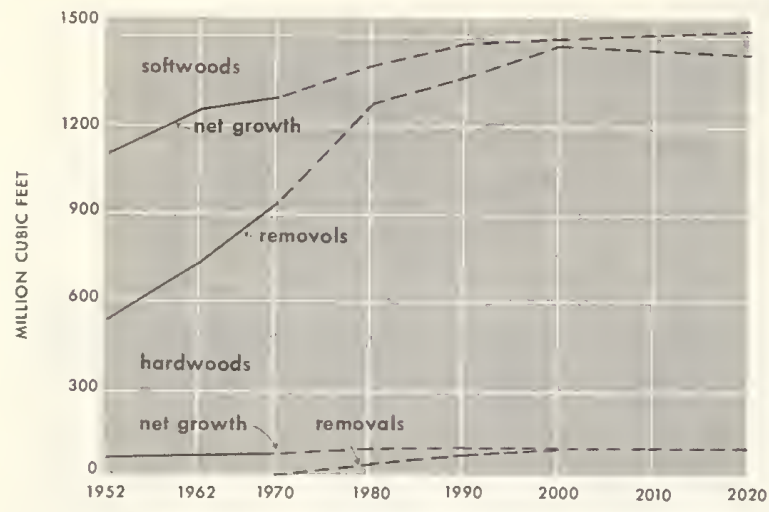

Figure 34

Net growth and removals from sawtimber in the Rocky Mountains

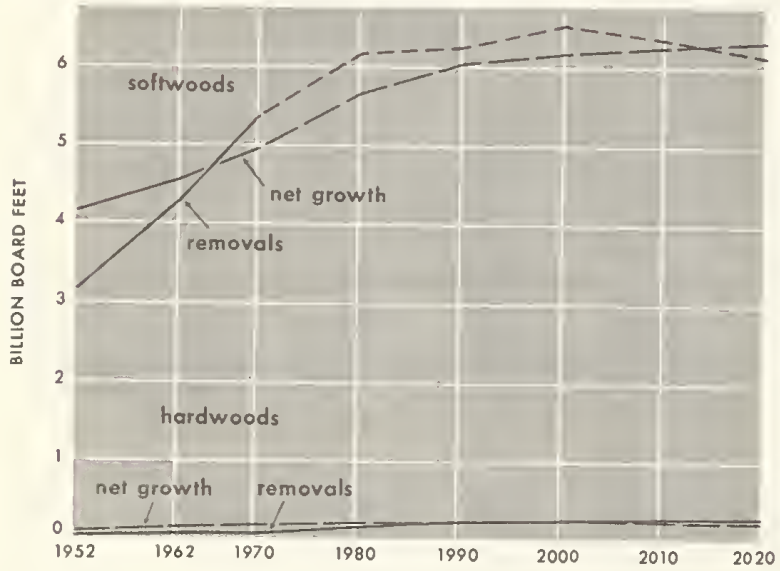

Figure 35 movals of timber volumes on lands shifted from timber to other uses.

It has been assumed in these base projections that an increasing amount of the material now left as logging residue will be utilized for products in the future. Other removals are projected at a relatively high level in accordance with earlier assumptions on area trends.

In addition to roundwood products from growing stock, some production of roundwood is obtained from rough, rotten, and dead trees and from trees on areas not classified as commercial timberland. Materials from these sources amounted to nearly 5 percent of all roundwood produced in 1970 (tables 60 and 61 ).

Available supplies of softwood roundwood from all sources are projected to increase about 50 percent between 1970 and 2000 to nearly 1.3 billion cubic feet (tables 60 and 63). A large projected increase in available output from National Forests mainly reflects the fact that actual timber harvests on National Forests in 1970 were about 27 percent below the estimated allowable cuts used as the basis for these supply projections.

Achievement of the full allowable cut as assumed would require higher prices than in 1970. Also, it appears that new studies of multiple-use management requirements, and new studies of areas for possible wilderness designation, will result in somewhat lower levels of allowable cut than estimated in this section. Increased management and/or utilization efforts could serve to prevent or minimize such reductions in available supplies, as indicated in the following chapter.

Sawtimber supplies.-Available output of softwood roundwood in board feet of sawtimber size material increases only moderately in these projections in contrast to the projected rise of 50 percent in available output in cubic feet (table 64 and fig. 36). Projected harvests from National Forests represent nearly 59 percent of the total projected output of sawtimber products.

Increases in sawtimber production also are projected for other public lands and for farm and

TABLE 62.-Components of softwood growing stock removals in the Rocky Mountains, 1952, 1962, and 1970, with projections to 2020

[Percent]

\begin{tabular}{|c|c|c|c|c|c|c|c|}
\hline \multirow{2}{*}{ Component } & \multirow{2}{*}{1952} & \multirow{2}{*}{1962} & \multirow{2}{*}{1970} & \multicolumn{4}{|c|}{ Projections } \\
\hline & & & & 1980 & 1990 & 2000 & 2020 \\
\hline $\begin{array}{l}\text { Roundwood products } \\
\text { Logging residue. } \\
\text { Other removals }\end{array}$ & $\begin{array}{r}87 \\
11 \\
2\end{array}$ & $\begin{array}{r}87 \\
11 \\
2\end{array}$ & $\begin{array}{r}87 \\
11 \\
2\end{array}$ & $\begin{array}{r}80 \\
8 \\
12\end{array}$ & $\begin{array}{r}81 \\
7 \\
12\end{array}$ & $\begin{array}{r}82 \\
6 \\
12\end{array}$ & $\begin{array}{r}83 \\
5 \\
12\end{array}$ \\
\hline Total removals & 100 & 100 & 100 & 100 & 100 & 100 & 100 \\
\hline
\end{tabular}


TABLE 63.- Supplies of roundwood products in the Rocky Mcinluins, by owner class and species group, 1952, 1962, and 1970, with projections to 2020

[Million cubic feet]

\begin{tabular}{|c|c|c|c|c|c|c|c|}
\hline \multirow{2}{*}{ Owner class and species group } & \multirow{2}{*}{$19 \tilde{2} 2$} & \multirow{2}{*}{1962} & \multirow{2}{*}{1970} & \multicolumn{4}{|c|}{ Projections } \\
\hline & & & & 1980 & 1990 & 2000 & 2020 \\
\hline $\begin{array}{l}\text { Wational Forests: } \\
\text { Softwoods } \\
\text { Hardwoods }\end{array}$ & $\begin{array}{r}218 \\
7\end{array}$ & $\begin{array}{r}387 \\
10\end{array}$ & $\begin{array}{r}519 \\
9\end{array}$ & $\begin{array}{r}702 \\
23\end{array}$ & $\begin{array}{r}697 \\
28 \\
\end{array}$ & $\begin{array}{r}692 \\
32\end{array}$ & $\begin{array}{r}685 \\
38\end{array}$ \\
\hline Total_..- & 225 & 397 & 528 & 725 & 725 & 724 & 723 \\
\hline $\begin{array}{l}\text { Other public: } \\
\text { Sof twoods } \\
\text { Hardwoods }\end{array}$ & $\begin{array}{r}72 \\
1\end{array}$ & $\begin{array}{r}78 \\
2\end{array}$ & $(1)^{78}$ & $\begin{array}{r}82 \\
4\end{array}$ & $\begin{array}{r}120 \\
7\end{array}$ & $\begin{array}{r}177 \\
10\end{array}$ & $\begin{array}{r}174 \\
10\end{array}$ \\
\hline Total _... & 74 & 80 & 78 & 86 & 127 & 187 & 184 \\
\hline $\begin{array}{l}\text { Forest industry } \\
\text { Softwoods } \\
\text { Hardwoods }\end{array}$ & (1) 90 & $\begin{array}{r}118 \\
1\end{array}$ & ${ }_{(1)}^{170}$ & $\begin{array}{r}146 \\
6\end{array}$ & $\begin{array}{r}127 \\
6\end{array}$ & $\begin{array}{r}100 \\
5\end{array}$ & $\begin{array}{r}102 \\
5\end{array}$ \\
\hline Total ..... & 91 & 119 & 170 & 152 & 133 & 105 & 107 \\
\hline $\begin{array}{l}\text { Farm and miscellaneous private: } \\
\text { Sof twoods } \\
\text { Hardwoods. }\end{array}$ & $\begin{array}{r}116 \\
2\end{array}$ & $\begin{array}{r}101 \\
2\end{array}$ & $\begin{array}{r}86 \\
1\end{array}$ & $\begin{array}{r}113 \\
12\end{array}$ & $\begin{array}{r}196 \\
24\end{array}$ & $\begin{array}{r}306 \\
41\end{array}$ & $\begin{array}{r}270 \\
36\end{array}$ \\
\hline Total .... & 118 & 103 & 87 & 125 & 220 & 347 & 306 \\
\hline $\begin{array}{l}\text { Total Rocky Mountains: } \\
\text { Softwoods_. } \\
\text { Hardwoods. }\end{array}$ & $\begin{array}{r}495 \\
11\end{array}$ & $\begin{array}{r}684 \\
14\end{array}$ & $\begin{array}{r}852 \\
11\end{array}$ & $\begin{array}{r}1,044 \\
46\end{array}$ & $\begin{array}{r}1,139 \\
65\end{array}$ & $\begin{array}{r}1,275 \\
89\end{array}$ & $\begin{array}{r}1,231 \\
89\end{array}$ \\
\hline Total $\ldots \ldots$ & 506 & 698 & 863 & 1,090 & 1,204 & 1,364 & 1,320 \\
\hline
\end{tabular}

1 Value is less than 0.5 million cubic feet.

miscellaneous ownerships. In the latter case, the projected change in roundwood output is based on the assumption that timber harrests will increase from the actual level of 1970 to a balance with growth on lands remaining in the commercial timberland category. On these farm and miscellaneous ownerships removals in 1970 amounted to only 31 percent of the net growth of growing stock and 56 percent of sawtimber growth.

Forest industry ownerships display almost an opposite trend. As reserves of industrial timber are harrested, projected output declines to about 63 percent of the 1970 level. Projected roundwood production per acre declines from a relatively high level of about 76 cubic feet in 1970 to 49 cubic feet by 2020 .

Projection alternatives.-A substantial increase in projected available supplies of roundwood products from the Rocky Mountains in the face of some decline in commercial timberland acreage and a drop in output on forest industry lands will be possible only if farm and miscellaneous private owners greatly increase removals and if harvests in National Forests actually rise to the allowable cut levels estimated in 1970 .

Furthermore, most of the projected increase in available timber supplies must come from smaller diameter trees. Available roundrood supplies from growing stock trees over 5 inches in diameter is estimated to increase 53 percent over 1970 levels. Available output of sawtimber, however, is projected to increase only 8 percent above the actual cut in 1970 . The preponderance of trees below 9 inches in diameter in the projections of available timber supplies indicates that improved utilization of trees by new types of milling equipment or use for pulprood will be necessary if these supplies are to be utilized.

While these projections of potential supply indicate what is biologically available under the specified assumptions, the Rocky Mountain area is faced with problems of economic inaccessibility of much timber, lack of markets for small wood, and possible increases in management constraints to protect environmental values. Consequently, estimates of timber supplies economically arailable with alternative price levels have been developed, as shown in the final section of this chapter. 
TABLE 64.-Supplies of sawtimber products in the Rocky Mountains, by owner class and species group, 1952, 1962, and 1970, with projections to 2020

[Million board feet]

\begin{tabular}{|c|c|c|c|c|c|c|c|}
\hline \multirow{2}{*}{ Owner class and species group } & \multirow{2}{*}{1952} & \multirow{2}{*}{1962} & \multirow{2}{*}{1970} & \multicolumn{4}{|c|}{ Projections } \\
\hline & & & & 1980 & 1990 & 2000 & 2020 \\
\hline $\begin{array}{l}\text { National Forests: } \\
\text { Softwoods } \\
\text { Hardwoods }\end{array}$ & $\begin{array}{r}1,362 \\
10\end{array}$ & $\begin{array}{r}2,370 \\
13\end{array}$ & $\begin{array}{r}3,209 \\
11\end{array}$ & $\begin{array}{r}3,884 \\
61\end{array}$ & $\begin{array}{r}3,692 \\
74\end{array}$ & $\begin{array}{r}3,528 \\
82\end{array}$ & $\begin{array}{r}3,287 \\
88\end{array}$ \\
\hline Total _.... & 1,372 & 2,383 & 3,220 & 3,945 & 3,766 & 3,610 & 3,375 \\
\hline $\begin{array}{l}\text { Other public: } \\
\text { Softwoods } \\
\text { Hardwoods. }\end{array}$ & $\begin{array}{r}451 \\
1\end{array}$ & $\begin{array}{r}470 \\
2\end{array}$ & $\begin{array}{r}490 \\
1\end{array}$ & $\begin{array}{r}396 \\
11\end{array}$ & $\begin{array}{r}537 \\
17\end{array}$ & $\begin{array}{r}752 \\
26\end{array}$ & $\begin{array}{r}733 \\
25\end{array}$ \\
\hline Total_. & 452 & 472 & 491 & 407 & 554 & 778 & 758 \\
\hline $\begin{array}{l}\text { Forest industry: } \\
\text { Softwoods } \\
\text { Hardwoods }\end{array}$ & $\begin{array}{r}606 \\
1\end{array}$ & $\begin{array}{r}760 \\
1\end{array}$ & $\underset{\left({ }^{(1)}\right.}{1,047}$ & $\begin{array}{r}801 \\
5\end{array}$ & $\begin{array}{r}624 \\
4\end{array}$ & $\begin{array}{r}453 \\
3\end{array}$ & $\begin{array}{r}455 \\
3\end{array}$ \\
\hline Total $\ldots . .$. & 607 & 761 & 1,047 & 806 & 628 & 456 & 458 \\
\hline $\begin{array}{l}\text { Farm and miscellaneous private: } \\
\text { Softwoods } \\
\text { Hardwoods }\end{array}$ & $\begin{array}{r}707 \\
3\end{array}$ & $\begin{array}{r}589 \\
3\end{array}$ & $\begin{array}{r}527 \\
1\end{array}$ & $\begin{array}{r}504 \\
31\end{array}$ & $\begin{array}{r}796 \\
53\end{array}$ & $\begin{array}{r}1,180 \\
85\end{array}$ & $\begin{array}{r}1,037 \\
74\end{array}$ \\
\hline Total & 710 & 592 & 528 & 535 & 849 & 1,265 & 1,111 \\
\hline $\begin{array}{l}\text { Total Rocky Mountains: } \\
\text { Softwoods_- } \\
\text { Hardwoods }\end{array}$ & $\begin{array}{r}3,126 \\
15\end{array}$ & $\begin{array}{r}4,189 \\
19\end{array}$ & $\begin{array}{r}5,273 \\
13\end{array}$ & $\begin{array}{r}5,585 \\
108\end{array}$ & $\begin{array}{r}5,648 \\
148\end{array}$ & $\begin{array}{r}5,914 \\
196\end{array}$ & $\begin{array}{r}5,511 \\
191\end{array}$ \\
\hline Total_ . & 3,141 & 4,208 & 5,286 & 5,693 & 5,796 & 6,110 & 5,702 \\
\hline
\end{tabular}

${ }^{1}$ Less than 0.5 million board feet.

Supplies of softwood sawtimber products in the Rocky Mountains, by owner class

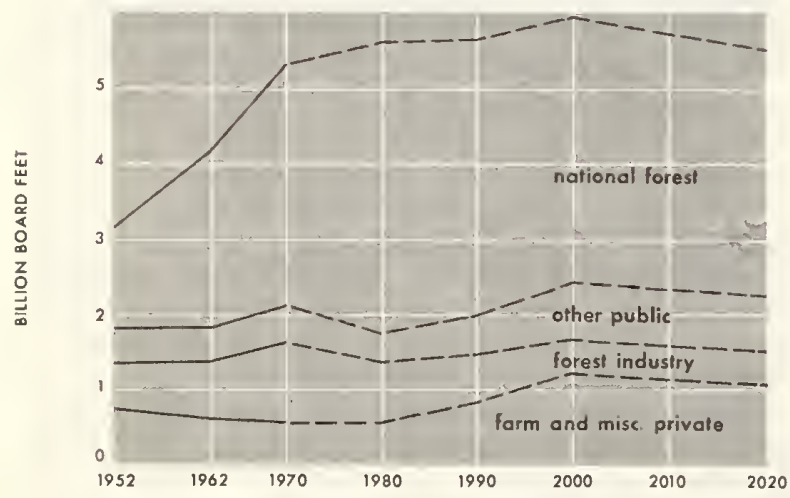

Figure 36

\section{Net Growth and Mortality}

Net growth of both growing stock and sawtimber are projected to increase somewhat under the management, cutting, and area assumptions adopted in this chapter. Projected growth of growing stock rises from 1.4 billion cubic feet in 1970 to 1.6 billion cubic feet in 2020-a rise of 19 percent (table 60 and fig. 34). Projected net growth of sawtimber rises about 29 percent (table 61 and fig. 35).

In terms of per acre figures, net growth of growing stock under the specified assumptions rises from about 24 cubic feet in 1970 to 29 cubic feet by 2020 (table 65). Net growth figures vary rather widely for different classes of ownership, depending on site quality, relative proportions of old-growth timber, and intensity of management.

A substantial part of the timber growth in the Rocky Mountains in the past has been offset by mortality, reflecting the large proportion of oldgrowth timber and major losses to insects such as bark beetles, diseases such as white pine blister rust, and frequent fires. In 1970, for example, estimated mortality amounted to more than 2.6 billion board feet, or more than one-third of the gross growth (tables 60 and 61). Mortality of sawtimber is expected to decline, however, with continued cutting of old-growth timber. 
TABLE 65.-Net growth and mortality of growing stock and sawtimber per acre in the Rocky Mountains, by owner class, 1952, 1962, and 1970, with projections to 2020

GROWING STOCK-CUBIC FEET

\begin{tabular}{|c|c|c|c|c|c|c|c|}
\hline \multirow{2}{*}{ Owner class and item } & \multirow{2}{*}{1952} & \multirow{2}{*}{1962} & \multirow{2}{*}{1970} & \multicolumn{4}{|c|}{ Projections } \\
\hline & & & & 1980 & 1990 & 2000 & 2020 \\
\hline National Forests: & & & & & & & \\
\hline $\begin{array}{l}\text { Net growth } \\
\text { Jortality }\end{array}$ & 17 & 19 & 23 & 21 & 23 & 24 & 27 \\
\hline Other public: & & & & & & & 11 \\
\hline $\begin{array}{l}\text { Net growth } \\
\text { Mortality }\end{array}$ & $\begin{array}{l}17 \\
10\end{array}$ & $\begin{array}{l}20 \\
10\end{array}$ & 23 & 27 & $\begin{array}{l}28 \\
12\end{array}$ & $\begin{array}{l}28 \\
12\end{array}$ & $\begin{array}{l}28 \\
12\end{array}$ \\
\hline Forest industry: & & & & & & & \\
\hline $\begin{array}{l}\text { Net growth } \\
\text { IIortality }\end{array}$ & 35 & 41 & 47 & 47 & 48 & 49 & 49 \\
\hline $\begin{array}{l}\text { Mortality } \\
\text { Farm and miscellaneous private: }\end{array}$ & 10 & 10 & 11 & 10 & 9 & 8 & 8 \\
\hline $\begin{array}{l}\text { Net growth } \\
\text { Mortality }\end{array}$ & 18 & 22 & 25 & 31 & 35 & 34 & 34 \\
\hline $\begin{array}{l}\text { Mortality -..- } \\
\text { All owners: }\end{array}$ & 8 & 8 & 9 & 10 & 12 & 12 & 12 \\
\hline Net growth & 18 & 20 & 24 & 25 & 26 & 27 & 29 \\
\hline Mortality & 9 & 10 & 11 & 10 & 11 & 11 & 11 \\
\hline
\end{tabular}

SAWTIMBER-BOARD FEET

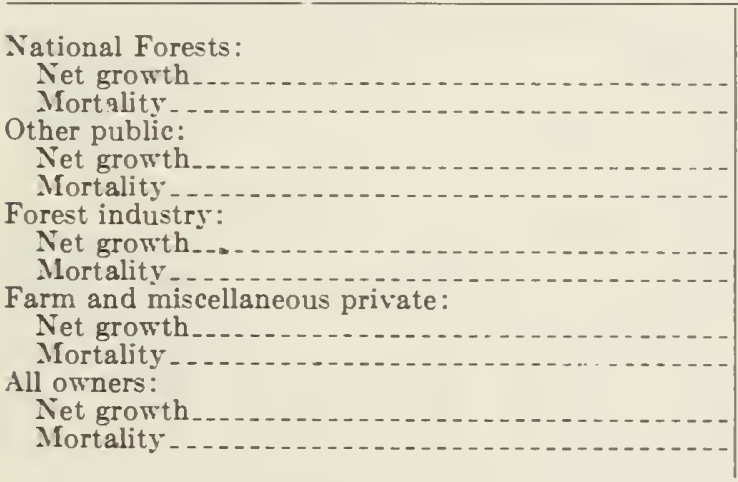

\begin{tabular}{r|r|r}
62 & 66 \\
42 & 43 & \\
64 & 72 & \\
42 & 40 & \\
168 & 186 & 48 \\
48 & 71 \\
64 & 29 \\
30 & & \\
67 & 72 & \\
40 & 40 &
\end{tabular}

\begin{tabular}{r|}
89 \\
55 \\
79 \\
39 \\
201 \\
47 \\
77 \\
29 \\
90 \\
47
\end{tabular}

\begin{tabular}{r|r|r|r}
87 & & & \\
38 & 35 & 101 & 112 \\
100 & 111 & 37 & 39 \\
39 & 42 & 44 & 110 \\
214 & 207 & 209 & 44 \\
40 & 35 & 33 & 209 \\
103 & 119 & 121 & 121 \\
35 & 38 & 40 & 40 \\
96 & 105 & 110 & 117 \\
38 & 38 & 38 & 40 \\
& & &
\end{tabular}

\section{Trends in Timber Inventories}

Average per acre inventories of timber increased about 17 percent on all ownerships combined in the Rocky Mountains between 1952 and 1970 (table 66). Under the management, cutting, and area assumptions specified in this section, cubic foot inventories per acre are projected to increase a further 6 percent by 2020 .

Estimated sawtimber inventories per acre have increased slightly in recent years to roughly 6,400 board feet per acre. Projected inventories of this class of material drop about 3 percent by 2020 .

\section{PROJECTIONS OF TIMBER SUPPLIES IN THE PACIFIC COAST SECTION}

The Pacific Coast section provided over half the softwood sawtimber products cut in 1970, and one-third of all timber products. Although proportions of the national timber harvest are expected to decline somewhat, this section represents a major part of the U.S. forest economy.

\section{Trends in Forest Area}

Recent trends indicate a continuing loss of commercial timberland in the Pacific Coast States of California, Washington, Oregon, and coastal Alaska. Thus between 1952 and 1970 , commercial timberland areas decreased 1.2 million acres, or almost 2 percent (table 67 ).

Changes in the timber growing base have occurred as a result of expanding populations and related development of urban areas, roads and powerlines, and recreational facilities. Trends in land use are especially critical for timber production in areas such as western Washington where forest lands are highly productive for timber. Communities in this area have been expanding rapidly into areas that were formerly commercial timberland. 
TABLE 66.-Inventory volumes per acre in the Rocky Mountains, by owner class, 1952, 1962, and 1970, with projections to 2020

GROWING STOCK-CUBIC FEET

\begin{tabular}{|c|c|c|c|c|c|c|c|}
\hline \multirow{2}{*}{ Owner class } & \multirow{2}{*}{1952} & \multirow{2}{*}{1962} & \multirow{2}{*}{1970} & \multicolumn{4}{|c|}{ Projections } \\
\hline & & & & 1980 & 1990 & 2000 & 2020 \\
\hline $\begin{array}{l}\text { National Forest } \\
\text { Other public } \\
\text { Forest industry } \\
\text { Farm and miscellaneous private.- }\end{array}$ & $\begin{array}{l}1,426 \\
1,432 \\
2,123 \\
1,128\end{array}$ & $\begin{array}{l}1,522 \\
1,476 \\
2,260 \\
1,209\end{array}$ & $\begin{array}{l}1,732 \\
1,520 \\
2,367 \\
1,275\end{array}$ & $\begin{array}{l}1,520 \\
1,679 \\
2,082 \\
1,511\end{array}$ & $\begin{array}{l}1,545 \\
1,799 \\
1,889 \\
1,687\end{array}$ & $\begin{array}{l}1,584 \\
1,853 \\
1,816 \\
1,767\end{array}$ & $\begin{array}{l}1,702 \\
1,853 \\
1,816 \\
1,767\end{array}$ \\
\hline All owners_-- & 1,393 & 1,482 & 1,630 & 1,558 & 1,614 & 1,658 & 1,735 \\
\hline
\end{tabular}

SAWTIMBER-BOARD FEET

\begin{tabular}{|c|c|c|c|c|c|c|c|}
\hline $\begin{array}{l}\text { National Forest. } \\
\text { Other public. } \\
\text { Forest industry } \\
\text { Farm and miscellaneous private. }\end{array}$ & $\begin{array}{r}6,046 \\
6,350 \\
10,564 \\
4,402\end{array}$ & $\begin{array}{r}6,243 \\
6,187 \\
10,663 \\
4,486\end{array}$ & $\begin{array}{r}6,912 \\
6,107 \\
10,673 \\
4,553\end{array}$ & $\begin{array}{l}5,846 \\
6,256 \\
8,807 \\
5,220\end{array}$ & $\begin{array}{l}5,780 \\
6,653 \\
7,677 \\
5,741\end{array}$ & $\begin{array}{l}5,816 \\
6,843 \\
7,284 \\
5,989\end{array}$ & $\begin{array}{l}6,135 \\
6,843 \\
7,284 \\
5,989\end{array}$ \\
\hline All owners & 5,917 & 6,051 & 6,440 & 5,881 & 5,947 & 6,026 & 6,242 \\
\hline
\end{tabular}

TABle 67.-Area of commercial timberland on the Pacific Coast, by owner class, 1952, 1962, and 1970, with projections to 2020

[Million acres]

\begin{tabular}{|c|c|c|c|c|c|c|c|}
\hline \multirow{2}{*}{ Owner class } & \multirow{2}{*}{1952} & \multirow{2}{*}{1962} & \multirow{2}{*}{1970} & \multicolumn{4}{|c|}{ Projections } \\
\hline & & & & 1980 & 1990 & 2000 & 2020 \\
\hline $\begin{array}{l}\text { National Forest } \\
\text { Other public } \\
\text { Forest industry } \\
\text { Farm and miscellaneous private }\end{array}$ & $\begin{array}{l}30.5 \\
10.4 \\
11.2 \\
16.7\end{array}$ & $\begin{array}{r}\text { 31. } 3 \\
9.2 \\
11.9 \\
16.1\end{array}$ & $\begin{array}{r}30.9 \\
9.0 \\
12.2 \\
15.4\end{array}$ & $\begin{array}{r}30.7 \\
8.8 \\
12.0 \\
14.9\end{array}$ & $\begin{array}{r}\text { 30. } 4 \\
\text { 8. } 7 \\
11.9 \\
14.6\end{array}$ & $\begin{array}{r}\text { 30. } 1 \\
8.6 \\
11.7 \\
14.3\end{array}$ & $\begin{aligned} 29 . & 5 \\
8 . & 5 \\
11 . & 4 \\
14 . & 1\end{aligned}$ \\
\hline Total_- & 68.8 & 68.5 & ${ }^{1} 67.6$ & 66.5 & 65.5 & 64.7 & 63.4 \\
\hline
\end{tabular}

1 Includes 1.1 million acres in Hawaii not considered in projecting timber supplies.

Considerable acreages of commercial timberland also have been converted to farm and pasture land in the Douglas-fir region, for example, and in the coastal area of California. Although the rate of land clearing for agricultural use appears to have diminished, many owners have preferred more immediate income-producing pursuits such as the grazing of sheep and cattle to uncertain and deferred returns from timber growing.

Road construction also has accounted for significant losses of commercial timberland on the Pacific Coast. The public highway system has been greatly extended and many existing highways have been widened. Also a major portion of public and private timberlands have been roaded with timber access roads, with consequent reduction of the commercial timberland base. Many electric and gas transmission lines also pass through commercial timberland, and numerous reservcirs have been constructed in forested areas of the Douglas-fir region and in California.

Considerable shifts in commercial timberland acreage also have occurred within the four ownership groups considered. In eastern Oregon, a substantial increase in commercial timberland in National Forests was due to the 1960 transfer of almost one-half million acres from the Klamath Indian Reservation to the Winema National Forest. Commercial timberland in other public ownerships also decreased between 1952 and 1970 as a result of the return of tax deeded land in California to private ownerships, and sale of certain public domain and Indian trust lands.

Forest industry increased its ownership of 
commercial timberland during this same period, largely as a result of acquisition from other private ownerships. Farm and miscellaneous private ownership of commercial timberland has generally decreased, largelr because of shifts to industrial ownership and conversion of substantial areas to nonforest uses such as urban development and pasture.

The projected changes in commercial timberland during the period 1970-2020 assume some continued losses of forest land to rarious nontimber uses such as indicated above. Thus, in coastal Alaska 326 thousand acres of commercial timber land was assumed to be withdrarm in the the 1970's for recreational use. It is of course possible that growing needs for recreational and environmental uses of forest land will lead to further withdrawals of land from timber harvesting. Hence these projections of commercial timberland, and related projections of future timber supplies, must be considered as approximations that appear reasonable at this time.

\section{Timber Removals}

A summary of trends in removals, and their relationship to other variables such as net growth, roundwood products, and inventories, is presented in tables 68 and 69 . Remorals of grorring stock

TABLE 68.-Timber removals, net growth, mortality, supplies of roundwood products, and inventories in the Pacific Coast Section, 1952, 1962, and 1970, with projections (1970 level of management) ${ }^{1}$ to 2020

[Million cubic feet]

\begin{tabular}{|c|c|c|c|c|c|c|c|}
\hline \multirow{2}{*}{ Item } & \multirow{2}{*}{1952} & \multirow{2}{*}{1962} & \multirow{2}{*}{1970} & \multicolumn{4}{|c|}{ Projections } \\
\hline & & & & 1980 & 1990 & 2000 & 2020 \\
\hline SOFTWOODS & & & & & & & \\
\hline $\begin{array}{l}\text { Removals from growing stock: } \\
\text { Roundwood products } \\
\text { Logging residues } \\
\text { Other removals }\end{array}$ & $\begin{array}{r}2,821 \\
568 \\
98\end{array}$ & $\begin{array}{r}2,926 \\
511 \\
95\end{array}$ & $\begin{array}{r}3,469 \\
496 \\
99\end{array}$ & $\begin{array}{r}3,337 \\
461 \\
106\end{array}$ & $\begin{array}{r}3,099 \\
417 \\
108\end{array}$ & $\begin{array}{r}3,058 \\
404 \\
111\end{array}$ & $\begin{array}{r}3,200 \\
409 \\
116\end{array}$ \\
\hline Total_. & 3,487 & 3,532 & 4,064 & 3,904 & 3,624 & 3,573 & 3,725 \\
\hline $\begin{array}{l}\text { Net growth } \\
\text { ilortality }\end{array}$ & $\begin{array}{l}1,999 \\
1,493\end{array}$ & $\begin{array}{l}2,328 \\
1,434\end{array}$ & $\begin{array}{l}2,589 \\
1,378\end{array}$ & $\begin{array}{l}2,798 \\
1,313\end{array}$ & $\begin{array}{l}3,016 \\
1,300\end{array}$ & $\begin{array}{l}3,211 \\
1,314\end{array}$ & $\begin{array}{l}3,480 \\
1,375\end{array}$ \\
\hline $\begin{array}{l}\text { Roundwood supplies: } \\
\text { From growing stock } \\
\text { From other sources }{ }^{2}\end{array}$ & $\begin{array}{r}2,821 \\
418\end{array}$ & $\begin{array}{r}2,926 \\
398\end{array}$ & $\begin{array}{r}3,469 \\
336\end{array}$ & $\begin{array}{r}3,337 \\
305\end{array}$ & $\begin{array}{r}3,099 \\
277\end{array}$ & $\begin{array}{r}3,058 \\
274\end{array}$ & $\begin{array}{r}3,200 \\
291\end{array}$ \\
\hline Total $\ldots . .$. & 3,239 & 3,324 & 3,805 & 3,642 & 3,376 & 3,332 & 3,491 \\
\hline Inventory of growing stock & 243,077 & 235,150 & 226,643 & 210,861 & 204,072 & 200,374 & 195,773 \\
\hline HARDWOODS & & & & & & & \\
\hline $\begin{array}{l}\text { Removals from growing stock: } \\
\text { Roundwood products } \\
\text { Logging residues } \\
\text { Other removals. }\end{array}$ & $\begin{array}{r}29 \\
12 \\
3\end{array}$ & $\begin{array}{r}53 \\
20 \\
5\end{array}$ & $\begin{array}{r}75 \\
30 \\
9\end{array}$ & $\begin{array}{l}74 \\
27 \\
28\end{array}$ & $\begin{array}{l}87 \\
31 \\
23\end{array}$ & $\begin{array}{l}95 \\
32 \\
20\end{array}$ & $\begin{array}{r}103 \\
36 \\
4\end{array}$ \\
\hline Total. . & 44 & 78 & 114 & 129 & 141 & 147 & 143 \\
\hline $\begin{array}{l}\text { Net growth } \\
\text { Mortality }\end{array}$ & $\begin{array}{r}297 \\
62\end{array}$ & $\begin{array}{r}383 \\
76\end{array}$ & $\begin{array}{r}467 \\
87\end{array}$ & $\begin{array}{l}384 \\
125\end{array}$ & $\begin{array}{l}294 \\
146\end{array}$ & $\begin{array}{l}229 \\
160\end{array}$ & $\begin{array}{l}172 \\
175\end{array}$ \\
\hline $\begin{array}{l}\text { Roundwood supplies: } \\
\text { From growing stock } \\
\text { From other sources }{ }^{2}-\ldots\end{array}$ & $\begin{array}{r}29 \\
6\end{array}$ & $\begin{array}{r}53 \\
9\end{array}$ & $\begin{array}{l}75 \\
10\end{array}$ & $\begin{array}{r}74 \\
8\end{array}$ & $\begin{array}{r}87 \\
9\end{array}$ & $\begin{array}{l}95 \\
10\end{array}$ & $\begin{array}{r}103 \\
11\end{array}$ \\
\hline Total. & 35 & 62 & 85 & 82 & 96 & 105 & 114 \\
\hline Inventory of growing stock & 10,427 & 12,749 & 14,822 & 17,584 & 19,526 & 20,624 & 21,530 \\
\hline
\end{tabular}

1 Plus other area and harvesting assumptions specified in this chapter.

2 Includes roundwood products from rough and rotten trees, dead trees, and trees on noncommercial and non- forest land.

Note: Estimates are for trend levels and consequently may differ from actual figures for the specified years. 
TABLE 69.- Sawtimber removals, net growth, mortality, supplies of roundwood products, and inventories in the Pacific Coast Section, 1952, 1962, and 1970, with projections (1970 level of management) ${ }^{1}$ to 2020

[Million board feet]

\begin{tabular}{|c|c|c|c|c|c|c|c|}
\hline \multirow{2}{*}{ Item } & \multirow{2}{*}{$19 \tilde{2} 2$} & \multirow{2}{*}{1962} & \multirow{2}{*}{1970} & \multicolumn{4}{|c|}{ Projections } \\
\hline & & & & 1980 & 1990 & 2000 & 2020 \\
\hline SOFTWOODS & & & & & & & \\
\hline $\begin{array}{l}\text { Removals from sawtimber: } \\
\text { Roundwood products } \\
\text { Logging residues } \\
\text { Other removals }\end{array}$ & $\begin{array}{r}19,905 \\
1,783 \\
603\end{array}$ & $\begin{array}{r}19,872 \\
1,632 \\
575\end{array}$ & $\begin{array}{r}22,849 \\
1,532 \\
\$ 55\end{array}$ & $\begin{array}{r}21,100 \\
1,384 \\
552\end{array}$ & $\begin{array}{r}19,115 \\
1,233 \\
545\end{array}$ & $\begin{array}{r}18,261 \\
1,175 \\
534\end{array}$ & $\begin{array}{r}17,394 \\
1,159 \\
514\end{array}$ \\
\hline Total $\ldots \ldots \ldots$ & 22,291 & 22,079 & 25,236 & 23,036 & 20,893 & 19,970 & 19,567 \\
\hline $\begin{array}{l}\text { Net growth } \\
\text { Mortality }\end{array}$ & $\begin{array}{l}9,354 \\
8,172\end{array}$ & $\begin{array}{r}10,656 \\
7,559\end{array}$ & $\begin{array}{r}11,631 \\
6, \succ 76\end{array}$ & $\begin{array}{r}12,127 \\
6,262\end{array}$ & $\begin{array}{r}12,832 \\
5,831\end{array}$ & $\begin{array}{r}13,632 \\
5,535\end{array}$ & $\begin{array}{r}14,922 \\
5,169 \\
\end{array}$ \\
\hline $\begin{array}{l}\text { Roundwood supplies: } \\
\text { From sawtimber } \\
\text { From other sources }{ }^{2}-\ldots\end{array}$ & $\begin{array}{r}19,905 \\
2,534\end{array}$ & $\begin{array}{r}19,872 \\
2,668\end{array}$ & $\begin{array}{r}22,849 \\
2,334\end{array}$ & $\begin{array}{r}21,100 \\
2,164 \\
\end{array}$ & $\begin{array}{r}19,115 \\
2,208\end{array}$ & $\begin{array}{r}18,261 \\
2,386\end{array}$ & $\begin{array}{r}17,894 \\
2,828 \\
\end{array}$ \\
\hline Total .... & 22,439 & 22,540 & 25,183 & 23,264 & 21,323 & 20,647 & 20,722 \\
\hline Inventory of s?wtimber & $1,365,202$ & $1,274,583$ & $1,194,245$ & $1,056,858$ & 973,417 & 908,460 & 810,276 \\
\hline HARDWOODS & & & & & & & \\
\hline $\begin{array}{l}\text { Removals from sawtimber: } \\
\text { Roundwood products } \\
\text { Logging residues } \ldots \\
\text { Other removals } \ldots\end{array}$ & $\begin{array}{r}112 \\
26 \\
10\end{array}$ & $\begin{array}{r}179 \\
52 \\
18\end{array}$ & $\begin{array}{r}295 \\
49 \\
32\end{array}$ & $\begin{array}{r}354 \\
44 \\
88\end{array}$ & $\begin{array}{r}405 \\
52 \\
72\end{array}$ & $\begin{array}{r}438 \\
5.5 \\
59\end{array}$ & $\begin{array}{r}467 \\
62 \\
11\end{array}$ \\
\hline Total_....... & 148 & 249 & 376 & 486 & 529 & 552 & 540 \\
\hline $\begin{array}{l}\text { Net growth } \\
\text { Mortality }\end{array}$ & $\begin{array}{l}923 \\
192 \\
\end{array}$ & $\begin{array}{r}1,242 \\
225 \\
\end{array}$ & $\begin{array}{r}1,510 \\
267 \\
\end{array}$ & $\begin{array}{r}1,284 \\
339 \\
\end{array}$ & $\begin{array}{r}1,003 \\
390\end{array}$ & $\begin{array}{l}800 \\
426 \\
\end{array}$ & $\begin{array}{l}604 \\
458 \\
\end{array}$ \\
\hline $\begin{array}{l}\text { Roundwood supplies: } \\
\text { From sawtimber } \\
\text { From other sources }{ }^{2}-\end{array}$ & $\begin{array}{r}112 \\
10\end{array}$ & $\begin{array}{r}179 \\
22\end{array}$ & $\begin{array}{r}295 \\
27 \\
\end{array}$ & $\begin{array}{r}354 \\
26\end{array}$ & $\begin{array}{r}405 \\
30\end{array}$ & $\begin{array}{r}438 \\
31\end{array}$ & $\begin{array}{r}467 \\
36\end{array}$ \\
\hline Total ................ & 122 & 201 & 322 & 380 & 435 & 469 & 503 \\
\hline Inventory of sawtimber.... & 31,307 & 39,209 & 46,394 & 54,840 & $60,88.5$ & 64,231 & 66,820 \\
\hline
\end{tabular}

1 Plus other area and harvesting assumptions specified in this chapter.

2 Includes roundwood products from rough and rotten trees, dead trees, and trees on noncommercial and non-

and sawtimber shown in these tables reflect both harvesting of timber and volumes withdrawn for other purposes. Timber removals on the Pacific Coast are dominated by softwoods; hardwoods account for a very small portion of the inventory and a negligible portion of removals.

Not all timber removals are available to the forest industries in the form of roundwood products such as saw logs, veneer logs, and pulpwood. In 1970 roundwood products made up only 85 percent of the softwood removals from growing stock on the Pacific Coast (table 70). Logging residues accounted for 12 percent, and other re- forest land. Also includes saw logs from trees less than sawtimber size.

Note: Estimates are for trend levels and consequently may differ from actual figures for the specified years.

movals of softwood timber on lands transferred to other uses an estimated 3 percent of the total.

In these base projections, it was assumed that the proportion of timber harvests left as logging residue would drop to about 11 percent of removals. Other removals were assumed to remain close to the level of 1970 .

In addition to output from growing stock, substantial quantities of roundwood products have been produced from dead and rough and rotten trees in old-growth stands. Decreasing amounts of small trees of less than sawtimber size as defined in 1970 also have been used as saw logs. Future 
TABLE 70.-Components of growing stock removals on the Pacific Coast, 1952, 1962, and 1970, with projections to 2020

[Percent]

\begin{tabular}{|c|c|c|c|c|c|c|c|}
\hline \multirow{2}{*}{ Component } & \multirow{2}{*}{1952} & \multirow{2}{*}{1962} & \multirow{2}{*}{1970} & \multicolumn{4}{|c|}{ Projections } \\
\hline & & & & $19 ১ 0$ & 1990 & 2000 & 2020 \\
\hline SOFTWOODS & & & & & & & \\
\hline $\begin{array}{l}\text { Roundwood products } \\
\text { Logging residue } \\
\text { Other removals }\end{array}$ & $\begin{array}{r}81 \\
16 \\
3\end{array}$ & $\begin{array}{r}83 \\
14 \\
3\end{array}$ & $\begin{array}{r}85 \\
12 \\
3\end{array}$ & $\begin{array}{r}85 \\
12 \\
3\end{array}$ & $\begin{array}{r}85 \\
12 \\
3\end{array}$ & $\begin{array}{r}86 \\
11 \\
3\end{array}$ & $\begin{array}{r}86 \\
11 \\
3\end{array}$ \\
\hline Total removals & 100 & 100 & 100 & 100 & 100 & 100 & 100 \\
\hline HARDWOODS & & & & & & & \\
\hline $\begin{array}{l}\text { Roundwood products.... } \\
\text { Logging residue........ } \\
\text { Other removals.. }\end{array}$ & $\begin{array}{l}66 \\
27 \\
7\end{array}$ & $\begin{array}{r}68 \\
26 \\
6\end{array}$ & $\begin{array}{r}66 \\
26 \\
8\end{array}$ & $\begin{array}{l}57 \\
21 \\
22\end{array}$ & $\begin{array}{l}61 \\
22 \\
17\end{array}$ & $\begin{array}{l}65 \\
22 \\
13\end{array}$ & $\begin{array}{r}72 \\
25 \\
3\end{array}$ \\
\hline Total removals_._. & 100 & 100 & 100 & 100 & 100 & 100 & 100 \\
\hline
\end{tabular}

output from these nongroming stock sources is projected to decrease further from the 1970 level.

\section{Supplies of Round wood Products}

Harrests of softwood roundrood on the Pacific Coast increased orer 17 percent between 1952 and 1970 from 3.2 to 3.8 billion cubic feet (table 6S). Output of softwood products in board feet increased about 12 percent from 22.4 to 25.2 billion board feet (table 69 and fig. 37).

The Pacific Coast preeminence as a major source of timber products until recently was achieved by a high level of production from forest industry and other private lands. Almost all of the recent production gains, however, were attributable to increased timber harvests on National

\section{Supplies of softwood sawtimber products in the Pacific Coast, by owner class}

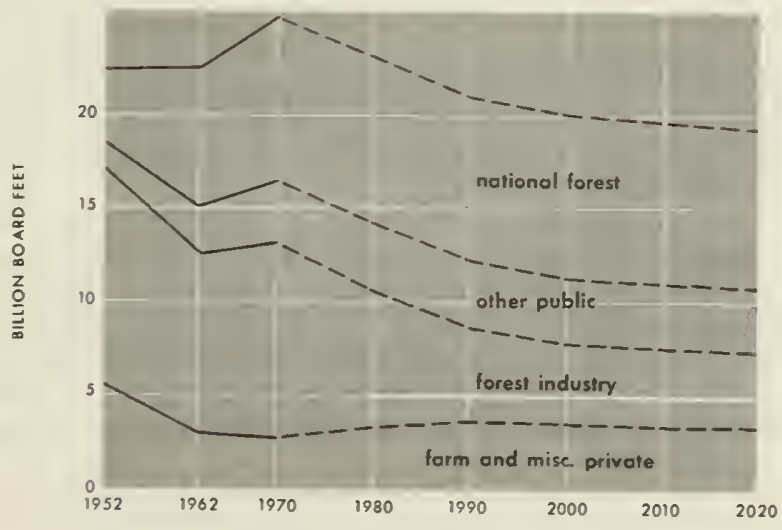

Figure 37
Forests and other public ownerships, with the share of total output from these lands increasing from 23 percent in 1952 to 45 percent in 1970 (table 71). Increased production from public lands resulted both from increasing demands from the timber industry and from reappraisals of future growth and utilization potentials. The increase from public lands not only offset decreases in production from private ownerships, but also pushed regional production to an all-time peak.

With public lands dedicated to a sustained level of production, and with industry faced with deficiencies in harvestable age classes in the near future, somewhat different trends are anticipated (tables 71 and 72). By the year 2000, under the assumptions of these base projections softwood roundwood output is estimated to decrease about 12 percent to 3.3 billion cubic feet, including 20.6 billion board feet of sawtimber. This drop would be largely a result of a nearly 50 percent decrease in log production on forest industry lands.

National Forests.-Projected output from $\mathrm{Na}$ tional Forest lands, assuming 1970 levels of management and allowable cuts, remain at about .13 billion cubic feet over the projection period, including about 9 billion board feet of sawtimber (tables 71 and 72).

Beyond 2020, however, results of recent projections and a recent comprehensive study of National Forests in the Douglas-fir region ${ }^{6}$ point to an ultimate falldown in arailable harrests unless forest management is materially accelerated. For this reason these base projections may orerstate supplies actually arailable with 1970 levels of management.

${ }^{6}$ U.S. Department of Agriculture, Forest Service. Douglas-fir supply study. 53 p. 1969. 
TABLE 71.- Supplies of roundwood products in the Pacific Coxst Section, by owner class and species group, 1952, 1962, and 1970, with projections to 2020

[Million cubic feet]

\begin{tabular}{|c|c|c|c|c|c|c|c|}
\hline \multirow{2}{*}{ Owner class and species group } & \multirow{2}{*}{1952} & \multirow{2}{*}{1962} & \multirow{2}{*}{1970} & \multicolumn{4}{|c|}{ Projections } \\
\hline & & & & 1980 & 1990 & 2000 & 2020 \\
\hline $\begin{array}{l}\text { National Forest: } \\
\text { Softwoods-1 } \\
\text { Hardwoods }\end{array}$ & $\begin{array}{r}537 \\
2\end{array}$ & $\begin{array}{r}1,07 / 3 \\
4 \\
\end{array}$ & $\begin{array}{r}1,274 \\
12\end{array}$ & $\begin{array}{r}1,341 \\
13 \\
\end{array}$ & $\begin{array}{r}1,342 \\
13\end{array}$ & $\begin{array}{r}1,348 \\
13\end{array}$ & $\begin{array}{r}1,361 \\
13\end{array}$ \\
\hline Total__..- & 539 & 1,080 & 1,286 & 1,354 & 1,355 & 1,361 & 1,374 \\
\hline $\begin{array}{l}\text { Other public: } \\
\text { Softwoods } \\
\text { Hardwoods }\end{array}$ & $\begin{array}{r}199 \\
\text { bे }\end{array}$ & $\begin{array}{r}355 \\
4\end{array}$ & $\begin{array}{r}471 \\
12\end{array}$ & $\begin{array}{r}510 \\
8\end{array}$ & $\begin{array}{r}525 \\
8\end{array}$ & $\begin{array}{r}542 \\
8\end{array}$ & $\begin{array}{r}602 \\
8\end{array}$ \\
\hline Total_- & 205 & 359 & 483 & 518 & 533 & 550 & 610 \\
\hline $\begin{array}{l}\text { Forest industry: } \\
\text { Softwoods } \\
\text { Hardwoods }\end{array}$ & $\begin{array}{r}1,644 \\
19\end{array}$ & $\begin{array}{r}1,400 \\
25\end{array}$ & $\begin{array}{r}1,601 \\
36\end{array}$ & $\begin{array}{r}1,207 \\
40\end{array}$ & $\begin{array}{r}862 \\
51\end{array}$ & $\begin{array}{r}801 \\
59\end{array}$ & $\begin{array}{r}888 \\
68\end{array}$ \\
\hline Total_- & 1,663 & 1,425 & 1,637 & 1,247 & 913 & 860 & 956 \\
\hline $\begin{array}{l}\text { Farm and miscellaneous private: } \\
\text { Softwoods } \\
\text { Hardwoods.- }\end{array}$ & $\begin{array}{r}859 \\
8\end{array}$ & $\begin{array}{r}492 \\
29\end{array}$ & $\begin{array}{r}459 \\
25\end{array}$ & $\begin{array}{r}583 \\
22\end{array}$ & $\begin{array}{r}646 \\
24\end{array}$ & $\begin{array}{r}641 \\
24\end{array}$ & $\begin{array}{r}639 \\
26\end{array}$ \\
\hline Total_-..- & 867 & 521 & 484 & 605 & 670 & 665 & 665 \\
\hline $\begin{array}{l}\text { All owners: } \\
\text { Softwoods }-.- \\
\text { Hardwoods.-. }\end{array}$ & $\begin{array}{r}3,239 \\
35\end{array}$ & $\begin{array}{r}3,324 \\
62\end{array}$ & $\begin{array}{r}3,805 \\
85\end{array}$ & $\begin{array}{r}3,642 \\
82\end{array}$ & $\begin{array}{r}3,376 \\
96\end{array}$ & $\begin{array}{r}3,332 \\
105\end{array}$ & $\begin{array}{r}3,491 \\
114\end{array}$ \\
\hline Total_- & 3,274 & 3,386 & 3,890 & 3,724 & 3,472 & 3,437 & 3,605 \\
\hline
\end{tabular}

Other public lands.-On public lands managed by the Bureau of Land Management and Bureau of Indian Affairs, and on land in State ownership, timber harvests are also based on allowable cut calculations. Although the area in these public ownerships decreased approximately 13 percent between 1952 and 1970 , removals more than doubled as a result of the growth in local demands for timber that also resulted in increasing timber cutting on National Forests. Another major factor was greater investment in forest management practices provided directly or indirectly from timber receipts. On these public ownerships, projections of roundwood timber harvests average about 3.5 billion board feet (table 72 ).

Forest industry.-Roundwood timber harvests on forest industry lands showed a slight downward trend in the 1952-70 period to 10.6 billion board feet. However, substantial changes occurred internally within the Pacific Coast area. Most striking was an 85 percent increase in harvests, mainly in young-growth forests, on industry lands in western Washington, in contrast to a 25 percent reduction in western Oregon and a 30 percent reduction in California. The sharp drop in timber harvests in these latter areas reflected past heavy cutting on industry lands and resulting depletion of inventory.

Over the projection period roundwood harvests from industry lands were projected to decrease sharply as a result of reduction of old-growth forests to about 4.8 billion board feet by 2000 (table 72).

Farm and miscellaneous private.-On nonindustrial private timberlands in farmer and miscellaneous private ownerships, roundwood harvests in board feet decreased one-half between 1952 and 1970 , largely as a result of cutting residual oldgrowth stands on the remaining accessible forests in these ownerships (tables 71 and 72). In addition, approximately 8 percent of these lands were sold to industrial owners.

The reduction in harvests on farm and miscellaneous private ownerships was especially pronounced in California, with a drop of 69 percent between 1952 and 1970. On many of the cutover lands in this area, as in other parts of the Northwest, hardwoods have taken over much of the land following timber harvesting. ${ }^{7}$ In other areas,

${ }^{7}$ Oswald, Daniel D. Timber resources of Mendocino and Sonoma Counties, California. USDA Forest Service Resource Bull. PNW-40,76 p. Pacific Northwest Forest and Range Experiment Station, Portland, Oregon 1972. 
TABLE 72.-Supplies of sautimber products in the Pacific Coast Section, by owner class and species group, 1952,1962 , and 1970, with projections to 2020

[Million board feet]

\begin{tabular}{|c|c|c|c|c|c|c|c|}
\hline \multirow{2}{*}{ Orner class and species group } & \multirow{2}{*}{1952} & \multirow{2}{*}{1962} & \multirow{2}{*}{1970} & \multicolumn{4}{|c|}{ Projections } \\
\hline & & & & 1980 & 1990 & 2000 & 2020 \\
\hline $\begin{array}{l}\text { National Forest: } \\
\text { Softwoods..... } \\
\text { Hardwoods.... }\end{array}$ & $\begin{array}{r}3,864 \\
4\end{array}$ & $\begin{array}{r}7,449 \\
13 \\
\end{array}$ & $\begin{array}{r}8,769 \\
43 \\
\end{array}$ & $\begin{array}{r}9,102 \\
66 \\
\end{array}$ & $\begin{array}{r}9,054 \\
67 \\
\end{array}$ & $\begin{array}{r}9,023 \\
66\end{array}$ & $\begin{array}{r}8,874 \\
65\end{array}$ \\
\hline Total_- & 3,868 & 7,462 & 8,812 & 9,168 & 9,121 & 9,089 & 8,939 \\
\hline $\begin{array}{l}\text { Other public: } \\
\text { Softwoods.-.- } \\
\text { Hardwoods.-- }\end{array}$ & $\begin{array}{r}1,438 \\
24 \\
\end{array}$ & $\begin{array}{r}2,513 \\
11 \\
\end{array}$ & $\begin{array}{r}3,264 \\
47 \\
\end{array}$ & $\begin{array}{r}3,391 \\
32 \\
\end{array}$ & $\begin{array}{r}3,414 \\
32 \\
\end{array}$ & $\begin{array}{r}3,457 \\
33\end{array}$ & $\begin{array}{r}3,607 \\
36 \\
\end{array}$ \\
\hline Total_.-- & 1,462 & 2,524 & 3,310 & 3,423 & 3,446 & 3,490 & 3,643 \\
\hline $\begin{array}{l}\text { Forest industry: } \\
\text { Soft woods...-- } \\
\text { Hardwoods..-- }\end{array}$ & $\begin{array}{r}11,464 \\
72 \\
\end{array}$ & $\begin{array}{r}9,496 \\
84 \\
\end{array}$ & $\begin{array}{r}10,432 \\
141 \\
\end{array}$ & $\begin{array}{r}7,475 \\
183 \\
\end{array}$ & $\begin{array}{r}5,229 \\
223 \\
\end{array}$ & $\begin{array}{r}4,563 \\
256\end{array}$ & $\begin{array}{r}4,726 \\
280\end{array}$ \\
\hline Total $\ldots$ & 11,536 & 9,580 & 10,573 & 7,658 & 5,452 & 4,819 & 5,006 \\
\hline $\begin{array}{l}\text { Farm and miscellaneous private: } \\
\text { Softwoods. } \\
\text { Hardwoods. }\end{array}$ & $\begin{array}{r}5,674 \\
22 \\
\end{array}$ & $\begin{array}{r}3,082 \\
94 \\
\end{array}$ & $\begin{array}{r}2,719 \\
91 \\
\end{array}$ & $\begin{array}{r}3,295 \\
100 \\
\end{array}$ & $\begin{array}{r}3,626 \\
113 \\
\end{array}$ & $\begin{array}{r}3,604 \\
114\end{array}$ & $\begin{array}{r}3,515 \\
122 \\
\end{array}$ \\
\hline Total & 5,696 & 3,176 & 2,810 & 3,395 & 3,739 & 3,718 & 3,637 \\
\hline $\begin{array}{l}\text { All owners: } \\
\text { Softwoods_-- } \\
\text { Hardwoods - }\end{array}$ & $\begin{array}{r}22,439 \\
122 \\
\end{array}$ & $\begin{array}{r}22,540 \\
201 \\
\end{array}$ & $\begin{array}{r}25,182 \\
322 \\
\end{array}$ & $\begin{array}{r}23,264 \\
380\end{array}$ & $\begin{array}{r}21,323 \\
435\end{array}$ & $\begin{array}{r}20,647 \\
469\end{array}$ & $\begin{array}{r}20,722 \\
503 \\
\end{array}$ \\
\hline Total _.- & 22,561 & 22,741 & $2 \overline{5}, 504$ & 23,644 & 21,758 & 21,116 & 21,225 \\
\hline
\end{tabular}

TABLE 73.-Supplies of roundwood products per acre in the Pacific Coast Section, by owner class, 1952, 1962, and 1970, with projections to 2020

[Cubic feet per acre]

\begin{tabular}{|c|c|c|c|c|c|c|c|}
\hline \multirow{2}{*}{ Owner class } & \multirow{2}{*}{1952} & \multirow{2}{*}{1962} & \multirow{2}{*}{1970} & \multicolumn{4}{|c|}{ Projections } \\
\hline & & & & 1980 & 1990 & 2000 & 2020 \\
\hline $\begin{array}{l}\text { National Forest } \\
\text { Other public } \\
\text { Forest industry } \\
\text { Farm and miscellaneous private. }\end{array}$ & $\begin{array}{r}17.7 \\
19.6 \\
148.3 \\
52.1\end{array}$ & $\begin{array}{r}34.5 \\
39.1 \\
119.5 \\
32.3 \\
\end{array}$ & $\begin{array}{r}41.6 \\
53.4 \\
134.0 \\
31.3\end{array}$ & $\begin{array}{r}44.1 \\
65.7 \\
104.5 \\
42.2\end{array}$ & $\begin{array}{l}44.6 \\
69.1 \\
77.8 \\
48.1\end{array}$ & $\begin{array}{l}45.2 \\
72.1 \\
74.4 \\
48.5\end{array}$ & $\begin{array}{l}\text { 46. } 6 \\
81.2 \\
83.7 \\
49.4\end{array}$ \\
\hline All owners & 47. 6 & 49. 4 & 57.5 & 57.4 & 54.4 & 54.5 & 58.3 \\
\hline
\end{tabular}

particularly in western Washington, early cutting on the relatively accessible forest lands in these ownerships, and subsequent fire control, resulted in establishment of extensive young-growth stands capable of supporting an increasing cut in the future.

For all lands in farm and miscellaneous private ownerships, roundwood harvests were projected to rise about 37 percent by 2020 (table 71 ).
Harvests of hardwood products amounted to only 85 million cubic feet in 1970 , or 2.2 percent of the total timber harvest. Even with a projected increase in the hardwood cut, and a decrease in softwood output, hardwoods make up only 3 percent of projected supplies of roundwood in 2000.

Roundwood production per acre.-Timber harrests per acre in recent years have varied widely by ownership (table 73). For all ownerships combined, roundwood output in 1970 a veraged 57.5 
cubic feet per acre of commercial timberland, but this figure varied from a low of about 31 cubic feet on farm and miscellaneous private lands and 42 cubic feet on National Forests to a high of 134 cubic feet per acre on forest industry lands.

The low cutting level on farm and miscellaneous lands in this period largely reflected low levels of inventory due to past heavy cutting. The limited harvesting of timber on public lands, despite large inventory volumes, has been a result of long rotations to achieve agency objectives, as well as lower inherent site productivity of many areas in public ownership.

Projections of available roundwood supplies per acre increase ultimately for all ownerships combined, with a narrowing of the range in harvests per acre among the different owner classes. The highest projected output is for industry-owned lands, in spite of a rapidly shrinking inventory, largely due in part to the concentration of the most productive lands in these holdings and relatively intensive management.

\section{Net Growth in Relation to Removals}

Long-run trends in future timber harvests, after the conversion of most old-growth stands, will be determined essentially by trends in growth. Although net growth has been less than harvests, growth has been rising steadily and future sizable increases are projected, particularly in terms of cubic feet (tables 68 and 69 , and figs. 38 and 39 ).

For all owners combined, a continued excess of removals over net growth is expected for both growing stock and sawtimber over the projection period. Thereafter a prospective drop in National Forest sawtimber production-assuming 1970 management levels-would tend to bring removals and growth into balance at some reduced level.

Net growth per acre.-Net growth per acre on the Pacific Coast has trended upward over the past 20 years as more old-growth timber with low growth rates has been replaced by faster growing young trees. For all forest owners combined, net growth areraged 45 cubic feet per acre in 1970 (table 74 ) - about 35 percent higher than in 1952. In future decades net growth for all owners is projected to increase to an average of 59 cubic feet per acre under the assumptions of this base projection.

Net growth on National Forest lands in 1970 was much below that on other ownerships, due to the heavy inventories of old-growth timber on these public lands of generally lower sites.

Net growth rates of softwood growing stock averaged only 1.1 percent of the softwood inventory in 1970-a consequence of the predominance of old-growth timber with high volumes and high mortality rates. Net growth of softwood growing stock varied from 0.6 percent on National Forests to 2.5 percent on farm and miscellaneous private lands. Over the projection period growth rates
Net growth and removals of growing stock in the Pacific Coast

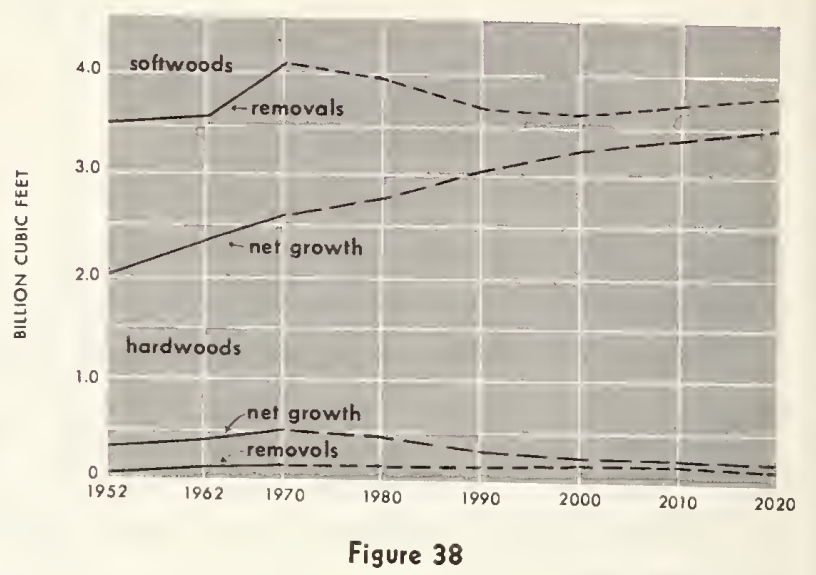

Net growth and removals of sawtimber in the Pacific Coast

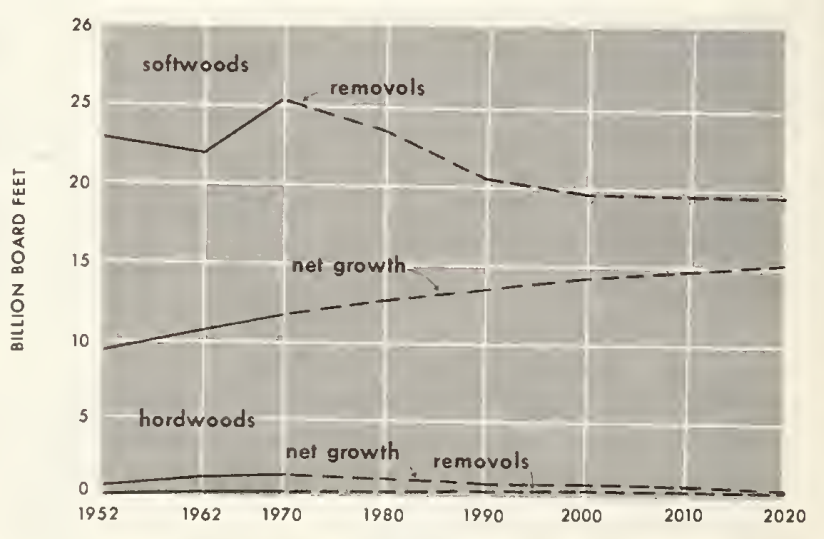

Figure 39

increase on all categories of ownership except on farm and miscellaneous holdings to an estimated average of 1.8 percent by 2020 (table 75 ).

Mortality.-Natural losses of softwood timber on all ownerships combined averaged about 20 cubic feet per acre in 1970 , or about one-third of gross growth (tables 68, 69, and 76). This relati vely high level of mortality was a result of the preponderance of old-growth timber in this section, and existing levels of forest protection and management. Mortality on farm and miscellaneous ownerships was considerably below that on other lands in the 1952-70 period, one factor veing the comparatively young age of stands on these nonindustrial private lands.

While the projected mortality figures for softwood sawtimber show a steady decline over the projection period (fig. 40), there are diverging trends amongst the various ownerships. Projec- 
TABLE 74.-Net growth of growing stock per acre in the Pacific Coast Section, by owner class and species group, 1952, 1962, and 1970, with projections to 2020

[Cubic feet]

\begin{tabular}{|c|c|c|c|c|c|c|c|}
\hline \multirow{2}{*}{ Owner class and species group } & \multirow{2}{*}{1952} & \multirow{2}{*}{1962} & \multirow{2}{*}{1970} & \multicolumn{4}{|c|}{ Projections } \\
\hline & & & & 1980 & 1990 & 2000 & 2020 \\
\hline $\begin{array}{l}\text { National Forests: } \\
\text { Softwoods.-..- } \\
\text { Hardwoods.-..- }\end{array}$ & $\begin{array}{r}20.5 \\
1.4 \\
\end{array}$ & $\begin{array}{r}23.1 \\
1.4\end{array}$ & $\begin{array}{r}25.5 \\
1.5\end{array}$ & $\begin{array}{r}28.2 \\
1.3\end{array}$ & $\begin{array}{r}31.1 \\
1.2\end{array}$ & $\begin{array}{r}34.1 \\
1.1\end{array}$ & $\begin{array}{r}41.0 \\
.9\end{array}$ \\
\hline Total.... & 21.9 & 24. $\tilde{5}$ & 27. 0 & 29.5 & 32. 3 & 35.2 & 41. 9 \\
\hline $\begin{array}{l}\text { Other public: } \\
\text { Soft woods----. } \\
\text { Hardwoods.-. }\end{array}$ & $\begin{array}{r}31.9 \\
3.8\end{array}$ & $\begin{array}{r}43.4 \\
6.8\end{array}$ & $\begin{array}{r}50.0 \\
9.8\end{array}$ & $\begin{array}{r}62.1 \\
8.6 \\
\end{array}$ & $\begin{array}{r}\text { 69. } 0 \\
\text { 5. } 9\end{array}$ & $\begin{array}{r}74.8 \\
4.0\end{array}$ & $\begin{array}{r}82.3 \\
2.1\end{array}$ \\
\hline Total.... & 35.7 & 50.2 & 59.8 & 70. 7 & 74. 9 & 78.8 & 84.4 \\
\hline $\begin{array}{l}\text { Forest industry: } \\
\text { Softwoods } \\
\text { Hardwoods..-- }\end{array}$ & $\begin{array}{r}43.6 \\
7.7\end{array}$ & $\begin{array}{r}48.5 \\
9.5\end{array}$ & $\begin{array}{l}529 \\
11.6\end{array}$ & $\begin{array}{l}59.5 \\
10.3\end{array}$ & $\begin{array}{r}66.1 \\
8.8\end{array}$ & $\begin{array}{r}72.4 \\
8.0\end{array}$ & $\begin{array}{r}77.7 \\
7.4\end{array}$ \\
\hline Total_.. & 51.3 & 58. 0 & 64.5 & 69.8 & 74. 9 & 80.4 & 85.1 \\
\hline $\begin{array}{l}\text { Farm and miscellaneous private: } \\
\text { Softwoods } \\
\text { Hardwoods }\end{array}$ & $\begin{array}{r}\text { 33. } 1 \\
7.7\end{array}$ & $\begin{array}{l}39.1 \\
10.0\end{array}$ & $\begin{array}{l}45.4 \\
12.4\end{array}$ & $\begin{array}{l}51.2 \\
10.6\end{array}$ & $\begin{array}{r}54.8 \\
7.7\end{array}$ & $\begin{array}{r}56.5 \\
5.4\end{array}$ & $\begin{array}{r}56.9 \\
3.4\end{array}$ \\
\hline Total ... & 40. 8 & 49. 1 & 57.8 & 61.8 & 62.5 & 61.9 & 60.3 \\
\hline $\begin{array}{l}\text { All owners: } \\
\text { Softwoods } \\
\text { Hardwoods.... }\end{array}$ & $\begin{array}{r}29.1 \\
4.3\end{array}$ & $\begin{array}{r}34.0 \\
5.6\end{array}$ & $\begin{array}{r}38.3 \\
6.9\end{array}$ & $\begin{array}{r}\text { 43. } 2 \\
5.9\end{array}$ & $\begin{array}{r}47.3 \\
4.6\end{array}$ & $\begin{array}{r}51.0 \\
3.6\end{array}$ & $\begin{array}{r}56.2 \\
2.8\end{array}$ \\
\hline Total . & 33.4 & 39. 6 & 45. 2 & 49. 1 & 51.9 & 54.6 & 59.0 \\
\hline
\end{tabular}

TABLE 75.-Net growth rates of growing stock by owner class in the Pacific Coast Section, 1952, 1962, and 1970 , with projections to 2020

[Percent of inventory]

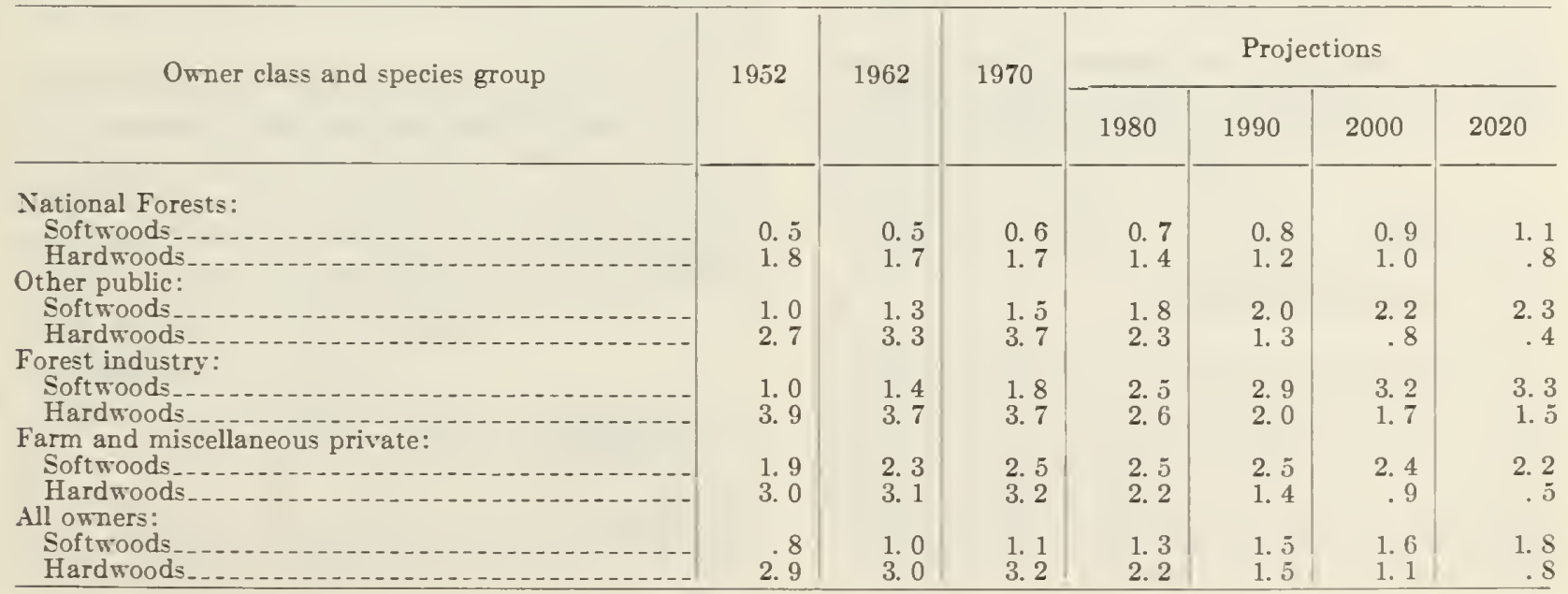


TABLE 76.-Mortality of softwood growing stock and sawtimber per acre in the Pacific Coast Section, by owner class, 1952, 1962, and 1970, with projections to 2020

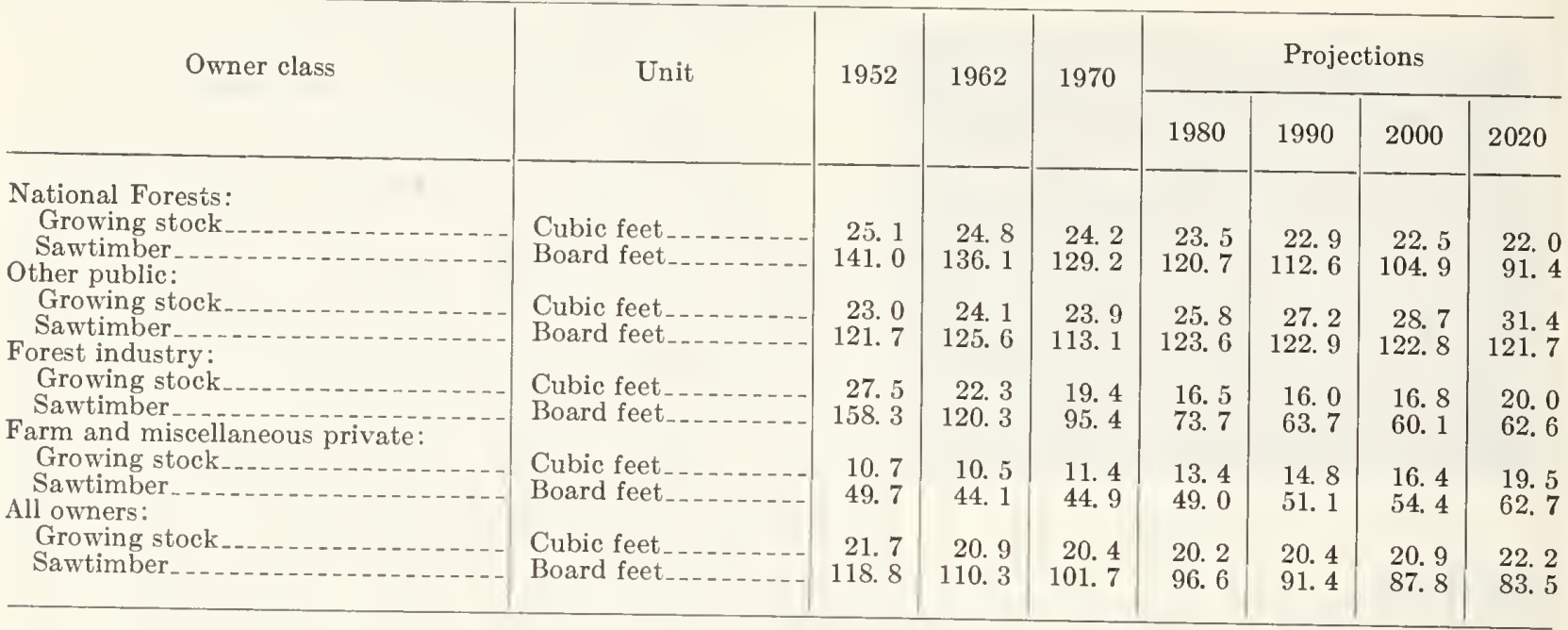

Net growth and mortality of sawtimber in the Pacific Coast

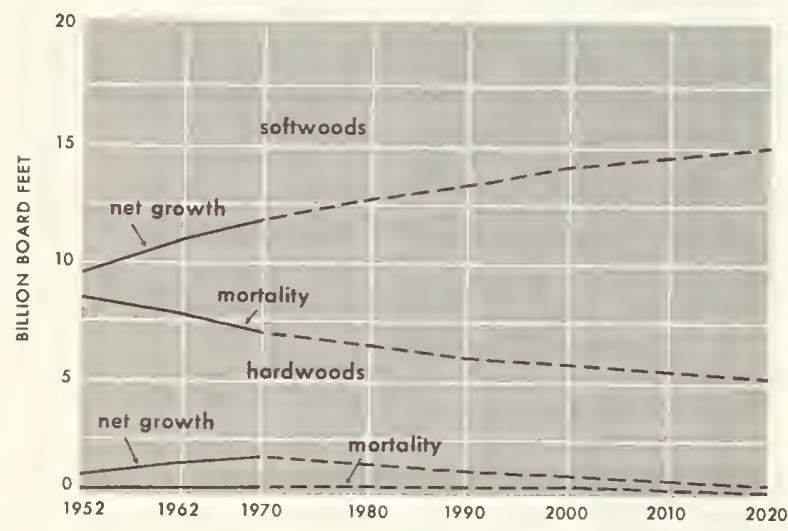

Figure 40

tions for National Forests and forest industry lands decline substantially thereafter. Projections for farm and miscellaneous lands show an increase orer the period as a result of projected increases in inventories. Estimates for other public lands indicate relatively constant mortality per acre.

\section{Trends in Inventory Volumes}

The excess of removals over growth that characterizes the old-growth timber economy of the Pacific Coast States has resulted in a downward trend in inventories of standing timber (tables 68 and 69). Growing stock volumes dropped about 5 percent in the $1952-70$ period and sawtimber volumes about 11 percent.
On a per-acre basis, volumes for all owners combined areraged 3,571 cubic feet and 18,347 board feet (tables 77 and 78). By the year 2020, average volumes are projected to decline further to 14.2 thousand board feet per acre, or 23 percent less than in 1970.

These projections indicate that the smallest sawtimber inventories per acre in the year 2020 will be carried on industry lands, with the largest inventories still on public lands. Only on farm and miscellaneous private ownerships does the projected average saw timber volume per acre increase.

The prospective replacement of old-growth forests by younger age classes with smaller trees is evident by comparing these trends in sawtimber volumes with trends in growing stock volumes. For all ownerships combined, projections of inventories in cubic feet drop only moderately in this base projection, in contrast to a sizable drop in board feet inventories.

Although the Pacific Coast States will still contain most of the Nation's large trees over the next few decades, a shift toward smaller tree sizes can be expected, as illustrated by the following tabulation of percentage distributions of growing stock inventories by tree sizes for selected areas:

\begin{tabular}{|c|c|c|c|c|}
\hline \multirow[b]{2}{*}{$\begin{array}{c}\text { Tree diameter class } \\
\text { (inches) }\end{array}$} & \multicolumn{2}{|c|}{$\begin{array}{c}\text { National Forests, } \\
\text { Western Oregon }\end{array}$} & \multicolumn{2}{|c|}{$\begin{array}{c}\text { Other public, } \\
\text { Western } \\
\text { Washington }\end{array}$} \\
\hline & 1970 & 2020 & 1970 & 2020 \\
\hline $\begin{array}{l}5 \text { to } 11 \\
11 \text { to } 20 \\
20 \text { and larger. }\end{array}$ & $\begin{array}{r}8 \\
25 \\
67\end{array}$ & $\begin{array}{l}18 \\
32 \\
50\end{array}$ & $\begin{array}{l}16 \\
35 \\
49\end{array}$ & $\begin{array}{l}26 \\
61 \\
13\end{array}$ \\
\hline Total $\ldots \ldots$ & 100 & 100 & 100 & 100 \\
\hline
\end{tabular}


TABLE 77.-Inventory of growing stoch per acre in the Pacific Coast Section, by owner class and species group, 1952, 1962, and 1970, with projections to 2020

[Cubic feet]

\begin{tabular}{|c|c|c|c|c|c|c|c|}
\hline \multirow{2}{*}{ Orner class and species group } & \multirow{2}{*}{1952} & \multirow{2}{*}{1962} & \multirow{2}{*}{1970} & \multicolumn{4}{|c|}{ Projections } \\
\hline & & & & 1980 & 1990 & 2000 & 2020 \\
\hline $\begin{array}{l}\text { National Forests: } \\
\text { Softwoods....- } \\
\text { Hardwoods...- }\end{array}$ & $\begin{array}{r}4,366 \\
79 \\
\end{array}$ & $\begin{array}{r}4,348 \\
82\end{array}$ & $\begin{array}{r}4,268 \\
85\end{array}$ & $\begin{array}{r}4,105 \\
94\end{array}$ & $\begin{array}{r}3,958 \\
101\end{array}$ & $\begin{array}{r}3,836 \\
107\end{array}$ & $\begin{array}{r}3,673 \\
116\end{array}$ \\
\hline Total $\ldots$ & 4,445 & 4,430 & 4,353 & 4,199 & 4,059 & 3,943 & 3,789 \\
\hline $\begin{array}{l}\text { Other public: } \\
\text { Soft woods._... } \\
\text { Hard woods }\end{array}$ & $\begin{array}{r}3,115 \\
141\end{array}$ & $\begin{array}{r}3,328 \\
206\end{array}$ & $\begin{array}{r}3,319 \\
269\end{array}$ & $\begin{array}{r}3,356 \\
379\end{array}$ & $\begin{array}{r}3,403 \\
446\end{array}$ & $\begin{array}{r}3,458 \\
487\end{array}$ & $\begin{array}{r}3,534 \\
525\end{array}$ \\
\hline Total. & 3,256 & 3,534 & 3,588 & 3,735 & 3,849 & 3,945 & 4,059 \\
\hline $\begin{array}{l}\text { Forest industry: } \\
\text { Softwoods } \\
\text { Hardwoods.-.- }\end{array}$ & $\begin{array}{r}4,278 \\
199\end{array}$ & $\begin{array}{r}3,419 \\
262\end{array}$ & $\begin{array}{r}2,953 \\
316\end{array}$ & $\begin{array}{r}2,401 \\
396\end{array}$ & $\begin{array}{r}2,271 \\
447\end{array}$ & $\begin{array}{r}2,292 \\
476\end{array}$ & $\begin{array}{r}2,337 \\
496\end{array}$ \\
\hline Total _.. & 4,477 & 3,681 & 3,269 & 2,797 & 2,718 & 2,768 & 2,833 \\
\hline $\begin{array}{l}\text { Farm and miscellaneous private: } \\
\text { Sof twoods } \\
\text { Hardwoods }\end{array}$ & $\begin{array}{r}1,768 \\
259\end{array}$ & $\begin{array}{r}1,721 \\
319\end{array}$ & $\begin{array}{r}1,850 \\
383\end{array}$ & $\begin{array}{r}2,073 \\
488\end{array}$ & 2, 213 & $\begin{array}{r}2,337 \\
596\end{array}$ & $\begin{array}{r}2,541 \\
633\end{array}$ \\
\hline Total $\ldots$ & 2,027 & 2,040 & 2,233 & 2,561 & 2,770 & 2,933 & 3,174 \\
\hline $\begin{array}{l}\text { All owners: } \\
\text { Softwoods.-- } \\
\text { Hardwoods.- }\end{array}$ & $\begin{array}{r}3,533 \\
151\end{array}$ & $\begin{array}{r}3,431 \\
186\end{array}$ & $\begin{array}{r}3,352 \\
219\end{array}$ & $\begin{array}{r}3,252 \\
271\end{array}$ & $\begin{array}{r}3,199 \\
306\end{array}$ & $\begin{array}{r}3,180 \\
327\end{array}$ & $\begin{array}{r}3,164 \\
348\end{array}$ \\
\hline Total & 3,684 & 3,617 & 3,571 & 3,523 & 3,505 & 3,507 & 3,512 \\
\hline
\end{tabular}

Forest industry, North Coast, California

Farm and miscellaneous, Eastern Oregon

Tree diameter class (inches)

5 to 11 . inches)

11 to $20 \ldots$

20 and larger.....

Total

$1970 \quad 2020$

19702020

19

$\begin{array}{r}4 \\ 19 \\ 77 \\ \hline\end{array}$

$\begin{array}{r}11 \\ 41 \\ 48 \\ \hline 100\end{array}$
31

60

100
ECONOMIC PROJECTIONS OF SUPPLY WITH 1970 LEVELS OF MANAGEMENT

Supplies of timber products arailable in any period depend not only on factors of timber inventories, growth, and established harresting practices and trends, but also upon rarious economic, social, technical, and institutional factors that were only partially considered in the base projections presented above. ${ }^{8}$

${ }^{8}$ See for example: Morgan, James T. Three ways to look at Lake States timber supplies. Proceedings of the Society of American Foresters. Detroit, Michigan. p. 201203. 1965.

Guttenberg, Sam. Converting forest resource statistics to timber supply. Proceedings of the 7 th Conf. on Southern Industrial Forest Wanagement. Duke Univ., Durham, N.C. p. 46-51. 1967 .
Prices of timber and timber products in particular affect both the economic operability of existing timber resources and owners' willingness to sell. With rising prices of timber products and stumpage, many timber owners and operators could be expected to increase timber sales, harvests, and utilization, with resulting different relationships to timber growth than assumed in the base projections of timber supplies. Statistical information on supply responses to price changes is limited, however, and projections of economically available timber supplies therefore depend to a major degree on judgment. ${ }^{9}$

- See for example:

Adams, D. M. The impact of changes on Federal timber sales policies on the Douglas-fir region forest economy: An econometric simulation. Ph.D. dissertation, Univ. of California, Berkeley. 1972.

McKillop, W. L. M. Supply and demand for forest products-an econometric study. Hilgardia 38:1-132. 1967.

Mills, Thomas J. An econometric analysis of market factors determining supply and demand for softwood lumber. Ph.D. dissertation, Michigan State University, East Lansing. 182 p. 1972.

Wall, Brian R. Relationship of log production in Oregon and Washington to economic conditions. USDA FS Res. Pap. PNW-147, 13 p. 1972. 
TABLE 78.-Inventory of sawtimber per acre in the Pacific Coast Section, by owner class and species group, 1952, 1962, and 1970, with projections to 2020

[Board feet]

\begin{tabular}{|c|c|c|c|c|c|c|c|}
\hline \multirow{2}{*}{ Owner class and species group } & \multirow{2}{*}{1952} & \multirow{2}{*}{1962} & \multirow{2}{*}{1970} & \multicolumn{4}{|c|}{ Projections } \\
\hline & & & & 1980 & 1990 & 2000 & 2020 \\
\hline $\begin{array}{l}\text { National Forests: } \\
\text { Softwoods } \\
\text { Hard woods }\end{array}$ & $\begin{array}{r}24,510 \\
248\end{array}$ & $\begin{array}{r}23,892 \\
274\end{array}$ & $\begin{array}{r}23,044 \\
289\end{array}$ & $\begin{array}{r}21,405 \\
314\end{array}$ & $\begin{array}{r}19,887 \\
331\end{array}$ & $\begin{array}{r}18,489 \\
346\end{array}$ & $\begin{array}{r}16,282 \\
366\end{array}$ \\
\hline Total_- & 24,758 & 24,166 & 23,333 & 21,719 & 20,218 & 18,835 & 16,648 \\
\hline $\begin{array}{l}\text { Other public: } \\
\text { Softwoods_-_- } \\
\text { Hardwoods_-_- }\end{array}$ & $\begin{array}{r}17,381 \\
403\end{array}$ & 18, $\begin{array}{r}116 \\
606\end{array}$ & $\begin{array}{r}17,578 \\
804\end{array}$ & $\begin{array}{r}16,842 \\
1,131\end{array}$ & $\begin{array}{r}16,106 \\
1,354\end{array}$ & $\begin{array}{r}15,398 \\
1,499\end{array}$ & $\begin{array}{r}14,070 \\
1,657 \\
\end{array}$ \\
\hline Total_.... & 17,784 & 18,722 & 18,382 & 17,973 & 17,460 & 16,897 & 15,727 \\
\hline $\begin{array}{l}\text { Forest industry: } \\
\text { Softwoods_-_.- } \\
\text { Hardwoods._- }\end{array}$ & $\begin{array}{r}25,433 \\
636\end{array}$ & $\begin{array}{r}19,270 \\
812\end{array}$ & $\begin{array}{r}15,870 \\
973\end{array}$ & $\begin{array}{r}11,674 \\
1,194\end{array}$ & $\begin{array}{l}9,994 \\
1,325\end{array}$ & $\begin{array}{l}9,207 \\
1,388\end{array}$ & $\begin{array}{l}8,160 \\
1,400\end{array}$ \\
\hline Total_ _ & 26,069 & 20,082 & 16,843 & 12,868 & 11,319 & 10,595 & 9,560 \\
\hline $\begin{array}{l}\text { Farm and miscellaneous private: } \\
\text { Softwoods } \\
\text { Hardwoods. }\end{array}$ & $\begin{array}{r}9,077 \\
744\end{array}$ & $\begin{array}{r}8,108 \\
953\end{array}$ & $\begin{array}{l}8,350 \\
1,184\end{array}$ & $\begin{array}{l}8,907 \\
1,538\end{array}$ & $\begin{array}{l}9,136 \\
1,780\end{array}$ & $\begin{array}{l}9,339 \\
1,920\end{array}$ & $\begin{array}{l}9,745 \\
2,052\end{array}$ \\
\hline Total $\ldots$ & 9,821 & 9,061 & 9,534 & 10,445 & 10,916 & 11,259 & 11,797 \\
\hline $\begin{array}{l}\text { All owners: } \\
\text { Softwoods_-_-. } \\
\text { Hard woods.-- }\end{array}$ & $\begin{array}{r}19,842 \\
455\end{array}$ & $\begin{array}{r}18,597 \\
572\end{array}$ & $\begin{array}{r}17,661 \\
686\end{array}$ & $\begin{array}{r}16,297 \\
846\end{array}$ & $\begin{array}{r}15,260 \\
955\end{array}$ & $\begin{array}{r}14,418 \\
1,020\end{array}$ & $\begin{array}{r}13,094 \\
1,080\end{array}$ \\
\hline Total_... & 20,297 & 19,169 & 18,347 & 17,143 & 16,215 & 15,438 & 14,174 \\
\hline
\end{tabular}

This section presents some estimates of supplyprice relationships for softwood sawtimber, which represents a major and critical part of the total timber situation. No estimates of the economic availability of all softwood material or of hardwoods are available at this time. However, comparisons of the base projections with the following economic projections for softwood sawtimber may cast some light on possible trends in the economic availability of other material.

\section{Recent Supply-Price Relationships for Timber Products}

During 1971 and 1972 the reported index of wholesale prices of softwood lumber relative to the general price level increased about 40 percent, and for softwood plywood about 25 percent. Because of changes in the pattern of prices of different grades and sizes of these products associated with price control programs, however, the industry average of all sales appears to have risen somewhat more than these reported indexes. Reported prices of pulp and paper products showed little or no change in this short period.

Total harvests of softwood sawtimber from the U.S. forests for lumber, plywood, and other products rose some 4.6 billion board feet between
1970 and 1972 , or a 10 percent increase (table 79). This included a 12 percent increase in domestic production of softwood lumber, a 29 percent increase in production of softwood plywood, and some decline in estimated production of pulpwood from sawtimber resources. Imports of softwood lumber increased 55 percent in this period in response to price increases that were reportedly greater than those prevailing under U.S. price controls.

The short-run elasticity of supply of domestic softwood sawtimber products in the 1970-72 period-defined here as the ratio between the percentage increase in total supplies of softwood sawtimber products and the percentage increase in weighted average U.S. wholesale prices of softwood lumber and plywood-was apparently between 0.2 and 0.3 . This was not greatly different from apparent short-run supply responses to price changes for softwood sawtimber products during cyclical changes in most years of the 1950 's and 1960's.

Longer run relationships between prices and supplies of timber products, however, have been quite different from short-run relationships in these recent decades. Factors such as the rise in 
TABLE 79.-Softwood sawtimber supplies at alternative price levels for lumber and plyuood

[Billion board feet]

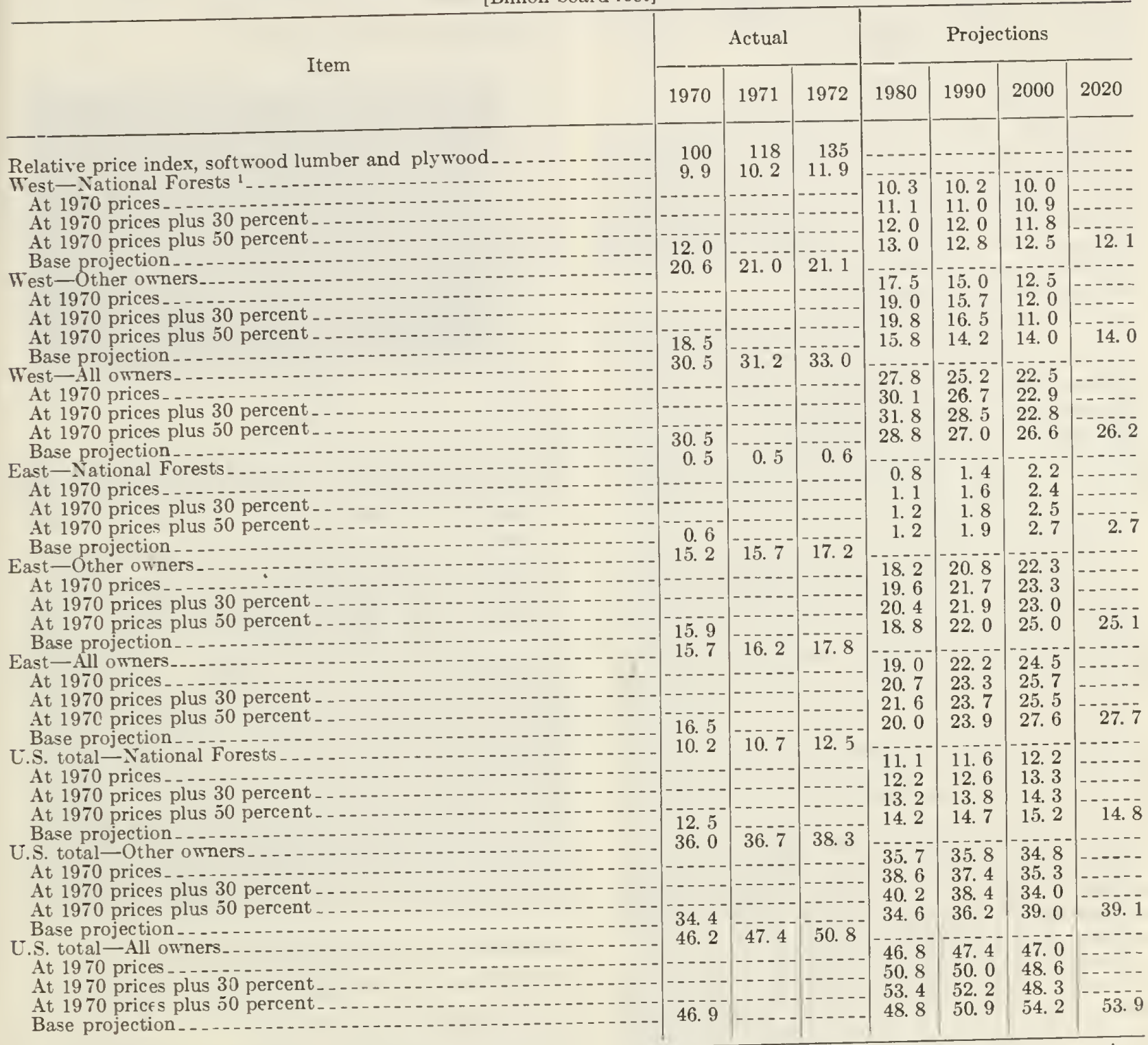

1 Projections assume 1970 proportions of operator-financed and federally financed roads as well as other practices at 1970 levels.

relative prices of lumber and stumpage prior to 1950 , for example, made it economically feasible to develop the timber resources in previously undeveloped areas in National Forests in the West and in British Columbia. This was also a period when recovery of forests in the South permitted increased timber harvesting, and when new technology broadened the raw material base and led to more efficient and expanded production in the plywood and lumber industries.

As a result of these developments more supplies of timber products became available at a given price level. This shift in supply-price relationships for softwood sawtimber was equivalent to an apparent long-run supply function of much greater elasticity than for short periods.

It is anticipated that timber supply-price relationships will continue to shift from decade to decade in the future as a result of prospective changes in timber resource conditions. Some anticipated changes represent a reversal of past trends, as in the Pacific Coast States where a continued shrinkage of timber harvests on industrial ownerships must be expected, particularly 
with 1970 management levels and policies. In other cases, as in the South, continuing increases in timber supplies from an expanding resource are anticipated. Supply prospects also differ by ownerships, as pointed out below.

\section{Projected Supplies From National Forests}

Estimates of potential supplies of softwood sawtimber from National Forests at alternative price levels, shown in table 79 , were based on estimates of allowable harvests as established in 1970, modified by judgment as to timber operability, utilization potentials, and recent reevaluations of allowable harvests in some areas resulting from new environmental constraints.

Allowable harvest limitations.-On National Forests and on certain other Federal and State ownerships sales of timber are limited to the allowable harvests set by sustained yield policies and multiple-use standards and guidelines. Timber sales and harvests on public lands also may be restricted, at least temporarily as in the 1970-72 period, by such factors as environmental studies, law suits to halt timber cutting, and availability of funds and manpower.

Except for temporary increases in harvesting of timber already under contract, timber sales and harvests on these public lands cannot be increased significantly above allowable amounts, even with much higher demands and prices. Nevertheless, with increased prices timber on public lands can be utilized more closely, resulting in an increase in roundwood output and a corresponding reduction of residues on logging areas. Much of the material that could be made available in this way is suitable only for products such as pulp or particleboard, but some material can be utilized for lumber or plywood. Also, increased sales and harvesting of timber that may not be in the allowable harvest, such as certain thinnings, timber in remote areas, and increased salvage of dead timber, become more feasible with higher prices.

The amount of such possible increases in supplies of roundwood with higher prices varies in different areas, depending on such factors as amounts and types of materials left after logging, accessibility of areas logged, attitudes of loggers, equipment available, methods of pricing low-valued timber, and size and nature of available markets.

Supplies from western National Forests.-At 1970 prices and 1970 level of management, projected supplies of softwood sawtimber products from western National Forests total about 10 billion board feet annually-close to the actual harvest in 1970 and 1971 (table 79 and fig. 41). With prices 50 percent higher than in 1970 , harvests are estimated to reach about 12 billion board feet annually.

These estimates of potential timber harvests with higher prices largely reflect an anticipated increase in utilization on logging operations,
Softwood sawtimber supplies ( 1970 level of management ) total Western United States

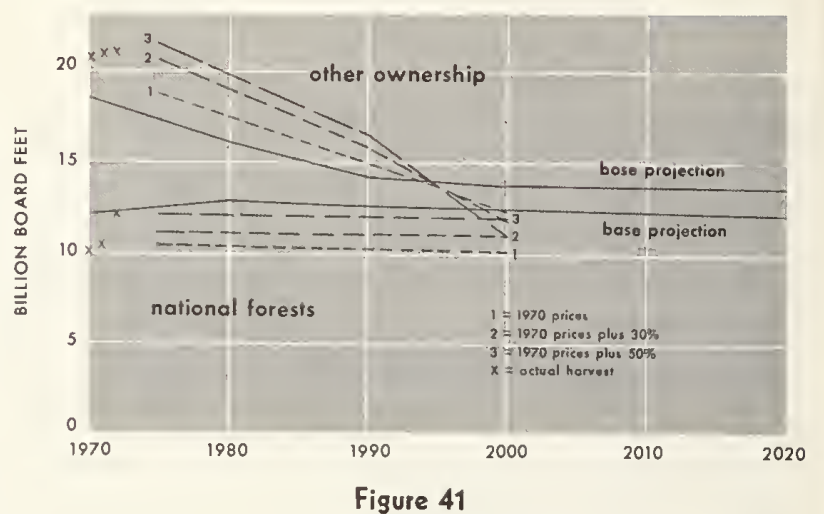

increased thinnings and salvage, and-in the Rocky Mountains and Alaska-greater economic accessibility of some timber that would be inoperable at 1970 prices.

Supplies from eastern National Forests.Harvests of softwood sawtimber from National Forests in the eastern United States, at 1970 prices and level of management, were estimated to increase from about 0.5 billion board feet in 1970-72 to 2.2 billion board feet by the year 2000 (fig. 42). This substantial rise in output reflects a continuing buildup of timber inventories that is expected on these lands and resulting rises in allowable harvests. With higher prices somewhat closer utilization also can be expected to lead to some additional modest increases in log supplies.

Total supplies from National Forests. - At 1970 prices and level of management, these projections for all National Forests in the United States show

\section{Softwood sawtimber supplies}

( 1970 level of management )

total Eastern United States

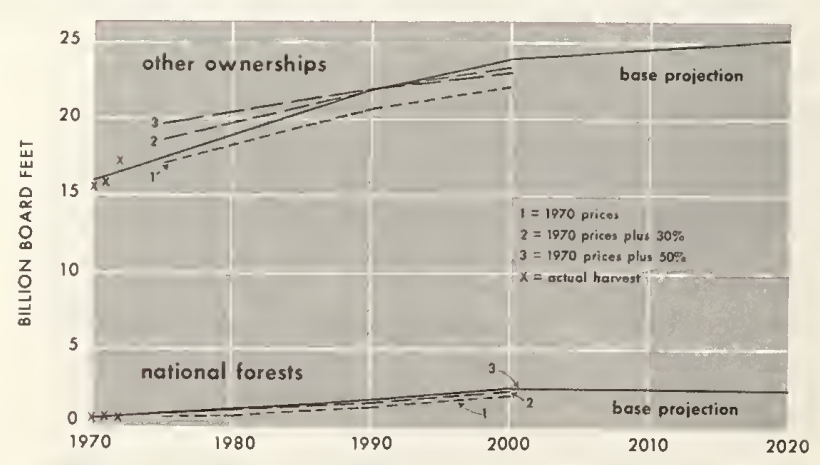

Figure 42 
ittle change from the average of 11.2 billion board eet of softwood sawtimber actually cut in the seriod 1970-72 (table 79 and fig. 43). With price ncreases for lumber and plywood averaging 30 jercent above 1970 levels, potential harvests of softwood sawtimber in 1980, for example, were stimated at 10 percent more than with 1970 rice assumptions. With assumed price increases if 50 percent over 1970 , potential harvests in 1980 rere projected to 19 percent above the actual cut if 1970.

These economic projections of arailable softrood sawtimber supplies are lower than the base rojections presented earlier in this chapter, rhich represented allowable harvests on National iorest lands as established in 1970. These lower stimates reflect in part new classifications of ommercial timberlands, new environmental contraints on timber management, and particularly he fact that substantial inventories of National Forest timber in the Rocky Mountains and llaska would not be economically operable xcept with timber product and stumpage prices ubstantially abore 1970 levels.

\section{'rojected Supplies From Other Lands}

Procedures for estimating prospectively arailible supplies of softwood sawtimber products rom other lands raried somewhat by region and "rnership.

Supplies from western areas.-Potential harvests $f$ timber from public lands in the West were stimated on the basis of reported allowable arrests and possible increases in timber utiliation in much the same way as for National 'orests.

Estimates for private lands in the West were lade on the basis of judgment as to (1) prorective economic operability of timber inventories different price levels, and (2) consideration

\section{sftwood sawtimber supplies}

\section{0 level of management )}

\section{tal United States}

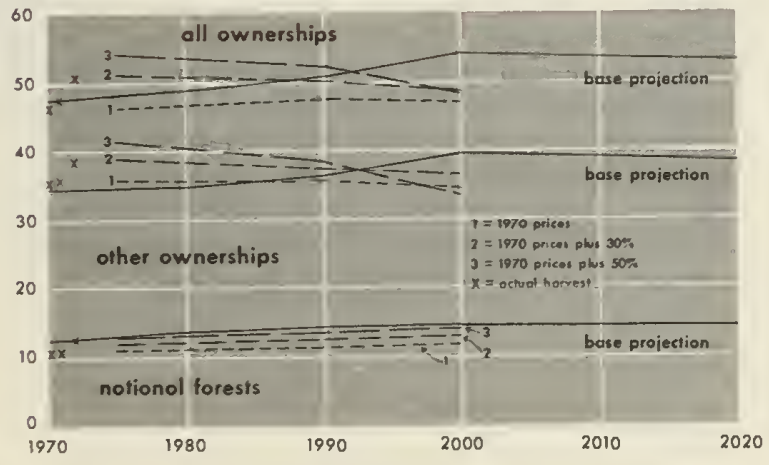

Figure 43 of owners' willingness to sell their timber. These judgments in turn were based on such factors as past responses to price increases, studies of owner attitudes toward selling timber, and possible impacts of changing technology on timber operability and utilization. The base projections of timber inventories and growth presented in the previous part of this chapter and several related projections using different cutting assumptions also provided some guides for these estimates.

Timber harvesting responses to increased prices appear to vary widely among different owners. Some farm and miscellaneous private owners, for example, willingly increase timber sales as prices rise, whereas other private owners hold forest land and timber primarily for nontimber puposes, and have little or no interest in selling timber even at relatively high prices.

On industrial forest lands, cutting is often related to plant capacity or related long-term objectives that tend to limit increases in harvesting in response to rising prices. The time required to install new plant capacity or recruit additional workers also has a short-run influence on the rate at which supplies of lumber or other finished products can be increased in response to higher demands and prices.

With prices and management at 1970 levels, it is estimated that harvests of softwood sawtimber on other ownerships in the West would decline steadily from about 21 billion board feet of actual harvests in 1970 to possibly 12.5 billion board feet by $2000-$ a drop of 40 percent (table 79 and fig. 41)

With higher prices than in 1970 , it is estimated that additional harvests of roundwood could be obtained by closer utilization of timber felled or formerly passed up in logging operations, by increased salvage of dead or dying timber, and by increased harvesting of other nongrowing stock. Supplies could also be increased by accelerated sale and harvesting of standing timber inventories.

At these higher prices, estimates based mainly on judgment show a more sustained trend in harresting over the next couple of decades, but a sharp decline thereafter to lower levels than expected with 1970 prices. Holding cutting at higher levels during the 1970's and 1980's in response to relatively high prices would thus mean an accelerated reduction of supplies by 2000 and thereafter.

Supplies from eastern areas.-Projections of softwood sawtimber supplies from other ownerships in the East, with prices and management at 1970 levels, were based on the assumption that these owners would continue to sell or cut about the same percentage of standing timber inventories as in 1970 . (Timber harvests on other ownerships in that year averaged 4.8 percent of softwood sawtimber inventories in eastern forests, compared to 3.5 percent in the West.) Because of the upward 
trend in timber inventories and growth on these lands' resulting from past and current forestry programs, this procedure resulted in a projected increase of 47 percent in harvests of eastern sof twood sawtimber between 1970 and 2000 (fig. 42).

With higher prices it was estimated, as in the West, that rates of harvesting would be further increased. A coefficient of supply-price elasticity of 0.5 was assumed in estimating initial responses to price increases for softwood lumber and plywood averaging 30 percent and 50 percent above 1970 levels. This meant an increase of 15 and 25 percent respectively in percentages of softwood sawtimber inventories harvested. These higher cutting rates were then used in the projection system to estimate annual changes in future harvests, net growth, and inventories.

Use of this procedure resulted in a significant increase in harvests of sof twood sawtimber products above output estimated with 1970 prices throughout the period from the 1970's to the year 2000. These higher projections also are somewhat above the base projection for the 1970-1990 period.

Total supplies from other ownerships.-Under the assumption of 1970 prices and level of forest management, it is estimated that supplies of softwood sawtimber products from other ownerships in the United States would drop slightly from the actual harvest of 36.0 billion board feet in 1970 (table 79 and fig. 43). With price increases of 50 percent over 1970 , on the other hand, supplies in the year 1980 might be roughly 5 billion board feet greater than could be expected at 1970 prices. By the year 2000 , however, all projections for these ownerships show somewhat less timber available than was harvested in 1970.

\section{Projected Supplies From All Ownerships}

Projections of economically available supplies of softwood sawtimber products from all ownerships in the United States, at 1970 prices and management level, remain fairly close to the 1970 harvest of 46.5 billion board feet. (fig. 43). Projected decreases in supplies in the West just about offset increases in the East.

With an assumed increase of 50 percent in softwood lumber and plywood prices over 1970 levels, projected harvests in 1980 total about 53 billion board feet, but then gradually drop to less than 50 billion board feet by 2000 , and to somewhin lower levels thereafter. Projections assuming a 30 percent rise in prices are intermediate between these two projections.
These price-related projections indicate that with increased prices roundwood supplies could exceed the base projections of timber supply developed earlier in this chapter at least for the next couple of decades. It is readily apparent, however, that with no increases over 1970 levels of management, accelerated timber harvesting would, in time, result in a reduction in both the quantity and quality of available roundwood supplies below 1970 levels of output.

It must be recognized that these estimates necessarily involve a large measure of judgment. The time paths of future harvests appear consistent with supply-price relationships in recent decades but could be quite different with major changes in prices, a tighter timber supply situation, or other factors. All the projections developed, however, indicate that if forest management and forestry investments are maintained at 1970 levels prospects for increased supplies of softwood sawtimber products are limited.

Available supplies of softwood sawtimber in the past have been used for both solid wood products such as lumber and plywood and for woodpulp. With higher timber prices there may be increased incentives to reallocate logs used for pulp to sawmills and plywood plants, with a shift of pulpwood procurement to residues and small or low-quality timber. Whether this occurs depends on numerous factors affecting competition for wood in many local areas.

In addition to increased timber harvesting and closer utilization of available supplies expected with rising prices of timber products and stumpage, it seems likely that many industrial and some other forest owners would intensify timber management programs above 1970 levels.

The biological potential for future timber growth and harvests is considerably greater than the projections of potential supplies that could be anticipated with 1970 levels of management on National Forests and other ownerships. More of this potential could be captured by intensified management and utilization.

Some intensified management and utilization practices could have early impacts on timber supplies, particularly in areas with old-growth timber. Because of the time required to grow merchantable sizes of trees, however, such potential increases in timber supplies - though of major importance in the long run-would largely be realized beyond the projection period used in this analysis. Some information on possible opportunities for such intensification of forest management is presented in the following chapter. 
In this chapter estimates are presented of potential increases in timber supplies, over and above projected supplies with 1970 management levels as described in Chapter II, that might be achieved in coming decades by an acceleration of certain cultural measures and by closer timber utilization. The amount of such increases economically attainable will depend to a large degree on trends in timber prices, hence some price alternatives were considered in this analysis.

The following material includes a general indication of opportunities for intensified management of the Nation's forests. This is followed by a summary of an initial study of opportunities for intensified forestry on National Forests and farm and miscellaneous ownerships throughout the United States. More detailed case studies are then presented for the Southeast, Northeast, North Central, and Pacific Northwest regions to illustrate procedures for analysis and preliminary findings of intensification opportunities.

It is not possible with the data available at this time to estimate with a high degree of accuracy how much future timber growth and harvests might be increased as a result of higher levels of investment in forestry practices, nor related impacts on nontimber costs and benefits. The increases in timber supplies resulting from intensified management as described in this chapter are believed to be reasonable approximations, but much additional study will be necessary for more complete evaluations of potentials.

\section{GENERAL OPPORTUNITIES FOR MANAGE. MENT INTENSIFICATION}

With 1970 levels of forest management and related harvesting and area assumptions, available supplies of timber from U.S. forests were projected to increase moderately over the next few decades. These projections, shown in Chapter II, are considerably below yields attained in fully stocked natural stands, and much less than yields attainable with intensive practices.

Both technical opportunities for increasing yields and economic returns from investments in intensified management vary widely from stand to stand and from place to place depending on a variety of factors. The examples of intensification opportunities described in later sections of this chapter indicate some of the variations in quantity, quality, and value of increased growth and harvests that might be obtained from selected treatments.
Differences in treatment opportunities stem in part from site and stand conditions. Thus the timber-growing capacity of commercial timberlands ranges from as little as 20 cubic feet per acre per year on the poorest sites included in the "commercial timberland" category to highly productive areas-mainly on the West Coast - that have the capability of producing more than 200 cubic feet of timber annually.

Stocking, species composition, tree diameter distribution, and regeneration requirements also vary widely in different stands and directly affect management opportunities. Additional factors of accessibility and operability of forest areas and nature of available markets also influence the economic feasibility of intensified management.

In many cases the necessity of modifying timber management to enhance enviroumental protection and to maintain recreation, wildlife, and aesthetic values increases management costs or reduces amounts of timber growth available for harvest. Areas such as roadside zones and scenic areas on the National Forests, for example, may provide some timber but only incidental to management for other uses.

Increased timber production on areas suitable for treatment, supplementing harvests prospectively available with 1970 management, can be achieved by a variety of measures, including accelerated regeneration, stand conversion, stand improvement, commercial thinning, fertilization, water control, improved harvesting practices, and intensified protection.

Regeneration.-Much has been done to improve regeneration following logging, both by modifying harvesting practices to obtain natural regeneration and by establishment of planted stands through site preparation and planting, or seeding. Establishment of plantations on abandoned farmland or other open areas has also been of large importance in the South and elsewhere. As pointed out in Chapter II, planting at the "1970 level" of management covered about 1.5 million acres annually.

Large additional gains in timber supplies can be achieved both by expansion of planting efforts and by greater use of genetically improved planting stock. Considerable progress has been made already in use of improved stock, particularly in the South where an estimated quarter of the planting stock seed used by the timber industry in 1970 came from selected superior trees.

About 15 percent of the 700 million seedlings produced by State and Federal nurseries in recent years has been grown with seeds derived from superior trees. Programs underway will steadily expand this proportion in the years ahead. Reduction of the regeneration period after logging also is of large importance, particularly in a number of western forest types. 
Accelerated planting efforts, as in the case of much current planting, will often require such measures as clearing areas of economic size; piling, chipping, disking, or burning logging debris; bedding prior to planting to improve drainage; chemical destruction of competing regetation; or combinations of such measures.

Stand conversion.-Many areas in both the East and the West Coast support poorly stocked stands of hardwood trees of inferior species or quality that can be expected to produce little rolume or value growth. Clearing of such stands and planting to softrood is being done successfully on a rather wide scale on industrial and certain other lands, and numerous opportunities exist for expansion of such stand conversion programs, especially in the South. Also, in the case of certain stagnated stands of species such as lodgepole pine in the West, removal of the present trees and replacement by new stands of the same or different species is the only way to achieve full use of the site potential. Such conversion in some areas, however, may be limited by low sites or because of wildlife or other nontimber considerations.

Stand improvement.-Precommercial thinning in the early years of the life of timber stands in many cases has major impacts on timber vields. Such thinning produces no immediate usable wood but has its paroff in faster growth, shorter rotations, more growth in usable trees and higher quality wood.

In most timber types indiridual trees assert dominance over the others and stands develop efficiently. In other cases, crowding becomes progressively more serious and long rotations are required to produce merchantable wood. At its worst this crowding results in stagnation, especially on poor sites, with resulting spindly stands of small trees that never become merchantable-at least by prospective standards.

Precommercial thinning of heavily stocked stands is one of the major technical opportunities for increasing yields in many forests. Other measures that require out-of-pocket investments to increase timber volumes and values include removal of undesirable overstory trees in young stands haring sufficient "crop" trees to utilize the site.

Commercial thinning.-Cutting of merchantable trees to improve spacing and stimulate growth of crop trees is still a relatively limited practice in the United States. Nevertheless, numerous research studies indicate that commercial thinning often can provide early returns, utilize material otherwise lost as mortality, and concentrate growth on the more valuable trees. This is particularly the case on lands where production of sawtimber is the objective of management.
In reaching decisions as to thinning opportunities, land managers in some cases must also consider certain adrerse factors, such as possible logging damage to residual stands, increased fire hazards from thinning slash, problems of access in mountainous country, and problems of windthrow in some areas.

Salvage.-Harresting of a larger portion of the 2.8 billion cubic feet of softwood timber killed annually by fire, insects, or other causes also represents an important potential for increasing log supplies in some areas.

Fertilization.-As indicated in the previous chapter, there has been increasing experience in recent years in the use of forest fertilizers to accelerate and improve tree growth. Most of the activity in this regard has been in the Pacific Northwest and in the South-practically all by industrial owners.

Experience suggests that timber yields can be increased rather substantially with applications of nitrogen and in some cases with other nutrients such as phosphorus. While adequate information is not yet arailable on costs and benefits of increased fertilizer application, it seems likely that fertilization will prove to be economically attractive on millions of acres of productive forest lands, particularly with increases in timber prices.

Protection against insects and diseases.-As indicated earlier, insects and diseases take a heary toll of timber by killing trees and by reducing timber growth. The annual mortality and growth reduction attributable to only three pests, for example-western dwarf mistletoes, western bark beetles, and southern pine beetles-alone are estimated to equal about 13 percent of the current timber harrest.

A number of major protection programs against forest pests have been undertaken in past years. For the most part these have been only partially successful, presumably because not enough has been known about how to deal with these pests. Iore effective research and action programs could have the effect of materially increasing future wood supplies.

Timber yields could be enhanced, for example, through control of dwarf mistletoe, bark beetles, larch case bearer, and other insects and diseases through development and use of attractants, repellants, feeding deterrents, hormones, sterilants, and parasites, as well as use of pesticides and improved cultural measures.

Protection against fire.-The largest and most effective forestry effort in the United States, as pointed out in Chapter II, has been in the control of forest fires. The results hare been remarkable, with a decline in area burned from 30 to 40 million acres annually at the beginning of the century to about 5 million acres annually, in the late 1960's. 
There still appear to be important opportunities, however, to further reduce fire losses and costs through development and use of improved technology in fire prevention, presuppression, and suppression-including better understanding of ways to reduce numbers of fires, development of improved fire detection systems using airborne infrared equipment, for example, and development of techniques for more effective control of fires. Through such means fire suppression, particularly of large fires that characteristically result in most fire damage, could be more efficient and losses correspondingly reduced.

Fire losses also might be cut by reducing fuel accumulation on cutover areas through development of markets for logging residues and/or improved cleanup of cutover areas. Further improvement of techniques for use of prescribed fire in hazard reduction could also help reduce the intensity of and losses to wildfires.

The focus of improved protection efforts by fire control agencies is also suggested by data on areas burned annually, by cause. During the period 1966-70 the largest areas of forest land burned in the United States resulted from incendiary fires, followed by debris burning, lightning, and smokers.

\section{THE ROLE OF RESEARCH}

Much can be done to increase timber growth and harvests by utilizing existing technology. But investments in intensified management and utilization could be made more effective by improving the technological base for such efforts. More information is needed, for example, about the responses of forest stands of different types, ages, and sites to treatments such as thinning. Before the most effective tree fertilizing programs can be achieved more knowledge must be obtained on the response of trees on various soils, and effects of fertilizers on the environment. Research on genetic improvements in timber growing should include improved methods of progeny testing to detect natural resistance to insects and diseases.

There are substantial areas of poorly stocked forests, and areas where planting costs are high, where lower cost techniques for site preparation and planting would improve returns from forest investments. Better knowledge of spacing control in precommercial thinning and subsequent intermediate cutting could help increase output of both timber and nontimber values.

In many forest types development of more effective methods of timber harvesting that will insure natural regeneration of desirable timber species is of key significance in order to assure prompt and low-cost establishment of new stands and to protect aesthetic or other nontimber values. Improvement of aerial logging techniques using skyline systems, or helicopters, for example, could increase timber harvests as well as enhance environmental values.

It is not possible to quantify the impacts of accelerated research efforts, nor rates of subsequent extension and application of new technologies. However, it is believed there are substantial potentials for increasing timber growth and for extending timber supplies beyond projections in this chapter by development and application of improved technology.

\section{THE IMPORTANCE OF FOREST OWNERSHIP}

While there are many technical and economic opportunities for increasing timber growth and harvests in the various regions of the United States, a number of ownership constraints tend to limit practical increases in timber supply. The long investment period for most forestry practices is a significant barrier to intensified management by most private owners. Rates of return from timber growing investments usually are relatively low. And land use objectives and other factors also have a marked influence on the actions of forest owners.

Farm and miscellaneous private owners.-About 59 percent of the Nation's forest lands are owned by several million nonindustrial private ownersfarmers, businessmen, housewives, power companies, mining companies, and numerous other occupational groups. A number of studies have shown that these owners have many objectives in owning forest lands, widely differing characteristics and attitudes, and varying willingness and capacity to invest funds in timber growing. ${ }^{1}$

In reporting on their objectives in owning forest lands, a minority of the nonindustrial private owners sampled stated that timber growing was their principal objective. Most of these owners, rather, held forest land for various nontimber goals such as recreation, wildlife protection, aesthetics, or speculation, with timber production a secondary goal at best. Most had little interest in making sizable investments in timber growing, and many owners were reluctant to harvest timber for environmental or other reasons. In the latter case, however, changing circumstances, such as need for income or change in tenure at time of death, have tended at some time in the life of most stands to result in willingness to harvest the timber that nature has provided.

Growing concern about future timber supply has led to adoption of a variety of institutional

1 McClay, T. A. Rating private nonindustrial ownerships for increased timber productivity and supply. U.S. Forest Service. (Processed.) 1971. 
measures to encourage more intensive forestry on private lands, including general forest protection from fire and other destructice agents, public technical assistance and educational efforts, public cost-sharing of forestry practices on private lands, leasing of forest land by forest industries, pooling arrangements for management of small forest holdings, use of consultants, and legislative controls on timber cutting practices and forest protection.

In view of the attitudes of forest owners revealed by various studies, it is not surprising that only a small portion of nonindustrial private owners with a small part of the private forest land have participated in these assistance programs of Federal, State, and private agencies. It was estimated as of 1970 , for example, that only a quarter of the several million farm and miscellaneous private owners have sought marketing advice or other technical serrices.

Where owners have invested in forestry practices such as planting or stand improvement, financial standing and size of forest holdings have been most generally correlated with adoption of such practices. People with higher incomes appear more willing to make long-term investments as well as better able to take advantage of cost-sharing or technical assistance programs. Inrestors in timber production also tend to include people classed as "innorators" and owners with better than average knowledge of forestry. Such factors as occupation, length of tenure, age of owner, distance to residence from forest property, or method of acquiring property were not found to be strongly related to adoption of forestry measures.

The population of nonindustrial private owners also is constantly changing in terms of indiriduals, types of owners, and size of holdings. Thus in the southern States, forest land owned by farmers dropped from 48 percent of the total forest area in 1952 to 34 percent in 1970 . In the same period the proportion of forest land held by a variety of miscellaneous owners rose from 27 percent to 39 percent of the total.

A very rough classification of the 296 million acres of the Nation's commercial timberland in farm and miscellaneous pricate ownerships, based upon interpretation of several ownership studies, suggests a breakdown about as follows:

a. Perhaps 5 percent of the land in these ownerships is intensively managed on a continuing basis. Tree crops are grown for harresting and manufacture, with owners using all or most practices considered practicable. Most lands leased to industry fall in this category. This group is estimated to rary from as little as 2 percent of the total acreage of these ownerships in the North to as much as 8 percent in the South. b. About a third of the farm and miscellaneous owners have some interest in forestry and manage their lands under extensive forestry practices that are usually unplanned or accomplished at random. This category includes most lands under long-term cutting contracts. This group varies from as little as 20 percent in the North to an estimated 45 percent in the South.

c. Owners of nearly half of these holdings display no interest in intensified forestry practices. From time to time owners sell timber grown by nature.

d. Possibly 15 percent of these ownerships are held by owners essentially for nontimber purposes. This includes land held for speculation as well as land held for recreation or other nontimber values.

Most forest owners hare appeared to be more interested in simply obtaining periodic income from selling timber than in making forest management investments to increase future grow th and returns. Participants in the Federal-State cooperative forest, management programs, for example, reported a 40 percent increase in area of forest land harvested during the period 1960 to 1970 , but both timber stand improvement and planting activity on such ownerships decreased during this period.

A general conclusion reached in these investigations is that most forest owners do not consider timber growing investments to be sufficiently profitable to take priority over other investment or consumption opportunities. Many holdings are too small for efficient timber production. Also, in some cases, woodland owners must devote what time and money they have to obtaining other sources of income.

Increases in prices of timber could change this picture somewhat and lead to more investment in intensified management practices. New information on timber growing opportunities and more assistance also may be necessary to change landowner attitudes and willingness to invest in timber production.

Bringing additional owners into forestry programs would undoubtedly involve increasing expenditures per person assisted as programs reach less interested owners. But without such public and/or private action to persuade and assist forest owners intensify timber management, most holders of nonindustrial private lands cannot be expected to recognize and act upon opportunities for more intensive use of their timber resources.

Indifference of forest owners to management opportunities, and anticipated diminishing returns in expanding programs of "persuasion" thus suggests that all opportunities for timber manage- 
ment intensification, based upon a criterion such as 5 percent or more rate of return, are not likely to be realized. This likelihood has been considered, necessarily on a judgment basis, in the studies described below by adjusting estimates of areas "available" for intensified management in nonindustrial private ownerships.

Under these circumstances future timber harvests will depend largely on public programs of fire protection and control of insects and diseases, and natural regeneration of volunteer stands. Because of their widespread importance-59 percent of the total commercial timberland in the United States-future timber supplies will depend to a major degree on what is done on these lands.

Forest industry ownerships.-There still is a wide range in management intensity on forest industry lands, but the forest industries have made substantial advances in reforestation and other cultural and protection activities in recent decades. Surveys of forest industry holdings in the South, for example, indicated that if recent trends are continued most industry lands in that region will be under relatively intensive management by $1980 .^{2}$ Continued upward trends in forest management on industry lands would mean somewhat higher projections for these owners than shown in Chapter II, particularly after the year 2000 .

Public owners.-National Forests and other public forest lands have been managed at variable levels of intensity. These agencies also must increasingly manage forest land with a variety of objectives, including not only timber but recreation, watershed protection, and other uses. The policy of sustained yield under which National Forest and many other public and some private ownerships are managed also limits the rate at which forest areas can be cutover, but management intensification nevertheless will often permit substantial increases in timber harvests on these lands.

\section{ENVIRONMENTAL FACTORS RELATING TO INTENSIFICATION OF FOREST MANAGEMENT}

Environmental considerations are having increasing impacts on costs of forest management and processing of timber products. They also affect acceptance of timber-growing and harvesting practices by the general public.

Intensification of forest management by such measures as thinning, timber stand improvement, reforestation, prescribed burning, fertilization, etc., and associated timber cutting, road con-

${ }^{2}$ Guttenberg, Sam. Forestry goals and practices on large ownerships in the South. J. of Forestry 67(7):456-461. July 1969 . struction, slash burning, or other disturbances, have varying impacts on forest resources and uses. It is difficult to generalize about the net impacts of intensified forestry practices on nontimber values. Conditions of ten vary widely, knowledge of specific impacts is generally lacking, and plus and minus factors may be offsetting.

Water yields, for example, will probably increase somewhat if a substantial portion of the timber in a drainage is removed. Excessive stream sedimentation, with a reduction in water quality, also could occur if roads and landings are not carefully planned and constructed. Forest fertilization will require careful application to minimize nutrient input to streams and lakes.

Habitat for some kinds of wildlife is generally improved with thinnings and other measures which open the forest canopy and increase supplies of food plants for game animals such as deer and elk. Conversion of brush fields or poor-quality stands by site preparation and planting, on the other hand, may damage habitat for other species of wildlife, particularly in plantations where complete forest canopies develop.

Recreational access for hunting and fishing and some other recreation travel is usually improved with road construction for logging and other forestry operations. Adverse recreational impacts are also common, however, as in cases where aesthetic qualities of forest areas for recreational viewing, hiking, or camping are reduced by logging operations. Consequently, management of "visual resources," particularly in mountainous areas in public ownership, may limit the extent to which timber management can be acceptably intensified.

Costs of land management must include careful design and location of roads and cutting areas if erosion or other environmental impacts are to be minimized. Fire control problems and costs likewise are likely to be increased with greater access to the forest and increases in production of slash or debris from expanded harvesting operations. Conventional slash burning and prescribed burning may be limited by opposition to resulting air pollution effects or other impacts.

Such environmental impacts from accelerated reforestation, stand improvement, or other forestry operation are likely to be limited at any given time to a small percentage of the total forest area. Thus an accelerated regime of accelerated management practices in the southeastern United States described below would cover less than 2 million acres annually, or roughly 1 percent of total commercial timberland in that region.

In West Coast stands under intensive management, it is estimated that entries into a forest will normally be made with some type of equipment every 10 years or so for such purposes as planting, 
precommercial thinning, commercial thinning, prelogging, and final harrest. It may also be necessary to enter the forests on other occasions for fire control or salvage of blowdown or insect-killed timber.

The type of soils and terrain and the type of equipment used are major considerations in determining the amount and consequences of such actirities. Studies on National Forests in the Douglas-fir region, for example, showed that costs of road construction with adequate drainage, seeding of cuts and fills, and other desirable practices would require at least a 26 percent increase in road costs over construction formerly consideerd normal. ${ }^{3}$ In some areas of difficult terrain, road construction also may be unacceptable in riew of the need to protect scenic resources, prevent soil movement, or protect water ralues. Under such conditions timber harresting may be feasible only with systems involving skylines, balloons, or helicopters.

In riew of the growing importance of environmental factors, rarious modifications of forestry practices will be essential, particularly on public lands, to insure that intensification of timber management does not seriously impair the environment or damage nontimber uses. These may include treatment of relatively small areas, for example, and clean up of thinning and logging slash. Protection of stream channels for wildlife and water values will require that cutting be restricted along streams. Learing uncut areas for animal escape and cover may be necessary to maintain desired animal populations. Programs for salrage of dead and dying trees may have to be aroided in some areas, and patches of other timber left to protect food supplies and nesting sites for certain animals and birds. Such practices may hare appreciable effects on allowable cuts, particularly on public lands.

In evaluating opportunities in this chapter for intensification of timber management on public lands, estimates were made of the extra costs to protect environmental values. It is of course possible that still further emphasis on environmental factors may limit yields of timber more than assumed in this and the preceding chapter.

\section{AN EXAMPLE OF POTENTIALS FOR INCREAS- ING SUPPLIES OF SOFTWOOD SAWTIMBER IN THE UNITED STATES}

In 1972 the Forest Service prepared a set of estimates of some possible nationwide increases

${ }^{3}$ USDA Forest Service. Douglas-fir supply studyalternative programs for increasing timber supplies from National Forest lands. 52 p. 1969. in supplies of softwood sawtimber that might be realized through certain management intensification, using as a criterion economic returns on additional investments. This initial analysis necessarily involved numerous judgment estimates by field personnel as well as information from timber management plans, yield studies, and related arailable sources. Continuing studies to improve the data base and analytical procedures could result in considerable adjustment of the resulting estimates which are presented below.

The analysis of management alternatives in this initial study included only National Forests and farm and miscellaneous private holdings. No national estimates are available at this time for other public lands, which comprise 9 percent of all commercial timberlands, nor for forest industry lands which make up 13 percent of the total commercial timberland.

Forest industry owners already implement forestry programs for softwood production at. relatively high levels compared with other owners. In 1971, for example, over half of all forest planting was on industrial land, although planting has covered only a small portion of the total areas harvested in recent years. It was assumed in Chapter II that industrial forest owners will continue planting and other timber management practices as in recent years. But there are undoubtedly additional opportunities for management intensification on industrial holdings, as well as on public lands, that are not included in this initial analysis. It is likely that many of these opportunities on industrial lands, and on other public lands, will be acted upon, particularly with the expectation of higher timber prices in the future.

Management practices considered in this study included reforestation, stand release, precommercial thinning, and commercial thinning and salvage.

Other measures such as fertilization and accelerated use of improved genetic planting stock, and increased utilization, were not specifically considered in this study. These also will presumably be feasible in some areas, and could of course supplement output beyond amounts estimated below.

The analytical process used to estimate potential increases in timber harvests from intensified management involved (a) a classification of areas in terms of physical conditions and related management options, (b) estimation of costs of intensified timber growing practices, including costs of environmental protection, on each class of forest land, (c) estimation of amounts, timing, and values of increased timber harvests over and above outputs with 1970 levels of management 
and the "base" projection of harvests shown in the first part of Chapter II, and (d) calculation of rates of return on increased investments and an economic ranking of investment opportunities.

In this study it was not possible to develop specific measures of relationships between treatments and nontimber uses and environmental factors. As indicated earlier, silvicultural activities influence the ouality and quantity of water, recreation, grazing, and wildlife habitat, but whether these effects represent a net benefit or a net cost in given situations has been difficult to determine.

\section{Area Classification}

A classification of forest areas in each region was first made to group areas of more or less homogeneous conditions, treatment options, and potentials for management. This classification for most regions was based on factors of type, site, and stand-size class, such as indicated in tables 45-48 of Appendix I. In other areas stand age was also used in this classification. In the case of National Forests on the Pacific Coast, estimates were based on "project work inventories." Acreage figures developed in this way applied essentially to conditions existing in 1970 , and did not include changes to be expected from future harvesting, for example, or shifts in land uses.

The second step was to classify each of the "cells" indicated above in accordance with general opportunities for intensified management, including the following general categories:

a. Areas on which economic opportunities for intensification of management are apparently limited because forests are already in good shape for timber growing. Yields may be inincreased in some cases, however, by commercial thinning, fertilization, or drainage. Where management objectives can be met with short rotations such as 25 to 30 years, as in certain plantations in the South, no treatment may be feasible because volume yields appear to be about the same with or without thinning. In other cases with longer rotations, as in the West, thinnings were considered appropriate to increase both volume and value growth.

b. Areas on which stands have passed the age where they would benefit appreciably from thinning or other cultural measures. It was assumed that such stands should merely be allowed to grow until ready for final harvests, although in some cases there may be opportunities for investments in protection, salvage of dying trees, or fertilization.

c. Areas of poor site quality which will not respond sufficiently to cultural treatment to make investments worthwhile. d. Areas with existing stands that would yield substantial increases in timber volumes and/or values as a result of cultural practices such as precommercial or commercial thinning, or other measures such as fertilization or drainage.

e. Areas having little or no present or prospective timber values, but suitable for reforestation. These included areas of low stocking and poor hardwood stands that might be replaced with softwoods through stand conversion.

\section{Selection of Areas for Analyses of Management Alter- natives}

From stands listed in subparagraphs above, estimates were made of acreages considered economically suitable for intensification of management. This selection, and estimation of acreages available, depended on such criteria as stand condition, accessibility, size of forest tracts, and preliminary estimates of potential returns from intensification. Estimates were also made of the areas being treated under on-going programs in deriving estimates of potential intensification.

In the case of farm and miscellaneous private lands an additional critical judgment was also made as to the area of commercial timberland held by owners considered likely to make investments in response to cost-sharing or other incentives. Without this assumption of technical assistance, areas "available" for intensification would undoubtedly be less than shown by the following estimates.

In this process 278 of the "most promising" classes of land were selected for detailed analysis of intensification potentials. These included some 4.5 million acres of National Forest lands, in contrast to a reported backlog of about 17 million acres considered silviculturally suitable for treatment, plus 12.7 million acres of farm and miscellaneous private lands.

Since these selections of areas to be studied were based in part on judgment, some economically promising areas undoubtedly were not included. On the other hand, some areas were included that may yield less than the indicated average rate of return for a given class of land. Additional areas of farm and miscellaneous private land beyond those included in this analysis also might be managed more intensively if "persuasion" costs could be lowered by finding more efficient ways of persuading owners to be responsive to management opportunities. 


\section{Costs of Intensified Management}

Additional costs of intensified management for each of the strata selected for eraluation of m inagement opportunities were based upon 197071 cost experience in the case of National Forest lands, and on reported costs for private forestry operations updated to 1970-71. Costs included both direct on-the-ground costs of treatment such as reforestation, together with certain costs of enrironmental protection and local orerhead costs. Road construction costs were not included, nor were indirect costs of National Forest general overhead.

For farm and miscellaneous prirate lands, in addition to direct costs, technical assistance from public agencies was included as an orerhead cost corresponding to technical supervision by National Forest field staff personnel. Federal costs for assisting owners of private land also were estimated assuming a 75 -percent share of direct treatment costs, plus technical assistance. It was also assumed for this analysis that property tax leries or general administrative costs would not be changed appreciably by intensification of management.

Costs per acre of management intensification are influenced by many factors and rary widely from place to place and over time. Examples of ranges in costs assumed for National Forest lands are shown in table 80. An example of costs used for analysis of opportunities on farm and miscellaneous private lands in the South is presented in table 81 . Other specific costs per acre appropriate to each situation studied weroapplied in analyzing local inrestment opportunities.

\section{Yields From Intensified Management}

Yields from accelerated management activities were estimated for each of the selected treatment situations in terms of the amounts of increased harrests that might be obtained, by decade, over and abore yields to be expected with 1970 management levels. Yields from plantations, for example, were estimated from arailable plantation yield tables or through adjustment of normal yield tables, with the growth anticipated without reforestation subtracted therefrom.

Estimates of expected responses to treatments such as precommercial thinning, involving estimates both with and without treatment, were based upon local studies or local judgments as to responses to be expected. Information on response to different management activities is quite limited and it was consequently necessary to depend to a considerable degree on judgment of forest research and management personnel familiar with local conditions.
TABLE 80.-Range of direct costs per acre for intensified manugement on National Forests, $1970-71^{1}$

[Dollars]

\begin{tabular}{c|r|r|r}
\hline \multicolumn{1}{c|}{ Region } & $\begin{array}{c}\text { Reforest- } \\
\text { ation }^{2}\end{array}$ & $\begin{array}{c}\text { Precommercial } \\
\text { thinning }\end{array}$ & $\begin{array}{c}\text { Stand } \\
\text { release }\end{array}$ \\
\hline North_. & $30-80$ & $15-25$ & $15-25$ \\
South & $25-60$ & $10-20$ & $15-25$ \\
Rocky Mountain..- & $40-70$ & $25-40$ & $15-20$ \\
Pacific Coast_...- & $60-70$ & $25-40$ & $15-20$
\end{tabular}

1 Total costs on National Forests are approximately double these estimates due to indirect costs charged against a project but not incurred "on-the-job."

2 Includes planting and varying degrees of site preparation.

TABLE 81.-Estimated treatment costs of accelerated management on nonindustrial forest lands in the East, 1970-71

[Dollars per acre]

\begin{tabular}{|c|c|c|}
\hline Items & $\begin{array}{c}\text { Aver- } \\
\text { age }\end{array}$ & Range \\
\hline Site preparation & 20 & $5-40$ \\
\hline Natural regeneration: & & \\
\hline Pine type & 5 & \\
\hline Oak-pine type & 15 & \\
\hline 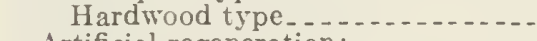 & 15 & \\
\hline Artificial regeneration: & & \\
\hline Pine type & 15 & \\
\hline Oak-pine type & 20 & \\
\hline Hardwood type $\ldots \ldots \ldots$ & 25 & \\
\hline $\begin{array}{l}\text { Stand conversion } \\
\text { Average stand d.b.h. under } 10\end{array}$ & 20 & $10-50$ \\
\hline $\begin{array}{l}\text { Average stand d.b.h. under } 10 \\
\text { inches or basal area under } 50 \\
\text { square feet. }\end{array}$ & & \\
\hline $\begin{array}{l}\text { square feet } \\
\text { All other conditions }\end{array}$ & 30 & \\
\hline Planting: & & \\
\hline 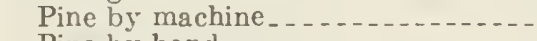 & 15 & $10-25$ \\
\hline Pine by hand & 20 & $15-35$ \\
\hline Hardwood by hand ...................... & 35 & $25-50$ \\
\hline Direct seeding pine & 10 & $5-20$ \\
\hline Aerial & 7 & \\
\hline $\begin{array}{l}\text { Ground } \\
\text { Timber stand improvement: }\end{array}$ & 13 & \\
\hline Cull tree removal & 10 & $2-15$ \\
\hline $\begin{array}{l}\text { Precommercial thinning and clean- } \\
\text { ing - Marking: }\end{array}$ & 15 & $5-30$ \\
\hline Commercial thinning and cull tree & 4 & $2-10$ \\
\hline $\begin{array}{l}\text { Precommercial thinning and clean- } \\
\text { ing } \\
\text { Prescribed burning } \\
\text { Fertilization.... }\end{array}$ & $\begin{array}{r}8 \\
1.50 \\
20\end{array}$ & $\begin{array}{l}0.5-15 \\
25-3.50 \\
10-30\end{array}$ \\
\hline
\end{tabular}

Source: Based on data in McClay, T. A. Treatment costs-southern supply study. USDA Forest Serv., Div. Forest Econ. and MIark. Res. office report. 1969.

\section{Vslues of Increased Yields}

In the initial analysis of management opportunities, values of the increased timber harrests resulting from intensification of management on 
TABLE 82.- Sawtimber stumpage prices on National Forests, by region, 1970-71

[Dollars per MBM, Scribner scale]

\begin{tabular}{|c|c|c|c|c|c|c|}
\hline Species & $\begin{array}{l}\text { Northern } \\
\text { Rocky } \\
\text { Mountain }\end{array}$ & $\begin{array}{l}\text { Southern } \\
\text { Rocky } \\
\text { Mountain }\end{array}$ & California & $\begin{array}{c}\text { Pacific } \\
\text { Northwest }\end{array}$ & South & North \\
\hline $\begin{array}{l}\text { Doulas-fir } \\
\text { Ponderosa pine } \\
\text { Lodgepole pine } \\
\text { Fir-spruce } \\
\text { Larch-western white pine } \\
\text { Mixed conifers }{ }^{2} \\
\text { Southern pine } \\
\text { Red pine-white pine }\end{array}$ & $\begin{array}{c}5-12 \\
12-17 \\
8.50 \\
7-9.50 \\
21 \\
15 \\
-\end{array}$ & 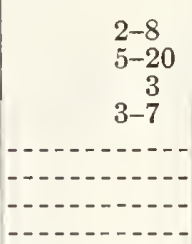 & 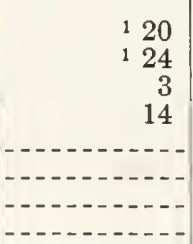 & 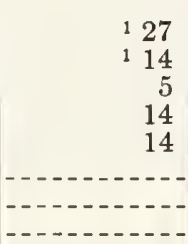 & 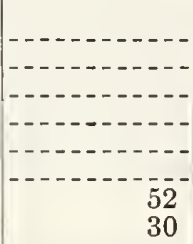 & $\begin{array}{r}18 \\
25\end{array}$ \\
\hline
\end{tabular}

1 Reduced to 65 percent of reported rate based on R-6 study comparing current old-growth and secondgrowth timber prices.

National Forest lands were based upon 1970-71 stumpage prices, as shown in table 82 . These ranged from negligible values for some hardwoods removed in conversion programs, for example, to as much as $\$ 52$ per thousand board feet for increased output of southern pine sawtimber and $\$ 27$ for Douglas-fir sawtimber. The latter figure, derived by adjustments from old-growth timber sales, may be conservative.

Stumpage prices used in calculations of values of increased harvests on farm and miscellaneous private ownerships in the South, for example, are shown in table 83. These were derived from various local price reports and local studies of value differentials by tree diameter class.

A second set of estimates of values of potential harvest increases also was developed assuming a higher level of timber products and stumpage prices. These assumed a 30 percent rise in softwood lumber and plywood prices over 1970, and an assumed $\$ 20$ per $M$ board feet increase in stumpage values, except for lodgepole pine for which price increases were assumed to average $\$ 12$ per $M$ board feet. No adjustments were made for changes in relative costs of intensification, partly because these occur early in the investment period.

Both price assumptions were used in evaluations of rates of return on investments in intensified management in order to provide some measure of sensitivity to price. Because of the general outlook for increasing prices of timber in future years indicated in Chapter VI, the analysis with the higher price assumption is believed to provide a more realistic view of potential investment returns.

\section{Ranking Opportunities}

Several indicators of economic ranking of investment opportunities were calculated in this analysis from the schedules of treatment costs and increased yields and values. These included rate of
${ }^{2}$ Weighted average of all conifers except lodgepole pine-based on CY 1971 timber sales in $\mathrm{R}-1$.

TABLE 83.- Stumpage prices for timber from farm and miscellaneous ownerships, 1970-71

\begin{tabular}{c|r|r}
\hline $\begin{array}{c}\text { Average d.b.h. } \\
\text { of timber }\end{array}$ & $\begin{array}{c}\text { Southern } \\
\text { pine }\end{array}$ & $\begin{array}{r}\text { Eastern white } \\
\text { pine }\end{array}$ \\
\cline { 1 - 2 } Inches & $\begin{array}{r}\text { Cents per cubic foot } \\
7\end{array}$ & $\begin{array}{r}\text { Cents per cubic joot } \\
2 \\
8\end{array}$ \\
11 & 5 \\
10 & 12 & 8 \\
16 & 15 & 16 \\
\hline
\end{tabular}

return on increased investments before income taxes, increases in present net worth, and benefitcost ratios.

For the summaries presented below opportunities were evaluated and ranked in terms of rate of return. Most estimates were related to a minimum rate of return of 5 percent-an arbitrary rate that might be considered reasonable to illustrate this type of investment analysis. The opportunities for intensification indicated by this criterion have been designated "most promising," in recognition of the selection process used.

\section{Increased Yields From Farm and Miscellaneous Private Lands}

Areas.-At 1970-71 average prices and costs, these estimates indicated that about 9 million acres of the 12.7 million acres studied in detail would return more than 5 percent on additional costs of accelerated management (Append. III, table 1). Nearly half of the 9 million acres would yield returns of more than 7.5 percent. An estimated 3.7 million acres of the area studied would yield from 2.5 to 5 percent return at 1970-71 prices. 
Costs.-Costs of accelerated practices on the 9 million acres with returns in excess of 5 percent at 1970-71 prices were estimated at $\$ 346$ million, or an arerage of somewhat more than $\$ 38$ per acre. A major share of this cost was assumed to be prorided by public agencies.

Out-of-pocket costs per unit of increased output orer the next 50 years, excluding interest on investments, were estimated at about $\$ 6$ per M board feet.

Additional harvests. - The estimated additional harrests resulting from intensified practices on 9 million acres total nearly 56 billion board feet spread over the next 50 years, or an average of somewhat more than 1.0 billion board feet annually. Howerer, harrest increases are relatirely small until year 25 or so, after which harrests increase rapidly. In thefirst two decades some limited rolumes are arailable from commercial thinning and from remoral of softwoods on areas converted to plantations. The major portion of increased yields become available after 2 or 3 decades, reaching 2.5 billion board feet per year in the fifth decade (fig. 44 and Append. III, table 1). This timing reflects the predominance in these figures of reforestation opportunities in the South, and an assumption of short rotations.

With a one-time intensified 10-year program as assumed in this example, harvest increases rise to a peak then drop off after the fiftieth year. However, it is anticipated that a series of intensified programs would be economically feasible in future periods as a result of changing forest conditions following harvesting or other forest disturbances. Thus increases in timber harvests could be maintained or increased over longer periods by such a series of programs, as illustrated later.

Increased annual harvests of softwood sawtimber on nonindustrial private lands resulting from intensified management of 12.7 million acres, by rate of return at 1970 prices

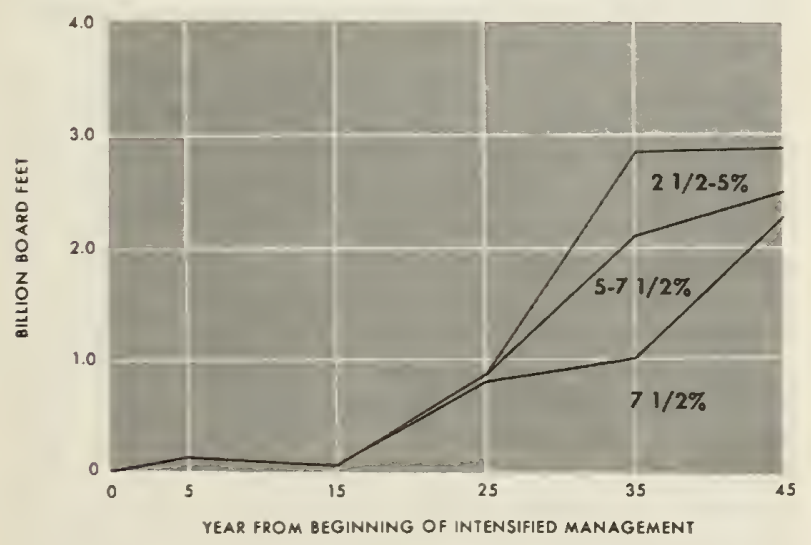

Figure 44
Harrest schedules shown in figure 44 represent a summation of harvest schedules for individual situations without adjustments for factors such as maintenance of a given flow of timber harvests over time. It was also assumed that the entire acreage listed would be treated over the next decade if funds were available. Areas considered suitable and available for treatment already have been scaled down for economic and ow nership reasons, as indicated earlier, but it is of course possible that intensification might have to be spread over a longer period.

\section{Increased Yields From National Forest Lands}

A similar analysis of opportunities for accelerated reforestation and stand improvement on National Forest lands was developed, including evaluations both with and without an "allowable cut effect," that is, an almost immediate increase in harvesting of overmature stands following intensification of management in anticipation of a higher level of timber availability in future years. ${ }^{4}$

Potential increases in harvests resulting from intensified management on western National Forests are shown in table 2 of Appendix III with an allowable cut effect, but calculations of rates of returns were based initially upon harvests from individual treatments without allowable cut effects. This procedure was followed partly because of uncertainties as to allowable cut effects, and partly to have direct comparisons with returns from alternative investments and alternative areas. $^{5}$ If allowable cut effects are utilized in the rate of return analysis, returns are increased substantially, as illustrated by the following example:

\section{Trealment}

$\frac{\text { Rate of return }}{\begin{array}{c}\text { With allow- } \\ \text { able cut } \\ \text { effect }\end{array}} \begin{gathered}\begin{array}{c}\text { Without } \\ \text { cut effec }\end{array} \\ \text { cuble }\end{gathered}$

Reforest spruce fir, site 3......... Release mixed conifer, site $3 \ldots \ldots$

7. 3

1. 7

21. 6

5. 9

Area treated.-The resulting estimates-that is, calculating rate of return from individual treatments without credit for allowable cut effectsindicate that at $1970-71$ prices and costs, roughly 1.7 million acres of the 4.5 million acres studied in this analysis would produce more than 5 percent return on accelerated investments (Append. III, table 2). If returns were calculated with the allowable cut effect, most of the 4.5 million acres

\footnotetext{
'See, for example: Schweitzer, Dennis L., Robert N. Sassaman, and Con H. Schallau. Allowable cut effectsome physical and economic implications. J. of Forestry $70(7): 415-418.1972$.

5 Haley, David. The economic analysis of activities designed to accelerate stand growth in the context of the managed forest. Paper presented at Western Forestry and Conservation Association. Seattle, Washington. December 6, 1972.
} 
studied would return more than 5 percent on increased management investments.

Costs.-Additional costs required for intensification on these 1.7 million acres were estimated at $\$ 82$ million-an average of $\$ 50$ per acre. This included $\$ 41$ million of direct costs for on-theground activities. Estimated costs for intensification on 4.5 million acres total $\$ 356$ million-an average of $\$ 79$ per acre.

Harvest increases. - Increased harvest yields over the next 50 years on the most promising 1.7 million acres of National Forest land are estimated at about 25 billion board feet of softwood sawtimber, or an average increase of 0.5 billion board feet per year. Projected yield increases total an estimated 350 million board feet annually by the fifteenth year and 780 million board feet by the forty-fifth year.

Increased harvests from the entire 4.5 million acres of National Forest land included in this analysis would amount to an estimated 68 billion board feet over the next 5 decades or an average of 1.4 billion board feet per year. These increased yields would peak at about 1.8 billion board feet annually in the fifth decade.

It is possible that the allowable cut effect involved in these estimates of increased timber harvests may be overstated somewhat. One reason relates to time lags in accomplishing accelerated programs. Another relates to delays before effects are allowed for in revised timber management plans. Also, allowable cut effects in this example were based upon reserves of merchantable timber by geographic sections, rather than by specific management units such as used in management plans. If allowable cut effects are not considered, and increases in harvests become available only after timber from treated areas matures, the projected increased cuts resulting from intensification of management would be deferred much further into the future than shown in Appendix III, table 2 .

\section{Sensitivity to Price Assumptions}

The effect of using alternative assumptions as to future relative prices of timber has also been illustrated by assuming a 30-percent increase in relative lumber and plywood prices over 1970-71 levels and related stumpage prices as shown in tables 82 and 83 .

Farm and miscellaneous private lands.-At these higher price levels, all 12.7 million acres of farm and miscellaneous private lands studied in this analysis would return more than 5 percent on investments in intensified management-in contrast to 9 million acres at 1970 prices (Append. III, table 3). By far the major part of these investment opportunities were for reforestation, with lesser areas meeting criteria for commercial thinning and timber stand improvement. More than 90 percent of the acreage of these estimated opportunities for intensification were located in the South.

Intensified management of the 12.7 million acres studied would require an estimated $\$ 546$ million, or about $\$ 43$ per acre, and about $\$ 8$, excluding interest, per M board feet of increased output over the next 50 years (1970-71 prices).

Estimated increases in timber harvests from 12.7 million acres reach an estimated peak of 2.9 billion board feet in the fiftieth year, in contrast to about 2.5 billion board feet from 9 million acres, and a total of 69 billion board feet over the 50 year period.

National Forest areas.-With the higher price assumption, some 3.2 million acres of National Forest land would return more than 5 percent on increased reforestation and stand improvement, compared with 1.7 million acres at 1970-71 prices (Append. III, table 4). Timber stand improvement accounted for the major part of the indicated investment opportunities on National Forest lands, followed by reforestation of nonstocked lands in old cutovers and burns. Reforestation of newly harvested areas was assumed to be provided for as part of 1970 levels of management.

Intensified management on 3.2 million acres was estimated to cost $\$ 191$ million-about $\$ 60$ per acre.

The 3.2 million acres of National Forest land on which returns of more than 5 percent could be expected at the higher prices would yield an estimated additional harvest of 480 million board feet annually in the first decade, and 1.3 billion board feet per year by the fifth decade. These estimates of yields assume significant allowable cut effects on timing of harvests in western regions.

Inclusion of the entire 4.5 million acres analyzed would produce increases in future harvests reaching 1.8 billion board feet per year in the fifth decade (Append. III, table 4). With the allowable cut effect included in calculating rate of return, most of this area would return more than 5 percent on additional investments.

Addditional yields from commercial thinnings on National Forests.-Opportunities for commercial thinning on National Forest lands were not evaluated in comparable detail in this initial study of investment opportunities. However, preliminary estimates based on judgments of field personnel indicate that increased harvests from commercial thinning and salvage operations on National Forests might total about 1.1 billion board feet annually (International 1/4-inch rule) by 1980 , increasing to 2.3 billion board feet annually by 2000 . These largely represent "silvicultural" operations that would be possible on accessible areas of "standard" timber growing lands, excluding eastern forests, Alaska, and 
lodgepole pine stands, assuming some increases in prices orer 1970 lerels.

Substantial road construction and increased expenditures for timber sales would be necessary to achiere these increases, hence these opportunities were not included in Chapter II under 1970 levels of management. Somewhat more than half of these estimated thinning potentials are in the Rockr Mountain area and the remainder on the Pacific Coast.

\section{Possible Succession of Treatment Programs}

The estimates developed as described abore assumed one 10-year program of intensification. In some areas such as the South, it seems likely that programs of similar magnitude could be repeated in subsequent decades, with reasonably similar increases in rields. The area inrolred in this preliminary analysis of "most promising" opportunities is a relatively small part of the total commercial timberland.

In other areas such as the Pacific Coast the extent and mixture of treatment opportunities might be quite different. In assuming "continued" programs it is recognized that errors may be in the direction of orerstating opportunities since repeated programs should in time exhaust the best opportunities, with resulting smaller additions to vields and poorer in restment opportunities.

Increased harrests within the projection period 1970-2020 would be obtained from intensification programs conducted in the 1970's and 1980's. A sequence of programs would proride additional harrests but most of these would become arailable beyond the 50-year projection period of this study.

Increases from farm and miscellaneous private lands. - An example of continuing programs of intensified reforestation, stand improrement, and commercial thinnings assumed treatment of an estimated 1.3 million acres annually orer the next three decades at a cost of $\$ 54.6$ million per yearan arerage of $\$ 43$ per acre (Append. III, table 5). Estimates dereloped as described above indicate this level of activity would return more than 5 percent on investments at 1970 prices plus 30 percent.

Projected increases in annual harrests of softwood sawtimber with this regime reach 1 billion board feet by the twenty-fifth year and 6.8 billion board feet by the forty-fifth year, as illustrated in figure 45 .

Increases from National Forest lands.-A continuing program of intensification, including stand improrement at the same rate as in the 10-year program and reforestation of 0.84 million acres orer a 20-year period, would corer an estimated 275 thousand acres annually, at a total cost of \$14.5 million per year (Append. III, table 6). Increased harvests of softwood sawtimber resulting from such continuing efforts are estimated

\section{Softwood sawtimber supply alternatives}

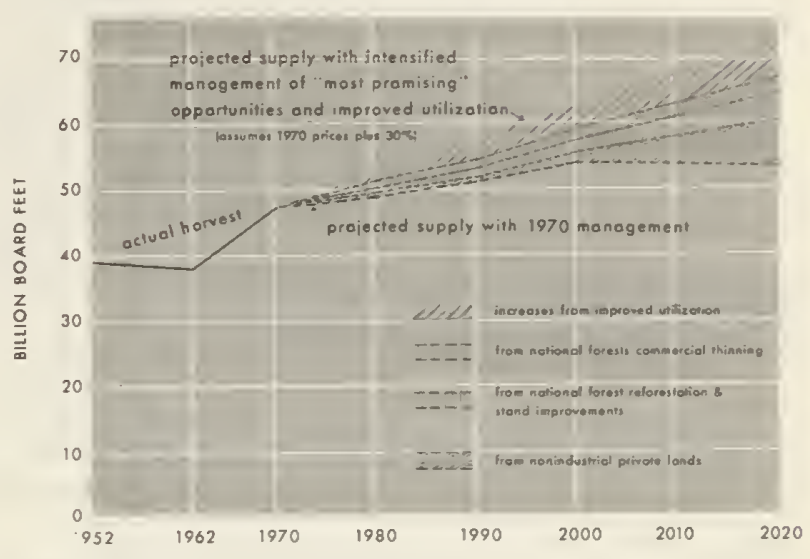

Figure 45

at 1.1 billion board feet by the fifteenth year, increasing to over 4 billion board feet per year by the forty-fifth year (fig. 45).

\section{Summary of Potentials for Intensification of Manage. ment}

Possible increases in harrests from a continuing series of programs of intensified management on lands estimated to represent the "most promising" opportunities for intensification are summarized in figure 45 and table 84 . These estimates assume a criterion of 5 percent or more return on investments, prices of softwood lumber and plywood 30 percent abore 1970 lerels, and an allowable cut effect in estimating increases in yields on National Forest lands.

These selected opportunities would provide an additional 1.6 billion board feet by 1980 and as much as 13 billion board feet by 2020. Estimated annual costs (1970-71 dollars) total $\$ 73.7$ million for reforestation and stand improrement. Funds for road construction, timber sale administration, and general agency orerhead are not included in these figures. The estimated increases in harrests from such a program amount to 3 percent more than projected supplies with 1970 levels of management by 1980 and 25 percent more by 2020 .

These estimates of potential increases are necessarily preliminary. They could be extensively revised as a result of continuing research underway on timber yields and other factors bearing on response to management.

\section{General Comparison of Alternatives Studied}

The data summarized in this analys of the "most promising" available opportunities for intensification beyond 1970 forest management levels indicate that additional program expenditures can be made only with progressively lower cost effectireness. Thus inclusion in the National 
TABLE 84.-Projected increases in softwood sawtimber supplies from continuing programs of intensified management of selected areas

\begin{tabular}{|c|c|c|c|c|c|c|c|}
\hline \multirow{2}{*}{ Ownership } & \multirow{2}{*}{$\begin{array}{l}\text { Area } \\
\text { treated } \\
\text { annu- } \\
\text { ally }\end{array}$} & \multirow{2}{*}{$\begin{array}{l}\text { Annual } \\
\text { costs }\end{array}$} & \multicolumn{5}{|c|}{ Increased harvests, by year } \\
\hline & & & 1980 & 1990 & 2000 & 2010 & 2020 \\
\hline Nonindustrial private_. & $\begin{array}{l}\text { Million } \\
\text { acres } \\
1,270\end{array}$ & $\begin{array}{l}\text { Million } \\
\text { dollars } \\
54.6\end{array}$ & $\begin{array}{l}\text { Billion } \\
\text { bd.ft. } \\
0.1\end{array}$ & $\begin{array}{l}\text { Billion } \\
\text { bd. ft. } \\
0.2\end{array}$ & $\begin{array}{l}\text { Billion } \\
\text { bd.ft. } \\
\quad 1.0\end{array}$ & $\begin{array}{l}\text { Billion } \\
\text { bd. ft. } \\
\text { 3.9 } 9\end{array}$ & $\begin{array}{l}\text { Billion } \\
\text { bd. ft. } \\
\quad 6.8\end{array}$ \\
\hline $\begin{array}{l}\text { Reforestation and stand improvement } \\
\text { Commercial thinning. }\end{array}$ & $\begin{array}{l}275 \\
\text { n.a. }\end{array}$ & $\frac{14.5}{(1)}$ & $\begin{array}{r}.4 \\
1.1\end{array}$ & $\begin{array}{l}\text { 1. } 1 \\
\text { 1. } 4\end{array}$ & $\begin{array}{l}2.0 \\
1.7\end{array}$ & $\begin{array}{l}\text { 3. } 0 \\
\text { 2. } 0\end{array}$ & $\begin{array}{l}\text { 4. } 1 \\
\text { 2. } 2\end{array}$ \\
\hline Total_..... & & & 1. 6 & 2. 7 & 4. 7 & 8.9 & 13. 1 \\
\hline
\end{tabular}

1 Requires substantial costs for road construction and timber sale administration.

Forest analysis of reforestation opportunities that fail to yield 5 percent at 1970 prices plus 30 percent would raise annual costs by over 55 percent, while increasing harvests by an estimated 12 percent in year 45 after program initiation (Append. III, table 6).

This analysis also indicates that estimated future harvest increases from the "most promising" opportunities studied on farm and miscellaneous private lands come mainly from reforestation. Almost the opposite occurs on National Forests where most of the estimated harvest increases possible with the specified economic criteria are derived from increased timber stand improvement.

Both a higher general level of profitability on farm and miscellaneous private lands, and the preponderance of reforestation opportunities on these ownerships, are as one would expect. Farm and miscellaneous private lands generally have a higher inherent productivity, especially in the South where over 75 percent of the "most promising" private opportunities occur. Also, National Forest lands are already operated at higher levels of intensification than most farm and miscellaneous private ownerships.

\section{Additional Managenent Opportunities}

There are undoubtedly additional opportunities for intensified timber management beyond those indicated in this initial study that would yield more than 5 percent on additional investments. The judgment process of screening promising situations no doubt excluded some areas where intensification would be profitable. With a multitude of situations, however, some screening process is essential. Prices higher than assumed in this study would also increase the attractiveness of management in tensification.

In addition, increases in timber growth and harvests are surely obtainable from intensified management on many industrial and other public lands that were not covered in this analysis.
Further additions to timber supplies might be obtained from such measures as increased forest fertilization, more intensive forest protection against fire, insects, and diseases, and accelerated genetic improvement of planting stock.

The use of criteria other than the conventional rate-of-return concept used in this illustration of the "most promising" opportunities could also lead to adoption of different programs of forest management than illustrated in this chapter. These might include such economic and social criteria as indirect and secondary benefits from maintenance of a viable forest economy in areas where forest industries are established. Other criteria might include a goal of avoiding adverse economic and environmental impacts resulting from higher timber prices and shifts to competitive materials. Still another goal could aim to assure ample timber supplies than would otherwise exist as a hedge against the long-range future when scarcities of raw materials may be more genera].

Other opportunities for extending timber supplies through closer utilization also are outlined in a later section of this chapter.

\section{AN EXAMPLE OF OPPORTUNITIES FOR INTEN- SIFYING FOREST MANAGEMENT IN THE SOUTHEAST}

Results of this analysis of timber management investment opportunities in the Southeast were included in the national summary just described, but are presented here in greater detail to illustrate some of the procedures that may be used in investment analyses.

The Southeast, including Florida, Georgia, South Carolina, North Carolina, and Virginia, is one of the Nation's primary timber producing regions, with forests occupying some 93 million acres, or almost 63 percent of the land area. Because of differences in species composition, site 
TABLE 85.-Timber supplies in the Southeast, assuming 1970 level of management

\begin{tabular}{|c|c|c|c|c|}
\hline \multirow{2}{*}{ Species group } & \multirow{2}{*}{1970} & \multicolumn{3}{|c|}{ Projections } \\
\hline & & 1980 & 2000 & 2020 \\
\hline $\begin{array}{l}\text { Softwoods_. } \\
\text { Hardwoods }\end{array}$ & $\begin{array}{c}\text { Minion } \\
\text { eubic feet } \\
1,799 \\
1,059\end{array}$ & $\begin{array}{c}\text { Million } \\
\text { cubic fet } \\
2,132 \\
1,317\end{array}$ & $\begin{array}{c}\text { Million } \\
\text { cubic feet } \\
2,774 \\
1,736\end{array}$ & $\begin{array}{r}\text {.Million } \\
\text { cubic feet } \\
2,788 \\
1,719 \\
\end{array}$ \\
\hline Total & 2,858 & 3,449 & 4,510 & 4,507 \\
\hline $\begin{array}{l}\text { Softwoods... } \\
\text { Hardwoods. }\end{array}$ & $\begin{array}{c}\text { Minion } \\
\text { board feet } \\
5,833 \\
2,942\end{array}$ & 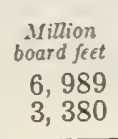 & $\begin{array}{r}\text { Million } \\
\text { board f } f \in t \\
9,258 \\
3,429\end{array}$ & $\begin{array}{r}\text { Million } \\
\text { board feet } \\
9,417 \\
3,440 \\
\end{array}$ \\
\hline Total _. & 8,775 & 10,369 & 12,687 & 12,857 \\
\hline
\end{tabular}

capability, land ownership patterns, and other forest characteristics, opportunities for altering prospective timber supplies rary widely.

Estimates of possible increases in timber supplies from intensified management were calculated by taking as a base the projections of prospective timber supplies assuming 1970 levels of management and the cutting and area assumptions specified in Chapter II. In brief, these projections showed prospectire increases in arailable timber remorals amounting to 58 percent by 2000 in the case of growing stock material and about 45 percent in the case of saitimber (table 85 ).

\section{Identifying Areas Suitable for Intensified Manage- ment}

1. The first step in identifying opportunities for intensified management over and above that provided at 1970 lerels was to break down the total forest area into meaningful management classes. These involved some 89.8 million acres classified as commercial timberland, plus an estimated 2.4 million acres of idle cropland which was included under the presumption that part of these lands would represent an opportunity for increasing future timber supplies. Although a detailed breakdown of these lands by management condition would be desirable, practicality required focusing on a limited number of "treatment opportunity" classes, as shown in table 86 .

2. The second step involved the elimination from detailed analyses of areas not considered suitable for intensification of management. These included:

a. Areas of low timber potential because of poor or adrerse sites; in this initial effort areas incapable of producing more than 50 cubic feet of timber per acre when fully stocked with trees were eliminated. This involved some 26.4 million acres. This procedure reduced National Forest areas to 43 percent of the total acreages listed in table 86 , compared to 76 percent for forest industries, and 73 percent for farm and miscellaneous private lands.

b. Areas already in good condition from the standpoint of timber culture. Standards of good condition were based on forest characteristics such as type, stand size, stand age, volume, and growth, and a vailable results of management research and experience. This procedure eliminated 19.3 million acres.

c. Areas occupied by mature stands ready for harvest and regeneration, amounting to 9.2 million acres. In some cases production on these areas could be increased by fertilization or by use of improved genetic stock for regeneration following logging, but these opportunities were not evaluated.

The areas remaining after this process included 10.7 million acres of young stands judged to be

TABLE 86.-Area of commercial timberland in the Southeast, by ownership and treatment class, 1970

[Million acres]

\begin{tabular}{|c|c|c|c|c|c|}
\hline Class & Total & $\begin{array}{c}\text { National } \\
\text { Forest }\end{array}$ & $\begin{array}{l}\text { Other } \\
\text { public }\end{array}$ & $\begin{array}{c}\text { Forest } \\
\text { industry } 1\end{array}$ & $\begin{array}{l}\text { Farm and } \\
\text { miscel- } \\
\text { laneous } \\
\text { private }\end{array}$ \\
\hline $\begin{array}{l}\text { Poor sites } \\
\text { Stands in good condition } \\
\text { Harvesting } \\
\text { Intermediate cutting } \\
\text { Conversion or regeneration }\end{array}$ & $\begin{array}{r}26.4 \\
19.3 \\
9.2 \\
10.7 \\
26.5\end{array}$ & $\begin{array}{r}2.6 \\
.5 \\
.5 \\
.3 \\
.7\end{array}$ & $\begin{array}{l}1.4 \\
.6 \\
.3 \\
.4 \\
.7\end{array}$ & $\begin{array}{l}\text { 4. } 3 \\
5.3 \\
1.8 \\
2.1 \\
4.3\end{array}$ & $\begin{array}{r}18.1 \\
12.9 \\
6.6 \\
7.9 \\
20.8 \\
\end{array}$ \\
\hline Total & 92.1 & 4. 6 & 3.4 & 17. 8 & 66. 3 \\
\hline
\end{tabular}

1 Includes lands under long-term lease.

2 Includes 2.4 million acres of idle cropland. 
overstocked, plus 26.5 million acres on which a manageable stand was lacking and which would contribute very little to the timber supply until converted, planted, or regenerated (table 86). Results of this analysis clearly indicated that within each ownership class there is a large accumulation of idle, nonstocked or poorly stocked acres where planting, conversion, or regeneration will be necessary if the large differences between prospective and potential timber yields from the lands are to be eliminated or reduced.

Of the 10.7 million acres of young immature stands identified as overstocked, a commercial thinning opportunity was estimated to exist on 7.8 million acres. On the remaining 2.9 million acres, it was judged that precommercial thinning would be required to correct overstocking problems.

3. The third step involved a breakdown by broad management classes and by ownership of the 26.5 million acres considered suitable for intensive management but where there is an absence of a management stand (table 87). These included a range of types and stocking conditions. The category of farm and miscellaneous private ownerships accounted for a major part of the total, with 20.8 million acres where conversion or regeneration will be necessary to obtain satisfactory yields.

4. The fourth step involved an estimate of current levels of forestry activities to aid in determining additional areas where management might be intensified. These data, based upon estimates of past treatment and disturbance on measured field plots, showed an estimated level of forestry activities in 1970 as follows:

\begin{tabular}{|c|c|}
\hline Practice & $\underset{\text { acres }}{\text { Million }}$ \\
\hline Harvesting $\ldots$ & 1. 7 \\
\hline Intermediate cutting & 1. 6 \\
\hline Planting & 0.5 \\
\hline
\end{tabular}

These data suggest that for the category of farm and miscellaneous ownerships expected accomplishments over the next decade with current management would leave about 19.6 million acres untreated. The make-up of this area is shown in table 88 and figure 46.

In this detailed analysis for the farm and miscellaneous category of ownership, some 5 million acres of hardwood types were eliminated from detailed study, not because of the unimportance of hardwoods, but rather because of primary concern at this time over supplies of softwood sawtimber.

\section{Estimated Increases in Yields}

The potential yields of pine plantations that might be established on areas converted or regenerated vary widely depending upon site, species, density, and age. Forest areas were, therefore,

\section{Forest conditions in the southeast, 1970}

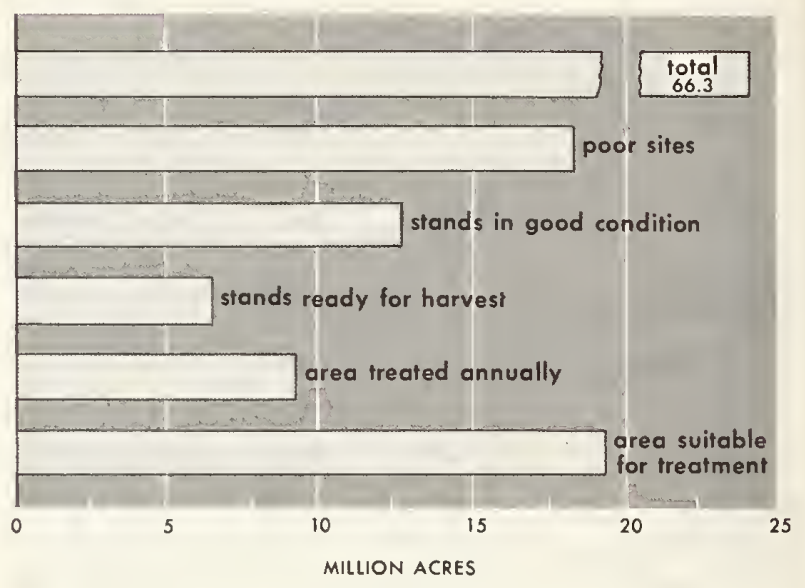

Figure 46

divided into good and medium sites in order to take account of the considerable differences in potential yields attributable to site differences. Areas by site were estimated from Forest Survey plot data, except for idle cropland where it was assumed that half of the acreage available would occur on good sites and half on medium sites.

Available yield tables for slash pine and loblolly pine were utilized in estimating potential increases in harvests after allowances for understocking and losses to destructive agents.

Evaluation of thinning opportunities required taking into account the product objectives of forest landowners. Thus, for pulpwood production many owners select spacings that do not require thinning during the rotation. Others insist that thinning must be financially advantageous, even for pulpwood rotations. On the other hand, in all-purpose management that includes both small and large product objectives, thinnings will of necessity play a role in maintaining stand structure and diameter growth. Also in overstocked stands precommercial thinning may be an important management opportunity.

Estimates of increased future harvests obtainable from thinning treatment were developed by a stand table projection method.

In such growth projections, it was assumed that the current program of prescribed burning would be continued along with other protection activities. Estimated yields necessarily included a substantial allowance for probable losses in plantations and in natural stands from destructive agents such as fire, insects, and disease. Forest Survey findings in this region indicate that mortality losses have been reducing gross grow th by an estimated 10 to 12 percent, while other growth losses resulted in additional differences between current growth and potential growth. 
TABLE S7.- Areas in the Southeast suitable for intensive timber management but without manageable stands, by management and ounership classes, 1970

[Thousand acres]

\begin{tabular}{|c|c|c|c|c|c|}
\hline \multirow[b]{2}{*}{ Management class } & \multirow[b]{2}{*}{$\underset{\text { ownerships }}{\text { All }}$} & \multicolumn{4}{|c|}{ Ownership class } \\
\hline & & $\begin{array}{c}\text { National } \\
\text { Forest }\end{array}$ & $\begin{array}{l}\text { Other } \\
\text { public }\end{array}$ & $\begin{array}{l}\text { Forest } \\
\text { industry }\end{array}$ & $\begin{array}{c}\text { Farm and } \\
\text { miscel- } \\
\text { laneous } \\
\text { private }\end{array}$ \\
\hline $\begin{array}{l}\text { Idle cropland } \\
\text { Nonstocked forest } \\
\text { Pine plantations } \\
\text { Patural pine stands } \\
\text { Oak-pine stands } \\
\text { Upland hardwood stands } \\
\text { Bottomland hardwood stands }\end{array}$ & $\begin{array}{r}2,353.7 \\
946.1 \\
927.1 \\
4,710.2 \\
4,165.5 \\
7,544.0 \\
5,834.9\end{array}$ & $\begin{array}{r}21.8 \\
40.9 \\
191.4 \\
95.0 \\
322.3 \\
37.0\end{array}$ & $\begin{aligned} 45.8 \\
20.3 \\
162.2 \\
157.4 \\
187.3 \\
137.5\end{aligned}$ & $\begin{array}{r}262.4 \\
543.6 \\
885.3 \\
636.6 \\
706.2 \\
1,239.8\end{array}$ & $\begin{array}{r}2,353.7 \\
616.1 \\
322.3 \\
3,471.3 \\
3,276.5 \\
6,328.2 \\
4,420.6\end{array}$ \\
\hline Total area & $26,491.5$ & 708.4 & 710.5 & $4,273.9$ & $20,788.7$ \\
\hline Percent of total in table 86 & 28.7 & 15.3 & 21.0 & 24.0 & 31.3 \\
\hline
\end{tabular}

${ }_{1}^{1}$ Estimated acreage in pine plantations with poor survival and plantations severely damaged by fire, insects, disease, etc.

TABLE 88.--Area of farm and miscellaneous private ownerships in the Southeast suitable for more intensive timber culture, by management and condition class, 1970

[Thousand acres]

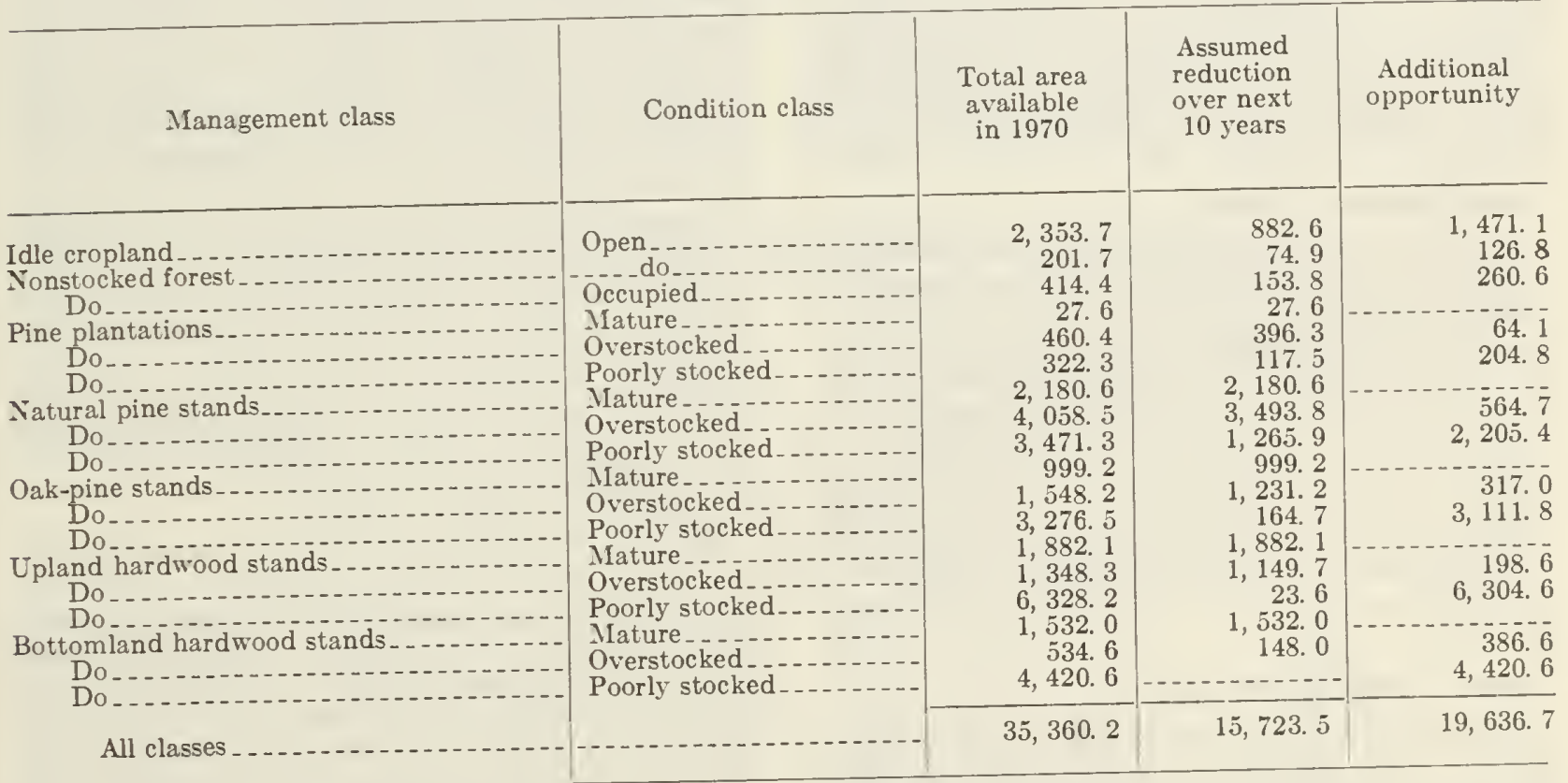

In the case of fusiform rust, which is one of the major damaging agents for both loblolly pine and slash pine, the most promising control measure appears to be the development of more resistant planting stock through genetic improvement. Better control of reproduction weevils in pine plantations will also require planting delays or treatment of seedlings with insecticides. Prevention of losses from fomes annosus root rot will require control measures such as chemical treatment of stump surfaces after felling. For the many bark beetles that plague the southern pine, salrage currently appears to be the most practical form of control. 
In this initial study it was not possible to adequately evaluate opportunities for control of insects and disease nor of opportunities for intensified fire protection. Impact studies will be needed for each major cause of mortality before it will be possible to measure the economic efficiency of adding to prospective timber supplies through more intensified protection.

In addition to the potential increases in yields through cultural measures as estimated in this study, additonal increases in future timber supplies also might be obtained through more complete utilization of the available timber.

Recent Survey findings indicate that up to 12 percent of the total softwoods and 43 percent of the total hardwoods removed from growing stock are not used for products. If only half this wood fiber could be channelled into use, the annual output of timber products could be increased over 5 percent without any increase in timber removals. Additional volumes might be obtained from rough and rotten trees that are now typically left standing in harvesting operations and even from trees in urban areas.

Other possible actions to improve timber yields beyond the estimates in this analysis include the development of genetically improved planting stock, and application of fertilizer to enhance soil fertility. It is estimated, for example, that genetic gains from first generation stock will average 15 to 20 percent higher volume growth than obtainable with seed from existing stands. Management to put the right species on the right site also could substantially increase future timber harvests.

\section{Costs of Forestry Practices}

Average costs of forestry practices assumed in this study for the Southeast are summarized in table 89. On some idle and open areas where extensive site preparation is not required, pine plantations can be established at perhaps half the costs shown in this table. However, a large share of these easy planting opportunities have been exhausted and attention now must be focused largely on those lands that can only be restored through site preparation or type conversion. For most of the area considered in the study it is believed that these costs were fairly representative as of 1970 .

\section{Values of Increased Harvests}

In addition to the estimates of increased yields possible with intensified management practices and estimated costs of such measures, estimates were developed of the values of increased softwood timber output at 1970 prices, as follows:

$\begin{array}{cc}\text { Tree diameter } & \text { Cents per cubic foot } \\ 6 & 7 \\ 8 & 11 \\ 10 & 12 \\ 14 & 15 \\ 18 & 18\end{array}$

TABLE 89.-Estimated average costs of forestry practices in the Southeast, 1970

\begin{tabular}{|c|c|}
\hline Practice or item & Cost \\
\hline $\begin{array}{l}\text { Establishment of pine plantation on cutover lands: } \\
\text { Site preparation } \\
\text { Pine seedlings } \\
\text { Insecticide treatment of seedlings for } \\
\text { protection against weevils. }\end{array}$ & $\begin{array}{r}\text { Dollars } \\
28.25 \\
5.25\end{array}$ \\
\hline $\begin{array}{l}\text { Planting } \\
\text { Total average establishment cost } \text { per acre.- }\end{array}$ & \\
\hline 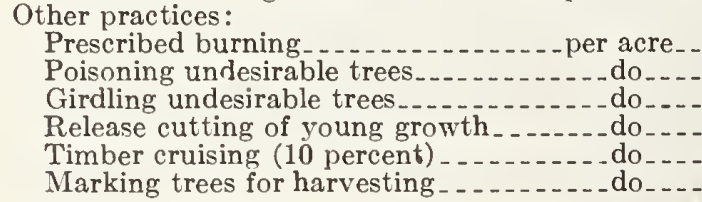 & $\begin{array}{r}2.05 \\
11.30 \\
9.65 \\
15.50 \\
.90 \\
3.60\end{array}$ \\
\hline
\end{tabular}

\section{Areas Suitable for Treatment}

On farm and miscellaneous private ownerships investment opportunities were identified on some 14.5 million acres. Although amounting to only 20 percent of all forest lands in this ownership category, this estimate may overstate the area on which landowners would be both able and willing to intensify management. There are over 700 thousand private farm and miscellaneous private landowners who collectively own over 70 percent of the land included in this study. For the most part these lands are in small tracts. Tenure is generally short in comparison with the period required for forestry investments to pay out. Lands are owned for a variety of reasons, and responses to forestry programs have been limited.

For such reasons adjustments of "available" areas were made in the national study reported earlier to allow for landowners' indifference to investment opportunities. It is likely that new approaches will have to be devised, and substantial financial incentives made available, before intensified management can be expected on all of the acreage where more intensive forestry practices would yield significant returns.

On forest industry lands in the Southeast, the backlog of poorly stocked stands for conversion, regeneration, or intermediate cutting is much smaller than for farm and miscellaneous private lands. Nevertheless, more than 6 million acres of industrial lands were in these categories in 1970 (table 87). One might assume that management on industrial holdings will be further intensified over time in view of the major progress made to date, but economic considerations may well prevent realization of all investment opportunities.

National Forests and other publicly owned lands are of much smaller importance in the Southeast and areas suitable for intensification are correspondingly limited. Also, the primary objective of management of these lands is not to maxi- 
mize rolumes of timber or timber-growing profits but rather to produce a variety of outputs under multiple-use management. On other public lands in military installations or in local gorernment holdings, some intensire timber management is found but a dirersity of land management objectives limits efforts to accelerate timber culture. In this initial study public lands as well as industry lands were excluded from detailed analysis.

\section{Rates of Return on Investments}

Rates of return from specified practices were calculated in turn from data on costs, yields, and values. A listing of treatment opportunities ranked in order of rates of return is presented in table 90 for farm and miscellaneous private lands in the Southeast.

Results of this study indicated that of the 8 million acres of land in farm and miscellaneous holdings classified as having intermediate cutting opportunities and the 19.6 million acres where regeneration is needed to increase productivity, investments in intensified management would return more than 5.0 percent on some 8.1 million acres suitable for growing pine. With a 4 -percent minimum rate of return, an estimated 14.5 million acres would be suitable for intensification.

Short rotations of 30 years were assumed in this analysis in calculating yields and rates of return. Increases in mean annual increment of pine resulting from added forestry inrestments and 30 -year rotations were estimated at about 1.3 billion cubic feet, including 1.6 billion board feet of sawtimber (table 90). The cost of such a program at 1970 price levels was estimated at $\$ 724$ million, or an arerage of about $\$ 50$ per acre.

If such a program were spread over a 10-year period it would involve more than a doubling of the 1970 rate of timber cultural practices within the farm and miscellaneous private ownership class. The higher the goal the more likely that available labor, equipment, planting stock, or number of cooperating landowners would become limiting factors. Implementation of any major program for this owner category also would undoubtedly require some form of cost-sharing arrangement or other incentives to help motivate the landowners involved.

Because timing of yields is of critical importance, potential increases in softwood timber harvests from the farm and miscellaneous private class are shown in table 91 by the decade when such increased cuts are estimated to occur. These projections indicate very limited opportunity for increasing cuts during the first decade or two. In the third decade increases in yield are estimated at 1.3 billion cubic feet, including 1.6 billion board feet of sawtimber. This would represent an increase of 48 percent above the projection of available sof twood harvests under 1970 levels of management shown in table 85 .

It is apparent from this analysis that identifying opportunities for increasing prospective timber supplies requires a wide range of input data that involves most forestry disciplines. Essential inputs include a reasonably accurate measure of the

TABLE 90.-Areas, costs, and increased yields from intensified management on farm and miscellaneous private lands in the Southeast, by estimated rate of return on investments

\begin{tabular}{|c|c|c|c|c|c|c|c|}
\hline \multirow{2}{*}{ Management class } & \multirow{2}{*}{ Treatment } & \multirow{2}{*}{$\begin{array}{l}\text { Rate } \\
\text { return }\end{array}$} & \multicolumn{2}{|c|}{ Area } & \multirow{2}{*}{$\begin{array}{l}\text { Cumu- } \\
\text { lative } \\
\text { cost } \\
\text { totals }\end{array}$} & \multicolumn{2}{|c|}{$\begin{array}{l}\text { Cumulative incre ase in } \\
\text { annual volume of pine } \\
\text { harvests }\end{array}$} \\
\hline & & & $\begin{array}{l}\mathrm{By} \\
\text { class }\end{array}$ & $\begin{array}{l}\text { Cumu- } \\
\text { lative }\end{array}$ & & $\begin{array}{l}\text { Growing } \\
\text { stock }\end{array}$ & Sawtimber \\
\hline 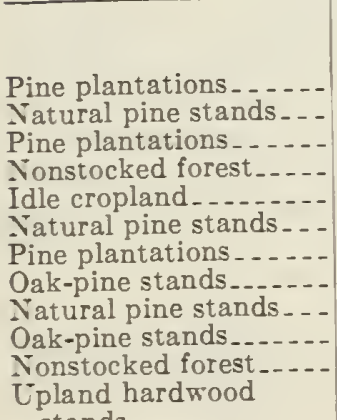 & 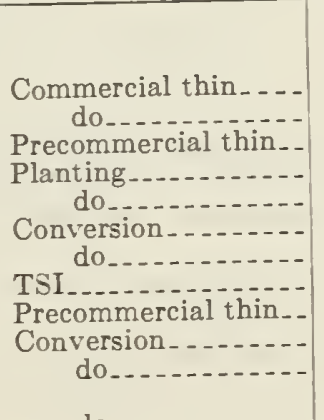 & $\begin{array}{r}\text { Percent } \\
\infty \\
\infty \\
7.8 \\
7.8 \\
7.3 \\
7.1 \\
6.9 \\
6.7 \\
6.3 \\
6.3 \\
5.7\end{array}$ & $\begin{array}{r}\text { Thousand } \\
\text { acres } \\
27 \\
429 \\
37 \\
127 \\
1,471 \\
2,205 \\
205 \\
139 \\
136 \\
3,112 \\
261\end{array}$ & $\begin{array}{r}\text { Thousand } \\
\text { acres } \\
27 \\
456 \\
493 \\
620 \\
2,091 \\
4,297 \\
4,501 \\
4,640 \\
4,776 \\
7,887 \\
8,148\end{array}$ & $\begin{array}{r}\text { Million } \\
\text { dollars } \\
0.2 \\
4.6 \\
5.0 \\
8.4 \\
39.6 \\
153.4 \\
158.8 \\
161.7 \\
164.9 \\
334.8 \\
348.2\end{array}$ & $\begin{array}{rr}\text { Million } & \\
\text { cu.ft. } & 1 \\
& 20 \\
21 \\
32 \\
141 \\
323 \\
340 \\
345 \\
349 \\
655 \\
681\end{array}$ & $\begin{array}{l}\text { Million } \\
\text { bd. ft. } \\
\\
\\
\quad 53 \\
56 \\
72 \\
252 \\
252 \\
469 \\
476 \\
483 \\
497 \\
768 \\
801\end{array}$ \\
\hline $\begin{array}{l}\text { stands } \\
\text { Oak-pine stands }\end{array}$ & $\begin{array}{r}\text { do } \\
\text { Commercial thin }\end{array}$ & $\begin{array}{c}4.0 \\
\text { Negative }\end{array}$ & $\begin{array}{r}6,305 \\
178\end{array}$ & $\begin{array}{l}14,453 \\
14,631\end{array}$ & $\begin{array}{l}\text { 723. } 9 \\
\text { 727. } 2\end{array}$ & $\begin{array}{l}1,319 \\
1,320\end{array}$ & $\begin{array}{l}1,552 \\
1,564\end{array}$ \\
\hline
\end{tabular}

1 Within each management class rates of return vary above or below these averages, depending on local factors influencing costs or yields. 
'ГABLE 91.-Projected softwood timber supplies from farm and miscellaneous private ownerships in the Southeast, with different levels of management

\section{'TOTAL GROWING STOCK (MILLION CUBIC FEET)}

\begin{tabular}{c|r|r|r|r}
\hline & & \multicolumn{3}{|c}{$\begin{array}{c}\text { Projected annual } \\
\text { removals }\end{array}$} \\
$\begin{array}{c}\text { Level of } \\
\text { management }\end{array}$ & 1970 & $\begin{array}{c}\text { First } \\
\text { decade }\end{array}$ & $\begin{array}{c}\text { Second } \\
\text { decade }\end{array}$ & $\begin{array}{c}\text { Third } \\
\text { decade }\end{array}$ \\
\cline { 3 - 5 } 1970 level _..... & 1,348 & 1,513 & 1,721 & 1,866 \\
Intensified 1.... & 1,348 & 1,533 & 1,751 & 3,185 \\
\hline
\end{tabular}

SAWTIMBER (MILLION BOARD FEET)

\begin{tabular}{|c|c|c|c|c|}
\hline $\begin{array}{l}1970 \text { level } \\
\text { Intensified } 1 \text { - }\end{array}$ & $\begin{array}{l}4,262 \\
4,262\end{array}$ & $\begin{array}{l}4,847 \\
4,899\end{array}$ & $\begin{array}{l}5,464 \\
5,540\end{array}$ & $\begin{array}{l}5,974 \\
7,526\end{array}$ \\
\hline
\end{tabular}

1 Includes treatment of an additional 14.5 million acres over the next 10 years where the treatment opportunities promise a 4.0 percent or better rate of return on the investments. Annual costs of treating these additional acres are estimated to total $\$ 72.4$ million.

extent, condition, and productive capability of the land, together with prospective yields of timber and related forest values-under both current and intensified management. Procedures must provide for development of criteria for identifying and ranking opportunities for increasing yields, including specific treatment opportunities, estimated costs of implementing treatments and the likely response in terms of added volume and value.

Although the procedures as presented herein suggest a ranking of opportunities on the basis of economic efficiency, policy makers also may need to interject social, environmental, or other considerations in developing management and utilization programs.

\section{AN EXAMPLE OF POTENTIALS FOR INTEN. SIFIED FOREST MANAGEMENT IN THE NORTHEAST REGION}

Approximately 28 percent of the commercial timberland in the Northeast is in the oak-hickory type, and 23 percent in the maple-beech-birch type. Because of the substantial acreage covered by these two hardwood types, 42 million acres, they were selected for detailed evaluation of intensified management. This does not imply, however, that other forest types in the Northeast present no opportunities for intensified management. Farm and miscellaneous private owners hold about 85 percent of the oak-hickory type and over 70 percent of the maple-beech-birch type.
Specific areas within the region where recent data were available were first selected for detailed analysis and case study results then extrapolated to the region. Opportunities in the oak-hickory type were analyzed in southeastern Ohio. The maple-beech-birch type was studied in Maine. Evaluation procedures are outlined below in some detail for the oak-hickory case. The same general approach was used in the maple-beech-birch case study.

\section{Designation of Management Classes}

Since the 2.3 million acres of oak-hickory type in southeastern Ohio contain a broad continuum of stand conditions, the area was first divided into relatively homogenous cells, based upon a classification of 680 Forest Survey plots measured in 1968. Each plot was placed in a matrix according to six basal area classes, three tree stocking levels, two average diameter classes, and five site productivity classes. Based upon this classification, 77 distinct "management classes" were identified.

Individual management classes entailing less than 15 thousand acres were excluded from further analysis because of large sampling errors. Management classes of site productivity below 50 cubic feet per acre per year of potential grow th also were dropped because of low potential returns. These exclusions left 36 management classes for detailed study, aggrega ting approximately 1.8 million acres.

Stand profiles.-As a basis for in-depth evaluation of intensified treatments, more detailed stand profiles than used for management class identification were then developed for the 36 management classes retained for study. Information was compiled on numbers of trees per acre by species group, tree quality and diameter class, using Forest Survey plot records.

Stocking classes.-The 36 management classes were all classified into one of three stocking classes specified in a "1972 Timber Management Guide for Upland Central Hardwoods." 6

Stocking classes in each management class were based on stocking of "acceptable" trees according to the formula: where

$$
S=-0.00507 N+0.01698 \sum D+0.00317 \sum D^{2}
$$

$S=$ level of stocking with acceptable trees

$N=$ number of acceptable trees

$D=$ diameter acceptable trees.

Management strategies. - Strategies for stands in each of the 36 management classes were based

6 USDA Forest Service, Central States Forest Experiment Station and North Central Region. 1972 Timber management guide for upland central hardwoods. $33 \mathrm{p}$. 1972 . 
upon the objective of growing the most highquality sawtimber the site could produce in the shortest reasonable time. Giren this objective two broad treatment regimes were assigned to 23 of the 36 management classes, based upon the acceptable tree stocking lerels.

Nine of these 23 management classes had insufficient stocking levels to fully utilize their sites for several rears to come. The intensified management regimes prescribed for these areas entailed an immediate regeneration harrest, stand reestablishment to oak-hickory, stand cleaning at an early age, periodic thinning to promote rapid sawtimber growth, and final harrest. About 24 percent of the 1.8 million acres analyzed in the case studr area, or 424 thousand acres, fell into this stocking class and treatment regime.

Fourteen management classes had excess stocking. The intensified management regime specified for these stands entailed an improrement cut to get stocking down to a desirable level, followed by periodic thinnings and final harrest. These classes contained 46 percent of the 1.S million study acres, or $\$ 27$ thousand acres.

Thirteen management classes were judged to hare sufficient stocking of acceptable trees for the next 10 years, and were not assigned an intensified management regime. These covered 31 percent of the study group, or 551 thousand acres.

\section{Projecting Stand Development}

Increased yields from intensification of management were estimated by simulating stand derelopmeat under both current and intensified management, using growth models dereloped br Timber Management Research. Projected growth and harrests under intensified management were estimated by applying the prescriptions described abore. Projected harrests under current management were estimated by applying 1970 removal rates by diameter class to the inventory in Ohio and holding this constant over the projection period (table 92). These were average remoral rates and did not provide for specific treatment schedules as in the intensified regimes, but are beliered to proride a good proxy for results of current management.

Arerage diameters were employed as measures of stand maturity in the analysis of intensified management. These varied according to site class (potential cubic feet per acre per year) as follows:

$\begin{array}{cc}\text { Sile class } & \begin{array}{c}\text { Average diameler at maturity } \\ \text { (inches) }\end{array} \\ 50-59 & 12 \\ 60-69 & 15 \\ 70-79 & 18 \\ 80 \text { plus } & 21\end{array}$

In the simulation of stand development residual stands of trees were left after thinnings in both management regimes. The current management
TABLE 92.-Projected inventories, growth, and removals with continuation of 1970 management and cutting practices in oak-hickory stands of the Northeast, and values at alternative price levels

\begin{tabular}{|c|c|c|c|c|}
\hline \multirow{2}{*}{ Decade } & \multirow{2}{*}{$\begin{array}{l}\text { Inventory } \\
\text { at be- } \\
\text { ginning } \\
\text { of decade }\end{array}$} & \multirow{2}{*}{$\begin{array}{l}\text { Decadal } \\
\text { growth }\end{array}$} & \multicolumn{2}{|c|}{ Decadal removals } \\
\hline & & & Volume & Value \\
\hline & Million cords & $\begin{array}{l}\text { Million } \\
\text { cords }\end{array}$ & $\begin{array}{l}\text { Million } \\
\text { cords }\end{array}$ & $\begin{array}{l}\text { Million } \\
\text { dollars }\end{array}$ \\
\hline 1st....... & $4 \$ 1.0$ & 159. 2 & 109.6 & $\begin{array}{l}11007 \\
21856\end{array}$ \\
\hline $2 \mathrm{~d}_{\ldots} \ldots \ldots$ & 530.6 & 208. 9 & 109. 6 & 11007 \\
\hline $3 d \ldots \ldots$ & 629.9 & 190. 9 & 109. 6 & $\begin{array}{l}11007 \\
21856\end{array}$ \\
\hline 4 th $\ldots . . .-$ & 711.2 & 227.6 & 109.6 & $\begin{array}{l}11007 \\
21856\end{array}$ \\
\hline 5̆th & 829. 2 & 115.9 & 109. 6 & $\begin{array}{l}11007 \\
21 \times 56\end{array}$ \\
\hline 6 th $\ldots .$. & 835. 5̃ & & & \\
\hline
\end{tabular}

1 With 1970 prices and costs.

2 With a $30 \%$ increase in prices of lumber and allocation of $75 \%$ of the increase to st umpage, a $\$ 5$ per cord increase in prices of pulpwood stumpage, and 1970 management costs.

regime left stands with more small diameter trees than in the case of intensified management.

Treatment costs. - Estimated costs of intensified management included costs of remoring nonmerchantable trees in regeneration cuts, improrement cuts, and precommercial cleanings. Any cut producing less than 5 cords per acre was assumed to be unmerchantable.

Costs for removing trees in stand conversions and cost of improvement cuts were based upon an equation using numbers and diameter of trees removed, along with other input costs. Costs of stand conversion ranged from $\$ 10-\$ 20$ and averaged about $\$ 15$ per acre. Costs of improvement cutting ranged from \$14-\$28 and areraged about $\$ 19$ per acre. Costs of precommercial cleanings areraged $\$ 21.50$ per acre.

Stumpage values.-Values of timber harrested in future thinnings and final harvest cuts were calculated by a conversicn surplus procedure similar to that employed on National Forests in timber appraisals. The saw-log portions of growing stock trees were ralued by diameter class based on the price of $4 / 4$ lumber that could be produced, minus all costs necessary to convert stumpage to lumber. These timber values were adjusted to account for variations in lumber quality and costs resulting from differences in species mix, site productivity, and management intensity. Timber sale price differences have been demonstrated to be associated with such stand characteristics:"

7 See, for example: Anderson, Walter C. Pine sawtimber price behavior in South Carolina. USDA Forest Serv., Res. Pap. SO-42, 12 p. 1969. 
Saw-log values in the oak-hickory study ranged from $\$ 6$ to $\$ 160$ per thousand board feet. Typical examples of how prices varied by diameter, stocking class, and site index are as follows:

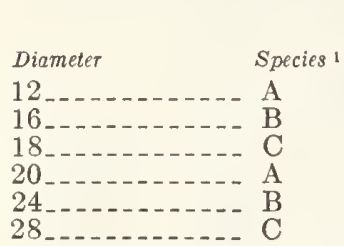

Site index
55
65
75
$80+$
55
65

Dollars per
thousand
board feet
15
27
35
95
74
92

$1 \mathrm{~A}=$ Yellow-poplar and black walnut $\mathrm{B}=$ Red oak and ash

$\mathrm{C}=$ Other specles.

An alternative value assumption was also employed in evaluating the economic feasibility of intensified management. Cordwood prices were raised $\$ 5.00$ per cord and saw-log prices were raised 75 percent. 'This adjustment roughly corresponded to a 30 -percent increase in final product prices.

Increases in timber values from management intensification included both the value of increased intermediate thinnings and increased values of residual stands at the end of 50 years. The total increases in value were compared with costs of intensified management in evaluating the economic potentials for intensification.

Economic evaluation of intensification.-The economic feasibility of undertaking intensified management was evaluated using present net worth and benefit/cost calculations, both of which gave the same results. Benefits and cost schedules over time were discounted at 5 percent. Any opportunity which had a positive present net worth thus had an internal rate of return in excess of 5 percent and a benefit/cost ratio in excess of 1.0. The 5 percent rate provides comparability between this and other case studies. This is not implied that 5 percent is necessarily the most appropriate selection-rejection level.

Opportunities with 1970 stumpage prices.-Under the 1970 price assumption, investments in 9 of the 23 management classes for intensified management would return over 5 percent. Six of these entailed treatments starting with immediate stand replacement. Three involved initial improvement cutting to change stand composition.

The increase in present net worth per acre due to intensification averaged $\$ 34.14$ for the regeneration treatment on 219,000 acres in the pilot area, at an average cost of $\$ 27.32$ per acre. For the stand improvement opportunities, the average increase in present net worth was $\$ 12.56$ on 168,000 acres. The average cost was $\$ 17.22$ per acre.

Opportunities with the higher price assumption.Use of higher price levels resulted in the addition of only two management classes, both entailing regeneration treatments. Use of the higher price levels raised the acreage economically treatable in the pilot area by 37 percent, or 145 thousand acres.

Present net worth per acre was more sensitive to price changes. With the higher price assumption, present net worth for regeneration treatments

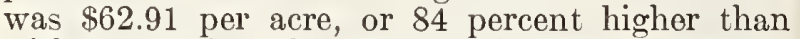
with 1970 prices. The average increase in present net worth from stand improvement treatment was $\$ 31.84$ per acre, or 153 percent higher than with 1970 prices.

\section{Regional Expansion of the Oak-Hickory Pilot Study}

The results of the southeastern Ohio case study were expanded to the Northeast region by the ratio between the oak-hickory acreage in the pilot area (2.3 million acres) and the oakhickory acreage in the region (35.3 million acres). Such extrapolations must be used with caution, however, because they assume costs, prices, yield increases, and other factors applying in the pilot areas are also applicable regionwide. They also assume that the region contains the same proportions of area in the various "management classes" found in the pilot area. It is believed, however, that they provide a reasonable initial indication of management opportunities.

Opportunities with 1970 stumpage prices.Accomplishment of intensified management in oak-hickory types in the Northeast, including opportunities that return 5 percent or more at 1970 prices, would cover roughly 6.0 million acres at a cost of $\$ 165$ million, or $\$ 27.40$ per acre (table 93). This intensification would lower timber inventories at the beginning of the sixth decade by 36 million cords, or 4 percent, below the inventory expected with current management as shown in table 92 . The stumpage value of this residual inventory would be increased a substantial 34 percent through management intensification by concentrating growth on larger and higher quality trees of desirable species.

Projected decadal growth with intensified management fluctuates about the current growth level. In the fourth decade projected growth is 27 percent lower than with current management, but in the fifth decade is 40 percent higher.

Increases in timber removals over the five decade period due to intensification total 56.3 million cords, or 10 percent more than expected with current management. Just as with inventory estimates, however, a greater impact registers in the value of removals, which would be $\$ 991$ million, or 20 percent higher under intensified management. Physical volumes are increased by intensification but an even greater effect arises from harvesting of larger and higher quality trees.

Opportunities with higher stumpage price assumptions.- Similar results occur when opportunities are undertaken which return 5 percent under the assumed higher price levels. Intensified 
TABLE 93.-Net changes in inventories, growth, and removals with intensified management of oak-hickory stands in the Northeast (1970 product prices) ${ }^{1}$

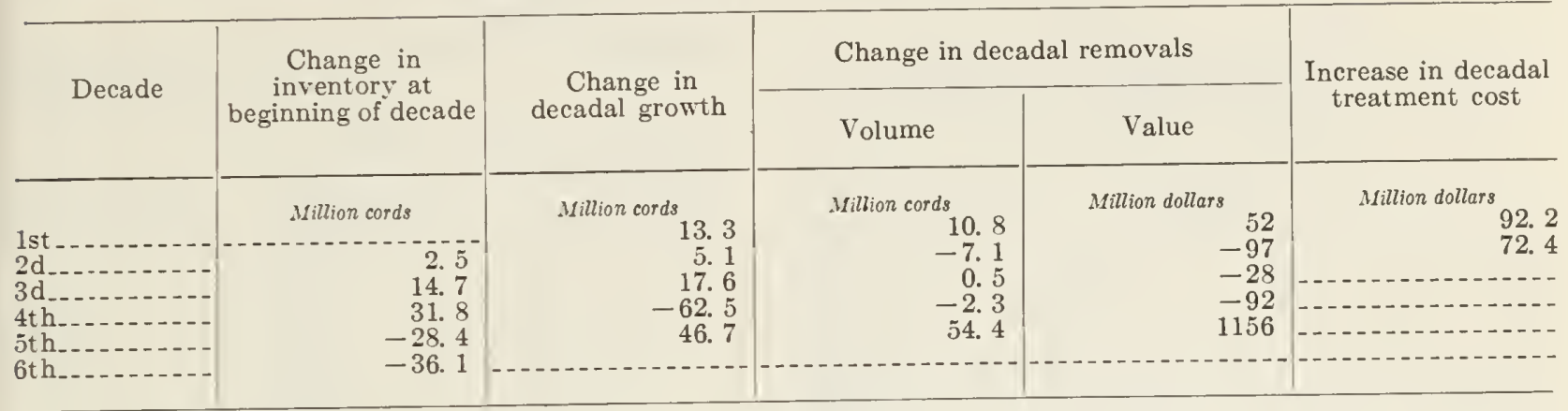

1 Including 9 intensified management opportunities on 6.0 million acres that would return more than 5 percent on investments in intensified management.

treatment would be economic on 8.8 million acres, at a cost of $\$ 258$ million, or $\$ 29$ per acre (table 94 ). Inventory volumes at the beginning of the sixth decade would be reduced below the current management level by 29 million cords, or slightly less than the reduction under the 1970 price assumption. The value of the inventory, however, would be 40 percent greater. Growth under intensified management would be slightly higher, 7.3 percent, than with current management.

The total increase in available removals with intensified management would be 95 million cords orer five decades, or a 17 percent increase. The ralue of remorals would exceed values with current management by $\$ 2110$ million, or 23 percent. This would be slightly more than the 20 percent increase in values with intensified management under the 1970 price assumptions.

\section{Maple-Beech-Birch Pilot Study}

The procedural steps inrolved in the Maine pilot study of maple-beech-birch were essentially the same as those for the oak-hickory case. Selection of management classes for economic evaluation
Was based upon a comparison of current conditions with a desirable stocking guide. This led to identification of four opportunities covering 957 thousand acres, or 27 percent of the maple-beechbirch type in Maine. The site index was above 55 for all four situations; the average diameter of all four situations was from 3 to 5 inches. Basal areas fell into two classes, 80-99 and 100-119 square feet. Percentage stocking of yellow birch was identified as either above or below 10 percent.

The intensified management strategy for all classes included an immediate stand improvement cut, subsequent thinnings, and final harvest $80-87$ years from initial treatment. All four opportunities would return over 5 percent on treatment costs under both price assumptions. The average increase in present net worth per acre due to intensification was estimated at $\$ 54$ at 1970 prices, and $\$ 110$ at the higher price level.

Results from the Maine pilot area were expanded to the entire Northeast region on the basis of the maple-beech-birch acreages in the two areas. Estimated impacts on regional inventories, net growth, and removals were very similar to

TABLE 94.-Net changes in inventories, growth, and removals with intensified management of oak-hickory stands in the Northeast (1970 prices plus 30 percent $)^{12}$

\begin{tabular}{|c|c|c|c|c|c|}
\hline \multirow{2}{*}{ Decade } & \multirow{2}{*}{$\begin{array}{c}\text { Change in } \\
\text { inventory at } \\
\text { beginning of decade }\end{array}$} & \multirow{2}{*}{$\begin{array}{l}\text { Change in } \\
\text { decadal growth }\end{array}$} & \multicolumn{2}{|c|}{ Change in decadal removals } & \multirow{2}{*}{$\begin{array}{l}\text { Increase in decadal } \\
\text { treatment cost }\end{array}$} \\
\hline & & & Volume & Value & \\
\hline $\begin{array}{l}1 \text { st } \ldots \ldots \\
2 \mathrm{~d} \\
3 \mathrm{~d} \\
4 \mathrm{th} \\
5 \text { th } \\
6 \text { th. }\end{array}$ & $\begin{array}{r}\text { Million cords } \\
-10.4 \\
13.4 \\
44.4 \\
-25.0 \\
-29.1\end{array}$ & $\begin{array}{r}\text { Million cords } 7 \\
17.1 \\
35.0 \\
-49.6 \\
59.7\end{array}$ & $\begin{array}{r}\text { Million cords } \\
14.1 \\
-6.7 \\
4.0 \\
19.8 \\
63.8\end{array}$ & $\begin{array}{r}\text { Million dollars } \\
66 \\
-177 \\
-25 \\
141 \\
2,110\end{array}$ & $\begin{array}{r}\text { Million dollars } \\
138.2 \\
120.2 \\
\hdashline\end{array}$ \\
\hline
\end{tabular}

1 Including 12 intensified management opportunities on 8.8 million acres that would return more than 5 percent on investments in intensified management.
2 Sawtimber prices raised 75 percent of a 30 percent increase in lumber prices; and pulpwood prices raised $\$ 5$ per cord over 1970 levels. 
TABLE 95.-Net change in inventories, growth, and removals with intensified management of maple-beech stands in the Northeast $\left(1970\right.$ prices) ${ }^{1}$

\begin{tabular}{|c|c|c|c|c|c|}
\hline \multirow{2}{*}{ Decade } & \multirow{2}{*}{$\begin{array}{c}\text { Change in } \\
\text { inventory at } \\
\text { beginning of decade }\end{array}$} & \multirow{2}{*}{$\begin{array}{c}\text { Change in } \\
\text { decadal growth }\end{array}$} & \multicolumn{2}{|c|}{ Change in decadal removals } & \multirow{2}{*}{$\begin{array}{l}\text { Increase in decadal } \\
\text { treatment cost }\end{array}$} \\
\hline & & & Volume & Value & \\
\hline 1st_. & Million cords & $\begin{array}{r}\text { Million cords } \\
18.0\end{array}$ & $\begin{array}{r}\text { Million cords } \\
50.4\end{array}$ & $\begin{array}{l}\text { Million dollars } \\
2 \\
123\end{array}$ & Million dollars 74.8 \\
\hline $2 \mathrm{~d}_{--}$ & -32.4 & 22. 1 & -16.3 & $\begin{array}{r}{ }^{3} 231 \\
-237\end{array}$ & \\
\hline $3 d_{\ldots} \ldots$ & 6. 0 & 25.0 & 50.2 & $\begin{array}{r}-421 \\
790\end{array}$ & 46. 1 \\
\hline 4 th...... & -18.2 & 25. 7 & -16.3 & $\begin{array}{l}1,414 \\
-237\end{array}$ & \\
\hline 5 th... & 22.8 & 13. 6 & 28. 6 & $\begin{array}{r}-421 \\
969\end{array}$ & \\
\hline 6th_. & 7.8 & & & 1,724 & \\
\hline
\end{tabular}

1 Includes 4 intensified management opportunities on 5.7 million acres.

2 With 1970 prices and costs.

${ }^{3}$ With a 30 percent increase in the base price of lumber

those resulting from management intensification in oak-hickory stands.

An estimated 5.7 million acres of maple-beechbirch in the region were identified as economically suitable for stand improvement treatments at an a verage cost of $\$ 21.20$ per acre (table 95 ). With intensification, inventories at the beginning of the sixth decade would be almost $\&$ million cords greater than with current management, and values of the residual inventory would be $\$ 1.7$ billion more than with current management. Growth would be over 100 million cords greater with intensified management than with current management. Estimated increases in removals with intensified management total 96.6 million cords over five decades, valued at $\$ 1.4$ billion at 1970 prices.

\section{AN EXAMPLE OF POTENTIALS FOR INTENSI- FIED FOREST MANAGEMENT IN THE NORTH CENTRAL REGION}

Detailed per acre evaluation of intensified management opportunities were undertaken for three pilot areas: northeastern Wisconsin, southern Indiana and Illinois, and southein Missouri. These areas contain forest situations believed typical of the predominantly hardwood forests of this region. The case study areas collectively covered 11 million acres, or 12 percent of the total area of 96 million acres of commercial timberland in the region.

Estimates of opportunities for intensified forest management presented below indicate that with a 5 percent rate of return criterion, and 1970 price levels plus 30 percent, about 6.2 million acres in the region would be economically suitable for and allocation of 75 percent of the increase to stumpage, a $\$ 5$ per cord increase in prices of pulpwood stumpage, and 1970 management costs.

intensified silvicultural treatment. Increased harvests resulting from intensified management of these acres would total about 13.9 billion board feet of sawtimber, including 12.3 billion board feet of softwood, plus 4.4 billion cubic feet of pulpwood, over the next 50 years.

\section{Selection of Areas for Analysis of Treatments}

Inclusion of individual areas for detailed evaluation of potentials for intensification was based primarily upon current stocking, current species dominance, suitability for planting alternative species, site class, and size of area in the opportunity class.

Based upon these screening factors, a number of possible situations were excluded from analysis. Thus options on low sites were not considered, e.g., planting red pine on nonstocked forest land on site classes less than 50. Commercial thinning of pine plantations was excluded because of the Jimited area involved. Similarly, maple-beechbirch stands which already had desirable stocking levels ${ }^{8}$ were excluded from this evaluation.

This screening process left for analysis areas where management intensification appeared likely to have major impacts upon timber supplies in the pilot areas and return more than 5 percent on treatment costs. These included:

(1) Situations having relatively high site productivity but poor or nonexistent stocking and apparently suitable for reforestation with sof twoods such as red pine and white pine. These included both areas of idle cropland indicated

\footnotetext{
${ }^{8}$ Arbogast, Carl, Jr. Marking guides for northern hardwoods under the selection system. USDA Forest Serv., Lake States Forest Exp. Sta., Sta. Pap. 56, 20 p., illus. St. Paul, Minn. 1957.
} 
by the USDA Conservation Needs Inventory and areas of nonstocked land in Wisconsin of site class 50 and better. These softrood planting situations all entailed a schedule of thinnings prior to final harvest.

(2) Situations in northern hardwood stands on productive sites where stand characteristics indicated farorable responses to cull tree remoral or improvement cutting, and a source of thinnings in poletimber and sawtimber stands. These were designed to adjust stocking to an "ideal" of 87 square feet per acre.

(3) Site preparation for natural regeneration of aspen in recently harrested stands.

\section{Yields, Prices, and Costs}

Yields of natural forests to be expected with current management, as in other regions, were assumed to be represented by Forest Survey plot information. Yield estimates for more intensirely managed stands were derived from Forest Surrey plot information and published rield tables, or in the case of hardwood treatments from a growth simulator. ${ }^{9}$ Documented yield information for both current and intensified management is scanty and had to be augmented by generous applications of judgment. No estimates were prepared regarding the net impact upon nontimber resources and uses.

Stumpage prices were derived from reports of recent timber sales adjusted to approximate 1970 price lerels. Estimates of National Forest stumpage prices were used for shortleaf pine.

A second set of stumpage prices employed in this analysis assumed timber product prices 30 percent above 1970 levels, with an estimated 75 percent of the increase in products prices assumed to go to stumpage. This roughly doubled most 1970 stumpage prices.

Estimated treatment costs were based largely on Forest Service contract experience ${ }^{10}$ and special local studies.

The estimates of yields, costs, and stumpage returns with current and intensified management of the selected situations were then evaluated to sort out those that promised to return more than 5 percent on increased investments, both at 1970 timber product prices and at 1970 prices plus 30 percent.

It is recognized that the forest situations selected for detailed study were not necessarily the only management intensification opportunities which would return 5 percent or more. Some may have been omitted in the screening process. Also, the input data used in this analysis are subject to considerable uncertainty.

Skog, K. E., and R. A. Leary. A computer simulator of northern hardwood forest stand growth and management.

10 Row, Clark. Silvicultural service contract cost study; FY 1970. USDA Forest Serv., Econ. and Mark. Res., Washington, D.C., preliminary report. August 8, 1971.

\section{Regional Estimates of Management Opportunities at 1970 Prices}

Once the eraluations of opportunities in the pilot areas were analyzed on a per-acre basis, results were generalized to the North Central Region on the basis of total estimated areas of each trpe of situation. This area expansion, although based on area stratifications such as shown in table 45 of Appendix I, involved considerable judgment. It was assumed that the yield, price, and cost estimates used in the analysis for pilot areas, and therefore present net worths at a 5 -percent discount rate, would apply across the entire region. These region wide extrapolations also assumed that all areas meeting the 5-percent criterion would be available for intensification, re rardless of tract size or owner objectives.

Plantations.-At 1970 prices and costs, about 160 thousand acres of softwood planting in the next decade would yield 5-percent or more return on planting and thinning investments (table 96). Estimated costs of intensified management were estimated at $\$ 7.3$ million, or $\$ 45.60$ per acre.

The softwood sawtimber harrest increases resulting from a 10-year program of accelerated planting would be minimal until the 4 th decade when projected increases in arailable harvests reach 5.3 million board feet annually. In the 8th decade a single 10-year program would produce estimated final harvest increases of 567 million board feet annually. This would proride a harvest double the 1970 level of softwood sawtimber output of 5.39 million board feet from all ownerships in the North Central Region.

Site preparation.-Investments in site preparation of aspen areas would return 5 percent on an estimated 654 thousand acres in the region at a cost of $\$ 3.4$ million, or $\$ 5.20$ per acre. The pulpwood harrest increase due to this treatment was estimated at 130 million cubic feet per year in the 5 th decade.

Stand improvement.-Improvement of northern hardwood stands would return 5 percent at 1970 prices on an estimated 701 thousand acres at a cost of $\$ 9.1$ million, or $\$ 13$ per acre. The net effect upon hardwood sawtimber output would be small until the 6th decade when projected increases in harrests arerage 344 million board feet annually. This would be an increase of approximately io percent above the 1970 regional output of hardwood roundwood of 3.28 billion board feet.

\section{Regional Estimates of Opportunities at Higher Prices}

Under the assumption that future stumpage prices would be about double the 1970 level, the estimate of areas that could be treated with a criterion of 5 percent return on investment rose sharply from 1.5 million to 6.3 million acres (table 97). Four additional softwood planting situations were addled, including planting nonstocked forest 


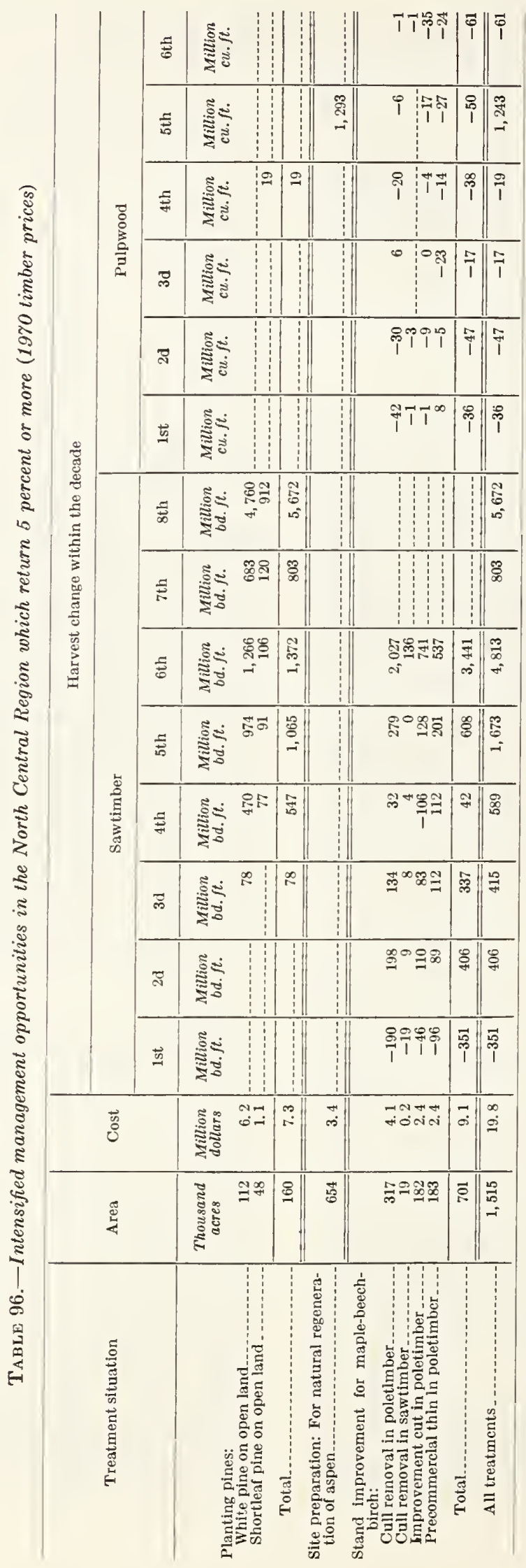




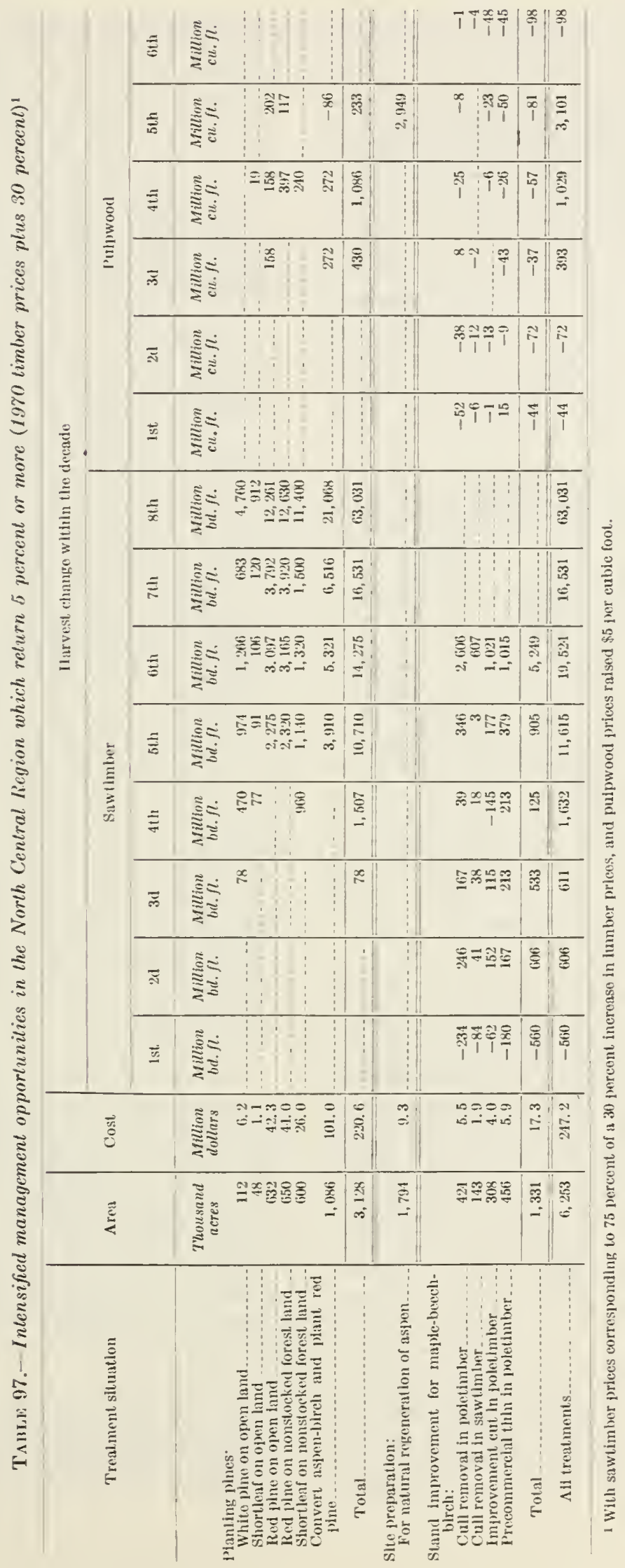


land and conversion of aspen-birch. Site preparation and stand improvement areas also were expanded.

Planting.-Softwood planting opportunities at the higher price level were estimated to cover nearly five times more area than with 1970 prices. Projected harrest increases due to intensification include over 1.0 billion board feet annually of softwood saw timber by the fifth decade, and 6.3 billion board feet annually during the eighth decade, plus additional volumes of pulpwood size material.

These estimated increases in softwood harvests over the next eight decades are 11 times greater with the higher price assumption than with 1970 prices. However, estimated costs of the larger program with the higher price assumption are 30 times greater than the program included with 1970 prices.

Site preparation.-Aspen site preparation was estimated to be feasible on almost three times more area than with 1970 prices. Projected harvest increases totaled about 300 million cubic feet per year in the fifth decade.

Marginal sites for such treatments as aspen site preparation proved to be sensitive to stumpage price and treatment cost assumptions. Thus an increase of a dollar a cord in aspen stumpage prices had the effect of nearly doubling treatable areas. On the other hand, a rise in treatment costs from about $\$ 5$ to $\$ 10$ per acre would largely eliminate aspen site preparation at 1970 prices and a 5-percent discount rate.

Stand improvement.-Estimates of increased harvests of hardwood sawtimber reach 525 million board feet annually by the sixth decade, or 56 percent above increases estimated to be economically possible with 1970 price levels.

\section{Limitations of Current Study}

Additional research will be necessary to refine these initial estimates of management opportunities and reduce uncertainties. Projected increases in timber harvests due to treatment were estimated from limited growth and yield data based upon individual plot studies rather than large-scale treatments. Although yields were reduced to allow for this, the reduction factor used (generally about 20 percent) was necessarily based on judgment. Prices and costs were available only from local sources and may not be applicable to all areas and ownerships in the region. Estimates of acres suitable for treatment also must be regarded as preliminary.

In addition, rates of adoption of economically feasible treatments by various owner classes are unknown, and all the acres economically suitable for treatment are not likely to be treated. In addition to problems of financing forestry improve- ments, treatments such as site preparation or elimination of rough and rotten trees in northern hardwood stands may conflict with other objectives such as wildlife management.

For this reason the estimates in this case study show considerably larger areas aconomically suitable for treatment than were included in the national study described earlier; in that analysis acreages were reduced for such factors as size and location of tracts, availability of forestry labor and facilities, and willingness of owners to respond to forestry assistance programs.

\section{AN EXAMPLE OF INTENSIFIED MANAGEMENT POTENTIALS IN WASHINGTON, OREGON, AND CALIFORNIA}

In this analysis economic potentials for intensified management were analyzed for public ownerships other than National Forests, for forest industry lands, and for other private lands in the States of Washington, Oregon, and California. These 3 classes of forest ownerships included some 35.1 million acres of commercial timberland in 1970 , including 8.1 million acres in other public ownerships, 12.2 million acres in forest industry holdings, and 14.8 million acres in other private holdings.

Timber harvests on these lands in 1970 amounted to 16.6 billion board feet, or 65 percent of the total sawtimber output on the Pacific Coast. The "base" projections of future timber harvests with 1970 levels of management, summarized in Chapter II, indicate a drop in prospective sawtimber harvests on these lands to 14.7 billion board feet by 1980 , and to 11.8 billion board feet by the year 2000. The estimates developed in this study indicate that with higher timber prices substantial increases in these harvests would be economically feasible.

\section{Area Classification}

Forest types considered in this analysis included: (1) Douglas-fir, western hemlock, and Sitka spruce in western Oregon and Washington and northwest California, (2) ponderosa pine in eastern Oregon and Washington and the interior of California, and (3) lodgepole pine in eastern Washington, Oregon, and California. It was not considered possible to make a reasonable analysis of opportunities for management intensification in other types because of absence of yield tables or limited acreages of conditions suitable for management intensification.

Westside conifer stands were first stratified in terms of site productivity classes, stand age, stocking, and numbers of trees per acre.

In order for westside conifer stands to be con- 
sidered suitable for treatment they had to meet certain requirements as follows:

\begin{tabular}{|c|c|c|c|}
\hline Treatment & Stand age & Stocking & $\begin{array}{c}\text { Trees } \\
\text { Defre }\end{array}$ \\
\hline $\begin{array}{l}\text { Commercial thin- } \\
\text { ning }\end{array}$ & $35-75$ & $\begin{array}{l}\text { More than } 70 \\
\text { percent }\end{array}$ & pet acte \\
\hline $\begin{array}{l}\text { Precommercial thin- } \\
\text { ning }\end{array}$ & $15-25$ & $\begin{array}{l}\text { More than } 30 \\
\text { percent }\end{array}$ & 450 \\
\hline
\end{tabular}

For ponderosa pine and lodgepole pine stands, the area classification shown in table 48 of Appendir I was eraluated on a judgment basis to determine areas most suitable for management.

\section{Mariagement Practices Considered}

For each of the areas selected as indicated above, management regimes were eraluated to determine practices and areas that would produce at least $\bar{j}$ percent return on investments in intensified management. These included:

1. Testside conifer stands

a. Commercial thinning of stands at ages 30 through 70

b. Precommercial thinning of 15-year-old stands, followed by commercial thinning

c. Fertilization and commercial thinning of stands of ages 30 through 70

d. Precommercial thinning of 15 -year-old stands, followed with fertilization and commercial thinning

e. Conrersion of hardwood stands to Douglas-fir

f. Planting of nonstocked areas following harrest

g. Planting of nonstocked areas with genetically superior stock following harrest

2. Ponderosa pine

a. Commercial thinnings of small samtimber stands

b. Precommercial thinnings of 15-year-old and stagnated stands, followed with commercial thinnings

3. Lodgepole pine

a. Precommercial thinning of 15-year-old stands and stagnated stands, followed with commercial thinnings.

In some cases current management was limited to protection from fire, insects, and disease. In other cases significant areas were already being treated according to these management prescriptions. These acres already being treated were subtracted in estimating areas arailable for management intensification.

\section{Yield Assumptions}

The yield estimates used in this analysis included data for expected harrests with 1970 levels of management, and increases in harrests possible with intensified management. 'These yield esti- mates were based upon arailable yield tables and judgments of timber managenient research specialists. Allowances were made for anticipated impacts of insects and diseases in both managed and unmanaged stands. Estimated yields of westside conifers also were reduced to reflect discontinuities in forest corer that exist within the commercial forest land area. This reduction was assumed to be 15 percent for all sites and areas.

Increases in future harvests were determined by subtracting per-acre vields with ongoing programs from per-acre rields with intensified management and multiplying the increase by the appropriate number of acres. For public owners it was also assumed that allowable cut procedures will result in scheduling harrests in approximate line with increases in growth. This allowable cut effect was used to portray harrest increases but was not considered in calculating rate of return. The harvest arailable from individual treated acres was used in rate of return calculations.

\section{Cost Assumptions}

Costs of intensified management as of 1970 were dericed from a number of public and private sources in the Pacific Northwest. Assumed per-acre costs averaged as follows:

a. Planting westside conifers following harrest $-\$ 35$

b. Precommercial thinning- $\$ 50$

c. Commercial thinning (netted out of price)

d. Fertilization- $\$ 22$

e. Site preparation for conversion of hardwood stands less than 45 years of age $-\$ 40$

\section{Price Assumptions}

Two price assumptions were used in eraluation of the increased yields obtainable with intensified management-one based on National Forest timber sales in 1970 , with the second assuming a steady rise to 2020 at a compound rate of 1.5 percent annually in product prices, with 75 percent of the increase going to stumpage. Data in terms of Scribner log scale, primarily for old-grow th timber, were converted to prices for second-growth timber in terms of International $1 / 4$-inch $\log$ rule. This resulted in the following prices:

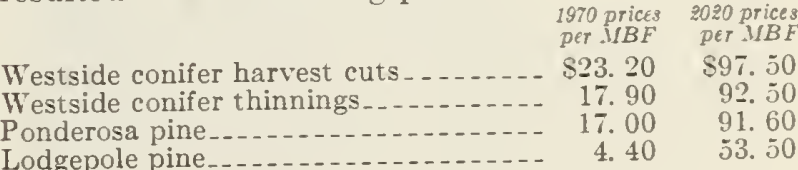

\section{Economic Analysis}

The estimates of yields, ralues, and costs dereloped for selected areas where management intensification appeared most promising were used in dereloping estimates of areas that would vield at least a 5-percent rate of return on marginal costs of intensification at both 1970 prices 
and the specified price increases. These calculations were on a "before taxes" basis. They were also made with consideration given to the timing of costs and yields for specific stands. Consequently, factors such as the need to sustain a given flow of timber harvest from an entire forest were not included.

\section{Intensification Potentials With 1970 Prices}

Under this price assumption the following practices promised to return more than 5 percent on increased expenditures for timber management in westside conifer areas. The acreages are for opportunities in addition to those assumed in the current trends of management:

a. Planting on high sites. This involved a total of 481,000 acres for the first decade.

b. Precommercial thinning followed by commercial thinning on medium and high sites, with short rotations of less than 50 years. This involved a total of 6,000 acres.

c. Commercial thinning in virtually all situations. This involved an estimated 166,000 acres.

d. Fertilization in stands to be thinned and given final harvest within 20 years. This involved an estimated 115,000 acres. (All but 23,000 of these acres are included in the 166,000 acres reported above in item c.)

e. Investments to develop and use genetically superior stock. This appeared justified only on high site lands managed under short rotations.

In eastside ponderosa pine stands commercial thinning of stands approximately 55 years old and having sufficient volume to support commercial operations also was found to be feasible. ${ }^{11}$ However, judgment of local foresters indicated that only about 5 percent of the stands in the eastside ponderosa pine region reach this condition naturally. This would represent about 183 thousand acres in the ponderosa pine region of Oregon, Washington, and interior California.

Increases in timber cut from intensified practices that passed the 5 percent "investment screen" with 1970 prices are shown in table 98. On the three classes of ownerships studied in this analysis for the Pacific Coast States, increases in harvests resulting from increased investments, assuming 1970 prices, averaged only about 1 percent for the first three decades, and 3 percent for the fourth and fifth decades. In decade six-beyond the projection period of this study-a jump in the harvest would occur as stands that were

1 See also: Sassaman, R. W., J. W. Barrett, and J. G. Smith. Economics of thinning stagnated ponderosa pine sapling stands in the pine-grass areas of central Washington. USDA Forest Serv. Res. Pap. PNW-144, 17p. 1972 . planted in decade one became available for harvest. However, the increased cut would drop off again unless a succession of management programs were continued.

This modest showing is a result of a combination of factors. With 1970 prices there were not many practices with substantial growth increases that passed the 5 percent screen. For those practices that did pass there were relatively few acres in appropriate age-stocking classes that were susceptible to treatment. And finally, the investments involved in 1970 levels of management, which had to be subtracted from a total program of intensification, already account for a significant portion of the feasible economic opportunitios.

\section{Management Potentials with Rising Prices}

With the higher prices for timber products specified earlier, additional practices that would pass a 5 percent investment screen in westside conifer stands included: (a) planting of all sites, with general use of genetic stock, except on low sites with long rotations (85 years) - a total of $1,287,000$ acres, and (b) conversion to softwoods of mature hardwood stands of more than 45 years of age on medium sites, and conversion of all hardwood stands on high sites $-1,384,000$ acres.

In eastside types (a) precommercial thinning of ponderosa pine on all sites, and (b) precommercial thinning of lodgepole pine on the higher sites also passed the 5 percent investment screen.

Even with the assumption of increasing prices, the potential rise in total timber harvests from the ownerships studied with intensification of the most promising management opportunities would still be modest, i.e., 3 to 4 percent during the first three decades. However, projected harvest increases in decades four and five reach 15 percent, and in decade six 40 percent more than anticipated with 1970 management levels. With a single 10-year program, increases in harvests after decade six would drop to a level roughly comparable to that achieved in the first three decades. The major part of the increase-70 percent-would come from forest industry lands and 78 percent would be in the Douglas-fir region (table 98).

The investment costs of planting and other measures indicated in this example of intensified management are estimated at $\$ 168$ million as shown in table 98 , an average of $\$ 50$ per acre.

It appears from this analysis that the only investment practices on these ownerships that would have a substantial impact on timber supplies in the Pacific Coast States within 50 years are planting of nonstocked areas and conversion of hardwoods to conifer stands on private lands where short rotations are assumed. These practices would be justified with a 5 percent cost of capital only with substantial price increases over 1970 levels. 
TABLE 9S.-Costs and responses to intensified forest management in Washington, Oregon, and California ${ }^{1}$

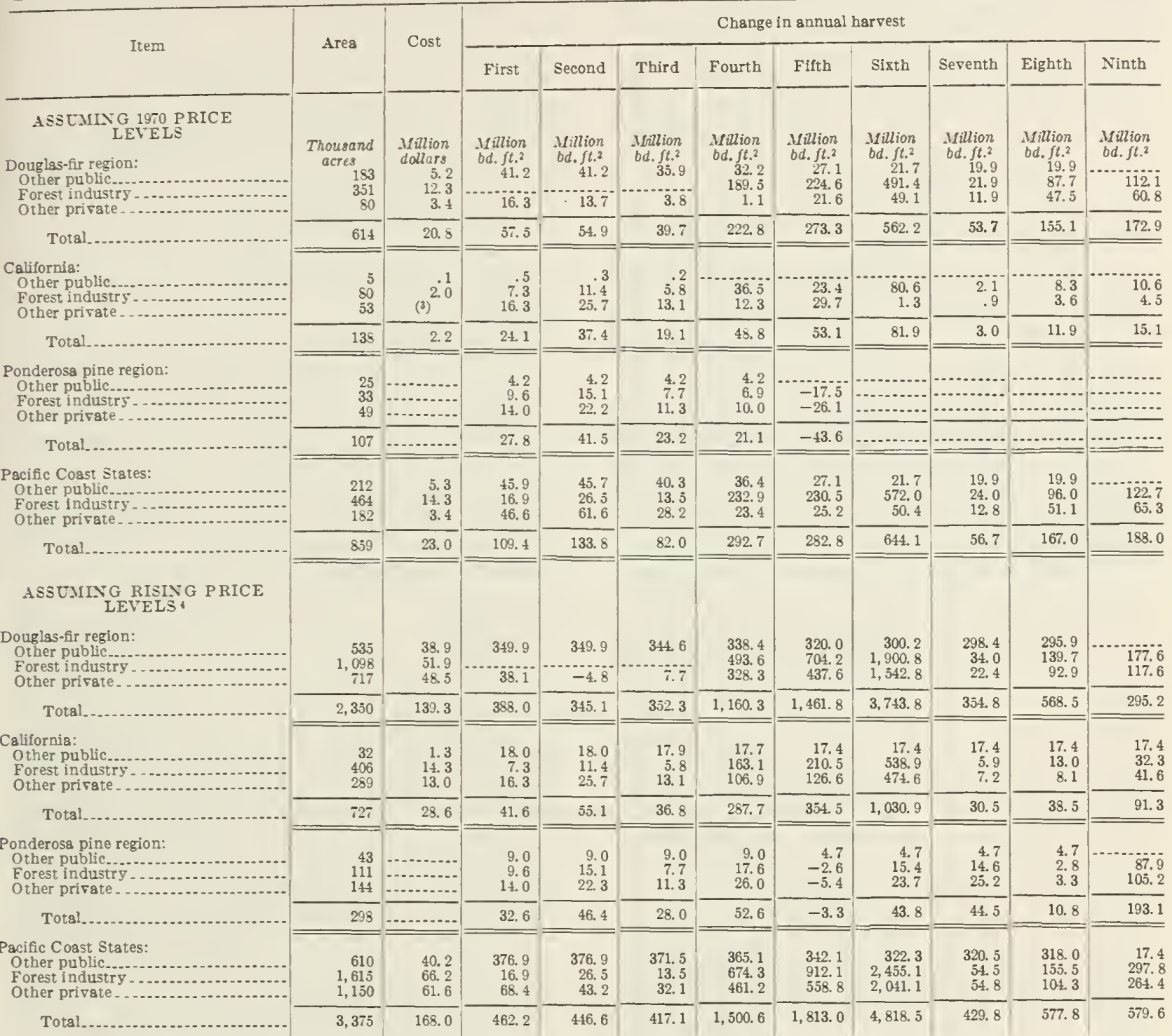

1 Includes intensified management opportunities returning $\mathbf{5}$ percent or more on forest Industry, farm and miscellaneous, and public lands other than National Forests.

\section{POTENTIAL INCREASES IN TIMBER SUPPLY FROM IMPROVED UTILIZATION}

In addition to increased timber output from cultural measures as illustrated abore, there appear to be substantial opportunities for extending timber supplies by improvements in timber utilization.

\section{Assumed Improvements in Utilization in Base Pro- jections}

As indicated in Chapters I and II, substantial progress has been made in improving utilization of
2 International $1 / 4$-inch rule.

Assumes stumpage prices rising 1.5 percent annually. timber on logging operations and in the processing of timber products. Nevertheless, in 1970-a rather poor year for the timber industries-nearly 1 billion cubic feet of plant residues was burned or discarded. On logging operations an additional 1.6 billion cubic feet of logging residues from growing stock, plus sizable volumes of limbs and other material from cull and dead trees, ras left in the woods unutilized. Residual rough and rotten trees passed by in logging also represented a major potential source of fiber. Unsalraged mortality of widely scattered trees lost to fire and other destructive agents totaled an estimated additional 4.2 billion cubic feet. 
With higher prices and strong markets in 1971-72, volumes of residues are estimated to have declined somewhat. Also, it has been estimated in Chapter V that prospective expansion of the pulp and particleboard industries will lead in a relatively few years to essentially complete utilization of coarse plant residues and much of the fine plant residues produced. It was also estimated in Chapter II that with rising timber prices much of the roundwood now left on logging operations would also be utilized in future years primarily for woodpulp. Salvage of dead timber for both solid wood and fiber products is also expected to increase with higher prices and expansion of forest road systems.

Similar technical progress also was assumed in converting projected product demands to roundwood requirements in Chapter $\mathrm{V}$. In the production of lumber, for example, it was estimated that with 1970 levels of research and development, prospective improvements in technology in the lumber industry would lead to increases in product output from a given volume of roundwood of 2 to 4 percent per decade. This would be in addition to the assumed 5 percent increase in recovery resulting from adoption in 1970 of new standards for softwood lumber. Increases in product recovery from such developments could be expected to increase stumpage values and the attractiveness of forestry investments, as well as extend timber supplies.

In addition to these developments in processing timber products, other technological changes were considered in Chapter $\mathrm{V}$ in estimating demands for lumber and other end products, such as increased efficiency in the use of timber products in construction, and use of plastics in lieu of lumber in the manufacture of furniture.

\section{Additional Opportunities for Improved Utilization}

There are nevertheless many additional opportunities for extending timber supplies beyond those assumed-particularly with increased relative prices of timber products. In the forest these include further increases in use of logging residues, use of wood fiber from nongrowing stock sources, and more complete salvage of mortality than is in prospect with 1970 management levels. In the mills these include greater use of modern equipment to increase output of lumber and other timber products from available log supplies. Further improvements are also possible in the use of wood products in construction and other end uses.

These possibilities for extending timber supplies might be captured by a combination of accelerated research and development efforts to gain new knowledge, increased efforts to inform possible users and to test new discoveries, subsequent industrial investments in plant and equipment, and in some cases changes in marketing practices in the forest industries.
The timing and extent of such further increases in timber utilization will of course depend on such factors as the rate of expansion of research and development, prospective rates of return from application of new technology, and the ability and willingness of forest industries to invest the required capital. In contrast to measures to increase timber growth which take considerable time to fully pay off, improved utilization of timber on areas currently harvested and in processing plants could have immediate as well as long-run results in extending timber supplies.

These potentials for further improvement of timber utilization may be illustrated by the following examples:

1. Timber sale practices, particularly on public lands, could be further modified to obtain more complete use of wood materials now wasted.

2. Research and development of methods of log extraction that will permit less road construction and minimize adverse environmental impacts could make timber management feasible on areas where timber harvesting is now uneconomic or unacceptable. Major advances are considered possible in use of aerial systems of logging, including use of cables, balloons, and helicopters, and in development of roads suitable for thinning operations.

3. Accelerated development and adoption of new processing technology in lumber and plywood manufacture could have the effect of extending available timber supplies. Much additional progress appears possible in adoption of thin kerf saws to increase lumber yields, for example, and in reducing or eliminating errors of judgment in cutting $\log _{\mathrm{s}}$ for maximum yield and optimum grade recovery. Lumber might also be sawed with greater precision and smoother surfaces and used "rough sawn" as is the custom in some foreign countries. Improved equipment for more accurate grading of structural lumber also could make possible greater efficiency in use of wood in construction.

4. Substitution of hardwoods for softwoods in construction, pulp, and possibly other uses would also help extend available softwood timber supplies.

5. Development of particleboards from residues or underutilized roundwood could serve in lieu of softwood plywood in various uses. Particleboard is now being produced in limited quantities for construction uses and current research indicates that various types of board could be made from a wide variety of materials of both softwood and hardwood species. ${ }^{12}$

6 . In the pulp and paper industry continued development of higher yielding pulping processes

12 Heebink, B. G., and Ray Dominick. Forest residues: A future source of particleboard? Wood \& Wood Prod. $76(11): 26-28.1971$. 
could lead to reduced wood use and a broadening of the resource base for pulping. Greater use of waste paper and board beyond that assumed in Chapter $Y$ may be possible through improved technology and/or changes in economic conditions or programs to increase consumer acceptance of paper with significant proportions of recycled fibers. Development and adoption of efficient methods of whole-tree harresting and bark-chip separation also could greatly expand the raw material base for pulpwood, and thus improve the supply situation for other timber products.

7. Improved construction designs for housing and other structures, and the derelopment and adoption of improred construction methods, could aid in conserving wood materials and reducing costs of end products. These might include stress skin panel construction systems, for example, or other improvements in design of structures or components. Many wooden structures are overdesigned and use more wood than necessary because of tradition, building codes, inadequate grading, or lack of knowledge. It is estimated that use of more efficient construction methods in residential building, for example, could reduce wood use as much as 10 to 20 percent with no significant sacrifice of performance. Also, increased use of wood preservative treatments in some construction uses would extend wood supplies.

8. Expansion of technical assistance to provide advice on adoption of new technology is also an important phase of accelerated efforts to improve timber utilization. Many examples can be found of poor log bucking practices, for example, or inefficiencies in lumber sawing and drying. Implementation of new technical discoreries is often a slow process, in part because of the slow spread of knowledge of new technology throughout producing industries.

It is of course difficult to quantify the costs, timing, and benefits of accelerated efforts to develop and apply new technology. Some programs, such as adoption of improred technology in lumber manufacture, could result in prompt increases in supply of wood products. Some other efforts are likely to require more time for acceptance and inrestment of capital in new plants. In any case it is apparent that there are many opportunities for extending arailable timber supplies by improved utilization over and above prospective trends.

\section{PROJECTION ALTERNATIVES}

The examples of timber management and utilization alternatives presented in this chapter should be regarded as preliminary. The major objectire of these initial studies was to develop procedures that might be used in evaluating alternatives on given forest properties or in local regions, and provide some general indication of the costs and benefits of intensifying forestry practices. Much additional work will be required to improve estimates of yield responses to forest management and the costs and values of increasing outputs of timber and related goods and services.

In addition to the illustrations cited, many opportunities for intensification of management undoubtedly exist on lands of the forest industries and on public ownerships other than National Forests. New technology such as fertilization also represents potentials that were not specifically included at this time.

Use of criteria other than the specific economic conditions assumed in this analysis also could warrant much larger forestry efforts than indicated. Higher relative prices of timber products than assumed herein could have the effect of substantially increasing areas economically suitable for intensification.

The acceptance of lower rates of return would have similar effects. The rates of return used in the above analysis are measured in constant dollars. If inflation continues, the rates of return measured in current dollars would be substantially higher. For example, if inflation continues at the rate prevailing in the past couple of decades a 5 -percent return in constant dollars would represent an 8- or 9-percent return in current dollars. 


\section{CHAPTER IV \\ AVAILABILITY OF WORLD TIMBER RESOURCES}

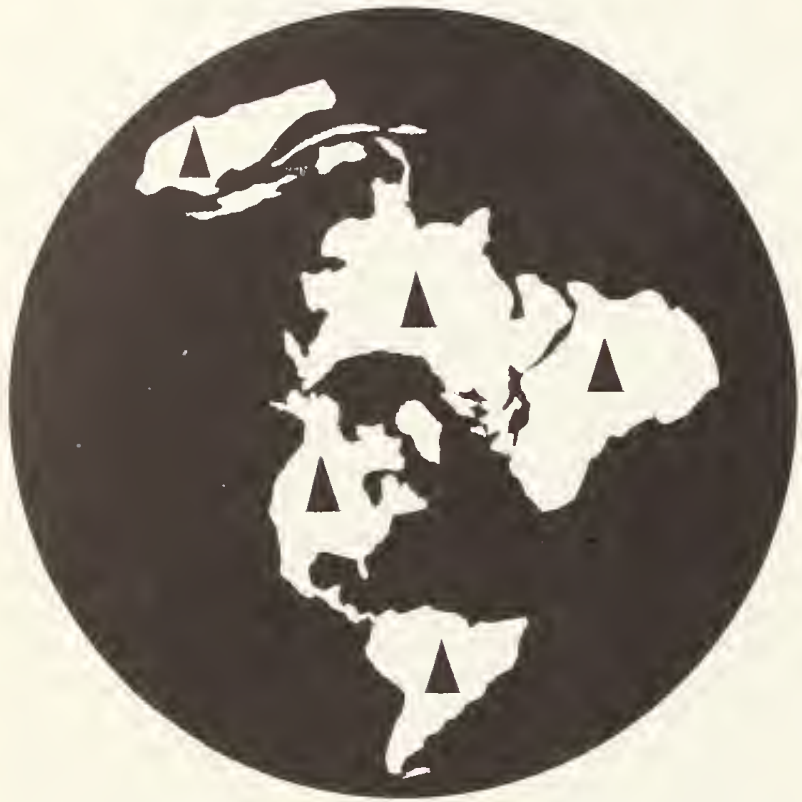

This chapter presents information on recent trends in U.S. imports and exports of timber products together with an appraisal of the timber demand and supply situation in the major importing and exporting countries or regions of the world.

This appraisal, along with the anaylsis of the domestic timber situation contained in other chapters of this report, provides the basis for the projections of timber product imports and exports summarized at the end of this chapter and shown in detail in Chapter $V$. In view of the projected growth in demand for timber products in the United States, and the economic and environmental constraints on increasing domestic timber supplies, potentials for future timber imports and exports are matters of major significance in evaluating the U.S. timber situation.

\section{TRENDS IN U.S. IMPORTS OF TIMBER PRODUCTS}

As consumption of industrial timber products has risen to higher levels in the United States, this country has purchased increasing amounts of lumber, newsprint, woodpulp, plywood, and other products from other parts of the world. In 1972, U.S. imports of timber products reached an alltime high of 2.9 billion cubic feet, roundrood equivalent. ${ }^{1}$ This was nearly two times the level of 1950 (fig. 47 and Append. IV, table 1). Timber imports in 1972 represented one-fifth of the total supply of timber products available to the United States.

The value of imports of timber products has also climbed rapidly, reaching $\$ 3.6$ billion in 1972 , or nearly double the value of exports (table 99). This represented about 6.5 percent of the value of all U.S. imports of merchandise.

Lumber.-Prior to 1941 the United States was a net lumber exporter but since then lumber imports have climbed steadily and rapidly. Between 1950 and 1972 lumber imports rose from 0.5 billion cubic feet ( 3.4 billion board feet) to 1.5 billion cubic feet (9.4 billion board feet) (fig. 47 and Append. IV, table 2) $\rightarrow$ a rise that accounted for over half of the total growth in imports during this period.

1 "Roundwood equivalent" represents the volume of logs or other round products required to produce woodpulp, paper, plywood, or other processed materials. It is recognized that portions of imports and exports of products such as woodpulp are produced from plant residues and thus do not actually represent roundwood production in addition to the logs used primarily for lumber or plywood. Figures for roundwood equivalent are used to indicate relative volumes of processed products. 


\section{Imports and exports of forest products}

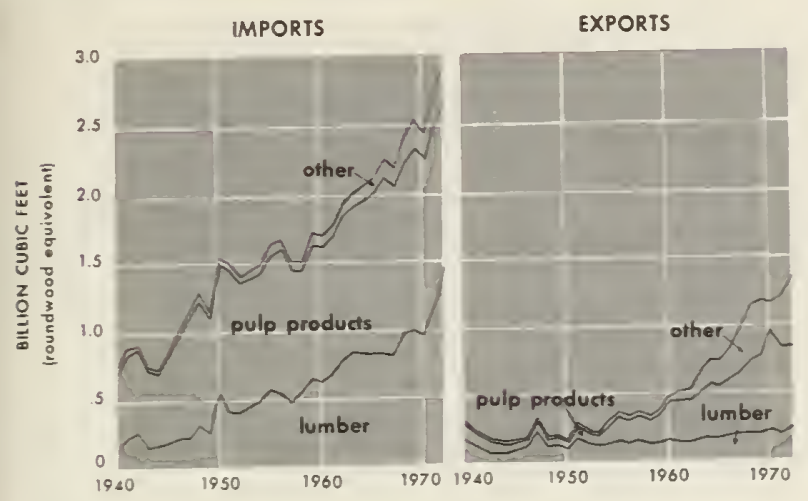

Figure 47

Nearly all of the growth in lumber imports has been composed of sof twoods from Canada, chiefly from British Columbia. Hardwood lumber imports, mostly from the tropical regions of the world and Canada, have fluctuated between 0.2 and 0.4 billion board feet per year during the past couple of decades.

Pulp products.-Imports of woodpulp, newsprint, and other grades of paper and board have also increased since 1950 . In earlier years much of the imported pulp and paper came from Scandinaria but recently by far the largest part of these imports have originated in Canada (Append. $\mathrm{V}$, tables 29 and 33 ).

About 7 percent of the imports of pulp products in 1972 was composed of round pulpwood and chips (Append. IV, table 3). In the past two decades, rolumes of pulpwood imports have fluctuated between 1.0 and 2.5 million cords. Most pulpwood imports hare come from Canada, although some imports have originated in the Bahamas in recent years.

Plywood and veneer.-Although not large in terms of cubic rolume, hardwood plywood and veneer imports have shown rery rapid growth since 1950 , rising from 5 million to over 200 million cubic feet, roundwood equiralent (Append. IV, tables 1, 4 , and 5). Over nine-tenths of these imports have come from Korea, Taiwan, Japan, and the Philippines. Most of the timber used in the manufacture of these products, howerer, has originated in tropical hardwood forests in the Philippines, Malaysia, and Indonesia.

Other.-Small volumes of logs, softwood plywood, particleboard, and miscellaneous roundwood products such as posts and poles also have been imported. Most of these imports hare been crossborder trade with Canada.
The rise in imports of timber products orer the past three decades is attributed to:

- rising consumption of industrial timber products in the United States,

a tightening domestic timber supply situation and economic development of timber resources in Canada and the Western Pacific Area,

effective marketing efforts by timber producers in exporting countries.

\section{TRENDS IN U.S. EXPORTS OF TIMBER PRODUCTS}

Exports of timber products in recent years have followed about the same upward trend as imports, rising from 0.1 billion cubic feet in 1950 to 1.3 billion in 1972 (fig. 47, and Append. IV, table 6).

Value of timber exports also climbed sharply to $\$ 2.0$ billion in 1972 , or about 4.2 percent of the total volume of all U.S. merchandise exports in that year (table 99).

Lumber.-Exports of lumber, chiefly softwoods, have roughly tripled since the early 1950 's, rising from 0.1 billion cubic feet roundwood equivalent ( 0.5 billion board feet) to 0.2 billion cubic feet in 1972 ( 1.5 billion board feet) (Append. IV, table 7). Iost of the increased shipments in recent years have gone to Japan, with smaller amounts to Europe, Latin America, and other countries.

Pulp products.-Exports of pulp products also increased rapidly in the 1950-72 period moving up from less than 0.1 to 0.6 billion cubic feet, roundwood equivalent. Western Europe has taken substantial amounts of pulp and liner board, for example, while large quantities of woodpulp have been shipped to the Far East, largely to Japrn (Append. $T$, tables 28 and 32).

Pulp chips produced from slabs and other residues of primary timber processing have made up a growing part of the shipments of pulp products to Japan since the mid-1960's (Append. IV, table 8). In 1972 , some 2.5 million tons of chips (142 million cubic feet roundwood equivalent) were exported to Japan from the Pacific Coast. Small rolumes of round pulpwood were exported to Canada.

Logs.-Exports of logs have also increased rapidly since the late 1950 's to about 0.5 billion cubic feet in 1972 (3.1 billion board feet local log scale or roughly 4.1 billion board feet lumber tall y). By far the largest part of these exports consisted of softwood logs ( 3.0 billion board feet), with nearly 90 percent of these going to Japan (Append. IV, tables 9 and 10). Log exports to Canada also have increased to a little over a half billion board feet in 1972 .

Other.-Exports of items such as plywood and veneer, poles, piling, etc., have grown, but the rolumes involved have represented a rery small part of the harrest of roundwood from U.S. forests. 
TABLE 99.-Imports and exports of timber products, volume and value, 1972

\begin{tabular}{|c|c|c|c|c|c|}
\hline \multirow{2}{*}{ Item } & \multirow{2}{*}{ Unit of measure } & \multicolumn{2}{|c|}{ Imports ${ }^{1}$} & \multicolumn{2}{|c|}{ Exports ${ }^{1}$} \\
\hline & & Volume & Value & Volume & Value \\
\hline $\begin{array}{l}\text { Logs: } \\
\text { Softwoods } \\
\text { Hardwoods } \ldots . . .\end{array}$ & Million board feet. & $\begin{array}{l}11.3 \\
28.0\end{array}$ & $\begin{array}{l}\text { Minlion } \\
\text { dollars } \\
0.7 \\
3.4\end{array}$ & $\begin{array}{r}3,049.4 \\
93.9\end{array}$ & $\begin{array}{l}\text { Million } \\
\text { dollars } \\
392.5 \\
42.1\end{array}$ \\
\hline Total ..... & $\ldots \mathrm{do}_{-\ldots}$ & 39. 3 & 4. 1 & $3,143.3$ & 434.5 \\
\hline $\begin{array}{l}\text { Lumber: } \\
\text { Softwoods } \\
\text { Hardwoods } \ldots . . \\
\text { Railroad ties....... }\end{array}$ & 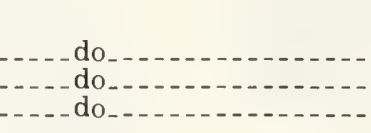 & $\begin{array}{r}8,976.9 \\
445.2 \\
7.9\end{array}$ & $\begin{array}{r}1,010.0 \\
88.8 \\
.8\end{array}$ & $\begin{array}{r}1,173.2 \\
249.7 \\
29.2\end{array}$ & $\begin{array}{r}201.9 \\
72.6 \\
5.0\end{array}$ \\
\hline Total_-. & -....do_.. & $9,430.1$ & $1,099.5$ & $1,452.1$ & 279. 5 \\
\hline $\begin{array}{l}\text { Veneer: } \\
\text { Softwoods } \\
\text { Hardwoods....-. }\end{array}$ & Million square feet. & $\begin{array}{r}365.4 \\
2,786.0\end{array}$ & $\begin{array}{r}5.8 \\
63.7\end{array}$ & $\begin{array}{l}287.4 \\
204.3\end{array}$ & $\begin{array}{r}9.2 \\
12.7\end{array}$ \\
\hline Total...... & .....do_.... & $3,151.4$ & 69.4 & 491.8 & 21.9 \\
\hline $\begin{array}{l}\text { Plywood: } \\
\text { Softwoods_._._._. } \\
\text { Hardwoods_._._. }\end{array}$ & $\begin{array}{l}-\mathrm{do}_{-} \\
-\mathrm{C}_{-}\end{array}$ & $\begin{array}{r}5.9 \\
6,427.3\end{array}$ & $\begin{array}{r}.5 \\
336.9\end{array}$ & $\begin{array}{r}220.4 \\
30.7\end{array}$ & $\begin{array}{r}31.5 \\
5.3\end{array}$ \\
\hline Total_. & $\ldots$. $\mathrm{do}_{\ldots} \ldots$ & $6,433.2$ & 337.3 & 251.1 & 36.9 \\
\hline $\begin{array}{l}\text { Pulpwood: } \\
\text { Round } \\
\text { Chips_._. }\end{array}$ & Thousand cords_ & $\begin{array}{l}307 \\
699\end{array}$ & $\begin{array}{l}10.0 \\
10.4\end{array}$ & $\begin{array}{r}142 \\
1,825\end{array}$ & $\begin{aligned} 3 . & 3 \\
57 . & 1\end{aligned}$ \\
\hline Total__... & 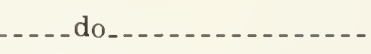 & 1,005 & 20.4 & 1,966 & 60.4 \\
\hline Woodpulp_-_._- & Thousand tons_....- & 3,728 & 494. 2 & 2,253 & 357.7 \\
\hline $\begin{array}{l}\text { Paper and board: } \\
\text { Newsprint } \\
\text { Other paper and board. } \\
\text { Paper and board produc }\end{array}$ & $2 x^{-1}$ & $\begin{array}{r}7,101 \\
893 \\
39\end{array}$ & $\begin{array}{r}1,056.1 \\
125.6 \\
32.8\end{array}$ & $\begin{array}{r}145 \\
2,856 \\
167\end{array}$ & $\begin{array}{r}20.4 \\
570.6 \\
135.4\end{array}$ \\
\hline Total_...... & _. do_-_._. & 8,033 & $1,214.6$ & 3,168 & 726.4 \\
\hline Other wood products ${ }^{2}-$ & $\ldots$. do _. & -........ & 367.2 & - - n & 120.4 \\
\hline Total, all timber pr & & - & $3,606.8$ & ..... & $2,037.8$ \\
\hline
\end{tabular}

1 Data may not add to totals because of rounding.

2 Includes poles and piling, fuelwood, particleboard, wood charcoal, cork, wastepaper, wood containers, wood doors, and other miscellaneous products. Does not include wood furniture nor printed materials.

The recent rise in exports of timber products from the United States is attributed to:

- rapid growth in world timber demands, particularly in Japan and Western Europe, availability of high-quality kraft pulp and liner board from the southern United States, and high-grade lumber, softwood logs, and chips from the Pacific Northwest,

a special situation in Alaska favoring pulp and lumber exports to Japan.
Sources: U.S. Department of Commerce, Bureau of the Census. U.S. imports, commodity by country, December 1972. FT 135; and U.S. exports, commodity by country, December 1972. FT 410. Supt. of Documents, U.S. Government Printing Office, Washington, D.C.

\section{TRENDS IN U.S. NET IMPORTS OF TIMBER PRODUCTS}

During the first five decades of this century the United States gradually changed from a net exporting country to a net importer (fig. 48). By 1950, the United States was dependent on foreign sources for about a tenth of all timber products consumed.

Between 1950 and 1970, net imports remained 


\section{U.S. timber import - export balances}

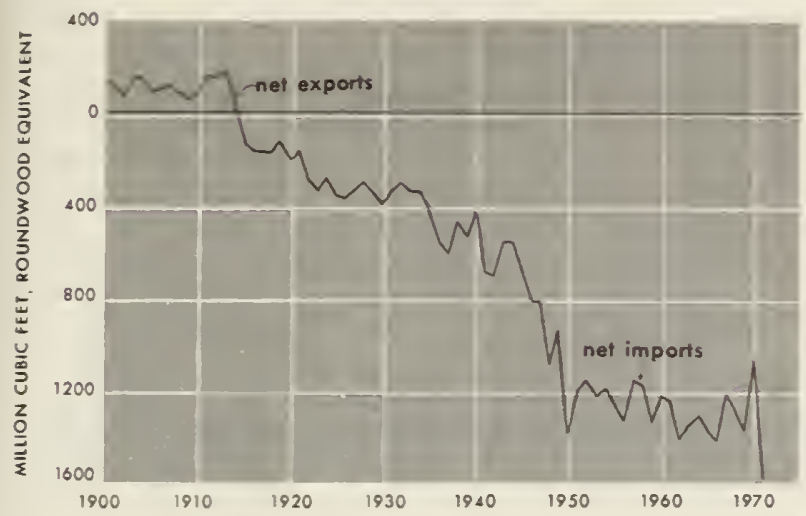

Figure 48

at about 1.3 billion cubic feet a year, but in 1972 net imports reached a new peak of 1.6 billion cubic feet (Append. $\boldsymbol{N}^{\top}$, table 11). This represented about 11 percent of the timber products consumed in the United States.

The balance of trade in timber products measured in dollars has been very similar to balances of physical rolumes (table 99). In most recent years values of imports exceeded ralues of exports by about $\$ 1$ billion a year.

Lumber.-Net imports of lumber amounted to $\delta$ billion board feet in 1972 , or 1.2 billion cubic feet roundwood equiralent. This represented 17 percent of the lumber consumed in the United States-a figure materially abore 1950 when net imports accounted for only 7 percent of U.S. lumber use.

Pulp products.-Net imports of pulp products in 1972 totaled about 0.6 billion cubic feet, roundwood equivalent-about a third below the early 1950's. Net imports as a proportion of U.S. consumption of pulp products also showed a sharp decline from 37 percent of total consumption in 1950 to 15 percent in 1972 .

Plywood and veneer.-Net imports of plywood and reneer in 1972 amounted to 0.2 billion cubic feet, roundwood equiralent-or 16 percent of total U.S. plywood and reneer consumption. Imports accounted for about 62 percent of the hardwood plywood and reneer consumed, but only a negligible part of softwood plywood consumption.

Logs.-In the early 1950's there was a small net import of logs, but this changed rapidly in the 1960 's to a net export volume of about 0.5 billion cubic feet in $1972-$ a volume equal to 4 percent of U.S. roundwood production.

Future trends in imports and exports of timber products will largely depend on the economic a railability of timber in the major forested regions of the world, and on the timber demand-supplyprice situation in the major consuming areas. The timber situation in Canada, the predominant source of U.S. imports, and to a lesser extent in the tropical hardwood areas, is of primary importance for timber supplies. Export markets in western Europe and Japan are of particular significance to U.S. exporters.

\section{WORLD TIMBER DEMANDS}

Consumption of industrial timber products has been growing rapidly in all parts of the world, with a rise of some 70 percent between 1950 and 1969. Projections prepared by the Food and Agriculture Organization of the United Nations and other organizations point to substantial increases in demands in the decades ahead. ${ }^{2}$

The United States, Europe, and Japan consume over half of all the industrial wood produced in the world, and are dependent on other regions for a significant part of this supply (table 100). The studies referred to abore indicate that this dependency on imports is likely to increase.

\section{The Situation in Europe}

In 1970 an estimated 11.9 billion cubic feet of industrial wood-about a quarter of world production-was consumed in Europe, excluding the Soriet Union. About two-thirds of this rolume was used in the European Economic Community (the Common Market), the British Isles, and northern Europe. Another fifth was consumed in eastern Europe, with the remaining volume about equally divided between central and southern Europe.

${ }^{2}$ Examples of relevant studies include:

Algvere, Karl Viktor. Forest economy in the USSR. Studia Forestalia Suecica, No. 39, Royal College of Forestry, Stockholm, Sweden. 1966.

Food and Agriculture Organization of the United Nations. Wood: World trends and prospects. FFHC Basic Study 16, 131 p. Rome. 1967.

- Outlook for pulp and paper consumption, production and trade to 1985. Second Consultation on World Pulp and Paper Demand, Supply and Trade. Rome. 1971.

and United Nations Economic Commission for Europe. European timber trends and prospects, 19501980 , an interim review. 2 V. (182 p. and 139 p.) Geneva. 1969 .

Japan Lumber Journal, Inc. Timber demand forecast for 1975. Japan Lumber J. 10(9):1, 4. May 31, 1969.

Solecki, J. S. Russia-China-Japan, economic growth, resources and forest industries. British Columbia Univ. 1967.

Takeuchi, Kenji. The market potential for tropical hardwood with emphasis on the Asia Pacific region. International Bank for Reconstruction and Development, Office Rpt. September 1971.

United Nations Centre for Housing, Building and Planning. Housing needs, trends and prospects. Unasylra Vol. 25(2-3-4), nos. 101-102-103, p. 7-25. 1971

United Nations Economic and Social Council, Economic Commission for Europe Timber Committee. TIM Working Paper No. 173/Add. 1, 19 p. July 12, 1972. 
As indicated in the tabulation below, the 1970 level of timber consumption in Europe was nearly double the annual average of 1949-51.

Product

1949-51 1959-61

(Billion cubic feet wood raw material

Sawnwood.

Wood-based panels

Paper, paperboard, and

dissolving pulp.......

Pitprops and miscellane-

ous roundwood........

Total industrial

roundwood .....

\begin{tabular}{lll}
3.5 & 4.6 & 5.6 \\
0.2 & 0.6 & 1.4 \\
1.2 & 2.4 & 4.1 \\
1.3 & 1.2 & 0.8 \\
\hline
\end{tabular}

6. $2 \quad 8.8$

11. 9

1 Preliminary estimate.

Source: United Nations Economic and Social Council, Economic Com. mission for Europe Timber Committee. TIM/Working Paper No. 173/Add. 1, 19 p. July $1<, 1972$.

\section{TABLE 100.-World production and consumption of timber products, 1969}

[Billion cubic feet, roundwood equivalent]

ALL PRODUCTS

\begin{tabular}{|c|c|c|c|c|}
\hline Country & $\begin{array}{l}\text { Produc- } \\
\text { tion }\end{array}$ & $\begin{array}{l}\text { Net } \\
\text { im- } \\
\text { ports }\end{array}$ & $\begin{array}{c}\text { Net } \\
\text { ex- } \\
\text { ports }\end{array}$ & $\begin{array}{l}\text { Appar- } \\
\text { ent } \\
\text { con- } \\
\text { sump- } \\
\text { tion }\end{array}$ \\
\hline $\begin{array}{l}\text { United States } \\
\text { Europe } \\
\text { Japan } \\
\text { U.S.S.R } \\
\text { Rest of world }\end{array}$ & $\begin{array}{r}11.5 \\
11.1 \\
1.8 \\
13.4 \\
37.8\end{array}$ & $\begin{array}{r}1.4 \\
1.4 \\
1.4 \\
\hdashline-1--\end{array}$ & $\begin{array}{r}1.0 \\
\text { 3. } 2\end{array}$ & $\begin{array}{r}12.9 \\
12.5 \\
3.2 \\
12.4 \\
34.6\end{array}$ \\
\hline Total__._... & 75. 6 & 4. 2 & 4. 2 & 75. 6 \\
\hline
\end{tabular}

INDUSTRIAL WOOD

\begin{tabular}{|c|c|c|c|c|}
\hline $\begin{array}{l}\text { United States } \\
\text { Europe } \\
\text { Japan } \\
\text { U.S.S.R } \\
\text { Rest of world }\end{array}$ & $\begin{array}{r}\text { 10. } 9 \\
8.8 \\
1.6 \\
10.2 \\
11.2\end{array}$ & $\begin{array}{r}\text { 1. } 4 \\
\text { 1. } 4 \\
\text { 1. } 4 \\
\hdashline-. .--\end{array}$ & $\begin{array}{r}-1.0 \\
3.2\end{array}$ & $\begin{array}{r}\text { 12. } 3 \\
\text { 10. } 2 \\
3.0 \\
\text { 9. } 2 \\
\text { 8. } 0\end{array}$ \\
\hline Total _...... & 42.7 & 4. 2 & 4. 2 & 42.7 \\
\hline
\end{tabular}

Source: Food and Agriculture Organization of the United Nations. Yearbook of forest products, 1969-\%0. Rome. 1971.

Most of the growth in consumption in the 195070 period was in pulp products, although there were also substantial increases in sawnwood and wood-based panel products. During the 1960's Europe changed from a net exporter of pulp and panel products to a net importer of these items, including substantial quantities of kraft pulp and liner board and some imports of softwood plywood from the United States.

The major part of the other industrial wood products consumed in Europe was derived from European forests. Much of the consumption de- rived from net imports consisted of softwood lumber from the USSR, Canada, and the United States, and hardwood lumber from other countries such as West Africa and the Asia-Pacific area.

In general the dependence of Europe on imports from the Soviet Union and North America showed a marked rise in the 1950's and 1960's. There was also a significant increase in imports from Africa. The trade balance with the AsiaPacific region and Latin America was essentially unchanged.

Projections indicate that consumption of industrial timber products is likely to continue to rise with continued expansion of European economies. Estimated demands for industrial timber products increase by about 27 percent between 1970 and 1980 (table 101), and roughly double by $2000 .^{3}$ Most of the projected growth is for pulp and paper products and wood-based panels. Demands for sawnwood are expected to grow only a little faster than population, while demands for miscellaneous roundwood are expected to decline.

Studies of the prospective European timber supply situation indicate that timber supplies from European forests could be expanded. However, the increase in supplies is much below the anticipated growth in demands. As a result timber deficits are projected to 2.3 billion cubic feet by 1980 , some 60 percent above 1970 (table 101). Longer run assessments indicate that by 2000 the deficit may be somewhere between 4.2 and 7.9 billion cubic feet. ${ }^{3}$

Recent developments in Europe suggest the deficit may be in the higher part of this range. For example, rapid increases in labor costs in Europe and the need to protect the environment may constrain intensified timber management, as suggested by the following quotation from a report of the Timber Committee of the Economic Commission for Europe: ${ }^{4}$

"The rapid increase in the importance attached to environmental problems in Europe may have far-reaching repercussions on the management of existing forest resources, to the extent that environmental requirements may impose certain limitations on forestry's traditional role of supplying wood. These repercussions may be of different types: they may lead to certain forest areas being declared protection, conservation or recreation areas, with severe restrictions on their commercial exploitation, or they may constitute hindrances to normal management and exploitation because of landscaping and similar constraints and thus affect the economics of production."

Although future European timber deficits are uncertain, it seems reasonably clear that import

${ }^{3}$ United Nations Economic and Social Council, Economic Commission for Europe, Timber Committee. TIM/ Working Paper No. 173/Add. 1, 19 p. July 12, 1972.

4 Op. cit., p. 15, footnote 3 . 
TABLE 101.-Consumption and domestic supplies of industrial wood in Europe in 1965 and 1970, with
projections to 1980

[Million cubic feet, roundwood equivalent]

\begin{tabular}{|c|c|c|c|c|}
\hline \multirow{2}{*}{ Item } & \multirow{2}{*}{1965} & \multirow{2}{*}{1970} & \multicolumn{2}{|c|}{ Projections } \\
\hline & & & 1975 & 1980 \\
\hline $\begin{array}{l}\text { Consumption of sawn wood, plywood and veneers } \\
\text { European removals of saw logs, veneer logs, etc }\end{array}$ & $\begin{array}{l}5,579 \\
4,661\end{array}$ & $\begin{array}{l}6,073 \\
5,049\end{array}$ & $\begin{array}{l}6,179 \\
5,155\end{array}$ & $\begin{array}{l}6,426 \\
5,438\end{array}$ \\
\hline Apparent shortfall & 918 & 1,024 & 1,024 & 988 \\
\hline $\begin{array}{l}\text { Consumption of other industrisl forest products } \\
\text { European remorals of pulpwood, pitprops, and miscellaneous roundwood, and } \\
\text { transfer of residues. }\end{array}$ & $\begin{array}{l}4,696 \\
4,449\end{array}$ & $\begin{array}{l}5,897 \\
5,473\end{array}$ & $\begin{array}{l}7,133 \\
6,285 \\
\end{array}$ & $\begin{array}{l}8,757 \\
7,415 \\
\end{array}$ \\
\hline Apparent shortfall $\ldots . .$. & 247 & 424 & 848 & 1,342 \\
\hline $\begin{array}{l}\text { Consumption of all products } \\
\text { Total European removals and residues transfer }\end{array}$ & $\begin{array}{r}10,275 \\
9,110 \\
\end{array}$ & $\begin{array}{l}11,970 \\
10,522\end{array}$ & $\begin{array}{l}13,312 \\
11,440\end{array}$ & $\begin{array}{l}15,183 \\
12,853\end{array}$ \\
\hline Total apparent shortfall & 1,165 & 1,448 & 1,872 & 2,330 \\
\hline
\end{tabular}

Sources: 1965, $19 \overline{7}$ and 1980-Food and Agriculture Organization of the United Nations and United Nations Economic Commission for Europe. European timber trends and prospects, 1950-1980, an interim review. Vol. 1, 182 p. Genera. May 1969.

demands will continue to increase. These expectations in part underlie the projections of U.S. exports of pulp and paper products shown in Chapter $V$. In the case of lumber and logs, it seems likely that nearly all of the growth in European demands for these products will be met by imports from the Soriet Union, Canada, and tropical hardwood regions.

\section{The Situation in Japan}

The phenomenal economic growth of Japan in the last couple of decades resulted in a sixfold increase in industrial wood consumption between 1950 and 1972 to 3.6 billion cubic feet, roundwood equivalent (table 102).

Although Japan is heavily forested, its timber resources are relatively limited in relation to population. Japanese forests were also severely depleted by heavy cutting during World War II. To meet the rapidly increasing domestic and export demands for timber products, imports of logs and other products into Japan have increased sharply to 56 percent of total supplies in 1972.

For many years imports were mainly tropical hardwood logs for use in production of plywood, but since the early 1960's imports of softwood logs for the manufacture of lumber, and imports of chips for pulp manufacture, also have risen sharply. Most of the softwood log imports have originated in the United States and the Soriet Union. By far the largest part of the chip imports have come from the United States. Canada
1970-Cnited Nations Economic and Social Council, Economic Commission for Europe, Timber Committee. TIX/Working Paper No. 173/Add. 1, 19 p. July 12, 1972.

and the United States have supplied most of the imported pulp and paper.

Estimates of the Japanese Forestry Agency indicate that demand for timber products will continue to grow rapidly to an estimated 4.8 billion cubic feet by 1981 (table 103). Imports are expected to play an increasingly important role, rising to about 3 billion cubic feet by 1981 , or 63 percent of total projected demands. In time Japanese forests are expected to be capable of supplying an increasing share of total demands. By the year 2021, for example, domestic wood production is projected to reach 3.3 billion cubic feet-double the 1972 level of domestic timber harrests.

This outlook could, of course, be changed by shortfalls in forestry programs, diversions of forest land to other uses, or constraints on timber production associated with protection of the environment. In any event, it seems clear that Japan is likely to continue to be a major importer of timber products from North America, Siberia, Southeast Asia, and perhaps other areas during the next few decades. ${ }^{5}$

The projections of U.S. exports, summarized at the end of this chapter, assume that without U.S. export controls shipments to Japan of logs, chips, woodpulp, and lumber will continue to rise somewhat. However, it was also assumed

5 Crawford, G. S. The Japanese lumber markct, some trends in factors of significance for British Columbia. British Columbia Res. Counc., Vancouver, B.C. 1965. 
TABLE 102.-Timber products consumed in Japan, 1970-72, by source of supply

[Million cubic feet, roundwood equivalent]

\begin{tabular}{|c|c|c|c|}
\hline Item and source & 1970 & 1971 & 1972 \\
\hline Domestic supply -- & $1,632.7$ & $1,589.0$ & $1,585.4$ \\
\hline $\begin{array}{l}\text { Foreign supply: } \\
\text { Logs: } \\
\text { United States } \\
\text { U.S.S.R } \\
\text { Canada. } \\
\text { South Seas Lauan } \\
\text { New Zealand } \\
\text { Other }\end{array}$ & $\begin{array}{r}336.5 \\
247.2 \\
19.1 \\
614.4 \\
59.3 \\
113.3\end{array}$ & $\begin{aligned} & 251 . 1 \\
& 247 . 2 \\
& 23 . 0 \\
& 649 . 7 \\
& 62.5 \\
& 116.5\end{aligned}$ & $\begin{array}{r}366.2 \\
280.0 \\
9.5 \\
635.9 \\
63.6 \\
121.5\end{array}$ \\
\hline Total logs $\ldots \ldots$ & $1,389.8$ & $1,350.0$ & $1,476.7$ \\
\hline $\begin{array}{l}\text { Lumber: } \\
\text { United States } \\
\text { U.S.S.R. } \\
\text { Canada } \\
\text { South Sea Lauan } \\
\text { New Zealand } \\
\text { Other. }\end{array}$ & $\begin{aligned} 44 . & 4 \\
6 . & 0 \\
102 . & 6 \\
14 . & 4 \\
4 . & 8 \\
9 . & 0\end{aligned}$ & $\begin{array}{r}39.6 \\
6.0 \\
54.6 \\
12.6 \\
5.4 \\
6.6\end{array}$ & $\begin{aligned} & 52 . 2 \\
& 6 . 0 \\
& 55.8 \\
& 8.4 \\
& 6.0 \\
& 15.0\end{aligned}$ \\
\hline Total lumber $\ldots \ldots$ & 181. 2 & 124. 8 & 144.0 \\
\hline $\begin{array}{l}\text { Wood chips: } \\
\text { United States } \\
\text { New Zealand } \\
\text { Other }\end{array}$ & $\begin{array}{r}205.0 \\
10.5 \\
27.2\end{array}$ & $\begin{array}{r}116.7 \\
5.6 \\
47.5\end{array}$ & $\begin{array}{r}161.1 \\
6.8 \\
61.1\end{array}$ \\
\hline Total wood chips & 242. 6 & 169.8 & 229.0 \\
\hline 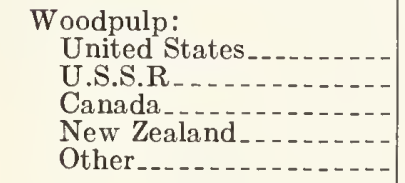 & $\begin{array}{r}60.6 \\
3.8 \\
85.2 \\
0.4 \\
8.9\end{array}$ & $\begin{array}{r}46.1 \\
2.1 \\
61.2 \\
0.3 \\
5.9\end{array}$ & $\begin{array}{r}58.0 \\
2.4 \\
66.0 \\
0.8 \\
10.1\end{array}$ \\
\hline Total woodpulp_._. & 158. 9 & 115. 7 & 137. 3 \\
\hline $\begin{array}{l}\text { Paper and board: } \\
\text { United States. } \\
\text { Canada } \\
\text { Other }\end{array}$ & $\begin{array}{l}\text { NA } \\
\text { NA } \\
\text { NA }\end{array}$ & $\begin{array}{l}0.8 \\
5.0 \\
1.3\end{array}$ & $\begin{array}{l}1.4 \\
8.1 \\
5.1\end{array}$ \\
\hline $\begin{array}{l}\text { Total paper and } \\
\text { board }\end{array}$ & 10.1 & 7. 1 & 14. 6 \\
\hline Total foreign supply & $1,982.6$ & $1,767.4$ & $2,001.6$ \\
\hline Total supply _. . . . . & $3,615.3$ & $3,357.4$ & $3,587.0$ \\
\hline
\end{tabular}

Sources: Derived from data published by Japan Forestry Agency. Timber demand and supply for 1971-1972. Japan Lumber Journal, 13(1), January 10, 1972; and Ministry of Finance, Japan Tariff Association, Japan exports and imports, commodity by country. Tokyo, December 1971 and November 1972.

that increases in exports will be limited by increasing competition and rising prices for logs on the Pacific Coast, anticipated expansion in use of wood by the U.S. pulp and paper industry, and possible increases in timber supplies from Siberia and tropical sources.
TABLE 103.-Consumption, domestic production, and imports of industrial timber products in Japan, 1969-71, with projections to $2021^{1}$

[Million cubic feet, roundwood equivalent]

\begin{tabular}{|c|c|c|c|c|}
\hline \multirow{2}{*}{ Item } & \multirow{2}{*}{$\begin{array}{l}1969-71 \\
\text { annual } \\
\text { average }\end{array}$} & \multicolumn{3}{|c|}{ Projections } \\
\hline & & 1981 & 1991 & 2021 \\
\hline $\begin{array}{l}\text { Consumption of indus- } \\
\text { trial timber for: } \\
\text { Lumber. } \\
\text { Pulp products.- } \\
\text { Plywood and mis- } \\
\text { cellaneous prod- } \\
\text { ucts.-. }\end{array}$ & 2, 133 & $\begin{array}{l}2,528 \\
1,416\end{array}$ & & \\
\hline $\begin{array}{l}\text { All products } \\
\text { Domestic production } \\
\text { Imports }\end{array}$ & $\begin{array}{l}3,527 \\
1,635 \\
1,893\end{array}$ & $\begin{array}{l}4,760 \\
1,755 \\
3,005\end{array}$ & $\begin{array}{l}5,201 \\
2,073 \\
3,128\end{array}$ & $\begin{array}{l}5.399 \\
3,330 \\
2,069\end{array}$ \\
\hline
\end{tabular}

1 Data may not add to totals because of rounding.

Source: Japan Ministry of Agriculture and Forestry. Basic plan relating to forest resources and long-term forecasts relating to the demand for and supply of important forest products. Cabinet Decision. February 16, 1973.

\section{The Situation in Other Countries and Regions}

Although most of the U.S. export trade in timber products has been with Europe and Japan, there have been significant exports of woodpulp, paper and board, lumber, logs, veneer, and plywood to Canada and other countries of the world and these exports have been rising slowly (Append. IV). In the projections shown in Chapter $V$ some allowances have been made for increased shipments to U.S. export markets around the world.

\section{WORLD FOREST LAND AND TIMBER RESOURCES}

A large part of the forest resources of the world has never been surveyed, and the available data on forest areas and timber volumes for many forested areas undoubtedly contain substantial errors of estimate. Nonetheless, it seems apparent that there are a number of potentials for expanding production and exports of timber products in various forested regions.

\section{Forest Areas}

Forests cover an estimated 9,172 million acres, or about 28 percent of the world's land area (table 104). About two-thirds of these forest lands support hardwood species; only one-third is classed as softwood forests. The world's softwood acreage is concentrated in the USSR $(1,366 \mathrm{mil}-$ lion acres) and in North America (1,087 million acres), with only 525 million acres in all other countries. 
TABLE 104.- Land and forest areas in the world

[Million acres]

\begin{tabular}{|c|c|c|c|c|c|}
\hline \multirow{2}{*}{ Area } & \multirow{2}{*}{$\begin{array}{c}\text { Total } \\
\text { land area }\end{array}$} & \multicolumn{3}{|c|}{ Forest land } & \multirow{2}{*}{$\begin{array}{l}\text { Forest land } \\
\text { available } \\
\text { for wood } \\
\text { production }\end{array}$} \\
\hline & & Total & Softwood & Hardwood & \\
\hline $\begin{array}{l}\text { North America } \\
\text { Latin America } \\
\text { Europe } \\
\text { Africa } \\
\text { Asia (except Japan and U.S.S.R.) } \\
\text { Japan } \\
\text { U.S.S.R R } \\
\text { Pacific area. }\end{array}$ & $\begin{array}{r}4,633 \\
5,019 \\
1,129 \\
7,339 \\
6,580 \\
247 \\
5,297 \\
2,081 \\
\end{array}$ & $\begin{array}{r}1,754 \\
1,962 \\
366 \\
1,757 \\
1,233 \\
59 \\
1,824 \\
227 \\
\end{array}$ & $\begin{array}{r}1,087 \\
86 \\
213 \\
10 \\
183 \\
25 \\
1,366 \\
7 \\
\end{array}$ & $\begin{array}{r}642 \\
1,831 \\
153 \\
1,700 \\
1,016 \\
32 \\
432 \\
210\end{array}$ & $\begin{array}{r}1,013 \\
862 \\
312 \\
729 \\
815 \\
57 \\
1,730 \\
118\end{array}$ \\
\hline World & 32,205 & 9,172 & 2,978 & 6,017 & 5,636 \\
\hline
\end{tabular}

Source: Food and Agriculture Organization of the United Nations. Supply of wood materials for housing. World Consultation on the Use of Wood in Housing, Secretariat Pap., Sect. 2. 1971.

A large part of the total forest area is not arailable for timber harrest-that is, it is reserved for other uses or is not productive enough to produce commercial crops of timber. However, some 5.6 billion acres, or 61 percent of the world's forest area, may be sufficiently productive and a vailable for commercial timber production.

\section{Timber Volumes}

The forests of the world contain an estimated 12.6 trillion cubic feet of timber (table 105). Softwoods make up only one-third of this timber inrentory. North America and the USSR contain the largest volumes of softwood growing stock, while Latin America, Africa, and Southeast Asia have most of the hardwood rolumes.

TABLE 105.-Forest growing stock in the world, by area and species group

[Billion cubic feet]

\begin{tabular}{|c|c|c|c|}
\hline Area & Total & $\begin{array}{c}\text { Soft- } \\
\text { woods }\end{array}$ & $\begin{array}{l}\text { Hard- } \\
\text { woods }\end{array}$ \\
\hline $\begin{array}{l}\text { North America } \\
\text { Latin America. } \\
\text { Europe. } \\
\text { Africa } \\
\text { Asia (except Japan and } \\
\text { U.S.S.R.) } \\
\text { Japan . S.S.S.R } \\
\text { Pacific Area. }\end{array}$ & $\begin{array}{r}2,083 \\
4,340 \\
473 \\
1,232 \\
\\
1,444 \\
67 \\
2,807 \\
177\end{array}$ & $\begin{array}{r}1,395 \\
99 \\
290 \\
11\end{array}$ & $\begin{array}{r}689 \\
4,241 \\
184 \\
1,222\end{array}$ \\
\hline World_. & 12,623 & 4,396 & 8,227 \\
\hline
\end{tabular}

Source: Food and Agriculture Organization of the United Nations. Supply of wood materials for housing. World Consultation on the Use of Wood Housing, Secretariat Pap., Sect. 2. 1971.

\section{Timber Production}

Total timber inventory volumes are not necessarily indicators of an area's importance as a timber producer. Other factors such as species and quality of timber, physical and economic accessibility, and institutional or political limitations also affect timber harvests and manufacturing. Thus about three-fourths of all timber cut for industrial use in 1967-69 was produced from softwood forests in North America, the USSR, Europe, and other countries (table 106). In recent decades growth in softwood production has been most rapid in the USSR, which has the greatest volume of untapped softwood forest resources.

Production of industrial wood products from hardwoods amounted to nearly one-fourth of the world harrest of roundwood in 1967-69. About two-thirds of this industrial hardwood timber production came from North America, Asia, and Europe-even though these areas contain only 25 percent of the world's hardwood growing stock inventory. Latin America contains over half the total world hardwood resources, but has accounted for less than 10 percent of world production of hardwood products.

\section{Timber Supply Potential}

Prospects for significant additions to softwood timber production and exports from existing but unutilized resources seem limited to the northern parts of Canada and Siberia. Both Canada and the USSR have indicated a desire to develop their. forest resources. Unused timber in both countries is under government control and hence government policies, as well as trends in prices and market and availability of investment capital, will be significant factors in determining low rapidly expansion of timber industries take place. 
TABLE 106.-Average annual harvest of industrial roundwood in the world, by area, 1950-52 and 1967-69 [Million cubic feet]

\begin{tabular}{|c|c|c|c|c|c|c|}
\hline \multirow{2}{*}{ Area } & \multicolumn{3}{|c|}{$1950-1952$} & \multicolumn{3}{|c|}{$1967-1969$} \\
\hline & Total & $\begin{array}{l}\text { Soft- } \\
\text { woods }\end{array}$ & $\begin{array}{l}\text { Hard- } \\
\text { woods }\end{array}$ & Total & $\begin{array}{l}\text { Soft- } \\
\text { woods }\end{array}$ & $\begin{array}{l}\text { Hard- } \\
\text { woods }\end{array}$ \\
\hline $\begin{array}{l}\text { North America } \\
\text { Latin America- } \\
\text { Europe- } \\
\text { Africa } \\
\text { Asia (except Japan and U.S.S.R.) } \\
\text { Japan } \\
\text { U.S.S.R R } \\
\text { Pacific Area. }\end{array}$ & $\begin{array}{r}11,017 \\
1,095 \\
6,391 \\
530 \\
1,942 \\
953 \\
6,250 \\
388\end{array}$ & $\begin{array}{r}8,933 \\
424 \\
5,191 \\
35 \\
742 \\
847 \\
5,402 \\
106\end{array}$ & $\begin{array}{r}2,083 \\
671 \\
1,201 \\
494 \\
1,201 \\
106 \\
847 \\
282\end{array}$ & $\begin{array}{r}14,548 \\
1,554 \\
8,616 \\
1,201 \\
3,778 \\
1,730 \\
10,205 \\
\quad 636\end{array}$ & $\begin{array}{r}11,864 \\
706 \\
6,179 \\
177 \\
1,130 \\
1,095 \\
9,039 \\
318\end{array}$ & $\begin{array}{r}2,684 \\
847 \\
2,436 \\
1,024 \\
2,648 \\
636 \\
1,165 \\
318\end{array}$ \\
\hline World & 28,566 & 21,680 & 6,885 & 42,266 & 30,508 & 11,758 \\
\hline
\end{tabular}

Source: Food and Agriculture Organization of the United Nations, Forest Industries and Trade Division, Supply of wood materials for housing. Unasylva $25(2-3-4) ; 28-52,1971$.

Hardwood forests in most of the hardwood regions of the world, including the United States, also could support higher levels of harvest in the next several decades. Most of this potential is in the hardwood forests of Southeast Asia, Africa, and Latin America. In many areas availability of capital and the rate of economic development will be important factors in determining future increases in hardwood timber supplies.

\section{POTENTIAL TIMBER SUPPLIES FROM CANADA}

The timber resources of Canada are of special significance to the United States, for both geographic and economic ties make Canada a primary timber supply region for this country. Canada is the leading timber exporting nation in the world, with three-fourths of her exports going to the United States.

\section{Forest Resources}

Canadian forests include some 588 million acres of forest land suitable and available for timber production (table 107), or 18 percent more area than the commercial timberlands of the United States. Timber volumes on Canada's inventoried nonreserved forest land totaled an estimated 503 billion cubic feet of softwoods in 1968 (table 108), some 71 billion cubic feet more than softwood inventories on commercial timberlands in the United States. Canadian forests also included an additional 127 billion cubic feet of hardwoods, about 90 billion cubic feet less than in the United States.

\section{Production Trends}

Output of both the lumber and pulp and paper industries in Canada has climbed steadily in recen $t$

\section{TABLE 107.-Forest land areas in Canada, by Province, 1967}

[Thousand acres]

\begin{tabular}{|c|c|c|c|c|}
\hline Province & Total & $\begin{array}{l}\text { Suitable } \\
\text { for regular } \\
\text { harvest }\end{array}$ & $\begin{array}{l}\text { Not suitable } \\
\text { for regular } \\
\text { harvest }\end{array}$ & Reserved \\
\hline $\begin{array}{l}\text { Atlantic }{ }^{1} \\
\text { Quebec } \\
\text { Ontario } \\
\text { Prairie }{ }^{2} \\
\text { British Columbia } \\
\text { Northwest Territories and Yukon }\end{array}$ & $\begin{array}{r}56,685 \\
171,827 \\
120,534 \\
132,712 \\
138,076 \\
176,512\end{array}$ & $\begin{array}{r}47,723 \\
121,845 \\
115,471 \\
119,608 \\
134,838 \\
48,808\end{array}$ & $\begin{array}{r}8,311 \\
49,920 \\
105 \\
4,979 \\
127,704\end{array}$ & $\begin{array}{r}651 \\
62 \\
4,958 \\
8,125 \\
3,238 \\
\end{array}$ \\
\hline Total $\ldots$ & 796,346 & 588,293 & 191,019 & 17,034 \\
\hline
\end{tabular}

\footnotetext{
${ }^{1}$ Includes Newfoundland, Prince Edward Island, Nova Scotia, and New Brunswick.

${ }^{2}$ Includes Manitoba, Saskatchewan, and Alberta.
}

Source: Manning, Glenn H., and H. Rae Grinnell. Forest resources and utilization in Canada to the year 2000. Canadiar Forestry Serv. Publ. 1304, 80 p. Ottawa, Ont. 1971. 
Table 108.-Merchantable timber in Canada on incentoried nonreserved forest land, by Province and by softwoods and hardwoods, $1968^{1}$

[Million cubic feet]

\begin{tabular}{|c|c|c|c|}
\hline Province & Total & $\begin{array}{l}\text { Soft- } \\
\text { woods }\end{array}$ & $\begin{array}{l}\text { Hard- } \\
\text { woods }\end{array}$ \\
\hline $\begin{array}{l}\text { British Columbia }{ }^{2} \\
\text { Prairie Provinces } \\
\text { Ontario } \\
\text { Quebec } \\
\text { Atlantic Provinces }\end{array}$ & $\begin{array}{r}268,635 \\
89,331 \\
111,423 \\
130,397 \\
29,612\end{array}$ & $\begin{array}{r}261,313 \\
55,923 \\
66,593 \\
96,954 \\
22,100\end{array}$ & $\begin{array}{r}7,322 \\
33,408 \\
44,830 \\
33,443 \\
7,512\end{array}$ \\
\hline Total & 629,398 & 502,883 & 126,515 \\
\hline
\end{tabular}

1 Includes 445 million acres of inventoried forest land. Excludes Labrador, Yukon, and Northwest Territories. 2 Mature timber volumes only.

Source: Manning, Glenn H., and H. Rae Grinnell. Forest resources and utilization in Canada to the year 2000. Dept. of the Environment, Canadian Forestry Serv. Publ. 1304,80 p. Ottawa, Ont. 1971.

decades, particularly following World War II. Between 1950 and 1971 annual production of lumber and paper and board roughly doubled (table 109). Output of plywood and reneer and of woodpulp climbed eren more rapidly.

These increases in output of industrial timber products hare been achiered with a much smaller rise in timber cut. Partly this has been due to a decline in fuelwood production. Partly it reflects a substantial improvement in timber utilization practices. In 1968, for example, 26 percent of the raw material used in Canadian pulp mills was wood chips and other residues, compared with only 2 percent in $1950 .^{6}$

\section{Production Potentials}

The 1970 timber cut of about 4.3 billion cubic feet in Canada was well below the calculated sustainable allowable cut of 10.7 billion cubic feet (table 110). Most of the unused Canadian timber is in the undereloped northern parts of the Canadian provinces where utilization will necessarily involve high development costs. Thus it appears unlikely that a significant portion of the unused allowable cut would be placed on the market at 1970 prices. Howerer, with June 1972 cost-price relationships for lumber and plywood, and somewhat higher prices for pulp and paper, the British Columbia Council of the Forest Industries has estimated that about 8 billion cubic feet of allowable cut would be economically arailable (table 110).

These and related projections of the Canadian Forestry Service indicated that by 2000 production of lumber, pulp, paper, and plywood could be substantially increased orer 1970 levels (table 111). These Canadian studies also indicate that

\footnotetext{
6 Manning, Glenn $H$. The utilization of wood residue in Canada. Canadian Forestry Serv., Forest Econ. Res. Inst. Ottawa. 1972.
}

TABLE 109.- Timber harvest and production of timber products in Canada, by major product, 1950-71

\begin{tabular}{|c|c|c|c|c|c|c|c|c|c|c|c|c|c|c|}
\hline \multirow[b]{2}{*}{ Year } & \multirow{2}{*}{$\begin{array}{c}\text { Total } \\
\text { timber } \\
\text { harvest }\end{array}$} & \multicolumn{3}{|c|}{ Lumber } & \multicolumn{3}{|c|}{ Plywood (1'y-inch basis) } & \multicolumn{3}{|c|}{ Veneer (3io-inch basis) } & \multicolumn{3}{|c|}{ Paper and board } & \multirow{2}{*}{$\begin{array}{l}\text { Wood- } \\
\text { pulp }\end{array}$} \\
\hline & & Total & $\begin{array}{l}\text { Soft- } \\
\text { wood }\end{array}$ & $\begin{array}{l}\text { Hard- } \\
\text { wood }\end{array}$ & Total & $\begin{array}{l}\text { Soft- } \\
\text { wood }\end{array}$ & $\begin{array}{l}\text { Hard- } \\
\text { wood }\end{array}$ & Total & $\begin{array}{l}\text { Soft- } \\
\text { wood }\end{array}$ & $\begin{array}{l}\text { Hard- } \\
\text { wood }\end{array}$ & Total & $\begin{array}{l}\text { News- } \\
\text { print }\end{array}$ & Other & \\
\hline $\begin{array}{l}1950 \ldots \ldots \\
1951 \ldots \ldots \\
1952 \ldots \ldots \\
1953 \ldots \ldots \\
1954 \ldots \ldots\end{array}$ & $\begin{array}{r}\text { Billion } \\
\text { cu. ft. } \\
\text { 3. } 0 \\
\text { 3. } 4 \\
\text { 3. } 2 \\
\text { 3. } 1 \\
\text { 3. } 1\end{array}$ & $\begin{array}{l}\text { Bulion } \\
\text { board } \\
\text { feet } \\
6.6 \\
6.9 \\
6.8 \\
7.3 \\
7.2\end{array}$ & $\begin{array}{r}\text { Billion } \\
\text { board } \\
\text { feet } \\
6.1 \\
6.4 \\
6.3 \\
6.8 \\
6.8\end{array}$ & $\begin{array}{l}\text { Bulion } \\
\text { board } \\
\text { feet } \\
0.5 \\
.5 \\
.5 \\
.5 \\
.4\end{array}$ & $\begin{array}{l}\text { Bullion } \\
\text { square } \\
\text { feet } \\
0.5 \\
.6 \\
.6 \\
.8 \\
.9\end{array}$ & $\begin{array}{l}\text { Billion } \\
\text { square } \\
\text { feet } \\
0.4 \\
.5 \\
.5 \\
.6 \\
.7\end{array}$ & $\begin{array}{l}\text { Billion } \\
\text { square } \\
\text { feet } \\
0.1 \\
.1 \\
.1 \\
.2 \\
.2\end{array}$ & $\begin{array}{l}\text { Billion } \\
\text { square } \\
\text { feet } \\
0.4 \\
.5 \\
.4 \\
.6 \\
.5\end{array}$ & $\begin{array}{c}\text { Billion } \\
\text { square } \\
\text { feet } \\
0.2 \\
.3 \\
.2 \\
.3 \\
.2\end{array}$ & $\begin{array}{r}\text { Billion } \\
\text { square } \\
\text { feet } \\
0.2 \\
.2 \\
.2 \\
.3 \\
.3\end{array}$ & $\begin{array}{r}\text { Million } \\
\text { tons } \\
6.8 \\
7.2 \\
7.2 \\
7.4 \\
7.7\end{array}$ & $\begin{array}{r}\text { Million } \\
\text { tons } \\
5.3 \\
5.5 \\
5.7 \\
5.8 \\
6.0\end{array}$ & $\begin{array}{r}\text { Million } \\
\text { tons } \\
1.5 \\
1.7 \\
1.5 \\
1.6 \\
1.7\end{array}$ & $\begin{array}{r}\text { Million } \\
\text { tons } \\
8.5 \\
9.3 \\
9.0 \\
9.1 \\
9.7\end{array}$ \\
\hline $\begin{array}{l}1955 \ldots . . \\
1956 \ldots \ldots \\
1957 \ldots \ldots \\
1958 \ldots \ldots \\
1959 \ldots \ldots\end{array}$ & $\begin{array}{l}3.3 \\
3.5 \\
3.2 \\
2.9 \\
3.2\end{array}$ & $\begin{array}{l}7.9 \\
7.7 \\
7.1 \\
7.2 \\
7.6\end{array}$ & $\begin{array}{l}7.5 \\
7.3 \\
6.7 \\
6.8 \\
7.2\end{array}$ & $\begin{array}{l}.4 \\
.4 \\
.4 \\
.4 \\
.4\end{array}$ & $\begin{array}{l}1.2 \\
1.3 \\
1.2 \\
1.5 \\
1.5\end{array}$ & $\begin{array}{l}1.0 \\
1.1 \\
1.1 \\
1.3 \\
1.2\end{array}$ & $\begin{array}{l}.2 \\
.2 \\
.1 \\
.2 \\
.3\end{array}$ & $\begin{array}{r}.6 \\
1.3 \\
.7 \\
.8 \\
.8\end{array}$ & $\begin{array}{r}.3 \\
1.1 \\
.5 \\
.6 \\
.6\end{array}$ & $\begin{array}{r}.3 \\
.2 \\
.2 \\
.2 \\
.2\end{array}$ & $\begin{array}{l}8.0 \\
8.5 \\
8.3 \\
8.1 \\
8.5\end{array}$ & $\begin{array}{r}6.2 \\
6.5 \\
6.4 \\
6.0 \\
6.3\end{array}$ & $\begin{array}{l}1.8 \\
2.0 \\
1.9 \\
2.1 \\
2.2\end{array}$ & $\begin{array}{l}10.2 \\
10.7 \\
10.4 \\
10.1 \\
10.8\end{array}$ \\
\hline $\begin{array}{l}1960 \ldots \\
1961 \ldots \ldots \\
1962 \ldots \ldots \\
1963 \ldots \ldots \\
1964 \ldots\end{array}$ & $\begin{array}{l}3.3 \\
3.2 \\
3.3 \\
3.5 \\
3.6\end{array}$ & $\begin{array}{r}8.0 \\
8.2 \\
8.8 \\
9.8 \\
10.3\end{array}$ & $\begin{array}{l}7.6 \\
7.8 \\
8.4 \\
9.4 \\
9.8\end{array}$ & $\begin{array}{l}.4 \\
.4 \\
.4 \\
.4 \\
.5\end{array}$ & $\begin{array}{l}1.6 \\
1.9 \\
2.0 \\
2.5 \\
2.6\end{array}$ & $\begin{array}{l}1.4 \\
1.6 \\
1.7 \\
2.1 \\
2.2\end{array}$ & $\begin{array}{l}.2 \\
.3 \\
.3 \\
.4 \\
.4\end{array}$ & $\begin{array}{r}.7 \\
.7 \\
.9 \\
1.1 \\
.9\end{array}$ & $\begin{array}{l}.5 \\
.5 \\
.6 \\
.8 \\
.6\end{array}$ & $\begin{array}{l}.2 \\
.2 \\
.3 \\
.3 \\
.3\end{array}$ & $\begin{array}{r}8.9 \\
9.1 \\
9.2 \\
9.3 \\
10.2\end{array}$ & $\begin{array}{l}6.7 \\
6.7 \\
6.7 \\
6.6 \\
7.4\end{array}$ & $\begin{array}{l}2.2 \\
2.4 \\
2.5 \\
2.7 \\
2.8\end{array}$ & $\begin{array}{l}11.5 \\
11.8 \\
12.1 \\
12.5 \\
13.7\end{array}$ \\
\hline $\begin{array}{l}1965 \ldots . . \\
1966 \ldots . \\
1967 \ldots \ldots \\
1968 \ldots \ldots \\
1969 \ldots . .\end{array}$ & $\begin{array}{l}3.7 \\
3.8 \\
3.8 \\
4.0 \\
4.3\end{array}$ & $\begin{array}{l}10.8 \\
10.6 \\
10.3 \\
11.4 \\
11.5\end{array}$ & $\begin{array}{r}10.3 \\
10.0 \\
9.7 \\
10.8 \\
11.0\end{array}$ & $\begin{array}{l}.5 \\
.6 \\
.6 \\
.6 \\
.5\end{array}$ & $\begin{array}{l}2.7 \\
3.0 \\
3.1 \\
3.3 \\
3.4\end{array}$ & $\begin{array}{l}2.3 \\
2.6 \\
2.7 \\
2.9 \\
3.0\end{array}$ & $\begin{array}{l}.4 \\
.4 \\
.4 \\
.4 \\
.4\end{array}$ & $\begin{array}{l}1.4 \\
1.9 \\
1.8 \\
1.9 \\
2.3\end{array}$ & $\begin{array}{l}1.0 \\
1.5 \\
1.4 \\
1.5 \\
1.9\end{array}$ & $\begin{array}{l}.4 \\
.4 \\
.4 \\
.4 \\
.4\end{array}$ & $\begin{array}{l}10.9 \\
11.9 \\
11.6 \\
11.8 \\
12.9\end{array}$ & $\begin{array}{l}7.8 \\
8.5 \\
8.2 \\
8.2 \\
8.9\end{array}$ & $\begin{array}{l}3.1 \\
3.4 \\
3.4 \\
3.6 \\
4.0\end{array}$ & $\begin{array}{l}14.6 \\
16.0 \\
15.9 \\
16.8 \\
18.6\end{array}$ \\
\hline $\begin{array}{l}1970 \ldots . . . \\
1971 \ldots .\end{array}$ & $\stackrel{4}{3}$ & $\begin{array}{l}11.3 \\
12.8\end{array}$ & $\begin{array}{l}10.8 \\
12.3\end{array}$ & $\begin{array}{l}.5 \\
.5\end{array}$ & $\begin{array}{l}3.1 \\
3.5\end{array}$ & $\begin{array}{l}2.8 \\
3.2\end{array}$ & $\begin{array}{l}.3 \\
.3\end{array}$ & $\begin{array}{l}2.2 \\
\mathrm{NA}\end{array}$ & $\begin{array}{r}1.9 \\
\text { NA }\end{array}$ & $\times 3$ & $\begin{array}{l}12.8 \\
12.4\end{array}$ & $\begin{array}{l}8.8 \\
8.3\end{array}$ & $\begin{array}{l}4.0 \\
4.1\end{array}$ & $\begin{array}{l}18.3 \\
17.9\end{array}$ \\
\hline
\end{tabular}

1 Excluding Labrador, Yukon, and Northwest Territorles.

Sources: 1950-68 (except woodpulp). Manning, Glenn H., and H. Rae Grinnell. Forest resources and utilization in Canada to the year 2000 . Dept. of the
Environment, Canadian Forestry Serv. Publ. 1304, 80 p. Ottawa, Ont. 1971. 1969-71 (except woodpulp). Statistics-Canada, Annual Census of ifantics. factures. 
TABLE 110.- Timber harvest in Canada, 1970, and estimated allowable annual timber cut, by Province ${ }^{1}$ [Million cubic feet]

\begin{tabular}{|c|c|c|c|c|c|c|c|c|c|}
\hline \multirow{3}{*}{ Region } & \multirow{2}{*}{\multicolumn{3}{|c|}{$\begin{array}{c}\text { Actual } 1970 \\
\text { production }\end{array}$}} & \multicolumn{6}{|c|}{ Annual allowable cut ${ }^{2}$} \\
\hline & & & & \multicolumn{3}{|c|}{ Gross physical } & \multicolumn{3}{|c|}{ Economic ${ }^{3}$} \\
\hline & Total & $\begin{array}{l}\text { Soft- } \\
\text { wood }\end{array}$ & $\begin{array}{l}\text { Hard- } \\
\text { wood }\end{array}$ & Total & $\begin{array}{l}\text { Soft- } \\
\text { wood }\end{array}$ & $\begin{array}{l}\text { Hard- } \\
\text { wood }\end{array}$ & Total & $\begin{array}{l}\text { Soft- } \\
\text { wood }\end{array}$ & $\begin{array}{l}\text { Hard- } \\
\text { wood }\end{array}$ \\
\hline $\begin{array}{l}\text { British Columbia. } \\
\text { Prairie Provinces. } \\
\text { Ontario } \\
\text { Quebec } \\
\text { Atlantic Provinces. }\end{array}$ & $\begin{array}{r}1,933 \\
275 \\
593 \\
1,021 \\
464\end{array}$ & $\begin{array}{r}1,922 \\
247 \\
468 \\
854 \\
416\end{array}$ & $\begin{array}{r}12 \\
28 \\
125 \\
167 \\
48\end{array}$ & $\begin{array}{r}3,351 \\
1,650 \\
2,626 \\
2,249 \\
866\end{array}$ & $\begin{array}{r}3,321 \\
1,040 \\
1,333 \\
1,837 \\
649\end{array}$ & $\begin{array}{r}30 \\
610 \\
1,293 \\
412 \\
217\end{array}$ & $\begin{array}{r}2,950 \\
1,155 \\
1,534 \\
1,592 \\
760\end{array}$ & $\begin{array}{r}2,935 \\
728 \\
718 \\
1,350 \\
570 \\
\end{array}$ & $\begin{array}{r}15 \\
427 \\
816 \\
242 \\
190\end{array}$ \\
\hline Total & 4,285 & 3,905 & 380 & 10,742 & 8,180 & 2,562 & 7,991 & 6,301 & 1,690 \\
\hline
\end{tabular}

${ }^{1}$ Excluding Labrador, Yukon, and Northwest Territories.

${ }^{2}$ On nonreserved inventoried public and private forest land (506.9 million acres). Some 272.4 million acres had not been inventoried in 1968. Three-quarters of this noninventoried acreage is located in Labrador, Yukon, and Northwest Territories. Includes timber on immature acreage in British Columbia.

${ }^{3}$ The annual allowable cut on acres physically accessible or becoming so which could be utilized under June 1972 cost price levels for lumber and plywood and somewhat improved prices for pulp and newsprint.

Sources: British Columbia Council of Forest Industries. Canada's forest resources and forest products potentials. Vancouver, B.C. 1972 .

Manning, Glenn H., and H. Rae Grinnell. Forest resources and utilization in Canada to the year 2000. Dept. of the Environment, Canadian Forestry Serv. Publ. 1304, 80 p. Ottawa, Ont. 1971.

TABLE 111.-Production of selected timber products in Canada, 1970, with projections to 2000

\begin{tabular}{|c|c|c|c|c|c|c|c|c|c|c|c|}
\hline \multirow[b]{2}{*}{ Year } & \multicolumn{3}{|c|}{ Lumber } & \multicolumn{3}{|c|}{ Plywood (3/8-inch basis) } & \multicolumn{3}{|c|}{ Paper and board } & \multirow{2}{*}{$\begin{array}{l}\text { Wood- } \\
\text { pulp }\end{array}$} & \multirow[b]{2}{*}{$\begin{array}{c}\text { Total } \\
\text { timber } \\
\text { cut }\end{array}$} \\
\hline & Total & $\begin{array}{l}\text { Soft- } \\
\text { wood }\end{array}$ & $\begin{array}{l}\text { Hard- } \\
\text { wood }\end{array}$ & Total & $\begin{array}{l}\text { Soft- } \\
\text { wood }\end{array}$ & $\begin{array}{l}\text { Hard- } \\
\text { wood }\end{array}$ & Total & $\begin{array}{l}\text { News- } \\
\text { print }\end{array}$ & Other & & \\
\hline $\begin{array}{l}1970 \ldots 0 \\
1980 \\
1990 \\
2000\end{array}$ & $\begin{array}{l}\text { Billion } \\
\text { board } \\
\text { feet } \\
11.3 \\
14.5 \\
17.4 \\
20.1\end{array}$ & $\begin{array}{c}\text { Billion } \\
\text { board } \\
\text { feet } \\
10.8 \\
13.8 \\
16.6 \\
19.3 \\
1(24.0)\end{array}$ & $\begin{array}{l}\begin{array}{l}\text { Billion } \\
\text { board } \\
\text { feet }\end{array} \\
0.5 \\
.7 \\
.8 \\
.9\end{array}$ & $\begin{array}{l}\begin{array}{l}\text { Billion } \\
\text { square } \\
\text { feet } \\
2.1 \\
4.3 \\
6.4 \\
8.8\end{array}\end{array}$ & 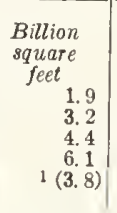 & $\begin{array}{l}\text { Billion } \\
\text { square } \\
\text { feet } \\
0.2 \\
1.1 \\
1.9 \\
2.6\end{array}$ & $\begin{array}{c}\text { Million } \\
\text { tons } \\
12.8 \\
16.9 \\
22.4 \\
27.4\end{array}$ & $\begin{array}{r}\text { Million } \\
\text { tons } \\
8.8 \\
10.8 \\
13.2 \\
15.3\end{array}$ & $\begin{array}{r}\text { Million } \\
\text { tons } \\
4.0 \\
6.2 \\
9.2 \\
12.1\end{array}$ & $\begin{array}{l}\text { Milion } \\
\text { tons } \\
18.3 \\
21.9 \\
28.5 \\
35.2\end{array}$ & $\begin{array}{r}\text { Billion } \\
\text { cu. ft. } \\
4.3 \\
5.4 \\
6.2 \\
9.1\end{array}$ \\
\hline
\end{tabular}

1 Numbers in parentheses are projections of softwood lumber and plywood production in 2000 prepared by the Council of Forest Industries of British Columbia. Canada's forest services and forest product pontentials.
June 1972 .

exports to the United States could be increased substantially.

Attainment of the total allowable cut in Canada, along with related exports of timber products to the United States will of course depend upon a number of economic and related factors. The remoteness and low-yield capability of some forest land, particularly in areas not yet allocated to timber production, may make it uneconomical to operate without substantial price increases. The fact that roughly a fourth of the allowable cut is aspen and other hardwoods, not as readily marketable as softwoods, may also slow development. Nevertheless, as the world timber supply situation becomes tighter, as seems likely, these less desirable resources may also become economically available.
Source: Manning, Glenn H., and H. Rao Grinnell. Forest resources and utilization in Canada to the year 2000 . Dept. of the Environment, Canadian Forestry Serv. Publ. 1304, 80 p. Ottawa, Ont. 1971.

It is also possible that additional areas of forest may be set aside in wilderness-type areas in Canada as in the United States. Many private lands in Canada, although of limited importance compared with public ownerships, may be held for nontimber purposes. A study in southwest Quebec, for example, showed that about a quarter of the owners did not reside on the land and were more interested in recreation and land speculation than in timber growing. ${ }^{\text {? }}$ U.S. experience also suggests that the acreage considered loggable may shrink to some degree in the years ahead as unstable lands and areas with difficult and costly

${ }^{7}$ Jones, A. R. C., and R. H. Lord. The private woodlot of southwest Quebec. Canadian Forestry Serv. Inf. Rpt. E-X-5. 1969 . 
regeneration problems or low productivity are identified and withdrawn from cutting.

Whether allowable cuts can be sustained in the longrun after virgin forests are liquidated also is an unanswered question that depends in large part on the level of forest management and protection in the coming decades.

\section{Utilization Trends}

As an offset to possible constraints on timber harresting, improvements in utilization may tend to increase arailability of timber products. British Columbia, for example, has been particularly successful in obtaining close utilization of much of the timber harrested, thus providing a basis for major expansion and sustained production of both lumber and pulp products. ${ }^{8}$.

New derelopments such as installation of chipping headrigs also appear likely to lead to increased production of lumber from eastern Canadian forests that have long been considered suitable and arailable only for pulpwood.

\section{Exports to the United States}

Since World War II, the United States has been Canada's principal timber export market. In 1972 nearly 9 billion board feet of Canadian lumber, or more than half of Canada's total lumber production, was shipped to the United States. The 10.4 million tons of pulp, paper, and paperboard exported to the United States in 1971 represented about six-tenths of Canada's total production.

Demands for timber products are growing rapidly in all countries of the world, however, including the major consuming and timber deficit countries of western Europe and Japan. Thus, competition for Canadian timber products could increase significantly in future years. Nonetheless, projections based on available studies and judgment point to a substantial increase in Canadian timber product exports to the United States. For example, with relative prices of lumber averaging 30 percent above 1970 , U.S. imports of softwood lumber have been estimated to rise to 12 billion board feet by 2000 . With relative prices of paper and board 10 percent above 1970, U.S. imports of pulpwood, pulp, papes and board-essentially all from Canada-are projected to rise to 2.2 billion cubic feet, roundwood equivalent, by 2000 .

\section{POTENTIAL SUPPLIES OF TROPICAL WOODS}

Tropical hardwood forests are important to the United States as sources of hardwood plywood, veneer, lumber, and logs, and as potential sources of pulp products. In the past about 70 percent of world timber trade in these hardwood timber products has originated in southeast Asia, with

${ }^{8}$ British Columbia Forest Service. Annual report, 1969. Victoria, B.C. 1970 . lesser amounts from Africa and from Canada and Latin America. This is in sharp contrast to the distribution of tropical timber resources.

Tropical forests are extensive and have a large capacity for timber growing but there are serious questions as to the ability of these forests to continue to supply high-quality timber products to world markets. ${ }^{9}$

Much of the tropical forest area is relatively inaccessible and development of timber resources is slow and expensive. Utilization of timber is also complicated by the great numbers of specios of widely different characteristics. In just one Amazon type, for example, 50 percent of the volume was found to be in 35 species, with the other 50 percent in more than 100 additional species. Such problems of hotorogeneity are less severe in Africa and least in southeast Asia but occur in all regions.

Determining the characteristics of the many different tropical hardwood species, and developing markets for them, are formidable tasks that have not yet been accomplished.

The problems of tropical forests are further complicated by the continuing search for agricultural land to accommodate rapidly expanding populations. In the Far East an estimated 21 million acres of tropical forest are reported to be cleared annually. In the Philippines, it was found that land clearing was destroying three times as much wood as was being logged for timber products. ${ }^{10}$ Similar expansion of agriculture is occurring in forest areas in Africa and Latin America. Studies in Indonesia also indicate that after allowances for agricultural development and reservations for watersheds, only 24 percent of the total forest area was considered suitable for permanent forest production. ${ }^{11}$

Much of the tropical forest, moreover, consists of low-quality stands with limited utility for timber production, and much land logged or cleared for agriculture reverts to such stands. It is possible that many presently commercial species will disappear in this process, and some ecologists are in fact describing the natural tropical rain forest as a nonrenewable resource.

Food and Agriculture Organization of the United Nations. Wood: World trends and prospects. Unasylva, Vol. 20(1-2), nos. 80-81, 136 p. 1966.

Rome. 1967. Timber trends and prospects in Africa. $90 \mathrm{p}$. Rome. 1967. Latin American timber trends and prospects. 117 p. New York. 1963

- Timbel trends and prospects in the Asia-Pacific Region. 224 p. Geneva. 1961.

10 Food and Agriculture Organization of the United Nations. Wood: World trends and prospects. Unasylva, Vol. 20(1-2), nos. 80-81, 136 p. 1966.

11 Payne, Burnett H., and David Nordwall. A review of certain aspects of the forestry program and organization in Indonesia. USDA Foreign Econ. Dev. Serv, and Forest Serv. cooperating with U.S. Agency for Int. Dev. 1971. 
Timber management of tropical forests also is limited, partly because of custom, lack of capital for forest replacement, and lack of knowledge concerning regenerative processes and cultural requirements of timber species in the tropical rain forest. ${ }^{12}$

Thus in the longer run there are serious questions as to whether the world can continue to draw heavily on the tropics for fine, high-quality logs. Utilization has tended to be highly selective, both as to species and sizes of trees cut, and supplies of such preferred timber are diminishing. In West Malaysia, for example, four-fifths of the forest resource available to wood-based plants which do not have timber concessions has been logged over at least once, and supplies of high-grade logs on the open market are in seriouśly short supply. ${ }^{13}$

The tropical wood industries are nevertheless still expanding and it seems likely that the output of hardwood logs, plywood, veneer, and lumber from natural forests of the Tropics will increase over the next few decades, particularly in Southeast Asia. Pringle, for example, has estimated that exports of hardwood products from the Tropics in 1985 will be about twice as high as in $1967 . .^{14}$ The projections for hardwood timber products therefore show sizable increases in imports of plywood and veneer, and some increases for lumber.

The United States has been importing small volumes of tropical hardwood timber products from Mexico, along with some softwood. Although these imports have been declining, Mexico has sufficient timber resources of both hardwoods and softwoods to support an increase in timber harvests and exports.

\section{POTENTIAL TIMBER SUPPLIES FROM TROPICAL AND SUBTROPICAL PLANTATIONS}

Plantations of softwoods and some hardwoods in tropical and subtropical areas can be expected to become increasingly important in the next few decades, particularly in supplying pulping and construction materials. Very high growth rates are being achieved by planting and cultivating fast-growing species of pines, eucalyptus, and other species. Both softwood pulpwood and saw logs of acceptable size can be produced in relatively short rotations.

Plantations in New Zealand, South Africa, and Latin America, for example, are supporting substantial production of pulp and lumber for local

12 Lamb, Bruce. Tropical American forest resources. Conference on Tropical Hardwoods Proc. New York State College of Forestry, Syracuse. 1969.

${ }^{13}$ Food and Agriculture Organization of the United Nations. The wood based industries of West Malaysia. FOD: SF/MAL 68/516, Tech. Rpt. 4. 1971.

${ }^{14}$ Pringle, S.L. World supply and demand of hardwoods. Conference on Tropical Hardwoods Proc. New York State College of Forestry, Syrcause, N.Y. 1969. markets and for export, and planting programs are being expanded in these and other countries. Availablility of capital has been a limiting factor in such expansion and major impacts on the world timber demand-supply situation, therefore, may not be felt for some time to come.

Teak plantations also are important in Indonesia and Burma, with a reported area in 1967 of about 2.5 million acres. ${ }^{15}$ Plantations offer no easy answer to increasing supplies of most preferred hardwood species as there is much yet to be learned about the establishment and management of such stands. But expansion of plantations could help offset declines in supplies of choice species from natural hardwood forests.

\section{POTENTIAL TIMBER SUPPLIES FROM THE USSR}

The Soviet Union has about one-third of the productive forests in the world-a greater forest area than North America and Europe combined. Also, most of the forest land in the USSR supports softwood timber.

Harvests of industrial roundwood in the USSR in 1967-69 amounted to 10.2 billion cubic feetabout 18 percent of the total world output (table 106). Exports of timber products in the same year amounted to some 1.1 billion cubic feet, roundwood equivalent. Lumber accounted for nearly half of these exports. Substantial volumes of logs also were exported to Japan and some pulpwood to European countries.

An estimated 737 million acres of forest land in the USSR have been classed as unsuitable for commercial use because of low sites or inoperable conditions. ${ }^{16}$ On approximately 800 million acres cutting has not reached harvest potentials. These are the acres that hold promise for achieving an estimated allowable harvest of roughly 18 billion cubic feet annually.

Population and timber industries are primarily concentrated in the southern and western parts of the USSR, and forests in these regions, amounting to an estimated 157 million acres. have been heavily overcut as a consequence. ${ }^{17}$ The bulk of unexploited forest resources now lies in northern Russia and Siberia.

The USSR has been engaged in a major effort to transfer timber harvests to timber surplus areas and to establish pulp, paper, lumber, and plywood plants close to new supply sources.

${ }^{15}$ Food and Agriculture Organization of the United Nations. Wood: World trends and prospects. FFHC Basic Study 16, 131 p. Rome. 1967.

${ }_{16}$ Solecki, J. S. Russia-China-Japan, economic growth, resources and forest industries. British Columbia Univ. Victoria, B. C. 1967.

${ }^{17}$ Algvere, Karl Viktor. Forest economy in the USSR. Studia Forestalia Suecica, Nr. 39. Royal College of Forestry, Stockholm, Sweden. 1966. 
This program has faced varied difficulties such as the long distances between forests and markets. In spite of remoteness of much forest land, low productivity of many sites, and newly recognized enrironmental questions, there are undoubtedly opportunities for large increases in timber harvests in the next sereral decades. Exports of lumber and $\operatorname{logs}$ are expected to continue to increase, although growing domestic needs and declining resource availability in European Russia may constrain this trade in the longer run.

Pulp and paper production in the Soviet Union has also grown rapidly during the past two decades, with almost all of this production being used domestically. The current low per capita consumption of paper products, and difficulties experienced in meeting planned production increases suggest that the Soriet Union is not likely to become a major supplier of pulp products to foreign markets for some time to come.

\section{A SUMMARY OF PROSPECTIVE TRENDS IN U.S. TIMBER IMPORTS AND EXPORTS}

In spite of growing world demands for timber products, it has been estimated in this study that potentials for increased harrests, especially in Canada and the tropical hardwood regions, are sufficient to provide significant increases in U.S. imports of timber products in the years immediately ahead. With prices areraging 30 percent above the 1970 level, for example, total projected imports rise from 2.9 billion cubic feet, roundwood equivalent, in 1972 to 4.7 billion cubic feet by the year 2000 (tables 112 and 113).

The largest increases in imports are expected in lumber and pulp and paper products from Canada. It also seems likely that the United States will draw somewhat more hearily on tropical forests for some time to come in spite of the uncertainties surrounding the long-term outlook.
Along with rising imports it also appears likely that exports of some U.S. timber products will increase somewhat as a result of expanding world markets (tables 112 and 113). Kraft pulp and paper products are expected to represent the bulk of increased exports. Some increases in exports of logs and chips also have been assumed, although it is of course possible that nonmarket factors outside the basic assumptions of this study might lead to restrictions on exports of these raw materials.

Looking some decades into the future, there are two possibilities that appear to be of particular importance in the long-run timber outlook:

- With the tightening of the timber supply situation that is in prospect, the United States will surely find it increasingly diffcult to supply wood products to other nations.

- Output of wood products in timber surplus countries may drop following the liquidation of accessible old-growth. In such case the United States may not be able to maintain the levels of timber imports temporarily achieved. Such possibilities could be deferred by development of forests in the USSR to supply more of the world timber market, by major expansion of plantations, and by greater use of the less desirable timber species in tropical forests. For the long run a question still remains, whether anticipated timber demands of the world can be supplied in the absence of a substantial improvement in forest management.

Projections of net timber imports developed under the assumptions of this study continue to rise over the next several decades and offer a partial solution to U.S. timber supply-demand problems. Other alternatives for increasing timber supplies from U.S. forests, and for obtaining closer utilization of arailable timber, also are of large importance in improring the timber outlook as indicated in other chapters of this report. 
TABLE 112.-Imports and exports of selected timber products, 1970-72, with projections under alternate price assumptions (medium projections of growth in population and economic activity) to 2000

IMPORTS

\begin{tabular}{|c|c|c|c|c|c|c|c|}
\hline \multirow{2}{*}{$\begin{array}{l}\text { Price assumption } \\
\text { and year }\end{array}$} & \multicolumn{2}{|c|}{ Lumber } & \multirow{2}{*}{$\begin{array}{l}\text { Hardwood } \\
\text { plywood }\end{array}$} & \multirow{2}{*}{ Pulp } & \multirow{2}{*}{$\begin{array}{l}\text { Paper and } \\
\text { board }\end{array}$} & \multicolumn{2}{|c|}{ Logs } \\
\hline & Softwoods & Hardwoods & & & & Softwoods & Hardwoods \\
\hline $\begin{array}{l}1970 \\
1971^{2} \\
1972^{2}-\ldots-10\end{array}$ & $\begin{array}{r}\text { Billion board feet, } \\
\text { lumber tally } \\
5.8 \\
7.2 \\
9.0\end{array}$ & $\begin{array}{r}\text { Billion board feet, } \\
\text { lumber tally } \\
0.3 \\
.4 \\
.4\end{array}$ & $\begin{array}{r}\text { Billion sguare } \\
\text { feet, } 3 \text {-inch basis } \\
2.0 \\
2.5 \\
3.2\end{array}$ & $\begin{array}{r}\text { Million tons } \\
3.5 \\
3.5 \\
2.7\end{array}$ & $\begin{array}{r}\text { Million tons } \\
7.2 \\
7.6 \\
7.9\end{array}$ & $\begin{array}{r}\text { Billion board feet, } \\
\text { International } \\
1 / 4 \text {-inch log rule } \\
0.1 \\
\text { (1) }\end{array}$ & $\begin{array}{l}\text { Billion board feet, } \\
\text { International } \\
1 / 4 \text {-inch log rule } \\
(1) \\
(1) \\
(1)\end{array}$ \\
\hline $\begin{array}{c}1970 \text { RELATIVE } \\
\text { PRICES }\end{array}$ & & & & & & & \\
\hline 1980 & $\begin{array}{l}\text { 7. } 0 \\
\text { 7. } 0 \\
\text { 7. } 0\end{array}$ & $\begin{array}{l}.4 \\
.4 \\
.4\end{array}$ & $\begin{array}{l}3.5 \\
3.5 \\
3.5\end{array}$ & $\begin{array}{l}\text { 4. } 0 \\
\text { 4. } 0 \\
\text { 4. } 0\end{array}$ & $\begin{array}{l}\text { 8. } 0 \\
8.0 \\
8.0\end{array}$ & $\begin{array}{l}.1 \\
.1 \\
.1\end{array}$ & $\begin{array}{r}0.1 \\
.1 \\
.1\end{array}$ \\
\hline $\begin{array}{c}\text { RISIING RELATIVE } \\
\text { PRICES }{ }^{3}\end{array}$ & & & & & & & \\
\hline $\begin{array}{l}1980 \\
1990 \\
2000\end{array}$ & $\begin{array}{r}9.5 \\
12.0 \\
13.0\end{array}$ & $\begin{array}{l}.5 \\
.7 \\
.9\end{array}$ & $\begin{array}{l}\text { 3. } 3 \\
\text { 3. } 9 \\
\text { 4. } 2\end{array}$ & $\begin{array}{l}6.0 \\
7.5 \\
8.5\end{array}$ & $\begin{array}{l}10.5 \\
12.5 \\
13.5\end{array}$ & $\begin{array}{l}.1 \\
.1 \\
.1\end{array}$ & $\begin{array}{l}.1 \\
.1 \\
.1\end{array}$ \\
\hline $\begin{array}{c}\text { RELATIVE PRICES } \\
\text { ABOVE } 1970 \\
\text { AVERA GES }\end{array}$ & & & & & & & \\
\hline $\begin{array}{l}1980 \\
1990 \\
2000\end{array}$ & $\begin{array}{l}10.5 \\
12.0 \\
12.0\end{array}$ & $\begin{array}{l}.6 \\
.6 \\
.6\end{array}$ & $\begin{array}{l}\text { 4. } 1 \\
\text { 4. } 2 \\
\text { 4. } 3\end{array}$ & $\begin{array}{l}\text { 6. } 0 \\
\text { 7. } 0 \\
\text { 7. } 5\end{array}$ & $\begin{array}{l}10.5 \\
11.5 \\
12.0\end{array}$ & $\begin{array}{l}.1 \\
.1 \\
.1\end{array}$ & $\begin{array}{l}1 \\
.1 \\
.1\end{array}$ \\
\hline
\end{tabular}

\begin{tabular}{|c|c|c|c|c|c|c|c|}
\hline \multicolumn{8}{|c|}{ EXPORTS } \\
\hline 1970 & $\begin{array}{l}1.2 \\
.9 \\
1.2\end{array}$ & $\begin{array}{l}1 \\
: 2 \\
3\end{array}$ & $\begin{array}{l}(8) \\
(8)\end{array}$ & $\begin{array}{l}\text { 3. } 1 \\
2.2 \\
2.2\end{array}$ & $\begin{array}{l}\text { 2. } 7 \\
\text { 3. } 0 \\
\text { 3. } 0\end{array}$ & $\begin{array}{l}\text { 3. } 4 \\
2.8 \\
\text { 3. } 8\end{array}$ & .1 \\
\hline $\begin{array}{l}1970 \text { RELATIVE } \\
\text { PRICES }\end{array}$ & & & & & & & \\
\hline 1980 & $\begin{array}{l}\text { 1. } 2 \\
\text { 1. } 2 \\
\text { 1. } 2\end{array}$ & $\begin{array}{l}1 \\
1 \\
1\end{array}$ & $\begin{array}{l}(8) \\
(5) \\
(8)\end{array}$ & $\begin{array}{l}3.5 \\
3.5 \\
3.5\end{array}$ & $\begin{array}{l}\text { 3. } 5 \\
\text { 3. } 5 \\
\text { 3. } 5\end{array}$ & $\begin{array}{l}\text { 4. } 5 \\
\text { 4. } 5 \\
4.5\end{array}$ & $\begin{array}{l}.1 \\
.1 \\
.1\end{array}$ \\
\hline $\begin{array}{l}\text { RISING RELATIVE } \\
\text { PRICES }^{3}\end{array}$ & & & & & & & \\
\hline 1980 & $\begin{array}{l}\text { 1. } 2 \\
\text { 1. } 2 \\
1.2\end{array}$ & $\begin{array}{l}1 \\
1 \\
1\end{array}$ & $\begin{array}{l}(8) \\
(5) \\
(5)\end{array}$ & $\begin{array}{l}\text { 3. } 5 \\
\text { 3. } 5 \\
\text { 3. } 5\end{array}$ & $\begin{array}{l}\text { 3. } 5 \\
\text { 3. } 5 \\
\text { 3. } 5\end{array}$ & $\begin{array}{l}4.5 \\
4.5 \\
4.5\end{array}$ & $\begin{array}{l}.1 \\
.1 \\
.1\end{array}$ \\
\hline $\begin{array}{c}\text { RELATIVE PRICES } \\
\text { ABOVE 1970 } \\
\text { AVERAGES }\end{array}$ & & & & & & & \\
\hline 1980 & $\begin{array}{l}\text { 1. } 2 \\
\text { 1. } 2 \\
\text { 1. } 2\end{array}$ & $\begin{array}{l}1 \\
1 \\
1\end{array}$ & $\begin{array}{l}(5) \\
(5) \\
(5)\end{array}$ & $\begin{array}{l}3.5 \\
3.5 \\
3.5\end{array}$ & $\begin{array}{l}\text { 3. } 5 \\
3.5 \\
3.5\end{array}$ & $\begin{array}{l}4.5 \\
4.5 \\
4.5\end{array}$ & $\begin{array}{l}1 \\
1 \\
1\end{array}$ \\
\hline
\end{tabular}

${ }^{1}$ Less than 50 million board feet.

2 Preliminary.

${ }^{3}$ Relative prices rising from 1970 trend levels as follows: lumber- 1.5 percent per year; plywood- 1.0 percent per year; and paper and board- 0.5 percent per year.

4 Relative prices of lumber and plywood- 30 percent, and paper and board-10 percent above their 1970 averages.
${ }^{5}$ Less than 500 million square feet.

Sources: 1970, 1971, and 1972-U.S. Department of Commerce, Bureau of the Census. U.S. Exports-schedule $B$, commodity and country. FT 410 (monthly); and U.S. imports-general and consumption, schedule $A$, commodity and country. FT 135 (monthly).

Projections: U.S. Department of Agriculture, Forest Service. 

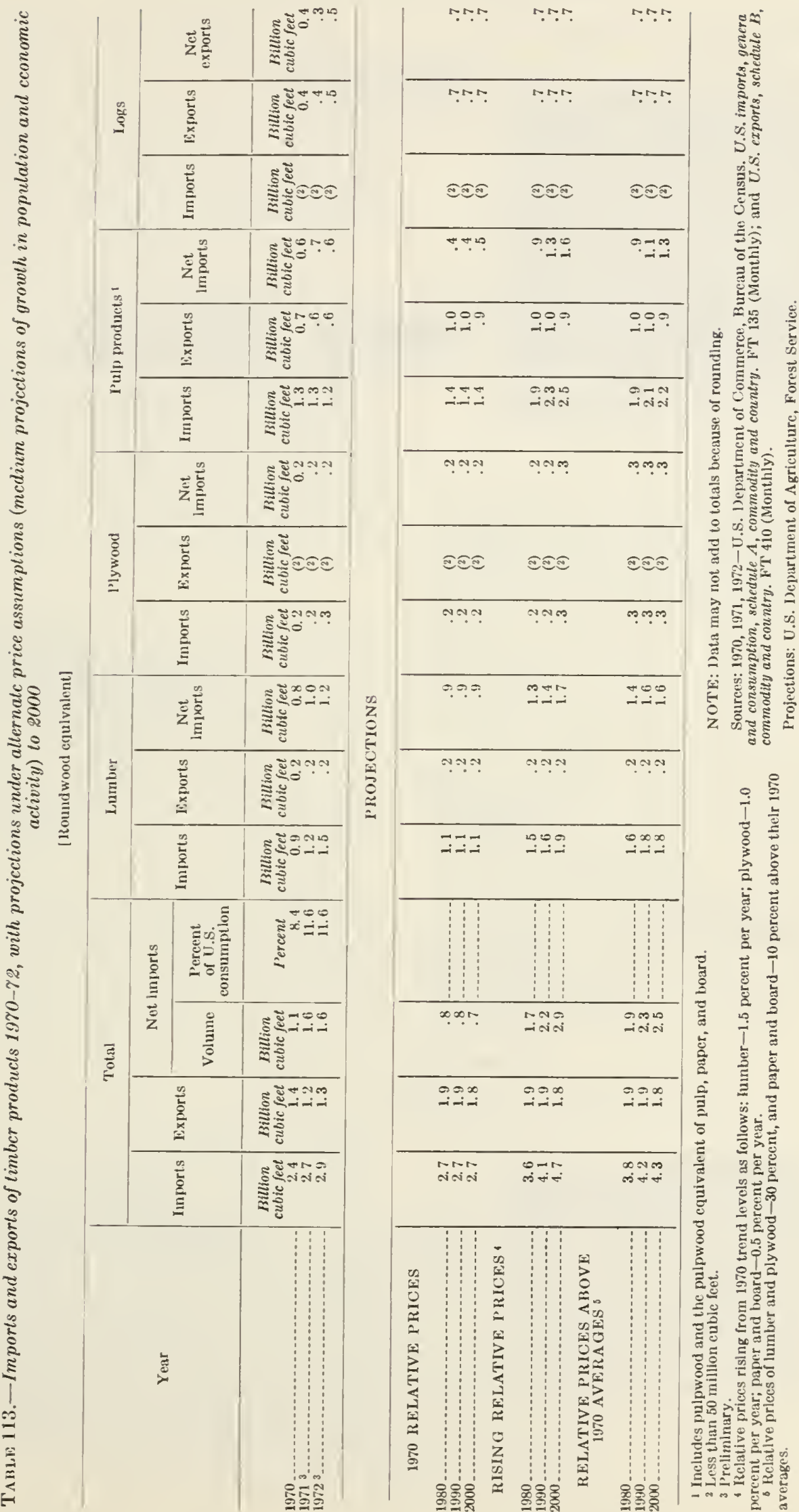


\section{CHAPTER V}

\section{DEMAND FOR TIMBER PRODUCTS}
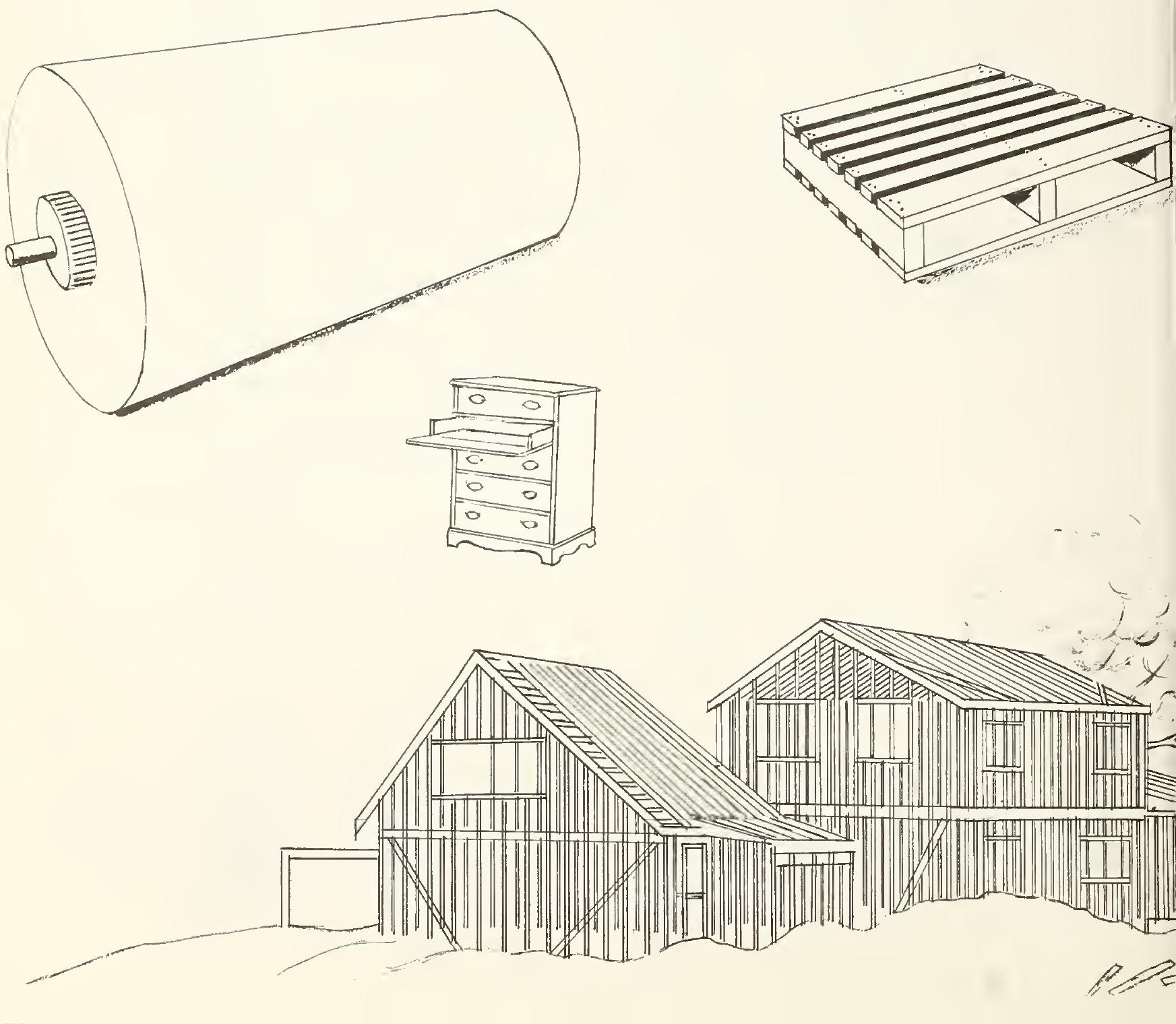
This chapter presents information on recent trends in consumption of timber products, together with projections of potential demands to the year 2000 .

The projections of demand indicate the volumes of timber products likely to be consumed under specified or implied assumptions on population and economic growth, technological and institutional changes, and trends in prices of timber products relative to the general price level and to most competitive materials. ${ }^{1}$

\section{BASIC ASSUMPTIONS}

In partial recognition of uncertainty, projections of timber demand have been prepared using three alternative assumptions on population and economic growth. The medium projections of demand have also been presented under three alternative price assumptions. Development of these alternatire projections was designed to aid in the evaluation of timber demand-supplyprice relationships in the last chapter of this report.

\section{Population Assumptions}

Changes in population have an important effect on the demand for many products such as houses, furniture, and paper. Population changes also influence the size of the labor force, a major determinant of the level of economic activity and related materials usage.

During the five decades 1920-70, the population of the United States increased by nearly 100 million persons, rising at an average annual rate of 1.3 percent (table 114, fig. 49 ; Append. V, table 1).

Recent projections of the Bureau of the Census ${ }^{2}$ indicate that population is likely to continue to grow fairly rapidly through the projection period. The medium projection used in this study shows population rising to 281 million in 2000 (table 114, fig. 49)-slightly above the median of the series of projections published by the Bureau of the Census in its 1972 report. The annual rate

For a more complete discussion of the nature and meaning of longrun projections of demand for timber products, problems involved in making projections, principal determinants of demand, models for making projections, and uses of projections, see Folia Forestalis 101. Forecasting in forestry and timber economy, preliminary report. IUFRO, Section 31, Working Group 4. 49 p. Metsantukimullaitos, Institutum Forestale Fenniae, Helsinki, Finland. 1971.

${ }^{2}$ U.S. Department of Commerce, Bureau of the Census. Projections of the population of the United States, by age and sex (interim revisions): 1970 to 2020. Cur. Pop. Reps. Ser. P-25, No. 448,50 p. 1970.

Projections of the population of the United States, by age and sex: 1970 to 2020. Cur. Pop. Reps. Ser. P-25, No. 470,56 p. 1971.

- Projections of the population of the United States, by age and sex: 1972 to 2020. Cur. Pop. Reps. Ser. P-25, No. 493, 26 p. 1972.
Population 1920 - 70, with projections to 2000

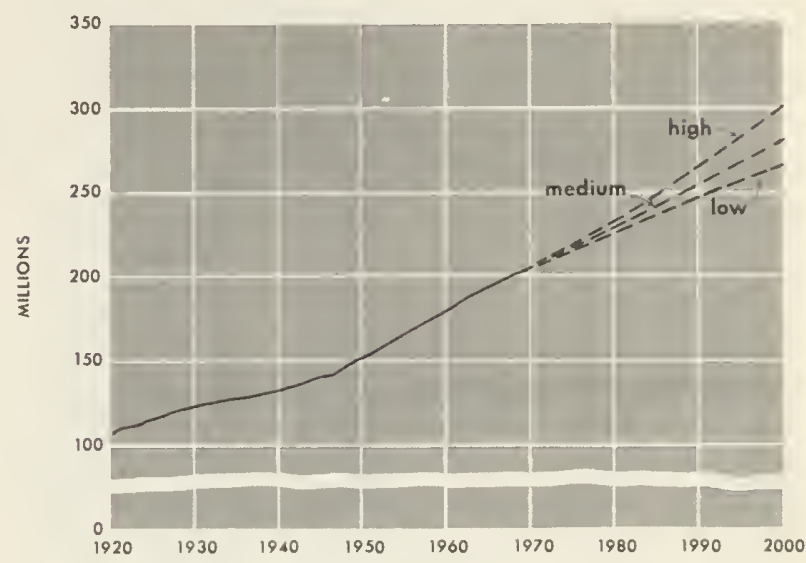

Figure 49

of population growth represented by this projection gradually declines from 1.1 percent in the 1970 's to 1.0 percent in the 1990 's.

Projections of population shown in table 114 are substantially lower than similar Census projections made in $1964^{3}$ and used in the preceding appraisal of the timber situation made by the Forest Service." The medium projection in the 1964 Census report, for example, indicated a population of 326 million in 2000 .

Fertility rates.-The revised population series used in this study reflect significant reductions in Census Bureau assumptions regarding future fertility rates. There have been large fluctuations in fertility rates in recent decades, as illustrate d in figure 50 , but since the late 1950 's the trend

${ }^{3}$ U.S. Department of Commerce, Bureau of the Census. Projections of the population of the United States, by age and sex: 1964 to 1985 with extensions to 2010. Cur. Pop. Reps. Ser. P-25, No. 286. 1964.

4 U.S. Department of Agriculture, Forest Service. Timber trends in the United States. Forest Resource Rep. 17, 235 p. 1965.

\section{Total fertility rates $1920-68$, with projections to 2000}

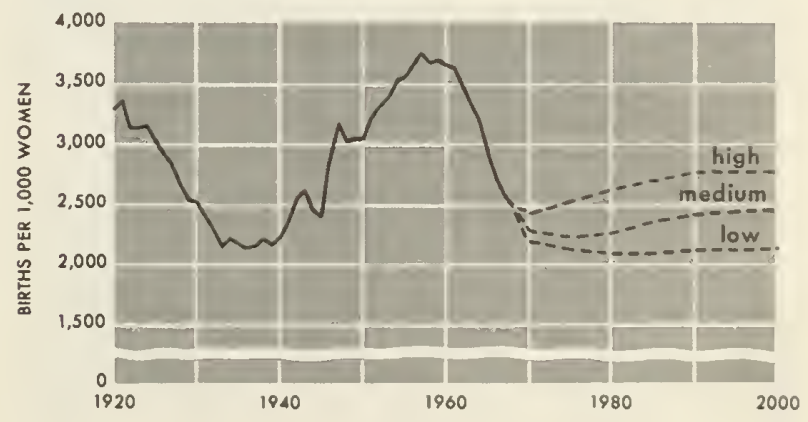

Figure 50 
TABLE 114.-Measures of population and economic growth, selected years 1920-72, with projections to 2000

\begin{tabular}{|c|c|c|c|c|c|c|c|c|c|c|c|c|}
\hline \multirow{6}{*}{$\begin{array}{l}\text { Year } \\
1920 \ldots \ldots \\
1925 \ldots \\
1930 \ldots \\
1940 \ldots\end{array}$} & \multicolumn{2}{|c|}{ Population } & \multicolumn{2}{|c|}{$\begin{array}{l}\text { Gross national } \\
\text { product } 1\end{array}$} & \multicolumn{2}{|c|}{$\begin{array}{l}\text { Per capita gross } \\
\text { national product }\end{array}$} & \multicolumn{2}{|c|}{$\begin{array}{l}\text { Disposable personal } \\
\text { income }\end{array}$} & \multicolumn{2}{|c|}{$\begin{array}{l}\text { Per capita disposable } \\
\text { personal income }\end{array}$} & \multicolumn{2}{|c|}{$\begin{array}{c}\text { Index of manufacturing } \\
\text { production }\end{array}$} \\
\hline & $\begin{array}{r}\text { Millions } \\
106.5\end{array}$ & $\begin{array}{c}\text { Annual } \\
\text { rate of } \\
\text { increase }\end{array}$ & $\begin{array}{l}\text { Billions } \\
\text { of } 1967 \\
\text { dollars } \\
160.5\end{array}$ & $\begin{array}{l}\text { Annual } \\
\text { rate of } \\
\text { increase }\end{array}$ & $\begin{array}{l}1967 \\
\text { dollars } \\
\quad 1,507\end{array}$ & $\begin{array}{c}\text { Annual } \\
\text { rate of } \\
\text { increase }\end{array}$ & $\begin{array}{l}\text { Billions } \\
\text { of } 1967 \\
\text { dollars }\end{array}$ & $\begin{array}{c}\text { Annual } \\
\text { rate of } \\
\text { increase }\end{array}$ & $\begin{array}{c}196 \% \\
\text { dollars }\end{array}$ & $\begin{array}{l}\text { Annual } \\
\text { rate of } \\
\text { increase }\end{array}$ & $\begin{array}{r}1967=100 \\
16.2\end{array}$ & $\begin{array}{l}\text { Annual } \\
\text { rate of } \\
\text { increase }\end{array}$ \\
\hline & 115.8 & 1.7 & 201.8 & 3.2 & 1,743 & 3.0 & . & (-n. & - & (n........ & 19.8 & 4.1 \\
\hline & 123.2 & 1.2 & 215.8 & 1. 4 & 1,752 & .1 & 159.1 & - & 1,391 & $-2-10-2=0$ & 18.7 & -1.1 \\
\hline & 127.4 & .7 & 199.3 & -1.6 & 1,564 & -2.3 & 150.8 & -1.1 & 1,184 & -1.7 & 18.0 & -.8 \\
\hline & 132.6 & & 267.1 & 3. 3 & 2,014 & 5.2 & 190.3 & 4.8 & 1,435 & 3.9 & 25.4 & 7.1 \\
\hline $1945 \ldots . . .$. & 140.5 & 1. 2 & 417.6 & 3.5 & 2,972 & 8.1 & 262.8 & 6.7 & 1,870 & 5.4 & 42.6 & 10.9 \\
\hline $1950 \ldots . . .$. & 152.3 & 1.6 & 417.8 & .1 & 2,743 & -1.6 & 285.6 & 1.7 & 1,875 & .1 & 45.0 & 1.1 \\
\hline 1955 & 165.9 & 1. 7 & 515. 0 & 4. 3 & 3,104 & 2.5 & 339.4 & 3.5 & 2,046 & 1.8 & 58. 2 & 5.3 \\
\hline $1960 \ldots \ldots . . .$. & 180.7 & 1.7 & 573. 4 & 2.2 & 3,173 & .4 & 389.2 & 2.8 & 2,154 & 1.0 & 65.4 & 2.4 \\
\hline $1965 \ldots \ldots$ & 194.3 & 1.5 & 726.4 & 4.8 & 3,739 & 3.3 & 497.7 & 5.0 & 2,562 & 3.5 & 89.1 & 6.4 \\
\hline $1966 \ldots \ldots . . .$. & 196.6 & 1.2 & 773.8 & 6.5 & 3,936 & 5.3 & 525.0 & 5.5 & 2,670 & 4. 3 & 98.3 & 10.3 \\
\hline $1967 \ldots \ldots . .$. & 198. 7 & 1.1 & 793. 9 & 2.6 & 3,995 & 1.5 & 546.3 & 4. 0 & 2,749 & 3.0 & 100.0 & 1. 7 \\
\hline $1968 \ldots \ldots \ldots$ & 200.7 & 1. 0 & 830.8 & 4.7 & 4,140 & 3.6 & 570.8 & 4.5 & 2,844 & 3.4 & 105. 7 & 5.7 \\
\hline & 202.7 & 1.0 & 853.2 & 2.7 & 4,209 & 1.7 & 587.6 & 2.9 & 2,899 & 1.9 & 110.5 & 4.5 \\
\hline $1970 \ldots . . . .$. & 204.9 & 1,1 & 849.0 & -.5 & 4,143 & -1.5 & 610.0 & 3.8 & 2,977 & 2.7 & 106.6 & -3.7 \\
\hline $1971 \ldots . . . .$. & 207.0 & 1.1 & 872.1 & 2.7 & 4,213 & 1.6 & 634.6 & 4. 0 & 3,066 & 2.9 & 106.8 & .2 \\
\hline $1972 \ldots \ldots$ & 208.8 & .9 & 928.3 & 6.4 & 4,446 & 5.5 & 662.0 & 4.3 & 3,170 & 3.4 & 114.4 & 7.1 \\
\hline
\end{tabular}

Low projections

\begin{tabular}{|c|c|c|c|c|c|c|c|c|c|c|c|c|}
\hline $\begin{array}{l}1980 \ldots \ldots \\
1990 \ldots \ldots \\
2000 \ldots \ldots\end{array}$ & $\begin{array}{l}226 \\
248 \\
266\end{array}$ & $\begin{array}{r}1.0 \\
.9 \\
.7\end{array}$ & $\begin{array}{r}1,240 \\
1,750 \\
\cdot 2,480\end{array}$ & $\begin{array}{l}3.5 \\
3.5 \\
3.5\end{array}$ & $\begin{array}{l}5,500 \\
7,080 \\
9,310\end{array}$ & $\begin{array}{l}2.5 \\
2.5 \\
2.8\end{array}$ & $\begin{array}{r}850 \\
1,190 \\
1,680\end{array}$ & $\begin{array}{l}3.5 \\
3.5 \\
3.5\end{array}$ & $\begin{array}{l}3,740 \\
4,810 \\
6,330\end{array}$ & $\begin{array}{l}2.5 \\
2.6 \\
2.8\end{array}$ & $\begin{array}{l}150 \\
210 \\
290\end{array}$ & $\begin{array}{l}3.5 \\
3.4 \\
3.3\end{array}$ \\
\hline
\end{tabular}

Medium projections

\begin{tabular}{|c|c|c|c|c|c|c|c|c|c|c|c|c|}
\hline $\begin{array}{l}1980 \ldots \ldots \ldots \\
1990 \ldots \ldots \ldots \\
2000 \ldots \ldots \ldots\end{array}$ & $\begin{array}{l}228 \\
255 \\
281\end{array}$ & $\begin{array}{l}1.1 \\
1.1 \\
1.0\end{array}$ & $\begin{array}{l}1,310 \\
1,930 \\
2,860\end{array}$ & $\begin{array}{l}4.0 \\
\text { 4. } 0 \\
\text { 4. } 0\end{array}$ & $\begin{array}{r}5,730 \\
7,580 \\
10,180\end{array}$ & $\begin{array}{l}2.9 \\
2.8 \\
3.0\end{array}$ & $\begin{array}{r}890 \\
1,310 \\
1,950\end{array}$ & $\begin{array}{l}4.0 \\
4.0 \\
4.0\end{array}$ & $\begin{array}{l}3,890 \\
5,160 \\
6,930\end{array}$ & $\begin{array}{l}2.9 \\
2.8 \\
3.0\end{array}$ & $\begin{array}{l}160 \\
230 \\
340\end{array}$ & $\begin{array}{l}4.1 \\
4.0 \\
3.9\end{array}$ \\
\hline
\end{tabular}

High profections

\begin{tabular}{|c|c|c|c|c|c|c|c|c|c|c|c|c|}
\hline $\begin{array}{l}1980 \ldots \ldots \\
1990 \ldots \ldots \\
2000 \ldots \ldots\end{array}$ & $\begin{array}{l}232 \\
266 \\
301\end{array}$ & $\begin{array}{l}1.3 \\
1.4 \\
1.2\end{array}$ & $\begin{array}{l}1,370 \\
2,130 \\
3,300\end{array}$ & $\begin{array}{l}4.5 \\
4.5 \\
4.5\end{array}$ & $\begin{array}{r}5,910 \\
8,000 \\
10,970\end{array}$ & $\begin{array}{l}3.2 \\
3.1 \\
3.2\end{array}$ & $\begin{array}{r}930 \\
1,450 \\
2,250\end{array}$ & $\begin{array}{l}4.5 \\
4.5 \\
4.5\end{array}$ & $\begin{array}{l}4,020 \\
5,440 \\
7,470\end{array}$ & $\begin{array}{l}3.2 \\
3.1 \\
3.2\end{array}$ & $\begin{array}{l}170 \\
260 \\
410\end{array}$ & $\begin{array}{l}4.7 \\
4.6 \\
4.5\end{array}$ \\
\hline
\end{tabular}

1 The 1970 trend level for the gross national product ( $\$ 882$ billion) and disposable personal income ( $\$ 600$ billion) were used as the base for calculating the projected values.

NOTE: Annual rates of increase are calculated for 5-year periods from 1920 through 1965, for 1-year periods 1965 through 1972, and for 10-year perlods 1970 through 2000.

Sources: Population, U.S. Department of Commerce, Bureau of the Census. 1920-45-Population estimates and projections. Cur. Pop. Reps. Ser. P-25, No. 442. 1970; 1950-70-Estimates of the population of the United States to December 1, 1971 . Cur. Pop. Reps. Ser. P-25, No. 474.1972; 1971-72-Estimates of the population of the United States to January 1, 1979. Cur. Pop. Reps. Ser. P-25. No. 496. 1973; 1980-2000-Profections of the population of the United States, by age and sex (interim revisions): 1970 to 2020. Cur. Pop. Reps. Ser. P-25, No. 448. 1970 .

has fallen sharply. ${ }^{5}$ The prevailing fertility rate in the period 1968-70 would result in a population close to the medium projection used in this study. The much lower fertility rates of 1971 and 1972 , would result in a population less than the low projection shown in figure 49.

Immigration.-The allowance for immigration, in the Census Bureau projections of future population growth averages 400,000 net immigrants

${ }^{\circ}$ These fertility rates indicate the number of births per 1000 women during their child bearing years. For a more detailed technical definition, see U.S. Department of Health, Education, and Welfare; Public Health Service. Natality Statistics Analysis United States, 1965-67. National Center for Health Statistics, Ser. 21, No. 19, 38 p. 1970.
Gross national product and per capita gross national product derived from data published in the following sources: 1920-25-U.S. Congress, Joint Com. mittee on the Economic Report. Potential econmic growth of the United States during the next decade. 83rd Cong., 2d sess. 1954; $1930-67$ and 1968-71U.S. Department of Commerce, Social and Economic Statistics, Bureau of Economic Analysis. Survey of current business. 52(7). July 1972; 1930-72Council of Economic Advisers. Economic re port of the President. January 1973. Disposable personal income and per capita disposable personal income derived from data published in the following source: 1930-72-Council of Economic Advisers. Economic report of the President. January 1973.

Index of Anufacturing production derived from data published in the Index of manufacturing production derived from data published in the
following sources: 1920-25-Federal Reserve System. Industrial production $195 \%-1959$ base. 1962; 1930-70-Council of Economic Advisers. Economic report of the President. January 1972;1971-72-U.S Department of Commerce, Social and Economic Statistics. Buresis of Fimnnmic Analysis. Survey of current business. 53(3). March 1973.

per year between 1970 and 2000-a significant part of the total population growth in the medium projection. Reductions in immigration, and thus in projected population growth, could result from mounting national concern about population size and environmental impacts.

\section{Gross National Product Assumptions}

Changes in the consumption of many timber products, as well as other industrial materials, have been closely associated in recent decades with changes in the Nation's gross national product, i.e., the value of all goods and services produced. In developing a number of the timber product projections shown in this chapter, pro- 
Gross national product $1920-70$,

with projections to 2000

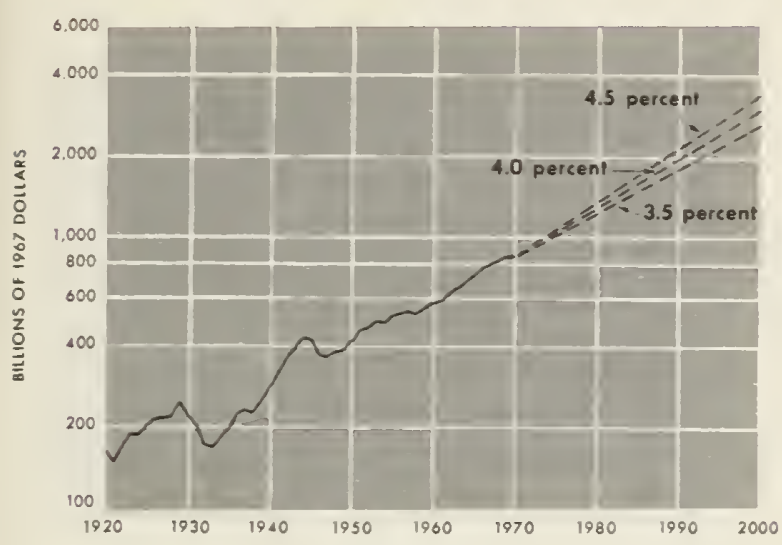

Figure 51

jected changes in the gross national product have been used as a principal indicator of changes in demand.

Between 1920 and 1970, the gross national product, measured in constant 1967 dollars, increased more than fire times-rising at an arerage annual rate of 3.4 percent (table 114, fig. 51; Append. $\mathrm{V}$, table 1). Annual changes hare fluctuated widely, from as much as +16.1 percent to -14.8 percent (fig. 52). The highest sustained rates of growth in gross national product occurred in the 1960 's, when growth areraged 4.5 percent per year.

The wide fluctuations in annual rates of growth in the gross national product have reflected such factors as differences in the rates of change in labor force, rates of unemployment, hours worked per year, and productivity. Cyclical factors will presumably continue to cause fluctuations in gross national product in the years ahead. But for this study only trends in growth were considered, using three different rates of growth: 3.5 percent, 4.0 percent, and 4.5 percent.

\section{Annual percentage change in gross national product $1920-70$}

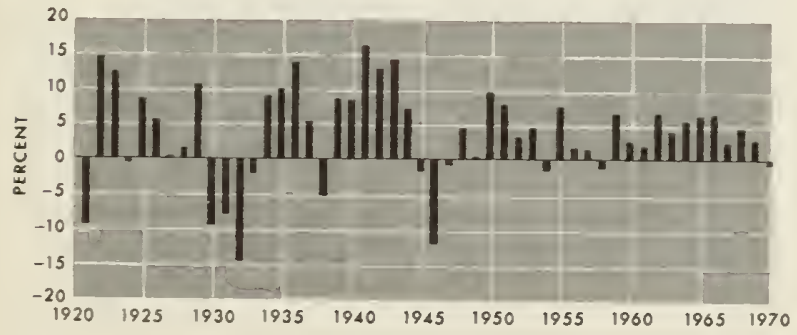

Figure 52
Basis for gross national product projections.These differences in assumed growth rates for gross national product partly reflect the different assumptions on population growth and the related size of the labor force. Thus, the highest rate of growth in gross national product is associated with the high projection of population. Howerer, most of the difference in projected rates is due to underlying assumptions on trends in productivity of the labor force.

Given a continuation of recent trends in labor force participation rates and hours worked per year, and an unemployment rate of 4 percent, the implied rates of increase in productivity in the private economy underlying the gross national product projections are about 3.0 percent, 3.4 percent, and 3.8 percent respectively. In the 1960 's productivity in the private economy increased about 3.6 percent per year.

The medium assumed rate of growth would result in a gross national product of $\$ 1,310$ billion in 1980-some 54 percent above that of 1970 (table 114). By 2000 this projection would reach $\$ 2,860$ billion-some 3.4 times that of 1970 . The associated projection of per capita gross national product in 2000 rises to $\$ 10,180$-nearly 2.5 times the 1970 arerage.

The projections of gross national product used in this study are substantially higher than those used in earlier appraisals of the timber situation by the Forest Service. For example, the medium projection of gross national product in 1980 is about 15 percent above that used in the preceding timber appraisal published in $1965 .{ }^{6}$ However, it is close to recent projections made by the Bureau of Labor Statistics, ${ }^{7}$ the National Planning Association, ${ }^{8}$ and the National Industrial Conference Board. ${ }^{9}$

Disposable personal income.-This measure of income available for spending or saving by the Nation's population is another important indicator of the demand for certain products such as furniture and various grades of paper and board. It also has a significant influence on household formation and size of dwellings.

Since 1950, disposable personal income has equaled about 68 percent of the gross national product. This historical and rather constant relationship was assumed to continue through the projection period (table 114).

- Op. cit. Timber trends in the United States.

7 U.S. Department of Labor, Bureau of Labor Statistics. Patterns of U.S. economic growth. Bull. 1672. 1970.

${ }^{8}$ National Planning Association. The technique of long-range economic projections. Projection Highlights, Vol. 1, No. 5. Washington, D.C. 1970.

- The U.S. economy in the coming decade. Projection Highlights, Vol. 2, No. 10. Washington, D.C. 1972.

- National Industrial Conference Board. Economic growth in the seventies. Washington, D.C. 1970. 
Manufacturing activity.-Future changes in manufacturing-a major wood-using sector of the U.S. economy-will also be important in determining the demand for some timber products. In the past several decades the index of manufacturing production published by the Federal Reserve Board, ${ }^{10}$ has shown a fairly consistent upward trend, and close relationship to changes in the gross national product (figs. 53 and 54).

The medium projections based on the historical trends and relationships show an increase in manufacturing production by 2000 to about 3.2 times the 1970 level.

Rates of growth in projections of manufacturing production, and in construction activity discussed later in this chapter, decline over the projection period. Transportation, trade, and other services account for a growing share of the projected gross national product, as in the past. In the period 1950-68, for example, the portion of the gross national product originating in these sectors rose from 46.5 to 49.6 percent.

The projections of manufacturing activity and construction adopted in this study rest on the assumption that the U.S. economy will contirute to be oriented largely to production of economic goods, and that adequate supplies of raw materials and energy sources will be available to support such sustained growth over the next three decades.

Both of these assumptions are being increasingly challenged, ${ }^{11}$ and for the longrun it is difficult to conceive of an indefinite continuation of high geometric growth rates. Also, concern over environmental factors could affect the types of goods produced, rates of productivity in manufacturing, and rates of increase in gross national product. For the projection period used in this study, however, it was assumed that the economic growth assumptions adopted provide an acceptable basis for evaluation of potential timber demands.

\section{Technological and Institutional Assumptions}

Institutional and technological changes in the U.S. economy have substantially influenced use of different raw materials. Some of these changes such as increasing urbanization, with resulting impacts on building heights and fire codes, for example, have led to partial displacement of timber products in construction. Technological developments in

10 Federal Reserve Board. Federal Reserve Bulletin. Washington, D.C. Monthly. This index measures changes in the physical volume or quantity of output in manufacturing industries.

11 See for example: Commoner, Barry. The closing circle. Alfred A. Knopf. 1971; Meadows, Donella H., Dennis L. Meadows, Jorgen Randus, and William W. Behrens. The limits of growth. Universe Books, New York. 1972.
Index of manufacturing production 1920 - 70, with projections to 2000

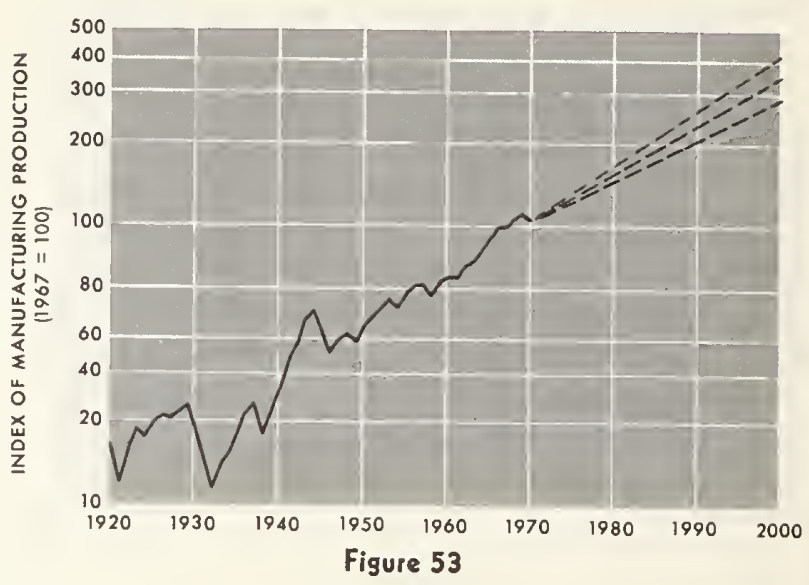

Index of manufacturing production in relation to gross national product, $1920-70$

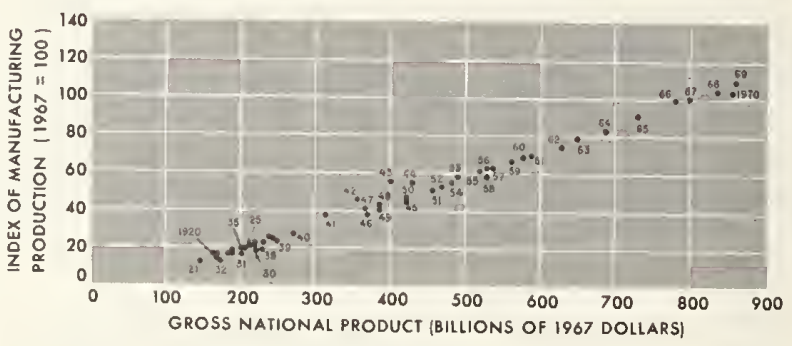

Figure 54

industries producing metals and plastics have also resulted in displacement of lumber and plywood in products such as furniture and containers.

On the other hand, new technology has simultaneously led to large increases in the use of lumber in pallets, greater use of plywood in construction, and use of pulp and paper, plywood, hardboard, and particleboard in a wide assortment of end uses.

In the following sections of this chapter, projections of demand for some products such as furniture have been adjusted for specific technological changes that appear to be in prospect. For other products, such as pulp and paper, use of historical data as a base for projections implicitly assumes a continuing stream of technological and institutional changes such as have occurred in the past, as well as other variables such as educational levels, capital availability, and military activities. 


\section{Price Assumptions}

Past increases in timber product prices have undoubtedly played an important role in determining levels of comsumption of timber products, both in actual terms and relative to competing materials. A number of closely related factors such as installation and maintenance costs, performance, useful life, and market promotion efforts have likerise affected actual and relative use.

To determine potential effects of alternative price levels, the medium projections of demand for major timber products were developed using three price assumptions, as follows:

(1) One set of projections was developed on the assumption that 1970 prices of timber products relative to average wholesale prices of all commodities and to most competing materials would not change significantly during the projection period. These were the price relationships prevailing during most of the 1950's and 1960's when most of the basic data on timber products use were compiled for this study. The 1970 prices were also intended as a base level for judging the size of price changes resulting from potential imbalances between timber demand and supply.

The 1970 price relationships could be expected to prevail only if supplies of stumpage meet demands at 1970 prices through the projection period-which later analyses indicate is not likely-and if productivity in the timber processing industries keeps pace with that in other industries.

In the past these conditions have not held for periods longer than a decade or two, and prices of most timber products have shown persistent longrun upward trends relative to the general price level (figs. 55, 56, and 57; Append. V, tables 2, 3, and 4). Timber product prices have also shown longrun upward trends relative to important com-

\section{Relative wholesale price index of lumber} $1800-1972$, with projections to 2000

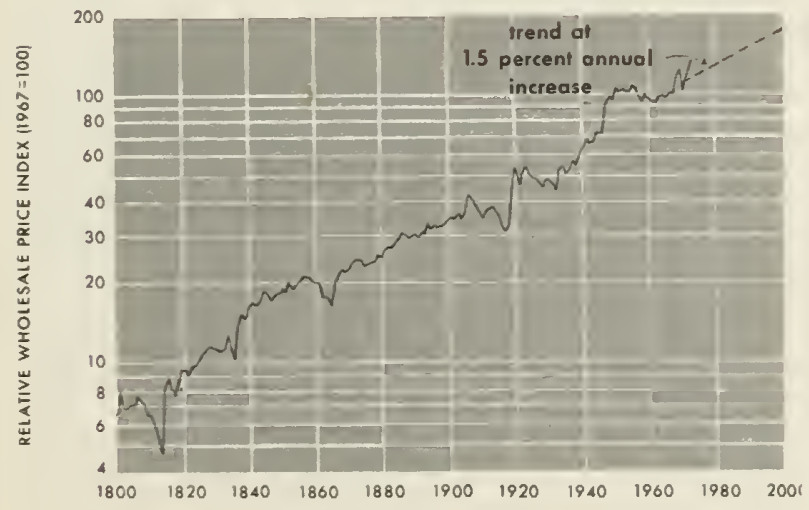

Figure 55
Relative wholesale price indexes of selected timber products 1940-72, and price assumptions 1970-2000
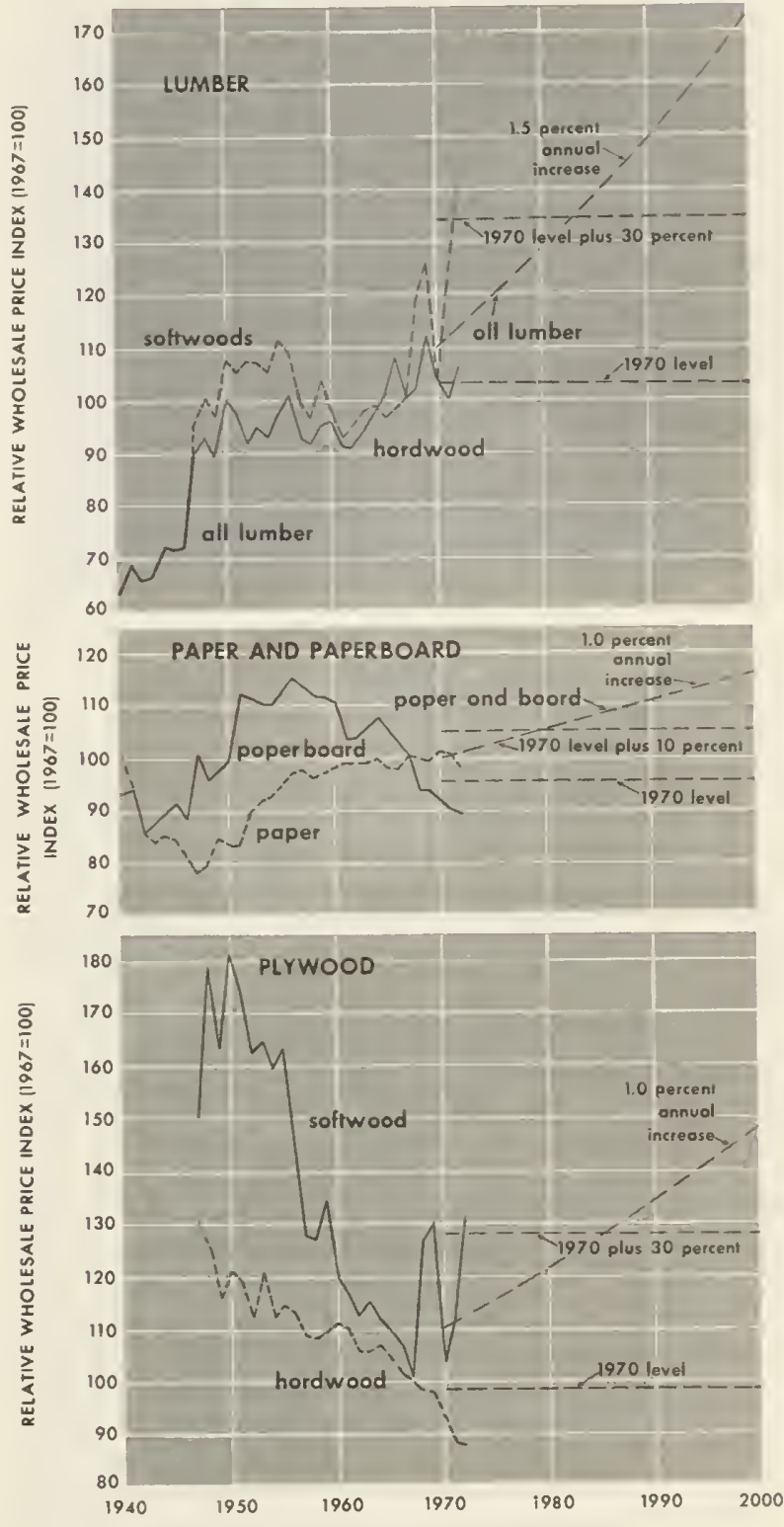

Figure 56

peting raw materials such as iron, aluminum, and nonmetallic minerals. ${ }^{12}$

12 Potter, Neal, and Francis T. Christy, Jr. Trends in natural resource commodities-statistics of prices, output, consumption, foreign trade, and employment in the United States, 1870-1957. The Johns Hopkins Press, Baltimore. 1962.

Fisher, Joseph L., and Neal Potter. World prospects for national resources. The Johns Hopkins Press, Baltimore. 1964. 
Stumpage prices for Douglas-fir and southern pine $1910-72$, with projections to 2000

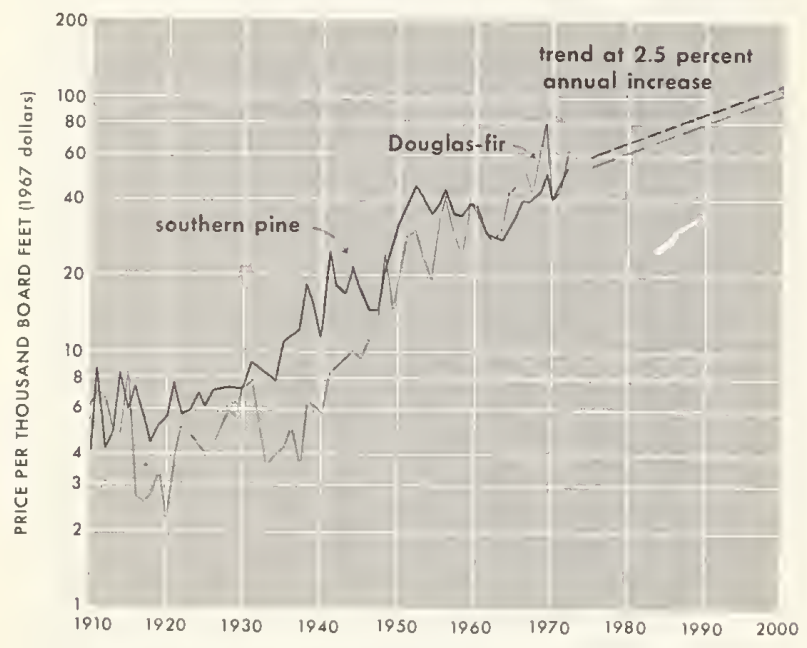

Figure 57

(2) In recognition of the likelihood of future price increases, a second set of demand projections was based on the assumption that through the projection period relative wholesale prices of lumber and plywood would be 30 percent, miscellaneous products and fuelwood 15 percent, and paper and board 10 percent above 1970 average prices.

The assumed level for lumber and plywood approximates the actual increases in relative softwood lumber and plywood prices between 1970 and 1972.

(3) A third set of projections was developed under the assumption that relative wholesale prices of timber products would rise from the 1970 trend level through the projection period much as in the past. For lumber the assumed average annual increase for these "rising" prices was 1.5 percent. For plywood, miscellaneous products, and fuelwood a 1.0 percent rise per year was assumed, and for paper and board 0.5 percent.

Since 1800 the relative wholesale price index for lumber increased at an average annual rate of 1.7 percent. There have been periods when this index showed little change, as in the period 1950-67 (fig. 55), but the longrun rising trend has been fairly steady.

Relative prices of pulp, paper, and board also leveled off in the 1952-70 period, but during the longer period from 1926 to 1970 , price increases averaged about 0.5 percent annually. Relative prices of softwood and hardwood plywood declined sharply after 1950 in response to major improvements in technology in these rapidly growing industrics but it was assumed for this projection, largely on the basis of prospective timber demandsupply balances, that future prices would rise as indicated above.

These three sets of price assumptions are summarized for the major timber products below:

\begin{tabular}{|c|c|c|c|c|}
\hline \multirow[b]{2}{*}{$\begin{array}{l}\text { Product and price assumptions } \\
\text { Lumber: }\end{array}$} & \multicolumn{4}{|c|}{ Relative wholesale price indexes } \\
\hline & 1970 & 1980 & 1990 & 2000 \\
\hline (1) 1970 level & 100 & 100 & 100 & 100 \\
\hline (2) 30 percent increase & 100 & 130 & $\begin{array}{l}100 \\
130\end{array}$ & 100 \\
\hline $\begin{array}{l}\text { (3) Rising prices } \\
\text { Plywood: }\end{array}$ & 110 & 128 & 148 & 172 \\
\hline (1) 1970 level $\ldots \ldots$ & 100 & 100 & 100 & 100 \\
\hline (2) 30 percent increase & 100 & 130 & 130 & 130 \\
\hline (3) Rising prices......... & 110 & 122 & 134 & 148 \\
\hline (1) 1970 level & 100 & 100 & 100 & 100 \\
\hline (2) 10 percent increase & 100 & 110 & 110 & 110 \\
\hline (3) Rising prices & 105 & 110 & 116 & 122 \\
\hline
\end{tabular}

Variables affecting prices of timber products.Past increases in relative prices of timber products presumably have resulted from a combination of factors such as increasing competition for the available timber, and in some cases, rising costs of timber harvesting and manufacturing due to slower rates of technological progress than in other economic sectors.

Variation in price trends among timber products are attributed in part to different trends in productivity. The differences also reflect the relative importance of stumpage costs. In recent years, stumpage costs have made up roughly 35 to 45 percent of the f.o.b. mill prices of softwood lumber, for example, compared to 5 to 10 percent of the mill price of the lower grades of paper and board.

Stumpage price trends.-Stumpage prices have risen more rapidly in recent decades than prices of lumber and other processed timber products. For example, between 1910 and 1970 relative prices of Douglas-fir stumpage rose an average of 3.5 percent annually, while soutliem pine stumpage increased about 3.2 percent annually (fig. 57; Append. V, table 2).

The faster percentage increase in stumpage prices in comparison to product prices suggests that growing economic scarcity of timber has been of greater importance than increases in costs of harvesting and manufacturing in determining product prices. Also, in recent years closer utilization of timber for a combination of products such as lumber, plywood, and pulp chips, and better allocation of timber for bighest valus products, have tended to increase stumpage values, as well as increase recovery of timber per acre logged.

Regardless of the cause, the differential rates of growth in stumpage and product prices mean that much of the increase in product prices has been passed on to stumpage owners. Based in part on past trends in relationships between stumpage and product prices shown by a number 
of recent studies, ${ }^{13}$ it has been assumed that an a verage of about 75 percent of future increases in timber product prices would go to stumpage. The remaining 25 percent of product price increases would be arailable to cover higher costs of harvesting and manufacture.

General approximations of the percentage increases in stumpage prices associated with the above assumptions, and the assumptions on product prices, are shown in the tabulation below:

\begin{tabular}{|c|c|c|c|c|c|c|}
\hline \multirow[b]{2}{*}{ Product and price assumptions } & \multicolumn{6}{|c|}{ Relatice stumpage price inderes } \\
\hline & 1970 & 1980 & 1990 & 2000 & 2010 & 2020 \\
\hline stumpage: & 100 & 100 & 100 & 100 & 100 & 100 \\
\hline 3rcent increase....... & 100 & 161 & 161 & 161 & 161 & 161 \\
\hline $\begin{array}{l}\text { sing prices } \\
\text { od stumpage: }\end{array}$ & 100 & 13 & $17:$ & 221 & 275 & 337 \\
\hline level & 100 & 100 & 100 & 100 & 100 & 100 \\
\hline ercent increase.... & 100 & 318 & 31 & 318 & 318 & 318 \\
\hline ng prices. & 100 & 212 & $3 x$ & 453 & 582 & 720 \\
\hline
\end{tabular}

There would, of course, be widely varying rates of increase in stumpage prices for different species and kinds of timber. Where stumpage prices are low and account for only a small percentage of the price of processed timber products, rising product prices would result in very large percentage increases in stumpage prices. $^{14}$

On the other hand, where stumpage prices comprise a substantial part of the price of the product, rates of growth in stumpage prices would be relatirely low. For example, estimated increases in Douglas-fir and southern pine stumpage prices associated with the third price assumption arerage about 2.7 percent per year-somewhat below the average rate between 1910 and 1970 .

The assumed relationships between product and stumpage prices also mean that stumpage in the future would account for an increasing proportion of product prices. For example, under the third price assumption, Douglas-fir and southern pine stumpage prices would rise to about 50 percent of the price of lumber by 2000 compared to roughly one-third in the $1965-70$

${ }^{13}$ Anderson, Walter C. Determinants of southern pine pulpwood prices. USDA Forest Serv. Res. Pap. SO-44, 10 p. 1969.

Guttenberg, Sam. Economics of southern pine pulpwood pricing. For. Prod. J. 20(4):15-18. 1970.

- - and Clyde A. Fasick. What decides southern pine stumpage prices? For. Ind. $92(13): 45-47.1965$.

Holley, Daniel L., Jr. Factors in 1959-69 price rise in southern pine sawtimber analyzed. For. Ind. $97(4): 40-41$. 1970 .

14 This can be illustrated as follows: In 1970 the stumpage price of lodgepole pine sold from the National Forests averaged about $\$ 4$ per thousand board feet while lodgepole pine $2 \times 4$ 's sold for about $\$ 70$ per thousand board feet. Given the assumptions on rates of increase in the price of lumber (e.g., 1.5 percent per year) and the proportion passed on to stumpage, the projected price of lodgepole pine stumpage and $2 \times 4$ 's in 2000 would be $\$ 33$ and $\$ 109$ respectively. The annual rate of increase in stumpage prices would average 7.8 percent in the 1970 's, with a fall to 3.3 percent in the 1990 's.

\section{Stumpage prices as a percent of lumber prices}

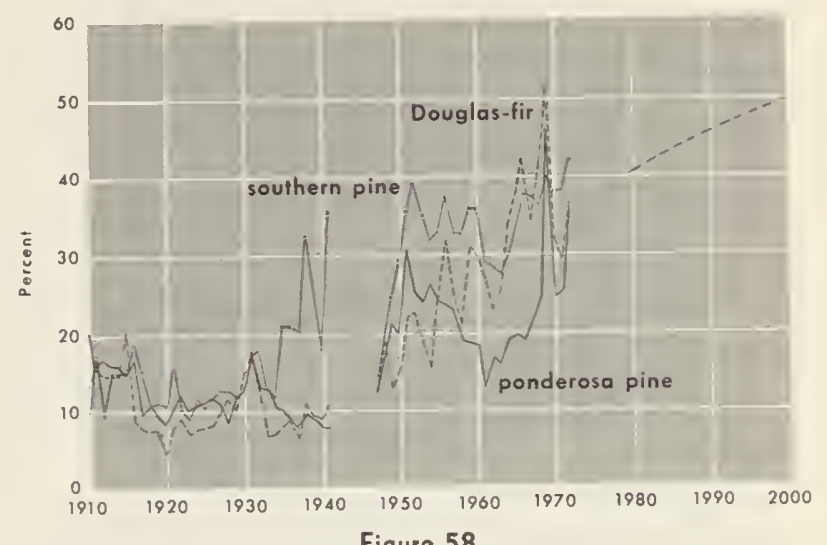

Figure 58

period, and 10-15 percent in the early 1900's (fig. 58).

Pulpwood stumpage prices under the third price assumption specified earlier would rise from around 5-10 percent of the price of the lowest priced grades of paper and board in 1970 to over 20 percent by 2000 .

\section{Effects of Price Increases on Timber Demands}

In preparing projections of demand for lumber and other timber products under these alternative price assumptions it has been necessary to make certain assumptions about the quantitative effects of price increases on projected demands.

General observation of timber markets indicates that in the shortrun price changes may hare only limited effects on quantities of timber products that consumers will buy. For example, the spectacular rise of lumber and plywood prices in 196869 , and a similar rise in $1971-72$, appears to have had very limited initial impacts on consumption of these products in most end uses. Orer the longer run, however, sustained upward shifts in prices of timber products relative to the wholesale price level and to competing products would undoubtedly lead to reduced demands for timber.

Longrun trends in lumber consumption and relative prices appear to illustrate this effect. Despite the very large expansion of major markets in construction, manufacturins, and shipping during the present century, lumber consumption in 1970 approximated the consumption level of the early 1900's. Presumably the increase in relative lumber prices-averaging 1.6 percent per vear in this period-was an important factor leading to increased use of substitutes and other changes affecting lumber uses.

In contrast to lumber, the demand for paper seems to be rather insensitive to price changes. This is believed to reflect the lack of acceptable 
low-cost substitutes for paper and board in most end uses. Also, for many items such as books, tissue paper, and various kinds of containers the cost of paper or board to the final consumer is so small. in relation to the total price of the product, or to consumer income, that even fairly large percentage changes in paper and board prices appear unlikely to have much impact on consumption.

Although such general relationships between timber product prices and demand seem reasonably clear, there are no valid quantitative measures of the longrun impacts of price increases on demand..$^{15}$ Estimates were therefore developed on a judgment basis to indicate the changes in demand expected to result from changes in product prices, as follows:

\begin{tabular}{|c|c|c|}
\hline \multirow[b]{2}{*}{ Years after price increase } & \multicolumn{2}{|c|}{$\begin{array}{c}\text { Change in demand resulting from a sustained } \\
\text { I percent rise in relatice prices }\end{array}$} \\
\hline & $\begin{array}{l}\text { Lumber, plywood, and mis- } \\
\text { cellaneous products (percent) }\end{array}$ & $\begin{array}{c}\text { Paper and boar } \\
\text { (percent) }\end{array}$ \\
\hline $\begin{array}{l}\text { 1st } \\
\text { 5th } \\
\text { 10th }\end{array}$ & $\begin{array}{l}-0.1 \\
-0.3 \\
-0.5\end{array}$ & $\begin{array}{l}-0.05 \\
-0.1 \\
-0.2\end{array}$ \\
\hline
\end{tabular}

These assumptions mean, for example, that a 10 percent increase in lumber prices would result in a 1 percent decrease in demand in the first year after the price increase. At the end of the fifth year, if the price increase were sustained, demand would decrease 3 percent, with a further fall to 5 percent in the tenth year and thereafter. This sequence recognizes that it takes time to change to alternative materials and ways of producing products.

Actual changes in future consumption and in equilibrium prices of timber products and stumpage-in con trast to the selected price assumptions presented in this chapter-wil] be determined both by future trends in demands for timber products and by availability of timber supplies.

${ }_{15}$ Several studies have examined demand-price relationships of timber products. Examples of recent studies of this kind include:

Gregory, G. Robinson. A statistical investigation of factors affecting the market for hardwood flooring. Forest Science 11(2): 200-203. 1965 .

Holland, I. Irving. Some factors affecting the consumption of lumber in the United States with emphasis on demand. Ph.D. dissertation. Sch. For., Univ. Calif., Berkeley. 1955.

- An explanation of changing lumber consumption and price. Forest Science 6(2):171-192. 1960.

McKillop, W. L. M. Supply and demand for forest products-an econometric study. Hilgardia 38(1). Univ. Calif., Berkeley. 1967.

Mead, Walter J. Competition and oligopsony in the Douglas-fir lumber industry. Univ. Calif., Berkeley and Los Angeles. 1966.

Mills, Thomas J. An econometric analysis of market factors determining supply and demand for softwood lumber. Ph.D. dissertation Dept. For., Mich. State Univ., Lansing. 1972 .

Zivnuska, J. A. Supply, demand and the lumber market. J. Forest. 53:547-553. 1955.
Such comparisons of timber demands and supplies, and related price implications, are presented in the final chapter of this report.

\section{DEMAND FOR TIMBER PRODUCTS IN NEW HOUSING}

In 1970 roughly a third of the softwood lumber and plywood, plus substantial volumes of other timber products such as hardwood plywood, particleboard, and insulation board, were used in the production of new housing. Future demand for housing is also expected to be of great importance in determining demand for timber products.

This section begins with an analysis of the demand for housing by source of demand, that is, new households, vacancies, and replacements. Because of the large variation in the average use of lumber and other wood products per housing unit, trends in the types of units produced, that is, single-family, multifamily, and mobile units, have also been evaluated. ${ }^{16}$ This is followed by an analysis of the use of various timber products per unit produced, and by projections of total demand for timber products in the housing sector.

\section{Household Formation}

New household formations have long constituted the major source of demand for housing. Although showing considerable fluctuation over the years, household formations have increased from an average of about 556 thousand annually in the 1920's to around 1 million in the 1960 's (table 115).

Headship rates.-Household formations depend both on total growth in population and on the number of individuals willing and able to occupy separate dwelling units. The latter in turn is determined largely by the age structure of the population and level of income, and is expressed by headship rates, that is, the proportion of the population in each age group that heads separate households.

There is a well defined relationship between age and headship (table 116, fig. 59). Typically headship rates rise abruptly from the 15-19 year age class to the 25-29 year age class. Rates continue to rise slowly until after ages 70-75 when individuals reach the point where they can no longer maintain separate households.

Between 1940 and 1970, headship rates increased significantly in every age class. The sizable increase in headships among older and younger age persons who have traditionally lived with relatives

16 The material on demand fc.r housing in this section has been based largely on a detailed study by Thomas E. Marcin (Projections of demand for housing by type of unit and region. U.S. Dept. Agri., Agri. Handb. 428, 76 p. 1972). Marcin's study also presents a computer model for estimating future demand for housing by type of unit and region. 
TABLE 115.-Households and household formations, by' decade, 1920-70, with projections to 2000

\begin{tabular}{|c|c|c|c|c|}
\hline Year & $\begin{array}{l}\text { Total } \\
\text { house- }\end{array}$ & \multicolumn{2}{|c|}{$\begin{array}{l}\text { Average annual } \\
\text { household increase }\end{array}$} & $\begin{array}{l}\text { Persons } \\
\text { per }\end{array}$ \\
\hline $\begin{array}{l}1920- \\
1930- \\
1940- \\
1950- \\
1950- \\
1970-\end{array}$ & $\begin{array}{r}\text { Thousands } \\
24,436 \\
30,002 \\
34,964 \\
42,969 \\
53,024 \\
63,417\end{array}$ & $\begin{array}{r}\text { Thousands } \\
556.6 \\
496.2 \\
800.5 \\
1,005.5 \\
1,039.3\end{array}$ & $\begin{array}{r}\text { Percent } \\
2.1 \\
1.5 \\
2.1 \\
2.1 \\
1.8\end{array}$ & $\begin{array}{r}\text { Number } \\
4.3 \\
4.1 \\
3.8 \\
3.5 \\
3.4 \\
3.2\end{array}$ \\
\hline
\end{tabular}

Low projections

\begin{tabular}{l|l|l|l|l}
\hline $1980 \ldots \ldots$ & 76,400 & $1,330.0$ & 1.9 & 3.0 \\
$1990 \ldots-$. & 88,500 & $1,210.0$ & 1.5 & 2.8 \\
$2000 \ldots \ldots-$ & 97,700 & 920.0 & 1.0 & 2.7 \\
\hline
\end{tabular}

Medium projections

\begin{tabular}{l|l|l|l|l}
\hline $1980 \ldots \ldots$ & 76,800 & $1,370.0$ & 2.0 & 3.0 \\
$1990 \ldots \ldots$ & 89,600 & $1,280.0$ & 1.6 & 2.8 \\
$2000 \ldots \ldots$ & 99,900 & $1,030.0$ & 1.1 & 2.8 \\
\hline
\end{tabular}

High projections

\begin{tabular}{r|r|r|r|r}
\hline $1980 \ldots \ldots$ & 77,200 & $1,410.0$ & 2.1 & 3.0 \\
$1990 \ldots \ldots$ & 90,400 & $1,320.0$ & 1.6 & 2.9 \\
$2000 \ldots \ldots$ & 102,700 & $1,230.0$ & 1.3 & 2.9 \\
\hline
\end{tabular}

1 Average annual increase for decade ending on December 31 of preceding year for projections (see note below). Decade average for $1970-80$ is calculated for 10 -year period based on 9.75 years.

Note: Historical data on households are for decennial census dates, generally April 1. Projected number of households are estimates as of January 1 of given year.

Sources: U.S. Department of Commerce, Bureau of the Census. 1920-60-United States census of housing, 1960. HC(1)-1. 1963; 1970-1970 Census of housing. Ser. HC (V1)-1. 1971.

Projections: U.S. Department of Agriculture, Forest Service.

largely reflects a substantial increase in per capita disposable personal income and social changes in this period. ${ }^{17}$

Projections of headship rates, based on past relationships with per capita income and expectations about further social changes, show a continuing rise for all age classes through the projection period (table 116, fig. 60).

17 For a more complete discussion of the factors affecting changes in headship rates see Campbell, Burnham $O$. Population change and building cycles. Univ. Ill. Bull. $64(27): 46-49.1966$.
Headship rates by age class, 1950 and 1970, with projections for 2000

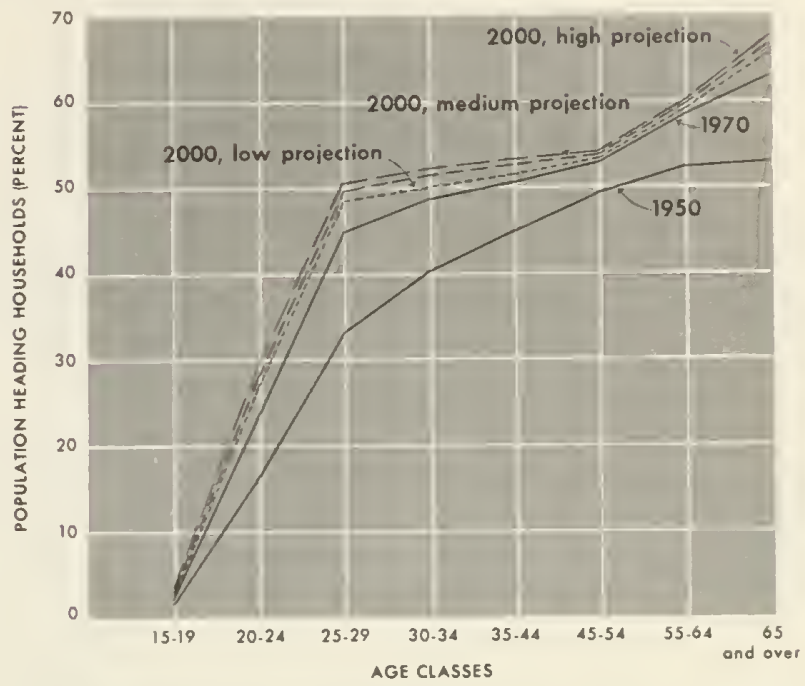

Figure 59

Projected household formations.-Projected household formations-based on the assumed headship rates and Census projections of population by age class-rise in the 1970's to a peak in the early 1980's, then decline through the rest of the 1980's and early 1990's. After that, projections depend increasingly on the population and economic assumptions adopted. Under the medium and high assumptions on population and economic growth, there would be a substantial rise in household formations after 1990.

'The relatively limited differences between the high, medium, and low projections of household formations in the 1970's and 1980's largely reflect effects on headship rates of economic growth assumptions. After 1990, however, alternative projections diverge more and more as effects of different rates of population growth become increasingly important.

Numbers of persons per household, which are inversely related to headship rates, have declined from 4.3 in 1920 to about 3.2 in 1970 . The projected headship rates indicate a further decline to 2.8 (medium level) in 2000 (table 115 ).

Household formations continue to be a major source of demand for housing through the projection period (table 117, fig. 61). However, they decline in importance, relative to replacements, falling from 59 percent of total projected demand in the 1960's to about 39 percent in the 1990-2000 decade.

Households by age class.-The distribution of households by age class is an important determinant of demand for the various types of 
THE OUTLOOK FOR TIMBER IN THE UNITED STATES

TABLE 116.-Headship rates by age class, 1940-70, with projections to 2000

[Percent]

\begin{tabular}{|c|c|c|c|c|c|c|c|c|}
\hline \multirow{2}{*}{ Year } & \multicolumn{8}{|c|}{ Age class } \\
\hline & $15-19$ & $20-24$ & $25-29$ & $30-34$ & $35-44$ & $45-54$ & $55-64$ & $\begin{array}{l}65 \text { and } \\
\text { over }\end{array}$ \\
\hline $\begin{array}{l}1940 \\
1950 \\
1960 \\
1970\end{array}$ & $\begin{array}{l}0.6 \\
\text { 1. } 2 \\
\text { 1. } 8 \\
\text { 1. } 8\end{array}$ & $\begin{array}{l}\text { 11. } 3 \\
16.1 \\
\text { 22. } 1 \\
23.1\end{array}$ & $\begin{array}{l}\text { 28. } 2 \\
32.9 \\
\text { 39. } 6 \\
44.6\end{array}$ & $\begin{array}{l}37.7 \\
39.9 \\
45.0 \\
48.4\end{array}$ & $\begin{array}{l}44.6 \\
44.8 \\
48.4 \\
50.4\end{array}$ & $\begin{array}{l}50.7 \\
49.2 \\
52.6 \\
52.8\end{array}$ & $\begin{array}{l}54.0 \\
52.2 \\
56.2 \\
58.3\end{array}$ & $\begin{array}{l}56.8 \\
52.8 \\
56.1 \\
62.9\end{array}$ \\
\hline
\end{tabular}

Low projections

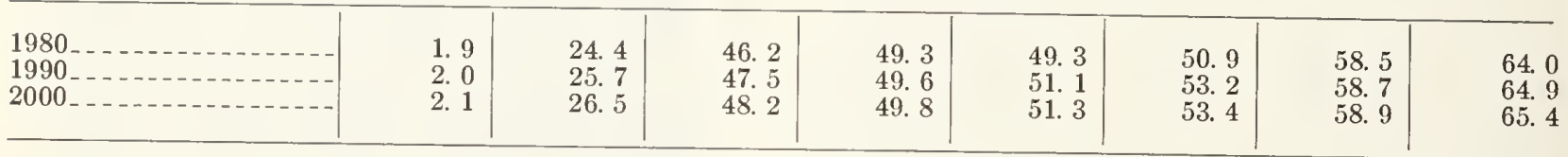

Medium projections

\begin{tabular}{|c|c|c|c|c|c|c|c|c|}
\hline 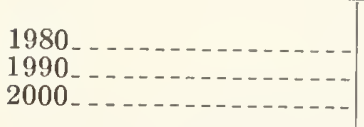 & $\begin{array}{l}2.0 \\
2.2 \\
2.4\end{array}$ & $\begin{array}{l}25.0 \\
26.5 \\
27.6\end{array}$ & $\begin{array}{l}46.7 \\
48.2 \\
49.3\end{array}$ & $\begin{array}{l}49.8 \\
50.7 \\
51.2\end{array}$ & $\begin{array}{l}51.5 \\
52.2 \\
52.5\end{array}$ & $\begin{array}{l}53.1 \\
53.3 \\
83.5\end{array}$ & $\begin{array}{l}59.0 \\
59.3 \\
59.5\end{array}$ & $\begin{array}{l}64.5 \\
65.8 \\
66.7\end{array}$ \\
\hline
\end{tabular}

High projections

\begin{tabular}{|c|c|c|c|c|c|c|c|c|}
\hline $\begin{array}{l}1980 \ldots \ldots \\
1990 \ldots 0 \\
2000 \ldots \ldots\end{array}$ & $\begin{array}{l}\text { 2. } 1 \\
\text { 2. } 4 \\
\text { 2. } 7\end{array}$ & $\begin{array}{l}25.9 \\
27.9 \\
29.1\end{array}$ & $\begin{array}{l}\text { 47. } 1 \\
49.0 \\
50.2\end{array}$ & $\begin{array}{l}50.1 \\
51.2 \\
51.9\end{array}$ & $\begin{array}{l}51.7 \\
52.6 \\
53.1\end{array}$ & $\begin{array}{l}53.3 \\
53.6 \\
53.8\end{array}$ & $\begin{array}{l}59.2 \\
59.6 \\
59.8\end{array}$ & $\begin{array}{l}64.9 \\
66.3 \\
67.3\end{array}$ \\
\hline
\end{tabular}

Note: Headship rate is the percentage of persons in each a६e class that heads a household.

Sources: 1940-50-Campbell, Burnham O. Population change and building cycles. Univ. Ill. Bull. 64(27): 46-

49. 1966; 1960-2000-Marcin, Thomas C. Projections of demand for housing by type of unit and region. U.S. Dep. Agr., Agr. Handbk. 428, 76 p. 1972.

\section{Headship in relation to per capita} disposable personal income (in 1967 dollars) for population 18 years of age and older

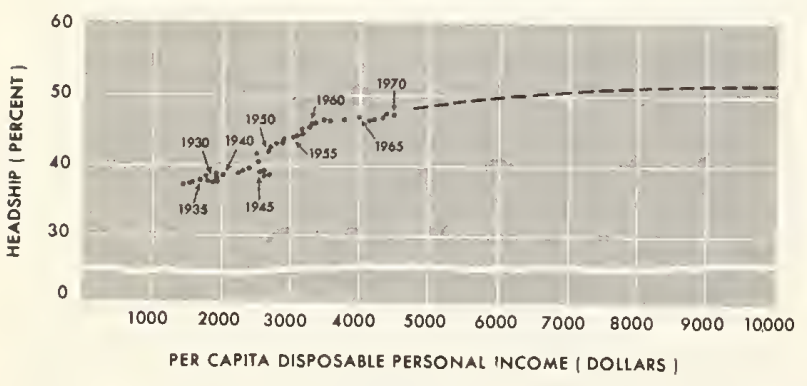

Figure 60

housing units, such as single-family and multifamily units.

Past fluctuations in the number of births result in fluctuations in projected numbers of households by age class and related changes in types of housing units demanded. As a result of the large number of births in the 1950's, for example, nearly 58 percent of the projected increase in households in the 1970's will have heads under 35 years old. Over four-fifths of these will be in ages $25-34$. In contrast, the number of households with heads 35-44 years old will remain virtually unchanged. After 1990, on the other hand, most of the growth in the projected numbers of households will be in the older age classes.

\section{Housing Replacements}

A second major component of housing demand is the replacement of units lost from the housing inventory. During the 1960's replacements accounted for about 40 percent of the total number of housing units provided.

In the past four decades, gross replacements have increased from an average of about 100,000 units to nearly 700,000 (table 118). This rise 
TABLE 117.-Average annual demand for housing, by source of demand, 1920-70, with projections to 2000 [Thousand units]

\begin{tabular}{|c|c|c|c|c|c|c|c|}
\hline \multirow[b]{2}{*}{ Period } & \multirow[b]{2}{*}{$\begin{array}{c}\text { Total } \\
\text { demand }\end{array}$} & \multirow[b]{2}{*}{$\begin{array}{l}\text { Household } \\
\text { formations }\end{array}$} & \multirow[b]{2}{*}{$\begin{array}{l}\text { Vacancies- } \\
\text { conventional } \\
\text { units }\end{array}$} & \multicolumn{3}{|c|}{ Net replacements } & \multirow{2}{*}{$\begin{array}{l}\text { Mobiles not } \\
\text { used as } \\
\text { primary } \\
\text { residences }\end{array}$} \\
\hline & & & & Total & $\begin{array}{c}\text { Conven- } \\
\text { tional } \\
\text { units }\end{array}$ & $\begin{array}{l}\text { Mobiles used } \\
\text { as primary } \\
\text { residences }\end{array}$ & \\
\hline $\begin{array}{l}1920-29- \\
1930-39- \\
1940-49- \\
1950-59- \\
1960-69-\end{array}$ & $\begin{array}{r}803.4 \\
365.1 \\
809.0 \\
1,522.4 \\
1,649.7\end{array}$ & $\begin{array}{r}556.6 \\
496.2 \\
800.5 \\
1,005.2 \\
1,039.3\end{array}$ & $\begin{array}{r}239.0 \\
-22.9 \\
80.7 \\
227.6 \\
-23.0\end{array}$ & $\begin{array}{r}7.8 \\
-108.2 \\
-72.2 \\
267.4 \\
591.3\end{array}$ & & & 22.2 \\
\hline
\end{tabular}

Low projections

\begin{tabular}{|c|c|c|c|c|c|c|c|}
\hline $\begin{array}{l}1970-79 \\
1980-89 \\
1990-99 \ldots\end{array}$ & $\begin{array}{l}2,400.0 \\
2,450.0 \\
2,290.0\end{array}$ & $\begin{array}{r}1,330.0 \\
1,210.0 \\
920.0\end{array}$ & $\begin{array}{l}170.0 \\
180.0 \\
160.0\end{array}$ & $\begin{array}{r}800.0 \\
960.0 \\
1,120.0\end{array}$ & $\begin{array}{l}657.0 \\
720.0 \\
\text { ชงย. } 0\end{array}$ & $\begin{array}{l}150.0 \\
240.0 \\
290.0\end{array}$ & $\begin{array}{r}100.0 \\
100.0 \\
90.0\end{array}$ \\
\hline
\end{tabular}

Medium projections

\begin{tabular}{|c|c|c|c|c|c|c|c|}
\hline $\begin{array}{l}1970-79 \ldots \\
1950-89 \ldots \\
1990-99\end{array}$ & $\begin{array}{l}2,500.0 \\
2,620.0 \\
2,560.0\end{array}$ & $\begin{array}{l}1,370.0 \\
1,280.0 \\
1,030.0\end{array}$ & $\begin{array}{l}200.0 \\
220.0 \\
220.0\end{array}$ & $\begin{array}{r}820.0 \\
1,020.0 \\
1,210.0\end{array}$ & $\begin{array}{l}660.0 \\
770.0 \\
920.0\end{array}$ & $\begin{array}{l}160.0 \\
250.0 \\
290.0\end{array}$ & $\begin{array}{l}110.0 \\
100.0 \\
100.0\end{array}$ \\
\hline
\end{tabular}

High projections

\begin{tabular}{ll|l|r|r|r|r}
\hline $1970-79 \ldots \ldots$ & $2,580.0$ & $1,410.0$ & 220.0 & 840.0 & 680.0 & 160.0 \\
$1080-89 \ldots \ldots$ & $2,780.0$ & $1,320.0$ & 260.0 & $1,090.0$ & 830.0 & 260.0 \\
$1930-99 \ldots \ldots$ & $2,930.0$ & $1,230.0$ & 280.0 & $1,310.0$ & 990.0 & 320.0 \\
\hline
\end{tabular}

Sources: Household formations: U'.S. Department of Commerce, Bureau of the Census. 1920-60-United St: tes census of housing, 1960. $\mathrm{HC}(1)-1$. 1963; 19701970 Census of housing. Ser. HC(VI)-1. 1971.

Vacancies, conventional units-Forest Service estimates derived from data in the following sources: $\tau$.S. Department of Commerce, Bureau of the Census. Historical statistics of the United States, colonial times to 195\%. 1960; 1970-Census of housing. Ser. HC(VI)-1. 1971.

Replacements-Forest Service estimates derived from data in the following sources: U.S. Department of Com-

reflected such factors as shifts of population from farms and small towns to urban areas, which in turn required replacement of large numbers of abandoned dwellings. Urban renewal and highway construction programs have led to remoral of many housing units. Dwellings have been lost through fire, flood, and other disasters. Some dwellings have been converted to other uses. Rising lerels of income and public housing programs have also made possible an upgrading of the housing stock by replacing dilapidated units earlier than would have been possible otherwise.

In riew of the growing numbers of older units in the Nation's housing stock, projected increases in per capita income, and a rising proportion of mobile homes with relatively short average merce, Bureau of the Census. Historical statistics of the United States, colonial times to 1957. 1960; United States census of housing, 1960. Vol. IV, Pt. 1-A. 1962.

Mobiles not used as primary residences-Forest Service estimates derived from data in L.S. Department of Commerce, Bureau of the Census. United States census of housing, 1960. Vol. IV, Pt. 1-A. 1962.

Projections: U.S. Department of Agriculture, Forest Service.

life, it has been assumed that replacements will continue to rise during the projection period.

With the assumed replacement rates, demand for replacement units becomes the major item of projected housing production by the last decade of the century (table 117, fig. 61). By the 1990's projected net replacements average about 1.2 million units a year-almost twice the arerage of the 1960's, and about half of the projected total demand for housing in that decade.

About a quarter of the projected replacement demand in the next three decades is for mobile homes. This reflects in large part the comparatively short life of mobile homes. Little reliable data are arailable on this matter and estimates of probable life vary widely. In this analysis an 
Demand for new housing by source of demand 1920-72 with projections (medium level) to 2000

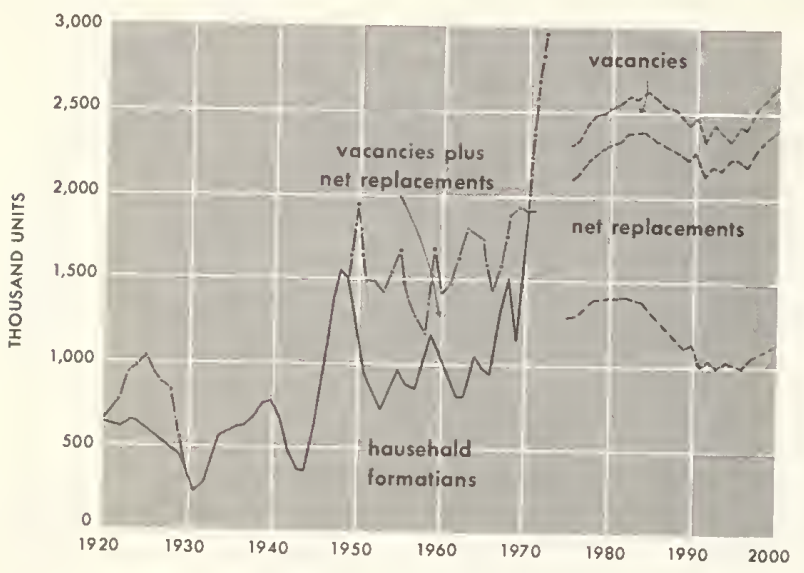

Figure 61

average life of about 12 years for mobile homes was assumed for the decade of the 1970's, increasing to about 20 years by 2000 . This upward trend in average life in effect assumes a general upgrading in the quality of the units built.

\section{Vacancies}

The third major component of housing demand is vacancies. For the purposes of this report, vacancies have been divided into (1) units for sale or rent, (2) second homes and other units not for sale or rent, and (3) dilapidated units.

The first category includes units intended for year-round occupancy and on the market for sale or rent, and units sold or rented and awaiting occupancy. Vacancy rates for this category have shown a wide range (table 119). Because the 3.5 percent rate of 1970 was apparently below normal, an increase to 4.1 percent-about the average of the late 1960's - was assumed for the projection period.

The second category of vacancies includes units intended for seasonal occupancy, plus units held for occasional use, units temporarily occupied by persons who have a usual place of residence elsewhere, and units held for personal reasons of the owner. In recent years, such vacancies have composed between 3.5 and 5.8 percent of the housing inventory.

With the increased income, leisure time, and mobility that has been assumed, it was estimated that demand for seasonal units would rise, so that this vacancy rate would increase from 3.5 percent in 1970 to about 4.6 percent by 1980 (medium projection), with a subsequent rise to about 6.3 percent in 2000 (table 119). Demand for seasonal units is closely related to per capita disposable personal income and to numbers of
TABLE 118.- Housing unit replacements, 1920-70, with projections to 2000

\begin{tabular}{|c|c|c|c|c|}
\hline \multirow{3}{*}{ Period } & \multirow{3}{*}{$\begin{array}{l}\text { Housing } \\
\text { unit } \\
\text { inven- } \\
\text { tory }^{1}\end{array}$} & \multicolumn{3}{|c|}{ Replacements 2} \\
\hline & & \multirow{2}{*}{ Gross 1} & \multicolumn{2}{|c|}{ Net } \\
\hline & & & Number ${ }^{1}$ & Rate \\
\hline $\begin{array}{l}1920-29 \\
1930-39 \\
1940-49 \\
1950-59 \\
1960-69\end{array}$ & $\begin{array}{l}\text { Thousands } \\
28,614 \\
34,958 \\
41,731 \\
52,302 \\
63,550\end{array}$ & $\begin{array}{r}\text { Thousands } \\
115.0 \\
105.0 \\
210.0 \\
453.1 \\
691.3\end{array}$ & $\begin{array}{r}\text { Thousands } \\
7.8 \\
-108.2 \\
-72.2 \\
267.4 \\
591.3\end{array}$ & $\begin{array}{l}\text { Percent } \\
\left({ }^{3}\right) \\
(3) \\
(3) \\
0.51 \\
.93\end{array}$ \\
\hline
\end{tabular}

Low projections

\begin{tabular}{r|r|r|r|r}
\hline $1970-79 \ldots--$ & 75,800 & 900.0 & 800.0 & 1.06 \\
$1980-89 .--$ & 90,200 & $1,060.0$ & 960.0 & 1.07 \\
$1990-99 \ldots--$ & 102,600 & $1,120.0$ & $1,120.0$ & 1.09 \\
\hline
\end{tabular}

Medium projections

\begin{tabular}{l|r|r|r|r}
\hline $1970-79 \ldots \ldots$ & 76,200 & 920.0 & 820.0 & 1.08 \\
$1980-89 \ldots$ & 91,500 & $1,120.0$ & $1,020.0$ & 1.11 \\
$1990-99 \ldots \ldots$ & 105,200 & $1,310.0$ & $1,210.0$ & 1.15 \\
\hline
\end{tabular}

High projections

\begin{tabular}{l|r|r|r|r}
\hline $1970-79 \ldots--$ & 76,400 & 940.0 & 840.0 & 1.10 \\
$1980-89 \ldots--$ & 92,500 & $1,190.0$ & $1,090.0$ & 1.18 \\
$1990-99 \ldots--$ & 107,900 & $1,410.0$ & $1,310.0$ & 1.21 \\
\hline
\end{tabular}

1 Average annual number for the period.

2 Gross replacement is the total number of units lost from the housing inventory. Net replacement is gross replacement less the number of units added by means other than new housing unit construction (that is, conversion of one unit to two or more units, conversion of nonresidential space to housing units, etc.).

${ }^{3}$ Less than 0.05 percent.

Sources: Housing unit inventory, 1920-30-Forest Service estimated average for the decade derived by adding estimated vacancies (table 119) to reported number of households (table 115).

Replacements, 1920-49-Forest Service estimates derived from demolition data published by U.S. Department of Commerce, Bureau of the Census. Historical statistics of the United States, colonial times to 1957. 1960; 1950-59United States census of housing, 1960. Vol. IV, Pt. 1-A 1962; 1960-69-Forest Service estimates derived from housing start vacancy change and housing inventory data.

Projections: U.S. Department of Agriculture, Forest Service.

people in the middle to older age classes. Hence, there are significant differences between projected high and low rates of second home demand, especially toward the end of the century.

Projected total vacancy rates rise from the 1970 level of 7.6 percent to 10.4 percent in 2000 
TABLE 119.-Housing vacancies, 1920-70, with projections to 2000

\begin{tabular}{|c|c|c|c|c|c|c|c|c|c|}
\hline \multirow[b]{2}{*}{ Year } & \multirow[b]{2}{*}{ Vacant units } & \multicolumn{8}{|c|}{ Proportion of housing inventory } \\
\hline & & Total & & $\begin{array}{l}\text { For sale or } \\
\text { rent }^{1}\end{array}$ & & $\begin{array}{l}\text { Not for sal } \\
\text { or rent }\end{array}$ & & Dilapidatec & \\
\hline $\begin{array}{l}1920 \\
1930 \\
1940 \\
1950 \\
1960 \\
1970\end{array}$ & 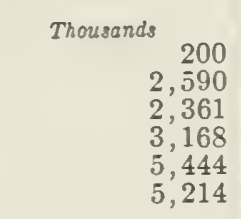 & Percent & $\begin{array}{l}0.8 \\
7.9 \\
6.3 \\
6.9 \\
9.3 \\
7.6\end{array}$ & Percent & $\begin{array}{l}\text { NA } \\
\text { NA } \\
4.1 \\
1.6 \\
3.5 \\
3.5\end{array}$ & Percent & $\begin{array}{l}\text { NA } \\
\text { NA } \\
2.2 \\
4.2 \\
4.9 \\
\text { 3. } 5\end{array}$ & Percent & $\begin{array}{r}\text { NA } \\
\text { NA } \\
1.1 \\
.9\end{array}$ \\
\hline
\end{tabular}

Low projections

\begin{tabular}{|c|c|c|c|c|c|}
\hline $\begin{array}{l}1980 \\
1990 \\
2000\end{array}$ & $\begin{array}{r}6,900 \\
8,700 \\
10,300\end{array}$ & $\begin{array}{l}8.3 \\
9.0 \\
9.5\end{array}$ & $\begin{array}{l}\text { 4. } 0 \\
\text { 4. } 1 \\
\text { 4. } 1\end{array}$ & $\begin{array}{l}\text { 4. } 3 \\
\text { 4. } 9 \\
\text { 5. } 4\end{array}$ & \\
\hline
\end{tabular}

Medium projections

\begin{tabular}{|c|c|c|c|c|c|}
\hline $\begin{array}{l}1980 \\
1990 \\
2000\end{array}$ & $\begin{array}{r}7,200 \\
9,400 \\
11,600\end{array}$ & $\begin{array}{r}8.6 \\
9.5 \\
10.4\end{array}$ & $\begin{array}{l}\text { 4. } 0 \\
\text { 4. } 1 \\
\text { 4. } 1\end{array}$ & $\begin{array}{l}\text { 4. } 6 \\
5.4 \\
6.3\end{array}$ & \\
\hline
\end{tabular}

High projections

\begin{tabular}{|c|c|c|c|c|c|}
\hline $\begin{array}{l}1980 \ldots+\ldots \\
1990 \\
2000\end{array}$ & $\begin{array}{r}7,400 \\
10,000 \\
12,800\end{array}$ & $\begin{array}{r}8.7 \\
10.0 \\
11.1\end{array}$ & $\begin{array}{l}\text { 4. } 0 \\
\text { 4. } 1 \\
\text { 4. } 1\end{array}$ & $\begin{array}{l}4.7 \\
5.9 \\
7.0\end{array}$ & 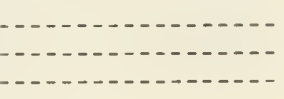 \\
\hline
\end{tabular}

1 Data for 1960,1970 , and projections include units available for sale or rent and and units sold or rented araiting occupancy. For 1940 and 1950 units sold or rented awaiting occupancy not included. For 1940 includes dilapidated units.

2 Data for 1960,1970 , and projections include seasonal units, units held for occasional use, temporarily occupied units, and units held for personal reasons of the owner. For 1940 and 1950 also includes units sold or awaiting oscupancy.

(medium level). The associated demand for new housing unit production is estimated at 200 thousand units annually in the 1970's (medium level), rising to 220 thousand units in the 1980's and 1990's (table 117, fig. 61).

These vacancy rates, and associated housing demand, do not include vacant mobile homes. The estima ${ }^{\dagger}$ es of mobile home demand (table 120), however, do include allowances for mobile home racancies, as well as for mobile home units used for nonhousing purposes.

\section{Total Demand for New Housing}

The total number of housing units produced in the United States during the 1960's averaged 1.65 million units per year (table 120). This was slightly above the average for the 1950's and about double the numbers produced in the 1920's and 1940's.
Note: Does not include vacant mobile homes.

Sources: Forest Service estimates derived from data in the following sources: U.S. Department of Commerce, Bureau of the Census. Historical statistics of the United States, colonial times to 1957.1960; 1970 census of housing. Ser. HC(V1)-1, 1971.

Projections: U.S. Department of Agriculture, Forest Service.

Production of housing units jumped to 2.4 million units in 1971 , and to 2.9 million units in 1972 - materially above the trend level projected in this study for the early 1970's. Howerer, ho'ssing has been highly cyclical (fig. 61), and production in peak years can be expected to substantially exceed trend values.

The trend level projections shown in this study and similar projections prepared by the National Association of Homebuilders, ${ }^{18}$ show a sharply rising trend in housing demand in the 1970's. By the early 1980's the medium projection of this study reaches more than 2.7 million units annually (fig. 62). Starting in the late 1980's there is some decline in projected housing demand-

\footnotetext{
${ }^{18}$ National Association of Home Builders. Housing requirements for the ' 70 's. Econ. News Notes 18(7). Washington. July 1972.
} 

TABLE 120.-Average annual production of new housing units, by type of unit, 1920-72, with projections
to 2000

[Thousand units]

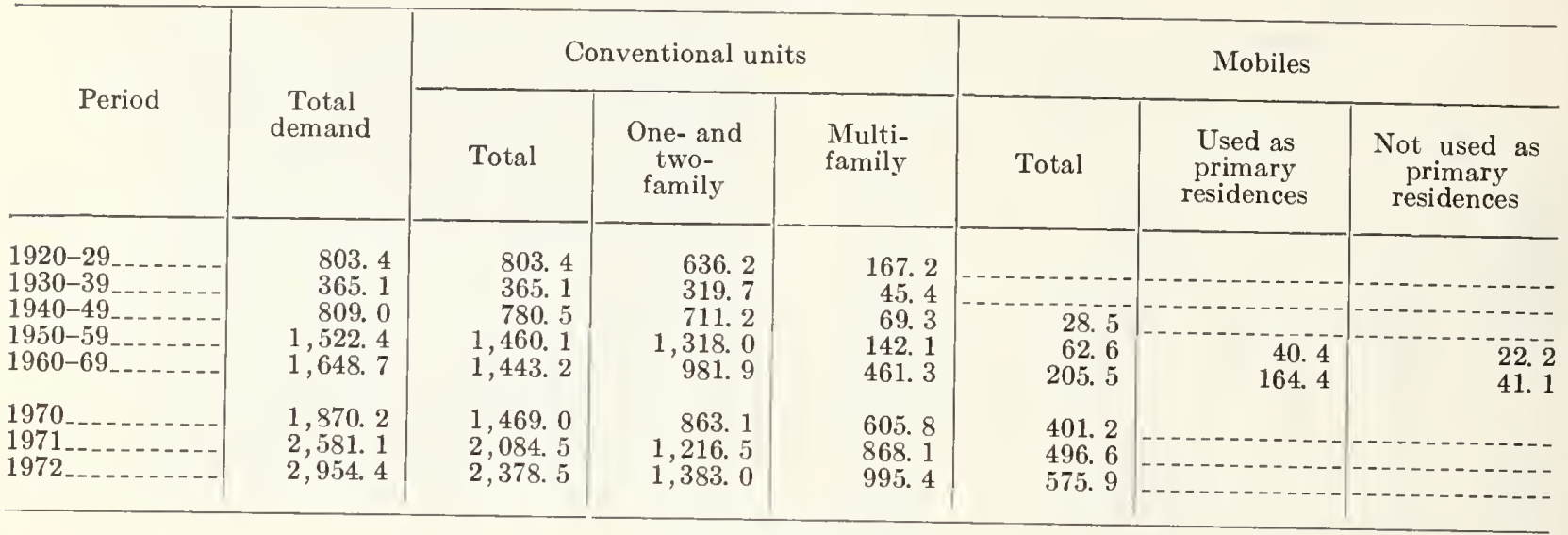

Low projections

\begin{tabular}{|c|c|c|c|c|c|c|c|}
\hline $\begin{array}{l}1970-79 \ldots \ldots \\
1980-89 \\
1990-99 \ldots \ldots\end{array}$ & $\begin{array}{l}2,400.0 \\
2,450.0 \\
2,290.0\end{array}$ & $\begin{array}{l}1,880.0 \\
1,960.0 \\
1,850.0\end{array}$ & $\begin{array}{l}1,110.0 \\
1,330.0 \\
1,350.0\end{array}$ & $\begin{array}{l}770.0 \\
630.0 \\
500.0\end{array}$ & $\begin{array}{l}520.0 \\
490.0 \\
440.0\end{array}$ & $\begin{array}{l}420.0 \\
390.0 \\
350.0\end{array}$ & $\begin{array}{r}100.0 \\
100.0 \\
90.0\end{array}$ \\
\hline
\end{tabular}

Medium projections

\begin{tabular}{|c|c|c|c|c|c|c|c|}
\hline $\begin{array}{l}1970-79 \\
1980-89 \\
1990-99 \ldots \ldots\end{array}$ & $\begin{array}{l}2,500.0 \\
2,620.0 \\
2,560.0\end{array}$ & $\begin{array}{l}1,970.0 \\
2,100.0 \\
2,070.0\end{array}$ & $\begin{array}{l}1,160.0 \\
1,410.0 \\
1,460.0\end{array}$ & $\begin{array}{l}810.0 \\
690.0 \\
610.0\end{array}$ & $\begin{array}{l}530.0 \\
520.0 \\
490.0\end{array}$ & $\begin{array}{l}420.0 \\
420.0 \\
400.0\end{array}$ & $\begin{array}{r}110.0 \\
100.0 \\
90.0\end{array}$ \\
\hline
\end{tabular}

High projections

\begin{tabular}{l|l|l|l}
$1970-79 \ldots \ldots-$ & $2,580.0$ & $2,040.0$ & $1,190.0$ \\
$1980-89 \ldots-\cdots$ & $2,780.0$ & $2,230.0$ & $1,490.0$ \\
$1990-99 \ldots \ldots-\cdots$ & $2,930.0$ & $2,370.0$ & $1,590.0$ \\
\hline
\end{tabular}

Sources: Housing starts, 1929-49 and 1960-62-Forest Service estimates derived from data in the following sources: U.S. Department of Commerce, Bureau of the Census: Housing construction statistics, 1889 to 1964. 1966 1950 census of housing. Vol. I, Pt. 2, 1953; U.S. Department of Labor, Bureau of Labor Statistics. Nonfarm housing starts, 1889-1958. Bull. 1260, 1959; U.S. Department of Commerce, Bureau of the Census. 1950-59-United States census of housing, 1960. Vol. IV, Pt. 1-A, 1962; 1963-69Housing starts. Cons. Rep. Ser. C27-71-6, 1971; 1970-72-. Housing starts. Cons. Rep. Ser. C20-73-3, 1973.

Total mobile homes, 1940-49-Forest Service estimates derived from data in U.S. Department of Commerce, Bureau of the Census. 1950 census of housing. Vol. I, Pt. 1, 1953; 1950-59-Forest Service estimates derived from data in U.S. Department of Commerce, Business and

a reflection of the decline in birth rates in the 1960 's. By 2000, however, projected housing demand rises again to about 2.8 million units. The high and low projections follow similar trends.

The projections of housing demand in the 1970's used in this study are somewhat below National housing goals. ${ }^{19}$ Differences between these goals and the high projection of this study, for example, amount to 0.8 million units over the 1973-78 period.

${ }^{10}$ U.S. Congress, House Committee on Housing and Currency. 2nd Annual report on national housing goals. U.S. Cong., 91st, 2nd sess., Hous. Doc. 91-292. 1970. 
New housing unit production by type of unit, 1920-72, with projections (medium level) to 2000

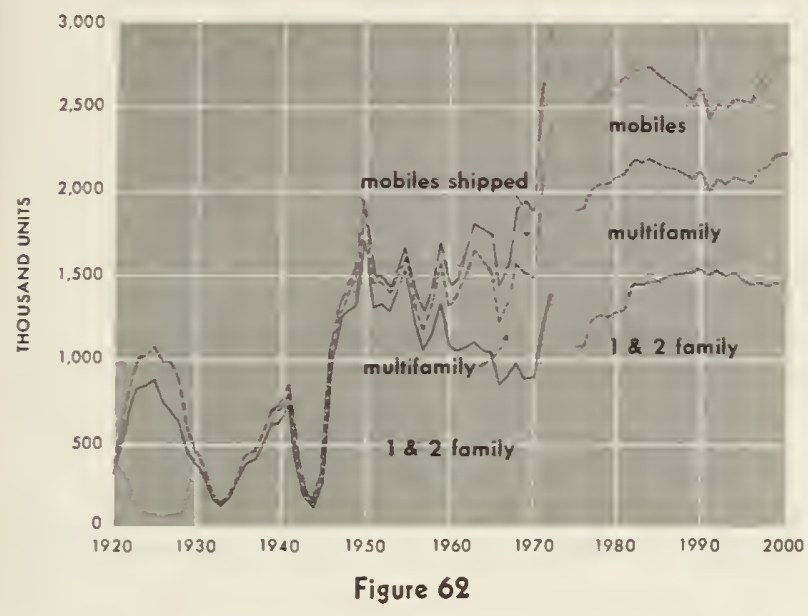

\section{Demand for New Housing by Type of Unit}

Because of large differences in quantities of timber products used per unit, type of housing units demanded is of major importance in projecting demands for timber products.

In the 1920-72 period 1- and 2-family units were the dominant types of new units produced (table 120, fig. 62). There has, howerer, been a substantial amount of variation in the relative importance of these units. During the 1920 's, proportions of 1and 2-family units reached a low of about 73 percent of all nerr units produced. By the mid1950 's such units accounted for over 90 percent of all new units. In the late 1950's the trend changed again and by 19721 - and 2 -family units accounted for only 47 percent of total housing production.

From the 1920's through most of the 1950's multifamily units accounted for the remaining housing output but by the late 1950's the mobile home had emerged as a significant source of new housing. In 1972 mobiles composed over 19 percent of total new housing production.

Single-family housing units have typically been occupied by middle age classes, a response to family size and income. Occupancy of multifamily units and mobile homes, on the other hand, has been highest among the younger age classes, which typically have small families and relatively lower incomes and among older age classes.

In this study, occupancy rates by age class and type of unit prevailing in the late 1960's were assumed to continue through the projection period. Prospective shifts in age distribution of the population indicated earlier in this section result in substantial changes in projected demands for the various types of units (table 120, fig. 62).

Projected demand for 1- and 2-family units continues to increase in the $1970-2000$ period and constitutes the major element of housing demand. Projected demand for multifamily units is relatively high in the 1970's, because of the large number of young households, but drops in the 1980's and early 1990's.

Projected demand for mobile units used as primary residences remains relatively constant during the projection period. Additional production of mobile homes is expected for part-time use as racation homes, offices, and other nondwelling purposes. An estimated 20 percent of all mobile units produced in 1970 was used in this way and this percentage is assumed to continue. Projected total demand for mobile homes thus averages about 500,000 units a year (medium level).

\section{Conversions}

Conversions of existing housing units into two or more units, and conversion of nonresidential structures to housing units, has at times met a substantial part of the Nation's housing demands. In the 1930's, for example, more than one-third of all units provided came from such conversions. Projected housing replacement demands include an allowance of 100,000 net conversions per year-about the same number as in the late 1960's (table 118).

\section{Timber Products Use Per Dwelling Unit}

Since the beginning of the 1960's there have been significant changes in average unit use of timber products in housing (table 121). Use of plywood and building boards, per unit, has risen substantially, while use of lumber has declined. These trends reflect factors such as changes in unit size, structural and architectural characteristics, and materials substitution.

Trends in unit size.-In the 1960's there was a fairly steady increase in size of single-family units constructed, with the average rising from 1,340 square feet in 1962 to 1,500 square feet in $19700^{20}$ This growth in size of units contributed to the rise in use of plywood per single-family unit and partially offset a downward trend in lumber use per square foot of floor area.

There also has been an increase in the average size of multifamily units. In 1965-the first year such data became available -5 percent of the new units in privately owned apartment buildings had three or more bedrooms, 44 percent had two bedrooms, and the remainder were one bedroom or efficiency units. By 1970, units with three or more

${ }^{20}$ U.S. Department of Commerce, Bureau of the Census. Characteristics of new one-family homes: 1970 . C25-70-13. 1971 . 
TABLE 121.-Timber products consumed per housing unit, by type f unit, 1962 and 1970, with projections (1970 relative prices) to $2000^{1}$

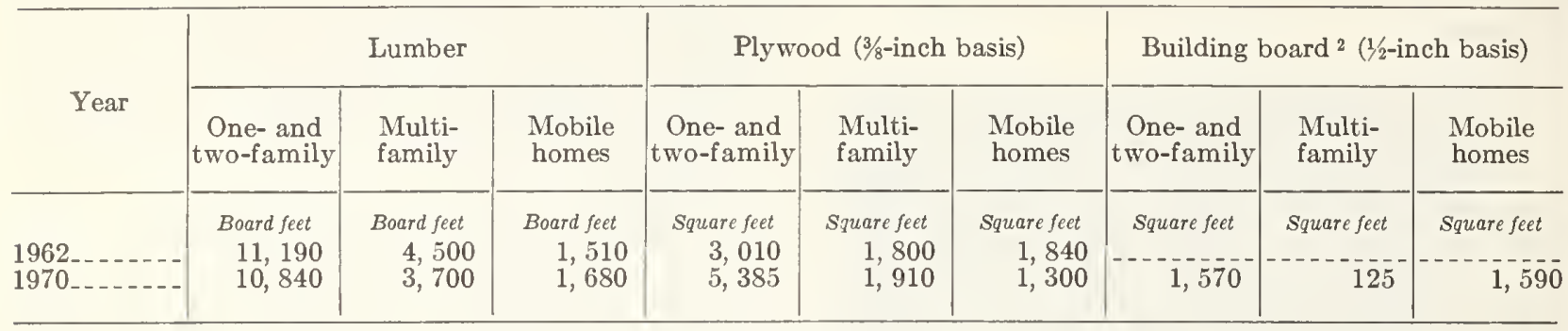

Projections

\begin{tabular}{|c|c|c|c|c|c|c|c|c|c|}
\hline $\begin{array}{l}1980 \ldots \\
1990 \ldots \\
2000 \ldots\end{array}$ & $\begin{array}{l}10,660 \\
10,500 \\
10,260\end{array}$ & $\begin{array}{l}3,400 \\
3,100 \\
2,900\end{array}$ & $\begin{array}{l}1,795 \\
1,895 \\
2,000\end{array}$ & $\begin{array}{l}6,140 \\
6,470 \\
6,670\end{array}$ & $\begin{array}{l}1,950 \\
1,975 \\
1,985\end{array}$ & $\begin{array}{l}1,510 \\
1,620 \\
1,720\end{array}$ & $\begin{array}{l}1,860 \\
2,100 \\
2,310\end{array}$ & $\begin{array}{l}140 \\
155 \\
170\end{array}$ & $\begin{array}{l}1,625 \\
1,680 \\
1,775\end{array}$ \\
\hline
\end{tabular}

1 Includes both hardwoods and softwoods. Includes allowance for on-site and manufacturing waste.

bedrooms had increased to 11 percent and two bedroom units to 47 percent of the total. ${ }^{21}$

Mobile homes have shown the largest increase in average size. In 1962 , only a fourth of the mobile homes produced were more than 10 feet wide, compared to over 90 percent in 1968. By 1970 an estimated 8 percent of the mobile homes produced were 14 feet wide and nearly 10 percent were double-wide sectional units. The double-wides are not only relatively large units but many utilize heavier framing members and pitched roofs. Lengths of mobile homes also increased substantially from typical lengths of 29 to 45 feet in the early 1960's to units as long as 70 feet.

For the future it was assumed that the rise in family incomes and preferences of home buyers will lead to further growth in average size of all types of housing units produced.

Structural and architectural characteristics.Along with growth in average size of units, the percentage of new single-family houses built with garages grew from 50 to 65 percent between 1950 and $1969 .{ }^{22}$ Given the growing affluence assumed in this study, the trend to more and larger garages appears likely to continue.

Other changes have led to the virtual disappearance of porches that were once a feature of nearly all one-family houses. Recently, however, many houses have been built with wooden decks which serve many of the purposes of the earlier porches.

${ }^{21}$ U.S. Department of Commerce, Bureau of the Census. Housing starts. C20-71-5. 1971.

${ }^{22}$ Characteristics of new one-family houses: 1970. op. cit.; U.S. Department of Labor, Bureau of Labor Statistics. New housing and its materials, 1940-56. Bull. 1231. 1968.
${ }^{2}$ Hardboard, insulation board, and particleboard. See Append V, table 5, for projections of demand for these products.

Average unit use of timber products, especially lumber, has been reduced with the rapid growth in proportions of housing units built with concrete slab foundations. Between 1956 and 1970, the proportion of single-family units constructed in this way rose from 16 percent to 36 percent. ${ }^{23}$ Construction of houses on slab foundations seems likely to continue to grow, although at a slower rate than in the past, in response to continued population shifts to the South and Southwestern sections of the Nation where slab construction is used in a large proportion of single-family houses.

A new construction innovation that may offset losses in timber products due to increased slab construction is the all-weather wood foundation system which uses substantial amounts of iumber and plywood instead of concrete or block construction.

Another change that has significantly reduced timber products use per unit has been the increased importance of two-story houses. In 1956 less than 10 percent of the new, one-family houses had two stories, in contrast to 17 percent a decade and a half later. ${ }^{24}$ This type of construction reduces substantially the roof area and roofing materials required to cover a given floor area. Two-story construction permits enlarging house size without increasing the size of the building lot, a factor that should become increasingly important in the future with rising land values.

Rising land values have apparently also been an important factor in the rapid growth in construction of townhouses or row houses in recent years. Most of these units have common masonry side

23 Ibid.

24 Ibid. 
walls with consequent sarings in the materials used for framing, sheathing and exterior walls. It was assumed in this analysis that proportions of townhouses will continue to increase.

Prefabrication of structural members such as roof trusses and increased factory fabrication of housing components and units have tended to lower average unit use of some rood products, primarily through reduction of waste and improved design. "This trend toward use of prefabricated housing components and some increase in factory fabrication is expected to continue through the projection period, although problems of building codes, consumer tastes, transportation costs, and fragmentation of the building industry may act as constraints on a major shift to industrialized housing.

In conventional on-site construction, more efficient use of rood, such as wider spacing of studs and other structural members, has tended to bring about somewhat lower use of timber products per unit. There are also opportunities for additional sarings in use of materials by changes in design and specifications.

Materials substitution.-The rising trends in use of plywood and building board per housing unit and the concomitant drop in lumber use has reflected extensive substitution of plywrood and building board for lumber in such uses as sheathing and subflooring. For example, between 1959 and 1968 , average lumber use for sheathing and subflooring in single-family houses inspected by FHA declined from 1,667 board feet per unit to 975 board feet. ${ }^{25}$

Plywood use for these components in this period rose from an average of 1,314 square feet to 3,086 square feet ( $3 / 8$-inch basis).

In addition to such wood-for-wood substitution, wood products have been displaced in a number of applications by metal siding, by plastic trim, and by nonwrood flooring materials. Substitution of carpeting for oak flooring has had a particularly marked effect on wood use in apartment construction.

Metal framing systems-steel and aluminumhave been used in single-family house construction as well as in multifamily structures. Although use of such systems in single-family construction has been quite limited, one recent study concluded that substantial displacement could occur with a 30 to 50 percent increase in relative prices of lumber over the 1970 level. ${ }^{26}$ Another study

${ }^{25}$ Phelps, Robert B. Wood products used in singlefamily houses inspected by the Federal Housing Administration, 1959, 1962, and 1968. USDA Stat. Bull. 452, 29 p. 1970.

${ }_{26}$ Kroll, Seymour and Associates, Inc. A comparative research study of wood and metal framing systems. Western Wood Products Association Report WWP-1, Copy 1. Portland, Oregon. 1971. indicated that with 1972 prices of materials and labor, that is, with relative lumber prices 35 percent above 1970, lumber retained a slight cost advantage over steel for exterior studs and for floor framing for most builders, but had a substantial disadvantage for interior studs. ${ }^{27}$

Projected timber products use factors. - The projections of lumber and other timber products used per housing unit shown in table 121 have been based upon a judgment evaluation of the various factors discussed above.

For the initial projection, with 1970 relative prices of timber products, it was assumed that total use of timber products per square foot of floor area in 1- and 2-family housing, would decline slightly, as shown by the following tabulation:

\begin{tabular}{|c|c|c|c|c|c|}
\hline Year & $\begin{array}{l}\text { Floor } \\
\text { area } \\
\text { (square } \\
\text { feet) }\end{array}$ & $\begin{array}{l}\text { Lumber } \\
\text { (board } \\
\text { feet) }\end{array}$ & $\begin{array}{c}\text { Plywood (square } \\
\text { feet, } 3 / 8 \text {-inch } \\
\text { basis) }\end{array}$ & $\begin{array}{l}\text { Building board } \\
\text { (square feet, } \\
1 / 2 \text {-inch basis) }\end{array}$ & $\begin{array}{l}\text { All timber } \\
\text { products (board } \\
\text { feet equivalent) }\end{array}$ \\
\hline $1962 . .$. & $\begin{array}{l}1,335 \\
1,475\end{array}$ & $\begin{array}{l}8.38 \\
7.35\end{array}$ & $\begin{array}{l}2.25 \\
3.65\end{array}$ & $\begin{array}{r}0.99 \\
1.06\end{array}$ & $\begin{array}{l}11.30 \\
11.54\end{array}$ \\
\hline & & & Projections & & \\
\hline $\begin{array}{l}1980 \ldots \\
1990 \ldots \\
2000 \ldots\end{array}$ & $\begin{array}{l}1,615 \\
1,680 \\
1,710\end{array}$ & $\begin{array}{l}6.60 \\
6.25 \\
6.00\end{array}$ & $\begin{array}{l}3.80 \\
3.85 \\
3.90\end{array}$ & $\begin{array}{l}1.15 \\
1.25 \\
1.35\end{array}$ & $\begin{array}{l}11.01 \\
10.80 \\
10.69\end{array}$ \\
\hline
\end{tabular}

Projected lumber use continues to drop while use of plywood and panel products is expected to rise. The projections assume substantial increases in the per unit use of building board in all types of units. Use of particleboard is expected to rise fairly rapidly, with moderate increases in use of hardboard, and a decline in use of insulation board per unit. There may be a much larger rise in the use of particleboard if structural grades are developed which can be substituted for plywood in roof sheathing and subflooring.

\section{Projected Demand for Timber Products in New Housing}

Total consumption of lumber in new residential construction amounted to an estimated 12.3 billion board feet in 1970 (table 122). This was somewhat below the arerage for the 1962-70 period and much below consumption of 19.5 billion board feet in 1972 .

The medium projection of lumber demandderived from the medium projection of demand for housing, the wood use factors shown in table 121 , and 1970 price relationships - rises substantially during the 1970 's and early 1980 's to more than 18 billion board feet by 1990 (table 122).

Demand for plywood and building board roughly doubles in the projection period to about 12 billion square feet of plywood and 4.4 billion square feet of building board.

Under the higher price assumptions specified earlier, projected demand for timber products

\footnotetext{
${ }_{27}$ Koeningshof, Gerald A. Comparative in-place cost between wood and steel residential floor and wall framing. Unpublished. U.S. Forest Serv. Washington. Dec. 1972.
} 
TABLE 122.-Timber products consumed in new housing, 1962 and 1970, with projections of demand (1970 relative prices) to $2000^{1}$

\begin{tabular}{|c|c|c|c|}
\hline Year & Lumber & $\begin{array}{c}\text { Plywood } \\
(3 / 8 \text {-inch basis })\end{array}$ & $\begin{array}{c}\text { Building } \\
\text { board }{ }^{2} \\
\text { (1/2-inch basis) }\end{array}$ \\
\hline $\begin{array}{l}1962 \ldots-\ldots \\
1970-\ldots\end{array}$ & $\begin{array}{r}\text { Mallion board feet } \\
13,940 \\
12,270\end{array}$ & $\begin{array}{r}\text { Million square feet } \\
4,180 \\
6,330\end{array}$ & $\begin{array}{r}\text { Million square feet } \\
1,660 \\
2,070\end{array}$ \\
\hline
\end{tabular}

Low projections

\begin{tabular}{l|r|r|r}
\hline $1980 \ldots-$ & 16,160 & 9,560 & 3,170 \\
$1990 \ldots$ & 17,310 & 10,900 & 3,800 \\
$2000 \ldots-$ & 16,000 & 10,680 & 3,980 \\
\hline
\end{tabular}

Medium projections

\begin{tabular}{l|l|l|l}
\hline $1980,--$ & 17,180 & 10,150 & 3,360 \\
$1990---$ & 18,650 & 11,750 & 4,080 \\
$2000-.-$ & 17,950 & 11,990 & 4,440 \\
\hline
\end{tabular}

High projections

\begin{tabular}{l|l|l|l}
\hline $1980 \ldots \ldots$ & 18,240 & 10,770 & 3,550 \\
$1990 \ldots \ldots$ & 20,000 & 12,600 & 4,370 \\
$2000 \ldots$ & 20,770 & 13,910 & 5,130 \\
\hline
\end{tabular}

${ }^{1}$ Includes both hardwoods and softwoods. Includes allowance fol on-site and manufacturing waste.

${ }^{2}$ Hardboard, insulation board, and particleboard.

in new housing would be significantly lower than the estimates shown in table 122. The summary section of this chapter includes estimates of the effect of alternative price assumptions on total demand for lumber, plywood, and building board in all uses.

\section{DEMAND FOR TIMBER PRODUCTS IN RESI- DENTIAL UPKEEP AND IMPROVEMENTS}

In addition to the timber products used in construction of new residential units, substantial volumes are used annually for the upkeep and improvement of units in the existing housing inventory.

\section{Expenditures for Residential Upkeep and Improve- ments}

In the period 1960-72, the years for which the most reliable data are available, expenditures for upkeep and improvements generally fluctuated between $\$ 12$ and $\$ 13$ billion annually (1967 dollars). For the purposes of this study it was assumed that in the projection period expenditures would grow at about the same rate as the housing inventory. Under this assumption, projected
TABLE 123.-Expenditures and timber products use per thousand dollars of expenditure, residential upkeep and improvements, 1970, with projections (1970 relative prices) to 2000

\begin{tabular}{|c|c|c|c|c|}
\hline \multirow[b]{2}{*}{ Year } & \multirow[b]{2}{*}{$\begin{array}{c}\text { Total } \\
\text { expenditures }\end{array}$} & \multicolumn{3}{|c|}{$\begin{array}{l}\text { Use per thousand } \\
\text { dollars of expenditures }\end{array}$} \\
\hline & & Lumber & $\begin{array}{c}\text { Plywood } \\
\text { (3/8-inch } \\
\text { basis) }\end{array}$ & $\begin{array}{l}\text { Building } \\
\text { board } 1 \\
\text { (1/2-inch } \\
\text { basis) }\end{array}$ \\
\hline $1970_{-}$ & $\begin{array}{c}\text { Millions of } \\
1967 \text { dollars } \\
12,067\end{array}$ & $\begin{array}{r}\text { Board feet } \\
390\end{array}$ & $\begin{array}{r}\text { Square feet } \\
210\end{array}$ & $\begin{array}{l}\text { Square feet } \\
90\end{array}$ \\
\hline
\end{tabular}

Low projections

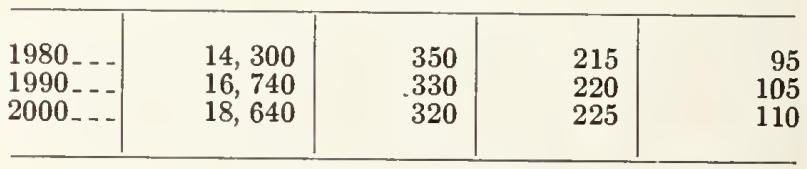

Medium projections

\begin{tabular}{r|r|r|r|r}
\hline $1980 \ldots$ & 14,470 & 350 & 215 & 95 \\
$1990 \ldots$ & 17,110 & 330 & 220 & 105 \\
$2000 \ldots$ & 19,320 & 320 & 225 & 110 \\
\hline
\end{tabular}

High projections

\begin{tabular}{r|r|r|r|r}
\hline $1980 \ldots \ldots$ & 14,610 & 350 & 215 & 95 \\
$199{ }_{2}$ & 17,390 & 330 & 220 & 105 \\
& 20,040 & 320 & 225 & 110 \\
\hline
\end{tabular}

${ }^{1}$ Includes hardboard, insulation board, and particleboard.

Sources: Expenditures: U.S. Department of Commerce, Bureau of the Census. Residential alterations and repairs. C50-67A, Pt. 1, 1968, and C50-70A, 1971. Timber products use: U.S. Department of Agriculture, Forest Service.

Projections: U.S. Department of Agriculture, Forest Service.

annual expenditures rise to about $\$ 19.3$ billion (medium level) by 2000 (table 123). This involves a slight increase in annual expenditures per household.

\section{Timber Products Use and Projected Demand}

Lumber consumption per thousand dollars of expenditure for upkeep and improvements of residential structures, based upon surveys in sample cities, was estimated at about 390 board feet in 1970 (table 123). It was assumed that future lumber use per dollar would decline at about the same rate as per unit use in new 1- and 2-family construction.

With the assumed increases in expenditures, total lumber demand rises from 4.7 billion board feet in 1970 to about 5.1 billion board feet by 1980 
TABLE 124.-Timber products consumed in residentzal upkeep and improvements, 1970, with projections of demand (1970 relative prices) to $2000^{1}$

\begin{tabular}{|c|c|c|c|}
\hline Year & Lumber & $\begin{array}{c}\text { Plywood } \\
(3 / 8 \text {-inch basis })\end{array}$ & $\begin{array}{c}\text { Building board }{ }^{2} \\
\text { (1/2-inch basis })\end{array}$ \\
\hline $1970 \ldots$ & $\begin{array}{l}\text { Milion board feet } \\
\quad 4,690\end{array}$ & $\begin{array}{l}\text { Milion square feet } \\
2,510\end{array}$ & $\begin{array}{l}\text { villion square feet } \\
\quad 1,060\end{array}$ \\
\hline
\end{tabular}

\begin{tabular}{|c|c|c|c|c|c|c|c|c|c|}
\hline \multicolumn{10}{|c|}{ Projections } \\
\hline Year & Low & Medium & High & Low & Medium & High & Low & Medium & High \\
\hline $\begin{array}{l}1980 \ldots \ldots \\
1990 \ldots \\
2000\end{array}$ & $\begin{array}{l}5,000 \\
5,560 \\
5,930\end{array}$ & $\begin{array}{l}5,060 \\
5,680 \\
6,140\end{array}$ & $\begin{array}{l}5,110 \\
5,770 \\
6,370\end{array}$ & $\begin{array}{l}3,060 \\
3,720 \\
4,190\end{array}$ & $\begin{array}{l}3,100 \\
3,800 \\
4,350\end{array}$ & $\begin{array}{l}3,130 \\
3,860 \\
4,510\end{array}$ & $\begin{array}{l}1,360 \\
1,720 \\
2,070\end{array}$ & $\begin{array}{l}1,370 \\
1,760 \\
2,140\end{array}$ & $\begin{array}{l}1,390 \\
1,790 \\
2,220\end{array}$ \\
\hline
\end{tabular}

1 Includes both hardwoods and softwoods. Includes allowance for on-site and manufacturing waste.
${ }^{2}$ Hardboard, insulation board, and particleboard. (medium projection at 1970 relative prices), with a further increase to 6.1 billion board feet by 2000 (table 124).

Plywood use per thousand dollars of expenditures in 1970 was estimated to be about 210 square feet. It was assumed that this arerage would rise slowly to about 225 square feet in 2000 , with the associated total demand (medium projection) over 4.3 billion square feet-about 70 percent above the level of use in 1970 .

Building board use areraged about 90 square feet per thousand dollars of expenditures in 1970 and is assumed to increase to about 110 square feet by 2000. Giren this arerage use and projected expenditures, projected demand for building board in 2000 is 2.1 billion square feet-nearly double the lerel of use in 1970 .

\section{DEMAND FOR TIMBER PRODUCTS IN NEW NONRESIDENTIAL CONSTRUCTION}

Nearly 10 percent of the lumber and plywood used in the United States in 1970--plus substantial rolumes of building board-was consumed in a wide rariety of nonresidential buildings and structures.

In this study, nonresidential construction was divided into five classes: (1) private commercial buildings (offices, stores, warehouses, etc.); (2) other buildings (public and private nonhousekeeping, industrial, educational, religious, hospital and institutional buildings); (3) utility, water, and sewer systems; (4) highways; and (5) all other (military facilities, conservation and development projects, railroad construction except track construction, and construction not included in other categories).

\section{Nonresidential Construction Expenditures}

Expenditures in these classes of construction in recent decades have fluctuated rather widely in response to changing economic conditions (table 125, fig. 63). The longrun trend has been strongly upward, however, with expenditures in most classes rising between three and fire times in the 50 vears 1920 to 1970 . Expenditures for highway construction have shown even larger increases, a reflection of the Federal-Aid Highway Act of 1956 which authorized the interstate highway system.

Per capita expenditures also increased in the 1920-70 period, roughly doubling for most classes of nonresidential construction (Append. $\mathrm{V}$, table $6)$.

Although growth rates for some classes are dropping, substantial increases are projected for each class of construction, ranging from around 2 times for highways to around 3 times for commercial buildings. Per capita expenditures almost double (medium projection) for all classes combined (Append. V, table 6). Total projected expenditures for new nonresidential construction rise from $\$ 49$ billion (1967 dollars) in 1970 to $\$ 145$ billion in 2000 (medium projection).

\section{Timber Products Use in Nonresidential Construction}

There have been divergent trends in the use of different timber products in nonresidential construction in recent years (table 126, fig. 64; Append. V, tables 7-9). Between 1962 and 1970, for example, estimated consumption of lumber dropped from 3.0 to 2.6 billion board feet. Plywood use, on the other hand, rose from 1.3 to 1.7 billion square feet ( $3 / 8$-inch basis) and building board increased from 0.4 to 0.7 billion square feet ( $1 / 2$-inch basis).

In the post World War II years total expenditures for nonresidential construction rose an average of 5.0 percent annually. During this period there were close statistical relationships between changes in expenditures for most classes of construction and changes in gross national product (fig. 63). 
TABLE 125.-Expenditures for new nonresidential construction ${ }^{1}$ by construction class 1920-70, with projections to 2000

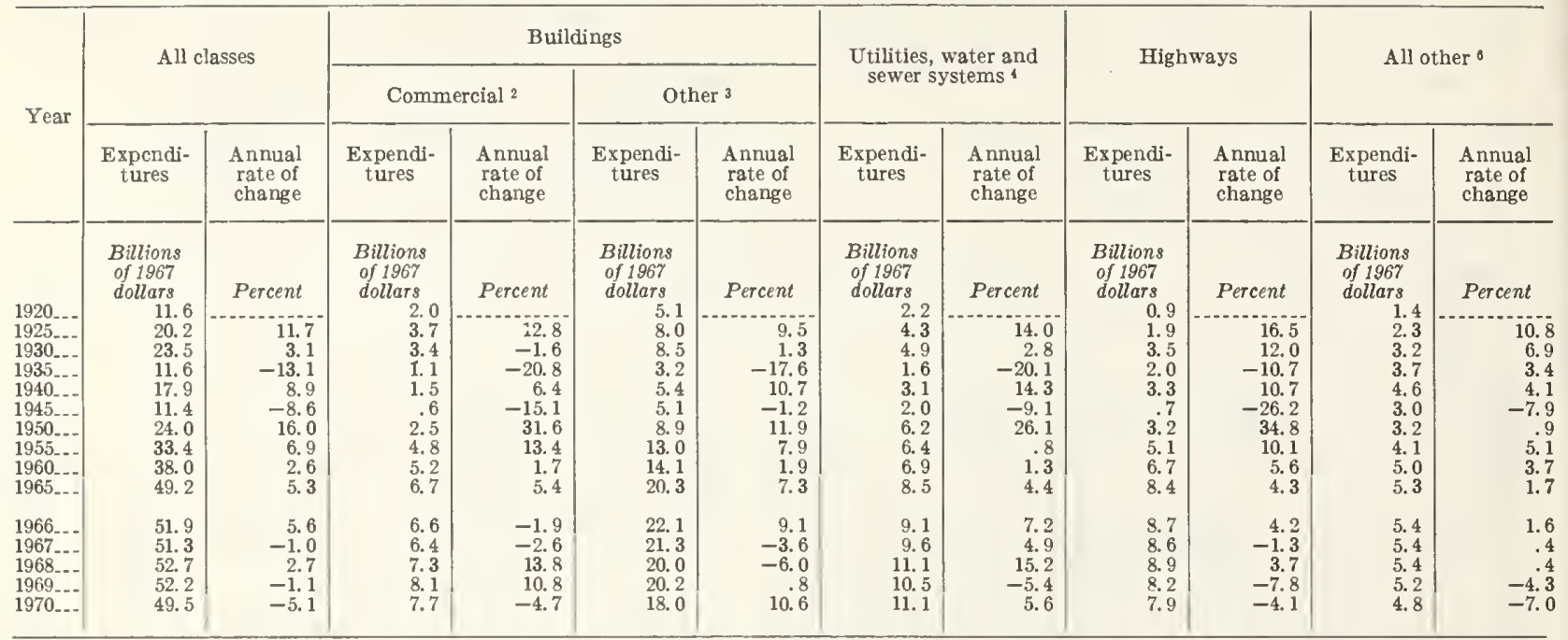

Low projections

\begin{tabular}{|c|c|c|c|c|c|c|c|c|c|c|c|c|}
\hline $\begin{array}{l}1980-. \\
1990-- \\
2000-.\end{array}$ & $\begin{array}{r}73.9 \\
98.2 \\
129.4\end{array}$ & $\begin{array}{r}3.0 \\
2.9 \\
2.8\end{array}$ & $\begin{array}{l}11.4 \\
15.4 \\
20.8\end{array}$ & $\begin{array}{r}03.2 \\
3.1 \\
3.0\end{array}$ & $\begin{array}{l}30.1 \\
40.5 \\
53.4\end{array}$ & $\begin{array}{r}03.2 \\
3.0 \\
2.8\end{array}$ & $\begin{array}{l}14.0 \\
19.7 \\
28.1\end{array}$ & $\begin{array}{r}3.4 \\
3.5 \\
3.6\end{array}$ & $\begin{array}{l}11.4 \\
13.9 \\
16.3\end{array}$ & $\begin{array}{r}2.4 \\
2.0 \\
1.6\end{array}$ & \begin{tabular}{r|}
7.0 \\
8.7 \\
10.8
\end{tabular} & $\begin{array}{r}0.3 \\
2.2 \\
2.1\end{array}$ \\
\hline
\end{tabular}

Medium projections

\begin{tabular}{|c|c|c|c|c|c|c|c|c|c|c|c|c|}
\hline $\begin{array}{l}1980 \ldots \\
1990 .-- \\
2000\end{array}$ & $\begin{array}{r}76.8 \\
106.2 \\
145.2\end{array}$ & $\begin{array}{r}3.4 \\
3.3 \\
3.2\end{array}$ & $\begin{array}{l}11.8 \\
16.7 \\
23.3\end{array}$ & $\begin{array}{r}3.6 \\
3.5 \\
3.4\end{array}$ & $\begin{array}{l}31.3 \\
43.8 \\
60.0\end{array}$ & $\begin{array}{r}3.6 \\
3.4 \\
3.2\end{array}$ & $\begin{array}{l}14.5 \\
21.3 \\
31.5\end{array}$ & $\begin{array}{r}3.8 \\
3.9 \\
4.0\end{array}$ & $\begin{array}{l}11.9 \\
15.0 \\
18.3\end{array}$ & $\begin{array}{r}8.8 \\
2.4 \\
2.0\end{array}$ & $\begin{array}{r}7.3 \\
9.4 \\
12.1\end{array}$ & $\begin{array}{r}2.7 \\
2.6 \\
2.5\end{array}$ \\
\hline
\end{tabular}

High projection

\begin{tabular}{|c|c|c|c|c|c|c|c|c|c|c|c|c|}
\hline $\begin{array}{l}1980 \ldots \\
1990- \\
2000 \ldots\end{array}$ & $\begin{array}{r}79.9 \\
114.8 \\
163.1\end{array}$ & $\begin{array}{r}3.8 \\
3.7 \\
3.6\end{array}$ & $\begin{array}{l}12.3 \\
18.0 \\
26.2\end{array}$ & $\begin{array}{r}6.4 .0 \\
3.9 \\
3.8\end{array}$ & $\begin{array}{l}32.6 \\
47.3 \\
673\end{array}$ & $\begin{array}{r}84.0 \\
3.8 \\
3.6\end{array}$ & $\begin{array}{l}15.1 \\
23.0 \\
35.4\end{array}$ & $\begin{array}{r}4.2 \\
4.3 \\
4.4\end{array}$ & $\begin{array}{l}12.3 \\
16.3 \\
20.6\end{array}$ & $\begin{array}{r}{ }^{6} 3.2 \\
2.8 \\
2.4\end{array}$ & $\begin{array}{r}7.6 \\
10.2 \\
13.6\end{array}$ & $\begin{array}{r}3.1 \\
3.0 \\
2.9\end{array}$ \\
\hline
\end{tabular}

Excludes farm construction.

2 Includes private commercial buildings such as offices, stores, warehouses,

and restaurants.
3 Includes public and private nonhousekeeping, industrial, educational,

religious, hospital and institutional, and similar miscellaneous buildings. ${ }^{4}$ Includes telephone and telegraph, other public utilities, sewer systems, and water supply facilities.

s Includes military facilities, conservation and development, raliroad construction except track construction, and all other public and private construction not included in other categories.

- Rates of increase calculated from the following 1970 trend values: All classes, $\$ 54.9$ billion; commercial buildings, $\$ 8.3$ billion; noncommercial buildings, $\$ 22.0$ billion; utilities, water and sewer systems, $\$ 10.0$ blllion; highways, $\$ 9.0$ billion; and all other, $\$ 5.6$ billion.

Projections based on those relationships, and t've assumed increases in the gross national product, indicate a continuing strong rise in expenditures for new nonresidential construction through the 1970-2000 period but at a declining rate in most classes. The drop in projected growth rates is largest for highways-a reflection of the expectation that the big increases in expenditures in the late 1950's and 1960's associated with funding of the interstate highway system will not be repeated. On the other hand, assumed increases in rates of growth in expenditures for utilities, and water and sewer systems are based on the expectation that increases will be necessary to maintain or improve the environment.
Note: Construction expenditures converted to 1967 dollars by U.S. Department of Agriculture, Forest Service. Annual rates of increase are calculated for 5-year periods from 1920 through 1965, for 1-year periods 1965 through 1970 , and for 10-year periods through 2000 .

Sources: Construction expenditures, U.S. Department of Commerce. 1920-61-A supplement to construction review, construction statistics 1915-1964. Business and Defense Services Administration, 1966; 1962-70-Value of new construction put in place 1968-1970. Bureau of the Census, Constr. Rept. Construction put

Projections-U.S. Department of Agriculture, Forest Service.

The major part ot the lumber consumed in nonresidential construction in 1970 was used in connection with concrete forming or other facilitating uses. The remainder went into structural uses such as decking, joists, rafters, beams, and prefabricated trusses and arches.

Most of the plywood consumed in 1970 also was used for facilitating purposes, primarily for the forming of concrete. The largest part of the building board consumed, was used for structural purposes such as decking, subflooring, and sheathing.

\section{Timber Products Use Per Dollar of Construction Expenditure}

The drop in consumption of lumber in the 196270 period reflected a general decline in the use of 


\section{Expenditures for new nonresidential construction}

\section{7 dollars}

\section{Relationships}
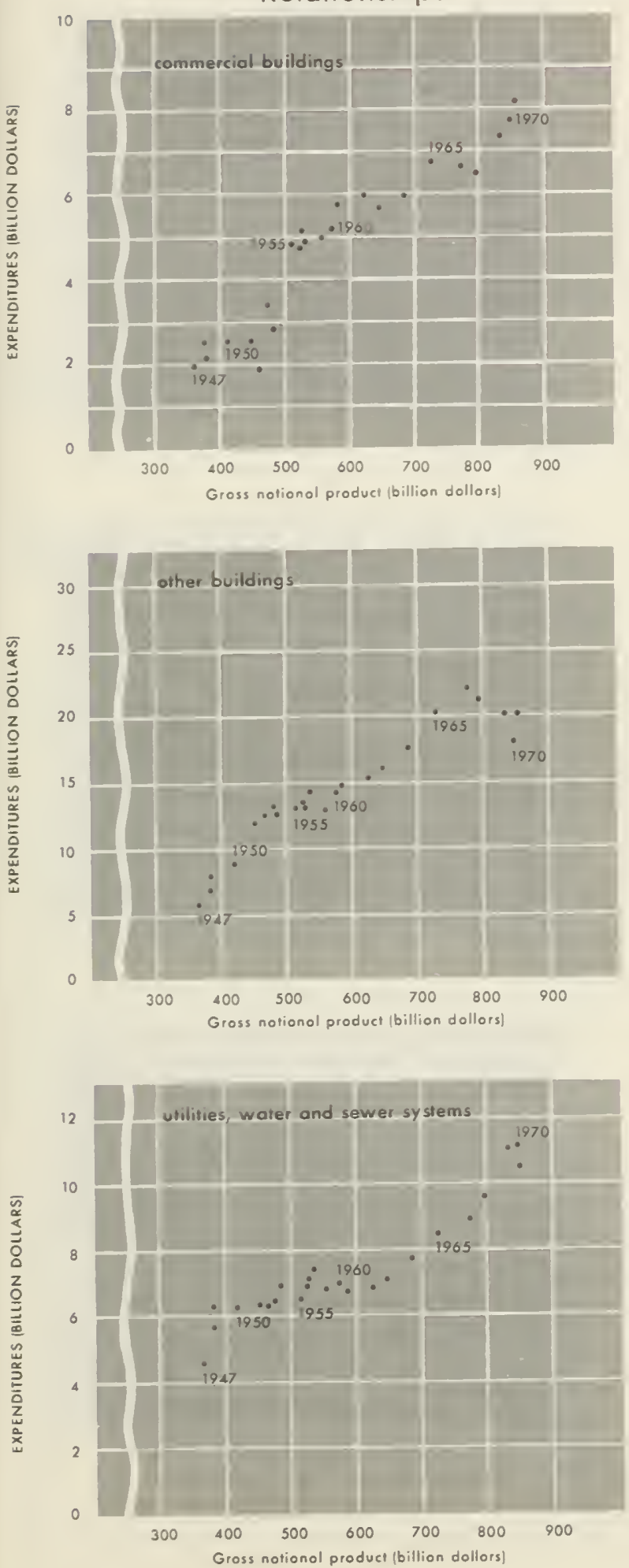
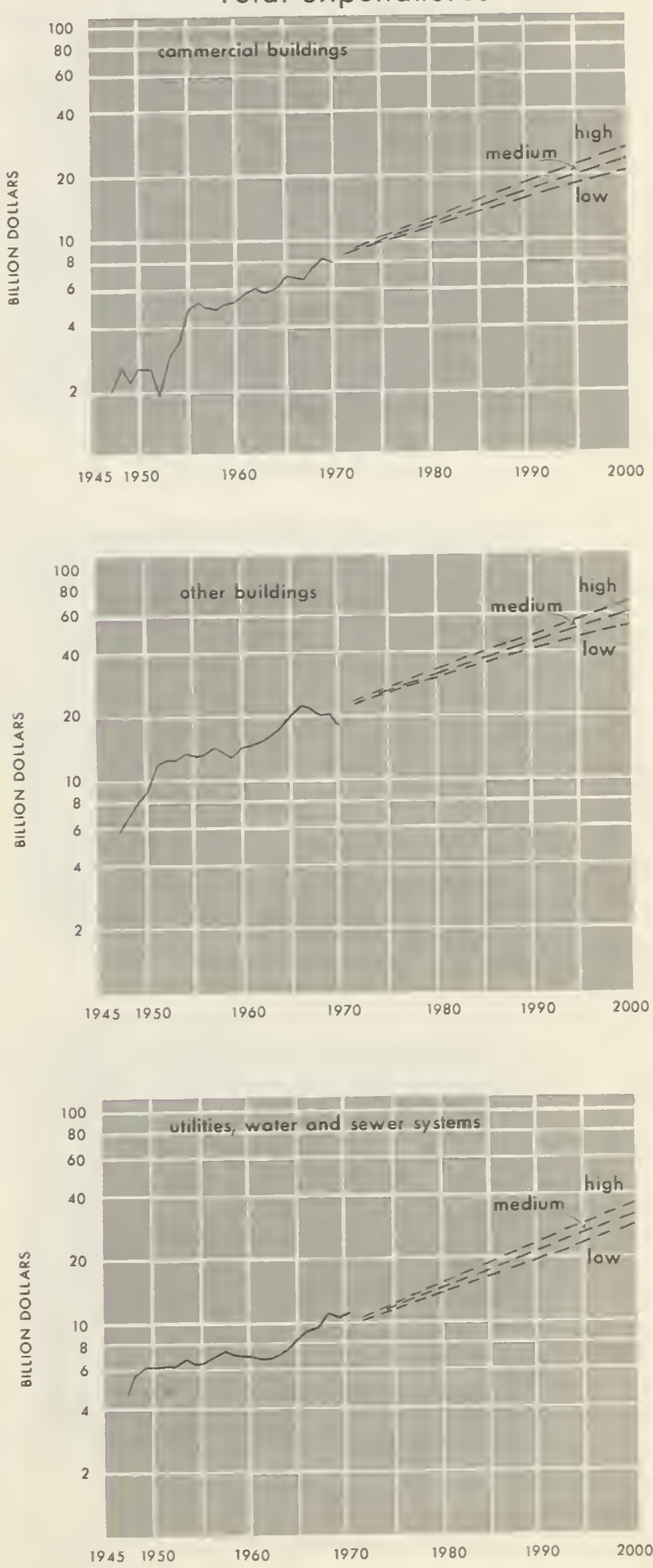


\section{Expenditures for new nonresidential construction 1967 dollars}

Relationships
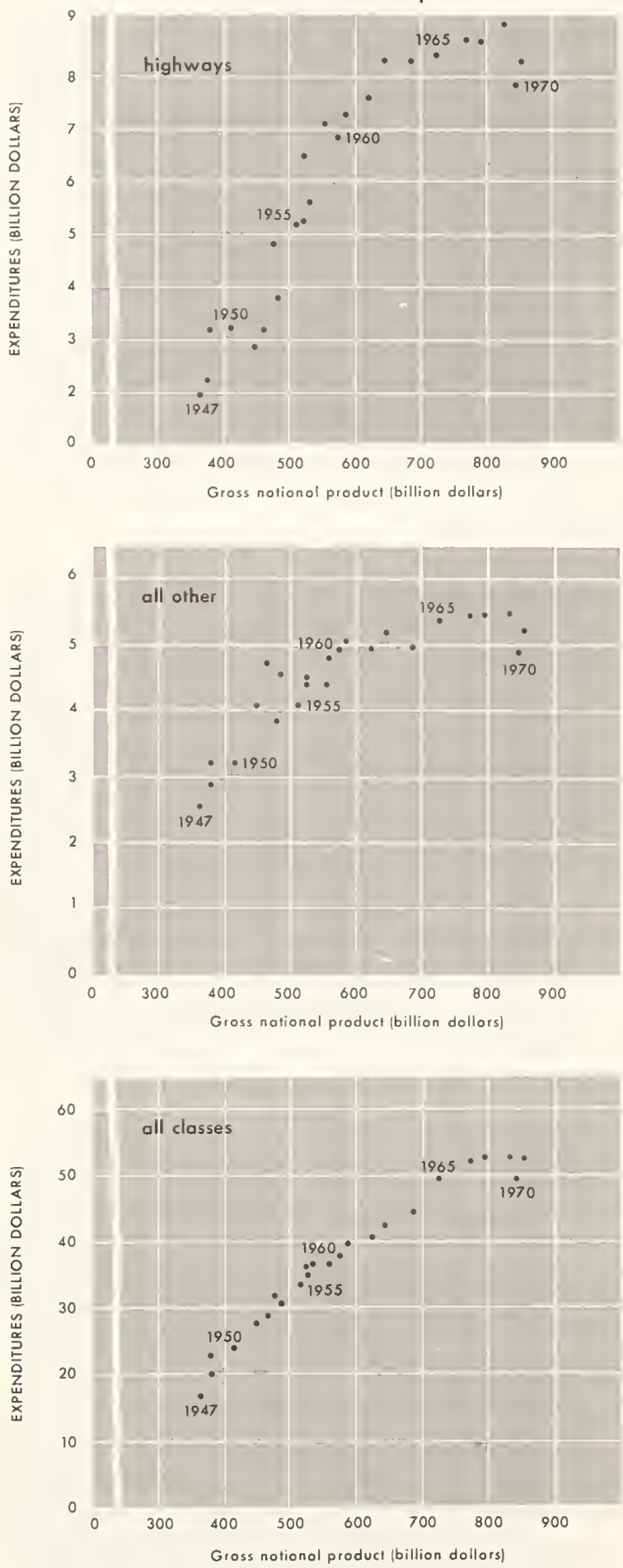

Total expenditures
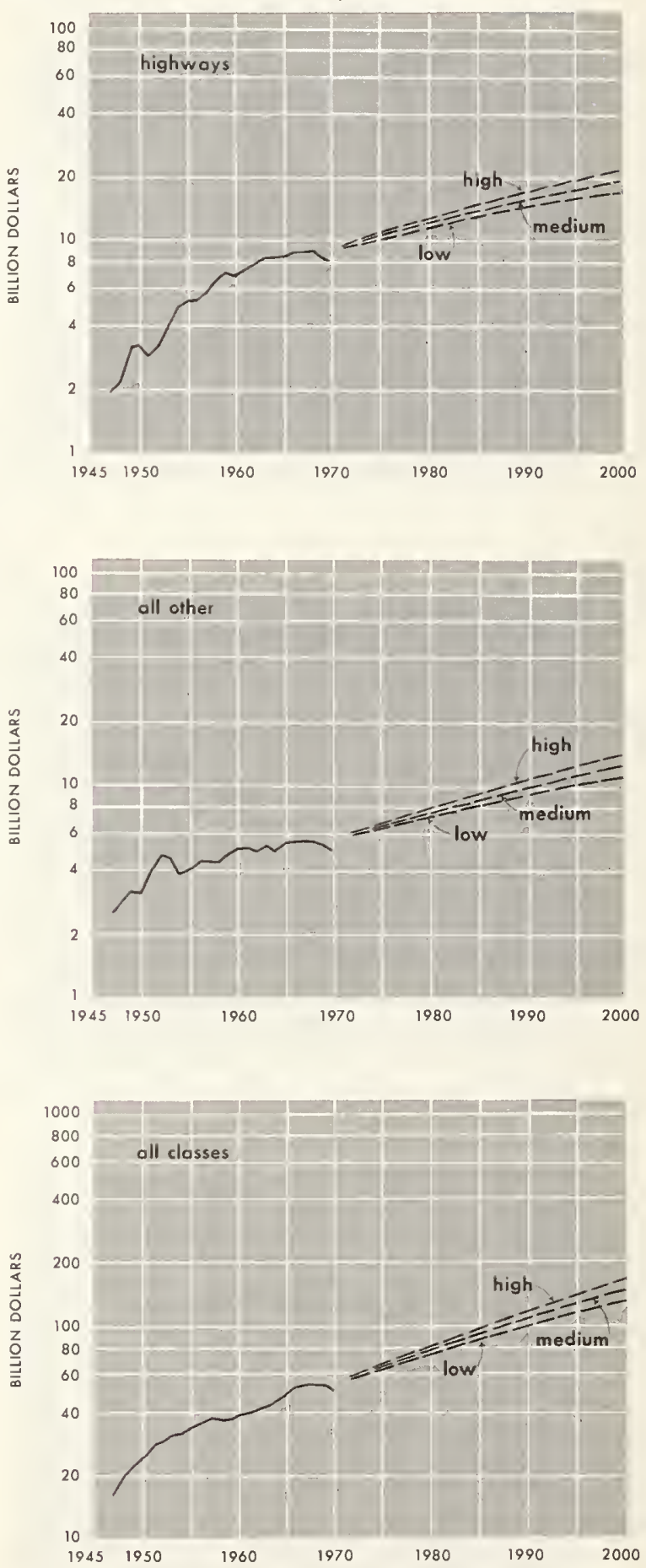

Figure 63 -Continued 
TABLE 126. - Timber products consumed in new nonresidential construction, by major product, 1962 and 1970 , with projections (1970 relative prices) to 2000

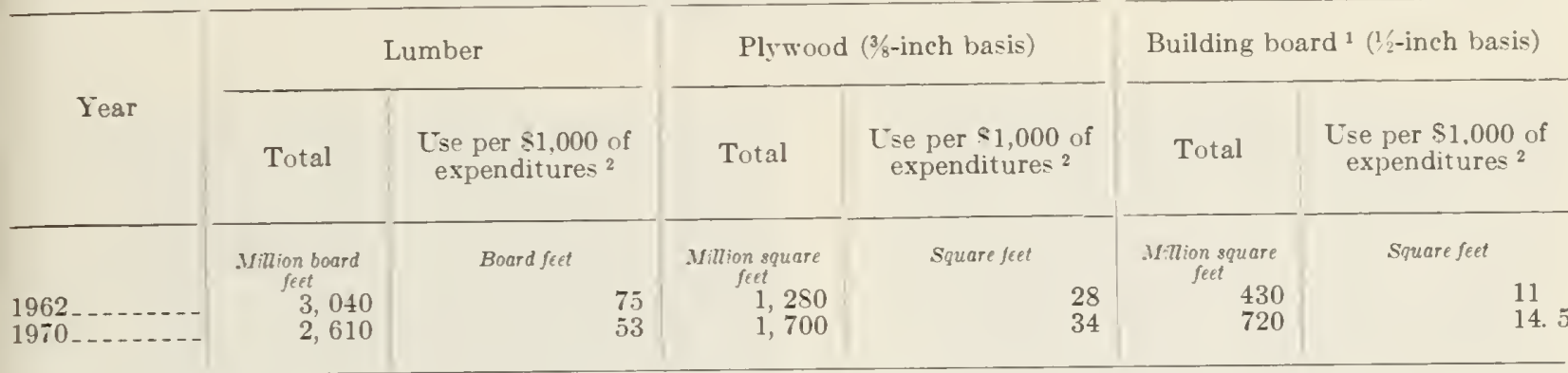

Low projections

\begin{tabular}{l|l|l|l|l|l|}
\hline & & 39 & 2,580 & 35 & 1,030 \\
$1980 \ldots \ldots$ & 3,920 & 34 & 3,260 & 33 & 1,280 \\
$2000 \ldots \ldots$ & 3,360 & 4,0 & 4,050 & 31 & 1,420 \\
\hline
\end{tabular}

Medium projections

\begin{tabular}{l|l|l|l|r|r|r}
\hline & & 39 & 2,680 & 35 & 1,080 \\
$1980 \ldots \ldots$ & 3,030 & 34 & 3,530 & 33 & 1,380 \\
$2000 \ldots \ldots$ & $3, \ldots 30$ & 4,550 & 31 & 1,600 \\
\hline
\end{tabular}

High projections

\begin{tabular}{l|l|l|l|l|l|}
\hline & & 39 & 2,800 & 35 & 1,120 \\
$1980 \ldots \ldots$ & 3,150 & 34 & 3,800 & 33 & 1,490 \\
$2000 \ldots \ldots$ & $3, \ldots 20$ & 5,100 & 31 & 1,790 \\
\hline
\end{tabular}

1 Includes hardboard, particleboard, insulation board.

21967 dollar $s$. Use per $\$ 1,000$ of construction expenditure for 1962 and 1970 computed by Forest Service. (See table 125 for construction expenditures.)

Source: Timber products use, 1962 and 1970, estimates

lumber per dollar of expenditure in most classes of construction, and some fall-off in construction activity in 1970. Plywood consumption per dollar also dropped in some classes, but there were substantial increases in noncommercial buildings, highways, and the "all other" class. Use of building board per dollar of construction expenditure rose in all classes.

These trends in use of timber products per dollar of expenditures reflect many technological and institutional forces. For example, boards and dimension lumber were formerly used for nearly all concrete form work. When plywood with synthetic glues came into wide use in the 1950's, plywood was substituted to an increasing degree for form lumber. Increased durability of plywood panels, which perm tted a larger number of reuses, has more recently had important effects on the consumption of plywood. Growing use of rented metal forms in concrete form work has likewise become important. With development of steel frames and connecting devices some supporting dimension lumber also has been eliminated. based on Forest Service surveys except highways, which were adapted from data provided by U.S. Department of Transportation, Bureau of Public Roads.

Projections: U.S. Department of Agriculture, Forest Service.

Growing use of metal studs, joists, and decking has also contributed to the decline in lumber use per dollar. Increased off-site forming of precast and prestressed concrete beams and decking in lieu of on-site forming have further reduced use of forming lumber and plywood per unit of nonresidential construction. And finally, use of timber products in nonresidential construction has been strongly influenced by building code restrictions and growing urbanization, with an associated growth in demand for large high-rise structures, constructed almost entirely of steel and concrete.

In contrast to the above forces, which have acted to reduce the demand for timber products there have been other developments which have tended to increase use. Use of structural wood items such as beams, trusses, and arches has been growing, especially in churches, supermarkets, schools, and warehouses. Certain architectural styles, such as the recent revival of the mansard roof, have also increased use of framing lumber and plywood. 


\section{Projected Demand for Timber Products in New Non- residential Construction}

With respect to the future, it has been assumed that the forces affecting demand will continue to reduce use of timber products per dollar of expenditures (table 126, fig. 64; Append. V, tables 7-9). The projected declines are not enough to offset expected increases in expenditure, however, and as a result projected demands for timber products at 1970 relative prices increase through the projection period. Projected demand for lumber by 2000 reaches 4.4 billion board feet (medium projection and 1970 prices)-some 67 percent above 1970. Projected demand for plywood under these assumptions rises about 2.7 times in the 30 -year period, and demand for building board more than doubles.

\section{DEMAND FOR TIMBER PRODUCTS IN RAILROAD CONSTRUCTION}

In 1970 close to a billion board feet of lumber, nearly all in the form of ties, and about 25 million square feet ( $3 / 8$-inch basis) of plywood were used by the railroad industry in the maintenance and construction of tracks and freight cars.

Substantial volumes of lumber and plywood were also used in the construction and maintenance of nonresidential structures used by railroads and in the manufacture of freight cars. Information on past use and projected demands for timber products in these uses is included in other sections of this report dealing with nonresidential construction and manufacturing.

Between the 1920's and the early 1960's, the number of railway crossties used annually dropped from an average of about 96 million to less than 15 million (table 127). The downward trend in use reflected a major reduction in construction of new track, a drop in railroad track mileage, increased average life of ties resulting from use of wood preservatives, use of various devices to reduce mechanical wear and splitting of wood ties, use of welded track, and a shift to diesel locomotives with reduced track wear.

Since the early 1960's the long downward trend in crosstie use has reversed and the number consumed has been rising slowly. This rise is expected to continue because of the growing need for improved track maintenance and some decline in average tie life resulting from the trend toward heavier wheel loads, higher speed trains, and the growing volume of rail traffic.

Replacement demand for crossties has therefore been projected to rise to 31 million (medium projection at 1970 relative prices) by 1980 and remain at or slightly below this level through 2000 . This rate of replacement implies an average tie life of about 30 years. It also assumes there will be no substantive reduction in the mileage of track operated.
Total demand for both crossties and switch and bridge ties is projected to rise to 1.4 billion board feet by 2000 - some 1.6 times consumption in 1970 .

In addition to ties, an estimated 200 million board feet of lumber and 25 million square feet (3/8-inch basis) of plywood was used annually in the 1960's in the construction and repair of railroad cars in industry owned facilities. Such factors as growing numbers of freight cars, increasing size of cars, and the use of heavier decking, will tend to increase demands for lumber and plywood in car repair. Changes in the types of cars, however, and use of other materials in car construction appear likely to limit demands for lumber and plywood. In view of these considerations demand for lumber for car construction and repair within the railroad industry has been projected at 300 million board feet, and demand for plywood at 50 million square feet, in all projection years.

\section{DEMAND FOR TIMBER PRODUCTS IN MANUFACTURING}

About a tenth of the lumber, veneer and plywood, and a third of the hardboard and particleboard, consumed in 1970 was used in the manufacture of a wide range of products such as furniture, truck bodies and other items listed in footnotes to table 128 .

These products have been divided into five groups, including: (1) household furniture, (2) commercial and institutional furniture, (3) consumer goods, (4) commercial and industrial equipment, and (5) other products. Products in each group have more or less similar characteristics in relation to timber products use, and similar relationships to basic determinants of demand such as gross national product or per capita disposable personal income.

In addition to these specified manufactured items, substantial volumes of timber products are used in other manufactured goods such as pallets, prefabricated wooden buildings and structural members, containers, mobile homes, millwork, and flooring. Information on use and projected demands for timber products in the manufacture of these items is included in other sections of this report dealing with construction and shipping.

\section{Timber Products Use in Manufacturing}

Consumption of timber products in the manufacture of goods included in this section increased substantially in the 1960 's (table 128). ${ }^{28}$ The most

28 The data for 1948,1960 , and 1965 shown in table 128 were obtained from Forest Service surveys of wood used in manufacturing industries. The 1970 estimates were updated from 1965 on the basis of changes in value of shipments and trends in wood use per dollar of shipments. 
Timber products consumed in new nonresidential construction 1962 and 1970 , with projections to 2000

Lumber
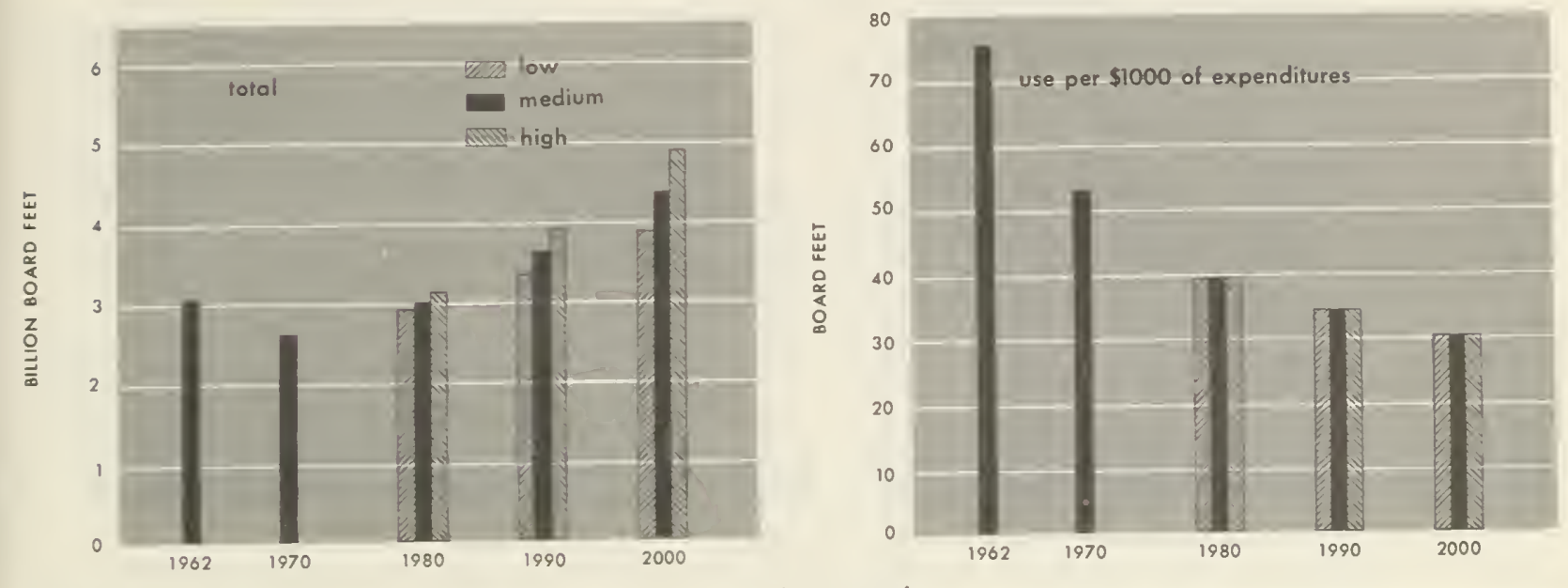

Plywood
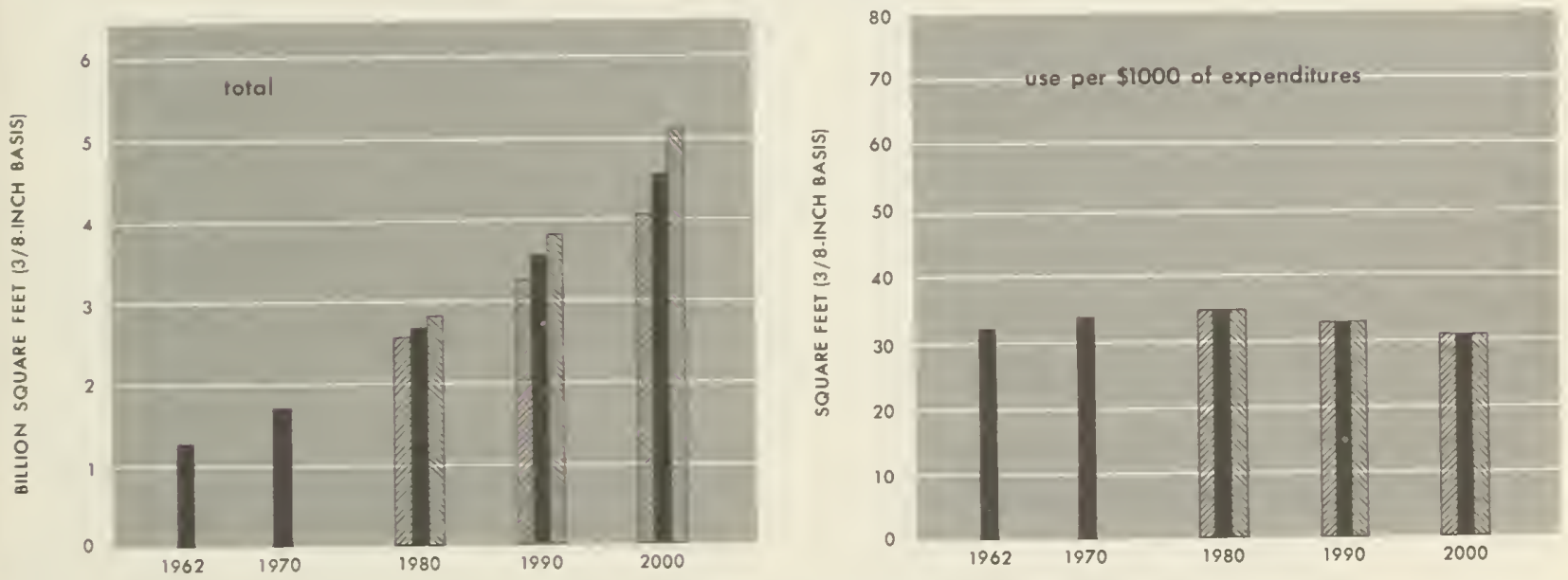

Building board
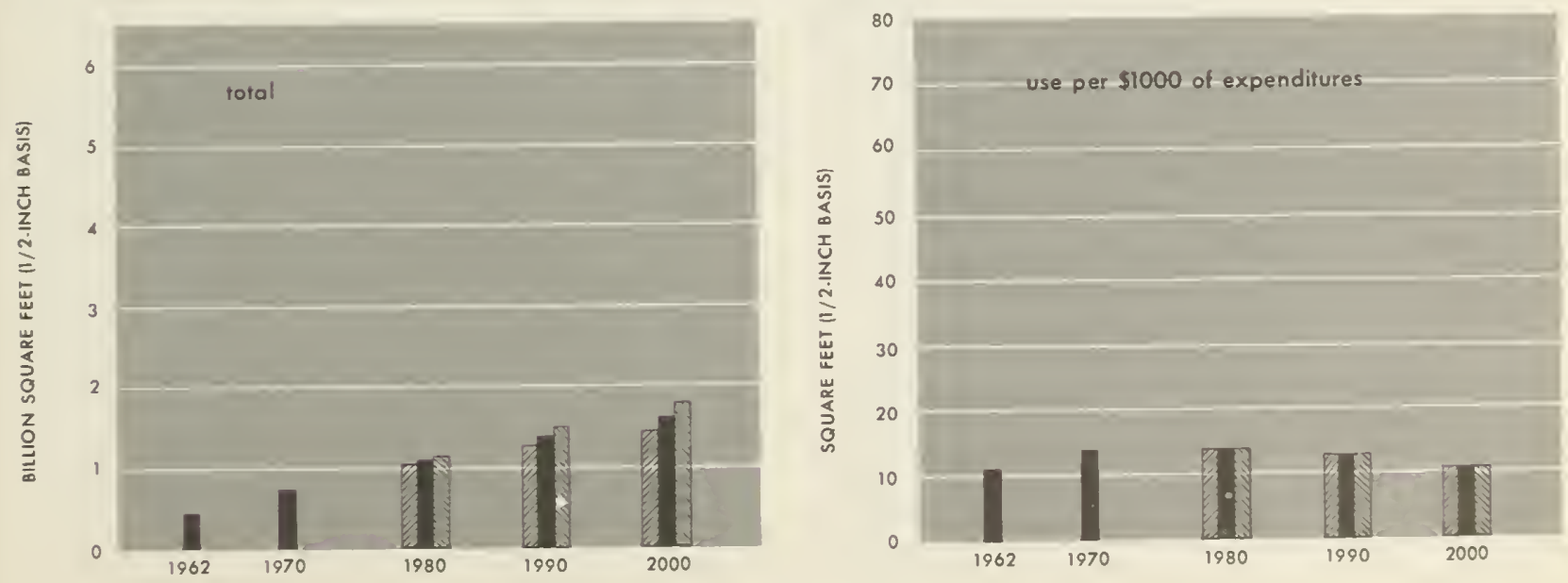
TABLE 127.-Railway mileage, and ties consumed, 1920-70, with projections (1970 relative prices) to 2000

\begin{tabular}{|c|c|c|c|c|c|c|c|c|c|c|c|}
\hline \multirow{4}{*}{ Year } & \multirow{2}{*}{\multicolumn{2}{|c|}{$\begin{array}{c}\text { Mileage of } \\
\text { track operated }\end{array}$}} & \multirow{4}{*}{$\begin{array}{l}\text { Crossties } \\
\text { per mile } \\
\text { of track }\end{array}$} & \multicolumn{8}{|c|}{ Tie consumption } \\
\hline & & & & \multirow{3}{*}{$\begin{array}{c}\text { Total } \\
\text { volume }\end{array}$} & \multicolumn{6}{|c|}{ Crossties } & \multirow{3}{*}{$\begin{array}{l}\text { Switch and } \\
\text { bridge ties, } \\
\text { volume }\end{array}$} \\
\hline & \multirow{2}{*}{ Total } & \multirow{2}{*}{$\begin{array}{l}\text { Laid on } \\
\text { crossties }\end{array}$} & & & \multicolumn{2}{|c|}{ Total } & \multicolumn{2}{|c|}{ In replacement } & \multicolumn{2}{|c|}{ In new track } & \\
\hline & & & & & Number & Volume & Number & Volume & Number & Volume & \\
\hline $\begin{array}{l}1920-291 \\
1930-39 \\
1940-49 \\
1950-59\end{array}$ & $\begin{array}{c}\text { Thousand } \\
\text { miles } \\
400.4 \\
399.9 \\
378.3 \\
369.8\end{array}$ & $\begin{array}{c}\text { Thousand } \\
\text { miles } \\
372.4 \\
371.9 \\
351.8 \\
343.9\end{array}$ & $\begin{array}{r}\text { Number } \\
2,986 \\
3,000 \\
3,015\end{array}$ & $\begin{array}{r}\text { Million } \\
\text { board feet } \\
3,598 \\
2,085 \\
2,000 \\
1,262\end{array}$ & $\begin{array}{c}\text { Thousands } \\
96,400 \\
52,506 \\
48,353 \\
29,523\end{array}$ & $\begin{array}{r}\text { Million } \\
\text { board feet } \\
3,278 \\
1,890 \\
1,837 \\
1,151\end{array}$ & $\begin{array}{r}\text { Thousands } \\
90,000 \\
50,552 \\
45,111 \\
26,431\end{array}$ & $\begin{array}{r}\text { Million } \\
\text { board feet } \\
3,060 \\
1,820 \\
1,714 \\
1,031\end{array}$ & $\begin{array}{r}\text { Thousands } \\
6,400 \\
1,954 \\
3,242 \\
3,092\end{array}$ & $\begin{array}{r}\text { Million } \\
\text { board feet } \\
218 \\
70 \\
123 \\
121\end{array}$ & $\begin{array}{r}\text { Million } \\
\text { board feet } \\
320 \\
195 \\
163 \\
111\end{array}$ \\
\hline $\begin{array}{l}1960 \ldots 1 \\
1961 \\
1962 \\
1963 \\
1964\end{array}$ & $\begin{array}{l}360.6 \\
357.9 \\
354.5 \\
352.3 \\
350.0\end{array}$ & $\begin{array}{l}335.3 \\
332.9 \\
329.6 \\
327.7 \\
325.5\end{array}$ & $\begin{array}{l}3,017 \\
3,017 \\
3,018 \\
3,019 \\
3,079\end{array}$ & $\begin{array}{l}745 \\
622 \\
693 \\
687 \\
750\end{array}$ & $\begin{array}{l}17,370 \\
14,210 \\
16,090 \\
16,000 \\
17,544\end{array}$ & $\begin{array}{l}677 \\
554 \\
628 \\
624 \\
684\end{array}$ & $\begin{array}{l}15,150 \\
12,719 \\
14,209 \\
14,463 \\
15,629\end{array}$ & $\begin{array}{l}591 \\
496 \\
555 \\
564 \\
609\end{array}$ & $\begin{array}{l}2,220 \\
1,489 \\
1,881 \\
1,537 \\
1,915\end{array}$ & $\begin{array}{l}86 \\
58 \\
73 \\
60 \\
75\end{array}$ & $\begin{array}{l}68 \\
68 \\
65 \\
63 \\
66\end{array}$ \\
\hline $\begin{array}{l}1965 \\
1966 \\
1967 \\
1969\end{array}$ & $\begin{array}{l}348.0 \\
346.6 \\
344.9 \\
343.1 \\
341.5\end{array}$ & $\begin{array}{l}323.6 \\
322.3 \\
320.8 \\
319.1 \\
317.6\end{array}$ & $\begin{array}{l}3,016 \\
3,021 \\
3,032 \\
3,031 \\
3,031\end{array}$ & $\begin{array}{l}776 \\
807 \\
832 \\
899 \\
899\end{array}$ & $\begin{array}{l}18,198 \\
18,979 \\
18,652 \\
20,322 \\
21,363\end{array}$ & $\begin{array}{l}710 \\
740 \\
765 \\
833 \\
833\end{array}$ & $\begin{array}{l}15,817 \\
16,436 \\
16,093 \\
18,323 \\
18,556\end{array}$ & $\begin{array}{l}617 \\
641 \\
660 \\
751 \\
724\end{array}$ & $\begin{array}{l}2,381 \\
2,543 \\
2,559 \\
1,999 \\
2,807\end{array}$ & $\begin{array}{r}93 \\
99 \\
105 \\
82 \\
109\end{array}$ & $\begin{array}{l}66 \\
67 \\
67 \\
66 \\
66\end{array}$ \\
\hline 1970 & 340.0 & 316.2 & 3,030 & 880 & 20,915 & 816 & 19,336 & 754 & 1,579 & 62 & 64 \\
\hline
\end{tabular}

Low projections

\begin{tabular}{|c|c|c|c|c|c|c|c|c|c|c|c|}
\hline $\begin{array}{l}1980 \ldots 0 \\
1990 \\
2000\end{array}$ & $\begin{array}{l}330.0 \\
325.0 \\
322.0\end{array}$ & $\begin{array}{l}307.0 \\
302.0 \\
299.0\end{array}$ & $\begin{array}{l}3,030 \\
3,025 \\
3,020\end{array}$ & $\begin{array}{l}1,250 \\
1,260 \\
1,270\end{array}$ & $\begin{array}{l}29,550 \\
29,590 \\
30,050\end{array}$ & $\begin{array}{l}1,180 \\
1,190 \\
1,200\end{array}$ & $\begin{array}{l}28,190 \\
27,680 \\
27,360\end{array}$ & $\begin{array}{l}1,130 \\
1,110 \\
1,090\end{array}$ & $\begin{array}{l}1,360 \\
1,910 \\
2,690\end{array}$ & $\begin{array}{r}50 \\
80 \\
110\end{array}$ & $\begin{array}{l}70 \\
70 \\
70\end{array}$ \\
\hline
\end{tabular}

Medium projections

\begin{tabular}{|c|c|c|c|c|c|c|c|c|c|c|c|}
\hline $\begin{array}{l}1980 \ldots 0 \\
1990 \\
2000\end{array}$ & $\begin{array}{l}330.0 \\
325.0 \\
322.0\end{array}$ & $\begin{array}{l}307.0 \\
302.0 \\
299.0\end{array}$ & $\begin{array}{l}3,030 \\
3,025 \\
3,020\end{array}$ & $\begin{array}{l}1,370 \\
1,380 \\
1,400\end{array}$ & $\begin{array}{l}32,450 \\
32,570 \\
33,240\end{array}$ & $\begin{array}{l}1,300 \\
1,310 \\
1,330\end{array}$ & $\begin{array}{l}31,010 \\
30,450 \\
30,100\end{array}$ & $\begin{array}{l}1,240 \\
1,220 \\
1,200\end{array}$ & $\begin{array}{l}1,440 \\
2,120 \\
3,140\end{array}$ & $\begin{array}{r}60 \\
90 \\
130\end{array}$ & $\begin{array}{l}70 \\
70 \\
70\end{array}$ \\
\hline
\end{tabular}

High projections

\begin{tabular}{|c|c|c|c|c|c|c|c|c|c|c|c|}
\hline $\begin{array}{l}1980 \\
1990 \\
2000\end{array}$ & $\begin{array}{l}330.0 \\
325.0 \\
322.0\end{array}$ & $\begin{array}{l}307.0 \\
302.0 \\
299.0\end{array}$ & $\begin{array}{l}3,030 \\
3,025 \\
3,020\end{array}$ & $\begin{array}{l}1,510 \\
1,520 \\
1,550\end{array}$ & $\begin{array}{l}35,960 \\
36,170 \\
37,060\end{array}$ & $\begin{array}{l}1,440 \\
1,450 \\
1,480\end{array}$ & $\begin{array}{l}34,450 \\
33,840 \\
33,440\end{array}$ & $\begin{array}{l}1,380 \\
1,350 \\
1,340\end{array}$ & $\begin{array}{l}1,510 \\
2,330 \\
3,620\end{array}$ & $\begin{array}{r}60 \\
100 \\
140\end{array}$ & $\begin{array}{l}70 \\
70 \\
70\end{array}$ \\
\hline
\end{tabular}

1 Data shown are annual averages for the decade.

Note: Data on tie consumption by class I railroads as reported by the ICC have been adjusted to include consumption by all railroads.

rapid growth was for particleboard, with consumption rising from 106 to 669 million square feet $\left(3 / 4^{-}\right.$ inch basis), and for hardboard, with use growing from 760 to 1,361 million square feet (1/8-inch basis). Lumber consumption also increased from 3.9 to 4.7 billion board feet in the 1960 's, but veneer and plywood use remained close to 1.7 billion square feet ( $3 / 8$-inch basis). These recent trends reflect both growth in the volume of production of manufactured products, and technological changes which have affected the kinds and amounts of materials consumed.

Manufacture of household furniture has been by far the largest end use of timber products, accounting for more than 60 percent of the total lumber and particleboard used in manufacturing in 1970 and about half the veneer and plywood and hardboard consumed. Moreover, use of timber products in household furniture manufacture has grown substantially in the past two decades. Wood use
Sources: U.S. Interstate Commerce Commission, Bureau of Transport Economics and Statistics. 1920-53-Statistics of railways in the United States; 1954-1970-Transportation Statistics in the United States.

Projections: U.S. Department of Agriculture, Forest Service.

by other product groups listed above has increased only moderately or has declined in recent years.

\section{Shipments of Manufactured Products}

Between 1960 and 1970, the value of shipments of the household furniture industry, measured in constant 1967 dollars and based on trend values, rose by an average of 4.5 percent annually (table 129 , fig. 65). Value of shipments on a per capita basis also increased during this decade, rising by 3.3 percent per year (Append. $V$, table 10).

Changes in the per capita value of household furniture shipments during recent years have been closely correlated with changes in per capita disposable personal income (fig. 65). Projections of the value of shipments of the household furniture industry based on this relationship, and on the population and income assumptions presented earlier in this chapter, increase threefold by 2000 (medium projection). 
TABLE 128.-Timber products consumed in manufacturing, by product group, 1948, 1960, 1965 and 1970

\begin{tabular}{|c|c|c|c|c|}
\hline Year and product group & Lumber & $\begin{array}{c}\text { Veneer and } \\
\text { plywood } \\
\text { (3/8-inch basis) }\end{array}$ & $\begin{array}{c}\text { Hardboard } \\
(1 / 8 \cdot \text { inch basis })\end{array}$ & $\begin{array}{l}\text { Particleboard } \\
(3 / 4 \text {-inch basis })\end{array}$ \\
\hline $\begin{array}{l}\text { 1948: } \\
\text { Household furniture. } \\
\text { Commercial and institutional furniture } \\
\text { Consumer goods }{ }^{1} \text {. } \\
\text { Commercial and industrial machinery and equip- } \\
\text { ment }{ }^{2} \text {. }\end{array}$ & $\begin{array}{r}\text { Million board feet } \\
1,970 \\
321 \\
723 \\
518 \\
392 \\
\end{array}$ & $\begin{array}{r}\text { Million square feet } \\
592 \\
274 \\
57 \\
73 \\
130\end{array}$ & $\begin{array}{r}\text { Million square feet } \\
\text { NA } \\
\text { NA } \\
\text { NA } \\
\text { NA }\end{array}$ & $\begin{array}{r}\text { Million square fett } \\
\text { NA } \\
\qquad \begin{array}{r}\text { NA } \\
\text { NA } \\
\text { NA }\end{array}\end{array}$ \\
\hline Total & 3924 & 1,126 & $\mathrm{NA}$ & NA \\
\hline $\begin{array}{l}1960 \text { : } \\
\text { Household furniture. } \\
\text { Commercial and institutional furniture } \\
\text { Consumer goods ' } \\
\text { Commercial and industrial machinery and equip- } \\
\text { ment }{ }^{2} \text { - } \\
\text { Other products }\end{array}$ & $\begin{array}{r}2,116 \\
289 \\
643 \\
\\
414 \\
403\end{array}$ & $\begin{array}{r}877 \\
342 \\
246 \\
\\
75 \\
282\end{array}$ & $\begin{array}{r}231 \\
140 \\
30 \\
\\
58 \\
296\end{array}$ & $\begin{array}{r}58 \\
34 \\
5\end{array}$ \\
\hline Total_ & 3,865 & 1,822 & 760 & 106 \\
\hline $\begin{array}{l}\text { Household furniture } \\
\text { Commercial and institutional furniture } \\
\text { Consumer goods }{ }^{1} \text {. } \\
\text { Commercial and industrial machinery and equip- } \\
\text { ment }{ }^{2} \text {. }\end{array}$ & $\begin{array}{r}2,987 \\
280 \\
518 \\
\\
619 \\
205\end{array}$ & $\begin{array}{l}789 \\
230 \\
273 \\
\\
170 \\
100\end{array}$ & $\begin{array}{r}526 \\
138 \\
43 \\
\\
41 \\
387\end{array}$ & $\begin{array}{r}312 \\
119 \\
10 \\
\\
16 \\
19\end{array}$ \\
\hline Total & 4,609 & 1,562 & 1,135 & 476 \\
\hline $\begin{array}{l}\text { 1970: } \\
\text { Household furniture } \\
\text { Commercial and institutional furniture } \\
\text { Consumer goods }{ }^{1} \text {. } \\
\text { Commercial and industrial machinery and equip- } \\
\text { ment }{ }^{2} \\
\text { Other products }\end{array}$ & $\begin{array}{r}2,961 \\
271 \\
621 \\
\\
620 \\
197 \\
\end{array}$ & $\begin{array}{l}838 \\
227 \\
303 \\
\\
179 \\
109\end{array}$ & $\begin{array}{r}663 \\
127 \\
48 \\
\\
49 \\
474\end{array}$ & $\begin{array}{r}427 \\
179 \\
14 \\
\\
19 \\
30\end{array}$ \\
\hline - n & 4,670 & 1,656 & 1,361 & $6 ; 9$ \\
\hline
\end{tabular}

1 Includes sporting goods, musical instruments, boat building and repair, toys and games, luggage and trunks, handles, mood pencils, morticians' goods, shoe and boot findings, and wood matches.

2 Includes commercial refrigeration, signs and displays, patterns and jigs, truck bodies and trailers, general machinery, agricultural implements, electrical equipment, and textile machinery supplies.

3 All manufactured products except those listed above and products such as pallets, prefabricated wooden buildings and structural members, containers, mobile homes,

Annual rates of growth show a substantial decline over the projection period from 4.5 percent in the 1960 's to 3.4 percent in the 1990's.

Shipments of the other manufactured products included in this section also rose substantially in the 1948-70 period, although there were significant differences in rates of growth (table 129, fig. 65). Despite such differences, there was a close relationship between changes in the ralue of shipments of each group of products and changes in gross national product or disposable personal income. mill sork, flooring, and other similar goods included in the construction and shipping sections of this study.

Sources: U.S. Depaltment of Agriculture, Forest Service. 1948-Wood used in manufacture, 1948. Forest Resource Rep. 2. 1951; 1960-Wood used in manufacturing industries, 1960. Stat. Bull. 353. 1965; 1965-Wood used in $n$ a uffacturing industries, 1965. Stat. Bull. 440. 1969; 1970 -Based on preliminary estimates of value of shipmen is (table 129) and trends in timber products use per dullar of shipments (table 130).

Projections to 2000 based on these past relationships rary from less than a threefold increase for "other products" to over a fivefold increase for commercial and industrial equipment (medium projection at 1970 prices). ${ }^{29} \mathrm{As}$ in the case of household furniture, assumed rates of increase in

${ }^{2 \theta}$ Separate projections of value of shipments were prepared for each of the important wood-using products listed in footnotes to table 129 , based upon recent relationships between changes in the value of shipments and changes in gross national product or dispcsable personal income. These separate projections were then added together to obtain totals for major categorics. 
Value of shipments of manufactured products

Relationships
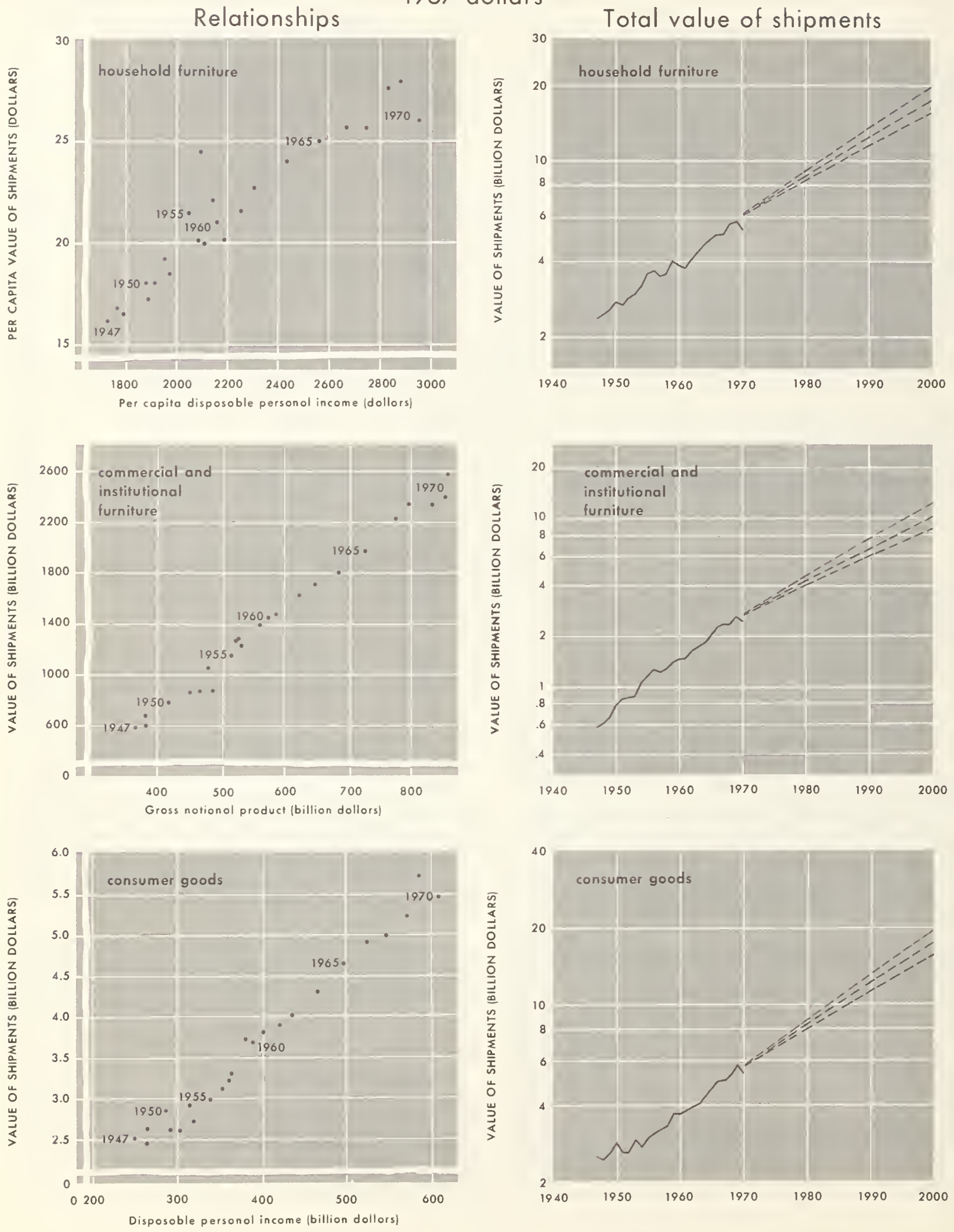
Value of shipments of manufactured products

Relationships
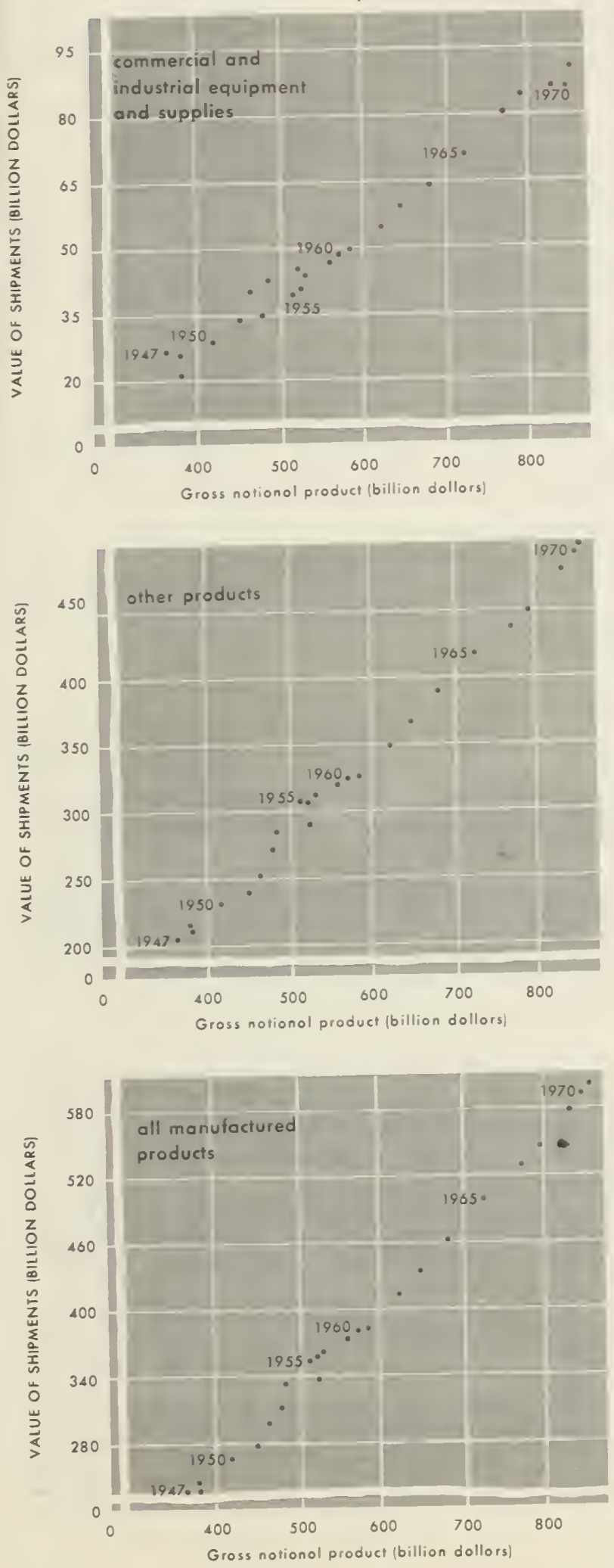

Total value of shipments
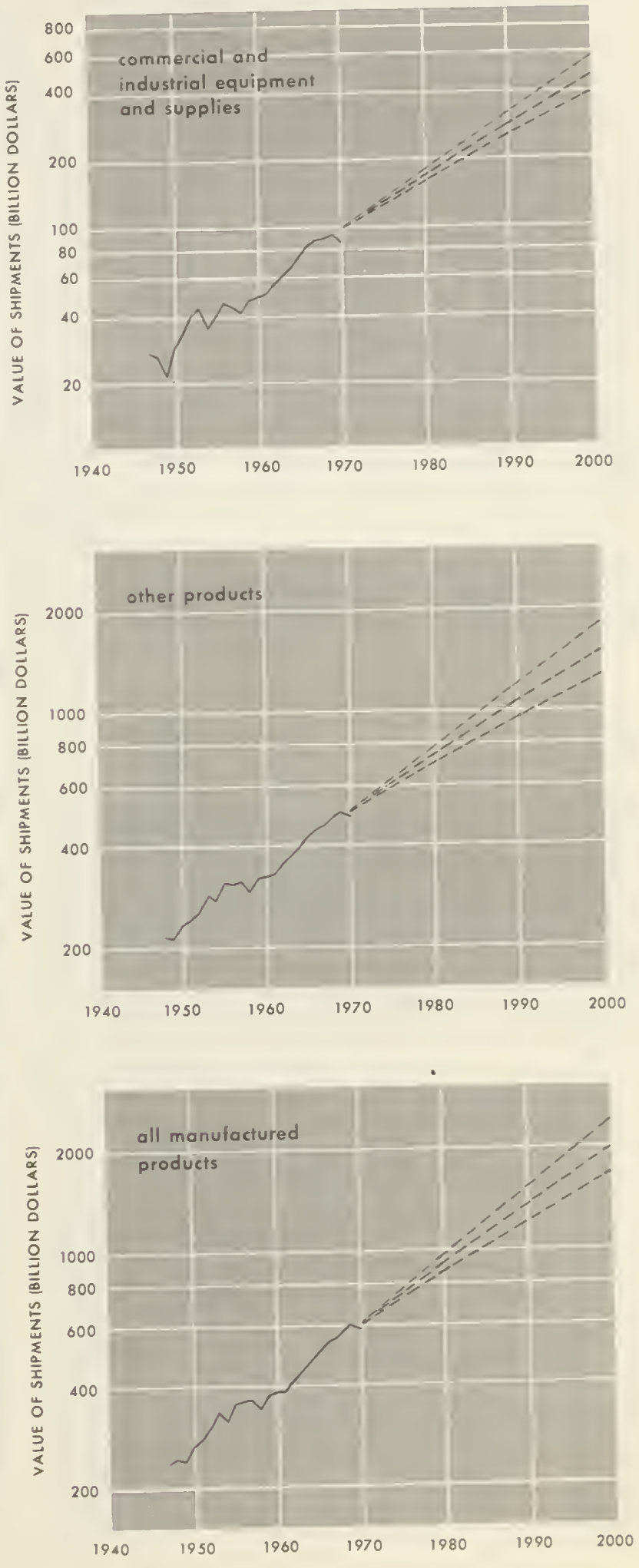
TABLE 129.-Value of manufacturing shipments by product group, specified years 1948-70, with projections to 2000

\begin{tabular}{|c|c|c|c|c|c|c|c|c|c|c|c|c|}
\hline \multirow{2}{*}{ Year } & \multicolumn{2}{|c|}{ All products } & \multicolumn{2}{|c|}{ Household furniture } & \multicolumn{2}{|c|}{$\begin{array}{l}\text { Commercial and insti- } \\
\text { tional furniture }\end{array}$} & \multicolumn{2}{|c|}{ Consumer goods 1} & \multicolumn{2}{|c|}{$\begin{array}{l}\text { Commercial and in- } \\
\text { dustrial equipment }{ }^{2}\end{array}$} & \multicolumn{2}{|c|}{ Other products ${ }^{3}$} \\
\hline & Value & $\begin{array}{l}\text { Annual } \\
\text { rate of } \\
\text { increase }\end{array}$ & Value & $\begin{array}{l}\text { Annual } \\
\text { rate of } \\
\text { increase }\end{array}$ & Value & $\begin{array}{l}\text { Annual } \\
\text { rate of } \\
\text { increase }\end{array}$ & Value & $\begin{array}{l}\text { Annual } \\
\text { rate of } \\
\text { increase }\end{array}$ & Value & $\begin{array}{l}\text { Annual } \\
\text { rate of } \\
\text { increase }\end{array}$ & Value & $\begin{array}{l}\text { Annual } \\
\text { rate of } \\
\text { increase }\end{array}$ \\
\hline $\begin{array}{l}1948 \ldots \\
1950 \\
1955 \\
1960 \\
1965\end{array}$ & $\begin{array}{l}\text { Billions } \\
\text { of 1967 } \\
\text { dollars } \\
244.0 \\
265.2 \\
352.7 \\
380.8 \\
498.1\end{array}$ & $\begin{array}{r}\text { Percent } \\
\\
4.3 \\
5.9 \\
1.6 \\
5.5\end{array}$ & $\begin{array}{r}\text { Billions } \\
\text { of } 1967 \\
\text { dollars } \\
2.4 \\
2.7 \\
3.5 \\
3.8 \\
4.9\end{array}$ & $\begin{array}{r}\text { Percent } \\
\\
6.1 \\
5.4 \\
1.3 \\
5.2\end{array}$ & $\begin{array}{c}\text { Billions } \\
\text { of } 1967 \\
\text { dollars } \\
0.6 \\
1.8 \\
1.1 \\
1.4 \\
2.0\end{array}$ & $\begin{array}{r}13.3 \\
8.3 \\
4.9 \\
6.4\end{array}$ & $\begin{array}{c}\text { Billions } \\
\text { of 1967 } \\
\text { dollars } \\
2.4 \\
2.8 \\
3.0 \\
3.7 \\
4.6\end{array}$ & $\begin{array}{r}\text { Percent } \\
\\
7.8 \\
1.0 \\
4.2 \\
4.9\end{array}$ & $\begin{array}{r}\text { Billions } \\
\text { of } 1867 \\
\text { dollars } \\
25.5 \\
28.0 \\
39.0 \\
47.8 \\
70.5\end{array}$ & $\begin{array}{r}\text { Percent } \\
\\
4.9 \\
6.9 \\
4.2 \\
8.1\end{array}$ & $\begin{array}{c}\text { Billions } \\
\text { of } 1967 \\
\text { dollars } \\
213.1 \\
230.9 \\
306.1 \\
324.1 \\
416.1\end{array}$ & $\begin{array}{r}\text { Percent } \\
\\
4.1 \\
5.8 \\
1.2 \\
5.1\end{array}$ \\
\hline $\begin{array}{l}1966 \\
1967 \\
1968 \\
1970\end{array}$ & $\begin{array}{l}528.0 \\
545.2 \\
577.0 \\
601.5 \\
591.6\end{array}$ & $\begin{array}{r}6.0 \\
3.3 \\
5.8 \\
4.2 \\
-1.6\end{array}$ & $\begin{array}{l}5.0 \\
5.1 \\
5.6 \\
5.7 \\
5.3\end{array}$ & $\begin{array}{r}3.8 \\
1.2 \\
8.9 \\
2.2 \\
-6.5\end{array}$ & $\begin{array}{l}2.2 \\
2.3 \\
2.3 \\
2.6 \\
2.4\end{array}$ & $\begin{array}{r}12.3 \\
5.3 \\
.1 \\
10.1 \\
-7.1\end{array}$ & $\begin{array}{l}4.9 \\
5.0 \\
5.2 \\
5.7 \\
5.4\end{array}$ & $\begin{array}{r}5.6 \\
1.7 \\
5.0 \\
9.0 \\
-4.6\end{array}$ & $\begin{array}{l}80.0 \\
84.1 \\
86.0 \\
89.7 \\
85.0\end{array}$ & \begin{tabular}{r|}
13.4 \\
5.1 \\
2.3 \\
4.4 \\
-5.3
\end{tabular} & $\begin{array}{l}435.9 \\
448.7 \\
477.9 \\
497.8 \\
493.5\end{array}$ & $\begin{array}{l}4.7 \\
3.0 \\
6.5 \\
4.15 \\
-.87\end{array}$ \\
\hline $1948-70 \ldots$ & & 4.1 & ...... & 3. 6 & & 6.5 & & 3.7 & & 5.6 & & 3.9 \\
\hline
\end{tabular}

Low projections

\begin{tabular}{|c|c|c|c|c|c|c|c|c|c|c|c|c|}
\hline $\begin{array}{l}1980 \\
1990 \\
2000\end{array}$ & $\begin{array}{r}856.4 \\
1,197.7 \\
1,661.4\end{array}$ & $\begin{array}{r}13.5 \\
3.4 \\
3.3\end{array}$ & $\begin{array}{r}8.3 \\
11.4 \\
15.3\end{array}$ & $\begin{array}{r}43.4 \\
3.2 \\
3.0\end{array}$ & $\begin{array}{l}4.0 \\
5.9 \\
8.4\end{array}$ & $\begin{array}{r}44.3 \\
4.0 \\
3.7\end{array}$ & $\begin{array}{r}8.0 \\
11.2 \\
15.4\end{array}$ & $\begin{array}{r}43.8 \\
3.9 \\
3.3\end{array}$ & $\begin{array}{l}152.7 \\
241.8 \\
375.9\end{array}$ & $\begin{array}{r}4.9 \\
4.7 \\
4.5\end{array}$ & $\begin{array}{r}683.4 \\
927.4 \\
1,246.4\end{array}$ & $\begin{array}{r}\text { r. } 2 \\
\text { 3. } 1 \\
\text { 3. } 0\end{array}$ \\
\hline
\end{tabular}

Medium projections

\begin{tabular}{|c|c|c|c|c|c|c|c|c|c|c|c|c|}
\hline $\begin{array}{l}1980 \ldots \\
1990 \ldots \\
2000\end{array}$ & $\begin{array}{r}907.0 \\
1,343.3 \\
1,964.0\end{array}$ & $\begin{array}{r}4.1 \\
4.0 \\
3.9\end{array}$ & $\begin{array}{r}8.6 \\
12.3 \\
17.2\end{array}$ & $\begin{array}{r}3.8 \\
3.6 \\
3.4\end{array}$ & $\begin{array}{l}4.2 \\
6.5 \\
9.9\end{array}$ & $\begin{array}{r}44.8 \\
4.5 \\
4.3\end{array}$ & $\begin{array}{r}8.3 \\
12.0 \\
17.3\end{array}$ & $\begin{array}{r}14.2 \\
3.8 \\
3.7\end{array}$ & $\begin{array}{l}161.7 \\
271.0 \\
445.7\end{array}$ & $\begin{array}{r}4.5 \\
5.3 \\
5.1\end{array}$ & $\begin{array}{r}724.2 \\
1,041.5 \\
1,473.9\end{array}$ & $\begin{array}{r}\text { 13.8 } \\
3.7 \\
3.5\end{array}$ \\
\hline
\end{tabular}

\begin{tabular}{|c|c|c|c|c|c|c|c|c|c|c|c|c|}
\hline $\begin{array}{l}1980 \\
1990 \\
2000\end{array}$ & $\begin{array}{r}962.1 \\
1,512.1 \\
2,358.5\end{array}$ & $\begin{array}{r}14.7 \\
4.6 \\
4.5\end{array}$ & $\begin{array}{r}9.1 \\
13.5 \\
19.5\end{array}$ & $\begin{array}{r}4.4 \\
4.0 \\
3.8\end{array}$ & $\begin{array}{r}4.5 \\
7.4 \\
12.1\end{array}$ & $\begin{array}{r}45.5 \\
5.2 \\
5.0\end{array}$ & $\begin{array}{r}8.6 \\
13.0 \\
19.5\end{array}$ & $\begin{array}{r}4.6 \\
4.2 \\
4.1\end{array}$ & $\begin{array}{l}172.8 \\
309.4 \\
543.7\end{array}$ & $\begin{array}{r}46.2 \\
6.0 \\
5.8\end{array}$ & $\begin{array}{r}767.1 \\
1,168.8 \\
1,763.7\end{array}$ & $\begin{array}{r}14.4 \\
4.3 \\
4.2\end{array}$ \\
\hline
\end{tabular}

1 Includes sporting goods, musical instruments, boat building and repair, toys and games, luggage and trunks, handles, wood pencils, morticians' goods, shoe and boot findings, and wood matches.

2 Includes commercial refrigeration, signs and displays, patterns and jigs, truck bodies and trailers, general machinery, agricultural implements, electrical equipment, and textile machinery supplies.

3 All manufactured products except those listed above and products as pallets, prefabricated wooden buildings and containers, mobile homes, millwork, flooring, and other similar goods included in the construction and shipping sections of this study.

1 Rates of increase calculated from the following 1970 trend values: all products, $\$ 606.9$ billion; household furniture, $\$ 5.9$ billion; commercial and institutional furniture, $\$ 2.63$ billion; consumer goods, $\$ 5.5$ billion; commercial and industrial equipment, $\$ 94.2$ billion; other products, $\$ 498.7$ billion.

value of shipments drop significantly over the projection period for all product groups.

\section{Timber Products Use Per Dollar of Shipments}

There have been divergent trends in use of lumber and other timber products per dollar of shipments of manufactured products (table 130). Use of lumber and veneer and plywood dropped substantially in most product groups, while there were fairly large increases in the use of hardboard and particleboard (Append. V, tables 11-14).

Part of the decline in use of lumber and plywood per dollar of shipments reflects inroads of alterna tive materials. Plastics have become particularly important substitutes in furniture manufacture. In this industry use of plastic resins has grown
Note: Conversion to 1967 dollars by U.S. Department of Agriculture, Forest Service. Annual rates of increase are calculated for 5-year periods from 1950 through 1965 , for 1 -year periods 1965 through 1970 , and for 10 -year periods 1970 through 2000.

Sources: Values of shipments, U.S. Department of Commerce, 1948 and 1950-Value of shipments of selected classes of products, for the United States. Bureau of the Census, MAS-53 (Final). 1955; 1955-Value of shipments of selected classes of products, for the United States. Bureau of the Census, MA-57-2. $1959 ; 1960-69-$ Growth in shipments by classes of manufact ured products. Bureau of Domestic Commerce. $1971 ; 1970$ - Preliminary Forest Service estimates
based on data published in General statistics for industry groups and industries. Bureau of the Census, M-70 (AS) -1.1972.

Projections: U.S. Department of Agriculture, Forest Service.

from a reported 317 million pounds in $1965,^{30}$ to 702 million pounds in $1970 .^{31}$ In the latter year plastics composed roughly 12 percent of the combined volume of wood and plastics used in the furniture industry.

This rapid growth in use of plastics in furniture manufacture was a result of a number of forces. ${ }^{32}$ Production costs of mass-produced plastic furni-

${ }^{30}$ Wood, Stuart. How are furniture people faring in the strange world of plastics? Here's how in their own words. Modern Plastics 45(11):176-197. 1968.

${ }^{31}$ Furniture, Phase II. Modern Plastics 47 (8) :5660. 1970 .

32 Anonymous. A plastic trend in furniture's future. Business Week 2144:112-113. Sept. 26, 1970.

Clark, Edward L. Plastics and the future of the furniture industry in the United States. Forest Prod. J. 21(8):14-16. 
TABLE 130.- Timber products consumed in manufacturing, specified years 1948-70, with projections (1970 relative prices) to 2000

\begin{tabular}{|c|c|c|c|c|c|c|c|c|}
\hline \multirow{2}{*}{ Year } & \multicolumn{2}{|c|}{ Lumber } & \multicolumn{2}{|c|}{$\begin{array}{l}\text { Veneer and plywood } \\
(3 / 8 \text {-inch basis) }\end{array}$} & \multicolumn{2}{|c|}{$\underset{\text { (1/8-inch basis) }}{\text { Hardboard }}$} & \multicolumn{2}{|c|}{$\begin{array}{l}\text { Particleboard } \\
(3 / 4 \text {-inch basis) }\end{array}$} \\
\hline & Total & $\begin{array}{l}\text { Per dollar } \\
\text { of } \\
\text { shipments } 1\end{array}$ & Total & $\begin{array}{l}\text { Per dollar } \\
\text { of } \\
\text { shipments }{ }^{1}\end{array}$ & Total & $\begin{array}{l}\text { Per dollar } \\
\text { of } \\
\text { shipments }{ }^{1}\end{array}$ & Total & $\begin{array}{l}\text { Per dollar } \\
\text { of } \\
\text { shipments } 1\end{array}$ \\
\hline $\begin{array}{l}1948 \ldots \\
1960-.- \\
1965 \ldots \\
1970 \ldots\end{array}$ & $\begin{array}{l}\begin{array}{l}\text { Million } \\
\text { board feet } \\
3,924 \\
3,865 \\
4,609 \\
4,670\end{array}\end{array}$ & $\begin{array}{r}\text { Board feet } \\
0.016 \\
.010 \\
.009 \\
.008\end{array}$ & 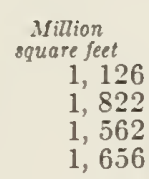 & $\begin{array}{r}\text { Square feet } \\
0.005 \\
.005 \\
.003 \\
.003\end{array}$ & $\begin{array}{r}\begin{array}{c}\text { Million } \\
\text { square feet } \\
\text { NA }\end{array} \\
760 \\
1,135 \\
1,361\end{array}$ & $\begin{array}{r}\text { Square feet } \\
0.0020 \\
.0023 \\
.0023\end{array}$ & $\begin{array}{r}\text { Million } \\
\text { square jeet } \\
\text { NA } \\
106 \\
476 \\
669\end{array}$ & $\begin{array}{r}\text { Square feet } \\
0.0003 \\
.0010 \\
.0011\end{array}$ \\
\hline
\end{tabular}

Low projections

\begin{tabular}{l|l|l|l|l|l|l|l|l}
\hline 1980 & 5,480 & .006 & 2,290 & .003 & 2,140 & .0025 & 1,330 & .0016 \\
$1990 \ldots$ & 6,290 & .005 & 2,950 & .002 & 3,050 & .0025 & 2,100 & .0018 \\
$2000 \ldots$ & 7,140 & .004 & 3,760 & .002 & 4,230 & .0025 & 3,090 & .0019 \\
\hline
\end{tabular}

Medium projections

\begin{tabular}{ll|l|l|l|l|l|l|l}
\hline & & & & & & & & \\
$1980 \ldots--$ & 5,720 & .006 & 2,400 & .003 & 2,240 & .0025 & 1,400 & .0015 \\
$1990-\ldots$ & 6,850 & .005 & 3,220 & .002 & 3,350 & .0025 & 2,300 & .0017 \\
$2000-.-$ & 8,130 & .004 & 4,300 & .002 & 4,850 & .0025 & 3,540 & .0018 \\
\hline
\end{tabular}

High projections

\begin{tabular}{ll|l|l|l|l|l|l|l}
\hline & & & & & & & \\
$1980--$ & 6,040 & .006 & 2,530 & .003 & 2,370 & .0025 & 1,480 & .0015 \\
$1990-\ldots$ & 7,560 & .005 & 3,570 & .002 & 3,720 & .0025 & 2,560 & .0017 \\
$2000-.-$ & 9,360 & .004 & 5,010 & .002 & 5,650 & .0025 & 4,140 & .0018 \\
\hline
\end{tabular}

11967 dollars. Use per dollar of shipments in the 1948-70 period computed by Forest Service (see table 129 for value of shipments).

Sources: Timber products use, U.S. Department of Agriculture, Forest Service. 1948- Wood used in manufacture, 1948. Forest Resource Rep. 2. 1951; 1960-Wood used in manufacturing industries, 1960. Stat. Bull. 353.

ture parts, especially the ornate highly detailed parts used in the manufacture of Spanish and Mediterranean styles of furniture, were reportedly below the costs of comparable parts made from lumber. In addition, plastics permit great freedom in design, and special effects not possible with lumber or other wood products, they have dimensional stability and resistance to damage from scratches and liquids. Shortages of skilled wood workers and rising costs of some fine hardwoods have also been contributing factors.

On the other hand, some forces favor use of timber products over plastics. Perhaps the most important of these is a deep seated consumer preference for wood furniture. In addition, timber products have some superior performance characteristics such as ease of refinishing and repair, greater fracture resistance, and higher loadbearing strength. Timber products also have a
$1965 ; 1965$ - Wood used in manufacturing indusiries, 1965. Stat. Bull. 440. 1969; 1970-Based on preliminary estimates of value of shipments (table 129) and trends in timber products use per dollar of shipments.

Projections, U.S. Department of Agriculture, Forest Service.

cost advantage over plastics for many furniture parts, especially those that are not produced in large numbers.

In the case of other manufactured products such as commercial and institutional furniture, boats, toys and handles, lumber and plywood have also been partially displaced by other nonwood materials such as steel or fiberglass having lower costs or preferred performance characteristics. Particleboard and hardboard have also partially displaced lumber and plywood in some manufactured products. This has been particularly important in furniture manufacture where particleboard is extensively used as core stock, and hardboard is used as facing material or components in such items as desks, bureaus, and cabinets.

Part of the decline in the use of lumber and plywood per dollar of shipments also reflects a 
general reduction in use of all raw materials per dollar of product value resulting from increases in the degree of processing of materials and rising relative costs of labor and capital per unit of production.

\section{Projected Demand for Timber Products in Manu- facturing}

Projections of timber products use per dollar of shipments-shown in table 130 and Append. $V$, tables 11-14-have been based on (1) recent changes in materials use, (2) judgment as to the influence of technological and economic factors in future decades, and (3) 1970 relative prices of materials and production costs. In general, these projections indicate a continuation of recent trends, including further declines in the use of lumber and plywood and increased use of hardboard and particleboard.

In spite of the projected decreases in use of lumber and veneer and plywood per dollar of shipments, total demands rise for all products because of the major increases projected in total value of shipments (table 130, fig. 66; Append. V, table 11-14).

Projections of demand for lumber, for example, rise nearly 75 percent by 2000 (medium projection at 1970 prices) from 4.7 to 8.1 billion board feet. Related demands for veneer and plywood are projected to more than double. Projected demands are up about 3.6 times for hardboard, and ircre..se about five times for particleboard.

The lumber and plywood used in manufactured products covered in this section consist largely of hardwoods. In the furniture industry, for example, 80 percent of the lumber, and three-fourths of the veneer and plywood, used in 1965 were hardwoods. Most of the hardwood lumber consumed has been produced from domestic species, and this is expected to continue through the projection period.

\section{DEMAND FOR TIMBER PRODUCTS IN SHIPPING}

In 1970 nearly 6 billion board feet of lumber and 600 million square feet of veneer and plywood ( $3 / 8$-inch basis) were used in shipping, that is, for the manufacture of pallets, boxes, crates, hampers, baskets, and other wood containers; and for dunnage, blocking, and bracing required for the transportation, handling, and storage of industrial, agricultural, and military products (table 131).

The 1970 level of lumber consumption was about 36 percent above that of 1960 . Use of veneer and plywood in 1970, on the other hand, was 48 percent below the 1960 level of use.

\section{Demand for Timber Products in Pallets}

Increased lumber use in shipping in the 1960's was entirely attributable to a major rise in pallet
TABLE 131.-Timber products consumed in shipping by end use $1948,1960,1965$, and 1970

\begin{tabular}{|c|c|c|c|}
\hline Year and product & Lumber & $\begin{array}{l}\text { Veneer } \\
\text { and } \\
\text { ply- } \\
\text { wood }\end{array}$ & $\begin{array}{l}\text { Hard- } \\
\text { board }\end{array}$ \\
\hline $\begin{array}{l}\text { 1948: } \\
\text { Containers, wood } \\
\text { Pallets_... } \\
\text { Dunnage, blocking, and } \\
\text { bracing_. }\end{array}$ & 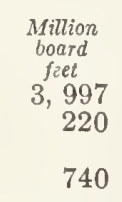 & $\begin{array}{l}\text { Million } \\
\text { square } \\
\text { feet } \\
1,672 \\
1 \\
\text { (1) }\end{array}$ & 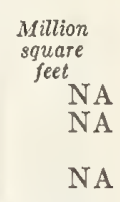 \\
\hline Total $\ldots$ & 4,957 & 1,673 & $\mathrm{NA}$ \\
\hline $\begin{array}{l}\text { 1960: } \\
\text { Containers, wood } \\
\text { Pallets } \\
\text { Dunnage, blocking, and } \\
\text { bracing }\end{array}$ & $\begin{array}{r}1,864 \\
1,550 \\
800\end{array}$ & $\begin{array}{r}1,125 \\
18 \\
1\end{array}$ & $\begin{array}{r}13 \\
2\end{array}$ \\
\hline Total $\ldots$ & 4,214 & 1,144 & 16 \\
\hline $\begin{array}{l}\text { 1965: } \\
\text { Containers, wood } \\
\text { Pallets.... } \\
\text { Dunnage, blocking, and } \\
\text { bracing }\end{array}$ & $\begin{array}{r}1,829 \\
2,200 \\
\\
856\end{array}$ & $\begin{array}{r}595 \\
75 \\
\\
12\end{array}$ & $\begin{array}{l}20 \\
16\end{array}$ \\
\hline Total $\ldots$ & 4,885 & 682 & 39 \\
\hline $\begin{array}{l}\text { 1970: } \\
\text { Containers, wood } \\
\text { Pallets_._. } \\
\text { Dunnage, blocking, and } \\
\text { bracing_. }\end{array}$ & $\begin{array}{r}1,755 \\
3,150 \\
820\end{array}$ & $\begin{array}{r}437 \\
140 \\
\\
14\end{array}$ & $\begin{array}{l}26 \\
28\end{array}$ \\
\hline Total $\ldots \ldots \ldots$ & 5,725 & 591 & 58 \\
\hline
\end{tabular}

\section{Negligible.}

Sources: Lumber for pallets: Forest Service estimates based on data published in: U.S. Department of Commerce, Business and Defense Administration. Wooden pallets. 1963; Pallet industry growing by leaps and bounds. Wood Construction and Building Materialist 56(11) :26-27; The Appalachian pallet industry. The Northein I.ogger and Timber Processor 20(2):22-23, 60-61; Pallets from low grade hardwoods. Forest Prod. J. 13(3):11-13; U.S. Department of Agriculture, Forest Service. Wood used in manufacturing industries, 1960. Stat. Bull. 353. 1965.

All other: U.S. Department of Agriculture, Forest Service. 1948-Wood used in manu facture, 19/48. Forest Resource Rep. 2. 1951; 1960-Wood used in man fucturing industries, 1960. Stat. Bull. 353. 1965; 1965-Wood uscd in manufacturing industries, 1965. Stat. Bull. 440. 1969; 1970Forest Service estimates based on pallet production, value of shipments of containers, and trends in timber prociusts use in dunnage, blocking, and bracing.

production. As new methods of materials handling were introduced, and new facilities geared to the use of pallets were constructed, pallet producticn doubled in the 1960's from 62 to 126 million units (table 132).

Since the mid-1950's there has been a close relationship between pallet output and manufacturing production (fig. 67). Projections based 
Timber products consumed in manufacturing 1948 - 70, with projections to 2000
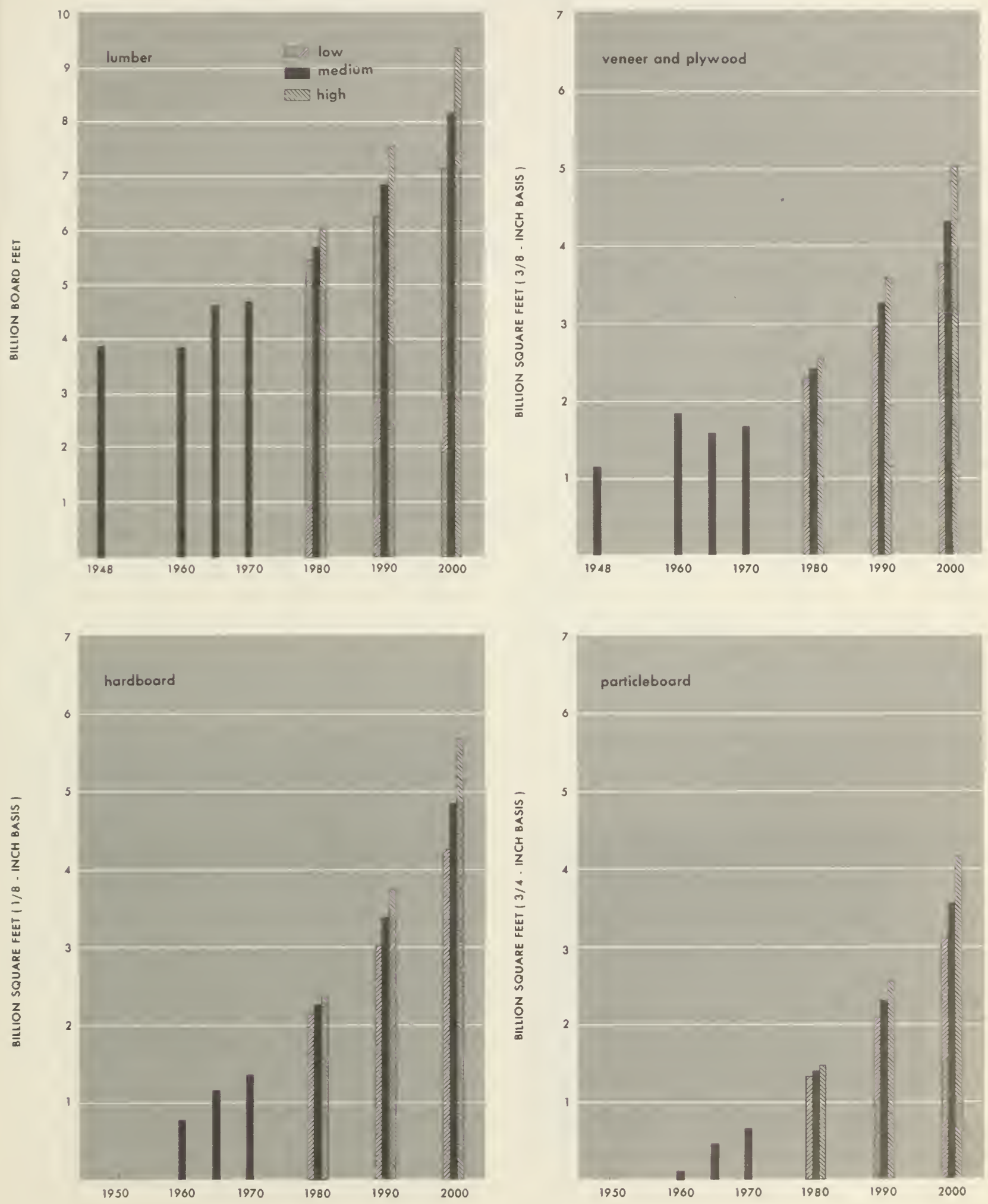

Figure 66 
TABLE 132.-Timber products consumed in the manufacture of pallets by product, specified years 1960-70, with projections of demand (1970 relative prices) to 2000

\begin{tabular}{|c|c|c|c|c|c|c|c|}
\hline \multirow{2}{*}{ Year } & \multirow{2}{*}{$\begin{array}{c}\text { Pallet } \\
\text { production }\end{array}$} & \multicolumn{2}{|c|}{ Lumber } & \multicolumn{2}{|c|}{ Plywood (3/8-inch basis) } & \multicolumn{2}{|c|}{ Hardboard (1/8-inch basis) } \\
\hline & & $\begin{array}{l}\text { Use per } \\
\text { pallet }\end{array}$ & Total & $\begin{array}{l}\text { Use per } \\
\text { pallet }\end{array}$ & Total & $\begin{array}{l}\text { Use per } \\
\text { pallet }\end{array}$ & Total \\
\hline $\begin{array}{l}1960 \ldots \\
1965 \\
1970\end{array}$ & $\begin{array}{r}\text { Millions } \\
62 \\
88 \\
126\end{array}$ & $\begin{array}{l}\text { Board feet } \\
25 \\
25 \\
25\end{array}$ & $\begin{array}{c}\text { Million board feet } \\
1,550 \\
2,200 \\
3,150\end{array}$ & $\begin{array}{l}\text { Square feet } \\
0.29 \\
.85 \\
1.11\end{array}$ & $\begin{array}{r}\text { Million square feet } \\
18 \\
75 \\
140\end{array}$ & $\begin{array}{r}\text { Square feet } \\
0.03 \\
.18 \\
.22\end{array}$ & $\begin{array}{r}\text { Million square feet } \\
2 \\
16 \\
28\end{array}$ \\
\hline
\end{tabular}

Low projections

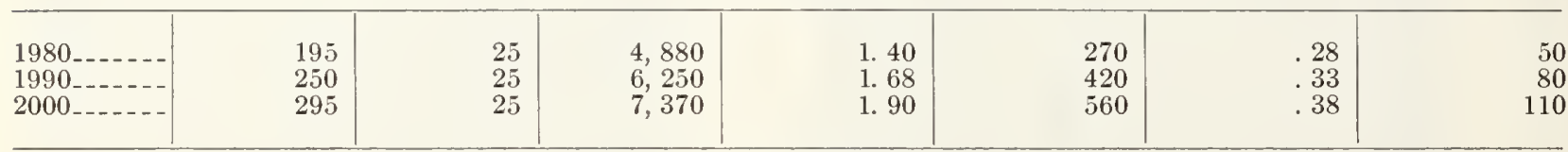

Medium projections

\begin{tabular}{r|r|r|r|r|r|r}
\hline $1980 \ldots \ldots$ & 209 & 25 & 5,220 & 1.40 & 290 & .28 \\
$1990 \ldots \ldots 0$ & 25 & 1.68 & .33 \\
$2000 \ldots \ldots$ & 278 & 25 & 8,500 & 1.90 & 650 & .38 \\
\hline
\end{tabular}

High projections

\begin{tabular}{|c|c|c|c|c|c|c|c|}
\hline 1980 & 225 & 25 & 5,600 & 1. 40 & 310 & .28 & 60 \\
\hline 1990 & 310 & 25 & 7,750 & 1. 68 & 520 & .33 & 100 \\
\hline $2000 \ldots$ & 390 & 25 & 9,750 & 1. 90 & 740 & .38 & 150 \\
\hline
\end{tabular}

Sources: Pallet production, 1960, 1965, and 1970 Based on data supplied by the National Wooden Pallet and Container Association.

\section{Relationship of pallet production to index of manufacturing production}

$$
(1967=100)
$$

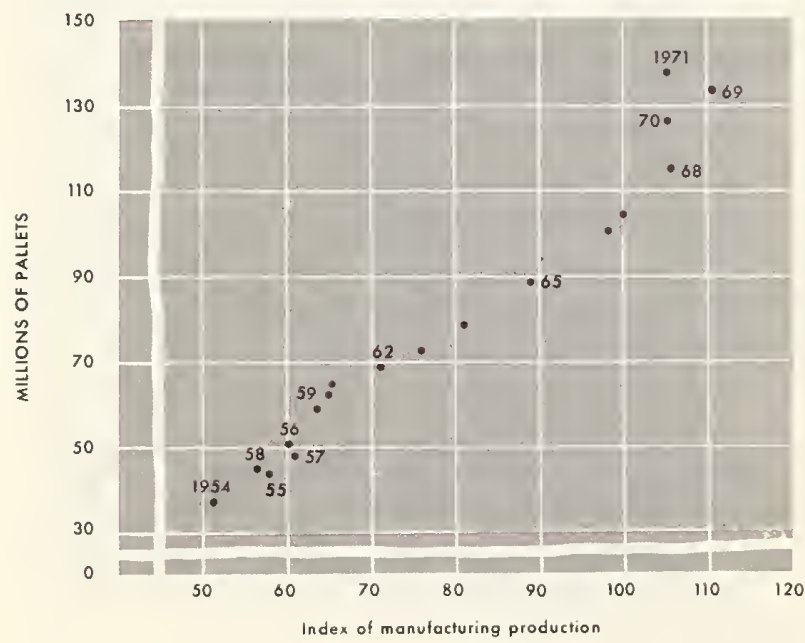

Figure 67
Wood use, see source note table 131.

Projections: U.S. Department of Agriculture, Forest Service.

on this relationship and assumed growth in industrial production show continuing large increases in demand for pallets (table 132). The medium projection at 1970 relative prices, for example, rises nearly threefold by 2000. Rates of growth in projected pallet demand, however, drop rapidly from an average of 7.3 percent annually in the 1960 's to 2.0 percent in the 1990's. Such a fall means that growth in demand for pallets associated with use in new materials handling systems gradually ends, and that the projected increases in demand depend to a greater and greater degree on growth in industrial and agricultural production.

Lumber use per pallet has averaged about 25 board feet in the last decade or so. ${ }^{33}$ This average

33 Anonymous. Pallet industry growing by leaps and bounds. Wood Construction and Building Materialist $56(11): 26-27.1970$.

The Appalachian pallet industry. Northern Logger and Timber Processor 20(2):22-23, 60-61. 1971. Baldwin, W. C. Pallets from low grade hardwoods. Forest Prod. J. 18(3):11-13. 1968.

U.S. Department of Commerce, Business and Defense Administration. Wooden pallets. 1963. 
is assumed to continue, eren though plywood, slice-wood, or other materials may be used to an increasing degree. Lumber use for pallets has, therefore, been projected to rise to some 8.5 billion board feet by 2000 (medium projection and 1970 prices)-some 2.7 times consumption in 1970 (table 132, fig. 68).

Small but increasing quantities of plywood and hardboard hare been used in pallet manufacture. It was assumed that demand for these products would also rise in line with the projected demand for pallets.

\section{Demand for Timber Products in Wooden Containers}

Between 1948 and 1960, the value of shipments (in 1967 dollars) of wooden containers, that is, boxes and crates, wirebound boxes and crates, and veneer and plywood containers, dropped more than 38 percent (table 133). This fall off largely reflected continuing displacement of wooden containers by fiber and plastic containers, metal and fiber barrels and pails, and multiwall bags.

Sereral factors contributed to this displacement, including lower costs of substitute containers, lower shipping weights and associated freight costs, and adaptability to automated packaging and shipping operations. However, in packaging some items, such as large bulky products, delicate instruments, glass, ceramics, and certain fruits and regetables, these adrantages

Lumber consumed in shipping, 1948-70, with projections of demand to 2000

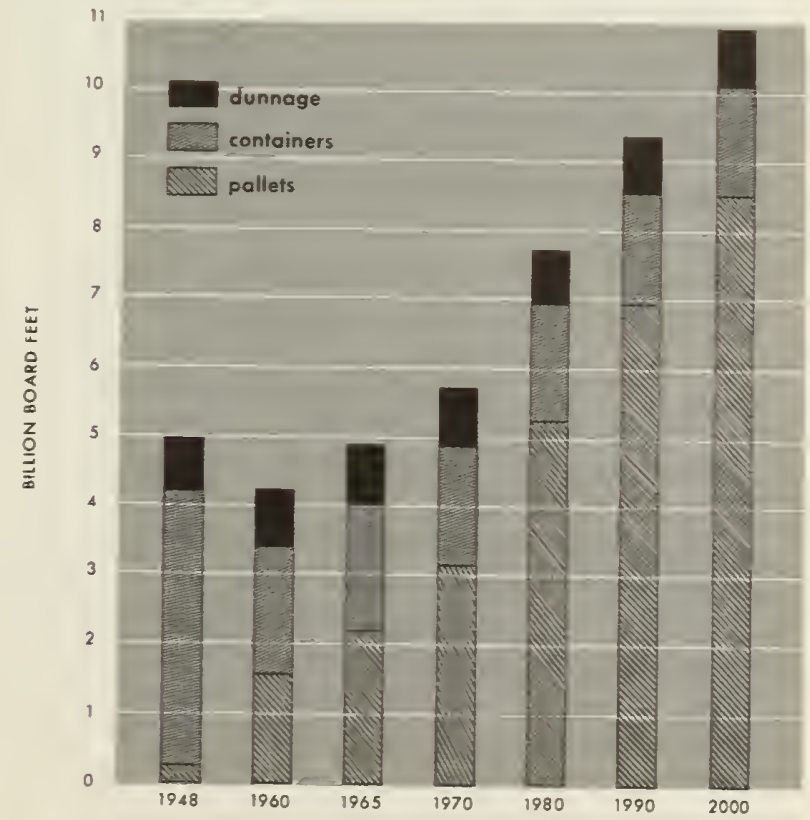

Figure 68 have been outweighed by the need for special protection.

Since 1960, growing shipments of these latter items hare led to a small rise in demand for wooden containers, as measured by ralue of shipments. In view of anticipated growth in manufacturing and agricultural production, continuing modest increases in the value of shipments of wooden containers have been projected.

The use of lumber and veneer and plywood per dollar of shipments of wooden containers has shown a consistent downward trend (table 133), reflecting such factors as greater use of paperboard and plastic containers and increases in containerized and bulk shipments. It seems likely that such trends will continue and use of lumber and reneer and plywood per dollar of shipments has therefore been projected to decline slowly.

These projected decreases in use per dollar of shipments roughly offset projected increases in total shipments. As a result, the medium projections of demand for lumber and reneer and plywood in wooden containers, at 1970 prices, remain close to recent levels through the 1970-2000 period.

\section{Demand for Timber Products in Dunnage}

In the past two decades use of lumber for dunnage, blocking, and bracing in railroad cars, trucks, and ships has amounted to an estimated 800 million board feet a year (table 131). This stability, in a period of rapid increases in the volume of goods transported, apparently reflects effects of growth in palletized, containerized, and bulk shipments. Growth in such shipments is expected to continue. The medium projection of demand for lumber for dunnage, blocking, and bracing at 1970 prices has therefore been projected to remain at about 800 million feet a year.

\section{Projected Demand for Timber Products in Shipping}

Projected total demand for lumber in shipping, that is pallets, containers, and dunnage rises rather sharply because of the projected growth in demand for pallets and by 2000 reaches 10.9 billion board feet (medium projection-1970 relative prices), nearly double consumption in 1970 (table 134, fig. 68). Projected demand for plywood and veneer rises to 1.1 billion square feet ( $3 / 8$-inch basis) in 2000-about 1.8 times consumption in 1970 .

\section{DEMAND FOR TIMBER PRODUCTS IN MISCEL- LANEOUS USES}

In addition to the major end uses corered abore, an estimated 8.5 billion board feet of lumber and substantial quantities of plywood and building board were used in 1970 for other purposes (table 135). These included upkeep and 
TABLE 133.-Value of shipments and timber products consumed in the manufacture of wood containers by product, specified years 1948-70, with projections of demand (1970 relative prices) to 2000

\begin{tabular}{|c|c|c|c|c|c|c|c|}
\hline \multirow{2}{*}{ Year } & \multirow{2}{*}{$\begin{array}{l}\text { Value of } \\
\text { shipments }\end{array}$} & \multicolumn{2}{|c|}{ Lumber } & \multicolumn{2}{|c|}{$\begin{array}{l}\text { Veneer and plywood (3/8-inch } \\
\text { basis) }\end{array}$} & \multicolumn{2}{|c|}{ Hardboard (1/8-inch basis) } \\
\hline & & $\begin{array}{c}\text { Use per } \\
\text { dollar of } \\
\text { shipments }\end{array}$ & Total & $\begin{array}{c}\text { Use per } \\
\text { dollar of } \\
\text { shipments }\end{array}$ & Total & $\begin{array}{c}\text { Use per } \\
\text { dollar of } \\
\text { shipments }{ }^{1}\end{array}$ & Total \\
\hline $\begin{array}{l}1948 \ldots \\
1960-. \\
1965- \\
1970 \\
--\end{array}$ & $\begin{array}{r}\text { Millions of } 1967 \\
\text { dollars } \\
579 \\
358 \\
382 \\
390\end{array}$ & $\begin{array}{r}\text { Board feet } \\
6.90 \\
5.20 \\
4.80 \\
4.50\end{array}$ & $\begin{array}{r}\text { Million board feet } \\
3,997 \\
1,864 \\
1,829 \\
1,755\end{array}$ & $\begin{array}{r}\text { Square feet } \\
2.89 \\
3.14 \\
1.56 \\
1.12\end{array}$ & $\begin{array}{r}\text { Million square feet } \\
1,672 \\
1,125 \\
595 \\
437\end{array}$ & $\begin{array}{r}\text { Square feet } \\
\mathrm{NA} \\
0.036 \\
.052 \\
.067\end{array}$ & $\begin{array}{r}\text { Million square feet } \\
\text { NA } \\
13 \\
20 \\
26\end{array}$ \\
\hline
\end{tabular}

Low projections

\begin{tabular}{l|l|l|l|l|l|l|l}
\hline 1980 & 402 & 4.00 & 1,610 & .94 & 380 & .079 & 30 \\
$1990 \ldots-0$ & 316 & 3.63 & 1,510 & .88 & 370 & .086 & 40 \\
$2000-0.35$ & 1,420 & .84 & 360 & .091 & 40 \\
\hline
\end{tabular}

Medium projections

\begin{tabular}{l|l|l|l|l|l|l|l}
\hline & & & & & & \\
1980 & 422 & 4.00 & 1,690 & .94 & 400 & .079 & 30 \\
$1990 \ldots-0$ & 452 & 3.63 & 1,640 & .88 & 400 & .086 & 40 \\
2000 & 3.35 & 1,610 & .84 & 400 & .091 & 40 \\
\hline
\end{tabular}

High projections

\begin{tabular}{|c|c|c|c|c|c|c|c|}
\hline $\begin{array}{l}1980 \\
1990 \\
2000\end{array}$ & $\begin{array}{l}439 \\
490 \\
541\end{array}$ & $\begin{array}{l}\text { 4. } 00 \\
\text { 3. } 63 \\
\text { 3. } 35\end{array}$ & $\begin{array}{l}1,760 \\
1,780 \\
1,810\end{array}$ & $\begin{array}{l}.94 \\
.88 \\
.84\end{array}$ & $\begin{array}{l}410 \\
430 \\
450\end{array}$ & $\begin{array}{l}.079 \\
.086 \\
.091\end{array}$ & $\begin{array}{l}30 \\
40 \\
50\end{array}$ \\
\hline
\end{tabular}

11967 dollars. Use per dollar of shipments computed by Forest Service.

Sources: Value of shipments, U.S. Department of Commerce, Bureau of the Census. 1948-Value of shipmenls of selected classes of products. Ser. MAS-53 (final). $1955 ; 1960$ and 1965-Growth in shipments by classes of manufactured products. 1971;1970-Forest Service estimate based on data published in Annual survey of manufactures, 1970. M-70 (AS)-1. 1972.

improvement of nonresidential structures; farm construction except housing; structures and roof supports in mines; made-at-home products such as furniture, boats, and picnic tables; and madeon-the-job products such as advertising and display structures.

There are no statistical data available showing actual consumption of timber products in these various uses. Accordingly, timber products use for these purposes was estimated by subtracting volumes of timber products consumed in the specific end uses discussed above from estimated total consumption of each product. This residual probably includes some volumes which may properly belong in the construction, manufacturing,
Timber products use, U.S. Department of Agriculture, Forest Service. 1948-Wood used in manufacture, 1948. Forest Resource Rep. 2. 1951; 1960-Wood used in manufacturing industries, 1960. Stat. Bull. 353. 1965; 1965Wood used in manufacturing industries, 1965. Stat. Bull. 440. 1969; 1970-Forest Service estimates.

Projections: U.S. Department of Agriculture, Forest Service.

or shipping sectors. The figures also include any statistical discrepancies associated with the estimates of production, imports, and exports used in estimating total consumption.

Because of the lack of a statistical base for projections of demand for these residual uses, it was assumed that demands for these uses would rise in line with projected demands for the total of all other items. Under this assumption, the medium level of demand for lumber in these "other" uses at 1970 prices rises to 12.9 billion board feet in 2000, some 53 percent above 1970 . Projected demands nearly double for plywood and triple for building board. 
TABLE 134.-Timber products consumed in shipping by products, specified years 1948-70, with projections of demand ( 1970 relative prices) to 2000

\begin{tabular}{|c|c|c|c|}
\hline Year & Lumber & $\begin{array}{l}\text { Veneer and } \\
\text { plywood ( } 3 / 8- \\
\text { inch basis) }\end{array}$ & $\begin{array}{l}\text { Hardboard } \\
\text { (1 } \text { s-inch }^{\prime} \\
\text { basis) }\end{array}$ \\
\hline $\begin{array}{l}1948-.- \\
1960-.- \\
1965--. \\
1970-. .\end{array}$ & $\begin{array}{r}\text { Million } \\
\text { boord feet } \\
4,957 \\
4,214 \\
4,885 \\
5,725\end{array}$ & $\begin{array}{l}\text { Million } \\
\text { square feet } \\
1,674 \\
1,144 \\
682 \\
591\end{array}$ & 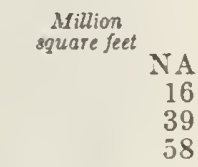 \\
\hline
\end{tabular}

Low projections

\begin{tabular}{r|r|r|r}
\hline $1950 \ldots \ldots .-$ & 7,090 & 670 & 80 \\
$1990 \ldots-$. & 8,360 & 810 & 120 \\
$2000 \ldots--$ & 9,390 & 940 & 150 \\
\hline
\end{tabular}

Medium projections

\begin{tabular}{r|r|r|r}
\hline $1980 \ldots--$ & 7,710 & 710 & 90 \\
$1990--$ & 9,390 & 890 & 130 \\
$2000-\cdots$ & 10,910 & 1,070 & 170 \\
\hline
\end{tabular}

High projections

\begin{tabular}{r|r|r|r}
\hline $1980 \ldots$ & 8,360 & 740 & 90 \\
$1990 \ldots$ & 10,530 & 980 & 140 \\
$2000 \ldots-$ & 12,560 & 1,220 & 200 \\
\hline
\end{tabular}

Sources: U.S. Department of Agriculture, Forest Service. 1943-Wood used in manufacture, 1948. Forest Resource Rep. 2. 1951;1960-Wood used in manufacturing industries, 1960. Stat. Bull. 353. 1965; 1965-Wood used in manufacturing industries, 1965. Stat. Bull. 440. 1969; 1970Forest Service estimates based on pallet production, value of shipments of containers, and trends in timber products use in dunnage, blocking, and bracing.

Projections: U.S. Department of Agriculture, Forest Service.

\section{SUMMARY OF DEMAND PROJECTIONS FOR LUMBER, PLYWOOD, AND BUILDING BOARD}

\section{Lumber Consumption and Demand}

Lumber consumption in all uses in 1970 was 39.5 billion board feet (tables 136 and 137, fig. 69 ; Append. V, table 15). This was about the same as the average annual consumption in the 1950's and 1960's. In 1972 lumber consumption rose to 47.4 billion board feet-20 percent more than in 1970 and above the record levels attained in the early 1900's when lumber was the chief raw material used in the U.S. for construction, manufactured products, and shipping materials.

Per capita consumption of lumber in the 1960's fluctuated around 200 board feet a year (Append. $\mathrm{V}$, table 15). This was far below figures for the early 1900's when per capita use reached a high
TABLE 135.-Timber products consumed in miscellaneous uses, ${ }^{1} 1962$ and 1970 , with projections (1970 relative prices) to 2000

\begin{tabular}{r|r|r|r}
\hline Year & Lumber & $\begin{array}{r}\text { Plywood (3/8- } \\
\text { inch basis) }\end{array}$ & $\begin{array}{r}\text { Building } \\
\text { board (3/8- } \\
\text { inch basis) }\end{array}$ \\
\hline $1962 \ldots$ & $\begin{array}{r}\text { million board feet } \\
6,450\end{array}$ & $\begin{array}{r}\text { million square feet } \\
3,356\end{array}$ & million square feet \\
$1970 \ldots$ & 5,626 & $2,68 \overline{3}$ \\
\hline
\end{tabular}

Low projections

\begin{tabular}{l|r|r|r}
\hline $1980 \ldots \ldots$ & 10,040 & 8,080 & 4,615 \\
$1990 \ldots \ldots$ & 9,625 & 6,125 \\
$2000 \ldots$ & 11,160 & 10,480 & 7,520 \\
\hline
\end{tabular}

Medium projections

\begin{tabular}{r|r|r|r}
\hline $1980 \ldots$ & 10,610 & 8,470 & 4,840 \\
$1990 \ldots$ & 12,060 & 10,305 & 6,575 \\
$2000 \ldots$ & 12,930 & 11,640 & 8,400 \\
\hline
\end{tabular}

High projections

\begin{tabular}{r|r|r|r}
\hline $1980 \ldots \ldots$ & 11,230 & 8,885 & 5,065 \\
$1990 \ldots$ & 13,040 & 11,010 & 7,100 \\
$2000 \ldots$ & 14,670 & 13,185 & 9,575 \\
\hline
\end{tabular}

${ }^{1}$ Includes upkeep and improvement of nonresidential buildings and structures; farm construction except housing; mining; made-at-home projects such as furniture, hoats, and picnic tables; made-on-the-job products like advertising and display structures; and a wide variety of other miscellaneous products and uses.

of over 500 board feet, and substantially under the average of 250 board feet in the early 1950 's.

Nearly a third of the lumber consumed in 1970 went into the production of new housing (table 136). Residential upkeep and improrements accounted for 12 percent and nonresidential construction 9 percent of the total. Of the remainder, 14 percent was used in shipping, 12 percent in manufacturing, and 21 percent in all other uses.

Projected demand for lumber with alternative growth assumptions. - Projected demand for lumber at 1970 relative prices shows a rather sharp rise to a 1980 level of 51 billion board feet (medium level), or 224 board feet per capita. This growth is attributable largely to the projected rise in demands for housing and for pallets.

After 1980, and mostly because of the leveling off in the demand for housing, projected demand at 1970 prices increases more : slowly to about 62 billion board feet in 2000 (medium level)-a volume some 1.6 times that of 1970 .

In recent decades softwoods have composed around four-fifths of the lumber consumed. This proportion is expected to be maintained without much change. 
Lumber consumption and projected demand under alternative assumptions of population and economic growth
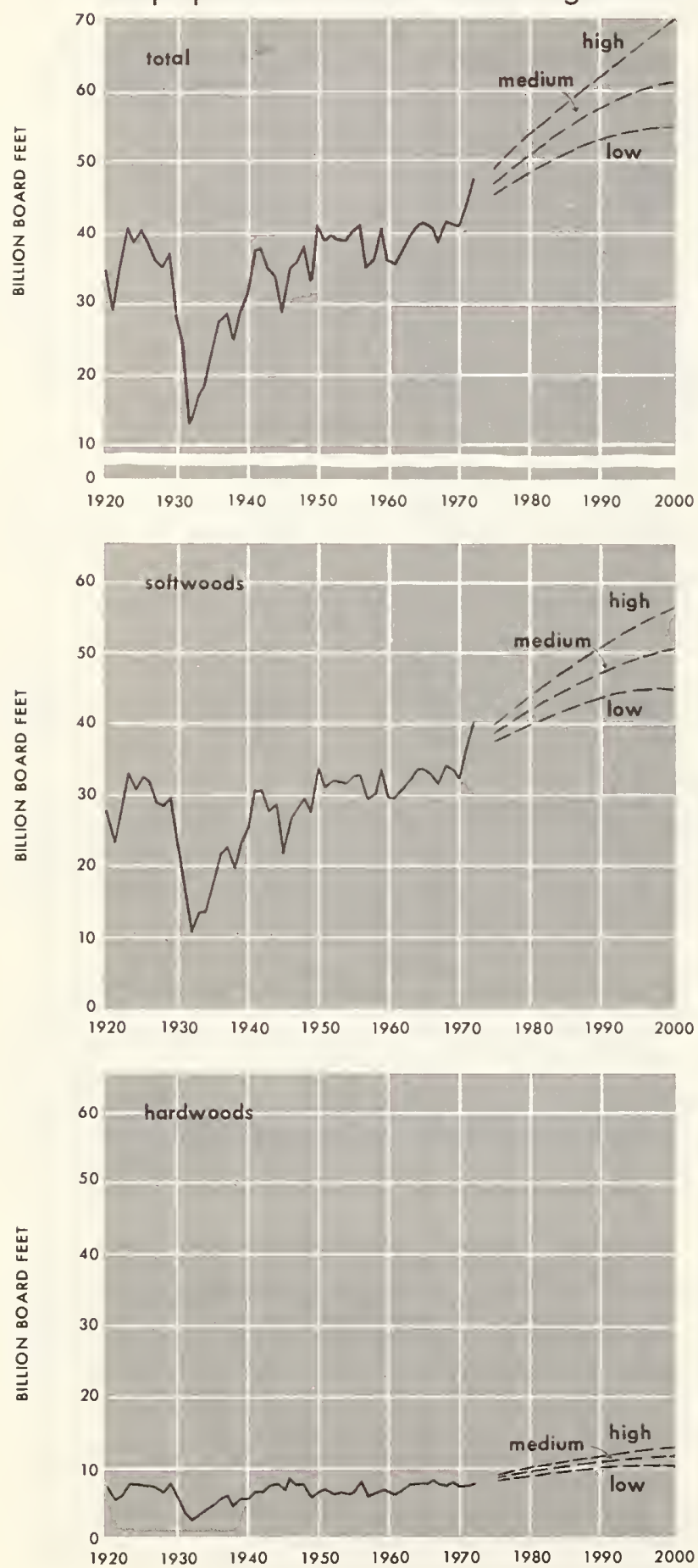

Lumber consumption and projected demand (medium level) under alternative price assumptions
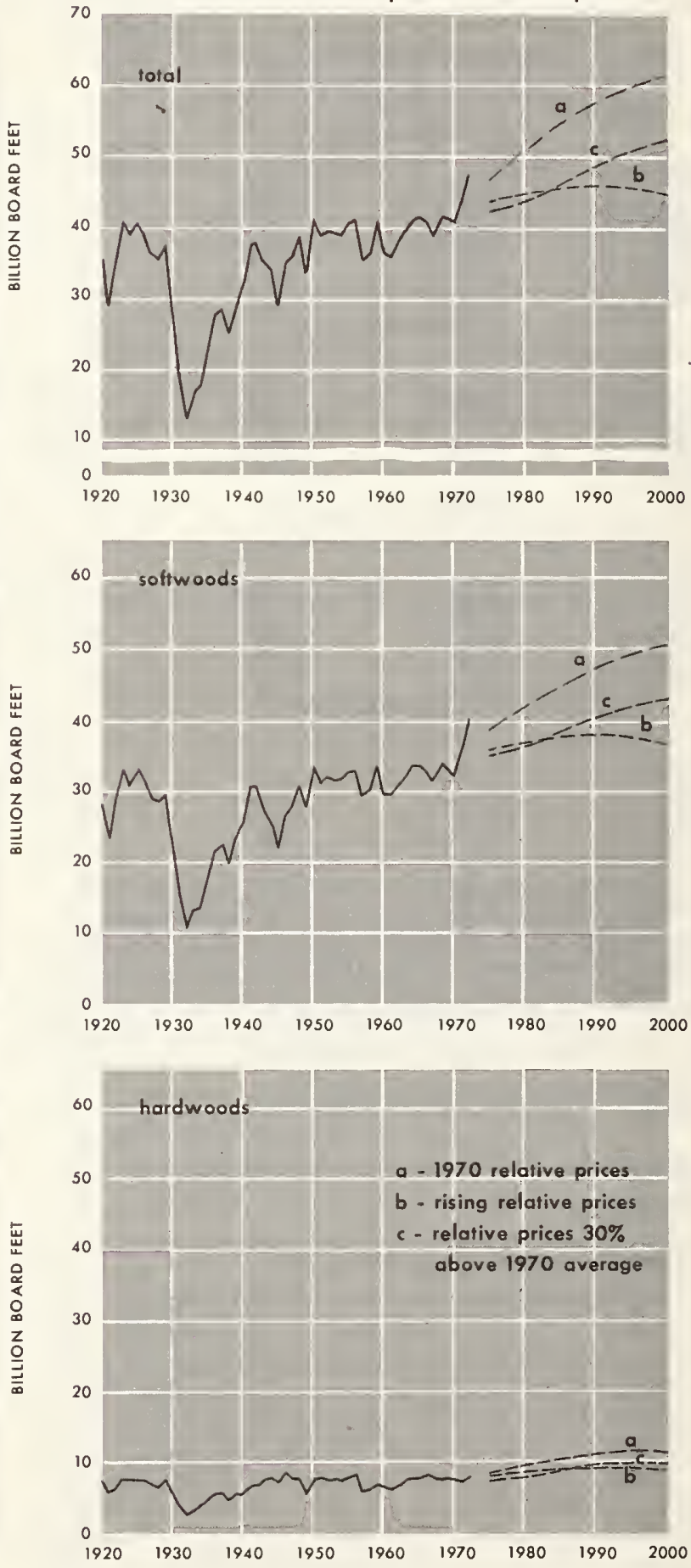
TABLE 136.-Lumber consumption, by major end use, species group, and per capita use, 1962 and 1970, with projections (1970 relative prices) to 2000

\begin{tabular}{|c|c|c|c|c|c|c|c|c|c|c|c|}
\hline \multirow{2}{*}{ Item } & \multirow{2}{*}{1962} & \multirow{2}{*}{1970} & \multicolumn{3}{|c|}{ Low projections 1} & \multicolumn{3}{|c|}{ Medium projections ! } & \multicolumn{3}{|c|}{ High projections 1} \\
\hline & & & 1950 & 1990 & 2000 & 1980 & 1990 & 2000 & 1980 & 1990 & 2000 \\
\hline 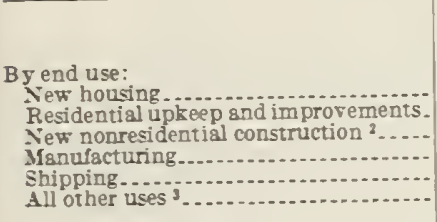 & $\begin{array}{c}\text { Million } \\
\text { board } \\
\text { feet } \\
13,940 \\
4,400 \\
3,930 \\
4,240 \\
4,340 \\
6,450 \\
\end{array}$ & $\begin{array}{c}\text { Million } \\
\text { board } \\
\text { feet } \\
12,270 \\
4,690 \\
3,690 \\
4,670 \\
5,720 \\
8,460\end{array}$ & $\begin{array}{c}\text { Million } \\
\text { board } \\
\text { feet } \\
16,160 \\
5,090 \\
4,470 \\
5,480 \\
7,090 \\
10,040\end{array}$ & $\begin{array}{c}\text { Million } \\
\text { board } \\
\text { feєt } \\
17,310 \\
5,560 \\
4,920 \\
6,290 \\
8,360 \\
11,160\end{array}$ & $\begin{array}{c}\text { Mizlion } \\
\text { board } \\
\text { feet } \\
16,000 \\
5,930 \\
5,450 \\
7,140 \\
9,390 \\
11,540\end{array}$ & $\begin{array}{c}\text { Million } \\
\text { board } \\
\text { feet } \\
17,180 \\
5,000 \\
4,700 \\
5,720 \\
7,710 \\
10,610\end{array}$ & $\begin{array}{c}\text { Miaion } \\
\text { board } \\
\text { feet } \\
18,650 \\
5,680 \\
5,310 \\
6,850 \\
9,390 \\
12,060\end{array}$ & $\begin{array}{c}\text { Million } \\
\text { board } \\
\text { feet } \\
17,950 \\
6,140 \\
6,060 \\
8,130 \\
10,910 \\
12,930 \\
\end{array}$ & $\begin{array}{c}\text { Million } \\
\text { board } \\
\text { feet } \\
18,240 \\
5,110 \\
4,960 \\
6,040 \\
8,360 \\
11,230\end{array}$ & $\begin{array}{c}\text { Million } \\
\text { board } \\
\text { feet } \\
20,000 \\
5,770 \\
5,740 \\
7,560 \\
10,530 \\
13,040\end{array}$ & $\begin{array}{l}\text { Million } \\
\text { board } \\
\text { feet } \\
20,770 \\
6,370 \\
6,740 \\
9,360 \\
12,560 \\
14,670 \\
\end{array}$ \\
\hline Total use... & 37,300 & 39,500 & 48,240 & 53,600 & 55,450 & 50,980 & 57,910 & 62,120 & 53,940 & 62,640 & 70,470 \\
\hline $\begin{array}{l}\text { By species group: } \\
\text { joftwoods...... } \\
\text { Hardwoods..... }\end{array}$ & $\begin{array}{r}30,800 \\
6,500\end{array}$ & $\begin{array}{r}32,100 \\
7,300\end{array}$ & $\begin{array}{r}39,560 \\
8,680\end{array}$ & $\begin{array}{l}13,420 \\
10,180\end{array}$ & $\begin{array}{l}44,360 \\
11,090\end{array}$ & $\begin{array}{r}41,800 \\
9,180\end{array}$ & $\begin{array}{l}46,930 \\
11,010\end{array}$ & $\begin{array}{l}49,700 \\
12,420 \\
\end{array}$ & $\begin{array}{r}44,230 \\
9,710\end{array}$ & $\begin{array}{l}50,740 \\
11,900\end{array}$ & $\begin{array}{l}56,380 \\
14,090\end{array}$ \\
\hline \multirow[t]{2}{*}{ Total use.. } & $3 \pi, 300$ & 39,500 & 48,240 & 53,600 & 55,450 & 50,980 & 57,940 & 62,120 & 53,940 & 62,640 & 70,470 \\
\hline & $\underset{\text { feet }}{\text { Board }}$ & $\begin{array}{c}\text { Board } \\
\text { feet }\end{array}$ & $\begin{array}{c}\text { Board } \\
\text { feet }\end{array}$ & $\underset{\text { feet }}{\text { Board }}$ & $\underset{\text { feet }}{B \text { oard }}$ & $\underset{\text { feet }}{\text { Board }}$ & $\underset{\text { feet }}{\text { Board }}$ & $\begin{array}{c}\text { Board } \\
\text { fett }\end{array}$ & $\begin{array}{c}\text { Board } \\
\text { feet }\end{array}$ & $\underset{\text { feet }}{\text { Board }}$ & $\underset{\substack{\text { Betd } \\
\text { fett }}}{\text { Board }}$ \\
\hline Per capita average use.. & 200 & 193 & 213 & 216 & 208 & 224 & 227 & 221 & 232 & 235 & 234 \\
\hline
\end{tabular}

1 Projections based on alternste assumptions about grokth in population and economic actirity as specified in the introductory section of this chapter. and economic actirity as specified in the introductory section as replacements In In addition to

in eristing track.
Includes upkeep and improrement of nonresidential buildings and struc-

The alternative assumptions on population and economic growth discussed in the introductory section of this chapter have substantial impacts on the demand for lumber in all end uses (table 136, fig. 69). As a result, by 2000 projected total demand at 1970 relative prices ranges from 55.5 billion board feet to 70.5 billion board feet.

Projected demand for lumber with alternative price assumptions.-The alternative assumptions on prices specified in the introductory section also have substantial impacts on projections of demand (table 137, fig. 69). Thus, with relative prices rising at 1.5 percent per year, projected demands for lumber (medium level) remain fairly constant over the projection period at about 45 billion board feet.

With prices of softwood lumber 30 percent above the 1970 average, projected demands for lumber in 1980 would be about the same as consumption in 1971. After 1980, however, projected demand under this price assumption rises rapidly to 53 billion board feet in 2000. This would be some 9 billion board feet below the projected level at 1970 relative prices-a measure of the possible loss of market share to competing materials as a result of higher lumber prices.

Lumber exports and imports.-In addition to domestic demand there has been a modest export demand for lumber for many decades (table 137; Append. V, table 15). Lumber exports average around 1.1 billion feet a year in the 1960 's, and this level, adjusted slightly for alternative price assumptions, was assumed to continue through the projection period. tures; farm construction except housing; mining; made-at-home projects such as furniture, boats, and picnic tables; made-on-the-job products like advertising and display structures; and a wide varlety of other miscellaneous products and uses.

Between the late 1940's and the late 1960's softwood lumber imports, nearly all from Canada, rose from less than a billion board feet to nearly 6 billion feet in 1970 and 9 billion board feet in 1972 (table 137). In years of reduced demand for lumber in the United States, Canadian imports have not dropped appreciably while production in U.S. mills has declined.

Findings of recent Canadian studies, summarized in Chapter IV of this study, show that Canada has the resources to support continued expansion of lumber production and shipments to the United States. However, in view of the higher harvesting, manufacturing and transportation costs associated with the development of the available resources, it appears that significant increases in imports could not be attained without a rise in relative prices of softwood lumber, as occurred in 1971 and 1972.

Accordingly, it was estimated that at 1970 relative prices, softwood lumber imports would remain close to the 1970 level. With relative lumber prices 30 percent above those of 1970 , and with prices rising at annual rates of 1.5 percent, softwood lumber imports by 2000 were projected to reach 12 and 13 billion board feet, respectively. These estimates are believed to be consistent with projections of softwood lumber production and exports contained in Canadian reports referred to in Chapter IV.

Small volumes of hardwood lumber also have been imported, mainly from Canada and various tropical countries. These imports are projected to range from 0.4 to 0.9 billion board feet by 2000 under the alternative price assumptions. 
TABLE 137.-Lumber consumption, exports, imports, and domestic production, selected years 1920-72, with projections under alternate price assumptions (medium projections of growth in population and economic activity) to 2000

\begin{tabular}{|c|c|c|c|c|c|c|c|c|c|c|c|c|c|}
\hline \multirow{2}{*}{ Year } & \multicolumn{4}{|c|}{ Domestic consumption } & \multicolumn{3}{|c|}{ Exports } & \multicolumn{3}{|c|}{ Imports } & \multicolumn{3}{|c|}{ Domestic production } \\
\hline & Total & Per capita & $\begin{array}{l}\text { Soft- } \\
\text { woods }\end{array}$ & $\begin{array}{l}\text { Hard- } \\
\text { woods }\end{array}$ & Total & $\begin{array}{c}\text { Soft- } \\
\text { woods }{ }^{1}\end{array}$ & $\begin{array}{l}\text { Hard- } \\
\text { woods }\end{array}$ & Total & $\begin{array}{c}\text { Soft- } \\
\text { woods }{ }^{1}\end{array}$ & $\begin{array}{l}\text { Hard- } \\
\text { woods }\end{array}$ & Total & $\begin{array}{l}\text { Soft- } \\
\text { woods }\end{array}$ & $\begin{array}{l}\text { Hard- } \\
\text { woods }\end{array}$ \\
\hline $\begin{array}{l}1920 \\
1925 \\
1930 \\
1935 \\
1940\end{array}$ & \begin{tabular}{|r|} 
Billion \\
board feet \\
34.6 \\
40.2 \\
28.2 \\
22.1 \\
31.0
\end{tabular} & $\begin{array}{r}\text { Board feet } \\
325 \\
347 \\
229 \\
173 \\
234\end{array}$ & \begin{tabular}{|c|} 
Billion \\
board feet \\
27.4 \\
32.8 \\
22.5 \\
17.6 \\
25.4
\end{tabular} & $\begin{array}{r}\text { Billion } \\
\text { board feet } \\
7.2 \\
7.5 \\
5.8 \\
4.5 \\
5.5\end{array}$ & \begin{tabular}{|r|} 
Billion \\
board feet \\
1.7 \\
2.6 \\
2.4 \\
1.3 \\
1.0
\end{tabular} & \begin{tabular}{|r} 
Billion \\
board feet \\
1.5 \\
2.2 \\
1.9 \\
1.0 \\
.8
\end{tabular} & $\begin{array}{r}\text { Billion } \\
\text { board feet } \\
0.2 \\
.4 \\
.4 \\
.3 \\
.2\end{array}$ & \begin{tabular}{|c|} 
Billion \\
board feet \\
1.4 \\
1.8 \\
1.2 \\
.4 \\
.7
\end{tabular} & \begin{tabular}{|r|} 
Billion \\
board feet \\
1.3 \\
1.7 \\
1.2 \\
.4 \\
.6
\end{tabular} & \begin{tabular}{r}
\multicolumn{1}{l}{ Billion } \\
board feet \\
$\left({ }^{2}\right)$ \\
0.1 \\
$(2)$ \\
.1 \\
.1
\end{tabular} & \begin{tabular}{|r|} 
Billion \\
board feet \\
35.0 \\
41.0 \\
29.4 \\
22.9 \\
31.2
\end{tabular} & \begin{tabular}{|r|} 
Billion \\
board feet \\
27.6 \\
33.3 \\
23.2 \\
18.2 \\
25.6
\end{tabular} & \begin{tabular}{r}
\multicolumn{1}{c}{ Billion } \\
board feet \\
7.4 \\
7.7 \\
6.1 \\
4.7 \\
5.5
\end{tabular} \\
\hline $\begin{array}{l}1945 \\
1950 \\
1955 \\
1960 \\
1965\end{array}$ & $\begin{array}{l}28.8 \\
40.9 \\
40.1 \\
36.0 \\
41.1\end{array}$ & $\begin{array}{l}205 \\
269 \\
242 \\
199 \\
212\end{array}$ & $\begin{array}{l}21.7 \\
33.4 \\
32.5 \\
29.6 \\
33.4\end{array}$ & $\begin{array}{l}7.0 \\
7.5 \\
7.6 \\
6.4 \\
7.7\end{array}$ & $\begin{array}{l}.4 \\
.5 \\
.8 \\
.9 \\
.9\end{array}$ & $\begin{array}{l}.3 \\
.4 \\
.7 \\
.7 \\
.8\end{array}$ & $\begin{array}{l}.1 \\
.1 \\
.2 \\
.2 \\
.1\end{array}$ & $\begin{array}{l}1.1 \\
3.4 \\
3.6 \\
3.9 \\
5.2\end{array}$ & $\begin{array}{r}.9 \\
3.1 \\
3.3 \\
3.6 \\
4.9\end{array}$ & $\begin{array}{r}.2 \\
.3 \\
.3 \\
.3 \\
.3\end{array}$ & $\begin{array}{l}28.1 \\
38.0 \\
37.4 \\
32.9 \\
36.8\end{array}$ & $\begin{array}{l}21.1 \\
30.6 \\
29.8 \\
26.7 \\
29.3\end{array}$ & $\begin{array}{l}7.0 \\
7.4 \\
7.6 \\
6.3 \\
7.5\end{array}$ \\
\hline $\begin{array}{l}1966 \\
1967 \\
1968 \\
1969 \\
1970\end{array}$ & $\begin{array}{l}40.8 \\
38.8 \\
41.5 \\
41.0 \\
39.5\end{array}$ & $\begin{array}{l}207 \\
195 \\
207 \\
202 \\
193\end{array}$ & $\begin{array}{l}32.8 \\
31.1 \\
34.0 \\
33.2 \\
32.1\end{array}$ & $\begin{array}{l}8.0 \\
7.6 \\
7.4 \\
7.8 \\
7.3\end{array}$ & $\begin{array}{l}1.0 \\
1.1 \\
1.2 \\
1.1 \\
1.3\end{array}$ & $\begin{array}{l}.9 \\
1.0 \\
1.0 \\
1.0 \\
1.2\end{array}$ & $\begin{array}{l}.2 \\
.2 \\
.1 \\
.1 \\
.1\end{array}$ & $\begin{array}{l}5.2 \\
5.1 \\
6.2 \\
6.3 \\
6.1\end{array}$ & $\begin{array}{l}4.8 \\
4.8 \\
5.8 \\
5.9 \\
5.8\end{array}$ & $\begin{array}{l}.4 \\
.3 \\
.3 \\
.4 \\
.3\end{array}$ & $\begin{array}{l}36.6 \\
34.7 \\
36.5 \\
35.8 \\
34.7\end{array}$ & $\begin{array}{l}28.8 \\
27.3 \\
29.3 \\
28.3 \\
27.5\end{array}$ & $\begin{array}{l}7.7 \\
7.4 \\
7.2 \\
7.5 \\
7.1\end{array}$ \\
\hline $1971^{3} 3$ & $\begin{array}{l}43.5 \\
47.4\end{array}$ & $\begin{array}{l}210 \\
227\end{array}$ & $\begin{array}{l}36.4 \\
40.0\end{array}$ & $\begin{array}{l}7.1 \\
7.4\end{array}$ & $\begin{array}{l}1.1 \\
1.5\end{array}$ & $\begin{array}{r}.9 \\
1.2\end{array}$ & .2 & $\begin{array}{l}7.6 \\
9.4\end{array}$ & $\begin{array}{l}7.2 \\
9.0\end{array}$ & $\begin{array}{l}.4 \\
.4\end{array}$ & $\begin{array}{l}37.0 \\
39.4\end{array}$ & $\begin{array}{l}30.3 \\
32.2\end{array}$ & $\begin{array}{l}6.9 \\
7.2\end{array}$ \\
\hline
\end{tabular}

Projections-1970 relatipe prices

\begin{tabular}{|c|c|c|c|c|c|c|c|c|c|c|c|c|c|}
\hline \multirow{2}{*}{$\begin{array}{c}\text { Year } \\
1980 \ldots \\
1990 \\
2000\end{array}$} & \multicolumn{4}{|c|}{ Domestic demand } & \multicolumn{3}{|c|}{ Exports } & \multicolumn{3}{|c|}{ Imports } & \multicolumn{3}{|c|}{ Demand on U.S. mills } \\
\hline & $\begin{array}{l}51.0 \\
57.9 \\
62.1\end{array}$ & $\begin{array}{l}224 \\
227 \\
221\end{array}$ & $\begin{array}{l}41.8 \\
46.9 \\
49.7\end{array}$ & $\begin{array}{r}9.2 \\
11.0 \\
12.4\end{array}$ & $\begin{array}{l}1.3 \\
1.3 \\
1.3\end{array}$ & $\begin{array}{l}1.2 \\
1.2 \\
1.2\end{array}$ & $\begin{array}{r}0.1 \\
.1 \\
.1\end{array}$ & $\begin{array}{l}7.4 \\
7.4 \\
7.4\end{array}$ & $\begin{array}{l}7.0 \\
7.0 \\
7.0\end{array}$ & $\begin{array}{r}0.4 \\
.4 \\
.4\end{array}$ & $\begin{array}{l}44.9 \\
51.8 \\
56.0\end{array}$ & $\begin{array}{l}36.0 \\
41.1 \\
43.9\end{array}$ & $\begin{array}{r}8.9 \\
10.7 \\
12.1\end{array}$ \\
\hline
\end{tabular}

Projections-rising relative prices

\begin{tabular}{|c|c|c|c|c|c|c|c|c|c|c|c|c|c|}
\hline $\begin{array}{l}1980 \\
1990 \\
2000\end{array}$ & $\begin{array}{l}44.5 \\
46.6 \\
45.7\end{array}$ & $\begin{array}{l}195 \\
183 \\
163\end{array}$ & $\begin{array}{l}36.5 \\
37.7 \\
36.6\end{array}$ & $\begin{array}{l}8.0 \\
8.9 \\
9.1\end{array}$ & $\begin{array}{l}1.3 \\
1.3 \\
1.3\end{array}$ & $\begin{array}{l}1.2 \\
1.2 \\
1.2\end{array}$ & $\begin{array}{l}.1 \\
.1 \\
.1\end{array}$ & $\begin{array}{l}10.0 \\
12.7 \\
13.9\end{array}$ & $\begin{array}{r}9.5 \\
12.0 \\
13.0\end{array}$ & $\begin{array}{l}.5 \\
.7 \\
.9\end{array}$ & $\begin{array}{l}35.8 \\
35.2 \\
33.1\end{array}$ & $\begin{array}{l}28.2 \\
26.9 \\
24.8\end{array}$ & $\begin{array}{l}7.6 \\
8.3 \\
8.3\end{array}$ \\
\hline
\end{tabular}

Projections-relative prices 30 percent above 1970 average ${ }^{5}$

\begin{tabular}{|c|c|c|c|c|c|c|c|c|c|c|c|c|c|}
\hline $\begin{array}{l}1980 \\
1990 \\
2000\end{array}$ & $\begin{array}{l}43.3 \\
49.3 \\
52.8\end{array}$ & $\begin{array}{l}190 \\
193 \\
188\end{array}$ & $\begin{array}{l}35.5 \\
39.9 \\
42.2\end{array}$ & $\begin{array}{r}7.8 \\
9.4 \\
10.6\end{array}$ & $\begin{array}{l}1.3 \\
1.3 \\
1.3\end{array}$ & $\begin{array}{l}1.2 \\
1.2 \\
1.2\end{array}$ & $\begin{array}{l}.1 \\
.1 \\
.1\end{array}$ & $\begin{array}{l}11.1 \\
12.6 \\
12.6\end{array}$ & $\begin{array}{l}10.5 \\
12.0 \\
12.0\end{array}$ & $\begin{array}{l}.6 \\
.6 \\
.6\end{array}$ & $\begin{array}{l}33.5 \\
38.0 \\
41.5\end{array}$ & $\begin{array}{l}26.2 \\
29.1 \\
31.4\end{array}$ & $\begin{array}{r}7.3 \\
8.9 \\
10.1\end{array}$ \\
\hline
\end{tabular}

' Includes small volumes of mixed species (not classified as hardwoods or softwoods).

${ }^{2}$ Less than 50 million board feet.

3 Preliminary Forest Service estimates.

1 With relative prices rising at an annual rate of 1.5 percent from the 1970
trend level.

${ }_{3}$ This approximates softwood lumber prices in early 1972.

Demand on U.S. mills for lumber.-Domestic lumber production was 34.7 billion board feet in 1970 , and 39.4 billion board feet in 1972-somewhat above the average of 36 billion board feet produced annually over the 1950's and 1960's (table 137 ; Append. $\mathrm{V}$, table 15).

Given the projections of total U.S. demand, imports and exports discussed above, projected demand for domestic lumber at 1970 relative prices rises to some 56 billion board feet by 2000 (medium projection). With relative prices rising at 1.5 percent per year, demand on U.S. mills in 1980 would be close to the average of the 1950's and 1960's (36 billion board feet), but would fall thereafter to about 33 billion board feet in 2000 . Under the third assumptions with relative prices 30 percent above the 1970 average, projected
Note: Data may not add to totals because of rounding.

Sources: 1920-71-U.S. Department of Commerce, Bureau of the Census. Production-Lumber production and mill stocks. Curr. Ind. Reps. Ser. MA-24T (annual); Exports-U.S. exports-schedule $B$ commodity and country. FT 410 (monthly); Imports-U.S. imports-general consumption, schedule $A$ commodity and country. FT 135 (monthly).

Projections: U.S. Department of Agriculture, Forest Service.

demands for domestically produced lumber would approximate 33.5 billion board feet in 1980 and 41.5 billion board feet in 2000 .

Since the early 1900's sof twoods have accounted for about 80 percent of the domestic cut. In response to differences in the projected rates of growth in demands in the major end uses, such as residential construction and furniture and pallet manufacture, the proportion of domestic production composed of sof twoods, is projected to decline slightly over the projection period, particularly under rising prices which would act to stimulate softwood lumber imports.

\section{Plywood Consumption and Demand}

Plywood consumption reached 17.8 billion square feet ( $3 / 8$-inch basis) in 1970 and 23.5 billion 
TABLE 138.-Plywood consumption, by major end use, species group, and per capita use, 1962 and 1970, with projections (1970 relative prices) to 2000

[3/8-inch basis]

\begin{tabular}{|c|c|c|c|c|c|c|c|c|c|c|c|}
\hline \multirow{2}{*}{ Item } & \multirow{2}{*}{1962} & \multirow{2}{*}{1970} & \multicolumn{3}{|c|}{ Low projections 1} & \multicolumn{3}{|c|}{ Medium projections ${ }^{1}$} & \multicolumn{3}{|c|}{ High projections 1} \\
\hline & & & 1980 & 1990 & 2000 & 1980 & 1990 & 2000 & 1980 & 1990 & 2000 \\
\hline 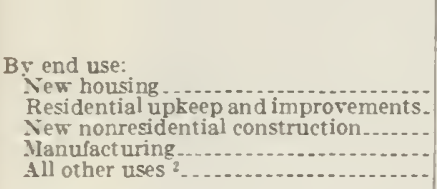 & $\begin{array}{c}\text { Million } \\
\text { square } \\
\text { fett } \\
4,180 \\
1,030 \\
1,280 \\
1,870 \\
3,356\end{array}$ & $\begin{array}{c}\text { Million } \\
\text { square } \\
\text { feet } \\
6,330 \\
2,510 \\
1,700 \\
1,656 \\
5,626\end{array}$ & $\begin{array}{c}\text { Million } \\
\text { square } \\
\text { feet } \\
9,560 \\
3,060 \\
2,580 \\
2,290 \\
8,080\end{array}$ & $\begin{array}{l}\text { Million } \\
\text { square } \\
\text { feet } \\
10,900 \\
3,720 \\
3,260 \\
2,950 \\
9,625\end{array}$ & $\begin{array}{l}\text { Million } \\
\text { square } \\
\text { feet } \\
10,680 \\
4,190 \\
4,050 \\
3,760 \\
10,480\end{array}$ & $\begin{array}{l}\text { Million } \\
\text { square } \\
\text { feet } \\
10,150 \\
3,100 \\
2,680 \\
2,400 \\
8,470\end{array}$ & $\begin{array}{l}\text { Million } \\
\text { square } \\
\text { feet } \\
11,750 \\
3,800 \\
3,530 \\
3,220 \\
10,305\end{array}$ & $\begin{array}{l}\text { Million } \\
\text { square } \\
\text { feet } \\
11,990 \\
4,350 \\
4,550 \\
4,300 \\
11,640\end{array}$ & $\begin{array}{l}\text { Million } \\
\text { square } \\
\text { feet } \\
10,770 \\
3,130 \\
2,800 \\
2,530 \\
8,885\end{array}$ & $\begin{array}{c}\text { Million } \\
\text { square } \\
\text { feet } \\
12,600 \\
3,860 \\
3,800 \\
3,570 \\
11,010\end{array}$ & $\begin{array}{l}\text { Million } \\
\text { square } \\
\text { feet } \\
13,910 \\
4,510 \\
5,100 \\
5,010 \\
13,185\end{array}$ \\
\hline Total use... & 11,716 & 17,822 & 25.570 & 30,455 & 33,160 & 26,800 & 32,605 & 36,830 & 28,115 & 34,840 & 41,715 \\
\hline $\begin{array}{l}\text { BE species group: } \\
\text { Soft woods. } \\
\text { Hard woods..... }\end{array}$ & $\begin{array}{l}9,311 \\
2,404\end{array}$ & $\begin{array}{r}14,038 \\
3,784\end{array}$ & $\begin{array}{r}19,945 \\
5,625\end{array}$ & $\begin{array}{r}23,755 \\
6,700\end{array}$ & $\begin{array}{r}25,865 \\
7,295\end{array}$ & $\begin{array}{r}20,905 \\
5,895\end{array}$ & $\begin{array}{r}25,430 \\
7,175\end{array}$ & $\begin{array}{r}28,725 \\
8,105\end{array}$ & $\begin{array}{r}21,930 \\
6,185\end{array}$ & $\begin{array}{r}27,175 \\
7,665\end{array}$ & $\begin{array}{r}32,540 \\
9,175\end{array}$ \\
\hline Total use... & 11,716 & 17,822 & 25,570 & 30.455 & 33,160 & 26,800 & 32,605 & 36,830 & 28,115 & 34,810 & 41,715 \\
\hline Per capita average use... & $\begin{array}{c}\text { Square } \\
\text { feet } \\
63\end{array}$ & $\begin{array}{c}\text { Square } \\
\text { feet } \\
87\end{array}$ & $\begin{array}{l}\text { Square } \\
\text { feet } \\
113\end{array}$ & $\begin{array}{l}\text { Square } \\
\text { feet } \\
\text { I23 }\end{array}$ & $\begin{array}{l}\text { Square } \\
\text { feet } \\
125\end{array}$ & $\begin{array}{c}\text { Square } \\
\text { feet } \\
118\end{array}$ & $\begin{array}{r}\text { Square } \\
\text { feet } \\
128\end{array}$ & $\begin{array}{l}\text { Square } \\
\text { feet } \\
131\end{array}$ & $\begin{array}{l}\text { Square } \\
\text { feet } \\
\quad 121\end{array}$ & $\begin{array}{l}\text { Square } \\
\text { feet } \\
131\end{array}$ & $\begin{array}{l}\text { Square } \\
\text { feet } \\
\\
139\end{array}$ \\
\hline
\end{tabular}

1 Projections based on alternate assumptions about growth in population and economic actirity as specified in the introductory section of this chapter. 2 Includes shipping; upkeep and improvement of nonresidential buildings and structures; farm construction except housing; mining; made-at-home projects such as furniture and boats; made-on-the-job products like adver-

square feet in 1972 (tables 138 and 139; fig. 70 ; Append. $\mathrm{V}$, table 16). Consumption in 1972 was about 6 times the rolume consumed in 1950and the peak in a trend that has been rising at aunual rate of 8.5 percent for more than two decades. Per capita consumption in this period also showed a sharp upward trend from around 25 square feet in 1950 to 112 square feet in 1972.

About 36 percent of the plywood consumed in 1970 went into the production of new housing, and 24 percent into other types of construction including residential upkeep and improvements. The remainder was used in manufacturing and other unclassified uses.

Data for the early 1960's indicate that sereral billion square feet of veneer was also used at that time in the manufacture of products such as furniture and matches and in shipping containers. Although separate estimates of veneer consumption and production are not shown here because of the lack of recent data, these items are included in the estimates of veneer log consumption and production shown later in this chapter.

The rapid rise in plywood consumption in 1950's and early 1960's was caused in large part by widespread substitution of softwood plywood for lumber in sheathing and subflooring in residential construction and in concrete formwork, and by the growing use of hardwood plywood for paneling in residential construction and the manufacture of furniture. Trends in use in the late 1960's and early 1970's and data obtained from studies of wood use in construction suggest that most of the potential substitution of softwood plywood for lumber in construction has taken place. tising and display structures; and a wide variety of other miscellaneous products and uses.

Note: Veneer is included in the estimates for manufacturing and shipping.

Projected demand for plywood.-Nonetheless, projected growth in construction and manufacturing is large enough to result in very substantial increases in projected demands for plywood. At 1970 relatiye prices, the medium projection of demand in 2000 is 36.8 billion square feet $(3 / 8$-inch basis) - slightly more than double consumption in 1970. Per capita demand is projected to increase by 1.5 times to 131 square feet.

As in the case of lumber, the alternative assumptions on growth in population and economic activity, and on prices, have substantial impacts on projected demand (tables 138 and 139, fig. 70). For example, if relative prices rise 1 percent per year, projected demand (medium level) in 2000 would be some 20 percent under the projected level assuming 1970 relative prices.

Since the late 1950's softwood plywood has composed about four-fifths of total plywood consumption. An analysis of prospective growth in demand by major end uses indicated that this percentage is likely to remain about the same through the projection period.

Plywood exports and imports.-Softwood plywood exports have been of minor importance, reaching a peak of about $200 \mathrm{mi}$ 'lion square feet (3/8-inch basis) in the late 1960's (table 139; Append. V, table 16). Although some further modest increases in exports are likely, the volume is not expected to be significant in relation to production or consumption.

Exports of hardwood plywood have amounted to less than 100 million square feet in recent decades. Such exports are also expected to remain small during the projection period. 
TABLE 139.-Plywood consumption, exports, imports, and domestic production, selected years 1950-72, with projections under alternate price assumptions (medium projections of growth in population and economic activity) to 2000

[3/8-inch basis]

\begin{tabular}{|c|c|c|c|c|c|c|c|c|c|c|c|c|c|}
\hline \multirow{2}{*}{ Year } & \multicolumn{4}{|c|}{ Domestic consumption } & \multicolumn{3}{|c|}{ Exports } & \multicolumn{3}{|c|}{ Imports } & \multicolumn{3}{|c|}{ Domestic production 1} \\
\hline & Total & Per capita & $\begin{array}{l}\text { Soft- } \\
\text { woods }\end{array}$ & $\begin{array}{l}\text { Hard- } \\
\text { woods }\end{array}$ & Total & $\begin{array}{l}\text { Soft- } \\
\text { woods }\end{array}$ & $\begin{array}{l}\text { Hard- } \\
\text { woods ? }\end{array}$ & Total & $\begin{array}{c}\text { Soft- } \\
\text { woods }\end{array}$ & $\begin{array}{l}\text { Hard- } \\
\text { woods }\end{array}$ & Total & $\begin{array}{c}\text { Soft- } \\
\text { woods }\end{array}$ & $\begin{array}{l}\text { Hard- } \\
\text { woods }\end{array}$ \\
\hline 1950 & $\begin{array}{l}\text { Billion } \\
\text { square } \\
\text { feet }\end{array}$ & $\begin{array}{c}\text { Square } \\
\text { feet }\end{array}$ & $\begin{array}{l}\text { Billion } \\
\text { square } \\
\text { feet } \\
2.7\end{array}$ & $\begin{array}{c}\text { Billion } \\
\text { square } \\
\text { feet }\end{array}$ & $\begin{array}{c}\text { Billion } \\
\text { square } \\
\text { feet } \\
(3)\end{array}$ & $\begin{array}{l}\text { Billion } \\
\text { square } \\
\text { feet } \\
(3)\end{array}$ & $\begin{array}{l}\text { Billion } \\
\text { square } \\
\text { fett } \\
(3)\end{array}$ & $\begin{array}{l}\text { Billion } \\
\text { square } \\
\text { feet } \\
(3)\end{array}$ & $\begin{array}{l}\text { Billion } \\
\text { square } \\
\text { feet } \\
(3)\end{array}$ & $\begin{array}{l}\text { Billion } \\
\text { square } \\
\text { feet } \\
(3)\end{array}$ & $\begin{array}{l}\text { Billion } \\
\text { square } \\
\text { feet }\end{array}$ & $\begin{array}{l}\text { Billion } \\
\text { square } \\
\text { feet } \\
2.7\end{array}$ & $\begin{array}{l}\text { Billion } \\
\text { square } \\
\text { feet }\end{array}$ \\
\hline $1955, \ldots .$. & $\begin{array}{l}7.1 \\
9.6\end{array}$ & 43 & $\begin{array}{l}5.3 \\
7.8\end{array}$ & 1.8 & $\begin{array}{l}(3) \\
(3)\end{array}$ & (3) & (3) & (3) & (3) & (3) & 6.6 & $\begin{array}{l}2.7 \\
5.3\end{array}$ & 1.4 \\
\hline $1965 \ldots$ & 15.5 & 80 & 12.4 & $\begin{array}{l}1.8 \\
3.1\end{array}$ & $\begin{array}{l}(3) \\
(3)\end{array}$ & $\begin{array}{l}(3) \\
(3)\end{array}$ & $\begin{array}{l}(3) \\
(3)\end{array}$ & $\begin{array}{l}0.7 \\
1.1\end{array}$ & $\begin{array}{l}\text { (3) } \\
\text { (3) }\end{array}$ & $\begin{array}{l}0.7 \\
1.0\end{array}$ & $\begin{array}{r}8.9 \\
14.5\end{array}$ & $\begin{array}{r}7.8 \\
12.4\end{array}$ & $\begin{array}{l}1.1 \\
2.0\end{array}$ \\
\hline $1966-\ldots$. & 16.1 & $\begin{array}{l}82 \\
80\end{array}$ & 12.8 & 3.3 & 0.1 & (3) & (3) & 1.3 & ${ }^{(3)}$ & 1.3 & 14.9 & 12.8 & 2.1 \\
\hline $1966-\ldots$ & $\begin{array}{l}15.9 \\
18.2\end{array}$ & $\begin{array}{l}80 \\
91\end{array}$ & $\begin{array}{l}12.8 \\
14.3\end{array}$ & $\begin{array}{l}3.2 \\
3.9\end{array}$ & $\begin{array}{l}.1 \\
.1\end{array}$ & 0.1 & $\begin{array}{l}(3) \\
(3)\end{array}$ & 1.2 & $\begin{array}{l}(3) \\
(3)\end{array}$ & 1.2 & 14.8 & 12.8 & 1.9 \\
\hline 1969 & 17.3 & 85 & 13.4 & 4.0 & .2 & .2 & (3) & 2.1 & (3) & 1.9 & 16.4 & 14.4 & 2.0 \\
\hline $1970 \ldots$ & 17.8 & 87 & 14.0 & 3.8 & .2 & .1 & 0.1 & 2.0 & (3) & 2.1 & $\begin{array}{l}15.4 \\
15.9\end{array}$ & $\begin{array}{l}13.5 \\
14.1\end{array}$ & $\begin{array}{l}1.9 \\
1.8\end{array}$ \\
\hline 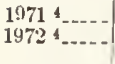 & $\begin{array}{l}20.7 \\
23.5\end{array}$ & $\begin{array}{l}100 \\
112\end{array}$ & $\begin{array}{l}16.3 \\
18.1\end{array}$ & $\begin{array}{l}4.5 \\
5.4\end{array}$ & 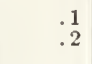 & .1 & $\begin{array}{l}(3) \\
(3)\end{array}$ & $\begin{array}{l}2.5 \\
3.2\end{array}$ & $\begin{array}{l}(3) \\
(3)\end{array}$ & $\begin{array}{l}2.5 \\
3.2\end{array}$ & $\begin{array}{l}18.3 \\
20.5\end{array}$ & $\begin{array}{l}16.4 \\
18.3\end{array}$ & $\begin{array}{l}1.9 \\
2.2\end{array}$ \\
\hline
\end{tabular}

Projections-1970 relative prices

\begin{tabular}{|c|c|c|c|c|c|c|c|c|c|c|c|c|c|}
\hline \multirow{2}{*}{$\begin{array}{c}\text { Year } \\
1090 \ldots \\
1090 \\
2000\end{array}$} & \multicolumn{4}{|c|}{ Domestic demand } & \multicolumn{3}{|c|}{ Exports } & \multicolumn{3}{|c|}{ Imports } & \multicolumn{3}{|c|}{ Demand on U.S. mills } \\
\hline & $\begin{array}{l}26.8 \\
32.6 \\
36.8\end{array}$ & $\begin{array}{l}118 \\
128 \\
131\end{array}$ & $\begin{array}{l}20.9 \\
25.4 \\
28.7\end{array}$ & $\begin{array}{l}5.9 \\
7.2 \\
8.1\end{array}$ & $\begin{array}{l}(3) \\
(3) \\
(3)\end{array}$ & $\begin{array}{l}(3) \\
(3) \\
(3)\end{array}$ & $\begin{array}{l}\text { (3) } \\
\text { (3) } \\
\text { (3) }\end{array}$ & $\begin{array}{l}3.5 \\
3.5 \\
3.5\end{array}$ & $\begin{array}{l}(3) \\
(3) \\
(3) \\
(3)\end{array}$ & $\begin{array}{l}3.5 \\
3.5 \\
3.5\end{array}$ & $\begin{array}{l}23.3 \\
29.1 \\
33.3\end{array}$ & $\begin{array}{l}20.9 \\
25.4 \\
28.7\end{array}$ & $\begin{array}{l}2.4 \\
3.7 \\
4.6\end{array}$ \\
\hline
\end{tabular}

Projections-rising relative prices $s$

\begin{tabular}{|c|c|c|c|c|c|c|c|c|c|c|c|c|c|}
\hline $\begin{array}{l}1980 \ldots \\
1990 \ldots \\
2000\end{array}$ & $\begin{array}{l}23.9 \\
27.6 \\
29.5\end{array}$ & $\begin{array}{l}105 \\
108 \\
105\end{array}$ & $\begin{array}{l}18.6 \\
21.5 \\
23.0\end{array}$ & $\begin{array}{l}5.3 \\
6.1 \\
6.5\end{array}$ & $\begin{array}{l}(3) \\
(3) \\
(3)\end{array}$ & $\begin{array}{l}(3) \\
(3) \\
(3)\end{array}$ & $\begin{array}{l}(3) \\
(3) \\
(3)\end{array}$ & $\begin{array}{l}3.3 \\
3.9 \\
4.2\end{array}$ & $\begin{array}{l}(3) \\
(3) \\
(3)\end{array}$ & $\begin{array}{l}3.3 \\
3.9 \\
4.2\end{array}$ & $\begin{array}{l}20.6 \\
23.7 \\
25.3\end{array}$ & $\begin{array}{l}18.6 \\
21.5 \\
23.0\end{array}$ & $\begin{array}{l}2.0 \\
2.2 \\
2.3\end{array}$ \\
\hline
\end{tabular}

Projections-relative prices 30 percent above 1970 average ${ }^{6}$

\begin{tabular}{|c|c|c|c|c|c|c|c|c|c|c|c|c|c|}
\hline $\begin{array}{l}1980 \ldots \\
1990 \\
2000\end{array}$ & $\begin{array}{l}22.8 \\
27.7 \\
31.3\end{array}$ & $\begin{array}{l}100 \\
109 \\
111\end{array}$ & $\begin{array}{l}17.8 \\
21.6 \\
24.4\end{array}$ & $\begin{array}{l}5.0 \\
6.1 \\
6.9\end{array}$ & $\begin{array}{l}(3) \\
(3) \\
(3)\end{array}$ & $\begin{array}{l}(3) \\
(3) \\
(3)\end{array}$ & $\begin{array}{l}(3) \\
(3) \\
(3)\end{array}$ & $\begin{array}{l}4.1 \\
4.2 \\
4.3\end{array}$ & $\begin{array}{l}(3) \\
(3) \\
(3)\end{array}$ & $\begin{array}{l}4.1 \\
4.2 \\
4.3\end{array}$ & $\begin{array}{l}18.7 \\
23.5 \\
27.0\end{array}$ & $\begin{array}{l}17.8 \\
21.6 \\
24.4\end{array}$ & $\begin{array}{l}0.9 \\
1.9 \\
2.6\end{array}$ \\
\hline
\end{tabular}

1 Includes production from both domestic and imported species.

2 Includes mixed species (not classified as hardwoods and softwoods).

3 Less than 50 million square feet in the years 1950-72 and 500 million square feet in 1980, 1990, and 2000.

4 Preliminary.

3 With relative prices rising at an annual rate of 1.0 percent from the 1970 trend level.

B This approximates prices of softwood plywood in early 1972

Veneer exports (not included in table 139) in 1972 totaled 492 million square feet (surface measure) roughly eight times the volume shipped in the early 1960's. Despite this increase veneer exports are not expected to become a significant source of demand for domestically produced veneer logs.

In contrast to limited exports, imports of hardwood plywood have risen rapidly in the last two decades to a total of 3.2 billion square feet $(3 / 8$-inch basis) in 1972 (table 139). Imports of softwood plywood, on the other hand, have not been significant and no change is assumed in the next few decades.

Over four-fifths of all plywood imports in 1972 were composed of lauan from the forests of insular Southeast Asia. Most of the remainder consisted of other tropical species such as sen, mahogany, and shiva.
Note: Data may not add to totals because of rounding.

Sources: 1950-72-U.S. Department of Commerce, Bureau of the Census. Production-Softwood plywood. Curr. Ind. Reps.'Ser. MA24H (annual); Hardwood plywood. Curr. Ind. Reps. Ser. MA24H (annual); Exports-U.S. exports-schedule B commodity and country. FT 410 (monthly); ImportsU.S. imports - general and consumption, schedule A commodity and country. F T 135 (monthly).

Projections: U.S. Department of Agriculture, Forest Service.

Assuming 1970 relative prices, hardwood plywood imports have been projected to rise to 3.5 billion square feet by 1980 and remain at this level through the rest of the projection period. Under the alternative higher price assumptions, plywood imports are projected to go as high as 4.3 billion square feet by 2000 .

Veneer imports have also increased rapidly, moving up from around 400 million square feet (surface measure) in the early 1950 's to 3.2 billion square feet in 1972. Hardwood veneer imports are expected to continue to rise for use in domestic production of plywood.

Demand on U.S. mills for plywood.-Domestic plywood production in 1972 reached 20.5 billion square feet (3/8-inch basis) - -more than 4 times the level of output in the early 1950's (table 139). Softwoods accounted for nearly all of the growth in this period. 
Plywood (3/8-inch basis) consumption and projected demand under alternative assumptions on population and economic growth
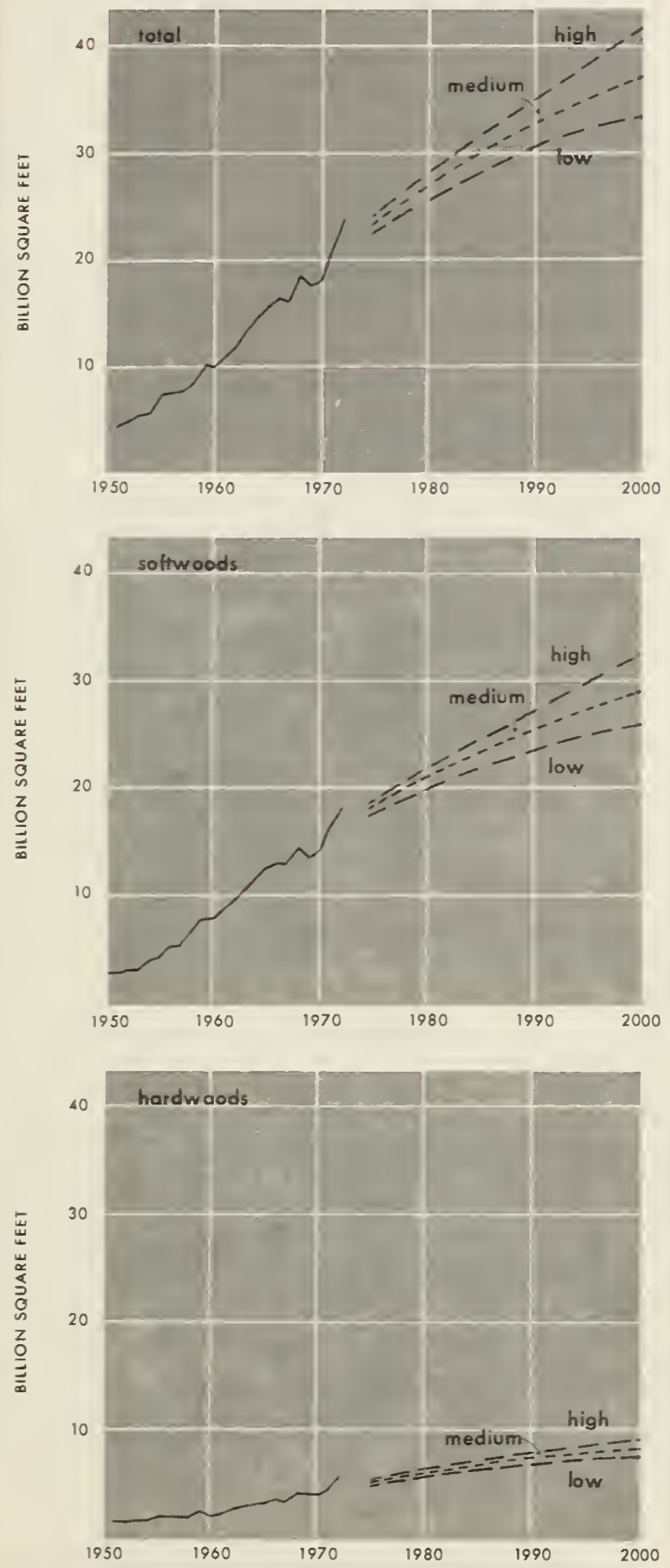

Plywood (3/8-inch basis) consumption and projected demand (medium level) under alternative price assumptions
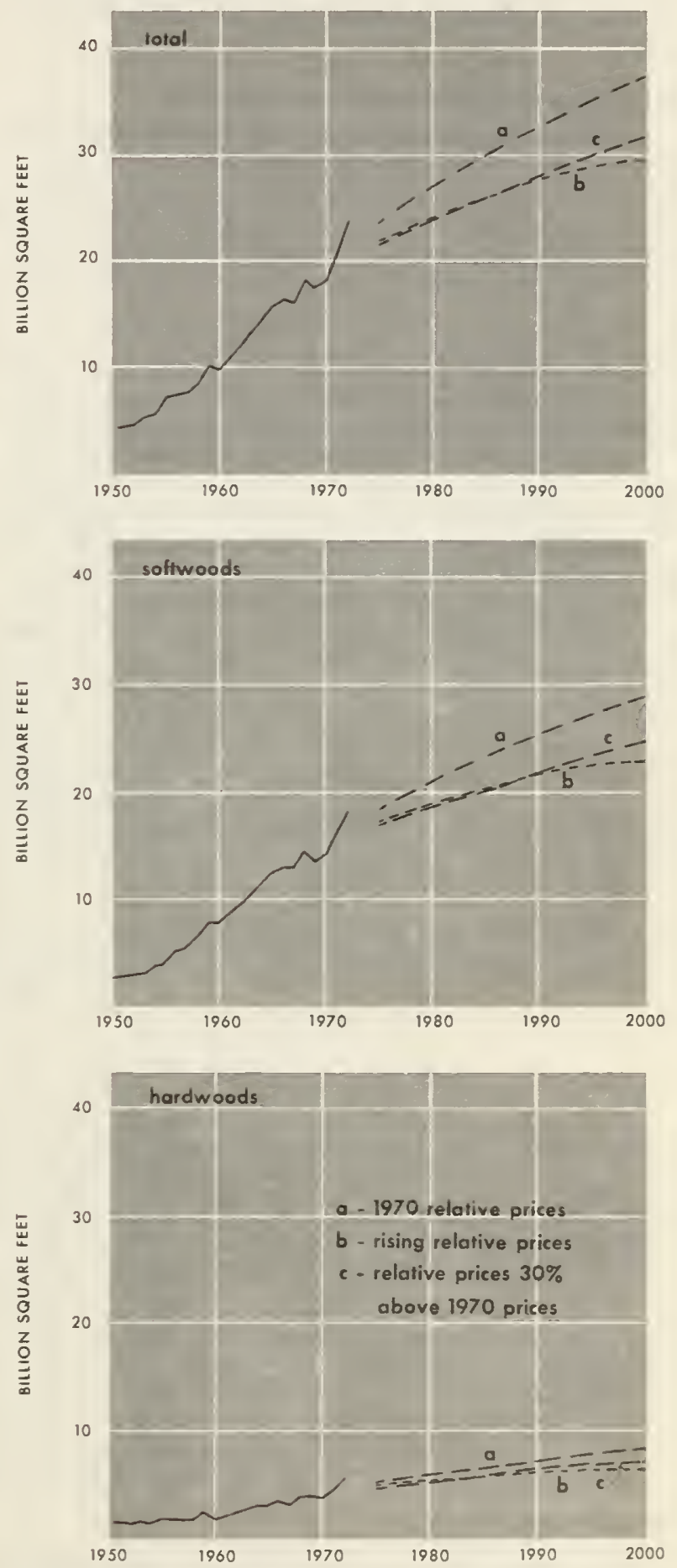

Figure 70 
Projected demand for plywood produced by domestic industries show continued and rapid growth under all price assumptions. By 2000 projected demands range from 25.3 billion square feet (with prices rising at 1 percent per year) to 33.3 billion square feet (at 1970 relative prices). Most of the projected increases are for softwood plywood.

\section{Building Board Consumption and Demand}

Building board consumption including insulation board, hardboard, and particleboard reached 14.1 billion square feet ( $3 / 8$-inch basis) in 1972 -over 4 times the volume consumed in 1950 (tables 140 and 141). Per capita consumption more than tripled in this period, rising from 22 to 68 square feet.

In the 1950's and 1960's particleboard consumption showed the largest increase, rising from less than 50 million square feet in 1950 to 6.3 billion square feet in 1972-an average annual rate of about 25 percent. Hardboard use also rose rapidly, with an average annual increase of 9.5 percent. Although use of insulation board has been relatively stable, this product still accounted for 40 percent of all building board consumed in 1972 .

The fast growth in use of particleboard largely reflects the substitution of this product for lumber and plywood used as core stock in the manufacture of furniture, doors, and cabinets. Much of the growth in use since the late 1950's reflects similar substitution for floor underlayment. Present work on the development of structural grades of particleboard also suggests the likelihood of further substitution for softwood plywood used as subflooring and roof sheathing in construction.
Much of the recent increase in the use of hardboard also reflects substitution for lumber and plywood, especially in the furniture industry. Use of insulation board, on the other hand, has been closely related to construction activity.

Projected demand for building board.-Projections of demand for building board (medium level) at 1970 relative prices reach 28 billion square feet ( $3 / 8$-inch basis) by 2000 - some 3 times the volume consumed in 1970 (table 140). Projected per capita demand roughly doubles rising from 47 to 100 square feet. Particleboard and hardboard are expected to show the largest increases as in recent years.

The alternative assumptions on growth in population and economic activity have substantial impacts with projected total demands in 2000 ranging from about 25 to 32 billion square feet (table 140). Alternative assumptions on prices, on the other hand, have relatively little effect, largely because of the small size of the assumed price increases and the assumed inelasticity of demand (table 141).

Demand on U.S. mills for building board.Exports and imports of building board have been relatively small, and this situation is expected to continue through the projection period. By far the largest part of projected demands will thus have to be supplied by U.S. industries from domestic timber resources. A substantial part of this demand for wood is expected to be supplied by plant residues.

Meeting the medium projection of demand in 2000 , at all assumed price levels, would involve more than doubling the size of the particleboard and hardboard industries and expanding the insu-

ТАВLE 140.-Building board consumption, by major end use, type of board, and per capita use, 1970, with projections (1970 relative prices) to 2000

$[3 / 8-i n c b$ basis $]$

\begin{tabular}{|c|c|c|c|c|c|c|c|c|c|c|}
\hline \multirow{2}{*}{ Item } & \multirow{2}{*}{1970} & \multicolumn{3}{|c|}{ Low projection 1} & \multicolumn{3}{|c|}{ Medium projection 1} & \multicolumn{3}{|c|}{ High projection 1} \\
\hline & & 1980 & 1990 & 2000 & 1980 & 1990 & 2000 & 1980 & 1990 & 2000 \\
\hline $\begin{array}{l}\text { Iy } \text { end use: } \\
\text { New housing } \\
\text { liesidential upkeep and improvements. } \\
\text { New nonresidential construction } \\
\text { Manufacturing } \\
\text { All otber uses } 2\end{array}$ & $\begin{array}{l}\text { Million } \\
\text { square } \\
\text { feet } \\
2,760 \\
1,415 \\
960 \\
1,790 \\
2,683\end{array}$ & $\begin{array}{c}\text { Million } \\
\text { square } \\
\text { feet } \\
4,225 \\
1,815 \\
1,375 \\
3,375 \\
4,615\end{array}$ & $\begin{array}{c}\text { Million } \\
\text { square } \\
\text { feet } \\
5,065 \\
2,295 \\
1,705 \\
5,215 \\
6,125\end{array}$ & $\begin{array}{c}\text { Million } \\
\text { square } \\
\text { feet } \\
5,305 \\
2,760 \\
1,890 \\
7,590 \\
7,520\end{array}$ & $\begin{array}{c}\text { Million } \\
\text { square } \\
\text { feet } \\
4,480 \\
1,825 \\
1,440 \\
3,545 \\
4,840\end{array}$ & 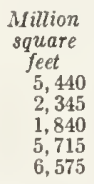 & $\begin{array}{c}\text { Million } \\
\text { square } \\
\text { feet } \\
5,920 \\
2,855 \\
2,130 \\
8,695 \\
8,400\end{array}$ & $\begin{array}{c}\text { Million } \\
\text { square } \\
\text { feet } \\
4,730 \\
1,855 \\
1,495 \\
3,750 \\
5,065\end{array}$ & $\begin{array}{c}\text { Million } \\
\text { square } \\
\text { feet } \\
5,825 \\
2,385 \\
1,985 \\
6,360 \\
7,100\end{array}$ & $\begin{array}{l}\text { Million } \\
\text { square } \\
\text { feet } \\
6,840 \\
2,960 \\
2,385 \\
10,165 \\
9,575\end{array}$ \\
\hline Total...... & 9,608 & 15,405 & 20,405 & 25,065 & 16,130 & 21,915 & 28,000 & 16,895 & 23,655 & 31,925 \\
\hline $\begin{array}{l}\text { 13y } 1 \text { p pe of board: } \\
\text { Insvlation board } \\
\text { Hardboard } \\
\text { P'articleboard. }\end{array}$ & $\begin{array}{l}4,552 \\
1,541 \\
3,515\end{array}$ & $\begin{array}{l}4,975 \\
2,475 \\
7,955\end{array}$ & $\begin{array}{r}5,690 \\
3,430 \\
11,285\end{array}$ & $\begin{array}{r}7,110 \\
4,380 \\
13,575\end{array}$ & $\begin{array}{l}5,330 \\
2,570 \\
8,230\end{array}$ & $\begin{array}{r}6,040 \\
3,905 \\
11,970\end{array}$ & $\begin{array}{r}7,820 \\
5,430 \\
14,750\end{array}$ & $\begin{array}{l}5,690 \\
2,760 \\
8,445\end{array}$ & $\begin{array}{r}6,755 \\
4,570 \\
12,330\end{array}$ & $\begin{array}{r}8,530 \\
7,145 \\
16,250\end{array}$ \\
\hline Total use... & 9,608 & 15,405 & 20,405 & 25,065 & 16,130 & 21,915 & 28,000 & 16,895 & 23,655 & 31,925 \\
\hline l'or capita average use.... & $\begin{array}{l}\text { Square } \\
\text { feet } \\
\\
47\end{array}$ & $\begin{array}{l}\text { Square } \\
\text { feet } \\
\\
68\end{array}$ & $\begin{array}{l}\text { Square } \\
\text { feet } \\
\quad 82\end{array}$ & $\begin{array}{l}\text { Square } \\
\text { feet } \\
\quad 94\end{array}$ & $\begin{array}{l}\text { Square } \\
\quad \text { feet } \\
\quad 71\end{array}$ & $\begin{array}{l}\text { Square } \\
\text { feet } \\
\quad 86\end{array}$ & $\begin{array}{l}\text { Square } \\
\text { feet } \\
100\end{array}$ & $\begin{array}{l}\text { Square } \\
\text { feet } \\
\quad 73\end{array}$ & $\begin{array}{l}\text { Square } \\
\text { feet } \\
\quad 89\end{array}$ & $\begin{array}{l}\text { Square } \\
\text { feet } \\
\\
106\end{array}$ \\
\hline
\end{tabular}

1 l'rojections based on alternate assumptions about growth in population and 'conomic activity as specified in tbe introductory section of this chapter.

2 Iucludes upkeep and improvement of nonresidential buildings and struc- tures; shipping; farm structures, except bousing; mining; made-at-home projects such as furniture; made-on-the-job products like advertising and display strue. tures; and a wide variety of other miscellaneous products and uses. 


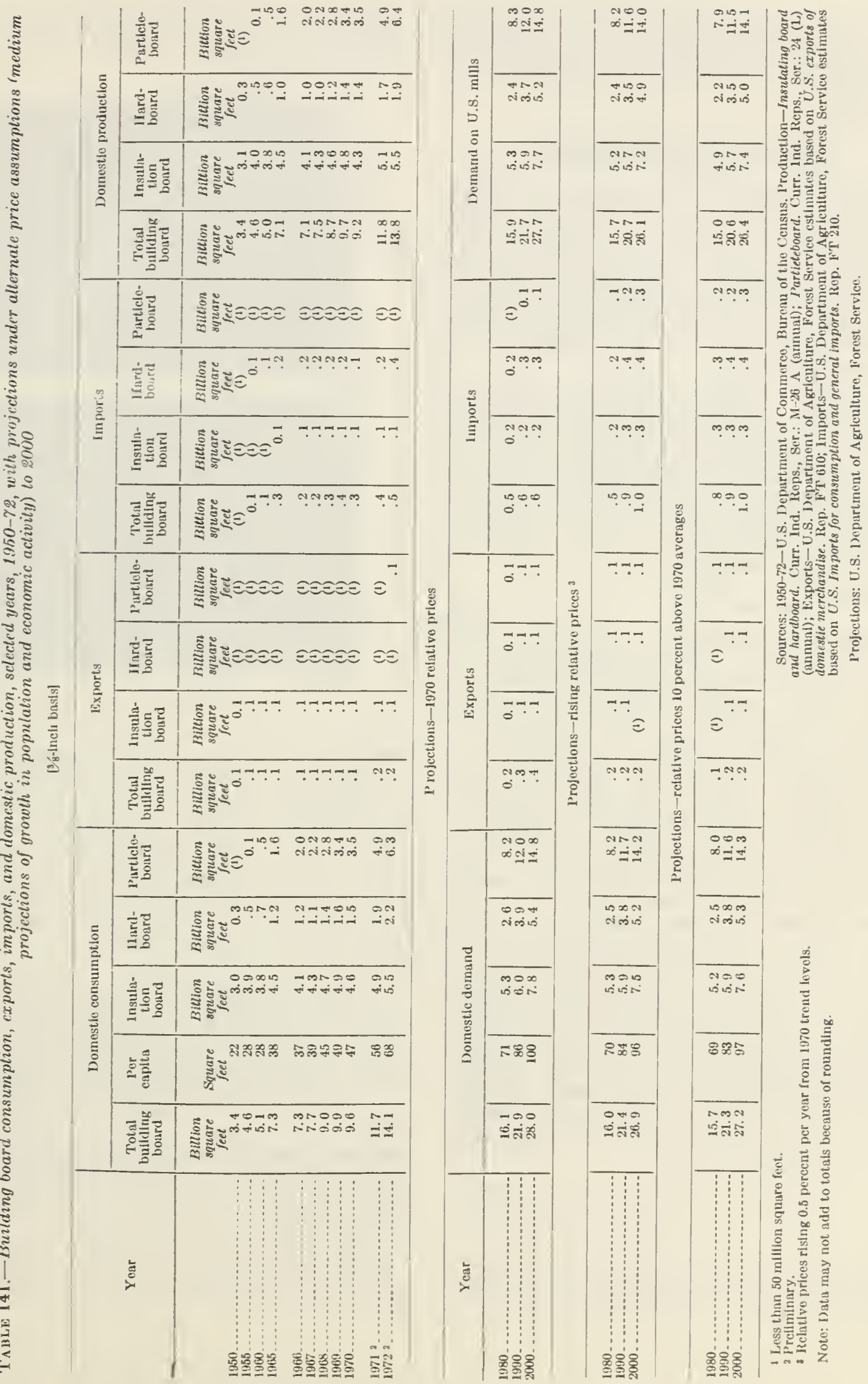


lation board industry about 50 percent. Projected demands for wood for such production are included with pulpwood for hardboard and insulation board, and with miscellaneous timber products for particleboard.

\section{DEMAND FOR PULPWOOD}

Since 1920 pulpwood consumption in United States mills has increased 12 times, rising to 5.6 billion cubic feet in $1972^{34}$ (72.4 million cords). Export demand, including the pulpwood equivalent of pulp and paper, increased nineteenfold to 0.7 billion cubic feet ( 9.5 million cords). As a result of such growth, nearly half of the cubic volume of timber harvested from domestic forests is used as pulpwood.

Demand for pulpwood is a derived demand in the sense that it is determined by demands for paper, board, and other pulp products. The analysis below consequently first considers trends in the use of these end products. Demands for paper and board are then converted to requirements for woodpulp, wastepaper, and other fibers. Projected demands for woodpulp are, in turn, converted to requirements for pulpwood.

\section{Demand for Paper and Board}

Consumption of paper and board increased from about 8 million tons in 1920 to 64 million tons in 1972 (table 142; fig. 71; Append. V, table 17). Annual rates of growth calculated from trend values, averaged 4.8 percent in the years $1920-40$ then fell to 4.1 percent in the $1950-70$ period.

Per capita consumption of paper and board increased about 4 times in the $1920-72$ period, rising from 145 to 616 pounds (table 143, fig. 71 ). Rates of growth in per capita use also showed a substantial decline falling from an average of 3.7 percent annually in the pre-World War II decades to 2.6 percent in the postwar decades.

Factors affecting consumption-Part of the growth in paper and board consumption in past decades can be attributed to increases in population, economic activity, and disposable personal income. Part of the growth is the result of major displacement of other materials such as lumber, veneer, cooperage, and metals in such products as shipping containers. Development of large markets for new products such as food board, milk cartons, and computer paper also has contributed to increases in consumption.

The declining rate of growth in consumption, on the other hand, is partly due to the fact that

${ }^{34}$ This included 3.7 billion cubic feet of roundwood used directly in pulping and 1.9 billion cubic feet of chips and sawdust obtained from slabs, edgings, veneer cores, and other residues of primary manufacturing plants.
Paper and board consumption, 1920-71, with projections to 2000
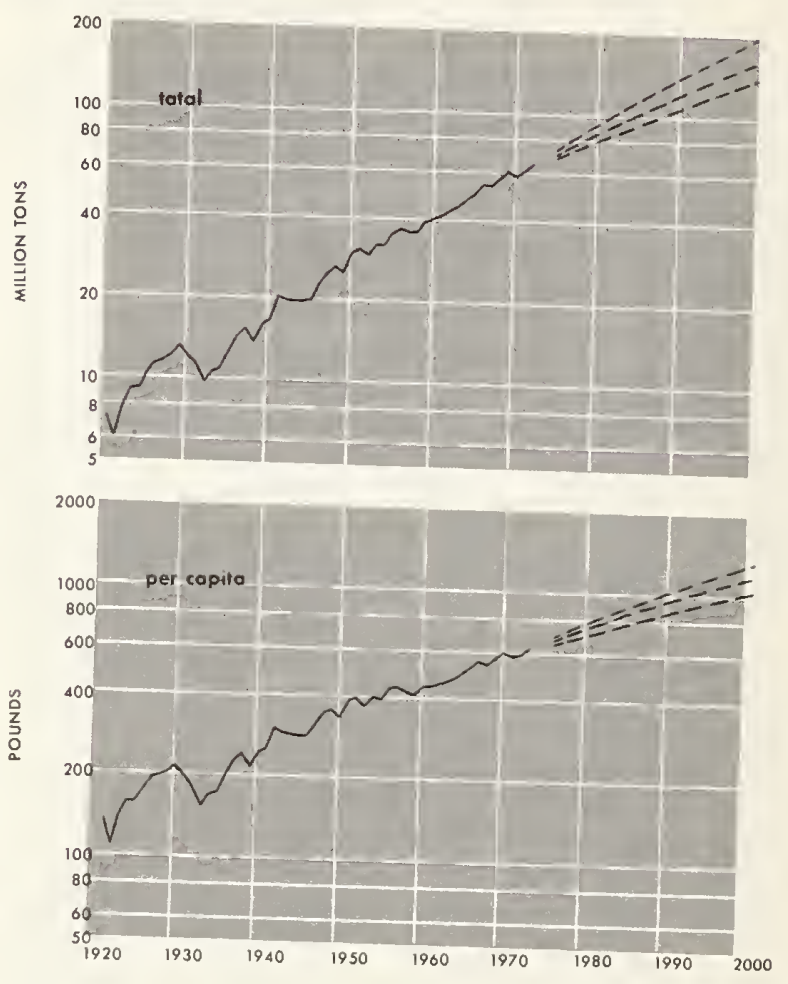

Figure 71

per capita use of some grades of paper and board is beginning to level off as it moves toward a saturation level. ${ }^{35}$ It also reflects stronger competition from materials that compete with paper and board. Use of plastics for packaging foods and many other products, for example, has cut into the demand for several grades of paper and board. Products such as synthetic writing and printing paper now under development also may affect demands in the future.

In projecting demands for paper and board, however, it seems likely that ultimate scarcities and rising prices of raw materials such as petroleum, together with environmental factors relating to manufacturing pollution, and problems of

${ }^{35}$ For a more complete discussion of the tendency of per capita consumption to approach a saturation value see:

U.S. Department of Agriculture, Forest Service. Use of regression equations for projecting trends in demand for paper and board. U.S. Dept. Agr. Forest Resource Rep. 18,178 p. 1967.

United Nations Food and Agriculture Organization. World demand for paper to 1975.1959 p. Rome. 1960.

United Nations Food and Agriculture Organization. Pulp and paper prospects in western Europe. 456 p. Rome. 
TABLE 142.--Paper and board consumption, selected years 1920-72, with projections of demand (1970 relative prices) to $2000^{1}$

\begin{tabular}{|c|c|c|c|c|c|c|c|c|}
\hline \multirow{2}{*}{ Year } & \multicolumn{2}{|c|}{$\begin{array}{l}\text { Total paper and } \\
\text { and board }\end{array}$} & \multicolumn{2}{|c|}{ Paper } & \multicolumn{2}{|c|}{ Paperboard ${ }^{2}$} & \multicolumn{2}{|c|}{ Building board } \\
\hline & Total & $\begin{array}{l}\text { Annual } \\
\text { rate of } \\
\text { change }{ }^{3}\end{array}$ & Total & $\begin{array}{l}\text { Annual } \\
\text { rate of } \\
\text { change }^{3}\end{array}$ & Total & $\begin{array}{l}\text { Annual } \\
\text { rate of } \\
\text { change }{ }^{3}\end{array}$ & Total & $\begin{array}{l}\text { Annual } \\
\text { rate of } \\
\text { change }^{3}\end{array}$ \\
\hline $\begin{array}{l}1920 \ldots \ldots \\
1925 \ldots \ldots \\
1930 \ldots \\
1935 \ldots \\
1940 \ldots\end{array}$ & $\begin{array}{r}\text { Million tons } \\
7.7 \\
10.4 \\
12.3 \\
12.8 \\
16.8\end{array}$ & $\begin{array}{r}\text { Percent } \\
\text { 6. } 2 \\
3.4 \\
.8 \\
5.6\end{array}$ & $\begin{array}{r}\text { Million tons } \\
5.4 \\
7.1 \\
8.4 \\
8.2 \\
10.6\end{array}$ & $\begin{array}{r}\text { Percent } \\
5.6 \\
3.4 \\
-.5 \\
5.3\end{array}$ & $\begin{array}{r}\text { Million tons } \\
2.3 \\
3.2 \\
3.8 \\
4.5 \\
6.0\end{array}$ & $\begin{array}{r}\text { Percent } \\
6.8 \\
3.5 \\
3.4 \\
5.9\end{array}$ & $\begin{array}{r}\text { Millir } n \text { tons } \\
0.1 \\
.1 \\
.1 \\
.2\end{array}$ & $\begin{array}{c}\text { Percent } \\
14.9\end{array}$ \\
\hline $\begin{array}{l}1945 \ldots \\
1950 \\
1955 \\
1960 \\
1965\end{array}$ & $\begin{array}{l}\text { 19. } 8 \\
29.1 \\
35.0 \\
39.3 \\
49.2\end{array}$ & $\begin{array}{l}\text { 3. } 3 \\
\text { 8. } 0 \\
\text { 3. } 8 \\
\text { 2. } 3 \\
\text { 4. } 6\end{array}$ & $\begin{array}{l}\text { 11. } 0 \\
\text { 16. } 8 \\
\text { 19. } 4 \\
22.1 \\
26.8\end{array}$ & $\begin{array}{l}.7 \\
\text { 8. } 8 \\
\text { 2. } 9 \\
2.6 \\
\text { 3. } 9\end{array}$ & $\begin{array}{r}\text { 7. } 9 \\
11.0 \\
13.9 \\
15.4 \\
19.9\end{array}$ & $\begin{array}{l}\text { 5. } 7 \\
\text { 6. } 8 \\
\text { 4. } 8 \\
\text { 2. } 1 \\
\text { 5. } 3\end{array}$ & $\begin{array}{l}.9 \\
\text { 1. } 2 \\
\text { 1. } 7 \\
\text { 1. } 9 \\
\text { 2. } 6\end{array}$ & $\begin{array}{r}35.0 \\
5.9 \\
7.2 \\
2.2 \\
6.5\end{array}$ \\
\hline $\begin{array}{l}1966 \\
1967 \\
1968 \\
1969\end{array}$ & $\begin{array}{l}52.8 \\
52.0 \\
55.8 \\
59.0 \\
58.1\end{array}$ & $\begin{array}{r}7.3 \\
-1.5 \\
7.3 \\
5.7 \\
-1.5\end{array}$ & $\begin{array}{l}28.9 \\
28.8 \\
30.2 \\
31.8 \\
31.7\end{array}$ & $\begin{array}{r}7.8 \\
-.3 \\
4.9 \\
5.3 \\
-.3\end{array}$ & $\begin{array}{l}21.5 \\
20.8 \\
22.8 \\
24.2 \\
23.5\end{array}$ & $\begin{array}{r}8.0 \\
-3.3 \\
9.6 \\
6.1 \\
-2.9\end{array}$ & $\begin{array}{l}\text { 2. } 4 \\
\text { 2. } 4 \\
\text { 2. } 8 \\
\text { 3. } 0 \\
\text { 2. } 8\end{array}$ & $\begin{array}{r}-7.7 \\
-16.7 \\
7.1 \\
-6.7\end{array}$ \\
\hline 1971 & $\begin{array}{l}59.7 \\
64.3\end{array}$ & 2. 8 & $\begin{array}{l}32.4 \\
34.1\end{array}$ & $\begin{array}{l}\text { 2. } 2 \\
\text { 5. } 2\end{array}$ & $\begin{array}{l}23.9 \\
26.4\end{array}$ & $\begin{array}{r}1.7 \\
10.5\end{array}$ & $\begin{array}{l}\text { 3. } 4 \\
\text { 3. } 8\end{array}$ & $\begin{array}{l}21.4 \\
11.8\end{array}$ \\
\hline
\end{tabular}

Low projections

\begin{tabular}{|c|c|c|c|c|c|c|c|}
\hline $\begin{array}{l}1980 \ldots \\
1990 \ldots 0 \\
2000\end{array}$ & $\begin{array}{r}78.2 \\
102.5 \\
130.4\end{array}$ & $\begin{array}{l}2.9 \\
2.7 \\
2.4\end{array}$ & $\begin{array}{l}\text { 41. } 0 \\
52.2 \\
64.4\end{array}$ & $\begin{array}{l}2.5 \\
2.5 \\
2.1\end{array}$ & $\begin{array}{l}33.2 \\
4.5 .1 \\
59.4\end{array}$ & $\begin{array}{l}\text { 3. } 3 \\
\text { 3. } 1 \\
2.8\end{array}$ & $\begin{array}{l}\text { 4. } 0 \\
5.2 \\
6.6\end{array}$ \\
\hline
\end{tabular}

Medium projections

\begin{tabular}{|c|c|c|c|c|c|c|c|c|}
\hline $\begin{array}{l}1980 \ldots \\
1990 \ldots \ldots \\
2000\end{array}$ & $\begin{array}{r}83.1 \\
116.1 \\
156.5\end{array}$ & $\begin{array}{l}\text { 3. } 5 \\
\text { 3. } 4 \\
\text { 3. } 0\end{array}$ & $\begin{array}{l}43.4 \\
59.2 \\
78.0\end{array}$ & $\begin{array}{l}\text { 3. } 1 \\
\text { 3. } 2 \\
\text { 2. } 8\end{array}$ & $\begin{array}{l}3.5 .5 \\
51.1 \\
70.7\end{array}$ & $\begin{array}{l}\text { 4. } 0 \\
\text { 3. } \\
\text { 3. } 3\end{array}$ & $\begin{array}{l}4.2 \\
\text { 5. } 8 \\
\text { 7. } 9\end{array}$ & $\begin{array}{l}\text { 3. } \tilde{3} \\
\text { 3. } 3 \\
\text { 3. } 1\end{array}$ \\
\hline
\end{tabular}

High projections

\begin{tabular}{|c|c|c|c|c|c|c|c|c|}
\hline $\begin{array}{l}1980 \\
1990 \\
2000\end{array}$ & $\begin{array}{r}\text { 89. } 0 \\
\text { 132. } 7 \\
190.2\end{array}$ & $\begin{array}{l}\text { 4. } 2 \\
\text { 4. } 1 \\
\text { 3. } 7\end{array}$ & $\begin{array}{l}46.5 \\
67.6 \\
94.1\end{array}$ & $\begin{array}{l}\text { 3. } 8 \\
\text { 3. } 8 \\
3.4\end{array}$ & $\begin{array}{l}38.0 \\
58.4 \\
86.4\end{array}$ & $\begin{array}{l}\text { 4. } \overline{1} \\
\text { 4. } 4 \\
\text { 4. } 0\end{array}$ & $\begin{array}{l}\text { 4. } \frac{5}{6} \\
6.7 \\
9.7\end{array}$ & $\begin{array}{l}\text { 4. } 2 \\
\text { 4. } 0 \\
\text { 3. } 8\end{array}$ \\
\hline
\end{tabular}

1 Projections based on alternative assumptions about growth in population and economic activity as specified in the introductory section of this chapter.

2 Includes wet machine board.

3 The average annual rate of change for 5 -year periods ending in the specified years except for the years 1965-72 when annual changes are shown.

* Preliminary.

Note: Data may not add to totals because of rounding.

Sources: American Paper Institute. The statistics of paper. (Annual, 1960 ed. and 1972 sup.), and Monthly statistical summary. New York; L.S. Department of Commerce, Bureau of the Census. Pulp, paper and board. Cur. Indus. Reps. Ser. M26A. (annual); L... Department of Commerce, Bureau of Domestic Conmerce. Pulp, paper and board. Quart. Indus. Rep.; and L.S. Department of Agriculture, Forest Service.

Projections: U.S. Department of Agriculture, Forest Service. 
TABLE 143.-Paper and board per capita consumption, selected zears 1920-72, with projections of demand (1970 relative prices) to $2000^{1}$

\begin{tabular}{|c|c|c|c|c|c|c|c|c|}
\hline \multirow{2}{*}{ Year } & \multicolumn{2}{|c|}{$\begin{array}{l}\text { Total paper and } \\
\text { and board }\end{array}$} & \multicolumn{2}{|c|}{ Paper } & \multicolumn{2}{|c|}{ Paperboard ${ }^{2}$} & \multicolumn{2}{|c|}{ Building board } \\
\hline & Total & $\begin{array}{l}\text { Annual } \\
\text { rate of } \\
\text { change }{ }^{3}\end{array}$ & Total & $\begin{array}{l}\text { Annual } \\
\text { rate of } \\
\text { change }{ }^{3}\end{array}$ & Total & $\begin{array}{l}\text { Annual } \\
\text { rate of } \\
\text { change }{ }^{3}\end{array}$ & Total & $\begin{array}{l}\text { Annual } \\
\text { rate of } \\
\text { change }{ }^{3}\end{array}$ \\
\hline 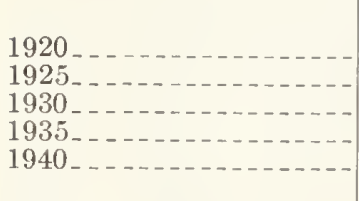 & $\begin{array}{r}\text { Pounds } \\
145 \\
180 \\
201 \\
201 \\
254\end{array}$ & $\begin{array}{r}\text { Percent } \\
4.4 \\
2.2 \\
-4.8\end{array}$ & $\begin{array}{r}\text { Pounds } \\
102 \\
123 \\
137 \\
129 \\
161\end{array}$ & $\begin{array}{r}\text { Percent } \\
-3 . \overline{8} \\
2.2 \\
-1.2 \\
4.5\end{array}$ & $\begin{array}{r}\text { Pounds } \\
43 \\
56 \\
62 \\
71 \\
91\end{array}$ & $\begin{array}{l}\text { Percent } \\
\text { 5. } 4 \\
\text { 2. } 1 \\
\text { 2. } 7 \\
\text { 5. } 1\end{array}$ & $\begin{array}{r}\text { Pounds } \\
-1 \\
2 \\
1 \\
2\end{array}$ & $\begin{array}{r}\text { Pcrcent } \\
-14.9 \\
-12.9 \\
14.9\end{array}$ \\
\hline $\begin{array}{l}1945 \ldots \ldots \\
1950 \ldots \\
1955 \ldots \\
1960 \ldots \\
1965 \ldots \ldots\end{array}$ & $\begin{array}{l}283 \\
382 \\
422 \\
435 \\
507\end{array}$ & $\begin{array}{l}\text { 2. } 2 \\
6.2 \\
2.0 \\
\text { 3. } 6 \\
\text { 3. }\end{array}$ & $\begin{array}{l}157 \\
221 \\
234 \\
244 \\
276\end{array}$ & $\begin{array}{r}-2.4 \\
\text { 7. } 1 \\
\text { 1. } 1 \\
\text {. } 8 \\
\text { 2. } 4\end{array}$ & $\begin{array}{l}113 \\
145 \\
167 \\
170 \\
205\end{array}$ & $\begin{array}{l}\text { 4. } 4 \\
\text { 5. } 1 \\
\text { 2. } 9 \\
\text { 3. } 4\end{array}$ & $\begin{array}{l}13 \\
16 \\
20 \\
21 \\
26\end{array}$ & $\begin{array}{r}45.4 \\
4.2 \\
4.6 \\
1.0 \\
4.4\end{array}$ \\
\hline 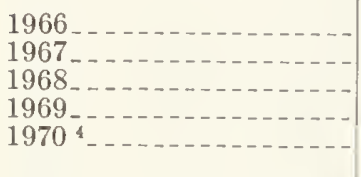 & $\begin{array}{l}537 \\
523 \\
556 \\
582 \\
567\end{array}$ & $\begin{array}{r}5.9 \\
-2.6 \\
6.3 \\
4.7 \\
-2.6\end{array}$ & $\begin{array}{l}294 \\
290 \\
301 \\
314 \\
309\end{array}$ & $\begin{array}{r}6.5 \\
-1.4 \\
3.8 \\
4.3 \\
-1.6\end{array}$ & $\begin{array}{l}219 \\
210 \\
227 \\
239 \\
229\end{array}$ & $\begin{array}{r}6.8 \\
-4.1 \\
8.1 \\
5.3 \\
-4.2\end{array}$ & $\begin{array}{l}24 \\
24 \\
28 \\
30 \\
27\end{array}$ & $\begin{array}{r}-7.7 \\
16.7 \\
7.1 \\
-10.0\end{array}$ \\
\hline $1971^{4} \ldots 72^{4} \ldots$ & $\begin{array}{l}577 \\
616\end{array}$ & $\begin{array}{l}1.8 \\
6.8\end{array}$ & $\begin{array}{l}313 \\
327\end{array}$ & $\begin{array}{l}1.3 \\
4.5\end{array}$ & $\begin{array}{l}231 \\
253\end{array}$ & 9.9 & $\begin{array}{l}33 \\
36\end{array}$ & $\begin{array}{r}22.2 \\
9.1\end{array}$ \\
\hline
\end{tabular}

Low projections

\begin{tabular}{|c|c|c|c|c|c|c|c|c|}
\hline 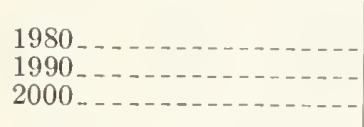 & $\begin{array}{l}692 \\
827 \\
981\end{array}$ & $\begin{array}{l}1.9 \\
1.8 \\
1.7\end{array}$ & $\begin{array}{l}363 \\
421 \\
484\end{array}$ & $\begin{array}{l}\text { 1. } 6 \\
\text { 1. } 5 \\
\text { 1. } 4\end{array}$ & $\begin{array}{l}294 \\
364 \\
447\end{array}$ & $\begin{array}{l}2.3 \\
\text { 2. } 2 \\
\text { 2. } 1\end{array}$ & $\begin{array}{l}35 \\
42 \\
50\end{array}$ & $\begin{array}{l}\text { 1. } 6 \\
\text { 1. } 8 \\
\text { 1. } 8\end{array}$ \\
\hline
\end{tabular}

\begin{tabular}{r|r|r|r|r|r|r|r|r}
\hline 1980 & 729 & 2.4 & 381 & 2.1 & 311 & 2.8 & 37 & 2.1 \\
1990 & 910 & 2.2 & 464 & 2.0 & 401 & 2.6 & 45 & 2.0 \\
2000 & 1,114 & 2.0 & 555 & 1.8 & 503 & 2.3 & 56 & 2.2 \\
\hline
\end{tabular}

High projections

\begin{tabular}{|c|c|c|c|c|c|c|c|c|}
\hline 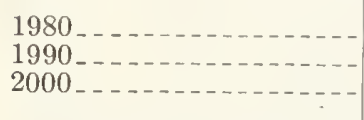 & $\begin{array}{r}768 \\
997 \\
1,263\end{array}$ & $\begin{array}{l}\text { 2. } 9 \\
\text { 2. } 6 \\
\text { 2. } 4\end{array}$ & $\begin{array}{l}401 \\
508 \\
625\end{array}$ & $\begin{array}{l}\text { 2. } 6 \\
\text { 2. } 4 \\
\text { 2. } 1\end{array}$ & $\begin{array}{l}328 \\
439 \\
574\end{array}$ & $\begin{array}{l}\text { 3. } 4 \\
3.0 \\
2.7\end{array}$ & $\begin{array}{l}39 \\
50 \\
64\end{array}$ & $\begin{array}{l}2.7 \\
2.5 \\
2.5\end{array}$ \\
\hline
\end{tabular}

1 Projections based on alternative assumptions about growth in population and economic activity as specified in the introductory section of this chapter.

${ }^{2}$ Includes wet machine board.

${ }^{3}$ The average annual rate of change for 5-year periods ending in the specified years except for the years 1965-72 when annual changes are shown.

${ }^{4}$ Preliminary.

Note: Data may not add to totals because of rounding. Sources: See source note, table 142. 
disposal of nonbiodegradable products, ${ }^{36}$ will tend to limit inroads of competitive materials in most markets for paper and board. This appears especially likely orer the range in which the prices of paper and board can reasonably be expected to increase in the next two or three decades.

While substitution mar be limited in the projection period, it nonetheless seemis likely that the rate of growth in consumption, and especially per capita consumption, will continue to decline as consumption approaches some maximum or saturation level for different products and uses.

Relationships between paper and board consumption and economic variables.- In the past there hare been large differences in rates of growth in consumption of the major grades of paper and board. These hare resulted from the derelopment of new pulp-based products, inroads of substitutes, varring rates of growth in major sectors of the economy, and other factors such as changes in consumer tastes.

In partial recognition of these differences the various types and grades of paper and board hare been grouped into three categories-paper, paperboard, and building board (insulation board and hardboard)-which have a common relationship to one or more of the basic determinants of demand discussed in the introductory section of this chapter (see Append. V, tables 18-20 for historical statistics for these categories). ${ }^{37}$

Because most paper is consumed in one form or another by individuals, with the level of use a function of income, there has been a close statistical relationship between changes in per capita consumption of paper and changes in per

\footnotetext{
${ }^{36}$ For a more complete discussion of the problems associated with the development and use of plastics in place of paper and board see:

Copelman, Serge, and Gur Jacqueline. synthetic paper: Japan leads the way in technological developinent. Pulp and Paper 45(5):111-115.

United Nations Food and Agriculture Organization. Note on substitution by and for paper and paperboard. FO:PAP/DST 71 1.3 of the second Consultation on World Pulp and Paper Demand, Supply and Trade. 1971.

United Vation: Food and Agriculture Organization. Present status of development of sinthetic paper in Japan. FP/PAP DST/1.9 of the second Consultation on World Pulp and Paper Demand, Supply and Trade. 1971.

${ }^{37}$ In previous Forest Service reports presenting estimates of demand for paper and board, as in $L^{\top} s e$ of regression equations for projecling trends in demand for paper and board, Op. cit., separate projections were made for a number of major types of paper and board, such as newsprint, printing papers, packaging papers, container board, etc. Such detailed projections are not presented in this study because of difficulties in developing statistical series as a result of extensive changes made in 1967 in the definitions and classifications of various grades of paper and board, and lack of recent information on the kind. of fibrous material- used in the furnish of different types of paper and board.
}

Relationship between per capita paper consumption and per capita disposable personal income, 1929-70

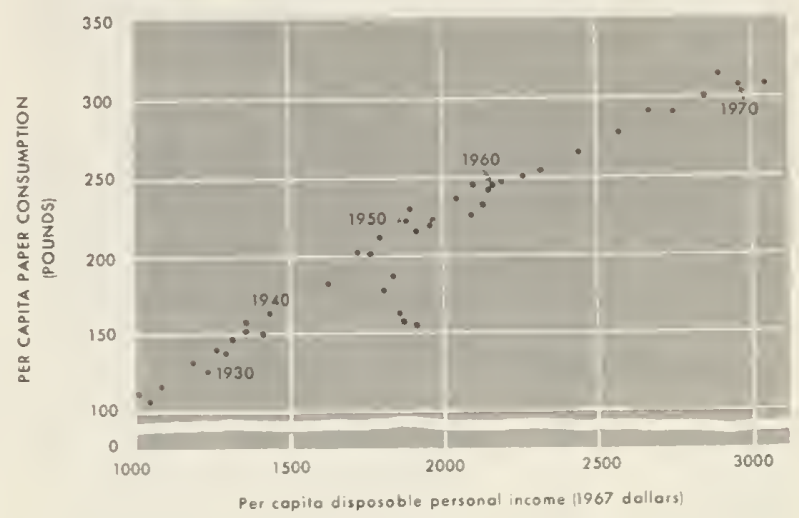

Relationship between per capita paper board consumption and per capita gross national product, $1920-70$

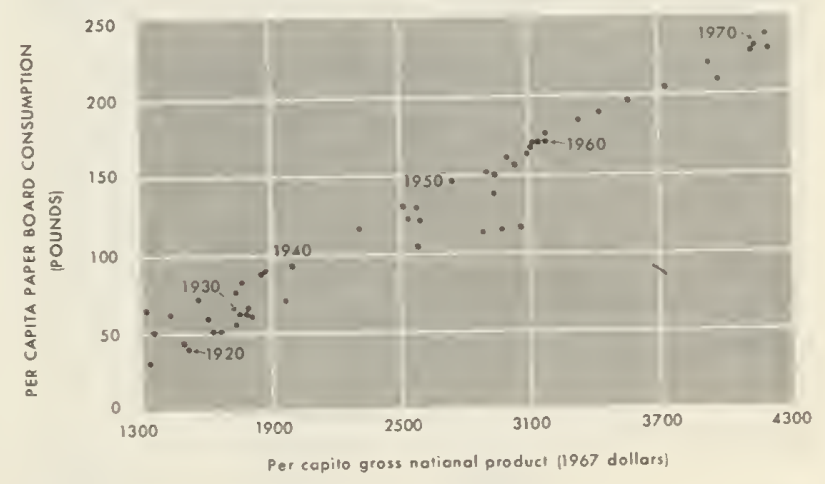

Figure 72

capita disposable personal income ${ }^{38}$ (fig. 72). In the case of paperboard, which is used primarily for packaging industrial and agricultural commodities, per capita consumption has shown a cloce relationship to changes in the per capita gross national product. Most of the growth in the consumption of building board (insulation board and hardboard), which is used in construction for such purposes as sheathing and underlavment and in manufacturing, has been associated with changes in these sectors of the eronomy.

Projected demands for paper and board.-On the basis of past relationships and trends in use, total demand for paper and board at 1970

${ }^{38}$ The choice of independent variable, base time period, units of measurement, form of equation, and kind of equation used in this analysis for projecting demand: for paper and paperboard were based on guides developed in the study Use of regression equations for projecting trends in demand for paper and board, Op. cit. 
relative prices is projected to rise to 83 million tons (medium level) in 1980, and to 157 million tons in 2000 -some 2.7 times consumption in 1970 (table 142, fig. 71). Projections of per capita demand also rise rapidly, reaching 729 pounds in 1980 and 1,114 pounds in 2000 (table 143, fig. 71).

As indicated in the following tabulation, the medium projections of demand for paper and board in 1980 are close to projections shown in a preceding Forest Service study ${ }^{39}$ and to those developed by Slatin of the American Paper Institute ${ }^{40}$ and the Midwest Research Institute. ${ }^{41}$

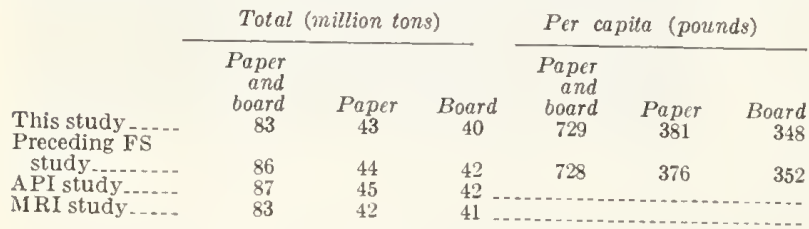

Annual rates of growth in both total and per capita demands for paper and board show substantial declines over the projection period. That for per capita demand, for example, falls from an average of 2.4 percent in the 1960 's to 2.0 percent in the 1990's.

Effects of the alternative assumptions on growth in population and gross national product are substantial, with projected total demand for paper and board ranging from 130 million tons to 190 million tous in 2000 (table 143 ). These projections would, of course, be somewhat lower with higher prices, as indicated in the tabulation below showing the medium projections of demand under alternative price assumptions.

Projections-1970 relative prices

\begin{tabular}{lccr}
\hline Year & $\begin{array}{c}\text { Total } \\
\text { (million }\end{array}$ & $\begin{array}{c}\text { Paper } \\
\text { (million } \\
\text { tons) }\end{array}$ & $\begin{array}{r}\text { Board } \\
\text { (million } \\
\text { tons) }\end{array}$ \\
$1980 \ldots \ldots$ & 83.1 & 43.4 & 39.7 \\
$1990 \ldots \ldots$ & 116.1 & 59.2 & 56.9 \\
$2000 \ldots \ldots$ & 156.6 & 78.0 & 78.6
\end{tabular}

Projections-relative prices rising 0.5 percent per year

$\begin{array}{lrrr}1980 \ldots \ldots & 82.6 & 43.1 & 39.5 \\ 1990 \ldots- & 114.3 & 58.3 & 56.0 \\ 2000 \ldots- & 152.5 & 76.0 & 76.5\end{array}$

Projections-relative prices 10 percent above 1970 average

$\begin{array}{lrrr}1980 \ldots \ldots & 81.4 & 42.5 & 38.9 \\ 1990 \ldots- & 113.8 & 58.0 & 55.8 \\ 2000 \ldots \ldots & 153.5 & 76.5 & 77.0\end{array}$

With inelastic demand, as assumed in the introductory section, projections would be lowered

${ }^{39}$ U.S. Department of Agriculture, Forest Service. Uise of regession equations for projecting trends in demand for paper and board. Op. cit.

${ }^{40}$ Slatin, Benjamin. Timber requirements of the paper industry in the seventies and eighties. American Paper Institute. New York. 1971.

${ }^{41}$ Midwest Research Institute. Paper recycling the art of the possible 1970-1985. Kansas City. 1973. appreciably only with very large increases in relative prices.

Exports of paper and board.-Exports of paper and board have been small in relation to U.S. consumption, but have risen rapidly in recent years to a 1972 total of 3 million tons (table 144;

TABLE 144.-Paper and board consumption, exports, imports, and domestic production, selected years 1920-72, with projections ${ }^{1}$ (1970 relative prices)

[Million tons]

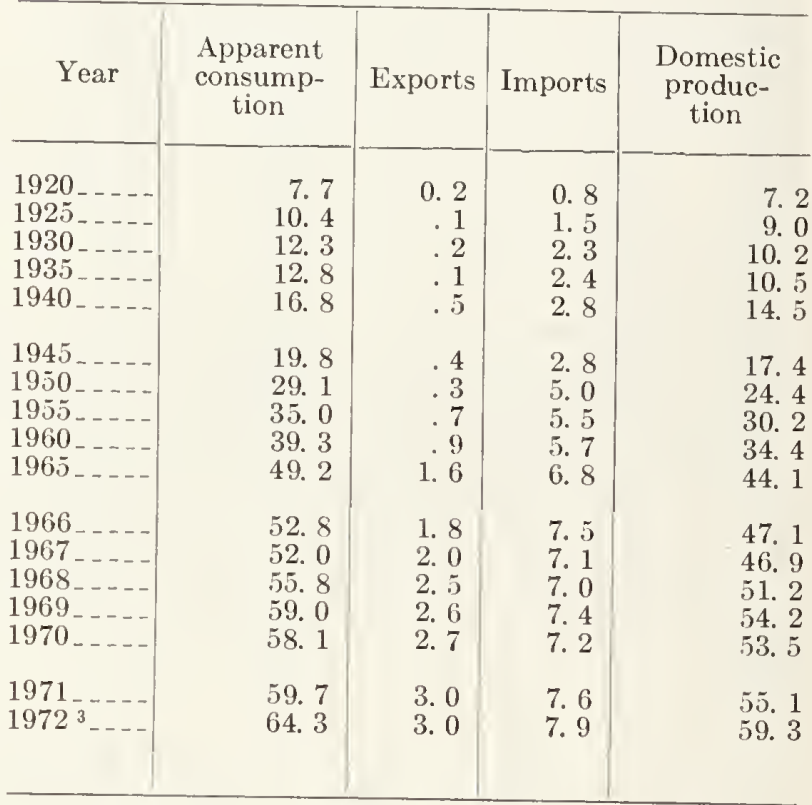

\begin{tabular}{|c|c|c|c|c|}
\hline \multicolumn{5}{|c|}{ Low projections } \\
\hline Year & $\begin{array}{l}\text { Domestic } \\
\text { demand }\end{array}$ & Exports & Imports & $\begin{array}{l}\text { Demand on } \\
\text { U.S. mills }\end{array}$ \\
\hline $\begin{array}{l}1980 \ldots \\
1990 \\
2000\end{array}$ & $\begin{array}{r}78.2 \\
102.5 \\
130.4\end{array}$ & $\begin{array}{l}3.5 \\
3.5 \\
3.5\end{array}$ & $\begin{array}{l}8.0 \\
8.0 \\
8.0\end{array}$ & $\begin{array}{r}\text { 73. } 7 \\
98.0 \\
125.9\end{array}$ \\
\hline \multicolumn{5}{|c|}{ Medium projections } \\
\hline $\begin{array}{l}1980 \ldots \\
1990 \ldots \\
2000 \ldots\end{array}$ & $\begin{array}{r}83.1 \\
116.1 \\
156.6\end{array}$ & $\begin{array}{l}3.5 \\
3.5 \\
3.5\end{array}$ & $\begin{array}{l}8.0 \\
8.0 \\
8.0\end{array}$ & $\begin{array}{r}78.6 \\
111.6 \\
152.1\end{array}$ \\
\hline
\end{tabular}

\begin{tabular}{|c|c|c|c|c|}
\hline \multicolumn{5}{|c|}{ High projections } \\
\hline $\begin{array}{l}1980_{\ldots} \ldots- \\
1990_{\ldots} \ldots- \\
2000_{\ldots}\end{array}$ & $\begin{array}{r}89.0 \\
132.7 \\
190.2\end{array}$ & $\begin{array}{l}3.5 \\
3.5 \\
3.5\end{array}$ & $\begin{array}{l}8.0 \\
8.0 \\
8.0\end{array}$ & $\begin{array}{r}84.5 \\
128.2 \\
185.7\end{array}$ \\
\hline
\end{tabular}

I Projections based on alternativc assumptions about growth in population and economic activity as specified in the introductory section of this chapter.

2 Data may not add to totals because of rounding.

3 Preliminary.

Sources: See source note, table 142. 
Append. T. tables 17-20). Exports of nearly all grades of paper and board have shown some increase, but kraft linerboard has accounted for br far the largest part of the recent growth.

Exports of paper and board hare moved to all regions of the world (Append. $V$, table 21). Howerer, in 1971 about 44 percent of the total went to Western Europe and another 23 percent to Latin America. Nearly all of the remainder was shipped to Japan, Canada, and Africa. Most of the growth in exports in the 1960's was to Western Europe and Latin America.

A recent study by the Food and Agriculture Organization of the United Nations indicates that world demands for paper and board are likely to continue to grow rapidly, as indicated in the tabulation below: ${ }^{42}$

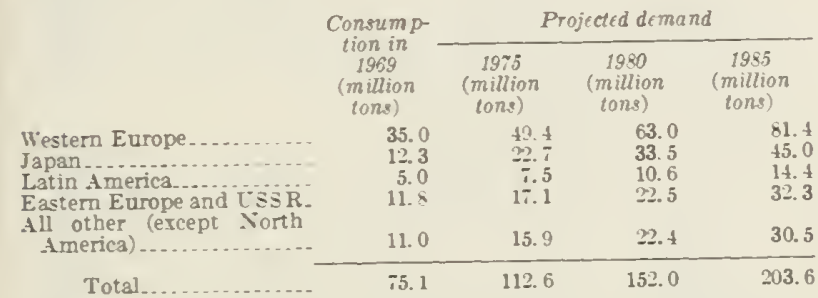

This, and other similar studies, conclude that forest resources in western Europe and Japan are not large enough to supply prospective demands for timber products. ${ }^{+3}$ (For a more detailed discussion of the timber demand and supply situation in western Europe and Japan see Chapter IV.) This means that more and more of the rapidly growing demands for paper and board in these countries must be supplied from timber resources in other parts of the world.

In view of the prospective demand and resource situation in the major importing areas it appears likely that export demands for paper and board produced in the United States will continue to increase in the rears immediately ahead. However, the United States is faced with a tightening timber supply situation (see Chapter VI) and consequently exports have been assumed to level off at 3.5 million tons a year.

Developments in other parts of the world could also change the outlook. For example, it may be technically and economically feasible to use increasing quantities of pulp made from tropical hardwoods, fast growing plantation

12 United Nations Food and Agriculture Organization. Outlook for pulp and paper consumption, production, and trade to 198.5. Second Consultation on World Pulp and Paper Demand Supply and Trade. Rome. 1971.

${ }_{43}$ United Nations Food and Agriculture Organization and United Nations Economic Commission for Europe. European timber trends and prospects, 1950-1980 and interim review. Geneva. 1966.

United Nations Food and Agriculture Organization. Wood-world trends and prospects. Rome. 1967.

Japan Lumber Journal, Inc. Japan Lumber Journal. Tokyo. Biweekly. species, or nonwood fibers. These sources of fiber could support large increases in pulp production in Latin America, Africa, and the Far East, and expanded paper and board production in western Europe and Japan. Also derelopment of the enormous softwood resources in the USSR could add to world supplies of market pulp.

Imports of paper and board.-U.S. imports of paper and board have been substantially larger than exports and have increased fairly steadily to a level of 7.9 million tons in 1972 (table 144; Append. $\mathrm{V}$, tables $17-20$ )

Newsprint has composed 70 percent or more of the imports since before 1920 . However, in recent vears some other grades, especially building board, have increased in relative importance. Canada provided about 95 percent of the imports of newsprint in 1971 and most other grades as well (Append. V, table 22).

Although imports have increased somewhat in the last few years, it appears unlikely that Canada could significantly increase recent levels of shipments to the United States unless prices rise enough to cover the higher costs of utilizing timber in the undereloped northern parts of the Canadian prorinces (see discussion Chapter IV). Thus, it was assumed that at 1970 relatire prices imports of paper and board would remain at about the 1972 level. With higher prices Canada could provide much larger volumes of paper and board, with actual imports depending in part on U.S. demand.

In the $1947-70$ period there was a close statistical relationship between paper and board imports and domestic consumption. Projections (medium level) based on this relationship, and the rising price assumption, rise to 13.5 million tons by 2000 - some 5.6 million tons above the 1972 volume as shown in the following tabulation.

\begin{tabular}{ccccc}
\multicolumn{5}{c}{ Projections -1970 relative prices } \\
\hline Year & $\begin{array}{c}\text { Total demand } \\
\text { (million } \\
\text { tons) }\end{array}$ & $\begin{array}{c}\text { Exports } \\
\text { (million } \\
\text { tons) }\end{array}$ & $\begin{array}{c}\text { Imports } \\
\text { (million } \\
\text { tons) }\end{array}$ & $\begin{array}{c}\text { Demand on U.S. } \\
\text { mills } \\
\text { (million tons) }\end{array}$ \\
$1980 \ldots \ldots$ & 83.1 & 3.5 & 8.0 & 78.6 \\
$1990 \ldots$ & 116.1 & 3.5 & 8.0 & 111.6 \\
$2000 \ldots$ & 156.6 & 3.5 & 8.0 & 152.1
\end{tabular}

Projections-relative prices rising 0.5 percent per year

\begin{tabular}{rrrrr}
$1980 \ldots \ldots$ & 82.6 & 3.5 & 10.5 & 75.6 \\
$1990 \ldots \ldots$ & 114.3 & 3.5 & 12.5 & 105.3 \\
$2000 \ldots \ldots$ & 152.5 & 3.5 & 13.5 & 142.5 \\
\multicolumn{7}{r}{ Projertions_relative prices } & 10 percent above 1970 average \\
$1980 \ldots \ldots$ & 81.4 & 3.5 & 10.5 & 74.4 \\
$1990 \ldots \ldots$ & 113.8 & 3.5 & 11.5 & 105.8 \\
$2000 \ldots \ldots$ & 153.5 & 3.5 & 12.0 & 145.0
\end{tabular}

Demand on U.S. mills for paper and board.Production of paper and board in U.S. mills has increased rapidly in recent decades to 59.3 million tons in 1972 (table 144). Meeting projected domestic and export demands at 1970 prices after allow- 
ances for imports, would require an increase in domestic production (demand on U.S. mills) to about 79 million tons by 1980 (medium projection), and to about 152 million toins in 2000 .

Annual growth rates for domestic production of paper and board averaged about 4.4 percent in the 1960 's. Projected increases in demand on U.S. mills (medium level-1970 relative prices) average only 3.9 percent anmually in the 1970's, and 3.1 percent in the 1990's.

Despite the drop in rates of growth, projected increases in demand on U.S. mills would require a very large expansion of the domestic paper and board industry in the next three decades. In the 1980 's the medium projection of demands, with rising relative prices, increases by about 3.0 million tons a year, with further growth to over 3.7 million tons annually in the 1990's. In the 1960's production increased about 1.9 million tons a year.

Under the alternative and higher price assumptions, demand on U.S. mills would be lowered somewhat (see tabulation above) because of a reduction in total demand and an increase in imports. Demands on U.S. mills would still involve a much larger expansion of the U.S. industry than anything experienced in the past.

\section{Demand for Fibrous Material for Paper and Board Manufacture}

The manufacture of 59.3 million tons of paper and board in the United States in 1972 required some 58.8 million tons of fibrous material, including some 46.6 million tons of woodpulp, 11.3 million tons of wastepaper, and 0.9 million tons of cotton, bagasse, and other fibers (table 145; fig. 73; Append. V, table 23). The trend in consumption of all fibrous material has closely paralleled the trend in paper and board production, more than doubling since 1950 and increasing about 9 times since 1919 .

In contrast to this upward trend, average use of fibrous materials per ton of paper and board produced has been nearly constant in recent decades-varying between 0.992 and 1.092 tons since the late 1920's (table 145, fig. 73; Append. $\mathrm{V}$, table 23). It was assumed that averagc use would remain at a level of 1.03 tons through the projection period. ${ }^{44}$

Although there has not been much change in the use of fibrous materials per ton of production, there have been large changes in the mix of fibers consumed. In the last two decades, for example, new woodpulp has risen from roughly 64 percent of the total fibrous materials used to around 80 percent of the total. Use of wastepaper, on the other hand, declined from 31 percent of the total fibers used in 1950 to around 19 percent in 1972. Use of other fibers dropped from about 5 percent to less than 2 percent.

The sharp upward trend in use of new woodpulp, and the concomitant decline in the proportion of wastepaper used, reflect many technical and economic factors. For example, use of new woodpulp results in relatively stronger and lightweight paper and board products. New woodpulps are relatively free of biological and other contaminants. Integration of the inclustry with production of both pulp and paper concentrated in large complexes designed to fully utilize the timber harvested has tended to favor production of viroin pulps over wastepaper reuse. Use of recycled

${ }^{44}$ The assumed increase in the use of wastepaper per ton of paper and board produced diseussed below would tend to raise this average. However, it was assumed that this would be offset by increasing use of nonfiber additives and improvements in technology.

\section{Fibrous materials consumed in the manufacture of paper and board, 1920-71, with projections to 2000}
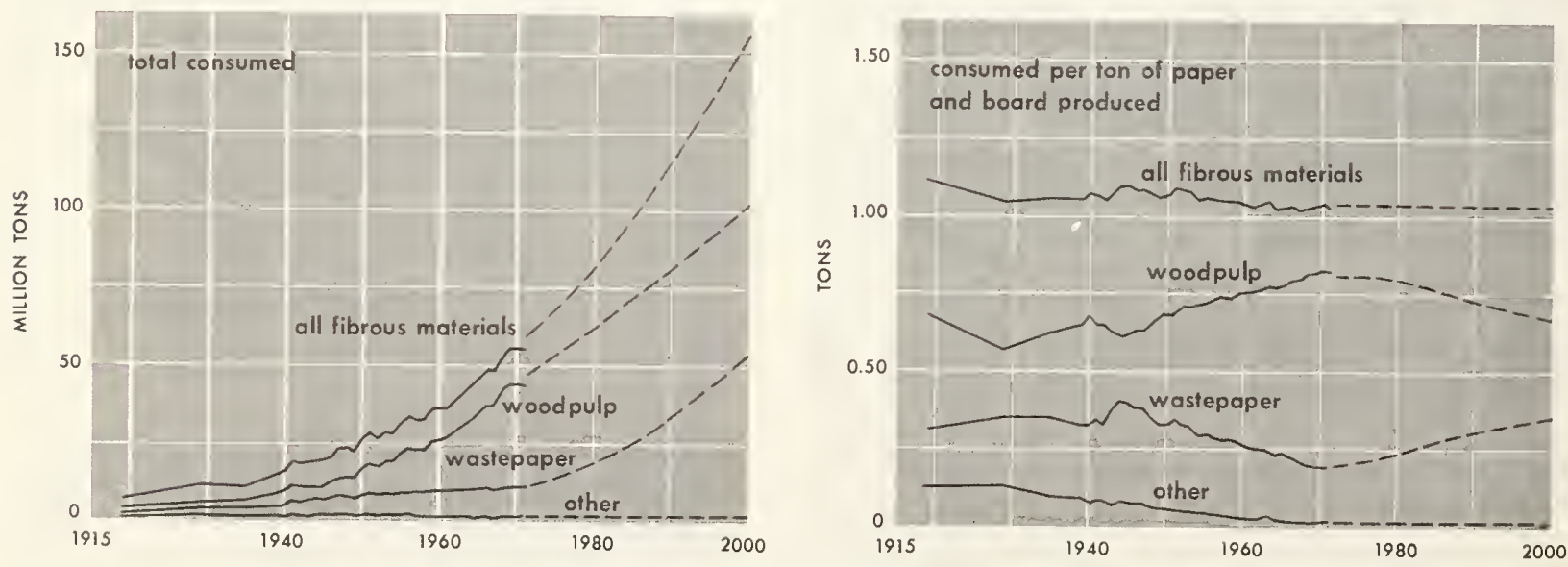

Figure 73 
TABLE 145. Fibrous materials consumed in the manufacture of paper and board 1919-72, with projections (1970 relative prices) to $2000^{1}$

\begin{tabular}{|c|c|c|c|c|c|c|c|c|}
\hline \multirow{2}{*}{ Year } & \multicolumn{4}{|c|}{ Consumption of fibrous materials } & \multicolumn{4}{|c|}{$\begin{array}{l}\text { Consumption of fibrous materials per } \\
\text { ton of paper and board produced }\end{array}$} \\
\hline & Total & $\begin{array}{l}\text { Wood- } \\
\text { pulp }\end{array}$ & $\begin{array}{l}\text { Waste- } \\
\text { paper }\end{array}$ & Other & Total & $\begin{array}{l}\text { Wood- } \\
\text { pulp }\end{array}$ & $\begin{array}{l}\text { Waste- } \\
\text { paper }\end{array}$ & Other \\
\hline 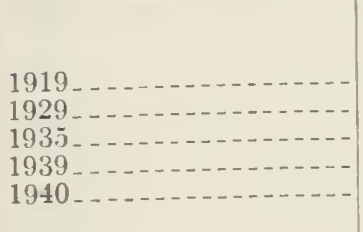 & $\begin{array}{r}\begin{array}{c}\text { Million } \\
\text { tons }\end{array} \\
6.6 \\
11.6 \\
11.0 \\
14.2 \\
15.5\end{array}$ & $\begin{array}{l}\begin{array}{l}\text { Million } \\
\text { lons }\end{array} \\
4.0 \\
6.3 \\
6.4 \\
8.7 \\
9.8\end{array}$ & $\begin{array}{r}\text { Millian } \\
\text { lons } \\
1.9 \\
3.8 \\
3.6 \\
4.4 \\
4.7\end{array}$ & $\begin{array}{l}\begin{array}{l}\text { Million } \\
\text { tons }\end{array} \\
0.7 \\
\text { 1. } 4 \\
\text { 1. } 0 \\
1.2 \\
1.0\end{array}$ & $\begin{array}{l}\text { Tons } \\
\text { 1. } 110 \\
1.039 \\
1.050 \\
1.049 \\
1.070\end{array}$ & $\begin{array}{l}\text { Tons } \\
\qquad \begin{array}{r}0.674 \\
.565 \\
.615 \\
.640 \\
.675\end{array}\end{array}$ & $\begin{array}{l}\text { Tons } \\
\begin{array}{r}0.311 \\
.345 \\
.342 \\
.323 \\
.322\end{array}\end{array}$ & $\begin{array}{r}\text { Tons } \\
\text { 0. } 125 \\
.129 \\
.092 \\
.086 \\
.072\end{array}$ \\
\hline $\begin{array}{l}1945 \ldots \\
1950 \ldots 5 \\
1950 \ldots 0 \\
1960 \ldots 5\end{array}$ & $\begin{array}{l}\text { 19. } 0 \\
25.9 \\
31.8 \\
35.7 \\
45.1\end{array}$ & $\begin{array}{l}10.8 \\
16.5 \\
21.5 \\
25.7 \\
34.0\end{array}$ & $\begin{array}{r}6.8 \\
8.0 \\
9.0 \\
9.0 \\
10.2\end{array}$ & $\begin{array}{r}1.3 \\
1.4 \\
1.3 \\
1.0 \\
.9\end{array}$ & $\begin{array}{l}\text { 1. } 092 \\
\text { 1. } 062 \\
\text { 1. } 056 \\
\text { 1. } 036 \\
\text { 1. } 024\end{array}$ & $\begin{array}{l}.623 \\
.677 \\
.711 \\
.746 \\
.772\end{array}$ & $\begin{array}{l}.391 \\
.326 \\
.300 \\
.262 \\
.232\end{array}$ & $\begin{array}{l}.077 \\
.059 \\
.045 \\
.028 \\
.020\end{array}$ \\
\hline $\begin{array}{l}1966 \ldots 6 \\
1967 \\
1968 \\
1969 \\
1970^{2} \ldots \ldots\end{array}$ & $\begin{array}{l}48.5 \\
47.7 \\
52.4 \\
55.5 \\
54.6\end{array}$ & $\begin{array}{l}\text { 36. } 9 \\
37.0 \\
41.3 \\
43.7 \\
43.2\end{array}$ & $\begin{array}{r}10.6 \\
9.9 \\
10.2 \\
10.9 \\
10.6\end{array}$ & $\begin{array}{r}1.0 \\
.8 \\
.9 \\
.9 \\
.8\end{array}$ & $\begin{array}{l}\text { 1. } 029 \\
\text { 1. } 017 \\
\text { 1. } 023 \\
\text { 1. } 024 \\
\text { 1. } 021\end{array}$ & $\begin{array}{l}.784 \\
.788 \\
.806 \\
.806 \\
.807\end{array}$ & $\begin{array}{l}.224 \\
.211 \\
.199 \\
.202 \\
.198\end{array}$ & $\begin{array}{l}.021 \\
.018 \\
.018 \\
.016 \\
.015\end{array}$ \\
\hline $1971^{2} \ldots$ & $\begin{array}{l}56.0 \\
58.8\end{array}$ & $\begin{array}{l}44.2 \\
46.6\end{array}$ & $\begin{array}{l}\text { 11. } 0 \\
\text { 11. } 3\end{array}$ & $\begin{array}{l}9 \\
9\end{array}$ & $\begin{array}{r}1.017 \\
.991\end{array}$ & $\begin{array}{l}.802 \\
.786\end{array}$ & $\begin{array}{l}.200 \\
.190\end{array}$ & $\begin{array}{l}.016 \\
.015\end{array}$ \\
\hline
\end{tabular}

Low projections

\begin{tabular}{|c|c|c|c|c|c|c|c|c|}
\hline \multirow[t]{2}{*}{ Year } & \multicolumn{4}{|c|}{$\begin{array}{l}\text { Demand for fibrous materials } \\
\text { by L.S. mills }\end{array}$} & \multicolumn{4}{|c|}{$\begin{array}{l}\text { Consumption of fibrous materials per } \\
\text { ton of paper and board produced }\end{array}$} \\
\hline & $\begin{array}{r}75.9 \\
101.0 \\
129.7\end{array}$ & $\begin{array}{l}58.2 \\
70.6 \\
84.3\end{array}$ & $\begin{array}{l}17.0 \\
29.4 \\
44.1\end{array}$ & $\begin{array}{r}.7 \\
\text { 1. } 0 \\
\text { 1. } 3\end{array}$ & $\begin{array}{l}\text { 1. } 030 \\
\text { 1. } 030 \\
1.030\end{array}$ & $\begin{array}{r}0.790 \\
.720 \\
.670\end{array}$ & $\begin{array}{r}0.230 \\
.300 \\
.350\end{array}$ & $\begin{array}{r}0.010 \\
.010 \\
.010\end{array}$ \\
\hline
\end{tabular}

Medium projections

\begin{tabular}{|c|c|c|c|c|c|c|c|c|}
\hline $\begin{array}{l}1980 \\
1990 \\
2000\end{array}$ & $\begin{array}{r}81.0 \\
115.0 \\
156.6\end{array}$ & $\begin{array}{r}62.1 \\
80.4 \\
101.9\end{array}$ & $\begin{array}{l}18.1 \\
33.5 \\
53.2\end{array}$ & $\begin{array}{l}.8 \\
1.1 \\
1.5\end{array}$ & $\begin{array}{l}\text { 1. } 030 \\
\text { 1. } 030 \\
\text { 1. } 030\end{array}$ & $\begin{array}{l}790 \\
720 \\
670\end{array}$ & $\begin{array}{l}.230 \\
.300 \\
.350\end{array}$ & $\begin{array}{l}.010 \\
.010 \\
.010\end{array}$ \\
\hline
\end{tabular}

High projections

\begin{tabular}{|c|c|c|c|c|c|c|c|c|}
\hline $\begin{array}{l}1980 \\
1990 \\
2000\end{array}$ & $\begin{array}{r}87.0 \\
132.1 \\
191.3\end{array}$ & $\begin{array}{r}66.8 \\
92.3 \\
124.4\end{array}$ & $\begin{array}{l}\text { 19. } 4 \\
38.5 \\
65.0\end{array}$ & $\begin{array}{l}.8 \\
1.3 \\
1.9\end{array}$ & $\begin{array}{l}\text { 1. } 030 \\
\text { 1. } 030 \\
1.030\end{array}$ & $\begin{array}{l}790 \\
.720 \\
.670\end{array}$ & $\begin{array}{l}230 \\
300 \\
350\end{array}$ & $\begin{array}{l}.010 \\
.010 \\
.010\end{array}$ \\
\hline
\end{tabular}

${ }^{1}$ Data may not add to totals beeause of rounding.

2 Preliminary.

Sourees: American Paper Institute. Wood pulp statis-

lics. New York. 1972. (annual); U.S. Department of
Commeree, Bureau of the Census. Pulp, paper and board. Cur. Indus. Reps. Ser. M26A. (annual); and U.S. Department of Agrieulture, Forest Serviee. 
fibers also has been inhibited by high costs of collecting, sorting, cleaning, and transporting wastepaper.

Projected use of wastepaper.-New forces are developing, however, that appear likely to change the relative importance of new and recycled pulps. ${ }^{45}$ Increasing concern over pollution of the environment, and the growing costs and difficulties of solid waste disposal, have stimulated much interest and action by Government and industry to increase recycling.

For example, Federal and other agencies have modified purchase specifications to require minimum proportions of recycled fibers in some paper and board purchases. Research also is being stepped up to identify ways of increasing reuse of wastepaper. Various other forms of assistance or regulation are being considered.

Although these things are underway announced expansion plans of the pulp and paper industry indicate that during the early 1970 's use of wastepaper as a proportion of total fibrous materials used is not likely to increase appreciably. In the longer run, however, factors favoring greater recycling such as mentioned above, together with increasing competition for arailable timber, point to the likelihood of substantial growth in recycling of wastepaper.

Use of recycled fibers per ton of paper and board produced has therefore been assumed to rise from 0.19 ton in 1972 to 0.23 ton by $1980{ }^{46}$ and to 0.35 ton by 2000 (table 145 , fig. 73 ). The latter level is close to rates currently achiered in such countries as Japan and the Netherlands, and to use achieved for a time in the United States during World War II. Conversely, projected use of new woodpulp drops from 0.81 ton in 1970 to 0.67 ton in 2000. Estimated use of other fibrous materials remains unchanged at about 1 percent of the total.

\section{See for example:}

American Paper Institute. 1970 a test of stamina. New York. 1971.

Joseph E. Atchison Consultants, Inc. Report on a preliminary study of waste paper and prospects for its increased recycling. New York. 1970.

Midwest Research Institute. Paper recycling, the art of the possible 1970-1985. Kansas City. 1973.

Perry, Henry J. The economics of waste paper use: Part I. Pulp and Paper 45(4):83-84; and The economics of waste paper reuse: Part II. Pulp and Paper 45(5):82-84.

Tuchman, Samson G. The economics of the wastc paper industry. Ph.D. dissertation. Dept. of Economics, New York Úniv. New York. 1963.

U.S. Department of Commerce, Bureau of Domestic Commerce. Pulp, paper and board. Industry Reps. XXVI (3). Quarterly. 1970.

Williams, Ward C. CCA makes corrugating medium at $1,100 \mathrm{ft} . / \mathrm{min}$. from $100 \%$ waste paper. Pulp and Paper 44(12):112-116; and Use it/reuse it! political, economic prcssures brighten future for waste. $44(10): 61-65$.

${ }_{48}$ The Midwest Research Institute in its report "Paper recycling the art of the possible," op. cit., estimated that the recycling rate would rise to 24 percent by 1990.
'Total demands for wastepaper given the above rates would rise from about 11 million tons in 1970 to 18 million tons by 1980 and to 53 million tons by 2000 . Such projected reuse in 2000 would probably be close to a practical maximum considering availability and cost factors. Part of the paper and board consumed for such purposes as books and records is not available for recycling. Other parts are scattered or in locations remote from recycling plants, so badly contaminated as to prohibit reuse, or destroyed by the first use.

Projected demand for woodpulp for paper and board.- Under the above assumptions on future fiber mix, the medium projection of demand for woodpulp for production of paper and board in the United States at 1970 relative prices rises from 46.6 million tons in 1972 to 62.1 million tons by 1980 , and to 101.9 million tons by 2000. 'This would require an average annual increase in woodpulp consumption of 1.9 million tons in the 1970 's and 2.2 million tons in the 1990's.

As in the case of paper and board, rates of increase in projected demand for woodpulp for the domestic manufacture of paper and board calculated from trend values fall rather sharply over the projection period, from 5.4 percent per year in the $1950-70$ period to 3.1 percent in the 1970 's and to 2.4 percent in the 1990's

Demand for woodpulp in nonpaper products.In addition to pulp used in the manufacture of paper and board, about 1.3 million tons of woodpulp was used in 1972 for products such as rayon, cellulose acetate, and plastics. This was below the peak of 1.5 million tons attained in 1969 , but some 4.6 times consumption in 1940 (table 146). Per capita use has also increased substantially since 1940 .

Since the late 1940's there has been a fairly close statistical relationship between changes in the consumption of woodpulp in the manufacture of nonpaper products and changes in gross national product. Primarily on the basis of this relationship, demand (medium level) was projected to grow to 2.2 million tons in 1980 , with a further increase to 4.4 million tons in 2000. Arerage annual rates of growth drop from 4.2 percent in the 1960 's to 3.9 percent in the 1970 's and 3.5 percent in the 1990's.

Total projected U.S. demand for woodpulp.Apparent consumption of woodpulp in the manufacture of both paper and board and nonpaper products in the United States totaled 47.8 million tons in 1972 (table 147 ; Append. V, table 24). The medium projection of demand at 1970 prices reaches 106.3 million tons by $2000-$ a 2.4 -fold increase over 1970. Ammual rates of growth in woodpulp demand decline from an average of 5.5 percent in the 1960 's to 4.0 percent in the 1970 's, and 2.4 percent in the 1990 's.

Exports of woodpulp.-In addition to domestic demand, a significant export market for woodpulp 
TABLE 146.- - II oodpulp consumed in the manufacture of nonpaper products, selected years 1940-72, with projections of demand (1970 relative prices) to $2000^{1}$

\begin{tabular}{|c|c|c|}
\hline Year & Total & Per capita \\
\hline $\begin{array}{l}1940 \ldots \\
1945 \ldots \\
1950 \\
1950 \\
1960 \\
1965\end{array}$ & $\begin{array}{l}\text { Thousand tons } \\
\qquad \begin{array}{r}278 \\
527 \\
703 \\
829 \\
1,025 \\
1,310\end{array}\end{array}$ & $\begin{array}{r}\text { Pounds } \\
\\
4 \\
8 \\
9 \\
10 \\
11 \\
14\end{array}$ \\
\hline $\begin{array}{l}1966 \ldots \\
1967 \ldots \\
1968 \ldots \\
1969\end{array}$ & $\begin{array}{l}1,370 \\
1,201 \\
1,441 \\
1,518 \\
1,238\end{array}$ & $\begin{array}{l}14 \\
12 \\
14 \\
15 \\
12\end{array}$ \\
\hline $\begin{array}{l}1971^{2}{ }^{2} \ldots \ldots \\
1972^{2} \ldots \ldots\end{array}$ & $\begin{array}{l}1,234 \\
1,290\end{array}$ & $\begin{array}{l}12 \\
12\end{array}$ \\
\hline
\end{tabular}

Low projections

\begin{tabular}{l|l|l}
\hline $1980 \ldots \ldots$ & 2,000 & 18 \\
$1990 \ldots \ldots+\ldots$ & 2,800 & 23 \\
$2000 \ldots \ldots+\ldots$ & 3,700 & 28 \\
\hline
\end{tabular}

Medium projections

\begin{tabular}{l|l|l}
\hline $1980 \ldots$ & 2,200 & 19 \\
1990 & 3,100 & 24 \\
2000 & 4,400 & 31 \\
\hline
\end{tabular}

High projections

\begin{tabular}{l|l|l}
\hline $1980 \ldots$ & 2,300 & 20 \\
$1990 \ldots$ & 3,500 & 26 \\
$2000 \ldots \ldots+\cdots$ & 5,200 & 35
\end{tabular}

${ }^{1}$ Projections based on alternative assumptions about growth in population and economic activity as specified in the introductory section of this chapter.

2 Preliminary.

Source: American Paper Institute. Wood pulp statistics. New York. 1972. (Annual).

has developed in recent rears. Between 1950 and 1970 , for example, woodpulp exports rose from 0.1 million to 3.1 million tons, but subsequently declined to 2.3 million tons in 1972 (table $14 \bar{i}$; Append. $T$, table 24). Most of the growth in exports in the 1960's was in sulphate pulp and dissolving and special alpha pulps.

Although woodpulp is shipped to all parts of the world, most exports go to western Europe, the Far East, and Latin America (Append. I, table 25). The increase in shipments to western Europe has been especially rapid, rising from 31,000 tolls in 1950 to 1.1 million in 1971. In the same period shipments to the Far East-chiefly to Japan, Korea, and India-rose from 6,000 tons
TABLE 147.-Woodpulp consumption, exports, imports, and domestic production, selected years 1920-72, with projections ${ }^{1}$ (1970 relative prices) to $2000^{2}$

[Million tons]

\begin{tabular}{|c|c|c|c|c|}
\hline Year & $\begin{array}{c}\text { Apparent } \\
\text { consumption }\end{array}$ & Exports & Imports & $\begin{array}{l}\text { Domestic } \\
\text { production }\end{array}$ \\
\hline $\begin{array}{l}1920-- \\
1925- \\
1930-- \\
1935-- \\
1940-\ldots\end{array}$ & $\begin{array}{l}4.7 \\
5.6 \\
6.4 \\
6.7 \\
9.7\end{array}$ & $\begin{array}{l}\left({ }^{3}\right) \\
\left({ }^{3}\right) \\
\left({ }^{3}\right) \\
0.2 \\
.5\end{array}$ & $\begin{array}{l}0.9 \\
1.7 \\
1.8 \\
1.9 \\
1.2\end{array}$ & $\begin{array}{l}3.8 \\
4.0 \\
4.6 \\
4.9 \\
9.0\end{array}$ \\
\hline $\begin{array}{l}1945-\ldots \\
1950-\ldots \\
1955-\ldots \\
1960-\ldots \\
1965 .-\end{array}$ & $\begin{array}{l}11.8 \\
17.1 \\
22.3 \\
26.6 \\
35.7\end{array}$ & $\begin{array}{r}.1 \\
.1 \\
.6 \\
\text { 1. } 1 \\
\text { 1. } 4\end{array}$ & $\begin{array}{l}\text { 1. } 8 \\
2.4 \\
2.2 \\
2.4 \\
\text { 3. } 1\end{array}$ & $\begin{array}{l}10.2 \\
14.8 \\
20.7 \\
25.3 \\
34.0\end{array}$ \\
\hline $\begin{array}{l}1966 \\
1967-\ldots \\
1968 \\
1969- \\
1970 \\
196\end{array}$ & $\begin{array}{l}38.4 \\
38.1 \\
42.5 \\
44.8 \\
44.1\end{array}$ & $\begin{array}{l}\text { 1. } 6 \\
\text { 1. } 7 \\
\text { 1. } 9 \\
\text { 2. } 1 \\
\text { 3. } 1\end{array}$ & $\begin{array}{l}3.4 \\
3.2 \\
3.5 \\
4.0 \\
3.5\end{array}$ & $\begin{array}{l}36.6 \\
36.7 \\
40.9 \\
42.8 \\
43.7\end{array}$ \\
\hline $\begin{array}{l}1971^{4}- \\
1972^{4}-\end{array}$ & $\begin{array}{l}45.3 \\
47.8\end{array}$ & $\begin{array}{l}\text { 2. } 2 \\
2.3\end{array}$ & $\begin{array}{l}3.5 \\
3.7\end{array}$ & $\begin{array}{l}43.9 \\
46.3\end{array}$ \\
\hline
\end{tabular}

Low projections

\begin{tabular}{r|r|r|r|r}
\hline Year & $\begin{array}{c}\text { Domestic } \\
\text { demand }\end{array}$ & Exports & Imports & $\begin{array}{r}\text { Demand } \\
\text { on U.S. } \\
\text { mills }\end{array}$ \\
\hline 1980 & 60.2 & 3.5 & 4.0 & 59.7 \\
\hline $1990 \ldots 00$ & 73.4 & 3.5 & 4.0 & 72.9 \\
\hline
\end{tabular}

Medium projections

\begin{tabular}{r|r|r|r|r}
\hline $1980 \ldots \ldots$ & 64.3 & 3.5 & 4.0 & 63.8 \\
$1990 \ldots \ldots$ & 83.5 & 3.5 & 4.0 & 83.0 \\
$2000 \ldots \ldots$ & 106.3 & 3.5 & 4.0 & 105.8 \\
\hline
\end{tabular}

High projections

\begin{tabular}{r|r|r|r|r}
\hline $1950 \ldots \ldots$ & 69.1 & 3.5 & 4.0 & 68.6 \\
$1990 \ldots-0.5$ & 4.0 & 95.3 \\
$2000 \ldots-$ & 95.8 & 3.5 & 4.5 & 129.1
\end{tabular}

${ }^{3}$ Projections based on alternative assumptions about growth in population and economic activity as specified in the introductory section of this chapter.

2 Data may not add to totals because of rounding.

${ }^{3}$ Less than 50,000 tons.

4 Preliminary.

Sources: American Paper Institutc. Wood pulp statistics. 1972. (Annual); and Monthly statistical summary. New York; and U.S. Department of Agriculture, Forest Service.

to 533,000 tons. Exports to Latin America have also shown substantial growth from 22,000 tons in 1950 to 277,000 tons in 1971 . 
As indicated in Chapter IV, various studies point to rapid and continuing increases in world demands for pulp and paper and board, as well as for other wood products. These studies also indicate that available timber supplies of acceptable quality may not be large enough to meet these expanding demands. Although expanded markets for pulp exports from the United States can be expected, it was assumed that pulp exports will level off at 3.5 million tons in view of the major rise in projected U.S. demands for pulp, tightening timber supply situation in the United States as described in Chapter VI and prospective increases in fiber supplies from other regions of the world.

Imports of woodpulp.-In contrast to the recent rise in pulp exports, the United States has long imported substantial volumes of woodpulp (table 147; Append. V, table 24). Pulp imports approached 2 million tons in the $1920^{\prime}$ s-a level that with some fluctuation was maintained through the 1950's. In the 1960's, however, pulp imports rose fairly rapidly, and in the late 60's and early 70 's were ranging between 3.5 and 4.0 million tons a year. In earlier years Scandinavia provided much of the imports, but in 1971, 96 percent of the imported pulp came from Canada (Append. V, table 26).

In view of the higher costs that would presumably be associated with the use of unexploited timber resources in Canada (see discussion Chapter IV), Canadian pulp producers probably would not significantly increase shipments over recent volumes unless prices rise above 1970 levels. Hence, it was assumed that at 1970 relative prices imports would remain about 4 million tons annually.

With higher prices it seems likely that Canadian producers would supply much larger quantities of woodpulp. Accordingly, woodpulp imports have been increased substantially under the higher price assumptions as shown in the following tabulation of medium projections of demand under alternative price assumptions:

\section{Projections- -1970 relative prices}

\begin{tabular}{|c|c|c|c|c|}
\hline Year & $\begin{array}{l}\text { Total demand } \\
\text { (million tons) }\end{array}$ & $\begin{array}{c}\text { Exports } \\
\text { (million tons) }\end{array}$ & $\begin{array}{c}\text { Imports } \\
\text { (million tons) }\end{array}$ & $\begin{array}{l}\text { Demand on } \\
\text { U.S. mills } \\
\text { (million tons) }\end{array}$ \\
\hline $1980 \ldots$ & $\quad 64.3$ & 3.5 & 4. 0 & 63. 8 \\
\hline $1990 \ldots$ & 83.5 & 3.5 & 4. 0 & 83.0 \\
\hline $2000 \ldots$ & 106.3 & 3.5 & 4. 0 & 105.8 \\
\hline
\end{tabular}

Projections-relative prices rising 0.5 percent per ycar

$\begin{array}{lllll}1980 \ldots \ldots & 61.9 & 3.5 & 6.0 & 59.4 \\ 1990 \ldots \ldots & 78.9 & 3.5 & 7.5 & 74.9 \\ 2000 \ldots \ldots & 99.8 & 3.5 & 8.5 & 94.8\end{array}$

Projections-relative prices 10 percent above 1970 average

$\begin{array}{rrrrr}1980 \ldots \ldots & 61.0 & 3.5 & 6.0 & 58.5 \\ 1990 \ldots \ldots & 79.2 & 3.5 & 7.0 & 75.7 \\ 2000 \ldots \ldots & 101.5 & 3.5 & 7.5 & 97.5\end{array}$

Demand on U.S. mills for woodpulp.-When projected pulp imports are subtracted from total domestic and export demands, an estimated 64 million tons (medium projection) of woodpulp would be demanded from U.S. mills by 1980 at 1970 relative prices (table 147 ). A further rise to 106 million tons by 2000 is projected.

Under the alternative higher prices demand on U.S. mills would be somewhat lower because of reductions in domestic demand and increased imports.

Annual rates of growth in demand drop under all assumptions. For example, with the medium projection of population and economic growth and 1970 relative prices, rates drop from 3.8 percent in the 1970 's to 2.5 percent in the 1990 's. Part of the decline after the mid-1970's reflects an anticipated fall-off in use of new woodpulp per ton of paper and board manufactured (fig. 73).

Projected increases in domestic production (medium projection) at 1970 relative prices indicate it would be necessary to expand U.S. woodpulp production by about 2 million tons a year in the 1970's. This would be close to the average increase in the 1960's. Under the rising price assumption the projected increase (medium projection) would average 1.6 million tons per year.

\section{Pulpwood Consumption and Demand}

Consumption of pulpwood in U.S. mills to produce the tonnage of pulp shown in table 147 increased from about 6 million cords in 1920 to more than 72 million cords in 1972 (table 148; Append. V, table 27).

Pulpwood used per ton of pulp.-Since 1920 average use of pulpwood per ton of pulp produced has not changed significantly, averaging about 1.6 cords per ton (fig. 74; Append. V, table 28). During this period some technological developments have tended to increase yields of pulp per cord of wood consumed. These have included a major shift from sulfite and soda processes to higher yielding sulfate and semichemical processes. There has also been a large relative increase in use of hardwoods which yield more pulp per cord than softwoods. Offsetting these trends, however, has been an increase in proportions of semibleached and bleached grades of woodpulp which require more wood per ton than unbleached grades.

It has been assumed that the net effect of technological developments in the future, together with further increases in use of hardwoods, will cause a slight decline in consumption of pulpwood per ton of pulp produced to an average of about 1.5 cords by 2000 .

Multiplying assumed wood requirements per ton of pulp by projected domestic production of woodpulp indicates a potential demand for pulpwood in U.S. mills (medium projection at 1970 relative prices) of about 98 million cords by 1980 , and 159 million cords by 2000 (table 148).

Exports of pulpwood.- Prior to the late 1960's pulpwood exports from the United States were 


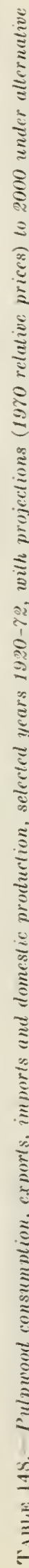
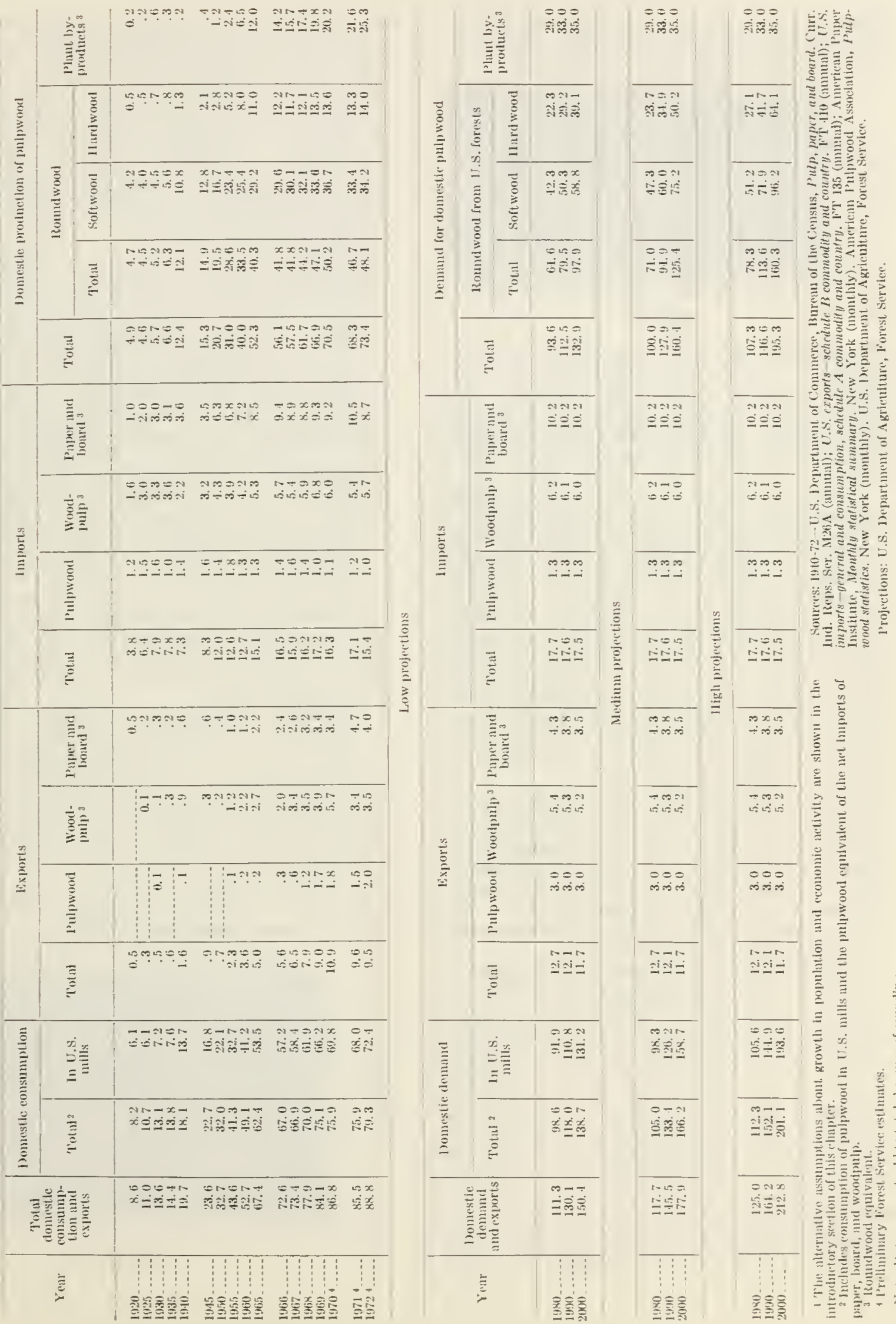
Pulpwood consumed per ton of woodpulp produced, $1920-70$ with projection to 2000

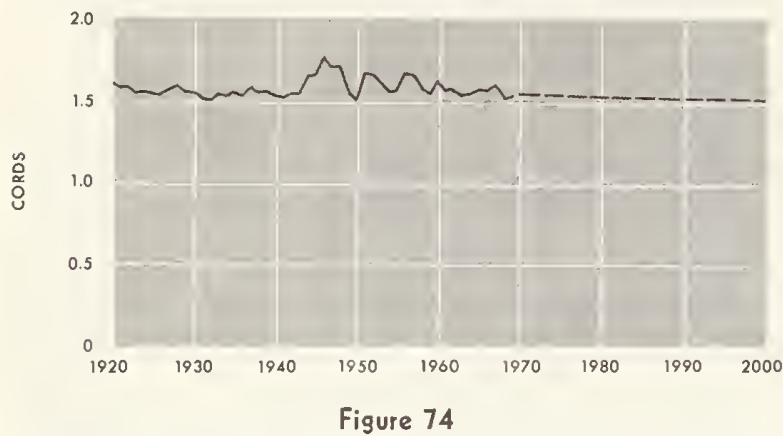

usually below 100,000 cords and were of little significance (table 148). Beginning in 1965, however, exports rose rapidly to a level of 2.0 million cords in 1972. Most of the increased exports went to Japan and were composed of chips produced from residues at sawmills on the Pacific Coast.

As discussed in Chapter IV, Japan is faced with growing timber deficits and rising demands for woodpulp and paper and board. It is thus likely to be in the market for larger and larger quantities of imported chips. Most of the presently available slabs, edgings, and veneer cores on the Pacific Coast are being utilized, but there are still substantial rolumes of logging and fine mill residues in that area. With projected growth in demand for pulpwood by U.S. mills, limitations on U.S. timber supplies, and expectations of higher timber prices necessary to permit utilization of material now left as logging residues, it seems likely that further increases in pulpwood exports will be limited as shown in table 148.

Imports of pulpwood.-Imports of pulpwood for consumption in U.S. mills, nearly all from Canada, have fluctuated between 1 and 2 million cords a year for several decades (table 148). Because of Canadian constraints on shipments of unmanufactured wood, and the relatively high transportation costs of shipping pulpwood, no growth is anticipated in pulpwood imports.

Demand for domestic pulpwood.-Domestic production of pulpwood in the United States rose from about 5 million cords in 1920 to 73 million cords in 1972 (table 148). Meeting projected increases in pulpwood demand at U.S. mills after allowing for exports and imports of pulpwood would require an increase in U.S. pulpwood production to 100 million cords by 1980 (medium projection - 1970 relative prices) and to 160 million cords by 2000. Rates of growth in these projections of pulpwood demand decline rather rapidly-from an average of 5.8 percent per year in the 1960's to 2.3 percent annually in the 1990 's.

Pulpwood from plant residues.-Part of the pulpwood consumed in U.S. mills and exported has come from slabs, edgings, veneer cores, sawdust, and other material produced at primary manufacturing plants. Between 1950 and 1972 use of these materials increased from 1.2 million cords to 25.3 million cords (table 148, fig. 75). Although most of the economically available coarse material and some fines were utilized, unused volumes of chippable residues in the United States still amounted to 5.2 million cords in 1970 . Unused sawdust and other fine residues in 1970 composed an additional 7.6 million cords of potentially usable material.

Some of the residues of primary manufacturing plants is so scattered geographically and in such small volumes that it will not be economically utilizable under foreseeable price increases. However, in estimating future demand for round pulpwood, it was assumed under all population, economic, and price assumptions that by 1980 most coarse plant residues, much of the fines, and some material formerly utilized as fuel would be used for pulp products or for particle board. It was also assumed that while greater use of smaller timber will tend to increase the total volume of residues, this would be offset by increased use of thimner saws and more precise manufacturing equipment which would reduce residue volumes.

Under these assumptions rolumes of plant byproducts used as pulpwood are projected to rise to 35 million cords by 2000 . These estimates of byproducts use are based upon the projections of timber supplies likely to be available for lumber and plywood production (with 1970 levels of forest management).

Demand for domestic roundwood.-Projected demands for domestic roundwood for pulpwood were derived by subtracting prospective supplies of plant byproducts from total projected demands for domestic pulpwood. The inedium projection for round wood at 1970 prices rises from 48.1 million cords in 1972 to 71 million cords in 1980, and to 125 million cords by 2000 .

\section{Pulpwood production, by source of material,} 1920-72, with projections to 2000

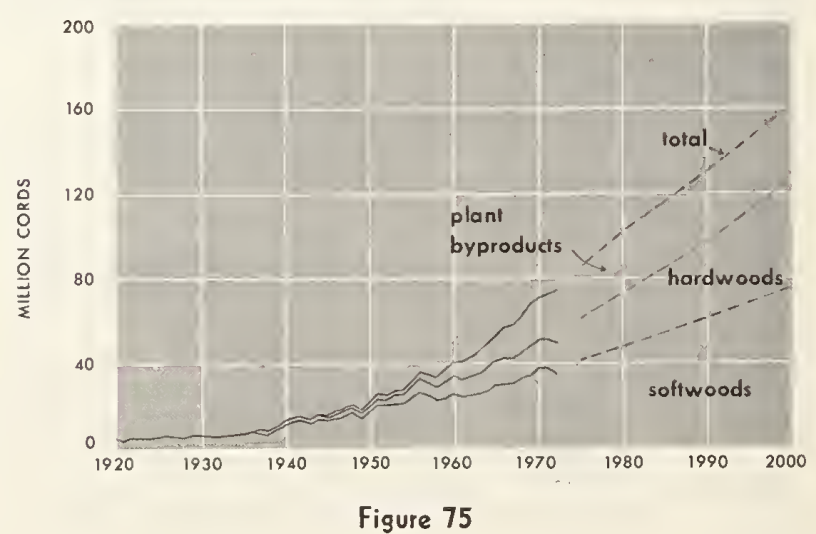


Softwoods have long been preferred for pulp and paper products because of such factors as relatively high strength properties and light color. In recent decades, however, use of hardwoods has increased rapidly-in response to technological improvements in pulping, arailability of substantial rolumes of hardwood at relatively lower costs per ton of fiber, improvements in properties of many grades of paper and board with the addition of hardwood pulps, and rising competition and prices for softwood timber. The trend toward increased use of hardwoods is likely to be encouraged by- a comparatively favorable supply situation, as indicated by the timber demandsupply comparisons in Chapter VI.

Based on recent trends and a vailable technology, proportions of softwoods in the pulpwood harvest were assumed to continue to decline from 71 percent of the total roundwood used in 1972 to about 66 percent by $19 S 0$ and 60 percent by 2000 , with corresponding increases in proportions of hardwood pulpwood.

Although pulpwood generally is obtained from smaller sizes and lower grades of timber, substantial rolumes of sawtimber suitable for lumber and plywood also are consumed in the production of paper and board. In 1970, for example, an estimated 7 billion board feet of softwood sawtimber, and 2 billion board feet of hardwood sawtimber, were used in pulp manufacture. In many cases the saw-log material used for pulp was of relatively low grade. In other cases, where sawtimber trees are scattered, for example, or where pulp timber is harvested from small tracts by small producers, considerable volumes of sawtimber of high quality have been used.

Other derelopments such as rising timber values and local shortages of wood have been encouraging greater use of small trees and material formerly left as logging residues. It also seems likely that new technological derelopments leading to practical methods of bark-chip separation, and/or acceptance of bark in the furnishes of some grades of paper and board, will lead to greater use of small stems, limbs, and cull trees that have been previously unused. It has, therefore, been assumed that while the total quantity of sawtimber used for pulp will continue to increase, the proportion of the total pulpwood mix made up of sawtimber will decline moderately.

Demand for pulpwood including the roundwood equivalent of net imports of paper, board, and woodpulp.-In addition to pulpwood from U.S. forests, a substantial rolume of wood is represented by imports of pulp, paper, and board. In 1972, for example, the roundwood equivalent of such net imports was 6.9 million cords. With this added to domestic production, the total rolume of pulpwood required to manufacture the paper, board, and woodpulp consumed in the United States in 1972 was 79.3 million cords.
Exports of pulpwood and pulpwood products (pulp, paper, and board) in 1972 were equivalent to 9.5 million cords. Thus, total domestic and export demand for pulpwood in 1972 amounted to SS.S million rords.

Projected demands for pulpwood for U.S. consumption, including the roundwood equivalent of net imports of woodpulp and paper and board, rise from 79.3 million cords in 1972 to 166 million cords by 2000 (medium projection, 1970 relative prices).

Total pulpwood demands for both U.S. consumption and exports - to be supplied from U.S. or foreign resources-are projected to increase to $17 \mathrm{~s}$ million cords by 2000, or double the 1972 levels.

Demand for pulpwood under alternative assumptions.-The alternative population and gross national product assumptions adopted in this study have a sizeable impact on demands for pulpwood at 1970 relative prices (table 148). For example, in 2000 projected demands for pulpwood for U.S. consumption vary between 139 million and 201 million cords.

As indicated in the introductory section of this Chapter, it has been assumed that demands for paper and board are quite inelastic, that is, price changes have relatively little effect on demand. Thus, the alternative price assumptions used in this study have relatively little effect on projected demands for pulpwood (table 149). For example, a rise in relative prices of paper and board at the longrun historical rate-about 0.5 percent per year-would reduce the medium projection of pulpwood demand in the United States by only 1.7 percent in the year 2000 (table 149).

If timber supplies are not adequate in future years to meet the projected increases in demands for both pulpwood and other timber products, as indicated by the data in Chapter VI, sizeable price increases for paper and board will be necessary to enable the pulp industry to compete for wood. Also other fibers-wastepaper, bark, limbs and tops, tropical hardwoods, kenaf, and plastics - would be used to a greater extent.

\section{DEMAND FOR MISCELLANEOUS TIMBER PRODUCTS}

As shown in the tabulation below, a rariety of miscellaneous industrial roundwood products are consumed in the United States.

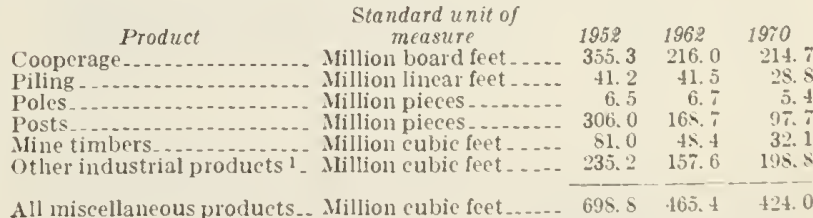

1 Includes charcoal wood, roundwood used in the manufacture of particleboard; poles and rails used in fencing. bolts used for products such as shingles, wood turnings, and handles, and other miscellaneous items such as lrop poles. 

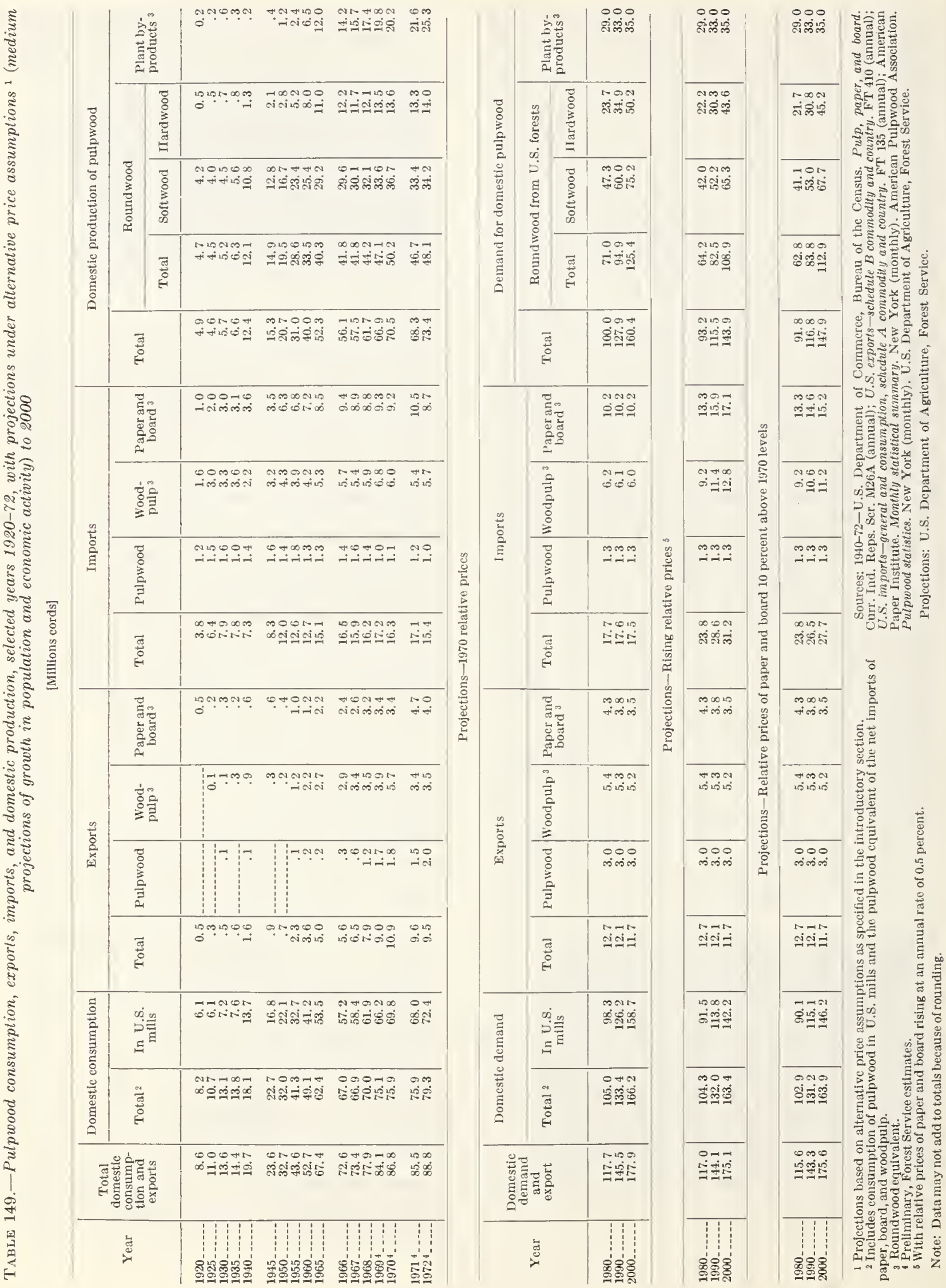
Total consumption of these products amounted to 424 million cubic feet in 1970. This was somewhat below the general lerel of the 1960's when estimated consumption areraged about 500 million cubic feet per rear, and far below consumption of more than 2 billion cubic feet annually in the early 1900's.

Additional rolumes of plant byproducts such as sawdust, slabs, and edgings used in the production of products such as charcoal and chemicals amounted to 155 million cubic feet in 1970 . Thus, total rood consumption for miscellaneous products in that year amounted to a little over 600 million cubic feet. International trade in these products is small and consumption has been roughly equal to production.

The downward trend in consumption of miscellaneous industrial roundwood products which began around 1910 appears to have leveled off in the past decade. For this report it was therefore assumed that demand for these products will remain close to 500 million cubic feet with all price assumptions. However, individual products are likely to show divergent trends as indicated below.

\section{Cooperage Logs and Bolts}

In the early 1900's roundwood used in manufacture of barrels, kegs. pails, and tubs made of wood stares totaled about $1 . S$ billion board feet annually-about 40 percent in tight cooperage and 60 percent in slack cooperage. Since then new technology, changes in consumer buying habits, and new packaging techniques hare sharply reduced demands for cooperage.

Br the 1960's consumption had dropped to about 200 million board feet, of which about 70 percent was for tight cooperage and 30 percent for slack cooperage. Orer half of the tight cooperage was used in bourbon barrels, with the remainder used for chemical and other containers. The slack cooperage was mainly- used for barrels for food and hardware. Future demands for cooperage logs and bolts are expected to continue close to the level of recent years.

\section{Poles and Piling}

Use of rood poles in the construction and maintenance of utility lines and other structures has been relatively stable in recent years. In the period 1962-70, for example, rolume of poles treated with preservatives averaged nearly 80 million cubic feet annually, or slightly more than in the previous decade. Although there is a trend away from use of poles in new residential areas, anticipated expansion of demands for electric and communication facilities, growing needs for pole replacements, and the expanding use of poles in construction are expected to result in some increase in demand for poles over the projection period.
Treated rood piling used in construction of locks, bridges, and buildings averaged about 17 million cubic feet a year in the period 1962-70. In addition, an estimated 10 million cubic feet of untreated piling was used annually in this period. In view of projected increases in construction, a modest increase in demand through the projection period is considered likely.

\section{Fence Posts}

Use of rood posts for farm fencing and other purposes such as highway barricades and yard enclosures dropped from an estimated 900 million posts in 1920 to about 170 million in 1962 and approximately 98 million (6s million cubic feet) in 1970 . This decline was a result of several factors, including substitution of steel posts, increased use of preservative-treated wood posts, and changes in farm size and farming methods that involve less use of fencing. 'I'hese forces are expected to result in further reduction in demands in future decades.

\section{Other Industria/Wood}

Use of round, split, and hewn mine timbers fell from an estimated 174 million cubic feet in 1923 to 48 million cubic feet in 1962 , and 32 million cubic feet in 1970 . Projected increases in production from underground mines, however, suggest that this trend may be reversed.

Consumption of rood for a wide variety of products such as particleboard, charcoal and wood distillation products, shingles, excelsior, hewn ties, turnery products, and miscellaneous farm timbers amounted to about 200 million cubic feet of roundwood plus an estimated 184 million cubic feet of plant byproducts in 1970 . Wood consumption for some of these products, especially particleboard, has been rising, but there have been offsetting declines in other uses. It has been assumed that future use will continue about at the 1970 level.

\section{DEMAND FOR FUELWOOD}

Fuelwood consumption in 1970 was estimated at 16 million cords. 'This included approximately 314 million cubic feet of roundwood from growing stock and 228 million cubic feet of roundwood from other sources such as dead and cull trees, plus 723 million cubic feet of primary plant residues. Fuelwood cut from roundwood was used almost entirely for domestic heating and cooking. Plant residues were used both for domestic purposes and for steam power in wood processing plants.

Fuelwood consumption dropped sharply in the first five decades of the present century because of the substitution of oil, gas, coal, and electricity in home cooking, heating, and industrial uses. In recent years, howerer, substantial markets have 
developed in metropolitan areas for fireplace wood. Expected increases in income, population, and residential construction indicate this market may continue to grow.

In this study it has been assumed that demand for round fuelwood would continue at about the 1970 level through the projection period although new air pollution standards could reduce this demand.

\section{LOG EXPORTS AND IMPORTS}

The above discussion has been primarily concerned with demand for processed timber products. In addition, between the late 1950's and 1972, exports of logs from the United States rose from around 100 million board feet (local log scale) to 3.1 billion board feet, shown by the following tabulation.

$$
\text { Volume and destination }
$$

(million board fect, local log rules)

$\begin{array}{lrrrr} & \text { Total } & \text { Japan } & \text { Canada } & \text { Other } \\ \text { Year } & 48 & 18 & 43 & 5 \\ 1950 \ldots \ldots \ldots & 166 & 18 & 138 & 10 \\ 1960 \ldots \ldots & 266 & 99 & 151 & 17 \\ 1965 \ldots \ldots & 1,193 & 804 & 353 & 35 \\ 1970 \ldots \ldots & 2,753 & 2,377 & 292 & 84 \\ 1971 \ldots \ldots \ldots & 2,292 & 1,847 & 343 & 102 \\ 1972 \ldots \ldots \ldots & 13,143 & 2,530 & 519 & 95\end{array}$

1 Equivalent to about 4.1 billion board feet, lumber tally, and 3.9 billion board feet, International $1 / 4$-inch $\log$ rule.

Nearly all of the recent increase in log exports was composed of softwood logs produced in western Washington, western Oregon, and northern California. The rapid growth in these exports was a result of large increases in demand in Japan-the destination of 96 percent of recent softwood $\log$ shipments. As indicated in Chapter IV, Japanese demands for wood are expected to continue to grow and continuing pressures to increase log imports can be expected.

Part of increased Japanese timber demands in the next couple of decarles could be met from the softwood forests of Siberia and from other sources such as New Zealand and tropical regions. Canada can be expected to supply larger quantities of softwood lumber to Japan but no significant exports of softwood logs since the export of logs from that country is controlled.

Although part of the Japanese import demand can be met from these sources, continuing growth in Japanese demand for logs from the Pacific Coast is likely, at least during the next two decades. However, the tightening timber supply situation in the United States is expected to eventually result in restrictions on $\log$ exports. It has, therefore, been assumed that sof twood log exports would not exceed 4.5 billion board feet annually (International 1/4-inch log rule).

Hardwood log exports hare not been large - 94 million board feet in 1972, for example-but these exports have consisted for the most part of scarce and highly valuable species like walnut. No significant change in such exports is projected.

Log imports in 1972 were 39 million board feet, $\log$ scale. This was materially below imports of over 200 million feet a year in the early 1950's and the annual average of about 100 million board feet in recent years. Over half of these $\log$ imports originated in Canada and consisted chiefly of sof twood logs for pulp and lumber. Most other log imports were tropical hardwoods for manufacture of veneer. Not much change from the level of log imports in the 1960's is expected during the projection period.

\section{SUMMARY OF DEMAND FOR TIMBER}

The projections of demand for timber products presented above have been in standard units of measure, that is, board feet of lumber, square feet of plywood, cords of pulpwood and fuelwood, and cubic feet of miscellaneous industrial roundwood products. In this section these projections are converted to common units of measure-cubic feet of roundwood and board feet of sawtimber. After allowances for exports and imports, these figures provide a measure of demand upon domestic timber resources which are comparable to the projections of domestic timber supplies shown in Chapters II and III.

\section{Improvements in Utilization}

An important factor in converting demands for timber products to roundwood is the prospective change in utilization practices. During the past couple of decades there have been substantial improvements in utilizing the timber harvested. This is illustrated in figure 76 which shows that during the period 1950-72 the tonnage of timber products consumed-lumber, plywood, woodpulp, etc.-increased 51 percent, while the cubic volume of roundwood utilized increased only 38 percent (Append. V, tables 29 and 30).

\section{Consumption of industrial wood}

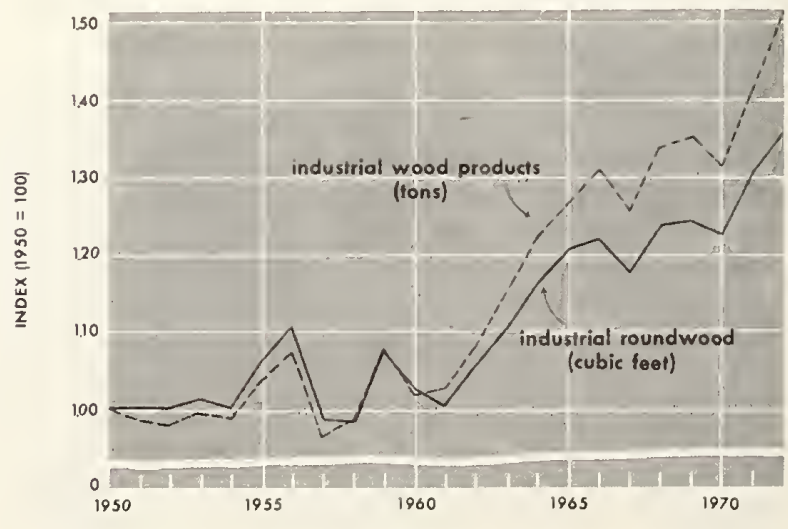

Figure 76 
Improvements in utilization have largely inrolved the growing use of slabs, edgings, sawdust, reneer cores, sharings, and other similar material for pulp and particleboard. Tarious technological changes have also led to increased product rield per unit of wood input although in the lumber industry this has apparently been offset by the use of smaller and lower quality material and the spreading use of chipping headrigs. Yields in the pulp industry have also been held down by a sharp rise in the production of bleached and semibleached pulps.

In converting projected demands for lumber, plywood, and pulpwood to roundwood and sawtimber rolumes, technological developments affecting product rields, and other factors such as changes in standards and prospective changes in the size and quality of timber, have been taken in to account. For example, projected demands for softwood lumber have been converted to demands for sawtimber and roundwood with an allowance for new softrood lumber standards that became effective in September 1970. These standards specify reduced thicknesses and widths of most sizes of softwood lumber, with an estimated arerage increase in lumber yields of approximately 5 percent per thousand board feet of $\operatorname{logs}$, International $1 / 4$-inch $\log$ rule. ${ }^{47}$

In addition to this adjustment, it was assumed that various other technological derelopments to be expected with 1970 levels of research and development, and prospective rates of adoption of new technology by the forest industries, would lead to increases in product output per unit of log input.

The growing use of thin-kerf high-strain bandsaws and thin-kerf circular saws is an example of technological derelopments affecting lumber yields. ${ }^{48}$ An estimated 22 percent of saw-log volumes has typically been converted into sawdust, and reduction of saw kerf from improvements in milling equipment and quality control could result in significant increases in lumber yields.

Another example of new technology is represented by the "Best Opening Face" system that uses automated headrig control by a minicomputer to locate precisely the best initial cut to maximize lumber vields. ${ }^{49}$ Calculations indicate that this BOF system, if universally applied, could increase lumber yields by- an estimated arerage of 10 percent.

\footnotetext{
17 National Forest Products Association. Evaluation of ASTII standards to develop " $E$ " values for structural lumber. Washington, D.C. 1970.

${ }_{48}$ Mason, H. C. Wood industry technology: what's new now, what's to come. Forest Industries 98(11):22-24. 1971.

${ }^{49}$ Hallock, Hiram, and David IV. I.ewis. Increasing softwood dimension yield from small logs. USDA Forest Serv., Res. Pap. FPL-166, 12 p. 1971.
}

Potential technological developments also include production of laminated lumber. This product is made by gluing together sliced sheets of veneer up to one-half inch in thickness and subsequently saming these into structural lumber, pallet stock, or other products. Preliminary work indicates that product rields might be substantially increased by this process..$^{50} \mathrm{~A}$ somewhat related system of producing sawn products involves live sawing logs into 2 -inch strips, positioning these strips to minimize effects of defects, edge-gluing them into wide panels, and ripping the panels into desired widths of dimension lumber.

The chipping headrig is a further example of new technology now coming into wide use for joint production of lumber and pulp chips. ${ }^{51} \mathrm{Al}-$ though lumber vields are relatively low, this equipment makes possible the profitable conversion of sniall logs into lumber and chips for pulping.

The rate of development, acceptance, and application of new technology such as illustrated above is necessarily highly uncertain. The financing and effectiveness of research efforts will determine how rapidly new discoveries are made. Educational efforts will determine how rapidly new discoveries are inarle known. The attitude and financial resources of forest industries will determine how rapidly new technology will be adopted.

New technologies that promise to produce an existing product more efficiently or save on use of raw material may or may not be promptly put into use by the forest industries, depending on such factors as price-cost relationships, consumer acceptance, or institutional obstacles. Wood particleboard. for instance, was patented in 1905 but large-scale commercial production did not get underway until a half century later.

Adoption of new technology will also be influenced by the availability of capital to the forest industries for modernization of plant and equipment and for changes in market strategy. The trend toward larger and more integrated firms in timber industries could be of help in obtaining financing for more rapid adoption of new technology than in the past.

Based on consideration of the above factors, 1970 levels of research and development, prospective rates of adoption of new technology, and projected changes in the size and quality of timber arailable, it has been assumed that there would be significant increases in timber product vields over the projection period. The assumed

${ }^{30}$ Bohlen, J. C. LTL-Laminated veneer lumber-development and economics. Forest Prod. J. 22(1):1S-26. 1972.

${ }^{51}$ Koch, Peter. Technological developments in the southern pine industry. Forest Farmer 30(7):16-20. 1971. 
increases from the 1970 base for lumber are shown in the tabulation below:

\begin{tabular}{|c|c|c|c|c|c|c|}
\hline \multirow{3}{*}{ Relative price assumptions } & \multicolumn{6}{|c|}{$\begin{array}{l}\text { Percent increase in lumber yiclds per thousand } \\
\text { board feet of logs, International } 1 / 4 \text {-inch log rule }\end{array}$} \\
\hline & \multicolumn{3}{|c|}{ Softwoods } & \multicolumn{3}{|c|}{ Hardwoods } \\
\hline & 1980 & 1990 & 2000 & 1980 & 1990 & 2000 \\
\hline 1970 relative prices......... & 17 & 10 & 12 & ? & 3 & 4 \\
\hline $\begin{array}{l}\text { Rising relative prices } \\
\text { Relative prices } 30 \text { percent }\end{array}$ & 18 & 12 & 15 & 3 & 4 & 5 \\
\hline above 1970 & 111 & 12 & 13 & 4 & 4 & 4 \\
\hline
\end{tabular}

1 Includes a 5 percent increase resulting from the change in lumber standards in 1970 .

It was assumed that plywood yields would also increase by roughly the same amounts.

As indicated in the above tabulation, higher relative prices of timber products would be expected to accelerate improvements in utilization because of competition for timber and increased capability of manufacturers to finance new plant and equipment.

Pulp yields, as indicated in the section on pulpwood, have been projected to rise about 7 percent over the 30-year projection period in response to expected increases in the use of hardwoods and technological developments. It was also estimated that use of plant residues and wastepaper would approach the limits imposed by the amounts of such material economically and physically available.

With more rapid advances in development and adoption of new technology, increases in product yields from available timber could, of course, be higher than estimated for these projections.

\section{Recent Trends in Roundwood Consumption}

In 1970 total U.S. consumption of timber products in terms of roundwood rolume was 12.7 billion cubic feet (table 150; Append. V, tables 30-32). ${ }^{52}$ Roundwood consumption rose to 14.2 billion cubic feet in 1972 , a peak in a trend that has risen from around 11 billion cubic feet in the early 1960's. Roundwood consumption in 1972 was also materially above the levels attained in the early 1900's when lumber use was at an alltime high and record volumes of fuelwood were consumed.

A little over half of the roundwood consumed in 1972 consisted of saw logs used for lumber. About a third was used for pulp products. Eleven percent was used for veneer and plywood. The remaining 7 percent was about equally divided between miscellaneous industrial products and fuelwood.

In the years from 1950 to 1972 there was a 16 percent rise in the volume of roundwood used for

52 Roundwood is derived both from the "growing stock" component of the forest (that is, live trees on commercial timberlands above 5.0 inches in diameter meeting certain standards of soundness and quality) and from other sources such as cull and dead trees and trees on noncommercial and nonforest lands. Projected supplies of roundwood from these sources are shown in Chapters II and III. lumber. Use of roundwood nearly doubled for pulp products, and quadrupled for veneer and plywood.

Use of roundwood for miscellaneous industrial products and fuelwood declined during the 1950's and most of the 1960's. It has been assumed, however, that the decline in consumption of these products has bottomed out.

\section{Projected demand for Roundwood}

Projected roundwood demands are materially affected by the assumptions on population and economic activity specified in the introductory section of this chapter. The range in projected total demand for roundwood in 2000 , for example, at 1970 prices is from 19.5 billion to 27.1 billion cubic feet (fig. 77).

The medium projection of demand reaches 16.4 billion cubic feet in 1980, with a continuing rise to 22.8 billion cubic feet in 2000-some 1.6 times consumption in 1972. Most of the projected growth in demand is for pulp products, and pulpwood consequently accounts for nearly half of the total demand for roundwood in 2000 .

Projected demands are also materially affected by the alternative price assumptions specified earlier. For example, the medium projections of demand by 2000 ranges between 22.8 billion cubic feet at 1970 price levels and 19.2 billion cubic feet with rising relative prices (that is, 1.5 percent per vear for lumber; 1.0 percent for plywood, miscellaneous products and fuelwood; and 0.5 percent for paper and board). Nearly all of the growth in demand under the latter price assumption would be for pulpwood.

With lumber and plywood prices 30 percent above the 1970 average, miscellaneous products and fuelwood up 15 percent, and paper and board prices 10 percent higher, the medium projection of demand rises relatively slowly in the 1970's,

\section{Roundwood consumption 1950-72, with} projected demand under alternative assumptions to 2000

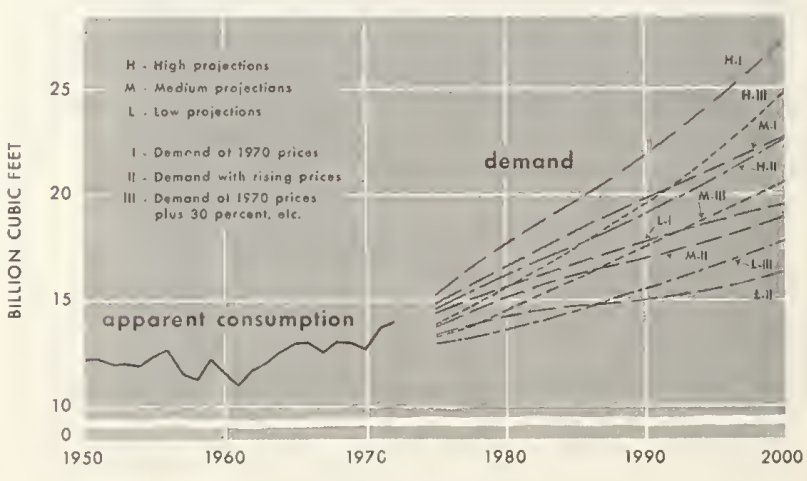

Figure 77 
TABLE 150.-Summary of rounduood consumption by species group and major product, 1952, 1962, and 1970, with projections of demand (medium level ${ }^{1}$ ) under alternative price assumptions to 2000

[Billion cubic feet, roundwood equivalent]

\begin{tabular}{|c|c|c|c|c|c|c|c|c|c|c|c|c|}
\hline \multirow{3}{*}{ Species group and product } & \multirow{3}{*}{1952} & \multirow{3}{*}{1962} & \multirow{3}{*}{1970} & \multicolumn{9}{|c|}{ Projections } \\
\hline & & & & \multicolumn{3}{|c|}{$\begin{array}{l}1970 \text { relative } \\
\text { prices }\end{array}$} & \multicolumn{3}{|c|}{$\begin{array}{l}\text { Rising relative } \\
\text { prices }^{2}\end{array}$} & \multicolumn{3}{|c|}{$\begin{array}{l}\text { Relative prices above } \\
1970 \text { averages }^{3}\end{array}$} \\
\hline & & & & 1980 & i990 & 2000 & 1980 & 1990 & 2000 & 1980 & 1990 & 2000 \\
\hline SOFTWOODS & & & & & & & & & & & & \\
\hline $\begin{array}{l}\text { Saw logs } \\
\text { Veneer logs } \\
\text { Pulpwood } \\
\text { Yliscellaneous products } \\
\text { Fuelwood }\end{array}$ & $\begin{array}{r}5.0 \\
.2 \\
2.4 \\
.3 \\
.5\end{array}$ & $\begin{array}{r}4.8 \\
.6 \\
2.6 \\
.3 \\
.2\end{array}$ & $\begin{array}{r}5.0 \\
.9 \\
3.4 \\
.2 \\
.1\end{array}$ & $\begin{array}{l}\text { 6. } 1 \\
\text { 1. } 4 \\
4.2 \\
.3 \\
.1\end{array}$ & $\begin{array}{l}\text { 6. } 7 \\
\text { 1. } 7 \\
5.3 \\
.3 \\
.1\end{array}$ & $\begin{array}{l}\text { 7. } 0 \\
\text { 1. } 9 \\
6.5 \\
.3 \\
.1\end{array}$ & $\begin{array}{l}\text { 5. } 3 \\
\text { 1. } 3 \\
4.2 \\
.3 \\
.1\end{array}$ & $\begin{aligned} & 5 . 3 \\
& 1.4 \\
& 5.4 \\
& .2 \\
& .1\end{aligned}$ & $\begin{array}{l}5.0 \\
1.5 \\
6.7 \\
.2 \\
.1\end{array}$ & $\begin{array}{l}\text { 5. } 0 \\
\text { 1. } 2 \\
\text { 4. } 2 \\
.2 \\
.1\end{array}$ & $\begin{array}{l}5.6 \\
1.4 \\
5.4 \\
.2 \\
.1\end{array}$ & $\begin{array}{l}5.9 \\
1.5 \\
6.6 \\
.2 \\
.1\end{array}$ \\
\hline Total ${ }^{6} \ldots \ldots$ & 8. 4 & 8. 5 & 9. 7 & 12. 1 & 14. 1 & 15. 8 & 11. 2 & 12. 4 & 13. 5 & 10. 7 & 12. 7 & 14. 3 \\
\hline $\begin{array}{l}\text { HARDWOODS } \\
\text { Saw logs } \\
\text { Veneer logs } \\
\text { Pulpwood } \\
\text { Miscellaneous products }{ }^{5}- \\
\text { Fuelwood_... }\end{array}$ & $\begin{array}{r}\text { 1. } 1 \\
.2 \\
.3 \\
.4 \\
1.5\end{array}$ & $\begin{array}{r}1.0 \\
.2 \\
.7 \\
.2 \\
.9\end{array}$ & $\begin{array}{r}\text { 1. } 1 \\
.3 \\
\text { 1. } 0 \\
.2 \\
.4\end{array}$ & $\begin{array}{r}1.5 \\
.4 \\
1.8 \\
.2 \\
.4\end{array}$ & $\begin{array}{r}1.8 \\
\text { 2. } \\
.2 \\
.4\end{array}$ & $\begin{array}{r}2.0 \\
.5 \\
3.9 \\
.2 \\
.4\end{array}$ & $\begin{array}{l}\text { 1. } 3 \\
\text {. } 3 \\
\text { 1. } 8 \\
.2 \\
.4\end{array}$ & $\begin{array}{r}1.4 \\
.3 \\
2.4 \\
.2 \\
.4\end{array}$ & $\begin{array}{r}1.4 \\
.4 \\
3.4 \\
.1 \\
.4\end{array}$ & $\begin{array}{r}1.2 \\
.4 \\
1.7 \\
.2 \\
.4\end{array}$ & $\begin{array}{r}1.5 \\
.4 \\
2.4 \\
.2 \\
.4\end{array}$ & $\begin{array}{r}1.7 \\
.5 \\
3.6 \\
.2 \\
.4\end{array}$ \\
\hline Total ${ }^{6} \ldots \ldots$ & 3.5 & 3. 1 & 3. 0 & 4. 3 & 5. 5 & 7. 0 & 4. 0 & 4. 7 & 5. 7 & 3. 9 & 4. 9 & 6. 4 \\
\hline 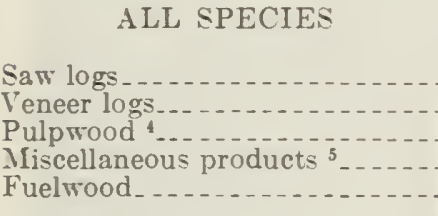 & $\begin{array}{r}\text { 6. } 1 \\
\text { 2. } \\
\text {. } 7 \\
\text { 2. } 0\end{array}$ & $\begin{array}{r}5.7 \\
.9 \\
\text { 3. } 3 \\
.5 \\
1.1\end{array}$ & $\begin{array}{r}6.1 \\
1.2 \\
4.4 \\
.4 \\
.5\end{array}$ & $\begin{array}{r}7.6 \\
\text { 1. } 8 \\
6.0 \\
.5 \\
.5\end{array}$ & $\begin{array}{r}8.5 \\
2.1 \\
8.0 \\
.5 \\
.5\end{array}$ & $\begin{array}{r}9.0 \\
2.4 \\
10.4 \\
.5 \\
.5\end{array}$ & $\begin{array}{r}6.6 \\
1.6 \\
6.0 \\
.5 \\
.5\end{array}$ & $\begin{array}{r}6.7 \\
\text { 1. } 7 \\
\text { 7. } 8 \\
.4 \\
.5\end{array}$ & $\begin{array}{r}6.4 \\
1.9 \\
10.1 \\
.3 \\
.5\end{array}$ & $\begin{array}{r}6.2 \\
1.6 \\
5.9 \\
.4 \\
.5\end{array}$ & $\begin{array}{r}\text { 7. } 1 \\
\text { 1. } 8 \\
\text { 7. } 8 \\
.4 \\
.5\end{array}$ & $\begin{array}{r}7.6 \\
2.0 \\
10.2 \\
.4 \\
.5\end{array}$ \\
\hline Total ${ }^{6} \ldots \ldots$ & 11. 9 & 11. 6 & 12. 7 & 16. 4 & 19. 6 & 22. 8 & 15. 2 & 17. 1 & 19. 2 & 14. 6 & 17. 6 & 20. 7 \\
\hline
\end{tabular}

${ }^{1}$ Based on the medium projections of growth in population and economic activity shown in the introductory section of this chapter.

${ }^{2}$ Relative prices rising from 1970 trend levels as follows: lumber-1.5 percent per year; plrwood, miscellaneous products, and fuelwood-1.0 percent per year; paper and board- 0.5 percent per year.

3 Relative prices of lumber and plywood-30 percent, miscellaneous products and fuelwood-15 percent, and paper and board-10 percent, above the 1970 averages.

Includes both pulpwood and the pulpwood equivalent of the net imports of woodpulp, paper, and board.

5 Includes cooperage logs, poles, piling, fence posts,

but fairly rapidly thereafter to orer 20 billion cubic feet in 2000 . Under this price assumption the demand for saw logs does not change in the 1970 's. By the 1980's howerer, projected demands for saw logs rise along with growing demands for veneer logs and pulpwood in response to growth in population and economic activity.

\section{Projected Demand by Species Groups}

Growth in roundwood consumption in the 1950-71 period consisted entirely of timber hewn ties, round mine timbers, box bolts, excelsior bolts, chemical wood, shingle bolts, and other miscellaneous items.

${ }^{6}$ Includes imported logs not shown by major product use.

Note: Data may not add to totals because of rounding.

Sources: 19.52, 1962, and 1970-Based on data published by the U.S. Departments of Commerce and Agriculture.

Projections: U.S. Department of Agriculture, Forest Service.

produced trom softwood species (Append. V, tables 30-32). Consumption of hardwood roundwood declined with a drop in use of miscellaneous industrial timber products and fuelwood. However, this trend was reversed in 1972 largely in response to increased use of lumber in furniture and pallet manufacture.

Projections show rather large increases for both softroods and hardwoods. Assuming 1970 relative prices, for example, the medium projection of demand for sof twoods increases about 
63 percent by 2000 - from 9.7 to 15.8 billion cubic feet. Demand for hardwoods is projected to rise about 133 percent from 3.0 to 7.0 billion cubic feet. The faster rate of growth in demand for hardwoods, and the reversal of the downward trend of recent years, largely reflects the projected rise in demand for hardwood roundwood for pulp products, hardwood lumber for pallets, and hardwood plywood and veneer for furniture manufacture.

\section{Projected Demand for Sawtimber}

About 70 percent of the roundwood consumed in 1970 came from the saw-log portion of sawtimber trees (See Append. II). Trends in consumption of sawtimber in the past couple of decades have been very similar to the trends for total roundwood, that is not much rise in the 1950 's but a fairly rapid upward movement in the 1960's and early 1970's (table 151, fig. 78; Append. V, tables 33-35).

With 1970 relative prices, projected demand (medium level) for softwood sawtimber rises from 47.6 billion board feet in 1970 to 72.6 billion board feet in 2000-an increase of 53 percent.

Projected demand for hardwood sawtimber (medium level-1970 prices) also mores up from 12.3 billion board feet in 1970 to 24.3 billion feet by 2000 , an increase of nearly 100 percent.

The alternative assumptions on population and economic activity result in a substantial range in projected demand for sawtimber. By 2000, projected demands at 1970 prices vary from about 63 billion to 84 billion board feet-levels that are respectively 13 percent below and 16 percent above the medium level.

Since most sawtimber is used for lumber and plywood, where demand is relatively responsive to price changes, projected demands under higher price assumptions are materially lower than with the 1970 price assumptions.

Thus, with rising prices (that is, with lumber prices rising at 1.5 percent, plywood prices rising by 1.0 percent, and paper and board prices rising by 0.5 percent) the medium projection of demand for sof twood sawtimber in 2000 anıounts to about 55 billion board feet-some 16 percent above 1970 , but 24 percent below the projected level with 1970 relative prices.

Projected hardwood sawtimber demand in 2000, under this rising price assumption, totals 19.1 billion board feet-55 percent above 1970 .

With prices of softwood lumber and plywood 30 percent above the 1970 average, paper and board prices 10 percent and other products 15 percent higher, projected demand for softwood sawtimber reaches 61.9 billion board feet by 2000 , and hardwood sawtimber about 21 billion board feet.

\section{Sawtimber consumption, 1950 -72 with projected demand (medium level) to 2000 under alternative price assumptions}

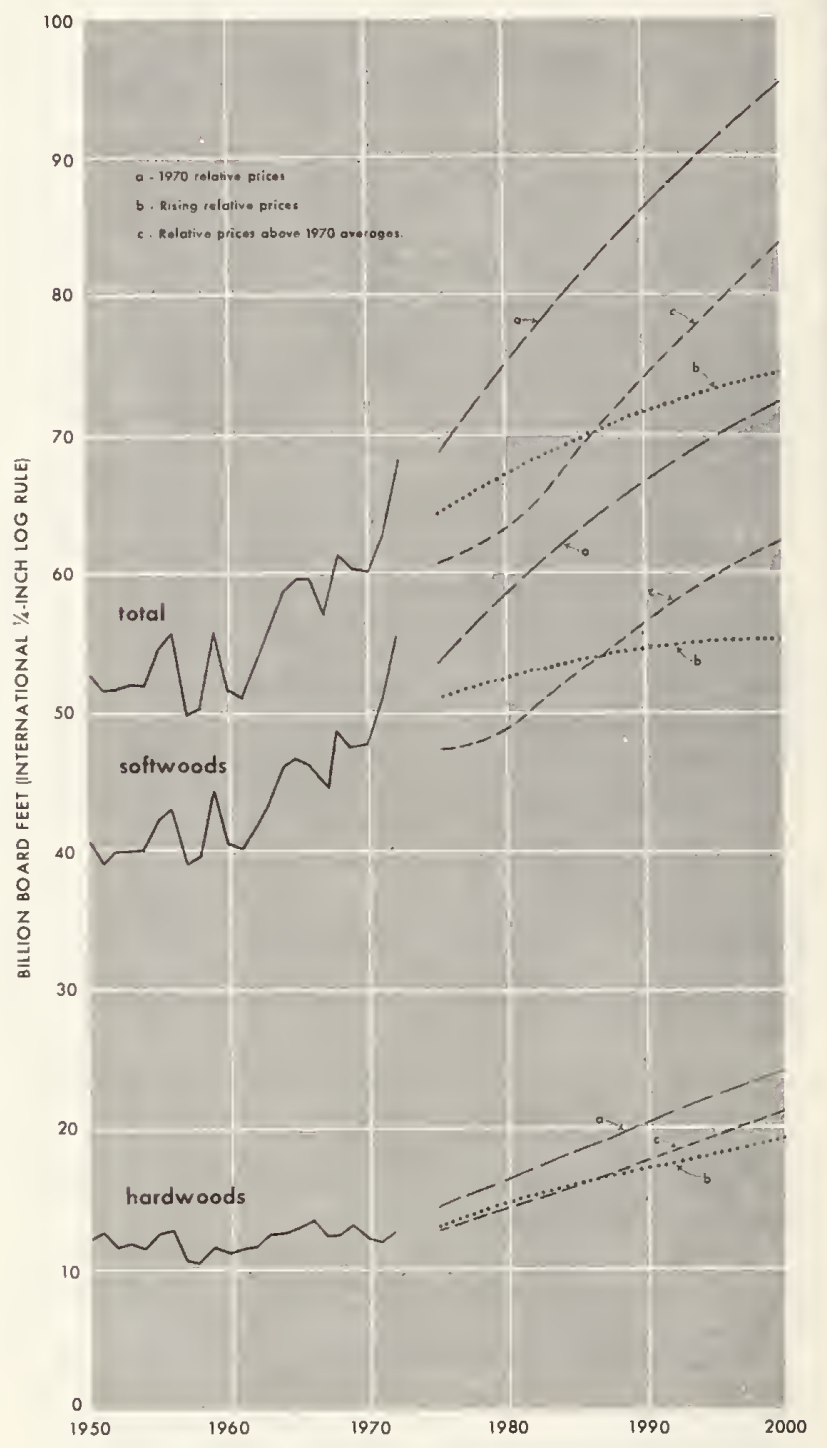

Figure 78

\section{Projected Export Demand}

The roundwood equivalent of exports of timber products-lumber, pulp products, logs, etc.increased from 0.1 billion cubic feet in 1950 to 1.4 billion cubic feet in 1970 (table 152, fig. 79; Append. V, tables 30-32). Most of the increase in exports in these two decades was for logs and pulp products produced mainly from softwood timber.

Estimated volumes of sawtimber used for exported products also showed a large increase 
TABLE 151.-Summary of sautimber consumption by species group and major product, 1952, 1962, and 1970, with projections of demand (medium level ${ }^{1}$ ) under alternative price assumptions to 2000

[Billion board feet, International 1/4-inch log rule]

\begin{tabular}{|c|c|c|c|c|c|c|c|c|c|c|c|c|}
\hline \multirow{3}{*}{ Species group and product } & \multirow{3}{*}{1952} & \multirow{3}{*}{1962} & \multirow{3}{*}{1970} & \multicolumn{9}{|c|}{ Projections } \\
\hline & & & & \multicolumn{3}{|c|}{1970 relative prices } & \multicolumn{3}{|c|}{$\begin{array}{l}\text { Rising relative } \\
\text { prices }{ }^{2}\end{array}$} & \multicolumn{3}{|c|}{$\begin{array}{l}\text { Relative prices above } \\
1970 \text { averages }^{3}\end{array}$} \\
\hline & & & & 1980 & 1990 & 2000 & 1980 & 1990 & 2000 & 1980 & 1990 & 2000 \\
\hline SOFTWOODS & & & & & & & & & & & & \\
\hline $\begin{array}{l}\text { Saw logs } \\
\text { Veneer logs } \\
\text { Pulpwood } \\
\text { Wiscellaneous products } \\
\text { Fuelwood. }\end{array}$ & $\begin{aligned} 31.8 \\
1.9 \\
4.3 \\
1.2 \\
.6\end{aligned}$ & $\begin{array}{r}30.8 \\
4.9 \\
5.0 \\
.9 \\
.1\end{array}$ & $\begin{aligned} \text { 31. } 6 \\
6.8 \\
8.0 \\
1.0 \\
.1\end{aligned}$ & $\begin{aligned} 38 . & 5 \\
10 . & 0 \\
9 . & 2 \\
1 . & 0 \\
. & 1\end{aligned}$ & $\begin{array}{r}42.2 \\
11.5 \\
11.6 \\
1.0 \\
.1\end{array}$ & $\begin{array}{r}\text { 43. } 9 \\
13.0 \\
14.5 \\
1.0 \\
.1\end{array}$ & $\begin{aligned} & \text { 33. } 3 \\
& 8.9 \\
& 8.2 \\
& .9 \\
& .1\end{aligned}$ & $\begin{aligned} & 33 . 1 \\
& 9.8 \\
& 10.1 \\
& .9 \\
& .1\end{aligned}$ & $\begin{array}{r}31.4 \\
10.0 \\
12.6 \\
.8 \\
.1\end{array}$ & $\begin{array}{r}31.5 \\
8.1 \\
8.0 \\
.9 \\
.1\end{array}$ & $\begin{array}{r}35.1 \\
9.4 \\
10.2 \\
.9 \\
.1\end{array}$ & $\begin{aligned} & 37 . 1 \\
& 10.6 \\
& 13 . \\
& .9 \\
& .1\end{aligned}$ \\
\hline Total ${ }^{5} \ldots$ & 39.9 & 41.7 & 47. 6 & 58.9 & 66.5 & 72.6 & 51.5 & 54.1 & 55.0 & 48. 7 & 55.8 & 61. \\
\hline 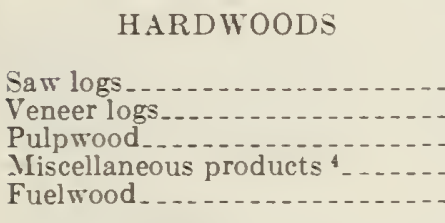 & $\begin{array}{l}\text { 7. } 1 \\
\text { 1. } 1 \\
\text { 1. } 4 \\
\text { 1. } 7\end{array}$ & $\begin{array}{r}6.5 \\
1.6 \\
2.2 \\
.6 \\
.7\end{array}$ & $\begin{aligned} 7.3 \\
1.8 \\
2.2 \\
.7 \\
.3\end{aligned}$ & $\begin{array}{r}8.9 \\
2.5 \\
3.8 \\
.7 \\
.3\end{array}$ & $\begin{aligned} \text { 10. } 6 \\
3.1 \\
5.5 \\
.7 \\
.3\end{aligned}$ & $\begin{array}{r}11.8 \\
3.5 \\
7.9 \\
.7 \\
.3\end{array}$ & $\begin{array}{r}\text { 7. } 7 \\
2.2 \\
\text { 3. } 5 \\
.7 \\
.3\end{array}$ & $\begin{array}{r}8.4 \\
2.5 \\
4.8 \\
.6 \\
.3\end{array}$ & $\begin{array}{r}8.6 \\
2.6 \\
6.9 \\
.6 \\
.3\end{array}$ & $\begin{array}{r}7.4 \\
2.1 \\
\text { 3. } 4 \\
.7 \\
.3\end{array}$ & $\begin{array}{r}9.0 \\
2.5 \\
4.8 \\
.7 \\
.3\end{array}$ & $\begin{array}{r}10 . \\
2 . \\
7 . \\
? \\
?\end{array}$ \\
\hline Total ${ }^{5} \ldots \ldots$ & 11.6 & 11. 7 & 12. 3 & 16. 3 & 20. 3 & 24. 3 & 14.5 & 16. 7 & 19. 1 & 14.0 & 17.4 & 21. \\
\hline $\begin{array}{l}\text { ALL SPECIES } \\
\text { Saw logs } \\
\text { Yeneer logs } \\
\text { Pulpwood } \\
\text { Miscellaneous products } 4 \\
\text { Fuelwood. }\end{array}$ & $\begin{array}{r}39.0 \\
3.0 \\
4.7 \\
2.4 \\
2.3\end{array}$ & $\begin{array}{r}37.2 \\
6.5 \\
7.2 \\
1.5 \\
.8\end{array}$ & $\begin{array}{r}38.9 \\
8.6 \\
10.2 \\
1.7 \\
.4\end{array}$ & $\begin{array}{r}47.4 \\
12.5 \\
13.0 \\
1.7 \\
.4\end{array}$ & $\begin{array}{r}52.8 \\
14.6 \\
17.1 \\
1.7 \\
.4\end{array}$ & $\begin{array}{r}55.7 \\
16.5 \\
22.4 \\
1.7 \\
.4\end{array}$ & $\begin{array}{r}41.0 \\
11.1 \\
11.7 \\
1.6 \\
.4\end{array}$ & $\begin{array}{r}41.5 \\
12.3 \\
14.9 \\
1.5 \\
.4\end{array}$ & $\begin{array}{r}40.0 \\
12.6 \\
19.5 \\
1.4 \\
.4\end{array}$ & $\begin{array}{r}38.9 \\
10.2 \\
11.4 \\
1.6 \\
.4\end{array}$ & $\begin{array}{r}44.1 \\
11.9 \\
15.0 \\
1.6 \\
.4\end{array}$ & $\begin{array}{r}47.2 \\
13.3 \\
20 . \\
1 .\end{array}$ \\
\hline Total $5 \ldots$ & 51.6 & 53. 3 & 59. 9 & 75.2 & 86. 8 & 96. 9 & 66. 0 & 70.8 & 74. 1 & 62. 7 & 73. 2 & 83. \\
\hline
\end{tabular}

Based on the medium projections of growth in population and economic activity shown in the introductory section of this chapter.

2 Relative prices rising from 1970 trend levels as follows: lumber-1.5 percent per year; plywood, miscellaneous product, and fuelwood-1.0 percent per year; paper and board- 0.5 percent per year.

${ }^{3}$ Relative prices of lumber and plywood-30 percent, miscellaneous products and fuelwood-15 percent, and paper and board-10 percent, above the 1970 averages.

Includes cooperage logs, poles, piling, fence posts, hewn ties, round mine timbers, box bolts, excelsior bolts,

between 1950 and 1970 , from 0.7 to 4.7 billion board feet (table 153 ; Append. V, tables 33-35).

Under the assumptions discussed above, projected exports in terms of roundwood rise to 1.8 billion cubic feet in 2000 , some 29 percent above the rolume shipped in 1970 . Projected sawtimber exports show about the same trends as roundwood.

\section{Projected Imports}

Total imports of timber products rose from 1.4 billion cubic feet roundwood equivalent in 1950 to 2.4 billion cubic feet in 1970 and to 2.9 billion chemical wood, shingle bolts, and other miscellaneous items.

${ }^{5}$ Includes imported logs not shown by major product use.

Note: Data may not add to totals because of rounding.

Sources: 1952, 1962, and 1970-Based on data published by the U.S. Departments of Commerce and Agriculture.

Projections: U.S. Department of Agriculture, Forest Service.

in 1972 (table 152 , fig. 79 ; Append. $Y$, tables 30 33). Most of these increased imports consisted of sof twood lumber and pulp products from Canada.

With 1970 relative prices, projected imports amount to 2.7 billion cubic feet of roundwood equivalent by 1980 (medium projection) and remain at this level through the projection period. With higher prices covering the costs of developing unused softwood resources in northern parts of Canada, projected imports approximate 4.6 billion cubic feet by 2000-nearly double the 1970 level (fig. 79). 
TABLE 152.-Summary of roundwood consumption, exports, imports, and production from U.S. forests, 1952, 1962, and 1970, with projections (medium level ${ }^{1}$ ) under alternative price assumptions to 2000

[Billion cubic feet, roundwood equivalent]

\begin{tabular}{|c|c|c|c|c|c|c|c|c|c|c|c|c|}
\hline \multirow{3}{*}{ Item } & \multirow{3}{*}{1952} & \multirow{3}{*}{1962} & \multirow{3}{*}{1970} & \multicolumn{9}{|c|}{ Projections } \\
\hline & & & & \multicolumn{3}{|c|}{$\begin{array}{l}1970 \text { relative } \\
\text { prices }\end{array}$} & \multicolumn{3}{|c|}{$\begin{array}{l}\text { Rising relative } \\
\text { prices }^{2}\end{array}$} & \multicolumn{3}{|c|}{$\begin{array}{l}\text { Relative prices } \\
\text { above } 1970 \\
\text { averages }^{3}\end{array}$} \\
\hline & & & & 1980 & 1990 & 2000 & 1980 & 1990 & 2000 & 1980 & 1990 & 2000 \\
\hline SOFTWOODS & & & & & & & & & & & & \\
\hline $\begin{array}{l}\text { U.S. consumption } \\
\text { Exports } \\
\text { Imports } \\
\text { Production from U.S. forests }\end{array}$ & $\begin{array}{l}\text { 8. } 4 \\
.2 \\
\text { 1. } 3 \\
\text { 7. } 3\end{array}$ & $\begin{array}{l}8.5 \\
.4 \\
1.7 \\
7.2\end{array}$ & $\begin{array}{l}\text { 9. } 7 \\
\text { 1. } 2 \\
\text { 2. } 1 \\
\text { 8. } 8\end{array}$ & $\begin{array}{r}12.1 \\
1.7 \\
2.3 \\
11.5\end{array}$ & $\begin{array}{r}14.1 \\
1.6 \\
2.3 \\
13.4\end{array}$ & $\begin{array}{r}15.8 \\
1.6 \\
2.3 \\
15.1\end{array}$ & $\begin{array}{r}11.2 \\
1.7 \\
3.1 \\
9.8\end{array}$ & $\begin{array}{r}12.4 \\
1.6 \\
3.7 \\
10.3\end{array}$ & $\begin{array}{r}13.5 \\
1.6 \\
4.0 \\
11.1\end{array}$ & $\begin{array}{r}\text { 10. } 7 \\
1.7 \\
\text { 3. } 2 \\
9.2\end{array}$ & $\begin{array}{r}12.7 \\
1.6 \\
3.6 \\
10.7\end{array}$ & $\begin{array}{r}14.3 \\
1.6 \\
3.7 \\
12.2\end{array}$ \\
\hline $\begin{array}{l}\text { HARDWOODS } \\
\text { U.S. consumption } \\
\text { Exports } \\
\text { Imports } \\
\text { Production from U.S. forests }\end{array}$ & $\begin{array}{l}3.5 \\
\left({ }^{4}\right) \\
\text { 3. } 1 \\
\text { 3. } 5\end{array}$ & $\begin{array}{r}3.1 \\
.1 \\
.2 \\
\text { 3. } 0\end{array}$ & $\begin{array}{r}3.0 \\
.2 \\
.3 \\
2.9\end{array}$ & $\begin{array}{r}4.3 \\
.2 \\
.4 \\
4.1\end{array}$ & $\begin{array}{r}5.5 \\
.2 \\
.4 \\
5.3\end{array}$ & $\begin{array}{r}7.0 \\
.2 \\
.4 \\
6.8\end{array}$ & $\begin{array}{r}4.0 \\
.2 \\
.5 \\
3.7\end{array}$ & $\begin{array}{r}4.7 \\
.2 \\
.5 \\
\text { 4. } 4\end{array}$ & $\begin{array}{r}5.7 \\
.2 \\
.6 \\
5.3\end{array}$ & $\begin{array}{r}3.9 \\
.2 \\
.6 \\
3.5\end{array}$ & $\begin{array}{r}4.9 \\
.2 \\
.6 \\
4.5\end{array}$ & $\begin{array}{r}6.4 \\
.2 \\
.6 \\
6.0 \\
\end{array}$ \\
\hline $\begin{array}{l}\text { ALL SPECIES } \\
\text { U.S. consumption } \\
\text { Exports } \\
\text { Imports } \\
\text { Production from U.S. forests }\end{array}$ & $\begin{array}{r}11.9 \\
.2 \\
1.4 \\
10.8\end{array}$ & $\begin{array}{r}11.6 \\
.5 \\
1.9 \\
10.2\end{array}$ & $\begin{array}{r}12.7 \\
1.4 \\
2.4 \\
11.7\end{array}$ & $\begin{array}{r}16.4 \\
1.9 \\
2.7 \\
15.6\end{array}$ & $\begin{array}{r}19.6 \\
1.8 \\
2.7 \\
18.7\end{array}$ & $\begin{array}{r}22.8 \\
1.8 \\
2.7 \\
21.9\end{array}$ & $\begin{array}{r}15.2 \\
1.9 \\
3.6 \\
13.5\end{array}$ & $\begin{array}{r}17.1 \\
1.8 \\
4.2 \\
14.7\end{array}$ & $\begin{array}{r}19.2 \\
1.8 \\
4.6 \\
16.4\end{array}$ & $\begin{array}{r}14.6 \\
1.9 \\
3.8 \\
12.7\end{array}$ & $\begin{array}{r}17.6 \\
1.8 \\
4.2 \\
15.2\end{array}$ & $\begin{array}{r}20.7 \\
1.8 \\
4.3 \\
18.2\end{array}$ \\
\hline
\end{tabular}

${ }^{1}$ Based on the medium projections of growth in population and economic activity shown in the introductory section of this chapter.

${ }^{2}$ Relative prices rising from 1970 trend level as follows: lumber-1.5 percent per year; plywood, miscellaneous products, and fuelwood-1.0 percent per year; paper and board -0.5 percent per year.

3 Relative prices of lumber and plywood-30 percent, miscellaneous products and fuelwood-15 percent, and paper and board-10 percent above the 1970 averages.

Imports and exports of timber products, 1940-72, with projections* to 2000

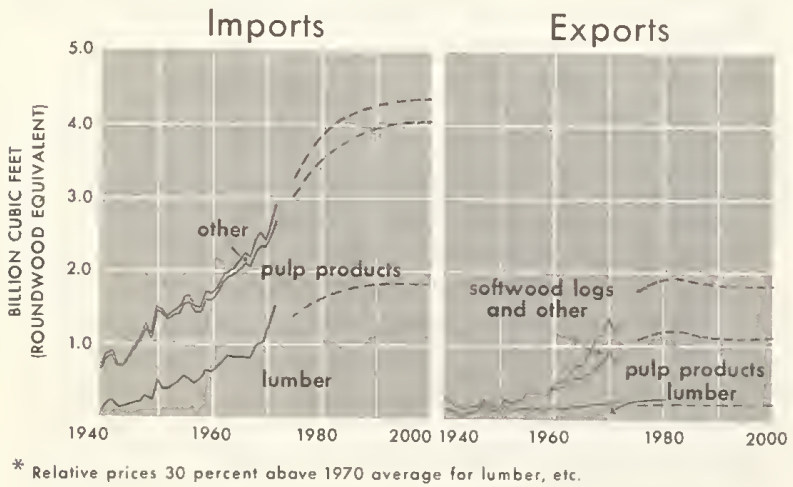

Figure 79
${ }^{4}$ Less than 50 million cubic feet.

5 The data for 1952,1962 , and 1970 are estimates of actual harvests and are not directly comparable with the trend level estimates of supply shown in Chapter II.

Note: Data may not add to totals because of rounding.

Sources: 1952-70-Based on data published by the U.S. Departments of Commerce and Agriculture.

Projections: U.S. Department of Agriculture, Forest Service.

Projected imports in terms of sawtimber follow about the same trend as total roundwood, that is, show comparatively little change with 1970 relative prices but substantial increases under the higher assumptions.

\section{Projected Net Imports}

Between 1950 and 1970 growth in imports roughly equalled the rise in exports; as a result, net annual imports remained fairly stable at about 1.3 billion cubic feet and composed about 11 percent of consumption. Net imports rose to a peak of 1.6 billion cubic feet in 1972 , but remain at about 11 percent of U.S. consumption.

Net imports of products derived from sawtimber increased from around 2 billion board feet in the early 1950's to over 4 billion feet in the early 1970 's. Most of this growth reflected the sharp rise 
TABLE 153.-Summary of sawtimber consumption, exports, imports, and production from U.S. forests, 1952, 1962, and 1970, with projections (medium level ${ }^{1}$ ) under alternative price assumptions to 2000

[Billion board feet, International 1/4-inch log rule]

\begin{tabular}{|c|c|c|c|c|c|c|c|c|c|c|c|c|}
\hline \multirow{3}{*}{ Item } & \multirow{3}{*}{1952} & \multirow{3}{*}{1962} & \multirow{3}{*}{1970} & \multicolumn{9}{|c|}{ Projections } \\
\hline & & & & \multicolumn{3}{|c|}{$\begin{array}{l}1970 \text { relative } \\
\text { prices }\end{array}$} & \multicolumn{3}{|c|}{$\begin{array}{l}\text { Rising relative } \\
\text { prices }^{2}\end{array}$} & \multicolumn{3}{|c|}{$\begin{array}{l}\text { Relative prices } \\
\text { above } 1970 \\
\text { averages }{ }^{3}\end{array}$} \\
\hline & & & & 1980 & 1990 & 2000 & 1980 & 1990 & 2000 & 1980 & 1990 & 2000 \\
\hline SOFTITOODS & & & & & & & & & & & & \\
\hline $\begin{array}{l}\text { U.S. consumption } \\
\text { Exports } \\
\text { Imports } \\
\text { Production form U.S. forests }\end{array}$ & $\begin{array}{r}39.9 \\
.7 \\
2.4 \\
38.2\end{array}$ & $\begin{array}{r}41.7 \\
1.2 \\
4.6 \\
38.3\end{array}$ & $\begin{array}{r}47.6 \\
4.6 \\
5.9 \\
46.2\end{array}$ & $\begin{array}{r}58.9 \\
5.6 \\
6.6 \\
57.9\end{array}$ & $\begin{array}{r}66.5 \\
5.6 \\
6.5 \\
65.6\end{array}$ & $\begin{array}{r}72.6 \\
5.6 \\
6.4 \\
71.8\end{array}$ & $\begin{array}{r}51.5 \\
5.6 \\
8.9 \\
48.2 \\
\end{array}$ & $\begin{array}{r}54.1 \\
5.6 \\
10.8 \\
48.9\end{array}$ & $\begin{array}{r}55.0 \\
5.5 \\
11.4 \\
49.1\end{array}$ & $\begin{array}{r}48.7 \\
5.6 \\
9.6 \\
44.7\end{array}$ & $\begin{array}{r}55.8 \\
5.6 \\
10.8 \\
50.6\end{array}$ & $\begin{array}{r}61.9 \\
5.6 \\
10.8 \\
56.7\end{array}$ \\
\hline HARDWOODS & & & & & & & & & & & & \\
\hline $\begin{array}{l}\text { U.S. consumption } \\
\text { Exports } \\
\text { Imports } \\
\text { Production from U.S. forests }\end{array}$ & $\begin{array}{r}11.6 \\
.2 \\
1.3 \\
11.5\end{array}$ & $\begin{array}{r}11.7 \\
.2 \\
1.0 \\
10.9\end{array}$ & $\begin{aligned} \text { 12. } 3 \\
.2 \\
1.3 \\
11.2\end{aligned}$ & $\begin{array}{r}16.3 \\
.2 \\
2.0 \\
14.5\end{array}$ & $\begin{array}{r}20.3 \\
.2 \\
2.0 \\
18.5\end{array}$ & $\begin{array}{r}24.3 \\
.2 \\
2.0 \\
22.5\end{array}$ & $\begin{array}{r}14.5 \\
.2 \\
2.0 \\
12.7\end{array}$ & $\begin{array}{r}16.7 \\
.2 \\
2.3 \\
14.6\end{array}$ & $\begin{array}{r}19.1 \\
2.2 \\
16.7 \\
16.6\end{array}$ & $\begin{array}{r}14.0 \\
.2 \\
2.4 \\
11.8\end{array}$ & $\begin{array}{r}17.4 \\
.2 \\
2.4 \\
15.2\end{array}$ & $\begin{array}{r}21.1 \\
.2 \\
2.4 \\
18.9\end{array}$ \\
\hline ALL SPECIES & & & & & & & & & & & & \\
\hline $\begin{array}{l}\text { U.S. consumption } \\
\text { Exports } \\
\text { Imports } \\
\text { Production from U.S. forests } 4\end{array}$ & $\begin{array}{r}51.6 \\
2.7 \\
49.6\end{array}$ & $\begin{aligned} 53 . & 3 \\
1 . & 4 \\
5 . & 6 \\
49 . & 1\end{aligned}$ & $\begin{array}{r}59.9 \\
4.7 \\
7.3 \\
57.3\end{array}$ & $\begin{array}{r}75.2 \\
5.8 \\
8.6 \\
72.4\end{array}$ & $\begin{aligned} 86.8 \\
5.8 \\
8.5 \\
84.1\end{aligned}$ & $\begin{array}{r}96.9 \\
5.8 \\
8.4 \\
94.3\end{array}$ & $\begin{array}{r}66.0 \\
5.8 \\
10.9 \\
60.9\end{array}$ & $\begin{array}{r}70.8 \\
5.8 \\
13.1 \\
63.5\end{array}$ & $\begin{array}{r}74.1 \\
5.7 \\
14.1 \\
65.7\end{array}$ & $\begin{array}{r}62.7 \\
5.8 \\
12.0 \\
56.5\end{array}$ & $\begin{array}{r}\text { 73. } 2 \\
5.8 \\
13.2 \\
65.8\end{array}$ & $\begin{array}{r}83.0 \\
5.8 \\
13.2 \\
75.6\end{array}$ \\
\hline
\end{tabular}

${ }^{1}$ Based on the medium projections of growth in population and economic activity shown in the introductory section of this chapter.

2 Relative prices rising from 1970 trend level as follows: lumber-1.5 percent per year; plywood, miscellaneous products, and fuelwood-1.0 percent per year; paper and board- -0.5 percent per year.

3 Relative prices of lumber and plywood-30 percent, miscellaneous products and fuelwood-15 percent, and paper and board-10 percent, above the 1970 averages.

in imports of softwood lumber and hardwood plywood.

Projected net imports of timber products increase moderately under the higher price assumptions. But net imports under all price assumptions remain comparatively small in relation to total U.S. demıands for timber products. Thus, it seems evident that the Nation must continue to depend largely on domestic forests to supply future timber markets.

\section{Projected Demand for Roundwood From U.S. Forests}

Production of softwood roundwood from U.S. forests showed little change in the 1950's but a fairly fast increase in the 1960's (table 152; Append. V, tables 30-32). Production of saw timber from U.S. forests followed similar trends (table 153; Append. T, tables 33-35).

In contrast, production of hardwood-roundwood and sawtimber-showed a slight downward trend during both decades.
4 The data for 1952,1962 , and 1970 are estimates of actual harvests and are not directly comparable with the trend level estimates of supply shown in Chapter II.

Note: Data may not add to totals because of rounding.

Sources: 1952-70-Based on data published by the U.S. Departments of Commerce and Agriculture.

Projections: U.S. Department of Agriculture, Forest Service.

Projected demand for timber from U.S. forestsmedium level and 1970 prices-rises from 11.7 billion cubic feet in 1970 to 21.9 billion cubic feet by $2000-$ a rise of 87 percent. Associated demands for sawtimber rise from 57.3 to 94.3 billion board feet. Most of the projected increases in demand is for softwoods. However, projected demand for hardwoods rises sharply-roughly doubling by 2000 .

As in the case of total demand, use of alternative economic and price assumptions has substantial impacts on projected demands for timber from U.S. forests. With relative prices 30 percent above the 1970 arerages, for example, projected demands on U.S. forests by 2000 reach 18.2 billion cubic feet, including 75.6 billion board feet of sawtimber. These volumes are 56 percent and 32 percent, respectively, above 1970 production levels.

Because of differences in the size of the assumed price increases by product, and differences in the sensitivity of demand for each product to rising 
prices, the impact of higher prices is primarily on demands for sawtimber products. For example, under the rising price assumption ( 1.5 percent per year for lumber; 1.0 percent for plywood, miscellaneous products, and fuelwood; and 0.5 percent for paper and board) demands for domestic sawtimber in 2000 would be 65.7 billion board feet-about 15 percent above production in 1970 . In contrast, projected demands for softwood roundwood rise by about 40 percent, largely because of increases in demand for pulpwood.

Although there are differences in the magnitudes of the increases, all projections indicate substantially larger demands on U.S. forests. There are fundamental questions as to the ability of U.S. forests to supply projected demands and the size of price increases necessary to bring demands into equilibrium with supplies. These questions are considered in the following chapter.

\section{DEMAND FOR INDUSTRIAL TIMBER PRODUCTS IN RELATION TO OTHER INDUSTRIAL RAW MATERIALS}

Timber is one of the basic industrial raw materials used in the U.S. economy. An analysis of prospective demands for other materials is of interest in judging the validity of timber demand projections and of likely changes in the relative importance of the major industrial raw materials. Mineral products, including metals, sand, gravel, and cement, are of special importance in this connection. Some competition also exists between timber products and other agricultural and related products such as fibers and rubber.

Between 1900 and 1969 consumption of all industrial raw materials increased from $\$ 4.5$ billion (1967 dollars) to $\$ 17.1$ billion (Append. $V$, table 36). Per capita use of materials in 1967 dollars rose from around $\$ 50$ to about $\$ 85$.

Annual rates of growth in use of industrial raw materials in these seven decades averaged about 2 percent per year--substantially below the rate of increase in the gross national product. This differential resulted from such factors as refinements in manufacturing that added more value to given amounts of raw materials; more complete utilization of raw materials; increased recycling of scrap and used materials; and relative increases in the transportation, trade, and service components of the gross national product.

During the first 5 decades of this century, there were some substantial shifts in the relative importance of various industrial raw materials (fig. 80). Industrial timber products declined in relative importance, falling from about 45 percent of all industrial raw materials consumed in 1900 to around 20 percent in 1950 while minerals showed an offsetting increase. Since the mid-

\section{Relative importance of industrial raw materials}

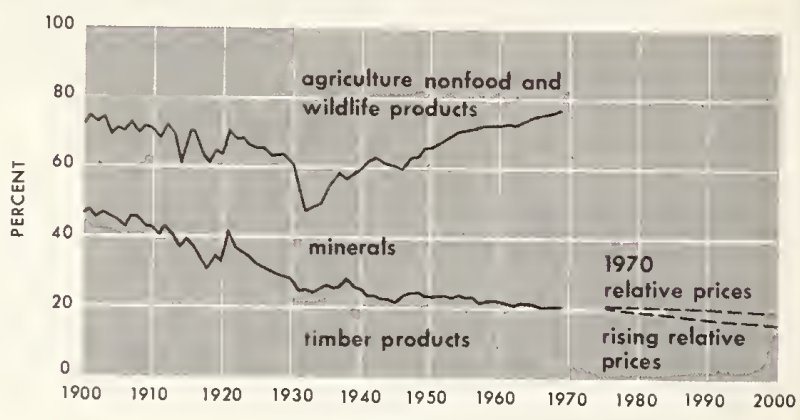

Figure 80

1950's, there has been little change in the composition of the raw materials used.

The decline in relative importance of industrial timber products before 1950 was presumably related to the fact that prices of most timber products showed substantial increases relative to the general price level and relative to prices of minerals and farm products. ${ }^{53}$ On the other hand, there was little change in timber product prices relative to the general price level and to most competing materials between 1950 and 1967 .

There has been a close statistical relationship between changes in the consumption of industrial raw materials and changes in the gross national product in the past two decades. Projections based on this relationship indicate that demand (medium level) for industrial raw materials may reach $\$ 30.8$ billion (1967 dollars) by 2000 (table 154). Rates of increase in this projection are about the same as projected rates of increase in demand for industrial roundwood at 1970 relative prices, as shown by the following tabulation of annual rates of increase.

\begin{tabular}{|c|c|c|c|c|}
\hline \multirow[b]{2}{*}{ Period } & \multirow{2}{*}{$\begin{array}{c}\text { All } \\
\text { industrial } \\
\text { raw } \\
\text { materials }\end{array}$} & \multicolumn{3}{|c|}{ Timber products } \\
\hline & & $\begin{array}{c}1970 \\
\text { relative } \\
\text { prices }\end{array}$ & $\begin{array}{l}\text { Rising } \\
\text { relative } \\
\text { prices } 1\end{array}$ & $\begin{array}{l}\text { Higher } \\
\text { relative } \\
\text { prices }{ }^{2}\end{array}$ \\
\hline $1940-69 \ldots$ & ${ }^{3} 2.4$ & ${ }^{3} 1.6$ & $-\ldots$ & 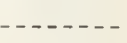 \\
\hline $1969-2000_{-}$ & - - & 1. 9 & 1. 3 & 1. 6 \\
\hline
\end{tabular}

A rise in relative prices of timber products, however, could be expected to reduce growth rates for timber products and shift demands to other industrial raw materials.

53 Sce Fisher, Joseph F., and Neal Potter. World prospects for national resources. The Johns Hopkins Press, Baltimore, Maryland. 1964. 
TABLE 154.-Consumption of industrial raw materials in the U.S. by broad product groups, selected years $1920-69$, with projections of demand to 2000

[Billions of 1967 dollars]

\begin{tabular}{|c|c|c|c|c|c|}
\hline \multirow[b]{2}{*}{ Year } & \multirow[b]{2}{*}{$\begin{array}{l}\text { All industrial } \\
\text { raw materials }\end{array}$} & \multirow[b]{2}{*}{$\begin{array}{l}\text { Industrial timber } \\
\text { products }^{1}\end{array}$} & \multicolumn{3}{|c|}{ Nonwood materials } \\
\hline & & & Total & $\begin{array}{l}\text { Minerals except } \\
\text { fuels }^{2}\end{array}$ & $\begin{array}{l}\text { Agriculture and } \\
\text { fisliery nonfoods and } \\
\text { wildlife products }{ }^{3}\end{array}$ \\
\hline $\begin{array}{l}1920 \ldots \ldots \\
1925 \ldots \ldots \\
1930 \ldots \ldots \\
1935 \ldots \ldots \\
1940 \\
1945 \ldots \ldots \ldots \\
1950 \ldots \ldots \\
1955 \ldots \ldots \ldots \\
1960 \ldots \ldots \\
1965 \ldots \ldots \\
1966 \ldots \ldots \\
1967 \ldots \ldots \\
1968 \\
1969\end{array}$ & $\begin{array}{r}\text { 7. } 01 \\
\text { 7. } 91 \\
6.99 \\
6.10 \\
8.66 \\
10.14 \\
12.48 \\
13.25 \\
13.47 \\
16.40 \\
17.10 \\
16.45 \\
17.16 \\
17.14\end{array}$ & $\begin{array}{l}\text { 2. } 27 \\
\text { 2. } 49 \\
\text { 1. } 93 \\
\text { 1. } 58 \\
\text { 2. } 14 \\
\text { 2. } 09 \\
\text { 2. } 81 \\
\text { 2. } 95 \\
\text { 2. } 83 \\
\text { 3. } 36 \\
\text { 3. } 39 \\
\text { 3. } 22 \\
\text { 3. } 40 \\
\text { 3. } 40\end{array}$ & $\begin{array}{r}\text { 4. } 74 \\
5.42 \\
5.06 \\
4.52 \\
6.52 \\
8.05 \\
9.67 \\
10.30 \\
\text { 10. } 64 \\
13.04 \\
13.71 \\
13.23 \\
13.76 \\
13.74\end{array}$ & $\begin{array}{l}\text { 2. } 11 \\
\text { 2. } 61 \\
\text { 2. } 32 \\
\text { 1. } 62 \\
\text { 2. } 94 \\
\text { 3. } 99 \\
5.30 \\
\text { 6. } 37 \\
6.83 \\
8.82 \\
9.35 \\
9.14 \\
9.57 \\
9.71\end{array}$ & $\begin{array}{l}\text { 2. } 63 \\
\text { 2. } 81 \\
\text { 2. } 74 \\
\text { 2. } 90 \\
\text { 3. } 58 \\
\text { 4. } 06 \\
\text { 4. } 37 \\
\text { 3. } 93 \\
\text { 3. } 81 \\
\text { 4. } 22 \\
\text { 4. } 36 \\
\text { 4. } 09 \\
\text { 4. } 19 \\
\text { 4. } 03\end{array}$ \\
\hline
\end{tabular}

Projections -1970 relative prices

\begin{tabular}{ll|l|l|l|l}
\hline & & & & \\
1980 & 22.18 & 4.40 & 17.58 & 13.78 & 4.00 \\
1990 & 26.62 & 5.28 & 21.06 & 17.34 & 4.00 \\
2000 & 30.80 & 6.11 & 24.60 & 20.69 & 4.00 \\
\hline
\end{tabular}

Projections-rising relative prices

\begin{tabular}{|c|c|c|c|c|c|}
\hline $\begin{array}{l}1980 \ldots \\
1990 \\
2000\end{array}$ & $\begin{array}{l}22.18 \\
26.62 \\
30.80\end{array}$ & $\begin{array}{l}\text { 4. } 01 \\
\text { 4. } 53 \\
\text { 5. } 06\end{array}$ & $\begin{array}{l}18.17 \\
22.09 \\
25.74\end{array}$ & $\begin{array}{l}\text { 14. } 17 \\
18.09 \\
21.74\end{array}$ & $\begin{array}{l}\text { 4. } 00 \\
\text { 4. } 00 \\
\text { 4. } 00\end{array}$ \\
\hline
\end{tabular}

Projections-relative prices above 1970 average $^{5}$

\begin{tabular}{|c|c|c|c|c|c|}
\hline $\begin{array}{l}1980 \ldots \ldots \\
1990 \ldots \ldots \\
2000\end{array}$ & $\begin{array}{l}22.18 \\
26.62 \\
30.80\end{array}$ & $\begin{array}{l}3.84 \\
4.67 \\
5.56\end{array}$ & $\begin{array}{l}\text { 18. } 34 \\
21.95 \\
25.24\end{array}$ & $\begin{array}{l}14.34 \\
17.95 \\
21.24\end{array}$ & $\begin{array}{l}\text { 4. } 00 \\
4.00 \\
4.00\end{array}$ \\
\hline
\end{tabular}

1 Includes saw logs; veneer logs; pulpwood; and miscellaneous products, such as poles, piling, and posts.

2 Includes mineral construction materials, such as dimension stone, crushed and broken stone, sand and gravel, fire clay, common clay and shale, gypsum, and other similar construction materials; metal ores; chemical and fertilizer minerals; abrasives and other minerals.

3 Includes cotton and other fiber, oils, rubber, furs, hides, and other similar products.

4 With relative prices of timber products rising from 1970 trend levels as follows: lumber-1.5 percent per year; plywood and miscellaneous products-1.0 pereent per year; paper and board- 0.5 percent paper year.

5 With relative prices of lumber and plywood 30 percent, miscellaneous products 1.5 percent, and paper and board 10 percent above the 1970 averages.

Source: 1920-69-U.S. Department of Commerce, Bureau of the Census, and C.S. Department of the Interior, Bureau of the Mines. Raw material in the $L$ nited States economy; 1900-1969. Working Paper 35. 1972.

Projections: U.S. Department of Agriculture, Forcst Service. 
This chapter presents comparisons of (1) projected demands for timber in the United States under alternative price assumptions and (2) projected timber supplies under alternative prices and levels of forest management. Some implications of these comparisons in terms of possible price trends and impacts on the major timber industries also are included. Finally, mention is made of the kinds of forestry measures that could increase or extend timber supplies, and thus modif economic and environmental impacts of inadequate supplies and rising prices of timber products.

Projections of demand and supplies developed in preceding chapters are summarized in tables 155 and 156 and in figures $81,82,83$, and 84 .

\section{SOFTWOOD DEMAND.SUPPLY BALANCES WITH 1970 LEVELS OF FOREST MANAGE- MENT}

Demands on U.S. forests for softwood timber products-after allowances for imports and exports-have been projected to increase from 8.8 billion cubic feet in 1970 to a range of 11.1 to 15.1 billion cubic feet by the year 2000 with the specified price assumptions used in this study and the medium level of population and economic growth (table 155 and fig. 81).

The base projection of sof twood timber supplies from U.S. forests rises from an estimated $\$ .8$ billion cubic feet in 1970 to 11.5 billion cubic feet by 2000 , that is, to the lower part of the projected range in demand.

Comparisons of these supply and demand projections indicate that under the economic and other conditions assumed in this analysis fairly substantial increases in prices of timber products relative to the general price level will be necessary

Softwood roundwood - demand on U.S. forests and domestic supply

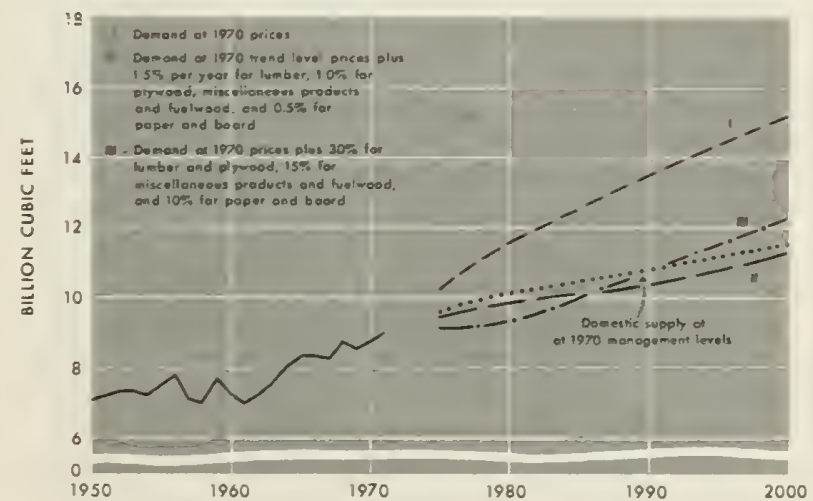

Figure 81 to balance demands and available supplies of timber. This is illustrated below for the softwood sawtimber component of the timber resource.

\section{SOFTWOOD SAWTIMBER SUPPLY-DEMAND BALANCES WITH 1970 LEVELS OF MAN- AGEMENT}

Projected demands on U.S. forests for softwood sawtimber products - after allowances for imports and exports-rise from actual consumption of 46.2 billion board feet in 1970 to a range of 49.1 to 71.8 billion board feet by 2000 under the specified price assumptions used in this analysis (table 155 and fig. 82).

The base projection of available supplies of softwood sawtimber from U.S. forests, assuming 1970 management levels and other conditions such as harresting schedules specified in Chapter II, show moderate increases to 54.2 billion board feet by 2000. Economic projections of supply related to alternative price levels for the most part are below these base projections.

These projections of economically available supplies of softwood sawtimber by 1980 range from 47 billion board feet annually at 1970 prices to about 53 billion board feet with prices of softwood lumber and plywood 50 percent above 1970 levels. In 2000 these economic projections of supply converge to nearly the same level. Differences in the time paths of timber supplies with alternative prices illustrate in part consequences of a faster increase in harresting in the 1970 's than assumed in the base projections.

Possible future price paths.-It is evident from these comparisons of demands and supplies that a significant rise in prices of softwood lumber and plywood over 1970 levels will be necessary to balance supply and demand in future decades under the economic and management conditions assumed in this analysis.

\section{Softwood sawtimber - demand on U.S. forests and domestic supply}

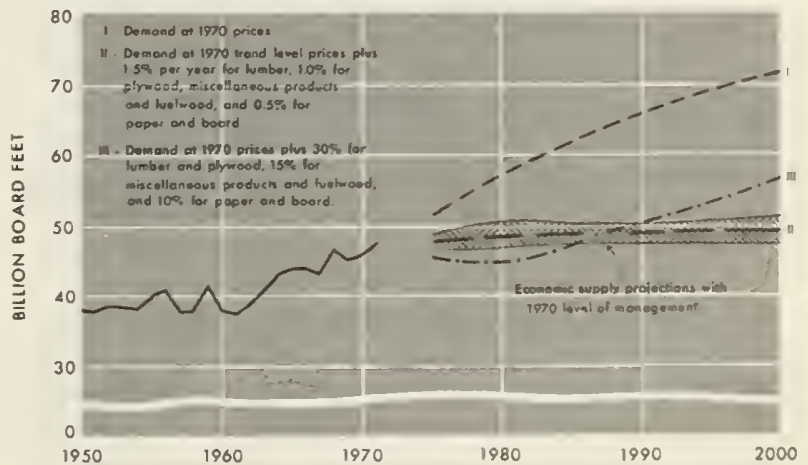

Figure 82 
TABLE 155.-Summary of softwood timber demand, exports, imports and demand on and supply from U.S. forests, 1952, 1962, and 1970, with projections to 2000 (medium level) under alternative price and man. agement assumptions

BILLION CUBIC FEET

\begin{tabular}{|c|c|c|c|c|c|c|c|c|c|c|c|c|}
\hline \multirow{3}{*}{ Item } & \multirow{3}{*}{$1952^{1}$} & \multirow{3}{*}{$1962^{1}$} & \multirow{3}{*}{$1970^{1}$} & \multicolumn{9}{|c|}{ Projections } \\
\hline & & & & \multicolumn{3}{|c|}{$\begin{array}{l}1970 \text { relative } \\
\text { prices }\end{array}$} & \multicolumn{3}{|c|}{$\begin{array}{c}\text { Rising relative } \\
\text { prices }{ }^{2}\end{array}$} & \multicolumn{3}{|c|}{$\begin{array}{l}\text { Relative prices } \\
\text { above } 1970 \\
\text { averages }{ }^{3}\end{array}$} \\
\hline & & & & 1980 & 1990 & 2000 & 1980 & 1990 & 2000 & 1980 & 1990 & 2000 \\
\hline \multirow{2}{*}{$\begin{array}{l}\text { Total U.S. demand } \\
\text { Exports. } \\
\text { Imports } \\
\text { Demand on U.S. forests. } \\
\text { Supply from U.S. forests- } \\
\text { base projections } \\
\text { Supply-demand balance }\end{array}$} & $\begin{array}{r}8.4 \\
.2 \\
1.3 \\
7.3\end{array}$ & $\begin{array}{r}8.5 \\
.4 \\
1.7 \\
7.2\end{array}$ & $\begin{array}{l}9.7 \\
1.2 \\
2.1 \\
8.8\end{array}$ & $\begin{array}{r}12.1 \\
1.7 \\
2.3 \\
11.5\end{array}$ & $\begin{array}{r}14.1 \\
1.6 \\
2.3 \\
13.4\end{array}$ & $\begin{array}{r}15.8 \\
1.6 \\
2.3 \\
15.1\end{array}$ & $\begin{array}{r}11.2 \\
1.7 \\
3.1 \\
9.8\end{array}$ & $\begin{array}{r}12.4 \\
1.6 \\
3.7 \\
10.3\end{array}$ & $\begin{array}{r}13.5 \\
1.6 \\
4.0 \\
11.1\end{array}$ & $\begin{array}{r}10.7 \\
1.7 \\
3.2 \\
9.2\end{array}$ & $\begin{array}{r}12.7 \\
1.6 \\
3.6 \\
10.7\end{array}$ & $\begin{array}{r}14.3 \\
1.6 \\
3.7 \\
12.2\end{array}$ \\
\hline & 7.3 & 7. 2 & 8.8 & $\begin{array}{r}10.1 \\
-1.4\end{array}$ & $\begin{array}{r}10.7 \\
-2.7\end{array}$ & $\begin{array}{r}11.5 \\
-3.6\end{array}$ & $\begin{array}{r}10.1 \\
+0.3\end{array}$ & $\begin{array}{r}10.7 \\
+0.4\end{array}$ & $\begin{array}{r}11.5 \\
+0.4\end{array}$ & $\begin{array}{r}10.1 \\
+0.9\end{array}$ & $\begin{array}{c}10.7 \\
-\end{array}$ & $\begin{array}{r}11.5 \\
-.7\end{array}$ \\
\hline
\end{tabular}

BILLION BOARD FEET, INTERNATIONAL 1/4-INCH LOG RULE

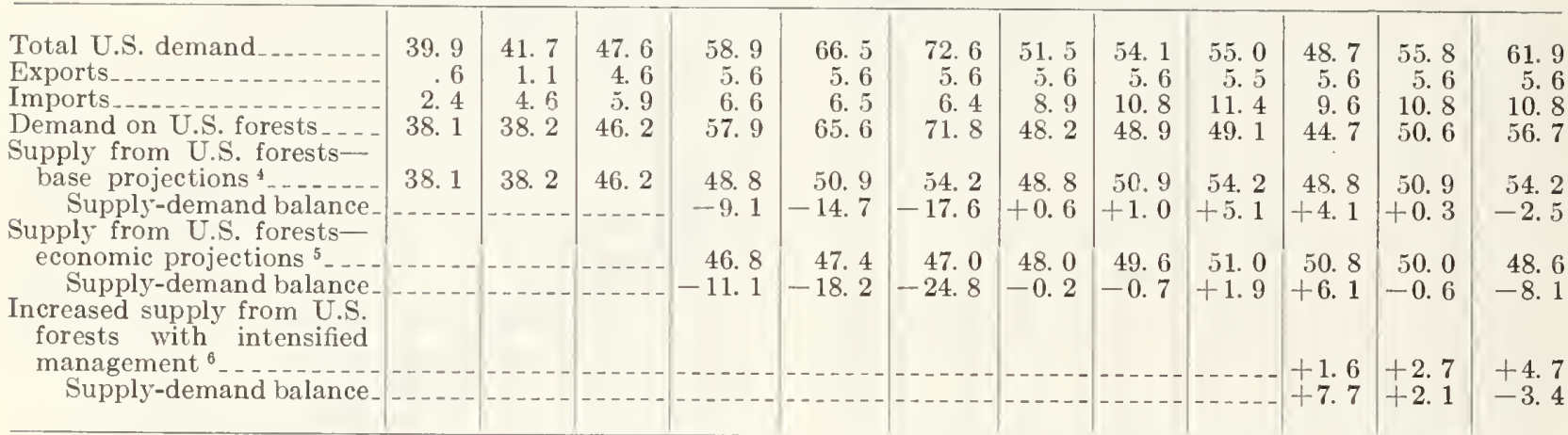

1 Data for 1952,1962 , and 1970 arc estimates of actual consumption and harvests and differ somewhat from the "trend" estimates shown in Chapter II.

${ }^{2}$ Relative prices rising from their 1970 trend levels as follows: lumber-1.5 percent per year; plywood, miscellaneous products and fuelwood- 1.0 percent per year; paper and board- 0.5 percent per year. This would mean a cumulative increase of 62 percent for lumber by the year 2000 , and 17 percent for paper and board.

${ }^{3}$ Relative prices of lumber and plywood 30 percent, miscellaneous products and fuelwood 15 percent, and paper and board 10 percent above their 1970 averages.

${ }^{4}$ Base projections of supply are defined in Chapter II as the amounts of timber that would be available for harvesting if: (1) forestry programs continued at 1970 levels, (2) timber removals in the East changed on a straight line basis from actual removals in 1970 to a balance with growth in the year 2000 and thereafter, (3) removals on private lands in the West followed trends suggested by recent management and operating practices, and allowable cuts on public lands remained at the 1970 level.

An equilibrium price path cannot be determined with any exactness, but under the specific conditions assumed in Chapters II and V, trend level prices of softwood lumber' and plywood (relative to the general price level) by $1980 \mathrm{might}$ a verage roughly $20-25$ percent above 1970 , with
5 Projections of supply related to alternative price levels, and 1970 level of management, with sonie adjustments for recent environmental constraints on National Forests harvests.

${ }^{6}$ Increases on supply from a program of $\$ 69$ million annually for commercial thinnings, planting, and timber stand improvement on areas of nonindustrial private and National Forest lands that will yield more than 5 pcrcent return on investments. Supplies could be further increased with other investment criteria, investments in other management or utilization opportunities, or investments on other ownerships.

Note: Data may not add to totals because of rounding.

Sources: Data for 1952, 1962, and 1970 based on information published by the U.S. Departments of Commerce and Agriculture.

Projections: U.S. Department of Agriculture, Forest Service.

an increase of roughly $50-60$ percent by the year 2000.

The indicated price path for softwood lumber that appears likely under these specific conditions would be generally consistent with price trends of prior decades when supplies and demands for 
TABLE 156. - Summary of hardwood timber demand, exports, imports and demand on and supply from U.S. forests, 1952, 1962, and 1970, with projections to 2000 (medium level) under alternatice price assumptions and 1970 level of management

BILLION CUBIC FEET

Total U.S. demand

Exports

Imports . . .

Demand on U.S. forests . .....

Supply from U.S. forests-base projections ${ }^{5}-1$.

Projections

\begin{tabular}{|c|c|c|c|c|c|c|c|c|c|c|c|}
\hline \multirow{3}{*}{$1952^{1}$} & \multirow{3}{*}{$1962^{1}$} & \multirow{3}{*}{$1970^{3}$} & \multicolumn{9}{|c|}{ Projections } \\
\hline & & & \multicolumn{3}{|c|}{$\begin{array}{l}1970 \text { relative } \\
\text { prices }\end{array}$} & \multicolumn{3}{|c|}{$\begin{array}{l}\text { Rising relative } \\
\text { prices }^{2}\end{array}$} & \multicolumn{3}{|c|}{$\begin{array}{c}\text { Relative prices } \\
\text { above } 1970 \\
\text { averages }^{3}\end{array}$} \\
\hline & & & 1980 & 1990 & 2000 & $19 S 0$ & 1990 & 2000 & 1980 & 1990 & 2000 \\
\hline $\begin{array}{l}3.5 \\
(4) \\
.1 \\
3.5\end{array}$ & $\begin{array}{r}3.1 \\
.1 \\
.2 \\
3.0\end{array}$ & $\begin{array}{r}3.0 \\
.2 \\
.3 \\
2.9\end{array}$ & $\begin{array}{r}4.3 \\
.2 \\
.4 \\
4.1\end{array}$ & $\begin{array}{r}5.5 \\
.2 \\
.4 \\
5.3\end{array}$ & $\begin{array}{r}7.0 \\
.2 \\
.4 \\
6.8\end{array}$ & $\begin{array}{r}4.0 \\
.2 \\
.5 \\
3.7\end{array}$ & $\begin{array}{r}4.7 \\
.2 \\
.5 \\
4.4\end{array}$ & $\begin{array}{r}5.7 \\
.2 \\
.6 \\
5.3\end{array}$ & $\begin{array}{r}3.9 \\
.2 \\
.6 \\
3.5\end{array}$ & $\begin{array}{r}\text { 4. } 9 \\
.2 \\
.6 \\
4.5\end{array}$ & $\begin{array}{r}6.4 \\
.2 \\
6 \\
6.0\end{array}$ \\
\hline 3.5 & 3. 0 & 2. 9 & $\begin{array}{r}5.2 \\
+1.1\end{array}$ & $\begin{array}{r}6.3 \\
+1.0\end{array}$ & $\begin{array}{r}7.4 \\
+0.6\end{array}$ & $\begin{array}{r}5.2 \\
+1.5\end{array}$ & $\begin{array}{r}6.3 \\
+1.9\end{array}$ & $\begin{array}{r}7.4 \\
+2.1\end{array}$ & $\begin{array}{r}5.2 \\
+1.7\end{array}$ & $\begin{array}{r}6.3 \\
+1.8\end{array}$ & $\begin{array}{r}7.4 \\
+1.4\end{array}$ \\
\hline
\end{tabular}

BILLION BOARD FEET, INTERNATIONAL 1/4-INCH LOG RULE

\begin{tabular}{|c|c|c|c|c|c|c|c|c|c|c|c|c|}
\hline $\begin{array}{l}\text { Total U.S. demand } \\
\text { Exports } \\
\text { Imports } \\
\text { Demand on U.S. forests }\end{array}$ & $\begin{array}{r}11.6 \\
.2 \\
.3 \\
11.5\end{array}$ & $\begin{array}{r}11.7 \\
.2 \\
1.0 \\
10.9\end{array}$ & $\begin{array}{r}12.3 \\
.2 \\
1.3 \\
11.2\end{array}$ & $\begin{array}{r}16.3 \\
.2 \\
2.0 \\
14.5\end{array}$ & $\begin{array}{r}20.3 \\
.2 \\
2.0 \\
18.5\end{array}$ & $\begin{array}{r}24.3 \\
2.2 \\
22.5\end{array}$ & $\begin{array}{r}14.5 \\
.2 \\
2.0 \\
12.7\end{array}$ & $\begin{array}{r}\text { 16. } 7 \\
.2 \\
2.3 \\
14.6\end{array}$ & $\begin{array}{r}19.1 \\
.2 \\
2.7 \\
16.6\end{array}$ & $\begin{array}{r}14.0 \\
.2 \\
2.4 \\
11.8\end{array}$ & $\begin{array}{r}17.4 \\
.2 \\
2.4 \\
15.2\end{array}$ & $\begin{array}{r}21.1 \\
.2 \\
2.4 \\
18.9\end{array}$ \\
\hline $\begin{array}{l}\text { Supply from U.S. forests-base } \\
\text { projections }{ }^{5} \text {-.... } \\
\text { Supply-demand balance.-. }\end{array}$ & 11.5 & 109 & 11. 2 & $\begin{array}{r}15.5 \\
+1.0\end{array}$ & $\begin{array}{r}18.2 \\
-0.3\end{array}$ & $\begin{array}{r}20.6 \\
-1.9\end{array}$ & $\begin{array}{r}15.5 \\
+2.8\end{array}$ & $\begin{array}{r}18.2 \\
+3.6\end{array}$ & $\begin{array}{r}20.6 \\
+4.0\end{array}$ & $\begin{array}{r}15.5 \\
+3.7\end{array}$ & $\begin{array}{r}18.2 \\
+3.0\end{array}$ & $\begin{array}{r}20.6 \\
+1.7\end{array}$ \\
\hline
\end{tabular}

Data for 1952,1962 , and 1970 are estimates of actual consumption and harvests and differ somewhat from the "trend" estimates shown in Chapter II.

2 Relative prices rising from their 1970 trend levels as follows: lumber-1.5 percent per year; plyood, miscellaneous products and fuelwood-1.0 percent per year; paper and board- -0.5 percent per year.

${ }^{3}$ Relative prices of lumber and plywood 30 percent, miscellaneous products and fuelwood 15 percent, and paper and board 10 percent above their 1970 averages.

4 Less than 50 million cubic feet.

5 Base projections of supply are defined in Chapter II as the amount of timber that would be available for harvesting if: (1) forestry programs continued at 1970 levels, (2) timber removals in the East changed on a

softwood lumber were balanced at successively higher relatire prices that increased an arerage of 1.7 percent annually.

Projected trends in such equilibrium prices for different timber products also differ as in the past. Thus, in contrast to a possible increase of 50-60 percent in prices of softwood lumber and plywood by 2000, under the conditions specified in this analysis relative prices of paper and board might be no more than 15-20 percent above 1970 prices. Greater increases in prices may be necessary in the pulp and paper industry, however, to attract the capital required to meet projected demands.

Stumpage price increases also could be expected to be considerably greater on a percentage basis than increases in equilibrium prices of processed products such as lumber. According to past straight-line basis from actual removals in 1970 to a balance with growth in the year 2000 and thereafter, (3) removals on private lands in the West followed trends suggested by recent management and operating practices, and allowable cuts on public lands remained at the 1970 level.

Note: Data may not add to totals because of rounding.

Sources: Data for 1952,1962 , and 1970 based on information published by the L.S. Departments of Commerce and Agriculture.

Projections: U.S. Department of Agriculture, Forest Service.

relationships such as described in Chapter $V$, an increase of 50-60 percent in softwood lumber and plywood prices, for example, would result in an average increase of over 100 percent in relative average prices of sofwood sawtimber stumpage.

Projection alternatices. - In view of the many uncertainties involved in both demand and supply projections, estimates of prices at which supply and demand might be balanced must be regarded as very general approximations that would only be realized under the assumed conditions underlying these specific projections.

Many factors could, of course, lead to different price paths than indicated by this analysis. These include different rates of economic growth, different trends in technology, or different demand elasticitics than specified in Chapter $V$, with consequent changes in demand projections. 
Supplies could be lower than projected as a result of various factors such as more diversion of forest lands to other uses than assumed, more constraints on timber management because of environmental factors, nontimber objectives of forest owners, or extraordinary mortality losses. Different supply responses to price changes than assumed in the economic supply projections also could result in higher or lower supply trends than shown by these projections. Intensification of forest management, or faster improvement in utilization in woods and mills than assumed, could add to these projections of supply.

\section{SOFTWOOD SAWTIMBER SUPPLIES WITH IN. TENSIFIED MANAGEMENT AND UTILIZA. TION}

An analysis of investment opportunities in reforestation, stand improvement, thinning, and other timber management practices, presented in Chapter III, illustrates numerous opportunities for increasing domestic timber supplies.

An example of investment opportunities on National Forests and farm and miscellaneous private ownerships judged to be capable of returning at least 5 percent on additional investments indicated that intensification of management could provide increases in supplies of softwood sawtimber of 1.6 billion board feet in $1980,4.7$ billion board feet in 2000, and 13 billion board feet in 2020 (table 155). Such a program of intensification assumed softwood lumber and plywood prices averaging 30 percent above 1970 and an estimated cost of $\$ 69$ million annually (at 1971 prices).

Some increases in timber supply from closer utilization, thinnings, and salvage could be achieved promptly. The allowable cut effect also would permit other early increases in harvesting following intensification of management on many public lands. Much of the increase in supply ${ }^{\text {from }}$ intensified management, however, would become available only after 2000 .

Biological limits of timber growth and potential harvests are estimated to be much in excess of these initial projections of intensification opportunities. More of the growth potential of the Nation's forests could be captured with similar intensification of forestry practices on industrial and other public lands, and with measures such as fertilization that were not included in the analysis in Chapter III. Use of investment criteria other than a minimum rate of return of 5 percent as used in this study could also permit intensification on more of the Nation's timberlands.

Timber supplies could be extended by improved technology, including adoption of processing equipment and methods that would increase recovery of usable products from available supplies of roundwood beyond amounts projected in this analysis.
If timber supplies were increased by such added investments in timber management and utilization, prospective rises in equilibrium prices of timber products could be significantly moderated, particularly after the turn of the century.

\section{HARDWOOD DEMAND-SUPPLY BALANCES WITH 1970 LEVELS OF FOREST MANAGE- MENT}

Demands on U.S. forests for hardwood timber products-after allowances for imports and exports-have been estimated to rise from about 2.9 billion cubic feet in 1970 to a range of 5.3 to 6.8 billion cubic feet by 2000 under the alternative price assumptions and the medium level of population and economic growth used in this analysis (table 156 and fig. 83).

Potentially arailable supplies of hardwood timber from U.S. forests, as indicated by the base projections developed in Chapter II, increase from 2.9 billion cubic feet in 1970 to about 7.4 billion cubic feet by 2000 . Thus, total supplies of hardwood potentially available in terms of cubic feet exceed projected demands throughout the 19702000 period. While this implies that increases in relative prices are not likely, wide differences in timber quality and availability indicate a variable outlook for supply-price relationships.

\section{HARDWOOD SAWTIMBER SUPPLY-DEMAND BALANCES WITH 1970 LEVELS OF FOREST MANAGEMENT}

In the case of hardwood sawtimber, projected demands on U.S. forests - after allowances for imports and exports-rise from 11.2 billion board feet in 1970 to a range of 16.6 to 22.5 billion board

\section{Hardwood roundwood - demand on U.S. forests and domestic supply}

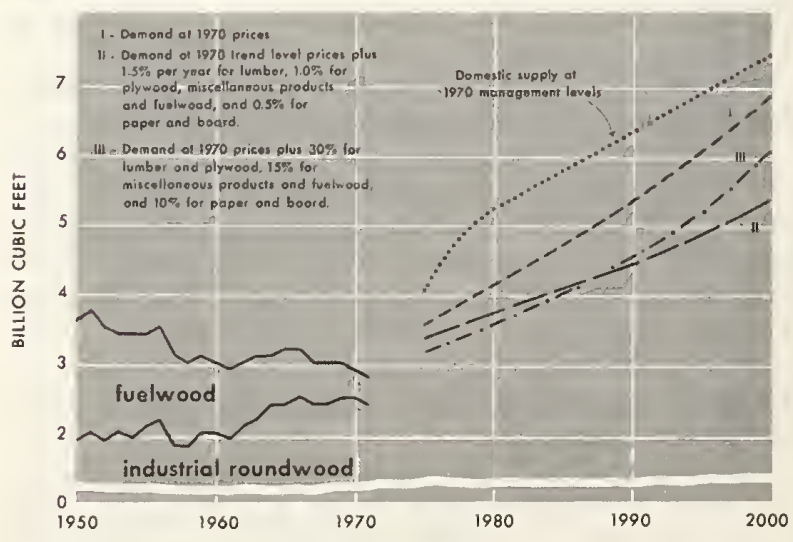

Figure 83 
Hardwood sawtimber - demand on U.S. forests and domestic supply

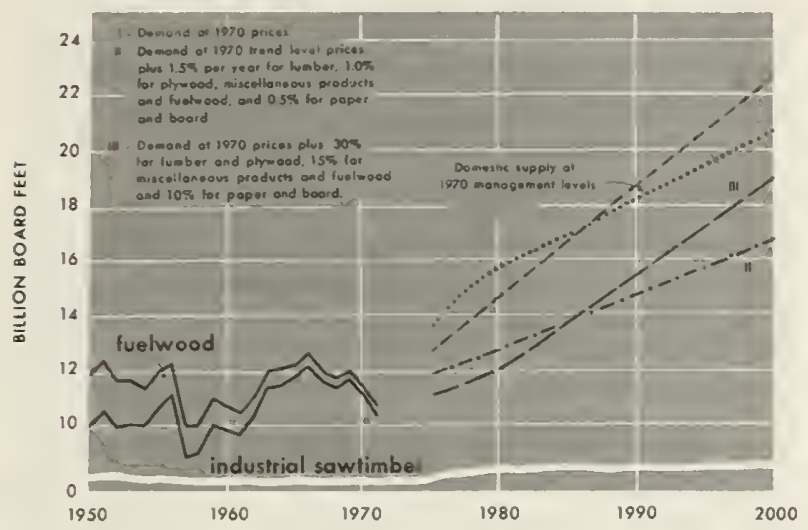

Figure 84

feet in 2000 , depending on the price assumption specified (table 156 and fig. 84).

Potentially arailable supplies of hardwood sawtimber products, as indicated by the base projection, rise from 11.2 billion board feet in 1970 to 20.6 billion board feet by 2000 . These projections of supply also exceed projected demands, except in the case of the 1970 price assumption af ter 1980 .

In general these projections for hardwood sawtimber show a more favorable supply and price outlook than for softwoods. However, it is quite possible as in the case of softwoods that not all of the potentially arailable supplies indicated by the base projection will in fact be actually available, particularly at 1970 price levels. Recent increases in relative prices of hardwood lumber, and sharp increases in prices for certain preferred species and higher grades of hardwood timber, indicate that statistics on total inventories, net growth, and arailable removals overstate volumes economically accessible and available for sale by the large numbers of private owners who own most hardwood timber resources.

Hardwood timber inventories and growth are far from homogeneous and statistics on supply and consumption do not include the same mix of species and sizes of timber. Much of the growth and available supply of hardwoods is in small trees and in large numbers of species for which markets are limited. A major part of the harvest, on the other hand, is concentrated on larger sizes of preferred species such as white oak, sweetgum, yellow birch, hard maple, walnut, and black cherry. Removals of such higher grade material and species have been close to or above annual growth.

It seems likely therefore, that relative prices of hardwood timber products may also continue to rise, particularly for the preferred species and larger sizes. For some time to come, however, hardwood price increases could be restrained by increased imports of tropical hardwood products, as indicated in Chapter IV.

\section{HARDWOOD SUPPLY-DEMAND VOLUMES WITH INTENSIFIED MANAGEMENT}

Supplies of hardwoods from domestic forests could be augmented in time by intensified forest management. As indicated by the case studies cited in Chapter III, hardwood supplies could be significantly increased in terms of value, and to lesser extent in terms of volume, by such practices as cleaning and precommercial thinning of young stands to improve species composition and spacing. Commercial thinning of older stands would concentrate growth on the more desirable trees. In many cases protection against animals such as deer also is necessary to assure desirable stand composition. Because of the large variety of species present in many hardwood stands, such measures are essential to capture value potentials.

\section{IMPLICATIONS FOR TIMBER INDUSTRIES}

The increases in timber prices and the supply problems that appear to be in prospect can be expected to have significant impacts on softwood lumber and plywood industries. Prospective limitations on timber supplies and increases in prices will limit expansion potentials for these products in housing and other markets, and necessitate greater dependence on competitive materials for many uses.

Producers of high-quality hardwood lumber and hardwood plywood face a similar situation of limited and higher cost wood supplies. The outlook is better, however, for producers of hardwood construction timber, pallet lumber, railroad ties, and other products that can be manufactured from the lower quality hardwoods that are in relatively abundant supply.

The outlook for the pulp and paper industry is relatively favorable to the extent that this industry can use small and low-quality material, hardwoods, plant and logging residues, and recycled fibers as well as round softwood pulpwood. Nevertheless, price increases for timber used by the lumber and plywood industries can be expected to have direct impacts on pulpwood prices. All the forest industries compete to some extent for the same sizes and species of timber, and price rises for larger and higher quality trees can be expected to extend to some extent to the entire timber resource. The pulp and paper industry as well as other timber users thus has a major interest in intensifying forest management and improving utilization to meet potential timber demands.

Higher prices for timber and timber products will of course improve the profitability of forest 
managment and thus should encourage more investments in timber growing and expansion of public forestry programs. This would help increase timber supplies although, as pointed out in Chapter III, these are largely long-range solutions to problems of timber supply.

Prospective trends in timber availability also point to changes in the geographic location of timber industries. A continuing drop in softwood timber supplies in the West can be expected, as shown in Chapter II, while a substantial expansion of timber supplies and wood-based industries is anticipated in the South.

\section{DEPENDENCE ON NET IMPORTS OF TIMBER}

The estimates of timber demands and supplies summarized in tables 155 and 156 include significant volumes of both imports and exports of timber products, both in 1970 and in the projection period. Net imports are assumed to increase from 8 percent of U.S. consumption in 1970 to about 15 percent of projected demands in 2000 under the assumption of "rising" timber prices.

Potentials for increases in net imports of timber products beyond amounts assumed in this analysis appear to be limited, both by physical availability of timber supplies from other countries and by economic and political factors. Not the least of the potential problems involved in greater dependence on net imports would be the increased need for foreign exchange and resulting adverse impacts on the U.S. balance of payments position.

\section{ECONOMIC AND ENVIRONMENTAL EFFECTS OF RISING TIMBER PRICES}

If timber supplies are insufficient to meet growing demands for lumber, plywood, and other wood products, builders and other users of these materials can shift many demands to competing materials such as metals, plastics, and concrete. Considerable substitution of this nature has, of course, occurred in the past with increasing relative prices of lumber. Mineral-based products and steel have made heavy inroads in many traditional wood uses in construction, for example, while plastics have been increasingly used for such items as boats, furniture, and packaging.

Higher prices of timber products and a shift to greater use of competitive materials will lead, however, to increased costs of houses, furniture, and many other goods. Although total and per capita incomes are assumed to increase substantially, higher materials costs would necessarily have some adverse impacts on volumes and quality of housing production, for example, and thus on consumer welfare.

Continuing shifts to other raw materials necessitated by limited timber supplies could also increase adverse industrial impacts on the environ- ment. The air, water, and land pollution resulting from production of substitute materials such as steel, concrete products, and aluminum is of greater magnitude than in the case of timber products such as lumber and plywood. In many cases such impacts apparently can be reduced to acceptable levels but the expenditures necessary to control pollution will tend to increase costs of these materials.

Energy requirements and costs of processing competing materials also are much higher than for timber products. It is estimated that use of steel framing for exterior walls in residential construction, for example, requires over three times the amount of processing energy needed to produce lumber for comparable installations. ${ }^{1}$ For aluminum and concrete blocks, energy requirements are estimated to average more than eight times the requirements for lumber. There are likewise substantial differences in typical heating and cooling costs with alternative materials that favor use of wood products in housing construction. ${ }^{2}$

While such estimates cannot be viewed as exact measures of energy requirements because of variations in structures, building practices, and other factors, differences in use of energy as well as relative pollution impacts are believed to be of considerable significance in evaluating the future situation and in developing programs to assure future raw inaterial supplies. ${ }^{3}$

${ }^{1}$ Dane, C. W. Energy requirements for wood and wood substitutes and the "energy crises." USDA Forest Serv., Forest Econ. and Market. Res., 17 p. Processed. 1972.

${ }^{2}$ National Forest Products Association. The energy conservation issue-how wood helps reduce power consumption and home operating costs. Washington, D.C. 1972 .

${ }^{3}$ For further discussion of these points, see:

Dane, C. W. The price outlook of steel products substitutable for wood. USDA Forest Serv., Forest Econ. and Market. Res., 38 p. Processed. 1972.

- The long-term price outlook for concrete products that are substitutable for wood. USDA Forest Serv., Forest Econ. and Market. Res., 39 p. Processed. 1972. The long-term price outlook for aluminum products substitutable for wood. USDA Forest Serv., Forest Econ. and Market. Res., 43 p. Processed. 1972. - Energy requirements for wood and wood substitutes and the "energy crises." USDA Forest Serv., Forest Econ. and Market. Res., 17 p. Processed. 1972. The hidden environmental costs of alternative materials available for residential construction. USDA Forest Serv., Forest Econ. and Market. Res., 14 p. Processed. 1972.

Haygreen, John G. Wood products an uncertain future. Minnesota Forest Products Marketing Bul. 15(2):1-3. June 1972.

Saeman, Jerome $F$. The wood resource and the environment-some national options and alternatives. USDA Forest Serv., Forest Prod. Lab. 1970.

Vaux, Henry J. Continuing education for a changing environment. Univ. of California, School of Forestry and Conservation. Berkeley. June 1972.

Zivnuska, John A. Will wood products be cheap or expensive? Seventh World Forestry Congress, Argentina. Oct. 1972. 
Among other aspects of the question of substitution is the increasingly serious problem of waste disposal. Wood products that are not recycled for paper and board, for example, are highly biodegradable in contrast to most competitive materials.

Another important consideration in a shift to greater use of nontimber materials is the long-run effect of accelerated use of nonrenewable stocks of ores and energy materials. Coal, petroleum, and natural gas once used are gone forerer, and minerals can be extracted only at rising real costs. Forests, on the other hand, constitute a renewable resource that can continue to produce timber indefinitely.

Substantial portions of the aluminum and steel consumed in the United States, moreorer, are derived from foreign sources, and projections indicate the necessity of more and more U.S. dependence on foreign supplies of metals, petroleum, and other materials. Increased use of wood substitutes consequently could have adverse impacts on the U.S. balance of payments.

For these various reasons, efforts to produce increased crops of timber, in lieu of increasing dependence on substitute materials, may have much more justification than indicated by conrentional cost-benefit analyses.

\section{OPPORTUNITIES FOR INTENSIFIED TIMBER MANAGEMENT AND UTILIZATION}

Additional supplies of timber beyond amounts arailable with 1970 lerels of management and utilization could be obtained from domestic forests, particularly under the stimulus of higher prices and adoption of improved technology. As indicated in Chapter III, many opportunities for increasing supplies exist on both public and private lands, including measures such as the following:

- Commercial thinning and salvage.-Intermediate harresting of timber stands could increase log supplies, especially on the Pacific Coast, and particularly with increased price levels and advance road construction to improve forest access. More salvage of the 11 billion board feet of annual mortality of softwood sawtimber scattered throughout the various regions also could help stretch arailable log supplies.

- Closer utilization of logging and plant residues.-About 3 billion cubic feet of sound wood was left unused on logging operations and in primary processing plants in 1970. Much more progress in utilizing such material is possible, especially with rising prices and continued expansion of the pulp and paper industry.
- Improved technology in wood processing and construction.-Many improvements in equipment and processing methods have been adopted by the forest industries in recent decades, and it has been assumed in this analysis that recovery of products from a railable log supplies will continue to increase. There are additional opportunities to further extend arailable log supplies, howerer, by use of new equipment such as high strain thin saws, for example, and modified pulping methods to produce higher pulp yields. Better design in construction of housing and other structures, including stress grading in some applications, also could save significant amounts of lumber and plywood.

- Increased recycling of wood fiber.-About 19 percent of the fibrous materials used for paper and board in the United States in 1970 , or 10.5 million tons, was recycled wastepaper and board. Such use of recrcled fiber has been assumed to rise to 34 percent of the total mix of fibers used in pulping by 2000 , or somewhat below experience in some other countries. Increases in recycling of paper and board of at least the magnitude assumed in this study appears likely to be both environmentally essential and economically desirable in meeting potential demands for fiber products.

- Tree planting.-On many areas conversion of the existing cover to plantations will be necessary to capture the timber growth potential. Use of genetically improved trees also will require planting rather than natural regenerating. Tree planting, together with other measures such as site preparation and prescribed burning where necessary, could increase timber vields on many millions of acres in the South and in other regions. Prompt restocking to shorten regeneration periods after harresting also could permit an almost immediate increase in allowable cuts on National Forests and certain other lands.

- Timber stand improvement.-Precommercial thinning and removal of cull trees offer many practical opportunities for enlancing future yields, especially with rising timber prices and particularly in hardwood stands and Rocky Mountain forests.

- Improved forest protection.-Better control of destructive insects and diseases such as bark beetles, dwarf mistletoe, and major defoliators, improved forest fire control, and prevention of animal damage could acld to available timber supples by reducing the substantial continuing mortality and growth losses to those destructive agents. 
- Forest fertilization.-Experience to date also indicates that forest fertilization will be a practical way to increase timber growth and yields in many situations.

- Improvements in technology.-Continuing research to provide new knowledge is of large importance in improving management of forest lands for timber production while assuring balanced output of both timber and other forest goods and services such as recreation, water, and wildlife.

Such measures to increase timber growth and harvests will require substantial public and private investments. Large expenditures also will be needed to provide the plant and equipment necessary to extend timber supplies by improved utilization in the harvesting, processing, and use of timber products.

Potential imbalances between rising demands for timber and available supplies are part of a worldwide problem of assuring adequate raw materials for housing and a multitude of other uses and products. A shift from timber to greater dependence on substitute materials is possible, but entails problems of cost, pollution impacts, dependence on foreign suppliers, and additional balance of payments problems. Increasing timber supplies from domestic forests, while assuring a balance with other uses and environmental protection, is an alternative that is technically and economically feasible even though time and substantial expenditures will be necessary. The outlook for timber is thus a matter of far-reaching public and private concern. 


\section{APPENDIX I}

\section{Forest Statistics, 1970}

Table

1 Land areas in the United States, by major class of land, section, region, and State, January 1, $1970 \ldots \ldots$

2 Area of commercial timberland in the United States, by ownership, and section, region, and State, as of December 31, 1952 and 1962, and January 1, 1970 . .

3 Area of commercial timberland in the United States, by ownership and stand-size class, section, region, and State, January 1, 1970_-

4 Area of commercial timberland in the United States, by ownership and stand-volume class, section, region, and State, January 1, 1970 ..

5 Area of commercial timberland in the United States, by ownership and site class, section, region, and State, January 1, 1970

6 Net volume of softrood growing stock on commercial timberland in the United States, by ownership and section, region, and State, as of December 31, 1952 and 1962, and January 1, $1970 \ldots \ldots \ldots$

7 Net volume of hardwood growing stock on commercial timberland in the United States, by ownership and section, region, and State, as of December 31, 1952 and 1962 , and January 1, 1970_................

8 Net volume of softwood sawtimber on commercial timberland in the United States, by ownership and section, region, and State, as of December 31, 1952 and 1962, and

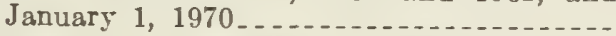

9 Net volume of hardwood sawtimber on commercial timberland in the United States, by ownership and section, region, and State, as of December 31, 1952 and 1962, and January 1, 1970 . . .

10 Net volume of timber on commercial timberland in the United States, by class of timber, softwoods and hardwoods, section, region, and State, January 1, 1970

11 Net volume of growing stock on commercial timberland in the United States, by diameter class, softwoods and hardwoods, and timber supply region, as of December 31, 1952 and 1962, and January 1, 1970

12 Net volume of santimber on commercial timberland in the United States, by diameter class, softroods and hardwoods, and timber supply region, as of December 31, 1952 and

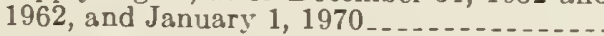

13 Net volume of growing stock on commercial timberland in the East, by species, diameter class, and timber supply region, January 1, $1970 \ldots$
Page Table

Page

14 Net volume of growing stock on commercial timberland in the West, by species, diameter class, and timber supply region, January 1, 1970

15 Net volume of santimber on commercial timberland in the East by species, diameter class, and timber supply region, January 1, 1970 .

16 Net volume of sawtimber on commercial timberland in the West, by species, diameter class, and timber supply region, January 1, 1970

23417 Net volume of growing stock on commercial timberland in the East, by species and section, region, and State, January 1, 1970 -

23718 Net volume of growing stock on commercial timberland in the West, by species and section, region, and State, January 1, 1970_.

19 Net volume of sawtimber on commercial timberland in the East, by species and section, region, and State, as of January 1, 1970

20 Net volume of sawtimber on commercial timberland in the West, by species and section, region, and State, January 1, 1970 .......

21 Net annual growth and removals of growing stock on commercial timberland in the United States, by softwoods and hardwoods, ownership and timber supply region, 1952, 1962 , and 1970

22 Net annual growth and removals of sawtimber on commercial timberland in the United States, by softwoods and hardwoods, ownership, and timber supply region, 1952, 1962, 1970 .

23 Net annual growth and removals of softrood growing stock and sawtimber on commercial timberland in the United States by species and timber supply region, 1970

24 Net annual growth and removals of hardwood growing stock and sawtimber on commercial timberland in the United States, by species and timber supply region, 1970

25 Net annual growth and removals of growing stock on commercial timberland in the United States, by softwoods and hardwoods,

251 and section, region, and State, 1970 .......

26 Net annual growth and removals of sawtimber on commercial timberland in the United States, by softwoods and hardwoods, and section, region, and State, 1970..........

25327 Annual mortality of growing stock and sawtimber on commercial timberland in the United States, by softwoods and hardwoods, ownership, and timber supply region, 1952, 1962 , and $1970 \ldots$

258 
Table

28 Output of timber products and timber removals for the Northeast supply region, by source of material and softwoods and hardwoods, 1970

29 Output of timber products and timber removals for the North Central supply region, by source of material and softwoods and hard-

30 Wutput of timber products and timber removals for the North, by source of material and sof twoods and hardwoods, 1970..........

31 Output of timber products and timber removals for the Southeast supply region, by source of material and softwoods and hardwoods, 1970

Output of timber products and timber removals for the South Central supply region, by source of material and softwoods and hardwoods, 1970

33 Output of timber products and timber removals for the South, by source of material and sof twoods and hardwoods, 1970..........

34 Output of timber products and timber removals for the Douglas-fir supply region, by source of material and softwoods and hardwoods, 1970

35 Output of timber products and timber removals for the Ponderosa pine supply region, by source of material and softwoods and hardwoods, 1970

36 Output of timber products and timber removals for coastal Alaska, by source of material and softwoods and hardwoods, $1970 \ldots \ldots$

Output of timber products and timber removals for California and Hawaii, by source of material and softwoods and hardwoods, 1970

38
Page Table

No.

39 Output of timber products and timber removals for the Northern Rocky Mountain States, by source of material and softwoods and hardwoods, 1970

40 Output of timber products and timber removals for the Southern Rocky Mountain States, by source of material and softwoods and hardwoods, 1970

41 Output of timber products and timber removals for the Rocky Mountain States, by source of material and softwoods and hardwoods, 1970

42 Output of timber products and timber removals for the United States by source of material and softwoods and hardwoods, 1970

43 Volume of unused residues at primary manufacturing plants in the United States, by timber supply region, industrial source, type of material, softwoods and hardwoods, $1970 \ldots$

44 Roundwood products, logging residues, and other removals from growing stock and sawtimber, by section, region, state and species group, 1970 .

45 Area of commercial timberland by ownership, forest type, stand size, and site, 1970North

46 Area of commercial timberland by ownership, forest type, stand size, and site, 1970-

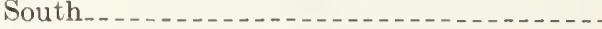

47 Area of commercial timberland by ownership, forest type, stand size, 1970 - Rocky Mountains

48 Area of commercial timberland by ownership, forest type, stand size, and site, 1970for the Pacific Coast, by source of material and softwoods and hardwoods, 1970
Page 
TABLE 1.-Land areas in the United States, by major class of land, section, region, and State, January 1, 1970 ${ }^{2}$

[Thousand acres]

\begin{tabular}{|c|c|c|c|c|c|c|c|c|}
\hline \multirow{2}{*}{ Section, region, and State } & \multirow{2}{*}{$\begin{array}{c}\text { Total land } \\
\text { area }^{2}\end{array}$} & \multicolumn{5}{|c|}{ Forest land } & \multirow{2}{*}{ Crop land ${ }^{3}$} & \multirow{2}{*}{ Other land } \\
\hline & & Total & Commercial & $\begin{array}{l}\text { Productire } \\
\text { reserved }\end{array}$ & Deferred & $\begin{array}{l}\text { Unproduc- } \\
\text { tive }\end{array}$ & & \\
\hline 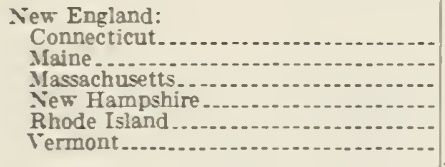 & $\begin{array}{r}3,116 \\
19,797 \\
5,013 \\
5,781 \\
671 \\
5,935 \\
\end{array}$ & $\begin{array}{r}2,186 \\
17,748 \\
3,520 \\
5,131 \\
433 \\
4,391 \\
\end{array}$ & $\begin{array}{r}2,169 \\
16,894 \\
3,491 \\
5,020 \\
429 \\
4,364 \\
\end{array}$ & $\begin{array}{r}11 \\
220 \\
18 \\
23 \\
4 \\
7\end{array}$ & $\begin{array}{l}0 \\
0 \\
0 \\
0 \\
0 \\
0 \\
\end{array}$ & $\begin{array}{r}6 \\
633 \\
11 \\
88 \\
0 \\
20 \\
\end{array}$ & $\begin{array}{r}225 \\
894 \\
250 \\
210 \\
35 \\
760 \\
\end{array}$ & $\begin{array}{r}705 \\
1,154 \\
1,243 \\
439 \\
203 \\
784\end{array}$ \\
\hline Total.... & 40,314 & 33,410 & 32,367 & 284 & 0 & 759 & 2,374 & 4,530 \\
\hline $\begin{array}{l}\text { Middle Atlantic: } \\
\text { Delaware } \\
\text { Maryland } \\
\text { New Jersey } \\
\text { New York } \\
\text { Pennsylrania.... } \\
\text { West Virginia...... }\end{array}$ & $\begin{array}{r}1,268 \\
6,369 \\
4,820 \\
30,636 \\
29,816 \\
15,413 \\
\end{array}$ & $\begin{array}{r}391 \\
2,960 \\
2,163 \\
17,377 \\
17,832 \\
12,172 \\
\end{array}$ & $\begin{array}{r}390 \\
2,882 \\
2,354 \\
14,489 \\
17,478 \\
12,092 \\
\end{array}$ & $\begin{array}{r}1 \\
35 \\
67 \\
2,480 \\
194 \\
46 \\
\end{array}$ & $\begin{array}{l}0 \\
0 \\
0 \\
0 \\
0 \\
0\end{array}$ & $\begin{array}{r}0 \\
43 \\
42 \\
407 \\
160 \\
34 \\
\end{array}$ & $\begin{array}{r}495 \\
1,780 \\
660 \\
5,825 \\
5,575 \\
880 \\
\end{array}$ & $\begin{array}{r}382 \\
1,629 \\
1,697 \\
7,433 \\
5,409 \\
2,361 \\
\end{array}$ \\
\hline Total... & 87,324 & 53,196 & 49,685 & 2,824 & 0 & 687 & 15,215 & 18,913 \\
\hline $\begin{array}{l}\text { Lake States: } \\
\text { Michigan. } \\
\text { Minnesota... } \\
\text { Worth Dakota } \\
\text { South Dakota (East) } \\
\text { Wisconsin.... }\end{array}$ & $\begin{array}{l}36,492 \\
50,745 \\
44,339 \\
41,727 \\
34,858\end{array}$ & $\begin{array}{r}19,273 \\
18,984 \\
421 \\
334 \\
14,945 \\
\end{array}$ & $\begin{array}{r}18,800 \\
16,8,5 \\
406 \\
223 \\
14,536\end{array}$ & $\begin{array}{r}268 \\
562 \\
3 \\
0 \\
34\end{array}$ & $\begin{array}{l}0 \\
0 \\
0 \\
0 \\
0\end{array}$ & $\begin{array}{r}205 \\
1,547 \\
12 \\
111 \\
374 \\
\end{array}$ & $\begin{array}{r}9,454 \\
22,243 \\
27,445 \\
18,129 \\
12,043\end{array}$ & $\begin{array}{r}7,764 \\
9,517 \\
16,471 \\
23,262 \\
7,869\end{array}$ \\
\hline Total... & 208,162 & $\mathbf{5 3}, 959$ & 50,840 & 867 & 0 & 2,251 & 89,316 & 64,885 \\
\hline $\begin{array}{l}\text { Central: } \\
\text { Illinois } \\
\text { Indiana } \\
\text { Iowa } \\
\text { Kansas } \\
\text { Kentucky } \\
\text { Mlissouri } \\
\text { Nebraska } \\
\text { Ohio }\end{array}$ & $\begin{array}{l}35,761 \\
23,161 \\
35,867 \\
52,515 \\
25,504 \\
44,189 \\
48,974 \\
26,251 \\
\end{array}$ & $\begin{array}{r}3,789 \\
3,908 \\
2,455 \\
1,314 \\
11,968 \\
14,919 \\
1,045 \\
6,498 \\
\end{array}$ & $\begin{array}{r}3,680 \\
3,810 \\
2,430 \\
1,187 \\
11,826 \\
14,600 \\
1,023 \\
6,422\end{array}$ & $\begin{array}{r}44 \\
38 \\
25 \\
0 \\
80 \\
91 \\
13 \\
76\end{array}$ & $\begin{array}{l}0 \\
0 \\
0 \\
0 \\
0 \\
0 \\
0 \\
0\end{array}$ & $\begin{array}{r}65 \\
30 \\
0 \\
157 \\
61 \\
228 \\
8 \\
0\end{array}$ & $\begin{array}{r}23,867 \\
13,317 \\
26,356 \\
29,421 \\
8,725 \\
17,960 \\
22,099 \\
11,525 \\
\end{array}$ & $\begin{array}{r}8,103 \\
5,935 \\
7,056 \\
21,750 \\
4,811 \\
11,310 \\
25,829 \\
8,228\end{array}$ \\
\hline Total & 292,225 & 45,928 & 45,008 & 370 & 0 & 550 & 153,272 & 93,024 \\
\hline Total, North & 628,026 & 186,494 & 177,901 & 4,345 & 0 & 4,247 & 260,178 & 181,353 \\
\hline $\begin{array}{l}\text { South Atlantic: } \\
\text { North Carolina } \\
\text { South Carolina } \\
\text { Virginia......... }\end{array}$ & $\begin{array}{l}31,367 \\
19,366 \\
25,496 \\
\end{array}$ & $\begin{array}{l}20,613 \\
12,493 \\
16,389\end{array}$ & $\begin{array}{l}20,192 \\
12,410 \\
15,859\end{array}$ & $\begin{array}{r}372 \\
70 \\
313\end{array}$ & $\begin{array}{l}0 \\
0 \\
0 \\
\end{array}$ & $\begin{array}{r}48 \\
12 \\
216\end{array}$ & $\begin{array}{l}5,274 \\
4,033 \\
3,438\end{array}$ & $\begin{array}{l}5,478 \\
2,838 \\
5,669\end{array}$ \\
\hline Total & 76,229 & 49,496 & 48,463 & 755 & 0 & 277 & 12,746 & - 13,986 \\
\hline $\begin{array}{l}\text { East Gulf: } \\
\text { Florida. } \\
\text { Georgia..... }\end{array}$ & $\begin{array}{l}35,179 \\
37,295\end{array}$ & $\begin{array}{l}17,932 \\
25,545\end{array}$ & $\begin{array}{l}16,231 \\
25,102\end{array}$ & $\begin{array}{r}94 \\
389\end{array}$ & $\begin{array}{l}0 \\
0\end{array}$ & $\begin{array}{r}1,606 \\
54 \\
\end{array}$ & $\begin{array}{l}3,692 \\
6,367 \\
\end{array}$ & $\begin{array}{r}13,554 \\
5,382\end{array}$ \\
\hline Total & 72,474 & 43,478 & 41,334 & 483 & 0 & 1,661 & 10,059 & 18,936 \\
\hline $\begin{array}{l}\text { Central Gulf: } \\
\text { Alabama } \\
\text { Mississippi } \\
\text { Tennessee }\end{array}$ & $\begin{array}{l}32,678 \\
30,290 \\
26,474\end{array}$ & $\begin{array}{l}21,770 \\
16,913 \\
13,136 \\
\end{array}$ & $\begin{array}{l}21,742 \\
16,891 \\
12,819\end{array}$ & $\begin{array}{r}21 \\
21 \\
316 \\
\end{array}$ & $\begin{array}{l}0 \\
0 \\
0\end{array}$ & $\begin{array}{l}6 \\
0 \\
0\end{array}$ & $\begin{array}{l}5,118 \\
6,565 \\
7,855\end{array}$ & $\begin{array}{l}5,789 \\
6,812 \\
5,483\end{array}$ \\
\hline Total & 89,441 & 51,819 & 51,453 & 359 & 0 & 6 & 19,539 & 18,085 \\
\hline $\begin{array}{l}\text { West Gulf: } \\
\text { Arkansas } \\
\text { Louisiana.tand } \\
\text { Oklahoma } \\
\text { Texas. }\end{array}$ & $\begin{array}{r}33,324 \\
28,867 \\
44,149 \\
168,300\end{array}$ & $\begin{array}{r}18,277 \\
15,380 \\
9,340 \\
24,091\end{array}$ & $\begin{array}{r}18,206 \\
15,342 \\
4,817 \\
12,924\end{array}$ & $\begin{array}{r}41 \\
38 \\
34 \\
7\end{array}$ & $\begin{array}{l}0 \\
0 \\
0 \\
0\end{array}$ & $\begin{array}{r}29 \\
0 \\
4,488 \\
11,160\end{array}$ & $\begin{array}{r}8,525 \\
5,558 \\
13,010 \\
34,268\end{array}$ & $\begin{array}{r}6,521 \\
7,938 \\
21,799 \\
109,940\end{array}$ \\
\hline Total & 274,642 & $6 \pi, 090$ & 51,230 & 120 & 0 & 15,678 & 61,362 & 146,189 \\
\hline 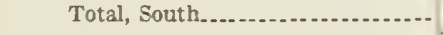 & 512,791 & 211,884 & 192,542 & 1,719 & 0 & 17,623 & 103,707 & 197,198 \\
\hline
\end{tabular}

See footnotes at end of tab?e. 
TABLE 1.-Land areas in the United States, by major class of land, section, region, and State, January 1, 1970 1-Continued

[Thousand acres]

\begin{tabular}{|c|c|c|c|c|c|c|c|c|}
\hline \multirow{2}{*}{ Section, region, and State } & \multirow{2}{*}{$\begin{array}{c}\text { Total land } \\
\text { area }^{2}\end{array}$} & \multicolumn{5}{|c|}{ Forest land } & \multirow{2}{*}{ Crop land ${ }^{3}$} & \multirow{2}{*}{ Other land } \\
\hline & & Total & Commercial & $\begin{array}{l}\text { Productive } \\
\text { reserved }\end{array}$ & Deferred & $\begin{array}{l}\text { Unproduc- } \\
\text { tive }\end{array}$ & & \\
\hline \multicolumn{8}{|l|}{$\begin{array}{l}\text { Pacific Northwest: } \\
\text { Alaska: }\end{array}$} & $\begin{array}{r}19,678 \\
226,729\end{array}$ \\
\hline Summary & 365,481 & 119,051 & 5,639 & 200 & 74 & 113,138 & 23 & 246,407 \\
\hline $\begin{array}{l}\text { Oregon: } \\
\text { Western } \\
\text { Eastern }\end{array}$ & $\begin{array}{l}19,171 \\
42,403 \\
\end{array}$ & $\begin{array}{l}15,791 \\
14,613\end{array}$ & $\begin{array}{l}14,635 \\
11,038 \\
\end{array}$ & $\begin{array}{l}271 \\
376\end{array}$ & $\begin{array}{r}3 \\
55 \\
\end{array}$ & $\begin{array}{r}882 \\
3,144 \\
\end{array}$ & $\begin{array}{l}1,690 \\
3,592\end{array}$ & $\begin{array}{r}1,690 \\
24,198 \\
\end{array}$ \\
\hline Summary & 61,574 & 30,404 & 25,673 & 647 & 58 & 4,026 & 5,282 & 25,888 \\
\hline $\begin{array}{l}\text { Washington: } \\
\text { Western } \\
\text { Eastern }\end{array}$ & $\begin{array}{l}15,843 \\
26,822 \\
\end{array}$ & $\begin{array}{l}12,743 \\
10,355\end{array}$ & $\begin{array}{l}9,991 \\
8,410 \\
\end{array}$ & $\begin{array}{r}1,073 \\
373 \\
\end{array}$ & $\begin{array}{l}55 \\
88 \\
\end{array}$ & $\begin{array}{l}1,624 \\
1,484\end{array}$ & $\begin{array}{r}769 \\
7,296 \\
\end{array}$ & $\begin{array}{l}2,331 \\
9,171 \\
\end{array}$ \\
\hline Summary & 42,665 & 23,098 & 18,401 & 1,446 & 143 & 3,108 & 8,065 & 11,502 \\
\hline Total. & 469,720 & 172,553 & 49,713 & 2,293 & 275 & 120,272 & 13,370 & 283,797 \\
\hline $\begin{array}{l}\text { Pacific Southwest: } \\
\text { California } \\
\text { Hawali }\end{array}$ & $\begin{array}{r}100,091 \\
4,106 \\
\end{array}$ & $\begin{array}{r}42,408 \\
1,974 \\
\end{array}$ & $\begin{array}{r}16,828 \\
1,081 \\
\end{array}$ & $\begin{array}{r}941 \\
86 \\
\end{array}$ & $\begin{array}{r}157 \\
0 \\
\end{array}$ & $\begin{array}{r}24,482 \\
807\end{array}$ & $\begin{array}{r}11,815 \\
490 \\
\end{array}$ & $\begin{array}{r}45,868 \\
1,641 \\
\end{array}$ \\
\hline Total.............. & 104,197 & 44,382 & 17,909 & 1,027 & 157 & 25,289 & 12,305 & 47,509 \\
\hline Total, Pacific Coast & 573,917 & 216,935 & 67,622 & 3,320 & 432 & 145,561 & 25,675 & 331,306 \\
\hline $\begin{array}{l}\text { Northern Rocky Mountain: } \\
\text { Idaho } \\
\text { Montana } \\
\text { South Dakota (West) } \\
\text { Wyoming. }\end{array}$ & $\begin{array}{r}52,933 \\
93,258 \\
6,878 \\
62,342\end{array}$ & $\begin{array}{r}21,591 \\
22,777 \\
1,399 \\
10,085\end{array}$ & $\begin{array}{r}15,192 \\
15,983 \\
1,310 \\
4,182\end{array}$ & $\begin{array}{r}1,837 \\
1,390 \\
15 \\
2,711 \\
\end{array}$ & $\begin{array}{r}735 \\
611 \\
0 \\
121\end{array}$ & $\begin{array}{r}3,826 \\
4,763 \\
73 \\
3,069 \\
\end{array}$ & $\begin{array}{r}5,181 \\
14,357 \\
535 \\
2,199\end{array}$ & $\begin{array}{r}26,159 \\
56,123 \\
4,943 \\
50,058\end{array}$ \\
\hline Total & 215,413 & 55,853 & 36,668 & 5,954 & 1,498 & 11,731 & 22,274 & 137,285 \\
\hline $\begin{array}{l}\text { Southern Rocky Mountaln: } \\
\text { Arizona } \\
\text { Colorado } \\
\text { Nevada. } \\
\text { New Mexico } \\
\text { Utah }\end{array}$ & $\begin{array}{l}72,688 \\
66,485 \\
70,264 \\
77,766 \\
52,697 \\
\end{array}$ & $\begin{array}{r}18,583 \\
22,534 \\
7,660 \\
18,313 \\
15,288\end{array}$ & $\begin{array}{r}3,689 \\
11,583 \\
128 \\
5,736 \\
3,824\end{array}$ & $\begin{array}{r}546 \\
537 \\
5 \\
584 \\
232\end{array}$ & $\begin{array}{r}10 \\
702 \\
0 \\
48 \\
22\end{array}$ & $\begin{array}{r}14,336 \\
9,711 \\
7,526 \\
11,944 \\
11,209\end{array}$ & $\begin{array}{r}1,447 \\
9,620 \\
568 \\
1,886 \\
1,627\end{array}$ & $\begin{array}{l}52,656 \\
34,330 \\
62,035 \\
57,566 \\
35,781\end{array}$ \\
\hline Total...................... & 339,901 & 82,380 & 24,963 & 1,906 & 783 & 54,727 & 15,151 & 242,369 \\
\hline Total, Rocky Mountain ........... & 555,315 & 138,234 & 61,631 & 7,861 & 2,281 & 66,459 & 37,425 & 379,655 \\
\hline Total, all regions. & $2,270,050$ & 753,549 & 499,697 & 17,246 & 2,713 & 233,891 & 426,986 & $1,089,513$ \\
\hline
\end{tabular}

1 Data may not add to totals because of truncating. Zeros indicate no data or negligible amounts.

${ }_{2}$ U.S. Bureau of Census, Land and Water Area of the United States, 1960.

${ }^{3}$ Source: 1964 Census of Agriculture.
4 Includes pasture and range, swampland, industrial and urban areas, other nonforest land.

5 Some parts of this area in Interior A laska meet standards for commercial forest land, but the detailed survey of the Interior is not complete. 
TABLE 2.-Area of commercial timberland in the United States, by ownership, and section, region, and State, as of December 31 , 1952 and 1962, and January 1, $1970^{1}$

[Thousand acres]

\begin{tabular}{|c|c|c|c|c|c|c|c|c|c|c|c|c|c|c|}
\hline \multirow{3}{*}{$\begin{array}{l}\text { Section, region, } \\
\text { and State }\end{array}$} & \multirow{3}{*}{ Year } & \multirow{3}{*}{$\begin{array}{l}\text { All } \\
\text { owner- } \\
\text { ships }\end{array}$} & \multicolumn{8}{|c|}{ Public } & \multicolumn{4}{|c|}{ Private } \\
\hline & & & \multirow{2}{*}{$\begin{array}{l}\text { Total } \\
\text { public }\end{array}$} & \multicolumn{5}{|c|}{ Federal } & \multirow{2}{*}{ State } & \multirow{2}{*}{$\begin{array}{l}\text { County } \\
\text { and } \\
\text { munic- } \\
\text { ipal }\end{array}$} & \multirow{2}{*}{$\begin{array}{l}\text { Total } \\
\text { private }\end{array}$} & \multirow{2}{*}{$\begin{array}{c}\text { Forest } \\
\text { industry }\end{array}$} & \multirow[b]{2}{*}{ Farmer } & \multirow{2}{*}{$\begin{array}{l}\text { Misc } \\
\text { laneous } \\
\text { private }\end{array}$} \\
\hline & & & & $\begin{array}{c}\text { Total } \\
\text { Federal }\end{array}$ & $\begin{array}{c}\text { National } \\
\text { Forest }\end{array}$ & $\begin{array}{l}\text { Bureau } \\
\text { of Land } \\
\text { Manage- } \\
\text { ment }\end{array}$ & Indian & $\begin{array}{c}\text { Miscel- } \\
\text { laneous } \\
\text { Federal }\end{array}$ & & & & & & \\
\hline $\begin{array}{l}\text { New England: } \\
\text { Connecticut....... }\end{array}$ & $\begin{array}{l}1970 \\
1962 \\
1952\end{array}$ & $\begin{array}{l}2,169 \\
2,105 \\
1,973\end{array}$ & $\begin{array}{l}155 \\
155 \\
155\end{array}$ & $\begin{array}{l}1 \\
1 \\
1\end{array}$ & $\begin{array}{l}0 \\
0 \\
0\end{array}$ & $\begin{array}{l}0 \\
0 \\
0\end{array}$ & $\begin{array}{l}0 \\
0 \\
0\end{array}$ & $\begin{array}{l}1 \\
1 \\
1\end{array}$ & $\begin{array}{l}122 \\
122 \\
122\end{array}$ & $\begin{array}{l}32 \\
32 \\
32\end{array}$ & $\begin{array}{l}2,014 \\
1,950 \\
1,818\end{array}$ & $\begin{array}{l}3 \\
3 \\
3\end{array}$ & $\begin{array}{l}304 \\
414 \\
670\end{array}$ & $\begin{array}{l}1,707 \\
1,533 \\
1,145\end{array}$ \\
\hline Maine & $\begin{array}{l}1970 \\
1962 \\
1952\end{array}$ & $\begin{array}{l}16,894 \\
16,-79 \\
16,609\end{array}$ & $\begin{array}{l}311 \\
205 \\
182\end{array}$ & $\begin{array}{l}73 \\
66 \\
93\end{array}$ & $\begin{array}{l}37 \\
39 \\
39\end{array}$ & $\begin{array}{l}0 \\
0 \\
0\end{array}$ & $\begin{array}{l}0 \\
0 \\
0\end{array}$ & $\begin{array}{l}35 \\
27 \\
51\end{array}$ & $\begin{array}{r}163 \\
64 \\
41\end{array}$ & $\begin{array}{l}75 \\
75 \\
51\end{array}$ & $\begin{array}{l}16,582 \\
16,574 \\
16,427\end{array}$ & $\begin{array}{l}8,255 \\
6,521 \\
6,617\end{array}$ & $\begin{array}{l}1,122 \\
2,146 \\
2,923\end{array}$ & $\begin{array}{l}7,205 \\
7,907 \\
6,887\end{array}$ \\
\hline Massachusetts..... & $\begin{array}{l}1970 \\
1962 \\
1952\end{array}$ & $\begin{array}{l}3,491 \\
3,417 \\
3,259\end{array}$ & $\begin{array}{l}399 \\
399 \\
399\end{array}$ & $\begin{array}{l}29 \\
29 \\
29\end{array}$ & $\begin{array}{l}0 \\
0 \\
0\end{array}$ & $\begin{array}{l}0 \\
0 \\
0\end{array}$ & $\begin{array}{l}0 \\
0 \\
0\end{array}$ & $\begin{array}{l}29 \\
29 \\
29\end{array}$ & $\begin{array}{l}280 \\
280 \\
280\end{array}$ & $\begin{array}{l}90 \\
90 \\
90\end{array}$ & $\begin{array}{l}3,092 \\
3,018 \\
2,860\end{array}$ & $\begin{array}{l}259 \\
259 \\
259\end{array}$ & $\begin{array}{l}442 \\
602 \\
887\end{array}$ & $\begin{array}{l}2,391 \\
2,157 \\
1,714\end{array}$ \\
\hline New Hampshire.-- & $\begin{array}{l}1970 \\
1962 \\
1952\end{array}$ & $\begin{array}{l}5,020 \\
4,937 \\
4,818\end{array}$ & $\begin{array}{l}696 \\
697 \\
682\end{array}$ & $\begin{array}{l}578 \\
579 \\
585\end{array}$ & $\begin{array}{l}568 \\
569 \\
580\end{array}$ & $\begin{array}{l}0 \\
0 \\
0\end{array}$ & $\begin{array}{l}0 \\
0 \\
0\end{array}$ & $\begin{array}{r}9 \\
10 \\
5\end{array}$ & $\begin{array}{l}65 \\
66 \\
45\end{array}$ & $\begin{array}{l}52 \\
52 \\
52\end{array}$ & $\begin{array}{l}4,324 \\
4,240 \\
4,136\end{array}$ & $\begin{array}{l}793 \\
793 \\
771\end{array}$ & $\begin{array}{r}642 \\
863 \\
1,333\end{array}$ & $\begin{array}{l}2,889 \\
2,584 \\
2,032\end{array}$ \\
\hline Rhode Island...... & $\begin{array}{l}1970 \\
1962 \\
1952\end{array}$ & $\begin{array}{l}429 \\
429 \\
430\end{array}$ & $\begin{array}{l}26 \\
26 \\
26\end{array}$ & $\begin{array}{l}0 \\
0 \\
0\end{array}$ & $\begin{array}{l}0 \\
0 \\
0\end{array}$ & $\begin{array}{l}0 \\
0 \\
0\end{array}$ & $\begin{array}{l}0 \\
0 \\
0\end{array}$ & $\begin{array}{l}0 \\
0 \\
0\end{array}$ & $\begin{array}{l}13 \\
13 \\
13\end{array}$ & $\begin{array}{l}13 \\
13 \\
13\end{array}$ & $\begin{array}{l}403 \\
403 \\
404\end{array}$ & $\begin{array}{l}0 \\
0 \\
0\end{array}$ & $\begin{array}{r}43 \\
67 \\
104\end{array}$ & $\begin{array}{l}360 \\
336 \\
300\end{array}$ \\
\hline Vermont........... & $\begin{array}{l}1970 \\
1962 \\
1952 \\
\end{array}$ & $\begin{array}{l}4,364 \\
4,210 \\
3,845 \\
\end{array}$ & $\begin{array}{l}405 \\
329 \\
297 \\
\end{array}$ & $\begin{array}{l}230 \\
231 \\
199 \\
\end{array}$ & $\begin{array}{l}226 \\
223 \\
191 \\
\end{array}$ & $\begin{array}{l}0 \\
0 \\
0 \\
\end{array}$ & $\begin{array}{l}0 \\
0 \\
0 \\
\end{array}$ & $\begin{array}{l}3 \\
8 \\
8 \\
\end{array}$ & $\begin{array}{r}131 \\
79 \\
79 \\
\end{array}$ & $\begin{array}{l}43 \\
19 \\
19 \\
\end{array}$ & $\begin{array}{l}3,958 \\
3,881 \\
3,548 \\
\end{array}$ & $\begin{array}{l}678 \\
528 \\
528 \\
\end{array}$ & $\begin{array}{l}1,084 \\
1,543 \\
1,925 \\
\end{array}$ & $\begin{array}{l}2,196 \\
1,810 \\
1,095 \\
\end{array}$ \\
\hline Total.......... & $\begin{array}{l}1970 \\
1962 \\
1952 \\
\end{array}$ & $\begin{array}{l}32,367 \\
31,878 \\
30,93 j\end{array}$ & $\begin{array}{l}1,993 \\
1,811 \\
1,741 \\
\end{array}$ & $\begin{array}{l}911 \\
906 \\
904 \\
\end{array}$ & $\begin{array}{l}832 \\
831 \\
810 \\
\end{array}$ & $\begin{array}{l}0 \\
0 \\
0 \\
\end{array}$ & $\begin{array}{l}0 \\
0 \\
0 \\
\end{array}$ & $\begin{array}{l}79 \\
75 \\
94 \\
\end{array}$ & $\begin{array}{l}775 \\
624 \\
580 \\
\end{array}$ & $\begin{array}{l}306 \\
281 \\
257 \\
\end{array}$ & $\begin{array}{l}30,374 \\
30,067 \\
29,194 \\
\end{array}$ & $\begin{array}{l}9,988 \\
8,104 \\
8,178 \\
\end{array}$ & $\begin{array}{l}3,637 \\
5,635 \\
7,842 \\
\end{array}$ & $\begin{array}{l}16,748 \\
16,328 \\
13,174 \\
\end{array}$ \\
\hline $\begin{array}{l}\text { Middle Atlantic: } \\
\text { Delaware.... }\end{array}$ & $\begin{array}{l}1970 \\
1962 \\
1952\end{array}$ & $\begin{array}{l}390 \\
391 \\
392\end{array}$ & $\begin{array}{r}9 \\
9 \\
13\end{array}$ & $\begin{array}{l}1 \\
1 \\
1\end{array}$ & $\begin{array}{l}0 \\
0 \\
0\end{array}$ & $\begin{array}{l}0 \\
0 \\
0\end{array}$ & $\begin{array}{l}0 \\
0 \\
0\end{array}$ & $\begin{array}{l}1 \\
1 \\
1\end{array}$ & $\begin{array}{r}8 \\
8 \\
10\end{array}$ & $\begin{array}{l}0 \\
0 \\
2\end{array}$ & $\begin{array}{l}381 \\
382 \\
379\end{array}$ & $\begin{array}{l}29 \\
24 \\
20\end{array}$ & $\begin{array}{l}142 \\
172 \\
213\end{array}$ & $\begin{array}{l}209 \\
185 \\
145\end{array}$ \\
\hline Maryland.............. & $\begin{array}{l}1970 \\
1962 \\
1952\end{array}$ & $\begin{array}{l}2,882 \\
2,845 \\
2,85-1\end{array}$ & $\begin{array}{l}189 \\
214 \\
214\end{array}$ & $\begin{array}{l}13 \\
54 \\
54\end{array}$ & $\begin{array}{l}0 \\
0 \\
0\end{array}$ & $\begin{array}{l}0 \\
0 \\
0\end{array}$ & $\begin{array}{l}0 \\
0 \\
0\end{array}$ & $\begin{array}{l}13 \\
54 \\
54\end{array}$ & $\begin{array}{r}144 \\
128 \\
\cdot \quad 128\end{array}$ & $\begin{array}{l}31 \\
32 \\
32\end{array}$ & $\begin{array}{l}2,692 \\
2,631 \\
2,640\end{array}$ & $\begin{array}{r}100 \\
57 \\
57\end{array}$ & $\begin{array}{r}728 \\
956 \\
1,278\end{array}$ & $\begin{array}{l}1,863 \\
1,618 \\
1,305\end{array}$ \\
\hline New Jersey......... & $\begin{array}{l}1970 \\
1962 \\
1952\end{array}$ & $\begin{array}{l}2,354 \\
2,262 \\
2,050\end{array}$ & $\begin{array}{l}254 \\
254 \\
181\end{array}$ & $\begin{array}{r}17 \\
17 \\
1\end{array}$ & $\begin{array}{l}0 \\
0 \\
0\end{array}$ & $\begin{array}{l}0 \\
0 \\
0\end{array}$ & $\begin{array}{l}0 \\
0 \\
0\end{array}$ & $\begin{array}{r}17 \\
17 \\
1\end{array}$ & $\begin{array}{l}237 \\
237 \\
130\end{array}$ & $\begin{array}{r}0 \\
0 \\
50\end{array}$ & $\begin{array}{l}2,100 \\
2,008 \\
1,869\end{array}$ & $\begin{array}{l}4 \\
4 \\
4\end{array}$ & $\begin{array}{l}195 \\
298 \\
443\end{array}$ & $\begin{array}{l}1,901 \\
1,706 \\
1,422\end{array}$ \\
\hline New York & $\begin{array}{l}1970 \\
1962 \\
1952\end{array}$ & $\begin{array}{l}14,489 \\
13,417 \\
11,952\end{array}$ & $\begin{array}{l}892 \\
895 \\
895\end{array}$ & $\begin{array}{l}57 \\
98 \\
98\end{array}$ & $\begin{array}{l}0 \\
0 \\
0\end{array}$ & $\begin{array}{l}0 \\
0 \\
0\end{array}$ & $\begin{array}{l}0 \\
0 \\
0\end{array}$ & $\begin{array}{l}57 \\
98 \\
98\end{array}$ & $\begin{array}{l}711 \\
714 \\
714\end{array}$ & $\begin{array}{r}123 \\
83 \\
83\end{array}$ & $\begin{array}{l}13,597 \\
12,522 \\
11,057\end{array}$ & $\begin{array}{l}1,180 \\
1,172 \\
1,172\end{array}$ & $\begin{array}{l}3,583 \\
4,158 \\
4,987\end{array}$ & $\begin{array}{l}8,833 \\
7,192 \\
4,898\end{array}$ \\
\hline Pennsylvania_..... & $\begin{array}{l}1970 \\
1962 \\
1952\end{array}$ & $\begin{array}{l}17,478 \\
16,279 \\
14,574\end{array}$ & $\begin{array}{l}3,406 \\
3,300 \\
3,229\end{array}$ & $\begin{array}{l}518 \\
48.5 \\
492\end{array}$ & $\begin{array}{l}488 \\
450 \\
454\end{array}$ & $\begin{array}{l}0 \\
0 \\
0\end{array}$ & $\begin{array}{l}0 \\
0 \\
0\end{array}$ & $\begin{array}{l}30 \\
35 \\
38\end{array}$ & $\begin{array}{l}2,646 \\
2,659 \\
2,580\end{array}$ & $\begin{array}{l}242 \\
156 \\
157\end{array}$ & $\begin{array}{l}14,072 \\
12,979 \\
11,345\end{array}$ & $\begin{array}{l}610 \\
442 \\
442\end{array}$ & $\begin{array}{l}3,188 \\
3,825 \\
4,728\end{array}$ & $\begin{array}{r}10,274 \\
8,712 \\
6,175\end{array}$ \\
\hline West Virginia...... & $\begin{array}{l}1970 \\
1962 \\
1952 \\
\end{array}$ & $\begin{array}{l}12,092 \\
11,543 \\
10,276 \\
\end{array}$ & $\begin{array}{r}1,046 \\
1,036 \\
982 \\
\end{array}$ & $\begin{array}{l}893 \\
883 \\
895 \\
\end{array}$ & $\begin{array}{l}879 \\
869 \\
881 \\
\end{array}$ & $\begin{array}{l}0 \\
0 \\
0 \\
\end{array}$ & $\begin{array}{l}0 \\
0 \\
0 \\
\end{array}$ & $\begin{array}{l}14 \\
14 \\
14 \\
\end{array}$ & $\begin{array}{r}144 \\
144 \\
83 \\
\end{array}$ & $\begin{array}{l}9 \\
9 \\
4 \\
\end{array}$ & $\begin{array}{r}11,045 \\
10,507 \\
9,294 \\
\end{array}$ & $\begin{array}{l}530 \\
530 \\
270 \\
\end{array}$ & $\begin{array}{l}2,071 \\
2,663 \\
3,465 \\
\end{array}$ & $\begin{array}{l}8,444 \\
7,314 \\
5,559 \\
\end{array}$ \\
\hline Total... & $\begin{array}{l}1970 \\
1962 \\
1952 \\
\end{array}$ & $\begin{array}{l}49,685 \\
46,737 \\
42,098 \\
\end{array}$ & $\begin{array}{l}5,796 \\
5,708 \\
5,514 \\
\end{array}$ & $\begin{array}{l}1,500 \\
1,538 \\
1,541 \\
\end{array}$ & $\begin{array}{l}1,367 \\
1,319 \\
1,335 \\
\end{array}$ & $\begin{array}{l}0 \\
0 \\
0\end{array}$ & $\begin{array}{l}0 \\
0 \\
0\end{array}$ & $\begin{array}{l}133 \\
219 \\
206 \\
\end{array}$ & $\begin{array}{l}3,890 \\
3,890 \\
3,645 \\
\end{array}$ & $\begin{array}{l}405 \\
280 \\
328 \\
\end{array}$ & $\begin{array}{l}43,888 \\
41,029 \\
36,584\end{array}$ & $\begin{array}{l}2,454 \\
2,229 \\
1,965 \\
\end{array}$ & $\begin{array}{r}9,907 \\
12,072 \\
15,114 \\
\end{array}$ & $\begin{array}{l}31,526 \\
26,728 \\
19,505 \\
\end{array}$ \\
\hline $\begin{array}{l}\text { Lake States: } \\
\text { Michigan }\end{array}$ & $\begin{array}{l}1970 \\
1962 \\
1952\end{array}$ & $\begin{array}{l}18,800 \\
19,121 \\
19,121\end{array}$ & $\begin{array}{l}6,440 \\
6,310 \\
6,310\end{array}$ & $\begin{array}{l}2,494 \\
2,530 \\
2,530\end{array}$ & $\begin{array}{l}2,422 \\
2,410 \\
2,410\end{array}$ & $\begin{array}{l}8 \\
9 \\
9\end{array}$ & $\begin{array}{l}17 \\
21 \\
21\end{array}$ & $\begin{array}{l}45 \\
90 \\
90\end{array}$ & $\begin{array}{l}3,838 \\
3,695 \\
3,695\end{array}$ & $\begin{array}{r}108 \\
85 \\
85\end{array}$ & $\begin{array}{l}12,359 \\
12,811 \\
12,811\end{array}$ & $\begin{array}{l}2,256 \\
1,548 \\
1,548\end{array}$ & $\begin{array}{l}3,429 \\
3,841 \\
3,841\end{array}$ & $\begin{array}{l}6,672 \\
7,422 \\
7,422\end{array}$ \\
\hline Minnesota ......... & $\begin{array}{l}1970 \\
1962 \\
1952\end{array}$ & $\begin{array}{l}16,875 \\
17,062 \\
17,368\end{array}$ & $\begin{array}{r}9,388 \\
9,539 \\
10,158\end{array}$ & $\begin{array}{l}2,781 \\
2,819 \\
3,055\end{array}$ & $\begin{array}{l}2,127 \\
2,141 \\
2,195\end{array}$ & $\begin{array}{l}64 \\
64 \\
49\end{array}$ & $\begin{array}{l}500 \\
521 \\
717\end{array}$ & $\begin{array}{l}92 \\
92 \\
94\end{array}$ & $\begin{array}{l}3,304 \\
3,303 \\
3,484\end{array}$ & $\begin{array}{l}3,300 \\
3,416 \\
3,619\end{array}$ & $\begin{array}{l}7,486 \\
7,522 \\
7,210\end{array}$ & $\begin{array}{l}814 \\
714 \\
578\end{array}$ & $\begin{array}{l}3,236 \\
3,344 \\
4,151\end{array}$ & $\begin{array}{l}3,436 \\
3,463 \\
2,481\end{array}$ \\
\hline North Dakota & $\begin{array}{l}1970 \\
1962 \\
1952\end{array}$ & $\begin{array}{l}406 \\
424 \\
451\end{array}$ & $\begin{array}{l}121 \\
128 \\
138\end{array}$ & $\begin{array}{l}114 \\
118 \\
128\end{array}$ & $\begin{array}{l}0 \\
0 \\
0\end{array}$ & $\begin{array}{l}1 \\
1 \\
0\end{array}$ & $\begin{array}{l}61 \\
63 \\
71\end{array}$ & $\begin{array}{l}52 \\
54 \\
56\end{array}$ & $\begin{array}{l}10 \\
10 \\
10\end{array}$ & $\begin{array}{l}0 \\
0 \\
0\end{array}$ & $\begin{array}{l}281 \\
296 \\
312\end{array}$ & $\begin{array}{l}0 \\
0 \\
0\end{array}$ & $\begin{array}{l}161 \\
173 \\
182\end{array}$ & $\begin{array}{l}119 \\
123 \\
130\end{array}$ \\
\hline (East) $\ldots \ldots$ & $\begin{array}{l}1970 \\
1962 \\
1952\end{array}$ & $\begin{array}{l}223 \\
230 \\
315\end{array}$ & $\begin{array}{r}77 \\
77 \\
106\end{array}$ & $\begin{array}{r}74 \\
74 \\
102\end{array}$ & $\begin{array}{l}0 \\
0 \\
0\end{array}$ & $\begin{array}{l}1 \\
1 \\
1\end{array}$ & $\begin{array}{l}68 \\
68 \\
93\end{array}$ & $\begin{array}{l}5 \\
5 \\
7\end{array}$ & $\begin{array}{l}3 \\
3 \\
4\end{array}$ & $\begin{array}{l}0 \\
0 \\
0\end{array}$ & $\begin{array}{l}145 \\
152 \\
208\end{array}$ & $\begin{array}{l}0 \\
0 \\
0\end{array}$ & $\begin{array}{l}142 \\
149 \\
204\end{array}$ & $\begin{array}{l}3 \\
3 \\
4\end{array}$ \\
\hline Wisconsin .......... & $\begin{array}{l}1970 \\
1962 \\
1952 \\
\end{array}$ & $\begin{array}{l}14,536 \\
14,693 \\
15,348 \\
\end{array}$ & $\begin{array}{l}4,525 \\
4,882 \\
5,099 \\
\end{array}$ & $\begin{array}{l}1,591 \\
1,910 \\
2,003 \\
\end{array}$ & $\begin{array}{l}1,317 \\
1,372 \\
1,357 \\
\end{array}$ & $\begin{array}{l}0 \\
5 \\
5 \\
\end{array}$ & $\begin{array}{l}156 \\
423 \\
379 \\
\end{array}$ & $\begin{array}{l}117 \\
110 \\
262 \\
\end{array}$ & $\begin{array}{l}568 \\
541 \\
444 \\
\end{array}$ & $\begin{array}{l}2,365 \\
2,431 \\
2,652 \\
\end{array}$ & $\begin{array}{r}10,011 \\
9,811 \\
10,249\end{array}$ & $\begin{array}{r}1,368 \\
933 \\
942 \\
\end{array}$ & $\begin{array}{l}4,723 \\
5,853 \\
6,252 \\
\end{array}$ & $\begin{array}{l}3,919 \\
3,025 \\
3,055 \\
\end{array}$ \\
\hline Total & $\begin{array}{l}1970 \\
1962 \\
1952 \\
\end{array}$ & $\begin{array}{l}50,840 \\
51,530 \\
52,604\end{array}$ & $\begin{array}{l}20,556 \\
20,936 \\
21,812 \\
\end{array}$ & $\begin{array}{l}7,059 \\
7,451 \\
7,818 \\
\end{array}$ & $\begin{array}{l}5,867 \\
5,923 \\
5,962 \\
\end{array}$ & $\begin{array}{l}74 \\
80 \\
65 \\
\end{array}$ & $\begin{array}{r}804 \\
1,096 \\
1,281 \\
\end{array}$ & $\begin{array}{l}312 \\
351 \\
509\end{array}$ & $\begin{array}{l}7,723 \\
7,553 \\
7,637 \\
\end{array}$ & $\begin{array}{l}5,774 \\
5,932 \\
6,356 \\
\end{array}$ & $\begin{array}{l}30,281 \\
30,593 \\
30,792\end{array}$ & $\begin{array}{l}4,438 \\
3,195 \\
3,068 \\
\end{array}$ & $\begin{array}{l}11,694 \\
13,360 \\
14,631\end{array}$ & $\begin{array}{l}14,151 \\
14,037 \\
13,092 \\
\end{array}$ \\
\hline
\end{tabular}

See footnote at end of table. 
TABLE 2.-Area of commercial timberland in the United States, by ownership, and section, region, and State, as of December 31, 1952 and 1962, and January 1, 1970 1-Continued

[Thousand acres]

\begin{tabular}{|c|c|c|c|c|c|c|c|c|c|c|c|c|c|c|}
\hline \multirow{3}{*}{$\begin{array}{l}\text { Section, region, } \\
\text { and State }\end{array}$} & \multirow{3}{*}{ Year } & \multirow{3}{*}{$\begin{array}{l}\text { All } \\
\text { owner- } \\
\text { ships }\end{array}$} & \multicolumn{8}{|c|}{ Public } & \multicolumn{4}{|c|}{ Private } \\
\hline & & & \multirow{2}{*}{$\begin{array}{l}\text { Total } \\
\text { public }\end{array}$} & \multicolumn{5}{|c|}{ Federal } & \multirow[b]{2}{*}{ State } & \multirow{2}{*}{$\begin{array}{c}\text { County } \\
\text { and } \\
\text { munic- } \\
\text { ipal }\end{array}$} & \multirow[b]{2}{*}{$\begin{array}{l}\text { Total } \\
\text { private }\end{array}$} & \multirow[b]{2}{*}{$\begin{array}{c}\text { Forest } \\
\text { industry }\end{array}$} & \multirow[b]{2}{*}{ Farmer } & \multirow{2}{*}{$\begin{array}{l}\text { Miscel- } \\
\text { laneous } \\
\text { private }\end{array}$} \\
\hline & & & & $\begin{array}{l}\text { Total } \\
\text { Federal }\end{array}$ & $\begin{array}{l}\text { National } \\
\text { Forest }\end{array}$ & $\begin{array}{c}\text { Bureau } \\
\text { of Land } \\
\text { Manage- } \\
\text { ment }\end{array}$ & Indian & $\begin{array}{c}\text { Miscel- } \\
\text { laneous } \\
\text { Federal }\end{array}$ & & & & & & \\
\hline $\begin{array}{l}\text { Central: } \\
\text { Illinois.......... }\end{array}$ & $\begin{array}{l}1970 \\
1962 \\
1952\end{array}$ & $\begin{array}{l}3,680 \\
3,761 \\
3,830\end{array}$ & $\begin{array}{l}267 \\
240 \\
226\end{array}$ & $\begin{array}{l}256 \\
229 \\
216\end{array}$ & $\begin{array}{l}214 \\
187 \\
184\end{array}$ & $\begin{array}{l}0 \\
0 \\
0\end{array}$ & $\begin{array}{l}0 \\
0 \\
0\end{array}$ & $\begin{array}{l}41 \\
41 \\
32\end{array}$ & $\begin{array}{l}11 \\
11 \\
10\end{array}$ & $\begin{array}{l}0 \\
0 \\
0\end{array}$ & $\begin{array}{l}3,412 \\
3,521 \\
3,604\end{array}$ & $\begin{array}{l}16 \\
16 \\
10\end{array}$ & $\begin{array}{l}2,107 \\
2,216 \\
2,961\end{array}$ & $\begin{array}{r}1,288 \\
1,288 \\
633\end{array}$ \\
\hline Indiana............. & $\begin{array}{l}1970 \\
1962 \\
1952\end{array}$ & $\begin{array}{l}3,840 \\
3,930 \\
4,015\end{array}$ & $\begin{array}{l}360 \\
294 \\
283\end{array}$ & $\begin{array}{l}213 \\
177 \\
172\end{array}$ & $\begin{array}{l}136 \\
112 \\
112\end{array}$ & $\begin{array}{l}0 \\
0 \\
0\end{array}$ & $\begin{array}{l}0 \\
0 \\
0\end{array}$ & $\begin{array}{l}77 \\
65 \\
60\end{array}$ & $\begin{array}{l}146 \\
115 \\
109\end{array}$ & $\begin{array}{l}1 \\
2 \\
2\end{array}$ & $\begin{array}{l}3,479 \\
3,636 \\
3,732\end{array}$ & $\begin{array}{r}21 \\
9 \\
9\end{array}$ & $\begin{array}{l}2,605 \\
2,853 \\
2,848\end{array}$ & $\begin{array}{l}851 \\
774 \\
875\end{array}$ \\
\hline Iowa_............ & $\begin{array}{l}1970 \\
1962 \\
1952\end{array}$ & $\begin{array}{l}2,430 \\
2,480 \\
2,595\end{array}$ & $\begin{array}{l}34 \\
36 \\
36\end{array}$ & $\begin{array}{l}10 \\
12 \\
12\end{array}$ & $\begin{array}{l}0 \\
2 \\
2\end{array}$ & $\begin{array}{l}0 \\
0 \\
0\end{array}$ & $\begin{array}{l}1 \\
1 \\
1\end{array}$ & $\begin{array}{l}9 \\
9 \\
9\end{array}$ & $\begin{array}{l}22 \\
22 \\
22\end{array}$ & $\begin{array}{l}1 \\
1 \\
1\end{array}$ & $\begin{array}{l}2,395 \\
2,443 \\
2,558\end{array}$ & $\begin{array}{l}9 \\
4 \\
0\end{array}$ & $\begin{array}{l}2,129 \\
2,175 \\
2,282\end{array}$ & $\begin{array}{l}257 \\
263 \\
276\end{array}$ \\
\hline Kansas. ............. & $\begin{array}{l}1970 \\
1962 \\
1952\end{array}$ & $\begin{array}{l}1,187 \\
1,194 \\
1,208\end{array}$ & $\begin{array}{l}36 \\
36 \\
26\end{array}$ & $\begin{array}{l}26 \\
26 \\
26\end{array}$ & $\begin{array}{l}0 \\
0 \\
0\end{array}$ & $\begin{array}{l}0 \\
0 \\
0\end{array}$ & $\begin{array}{l}0 \\
0 \\
0\end{array}$ & $\begin{array}{l}26 \\
26 \\
26\end{array}$ & $\begin{array}{l}8 \\
8 \\
0\end{array}$ & $\begin{array}{l}1 \\
1 \\
0\end{array}$ & $\begin{array}{l}1,150 \\
1,157 \\
1,181\end{array}$ & $\begin{array}{l}0 \\
0 \\
0\end{array}$ & $\begin{array}{l}798 \\
805 \\
821\end{array}$ & $\begin{array}{l}352 \\
352 \\
359\end{array}$ \\
\hline Kentucky . . ....... & $\begin{array}{l}1970 \\
1962 \\
1952\end{array}$ & $\begin{array}{l}11,826 \\
11,651 \\
11,497\end{array}$ & $\begin{array}{l}820 \\
652 \\
725\end{array}$ & $\begin{array}{l}738 \\
575 \\
672\end{array}$ & $\begin{array}{l}531 \\
438 \\
455\end{array}$ & $\begin{array}{l}0 \\
0 \\
0\end{array}$ & $\begin{array}{l}0 \\
0 \\
0\end{array}$ & $\begin{array}{l}207 \\
137 \\
217\end{array}$ & $\begin{array}{l}76 \\
77 \\
53\end{array}$ & $\begin{array}{l}5 \\
0 \\
0\end{array}$ & $\begin{array}{l}11,005 \\
10,999 \\
10,772\end{array}$ & $\begin{array}{l}227 \\
308 \\
308\end{array}$ & $\begin{array}{l}5,882 \\
6,420 \\
7,226\end{array}$ & $\begin{array}{l}4,895 \\
4,271 \\
3,238\end{array}$ \\
\hline Missouri_.......... & $\begin{array}{l}1970 \\
1962 \\
1952\end{array}$ & $\begin{array}{l}14,600 \\
14,850 \\
14,913\end{array}$ & $\begin{array}{l}1,586 \\
1,586 \\
1,617\end{array}$ & $\begin{array}{l}1,372 \\
1,362 \\
1,461\end{array}$ & $\begin{array}{l}1,321 \\
1,311 \\
1,339\end{array}$ & $\begin{array}{l}0 \\
0 \\
1\end{array}$ & $\begin{array}{l}0 \\
0 \\
0\end{array}$ & $\begin{array}{r}51 \\
51 \\
121\end{array}$ & $\begin{array}{l}188 \\
199 \\
156\end{array}$ & $\begin{array}{r}25 \\
25 \\
0\end{array}$ & $\begin{array}{l}13,013 \\
13,264 \\
13,296\end{array}$ & $\begin{array}{l}279 \\
276 \\
460\end{array}$ & $\begin{array}{l}8,850 \\
9,150 \\
8,347\end{array}$ & $\begin{array}{l}3,884 \\
3,836 \\
4,489\end{array}$ \\
\hline Nebraska.......... & $\begin{array}{l}1970 \\
1962 \\
1952\end{array}$ & $\begin{array}{l}1,023 \\
1,034 \\
1,050\end{array}$ & $\begin{array}{l}94 \\
93 \\
62\end{array}$ & $\begin{array}{l}83 \\
81 \\
50\end{array}$ & $\begin{array}{l}57 \\
57 \\
28\end{array}$ & $\begin{array}{l}0 \\
0 \\
0\end{array}$ & $\begin{array}{l}9 \\
7 \\
5\end{array}$ & $\begin{array}{l}17 \\
17 \\
17\end{array}$ & $\begin{array}{l}11 \\
11 \\
11\end{array}$ & $\begin{array}{l}0 \\
0 \\
0\end{array}$ & $\begin{array}{l}928 \\
940 \\
988\end{array}$ & $\begin{array}{l}0 \\
0 \\
0\end{array}$ & $\begin{array}{l}789 \\
802 \\
849\end{array}$ & $\begin{array}{l}138 \\
138 \\
138\end{array}$ \\
\hline Ohio & $\begin{array}{l}1970 \\
1962 \\
1952 \\
\end{array}$ & $\begin{array}{l}6,422 \\
6,041 \\
5,450 \\
\end{array}$ & $\begin{array}{l}365 \\
360 \\
297 \\
\end{array}$ & $\begin{array}{r}138 \\
88 \\
88 \\
\end{array}$ & $\begin{array}{r}129 \\
88 \\
88\end{array}$ & $\begin{array}{l}0 \\
0 \\
0\end{array}$ & $\begin{array}{l}0 \\
0 \\
0\end{array}$ & $\begin{array}{l}8 \\
0 \\
0\end{array}$ & $\begin{array}{l}222 \\
231 \\
168 \\
\end{array}$ & $\begin{array}{r}4 \\
41 \\
41 \\
\end{array}$ & $\begin{array}{l}6,056 \\
5,681 \\
5,153 \\
\end{array}$ & $\begin{array}{r}126 \\
74 \\
30 \\
\end{array}$ & $\begin{array}{l}2,616 \\
2,882 \\
3,512 \\
\end{array}$ & $\begin{array}{l}3,314 \\
2,725 \\
1,611 \\
\end{array}$ \\
\hline Total............. & $\begin{array}{l}1970 \\
1962 \\
1952 \\
\end{array}$ & $\begin{array}{l}45,008 \\
44,942 \\
44,559 \\
\end{array}$ & $\begin{array}{l}3,565 \\
3,299 \\
3,273 \\
\end{array}$ & $\begin{array}{l}2,840 \\
2,552 \\
2,699 \\
\end{array}$ & $\begin{array}{l}2,390 \\
2,196 \\
2,208 \\
\end{array}$ & $\begin{array}{l}0 \\
0 \\
1 \\
\end{array}$ & $\begin{array}{r}10 \\
8 \\
6 \\
\end{array}$ & $\begin{array}{l}438 \\
347 \\
483 \\
\end{array}$ & $\begin{array}{l}686 \\
674 \\
529 \\
\end{array}$ & $\begin{array}{l}39 \\
71 \\
45 \\
\end{array}$ & $\begin{array}{l}41,442 \\
41,642 \\
41,285 \\
\end{array}$ & $\begin{array}{l}681 \\
688 \\
817 \\
\end{array}$ & $\begin{array}{l}25,778 \\
27,304 \\
28,848 \\
\end{array}$ & $\begin{array}{l}14,982 \\
13,649 \\
11,620 \\
\end{array}$ \\
\hline Total, North - & $\begin{array}{l}1970 \\
1962 \\
1952 \\
\end{array}$ & $\begin{array}{l}177,901 \\
175,089 \\
170,198 \\
\end{array}$ & $\begin{array}{l}31,911 \\
31,755 \\
32,341 \\
\end{array}$ & $\begin{array}{l}12,311 \\
12,448 \\
12,962 \\
\end{array}$ & $\begin{array}{l}10,458 \\
10,270 \\
10,315 \\
\end{array}$ & $\begin{array}{l}74 \\
80 \\
66 \\
\end{array}$ & $\begin{array}{r}815 \\
1,105 \\
1,288 \\
\end{array}$ & $\begin{array}{r}963 \\
992 \\
1,292 \\
\end{array}$ & $\begin{array}{l}13,075 \\
12,741 \\
12,391 \\
\end{array}$ & $\begin{array}{l}6,524 \\
6,565 \\
6,986 \\
\end{array}$ & $\begin{array}{l}145,989 \\
143,334 \\
137,857\end{array}$ & $\begin{array}{l}17,563 \\
14,217 \\
14,028\end{array}$ & $\begin{array}{l}51,017 \\
\mathbf{5 8}, \mathbf{3 7 2} \\
66,435 \\
\end{array}$ & $\begin{array}{l}77,409 \\
70,743 \\
57,393 \\
\end{array}$ \\
\hline $\begin{array}{l}\text { South Atlantic: } \\
\text { North Carolina...- }\end{array}$ & $\begin{array}{l}1970 \\
1962 \\
1952\end{array}$ & $\begin{array}{l}20,192 \\
19,989 \\
19,582\end{array}$ & $\begin{array}{l}1,722 \\
1,720 \\
1,591\end{array}$ & $\begin{array}{l}1,349 \\
1,347 \\
1,303\end{array}$ & $\begin{array}{l}1,035 \\
1,033 \\
1,019\end{array}$ & $\begin{array}{l}0 \\
0 \\
0\end{array}$ & $\begin{array}{l}56 \\
56 \\
52\end{array}$ & $\begin{array}{l}257 \\
257 \\
231\end{array}$ & $\begin{array}{l}307 \\
307 \\
253\end{array}$ & $\begin{array}{l}65 \\
65 \\
35\end{array}$ & $\begin{array}{l}18,470 \\
18,268 \\
17,990\end{array}$ & $\begin{array}{l}2,785 \\
2,495 \\
2,584\end{array}$ & $\begin{array}{r}8,602 \\
9,503 \\
13,590\end{array}$ & $\begin{array}{l}7,082 \\
6,270 \\
1,816\end{array}$ \\
\hline South Carolina.... & $\begin{array}{l}1970 \\
1962 \\
1952\end{array}$ & $\begin{array}{l}12,410 \\
12,170 \\
11,883\end{array}$ & $\begin{array}{r}1,073 \\
1,033 \\
954\end{array}$ & $\begin{array}{l}840 \\
857 \\
801\end{array}$ & $\begin{array}{l}550 \\
563 \\
562\end{array}$ & $\begin{array}{l}0 \\
0 \\
0\end{array}$ & $\begin{array}{l}0 \\
0 \\
0\end{array}$ & $\begin{array}{l}289 \\
294 \\
239\end{array}$ & $\begin{array}{l}205 \\
153 \\
128\end{array}$ & $\begin{array}{l}26 \\
23 \\
25\end{array}$ & $\begin{array}{l}11,337 \\
11,136 \\
10,929\end{array}$ & $\begin{array}{l}2,047 \\
2,009 \\
1,650\end{array}$ & $\begin{array}{l}4,995 \\
5,637 \\
7,530\end{array}$ & $\begin{array}{l}4,294 \\
3,490 \\
1,749\end{array}$ \\
\hline 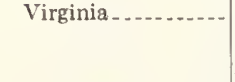 & $\begin{array}{l}1970 \\
1962 \\
1952 \\
\end{array}$ & $\begin{array}{l}15,859 \\
15,752 \\
15,496 \\
\end{array}$ & $\begin{array}{l}1,671 \\
1,535 \\
1,492 \\
\end{array}$ & $\begin{array}{l}1,437 \\
1,395 \\
1,355 \\
\end{array}$ & $\begin{array}{l}1,202 \\
1,202 \\
1,198 \\
\end{array}$ & $\begin{array}{l}0 \\
0 \\
0 \\
\end{array}$ & $\begin{array}{l}0 \\
0 \\
0 \\
\end{array}$ & $\begin{array}{l}233 \\
192 \\
157 \\
\end{array}$ & $\begin{array}{r}181 \\
88 \\
86 \\
\end{array}$ & $\begin{array}{l}53 \\
52 \\
51\end{array}$ & $\begin{array}{l}14,187 \\
14,216 \\
14,003\end{array}$ & $\begin{array}{l}1,634 \\
1,454 \\
1,094 \\
\end{array}$ & $\begin{array}{r}6,701 \\
8,000 \\
10,817 \\
\end{array}$ & $\begin{array}{l}5,851 \\
4,761 \\
2,091 \\
\end{array}$ \\
\hline Total........... & $\begin{array}{l}1970 \\
1962 \\
1952 \\
\end{array}$ & $\begin{array}{l}48,463 \\
47,911 \\
46,962 \\
\end{array}$ & $\begin{array}{l}4,468 \\
4,289 \\
4,039 \\
\end{array}$ & $\begin{array}{r}3,627 \\
3,600 \\
3,459 \\
\end{array}$ & $\begin{array}{r}2,789 \\
2,799 \\
2,780 \\
\end{array}$ & $\begin{array}{l}0 \\
0 \\
0 \\
\end{array}$ & $\begin{array}{l}57 \\
57 \\
52 \\
\end{array}$ & $\begin{array}{r}780 \\
743 \\
627 \\
\end{array}$ & $\begin{array}{r}694 \\
548 \\
467 \\
\end{array}$ & $\begin{array}{l}145 \\
140 \\
112 \\
\end{array}$ & $\begin{array}{l}\mathbf{4 3}, 995 \\
\mathbf{4 3}, 622 \\
42,923 \\
\end{array}$ & $\begin{array}{l}6,467 \\
5,959 \\
5,328 \\
\end{array}$ & $\begin{array}{l}20,299 \\
23,140 \\
31,937 \\
\end{array}$ & $\begin{array}{r}17,228 \\
14,522 \\
5,657 \\
\end{array}$ \\
\hline $\begin{array}{l}\text { East Gulf: } \\
\text { Florida..- }\end{array}$ & $\begin{array}{l}1970 \\
1962 \\
1952\end{array}$ & $\begin{array}{l}16,231 \\
16,830 \\
18,135\end{array}$ & $\begin{array}{l}2,145 \\
2,219 \\
2,251\end{array}$ & $\begin{array}{l}1,653 \\
1,640 \\
1,813\end{array}$ & $\begin{array}{l}1,035 \\
1,030 \\
1,035\end{array}$ & $\begin{array}{r}0 \\
2 \\
14\end{array}$ & $\begin{array}{r}8 \\
18 \\
36\end{array}$ & $\begin{array}{l}609 \\
588 \\
728\end{array}$ & $\begin{array}{l}466 \\
539 \\
382\end{array}$ & $\begin{array}{l}26 \\
40 \\
56\end{array}$ & $\begin{array}{l}14,086 \\
14,610 \\
15,884\end{array}$ & $\begin{array}{l}5,216 \\
4,767 \\
4,369\end{array}$ & $\begin{array}{l}2,915 \\
3,593 \\
7,280\end{array}$ & $\begin{array}{l}5,953 \\
6,249 \\
4,235\end{array}$ \\
\hline Georgia...... & $\begin{array}{l}1970 \\
1962 \\
1952 \\
\end{array}$ & $\begin{array}{l}25,102 \\
26,298 \\
23,969 \\
\end{array}$ & $\begin{array}{l}1,407 \\
1,813 \\
1,684 \\
\end{array}$ & $\begin{array}{l}1,326 \\
1,678 \\
1,560 \\
\end{array}$ & $\begin{array}{l}806 \\
745 \\
643 \\
\end{array}$ & $\begin{array}{l}0 \\
0 \\
0 \\
\end{array}$ & $\begin{array}{l}0 \\
0 \\
0\end{array}$ & $\begin{array}{l}520 \\
933 \\
916 \\
\end{array}$ & $\begin{array}{r}56 \\
111 \\
101 \\
\end{array}$ & $\begin{array}{l}24 \\
24 \\
23\end{array}$ & $\begin{array}{l}23,695 \\
24,484 \\
22,284\end{array}$ & $\begin{array}{l}4,700 \\
4,686 \\
4,246\end{array}$ & $\begin{array}{l}12,110 \\
14,865 \\
15,854 \\
\end{array}$ & $\begin{array}{l}6,885 \\
4,933 \\
2,184 \\
\end{array}$ \\
\hline Total _. & $\begin{array}{l}1970 \\
1962 \\
1952 \\
\end{array}$ & $\begin{array}{l}41,334 \\
43,128 \\
42,104 \\
\end{array}$ & $\begin{array}{l}3,552 \\
4,033 \\
3,935 \\
\end{array}$ & $\begin{array}{l}2,980 \\
3,318 \\
3,373 \\
\end{array}$ & $\begin{array}{l}1,842 \\
1,775 \\
1,678 \\
\end{array}$ & $\begin{array}{r}0 \\
2 \\
14 \\
\end{array}$ & $\begin{array}{r}8 \\
18 \\
36 \\
\end{array}$ & $\begin{array}{l}1,129 \\
1,521 \\
1,644 \\
\end{array}$ & $\begin{array}{r}522 \\
650 \\
483 \\
\end{array}$ & $\begin{array}{l}50 \\
64 \\
79 \\
\end{array}$ & $\begin{array}{l}37,781 \\
39,094 \\
38,168 \\
\end{array}$ & $\begin{array}{l}9,916 \\
9,453 \\
8,615\end{array}$ & $\begin{array}{l}15,026 \\
18,458 \\
23,134\end{array}$ & $\begin{array}{r}12,839 \\
11,183 \\
6,419 \\
\end{array}$ \\
\hline
\end{tabular}

See footnote at end of table. 
TABLE 2.-Area of commercial timberland in the United States, by ownership, and section, region, and State, as of December 31 , 1952 and 1962, and January 1, $1970^{1}$-Continued

[Thousand acres]

\begin{tabular}{|c|c|c|c|c|c|c|c|c|c|c|c|c|c|c|}
\hline \multirow{3}{*}{$\begin{array}{l}\text { Section, region, } \\
\text { and State }\end{array}$} & \multirow{3}{*}{ Year } & \multirow{3}{*}{$\begin{array}{l}\text { All } \\
\text { owner- } \\
\text { ships }\end{array}$} & \multicolumn{8}{|c|}{ Public } & \multicolumn{4}{|c|}{ Private } \\
\hline & & & \multirow{2}{*}{$\begin{array}{l}\text { Total } \\
\text { public }\end{array}$} & \multicolumn{5}{|c|}{ Federal } & \multirow{2}{*}{ State } & \multirow{2}{*}{$\begin{array}{c}\text { County } \\
\text { and } \\
\text { munic- } \\
\text { ipal }\end{array}$} & \multirow{2}{*}{$\begin{array}{c}\text { Total } \\
\text { private }\end{array}$} & \multirow{2}{*}{$\begin{array}{l}\text { Forest } \\
\text { industry }\end{array}$} & \multirow[b]{2}{*}{ Farmer } & \multirow{2}{*}{$\begin{array}{l}\text { Miscel- } \\
\text { laneous } \\
\text { private }\end{array}$} \\
\hline & & & & $\begin{array}{c}\text { Total } \\
\text { Federal }\end{array}$ & $\begin{array}{c}\text { National } \\
\text { Forest }\end{array}$ & $\begin{array}{l}\text { Bureau } \\
\text { of Land } \\
\text { Mlanage- } \\
\text { ment }\end{array}$ & Indian & $\begin{array}{c}\text { Miscel- } \\
\text { laneous } \\
\text { Federal }\end{array}$ & & & & & & \\
\hline $\begin{array}{l}\text { Central Gulf: } \\
\text { Alabama }\end{array}$ & $\begin{array}{l}1970 \\
1962 \\
1952\end{array}$ & $\begin{array}{l}21,742 \\
21,742 \\
20,756\end{array}$ & $\begin{array}{r}997 \\
1,001 \\
968\end{array}$ & $\begin{array}{l}795 \\
799 \\
791\end{array}$ & $\begin{array}{l}625 \\
629 \\
616\end{array}$ & $\begin{array}{r}2 \\
2 \\
10\end{array}$ & $\begin{array}{l}0 \\
0 \\
0\end{array}$ & $\begin{array}{l}166 \\
166 \\
165\end{array}$ & $\begin{array}{l}156 \\
156 \\
150\end{array}$ & $\begin{array}{l}45 \\
45 \\
27\end{array}$ & $\begin{array}{l}20,744 \\
20,740 \\
19,788\end{array}$ & $\begin{array}{l}3,818 \\
3,818 \\
3,138\end{array}$ & $\begin{array}{l}7,628 \\
7,631 \\
8,114\end{array}$ & $\begin{array}{l}9,298 \\
9,291 \\
8,536\end{array}$ \\
\hline Mississippi........ & $\begin{array}{l}1970 \\
1962 \\
1962\end{array}$ & $\begin{array}{l}16,891 \\
17,976 \\
16,440\end{array}$ & $\begin{array}{l}1,770 \\
1,719 \\
1,718\end{array}$ & $\begin{array}{l}1,299 \\
1,267 \\
1,245\end{array}$ & $\begin{array}{l}1118 \\
1,108 \\
1,036\end{array}$ & $\begin{array}{l}1 \\
4 \\
4\end{array}$ & $\begin{array}{l}13 \\
12 \\
10\end{array}$ & $\begin{array}{l}166 \\
143 \\
195\end{array}$ & $\begin{array}{l}93 \\
55 \\
54\end{array}$ & $\begin{array}{l}377 \\
397 \\
419\end{array}$ & $\begin{array}{l}15,121 \\
16,257 \\
14,722\end{array}$ & $\begin{array}{l}2,505 \\
2,683 \\
2,602\end{array}$ & $\begin{array}{l}6,204 \\
5,849 \\
6,958\end{array}$ & $\begin{array}{l}6,412 \\
7,724 \\
5,162\end{array}$ \\
\hline Tennessee......... & $\begin{array}{l}1970 \\
1962 \\
1952 \\
\end{array}$ & $\begin{array}{l}12,819 \\
13,643 \\
12,301 \\
\end{array}$ & $\begin{array}{l}1,286 \\
1,199 \\
1,172\end{array}$ & $\begin{array}{l}940 \\
834 \\
833\end{array}$ & $\begin{array}{l}599 \\
591 \\
566 \\
\end{array}$ & $\begin{array}{l}0 \\
0 \\
0\end{array}$ & $\begin{array}{l}0 \\
0 \\
0\end{array}$ & $\begin{array}{l}340 \\
243 \\
267\end{array}$ & $\begin{array}{l}324 \\
344 \\
329 \\
\end{array}$ & $\begin{array}{l}22 \\
21 \\
10\end{array}$ & $\begin{array}{l}11,533 \\
12,444 \\
11,129 \\
\end{array}$ & $\begin{array}{r}1,121 \\
946 \\
750 \\
\end{array}$ & $\begin{array}{l}5,079 \\
5,745 \\
6,126 \\
\end{array}$ & $\begin{array}{l}5,333 \\
5,753 \\
4,253 \\
\end{array}$ \\
\hline Total & $\begin{array}{l}1970 \\
1962 \\
1952 \\
\end{array}$ & $\begin{array}{l}51,453 \\
53,361 \\
49,497 \\
\end{array}$ & $\begin{array}{l}4,053 \\
3,919 \\
3,858 \\
\end{array}$ & $\begin{array}{l}3,034 \\
2,900 \\
2,869 \\
\end{array}$ & $\begin{array}{l}2,344 \\
2,328 \\
2,215\end{array}$ & $\begin{array}{r}3 \\
6 \\
14 \\
\end{array}$ & $\begin{array}{l}13 \\
12 \\
10 \\
\end{array}$ & $\begin{array}{l}673 \\
552 \\
627 \\
\end{array}$ & $\begin{array}{l}574 \\
555 \\
533 \\
\end{array}$ & $\begin{array}{l}445 \\
463 \\
456 \\
\end{array}$ & $\begin{array}{l}47,400 \\
49,441 \\
45,639 \\
\end{array}$ & $\begin{array}{l}7,444 \\
7,447 \\
6,490\end{array}$ & $\begin{array}{l}18,912 \\
19,226 \\
21,198\end{array}$ & $\begin{array}{l}21,043 \\
22,768 \\
17,951\end{array}$ \\
\hline $\begin{array}{l}\text { West Gulf: } \\
\text { Arkansas... }\end{array}$ & $\begin{array}{l}1970 \\
1962 \\
1952\end{array}$ & $\begin{array}{l}18,206 \\
21,500 \\
19,265\end{array}$ & $\begin{array}{l}2,938 \\
2,846 \\
2,910\end{array}$ & $\begin{array}{l}2,682 \\
2,641 \\
2,802\end{array}$ & $\begin{array}{l}2,378 \\
2,373 \\
2,326\end{array}$ & $\begin{array}{r}1 \\
3 \\
122\end{array}$ & $\begin{array}{l}0 \\
0 \\
0\end{array}$ & $\begin{array}{l}302 \\
265 \\
354\end{array}$ & $\begin{array}{l}236 \\
194 \\
106\end{array}$ & $\begin{array}{r}19 \\
11 \\
2\end{array}$ & $\begin{array}{l}15,268 \\
18,654 \\
16,355\end{array}$ & $\begin{array}{l}3,950 \\
4,028 \\
4,118\end{array}$ & $\begin{array}{l}4,800 \\
5,613 \\
6,733\end{array}$ & $\begin{array}{l}6,517 \\
9,013 \\
5,504\end{array}$ \\
\hline Louisiana_....... & $\begin{array}{l}1970 \\
1962 \\
1952\end{array}$ & $\begin{array}{l}15,342 \\
16,512 \\
16,038\end{array}$ & $\begin{array}{l}860 \\
885 \\
848\end{array}$ & $\begin{array}{l}692 \\
704 \\
667\end{array}$ & $\begin{array}{l}551 \\
575 \\
536\end{array}$ & $\begin{array}{r}6 \\
11 \\
4\end{array}$ & $\begin{array}{l}0 \\
0 \\
0\end{array}$ & $\begin{array}{l}134 \\
118 \\
127\end{array}$ & $\begin{array}{l}163 \\
176 \\
176\end{array}$ & $\begin{array}{l}4 \\
5 \\
5\end{array}$ & $\begin{array}{l}14,482 \\
15,627 \\
15,190\end{array}$ & $\begin{array}{l}3,180 \\
3,084 \\
3,452\end{array}$ & $\begin{array}{l}2,284 \\
2,813 \\
3,189\end{array}$ & $\begin{array}{l}9,017 \\
9,728 \\
8,549\end{array}$ \\
\hline Oklahoma............ & $\begin{array}{l}1970 \\
1962 \\
1952\end{array}$ & $\begin{array}{l}4,817 \\
4,711 \\
5,044\end{array}$ & $\begin{array}{l}577 \\
451 \\
448\end{array}$ & $\begin{array}{l}481 \\
391 \\
388\end{array}$ & $\begin{array}{l}233 \\
219 \\
212\end{array}$ & $\begin{array}{l}0 \\
3 \\
7\end{array}$ & $\begin{array}{l}136 \\
140 \\
140\end{array}$ & $\begin{array}{r}111 \\
29 \\
29\end{array}$ & $\begin{array}{l}86 \\
60 \\
60\end{array}$ & $\begin{array}{l}9 \\
0 \\
0\end{array}$ & $\begin{array}{l}4,240 \\
4,259 \\
4,595\end{array}$ & $\begin{array}{l}868 \\
969 \\
929\end{array}$ & $\begin{array}{l}1,411 \\
1,134 \\
1,586\end{array}$ & $\begin{array}{l}1,959 \\
2,156 \\
2,080\end{array}$ \\
\hline Texas................. & $\begin{array}{l}1970 \\
1962 \\
1952 \\
\end{array}$ & $\begin{array}{l}12,924 \\
12,-81 \\
13,171\end{array}$ & $\begin{array}{l}828 \\
753 \\
767 \\
\end{array}$ & $\begin{array}{l}778 \\
719 \\
736\end{array}$ & $\begin{array}{l}625 \\
618 \\
655 \\
\end{array}$ & $\begin{array}{l}0 \\
0 \\
0\end{array}$ & $\begin{array}{l}3 \\
1 \\
4 \\
\end{array}$ & $\begin{array}{r}149 \\
100 \\
77 \\
\end{array}$ & $\begin{array}{l}42 \\
32 \\
29 \\
\end{array}$ & $\begin{array}{l}6 \\
2 \\
2 \\
\end{array}$ & $\begin{array}{l}12,095 \\
12,028 \\
12,401\end{array}$ & $\begin{array}{l}3,496 \\
3,128 \\
3,123 \\
\end{array}$ & $\begin{array}{l}2,403 \\
2,787 \\
3,533\end{array}$ & $\begin{array}{l}6,195 \\
6,112 \\
5,748 \\
\end{array}$ \\
\hline Total ............ & $\begin{array}{l}1970 \\
1962 \\
1952 \\
\end{array}$ & $\begin{array}{l}51,290 \\
55,504 \\
53,518 \\
\end{array}$ & $\begin{array}{l}5,204 \\
4,935 \\
4,973 \\
\end{array}$ & $\begin{array}{l}4,634 \\
4,455 \\
4,593 \\
\end{array}$ & $\begin{array}{l}3,788 \\
3,785 \\
3,729 \\
\end{array}$ & $\begin{array}{r}7 \\
17 \\
133 \\
\end{array}$ & $\begin{array}{l}140 \\
141 \\
144\end{array}$ & $\begin{array}{l}699 \\
512 \\
587 \\
\end{array}$ & $\begin{array}{l}529 \\
462 \\
371 \\
\end{array}$ & $\begin{array}{r}39 \\
18 \\
9\end{array}$ & $\begin{array}{l}46,086 \\
50,569 \\
48,545 \\
\end{array}$ & $\begin{array}{l}11,496 \\
11,209 \\
11,622 \\
\end{array}$ & $\begin{array}{l}10,899 \\
12,349 \\
15,042 \\
\end{array}$ & $\begin{array}{l}23,690 \\
27,010 \\
21,881 \\
\end{array}$ \\
\hline Total, South... & $\begin{array}{l}1970 \\
1962 \\
1952 \\
\end{array}$ & $\begin{array}{l}192,542 \\
199,905 \\
192,082 \\
\end{array}$ & $\begin{array}{l}17,278 \\
17,17 \\
16,806\end{array}$ & $\begin{array}{l}14,277 \\
14,274 \\
14,295 \\
\end{array}$ & $\begin{array}{l}10,764 \\
10,689 \\
10,405\end{array}$ & $\begin{array}{r}11 \\
26 \\
161 \\
\end{array}$ & $\begin{array}{l}219 \\
229 \\
242 \\
\end{array}$ & $\begin{array}{l}3,282 \\
3,329 \\
3,486 \\
\end{array}$ & $\begin{array}{l}2,321 \\
2,217 \\
1,854 \\
\end{array}$ & $\begin{array}{l}680 \\
686 \\
656 \\
\end{array}$ & $\begin{array}{l}175,263 \\
182,-27 \\
175,276\end{array}$ & $\begin{array}{l}35,325 \\
34,069 \\
32,055\end{array}$ & $\begin{array}{l}65,136 \\
73,174 \\
91,311 \\
\end{array}$ & $\begin{array}{l}74,801 \\
75,484 \\
51,908 \\
\end{array}$ \\
\hline $\begin{array}{l}\text { Pacific Northwest: } \\
\text { Alaska: Coastal.... }\end{array}$ & $\begin{array}{l}1970 \\
1962 \\
1952 \\
\end{array}$ & $\begin{array}{l}5,639 \\
5,713 \\
5,713 \\
\end{array}$ & $\begin{array}{l}5,609 \\
5,683 \\
5,683 \\
\end{array}$ & $\begin{array}{l}5,256 \\
5,505 \\
5,683 \\
\end{array}$ & $\begin{array}{l}5,144 \\
5,224 \\
5,224 \\
\end{array}$ & $\begin{array}{r}83 \\
252 \\
430 \\
\end{array}$ & $\begin{array}{l}25 \\
25 \\
25 \\
\end{array}$ & $\begin{array}{l}4 \\
4 \\
4 \\
\end{array}$ & $\begin{array}{r}353 \\
178 \\
0 \\
\end{array}$ & $\begin{array}{l}0 \\
0 \\
0\end{array}$ & $\begin{array}{l}30 \\
30 \\
30 \\
\end{array}$ & $\begin{array}{l}0 \\
0 \\
0 \\
\end{array}$ & $\begin{array}{l}0 \\
0 \\
0 \\
\end{array}$ & $\begin{array}{l}30 \\
30 \\
30 \\
\end{array}$ \\
\hline $\begin{array}{l}\text { Oregon: } \\
\text { Western..... }\end{array}$ & $\begin{array}{l}1970 \\
1962 \\
1952\end{array}$ & $\begin{array}{l}14,635 \\
14,747 \\
14,601\end{array}$ & $\begin{array}{l}7,752 \\
7,820 \\
7,730\end{array}$ & $\begin{array}{l}6,884 \\
6,949 \\
6,748\end{array}$ & $\begin{array}{l}4,830 \\
4,857 \\
4,576\end{array}$ & $\begin{array}{l}2,046 \\
2,084 \\
2,150\end{array}$ & $\begin{array}{r}8 \\
8 \\
22\end{array}$ & $\begin{array}{l}0 \\
0 \\
0\end{array}$ & $\begin{array}{l}735 \\
733 \\
732\end{array}$ & $\begin{array}{l}133 \\
138 \\
250\end{array}$ & $\begin{array}{l}6,883 \\
6,927 \\
6,871\end{array}$ & $\begin{array}{l}3,624 \\
3,548 \\
3,128\end{array}$ & $\begin{array}{l}1,620 \\
1,682 \\
1,872\end{array}$ & $\begin{array}{l}1,639 \\
1,697 \\
1,871\end{array}$ \\
\hline Eastern .......... & $\begin{array}{l}1970 \\
1962 \\
1952 \\
\end{array}$ & $\begin{array}{l}11,038 \\
11,087 \\
11,087\end{array}$ & $\begin{array}{l}7,767 \\
7,803 \\
8,065\end{array}$ & $\begin{array}{l}7,697 \\
7,733 \\
7,995\end{array}$ & $\begin{array}{l}7,173 \\
7,208 \\
6,720\end{array}$ & $\begin{array}{l}200 \\
200 \\
200\end{array}$ & $\begin{array}{r}316 \\
317 \\
1,067\end{array}$ & $\begin{array}{l}8 \\
8 \\
8\end{array}$ & $\begin{array}{l}65 \\
65 \\
65\end{array}$ & $\begin{array}{l}5 \\
5 \\
5\end{array}$ & $\begin{array}{l}3,271 \\
3,284 \\
3,022\end{array}$ & $\begin{array}{l}1,582 \\
1,585 \\
1,533\end{array}$ & $\begin{array}{l}1,230 \\
1,236 \\
1,238\end{array}$ & $\begin{array}{l}459 \\
463 \\
251 \\
\end{array}$ \\
\hline Summary....... & $\begin{array}{l}1970 \\
1962 \\
1952 \\
\end{array}$ & $\begin{array}{l}25,673 \\
25,831 \\
25,688\end{array}$ & $\begin{array}{l}15,519 \\
15,623 \\
15,795\end{array}$ & $\begin{array}{l}14,581 \\
14,682 \\
14,743\end{array}$ & $\begin{array}{l}12,003 \\
12,065 \\
11,296\end{array}$ & $\begin{array}{l}2,216 \\
2,284 \\
2,350 \\
\end{array}$ & $\begin{array}{r}324 \\
325 \\
1,089 \\
\end{array}$ & $\begin{array}{l}8 \\
8 \\
8\end{array}$ & $\begin{array}{l}800 \\
798 \\
797 \\
\end{array}$ & $\begin{array}{l}138 \\
143 \\
255\end{array}$ & $\begin{array}{r}10,154 \\
10,211 \\
9,893\end{array}$ & $\begin{array}{l}5,206 \\
5,133 \\
4,661\end{array}$ & $\begin{array}{l}2,850 \\
2,918 \\
3,110\end{array}$ & $\begin{array}{l}2,098 \\
2,160 \\
2,122 \\
\end{array}$ \\
\hline $\begin{array}{l}\text { Washington: } \\
\text { Western... }\end{array}$ & $\begin{array}{l}1970 \\
1962 \\
1952\end{array}$ & $\begin{array}{r}9,991 \\
10,352 \\
10,628\end{array}$ & $\begin{array}{l}4,123 \\
4,250 \\
4,349\end{array}$ & $\begin{array}{l}2,581 \\
2,662 \\
2,701\end{array}$ & $\begin{array}{l}2,321 \\
2,398 \\
2,398\end{array}$ & $\begin{array}{r}2 \\
2 \\
26\end{array}$ & $\begin{array}{l}190 \\
193 \\
199\end{array}$ & $\begin{array}{l}68 \\
69 \\
78\end{array}$ & $\begin{array}{l}1,379 \\
1,410 \\
1,442\end{array}$ & $\begin{array}{l}163 \\
178 \\
206\end{array}$ & $\begin{array}{l}5,868 \\
6,102 \\
6,279\end{array}$ & $\begin{array}{l}3,598 \\
3,686 \\
3,748\end{array}$ & $\begin{array}{l}437 \\
505 \\
537\end{array}$ & $\begin{array}{l}1,833 \\
1,911 \\
1,994\end{array}$ \\
\hline Eastern.......... & $\begin{array}{l}1970 \\
1962 \\
1952 \\
\end{array}$ & $\begin{array}{l}8,410 \\
8,508 \\
8,560\end{array}$ & $\begin{array}{l}5,395 \\
5,500 \\
5,537\end{array}$ & $\begin{array}{l}4,652 \\
4,799 \\
4,8,6\end{array}$ & $\begin{array}{l}3,103 \\
3,196 \\
3,197 \\
\end{array}$ & $\begin{array}{r}46 \\
91 \\
148 \\
\end{array}$ & $\begin{array}{l}1,403 \\
1,439 \\
1,496\end{array}$ & $\begin{array}{r}100 \\
73 \\
35\end{array}$ & $\begin{array}{l}737 \\
690 \\
653 \\
\end{array}$ & $\begin{array}{r}6 \\
11 \\
8\end{array}$ & $\begin{array}{l}3,015 \\
3,008 \\
3,023 \\
\end{array}$ & $\begin{array}{l}750 \\
652 \\
637 \\
\end{array}$ & $\begin{array}{l}1,429 \\
1,697 \\
1,759\end{array}$ & $\begin{array}{l}836 \\
659 \\
627 \\
\end{array}$ \\
\hline Summary ..... & $\begin{array}{l}1970 \\
1962 \\
1952 \\
\end{array}$ & $\begin{array}{l}19,401 \\
18,860 \\
19,188\end{array}$ & $\begin{array}{l}9,518 \\
9,750 \\
9,886 \\
\end{array}$ & $\begin{array}{l}7,233 \\
7,461 \\
7,577\end{array}$ & $\begin{array}{l}5,424 \\
5,594 \\
5,595 \\
\end{array}$ & $\begin{array}{r}48 \\
93 \\
174 \\
\end{array}$ & $\begin{array}{l}1,593 \\
1,632 \\
1,695 \\
\end{array}$ & $\begin{array}{l}168 \\
142 \\
113 \\
\end{array}$ & $\begin{array}{l}2,116 \\
2,100 \\
2,095\end{array}$ & $\begin{array}{l}169 \\
189 \\
214 \\
\end{array}$ & $\begin{array}{l}8,883 \\
9,110 \\
9,302\end{array}$ & $\begin{array}{l}4,348 \\
4,338 \\
4,385 \\
\end{array}$ & $\begin{array}{l}1,866 \\
2,202 \\
2,296\end{array}$ & $\begin{array}{l}2,669 \\
2,570 \\
2,621 \\
\end{array}$ \\
\hline Total & $\begin{array}{l}1970 \\
1962 \\
1952 \\
\end{array}$ & $\begin{array}{l}49,713 \\
50,407 \\
50,589\end{array}$ & $\begin{array}{l}30,646 \\
31,056 \\
31,364\end{array}$ & $\begin{array}{l}27,070 \\
27,648 \\
28,003\end{array}$ & $\begin{array}{l}22,571 \\
22,883 \\
22,115\end{array}$ & $\begin{array}{l}2,377 \\
2,629 \\
2,954\end{array}$ & $\begin{array}{l}1,942 \\
1,982 \\
2,809\end{array}$ & $\begin{array}{l}180 \\
154 \\
125\end{array}$ & $\begin{array}{l}3,269 \\
3,076 \\
2,892\end{array}$ & $\begin{array}{l}307 \\
332 \\
469\end{array}$ & $\begin{array}{l}19,067 \\
19,351 \\
19,225\end{array}$ & $\begin{array}{l}9,554 \\
9,471 \\
9,046\end{array}$ & $\begin{array}{l}4,716 \\
5,120 \\
5,406\end{array}$ & $\begin{array}{l}4,797 \\
4,760 \\
4,773\end{array}$ \\
\hline
\end{tabular}

See footnote at end of table. 
TABLE 2.-Area of commercial timberland in the United States, by ownership, and section, region, and State, as of December 31, 1952 and 1962, and January 1, $1970^{1}$-Continued

[Thousand acres]

\begin{tabular}{|c|c|c|c|c|c|c|c|c|c|c|c|c|c|c|}
\hline \multirow{3}{*}{$\begin{array}{l}\text { Section, region, } \\
\text { and State }\end{array}$} & \multirow{3}{*}{ Year } & \multirow{3}{*}{$\begin{array}{c}\text { All } \\
\text { owner- } \\
\text { ships }\end{array}$} & \multicolumn{8}{|c|}{ Public } & \multicolumn{4}{|c|}{ Private } \\
\hline & & & \multirow{2}{*}{$\begin{array}{l}\text { Total } \\
\text { public }\end{array}$} & \multicolumn{5}{|c|}{ Federal } & \multirow{2}{*}{ State } & \multirow{2}{*}{$\begin{array}{l}\text { County } \\
\text { and } \\
\text { munic- } \\
\text { ipal }\end{array}$} & \multirow{2}{*}{$\begin{array}{c}\text { Total } \\
\text { private }\end{array}$} & \multirow{2}{*}{$\begin{array}{c}\text { Forest } \\
\text { industry }\end{array}$} & \multirow[b]{2}{*}{ Farmer } & \multirow{2}{*}{$\begin{array}{l}\text { Miscel- } \\
\text { laneous } \\
\text { private }\end{array}$} \\
\hline & & & & $\begin{array}{c}\text { Total } \\
\text { Federal }\end{array}$ & $\begin{array}{c}\text { National } \\
\text { Forest }\end{array}$ & $\begin{array}{l}\text { Bureau } \\
\text { of Land } \\
\text { Manage- } \\
\text { ment }\end{array}$ & Indian & $\begin{array}{l}\text { Miscel- } \\
\text { laneous } \\
\text { Federal }\end{array}$ & & & & & & \\
\hline $\begin{array}{l}\text { Pacific Southwest: } \\
\text { Callfornia }\end{array}$ & $\begin{array}{l}1970 \\
1962 \\
1952\end{array}$ & $\begin{array}{l}16,828 \\
17,043 \\
17,127\end{array}$ & $\begin{array}{l}8,820 \\
8,924 \\
9,075\end{array}$ & $\begin{array}{l}8,743 \\
8,850 \\
8,874\end{array}$ & $\begin{array}{l}8,344 \\
8,393 \\
8,372\end{array}$ & $\begin{array}{l}275 \\
303 \\
318\end{array}$ & $\begin{array}{l}102 \\
114 \\
144\end{array}$ & $\begin{array}{l}22 \\
40 \\
40\end{array}$ & $\begin{array}{r}72 \\
71 \\
193\end{array}$ & $\begin{array}{l}5 \\
3 \\
8\end{array}$ & $\begin{array}{l}8,008 \\
8,119 \\
8,052\end{array}$ & $\begin{array}{l}2,665 \\
2,457 \\
2,167\end{array}$ & $\begin{array}{l}1,524 \\
1,598 \\
1,664\end{array}$ & $\begin{array}{l}3,819 \\
4,064 \\
4,221\end{array}$ \\
\hline Hawaii_............ & $\begin{array}{l}1970 \\
1962 \\
1952 \\
\end{array}$ & $\begin{array}{r}1,081 \\
1,089 \\
1,089 \\
\end{array}$ & $\begin{array}{l}495 \\
496 \\
496 \\
\end{array}$ & $\begin{array}{l}8 \\
9 \\
9 \\
\end{array}$ & $\begin{array}{l}0 \\
0 \\
0 \\
\end{array}$ & $\begin{array}{l}0 \\
0 \\
0 \\
\end{array}$ & $\begin{array}{l}0 \\
0 \\
0 \\
\end{array}$ & $\begin{array}{l}8 \\
9 \\
9 \\
\end{array}$ & $\begin{array}{l}487 \\
487 \\
487 \\
\end{array}$ & $\begin{array}{l}0 \\
0 \\
0 \\
\end{array}$ & $\begin{array}{l}585 \\
593 \\
593 \\
\end{array}$ & $\begin{array}{l}0 \\
0 \\
0 \\
\end{array}$ & $\begin{array}{l}361 \\
366 \\
366 \\
\end{array}$ & $\begin{array}{l}223 \\
227 \\
227 \\
\end{array}$ \\
\hline Total & $\begin{array}{l}1970 \\
1962 \\
1952 \\
\end{array}$ & $\begin{array}{l}17,909 \\
18,132 \\
18,216 \\
\end{array}$ & $\begin{array}{l}9,315 \\
9,420 \\
9,571 \\
\end{array}$ & $\begin{array}{l}8,751 \\
8,859 \\
8,883 \\
\end{array}$ & $\begin{array}{l}8,344 \\
8,393 \\
8,372 \\
\end{array}$ & $\begin{array}{l}275 \\
303 \\
318 \\
\end{array}$ & $\begin{array}{l}102 \\
114 \\
144 \\
\end{array}$ & $\begin{array}{l}30 \\
49 \\
49 \\
\end{array}$ & $\begin{array}{l}559 \\
558 \\
680 \\
\end{array}$ & $\begin{array}{l}5 \\
3 \\
8 \\
\end{array}$ & $\begin{array}{l}8,593 \\
8,712 \\
8,645 \\
\end{array}$ & $\begin{array}{l}2,665 \\
2,457 \\
2,167 \\
\end{array}$ & $\begin{array}{l}1,885 \\
1,964 \\
2,030 \\
\end{array}$ & $\begin{array}{l}4,042 \\
4,291 \\
4,448 \\
\end{array}$ \\
\hline $\begin{array}{l}\text { Total, Pacific } \\
\text { Coast. }\end{array}$ & $\begin{array}{l}1970 \\
1962 \\
1952 \\
\end{array}$ & $\begin{array}{l}67,622 \\
68,539 \\
68,805 \\
\end{array}$ & $\begin{array}{l}39,961 \\
40,476 \\
40,935 \\
\end{array}$ & $\begin{array}{l}35,821 \\
36,507 \\
36,886 \\
\end{array}$ & $\begin{array}{l}30,915 \\
31,276 \\
30,487 \\
\end{array}$ & $\begin{array}{l}2,652 \\
2,932 \\
3,272 \\
\end{array}$ & $\begin{array}{l}2,044 \\
2,096 \\
2,953 \\
\end{array}$ & $\begin{array}{l}210 \\
203 \\
174 \\
\end{array}$ & $\begin{array}{l}3,828 \\
3,634 \\
3,572 \\
\end{array}$ & $\begin{array}{l}312 \\
335 \\
477 \\
\end{array}$ & $\begin{array}{l}27,660 \\
28,063 \\
27,870 \\
\end{array}$ & $\begin{array}{l}12,219 \\
11,928 \\
11,213 \\
\end{array}$ & $\begin{array}{l}6,601 \\
7,084 \\
7,436 \\
\end{array}$ & $\begin{array}{l}8,839 \\
9,051 \\
9,221 \\
\end{array}$ \\
\hline $\begin{array}{l}\text { Northern Rocky } \\
\text { Mountain: } \\
\text { Idaho.... }\end{array}$ & $\begin{array}{l}1970 \\
1962 \\
1952\end{array}$ & $\begin{array}{l}15,192 \\
15,881 \\
15,539\end{array}$ & $\begin{array}{l}12,171 \\
12,851 \\
12,496\end{array}$ & $\begin{array}{l}11,291 \\
11,968 \\
11,610\end{array}$ & $\begin{array}{l}10,731 \\
11,406 \\
11,045\end{array}$ & $\begin{array}{l}501 \\
502 \\
504\end{array}$ & $\begin{array}{l}51 \\
51 \\
52\end{array}$ & $\begin{array}{l}7 \\
7 \\
7\end{array}$ & $\begin{array}{l}861 \\
863 \\
867\end{array}$ & $\begin{array}{l}18 \\
18 \\
19\end{array}$ & $\begin{array}{l}3,020 \\
3,030 \\
3,043\end{array}$ & $\begin{array}{l}946 \\
949 \\
953\end{array}$ & $\begin{array}{l}777 \\
779 \\
782\end{array}$ & $\begin{array}{l}1,297 \\
1,301 \\
1,306\end{array}$ \\
\hline Montana & $\begin{array}{l}1970 \\
1962 \\
1952\end{array}$ & $\begin{array}{l}15,983 \\
16,879 \\
16,753\end{array}$ & $\begin{array}{l}11,418 \\
12,300 \\
12,154\end{array}$ & $\begin{array}{l}10,883 \\
11,764 \\
11,616\end{array}$ & $\begin{array}{r}9,732 \\
10,610 \\
10,456\end{array}$ & $\begin{array}{l}478 \\
479 \\
481\end{array}$ & $\begin{array}{l}620 \\
621 \\
624\end{array}$ & $\begin{array}{l}53 \\
53 \\
53\end{array}$ & $\begin{array}{l}529 \\
531 \\
533\end{array}$ & $\begin{array}{l}4 \\
4 \\
4\end{array}$ & $\begin{array}{l}4,565 \\
4,579 \\
4,599\end{array}$ & $\begin{array}{l}1,055 \\
1,058 \\
1,063\end{array}$ & $\begin{array}{l}1,952 \\
1,958 \\
1,966\end{array}$ & $\begin{array}{l}1,557 \\
1,562 \\
1,569\end{array}$ \\
\hline (West) $\ldots \ldots \ldots$ & $\begin{array}{l}1970 \\
1962 \\
1952\end{array}$ & $\begin{array}{l}1,310 \\
1,310 \\
1,306\end{array}$ & $\begin{array}{l}1,029 \\
1,029 \\
1,023\end{array}$ & $\begin{array}{l}967 \\
966 \\
960\end{array}$ & $\begin{array}{l}957 \\
957 \\
951\end{array}$ & $\begin{array}{l}5 \\
5 \\
5\end{array}$ & $\begin{array}{l}0 \\
0 \\
0\end{array}$ & $\begin{array}{l}4 \\
4 \\
4\end{array}$ & $\begin{array}{l}62 \\
62 \\
62\end{array}$ & $\begin{array}{l}0 \\
0 \\
0\end{array}$ & $\begin{array}{l}281 \\
281 \\
283\end{array}$ & $\begin{array}{l}17 \\
17 \\
17\end{array}$ & $\begin{array}{l}222 \\
223 \\
224\end{array}$ & $\begin{array}{l}41 \\
41 \\
41\end{array}$ \\
\hline Wyoming............. & $\begin{array}{l}1970 \\
1962 \\
1952 \\
\end{array}$ & $\begin{array}{l}4,182 \\
4,720 \\
4,738 \\
\end{array}$ & $\begin{array}{l}3,327 \\
3,862 \\
3,876 \\
\end{array}$ & $\begin{array}{l}3,216 \\
3,751 \\
3,765\end{array}$ & $\begin{array}{l}2,699 \\
3,232 \\
3,243 \\
\end{array}$ & $\begin{array}{l}393 \\
394 \\
396 \\
\end{array}$ & $\begin{array}{l}123 \\
124 \\
124\end{array}$ & $\begin{array}{l}0 \\
0 \\
0\end{array}$ & $\begin{array}{l}110 \\
111 \\
111\end{array}$ & $\begin{array}{l}0 \\
0 \\
0\end{array}$ & $\begin{array}{l}855 \\
857 \\
861\end{array}$ & $\begin{array}{l}54 \\
54 \\
54 \\
\end{array}$ & $\begin{array}{l}619 \\
621 \\
624 \\
\end{array}$ & $\begin{array}{l}181 \\
181 \\
182 \\
\end{array}$ \\
\hline Total & $\begin{array}{l}1970 \\
1962 \\
1952 \\
\end{array}$ & $\begin{array}{l}36,668 \\
38,792 \\
38,337 \\
\end{array}$ & $\begin{array}{l}27,946 \\
30,043 \\
29,551 \\
\end{array}$ & $\begin{array}{l}26,359 \\
28,451 \\
27,952 \\
\end{array}$ & $\begin{array}{l}24,120 \\
26,206 \\
25,697 \\
\end{array}$ & $\begin{array}{l}1,378 \\
1,382 \\
1,388 \\
\end{array}$ & $\begin{array}{l}795 \\
797 \\
801 \\
\end{array}$ & $\begin{array}{l}64 \\
65 \\
65 \\
\end{array}$ & $\begin{array}{l}1,563 \\
1,568 \\
1,574 \\
\end{array}$ & $\begin{array}{l}23 \\
23 \\
23 \\
\end{array}$ & $\begin{array}{l}8,722 \\
8,748 \\
8,786 \\
\end{array}$ & $\begin{array}{l}2,073 \\
2,079 \\
2,088 \\
\end{array}$ & $\begin{array}{l}3,572 \\
3,583 \\
3,598 \\
\end{array}$ & $\begin{array}{l}3,076 \\
3,086 \\
3,099 \\
\end{array}$ \\
\hline $\begin{array}{l}\text { Southern Rocky } \\
\text { Mountain: } \\
\text { Arizona.-.- }\end{array}$ & $\begin{array}{l}1970 \\
1962 \\
1952\end{array}$ & $\begin{array}{l}3,689 \\
3,692 \\
3,620\end{array}$ & $\begin{array}{l}3,523 \\
3,525 \\
3,453\end{array}$ & $\begin{array}{l}3,490 \\
3,492 \\
3,419\end{array}$ & $\begin{array}{l}2,347 \\
2,346 \\
2,268\end{array}$ & $\begin{array}{l}2 \\
2 \\
2\end{array}$ & $\begin{array}{l}1,140 \\
1,143 \\
1,148\end{array}$ & $\begin{array}{l}0 \\
0 \\
0\end{array}$ & $\begin{array}{l}32 \\
32 \\
32\end{array}$ & $\begin{array}{l}1 \\
1 \\
1\end{array}$ & $\begin{array}{l}166 \\
166 \\
167\end{array}$ & $\begin{array}{l}0 \\
0 \\
0\end{array}$ & $\begin{array}{l}81 \\
82 \\
82\end{array}$ & $\begin{array}{l}84 \\
84 \\
85\end{array}$ \\
\hline Colorado............. & $\begin{array}{l}1970 \\
1962 \\
1952\end{array}$ & $\begin{array}{l}11,583 \\
12,358 \\
12,282\end{array}$ & $\begin{array}{l}8,465 \\
9,230 \\
9,141\end{array}$ & $\begin{array}{l}8,231 \\
8,996 \\
8,905\end{array}$ & $\begin{array}{l}7,710 \\
8,473 \\
8,381\end{array}$ & $\begin{array}{l}413 \\
414 \\
416\end{array}$ & $\begin{array}{l}102 \\
103 \\
103\end{array}$ & $\begin{array}{l}4 \\
4 \\
4\end{array}$ & $\begin{array}{l}188 \\
189 \\
190\end{array}$ & $\begin{array}{l}45 \\
45 \\
45\end{array}$ & $\begin{array}{l}3,118 \\
3,127 \\
3,141\end{array}$ & $\begin{array}{l}14 \\
14 \\
14\end{array}$ & $\begin{array}{l}2,635 \\
2,643 \\
2,655\end{array}$ & $\begin{array}{l}467 \\
469 \\
471\end{array}$ \\
\hline Nevada.............. & $\begin{array}{l}1970 \\
1962 \\
1952\end{array}$ & $\begin{array}{l}128 \\
141 \\
142\end{array}$ & $\begin{array}{l}60 \\
72 \\
72\end{array}$ & $\begin{array}{l}55 \\
68 \\
68\end{array}$ & $\begin{array}{l}55 \\
68 \\
68\end{array}$ & $\begin{array}{l}0 \\
0 \\
0\end{array}$ & $\begin{array}{l}0 \\
0 \\
0\end{array}$ & $\begin{array}{l}0 \\
0 \\
0\end{array}$ & $\begin{array}{l}3 \\
3 \\
3\end{array}$ & $\begin{array}{l}1 \\
1 \\
1\end{array}$ & $\begin{array}{l}68 \\
68 \\
69\end{array}$ & $\begin{array}{l}8 \\
8 \\
8\end{array}$ & $\begin{array}{l}1 \\
1 \\
1\end{array}$ & $\begin{array}{l}58 \\
58 \\
58\end{array}$ \\
\hline New Mexico....... & $\begin{array}{l}1970 \\
1962 \\
1952\end{array}$ & $\begin{array}{l}5,736 \\
5,746 \\
5,626\end{array}$ & $\begin{array}{l}3,809 \\
3,813 \\
3,685\end{array}$ & $\begin{array}{l}3,638 \\
3,642 \\
3,513\end{array}$ & $\begin{array}{l}2,939 \\
2,940 \\
2,808\end{array}$ & $\begin{array}{l}76 \\
76 \\
76\end{array}$ & $\begin{array}{l}613 \\
615 \\
618\end{array}$ & $\begin{array}{l}8 \\
8 \\
8\end{array}$ & $\begin{array}{l}171 \\
171 \\
172\end{array}$ & $\begin{array}{l}0 \\
0 \\
0\end{array}$ & $\begin{array}{l}1,927 \\
1,932 \\
1,941\end{array}$ & $\begin{array}{l}137 \\
137 \\
138\end{array}$ & $\begin{array}{l}1,549 \\
1,554 \\
1,561\end{array}$ & $\begin{array}{l}240 \\
240 \\
242\end{array}$ \\
\hline Utah.............. & $\begin{array}{l}1970 \\
1962 \\
1952 \\
\end{array}$ & $\begin{array}{l}3,824 \\
3,871 \\
3,881 \\
\end{array}$ & $\begin{array}{l}3,163 \\
3,208 \\
3,216 \\
\end{array}$ & $\begin{array}{l}2,924 \\
2,968 \\
2,975 \\
\end{array}$ & $\begin{array}{l}2,613 \\
2,656 \\
2,662 \\
\end{array}$ & $\begin{array}{l}154 \\
154 \\
155 \\
\end{array}$ & $\begin{array}{l}157 \\
157 \\
158 \\
\end{array}$ & $\begin{array}{l}0 \\
0 \\
0\end{array}$ & $\begin{array}{l}239 \\
239 \\
240 \\
\end{array}$ & $\begin{array}{l}0 \\
0 \\
0 \\
\end{array}$ & $\begin{array}{l}660 \\
662 \\
665 \\
\end{array}$ & $\begin{array}{l}0 \\
0 \\
0 \\
\end{array}$ & $\begin{array}{l}537 \\
539 \\
541 \\
\end{array}$ & $\begin{array}{l}123 \\
123 \\
123 \\
\end{array}$ \\
\hline Total.......... & $\begin{array}{l}1970 \\
1962 \\
1952 \\
\end{array}$ & $\begin{array}{l}24,963 \\
25,810 \\
25,554 \\
\end{array}$ & $\begin{array}{l}19,022 \\
19,851 \\
19,569\end{array}$ & $\begin{array}{l}18,339 \\
19,167 \\
18,881\end{array}$ & $\begin{array}{l}15,666 \\
16,486 \\
16,189 \\
\end{array}$ & $\begin{array}{l}645 \\
647 \\
650\end{array}$ & $\begin{array}{l}2,013 \\
2,020 \\
2,028 \\
\end{array}$ & $\begin{array}{l}13 \\
13 \\
13\end{array}$ & $\begin{array}{l}634 \\
636 \\
639 \\
\end{array}$ & $\begin{array}{l}47 \\
47 \\
48 \\
\end{array}$ & $\begin{array}{l}5,941 \\
5,959 \\
5,984 \\
\end{array}$ & $\begin{array}{l}160 \\
160 \\
161\end{array}$ & $\begin{array}{l}4,807 \\
4,821 \\
4,842 \\
\end{array}$ & $\begin{array}{l}974 \\
977 \\
981 \\
\end{array}$ \\
\hline $\begin{array}{l}\text { Total, Rocky } \\
\text { Mountain }\end{array}$ & $\begin{array}{l}1970 \\
1962 \\
1952 \\
\end{array}$ & $\begin{array}{l}61,631 \\
64,603 \\
63,891 \\
\end{array}$ & $\begin{array}{l}46,968 \\
49,895 \\
49,120 \\
\end{array}$ & $\begin{array}{l}44,699 \\
47,619 \\
46,834\end{array}$ & $\begin{array}{l}39,787 \\
42,692 \\
41,886 \\
\end{array}$ & $\begin{array}{l}2,024 \\
2,030 \\
2,038 \\
\end{array}$ & $\begin{array}{l}2,809 \\
2,817 \\
2,830 \\
\end{array}$ & $\begin{array}{l}78 \\
78 \\
79 \\
\end{array}$ & $\begin{array}{l}2,197 \\
2,204 \\
2,214 \\
\end{array}$ & $\begin{array}{l}71 \\
71 \\
71 \\
\end{array}$ & $\begin{array}{l}14,663 \\
14,708 \\
14,771 \\
\end{array}$ & $\begin{array}{l}2,233 \\
2,240 \\
2,250 \\
\end{array}$ & $\begin{array}{l}8,379 \\
8,404 \\
8,440 \\
\end{array}$ & $\begin{array}{l}4,050 \\
4,063 \\
4,080 \\
\end{array}$ \\
\hline $\begin{array}{l}\text { Total, all } \\
\text { regions. }\end{array}$ & $\begin{array}{l}1970 \\
1962 \\
1952\end{array}$ & $\begin{array}{l}499,697 \\
508,137 \\
494,978\end{array}$ & $\begin{array}{l}136,120 \\
139,304 \\
139,202\end{array}$ & $\begin{array}{l}107,108 \\
110,849 \\
110,978\end{array}$ & $\begin{array}{l}91,924 \\
94,927 \\
93,094\end{array}$ & $\begin{array}{l}4,761 \\
5,068 \\
5,538\end{array}$ & $\begin{array}{l}5,888 \\
6,248 \\
7,313\end{array}$ & $\begin{array}{l}4,534 \\
4,604 \\
5,032\end{array}$ & $\begin{array}{l}21,422 \\
20,797 \\
20,032\end{array}$ & $\begin{array}{l}7,588 \\
7,657 \\
8,191\end{array}$ & $\begin{array}{l}363,576 \\
368,833 \\
355,775\end{array}$ & $\begin{array}{l}67,341 \\
62,455 \\
59,547\end{array}$ & $\begin{array}{l}131,134 \\
147,035 \\
173,624\end{array}$ & $\begin{array}{l}165,100 \\
159,342 \\
122,604\end{array}$ \\
\hline
\end{tabular}

Data may not add to totals because of truncating. Zeros indicate no data or negligible amounts. 
TABLE 3.-Area of commercial timberland in the United States, by ownership and stand-size class, section, region, and State, January 1, $1970^{1}$

[Thousand acres]

\begin{tabular}{|c|c|c|c|c|c|c|c|c|c|c|}
\hline \multirow{2}{*}{ Section, region, and State } & \multicolumn{5}{|c|}{ Total, all ownerships } & \multicolumn{5}{|c|}{ National forest } \\
\hline & Total & $\begin{array}{l}\text { Sawtimber } \\
\text { stands }\end{array}$ & $\begin{array}{c}\text { Poletimber } \\
\text { stands }\end{array}$ & $\begin{array}{l}\text { Seedling } \\
\text { sapling }\end{array}$ & $\begin{array}{c}\text { Nonstocked } \\
\text { areas }\end{array}$ & Total & $\begin{array}{l}\text { Sawtimber } \\
\text { stands }\end{array}$ & $\begin{array}{l}\text { Poletimber } \\
\text { stands }\end{array}$ & $\begin{array}{l}\text { Seedling } \\
\text { sapling }\end{array}$ & $\begin{array}{l}\text { Nonstocked } \\
\text { areas }\end{array}$ \\
\hline 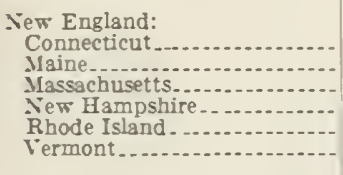 & $\begin{array}{r}2,169 \\
16,894 \\
3,491 \\
5,020 \\
429 \\
4,364 \\
\end{array}$ & $\begin{array}{r}366 \\
6,142 \\
414 \\
1,78 i \\
14 \\
1,796 \\
\end{array}$ & $\begin{array}{r}1,165 \\
5,339 \\
1,669 \\
2,369 \\
233 \\
1,524 \\
\end{array}$ & $\begin{array}{r}583 \\
5,268 \\
1,368 \\
693 \\
168 \\
1,004 \\
\end{array}$ & $\begin{array}{r}49 \\
143 \\
38 \\
171 \\
13 \\
40 \\
\end{array}$ & $\begin{array}{r}0 \\
37 \\
0 \\
568 \\
0 \\
226 \\
\end{array}$ & $\begin{array}{r}0 \\
19 \\
0 \\
341 \\
0 \\
125 \\
\end{array}$ & $\begin{array}{r}0 \\
15 \\
0 \\
131 \\
0 \\
63 \\
\end{array}$ & $\begin{array}{r}0 \\
2 \\
0 \\
96 \\
0 \\
37 \\
\end{array}$ & $\begin{array}{l}0 \\
0 \\
0 \\
0 \\
0 \\
0\end{array}$ \\
\hline Total....... & 32,367 & 10,521 & 12,304 & 9,056 & 455 & 832 & 486 & 209 & 135 & 0 \\
\hline 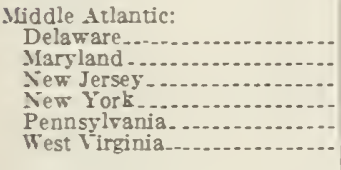 & $\begin{array}{r}390 \\
2,882 \\
2,354 \\
14,489 \\
17,47 \\
12,092 \\
\end{array}$ & $\begin{array}{r}210 \\
1,791 \\
599 \\
4,283 \\
7,665 \\
5,951 \\
\end{array}$ & $\begin{array}{r}128 \\
753 \\
794 \\
2,678 \\
6,0 \approx 1 \\
3,297 \\
\end{array}$ & $\begin{array}{r}45 \\
297 \\
803 \\
6,201 \\
3,399 \\
2,596 \\
\end{array}$ & $\begin{array}{r}6 \\
40 \\
157 \\
1,325 \\
333 \\
248 \\
\end{array}$ & $\begin{array}{r}0 \\
0 \\
0 \\
0 \\
488 \\
879 \\
\end{array}$ & $\begin{array}{r}0 \\
0 \\
0 \\
0 \\
265 \\
543 \\
\end{array}$ & $\begin{array}{r}0 \\
0 \\
0 \\
0 \\
209 \\
312 \\
\end{array}$ & $\begin{array}{r}0 \\
0 \\
0 \\
0 \\
7 \\
23 \\
\end{array}$ & $\begin{array}{l}0 \\
0 \\
0 \\
0 \\
6 \\
0\end{array}$ \\
\hline Total.... & 49,685 & 20,500 & 13,732 & 13,341 & 2,110 & 1,367 & 808 & 521 & 30 & 6 \\
\hline 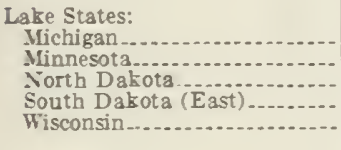 & $\begin{array}{r}18,800 \\
16,875 \\
406 \\
223 \\
14,536 \\
\end{array}$ & $\begin{array}{r}4,645 \\
2,360 \\
63 \\
103 \\
3,098 \\
\end{array}$ & $\begin{array}{r}8,055 \\
8,425 \\
158 \\
96 \\
6,579 \\
\end{array}$ & $\begin{array}{r}5,506 \\
4,247 \\
149 \\
19 \\
4,489 \\
\end{array}$ & $\begin{array}{r}592 \\
1,841 \\
34 \\
3 \\
369\end{array}$ & $\begin{array}{r}2,422 \\
2,127 \\
0 \\
0 \\
1,317 \\
\end{array}$ & $\begin{array}{r}378 \\
337 \\
0 \\
0 \\
84 \\
\end{array}$ & $\begin{array}{r}1,223 \\
1,33.5 \\
0 \\
0 \\
749 \\
\end{array}$ & $\begin{array}{r}761 \\
295 \\
0 \\
0 \\
420 \\
\end{array}$ & $\begin{array}{r}59 \\
159 \\
0 \\
0 \\
64 \\
\end{array}$ \\
\hline Total & 50,840 & 10,$2 ; 2$ & 23,315 & 14,412 & 2,811 & $5,86 i$ & 800 & $3,30 \bar{z}$ & 1,477 & 282 \\
\hline 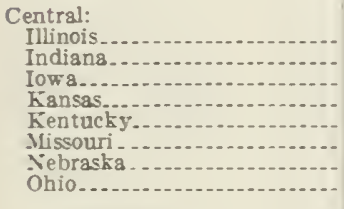 & $\begin{array}{r}3,680 \\
3,840 \\
2,430 \\
1,18 \\
11,826 \\
14,600 \\
1,023 \\
6,422 \\
\end{array}$ & $\begin{array}{r}2,101 \\
2,065 \\
942 \\
681 \\
5,633 \\
4,002 \\
253 \\
1,977 \\
\end{array}$ & $\begin{array}{r}934 \\
795 \\
777 \\
229 \\
2,798 \\
4,258 \\
310 \\
700 \\
\end{array}$ & $\begin{array}{r}599 \\
899 \\
268 \\
134 \\
3,317 \\
3,490 \\
103 \\
3,569 \\
\end{array}$ & $\begin{array}{r}44 \\
79 \\
442 \\
141 \\
78 \\
2,848 \\
355 \\
176 \\
\end{array}$ & $\begin{array}{r}214 \\
136 \\
0 \\
0 \\
531 \\
1,321 \\
57 \\
129\end{array}$ & $\begin{array}{r}94 \\
84 \\
0 \\
0 \\
426 \\
318 \\
2 \\
65 \\
\end{array}$ & $\begin{array}{r}73 \\
23 \\
0 \\
0 \\
94 \\
681 \\
27 \\
27 \\
12 \\
\end{array}$ & $\begin{array}{r}29 \\
22 \\
0 \\
0 \\
4 \\
311 \\
24 \\
32 \\
\end{array}$ & $\begin{array}{r}18 \\
6 \\
0 \\
0 \\
5 \\
10 \\
3 \\
18\end{array}$ \\
\hline Total ...... & 45,008 & 17,656 & 10,803 & 12,383 & 4,164 & 2,390 & 991 & 912 & 423 & 62 \\
\hline Total, North... & 177,901 & 58,949 & 60,156 & 49,223 & 9,571 & 10,458 & 3,087 & 4,951 & 2,067 & 351 \\
\hline 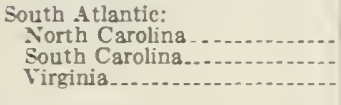 & $\begin{array}{l}20,192 \\
12,410 \\
15,859 \\
\end{array}$ & $\begin{array}{r}10,556 \\
4,907 \\
5,308 \\
\end{array}$ & $\begin{array}{l}4,255 \\
3,455 \\
5,981 \\
\end{array}$ & $\begin{array}{l}5,193 \\
3,649 \\
4,472 \\
\end{array}$ & $\begin{array}{r}187 \\
398 \\
96 \\
\end{array}$ & $\begin{array}{r}1,035 \\
550 \\
1,202 \\
\end{array}$ & $\begin{array}{l}743 \\
368 \\
619 \\
\end{array}$ & $\begin{array}{l}186 \\
136 \\
492 \\
\end{array}$ & $\begin{array}{r}102 \\
46 \\
75\end{array}$ & $\begin{array}{r}3 \\
0 \\
15 \\
\end{array}$ \\
\hline Total & 48,463 & 20,$7 ; 2$ & 13,692 & 13,315 & 682 & 2,789 & 1,730 & 815 & 224 & 18 \\
\hline $\begin{array}{l}\text { East Gulf: } \\
\text { Florida } \\
\text { Georgia.................. }\end{array}$ & $\begin{array}{l}16,231 \\
25,102 \\
\end{array}$ & $\begin{array}{l}4,987 \\
8,354 \\
\end{array}$ & $\begin{array}{l}4,150 \\
4,607 \\
\end{array}$ & $\begin{array}{r}4,529 \\
11,426 \\
\end{array}$ & $\begin{array}{r}2,563 \\
714 \\
\end{array}$ & $\begin{array}{r}1,035 \\
806 \\
\end{array}$ & $\begin{array}{l}419 \\
492\end{array}$ & $\begin{array}{l}305 \\
168 \\
\end{array}$ & $\begin{array}{l}244 \\
145 \\
\end{array}$ & $\begin{array}{r}66 \\
0 \\
\end{array}$ \\
\hline Total .......... & 41,334 & 13,342 & 8,758 & 15,955 & 3,267 & 1,842 & 911 & 474 & 389 & 66 \\
\hline $\begin{array}{l}\text { Central Gulf: } \\
\text { Alabama } \\
\text { Mississippi. } \\
\text { Tennessee. }\end{array}$ & $\begin{array}{l}21,742 \\
16,891 \\
12,819 \\
\end{array}$ & $\begin{array}{l}8,885 \\
4,557 \\
3,297 \\
\end{array}$ & $\begin{array}{l}5,224 \\
3,772 \\
4,893 \\
\end{array}$ & $\begin{array}{l}7,468 \\
8,427 \\
4,595 \\
\end{array}$ & $\begin{array}{r}164 \\
133 \\
32 \\
\end{array}$ & $\begin{array}{r}625 \\
1,118 \\
599 \\
\end{array}$ & $\begin{array}{l}428 \\
528 \\
257\end{array}$ & $\begin{array}{l}115 \\
149 \\
230\end{array}$ & $\begin{array}{r}81 \\
410 \\
112 \\
\end{array}$ & $\begin{array}{l}0 \\
0 \\
0\end{array}$ \\
\hline Total & 51,453 & 16,741 & 13,889 & 20,492 & 330 & 2,344 & 1,213 & 496 & 634 & 0 \\
\hline 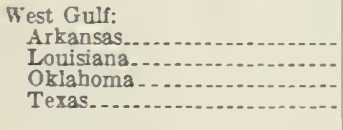 & $\begin{array}{r}18,206 \\
15,342 \\
4,817 \\
12,924 \\
\end{array}$ & $\begin{array}{l}5,443 \\
9,459 \\
1,261 \\
7,021 \\
\end{array}$ & $\begin{array}{r}4,759 \\
1,922 \\
943 \\
2,184 \\
\end{array}$ & $\begin{array}{l}7,922 \\
3,774 \\
2,498 \\
\mathbf{3}, 620 \\
\end{array}$ & $\begin{array}{r}81 \\
186 \\
114 \\
97 \\
\end{array}$ & $\begin{array}{r}2,378 \\
551 \\
233 \\
625 \\
\end{array}$ & $\begin{array}{l}732 \\
395 \\
112 \\
517 \\
\end{array}$ & $\begin{array}{r}863 \\
51 \\
45 \\
37 \\
\end{array}$ & $\begin{array}{r}782 \\
99 \\
75 \\
69 \\
\end{array}$ & $\begin{array}{l}0 \\
5 \\
0 \\
0\end{array}$ \\
\hline Total..... & 51,290 & 23,185 & 9,810 & 17,815 & 480 & 3,788 & 1,758 & 998 & 1,026 & 5 \\
\hline Total, South............. & 192,542 & 74,041 & 46,151 & 67,578 & 4,771 & 10,764 & 5,614 & 2,784 & 2,275 & 89 \\
\hline $\begin{array}{l}\text { Pacifie Northwest: } \\
\text { Alaska: Coastal.. }\end{array}$ & 5,639 & 5,112 & 180 & 300 & 47 & 5,144 & 4,651 & 173 & 273 & 474 \\
\hline $\begin{array}{l}\text { Oregon: } \\
\quad \text { Western } \\
\text { Eastern }\end{array}$ & $\begin{array}{l}14,635 \\
11,038 \\
\end{array}$ & $\begin{array}{l}8,923 \\
7,230 \\
\end{array}$ & $\begin{array}{l}1,370 \\
2,458 \\
\end{array}$ & $\begin{array}{r}3,5 ; 6 \\
932 \\
\end{array}$ & $\begin{array}{l}766 \\
418 \\
\end{array}$ & $\begin{array}{l}4,830 \\
7,173\end{array}$ & $\begin{array}{l}3,81 \frac{1}{4} \\
4,731\end{array}$ & $\begin{array}{r}459 \\
1,645 \\
\end{array}$ & $\begin{array}{l}410 \\
632 \\
\end{array}$ & $\begin{array}{l}147 \\
165\end{array}$ \\
\hline Summary -.. & 25,673 & 16,153 & 3,828 & 4,508 & 1,184 & 12,003 & 8,545 & 2,104 & 1,042 & 312 \\
\hline
\end{tabular}

See footnotes at end of table. 
TABLE 3.-Area of commercial timberland in the United States, by ownership and stand-size class, section, region, and State, January 1, $1970^{1}$-Continued

[Thousand acres]

\begin{tabular}{|c|c|c|c|c|c|c|c|c|c|c|}
\hline \multirow{2}{*}{ Section, region, and State } & \multicolumn{5}{|c|}{ Total, all ownerships } & \multicolumn{5}{|c|}{ National forest } \\
\hline & Total & $\begin{array}{l}\text { Sawtimber } \\
\text { stands }\end{array}$ & $\begin{array}{c}\text { Poletimber } \\
\text { stands }\end{array}$ & $\begin{array}{l}\text { Seedling } \\
\text { sapling }\end{array}$ & $\begin{array}{c}\text { Nonstocked } \\
\text { areas }\end{array}$ & Total & $\begin{array}{c}\text { Sawtimber } \\
\text { stands }\end{array}$ & $\begin{array}{c}\text { Poletimber } \\
\text { stands }\end{array}$ & $\begin{array}{l}\text { Seedling } \\
\text { sapling }\end{array}$ & $\begin{array}{c}\text { Nonstocked } \\
\text { areas }\end{array}$ \\
\hline $\begin{array}{l}\text { Pacific Northwest-Con. } \\
\text { Washington: } \\
\text { Western................. } \\
\text { Eastern............... }\end{array}$ & $\begin{array}{l}9,991 \\
8,410\end{array}$ & $\begin{array}{l}6,217 \\
4,902\end{array}$ & $\begin{array}{l}1,495 \\
1,778\end{array}$ & $\begin{array}{l}2,042 \\
1,240\end{array}$ & $\begin{array}{l}237 \\
490\end{array}$ & $\begin{array}{l}2,321 \\
3,103\end{array}$ & $\begin{array}{l}1,741 \\
1,875\end{array}$ & $\begin{array}{l}175 \\
679\end{array}$ & $\begin{array}{l}312 \\
514\end{array}$ & $\begin{array}{l}93 \\
35\end{array}$ \\
\hline Summary ... & 18,401 & 11,119 & 3,273 & 3,282 & 727 & 5,424 & 3,616 & 854 & 826 & 128 \\
\hline Total... & 49,713 & 32,384 & 7,281 & 8,090 & 1,958 & 22,571 & 16,812 & 3,131 & 2,141 & 487 \\
\hline 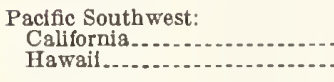 & $\begin{array}{r}16,828 \\
1,081\end{array}$ & $\begin{array}{r}13,616 \\
321\end{array}$ & $\begin{array}{l}766 \\
209\end{array}$ & $\begin{array}{r}1,194 \\
53\end{array}$ & $\begin{array}{r}1,252 \\
497\end{array}$ & $\begin{array}{r}8,344 \\
0\end{array}$ & $\begin{array}{r}7,240 \\
0 \\
\end{array}$ & $\begin{array}{r}325 \\
0 \\
\end{array}$ & $\begin{array}{r}352 \\
0\end{array}$ & $\begin{array}{r}427 \\
0\end{array}$ \\
\hline Total & 17,909 & 13,937 & 975 & 1,247 & 1,749 & 8,344 & 7,240 & 325 & 352 & 427 \\
\hline Total, Pacific Coast... & 67,622 & 46,321 & 8,256 & 9,337 & 3,707 & 30,915 & 24,052 & 3,456 & 2,493 & 914 \\
\hline $\begin{array}{l}\text { Northern Rocky Mountain: } \\
\text { Idaho }{ }^{2} \\
\text { Montana } 2 \\
\text { South Dakota (West) } \\
\text { Wyoming }{ }^{2}-\ldots\end{array}$ & $\begin{array}{r}15,192 \\
15,983 \\
1,310 \\
4,182\end{array}$ & $\begin{array}{r}9,835 \\
9,186 \\
708 \\
1,990 \\
\end{array}$ & $\begin{array}{r}1,775 \\
4,466 \\
483 \\
962\end{array}$ & $\begin{array}{r}1,879 \\
1,817 \\
46 \\
174\end{array}$ & $\begin{array}{r}706 \\
380 \\
15 \\
128\end{array}$ & $\begin{array}{r}10,731 \\
9,732 \\
957 \\
2,699\end{array}$ & $\begin{array}{r}6,391 \\
5,133 \\
569 \\
1,005\end{array}$ & $\begin{array}{r}1,479 \\
2,887 \\
284 \\
580\end{array}$ & $\begin{array}{r}1,375 \\
1,320 \\
34 \\
116\end{array}$ & $\begin{array}{r}488 \\
258 \\
12 \\
70\end{array}$ \\
\hline Total & 36,668 & 21,720 & 7,687 & 3,917 & 1,231 & 24,120 & 13,100 & 5,232 & 2,846 & 829 \\
\hline $\begin{array}{l}\text { Southern Rocky Mountain: } \\
\text { Arizona }{ }^{2} \\
\text { Colorado } 2 \\
\text { Nevada } 2 \\
\text { New Mexico } 2 \\
\text { Utah } 2\end{array}$ & $\begin{array}{r}3,689 \\
11,583 \\
128 \\
5,736 \\
3,824\end{array}$ & $\begin{array}{l}3,164 \\
4,567 \\
110 \\
4,655 \\
2,337\end{array}$ & $\begin{array}{r}182 \\
2,884 \\
3 \\
402 \\
969\end{array}$ & $\begin{array}{r}157 \\
564 \\
7 \\
319 \\
263\end{array}$ & $\begin{array}{r}133 \\
1,023 \\
7 \\
227 \\
48\end{array}$ & $\begin{array}{r}2,347 \\
7,710 \\
55 \\
2,939 \\
2,613\end{array}$ & $\begin{array}{r}1,882 \\
2,863 \\
41 \\
2,164 \\
1,568\end{array}$ & $\begin{array}{r}146 \\
1,142 \\
3 \\
252 \\
686\end{array}$ & $\begin{array}{r}136 \\
408 \\
5 \\
167 \\
125\end{array}$ & $\begin{array}{r}129 \\
752 \\
4 \\
224 \\
27\end{array}$ \\
\hline Total & 24,963 & 14,834 & 4,441 & 1,311 & 1,440 & 15,666 & 8,519 & 2,230 & 842 & 1,138 \\
\hline Total, Rocky Mountain. & 61,631 & 36,555 & 12,129 & 5,229 & 2,671 & 39,787 & 21,620 & 7,462 & 3,689 & 1,967 \\
\hline Total, all regions.... & 499,697 & 215,867 & 126,693 & 131,368 & 20,721 & 91,924 & 54,374 & 18,654 & 10,525 & 3,322 \\
\hline
\end{tabular}

\begin{tabular}{|c|c|c|c|c|c|c|c|c|c|c|c|c|c|c|c|}
\hline \multirow{2}{*}{ Section, region, and State } & \multicolumn{5}{|c|}{ Other public } & \multicolumn{5}{|c|}{ Forest industry } & \multicolumn{5}{|c|}{ Farm and miscellaneous private } \\
\hline & Total & $\begin{array}{l}\text { Saw- } \\
\text { timber } \\
\text { stands }\end{array}$ & $\begin{array}{c}\text { Pole- } \\
\text { timber } \\
\text { stands }\end{array}$ & $\begin{array}{c}\text { Seed- } \\
\text { ling } \\
\text { sapling }\end{array}$ & $\begin{array}{l}\text { Non- } \\
\text { stock- } \\
\text { ed } \\
\text { areas }\end{array}$ & Total & $\begin{array}{l}\text { Saw- } \\
\text { timber } \\
\text { stands }\end{array}$ & $\begin{array}{c}\text { Pole- } \\
\text { timber } \\
\text { stands }\end{array}$ & $\begin{array}{c}\text { Seed- } \\
\text { ling } \\
\text { sapling }\end{array}$ & $\begin{array}{l}\text { non- } \\
\text { stock- } \\
\text { ed } \\
\text { areas }\end{array}$ & Total & $\begin{array}{l}\text { Saw. } \\
\text { timber } \\
\text { stands }\end{array}$ & $\begin{array}{l}\text { Pole- } \\
\text { timber } \\
\text { stands }\end{array}$ & $\begin{array}{l}\text { Seed- } \\
\text { ling } \\
\text { sapling }\end{array}$ & $\begin{array}{l}\text { Non- } \\
\text { stock- } \\
\text { ed } \\
\text { areas }\end{array}$ \\
\hline 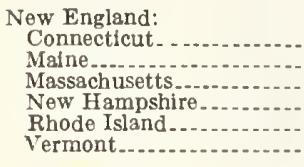 & $\begin{array}{r}155 \\
274 \\
399 \\
127 \\
26 \\
179\end{array}$ & $\begin{array}{r}27 \\
31 \\
34 \\
44 \\
5 \\
63\end{array}$ & $\begin{array}{r}103 \\
145 \\
218 \\
59 \\
17 \\
75\end{array}$ & $\begin{array}{r}20 \\
97 \\
143 \\
17 \\
3 \\
38\end{array}$ & $\begin{array}{l}5 \\
0 \\
4 \\
5 \\
1 \\
0\end{array}$ & $\begin{array}{r}3 \\
8,255 \\
259 \\
793 \\
0 \\
678\end{array}$ & $\begin{array}{r}2 \\
3,684 \\
140 \\
268 \\
0 \\
365\end{array}$ & $\begin{array}{r}1 \\
2,892 \\
83 \\
397 \\
0 \\
218\end{array}$ & $\begin{array}{r}0 \\
1,678 \\
36 \\
93 \\
0 \\
94\end{array}$ & $\begin{array}{r}0 \\
0 \\
0 \\
33 \\
0 \\
0\end{array}$ & $\begin{array}{r}2,011 \\
8,327 \\
2,833 \\
3,531 \\
403 \\
3,280\end{array}$ & $\begin{array}{r}337 \\
2,407 \\
240 \\
1,132 \\
9 \\
1,241\end{array}$ & $\begin{array}{r}1,064 \\
2,286 \\
1,368 \\
1,780 \\
216 \\
1,167\end{array}$ & $\begin{array}{r}563 \\
3,490 \\
1,189 \\
485 \\
165 \\
833\end{array}$ & $\begin{array}{r}44 \\
142 \\
34 \\
132 \\
12 \\
39\end{array}$ \\
\hline Total.. & 1,160 & 205 & 618 & 320 & 16 & 9,988 & 4,460 & 3,592 & 1,903 & 33 & 20,386 & 5,369 & 7,883 & 6,727 & 405 \\
\hline 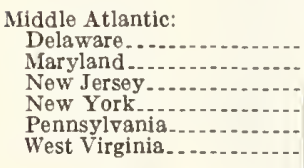 & $\begin{array}{r}9 \\
189 \\
254 \\
892 \\
2,918 \\
167\end{array}$ & $\begin{array}{r}1 \\
104 \\
19 \\
278 \\
1,235 \\
72\end{array}$ & $\begin{array}{r}7 \\
60 \\
124 \\
272 \\
1,326 \\
50\end{array}$ & $\begin{array}{r}1 \\
23 \\
100 \\
269 \\
334 \\
25\end{array}$ & $\begin{array}{r}0 \\
2 \\
11 \\
71 \\
23 \\
20\end{array}$ & $\begin{array}{r}29 \\
100 \\
4 \\
1,180 \\
610 \\
530\end{array}$ & $\begin{array}{r}21 \\
36 \\
1 \\
594 \\
241 \\
301\end{array}$ & $\begin{array}{r}5 \\
44 \\
2 \\
238 \\
238 \\
169\end{array}$ & $\begin{array}{r}3 \\
18 \\
1 \\
323 \\
131 \\
55\end{array}$ & $\begin{array}{r}0 \\
1 \\
0 \\
23 \\
0 \\
5\end{array}$ & $\begin{array}{r}351 \\
2,591 \\
2,096 \\
12,416 \\
13,462 \\
10,515\end{array}$ & $\begin{array}{r}187 \\
1,650 \\
579 \\
3,410 \\
5,924 \\
5,034\end{array}$ & $\begin{array}{r}116 \\
648 \\
668 \\
2,167 \\
4,307 \\
2,765\end{array}$ & $\begin{array}{r}41 \\
256 \\
702 \\
5,607 \\
2,926 \\
2,492\end{array}$ & $\begin{array}{r}6 \\
37 \\
146 \\
1,230 \\
303 \\
223\end{array}$ \\
\hline Total. & 4,429 & 1,709 & 1,839 & 752 & 127 & 2,454 & 1,195 & 697 & 531 & 29 & 41,433 & 16,786 & 10,674 & 12,026 & 1,946 \\
\hline $\begin{array}{l}\text { Lake States: } \\
\text { Milchigan } \\
\text { Minnesota........... } \\
\text { North Dakota- } \\
\text { South Dakota (East)- } \\
\text { Wisconsin }\end{array}$ & $\begin{array}{r}4,018 \\
7,261 \\
124 \\
77 \\
3,207\end{array}$ & $\begin{array}{r}892 \\
537 \\
19 \\
31 \\
405\end{array}$ & $\begin{array}{r}2,031 \\
3,412 \\
48 \\
41 \\
1,636\end{array}$ & $\begin{array}{r}980 \\
2,207 \\
46 \\
4 \\
1,101\end{array}$ & $\begin{array}{r}112 \\
1,103 \\
10 \\
0 \\
63\end{array}$ & $\begin{array}{r}2,256 \\
814 \\
0 \\
0 \\
1,368 \\
\end{array}$ & $\begin{array}{r}1,000 \\
110 \\
0 \\
0 \\
346\end{array}$ & $\begin{array}{r}693 \\
430 \\
0 \\
0 \\
599\end{array}$ & $\begin{array}{r}553 \\
234 \\
0 \\
0 \\
418\end{array}$ & $\begin{array}{r}9 \\
38 \\
0 \\
0 \\
4\end{array}$ & $\begin{array}{r}10,102 \\
6,672 \\
281 \\
145 \\
8,643\end{array}$ & $\begin{array}{r}2,373 \\
1,374 \\
43 \\
72 \\
2,262 \\
\end{array}$ & $\begin{array}{r}4,107 \\
3,247 \\
109 \\
54 \\
3,594\end{array}$ & $\begin{array}{r}3,210 \\
1,510 \\
103 \\
15 \\
2,549 \\
\end{array}$ & $\begin{array}{r}411 \\
540 \\
24 \\
3 \\
237\end{array}$ \\
\hline Total... & 14,688 & 1,886 & 7,171 & 4,340 & 1,290 & 4,438 & 1,457 & 1,722 & 1,206 & 52 & 25,845 & 6,127 & 11,114 & 7,388 & 1,216 \\
\hline 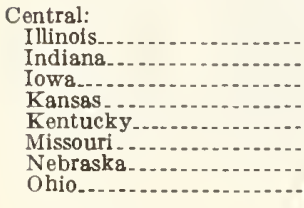 & $\begin{array}{r}52 \\
224 \\
34 \\
36 \\
289 \\
264 \\
37 \\
235\end{array}$ & $\begin{array}{r}26 \\
132 \\
13 \\
20 \\
173 \\
60 \\
10 \\
119\end{array}$ & $\begin{array}{r}11 \\
49 \\
11 \\
8 \\
53 \\
98 \\
16 \\
34\end{array}$ & $\begin{array}{r}10 \\
42 \\
3 \\
2 \\
55 \\
57 \\
8 \\
78\end{array}$ & $\begin{array}{r}3 \\
0 \\
6 \\
4 \\
6 \\
49 \\
2 \\
3\end{array}$ & $\begin{array}{r}16 \\
21 \\
9 \\
0 \\
227 \\
279 \\
0 \\
126\end{array}$ & $\begin{array}{r}16 \\
12 \\
3 \\
0 \\
148 \\
78 \\
0 \\
59\end{array}$ & $\begin{array}{r}0 \\
6 \\
2 \\
0 \\
38 \\
80 \\
0 \\
14\end{array}$ & $\begin{array}{r}0 \\
2 \\
1 \\
0 \\
41 \\
103 \\
0 \\
0 \\
52\end{array}$ & $\begin{array}{r}0 \\
0 \\
1 \\
0 \\
0 \\
16 \\
0 \\
0\end{array}$ & $\begin{array}{r}3,396 \\
3,457 \\
2,386 \\
1,150 \\
10,777 \\
12,734 \\
928 \\
5,930\end{array}$ & $\begin{array}{r}1,963 \\
1,837 \\
925 \\
660 \\
4,884 \\
3,544 \\
240 \\
1,732\end{array}$ & $\begin{array}{r}849 \\
716 \\
763 \\
221 \\
2,612 \\
3,398 \\
266 \\
637\end{array}$ & $\begin{array}{r}560 \\
830 \\
263 \\
132 \\
3,215 \\
3,019 \\
71 \\
3,405 \\
\end{array}$ & $\begin{array}{r}21 \\
72 \\
434 \\
136 \\
65 \\
2,772 \\
349 \\
154\end{array}$ \\
\hline Total....... & 1,175 & 557 & 282 & 258 & 76 & 681 & 318 & 143 & 201 & 18 & 40,761 & 15,788 & 9,465 & 11,499 & 4,007 \\
\hline Total, North..... & 21,453 & 4,360 & 9,911 & 5,672 & 1,510 & 17,563 & 7,431 & 6,155 & 3,842 & 133 & 128,426 & 44,071 & 39,137 & 37,641 & 7,576 \\
\hline
\end{tabular}

See footnotes at end of table. 
TABLE 3.- Area of commercial timberland in the United States, by ownership and stand-size class, section, region, and State, January 1, 1970 1 -Continued

[Thousand acres]

\begin{tabular}{|c|c|c|c|c|c|c|c|c|c|c|c|c|c|c|c|}
\hline \multirow{2}{*}{ Section, region, and State } & \multicolumn{5}{|c|}{ Other public } & \multicolumn{5}{|c|}{ Forest industry } & \multicolumn{5}{|c|}{ Farm and miscellaneous private } \\
\hline & Total & $\begin{array}{l}\text { Ssw- } \\
\text { timber } \\
\text { stands }\end{array}$ & $\begin{array}{l}\text { Pole- } \\
\text { timber } \\
\text { stands }\end{array}$ & $\begin{array}{c}\text { Seed- } \\
\text { ling } \\
\text { sapling }\end{array}$ & $\begin{array}{l}\text { Non- } \\
\text { stock- } \\
\text { ed } \\
\text { areas }\end{array}$ & Total & $\begin{array}{l}\text { Saw- } \\
\text { timber } \\
\text { stands }\end{array}$ & $\begin{array}{l}\text { Pole- } \\
\text { timber } \\
\text { stands }\end{array}$ & $\begin{array}{c}\text { Seed- } \\
\text { ling } \\
\text { sapling }\end{array}$ & $\begin{array}{l}\text { Non- } \\
\text { stock- } \\
\text { ed } \\
\text { areas }\end{array}$ & Total & $\begin{array}{l}\text { Saw- } \\
\text { timber } \\
\text { stands }\end{array}$ & \begin{tabular}{|c|} 
Pole- \\
timber \\
stands
\end{tabular} & $\begin{array}{c}\text { Seed- } \\
\text { ling } \\
\text { sapling }\end{array}$ & $\begin{array}{l}\text { Non- } \\
\text { stock- } \\
\text { ed } \\
\text { areas }\end{array}$ \\
\hline 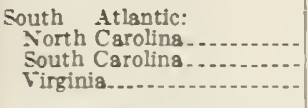 & $\begin{array}{l}657 \\
522 \\
469 \\
\end{array}$ & $\begin{array}{l}413 \\
213 \\
199 \\
\end{array}$ & $\begin{array}{l}122 \\
132 \\
199 \\
\end{array}$ & $\begin{array}{r}138 \\
153 \\
69 \\
\end{array}$ & $\begin{array}{r}13 \\
22 \\
0 \\
\end{array}$ & $\begin{array}{l}2,785 \\
2,047 \\
1,634 \\
\end{array}$ & $\begin{array}{r}1,323 \\
880 \\
515 \\
\end{array}$ & $\begin{array}{l}548 \\
511 \\
503 \\
\end{array}$ & $\begin{array}{l}869 \\
613 \\
609 \\
\end{array}$ & $\begin{array}{r}43 \\
42 \\
6 \\
\end{array}$ & $\begin{array}{r}15,684 \\
9,290 \\
12,553 \\
\end{array}$ & $\begin{array}{l}8,075 \\
3,446 \\
3,974 \\
\end{array}$ & $\begin{array}{l}3,398 \\
2,674 \\
4,785 \\
\end{array}$ & $\begin{array}{l}4,082 \\
2,836 \\
3,718 \\
\end{array}$ & $\begin{array}{r}127 \\
333 \\
75 \\
\end{array}$ \\
\hline Total.... & 1,678 & 826 & 455 & 360 & 36 & 6,467 & 2,719 & 1,563 & 2,092 & 92 & 37,527 & 15,496 & 10,858 & 10,637 & 536 \\
\hline $\begin{array}{l}\text { East Gulf: } \\
\text { Florida...... } \\
\text { Georgia..... }\end{array}$ & $\begin{array}{r}1,110 \\
600 \\
\end{array}$ & $\begin{array}{l}406 \\
253 \\
\end{array}$ & $\begin{array}{l}203 \\
100 \\
\end{array}$ & $\begin{array}{l}243 \\
210\end{array}$ & $\begin{array}{r}257 \\
36 \\
\end{array}$ & $\begin{array}{l}5,216 \\
4,700\end{array}$ & $\begin{array}{l}1,538 \\
1,585\end{array}$ & $\begin{array}{r}1,312 \\
862 \\
\end{array}$ & $\begin{array}{l}1,944 \\
2,073\end{array}$ & $\begin{array}{l}422 \\
178\end{array}$ & $\begin{array}{r}8,869 \\
18,995 \\
\end{array}$ & $\begin{array}{l}2,624 \\
6,023\end{array}$ & $\begin{array}{l}2,330 \\
3,476\end{array}$ & $\begin{array}{l}2,097 \\
8,996\end{array}$ & $\begin{array}{r}1,817 \\
493\end{array}$ \\
\hline Total.... & 1,710 & 6.59 & 303 & 454 & 293 & 9,916 & 3,123 & 2,174 & 4,017 & 600 & 27,865 & 8,647 & 5,806 & 11,093 & 2,317 \\
\hline $\begin{array}{l}\text { Central Gulf: } \\
\text { Alsbama } \\
\text { Mlississippi.-. } \\
\text { Tennessee }\end{array}$ & $\begin{array}{l}371 \\
651 \\
686 \\
\end{array}$ & $\begin{array}{l}201 \\
258 \\
297 \\
\end{array}$ & $\begin{array}{r}76 \\
139 \\
271 \\
\end{array}$ & $\begin{array}{r}93 \\
241 \\
117 \\
\end{array}$ & $\begin{array}{r}0 \\
12 \\
0 \\
\end{array}$ & $\begin{array}{l}3,818 \\
2,505 \\
1,121 \\
\end{array}$ & $\begin{array}{r}1,802 \\
839 \\
233 \\
\end{array}$ & $\begin{array}{l}816 \\
506 \\
432 \\
\end{array}$ & $\begin{array}{r}1,183 \\
1,154 \\
456 \\
\end{array}$ & $\begin{array}{r}16 \\
4 \\
0 \\
\end{array}$ & $\begin{array}{l}16,926 \\
12,616 \\
10,412 \\
\end{array}$ & $\begin{array}{l}6,453 \\
2,931 \\
2,509 \\
\end{array}$ & $\begin{array}{l}4,215 \\
2,976 \\
3,959 \\
\end{array}$ & $\begin{array}{l}6,110 \\
6,591 \\
3,910 \\
\end{array}$ & $\begin{array}{r}147 \\
117 \\
32 \\
\end{array}$ \\
\hline Total.. & 1,709 & 757 & 487 & 452 & 12 & 7,444 & 2,874 & 1,755 & 2,793 & 21 & 39,955 & 11,894 & 11,151 & 16,612 & 297 \\
\hline $\begin{array}{l}\text { West Gulf: } \\
\text { Arkansas } \\
\text { Louisiana } \\
\text { Oklahoma } \\
\text { Teras }\end{array}$ & $\begin{array}{l}560 \\
308 \\
343 \\
203 \\
\end{array}$ & $\begin{array}{r}220 \\
211 \\
72 \\
102 \\
\end{array}$ & $\begin{array}{r}119 \\
20 \\
75 \\
22 \\
\end{array}$ & $\begin{array}{r}214 \\
74 \\
191 \\
78 \\
\end{array}$ & $\begin{array}{l}5 \\
1 \\
4 \\
0 \\
\end{array}$ & $\begin{array}{r}3,950 \\
3,180 \\
868 \\
3,496 \\
\end{array}$ & $\begin{array}{r}1,863 \\
2,196 \\
408 \\
2,510 \\
\end{array}$ & $\begin{array}{l}745 \\
292 \\
193 \\
320 \\
\end{array}$ & $\begin{array}{r}1,322 \\
669 \\
261 \\
647 \\
\end{array}$ & $\begin{array}{r}19 \\
22 \\
5 \\
17 \\
\end{array}$ & $\begin{array}{r}11,317 \\
11,301 \\
3,371 \\
8,599 \\
\end{array}$ & $\begin{array}{r}2,626 \\
6,655 \\
667 \\
3,889 \\
\end{array}$ & $\begin{array}{r}3,032 \\
1,557 \\
629 \\
1,804 \\
\end{array}$ & $\begin{array}{l}5,602 \\
2,930 \\
1,969 \\
2,824 \\
\end{array}$ & $\begin{array}{r}56 \\
157 \\
104 \\
80 \\
\end{array}$ \\
\hline Total ..... & 1,415 & 607 & 236 & 559 & 11 & 11,496 & 6,979 & 1,551 & 2,901 & 64 & 34,589 & 13,893 & 7,024 & 13,327 & 398 \\
\hline Total, South... & 6,514 & 2,851 & 1,482 & 1,826 & 354 & 35,325 & 15,697 & 7,044 & 11,805 & 778 & 139,938 & $49,8 \pi 7$ & 34,840 & 51,670 & 3,549 \\
\hline $\begin{array}{l}\text { Pacific Northwest: } \\
\text { Alaska: Coastal ......... }\end{array}$ & 465 & 435 & 6 & 24 & 0 & 0 & 0 & 0 & 0 & 0 & 30 & 26 & 1 & 3 & 0 \\
\hline 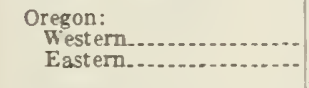 & $\begin{array}{r}2,922 \\
594 \\
\end{array}$ & $\begin{array}{r}1,779 \\
407 \\
\end{array}$ & $\begin{array}{l}234 \\
129 \\
\end{array}$ & $\begin{array}{r}690 \\
32 \\
\end{array}$ & $\begin{array}{r}219 \\
26 \\
\end{array}$ & $\begin{array}{l}3,624 \\
1,582 \\
\end{array}$ & $\begin{array}{l}1,793 \\
1,077 \\
\end{array}$ & $\begin{array}{r}338 \\
299 \\
\end{array}$ & $\begin{array}{r}1,325 \\
131 \\
\end{array}$ & $\begin{array}{r}168 \\
75 \\
\end{array}$ & $\begin{array}{l}3,259 \\
1,689 \\
\end{array}$ & $\begin{array}{l}1,537 \\
1,015 \\
\end{array}$ & $\begin{array}{l}339 \\
385 \\
\end{array}$ & $\begin{array}{r}1,151 \\
137 \\
\end{array}$ & $\begin{array}{l}232 \\
152 \\
\end{array}$ \\
\hline Summary... & 3,516 & 2,186 & 363 & 722 & 245 & 5,206 & 2,870 & 637 & 1,456 & 243 & 4,948 & 2,552 & 724 & 1,288 & 384 \\
\hline $\begin{array}{l}\text { Washington: } \\
\text { Western......... } \\
\text { Eastern......... }\end{array}$ & $\begin{array}{l}1,802 \\
2,292 \\
\end{array}$ & $\begin{array}{l}1,130 \\
1,568 \\
\end{array}$ & $\begin{array}{l}302 \\
345 \\
\end{array}$ & $\begin{array}{l}340 \\
26 \tau \\
\end{array}$ & $\begin{array}{r}30 \\
112 \\
\end{array}$ & $\begin{array}{r}3,598 \\
750 \\
\end{array}$ & $\begin{array}{r}2,049 \\
495 \\
\end{array}$ & $\begin{array}{l}540 \\
126 \\
\end{array}$ & $\begin{array}{l}942 \\
101 \\
\end{array}$ & $\begin{array}{l}67 \\
28 \\
\end{array}$ & $\begin{array}{l}2,270 \\
2,265 \\
\end{array}$ & $\begin{array}{r}1,297 \\
964 \\
\end{array}$ & $\begin{array}{l}478 \\
628 \\
\end{array}$ & $\begin{array}{l}448 \\
358 \\
\end{array}$ & $\begin{array}{r}47 \\
315 \\
\end{array}$ \\
\hline Summary........ & 4,094 & 2,698 & 647 & 607 & 142 & 4,348 & 2,544 & 666 & 1,043 & 95 & 4,535 & 2,261 & 1,106 & 806 & 362 \\
\hline Total. & 8,075 & 5,319 & 1,016 & 1,353 & 387 & 9,554 & 5,414 & 1,303 & 2,499 & 338 & 9,513 & 4,839 & 1,831 & 2,097 & 746 \\
\hline $\begin{array}{l}\text { Pacific Southwest: } \\
\text { California........... } \\
\text { Hawril. }\end{array}$ & $\begin{array}{l}476 \\
495 \\
\end{array}$ & $\begin{array}{l}339 \\
147 \\
\end{array}$ & 96 & $\begin{array}{l}62 \\
24 \\
\end{array}$ & $\begin{array}{r}66 \\
228 \\
\end{array}$ & $\begin{array}{r}2,665 \\
0 \\
\end{array}$ & $\begin{array}{r}2,132 \\
0 \\
\end{array}$ & $\begin{array}{r}2 \pi \\
0 \\
\end{array}$ & $\begin{array}{r}318 \\
0 \\
\end{array}$ & $\begin{array}{r}188 \\
0 \\
\end{array}$ & $\begin{array}{r}5,343 \\
585 \\
\end{array}$ & $\begin{array}{r}3,905 \\
173 \\
\end{array}$ & $\begin{array}{l}405 \\
113 \\
\end{array}$ & $\begin{array}{r}462 \\
28 \\
\end{array}$ & $\begin{array}{l}571 \\
269\end{array}$ \\
\hline Total & 971 & 486 & 105 & 86 & 294 & 2,665 & 2,132 & 27 & 318 & 188 & 5,928 & 4,078 & 518 & 490 & 840 \\
\hline Total, Pscific Coast.. & 9,046 & 5,805 & 1,121 & 1,439 & 681 & 12,219 & 7,546 & 1,330 & 2,817 & 526 & 15,441 & 8,917 & 2,349 & 2,587 & 1,586 \\
\hline $\begin{array}{l}\text { Northern Rocky Mountain: } \\
\text { Idaho }{ }^{2} \\
\text { Montans }{ }^{2} \\
\text { South Dakots (West)2. } \\
\text { Wyoming }{ }^{2}-\ldots\end{array}$ & $\begin{array}{r}1,440 \\
1,685 \\
71 \\
628 \\
\end{array}$ & $\begin{array}{r}1,152 \\
1,090 \\
39 \\
409 \\
\end{array}$ & $\begin{array}{r}114 \\
408 \\
30 \\
144 \\
\end{array}$ & $\begin{array}{r}136 \\
152 \\
1 \\
30 \\
\end{array}$ & $\begin{array}{r}36 \\
34 \\
0 \\
44 \\
\end{array}$ & $\begin{array}{r}946 \\
1,055 \\
17 \\
54\end{array}$ & $\begin{array}{r}813 \\
824 \\
6 \\
38 \\
\end{array}$ & $\begin{array}{r}21 \\
181 \\
9 \\
13 \\
\end{array}$ & $\begin{array}{r}89 \\
38 \\
0 \\
1 \\
\end{array}$ & $\begin{array}{r}22 \\
12 \\
0 \\
0 \\
\end{array}$ & $\begin{array}{r}2,074 \\
3,510 \\
263 \\
800 \\
\end{array}$ & $\begin{array}{r}1,477 \\
2,138 \\
92 \\
537 \\
\end{array}$ & $\begin{array}{l}160 \\
989 \\
158 \\
223 \\
\end{array}$ & $\begin{array}{r}278 \\
305 \\
9 \\
26 \\
\end{array}$ & $\begin{array}{r}158 \\
76 \\
3 \\
13 \\
\end{array}$ \\
\hline Total & 3,825 & 2,691 & 697 & 320 & 115 & 2,073 & 1,681 & 226 & 130 & 3.5 & 6,648 & 4,246 & 1,531 & 619 & 250 \\
\hline 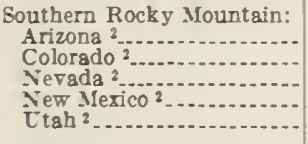 & $\begin{array}{r}1,175 \\
754 \\
4 \\
870 \\
550 \\
\end{array}$ & $\begin{array}{r}1,146 \\
428 \\
4 \\
828 \\
377 \\
\end{array}$ & $\begin{array}{r}21 \\
298 \\
0 \\
18 \\
102 \\
\end{array}$ & $\begin{array}{r}3 \\
20 \\
0 \\
19 \\
60 \\
\end{array}$ & $\begin{array}{l}3 \\
7 \\
0 \\
3 \\
9 \\
\end{array}$ & $\begin{array}{r}0 \\
14 \\
8 \\
137 \\
0\end{array}$ & $\begin{array}{r}0 \\
4 \\
7 \\
113 \\
0 \\
0\end{array}$ & $\begin{array}{r}0 \\
10 \\
0 \\
8 \\
0 \\
\end{array}$ & $\begin{array}{l}0 \\
0 \\
0 \\
9 \\
0 \\
\end{array}$ & $\begin{array}{l}0 \\
0 \\
0 \\
0 \\
0 \\
\end{array}$ & $\begin{array}{r}166 \\
3,103 \\
60 \\
1,790 \\
660\end{array}$ & $\begin{array}{r}135 \\
1,271 \\
56 \\
1,543 \\
391\end{array}$ & $\begin{array}{r}14 \\
1,432 \\
0 \\
123 \\
180\end{array}$ & $\begin{array}{r}17 \\
135 \\
1 \\
123 \\
77\end{array}$ & $\begin{array}{r}0 \\
264 \\
2 \\
0 \\
11 \\
\end{array}$ \\
\hline Total .................. & 3,355 & 2,786 & 441 & 105 & 24 & 160 & 130 & 18 & 10 & 0 & 5,781 & 3,398 & 1,750 & 355 & $2 \pi 7$ \\
\hline $\begin{array}{l}\text { Total, Rocky Moun- } \\
\text { tain- }\end{array}$ & 7,181 & 3,478 & 1,139 & 424 & 139 & 2. 233 & 1,812 & 245 & 140 & 35 & 12,429 & 7,644 & 3,281 & 975 & 528 \\
\hline Total, all regions..... & 44,196 & 18,494 & 13,653 & 9,362 & 2,685 & 67,341 & 32,486 & 14,775 & 18,605 & 1,473 & 296,235 & 110,511 & 79,609 & $92,8 i 4$ & 13,239 \\
\hline
\end{tabular}

1 Data may not add to totals because of truncating. Zeros indicate no data or negligible amounts.

2 Estimates of area subclasses do not include 5.0 million acres of Siational Forest lands in the Rocky. Mountain States that are not included in the base for allowable cut because of such factors as unstable soils, small size of isolated patches and stringers or special use constraints. Volume and growth data are also excluded for these areas. 
TABLE 4.-Area of commercial timberland in the United States, by ownership and stand-volume class, section, region, and State, January $1,1970^{1}$

[Thousand acres]

\begin{tabular}{|c|c|c|c|c|c|c|c|c|}
\hline \multirow{2}{*}{ Section, region, and State } & \multicolumn{4}{|c|}{ Total, All Ownerships } & \multicolumn{4}{|c|}{ National Forest } \\
\hline & Total & $\begin{array}{l}\text { Less than } \\
1,500 \text { bd. } \mathrm{ft} .\end{array}$ & $\begin{array}{c}1,500 \text { to } 5,000 \\
\text { bd. ft. }\end{array}$ & $\begin{array}{l}\text { More than } \\
5,000 \text { bd. ft. }\end{array}$ & Total & $\begin{array}{l}\text { Less than } \\
1,500 \text { bd. } \mathrm{ft} .\end{array}$ & $\begin{array}{c}1,500 \text { to } 5,000 \\
\text { bd. ft. }\end{array}$ & $\begin{array}{c}\text { More than } \\
5,000 \text { bd. ft. }\end{array}$ \\
\hline $\begin{array}{l}\text { New England: } \\
\text { Connecticut } \\
\text { Maine } \\
\text { Massachusetts } \\
\text { New Hampshire } \\
\text { Rhode Island } \\
\text { Vermont_... }\end{array}$ & $\begin{array}{r}2,169 \\
16,894 \\
3,491 \\
5,020 \\
429 \\
4,364\end{array}$ & $\begin{array}{r}1,802 \\
7,580 \\
3,076 \\
3,233 \\
415 \\
2,464 \\
\end{array}$ & $\begin{array}{r}319 \\
7,454 \\
371 \\
1,429 \\
14 \\
1,651\end{array}$ & $\begin{array}{r}47 \\
1,859 \\
43 \\
358 \\
0 \\
249\end{array}$ & $\begin{array}{r}0 \\
37 \\
0 \\
568 \\
0 \\
226\end{array}$ & $\begin{array}{r}0 \\
5 \\
0 \\
366 \\
0 \\
96\end{array}$ & $\begin{array}{r}0 \\
24 \\
0 \\
161 \\
0 \\
112\end{array}$ & $\begin{array}{r}0 \\
7 \\
0 \\
40 \\
0 \\
17\end{array}$ \\
\hline Total & 32,367 & 18,571 & 11,239 & 2,556 & 832 & 468 & 298 & 65 \\
\hline $\begin{array}{l}\text { Middle Atlantic: } \\
\text { Delaware } \\
\text { Maryland... } \\
\text { New Jersey } \\
\text { New York } \\
\text { Pennsylvania. } \\
\text { West Virginia...... }\end{array}$ & $\begin{array}{r}390 \\
2,882 \\
2,354 \\
14,489 \\
17,478 \\
12,092\end{array}$ & $\begin{array}{r}179 \\
1,404 \\
1,754 \\
8,885 \\
11,328 \\
5,316\end{array}$ & $\begin{array}{r}107 \\
1,024 \\
438 \\
4,964 \\
5,061 \\
4,843\end{array}$ & $\begin{array}{r}102 \\
453 \\
161 \\
639 \\
1,089 \\
1,933\end{array}$ & $\begin{array}{r}0 \\
0 \\
0 \\
0 \\
488 \\
879\end{array}$ & $\begin{array}{r}0 \\
0 \\
0 \\
0 \\
257 \\
290\end{array}$ & $\begin{array}{r}0 \\
0 \\
0 \\
0 \\
192 \\
413\end{array}$ & $\begin{array}{r}0 \\
0 \\
0 \\
0 \\
37 \\
175\end{array}$ \\
\hline Total $\ldots . . . . .$. & 49,685 & 28,867 & 16,439 & 4,378 & 1,367 & 547 & 605 & 213 \\
\hline $\begin{array}{l}\text { Lake States: } \\
\text { Michigan } \\
\text { Minnesota. } \\
\text { North Dakota } \\
\text { South Dakota (East) } \\
\text { Wisconsin... }\end{array}$ & $\begin{array}{r}18,800 \\
16,875 \\
406 \\
223 \\
14,536\end{array}$ & $\begin{array}{r}11,586 \\
14,512 \\
341 \\
148 \\
12,522\end{array}$ & $\begin{array}{r}5,065 \\
1,535 \\
37 \\
64 \\
1,162 \\
\end{array}$ & $\begin{array}{r}2,148 \\
826 \\
28 \\
10 \\
852 \\
\end{array}$ & $\begin{array}{r}2,422 \\
2,127 \\
0 \\
0 \\
1,317 \\
\end{array}$ & $\begin{array}{r}1,460 \\
1,829 \\
0 \\
0 \\
1,135\end{array}$ & $\begin{array}{r}673 \\
193 \\
0 \\
0 \\
105\end{array}$ & $\begin{array}{r}288 \\
104 \\
0 \\
0 \\
77\end{array}$ \\
\hline Total. & 50,840 & 39,110 & 7,864 & 3,865 & 5,867 & 4,424 & 972 & 470 \\
\hline $\begin{array}{l}\text { Central: } \\
\text { Illinois } \\
\text { Indians } \\
\text { Iowa. } \\
\text { Kansas } \\
\text { Kentucky } \\
\text { Missouri } \\
\text { Nebraska } \\
\text { Ohio. }\end{array}$ & $\begin{array}{r}3,680 \\
3,840 \\
2,430 \\
1,187 \\
11,826 \\
14,600 \\
1,023 \\
6,422\end{array}$ & $\begin{array}{r}1,810 \\
1,658 \\
1,488 \\
755 \\
5,728 \\
12,141 \\
6,651 \\
3,125\end{array}$ & $\begin{array}{r}1,420 \\
1,405 \\
598 \\
368 \\
4,730 \\
2,349 \\
317 \\
2,355\end{array}$ & $\begin{array}{r}448 \\
775 \\
343 \\
62 \\
1,368 \\
109 \\
53 \\
942\end{array}$ & $\begin{array}{r}214 \\
136 \\
0 \\
0 \\
531 \\
1,321 \\
57 \\
129\end{array}$ & $\begin{array}{r}105 \\
46 \\
0 \\
0 \\
96 \\
1,014 \\
55 \\
51\end{array}$ & $\begin{array}{r}82 \\
74 \\
0 \\
0 \\
330 \\
306 \\
2 \\
40\end{array}$ & $\begin{array}{r}26 \\
14 \\
0 \\
0 \\
103 \\
0 \\
0 \\
38\end{array}$ \\
\hline Total $\ldots$ & 45,008 & 27,359 & 13,545 & 4,103 & 2,390 & 1,369 & 837 & 183 \\
\hline Total, North................ & 177,901 & 113,909 & 49,088 & 14,903 & 10,458 & 6,810 & 2,714 & 933 \\
\hline $\begin{array}{l}\text { South Atlantic: } \\
\text { North Carolina } \\
\text { South Carolina. } \\
\text { Virginia. }\end{array}$ & $\begin{array}{l}20,192 \\
12,410 \\
15,859\end{array}$ & $\begin{array}{l}9,872 \\
6,046 \\
7,818 \\
\end{array}$ & $\begin{array}{l}6,912 \\
3,864 \\
5,834 \\
\end{array}$ & $\begin{array}{l}3,407 \\
2,498 \\
2,205\end{array}$ & $\begin{array}{r}1,035 \\
550 \\
1,202 \\
\end{array}$ & $\begin{array}{r}266 \\
71 \\
499\end{array}$ & $\begin{array}{l}527 \\
208 \\
562\end{array}$ & $\begin{array}{l}241 \\
271 \\
141\end{array}$ \\
\hline Total & 48,463 & 23,738 & 16,612 & 8,112 & 2,789 & 836 & 1,298 & 654 \\
\hline $\begin{array}{l}\text { East Gulf: } \\
\text { Florida } \\
\text { Georgia }\end{array}$ & $\begin{array}{l}16,231 \\
25,102\end{array}$ & $\begin{array}{l}10,135 \\
15,891\end{array}$ & $\begin{array}{l}4,224 \\
6,370 \\
\end{array}$ & $\begin{array}{l}1,871 \\
2,840\end{array}$ & $\begin{array}{r}1,035 \\
806\end{array}$ & $\begin{array}{l}554 \\
216\end{array}$ & $\begin{array}{l}333 \\
346\end{array}$ & $\begin{array}{l}147 \\
244 \\
\end{array}$ \\
\hline Total $\ldots \ldots$ & 41,334 & 26,026 & 10,595 & 4,712 & 1,842 & 771 & 679 & 391 \\
\hline $\begin{array}{l}\text { Central Gulf: } \\
\text { Alabama. } \\
\text { Mississippi } \\
\text { Tennessee. }\end{array}$ & $\begin{array}{l}21,742 \\
16,891 \\
12,819\end{array}$ & $\begin{array}{r}12,225 \\
8,417 \\
6,953\end{array}$ & $\begin{array}{l}6,897 \\
6,151 \\
4,555\end{array}$ & $\begin{array}{l}2,619 \\
2,323 \\
1,310\end{array}$ & $\begin{array}{r}625 \\
1,118 \\
599 \\
\end{array}$ & $\begin{array}{l}176 \\
288 \\
153\end{array}$ & $\begin{array}{l}309 \\
378 \\
285\end{array}$ & $\begin{array}{l}140 \\
452 \\
161\end{array}$ \\
\hline Total & 51,453 & 27,595 & 17,603 & 6,254 & 2,344 & 618 & 972 & 753 \\
\hline $\begin{array}{l}\text { West Gulf: } \\
\text { ArkansaS. } \\
\text { Louisiana } \\
\text { Oklahoma... } \\
\text { Texas }\end{array}$ & $\begin{array}{r}18,206 \\
15,342 \\
4,817 \\
12,924 \\
\end{array}$ & $\begin{array}{l}8,760 \\
6,329 \\
3,901 \\
6,320\end{array}$ & $\begin{array}{r}6,577 \\
5,769 \\
755 \\
4,329 \\
\end{array}$ & $\begin{array}{r}2,868 \\
3,243 \\
160 \\
2,274\end{array}$ & $\begin{array}{r}2,378 \\
551 \\
233 \\
625\end{array}$ & $\begin{array}{r}815 \\
136 \\
144 \\
55\end{array}$ & $\begin{array}{r}1,195 \\
208 \\
75 \\
182\end{array}$ & $\begin{array}{r}367 \\
206 \\
14 \\
387\end{array}$ \\
\hline Total & 51,290 & 25,311 & 17,432 & 8,546 & 3,788 & 1,151 & 1,661 & 974 \\
\hline Total, South & 192,542 & 102,672 & 62,243 & 27,625 & 10,764 & 3,377 & 4,612 & 2,773 \\
\hline $\begin{array}{l}\text { Pacific Northwest: } \\
\text { Alaska: Coastal ... }\end{array}$ & 5,639 & 482 & 216 & 4,941 & 5,144 & 446 & 198 & 4,500 \\
\hline $\begin{array}{l}\text { Oregon: } \\
\quad \text { Western } \\
\text { Eastern }\end{array}$ & $\begin{array}{l}14,635 \\
11,038\end{array}$ & $\begin{array}{l}3,398 \\
2,148\end{array}$ & $\begin{array}{l}1,865 \\
2,749\end{array}$ & $\begin{array}{l}9,372 \\
6,141\end{array}$ & $\begin{array}{l}4,830 \\
7,173\end{array}$ & $\begin{array}{r}610 \\
1,241\end{array}$ & $\begin{array}{r}316 \\
1,480 \\
\end{array}$ & $\begin{array}{l}3,904 \\
4,452\end{array}$ \\
\hline Summary & 25,673 & 5,546 & 4,614 & 15,513 & 12,003 & 1,851 & 1,796 & $\stackrel{8,356}{=}$ \\
\hline $\begin{array}{l}\text { Washington: } \\
\text { Western } \\
\text { Eastern }\end{array}$ & $\begin{array}{l}9,991 \\
8,410\end{array}$ & $\begin{array}{l}2,351 \\
1,553\end{array}$ & $\begin{array}{l}1,155 \\
2,279\end{array}$ & $\begin{array}{l}6,485 \\
4,578\end{array}$ & $\begin{array}{l}2,321 \\
3,103\end{array}$ & $\begin{array}{l}424 \\
467\end{array}$ & $\begin{array}{l}120 \\
625\end{array}$ & $\begin{array}{l}1,777 \\
2,011\end{array}$ \\
\hline Summary. - & 18,401 & 3,904 & 3,434 & 11,063 & 5,424 & 891 & 745 & $==$ \\
\hline Total & 49,713 & 9,932 & 8,264 & 31,517 & 22,571 & 3,188 & 2,739 & 16,644 \\
\hline
\end{tabular}

See footnotes at end of table. 
TABLE 4.-Area of commercial timberland in the U'nited States, by ownership and stand-volume class, section, region, and State, January $1,1970^{1}$ - Continued

[Thousand acres]

\begin{tabular}{|c|c|c|c|c|c|c|c|c|}
\hline \multirow{2}{*}{ Section, region, and State } & \multicolumn{4}{|c|}{ Total, All Ownerships } & \multicolumn{4}{|c|}{ National Forest } \\
\hline & Total & $\begin{array}{l}\text { Less than } \\
1,500 \text { bd. ft. }\end{array}$ & $\begin{array}{l}1,500 \text { to } 5,000 \\
\text { bd. ft. }\end{array}$ & $\begin{array}{l}\text { More than } \\
5,000 \text { bd. ft. }\end{array}$ & Total & $\begin{array}{l}\text { Less than } \\
1,500 \text { bd. ft. }\end{array}$ & $\begin{array}{l}1,500 \text { to } 5,000 \\
\text { bd. ft. }\end{array}$ & $\begin{array}{l}\text { More than } \\
5,000 \text { bd. } \mathrm{ft} \text {. }\end{array}$ \\
\hline $\begin{array}{l}\text { Pacific Southwest: } \\
\text { California } \\
\text { Hawaii. }\end{array}$ & $\begin{array}{r}16,825 \\
1,081 \\
\end{array}$ & $\begin{array}{r}1,602 \\
757\end{array}$ & $\begin{array}{r}2,111 \\
107\end{array}$ & $\begin{array}{r}13,115 \\
216\end{array}$ & $\begin{array}{r}8,344 \\
0 \\
\end{array}$ & $\begin{array}{r}583 \\
0 \\
\end{array}$ & $\begin{array}{r}470 \\
0\end{array}$ & $\begin{array}{r}7,291 \\
0\end{array}$ \\
\hline Total ...... & 17,909 & 2,359 & 2,218 & 13,331 & 8,344 & 583 & 470 & 7,291 \\
\hline Total, Pacific Coast & $6 \overline{7}, 622$ & 12,291 & 10,482 & 44,848 & 30,915 & 3,771 & 3,209 & 23,935 \\
\hline $\begin{array}{l}\text { Northern Rocky Mountain: } \\
\text { Idaho }{ }^{2} \\
\text { Montana } 2 \\
\text { South Dakota (West) } \\
\text { W yoming }{ }^{2}\end{array}$ & $\begin{array}{r}15,192 \\
15,963 \\
1,310 \\
4,182 \\
\end{array}$ & $\begin{array}{r}2,592 \\
3,750 \\
514 \\
934\end{array}$ & $\begin{array}{r}2,462 \\
4,767 \\
651 \\
1,431\end{array}$ & $\begin{array}{r}9,141 \\
7,332 \\
58 \\
889 \\
\end{array}$ & $\begin{array}{r}10,731 \\
9,732 \\
957 \\
2,699\end{array}$ & $\begin{array}{r}1,631 \\
2,410 \\
330 \\
451\end{array}$ & $\begin{array}{r}1,652 \\
2,410 \\
512 \\
465 \\
\end{array}$ & $\begin{array}{r}6,452 \\
4,778 \\
58 \\
855 \\
\end{array}$ \\
\hline Total............. & 36,668 & 7,821 & 9,313 & 17,422 & 24,120 & 4,823 & 5,040 & 12,144 \\
\hline $\begin{array}{l}\text { Southern Rocky Mountain: } \\
\text { Arizona }{ }^{2} \\
\text { Colorado } \\
\text { Nevada } 2 \\
\text { New Jiexico } \\
\text { Ttah } 2\end{array}$ & $\begin{array}{r}3,689 \\
11,583 \\
128 \\
5,736 \\
3,824\end{array}$ & $\begin{array}{r}467 \\
3,897 \\
14 \\
1,042 \\
1,053\end{array}$ & $\begin{array}{l}1,133 \\
1,537 \\
25 \\
3,262 \\
957\end{array}$ & $\begin{array}{r}2,035 \\
3,605 \\
88 \\
1,300 \\
1,608\end{array}$ & $\begin{array}{r}2,347 \\
7,710 \\
55 \\
2,939 \\
2,613\end{array}$ & $\begin{array}{r}409 \\
1,864 \\
7 \\
644 \\
611\end{array}$ & $\begin{array}{r}831 \\
1,076 \\
12 \\
1,202 \\
726\end{array}$ & $\begin{array}{r}1,054 \\
2,225 \\
34 \\
960 \\
1,069\end{array}$ \\
\hline Total.................. & 24,963 & 6,475 & 6,915 & 8,637 & 15,666 & 3,538 & 3,849 & 5,344 \\
\hline Total, Rocky Mountain ... & 61,631 & 14,296 & 16,228 & 26,059 & 39,787 & 8,361 & 8,889 & 17,488 \\
\hline Total, all regions.. & 499,697 & 243,170 & 138,042 & 113,437 & 91,924 & 22,321 & 19,425 & 45,130 \\
\hline
\end{tabular}

\begin{tabular}{|c|c|c|c|c|c|c|c|c|c|c|c|c|}
\hline \multirow{2}{*}{ Section, region, and State } & \multicolumn{4}{|c|}{ Other public } & \multicolumn{4}{|c|}{ Forest industry } & \multicolumn{4}{|c|}{ Farm and miscellaneous private } \\
\hline & Total & $\begin{array}{l}\text { Less } \\
\text { than } \\
1,500 \\
\text { bd. ft. }\end{array}$ & $\begin{array}{l}1,500 \text { to } \\
5,000 \\
\text { bd. ft. }\end{array}$ & $\begin{array}{l}\text { More } \\
\text { than } \\
5,000 \\
\text { bd. ft. }\end{array}$ & Total & $\begin{array}{l}\text { Less } \\
\text { than } \\
1,500 \\
\text { bd. ft. }\end{array}$ & $\begin{array}{l}1,500 \text { to } \\
5,000 \\
\text { bd. } \mathrm{ft} \text {. }\end{array}$ & $\begin{array}{l}\text { More } \\
\text { than } \\
5,000 \\
\text { bd. ft. }\end{array}$ & Total & $\begin{array}{l}\text { Less } \\
\text { than } \\
1,500 \\
\text { bd. ft. }\end{array}$ & $\begin{array}{l}1,500 \text { to } \\
5,000 \\
\text { bd. ft. }\end{array}$ & $\begin{array}{l}\text { More } \\
\text { than } \\
5,000 \\
\text { bd. ft. }\end{array}$ \\
\hline 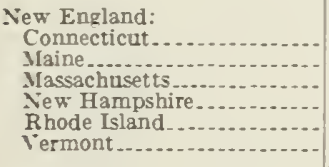 & $\begin{array}{r}155 \\
274 \\
399 \\
127 \\
26 \\
179 \\
\end{array}$ & $\begin{array}{r}128 \\
165 \\
365 \\
82 \\
21 \\
110 \\
\end{array}$ & $\begin{array}{r}24 \\
97 \\
30 \\
36 \\
5 \\
59\end{array}$ & $\begin{array}{r}3 \\
11 \\
4 \\
9 \\
0 \\
8\end{array}$ & $\begin{array}{r}3 \\
8,255 \\
259 \\
793 \\
0 \\
678 \\
\end{array}$ & $\begin{array}{r}1 \\
2,779 \\
119 \\
510 \\
0 \\
300\end{array}$ & $\begin{array}{r}2 \\
4,375 \\
125 \\
225 \\
0 \\
327\end{array}$ & $\begin{array}{r}0 \\
1,100 \\
15 \\
56 \\
0 \\
50\end{array}$ & $\begin{array}{l}2,011 \\
8,327 \\
2,833 \\
3,531 \\
403 \\
3,280\end{array}$ & $\begin{array}{l}1,673 \\
4,631 \\
2,592 \\
2,273 \\
394 \\
1,956\end{array}$ & $\begin{array}{r}293 \\
2,956 \\
216 \\
1,005 \\
9 \\
1,151\end{array}$ & $\begin{array}{r}41 \\
740 \\
24 \\
251 \\
0 \\
172\end{array}$ \\
\hline Total. - & 1,160 & 871 & 252 & 35 & 9,988 & 3,710 & 5,055 & 1,222 & 20,386 & 13,520 & 5,632 & 1,232 \\
\hline 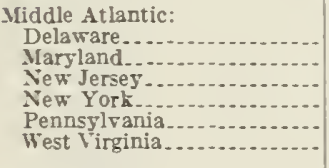 & $\begin{array}{r}9 \\
189 \\
254 \\
892 \\
2,918 \\
167\end{array}$ & $\begin{array}{r}7 \\
109 \\
235 \\
511 \\
1,913 \\
82\end{array}$ & $\begin{array}{r}1 \\
53 \\
14 \\
343 \\
799 \\
62\end{array}$ & $\begin{array}{r}1 \\
26 \\
5 \\
36 \\
176 \\
23\end{array}$ & $\begin{array}{r}29 \\
100 \\
4 \\
1,180 \\
610 \\
530\end{array}$ & $\begin{array}{r}8 \\
82 \\
3 \\
525 \\
426 \\
198\end{array}$ & $\begin{array}{r}11 \\
9 \\
1 \\
606 \\
150 \\
234\end{array}$ & $\begin{array}{r}10 \\
9 \\
0 \\
48 \\
34 \\
98\end{array}$ & $\begin{array}{r}351 \\
2,591 \\
2,096 \\
12,416 \\
13,462 \\
10,515\end{array}$ & $\begin{array}{r}164 \\
1,212 \\
1,516 \\
7,848 \\
8,701 \\
4,745\end{array}$ & $\begin{array}{r}95 \\
962 \\
423 \\
4,014 \\
3,919 \\
4,134 \\
\end{array}$ & $\begin{array}{r}91 \\
417 \\
156 \\
553 \\
841 \\
1,636\end{array}$ \\
\hline Total .......... & 4,429 & 2,888 & 1,272 & 268 & $2,45 t$ & 1,242 & 1,011 & 200 & 41,433 & 24,188 & 13,548 & 3,696 \\
\hline 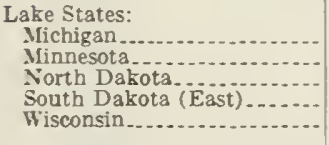 & $\begin{array}{r}4,018 \\
7,261 \\
124 \\
77 \\
3,207 \\
\end{array}$ & $\begin{array}{r}2,539 \\
6,214 \\
104 \\
50 \\
2,763\end{array}$ & $\begin{array}{r}1,048 \\
660 \\
11 \\
23 \\
256\end{array}$ & $\begin{array}{r}430 \\
355 \\
8 \\
3 \\
188\end{array}$ & $\begin{array}{r}2,256 \\
814 \\
0 \\
0 \\
1,368 \\
\end{array}$ & $\begin{array}{r}1,232 \\
700 \\
0 \\
0 \\
1,178\end{array}$ & $\begin{array}{r}696 \\
74 \\
0 \\
0 \\
109\end{array}$ & $\begin{array}{r}32 \pi \\
39 \\
0 \\
0 \\
80\end{array}$ & $\begin{array}{r}10,102 \\
6,672 \\
281 \\
145 \\
8,643\end{array}$ & $\begin{array}{r}6,354 \\
5,738 \\
236 \\
98 \\
7,445 \\
\end{array}$ & $\begin{array}{r}2,646 \\
607 \\
25 \\
40 \\
691\end{array}$ & $\begin{array}{r}1,101 \\
327 \\
19 \\
6 \\
506\end{array}$ \\
\hline Total & 14,688 & 11,701 & 2,000 & 986 & 4,438 & 3,111 & 879 & 448 & 25,845 & 19,873 & 4,011 & 1,961 \\
\hline $\begin{array}{l}\text { Central: } \\
\text { Illinois } \\
\text { Indiana } \\
\text { Iowa } \\
\text { Kansas. } \\
\text { Kentucky } \\
\text { Mlissouri. } \\
\text { Nebraska. } \\
\text { Ohio }\end{array}$ & $\begin{array}{r}52 \\
224 \\
34 \\
36 \\
289 \\
264 \\
37 \\
235\end{array}$ & $\begin{array}{r}25 \\
94 \\
21 \\
23 \\
106 \\
220 \\
36 \\
72\end{array}$ & $\begin{array}{r}20 \\
84 \\
8 \\
11 \\
140 \\
42 \\
1 \\
64\end{array}$ & $\begin{array}{r}6 \\
44 \\
4 \\
2 \\
42 \\
4 \\
2 \\
0 \\
98\end{array}$ & $\begin{array}{r}16 \\
21 \\
9 \\
0 \\
227 \\
279 \\
0 \\
126\end{array}$ & $\begin{array}{r}8 \\
8 \\
5 \\
0 \\
73 \\
232 \\
0 \\
34\end{array}$ & $\begin{array}{r}6 \\
8 \\
2 \\
0 \\
118 \\
44 \\
0 \\
55\end{array}$ & $\begin{array}{r}2 \\
4 \\
1 \\
0 \\
36 \\
2 \\
0 \\
37\end{array}$ & $\begin{array}{r}3,396 \\
3,457 \\
2,386 \\
1,150 \\
10,777 \\
12,734 \\
928 \\
5,930\end{array}$ & $\begin{array}{r}1,670 \\
1,508 \\
1,461 \\
732 \\
5,450 \\
10,675 \\
560 \\
2,967\end{array}$ & $\begin{array}{r}1,310 \\
1,237 \\
587 \\
357 \\
4,140 \\
1,954 \\
314 \\
2,194\end{array}$ & $\begin{array}{r}414 \\
711 \\
337 \\
60 \\
1,156 \\
104 \\
53 \\
768\end{array}$ \\
\hline Total ............... & 1,175 & 600 & 373 & 200 & 681 & 362 & 235 & 83 & 40,761 & 25,027 & 12,098 & 3,635 \\
\hline Total, North & 21,453 & 16,062 & 3,900 & 1,491 & 17,563 & 8,427 & 7,182 & 1,953 & 128,426 & 82,610 & 35,291 & 10,525 \\
\hline $\begin{array}{l}\text { South Atlantic: } \\
\text { North Carolina } \\
\text { South Carolina. } \\
\text { Virginia }\end{array}$ & $\begin{array}{l}687 \\
522 \\
469 \\
\end{array}$ & $\begin{array}{l}392 \\
262 \\
164\end{array}$ & $\begin{array}{l}183 \\
151 \\
212\end{array}$ & $\begin{array}{r}111 \\
108 \\
92\end{array}$ & $\begin{array}{l}2,785 \\
2,047 \\
1,634 \\
\end{array}$ & $\begin{array}{r}1,511 \\
927 \\
812 \\
\end{array}$ & $\begin{array}{l}769 \\
573 \\
518\end{array}$ & $\begin{array}{l}504 \\
546 \\
303\end{array}$ & $\begin{array}{r}15,644 \\
9,290 \\
12,553\end{array}$ & $\begin{array}{l}7,701 \\
4,786 \\
6,343\end{array}$ & $\begin{array}{l}5,432 \\
2,931 \\
4,540\end{array}$ & $\begin{array}{l}2,550 \\
1,5,2 \\
1,669\end{array}$ \\
\hline Total $\ldots$ & 1,678 & 819 & 547 & 311 & 6,467 & 3,251 & 1,861 & 1,354 & $3 \pi, 52 \pi$ & 18,831 & 12,904 & 5,792 \\
\hline
\end{tabular}



TABLE 4.-Area of commercial timberland in the United States, by ownership and stand-volume class, section, region, and State,
January 1, 1970 1-Continued

['Thousand acres]

\begin{tabular}{|c|c|c|c|c|c|c|c|c|c|c|c|c|}
\hline \multirow{2}{*}{ Section, region, and State } & \multicolumn{4}{|c|}{ Other public } & \multicolumn{4}{|c|}{ Forest industry } & \multicolumn{4}{|c|}{ Farm and miscellaneous private } \\
\hline & Total & $\begin{array}{l}\text { Less } \\
\text { than } \\
1,500 \\
\text { bd. ft. }\end{array}$ & $\begin{array}{l}1,500 \text { to } \\
5,000 \\
\text { bd. ft. }\end{array}$ & $\begin{array}{l}\text { More } \\
\text { than } \\
5,000 \\
\text { bd. ft. }\end{array}$ & Total & $\begin{array}{l}\text { Less } \\
\text { than } \\
1,500 \\
\text { bd. ft. }\end{array}$ & $\begin{array}{l}1,500 \text { to } \\
5,000 \\
\text { bd. ft. }\end{array}$ & $\begin{array}{l}\text { More } \\
\text { than } \\
5,000 \\
\text { bd. ft. }\end{array}$ & Total & $\begin{array}{l}\text { Less } \\
\text { than } \\
1,500 \\
\text { bd. ft. }\end{array}$ & $\begin{array}{l}1,500 \text { to } \\
5,000 \\
\text { bd. ft. }\end{array}$ & $\begin{array}{l}\text { More } \\
\text { than } \\
5,000 \\
\text { bd. ft. }\end{array}$ \\
\hline $\begin{array}{l}\text { East Gulf: } \\
\text { Florida.- } \\
\text { Gcorgia }\end{array}$ & $\begin{array}{r}1,110 \\
600 \\
\end{array}$ & $\begin{array}{l}706 \\
337\end{array}$ & $\begin{array}{l}236 \\
162 \\
\end{array}$ & $\begin{array}{l}117 \\
101 \\
\end{array}$ & $\begin{array}{l}5,216 \\
4,700 \\
\end{array}$ & $\begin{array}{l}3,158 \\
2,825 \\
\end{array}$ & $\begin{array}{l}1,374 \\
1,256 \\
\end{array}$ & $\begin{array}{l}683 \\
618 \\
\end{array}$ & $\begin{array}{r}8,869 \\
18,995 \\
\end{array}$ & $\begin{array}{r}5,715 \\
12,512 \\
\end{array}$ & $\begin{array}{l}2,230 \\
4,605 \\
\end{array}$ & $\begin{array}{r}923 \\
1,877 \\
\end{array}$ \\
\hline Total $\ldots$ & 1,710 & 1,043 & 448 & 218 & 9,916 & 5,984 & 2,630 & 1,301 & 27,865 & 18,227 & 6,836 & 2,801 \\
\hline $\begin{array}{l}\text { Central Gulf: } \\
\text { Alabama } \\
\text { Mississippi } \\
\text { Tennessee }\end{array}$ & $\begin{array}{l}371 \\
651 \\
686\end{array}$ & $\begin{array}{l}178 \\
206 \\
272\end{array}$ & $\begin{array}{l}130 \\
299 \\
265 \\
\end{array}$ & $\begin{array}{r}61 \\
145 \\
148 \\
\end{array}$ & $\begin{array}{l}3,818 \\
2,505 \\
1,121 \\
\end{array}$ & $\begin{array}{r}1,815 \\
1,055 \\
617 \\
\end{array}$ & $\begin{array}{r}1,255 \\
916 \\
380 \\
\end{array}$ & $\begin{array}{l}747 \\
533 \\
123 \\
\end{array}$ & $\begin{array}{l}16,926 \\
12,616 \\
10,412 \\
\end{array}$ & $\begin{array}{r}10,055 \\
6,866 \\
5,910 \\
\end{array}$ & $\begin{array}{l}5,201 \\
4,556 \\
3,624 \\
\end{array}$ & $\begin{array}{r}1,669 \\
1,193 \\
877 \\
\end{array}$ \\
\hline Total _.. & 1,709 & 658 & 695 & 355 & 7,444 & 3,487 & 2,553 & 1,403 & 39,955 & 22,832 & 13,382 & 3,741 \\
\hline $\begin{array}{l}\text { West Gulf: } \\
\text { Arkansas- } \\
\text { Louisiana } \\
\text { Oklahoma- } \\
\text { Texas. }\end{array}$ & $\begin{array}{l}560 \\
308 \\
343 \\
203 \\
\end{array}$ & $\begin{array}{r}234 \\
133 \\
295 \\
85 \\
\end{array}$ & $\begin{array}{r}193 \\
127 \\
32 \\
86 \\
\end{array}$ & $\begin{array}{r}132 \\
48 \\
15 \\
31 \\
\end{array}$ & $\begin{array}{r}3,950 \\
3,180 \\
868 \\
3,496 \\
\end{array}$ & $\begin{array}{l}959 \\
893 \\
427 \\
834 \\
\end{array}$ & $\begin{array}{r}1,657 \\
1,091 \\
350 \\
1,481 \\
\end{array}$ & $\begin{array}{r}1,334 \\
1,195 \\
90 \\
1,177 \\
\end{array}$ & $\begin{array}{r}11,317 \\
11,301 \\
3,371 \\
8,599 \\
\end{array}$ & $\begin{array}{l}6,751 \\
5,166 \\
3,032 \\
5,345 \\
\end{array}$ & $\begin{array}{r}3,531 \\
4,341 \\
297 \\
2,576 \\
\end{array}$ & $\begin{array}{r}1,034 \\
1,793 \\
40 \\
677 \\
\end{array}$ \\
\hline Total $\ldots$ & 1,415 & 748 & 439 & 228 & 11,496 & 3,115 & 4,583 & 3,798 & 34,589 & 20,296 & 10,747 & 3,545 \\
\hline Total, South & 6,514 & 3,269 & 2,131 & 1,113 & 35,325 & 15,838 & 11,629 & 7,857 & 139,938 & 80,186 & 43,870 & $15, \overline{880}$ \\
\hline $\begin{array}{l}\text { Pacific Northwest: } \\
\text { Alaska: Coastal... }\end{array}$ & 465 & 33 & 17 & 415 & 0 & 0 & 0 & 0 & 30 & 3 & 1 & 26 \\
\hline $\begin{array}{l}\text { Oregon: } \\
\quad \text { Western.....-.-- } \\
\text { Eastern.-.-.--.- }\end{array}$ & $\begin{array}{r}2,922 \\
594\end{array}$ & $\begin{array}{r}756 \\
73\end{array}$ & $\begin{array}{l}431 \\
126\end{array}$ & $\begin{array}{r}1,735 \\
395 \\
\end{array}$ & $\begin{array}{l}3,624 \\
1,582 \\
\end{array}$ & $\begin{array}{r}1,065 \\
252 \\
\end{array}$ & $\begin{array}{l}586 \\
539 \\
\end{array}$ & 1,973 & $\begin{array}{l}3,259 \\
1,689 \\
\end{array}$ & $\begin{array}{l}967 \\
582 \\
\end{array}$ & $\begin{array}{l}532 \\
604 \\
\end{array}$ & $\begin{array}{r}1,760 \\
503 \\
\end{array}$ \\
\hline Summary & 3,516 & 829 & 557 & 2,130 & 5,206 & 1,317 & 1,125 & 2,764 & 4,948 & 1,549 & 1,136 & 2,263 \\
\hline $\begin{array}{l}\text { Washington: } \\
\text { Western } \\
\text { Eastern }\end{array}$ & $\begin{array}{l}1,802 \\
2,292 \\
\end{array}$ & $\begin{array}{l}401 \\
246\end{array}$ & $\begin{array}{l}195 \\
597 \\
\end{array}$ & $\begin{array}{l}1,206 \\
1,449 \\
\end{array}$ & $\begin{array}{r}3,598 \\
750\end{array}$ & $\begin{array}{r}971 \\
93 \\
\end{array}$ & $\begin{array}{l}496 \\
233 \\
\end{array}$ & $\begin{array}{r}2,131 \\
424 \\
\end{array}$ & $\begin{array}{l}2,270 \\
2,265 \\
\end{array}$ & $\begin{array}{l}555 \\
747 \\
\end{array}$ & $\begin{array}{l}344 \\
824\end{array}$ & $\begin{array}{r}1,371 \\
694 \\
\end{array}$ \\
\hline Summary ......- & 4,094 & 647 & 792 & 2,655 & 4,348 & 1,064 & 729 & 2,555 & 4,535 & 1,302 & 1,168 & 2,065 \\
\hline Total & 8,075 & 1,509 & 1,366 & 5,200 & 9,554 & 2,381 & 1,854 & 5,319 & 9,513 & 2,854 & 2,305 & 4,354 \\
\hline $\begin{array}{l}\text { Pacific Southwest: } \\
\text { California } \\
\text { Hawaii }\end{array}$ & $\begin{array}{l}476 \\
495 \\
\end{array}$ & $\begin{array}{r}41 \\
347 \\
\end{array}$ & $\begin{array}{l}73 \\
49 \\
\end{array}$ & $\begin{array}{r}362 \\
99 \\
\end{array}$ & $\begin{array}{r}2,665 \\
0 \\
\end{array}$ & $\begin{array}{r}291 \\
0 \\
\end{array}$ & $\begin{array}{r}494 \\
0 \\
\end{array}$ & $\begin{array}{r}1,880 \\
0 \\
\end{array}$ & $\begin{array}{r}5,343 \\
585 \\
\end{array}$ & $\begin{array}{l}687 \\
410 \\
\end{array}$ & $\begin{array}{r}1,074 \\
58\end{array}$ & $\begin{array}{r}3,582 \\
117 \\
\end{array}$ \\
\hline Total & 971 & 388 & 122 & 461 & 2,665 & 291 & 494 & 1,880 & 5,928 & 1,097 & 1,132 & 3,699 \\
\hline Total, Pacific Coast . ... & 9,046 & 1,897 & 1,488 & 5,661 & 12,219 & 2,672 & 2,348 & 7,199 & 15,441 & 3,951 & 3,437 & 8,053 \\
\hline $\begin{array}{l}\text { Northern Rocky Mountain: } \\
\text { Idaho }{ }^{2} \\
\text { Montana }{ }^{2} \\
\text { South Dakota (West) }{ }^{2} \\
\text { Wyoming }{ }^{2}- \\
\text { yound }\end{array}$ & $\begin{array}{r}1,410 \\
1,685 \\
71 \\
628 \\
\end{array}$ & $\begin{array}{r}249 \\
365 \\
32 \\
215 \\
\end{array}$ & $\begin{array}{r}269 \\
669 \\
39 \\
407 \\
\end{array}$ & $\begin{array}{r}920 \\
651 \\
0 \\
5\end{array}$ & $\begin{array}{r}946 \\
1,055 \\
17 \\
54 \\
\end{array}$ & $\begin{array}{r}113 \\
92 \\
10 \\
15 \\
\end{array}$ & $\begin{array}{r}124 \\
296 \\
6 \\
31 \\
\end{array}$ & $\begin{array}{r}708 \\
666 \\
0 \\
7 \\
\end{array}$ & $\begin{array}{r}2,074 \\
3,510 \\
263 \\
800 \\
\end{array}$ & $\begin{array}{l}598 \\
881 \\
171 \\
252 \\
\end{array}$ & $\begin{array}{r}416 \\
1,392 \\
92 \\
527 \\
\end{array}$ & $\begin{array}{r}1,060 \\
1,235 \\
0 \\
20 \\
\end{array}$ \\
\hline Total & 3,825 & 862 & 1,385 & 1,577 & 2,073 & 232 & 457 & 1,383 & 6,648 & 1,903 & 2,429 & 2,316 \\
\hline $\begin{array}{l}\text { Southern Rocky Mountain: } \\
\text { Arizona }{ }^{2} \\
\text { Colorado }{ }^{2}- \\
\text { Nevada }{ }^{2}- \\
\text { New Mexico }{ }^{2}- \\
\text { Utah }^{2}\end{array}$ & $\begin{array}{r}1,175 \\
754 \\
4 \\
870 \\
550 \\
\end{array}$ & $\begin{array}{r}11 \\
296 \\
0 \\
133 \\
172 \\
\end{array}$ & $\begin{array}{r}182 \\
96 \\
0 \\
509 \\
83\end{array}$ & $\begin{array}{r}981 \\
361 \\
3 \\
226 \\
294 \\
\end{array}$ & $\begin{array}{r}0 \\
14 \\
8 \\
137 \\
0 \\
\end{array}$ & $\begin{array}{r}0 \\
8 \\
1 \\
17 \\
0 \\
\end{array}$ & $\begin{array}{r}0 \\
2 \\
1 \\
113 \\
0 \\
\end{array}$ & $\begin{array}{l}0 \\
3 \\
5 \\
5 \\
0 \\
\end{array}$ & $\begin{array}{r}166 \\
3,103 \\
60 \\
1,790 \\
660 \\
\end{array}$ & $\begin{array}{r}46 \\
1,728 \\
4 \\
246 \\
269 \\
\end{array}$ & $\begin{array}{r}119 \\
361 \\
10 \\
1,436 \\
148 \\
\end{array}$ & $\begin{array}{r}0 \\
1,013 \\
45 \\
107 \\
243 \\
\end{array}$ \\
\hline Total & 3,355 & 613 & 872 & 1,868 & 160 & 27 & 117 & 14 & 5,781 & 2,295 & 2,075 & $1, \overline{409}$ \\
\hline Total, Rocky Mountain_ & 7,181 & 1,476 & 2,258 & 3,446 & 2,233 & 259 & 575 & 1,398 & 12,429 & 4,198 & 4,504 & 3,726 \\
\hline Total, all regions......... & 44,196 & 22,705 & 9,778 & 11,712 & 67,341 & 27,197 & 21,735 & 18,408 & 296,235 & 170,947 & 87,103 & 38,185 \\
\hline
\end{tabular}

\footnotetext{
1. Data may not add to totals because of truncating. Zeros indicate no data $\quad{ }^{2}$ Sec footnote 2 , table 3.
or negligible amounts.
} 
T.BLE 5.-Area of commercial timberland in the United States, by ownership and site class, section, region, and State, January 1 , $1970^{1}$

[Thousand acres]

\begin{tabular}{|c|c|c|c|c|c|c|c|c|c|c|c|c|}
\hline \multirow{2}{*}{ Section, region, and State } & \multicolumn{6}{|c|}{ Total, all ownerships } & \multicolumn{6}{|c|}{ National Forest } \\
\hline & Total & $\begin{array}{l}165 \text { cu. ft. } \\
\text { or more }\end{array}$ & $\begin{array}{l}120 \text { to } 16 \overline{5} \\
\text { cu. ft. }\end{array}$ & $\begin{array}{l}85 \text { to } 120 \\
\text { cu. ft. }\end{array}$ & $\begin{array}{l}50 \text { to } 85 \\
\text { cu. ft. }\end{array}$ & $\begin{array}{l}\text { Less than } \\
50 \mathrm{cu} . \mathrm{ft} .\end{array}$ & Total & $\begin{array}{l}165 \mathrm{cu} \text {. ft. } \\
\text { or more }\end{array}$ & $\begin{array}{l}120 \text { to } 165 \\
\text { cu. ft. }\end{array}$ & $\begin{array}{l}85 \text { to } 120 \\
\text { cu. ft. }\end{array}$ & $\begin{array}{l}50 \text { to } 85 \\
\text { cu. ft. }\end{array}$ & $\begin{array}{l}\text { Less than } \\
50 \mathrm{cu} \text {. } \mathrm{ft} \text {. }\end{array}$ \\
\hline 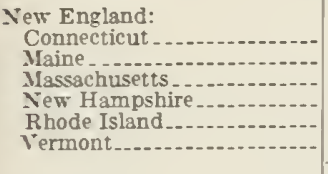 & $\begin{array}{r}2,169 \\
16,894 \\
3,491 \\
5,020 \\
429 \\
4,364 \\
\end{array}$ & $\begin{array}{l}0 \\
0 \\
0 \\
0 \\
0 \\
0\end{array}$ & $\begin{array}{r}412 \\
2,386 \\
664 \\
949 \\
81 \\
825\end{array}$ & $\begin{array}{r}409 \\
5,165 \\
659 \\
948 \\
81 \\
824 \\
\end{array}$ & $\begin{array}{r}776 \\
5,854 \\
1,250 \\
1,799 \\
153 \\
1,564 \\
\end{array}$ & $\begin{array}{r}571 \\
3,487 \\
917 \\
1,324 \\
113 \\
1,151 \\
\end{array}$ & $\begin{array}{r}0 \\
37 \\
0 \\
568 \\
0 \\
226\end{array}$ & $\begin{array}{l}0 \\
0 \\
0 \\
0 \\
0 \\
0\end{array}$ & $\begin{array}{r}0 \\
4 \\
0 \\
41 \\
0 \\
16\end{array}$ & $\begin{array}{r}0 \\
7 \\
0 \\
97 \\
0 \\
38\end{array}$ & $\begin{array}{r}0 \\
13 \\
0 \\
226 \\
0 \\
90\end{array}$ & $\begin{array}{r}0 \\
11 \\
0 \\
203 \\
0 \\
81\end{array}$ \\
\hline Total... & $32,36 i$ & 0 & 5,317 & 8,087 & 11,398 & 7,564 & 832 & 0 & 62 & 142 & 330 & 296 \\
\hline 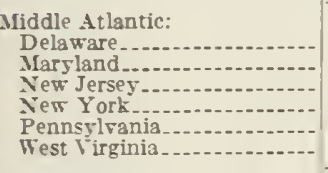 & $\begin{array}{r}390 \\
2,882 \\
2,354 \\
14,489 \\
17,478 \\
12,092\end{array}$ & $\begin{array}{l}0 \\
0 \\
0 \\
0 \\
0 \\
0\end{array}$ & $\begin{array}{r}16 \\
119 \\
96 \\
892 \\
723 \\
500\end{array}$ & $\begin{array}{r}188 \\
1,391 \\
1,145 \\
1,864 \\
8,439 \\
5,838\end{array}$ & $\begin{array}{r}157 \\
1,164 \\
943 \\
5,632 \\
7,060 \\
4,885\end{array}$ & $\begin{array}{r}28 \\
207 \\
169 \\
6,099 \\
1,256 \\
869\end{array}$ & $\begin{array}{r}0 \\
0 \\
0 \\
0 \\
488 \\
879 \\
\end{array}$ & $\begin{array}{l}0 \\
0 \\
0 \\
0 \\
0 \\
0 \\
\end{array}$ & $\begin{array}{r}0 \\
0 \\
0 \\
0 \\
35 \\
65 \\
\end{array}$ & $\begin{array}{r}0 \\
0 \\
0 \\
0 \\
115 \\
207 \\
\end{array}$ & $\begin{array}{r}0 \\
0 \\
0 \\
0 \\
306 \\
551\end{array}$ & $\begin{array}{r}0 \\
0 \\
0 \\
0 \\
30 \\
54\end{array}$ \\
\hline Total... & 49,865 & 0 & 2,347 & 18,866 & 19,842 & 8,628 & 1,367 & 0 & 100 & 322 & 858 & 85 \\
\hline 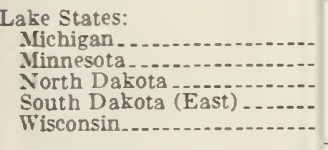 & $\begin{array}{r}18,800 \\
16,875 \\
406 \\
223 \\
14,536 \\
\end{array}$ & $\begin{array}{r}34 \\
0 \\
0 \\
0 \\
0 \\
15\end{array}$ & $\begin{array}{r}216 \\
4 \\
0 \\
0 \\
168\end{array}$ & $\begin{array}{r}1,453 \\
906 \\
0 \\
0 \\
1,489 \\
\end{array}$ & $\begin{array}{r}6,962 \\
7,670 \\
81 \\
26 \\
5,189\end{array}$ & $\begin{array}{r}10,133 \\
8,294 \\
324 \\
196 \\
7,674 \\
\end{array}$ & $\begin{array}{r}2,422 \\
2,127 \\
0 \\
0 \\
1,317 \\
\end{array}$ & $\begin{array}{l}0 \\
0 \\
0 \\
0 \\
1 \\
\end{array}$ & $\begin{array}{r}0 \\
0 \\
0 \\
0 \\
17\end{array}$ & $\begin{array}{r}1 \\
16 \\
0 \\
0 \\
206\end{array}$ & $\begin{array}{r}2,128 \\
1,564 \\
0 \\
0 \\
733\end{array}$ & $\begin{array}{r}292 \\
545 \\
0 \\
0 \\
358 \\
\end{array}$ \\
\hline Total_..- & 50,840 & 50 & 389 & 3,848 & 19,929 & 26,622 & 5,867 & 1 & 17 & 224 & 4,426 & 1,197 \\
\hline $\begin{array}{l}\text { Central: } \\
\text { Illinois } \\
\text { Indiana } \\
\text { Iowa } \\
\text { Kansas } \\
\text { Kentucky } \\
\text { Missouri } \\
\text { Mebraska } \\
\text { Nebro } \\
\text { Ohlo }\end{array}$ & $\begin{array}{r}3,680 \\
3,840 \\
2,430 \\
1,187 \\
11,826 \\
14,600 \\
1,023 \\
6,422\end{array}$ & $\begin{array}{l}0 \\
9 \\
4 \\
0 \\
0 \\
0 \\
0 \\
0\end{array}$ & $\begin{array}{r}400 \\
22 \\
14 \\
0 \\
489 \\
116 \\
0 \\
609\end{array}$ & $\begin{array}{r}924 \\
149 \\
102 \\
0 \\
5,710 \\
584 \\
0 \\
1,075\end{array}$ & $\begin{array}{r}1,729 \\
2,395 \\
1,494 \\
542 \\
4,777 \\
4,175 \\
81 \\
2,652\end{array}$ & $\begin{array}{r}626 \\
1,262 \\
814 \\
644 \\
850 \\
9,723 \\
941 \\
2,086\end{array}$ & $\begin{array}{r}214 \\
136 \\
0 \\
0 \\
531 \\
1,321 \\
57 \\
129\end{array}$ & $\begin{array}{l}0 \\
0 \\
0 \\
0 \\
0 \\
0 \\
0 \\
0\end{array}$ & $\begin{array}{r}0 \\
0 \\
0 \\
0 \\
43 \\
0 \\
0 \\
0\end{array}$ & $\begin{array}{r}11 \\
0 \\
0 \\
0 \\
64 \\
0 \\
0 \\
5\end{array}$ & $\begin{array}{r}194 \\
115 \\
0 \\
0 \\
414 \\
444 \\
0 \\
105\end{array}$ & $\begin{array}{r}9 \\
20 \\
0 \\
0 \\
8 \\
876 \\
57 \\
18\end{array}$ \\
\hline Total..... & 45,008 & 14 & 1,652 & 8,544 & 17,848 & 16,947 & 2,390 & 0 & 43 & 83 & 1,275 & 989 \\
\hline Total, North. & 177,901 & 64 & 9,706 & 39,347 & 69,019 & 59,763 & 10,458 & 1 & 224 & 773 & 6,890 & 2,568 \\
\hline $\begin{array}{l}\text { South A tlantic: } \\
\text { North Carolina } \\
\text { South Carolina. } \\
\text { Virginia }\end{array}$ & $\begin{array}{l}20,192 \\
12,410 \\
15,859\end{array}$ & $\begin{array}{r}349 \\
23 \\
125\end{array}$ & $\begin{array}{l}802 \\
274 \\
290\end{array}$ & $\begin{array}{l}4,214 \\
2,145 \\
1,705\end{array}$ & $\begin{array}{l}9,923 \\
7,429 \\
8,961\end{array}$ & $\begin{array}{l}4,902 \\
2,538 \\
4,776\end{array}$ & $\begin{array}{r}1,035 \\
550 \\
1,202\end{array}$ & $\begin{array}{r}17 \\
0 \\
0\end{array}$ & $\begin{array}{r}40 \\
25 \\
7\end{array}$ & $\begin{array}{r}144 \\
123 \\
38\end{array}$ & $\begin{array}{l}502 \\
340 \\
608\end{array}$ & $\begin{array}{r}329 \\
61 \\
549\end{array}$ \\
\hline Total & 48,463 & 498 & 1,366 & 8,066 & 26,314 & 12,217 & 2,789 & 17 & 73 & 306 & 1,450 & 940 \\
\hline $\begin{array}{l}\text { East Gulf: } \\
\text { Florida } \\
\text { Georgia............. }\end{array}$ & $\begin{array}{l}16,231 \\
25,102\end{array}$ & $\begin{array}{r}3 \\
711 \\
\end{array}$ & $\begin{array}{r}143 \\
1,631 \\
\end{array}$ & $\begin{array}{l}2,429 \\
9,382\end{array}$ & $\begin{array}{r}9,486 \\
11,584\end{array}$ & $\begin{array}{l}4,168 \\
1,792\end{array}$ & $\begin{array}{r}1,035 \\
806\end{array}$ & $\begin{array}{r}0 \\
16\end{array}$ & $\begin{array}{r}3 \\
38\end{array}$ & $\begin{array}{l}131 \\
252\end{array}$ & $\begin{array}{l}550 \\
452\end{array}$ & $\begin{array}{r}349 \\
46\end{array}$ \\
\hline Total .... & 41,334 & 715 & 1,775 & 11,812 & 21,070 & 5,961 & 1,842 & 16 & 42 & 383 & 1,003 & 396 \\
\hline 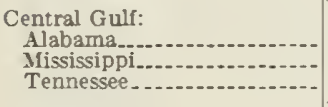 & $\begin{array}{l}21,742 \\
16,891 \\
12,819 \\
\end{array}$ & $\begin{array}{r}0 \\
544 \\
165 \\
\end{array}$ & $\begin{array}{r}2,867 \\
1,466 \\
379\end{array}$ & $\begin{array}{l}7,011 \\
5,815 \\
2,465\end{array}$ & $\begin{array}{l}9,859 \\
7,877 \\
6,497\end{array}$ & $\begin{array}{l}2,003 \\
1,187 \\
3,312\end{array}$ & $\begin{array}{r}625 \\
1,118 \\
599\end{array}$ & $\begin{array}{r}0 \\
55 \\
0\end{array}$ & $\begin{array}{r}53 \\
154 \\
5\end{array}$ & $\begin{array}{l}179 \\
523 \\
104\end{array}$ & $\begin{array}{l}315 \\
365 \\
331\end{array}$ & $\begin{array}{r}76 \\
20 \\
155\end{array}$ \\
\hline Total.... & 51,453 & 709 & 4,713 & 15,293 & 24,234 & 6,503 & 2,314 & 55 & 213 & 808 & 1,015 & 251 \\
\hline $\begin{array}{l}\text { West Gulf: } \\
\text { Arkansas } \\
\text { Louisiana_- } \\
\text { Okkahoma. } \\
\text { Texas }\end{array}$ & $\begin{array}{r}18,206 \\
15,342 \\
4,817 \\
12,924 \\
\end{array}$ & $\begin{array}{r}214 \\
506 \\
17 \\
59 \\
\end{array}$ & $\begin{array}{r}909 \\
1,435 \\
0 \\
557 \\
\end{array}$ & $\begin{array}{r}3,650 \\
8,602 \\
319 \\
5,709 \\
\end{array}$ & $\begin{array}{l}8,303 \\
3,019 \\
1,330 \\
5,353 \\
\end{array}$ & $\begin{array}{l}5,129 \\
1,778 \\
3,150 \\
1,243\end{array}$ & $\begin{array}{r}2,378 \\
551 \\
233 \\
625\end{array}$ & $\begin{array}{r}0 \\
16 \\
0 \\
5\end{array}$ & $\begin{array}{r}2 \\
67 \\
0 \\
57\end{array}$ & $\begin{array}{r}111 \\
249 \\
14 \\
342\end{array}$ & $\begin{array}{r}1,299 \\
163 \\
82 \\
214\end{array}$ & $\begin{array}{r}964 \\
55 \\
137 \\
5\end{array}$ \\
\hline Total..... & 51,290 & 798 & 2,902 & 18,280 & 18,007 & 11,301 & 3,788 & 21 & 127 & 718 & 1,758 & 1,161 \\
\hline Total, South... & 192,542 & 2,721 & 10,757 & 53,452 & 89,626 & 35,984 & 10,764 & 112 & 456 & 2,217 & 5,228 & 2,750 \\
\hline $\begin{array}{l}\text { Pacific Northwest: } \\
\text { Alaska: Coastal... }\end{array}$ & 5,639 & 144 & 1,608 & 2,609 & 1,161 & 117 & 5,144 & 131 & 1,535 & 2,440 & 945 & 93 \\
\hline $\begin{array}{l}\text { Oregon: } \\
\quad \text { Western } \\
\text { Eastern }\end{array}$ & $\begin{array}{l}14,635 \\
11,038\end{array}$ & $\begin{array}{r}3,334 \\
134\end{array}$ & $\begin{array}{r}4,810 \\
433\end{array}$ & $\begin{array}{l}2,964 \\
2,255\end{array}$ & $\begin{array}{l}2,920 \\
6,304\end{array}$ & $\begin{array}{r}607 \\
1,912\end{array}$ & $\begin{array}{l}4,830 \\
7,173\end{array}$ & $\begin{array}{r}656 \\
57\end{array}$ & $\begin{array}{r}1,363 \\
211\end{array}$ & $\begin{array}{l}1,172 \\
1,672\end{array}$ & $\begin{array}{l}1,413 \\
4,105\end{array}$ & $\begin{array}{r}226 \\
1,128\end{array}$ \\
\hline Summary .. & 25,673 & 3,468 & 5,243 & 5,219 & 9,224 & 2,519 & 12,003 & 713 & 1,574 & 2,844 & 5,518 & 1,354 \\
\hline $\begin{array}{l}\text { Washington: } \\
\text { Western } \\
\text { Eastern }\end{array}$ & $\begin{array}{l}9,991 \\
8,410\end{array}$ & $\begin{array}{r}2,905 \\
249\end{array}$ & $\begin{array}{r}3,316 \\
602\end{array}$ & $\begin{array}{l}1,859 \\
1,710\end{array}$ & $\begin{array}{l}1,751 \\
4,792\end{array}$ & $\begin{array}{r}160 \\
1,057 \\
\end{array}$ & $\begin{array}{l}2,321 \\
3,103\end{array}$ & $\begin{array}{l}390 \\
112\end{array}$ & $\begin{array}{l}596 \\
296\end{array}$ & $\begin{array}{l}517 \\
686\end{array}$ & $\begin{array}{r}721 \\
1,513\end{array}$ & $\begin{array}{r}97 \\
496\end{array}$ \\
\hline Summary .... & 18,401 & 3,154 & 3,918 & 3,569 & 6,543 & 1,217 & 5,424 & 502 & 892 & 1,203 & 2,234 & 593 \\
\hline Total & 49,713 & 6,766 & 10,769 & 11,397 & 16,928 & 3,853 & 22,571 & 1,346 & 4,001 & 6,487 & 8,697 & 2,040 \\
\hline
\end{tabular}


TABLE 5.-Area of commercial timberland in the United States, by ownership and site class, section, region, and State, January 1, $1970^{1}$ - Continued

[Thousand acres]

\begin{tabular}{|c|c|c|c|c|c|c|c|c|c|c|c|c|}
\hline \multirow{2}{*}{ Section, region, and State } & \multicolumn{6}{|c|}{ Total, all ownerships } & \multicolumn{6}{|c|}{ National Forest } \\
\hline & Total & $\begin{array}{l}165 \mathrm{cu} . \mathrm{ft} . \\
\text { or more }\end{array}$ & $\begin{array}{l}120 \text { to } 165 \\
\text { cu. ft. }\end{array}$ & $\begin{array}{l}85 \text { to } 120 \\
\text { cu. ft. }\end{array}$ & $\begin{array}{l}50 \text { to } 85 \\
\text { cu. } \mathrm{ft} .\end{array}$ & $\begin{array}{l}\text { Less than } \\
50 \mathrm{cu} . \mathrm{ft} .\end{array}$ & Total & $\begin{array}{l}165 \mathrm{cu} . \mathrm{ft} . \\
\text { or more }\end{array}$ & $\begin{array}{l}120 \text { to } 165 \\
\text { cu. ft. }\end{array}$ & $\begin{array}{l}85 \text { to } 120 \\
\text { cu. ft. }\end{array}$ & $\begin{array}{l}50 \text { to } 85 \\
\text { cu. ft. }\end{array}$ & $\begin{array}{l}\text { Less than } \\
50 \mathrm{cu} . \mathrm{ft} .\end{array}$ \\
\hline $\begin{array}{l}\text { Pacific Southwest: } \\
\text { California } \\
\text { Hawaii }\end{array}$ & $\begin{array}{r}16,828 \\
1,081\end{array}$ & $\begin{array}{l}1,789 \\
1,081\end{array}$ & $\begin{array}{r}3,223 \\
0\end{array}$ & $\begin{array}{r}4,175 \\
0\end{array}$ & $\begin{array}{r}5,976 \\
0\end{array}$ & $\begin{array}{r}1,665 \\
0\end{array}$ & $\begin{array}{r}8,344 \\
0\end{array}$ & $\begin{array}{r}459 \\
0\end{array}$ & $\begin{array}{r}889 \\
0\end{array}$ & $\begin{array}{r}2,214 \\
0\end{array}$ & $\begin{array}{r}3,821 \\
0\end{array}$ & $\begin{array}{r}961 \\
0\end{array}$ \\
\hline Total & 17,909 & 2,870 & 3,223 & 4,175 & 5,976 & 1,665 & 8,344 & 459 & 889 & 2,214 & 3,821 & 961 \\
\hline Total, Pacific Coast_-.. & 67,622 & 9,636 & 13,992 & 15,572 & 22,904 & 5,518 & 30,915 & 1,895 & 4,890 & 8,701 & 12,518 & 3,001 \\
\hline $\begin{array}{l}\text { Northern Rocky Mountain: } \\
\text { Idaho }{ }^{2} \\
\text { Montana }{ }^{2} \\
\text { South Dakota (West) }{ }^{2} \\
\text { Wyoming }{ }^{2}\end{array}$ & $\begin{array}{r}15,192 \\
15,983 \\
1,310 \\
4,182\end{array}$ & $\begin{array}{r}854 \\
224 \\
0 \\
0\end{array}$ & $\begin{array}{r}2,027 \\
1,496 \\
0 \\
0\end{array}$ & $\begin{array}{r}2,958 \\
3,962 \\
0 \\
77\end{array}$ & $\begin{array}{r}3,939 \\
4,801 \\
40 \\
468\end{array}$ & $\begin{array}{l}4,417 \\
5,365 \\
1,213 \\
2,710\end{array}$ & $\begin{array}{r}10,731 \\
9,732 \\
957 \\
2,699\end{array}$ & $\begin{array}{r}781 \\
197 \\
0 \\
0\end{array}$ & $\begin{array}{r}1,450 \\
1,435 \\
0 \\
0\end{array}$ & $\begin{array}{r}1,703 \\
3,632 \\
0 \\
33\end{array}$ & $\begin{array}{r}2,118 \\
2,773 \\
35 \\
267\end{array}$ & $\begin{array}{r}3,683 \\
1,559 \\
865 \\
1,470\end{array}$ \\
\hline Total & 36,668 & 1,078 & 3,523 & 6,998 & 9,249 & 13,707 & 24,120 & 978 & $2,88.5$ & 5,369 & 5,194 & 7,579 \\
\hline $\begin{array}{l}\text { Southern Rocky Mountain: } \\
\text { Arizona }{ }^{2} \\
\text { Colorado } \\
\text { Nevada }{ }^{2}- \\
\text { New Mexico }{ }^{2}- \\
\text { Utah }\end{array}$ & $\begin{array}{r}3,689 \\
11,583 \\
128 \\
5,736 \\
3,824\end{array}$ & $\begin{array}{r}0 \\
30 \\
0 \\
0 \\
9\end{array}$ & $\begin{array}{r}9 \\
40 \\
2 \\
50 \\
1\end{array}$ & $\begin{array}{r}165 \\
404 \\
12 \\
133 \\
75\end{array}$ & $\begin{array}{r}1,226 \\
1,365 \\
28 \\
1,663 \\
362\end{array}$ & $\begin{array}{r}2,235 \\
7,199 \\
83 \\
3,757 \\
3,170\end{array}$ & $\begin{array}{r}2,347 \\
7,710 \\
55 \\
2,939 \\
2,613\end{array}$ & $\begin{array}{r}0 \\
30 \\
0 \\
0 \\
9\end{array}$ & $\begin{array}{r}9 \\
33 \\
0 \\
0 \\
1\end{array}$ & $\begin{array}{r}61 \\
331 \\
1 \\
70 \\
9\end{array}$ & $\begin{array}{r}634 \\
1,144 \\
6 \\
846 \\
258\end{array}$ & $\begin{array}{r}1,589 \\
3,626 \\
46 \\
1,890 \\
2,129\end{array}$ \\
\hline Total & 24,963 & 39 & 104 & 790 & 4,646 & 16,446 & 15,666 & 39 & 44 & 474 & 2,890 & 9,282 \\
\hline Total, Rocky Mountain. & 61,631 & 1,118 & 3,627 & 7,789 & 13,895 & 30,153 & 39,787 & 1,018 & 2,930 & 5,844 & 8,085 & 16,861 \\
\hline Total, all regions.... & 499,697 & 13,540 & 38,083 & 116,161 & 195,445 & 131,419 & 91,924 & 2,937 & 8,500 & 17,535 & 32,721 & 25,181 \\
\hline
\end{tabular}

\begin{tabular}{|c|c|c|c|c|c|c|c|c|c|c|c|c|c|c|c|c|c|c|}
\hline \multirow[b]{2}{*}{$\begin{array}{l}\text { Section, region, and } \\
\text { State }\end{array}$} & \multicolumn{6}{|c|}{ Other public } & \multicolumn{6}{|c|}{ Forest industry } & \multicolumn{6}{|c|}{ Farm and miscellaneous private } \\
\hline & Total & $\begin{array}{l}165 \\
\text { cu. } \\
\text { ft. or } \\
\text { more }\end{array}$ & $\begin{array}{l}120 \\
\text { to } \\
165 \\
\text { cu. } \\
\text { ft. }\end{array}$ & $\begin{array}{l}85 \text { to } \\
120 \\
\mathrm{cu} . \\
\mathrm{ft} .\end{array}$ & $\begin{array}{l}50 \text { to } \\
85 \\
\text { cu. } \\
\text { ft. }\end{array}$ & $\begin{array}{c}\text { Less } \\
\text { than } \\
50 \mathrm{cu} . \\
\text { ft. }\end{array}$ & Total & $\begin{array}{l}165 \\
\text { cu. } \\
\text { ft. or } \\
\text { more }\end{array}$ & $\begin{array}{c}120 \\
\text { to } 165 \\
\text { cu. } \\
\mathrm{ft} .\end{array}$ & $\begin{array}{c}85 \\
\text { to } 120 \\
\text { cu. } \\
\mathrm{ft.}\end{array}$ & $\begin{array}{l}50 \text { to } \\
85 \\
\text { cu. } \\
\text { ft. }\end{array}$ & $\begin{array}{l}\text { Less } \\
\text { than } \\
50 \mathrm{cu} . \\
\text { ft. }\end{array}$ & Total & \begin{tabular}{c|}
165 \\
cu. \\
ft. or \\
more
\end{tabular} & $\begin{array}{l}120 \\
\text { to } 165 \\
\text { cu. } \\
\text { ft. }\end{array}$ & $\begin{array}{c}85 \\
\text { to } 120 \\
\text { cu. } \\
\text { ft. }\end{array}$ & $\begin{array}{l}50 \text { to } \\
85 \mathrm{cu} . \\
\text { ft. }\end{array}$ & $\begin{array}{c}\text { Less } \\
\text { than } \\
50 \\
\text { cu. } \\
\text { ft. }\end{array}$ \\
\hline 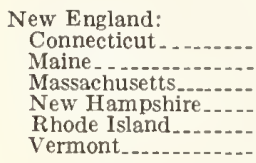 & $\begin{array}{r}155 \\
274 \\
399 \\
127 \\
26 \\
179\end{array}$ & $\begin{array}{l}0 \\
0 \\
0 \\
0 \\
0 \\
0\end{array}$ & $\begin{array}{r}11 \\
38 \\
29 \\
9 \\
2 \\
12\end{array}$ & $\begin{array}{r}26 \\
48 \\
68 \\
21 \\
4 \\
30\end{array}$ & $\begin{array}{r}62 \\
104 \\
159 \\
50 \\
10 \\
71\end{array}$ & $\begin{array}{r}56 \\
81 \\
143 \\
45 \\
10 \\
64\end{array}$ & $\begin{array}{r}3 \\
8,255 \\
259 \\
793 \\
0 \\
678\end{array}$ & $\begin{array}{l}0 \\
0 \\
0 \\
0 \\
0 \\
0\end{array}$ & $\begin{array}{r}0 \\
1,136 \\
48 \\
147 \\
0 \\
126\end{array}$ & $\begin{array}{r}1 \\
2,852 \\
53 \\
161 \\
0 \\
138\end{array}$ & $\begin{array}{r}1 \\
2,839 \\
86 \\
262 \\
0 \\
223\end{array}$ & $\begin{array}{r}1 \\
1,426 \\
72 \\
222 \\
0 \\
190\end{array}$ & $\begin{array}{r}2,011 \\
8,327 \\
2,833 \\
3,531 \\
403 \\
3,280\end{array}$ & $\begin{array}{l}0 \\
0 \\
0 \\
0 \\
0 \\
0\end{array}$ & $\begin{array}{r}401 \\
1,206 \\
587 \\
751 \\
79 \\
669\end{array}$ & $\begin{array}{r}382 \\
2,257 \\
538 \\
667 \\
77 \\
616\end{array}$ & $\begin{array}{r}713 \\
2,896 \\
1,005 \\
1,259 \\
143 \\
1,178\end{array}$ & $\begin{array}{r}514 \\
1,967 \\
702 \\
852 \\
103 \\
815\end{array}$ \\
\hline Total_... & 1,160 & 0 & 102 & 198 & 458 & 400 & 9,988 & 0 & 1,458 & 3,206 & 3,412 & 1,911 & 20,386 & 0 & 3,693 & 4,539 & 7,197 & 4,955 \\
\hline $\begin{array}{l}\text { Middle Atlantic: } \\
\text { Delaware } \\
\text { Maryland.... } \\
\text { New Jersey. } \\
\text { New York } \\
\text { Pennsylvania.... } \\
\text { West Virginia.... }\end{array}$ & $\begin{array}{r}9 \\
189 \\
254 \\
892 \\
2,918 \\
167\end{array}$ & $\begin{array}{l}0 \\
0 \\
0 \\
0 \\
0 \\
0\end{array}$ & $\begin{array}{r}0 \\
14 \\
19 \\
164 \\
216 \\
12\end{array}$ & $\begin{array}{r}2 \\
44 \\
60 \\
103 \\
686 \\
39\end{array}$ & $\begin{array}{r}6 \\
119 \\
160 \\
309 \\
1,836 \\
106\end{array}$ & $\begin{array}{r}1 \\
11 \\
15 \\
314 \\
180 \\
10\end{array}$ & $\begin{array}{r}29 \\
100 \\
4 \\
1,180 \\
610 \\
530\end{array}$ & $\begin{array}{l}0 \\
0 \\
0 \\
0 \\
0 \\
0\end{array}$ & $\begin{array}{r}3 \\
11 \\
1 \\
113 \\
68 \\
59\end{array}$ & $\begin{array}{r}12 \\
\mathbf{4 4} \\
2 \\
115 \\
268 \\
232\end{array}$ & $\begin{array}{r}8 \\
28 \\
1 \\
439 \\
170 \\
148\end{array}$ & $\begin{array}{r}5 \\
17 \\
0 \\
511 \\
104 \\
91\end{array}$ & $\begin{array}{r}351 \\
2,591 \\
2,096 \\
12,416 \\
13,462 \\
10,515\end{array}$ & $\begin{array}{l}0 \\
0 \\
0 \\
0 \\
0 \\
0\end{array}$ & $\begin{array}{r}12 \\
94 \\
76 \\
615 \\
403 \\
363\end{array}$ & $\begin{array}{r}173 \\
1,302 \\
1,083 \\
1,644 \\
7,369 \\
5,359\end{array}$ & $\begin{array}{r}143 \\
1,017 \\
782 \\
4,883 \\
4,747 \\
4,079\end{array}$ & $\begin{array}{r}22 \\
178 \\
154 \\
5,272 \\
941 \\
713\end{array}$ \\
\hline Total_. & 4,429 & $\overline{0}$ & 425 & 935 & 2,536 & 532 & 2,454 & 0 & 255 & 675 & 795 & 729 & 41,433 & 0 & 1,566 & 16,933 & 15,652 & 7,281 \\
\hline $\begin{array}{l}\text { Lake States: } \\
\text { Michigan } \\
\text { Minnesota- } \\
\text { North Dakota- } \\
\text { South Dakota (East) } \\
\text { Wisconsin }\end{array}$ & $\begin{array}{r}4,018 \\
7,261 \\
124 \\
77 \\
3,207\end{array}$ & $\begin{array}{l}3 \\
0 \\
0 \\
0 \\
1\end{array}$ & $\begin{array}{r}79 \\
2 \\
0 \\
0 \\
39\end{array}$ & $\begin{array}{r}280 \\
332 \\
0 \\
0 \\
304\end{array}$ & $\begin{array}{r}1,006 \\
3,004 \\
24 \\
3 \\
1,208\end{array}$ & $\begin{array}{r}2,648 \\
3,921 \\
99 \\
73 \\
1,653\end{array}$ & $\begin{array}{r}2,256 \\
814 \\
0 \\
0 \\
1,368\end{array}$ & $\begin{array}{l}0 \\
0 \\
0 \\
0 \\
0\end{array}$ & $\begin{array}{r}18 \\
0 \\
0 \\
0 \\
28\end{array}$ & $\begin{array}{r}120 \\
38 \\
0 \\
0 \\
134\end{array}$ & $\begin{array}{r}411 \\
379 \\
-\quad 0 \\
0 \\
491\end{array}$ & $\begin{array}{r}1,705 \\
395 \\
0 \\
0 \\
713\end{array}$ & $\begin{array}{r}10,102 \\
6,672 \\
281 \\
145 \\
8,643\end{array}$ & $\begin{array}{r}31 \\
0 \\
0 \\
0 \\
11\end{array}$ & $\begin{array}{r}118 \\
1 \\
0 \\
0 \\
83\end{array}$ & $\begin{array}{r}1,050 \\
517 \\
0 \\
0 \\
844\end{array}$ & $\begin{array}{r}3,415 \\
2,721 \\
56 \\
22 \\
2,756\end{array}$ & $\begin{array}{r}5,486 \\
3,432 \\
225 \\
122 \\
4,947\end{array}$ \\
\hline Total_. & 14,688 & 5 & 121 & 917 & 5,248 & 8,396 & 4,438 & 0 & 47 & 294 & 1,282 & 2,814 & 25,845 & 42 & 202 & 2,412 & 8,972 & 14,214 \\
\hline 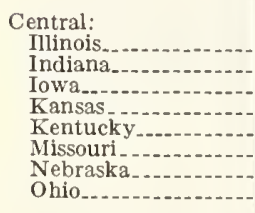 & $\begin{array}{r}52 \\
224 \\
34 \\
36 \\
289 \\
264 \\
37 \\
235 \\
\end{array}$ & $\begin{array}{l}0 \\
0 \\
0 \\
0 \\
0 \\
0 \\
0 \\
0\end{array}$ & $\begin{array}{r}0 \\
1 \\
0 \\
0 \\
18 \\
0 \\
0 \\
44\end{array}$ & $\begin{array}{r}13 \\
3 \\
1 \\
0 \\
119 \\
0 \\
0 \\
51\end{array}$ & $\begin{array}{r}26 \\
137 \\
21 \\
18 \\
113 \\
239 \\
0 \\
0.5\end{array}$ & $\begin{array}{l}13 \\
82 \\
11 \\
18 \\
38 \\
25 \\
37 \\
74\end{array}$ & $\begin{array}{r}16 \\
21 \\
9 \\
0 \\
227 \\
279 \\
0 \\
126\end{array}$ & $\begin{array}{l}0 \\
0 \\
0 \\
0 \\
0 \\
0 \\
0 \\
0\end{array}$ & $\begin{array}{r}0 \\
0 \\
0 \\
0 \\
25 \\
2 \\
0 \\
6 \\
6\end{array}$ & $\begin{array}{r}0 \\
0 \\
0 \\
0 \\
99 \\
\mathbf{1 2} \\
0 \\
22\end{array}$ & $\begin{array}{r}16 \\
7 \\
5 \\
0 \\
63 \\
58 \\
0 \\
53\end{array}$ & $\begin{array}{r}0 \\
13 \\
3 \\
0 \\
39 \\
205 \\
0 \\
44\end{array}$ & $\begin{array}{r}3,396 \\
3,457 \\
2,386 \\
1,150 \\
10,777 \\
12,734 \\
928 \\
5,930\end{array}$ & $\begin{array}{l}0 \\
9 \\
4 \\
0 \\
0 \\
0 \\
0 \\
0\end{array}$ & $\begin{array}{r}400 \\
20 \\
14 \\
0 \\
402 \\
114 \\
0 \\
557\end{array}$ & $\begin{array}{r}899 \\
145 \\
100 \\
0 \\
5,426 \\
570 \\
0 \\
995\end{array}$ & $\begin{array}{r}1,492 \\
2,135 \\
1,467 \\
524 \\
4,185 \\
3,432 \\
81 \\
2,428\end{array}$ & $\begin{array}{r}604 \\
1,146 \\
799 \\
626 \\
764 \\
8,617 \\
846 \\
1,948\end{array}$ \\
\hline Total $\ldots . .$. & 1,175 & 0 & 64 & 188 & 620 & 301 & 681 & 0 & 34 & 136 & 204 & 305 & 40,761 & 14 & 1,509 & 8,137 & 15,747 & 15,351 \\
\hline Total, North & 21,453 & 5 & 714 & 2,239 & 8,863 & 9,630 & 17,563 & 0 & 1,795 & 4,311 & 5,694 & 5,760 & 128,426 & 57 & 6,972 & 32,022 & 47,570 & 41,803 \\
\hline
\end{tabular}

See footnotes at end of table. 
TABLE 5.- Area of commercial timberland in the United States, by ownership and site class, section, region, and State, January 1, $1970^{1}$-Continued

[Thousand acres]

\begin{tabular}{|c|c|c|c|c|c|c|c|c|c|c|c|c|c|c|c|c|c|c|}
\hline \multirow[b]{2}{*}{$\begin{array}{l}\text { Section, region, and } \\
\text { State }\end{array}$} & \multicolumn{6}{|c|}{ Other public } & \multicolumn{6}{|c|}{ Forest industry } & \multicolumn{6}{|c|}{ Farm and miscellaneous private } \\
\hline & Total & $\begin{array}{l}165 \\
\text { cu. } \\
\text { ft. or } \\
\text { more }\end{array}$ & $\begin{array}{l}120 \\
\text { to } \\
165 \\
\text { cu. } \\
\text { ft. }\end{array}$ & $\begin{array}{l}85 \text { to } \\
120 \\
\text { cu. } \\
\text { ft. }\end{array}$ & $\begin{array}{l}50 \text { to } \\
85 \\
\text { cu. } \\
\text { ft. }\end{array}$ & $\begin{array}{l}\text { Less } \\
\text { than } \\
50 \mathrm{cu} . \\
\text { ft. }\end{array}$ & Total & $\begin{array}{l}165 \\
\text { cu. } \\
\text { ft. or } \\
\text { more }\end{array}$ & $\begin{array}{l}120 \\
\text { to } 165 \\
\text { cu. } \\
\text { ft. }\end{array}$ & $\begin{array}{l}85 \\
\text { to } 120 \\
\text { cu. } \\
\text { ft. }\end{array}$ & $\begin{array}{l}50 \text { to } \\
85 \\
\text { cu. } \\
\text { ft. }\end{array}$ & $\begin{array}{l}\text { Less } \\
\text { than } \\
50 \mathrm{cu} . \\
\text { ft. }\end{array}$ & Total & $\begin{array}{l}165 \\
\text { cu. } \\
\text { ft. or } \\
\text { more }\end{array}$ & $\begin{array}{l}120 \\
\text { to } 165 \\
\text { cu. } \\
\text { ft. }\end{array}$ & $\begin{array}{l}85 \\
\text { to } 120 \\
\text { cu. } \\
\text { ft. }\end{array}$ & $\begin{array}{l}50 \text { to. } \\
85 \mathrm{cu} \\
\mathrm{ft} \text {. }\end{array}$ & $\begin{array}{l}\text { Less } \\
\text { than } \\
50 \\
\text { cu. } \\
\text { ft. }\end{array}$ \\
\hline $\begin{array}{l}\text { South Atlantic: } \\
\text { North Carolina... } \\
\text { South Carolina... } \\
\text { Virginia..........- }\end{array}$ & $\begin{array}{l}687 \\
522 \\
469\end{array}$ & $\begin{array}{l}9 \\
0 \\
1 \\
\end{array}$ & $\begin{array}{r}20 \\
4 \\
10 \\
\end{array}$ & $\begin{array}{l}98 \\
53 \\
76 \\
\end{array}$ & $\begin{array}{l}285 \\
298 \\
276\end{array}$ & $\begin{array}{l}274 \\
166 \\
103\end{array}$ & $\begin{array}{l}2,785 \\
2,047 \\
1,634 \\
\end{array}$ & $\begin{array}{r}35 \\
7 \\
3 \\
\end{array}$ & $\begin{array}{l}81 \\
49 \\
19 \\
\end{array}$ & $\begin{array}{l}652 \\
500 \\
212 \\
\end{array}$ & $\begin{array}{l}1,275 \\
1,161 \\
1,006\end{array}$ & $\begin{array}{l}741 \\
328 \\
393 \\
\end{array}$ & $\begin{array}{r}15,684 \\
9,290 \\
12,553 \\
\end{array}$ & $\begin{array}{r}287 \\
15 \\
120 \\
\end{array}$ & $\begin{array}{l}659 \\
195 \\
253\end{array}$ & $\begin{array}{l}3,319 \\
1,468 \\
1,378 \\
\end{array}$ & $\begin{array}{l}7,860 \\
5,629 \\
7,070 \\
\end{array}$ & $\begin{array}{l}3,557 \\
1,981 \\
3,730 \\
\end{array}$ \\
\hline Total. . & 1,678 & 10 & 35 & 227 & 860 & 544 & 6,467 & 46 & 150 & 1,365 & 3,443 & 1,462 & 37,527 & 423 & 1,108 & 6,166 & 20,559 & 9,270 \\
\hline $\begin{array}{l}\text { East Gulf: } \\
\text { Florida } \\
\text { Georgia } \\
\end{array}$ & $\begin{array}{r}1,110 \\
600\end{array}$ & $\begin{array}{r}0 \\
17\end{array}$ & $\begin{array}{r}2 \\
40 \\
\end{array}$ & $\begin{array}{l}119 \\
224\end{array}$ & $\begin{array}{l}527 \\
240\end{array}$ & $\begin{array}{r}461 \\
76\end{array}$ & $\begin{array}{l}5,216 \\
4,700\end{array}$ & $\begin{array}{r}0 \\
179 \\
\end{array}$ & $\begin{array}{r}33 \\
410\end{array}$ & $\begin{array}{l}1,037 \\
1,953\end{array}$ & $\begin{array}{l}3,294 \\
1,810\end{array}$ & $\begin{array}{l}851 \\
345\end{array}$ & $\begin{array}{r}8,869 \\
18,995\end{array}$ & $\begin{array}{r}3 \\
497 \\
\end{array}$ & $\begin{array}{r}104 \\
1,140\end{array}$ & $\begin{array}{l}1,141 \\
6,952\end{array}$ & $\begin{array}{l}5,114 \\
9,080\end{array}$ & $\begin{array}{l}2,505 \\
1,323\end{array}$ \\
\hline Total.... & 1,710 & 17 & 43 & 343 & 767 & 538 & 9,916 & 179 & 444 & 2,991 & 5,104 & 1,197 & 27,865 & 501 & 1,245 & 8,094 & 14,195 & 3,829 \\
\hline $\begin{array}{l}\text { Central Gulf: } \\
\text { Alabama } \\
\text { Mississippi } \\
\text { Tennessee. }\end{array}$ & $\begin{array}{l}371 \\
651 \\
686 \\
\end{array}$ & $\begin{array}{r}0 \\
60 \\
16 \\
\end{array}$ & $\begin{array}{l}28 \\
63 \\
50 \\
\end{array}$ & $\begin{array}{l}105 \\
243 \\
160 \\
\end{array}$ & $\begin{array}{l}193 \\
254 \\
335\end{array}$ & $\begin{array}{r}44 \\
29 \\
123 \\
\end{array}$ & $\begin{array}{l}3,818 \\
2,505 \\
1,121 \\
\end{array}$ & $\begin{array}{r}0 \\
110 \\
40 \\
\end{array}$ & $\begin{array}{r}713 \\
297 \\
11 \\
\end{array}$ & $\begin{array}{r}1,212 \\
912 \\
151 \\
\end{array}$ & $\begin{array}{r}1,505 \\
1,039 \\
626 \\
\end{array}$ & $\begin{array}{l}386 \\
145 \\
291 \\
\end{array}$ & & $\begin{array}{r}0 \\
317 \\
107 \\
\end{array}$ & $\begin{array}{r}2,071 \\
950 \\
312 \\
\end{array}$ & $\begin{array}{l}5,514 \\
4,136 \\
2,049 \\
\end{array}$ & $\begin{array}{l}7,844 \\
6,218 \\
5,201 \\
\end{array}$ & $\begin{array}{r}1,496 \\
993 \\
2,741 \\
\end{array}$ \\
\hline Total. . & 1,709 & 77 & 142 & 508 & 783 & 197 & 7.444 & 151 & 1,022 & 2,275 & 3, 171 & 824 & 39,955 & 424 & 3,335 & 11,700 & 19,264 & 5,230 \\
\hline 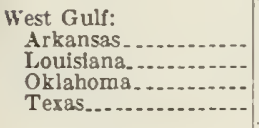 & $\begin{array}{l}560 \\
308 \\
343 \\
203 \\
\end{array}$ & $\begin{array}{r}6 \\
25 \\
4 \\
0 \\
\end{array}$ & $\begin{array}{r}76 \\
11 \\
0 \\
8 \\
\end{array}$ & $\begin{array}{r}112 \\
157 \\
40 \\
80\end{array}$ & $\begin{array}{r}227 \\
44 \\
73 \\
105\end{array}$ & $\begin{array}{r}137 \\
68 \\
225 \\
9\end{array}$ & $\begin{array}{r}3,950 \\
3,180 \\
868 \\
3,496 \\
\end{array}$ & $\begin{array}{r}67 \\
107 \\
0 \\
42\end{array}$ & $\begin{array}{r}420 \\
532 \\
0 \\
307\end{array}$ & $\begin{array}{r}1,469 \\
1,624 \\
68 \\
2,004\end{array}$ & $\begin{array}{r}1,733 \\
668 \\
386 \\
1,060 \\
\end{array}$ & $\begin{array}{r}260 \\
248 \\
413 \\
82 \\
\end{array}$ & $\begin{array}{r}11,317 \\
11,301 \\
3,371 \\
8,599 \\
\end{array}$ & $\begin{array}{r}141 \\
357 \\
12 \\
11 \\
\end{array}$ & $\begin{array}{r}410 \\
823 \\
0 \\
184 \\
\end{array}$ & $\begin{array}{r}1,956 \\
6,570 \\
195 \\
3,282 \\
\end{array}$ & $\begin{array}{r}5,043 \\
2,142 \\
788 \\
3,973 \\
\end{array}$ & $\begin{array}{l}3,766 \\
1,406 \\
2,374 \\
1,147 \\
\end{array}$ \\
\hline Total. . & 1,415 & 36 & 97 & 390 & 451 & 433 & 11,496 & 216 & 1,260 & 5,166 & 3,849 & 1,004 & 34,589 & 522 & 1,418 & 12,005 & 11,947 & 8,695 \\
\hline Total, South..... & 6,514 & 143 & 317 & 1,470 & 2,863 & 1,720 & $=35,325$ & 593 & 2,876 & 11,798 & 15,568 & 4,488 & 139,938 & 1,872 & 7,106 & 37,966 & 65,967 & 27,025 \\
\hline $\begin{array}{l}\text { Pacific Northwest: } \\
\text { Alaska: Coastal. .... }\end{array}$ & 465 & 12 & 65 & 155 & 210 & 23 & 0 & 0 & 0 & 0 & 0 & 0 & 30 & 1 & 8 & 14 & 6 & 1 \\
\hline $\begin{array}{l}\text { Oregon: } \\
\text { Western........ } \\
\text { Eastern......... }\end{array}$ & $\begin{array}{r}2,922 \\
594 \\
\end{array}$ & $\begin{array}{r}597 \\
30 \\
\end{array}$ & $\begin{array}{r}1,294 \\
81 \\
\end{array}$ & $\begin{array}{r}515 \\
76 \\
\end{array}$ & $\begin{array}{l}466 \\
334\end{array}$ & $\begin{array}{l}50 \\
73\end{array}$ & $\begin{array}{l}3,624 \\
1,582 \\
\end{array}$ & $\begin{array}{r}1,285 \\
47 \\
\end{array}$ & $\begin{array}{r}1,140 \\
77 \\
\end{array}$ & $\begin{array}{l}648 \\
305 \\
\end{array}$ & $\begin{array}{l}415 \\
902 \\
\end{array}$ & $\begin{array}{l}136 \\
251 \\
\end{array}$ & $\begin{array}{l}3,259 \\
1,689\end{array}$ & $\begin{array}{r}796 \\
0\end{array}$ & $\begin{array}{r}1,013 \\
64 \\
\end{array}$ & $\begin{array}{l}629 \\
202 \\
\end{array}$ & $\begin{array}{l}626 \\
963\end{array}$ & $\begin{array}{l}195 \\
460 \\
\end{array}$ \\
\hline Summary .... & 3,516 & 627 & 1,375 & 591 & 800 & 123 & 5,206 & 1,332 & 1,217 & 953 & 1,317 & 387 & 4,948 & 796 & 1,077 & 831 & 1,589 & 655 \\
\hline $\begin{array}{l}\text { Washington: } \\
\text { Western } \\
\text { Eastern............... }\end{array}$ & $\begin{array}{l}1,802 \\
2,292 \\
\end{array}$ & $\begin{array}{r}639 \\
58 \\
\end{array}$ & $\begin{array}{l}636 \\
122 \\
\end{array}$ & $\begin{array}{l}301 \\
431\end{array}$ & $\begin{array}{r}187 \\
1,416 \\
\end{array}$ & $\begin{array}{r}39 \\
265\end{array}$ & $\begin{array}{r}3,598 \\
750\end{array}$ & $\begin{array}{r}1,450 \\
27 \\
\end{array}$ & $\begin{array}{r}1,198 \\
52 \\
\end{array}$ & $\begin{array}{l}545 \\
166\end{array}$ & $\begin{array}{l}386 \\
465 \\
\end{array}$ & $\begin{array}{l}19 \\
40 \\
\end{array}$ & $\begin{array}{l}2,270 \\
2,265 \\
\end{array}$ & $\begin{array}{r}426 \\
52 \\
\end{array}$ & $\begin{array}{l}886 \\
132 \\
\end{array}$ & $\begin{array}{l}496 \\
427 \\
\end{array}$ & $\begin{array}{r}457 \\
1,398 \\
\end{array}$ & $\begin{array}{r}5 \\
256 \\
\end{array}$ \\
\hline Summary.... & 4,094 & 697 & 758 & 732 & 1,603 & 304 & 4.348 & 1,477 & 1,250 & 711 & 851 & 59 & 4,535 & 478 & 1,018 & 923 & 1,855 & 261 \\
\hline Total & 8,075 & 1,336 & 2,198 & 1,478 & 2,613 & 450 & 9,554 & 2,809 & 2,467 & 1,664 & 2,168 & 446 & 9,513 & 1,275 & 2,103 & 1,768 & 3,450 & 917 \\
\hline $\begin{array}{l}\text { Pacific Southwest: } \\
\text { California............... } \\
\text { Hawaii. .............. }\end{array}$ & $\begin{array}{l}476 \\
495 \\
\end{array}$ & $\begin{array}{r}31 \\
495 \\
\end{array}$ & $\begin{array}{r}75 \\
0 \\
\end{array}$ & $\begin{array}{r}91 \\
0\end{array}$ & $\begin{array}{r}243 \\
0\end{array}$ & $\begin{array}{r}36 \\
0\end{array}$ & $\begin{array}{r}2,665 \\
0 \\
\end{array}$ & $\begin{array}{r}680 \\
0 \\
\end{array}$ & $\begin{array}{r}706 \\
0 \\
\end{array}$ & $\begin{array}{r}681 \\
0\end{array}$ & $\begin{array}{r}572 \\
0\end{array}$ & $\begin{array}{r}26 \\
0\end{array}$ & $\begin{array}{r}5,343 \\
585 \\
\end{array}$ & $\begin{array}{l}619 \\
585\end{array}$ & $\begin{array}{r}1,553 \\
0\end{array}$ & $\begin{array}{r}1,189 \\
0\end{array}$ & $\begin{array}{r}1,340 \\
0 \\
\end{array}$ & $\begin{array}{r}642 \\
0 \\
\end{array}$ \\
\hline Total & 971 & 526 & 75 & 91 & 243 & 36 & 2,665 & 680 & 706 & 681 & 572 & 26 & 5,928 & 1,204 & $1,5 \bar{z} 3$ & 1,189 & 1,340 & 642 \\
\hline $\begin{array}{l}\text { Total, Pacific } \\
\text { Coast }\end{array}$ & 9,046 & 1,862 & 2,273 & 1,569 & 2,856 & 486 & 12,213 & 3,489 & 3,173 & 2,345 & 2,740 & 472 & 15,441 & 2,479 & 3,656 & 2,957 & 4,790 & 1,559 \\
\hline 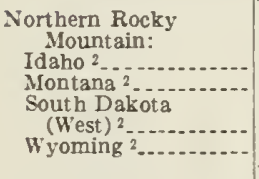 & $\begin{array}{r}1,440 \\
1,685 \\
71 \\
628 \\
\end{array}$ & $\begin{array}{l}6 \\
6\end{array}$ & $\begin{array}{r}177 \\
15 \\
0 \\
0 \\
\end{array}$ & $\begin{array}{r}455 \\
81 \\
\\
0 \\
30 \\
\end{array}$ & $\begin{array}{r}541 \\
522 \\
1 \\
136 \\
\end{array}$ & $\begin{array}{r}259 \\
1,059 \\
70 \\
460\end{array}$ & $\begin{array}{r}946 \\
1,055 \\
17 \\
54\end{array}$ & $\begin{array}{r}30 \\
8\end{array}$ & $\begin{array}{r}179 \\
18 \\
0 \\
0\end{array}$ & $\begin{array}{r}243 \\
122 \\
0 \\
0\end{array}$ & $\begin{array}{r}396 \\
473 \\
0 \\
3 \\
\end{array}$ & $\begin{array}{r}97 \\
433 \\
17 \\
49 \\
\end{array}$ & $\begin{array}{r}2,074 \\
3,510 \\
\\
263 \\
800\end{array}$ & $\begin{array}{l}36 \\
11\end{array}$ & $\begin{array}{r}220 \\
26 \\
0 \\
0\end{array}$ & $\begin{array}{r}556 \\
126 \\
0 \\
12\end{array}$ & $\begin{array}{r}883 \\
1,031 \\
3 \\
60 \\
\end{array}$ & $\begin{array}{r}378 \\
2,313 \\
260 \\
728 \\
\end{array}$ \\
\hline Total...... & 3,825 & 13 & 192 & 568 & 1,201 & 1,849 & 2,073 & 38 & 197 & 366 & 874 & 597 & 6,648 & 47 & 247 & 694 & 1,978 & 3,680 \\
\hline $\begin{array}{l}\text { Southern Rocky } \\
\text { Mountain: } \\
\text { Arizona } 20 \\
\text { Colorado } \\
\text { Nerada } 2 \\
\text { New Mexico } \\
\text { Utah 2 }\end{array}$ & $\begin{array}{r}1,175 \\
754 \\
4 \\
870 \\
550 \\
\end{array}$ & $\begin{array}{l}0 \\
0 \\
0 \\
0 \\
0 \\
\end{array}$ & $\begin{array}{l}0 \\
1 \\
0 \\
6 \\
0\end{array}$ & $\begin{array}{r}101 \\
15 \\
0 \\
5 \\
36\end{array}$ & $\begin{array}{r}511 \\
53 \\
1 \\
198 \\
57\end{array}$ & $\begin{array}{r}562 \\
684 \\
2 \\
660 \\
456\end{array}$ & $\begin{array}{r}0 \\
14 \\
8 \\
137 \\
0\end{array}$ & $\begin{array}{l}0 \\
0 \\
0 \\
0 \\
0\end{array}$ & $\begin{array}{l}0 \\
0 \\
0 \\
3 \\
0\end{array}$ & $\begin{array}{l}0 \\
0 \\
0 \\
2 \\
0\end{array}$ & $\begin{array}{r}0 \\
0 \\
2 \\
43 \\
0\end{array}$ & $\begin{array}{r}0 \\
13 \\
4 \\
87 \\
0\end{array}$ & $\begin{array}{r}166 \\
3,103 \\
60 \\
1,790 \\
660\end{array}$ & $\begin{array}{l}0 \\
0 \\
0 \\
0 \\
0\end{array}$ & $\begin{array}{r}0 \\
4 \\
2 \\
41 \\
0\end{array}$ & $\begin{array}{r}2 \\
57 \\
9 \\
54 \\
29\end{array}$ & $\begin{array}{r}80 \\
166 \\
18 \\
575 \\
46 \\
\end{array}$ & $\begin{array}{r}83 \\
2,874 \\
30 \\
1,119 \\
585\end{array}$ \\
\hline Total & 3,355 & 0 & 8 & 158 & 822 & 2,365 & 160 & 0 & 3 & 3 & 46 & 106 & 5,781 & 0 & 47 & 154 & 886 & 4,692 \\
\hline $\begin{array}{l}\text { Total, Rocky } \\
\text { Mountain }\end{array}$ & 7,181 & 13 & 201 & 726 & 2,024 & 4,215 & 2,233 & 38 & 200 & 370 & 920 & 703 & 12,429 & 47 & 294 & 848 & 2,865 & 8,373 \\
\hline Total all regions & 44,196 & 2,024 & 3,506 & 6,005 & 16,607 & 6,052 & 67,341 & 4,121 & 8,046 & 18,825 & 24,923 & 11,424 & 296,235 & 4,456 & 18,030 & 73,794 & 121,192 & 78,761 \\
\hline
\end{tabular}


TABLE 6.-Net volume of softwood growing stock on commercial timberland in the United States, by ownership and section, region, and State, as of December 31, 1952 and 1962, and January 1, 1970 1

[Million cubic feet]

\begin{tabular}{|c|c|c|c|c|c|c|c|c|c|c|c|c|c|c|c|}
\hline \multirow{2}{*}{ Section, region, and State } & \multicolumn{3}{|c|}{ Total, all ownerships } & \multicolumn{3}{|c|}{ National Forest } & \multicolumn{3}{|c|}{ Other public } & \multicolumn{3}{|c|}{ Forest industry } & \multicolumn{3}{|c|}{$\begin{array}{c}\text { Farm and miscellaneous } \\
\text { private }\end{array}$} \\
\hline & 1970 & 1962 & 1952 & 1970 & 1962 & 1952 & 1970 & 1962 & 1952 & 1970 & 1962 & 1952 & 1970 & 1962 & 1952 \\
\hline $\begin{array}{l}\text { New England: } \\
\text { Connecticut } \\
\text { Maine } \\
\text { Massachusetts, } \\
\text { New Hampshire } 1 . . \\
\text { Rhode Island. } \\
\text { Vermont_. }\end{array}$ & $\begin{array}{r}228 \\
14,763 \\
769 \\
2,901 \\
19 \\
1,507\end{array}$ & $\begin{array}{r}202 \\
12,562 \\
-732 \\
2,534 \\
18 \\
1,379 \\
\end{array}$ & $\begin{array}{r}158 \\
10,092 \\
631 \\
2,207 \\
15 \\
1,250 \\
\end{array}$ & $\begin{array}{r}0 \\
20 \\
0 \\
332 \\
0 \\
42\end{array}$ & $\begin{array}{r}0 \\
18 \\
0 \\
290 \\
0 \\
38\end{array}$ & $\begin{array}{r}0 \\
14 \\
0 \\
252 \\
0 \\
34\end{array}$ & $\begin{array}{r}23 \\
244 \\
95 \\
80 \\
1 \\
45\end{array}$ & $\begin{array}{r}20 \\
135 \\
90 \\
70 \\
1 \\
41\end{array}$ & $\begin{array}{r}16 \\
112 \\
78 \\
61 \\
1 \\
37 \\
\end{array}$ & $\begin{array}{r}0 \\
8,383 \\
63 \\
487 \\
0 \\
221 \\
\end{array}$ & $\begin{array}{r}0 \\
5,221 \\
60 \\
426 \\
0 \\
203\end{array}$ & $\begin{array}{r}0 \\
4,193 \\
52 \\
371 \\
0 \\
184\end{array}$ & $\begin{array}{r}204 \\
6,115 \\
611 \\
2,000 \\
18 \\
1,197\end{array}$ & $\begin{array}{r}181 \\
7,186 \\
581 \\
1,747 \\
17 \\
1,095 \\
\end{array}$ & $\begin{array}{r}141 \\
5,772 \\
501 \\
1,521 \\
13 \\
993\end{array}$ \\
\hline Total $\ldots . . . . . .$. & 20,190 & 17,428 & 14,354 & 395 & 346 & 302 & 490 & 360 & 306 & 9,157 & 5,911 & 4,800 & 10,147 & 10,810 & 8,944 \\
\hline $\begin{array}{l}\text { Middle Atlantic: } \\
\text { Delaware } \\
\text { Maryland } \\
\text { New Jersey } \\
\text { New York } \\
\text { Pennyslvania... } \\
\text { West Virginia........... }\end{array}$ & $\begin{array}{r}229 \\
531 \\
385 \\
3,291 \\
1,600 \\
657 \\
\end{array}$ & $\begin{array}{r}229 \\
639 \\
319 \\
3,036 \\
1,435 \\
583 \\
\end{array}$ & $\begin{array}{r}236 \\
716 \\
249 \\
2,748 \\
1,229 \\
492 \\
\end{array}$ & $\begin{array}{r}0 \\
0 \\
0 \\
0 \\
49 \\
158 \\
\end{array}$ & $\begin{array}{r}0 \\
0 \\
0 \\
0 \\
44 \\
140\end{array}$ & $\begin{array}{r}0 \\
0 \\
0 \\
0 \\
38 \\
118\end{array}$ & $\begin{array}{r}4 \\
20 \\
39 \\
412 \\
191 \\
37\end{array}$ & $\begin{array}{r}4 \\
25 \\
32 \\
380 \\
172 \\
33\end{array}$ & $\begin{array}{r}5 \\
28 \\
25 \\
344 \\
147 \\
27\end{array}$ & $\begin{array}{r}15 \\
47 \\
0 \\
356 \\
63 \\
25\end{array}$ & $\begin{array}{r}16 \\
56 \\
0 \\
329 \\
57 \\
22\end{array}$ & $\begin{array}{r}14 \\
63 \\
0 \\
298 \\
49 \\
19\end{array}$ & $\begin{array}{r}209 \\
462 \\
344 \\
2,521 \\
1,294 \\
436\end{array}$ & $\begin{array}{r}208 \\
557 \\
285 \\
2,326 \\
1,161 \\
387\end{array}$ & $\begin{array}{r}217 \\
624 \\
223 \\
2,106 \\
994 \\
327\end{array}$ \\
\hline Total & 6,694 & 6,243 & 5,673 & 207 & 184 & 156 & 706 & 648 & 578 & 509 & 483 & 444 & 5,270 & 4,927 & 4,493 \\
\hline $\begin{array}{l}\text { Lake States: } \\
\text { Michigan } \\
\text { Minnesota. } \\
\text { North Dakota } \\
\text { South Dakota (East) } \\
\text { Wisconsin.... }\end{array}$ & $\begin{array}{r}4,313 \\
3,896 \\
0 \\
18 \\
2,662 \\
\end{array}$ & $\begin{array}{r}3,508 \\
3,607 \\
0 \\
15 \\
2,067 \\
\end{array}$ & $\begin{array}{r}2,369 \\
2,849 \\
0 \\
13 \\
1,550\end{array}$ & $\begin{array}{r}695 \\
977 \\
0 \\
0 \\
379\end{array}$ & $\begin{array}{r}553 \\
905 \\
0 \\
0 \\
293\end{array}$ & $\begin{array}{r}270 \\
780 \\
0 \\
0 \\
136\end{array}$ & $\begin{array}{r}1,015 \\
1,861 \\
0 \\
17 \\
625\end{array}$ & $\begin{array}{r}801 \\
1,723 \\
0 \\
13 \\
486\end{array}$ & $\begin{array}{r}533 \\
1,285 \\
0 \\
11 \\
485\end{array}$ & $\begin{array}{r}764 \\
306 \\
0 \\
0 \\
470\end{array}$ & $\begin{array}{r}661 \\
283 \\
0 \\
0 \\
366\end{array}$ & $\begin{array}{r}563 \\
232 \\
0 \\
0 \\
110\end{array}$ & $\begin{array}{r}1,837 \\
749 \\
0 \\
1 \\
1,188 \\
\end{array}$ & $\begin{array}{r}1,491 \\
694 \\
0 \\
2 \\
922 \\
\end{array}$ & $\begin{array}{r}1,002 \\
551 \\
0 \\
2 \\
818 \\
\end{array}$ \\
\hline Total & 10,891 & 9,199 & 6,782 & 2,052 & 1,752 & 1,187 & 3,519 & 3,024 & 2,316 & 1,541 & 1,311 & 905 & 3,777 & 3,110 & 2,374 \\
\hline $\begin{array}{l}\text { Central: } \\
\text { Illinois } \\
\text { Indiana } \\
\text { Iowa_..... } \\
\text { Kansas } \\
\text { Kentucky } \\
\text { Missouri } \\
\text { Nebraska } \\
\text { Ohio }\end{array}$ & $\begin{array}{r}19 \\
70 \\
3 \\
0 \\
621 \\
384 \\
114 \\
123\end{array}$ & $\begin{array}{r}16 \\
49 \\
4 \\
0 \\
554 \\
316 \\
98 \\
108\end{array}$ & $\begin{array}{r}16 \\
27 \\
3 \\
0 \\
492 \\
259 \\
72 \\
94 \\
\end{array}$ & $\begin{array}{r}13 \\
10 \\
0 \\
0 \\
175 \\
199 \\
28 \\
8\end{array}$ & $\begin{array}{r}11 \\
5 \\
0 \\
0 \\
156 \\
163 \\
25 \\
7\end{array}$ & $\begin{array}{r}5 \\
3 \\
0 \\
0 \\
139 \\
132 \\
19 \\
6\end{array}$ & $\begin{array}{r}0 \\
16 \\
0 \\
0 \\
78 \\
7 \\
5 \\
11\end{array}$ & $\begin{array}{r}0 \\
14 \\
0 \\
0 \\
70 \\
7 \\
4 \\
10 \\
\end{array}$ & $\begin{array}{r}0 \\
14 \\
0 \\
0 \\
62 \\
5 \\
3 \\
8\end{array}$ & $\begin{array}{r}1 \\
0 \\
0 \\
0 \\
12 \\
10 \\
0 \\
4\end{array}$ & $\begin{array}{r}1 \\
0 \\
0 \\
0 \\
11 \\
9 \\
0 \\
4\end{array}$ & $\begin{array}{r}0 \\
0 \\
0 \\
0 \\
10 \\
7 \\
0 \\
3\end{array}$ & $\begin{array}{r}4 \\
42 \\
3 \\
0 \\
354 \\
167 \\
80 \\
98\end{array}$ & $\begin{array}{r}3 \\
29 \\
4 \\
0 \\
316 \\
137 \\
69 \\
87\end{array}$ & $\begin{array}{r}10 \\
9 \\
3 \\
0 \\
280 \\
115 \\
50 \\
75 \\
\end{array}$ \\
\hline Total ............. & 1,338 & 1,148 & 967 & 436 & 368 & 304 & 120 & 107 & 94 & 29 & 26 & 21 & 751 & 646 & 546 \\
\hline Total, North . .......... & 39,114 & 34,020 & 27,777 & 3,091 & 2,652 & 1,951 & 4,838 & 4,141 & 3,295 & 11,237 & 7,732 & 6,172 & 19,946 & 19,494 & 16,357 \\
\hline $\begin{array}{l}\text { South Atlantic: } \\
\text { North Carolina. } \\
\text { South Carolina. } \\
\text { Virginia... }\end{array}$ & $\begin{array}{l}8,509 \\
6,369 \\
4,215 \\
\end{array}$ & $\begin{array}{l}7,938 \\
5,324 \\
4,343 \\
\end{array}$ & $\begin{array}{l}7,421 \\
4,800 \\
4,439 \\
\end{array}$ & $\begin{array}{l}317 \\
649 \\
171\end{array}$ & $\begin{array}{l}295 \\
567 \\
188\end{array}$ & $\begin{array}{l}274 \\
581 \\
193\end{array}$ & $\begin{array}{l}301 \\
326 \\
183\end{array}$ & $\begin{array}{l}281 \\
238 \\
181\end{array}$ & $\begin{array}{l}219 \\
112 \\
185\end{array}$ & $\begin{array}{l}1,181 \\
1,304 \\
710\end{array}$ & $\begin{array}{r}1,102 \\
1,017 \\
659\end{array}$ & $\begin{array}{r}1,262 \\
700 \\
673\end{array}$ & $\begin{array}{l}6,708 \\
4,088 \\
3,149\end{array}$ & $\begin{array}{l}6,259 \\
3,502 \\
3,314\end{array}$ & $\begin{array}{l}5,665 \\
3,406 \\
3,387 \\
\end{array}$ \\
\hline Total & 19,093 & 17,606 & 16,661 & 1,138 & 1,051 & 1,049 & 812 & 701 & 517 & 3,196 & 2,778 & 2,635 & 13,946 & 13,075 & 12,459 \\
\hline $\begin{array}{l}\text { East Gulf: } \\
\text { Florida } \\
\text { Georgia }\end{array}$ & $\begin{array}{r}6,904 \\
11,839\end{array}$ & $\begin{array}{r}5,870 \\
10,215\end{array}$ & $\begin{array}{l}5,108 \\
8,924\end{array}$ & $\begin{array}{l}754 \\
395\end{array}$ & $\begin{array}{l}616 \\
341\end{array}$ & $\begin{array}{l}521 \\
297\end{array}$ & $\begin{array}{l}510 \\
724\end{array}$ & $\begin{array}{l}379 \\
625\end{array}$ & $\begin{array}{l}295 \\
545\end{array}$ & $\begin{array}{l}2,219 \\
2,240 \\
\end{array}$ & $\begin{array}{l}1,860 \\
1,932\end{array}$ & $\begin{array}{l}1,602 \\
1,688\end{array}$ & $\begin{array}{l}3,419 \\
8,479\end{array}$ & $\begin{array}{l}3,013 \\
7,316 \\
\end{array}$ & $\begin{array}{l}2,689 \\
6,391 \\
\end{array}$ \\
\hline Total $\ldots$ & 18,743 & 16,086 & 14,032 & 1,150 & 957 & 818 & 1,234 & 1,004 & 841 & 4,459 & 3,793 & 3, 291 & 11,898 & 10,330 & 9,081 \\
\hline $\begin{array}{l}\text { Central Gulf: } \\
\text { Alabama } \\
\text { Mississippi. } \\
\text { Tennessee... }\end{array}$ & $\begin{array}{l}9,232 \\
7,188 \\
1,799\end{array}$ & $\begin{array}{l}7,673 \\
5,259 \\
1,479\end{array}$ & $\begin{array}{l}5,875 \\
3,673 \\
1,226\end{array}$ & $\begin{array}{r}443 \\
1,074 \\
261\end{array}$ & $\begin{array}{r}368 \\
1,089 \\
293\end{array}$ & $\begin{array}{l}278 \\
578 \\
219\end{array}$ & $\begin{array}{l}178 \\
373 \\
197\end{array}$ & $\begin{array}{l}147 \\
221 \\
101\end{array}$ & $\begin{array}{r}98 \\
341 \\
101\end{array}$ & $\begin{array}{r}2,555 \\
1,373 \\
170 \\
\end{array}$ & $\begin{array}{r}2,124 \\
1,450 \\
96\end{array}$ & $\begin{array}{r}1,634 \\
1,419 \\
79\end{array}$ & $\begin{array}{l}6,055 \\
4,368 \\
1,170\end{array}$ & $\begin{array}{r}5,032 \\
2,498 \\
987\end{array}$ & $\begin{array}{r}3,864 \\
1,334 \\
826\end{array}$ \\
\hline Total & 18,220 & 14,411 & 10,776 & 1,778 & 1,750 & 1,076 & 748 & 470 & 541 & 4,100 & 3,671 & 3,132 & 11,593 & 8,519 & 6,025 \\
\hline $\begin{array}{l}\text { West Gulf: } \\
\text { Arkansas_....... } \\
\text { Louisiana..... } \\
\text { Oklahoma. } \\
\text { Texas. }\end{array}$ & $\begin{array}{r}6,539 \\
7,595 \\
850 \\
7,361 \\
\end{array}$ & $\begin{array}{r}5,810 \\
6,118 \\
692 \\
6,061 \\
\end{array}$ & $\begin{array}{r}4,640 \\
4,253 \\
539 \\
4,211 \\
\end{array}$ & $\begin{array}{r}1,227 \\
575 \\
102 \\
948\end{array}$ & $\begin{array}{r}1,148 \\
472 \\
117 \\
1,156 \\
\end{array}$ & $\begin{array}{r}885 \\
267 \\
73 \\
679 \\
\end{array}$ & $\begin{array}{r}90 \\
103 \\
26 \\
125 \\
\end{array}$ & $\begin{array}{r}54 \\
110 \\
2 \\
85\end{array}$ & $\begin{array}{r}40 \\
82 \\
2 \\
49 \\
\end{array}$ & $\begin{array}{r}2,685 \\
2,420 \\
501 \\
3,250 \\
\end{array}$ & $\begin{array}{r}3,275 \\
3,003 \\
456 \\
2,662 \\
\end{array}$ & $\begin{array}{r}2,383 \\
2,145 \\
359 \\
1,901 \\
\end{array}$ & $\begin{array}{r}2,535 \\
4,496 \\
220 \\
3,037\end{array}$ & $\begin{array}{r}1,332 \\
2,532 \\
116 \\
2,156\end{array}$ & $\begin{array}{r}1,330 \\
1,758 \\
104 \\
1,582 \\
\end{array}$ \\
\hline Total & 22,346 & 18,682 & 13,645 & 2,853 & 2,895 & 1,905 & 345 & 252 & 175 & 8,856 & 9,396 & 6,788 & 10,290 & 6,138 & 4,775 \\
\hline Total, South.... & 78,404 & 66,786 & 55,115 & 6,921 & 6,654 & 4,851 & 3,140 & 2,428 & 2,075 & 20,613 & 19,639 & 15,818 & 47,729 & 38,063 & 32,340 \\
\hline
\end{tabular}

See footnote at end of table. 
T.1BLE 6.-- Vet volume of softuood growing stock on commercial timberland in the Lnited States, by ownership and section, region, and State, as of December 31, 1952 and 1962, and January 1, 1970-Continued

[Million cubic feet]

\begin{tabular}{|c|c|c|c|c|c|c|c|c|c|c|c|c|c|c|c|}
\hline \multirow{2}{*}{ Section, region, and State } & \multicolumn{3}{|c|}{ Total, all ownerships } & \multicolumn{3}{|c|}{ National Forest } & \multicolumn{3}{|c|}{ Other public } & \multicolumn{3}{|c|}{ Forest industry } & \multicolumn{3}{|c|}{$\begin{array}{c}\text { Farm and miscellaneous } \\
\text { private }\end{array}$} \\
\hline & 1970 & 1962 & 1952 & 1970 & 1962 & 1952 & 1970 & 1962 & 1952 & 1970 & 1962 & 1952 & 1970 & 1962 & 1952 \\
\hline $\begin{array}{l}\text { Pacific Northwest: } \\
\text { Alaska: Coastal.. }\end{array}$ & 34,468 & 35,485 & $3.5,493$ & 31,616 & 32,548 & 32,531 & $2,6 \pi 1$ & 2,749 & 2,773 & 0 & 0 & 0 & 181 & 187 & 188 \\
\hline $\begin{array}{l}\text { Oregon: } \\
\text { Western... } \\
\text { Eastern... }\end{array}$ & $\begin{array}{l}56,823 \\
24,238 \\
\end{array}$ & $\begin{array}{r}60,155 \\
23,989 \\
\end{array}$ & $\begin{array}{l}64,302 \\
23,2,5 \\
\end{array}$ & $\frac{29,674}{17,67 \pi}$ & $\begin{array}{l}30,723 \\
17,373\end{array}$ & $\begin{array}{l}30,047 \\
15,411 \\
\end{array}$ & $\begin{array}{r}11,295 \\
1,590\end{array}$ & $\begin{array}{r}11,652 \\
1,692 \\
\end{array}$ & $\begin{array}{r}12,283 \\
2,989\end{array}$ & $\begin{array}{r}10,304 \\
2,257 \\
\end{array}$ & $\begin{array}{r}12,695 \\
2,539 \\
\end{array}$ & $\begin{array}{r}16,386 \\
2,674 \\
\end{array}$ & $\begin{array}{l}5,550 \\
2,714\end{array}$ & $\begin{array}{l}5,080 \\
2,385\end{array}$ & $\begin{array}{l}5,586 \\
2,174\end{array}$ \\
\hline summary... & $\$ 1,061$ & $84,1+4$ & $8 \bar{i}, 580$ & 47,351 & 45,101 & 45,488 & 12,885 & 13,344 & 15,272 & 12,561 & 15,234 & 19,060 & 8,264 & 7,465 & 7,760 \\
\hline $\begin{array}{l}\text { Washington: } \\
\text { Western.... } \\
\text { Eastern.... }\end{array}$ & $\begin{array}{l}42,336 \\
17,621 \\
\end{array}$ & $\begin{array}{l}44,255 \\
17,312 \\
\end{array}$ & $\begin{array}{l}45,602 \\
16,392 \\
\end{array}$ & $\begin{array}{r}15,804 \\
8,234 \\
\end{array}$ & $\begin{array}{r}16,976 \\
8,385 \\
\end{array}$ & $\begin{array}{r}17,537 \\
7,967 \\
\end{array}$ & $\begin{array}{l}8,315 \\
4,516 \\
\end{array}$ & $\begin{array}{l}8,135 \\
4,953 \\
\end{array}$ & $\begin{array}{l}7,802 \\
4,803 \\
\end{array}$ & $\begin{array}{r}13,463 \\
1,371\end{array}$ & $\begin{array}{r}14,704 \\
1,203\end{array}$ & $\begin{array}{r}16,339 \\
1,301\end{array}$ & $\begin{array}{l}4,754 \\
3,140 \\
\end{array}$ & $\begin{array}{l}4,440 \\
2,771 \\
\end{array}$ & $\begin{array}{l}3,924 \\
2,321\end{array}$ \\
\hline Summary... & 59,957 & 61,567 & 61,994 & 24.038 & 25,361 & 25,504 & 13,191 & 13,088 & 12,605 & 14,834 & 15,907 & 17,640 & 7,894 & 7,211 & 6,245 \\
\hline Total.. & 175,456 & 181,196 & 155,067 & 103,005 & 106,010 & 103,523 & $28,74 \pi$ & 29,181 & 30,650 & 27,395 & 31,141 & 36,700 & 16,339 & 14,863 & 14,193 \\
\hline $\begin{array}{l}\text { Pacific Southwest: } \\
\text { California... } \\
\text { Hawaii. }\end{array}$ & $\begin{array}{r}51,152 \\
4 \\
\end{array}$ & $\begin{array}{r}53,950 \\
3 \\
\end{array}$ & $\begin{array}{r}58,006 \\
3\end{array}$ & $\begin{array}{r}28,955 \\
0 \\
\end{array}$ & $\begin{array}{r}29,976 \\
0 \\
\end{array}$ & $\begin{array}{r}29,590 \\
0 \\
\end{array}$ & $\begin{array}{r}1,280 \\
2 \\
\end{array}$ & $\begin{array}{r}1,435 \\
2 \\
\end{array}$ & 1,892 & $\begin{array}{r}8,688 \\
0 \\
\end{array}$ & $\begin{array}{r}9,639 \\
0\end{array}$ & $\begin{array}{r}11,268 \\
0\end{array}$ & $\begin{array}{r}12,229 \\
1\end{array}$ & $\begin{array}{r}12,900 \\
1\end{array}$ & $\begin{array}{r}15,256 \\
1\end{array}$ \\
\hline Total.. & 51,156 & 53,953 & 58,009 & 28,955 & 29,976 & 29,590 & 1,282 & 1,437 & 1,894 & 8.688 & 9.639 & 11,268 & 12,230 & 12,901 & $15,25 \pi$ \\
\hline Total, Pacific Cosst... & 226,643 & 235,150 & $243,0 \pi$ & 131,960 & 135,986 & 133,113 & 30,029 & 30,619 & 32,545 & 36,083 & 40,780 & 47,968 & 28,569 & 27,764 & 29,450 \\
\hline $\begin{array}{l}\text { Jorthern Rocky Mountain: } \\
\text { Idaho } \\
\text { Jontana. } \\
\text { South Dakota (West) } \\
\text { Wyorning }\end{array}$ & $\begin{array}{r}29,257 \\
28,376 \\
1,001 \\
4,471 \\
\end{array}$ & $\begin{array}{r}29,578 \\
29,044 \\
925 \\
5,543 \\
\end{array}$ & $\begin{array}{r}27,736 \\
26,290 \\
825 \\
5,260 \\
\end{array}$ & $\begin{array}{r}19,185 \\
15,775 \\
753 \\
3,074\end{array}$ & $\begin{array}{r}20,212 \\
19,612 \\
711 \\
4,233\end{array}$ & $\begin{array}{r}18,893 \\
17,443 \\
648 \\
4,074 \\
\end{array}$ & $\begin{array}{r}3,267 \\
2,543 \\
55 \\
576\end{array}$ & $\begin{array}{r}3,091 \\
2,493 \\
47 \\
541\end{array}$ & $\begin{array}{r}2,991 \\
2,334 \\
39 \\
490\end{array}$ & $\begin{array}{r}2,912 \\
2,097 \\
11 \\
60\end{array}$ & $\begin{array}{r}2,682 \\
2,116 \\
10 \\
5 \% \\
\end{array}$ & $\begin{array}{r}2,497 \\
2,027 \\
8 \\
51 \\
\end{array}$ & $\begin{array}{r}3,892 \\
4,960 \\
180 \\
757 \\
\end{array}$ & $\begin{array}{r}3,592 \\
4,822 \\
155 \\
711 \\
\end{array}$ & $\begin{array}{r}3,353 \\
4,484 \\
128 \\
643\end{array}$ \\
\hline Total... & 63.106 & 65,091 & 60,111 & 41,791 & 44,768 & 41,060 & 6,442 & 6,174 & $5,8.56$ & 5,052 & 4,866 & 4,585 & 9,790 & 9,281 & 8,609 \\
\hline 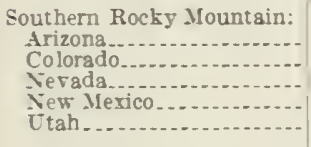 & $\begin{array}{r}4,583 \\
10,360 \\
, 237 \\
5,735 \\
3,689 \\
\end{array}$ & $\begin{array}{r}4,688 \\
11,7-74 \\
244 \\
5,739 \\
3,726\end{array}$ & $\begin{array}{r}4,600 \\
10,925 \\
234 \\
5,513 \\
3,656 \\
\end{array}$ & $\begin{array}{l}3,028 \\
7,222 \\
7,74 \\
2,810 \\
2,935\end{array}$ & $\begin{array}{l}3,077 \\
8,823 \\
86 \\
2,836 \\
2,937\end{array}$ & $\begin{array}{l}2,888 \\
8,204 \\
2,797 \\
2,784 \\
\end{array}$ & 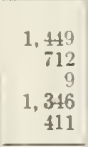 & $\begin{array}{r}1,502 \\
670 \\
8 \\
1,337 \\
431 \\
\end{array}$ & $\begin{array}{r}1,596 \\
618 \\
8 \\
1,352 \\
476 \\
\end{array}$ & $\begin{array}{r}0 \\
21 \\
15 \\
112 \\
0\end{array}$ & $\begin{array}{r}0 \\
20 \\
15 \\
112 \\
0\end{array}$ & $\begin{array}{r}0 \\
18 \\
14 \\
113 \\
0\end{array}$ & $\begin{array}{r}105 \\
2,403 \\
138 \\
1,464 \\
342 \\
\end{array}$ & $\begin{array}{r}109 \\
2,260 \\
134 \\
1,454 \\
358\end{array}$ & $\begin{array}{r}116 \\
2,083 \\
132 \\
1,470 \\
395\end{array}$ \\
\hline Total... & 24,605 & 26,173 & 24,931 & 16,071 & 17.759 & 16,534 & 3,929 & 3,949 & 4,051 & 149 & $14 i$ & 146 & 4,455 & 4,316 & 4,198 \\
\hline $\begin{array}{l}\text { Total, Rocky } \\
\text { Mountain.... }\end{array}$ & $8 i, 711$ & 91,264 & 85,043 & $5 \bar{i}, 862$ & 62,528 & 57,595 & $10,3 \pi 2$ & 10,124 & $9,90 \pi$ & 5,231 & 5,013 & 4,732 & 14,245 & 13,598 & 12,808 \\
\hline Total, all regions ... & $431,8: 3$ & 426,221 & 411,012 & 199,835 & 207,821 & 197,511 & 48,380 & 47,314 & 47,824 & 73,166 & 73,165 & 74,720 & 110,491 & 98,920 & 90,957 \\
\hline
\end{tabular}

${ }_{1}$ Data may not add to totals because of truncating. Zeros indicate no data or negligible amounts. 
TABLE 7.-Net volume of hardwood growing stock on commercial timberland in the United States, by ownership and section, region, and State, as of December 31,1952 and 1962, and January 1, 19701

[Million cubic feet]

\begin{tabular}{|c|c|c|c|c|c|c|c|c|c|c|c|c|c|c|c|}
\hline \multirow{2}{*}{ Section, region, and State } & \multicolumn{3}{|c|}{ Total, all ownerships } & \multicolumn{3}{|c|}{ National Forest } & \multicolumn{3}{|c|}{ Other public } & \multicolumn{3}{|c|}{ Forest industry } & \multicolumn{3}{|c|}{$\begin{array}{c}\text { Farm and miscellaneous } \\
\text { private }\end{array}$} \\
\hline & 1970 & 1962 & 1952 & 1970 & 1962 & 1952 & 1970 & 1962 & 1952 & 1970 & 1962 & 1952 & 1970 & 1962 & 1952 \\
\hline $\begin{array}{l}\text { New England: } \\
\text { Connecticut } \\
\text { Maine } \\
\text { Massachusetts. } \\
\text { New Hampshire. } \\
\text { Rhode Island. } \\
\text { Vermont }\end{array}$ & $\begin{array}{r}1,670 \\
6,490 \\
1,946 \\
2,245 \\
246 \\
2,420 \\
\end{array}$ & $\begin{array}{r}1,596 \\
6,047 \\
1,734 \\
2,021 \\
205 \\
2,318\end{array}$ & $\begin{array}{r}1,146 \\
5,378 \\
1,240 \\
1,756 \\
146 \\
2,227\end{array}$ & $\begin{array}{r}0 \\
45 \\
0 \\
617 \\
0 \\
163\end{array}$ & $\begin{array}{r}0 \\
21 \\
0 \\
556 \\
0 \\
157\end{array}$ & $\begin{array}{r}0 \\
18 \\
0 \\
483 \\
0 \\
151\end{array}$ & $\begin{array}{r}176 \\
86 \\
258 \\
48 \\
18 \\
118\end{array}$ & $\begin{array}{r}168 \\
59 \\
229 \\
43 \\
15 \\
113\end{array}$ & $\begin{array}{r}121 \\
50 \\
164 \\
37 \\
10 \\
109\end{array}$ & $\begin{array}{r}2 \\
3,284 \\
150 \\
307 \\
0 \\
418\end{array}$ & $\begin{array}{r}2 \\
2,489 \\
133 \\
276 \\
0 \\
400\end{array}$ & $\begin{array}{r}1 \\
2,215 \\
95 \\
240 \\
0 \\
385\end{array}$ & $\begin{array}{r}1,491 \\
3,073 \\
1,538 \\
1,271 \\
228 \\
1,720\end{array}$ & $\begin{array}{r}1,425 \\
3,477 \\
1,371 \\
1,144 \\
190 \\
1,646\end{array}$ & $\begin{array}{r}1,023 \\
3,094 \\
980 \\
994 \\
135 \\
1,582\end{array}$ \\
\hline Total ... & 15,019 & 13,923 & 11,894 & 826 & 735 & 653 & 706 & 630 & 494 & 4,162 & 3,303 & 2,938 & 9,324 & 9,254 & 7,809 \\
\hline $\begin{array}{l}\text { Middle Atlantic: } \\
\text { Delaware } \\
\text { Maryland.... } \\
\text { New Jersey. } \\
\text { New York } \\
\text { Pennsylvania. } \\
\text { West Virginia......... }\end{array}$ & $\begin{array}{r}428 \\
2,543 \\
1,343 \\
9,226 \\
18,670 \\
13,428\end{array}$ & $\begin{array}{r}318 \\
2,304 \\
1,139 \\
8,604 \\
15,602 \\
11,080\end{array}$ & $\begin{array}{r}219 \\
2,053 \\
916 \\
7,775 \\
11,716 \\
8,621 \\
\end{array}$ & $\begin{array}{r}0 \\
0 \\
0 \\
0 \\
707 \\
1,380\end{array}$ & $\begin{array}{r}0 \\
0 \\
0 \\
0 \\
591 \\
1,139\end{array}$ & $\begin{array}{r}0 \\
0 \\
0 \\
0 \\
444 \\
886\end{array}$ & $\begin{array}{r}8 \\
176 \\
68 \\
613 \\
3,604 \\
524\end{array}$ & $\begin{array}{r}6 \\
159 \\
58 \\
\mathbf{5 7 2} \\
3,012 \\
432\end{array}$ & $\begin{array}{r}4 \\
141 \\
46 \\
517 \\
2,262 \\
336\end{array}$ & $\begin{array}{r}29 \\
65 \\
2 \\
855 \\
816 \\
781\end{array}$ & $\begin{array}{r}23 \\
59 \\
2 \\
797 \\
681 \\
645\end{array}$ & $\begin{array}{r}13 \\
52 \\
1 \\
720 \\
512 \\
502\end{array}$ & $\begin{array}{r}390 \\
2,301 \\
1,272 \\
7,757 \\
13,542 \\
10,741\end{array}$ & $\begin{array}{r}288 \\
2,085 \\
1,079 \\
7,234 \\
11,316 \\
8,863 \\
\end{array}$ & $\begin{array}{r}202 \\
1,858 \\
867 \\
6,537 \\
8,498 \\
6,896 \\
\end{array}$ \\
\hline Total... & 45,639 & 39,049 & 31,302 & 2,088 & 1,730 & 1,330 & 4,996 & 4,241 & 3,308 & 2,550 & 2,209 & 1,803 & 36,004 & 30,868 & 24,860 \\
\hline $\begin{array}{l}\text { Lake States: } \\
\text { Michigan } \\
\text { Minnesota. } \\
\text { North Dakota } \\
\text { South Dakota (East) } \\
\text { Wisconsin }\end{array}$ & $\begin{array}{r}12,245 \\
7,830 \\
276 \\
83 \\
8,748\end{array}$ & $\begin{array}{r}10,387 \\
6,194 \\
265 \\
71 \\
7,729 \\
\end{array}$ & $\begin{array}{r}7,609 \\
4,399 \\
257 \\
73 \\
6,411 \\
\end{array}$ & $\begin{array}{r}1,189 \\
1,021 \\
0 \\
0 \\
762 \\
\end{array}$ & $\begin{array}{r}948 \\
808 \\
0 \\
0 \\
672\end{array}$ & $\begin{array}{r}578 \\
570 \\
0 \\
0 \\
564 \\
\end{array}$ & $\begin{array}{r}2,492 \\
3,012 \\
85 \\
15 \\
1,654 \\
\end{array}$ & $\begin{array}{r}2,072 \\
2,382 \\
82 \\
12 \\
1,460 \\
\end{array}$ & $\begin{array}{r}1,418 \\
1,652 \\
79 \\
12 \\
1,192 \\
\end{array}$ & $\begin{array}{r}1,604 \\
373 \\
0 \\
0 \\
841\end{array}$ & $\begin{array}{r}1,410 \\
295 \\
0 \\
0 \\
742\end{array}$ & $\begin{array}{r}1,174 \\
213 \\
0 \\
0 \\
423\end{array}$ & $\begin{array}{r}6,959 \\
3,423 \\
191 \\
67 \\
5,490 \\
\end{array}$ & $\begin{array}{r}5,957 \\
2,708 \\
182 \\
58 \\
4,854\end{array}$ & $\begin{array}{r}4,438 \\
1,963 \\
178 \\
60 \\
4,231\end{array}$ \\
\hline Total . & 29,184 & 24,648 & 18,751 & 2,973 & 2,428 & 1,713 & 7,259 & 6,011 & 4,355 & 2,818 & 2,447 & 1,811 & 16,131 & 13,761 & 10,872 \\
\hline $\begin{array}{l}\text { Central: } \\
\text { Illinois } \\
\text { Indiana... } \\
\text { Iowa } \\
\text { Kansas } \\
\text { Kentucky } \\
\text { Missouri } \\
\text { Nebraska...... } \\
\text { Ohio......... }\end{array}$ & $\begin{array}{r}2,308 \\
3,536 \\
1,803 \\
533 \\
7,925 \\
6,111 \\
391 \\
4,109 \\
\end{array}$ & $\begin{array}{r}2,328 \\
3,319 \\
1,570 \\
478 \\
6,835 \\
4,903 \\
361 \\
3,760\end{array}$ & $\begin{array}{r}2,356 \\
2,876 \\
1,356 \\
476 \\
5,859 \\
3,836 \\
284 \\
3,152\end{array}$ & $\begin{array}{r}108 \\
150 \\
1 \\
0 \\
425 \\
700 \\
0 \\
93\end{array}$ & $\begin{array}{r}109 \\
116 \\
1 \\
0 \\
366 \\
564 \\
0 \\
85\end{array}$ & $\begin{array}{r}69 \\
50 \\
1 \\
0 \\
314 \\
406 \\
0 \\
72\end{array}$ & $\begin{array}{r}43 \\
241 \\
24 \\
22 \\
245 \\
114 \\
9 \\
243\end{array}$ & $\begin{array}{r}44 \\
222 \\
19 \\
19 \\
211 \\
86 \\
8 \\
222\end{array}$ & $\begin{array}{r}35 \\
185 \\
18 \\
16 \\
181 \\
75 \\
6 \\
186\end{array}$ & $\begin{array}{r}6 \\
20 \\
6 \\
0 \\
231 \\
118 \\
0 \\
113\end{array}$ & $\begin{array}{r}6 \\
21 \\
5 \\
0 \\
199 \\
89 \\
0 \\
103\end{array}$ & $\begin{array}{r}15 \\
20 \\
5 \\
0 \\
171 \\
78 \\
0 \\
86\end{array}$ & $\begin{array}{r}2,149 \\
3,124 \\
1,771 \\
511 \\
7,023 \\
5,177 \\
382 \\
3,658\end{array}$ & $\begin{array}{r}2,168 \\
2,959 \\
1,545 \\
458 \\
6,057 \\
4,162 \\
352 \\
3,348\end{array}$ & $\begin{array}{r}2,266 \\
2,619 \\
1,331 \\
460 \\
5,192 \\
3,277 \\
277 \\
2,807\end{array}$ \\
\hline Total $\ldots$ & 26,719 & 23,556 & 20,228 & 1,479 & 1,242 & 912 & 943 & 834 & 705 & 497 & 426 & 377 & 23,798 & 21,052 & 18,233 \\
\hline Total, North............ & 116,563 & 101,177 & 82,177 & 7,368 & 6,137 & 4,608 & 13,906 & 11,717 & 8,863 & 10,028 & 8,386 & 6,929 & 85,260 & 74,936 & 61,775 \\
\hline $\begin{array}{l}\text { South Atlantic: } \\
\text { North Carolina } \\
\text { South Carolina. } \\
\text { Virginia. }\end{array}$ & $\begin{array}{r}11,171 \\
6,330 \\
10,955\end{array}$ & $\begin{array}{r}10,391 \\
5,652 \\
10,171\end{array}$ & $\begin{array}{l}9,547 \\
5,411 \\
9,010 \\
\end{array}$ & $\begin{array}{l}960 \\
275 \\
939\end{array}$ & $\begin{array}{l}893 \\
236 \\
817\end{array}$ & $\begin{array}{l}730 \\
195 \\
724\end{array}$ & $\begin{array}{l}253 \\
193 \\
361\end{array}$ & $\begin{array}{l}235 \\
151 \\
213\end{array}$ & $\begin{array}{r}153 \\
75 \\
189\end{array}$ & $\begin{array}{r}1,154 \\
1,313 \\
881\end{array}$ & $\begin{array}{r}1,073 \\
1,062 \\
821\end{array}$ & $\begin{array}{r}1,353 \\
650 \\
727\end{array}$ & $\begin{array}{l}8,803 \\
4,547 \\
8,769\end{array}$ & $\begin{array}{l}8,188 \\
4,202 \\
8,318\end{array}$ & $\begin{array}{l}7,299 \\
\mathbf{4}, 489 \\
7,369 \\
\end{array}$ \\
\hline Total_... & 28,456 & 26,215 & 23,968 & 2,175 & 1,947 & 1,649 & 808 & 601 & 418 & 3,352 & 2,957 & 2,742 & 22,120 & 20,709 & 19,158 \\
\hline $\begin{array}{l}\text { East Gulf: } \\
\text { Florida } \\
\text { Georgia........ }\end{array}$ & $\begin{array}{l}3,984 \\
7,855 \\
\end{array}$ & $\begin{array}{l}3,706 \\
7,624 \\
\end{array}$ & $\begin{array}{l}3,517 \\
7,467 \\
\end{array}$ & $\begin{array}{l}171 \\
560\end{array}$ & $\begin{array}{l}129 \\
544\end{array}$ & $\begin{array}{l}102 \\
533\end{array}$ & $\begin{array}{l}128 \\
228\end{array}$ & $\begin{array}{l}100 \\
220\end{array}$ & $\begin{array}{r}75 \\
216\end{array}$ & $\begin{array}{l}1,302 \\
1,075 \\
\end{array}$ & $\begin{array}{l}1,120 \\
1,043 \\
\end{array}$ & $\begin{array}{l}1,053 \\
1,022 \\
\end{array}$ & $\begin{array}{l}2,382 \\
5,991 \\
\end{array}$ & $\begin{array}{l}2,357 \\
5,815 \\
\end{array}$ & $\begin{array}{l}2,285 \\
5,695 \\
\end{array}$ \\
\hline Total $\ldots$ & 11,839 & 11,331 & 10,984 & 731 & 673 & 636 & 356 & 320 & 392 & 2,378 & 2,164 & 2,075 & 8,373 & 8,173 & 7,980 \\
\hline $\begin{array}{l}\text { Central Gulf: } \\
\text { Alabama } \\
\text { Mississippi. } \\
\text { Tennessee }\end{array}$ & $\begin{array}{l}6,777 \\
6,689 \\
8,596 \\
\end{array}$ & $\begin{array}{l}6,774 \\
6,281 \\
7,819 \\
\end{array}$ & $\begin{array}{l}6,476 \\
6,370 \\
7,023 \\
\end{array}$ & $\begin{array}{l}190 \\
342 \\
475\end{array}$ & $\begin{array}{l}190 \\
394 \\
387\end{array}$ & $\begin{array}{l}146 \\
143 \\
275\end{array}$ & $\begin{array}{l}\mathbf{1 2 3} \\
\mathbf{3 3 5} \\
\mathbf{5 2 6}\end{array}$ & $\begin{array}{l}123 \\
187 \\
402\end{array}$ & $\begin{array}{r}82 \\
199 \\
377\end{array}$ & $\begin{array}{r}1,071 \\
943 \\
733\end{array}$ & $\begin{array}{r}1,071 \\
970 \\
563 \\
\end{array}$ & $\begin{array}{l}887 \\
648 \\
436\end{array}$ & $\begin{array}{l}5,392 \\
5,067 \\
6,860 \\
\end{array}$ & $\begin{array}{l}5,390 \\
4,728 \\
6,465 \\
\end{array}$ & $\begin{array}{l}5,360 \\
5,380 \\
5,932 \\
\end{array}$ \\
\hline Total $\ldots$ & 22,062 & 20,875 & 19,871 & 1,007 & 972 & 566 & 986 & 714 & 659 & 2,748 & 2,604 & 1,972 & 17,319 & 16,584 & 16,673 \\
\hline 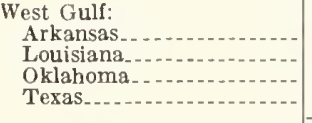 & $\begin{array}{r}8,826 \\
6,006 \\
798 \\
3,121 \\
\end{array}$ & $\begin{array}{r}9,256 \\
6,395 \\
827 \\
3,353 \\
\end{array}$ & $\begin{array}{r}9,468 \\
6,756 \\
839 \\
3,680 \\
\end{array}$ & $\begin{array}{r}1,076 \\
107 \\
20 \\
106\end{array}$ & $\begin{array}{r}997 \\
113 \\
55 \\
145 \\
\end{array}$ & $\begin{array}{r}656 \\
89 \\
42 \\
115\end{array}$ & $\begin{array}{r}444 \\
138 \\
70 \\
53\end{array}$ & $\begin{array}{r}562 \\
109 \\
30 \\
23\end{array}$ & $\begin{array}{r}359 \\
114 \\
30 \\
18\end{array}$ & $\begin{array}{r}1,910 \\
1,197 \\
135 \\
851\end{array}$ & $\begin{array}{r}2,197 \\
1,186 \\
130 \\
1,001\end{array}$ & $\begin{array}{r}1,366 \\
1,183 \\
128 \\
969\end{array}$ & $\begin{array}{r}5,395 \\
4,563 \\
571 \\
2,109\end{array}$ & $\begin{array}{r}5,498 \\
4,986 \\
610 \\
2,183\end{array}$ & $\begin{array}{r}7,085 \\
5,369 \\
637 \\
2,576\end{array}$ \\
\hline Total $\ldots \ldots \ldots$ & 18,753 & 19,832 & 20,745 & 1,311 & 1,310 & 903 & 706 & 726 & 523 & 4,095 & 4,516 & 3,647 & 12,639 & 13,279 & 15,669 \\
\hline Total, South $\ldots . . .$. & 81,112 & 78,255 & 75,569 & 5,226 & 4,903 & 3,755 & 2,857 & 2,363 & 1,894 & 12,574 & 12,243 & 10,437 & 60,453 & 58,745 & 59,481 \\
\hline
\end{tabular}

See footnotes at end of table. 
TABLE 7.- Net volume of hardwood growing stock on commercial timberland in the United States, by ownership and section, region, and State, as of December 31, 1952 and 1962, and January 1, 1970 1-Continued

[Million cubic feet]

\begin{tabular}{|c|c|c|c|c|c|c|c|c|c|c|c|c|c|c|c|}
\hline \multirow{2}{*}{ Section, region, and State } & \multicolumn{3}{|c|}{ Total, all ownerships } & \multicolumn{3}{|c|}{ National Forest } & \multicolumn{3}{|c|}{ Other public } & \multicolumn{3}{|c|}{ Forest industry } & \multicolumn{3}{|c|}{$\begin{array}{c}\text { Farm and miscellaneous } \\
\text { private }\end{array}$} \\
\hline & 1970 & 1962 & 1952 & 1970 & 1962 & 1952 & 1970 & 1962 & 1952 & 1970 & 1962 & 1952 & 1970 & 1962 & 1952 \\
\hline $\begin{array}{l}\text { Pacific Northwest: } \\
\text { Alaska: Coastal . }\end{array}$ & 298 & 300 & 298 & 274 & 275 & 273 & 23 & 23 & 23 & 0 & 0 & 0 & 1 & 1 & 1 \\
\hline $\begin{array}{l}\text { Oregon: } \\
\text { Western.......... } \\
\text { Eastern......... }\end{array}$ & $\begin{array}{r}5,994 \\
38\end{array}$ & $\begin{array}{r}5,119 \\
35\end{array}$ & $\begin{array}{r}4,192 \\
31\end{array}$ & $\begin{array}{r}925 \\
11\end{array}$ & $\begin{array}{r}859 \\
10\end{array}$ & $\begin{array}{r}714 \\
9\end{array}$ & $\begin{array}{r}1,098 \\
2\end{array}$ & $\begin{array}{r}829 \\
2\end{array}$ & $\begin{array}{r}627 \\
3\end{array}$ & $\begin{array}{r}1,410 \\
1\end{array}$ & $\begin{array}{r}1,210 \\
1\end{array}$ & $\begin{array}{r}939 \\
1\end{array}$ & $\begin{array}{r}2,561 \\
24\end{array}$ & $\begin{array}{r}2,221 \\
22\end{array}$ & $\begin{array}{r}1,912 \\
18\end{array}$ \\
\hline Summary--- & 6,032 & 5,154 & 4,223 & 936 & 869 & 723 & 1,100 & 831 & 630 & 1,411 & 1,211 & 940 & 2,585 & 2,243 & 1,930 \\
\hline $\begin{array}{l}\text { Washington: } \\
\text { Western..... } \\
\text { Eastern..... }\end{array}$ & $\begin{array}{r}4,95 i \\
171 \\
\end{array}$ & $\begin{array}{r}3,944 \\
157 \\
\end{array}$ & $\begin{array}{r}2,716 \\
143 \\
\end{array}$ & $\begin{array}{r}125 \\
33 \\
\end{array}$ & $\begin{array}{r}113 \\
33\end{array}$ & $\begin{array}{l}90 \\
31\end{array}$ & $\begin{array}{r}932 \\
58\end{array}$ & $\begin{array}{r}697 \\
57 \\
\end{array}$ & $\begin{array}{r}453 \\
54\end{array}$ & $\begin{array}{r}1,854 \\
17 \\
\end{array}$ & $\begin{array}{r}1,453 \\
11\end{array}$ & $\begin{array}{r}950 \\
10\end{array}$ & $\begin{array}{r}2,073 \\
63 \\
\end{array}$ & $\begin{array}{r}1,681 \\
56 \\
\end{array}$ & $\begin{array}{r}1,223 \\
45\end{array}$ \\
\hline Summary -... & 5,158 & 4,101 & 2,859 & 161 & 146 & 121 & 990 & 754 & 507 & 1,871 & 1,464 & 960 & 2,136 & 1,737 & 1,271 \\
\hline Total .. & 11,488 & 9,555 & 7.380 & 1,371 & 1,290 & 1,117 & 2,113 & 1,608 & 1,160 & 3,282 & 2,675 & 1,900 & 4,722 & 3,981 & 3,202 \\
\hline $\begin{array}{l}\text { Pacific Southwest: } \\
\text { California........ } \\
\text { Hawaii }\end{array}$ & $\begin{array}{r}3,099 \\
234 \\
\end{array}$ & $\begin{array}{r}2,975 \\
219\end{array}$ & $\begin{array}{r}2,828 \\
219\end{array}$ & $\begin{array}{r}1,255 \\
0 \\
\end{array}$ & $\begin{array}{r}1,236 \\
0\end{array}$ & $\begin{array}{r}1,2 \pi 6 \\
0\end{array}$ & $\begin{array}{l}205 \\
111 \\
\end{array}$ & $\begin{array}{r}190 \\
95 \\
\end{array}$ & $\begin{array}{r}218 \\
98 \\
\end{array}$ & $\begin{array}{r}576 \\
0 \\
\end{array}$ & $\begin{array}{r}449 \\
0\end{array}$ & $\begin{array}{r}336 \\
0\end{array}$ & $\begin{array}{r}1,063 \\
123\end{array}$ & $\begin{array}{r}1,050 \\
120\end{array}$ & $\begin{array}{l}998 \\
120\end{array}$ \\
\hline Total ... & 3,333 & 3,194 & 3,047 & 1,255 & 1,286 & 1,276 & 316 & 288 & 316 & 576 & 449 & 336 & 1,186 & 1,170 & 1,118 \\
\hline Total, Pacific Coast...- & 14,822 & 12,749 & 10,427 & 2,626 & 2,576 & 2,393 & 2,429 & 1,897 & $1,4 i 6$ & 3,858 & 3,124 & 2,236 & 5,909 & 5,152 & 4,321 \\
\hline 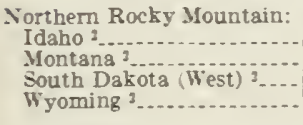 & $\begin{array}{r}239 \\
273 \\
6 \\
201 \\
\end{array}$ & $\begin{array}{r}224 \\
265 \\
4 \\
207\end{array}$ & $\begin{array}{r}199 \\
244 \\
3 \\
187 \\
\end{array}$ & $\begin{array}{r}84 \\
33 \\
0 \\
51\end{array}$ & $\begin{array}{r}85 \\
32 \\
0 \\
67\end{array}$ & $\begin{array}{r}76 \\
26 \\
0 \\
61\end{array}$ & $\begin{array}{r}48 \\
61 \\
1 \\
57 \\
\end{array}$ & $\begin{array}{r}45 \\
59 \\
0 \\
53 \\
\end{array}$ & $\begin{array}{r}41 \\
55 \\
0 \\
43 \\
\end{array}$ & $\begin{array}{r}27 \\
6 \\
0 \\
3 \\
\end{array}$ & $\begin{array}{r}24 \\
6 \\
0 \\
3 \\
\end{array}$ & $\begin{array}{r}21 \\
5 \\
0 \\
2 \\
\end{array}$ & $\begin{array}{r}78 \\
172 \\
4 \\
89\end{array}$ & $\begin{array}{r}68 \\
166 \\
3 \\
83 \\
\end{array}$ & $\begin{array}{r}59 \\
155 \\
2 \\
74 \\
\end{array}$ \\
\hline Total .... & 721 & 701 & 634 & 168 & 185 & 165 & 169 & 159 & 145 & 37 & 34 & 30 & 346 & 322 & 292 \\
\hline 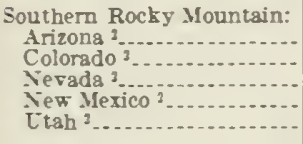 & $\begin{array}{r}226 \\
1,907 \\
12 \\
600 \\
1,038 \\
\end{array}$ & $\begin{array}{r}206 \\
2,030 \\
14 \\
544 \\
989\end{array}$ & $\begin{array}{r}173 \\
1,786 \\
12 \\
456 \\
896\end{array}$ & $\begin{array}{r}139 \\
1,132 \\
12 \\
242 \\
604 \\
\end{array}$ & $\begin{array}{r}126 \\
1,315 \\
14 \\
222 \\
592\end{array}$ & $\begin{array}{r}102 \\
1,147 \\
12 \\
177 \\
545\end{array}$ & $\begin{array}{r}47 \\
149 \\
0 \\
31 \\
1+5\end{array}$ & $\begin{array}{r}44 \\
138 \\
0 \\
28 \\
132\end{array}$ & $\begin{array}{r}39 \\
123 \\
0 \\
24 \\
117\end{array}$ & $\begin{array}{r}0 \\
0 \\
0 \\
17 \\
0\end{array}$ & $\begin{array}{r}0 \\
0 \\
0 \\
15 \\
0\end{array}$ & $\begin{array}{r}0 \\
0 \\
0 \\
13 \\
0\end{array}$ & $\begin{array}{r}39 \\
624 \\
0 \\
310 \\
288\end{array}$ & $\begin{array}{r}36 \\
576 \\
0 \\
278 \\
264\end{array}$ & $\begin{array}{r}32 \\
515 \\
0 \\
240 \\
233\end{array}$ \\
\hline Total & $3,7 \times 5$ & $3,-784$ & 3,325 & 2,130 & 2,269 & 1,985 & $3 \pi 4$ & 344 & 305 & 17 & 15 & 13 & 1,262 & 1,155 & 1,021 \\
\hline $\begin{array}{l}\text { Total, Rocky Moun- } \\
\text { tain }\end{array}$ & 4,507 & 4,486 & 3,960 & 2,299 & 2,455 & 2,150 & 544 & 503 & 450 & 54 & 49 & 44 & 1,608 & 1,478 & 1,314 \\
\hline Total, all regions...... & 217,005 & 196,669 & 172,134 & 17,520 & 16,072 & 12,908 & 19,736 & 16,481 & 12,686 & 26,516 & 23,803 & 19,647 & 153,231 & 140,313 & 126,892 \\
\hline
\end{tabular}

Data may not add to totals because of truncating. Zeros indicate no data 2 See footnote 2 , table 3. 
TABLE 8.-Net volume of softwood sawtimber on commercial timberland in the United States, by ownership and section, region, and State, as of December 31, 1952 and 1962, and January 1, 1970 1

[Million board feet, International $1 / 4$-inch $\log$ rule]

\begin{tabular}{|c|c|c|c|c|c|c|c|c|c|c|c|c|c|c|c|}
\hline \multirow{2}{*}{$\begin{array}{l}\text { Section, region, } \\
\text { and State }\end{array}$} & \multicolumn{3}{|c|}{ Total, all ownerships } & \multicolumn{3}{|c|}{ National Forest } & \multicolumn{3}{|c|}{ Other public } & \multicolumn{3}{|c|}{ Forest industry } & \multicolumn{3}{|c|}{$\begin{array}{l}\text { Farm and } \\
\text { miscellaneous private }\end{array}$} \\
\hline & 1970 & 1962 & 1952 & 1970 & 1962 & 1952 & 1970 & 1962 & 1952 & 1970 & 1962 & 1952 & 1970 & 1962 & 1952 \\
\hline $\begin{array}{l}\text { New England: } \\
\text { Connecticut ..... } \\
\text { Maine } \\
\text { Massachusetts.... } \\
\text { New Hampshire. } \\
\text { Rhode Island } \\
\text { Vermont......... }\end{array}$ & $\begin{array}{r}345 \\
23,455 \\
1,324 \\
6,861 \\
25 \\
2,800\end{array}$ & $\begin{array}{r}304 \\
20,144 \\
1,309 \\
5,977 \\
27 \\
2,775\end{array}$ & $\begin{array}{r}263 \\
17,233 \\
1,299 \\
5,381 \\
29 \\
3,270\end{array}$ & $\begin{array}{r}0 \\
40 \\
0 \\
749 \\
0 \\
76 \\
\end{array}$ & $\begin{array}{r}0 \\
38 \\
0 \\
653 \\
0 \\
75 \\
\end{array}$ & $\begin{array}{r}0 \\
36 \\
0 \\
588 \\
0 \\
89 \\
\end{array}$ & $\begin{array}{r}30 \\
279 \\
129 \\
194 \\
1 \\
107 \\
\end{array}$ & $\begin{array}{r}27 \\
234 \\
127 \\
169 \\
2 \\
107 \\
\end{array}$ & $\begin{array}{r}23 \\
228 \\
126 \\
152 \\
2 \\
126 \\
\end{array}$ & $\begin{array}{r}0 \\
12,614 \\
112 \\
1,166 \\
0 \\
402\end{array}$ & $\begin{array}{r}0 \\
8,474 \\
110 \\
1,015 \\
0 \\
398\end{array}$ & $\begin{array}{r}0 \\
7,236 \\
109 \\
914 \\
0 \\
470\end{array}$ & $\begin{array}{r}315 \\
10,521 \\
1,083 \\
4,751 \\
23 \\
2,213\end{array}$ & $\begin{array}{r}276 \\
11,396 \\
1,070 \\
4,138 \\
25 \\
2,192\end{array}$ & $\begin{array}{r}239 \\
9,731 \\
1,062 \\
3,725 \\
26 \\
2,584\end{array}$ \\
\hline Total . & 34,813 & 30,536 & 27,475 & 866 & 767 & 713 & 743 & 667 & 659 & 14,295 & 10,000 & 8,731 & 18,906 & 19,100 & 17,370 \\
\hline $\begin{array}{l}\text { Middle Atlantic: } \\
\text { Delaware..... } \\
\text { Maryland } \\
\text { New Jersey..... } \\
\text { New York } \\
\text { Pennsylvania } \\
\text { West Virginia.-- }\end{array}$ & $\begin{array}{r}459 \\
1,281 \\
748 \\
7,273 \\
3,433 \\
1,835\end{array}$ & $\begin{array}{r}491 \\
1,504 \\
588 \\
6,769 \\
3,223 \\
1,646\end{array}$ & $\begin{array}{r}539 \\
1,472 \\
406 \\
6,310 \\
2,988 \\
1,394\end{array}$ & $\begin{array}{r}0 \\
0 \\
0 \\
0 \\
133 \\
508\end{array}$ & $\begin{array}{r}0 \\
0 \\
0 \\
0 \\
125 \\
455\end{array}$ & $\begin{array}{r}0 \\
0 \\
0 \\
0 \\
116 \\
386\end{array}$ & $\begin{array}{r}5 \\
49 \\
67 \\
617 \\
512 \\
133 \\
\end{array}$ & $\begin{array}{r}6 \\
57 \\
52 \\
574 \\
481 \\
119 \\
\end{array}$ & $\begin{array}{r}6 \\
56 \\
36 \\
535 \\
446 \\
101 \\
\end{array}$ & $\begin{array}{r}34 \\
106 \\
1 \\
800 \\
133 \\
66\end{array}$ & $\begin{array}{r}40 \\
124 \\
1 \\
745 \\
125 \\
59\end{array}$ & $\begin{array}{r}36 \\
122 \\
0 \\
694 \\
116 \\
50\end{array}$ & $\begin{array}{r}419 \\
1,125 \\
679 \\
5,855 \\
2,654 \\
1,127\end{array}$ & $\begin{array}{r}444 \\
1,321 \\
533 \\
5,449 \\
2,491 \\
1,010\end{array}$ & $\begin{array}{r}495 \\
1,293 \\
368 \\
5,079 \\
2,309 \\
855\end{array}$ \\
\hline Total. . & 15,032 & 14,221 & 13,109 & 641 & 581 & 502 & 1,386 & 1,292 & 1,183 & 1,143 & 1,096 & 1,021 & 11,861 & 11,250 & 10,402 \\
\hline $\begin{array}{l}\text { Lake States: } \\
\text { Michigan } \\
\text { Minnesota-...- } \\
\text { North Dakota.- } \\
\text { South Dakota } \\
\text { (East) } \\
\text { Wisconsin.......- }\end{array}$ & $\begin{array}{r}11,025 \\
8,041 \\
0 \\
58 \\
6,963\end{array}$ & $\begin{array}{r}8,792 \\
6,559 \\
0 \\
46 \\
5,563 \\
\end{array}$ & $\begin{array}{r}5,929 \\
4,968 \\
0 \\
42 \\
4,495 \\
\end{array}$ & $\begin{array}{r}1,225 \\
1,511 \\
0 \\
0 \\
828\end{array}$ & $\begin{array}{r}1,174 \\
1,233 \\
0 \\
0 \\
662\end{array}$ & $\begin{array}{r}428 \\
1,006 \\
0 \\
0 \\
346\end{array}$ & $\begin{array}{r}2,672 \\
4,004 \\
0 \\
52 \\
1,496 \\
\end{array}$ & $\begin{array}{r}2,001 \\
3,266 \\
0 \\
42 \\
1,196 \\
\end{array}$ & $\begin{array}{r}1,334 \\
2,330 \\
0 \\
39 \\
1,609 \\
\end{array}$ & $\begin{array}{r}2,511 \\
651 \\
0 \\
0 \\
1,503 \\
\end{array}$ & $\begin{array}{r}2,154 \\
531 \\
0 \\
0 \\
1,201 \\
\end{array}$ & $\begin{array}{r}1,836 \\
480 \\
0 \\
0 \\
301\end{array}$ & $\begin{array}{r}4,617 \\
1,874 \\
0 \\
5 \\
3,135\end{array}$ & $\begin{array}{r}3,461 \\
1,528 \\
0 \\
4 \\
4 \\
2,503\end{array}$ & $\begin{array}{r}2,329 \\
1,151 \\
0 \\
3 \\
3,238\end{array}$ \\
\hline Total. & 26,088 & 20,960 & 15,434 & 3,565 & 3,069 & 1,781 & 8,225 & 6,505 & 5,312 & 4,665 & 3,887 & 2,617 & 9,632 & 7,497 & 5,722 \\
\hline $\begin{array}{l}\text { Central: } \\
\text { Illinois..... } \\
\text { Indiana } \\
\text { Iowa } \\
\text { Kansas... } \\
\text { Kentucky } \\
\text { Missouri } \\
\text { Nebraska... } \\
\text { Ohio }\end{array}$ & $\begin{array}{r}24 \\
183 \\
10 \\
0 \\
1,968 \\
1,071 \\
489 \\
377 \\
\end{array}$ & $\begin{array}{r}28 \\
141 \\
7 \\
0 \\
1,765 \\
813 \\
388 \\
342 \\
\end{array}$ & $\begin{array}{r}31 \\
78 \\
6 \\
0 \\
1,607 \\
613 \\
260 \\
326 \\
\end{array}$ & $\begin{array}{r}5 \\
10 \\
0 \\
0 \\
502 \\
591 \\
111 \\
23\end{array}$ & $\begin{array}{r}5 \\
9 \\
0 \\
0 \\
450 \\
500 \\
79 \\
21\end{array}$ & $\begin{array}{r}1 \\
1 \\
0 \\
0 \\
410 \\
311 \\
64 \\
20\end{array}$ & $\begin{array}{r}0 \\
53 \\
0 \\
0 \\
20 \\
20 \\
24 \\
36\end{array}$ & $\begin{array}{r}0 \\
47 \\
0 \\
0 \\
18 \\
15 \\
18 \\
32\end{array}$ & $\begin{array}{r}0 \\
47 \\
0 \\
0 \\
16 \\
11 \\
13 \\
31\end{array}$ & $\begin{array}{r}7 \\
0 \\
0 \\
0 \\
58 \\
28 \\
0 \\
19\end{array}$ & $\begin{array}{r}7 \\
0 \\
0 \\
0 \\
52 \\
21 \\
0 \\
17\end{array}$ & $\begin{array}{r}3 \\
0 \\
0 \\
0 \\
47 \\
17 \\
0 \\
17\end{array}$ & $\begin{array}{r}12 \\
119 \\
10 \\
0 \\
1,387 \\
432 \\
353 \\
297\end{array}$ & $\begin{array}{r}14 \\
83 \\
6 \\
0 \\
1,244 \\
277 \\
290 \\
269 \\
\end{array}$ & $\begin{array}{r}27 \\
28 \\
5 \\
0 \\
1,132 \\
274 \\
181 \\
257 \\
\end{array}$ \\
\hline Total. ... & 4,126 & 3,485 & 2,921 & 1,244 & 1,066 & 808 & 154 & 133 & 120 & 114 & 99 & 84 & 2,613 & 2,185 & 1,907 \\
\hline Total, North. & 80,061 & 69,202 & 58,939 & 6,318 & 5,484 & 3,806 & 10,510 & 8,599 & 7,276 & 20,219 & 15,083 & 12,454 & 43,013 & 40,034 & 35,402 \\
\hline $\begin{array}{l}\text { South Atlantic: } \\
\text { North Carolina } \\
\text { South Carolina } \\
\text { Virginia } \\
\text {.....-. }\end{array}$ & $\begin{array}{l}28,611 \\
20,381 \\
11,884 \\
\end{array}$ & $\begin{array}{l}25,878 \\
16,811 \\
11,691 \\
\end{array}$ & $\begin{array}{l}23,715 \\
15,449 \\
11,616\end{array}$ & $\begin{array}{r}1,085 \\
2,399 \\
621\end{array}$ & $\begin{array}{r}981 \\
2,023 \\
687\end{array}$ & $\begin{array}{r}877 \\
1,455 \\
683\end{array}$ & $\begin{array}{r}986 \\
1,036 \\
525 \\
\end{array}$ & $\begin{array}{l}892 \\
724 \\
566\end{array}$ & $\begin{array}{l}699 \\
479 \\
562\end{array}$ & $\begin{array}{l}4,439 \\
3,985 \\
2,186\end{array}$ & $\begin{array}{l}4,014 \\
3,124 \\
2,022\end{array}$ & $\begin{array}{l}4,031 \\
2,782 \\
2,009\end{array}$ & $\begin{array}{r}22,100 \\
12,960 \\
8,551 \\
\end{array}$ & $\begin{array}{r}19,989 \\
10,939 \\
8,415 \\
\end{array}$ & $\begin{array}{r}18,106 \\
10,731 \\
8,361 \\
\end{array}$ \\
\hline Total. - & 60,877 & 54,380 & 50,780 & 4,106 & 3,692 & 3,015 & 2,548 & 2,182 & 1,741 & 10,611 & 9,161 & 8,823 & 43,612 & 39,343 & 37,199 \\
\hline $\begin{array}{l}\text { East Gulf: } \\
\text { Florida. } \\
\text { Georgia... }\end{array}$ & $\begin{array}{l}19,966 \\
33,868\end{array}$ & $\begin{array}{l}16,789 \\
29,873 \\
\end{array}$ & $\begin{array}{l}14,707 \\
26,839\end{array}$ & $\begin{array}{l}2,154 \\
1,404 \\
\end{array}$ & $\begin{array}{l}1,670 \\
1,239\end{array}$ & $\begin{array}{r}1447 \\
1,114 \\
\end{array}$ & $\begin{array}{l}1,694 \\
2,636\end{array}$ & $\begin{array}{l}1,223 \\
2,324\end{array}$ & $\begin{array}{r}936 \\
2,087\end{array}$ & $\begin{array}{l}6,280 \\
6,414\end{array}$ & $\begin{array}{l}5,288 \\
5,658\end{array}$ & $\begin{array}{l}4,610 \\
5,083\end{array}$ & $\begin{array}{r}9,836 \\
23,412\end{array}$ & $\begin{array}{r}8,607 \\
20,651\end{array}$ & $\begin{array}{r}7,712 \\
18,553\end{array}$ \\
\hline Total_. & 53,834 & 46,662 & 41,546 & 3,559 & 2,909 & 2,56 & 4,330 & 3,547 & 3,024 & 12,694 & 10,946 & 9,693 & 33,249 & 29,259 & 26,266 \\
\hline $\begin{array}{l}\text { Central Gulf: } \\
\text { Alabama..--. } \\
\text { Mississippi.-- } \\
\text { Tennessee.-. }\end{array}$ & $\begin{array}{r}34,874 \\
28,079 \\
4,699\end{array}$ & $\begin{array}{r}28,306 \\
20,008 \\
3,996\end{array}$ & $\begin{array}{r}21,273 \\
13,832 \\
3,412\end{array}$ & $\begin{array}{r}1,912 \\
5,133 \\
863\end{array}$ & $\begin{array}{r}1,552 \\
5,030 \\
929\end{array}$ & $\begin{array}{r}1,101 \\
2,899 \\
814 \\
\end{array}$ & $\begin{array}{r}630 \\
1,474 \\
621 \\
\end{array}$ & $\begin{array}{l}511 \\
760 \\
285 \\
\end{array}$ & $\begin{array}{r}301 \\
1,180 \\
309 \\
\end{array}$ & $\begin{array}{r}10,360 \\
5,959 \\
446 \\
\end{array}$ & $\begin{array}{r}8,409 \\
5,254 \\
275 \\
\end{array}$ & $\begin{array}{r}6,275 \\
6,413 \\
257\end{array}$ & $\begin{array}{r}21,970 \\
15,511 \\
2,767 \\
\end{array}$ & $\begin{array}{r}17,832 \\
8,964 \\
2,505 \\
\end{array}$ & $\begin{array}{r}13,596 \\
3,340 \\
2,030\end{array}$ \\
\hline Total . . & 67,652 & 52,310 & 38,517 & 7,910 & 7,511 & 4,814 & 2,726 & 1,557 & 1,790 & 16,766 & 13,938 & 12,945 & 40,248 & 29,302 & 18,966 \\
\hline $\begin{array}{l}\text { West Gulf: } \\
\text { Arkansas } \\
\text { Louisiana... } \\
\text { Oklahoma... } \\
\text { Texas........ }\end{array}$ & $\begin{array}{r}25,251 \\
35,011 \\
2,788 \\
30,459 \\
\end{array}$ & $\begin{array}{r}22,022 \\
28,271 \\
2,295 \\
24,457 \\
\end{array}$ & $\begin{array}{r}17,408 \\
19,560 \\
1,771 \\
15,989\end{array}$ & $\begin{array}{r}4,378 \\
2,781 \\
383 \\
4,632\end{array}$ & $\begin{array}{l}4,051 \\
2,291 \\
503 \\
5,390\end{array}$ & $\begin{array}{l}3,346 \\
1,292 \\
307 \\
2,759\end{array}$ & $\begin{array}{l}374 \\
475 \\
101 \\
516\end{array}$ & $\begin{array}{r}195 \\
452 \\
8 \\
272\end{array}$ & $\begin{array}{r}158 \\
325 \\
7 \\
149\end{array}$ & $\begin{array}{r}11,686 \\
11,902 \\
1,715 \\
14,673\end{array}$ & $\begin{array}{r}13,638 \\
13,023 \\
1,463 \\
11,578 \\
\end{array}$ & $\begin{array}{r}11,676 \\
10,048 \\
1,241 \\
8,071 \\
\end{array}$ & $\begin{array}{r}8,812 \\
19,852 \\
587 \\
10,637 \\
\end{array}$ & $\begin{array}{r}4,138 \\
12,505 \\
321 \\
7,217 \\
\end{array}$ & $\begin{array}{r}2,228 \\
7,895 \\
216 \\
\mathbf{5}, 010 \\
\end{array}$ \\
\hline Total... & 93,511 & 77,045 & 54,728 & 12,175 & 12,235 & 7,704 & 1,467 & 927 & 636 & 39,977 & 39,702 & 31,036 & 39,890 & 24,181 & 15,349 \\
\hline Total, SouthJ & 275,875 & 230,397 & 185,571 & 27,751 & 26,348 & 18,095 & 11,072 & 8,214 & 195 & 80,050 & 73,748 & 62,499 & 157,001 & $112,086$. & $.97,781$ \\
\hline
\end{tabular}

See footnotes at end of table. 
TABLE 8. - Net volume of softwood sautimber on commercial timberland in the United States, by ownership and section, region, and State, as of December 31,1952 and 1962, and January 1, 1970 1 -Continued

[Million board feet, International 1/4-inch $\log$ rule]

\begin{tabular}{|c|c|c|c|c|c|c|c|c|c|c|c|c|c|c|c|}
\hline \multirow{2}{*}{$\begin{array}{l}\text { Section, region, } \\
\text { and Stste }\end{array}$} & \multicolumn{3}{|c|}{ Total, all ownerships } & \multicolumn{3}{|c|}{ National Forest } & \multicolumn{3}{|c|}{ Other public } & \multicolumn{3}{|c|}{ Forest industry } & \multicolumn{3}{|c|}{$\begin{array}{l}\text { Farm and } \\
\text { miscellaneous private }\end{array}$} \\
\hline & 1970 & 1962 & 1952 & 1970 & 1962 & 1952 & 1970 & 1962 & 1952 & 1970 & 1962 & 1952 & 1970 & 1962 & 1952 \\
\hline $\begin{array}{l}\text { Pacific Northwest: } \\
\text { Alaska: Coastal.- }\end{array}$ & 175,101 & $1 S 2,224$ & 183,925 & 163,361 & $16 \pi, 143$ & 168,706 & 13,801 & 14,120 & 14,252 & 0 & 0 & 0 & 928 & 960 & 969 \\
\hline $\begin{array}{l}\text { Oregon: } \\
\text { Western........ } \\
\text { Eastern........ }\end{array}$ & $\begin{array}{l}327,862 \\
106,809\end{array}$ & $\begin{array}{l}356,072 \\
111,316\end{array}$ & $\begin{array}{l}391,046 \\
115,304\end{array}$ & $\left\{\begin{array}{r}172,354 \\
81,211\end{array}\right.$ & $\begin{array}{r}180,645 \\
83,467\end{array}$ & $\begin{array}{r}178,851 \\
78,260\end{array}$ & $\begin{array}{r}67,119 \\
7,050\end{array}$ & $\begin{array}{r}70,879 \\
7,813\end{array}$ & $\begin{array}{l}76,053 \\
11,320\end{array}$ & $\begin{array}{r}60,814 \\
9,457\end{array}$ & $\begin{array}{l}78,459 \\
11,440\end{array}$ & $\begin{array}{r}105,732 \\
13,767\end{array}$ & $\begin{array}{r}27,575 \\
9,091\end{array}$ & $\begin{array}{r}26,089 \\
8,596\end{array}$ & $\begin{array}{r}30,410 \\
9,857\end{array}$ \\
\hline Summary...... & $434,6: 1$ & $46 \pi, 355$ & 506,350 & 253,565 & 264,112 & 257,111 & 74,169 & 78,692 & 9,373 & 70,271 & 89,899 & 119,499 & 36,666 & 34,685 & 39,367 \\
\hline $\begin{array}{l}\text { Washington: } \\
\text { Western...... } \\
\text { Eastern....... }\end{array}$ & $\begin{array}{r}234,179 \\
75,323\end{array}$ & $\begin{array}{r}251,635 \\
76,703\end{array}$ & $\begin{array}{r}267,905 \\
75,855\end{array}$ & $\begin{array}{l}95,294 \\
35,659\end{array}$ & $\begin{array}{r}103,339 \\
40,496 \\
\end{array}$ & $\begin{array}{r}107,965 \\
39,411\end{array}$ & $\begin{array}{l}43,128 \\
21,110\end{array}$ & $\begin{array}{l}43,990 \\
22,014 \\
\end{array}$ & $\begin{array}{l}44,208 \\
21,957\end{array}$ & $\begin{array}{r}74,828 \\
5,406\end{array}$ & $\begin{array}{r}84,264 \\
5,145\end{array}$ & $\begin{array}{r}97,3+0 \\
6,161\end{array}$ & $\begin{array}{l}21,229 \\
10,148\end{array}$ & $\begin{array}{r}20,042 \\
9,048\end{array}$ & $\begin{array}{r}18,395 \\
8,293 \\
\end{array}$ \\
\hline Summars...... & 309,802 & 325,335 & 343,763 & 133,953 & 143,835 & $.147,409$ & 64,235 & $66,00 t$ & 66,165 & 80,234 & 89,409 & 103,501 & 31,377 & 29,090 & 26,688 \\
\hline Total & 922,574 & $97 \pi, 950$ & $1,034,0 \pm 1$ & 550,879 & 575,090 & 573,226 & 152,205 & 158,816 & 170,790 & 150,505 & $179,30 s$ & 223,000 & 68,981 & 64,735 & 67,024 \\
\hline $\begin{array}{l}\text { Pacific Southwest: } \\
\text { California....... } \\
\text { Haw aii......... }\end{array}$ & $\begin{array}{r}271,653 \\
18\end{array}$ & $\begin{array}{r}296,617 \\
16\end{array}$ & $\begin{array}{r}331,145 \\
16\end{array}$ & $\begin{array}{r}161,514 \\
0\end{array}$ & $\begin{array}{r}172,155 \\
0\end{array}$ & $\begin{array}{r}173,999 \\
0\end{array}$ & $\begin{array}{r}6,786 \\
11 \\
\end{array}$ & $\begin{array}{r}7,844 \\
10\end{array}$ & $\begin{array}{r}10,799 \\
10\end{array}$ & $\begin{array}{r}43,405 \\
0\end{array}$ & $\begin{array}{r}50,539 \\
0\end{array}$ & $\begin{array}{r}62,18.5 \\
0\end{array}$ & $\begin{array}{r}59,945 \\
6\end{array}$ & 66,079 & 84,162 \\
\hline Total........ & 271,671 & 296,633 & 331,161 & 161,514 & 172,155 & 173,999 & 6,797 & $i, 854$ & 10,809 & 43,405 & 50,539 & 62,185 & 59,954 & 66,084 & 84,167 \\
\hline $\begin{array}{l}\text { Total, Pacif- } \\
\text { ic Coast.... }\end{array}$ & $1,194,245$ & $1,2 i t, 583$ & $1,365,202$ & 712,393 & 747,245 & 747,225 & 159,006 & 166,671 & 181,600 & 193,910 & 229,817 & 285,185 & 128,935 & 130,819 & 151,191 \\
\hline $\begin{array}{l}\text { Northern Rocky } \\
\text { Mftn.: } \\
\text { Idaho } \\
\text { Montana } \\
\text { South Dakota }\end{array}$ & $\begin{array}{l}130,956 \\
100,925\end{array}$ & $\begin{array}{l}136,606 \\
106,702\end{array}$ & $\begin{array}{l}132,869 \\
100,23\end{array}$ & $\begin{array}{l}87,366 \\
64,748\end{array}$ & $\begin{array}{l}93,731 \\
69,792\end{array}$ & $\begin{array}{l}89,475 \\
64,182\end{array}$ & $\begin{array}{r}14,425 \\
9,219\end{array}$ & $\begin{array}{r}14,471 \\
9,378\end{array}$ & $\begin{array}{r}15,060 \\
9,141\end{array}$ & $\begin{array}{r}13,290 \\
9,526\end{array}$ & $\begin{array}{r}12,902 \\
9,964\end{array}$ & $\begin{array}{r}12,831 \\
9,912\end{array}$ & $\begin{array}{l}15,904 \\
17,431\end{array}$ & $\begin{array}{l}15,500 \\
17,567\end{array}$ & $\begin{array}{l}15,502 \\
17,001\end{array}$ \\
\hline $\begin{array}{l}\text { South Dacota } \\
\text { (Wyest) }{ }^{2}-\ldots \text { ming }{ }^{2}-\ldots . . .\end{array}$ & $\begin{array}{r}3,434 \\
16,040 \\
\end{array}$ & $\begin{array}{r}3,510 \\
20,489\end{array}$ & $\begin{array}{r}3,516 \\
19,948\end{array}$ & $\begin{array}{r}2,624 \\
11,325\end{array}$ & $\begin{array}{r}2,765 \\
16,032\end{array}$ & $\begin{array}{r}2,852 \\
15,891\end{array}$ & $\begin{array}{r}194 \\
1,951\end{array}$ & $\begin{array}{r}179 \\
1,841\end{array}$ & $\begin{array}{r}159 \\
1,679 \\
\end{array}$ & $\begin{array}{r}35 \\
220\end{array}$ & $\begin{array}{r}35 \\
208\end{array}$ & $\begin{array}{r}31 \\
189\end{array}$ & $\begin{array}{r}576 \\
2,543\end{array}$ & $\begin{array}{r}530 \\
2,404\end{array}$ & $\begin{array}{r}472 \\
2,188\end{array}$ \\
\hline Total... & $251,38 \pi$ & $26 \bar{i}, 30 \bar{i}$ & 256,570 & 166,065 & 182,320 & 172,400 & 25,790 & 25,874 & 26,040 & 23,075 & 23,110 & 22,961 & 36,456 & 36,002 & 35,164 \\
\hline 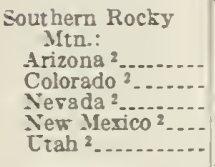 & $\begin{array}{r}20,902 \\
42,633 \\
1,319 \\
24,054 \\
14,809\end{array}$ & $\begin{array}{r}22,218 \\
49,965 \\
1,362 \\
25,168 \\
15,324\end{array}$ & $\begin{array}{r}22,714 \\
47,598 \\
1,327 \\
25,422 \\
15,542\end{array}$ & $\begin{array}{r}13,816 \\
31,434 \\
373 \\
12,181 \\
11,710\end{array}$ & $\begin{array}{r}14,707 \\
39,329 \\
441 \\
12,847 \\
11,904\end{array}$ & $\begin{array}{r}14,494 \\
37,598 \\
411 \\
12,254 \\
11,520\end{array}$ & $\begin{array}{r}6,727 \\
2,567 \\
51 \\
5,876 \\
1,685\end{array}$ & $\begin{array}{r}7,130 \\
2,438 \\
49 \\
6,098 \\
1,860 \\
\end{array}$ & $\begin{array}{r}7,803 \\
2,292 \\
49 \\
6,517 \\
2,1 \leq 8\end{array}$ & $\begin{array}{r}0 \\
74 \\
86 \\
430 \\
0\end{array}$ & $\begin{array}{r}0 \\
70 \\
84 \\
446 \\
0\end{array}$ & $\begin{array}{r}0 \\
66 \\
83 \\
477 \\
0\end{array}$ & $\begin{array}{r}358 \\
8,556 \\
808 \\
5,566 \\
1,413\end{array}$ & $\begin{array}{r}350 \\
8,126 \\
787 \\
5,776 \\
1,559\end{array}$ & $\begin{array}{r}416 \\
7,640 \\
782 \\
6,173 \\
1,834\end{array}$ \\
\hline Total........ & 103,719 & 114,037 & 112,603 & 69,516 & 79,228 & 76,277 & 16,908 & 17,577 & 18,851 & 591 & 601 & 627 & 16,703 & 16,629 & 16,847 \\
\hline $\begin{array}{l}\text { Total, } \\
\text { Rocky } \\
\text { Mountains. }\end{array}$ & 355,106 & 381,344 & 369,173 & 235,581 & 261,548 & $248,6 \pi$ & 42,699 & 43,452 & 44,892 & 23,666 & 23,711 & 23,592 & 53,159 & 52,632 & 52,011 \\
\hline $\begin{array}{l}\text { Total, all } \\
\text { regions... }\end{array}$ & $1,905,289$ & $1,955,527$ & $1,978,886$ & $982,04 \overline{5}$ & $1,040,625$ & $1,017,803$ & 223,287 & 226,938 & 240,964 & 317,846 & 342,391 & 383,731 & 382,110 & 345,572 & 336,387 \\
\hline
\end{tabular}

1 Dats may not add to totsls because of truncating. Zeros indicate no data 2 See footnote 2 , table 3 . or negligible amounts. 
TABLE 9.-Net volume of hardwood sawtimber on commercial timberland in the United States, by ownership and section, region, and State, as of December 31, 1952 and 1962, and January 1, 1970 1

[Million board feet, International 1/4-inch $\log$ rule]

\begin{tabular}{|c|c|c|c|c|c|c|c|c|c|c|c|c|c|c|c|}
\hline \multirow{2}{*}{ Section, region, and State } & \multicolumn{3}{|c|}{ Total, all ownerships } & \multicolumn{3}{|c|}{ National Forest } & \multicolumn{3}{|c|}{ Other public } & \multicolumn{3}{|c|}{ Forest industry } & \multicolumn{3}{|c|}{$\begin{array}{c}\text { Farm and miscellaneous } \\
\text { private }\end{array}$} \\
\hline & 1970 & 1962 & 1952 & 1970 & 1962 & 1952 & 1970 & 1962 & 1952 & 1970 & 1962 & 1952 & 1970 & 1962 & 1952 \\
\hline $\begin{array}{l}\text { New England: } \\
\text { Connecticut..... } \\
\text { Maine } \\
\text { Massachusetts... } \\
\text { New Hampshire. } \\
\text { Rhode Island.... } \\
\text { Vermont......... }\end{array}$ & $\begin{array}{r}2,265 \\
11,063 \\
1,803 \\
3,178 \\
167 \\
3,977\end{array}$ & $\begin{array}{r}2,106 \\
10,556 \\
1,660 \\
2,995 \\
146 \\
4,124\end{array}$ & $\begin{array}{r}1,596 \\
9,807 \\
1,360 \\
3,075 \\
136 \\
4,626\end{array}$ & $\begin{array}{r}0 \\
104 \\
0 \\
1,162 \\
0 \\
403\end{array}$ & $\begin{array}{r}0 \\
41 \\
0 \\
1,095 \\
0 \\
421\end{array}$ & $\begin{array}{r}0 \\
41 \\
0 \\
1,124 \\
0 \\
473\end{array}$ & $\begin{array}{r}192 \\
104 \\
162 \\
61 \\
21 \\
189\end{array}$ & $\begin{array}{r}178 \\
97 \\
149 \\
58 \\
18 \\
196 \\
\end{array}$ & $\begin{array}{r}135 \\
98 \\
122 \\
59 \\
17 \\
220\end{array}$ & $\begin{array}{r}4 \\
6,450 \\
153 \\
383 \\
0 \\
730\end{array}$ & $\begin{array}{r}4 \\
4,420 \\
141 \\
361 \\
0 \\
760\end{array}$ & $\begin{array}{r}3 \\
4,102 \\
115 \\
371 \\
0 \\
852\end{array}$ & $\begin{array}{r}2,068 \\
4,404 \\
1,487 \\
1,571 \\
145 \\
2,654\end{array}$ & $\begin{array}{l}1,923 \\
5,997 \\
1,369 \\
1,480 \\
127 \\
2,745\end{array}$ & $\begin{array}{r}1,457 \\
5,564 \\
1,121 \\
1,519 \\
118 \\
3,080\end{array}$ \\
\hline Total... & 22,456 & 21,587 & 20,600 & 1,670 & 1,558 & 1,639 & 731 & 698 & 653 & 7,722 & 5,687 & 5,444 & 12,332 & 13,643 & 12,862 \\
\hline $\begin{array}{l}\text { Middle Atlantic: } \\
\text { Delaware } \\
\text { Maryland } \\
\text { New Jersey } \\
\text { New York } \\
\text { Pennsylvania. } \\
\text { West Virginia..... }\end{array}$ & $\begin{array}{r}900 \\
5,680 \\
3,527 \\
17,706 \\
26,182 \\
33,850\end{array}$ & $\begin{array}{r}734 \\
5,291 \\
2,975 \\
16,971 \\
21,908 \\
28,538 \\
\end{array}$ & $\begin{array}{r}573 \\
5,042 \\
2,325 \\
16,096 \\
16,670 \\
22,716\end{array}$ & $\begin{array}{r}0 \\
0 \\
0 \\
0 \\
1,096 \\
3,052 \\
\end{array}$ & $\begin{array}{r}0 \\
0 \\
0 \\
0 \\
917 \\
2,573 \\
\end{array}$ & $\begin{array}{r}0 \\
0 \\
0 \\
0 \\
697 \\
2,048 \\
\end{array}$ & $\begin{array}{r}10 \\
306 \\
98 \\
1,216 \\
5,033 \\
1,193 \\
\end{array}$ & $\begin{array}{r}8 \\
284 \\
83 \\
1,165 \\
4,211 \\
1,005 \\
\end{array}$ & $\begin{array}{r}6 \\
271 \\
65 \\
1,105 \\
3,204 \\
800 \\
\end{array}$ & $\begin{array}{r}68 \\
57 \\
7 \\
1,994 \\
1,100 \\
1,945 \\
\end{array}$ & $\begin{array}{r}60 \\
53 \\
6 \\
1,911 \\
921 \\
1,639 \\
\end{array}$ & $\begin{array}{r}39 \\
51 \\
4 \\
1,813 \\
700 \\
1,305 \\
\end{array}$ & $\begin{array}{r}822 \\
5,317 \\
3,421 \\
14,495 \\
18,951 \\
27,660 \\
\end{array}$ & $\begin{array}{r}665 \\
4,952 \\
2,885 \\
13,893 \\
15,857 \\
23,319\end{array}$ & $\begin{array}{r}527 \\
4,719 \\
2,255 \\
13,177 \\
12,066 \\
18,561 \\
\end{array}$ \\
\hline Total.. & 87,848 & 76,417 & 63,422 & 4,148 & 3,490 & 2,746 & 7,857 & 6,759 & 5,454 & 5,173 & 4,592 & 3,914 & 70,668 & 61,574 & 51,307 \\
\hline $\begin{array}{l}\text { Lake States: } \\
\text { Michigan... } \\
\text { Minnesota.-. } \\
\text { North Dakota } \\
\text { South Dakota (Ea } \\
\text { Wisconsin... }\end{array}$ & $\begin{array}{r}27,061 \\
12,025 \\
563 \\
280 \\
15,332 \\
\end{array}$ & $\begin{array}{r}22,339 \\
8,958 \\
524 \\
228 \\
\mathbf{1 3}, \mathbf{5 8 2} \\
\end{array}$ & $\begin{array}{r}16,764 \\
6,354 \\
509 \\
204 \\
10,260 \\
\end{array}$ & $\begin{array}{r}1,864 \\
815 \\
0 \\
0 \\
806 \\
\end{array}$ & $\begin{array}{r}1,619 \\
607 \\
0 \\
0 \\
706 \\
\end{array}$ & $\begin{array}{r}865 \\
312 \\
0 \\
0 \\
687 \\
\end{array}$ & $\begin{array}{r}5,470 \\
3,803 \\
173 \\
38 \\
1,987 \\
\end{array}$ & $\begin{array}{r}4,377 \\
2,833 \\
162 \\
31 \\
1,765 \\
\end{array}$ & $\begin{array}{r}3,070 \\
1,782 \\
156 \\
27 \\
1,672 \\
\end{array}$ & $\begin{array}{r}4,665 \\
516 \\
0 \\
0 \\
1,683 \\
\end{array}$ & $\begin{array}{r}3,948 \\
385 \\
0 \\
0 \\
1,494 \\
\end{array}$ & $\begin{array}{r}3,369 \\
288 \\
0 \\
0 \\
707 \\
\end{array}$ & $\begin{array}{r}15,061 \\
6,889 \\
390 \\
242 \\
10,855 \\
\end{array}$ & $\begin{array}{r}12,394 \\
5,132 \\
361 \\
196 \\
9,616 \\
\end{array}$ & $\begin{array}{r}9,458 \\
3,971 \\
352 \\
176 \\
7,192 \\
\end{array}$ \\
\hline Total & 55,263 & 45,631 & 34,091 & 3,486 & 2,933 & 1,864 & 11,473 & 9,170 & 6,709 & 6,865 & 5,827 & 4,366 & 33,438 & 27,700 & 21,151 \\
\hline $\begin{array}{l}\text { Central: } \\
\text { Illinois... } \\
\text { Indiana... } \\
\text { Iowa } \\
\text { Kansas } \\
\text { Kentucky } \\
\text { Missouri } \\
\text { Nebraska. } \\
\text { Ohio }\end{array}$ & $\begin{array}{r}7,809 \\
11,025 \\
6,586 \\
1,902 \\
28,231 \\
14,977 \\
1,502 \\
14,201\end{array}$ & $\begin{array}{r}8,548 \\
10,258 \\
5,709 \\
1,760 \\
24,382 \\
12,600 \\
1,441 \\
13,148\end{array}$ & $\begin{array}{r}9,488 \\
8,754 \\
5,053 \\
1,706 \\
21,311 \\
10,828 \\
1,070 \\
11,039 \\
\end{array}$ & $\begin{array}{r}328 \\
354 \\
5 \\
0 \\
972 \\
1,091 \\
0 \\
343\end{array}$ & $\begin{array}{r}359 \\
300 \\
5 \\
0 \\
839 \\
1,117 \\
0 \\
318 \\
\end{array}$ & $\begin{array}{r}245 \\
165 \\
4 \\
0 \\
734 \\
606 \\
0 \\
267 \\
\end{array}$ & $\begin{array}{r}139 \\
809 \\
86 \\
86 \\
1,027 \\
236 \\
41 \\
882 \\
\end{array}$ & $\begin{array}{r}152 \\
733 \\
73 \\
78 \\
887 \\
191 \\
40 \\
817\end{array}$ & $\begin{array}{r}133 \\
606 \\
66 \\
62 \\
775 \\
177 \\
29 \\
686 \\
\end{array}$ & $\begin{array}{r}22 \\
65 \\
24 \\
0 \\
981 \\
228 \\
0 \\
407\end{array}$ & $\begin{array}{r}24 \\
67 \\
21 \\
0 \\
847 \\
175 \\
0 \\
377\end{array}$ & $\begin{array}{r}61 \\
64 \\
19 \\
0 \\
741 \\
171 \\
0 \\
316\end{array}$ & $\begin{array}{r}7,319 \\
9,796 \\
6,470 \\
1,816 \\
25,250 \\
13,421 \\
1,460 \\
12,567\end{array}$ & $\begin{array}{r}8,012 \\
9,157 \\
5,608 \\
1,682 \\
21,807 \\
11,116 \\
1,401 \\
11,635 \\
\end{array}$ & $\begin{array}{r}9,049 \\
7,918 \\
4,963 \\
1,644 \\
19,060 \\
9,873 \\
1,041 \\
9,768 \\
\end{array}$ \\
\hline Total $\ldots \ldots$ & 86,237 & 77,848 & 69,251 & 3,095 & 2,940 & 2,021 & 3,309 & 2,973 & 2,537 & 1,730 & 1,513 & 1,373 & 78,102 & 70,421 & 63,319 \\
\hline Total, North. & 251,806 & 221,484 & 187,364 & 12,400 & 10,921 & 8,271 & 23,372 & 19,601 & 15,353 & 21,492 & 17,621 & 15,099 & 194,542 & 173,339 & 148,640 \\
\hline $\begin{array}{l}\text { South A tlantic: } \\
\text { North Carolina } \\
\text { South Carolina. } \\
\text { Virginia. }\end{array}$ & $\begin{array}{l}29,516 \\
16,051 \\
27,342 \\
\end{array}$ & $\begin{array}{l}27,998 \\
14,305 \\
25,480 \\
\end{array}$ & $\begin{array}{l}26,327 \\
14,259 \\
22,827 \\
\end{array}$ & $\begin{array}{r}2,808 \\
681 \\
2,494 \\
\end{array}$ & $\begin{array}{r}2,664 \\
548 \\
1,883 \\
\end{array}$ & $\begin{array}{r}2,014 \\
409 \\
1,687 \\
\end{array}$ & $\begin{array}{l}764 \\
467 \\
873 \\
\end{array}$ & $\begin{array}{l}724 \\
371 \\
507\end{array}$ & $\begin{array}{l}424 \\
260 \\
453 \\
\end{array}$ & $\begin{array}{l}3,015 \\
3,567 \\
2,074 \\
\end{array}$ & $\begin{array}{l}2,860 \\
2,804 \\
2,280 \\
\end{array}$ & $\begin{array}{l}3,762 \\
2,375 \\
2,043 \\
\end{array}$ & $\begin{array}{l}22,927 \\
11,336 \\
21,900 \\
\end{array}$ & $\begin{array}{l}21,748 \\
10,581 \\
20,809 \\
\end{array}$ & $\begin{array}{l}20,126 \\
11,213 \\
18,642 \\
\end{array}$ \\
\hline Total & 72,910 & 67,783 & 63,413 & 5,984 & 5,095 & 4,110 & 2,104 & 1,602 & 1,138 & 8,657 & 7,944 & 8,180 & 56,164 & 53,139 & 49,982 \\
\hline $\begin{array}{l}\text { East Gulf: } \\
\text { Florida } \\
\text { Georgia... }\end{array}$ & $\begin{array}{l}10,498 \\
18,893\end{array}$ & $\begin{array}{r}9,541 \\
19,519 \\
\end{array}$ & $\begin{array}{r}9,207 \\
20,259\end{array}$ & $\begin{array}{r}425 \\
1,625 \\
\end{array}$ & $\begin{array}{r}308 \\
1,679 \\
\end{array}$ & $\begin{array}{r}249 \\
1,741 \\
\end{array}$ & $\begin{array}{l}311 \\
522\end{array}$ & $\begin{array}{l}232 \\
540\end{array}$ & $\begin{array}{l}192 \\
561\end{array}$ & $\begin{array}{l}3,449 \\
2,653 \\
\end{array}$ & $\begin{array}{l}3,174 \\
2,740 \\
\end{array}$ & $\begin{array}{l}3,088 \\
2,844 \\
\end{array}$ & $\begin{array}{r}6,312 \\
14,092 \\
\end{array}$ & $\begin{array}{r}5,824 \\
14,558 \\
\end{array}$ & $\begin{array}{r}5,676 \\
15,111 \\
\end{array}$ \\
\hline Total & 29,392 & 29,060 & 29,466 & 2,050 & 1,987 & 1,991 & 834 & 733 & 754 & 6,103 & 5,915 & 5,932 & 20,404 & 20,383 & 20,787 \\
\hline $\begin{array}{l}\text { Central Gulf: } \\
\text { Alabama } \\
\text { Mississippi } \\
\text { Tennessee............ }\end{array}$ & $\begin{array}{l}17,894 \\
16,652 \\
21,641\end{array}$ & $\begin{array}{l}18,295 \\
16,051 \\
19,431\end{array}$ & $\begin{array}{l}18,194 \\
16,854 \\
18,128\end{array}$ & $\begin{array}{r}503 \\
905 \\
1,232 \\
\end{array}$ & $\begin{array}{r}515 \\
874 \\
1,070 \\
\end{array}$ & $\begin{array}{l}421 \\
314 \\
784\end{array}$ & $\begin{array}{r}358 \\
1,006 \\
1,545 \\
\end{array}$ & $\begin{array}{r}366 \\
525 \\
1,075 \\
\end{array}$ & $\begin{array}{l}247 \\
508 \\
975\end{array}$ & $\begin{array}{l}2,921 \\
2,634 \\
1,960\end{array}$ & $\begin{array}{l}2,987 \\
1,703 \\
1,293\end{array}$ & $\begin{array}{l}2,735 \\
1,295 \\
1,018\end{array}$ & $\begin{array}{l}14,110 \\
12,106 \\
16,902\end{array}$ & $\begin{array}{l}14,426 \\
12,979 \\
15,991 \\
\end{array}$ & $\begin{array}{l}14,791 \\
14,737 \\
15,350\end{array}$ \\
\hline Total = & 56,188 & 53,807 & 53,176 & 2,642 & 2,460 & 1,519 & 2,909 & 1,967 & 1,730 & 7,516 & 5,983 & 5,048 & 43,119 & $\begin{array}{r}43,396 \\
=\end{array}$ & 44,878 \\
\hline $\begin{array}{l}\text { West Gulf: } \\
\text { Arkansas. } \\
\text { Louisiana } \\
\text { Oklahoma. } \\
\text { Texas }\end{array}$ & $\begin{array}{r}21,134 \\
18,985 \\
1,701 \\
7,662 \\
\end{array}$ & $\begin{array}{r}22,828 \\
20,594 \\
1,844 \\
8,614 \\
\end{array}$ & $\begin{array}{r}25,031 \\
22,397 \\
1,988 \\
10,025\end{array}$ & $\begin{array}{r}2,381 \\
293 \\
31 \\
273\end{array}$ & $\begin{array}{r}2,509 \\
269 \\
97 \\
586 \\
\end{array}$ & $\begin{array}{r}1,509 \\
209 \\
74 \\
447 \\
\end{array}$ & $\begin{array}{r}1,430 \\
424 \\
143 \\
141 \\
\end{array}$ & $\begin{array}{r}1,851 \\
407 \\
70 \\
104 \\
\end{array}$ & $\begin{array}{r}1,086 \\
402 \\
74 \\
85 \\
\end{array}$ & $\begin{array}{r}5,254 \\
4,168 \\
266 \\
2,233\end{array}$ & $\begin{array}{r}5,982 \\
3,488 \\
244 \\
2,424 \\
\end{array}$ & $\begin{array}{r}3,729 \\
3,694 \\
261 \\
2,512 \\
\end{array}$ & $\begin{array}{r}12,067 \\
14,099 \\
1,259 \\
5,013 \\
\end{array}$ & $\begin{array}{r}12,486 \\
16,430 \\
1,433 \\
5,500 \\
\end{array}$ & $\begin{array}{r}18,707 \\
18,092 \\
1,579 \\
6,981 \\
\end{array}$ \\
\hline Total & 49,483 & 53,880 & 59,441 & 2,980 & 3,461 & 2,239 & 2,139 & 2,432 & 1,647 & 11,923 & 12,138 & 10,196 & 32,440 & 35,849 & 45,359 \\
\hline Total, South & 207,974 & 204,530 & 205,496 & 13,657 & 13,004 & 9.860 & 7,988 & 6,775 & 5,270 & 34,200 & 31,981 & 29,358 & 152,129 & 152,768 & 161,007 \\
\hline
\end{tabular}

See footnotes at end of tatle. 
TABLE 9.- Vet volume of hardwood sawtimber on commercial timberland in the United States, by ownership and section, region, and State, as of December 31, 1952 and 1962, and January 1, 1970-Continued

[Million board feet, International 34-inch log rule]

\begin{tabular}{|c|c|c|c|c|c|c|c|c|c|c|c|c|c|c|c|}
\hline \multirow{2}{*}{ Section, region, and State } & \multicolumn{3}{|c|}{ Total, all ownerships } & \multicolumn{3}{|c|}{ National Forest } & \multicolumn{3}{|c|}{ Other public } & \multicolumn{3}{|c|}{ Forest industry } & \multicolumn{3}{|c|}{$\begin{array}{c}\text { Farm and miscellaneous } \\
\text { private }\end{array}$} \\
\hline & 1970 & 1962 & 1952 & 1970 & 1962 & 1952 & 1970 & 1962 & 1952 & 1970 & 1962 & 1952 & 1970 & 1962 & 1952 \\
\hline $\begin{array}{l}\text { Pacific Northwest: } \\
\text { Alaska: Coastal . .......... }\end{array}$ & 1,273 & 1,279 & 1,268 & 1,168 & 1,174 & 1,163 & 98 & 99 & 98 & 0 & 0 & 0 & 6 & 6 & 6 \\
\hline $\begin{array}{l}\text { Oregon: } \\
\text { Western. } \\
\text { Eastern. }\end{array}$ & $\begin{array}{r}22,975 \\
89\end{array}$ & $\begin{array}{r}19,564 \\
80\end{array}$ & $\begin{array}{r}15,-733 \\
65\end{array}$ & $\begin{array}{r}4,898 \\
38\end{array}$ & $\begin{array}{r}4,461 \\
32\end{array}$ & $\begin{array}{r}3,593 \\
24\end{array}$ & $\begin{array}{r}3,577 \\
16\end{array}$ & $\begin{array}{r}2,670 \\
14\end{array}$ & $\begin{array}{r}2,000 \\
22\end{array}$ & $\begin{array}{r}5,612 \\
0\end{array}$ & $\begin{array}{r}5,023 \\
0\end{array}$ & $\begin{array}{r}4,093 \\
0\end{array}$ & $\begin{array}{r}8,888 \\
35\end{array}$ & $\begin{array}{r}7,410 \\
34\end{array}$ & $\begin{array}{r}6,047 \\
22\end{array}$ \\
\hline Summary ..... & 23,064 & 19,644 & 15,801 & 4,936 & 4,493 & 3,617 & 3,593 & 2,684 & 2,022 & 5,612 & 5,023 & 4,093 & 8,923 & 7,444 & 6,063 \\
\hline $\begin{array}{l}\text { Washington: } \\
\text { Western... } \\
\text { Eastern.... }\end{array}$ & $\begin{array}{r}14,893 \\
423\end{array}$ & $\begin{array}{r}11,473 \\
366\end{array}$ & $\begin{array}{r}7,585 \\
356\end{array}$ & $\begin{array}{r}640 \\
80\end{array}$ & $\begin{array}{r}579 \\
84 \\
\end{array}$ & $\begin{array}{r}443 \\
81\end{array}$ & $\begin{array}{r}2,545 \\
216\end{array}$ & $\begin{array}{r}1,873 \\
188\end{array}$ & $\begin{array}{r}1,110 \\
182\end{array}$ & $\begin{array}{r}5,106 \\
44\end{array}$ & $\begin{array}{r}3,743 \\
27\end{array}$ & $\begin{array}{r}2,289 \\
30\end{array}$ & $\begin{array}{r}6,607 \\
83\end{array}$ & $\begin{array}{r}5,278 \\
67\end{array}$ & $\begin{array}{r}3,743 \\
63\end{array}$ \\
\hline Summary _-_._. & 15,321 & 11,839 & 7,941 & 720 & 663 & 524 & 2,761 & 2,061 & 1,292 & 5,150 & 3,770 & 2,319 & 6,630 & 5,345 & 3,806 \\
\hline Total. . & 39,655 & $32, \div 62$ & 25,010 & 6,824 & 6,330 & 5,304 & 6,452 & 4,814 & 3,412 & 10,762 & 8,793 & 6,412 & 15,619 & 12,795 & 9,881 \\
\hline $\begin{array}{l}\text { Pacific Southwest: } \\
\text { California... } \\
\text { Hawaii }\end{array}$ & $\begin{array}{r}5,901 \\
834 \\
\end{array}$ & $\begin{array}{r}5,725 \\
722 \\
\end{array}$ & $\begin{array}{r}5,575 \\
722 \\
\end{array}$ & $\begin{array}{r}2,120 \\
0\end{array}$ & $\begin{array}{r}2,237 \\
0 \\
\end{array}$ & $\begin{array}{r}2,274 \\
0 \\
\end{array}$ & $\begin{array}{l}423 \\
399 \\
\end{array}$ & $\begin{array}{l}403 \\
326 \\
\end{array}$ & $\begin{array}{l}474 \\
326\end{array}$ & $\begin{array}{r}1,129 \\
0 \\
\end{array}$ & $\begin{array}{r}836 \\
0\end{array}$ & $\begin{array}{r}714 \\
0\end{array}$ & $\begin{array}{r}2,229 \\
435\end{array}$ & $\begin{array}{r}2,189 \\
395\end{array}$ & $\begin{array}{r}2,113 \\
395 \\
\end{array}$ \\
\hline Total & 6,735 & 6,447 & 6,297 & 2,120 & 2,237 & 2,274 & 822 & 729 & 800 & 1,129 & 896 & 714 & 2,664 & 2,584 & 2,508 \\
\hline Total, Pacific Coast_... & 46,394 & 39,209 & $31,30 \pi$ & 8,944 & 8,567 & 7,578 & 7,275 & 5,573 & 4,212 & 11,891 & 9,689 & 7,126 & 18,284 & 15,380 & 12,390 \\
\hline $\begin{array}{l}\text { Northern Rocky Mountain: } \\
\text { Idaho } \\
\text { Montana } 3 \\
\text { South Dakota (West) } \\
\text { Wyoming }{ }^{2} \text {. }\end{array}$ & $\begin{array}{r}679 \\
1,092 \\
9 \\
324 \\
\end{array}$ & $\begin{array}{r}698 \\
1.070 \\
720 \\
\end{array}$ & $\begin{array}{r}700 \\
1,006 \\
6 \\
291 \\
\end{array}$ & $\begin{array}{r}216 \\
81 \\
0 \\
33\end{array}$ & $\begin{array}{r}225 \\
84 \\
0 \\
46\end{array}$ & $\begin{array}{r}209 \\
76 \\
0 \\
43\end{array}$ & $\begin{array}{r}164 \\
270 \\
1 \\
110\end{array}$ & $\begin{array}{r}164 \\
262 \\
1 \\
104\end{array}$ & $\begin{array}{r}159 \\
247 \\
0 \\
94 \\
\end{array}$ & $\begin{array}{r}97 \\
20 \\
0 \\
2 \\
\end{array}$ & $\begin{array}{r}99 \\
21 \\
0 \\
2\end{array}$ & $\begin{array}{r}105 \\
20 \\
0 \\
2 \\
\end{array}$ & $\begin{array}{r}201 \\
719 \\
7 \\
177\end{array}$ & $\begin{array}{r}209 \\
701 \\
5 \\
167\end{array}$ & $\begin{array}{r}226 \\
661 \\
4 \\
151\end{array}$ \\
\hline Total. & 2,105 & 2,095 & 2,003 & 331 & 355 & 328 & 547 & 532 & 502 & 121 & 124 & 128 & 1,105 & 1,083 & 1,044 \\
\hline 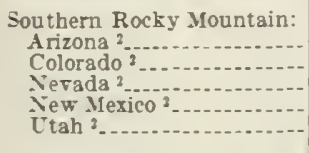 & $\begin{array}{r}678 \\
3,442 \\
24 \\
1,574 \\
1,476 \\
\end{array}$ & $\begin{array}{r}646 \\
3,832 \\
27 \\
1,505 \\
1,475 \\
\end{array}$ & $\begin{array}{r}572 \\
3,517 \\
24 \\
1,372 \\
1,416 \\
\end{array}$ & $\begin{array}{r}454 \\
2,206 \\
24 \\
464 \\
1,052 \\
\end{array}$ & $\begin{array}{r}434 \\
2,677 \\
27 \\
448 \\
1,054 \\
\end{array}$ & $\begin{array}{r}376 \\
2,465 \\
24 \\
385 \\
1,000 \\
\end{array}$ & $\begin{array}{r}99 \\
280 \\
0 \\
95 \\
133\end{array}$ & $\begin{array}{r}94 \\
261 \\
0 \\
90 \\
132\end{array}$ & $\begin{array}{r}87 \\
238 \\
0 \\
84 \\
130\end{array}$ & $\begin{array}{r}0 \\
0 \\
0 \\
52 \\
0\end{array}$ & $\begin{array}{r}0 \\
0 \\
0 \\
49 \\
0\end{array}$ & $\begin{array}{r}0 \\
0 \\
0 \\
46 \\
0\end{array}$ & $\begin{array}{r}124 \\
955 \\
0 \\
962 \\
290\end{array}$ & $\begin{array}{r}117 \\
892 \\
0 \\
916 \\
288\end{array}$ & $\begin{array}{r}108 \\
812 \\
0 \\
856 \\
285\end{array}$ \\
\hline Total & 7,196 & $7,48.5$ & 6,901 & 4,202 & 4,640 & 4,250 & 608 & 578 & 540 & 53 & 50 & 47 & 2,332 & 2,215 & 2,063 \\
\hline $\begin{array}{l}\text { Total, Rocky Moun- } \\
\text { tain. }\end{array}$ & 9,301 & 9,580 & 8,904 & 4,533 & 4,995 & 4,578 & 1,155 & 1,111 & 1,043 & 174 & 174 & 175 & 3,438 & 3,299 & 3,107 \\
\hline Total, all regions.... & $515,47 \pi$ & 474,804 & 433,072 & 39,536 & 37,488 & 30,288 & 39,790 & 33,061 & 25,879 & 67,757 & 59,466 & 51,759 & 368,393 & 341,787 & 325,145 \\
\hline
\end{tabular}


TABLE 10.-Net volume of timber on commercial timberland in the United States, by class of timber, softwoods and hardwoods, section, region, and State, January 1, $1970^{1}$

[Million cubic feet]

\begin{tabular}{|c|c|c|c|c|c|c|c|c|c|c|c|c|}
\hline \multirow{3}{*}{ Section, region, and State } & \multicolumn{3}{|c|}{ Total, all timber } & \multicolumn{9}{|c|}{ Growing-stock trees } \\
\hline & \multirow{2}{*}{$\underset{\text { species }}{\text { All }}$} & \multirow{2}{*}{$\begin{array}{l}\text { Soft- } \\
\text { woods }\end{array}$} & \multirow{2}{*}{$\begin{array}{l}\text { Hard- } \\
\text { woods }\end{array}$} & \multicolumn{3}{|c|}{ Total } & \multicolumn{3}{|c|}{ Sawtimber trees } & \multicolumn{3}{|c|}{ Poletimber trees } \\
\hline & & & & $\begin{array}{c}\text { All } \\
\text { species }\end{array}$ & $\begin{array}{l}\text { Soft- } \\
\text { woods }\end{array}$ & $\begin{array}{l}\text { Hard- } \\
\text { woods }\end{array}$ & $\begin{array}{l}\text { All } \\
\text { species }\end{array}$ & $\begin{array}{c}\text { Soft- } \\
\text { woods }\end{array}$ & $\begin{array}{l}\text { Hard- } \\
\text { woods }\end{array}$ & $\underset{\text { species }}{\text { All }}$ & $\begin{array}{c}\text { Soft- } \\
\text { woods }\end{array}$ & $\begin{array}{l}\text { Hard- } \\
\text { woods }\end{array}$ \\
\hline $\begin{array}{l}\text { New England: } \\
\text { Connecticut } \\
\text { Maine } \\
\text { Massachusetts } \\
\text { New Hamphire.................... } \\
\text { Rhode Island } \\
\text { Vermont }\end{array}$ & $\begin{array}{r}2,294 \\
24,061 \\
3,408 \\
5,942 \\
350 \\
4,413\end{array}$ & $\begin{array}{r}278 \\
16,125 \\
883 \\
3,287 \\
27 \\
1,636\end{array}$ & $\begin{array}{l}2,015 \\
7,936 \\
2,524 \\
2,655 \\
322 \\
2,777\end{array}$ & $\begin{array}{r}1,898 \\
21,253 \\
2,716 \\
5,147 \\
266 \\
3,928\end{array}$ & $\begin{array}{r}228 \\
14,763 \\
769 \\
2,901 \\
19 \\
1,507\end{array}$ & $\begin{array}{l}1,670 \\
6,490 \\
1,946 \\
2,245 \\
246 \\
2,420\end{array}$ & $\begin{array}{r}766 \\
9,059 \\
985 \\
2,481 \\
61 \\
1,790\end{array}$ & $\begin{array}{r}121 \\
6,356 \\
428 \\
1,758 \\
10 \\
787\end{array}$ & $\begin{array}{r}644 \\
2,702 \\
556 \\
722 \\
51 \\
1,002\end{array}$ & $\begin{array}{r}1,132 \\
12,193 \\
1,731 \\
2,665 \\
204 \\
2,138\end{array}$ & $\begin{array}{r}106 \\
8,406 \\
340 \\
1,143 \\
9 \\
720\end{array}$ & $\begin{array}{r}1,026 \\
3,787 \\
1,390 \\
1,522 \\
195 \\
1,418\end{array}$ \\
\hline Total... & 40,471 & 22,239 & 18,232 & 35,210 & 20,190 & 15,019 & 15,144 & 9,464 & 5,680 & 20,065 & 10,726 & 9,339 \\
\hline 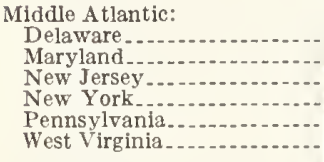 & $\begin{array}{r}698 \\
3,277 \\
1,839 \\
15,135 \\
22,702 \\
15,290\end{array}$ & $\begin{array}{r}237 \\
540 \\
396 \\
3,822 \\
1,794 \\
680\end{array}$ & $\begin{array}{r}461 \\
2,737 \\
1,442 \\
11,312 \\
20,908 \\
14,609\end{array}$ & $\begin{array}{r}657 \\
3,074 \\
1,729 \\
12,517 \\
20,270 \\
14,085\end{array}$ & $\begin{array}{r}229 \\
531 \\
385 \\
3,291 \\
1,600 \\
657\end{array}$ & $\begin{array}{r}428 \\
2,543 \\
1,343 \\
9,226 \\
18,670 \\
13,428\end{array}$ & $\begin{array}{r}342 \\
1,807 \\
1,051 \\
6,220 \\
9,126 \\
8,368\end{array}$ & $\begin{array}{r}134 \\
373 \\
219 \\
1,875 \\
900 \\
422\end{array}$ & $\begin{array}{r}207 \\
1,433 \\
832 \\
4,344 \\
8,226 \\
7,946\end{array}$ & $\begin{array}{r}315 \\
1,266 \\
678 \\
6,296 \\
11,143 \\
5,717\end{array}$ & $\begin{array}{r}94 \\
157 \\
166 \\
\mathbf{1}, 415 \\
699 \\
235\end{array}$ & $\begin{array}{r}220 \\
1,109 \\
511 \\
4,881 \\
10,443 \\
5,482\end{array}$ \\
\hline Total... & 58,944 & 7,471 & 51,472 & 52,333 & 6,694 & 45,639 & 26,916 & 3,925 & 22,991 & 25,417 & 2,769 & 22,648 \\
\hline $\begin{array}{l}\text { Lake States: } \\
\text { Michigan } \\
\text { Minnesota } \\
\text { North Dakota } \\
\text { South Dakota (East) } \\
\text { Wisconsin }\end{array}$ & $\begin{array}{r}17,909 \\
12,387 \\
382 \\
131 \\
12,188\end{array}$ & $\begin{array}{r}4,490 \\
3,988 \\
0 \\
19 \\
2,747\end{array}$ & $\begin{array}{r}13,419 \\
8,399 \\
382 \\
111 \\
9,441\end{array}$ & $\begin{array}{r}16,558 \\
11,726 \\
276 \\
102 \\
11,411\end{array}$ & $\begin{array}{r}4,313 \\
3,896 \\
0 \\
18 \\
2,662\end{array}$ & $\begin{array}{r}12,245 \\
7,830 \\
276 \\
83 \\
8,748\end{array}$ & $\begin{array}{r}7,415 \\
3,635 \\
117 \\
64 \\
4,547\end{array}$ & $\begin{array}{r}2,103 \\
1,607 \\
0 \\
10 \\
1,349\end{array}$ & $\begin{array}{r}5,312 \\
2,028 \\
117 \\
54 \\
3,197\end{array}$ & $\begin{array}{r}9,142 \\
8,091 \\
158 \\
37 \\
6,863\end{array}$ & $\begin{array}{r}2,209 \\
2,289 \\
0 \\
8 \\
1,313\end{array}$ & $\begin{array}{r}6,933 \\
5,802 \\
158 \\
29 \\
5,550\end{array}$ \\
\hline Total... & 43,000 & 11,245 & 31,754 & 40,075 & 10,891 & 29,184 & 15,780 & 5,071 & 10,709 & 24,294 & 5,820 & 18,474 \\
\hline $\begin{array}{l}\text { Central: } \\
\text { Illinois... } \\
\text { Indiana_. } \\
\text { Iowa } \\
\text { Kansas } \\
\text { Kentucky } \\
\text { Missouri } \\
\text { Nebraska } \\
\text { Ohio }\end{array}$ & $\begin{array}{r}2,395 \\
4,020 \\
2,180 \\
899 \\
8,863 \\
8,083 \\
651 \\
4,916\end{array}$ & $\begin{array}{r}19 \\
74 \\
3 \\
1 \\
642 \\
405 \\
126 \\
133 \\
\end{array}$ & $\begin{array}{l}2,375 \\
3,946 \\
2,176 \\
897 \\
8,221 \\
7,678 \\
525 \\
4,782\end{array}$ & $\begin{array}{r}2,327 \\
3,606 \\
1,807 \\
534 \\
8,546 \\
-6,495 \\
506 \\
4,232 \\
\end{array}$ & $\begin{array}{r}19 \\
70 \\
3 \\
0 \\
621 \\
384 \\
114 \\
123\end{array}$ & $\begin{array}{r}2,308 \\
3,536 \\
1,803 \\
533 \\
7,925 \\
6,111 \\
391 \\
4,109\end{array}$ & $\begin{array}{l}1,391 \\
2,448 \\
1,358 \\
387 \\
5,295 \\
2,746 \\
390 \\
2,678\end{array}$ & $\begin{array}{r}5 \\
34 \\
2 \\
0 \\
412 \\
218 \\
88 \\
67\end{array}$ & $\begin{array}{r}1,386 \\
2,413 \\
1,356 \\
387 \\
4,883 \\
2,528 \\
302 \\
2,611\end{array}$ & $\begin{array}{r}936 \\
1,158 \\
449 \\
147 \\
3,251 \\
3,749 \\
115 \\
1,554\end{array}$ & $\begin{array}{r}14 \\
35 \\
1 \\
0 \\
209 \\
166 \\
26 \\
56\end{array}$ & $\begin{array}{r}922 \\
1,123 \\
447 \\
146 \\
3,041 \\
3,583 \\
89 \\
1,497\end{array}$ \\
\hline Total ... & 32,009 & 1,405 & 30,604 & 28,057 & 1,338 & 26,719 & 16,696 & 828 & 15,867 & 11,361 & 509 & 10,852 \\
\hline Total, North... & 174,425 & 42,362 & 132,063 & 155,677 & 39,114 & 116,563 & 74,537 & 19,288 & 55,248 & 81,139 & 19,825 & 61,314 \\
\hline $\begin{array}{l}\text { South A tlantic: } \\
\text { North Carolina........... } \\
\text { South Carolina } . . . \\
\text { Virginia }\end{array}$ & $\begin{array}{l}22,222 \\
14,958 \\
18,797\end{array}$ & $\begin{array}{l}8,743 \\
6,614 \\
4,548\end{array}$ & $\begin{array}{r}13,479 \\
8,344 \\
14,248\end{array}$ & $\begin{array}{l}19,680 \\
12,699 \\
15,171\end{array}$ & $\begin{array}{l}8,509 \\
6,369 \\
4,215\end{array}$ & $\begin{array}{r}11,171 \\
6,330 \\
10,955\end{array}$ & $\begin{array}{r}13,156 \\
9,198 \\
9,604\end{array}$ & $\begin{array}{l}6,331 \\
4,813 \\
2,847\end{array}$ & $\begin{array}{l}6,824 \\
4,384 \\
6,757\end{array}$ & $\begin{array}{l}6,524 \\
3,501 \\
5,566\end{array}$ & $\begin{array}{l}2,177 \\
1,555 \\
1,368\end{array}$ & $\begin{array}{l}4,346 \\
1,945 \\
4,198\end{array}$ \\
\hline Total & 55,979 & 19,906 & 36,072 & 47,550 & 19,093 & 28,456 & 31,958 & 13,992 & 17,966 & 15,592 & 5,101 & 10,490 \\
\hline $\begin{array}{l}\text { East Gulf: } \\
\text { Florida....- } \\
\text { Georgia..... }\end{array}$ & $\begin{array}{l}12,565 \\
21,355\end{array}$ & $\begin{array}{r}7,099 \\
12,139\end{array}$ & $\begin{array}{l}5,465 \\
9,216\end{array}$ & $\begin{array}{l}10,888 \\
19,695\end{array}$ & $\begin{array}{r}6,904 \\
11,839\end{array}$ & $\begin{array}{l}3,984 \\
7,855\end{array}$ & $\begin{array}{r}6,930 \\
11,964\end{array}$ & $\begin{array}{l}4,407 \\
7,716\end{array}$ & $\begin{array}{l}2,523 \\
4,248\end{array}$ & $\begin{array}{l}3,958 \\
7,730\end{array}$ & $\begin{array}{l}2,497 \\
4,123\end{array}$ & $\begin{array}{l}1,461 \\
3,606\end{array}$ \\
\hline Total.... & 33,921 & 19,239 & 14,681 & 30,583 & 18,743 & 11,839 & 18,895 & 12,123 & 6,771 & 11,688 & 6,620 & 5,067 \\
\hline $\begin{array}{l}\text { Central Gulf: } \\
\text { Alabama } \\
\text { Mississippi } \\
\text { Tennessee.............. }\end{array}$ & $\begin{array}{l}17,890 \\
15,969 \\
12,139\end{array}$ & $\begin{array}{l}9,400 \\
7,280 \\
1,870\end{array}$ & $\begin{array}{r}8,490 \\
8,688 \\
10,268\end{array}$ & $\begin{array}{l}16,009 \\
13,878 \\
10,395\end{array}$ & $\begin{array}{l}9,232 \\
7,188 \\
1,799\end{array}$ & $\begin{array}{l}6,777 \\
6,689 \\
8,596\end{array}$ & $\begin{array}{r}10,845 \\
8,821 \\
5,904\end{array}$ & $\begin{array}{l}6,921 \\
5,252 \\
1,038\end{array}$ & $\begin{array}{l}3,923 \\
3,569 \\
4,866\end{array}$ & $\begin{array}{l}5,164 \\
5,056 \\
4,491\end{array}$ & $\begin{array}{r}2,311 \\
1,936 \\
761\end{array}$ & $\begin{array}{l}2,853 \\
3,120 \\
3,729\end{array}$ \\
\hline Total.. & 45,999 & 18,550 & 27,448 & 40,283 & 18,220 & 22,062 & 25,571 & 13,212 & 12,359 & 14,712 & 5,008 & 9,703 \\
\hline 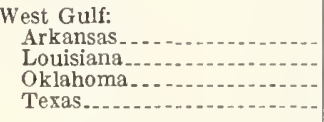 & $\begin{array}{r}17,848 \\
16,279 \\
2,415 \\
12,093 \\
\end{array}$ & $\begin{array}{r}6,630 \\
7,781 \\
861 \\
7,412\end{array}$ & $\begin{array}{r}11,217 \\
8,497 \\
1,554 \\
4,680\end{array}$ & $\begin{array}{r}15,365 \\
13,602 \\
1,648 \\
10,482\end{array}$ & $\begin{array}{r}6,539 \\
7,595 \\
850 \\
7,361\end{array}$ & $\begin{array}{l}8,826 \\
6,006 \\
798 \\
3,121\end{array}$ & $\begin{array}{r}9,764 \\
10,424 \\
944 \\
7,488 \\
\end{array}$ & $\begin{array}{r}4,970 \\
6,263 \\
\mathbf{5 8 4} \\
5,823\end{array}$ & $\begin{array}{r}4,793 \\
4,161 \\
359 \\
1,665 \\
\end{array}$ & $\begin{array}{r}5,601 \\
3,177 \\
704 \\
2,994\end{array}$ & $\begin{array}{r}1,568 \\
1,332 \\
266 \\
1,538 \\
\end{array}$ & $\begin{array}{r}4,032 \\
1,845 \\
438 \\
1,456\end{array}$ \\
\hline Total.... & 48,636 & 22,686 & 25,950 & 41,099 & 22,346 & 18,753 & 28,621 & 17,641 & 10,980 & 12,477 & 4,705 & 7,772 \\
\hline Total, South. & 184,535 & 80,383 & 104,152 & 159,517 & 78,404 & 81,112 & 105,046 & 56,968 & 48,078 & 54,470 & 21,436 & 33,034 \\
\hline
\end{tabular}

See footnotes at end of table. 
TABLE 10. - Vet volume of timber on commercial timberland in the United States, by class of timber, softwoods and hardwoods, section, region, and State, January 1, $1970^{1}$-Continued

[Million cubic feet]

\begin{tabular}{|c|c|c|c|c|c|c|c|c|c|c|c|c|}
\hline \multirow{3}{*}{ Section, region, and State } & \multicolumn{3}{|c|}{ Total, all timber } & \multicolumn{9}{|c|}{ Growing-stock trees } \\
\hline & \multirow{2}{*}{$\underset{\text { species }}{\text { All }}$} & \multirow{2}{*}{$\begin{array}{c}\text { Soft- } \\
\text { woods }\end{array}$} & \multirow{2}{*}{$\begin{array}{l}\text { Hard- } \\
\text { woods }\end{array}$} & \multicolumn{3}{|c|}{ Total } & \multicolumn{3}{|c|}{ Sawtimber trees } & \multicolumn{3}{|c|}{ Poletimber trees } \\
\hline & & & & $\underset{\text { species }}{\text { All }}$ & $\begin{array}{c}\text { Soft- } \\
\text { woods }\end{array}$ & $\begin{array}{l}\text { Hard- } \\
\text { woods }\end{array}$ & $\underset{\text { species }}{\text { All }}$ & $\begin{array}{c}\text { Soft- } \\
\text { woods }\end{array}$ & $\begin{array}{l}\text { Hard- } \\
\text { woods }\end{array}$ & $\begin{array}{l}\text { All } \\
\text { species }\end{array}$ & $\begin{array}{l}\text { Soft- } \\
\text { woods }\end{array}$ & $\begin{array}{l}\text { Hard- } \\
\text { woods }\end{array}$ \\
\hline $\begin{array}{l}\text { Pacific Northwest: } \\
\text { Alaska: Coastal.- }\end{array}$ & 35,972 & 35,668 & 304 & 34,767 & 34,468 & 298 & 32,527 & 32,294 & 233 & 2,239 & 2,174 & 65 \\
\hline $\begin{array}{l}\text { Oregon: } \\
\text { Western } \\
\text { Eastern }\end{array}$ & $\begin{array}{l}65,898 \\
24,905\end{array}$ & $\begin{array}{l}59,133 \\
24,845 \\
\end{array}$ & $\begin{array}{r}6,765 \\
60 \\
\end{array}$ & $\begin{array}{l}62,817 \\
24,276\end{array}$ & $\begin{array}{l}56,823 \\
24,238\end{array}$ & $\begin{array}{r}5,994 \\
38 \\
\end{array}$ & $\begin{array}{l}55,073 \\
18,441\end{array}$ & $\begin{array}{l}51,455 \\
18,431\end{array}$ & $\begin{array}{r}3,618 \\
10 \\
\end{array}$ & $\begin{array}{l}7,744 \\
5,835 \\
\end{array}$ & $\begin{array}{l}5,368 \\
5,807\end{array}$ & $\begin{array}{r}2,376 \\
28 \\
\end{array}$ \\
\hline Summary .... & 90,803 & 83,978 & 6,825 & 87,093 & 81,061 & 6,032 & 73,514 & 69,886 & 3,628 & 13,579 & 11,175 & 2,404 \\
\hline $\begin{array}{l}\text { Washington: } \\
\text { Western...... } \\
\text { Eastern....... }\end{array}$ & $\begin{array}{l}50,023 \\
18,363 \\
\end{array}$ & $\begin{array}{l}44,693 \\
18,119 \\
\end{array}$ & $\begin{array}{r}5,330 \\
244 \\
\end{array}$ & $\begin{array}{l}47,323 \\
17,792 \\
\end{array}$ & $\begin{array}{l}42,336 \\
17,621\end{array}$ & $\begin{array}{r}4,987 \\
171 \\
\end{array}$ & $\begin{array}{l}39,675 \\
12,963\end{array}$ & $\begin{array}{l}36,925 \\
12,883\end{array}$ & $\begin{array}{r}2,750 \\
80 \\
\end{array}$ & $\begin{array}{l}7,648 \\
4,829 \\
\end{array}$ & $\begin{array}{l}5,411 \\
4,738\end{array}$ & $\begin{array}{r}2,237 \\
91 \\
\end{array}$ \\
\hline Summary ...... & 68,386 & 62,812 & 5,574 & 65,115 & 59,957 & 5,158 & 52,638 & 49,808 & 2,830 & 12,477 & 10,149 & 2,328 \\
\hline Total. .......... & 195,161 & 182,458 & 12,703 & 186,975 & 175,486 & 11,488 & 158,679 & 151,988 & 6,691 & 28,295 & 23,498 & 4,797 \\
\hline $\begin{array}{l}\text { Pacific Southwest: } \\
\text { California......... } \\
\text { Hawaí........... }\end{array}$ & $\begin{array}{r}55,716 \\
470 \\
\end{array}$ & $\begin{array}{r}52,128 \\
5 \\
\end{array}$ & $\begin{array}{r}3,588 \\
464 \\
\end{array}$ & $\begin{array}{r}54,251 \\
238 \\
\end{array}$ & $\begin{array}{r}51,152 \\
4 \\
\end{array}$ & $\begin{array}{r}3,099 \\
234 \\
\end{array}$ & $\begin{array}{r}48,452 \\
194 \\
\end{array}$ & $\begin{array}{r}46,138 \\
3 \\
\end{array}$ & $\begin{array}{r}2,314 \\
190 \\
\end{array}$ & $\begin{array}{r}5,799 \\
44 \\
\end{array}$ & $\begin{array}{r}5,014 \\
0 \\
\end{array}$ & $\begin{array}{r}785 \\
44 \\
\end{array}$ \\
\hline Total.... & 56,186 & 52,133 & 4,052 & 54,489 & 51,156 & 3,333 & 48,646 & 46,141 & 2,504 & 5,843 & 5,014 & 829 \\
\hline Total, Pacific Coast.... & 251,347 & 234,591 & 16,756 & 241,465 & 226,643 & 14,822 & 207,326 & 198,130 & 9,195 & 34,139 & 28,512 & 5,627 \\
\hline $\begin{array}{l}\text { Northern Rocky Mountain: } \\
\text { Idaho }{ }^{2} \\
\text { Montana } \\
\text { South Dakota (West) }{ }^{2}-\ldots \\
\text { Wyoming }{ }^{2}-\end{array}$ & $\begin{array}{r}31,563 \\
33,181 \\
1,060 \\
5,412 \\
\end{array}$ & $\begin{array}{r}31,234 \\
32,861 \\
1,052 \\
5,161 \\
\end{array}$ & $\begin{array}{r}329 \\
320 \\
7 \\
251 \\
\end{array}$ & $\begin{array}{r}29,497 \\
28,650 \\
1,007 \\
4,673 \\
\end{array}$ & $\begin{array}{r}29,257 \\
28,376 \\
1,001 \\
4,471 \\
\end{array}$ & $\begin{array}{r}239 \\
273 \\
6 \\
601 \\
\end{array}$ & $\begin{array}{r}24,020 \\
19,677 \\
695 \\
3,173 \\
\end{array}$ & $\begin{array}{r}23,897 \\
19,465 \\
693 \\
3,123 \\
\end{array}$ & $\begin{array}{r}122 \\
211 \\
1 \\
50 \\
\end{array}$ & $\begin{array}{r}5,477 \\
8,972 \\
311 \\
1,499 \\
\end{array}$ & $\begin{array}{r}5,360 \\
8,910 \\
307 \\
1,347 \\
\end{array}$ & $\begin{array}{r}117 \\
62 \\
4 \\
151 \\
\end{array}$ \\
\hline Total.. & 71,218 & 70,309 & 908 & 63,827 & 63,106 & 721 & 47,566 & 47,181 & 385 & 16,261 & 15,925 & 336 \\
\hline 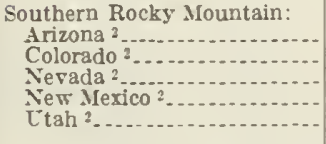 & $\begin{array}{r}5,218 \\
14,942 \\
278 \\
7,183 \\
5,397 \\
\end{array}$ & $\begin{array}{r}4,861 \\
12,059 \\
254 \\
6,324 \\
4,021 \\
\end{array}$ & $\begin{array}{r}356 \\
2,882 \\
24 \\
858 \\
1,375 \\
\end{array}$ & $\begin{array}{r}4,809 \\
12,267 \\
250 \\
6,336 \\
4,727\end{array}$ & $\begin{array}{r}4,583 \\
10,360 \\
237 \\
5,735 \\
3,689 \\
\end{array}$ & $\begin{array}{r}226 \\
1,907 \\
12 \\
600 \\
1,038 \\
\end{array}$ & $\begin{array}{l}4,323 \\
8,083 \\
232 \\
5,158 \\
3,100 \\
\end{array}$ & $\begin{array}{r}4,190 \\
7,392 \\
227 \\
4,889 \\
2,765 \\
\end{array}$ & $\begin{array}{r}132 \\
691 \\
5 \\
269 \\
335 \\
\end{array}$ & $\begin{array}{r}486 \\
4,183 \\
17 \\
1,178 \\
1,627 \\
\end{array}$ & $\begin{array}{r}393 \\
2,968 \\
10 \\
846 \\
923 \\
\end{array}$ & $\begin{array}{r}93 \\
1,215 \\
7 \\
331 \\
703 \\
\end{array}$ \\
\hline Total & 33,019 & 27,521 & 5,497 & 28,391 & 24,605 & 3,785 & 20,898 & 19,464 & 1,434 & 7,492 & 5,141 & 2,351 \\
\hline Total, Rocky Mountain & 104,237 & 97,830 & 6,406 & 92,218 & 87,711 & 4,507 & 68,464 & 66,645 & 1,819 & 23,753 & 21,066 & 2,687 \\
\hline Total, all regions...... & 714,545 & 455,168 & 259,377 & 648,879 & 431,873 & 217,005 & 455,375 & 341,033 & 114,341 & 193,503 & 90,810 & 102,663 \\
\hline
\end{tabular}

\begin{tabular}{|c|c|c|c|c|c|c|c|c|c|}
\hline \multirow{2}{*}{ Section, region, and State } & \multicolumn{3}{|c|}{ Rough trees } & \multicolumn{3}{|c|}{ Rotten trees } & \multicolumn{3}{|c|}{ Salvable dead trees } \\
\hline & All species & Softwoods & Hardwoods & All species & Softwoods & Hardwoods & All species & Softwoods & Hardwoods \\
\hline 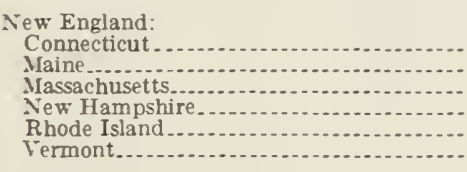 & $\begin{array}{r}283 \\
1,389 \\
535 \\
494 \\
63 \\
319\end{array}$ & $\begin{array}{r}44 \\
777 \\
108 \\
358 \\
8 \\
113\end{array}$ & $\begin{array}{r}239 \\
612 \\
427 \\
135 \\
55 \\
205\end{array}$ & $\begin{array}{r}112 \\
1,418 \\
155 \\
301 \\
20 \\
166\end{array}$ & $\begin{array}{r}5 \\
585 \\
4 \\
27 \\
0 \\
14\end{array}$ & $\begin{array}{r}106 \\
833 \\
150 \\
274 \\
20 \\
151\end{array}$ & $\begin{array}{l}0 \\
0 \\
0 \\
0 \\
0 \\
0\end{array}$ & $\begin{array}{l}0 \\
0 \\
0 \\
0 \\
0 \\
0\end{array}$ & $\begin{array}{l}0 \\
0 \\
0 \\
0 \\
0 \\
0\end{array}$ \\
\hline Total..... & 3,086 & 1,411 & 1,674 & 2,175 & 637 & 1,537 & 0 & 0 & 0 \\
\hline 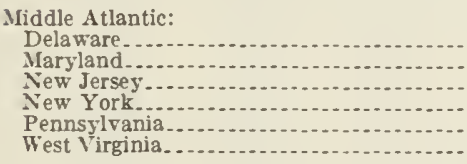 & $\begin{array}{r}24 \\
139 \\
60 \\
1,524 \\
1,766 \\
309\end{array}$ & $\begin{array}{r}6 \\
7 \\
7 \\
445 \\
173 \\
18\end{array}$ & $\begin{array}{r}18 \\
132 \\
53 \\
1,078 \\
1,593 \\
290\end{array}$ & $\begin{array}{r}17 \\
63 \\
49 \\
1,093 \\
665 \\
895\end{array}$ & $\begin{array}{r}2 \\
1 \\
4 \\
85 \\
20 \\
4\end{array}$ & $\begin{array}{r}15 \\
62 \\
45 \\
1,008 \\
645 \\
890\end{array}$ & $\begin{array}{l}0 \\
0 \\
0 \\
0 \\
0 \\
0\end{array}$ & $\begin{array}{l}0 \\
0 \\
0 \\
0 \\
0 \\
0\end{array}$ & $\begin{array}{l}0 \\
0 \\
0 \\
0 \\
0 \\
0\end{array}$ \\
\hline Total & 3,825 & 658 & 3,166 & 2,785 & 118 & 2,666 & 0 & 0 & 0 \\
\hline 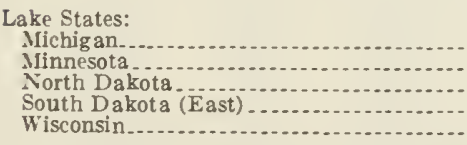 & $\begin{array}{r}1,021 \\
232 \\
63 \\
9 \\
452\end{array}$ & $\begin{array}{r}121 \\
28 \\
0 \\
0 \\
43\end{array}$ & $\begin{array}{r}899 \\
204 \\
63 \\
9 \\
409\end{array}$ & $\begin{array}{r}266 \\
415 \\
42 \\
19 \\
269\end{array}$ & $\begin{array}{r}34 \\
55 \\
0 \\
0 \\
26\end{array}$ & $\begin{array}{r}232 \\
360 \\
42 \\
19 \\
242\end{array}$ & $\begin{array}{r}63 \\
12 \\
0 \\
0 \\
55\end{array}$ & $\begin{array}{r}21 \\
9 \\
0 \\
0 \\
14\end{array}$ & $\begin{array}{r}41 \\
3 \\
0 \\
0 \\
41\end{array}$ \\
\hline Total.. & 1,780 & 193 & 1,586 & 1,013 & 116 & 897 & 131 & 45 & 86 \\
\hline
\end{tabular}

See footnotes at end of table. 

TABLE 10.- Net volume of timber on commercial timberland in the United States, by class of timber, softwoods and hardwoods,
section, region, and State, January 1, $1970^{1}$-Continued

[Million cubic feet]

\begin{tabular}{|c|c|c|c|c|c|c|c|c|}
\hline \multicolumn{3}{|c|}{ Rough trees } & \multicolumn{3}{|c|}{ Rotten trees } & \multicolumn{3}{|c|}{ Salvable dead trees } \\
\hline All species & Softwoods & Hardwoods & All species & Softwoods & Hardwoods & All species & Softwoods & Hardwoods \\
\hline $\begin{array}{r}51 \\
319 \\
247 \\
338 \\
197 \\
687 \\
107 \\
396\end{array}$ & $\begin{array}{r}0 \\
3 \\
0 \\
0 \\
17 \\
15 \\
9 \\
7\end{array}$ & $\begin{array}{r}51 \\
315 \\
247 \\
337 \\
180 \\
672 \\
97 \\
388 \\
\end{array}$ & $\begin{array}{r}8 \\
71 \\
125 \\
21 \\
95 \\
849 \\
31 \\
286\end{array}$ & $\begin{array}{l}0 \\
0 \\
0 \\
0 \\
1 \\
1 \\
1 \\
1\end{array}$ & $\begin{array}{r}8 \\
71 \\
125 \\
21 \\
93 \\
847 \\
30 \\
285\end{array}$ & $\begin{array}{r}8 \\
22 \\
0 \\
4 \\
24 \\
50 \\
5 \\
0 \\
\end{array}$ & $\begin{array}{l}0 \\
0 \\
0 \\
0 \\
1 \\
3 \\
0 \\
0\end{array}$ & $\begin{array}{r}8 \\
22 \\
0 \\
4 \\
23 \\
46 \\
5 \\
0\end{array}$ \\
\hline 2,345 & 55 & 2,290 & 1,489 & 6 & 1,483 & 115 & 5 & 110 \\
\hline 11,037 & 2,318 & 8,718 & 7,463 & 879 & 6,584 & 247 & 60 & 196 \\
\hline $\begin{array}{l}1,509 \\
1,750 \\
2,994 \\
\end{array}$ & $\begin{array}{l}177 \\
197 \\
316 \\
\end{array}$ & $\begin{array}{l}1,331 \\
1,553 \\
2,678 \\
\end{array}$ & $\begin{array}{r}1,012 \\
484 \\
627 \\
\end{array}$ & $\begin{array}{l}47 \\
31 \\
14 \\
\end{array}$ & $\begin{array}{l}964 \\
452 \\
613\end{array}$ & $\begin{array}{r}20 \\
23 \\
4 \\
\end{array}$ & $\begin{array}{r}9 \\
16 \\
1\end{array}$ & $\begin{array}{r}11 \\
7 \\
2\end{array}$ \\
\hline 6,255 & 692 & 5,563 & 2,124 & 93 & 2,030 & 48 & 27 & 21 \\
\hline $\begin{array}{l}1,353 \\
1,160 \\
\end{array}$ & $\begin{array}{l}132 \\
240 \\
\end{array}$ & $\begin{array}{r}1,221 \\
920 \\
\end{array}$ & $\begin{array}{l}308 \\
487\end{array}$ & $\begin{array}{l}52 \\
47\end{array}$ & $\begin{array}{l}256 \\
439\end{array}$ & $\begin{array}{l}15 \\
12 \\
\end{array}$ & $\begin{array}{l}10 \\
12 \\
\end{array}$ & $\begin{array}{l}4 \\
0\end{array}$ \\
\hline 2,514 & 372 & 2,142 & 795 & 100 & 695 & 27 & 23 & 4 \\
\hline $\begin{array}{l}1,304 \\
1,491 \\
1,111 \\
\end{array}$ & $\begin{array}{r}111 \\
55 \\
37\end{array}$ & $\begin{array}{l}1,192 \\
1,435 \\
1,074 \\
\end{array}$ & $\begin{array}{l}506 \\
595 \\
605\end{array}$ & $\begin{array}{l}20 \\
32 \\
20 \\
\end{array}$ & $\begin{array}{l}486 \\
562 \\
584 \\
\end{array}$ & $\begin{array}{r}70 \\
5 \\
26 \\
\end{array}$ & $\begin{array}{r}35 \\
3 \\
12\end{array}$ & $\begin{array}{r}34 \\
1 \\
14 \\
\end{array}$ \\
\hline$\stackrel{3,906}{=}$ & 204 & $\begin{array}{l}3,702 \\
\end{array}$ & 1,706 & 73 & 1,633 & 102 & 52 & 49 \\
\hline $\begin{array}{r}1,602 \\
1,743 \\
596 \\
1,101 \\
\end{array}$ & $\begin{array}{r}54 \\
84 \\
7 \\
39 \\
\end{array}$ & $\begin{array}{r}1,547 \\
1,658 \\
588 \\
1,062 \\
\end{array}$ & $\begin{array}{l}850 \\
920 \\
167 \\
506\end{array}$ & $\begin{array}{r}25 \\
95 \\
3 \\
10 \\
\end{array}$ & $\begin{array}{l}825 \\
824 \\
164 \\
496 \\
\end{array}$ & $\begin{array}{r}29 \\
13 \\
3 \\
2 \\
\end{array}$ & $\begin{array}{r}12 \\
5 \\
0 \\
1 \\
\end{array}$ & $\begin{array}{r}17 \\
7 \\
3 \\
1 \\
\end{array}$ \\
\hline 5,042 & 185 & 4,856 & 2,445 & 134 & 2,310 & 49 & 19 & 30 \\
\hline 17,718 & 1,454 & 16,264 & 7,071 & 401 & 6,670 & 227 & 122 & $\overline{105}$ \\
\hline$\underline{112}$ & 110 & 2 & 735 & 731 & 3 & 357 & 357 & 0 \\
\hline $\begin{array}{l}949 \\
281 \\
\end{array}$ & $\begin{array}{l}244 \\
260\end{array}$ & $\begin{array}{r}705 \\
21 \\
\end{array}$ & $\begin{array}{r}197 \\
68\end{array}$ & $\begin{array}{r}171 \\
67\end{array}$ & $\begin{array}{r}26 \\
1\end{array}$ & $\begin{array}{r}1,935 \\
280 \\
\end{array}$ & $\begin{array}{r}1,895 \\
280 \\
\end{array}$ & $\begin{array}{r}40 \\
0\end{array}$ \\
\hline 1,230 & 504 & 726 & 265 & 238 & 27 & 2,215 & 2,175 & 40 \\
\hline $\begin{array}{l}583 \\
113\end{array}$ & $\begin{array}{r}295 \\
46\end{array}$ & $\begin{array}{r}288 \\
67 \\
\end{array}$ & $\begin{array}{r}428 \\
83\end{array}$ & $\begin{array}{r}409 \\
77\end{array}$ & $\begin{array}{r}19 \\
6\end{array}$ & $\begin{array}{r}1,689 \\
375\end{array}$ & $\begin{array}{r}1,653 \\
375 \\
\end{array}$ & $\begin{array}{r}36 \\
0 \\
\end{array}$ \\
\hline 696 & 341 & 355 & 511 & 486 & 25 & 2,064 & 2,028 & 36 \\
\hline 2,038 & 955 & 1,083 & 1,511 & 1,455 & 55 & 4,636 & 4,560 & 76 \\
\hline $\begin{array}{l}415 \\
187 \\
\end{array}$ & $\begin{array}{r}56 \\
1 \\
\end{array}$ & $\begin{array}{l}359 \\
186 \\
\end{array}$ & $\begin{array}{r}828 \\
42 \\
\end{array}$ & $\begin{array}{r}698 \\
0\end{array}$ & $\begin{array}{r}130 \\
42 \\
\end{array}$ & $\begin{array}{r}222 \\
1 \\
\end{array}$ & $\begin{array}{r}222 \\
0\end{array}$ & $\begin{array}{l}0 \\
1\end{array}$ \\
\hline 602 & 57 & 545 & 870 & 698 & 172 & 223 & 222 & 1 \\
\hline 2,640 & 1,012 & 1,628 & 2,381 & 2,153 & 227 & 4,860 & 4,782 & 77 \\
\hline $\begin{array}{r}572 \\
846 \\
2 \\
86 \\
\end{array}$ & $\begin{array}{r}521 \\
823 \\
1 \\
82 \\
\end{array}$ & $\begin{array}{r}50 \\
23 \\
1 \\
4 \\
\end{array}$ & $\begin{array}{r}554 \\
684 \\
3 \\
75\end{array}$ & $\begin{array}{r}525 \\
672 \\
3 \\
55\end{array}$ & $\begin{array}{r}28 \\
12 \\
0 \\
20\end{array}$ & $\begin{array}{r}940 \\
3,000 \\
47 \\
577\end{array}$ & $\begin{array}{r}929 \\
2,990 \\
47 \\
552\end{array}$ & $\begin{array}{r}10 \\
10 \\
0 \\
25\end{array}$ \\
\hline 1,507 & 1,428 & 78 & 1,318 & 1,256 & 62 & 4,564 & 4,518 & 46 \\
\hline $\begin{array}{r}199 \\
317 \\
6 \\
351 \\
141 \\
\end{array}$ & $\begin{array}{r}132 \\
246 \\
4 \\
253 \\
60\end{array}$ & $\begin{array}{r}67 \\
71 \\
1 \\
97 \\
81\end{array}$ & $\begin{array}{r}75 \\
1,016 \\
11 \\
148 \\
223\end{array}$ & $\begin{array}{r}17 \\
243 \\
3 \\
36 \\
31\end{array}$ & $\begin{array}{r}58 \\
773 \\
7 \\
112 \\
192\end{array}$ & $\begin{array}{r}133 \\
1,340 \\
10 \\
346 \\
303\end{array}$ & $\begin{array}{r}128 \\
1,210 \\
9 \\
299 \\
240\end{array}$ & $\begin{array}{r}4 \\
130 \\
1 \\
47 \\
63 \\
\end{array}$ \\
\hline 1,016 & 696 & 319 & 1,476 & 331 & 1,144 & 2,134 & 1,887 & 247 \\
\hline 2,523 & 2,125 & 398 & 2,794 & 1,587 & 1,206 & 6,699 & 6,405 & 293 \\
\hline 33,920 & 6,910 & 27,010 & 19,711 & 5,022 & 14,688 & 12,034 & 11,361 & 673 \\
\hline
\end{tabular}


TABE 11. - Vet volume of growing stock on commercial timberland in the United States, by diameter class, softwocds and hardwcods, and timber supply region, as of December S1, 1952 and 1962, and January 1, $1970{ }^{1}$

[Million cubic feet]

SOFTWOOD GROWING STOCK

\begin{tabular}{|c|c|c|c|c|c|c|c|c|c|c|c|c|}
\hline \multirow[b]{2}{*}{ Timber supply region } & \multirow[b]{2}{*}{ Year } & \multirow[b]{2}{*}{ Total } & \multicolumn{10}{|c|}{ Diameter class (inches) } \\
\hline & & & 5.0 to 7.0 & 7.0 to 9.0 & $\begin{array}{c}9.0 \text { to } \\
11.0\end{array}$ & $\begin{array}{c}11.0 \text { to } \\
13.0\end{array}$ & $\begin{array}{c}13.0 \text { to } \\
15.0\end{array}$ & $\begin{array}{c}15.0 \text { to } \\
17.0\end{array}$ & $\begin{array}{c}17.0 \text { to } \\
19.0\end{array}$ & $\begin{array}{c}19.0 \text { to } \\
21.0\end{array}$ & $\begin{array}{c}21.0 \text { to } \\
29.0\end{array}$ & $29.0+$ \\
\hline Northeast_.......... & $\begin{array}{l}1970 \\
1962 \\
1952\end{array}$ & $\begin{array}{l}26,881 \\
23,672 \\
20,027\end{array}$ & $\begin{array}{l}6,936 \\
6,065 \\
4,627 \\
\end{array}$ & $\begin{array}{l}6,559 \\
5,696 \\
4,734 \\
\end{array}$ & $\begin{array}{l}4,720 \\
3,996 \\
3,146 \\
\end{array}$ & $\begin{array}{l}3,235 \\
2,817 \\
2,497 \\
\end{array}$ & $\begin{array}{l}2,111 \\
1,913 \\
1,791 \\
\end{array}$ & $\begin{array}{l}1,361 \\
1,248 \\
1,190 \\
\end{array}$ & $\begin{array}{l}793 \\
742 \\
720 \\
\end{array}$ & $\begin{array}{l}480 \\
484 \\
527 \\
\end{array}$ & $\begin{array}{l}611 \\
623 \\
701 \\
\end{array}$ & $\begin{array}{l}74 \\
84 \\
90\end{array}$ \\
\hline Northcentral & $\begin{array}{l}1970 \\
1962 \\
1952\end{array}$ & $\begin{array}{r}12,229 \\
10,347 \\
7,749\end{array}$ & $\begin{array}{l}3,321 \\
2,993 \\
2,207 \\
\end{array}$ & $\begin{array}{l}3,008 \\
2,579 \\
1,925 \\
\end{array}$ & $\begin{array}{l}1,919 \\
1,588 \\
1,196\end{array}$ & $\begin{array}{r}1,320 \\
1,085 \\
8.54 \\
\end{array}$ & $\begin{array}{l}873 \\
697 \\
535\end{array}$ & $\begin{array}{l}632 \\
495 \\
329 \\
\end{array}$ & $\begin{array}{l}420 \\
325 \\
232 \\
\end{array}$ & $\begin{array}{l}300 \\
219 \\
172\end{array}$ & $\begin{array}{l}376 \\
316 \\
259\end{array}$ & $\begin{array}{l}55 \\
46 \\
35 \\
\end{array}$ \\
\hline Total, North.................. & $\begin{array}{l}1970 \\
1962 \\
1952 \\
\end{array}$ & $\begin{array}{l}39,114 \\
31,020 \\
27,775\end{array}$ & $\begin{array}{r}10,257 \\
9,058 \\
6,835 \\
\end{array}$ & $\begin{array}{l}9,567 \\
8,276 \\
6,659 \\
\end{array}$ & $\begin{array}{l}6,640 \\
5,585 \\
4,343 \\
\end{array}$ & $\begin{array}{l}4,556 \\
3,902 \\
3,352 \\
\end{array}$ & $\begin{array}{l}2,984 \\
2,611 \\
2,326 \\
\end{array}$ & $\begin{array}{l}1,994 \\
1,744 \\
1,520 \\
\end{array}$ & $\begin{array}{r}1,213 \\
1,067 \\
953 \\
\end{array}$ & $\begin{array}{l}780 \\
703 \\
699 \\
\end{array}$ & $\begin{array}{l}988 \\
939 \\
961 \\
\end{array}$ & $\begin{array}{l}130 \\
130 \\
126 \\
\end{array}$ \\
\hline Southeast & $\begin{array}{l}1970 \\
1962 \\
1952 \\
\end{array}$ & $\begin{array}{l}37,837 \\
33,692 \\
30,694\end{array}$ & $\begin{array}{l}4,905 \\
4,255 \\
3,687\end{array}$ & $\begin{array}{l}6,817 \\
6,292 \\
5,805\end{array}$ & $\begin{array}{l}7,422 \\
6,815 \\
6,405 \\
\end{array}$ & $\begin{array}{l}6,621 \\
6,056 \\
5,669\end{array}$ & $\begin{array}{l}4,883 \\
4,243 \\
3,766\end{array}$ & $\begin{array}{l}3,138 \\
2,646 \\
2,289 \\
\end{array}$ & $\begin{array}{l}1,869 \\
1,536 \\
1,305 \\
\end{array}$ & $\begin{array}{r}1,007 \\
826 \\
720\end{array}$ & $\begin{array}{r}1,023 \\
864 \\
908\end{array}$ & $\begin{array}{l}149 \\
127 \\
134\end{array}$ \\
\hline Southcentral_.....- & $\begin{array}{l}1970 \\
1962 \\
1952\end{array}$ & $\begin{array}{l}40,567 \\
33,094 \\
24,421\end{array}$ & $\begin{array}{l}3,924 \\
3,307 \\
2,531\end{array}$ & $\begin{array}{l}5,789 \\
4,845 \\
3,740\end{array}$ & $\begin{array}{l}6,677 \\
5,681 \\
4,462\end{array}$ & $\begin{array}{l}6,814 \\
5,611 \\
4,254 \\
\end{array}$ & $\begin{array}{l}5,982 \\
4,695 \\
3,409 \\
\end{array}$ & $\begin{array}{l}4,498 \\
3,622 \\
2,516 \\
\end{array}$ & $\begin{array}{l}2,929 \\
2,365 \\
1,622\end{array}$ & $\begin{array}{r}1,869 \\
1,422 \\
874 \\
\end{array}$ & $\begin{array}{r}1,903 \\
1,415 \\
889\end{array}$ & $\begin{array}{l}178 \\
126 \\
119\end{array}$ \\
\hline Total, South.................. & $\begin{array}{l}1970 \\
1962 \\
1952 \\
\end{array}$ & $\begin{array}{l}78,404 \\
66,786 \\
55,115 \\
\end{array}$ & $\begin{array}{l}8,829 \\
7,593 \\
6,219 \\
\end{array}$ & $\begin{array}{r}12,606 \\
11,137 \\
9,545 \\
\end{array}$ & $\begin{array}{l}14,100 \\
12,496 \\
10,868 \\
\end{array}$ & $\begin{array}{r}13,435 \\
11,667 \\
9,923 \\
\end{array}$ & $\begin{array}{r}10,865 \\
8,938 \\
7,176\end{array}$ & $\begin{array}{l}7,636 \\
6,268 \\
4,806 \\
\end{array}$ & $\begin{array}{l}4,799 \\
3,901 \\
2,927 \\
\end{array}$ & $\begin{array}{l}2,876 \\
2,248 \\
1,595 \\
\end{array}$ & $\begin{array}{l}2,926 \\
2,280 \\
1,797 \\
\end{array}$ & $\begin{array}{l}327 \\
254 \\
254 \\
\end{array}$ \\
\hline PNW Douglas-fir & $\begin{array}{l}1970 \\
1962 \\
1952 \\
\end{array}$ & $\begin{array}{r}99,159 \\
104,410 \\
109,904 \\
\end{array}$ & $\begin{array}{l}2,479 \\
2,205 \\
2,011 \\
\end{array}$ & $\begin{array}{l}3,645 \\
3,345 \\
2,858 \\
\end{array}$ & $\begin{array}{l}4,655 \\
4,264 \\
3,718\end{array}$ & $\begin{array}{l}5,281 \\
5,049 \\
4,647 \\
\end{array}$ & $\begin{array}{l}5,722 \\
5,368 \\
4,618 \\
\end{array}$ & $\begin{array}{l}5,917 \\
5,674 \\
5,416 \\
\end{array}$ & $\begin{array}{l}5,840 \\
5,659 \\
5,237\end{array}$ & $\begin{array}{l}5,567 \\
5,571 \\
5,507 \\
\end{array}$ & $\begin{array}{l}19,716 \\
19,966 \\
20,438\end{array}$ & $\begin{array}{l}40,337 \\
47,309 \\
55,454 \\
\end{array}$ \\
\hline PNW ponderosa pine............... & $\begin{array}{l}1970 \\
1962 \\
1952\end{array}$ & $\begin{array}{l}41,859 \\
41,301 \\
39,670 \\
\end{array}$ & $\begin{array}{l}3,049 \\
2,777 \\
2,253\end{array}$ & $\begin{array}{l}3,679 \\
3,286 \\
2,735 \\
\end{array}$ & $\begin{array}{l}3,817 \\
3,336 \\
2,648 \\
\end{array}$ & $\begin{array}{l}3,701 \\
3,265 \\
2,723\end{array}$ & $\begin{array}{l}3,449 \\
3,092 \\
2,624 \\
\end{array}$ & $\begin{array}{l}3,229 \\
2,989 \\
2,674 \\
\end{array}$ & $\begin{array}{l}3,013 \\
2,879 \\
2,607\end{array}$ & $\begin{array}{l}2,661 \\
2,577 \\
2,460\end{array}$ & $\begin{array}{l}8,392 \\
8,876 \\
9,069\end{array}$ & $\begin{array}{l}6,869 \\
8,224 \\
9,877 \\
\end{array}$ \\
\hline Alaska-Coastal ...... & $\begin{array}{l}1970 \\
1962 \\
1952\end{array}$ & $\begin{array}{l}34,468 \\
35,485 \\
35,493\end{array}$ & $\begin{array}{l}404 \\
674 \\
674 \\
\end{array}$ & $\begin{array}{l}691 \\
674 \\
674 \\
\end{array}$ & $\begin{array}{r}1,078 \\
674 \\
674\end{array}$ & $\begin{array}{r}1,436 \\
958 \\
958\end{array}$ & $\begin{array}{l}1,782 \\
2,909 \\
2,910\end{array}$ & $\begin{array}{l}2,026 \\
1,987 \\
1,987\end{array}$ & $\begin{array}{l}2,302 \\
1,880 \\
1,881\end{array}$ & $\begin{array}{l}2,357 \\
1,951 \\
1,952 \\
\end{array}$ & $\begin{array}{l}9,325 \\
9,545 \\
9,547 \\
\end{array}$ & $\begin{array}{l}13,064 \\
14,229 \\
14,233\end{array}$ \\
\hline California and Hawaii........... & $\begin{array}{l}1970 \\
1962 \\
1952\end{array}$ & $\begin{array}{l}51,156 \\
53,953 \\
58,009\end{array}$ & $\begin{array}{r}1,088 \\
958 \\
766 \\
\end{array}$ & $\begin{array}{l}1,756 \\
1,529 \\
1,245\end{array}$ & $\begin{array}{l}2,170 \\
1,920 \\
1,603 \\
\end{array}$ & $\begin{array}{l}2,375 \\
2,138 \\
1,835 \\
\end{array}$ & $\begin{array}{l}2,465 \\
2,276 \\
2,055\end{array}$ & $\begin{array}{l}2,529 \\
2,369 \\
2,159 \\
\end{array}$ & $\begin{array}{l}2,535 \\
2,415 \\
2,268 \\
\end{array}$ & $\begin{array}{l}2,481 \\
2,397 \\
2,281\end{array}$ & $\begin{array}{r}9,829 \\
9,998 \\
10,140\end{array}$ & $\begin{array}{l}23,924 \\
27,950 \\
33,654 \\
\end{array}$ \\
\hline Total, Pacific Coast......... & $\begin{array}{l}1970 \\
1962 \\
1952 \\
\end{array}$ & $\begin{array}{l}226,643 \\
235,150 \\
243,07 \%\end{array}$ & $\begin{array}{l}7,020 \\
6,614 \\
5,704 \\
\end{array}$ & $\begin{array}{l}9,771 \\
8,834 \\
7,512 \\
\end{array}$ & $\begin{array}{r}11,720 \\
10,194 \\
8,643 \\
\end{array}$ & $\begin{array}{l}12,793 \\
11,410 \\
10,163\end{array}$ & $\begin{array}{l}13,419 \\
13,646 \\
12,207\end{array}$ & $\begin{array}{l}13,702 \\
13,019 \\
12,237\end{array}$ & $\begin{array}{l}13,691 \\
12,831 \\
11,993 \\
\end{array}$ & $\begin{array}{l}13,066 \\
12,497 \\
12,200\end{array}$ & $\begin{array}{l}47,262 \\
48,386 \\
49,195 \\
\end{array}$ & $\begin{array}{r}84,194 \\
97,712 \\
113,218 \\
\end{array}$ \\
\hline Northern Rocky Mountain 2..... & $\begin{array}{l}1970 \\
1962 \\
1952\end{array}$ & $\begin{array}{l}63,106 \\
65,091 \\
60,111\end{array}$ & $\begin{array}{l}7,081 \\
7,760 \\
6,371\end{array}$ & $\begin{array}{r}8,840 \\
7,688 \\
6,489 \\
\end{array}$ & $\begin{array}{l}8,509 \\
7,863 \\
6,789 \\
\end{array}$ & $\begin{array}{l}7,400 \\
7,393 \\
6,500 \\
\end{array}$ & $\begin{array}{l}6,260 \\
6,696 \\
6,007\end{array}$ & $\begin{array}{l}5,185 \\
5,828 \\
5,313 \\
\end{array}$ & $\begin{array}{l}4,245 \\
4,865 \\
4,551 \\
\end{array}$ & $\begin{array}{l}3,429 \\
3,999 \\
3,808 \\
\end{array}$ & $\begin{array}{l}8,308 \\
9,437 \\
9,497 \\
\end{array}$ & $\begin{array}{l}3,810 \\
3,559 \\
4,782 \\
\end{array}$ \\
\hline Southern Rocky Mountain ${ }^{2}$ & $\begin{array}{l}1970 \\
1962 \\
1952 \\
\end{array}$ & $\begin{array}{l}24,605 \\
26,173 \\
24,931\end{array}$ & $\begin{array}{l}2,722 \\
2,528 \\
2,108 \\
\end{array}$ & $\begin{array}{l}2,418 \\
2,252 \\
1,861\end{array}$ & $\begin{array}{l}2,484 \\
2,399 \\
2,036 \\
\end{array}$ & $\begin{array}{l}2,534 \\
2,689 \\
2,356 \\
\end{array}$ & $\begin{array}{l}2,464 \\
2,691 \\
2,437 \\
\end{array}$ & $\begin{array}{l}2,441 \\
2,641 \\
2,463\end{array}$ & $\begin{array}{l}2,193 \\
2,353 \\
2,260\end{array}$ & $\begin{array}{l}1,819 \\
2,018 \\
2,006 \\
\end{array}$ & $\begin{array}{l}4,300 \\
4,924 \\
5,226 \\
\end{array}$ & $\begin{array}{l}1,226 \\
1,673 \\
2,174 \\
\end{array}$ \\
\hline Total, Rocky Mountain & $\begin{array}{l}1970 \\
1962 \\
1952 \\
\end{array}$ & $\begin{array}{l}87,711 \\
91,264 \\
85,043 \\
\end{array}$ & $\begin{array}{r}9,806 \\
10,288 \\
8,480 \\
\end{array}$ & $\begin{array}{r}11,259 \\
9,940 \\
8,351 \\
\end{array}$ & $\begin{array}{r}10,994 \\
10,262 \\
8,826 \\
\end{array}$ & $\begin{array}{r}9,934 \\
10,082 \\
8,856 \\
\end{array}$ & $\begin{array}{l}8,725 \\
9,387 \\
8,445 \\
\end{array}$ & $\begin{array}{l}7,626 \\
8,470 \\
7,776\end{array}$ & $\begin{array}{l}6,439 \\
7,219 \\
6,811 \\
\end{array}$ & $\begin{array}{l}5,249 \\
6,018 \\
5,814 \\
\end{array}$ & $\begin{array}{l}12,608 \\
14,362 \\
14,723 \\
\end{array}$ & $\begin{array}{l}5,066 \\
5,232 \\
6,956 \\
\end{array}$ \\
\hline Total, softwoods................ & $\begin{array}{l}1970 \\
1962 \\
1952\end{array}$ & $\begin{array}{l}431,873 \\
427,221 \\
411,012\end{array}$ & $\begin{array}{l}35,914 \\
33,554 \\
27,239\end{array}$ & $\begin{array}{l}43,205 \\
38,188 \\
32,068\end{array}$ & $\begin{array}{l}43,455 \\
38,539 \\
32,681\end{array}$ & $\begin{array}{l}40,720 \\
37,063 \\
32,296\end{array}$ & $\begin{array}{l}35,995 \\
34,583 \\
30,156\end{array}$ & $\begin{array}{l}30,959 \\
29,503 \\
26,340\end{array}$ & $\begin{array}{l}26,144 \\
25,023 \\
22,686\end{array}$ & $\begin{array}{l}21,973 \\
21,467 \\
20,310\end{array}$ & $\begin{array}{l}63,786 \\
65,967 \\
66,677\end{array}$ & $\begin{array}{r}89,718 \\
103,330 \\
120,555\end{array}$ \\
\hline
\end{tabular}

See footnotes at end of table. 
TABLE 11. - Net volume of growing stock on commercial timberland in the United States, by diameter class, softwoods and hardwoods, and timber supply region, as of December 31,1952 and 1962, and January 1, 19701-Continued

HARDWOOD GROWING STOCK

\begin{tabular}{|c|c|c|c|c|c|c|c|c|c|c|c|c|}
\hline \multirow[b]{2}{*}{ Timber supply region } & \multirow[b]{2}{*}{ Year } & \multirow[b]{2}{*}{ Total } & \multicolumn{10}{|c|}{ Diameter class (inches) } \\
\hline & & & 5.0 to 7.0 & 7.0 to 9.0 & $\begin{array}{l}9.0 \text { to } \\
11.0\end{array}$ & $\begin{array}{c}11.0 \text { to } \\
13.0\end{array}$ & $\begin{array}{c}13.0 \text { to } \\
15.0\end{array}$ & $\begin{array}{c}15.0 \text { to } \\
17.0\end{array}$ & $\begin{array}{c}17.0 \text { to } \\
19.0\end{array}$ & $\begin{array}{c}19.0 \text { to } \\
21.0\end{array}$ & $\begin{array}{c}21.0 \text { to } \\
29.0\end{array}$ & $29.0+$ \\
\hline Northeast....... & $\begin{array}{l}1970 \\
1962 \\
1952\end{array}$ & $\begin{array}{l}60,659 \\
52,973 \\
43,197\end{array}$ & $\begin{array}{l}9,937 \\
8,634 \\
6,925\end{array}$ & $\begin{array}{r}11,168 \\
9,735 \\
7,703\end{array}$ & $\begin{array}{r}10,881 \\
9,392 \\
7,331 \\
\end{array}$ & $\begin{array}{l}8,696 \\
7,392 \\
5,712\end{array}$ & $\begin{array}{l}6,735 \\
5,809 \\
4,651\end{array}$ & $\begin{array}{l}4,755 \\
4,173 \\
3,577\end{array}$ & $\begin{array}{l}3,205 \\
2,874 \\
2,532\end{array}$ & $\begin{array}{l}1,975 \\
1,815 \\
1,659\end{array}$ & $\begin{array}{l}2,845 \\
2,729 \\
2,708\end{array}$ & $\begin{array}{l}456 \\
416 \\
394\end{array}$ \\
\hline Northcentral & $\begin{array}{l}1970 \\
1962 \\
1952 \\
\end{array}$ & $\begin{array}{l}55,903 \\
48,204 \\
38,979\end{array}$ & $\begin{array}{l}9,363 \\
8,020 \\
5,810 \\
\end{array}$ & $\begin{array}{r}10,521 \\
8,825 \\
6,616\end{array}$ & $\begin{array}{l}9,441 \\
8,135 \\
6,717 \\
\end{array}$ & $\begin{array}{l}7,385 \\
6,321 \\
4,950 \\
\end{array}$ & $\begin{array}{l}5,955 \\
5,094 \\
4,219\end{array}$ & $\begin{array}{l}4,475 \\
3,841 \\
3,226\end{array}$ & $\begin{array}{l}3,055 \\
2,658 \\
2,367 \\
\end{array}$ & $\begin{array}{l}1,917 \\
1,735 \\
1,606 \\
\end{array}$ & $\begin{array}{l}3,234 \\
3,045 \\
2,975 \\
\end{array}$ & $\begin{array}{l}553 \\
528 \\
489 \\
\end{array}$ \\
\hline Total, North & $\begin{array}{l}1970 \\
1962 \\
1952 \\
\end{array}$ & $\begin{array}{r}116,563 \\
101,177 \\
82,177 \\
\end{array}$ & $\begin{array}{l}19,300 \\
16,654 \\
12,736 \\
\end{array}$ & $\begin{array}{l}21,690 \\
18,560 \\
14,319 \\
\end{array}$ & $\begin{array}{l}20,323 \\
17,527 \\
14,048\end{array}$ & $\begin{array}{l}16,082 \\
13,714 \\
10,662 \\
\end{array}$ & $\begin{array}{r}12,691 \\
10,904 \\
8,871 \\
\end{array}$ & $\begin{array}{l}9,231 \\
8,014 \\
6,804 \\
\end{array}$ & $\begin{array}{l}6,260 \\
5,532 \\
4,900 \\
\end{array}$ & $\begin{array}{l}3,893 \\
3,550 \\
3,266\end{array}$ & $\begin{array}{l}6,079 \\
5,775 \\
5,684 \\
\end{array}$ & $\begin{array}{r}1,009 \\
945 \\
883 \\
\end{array}$ \\
\hline Southeast_.......... & $\begin{array}{l}1970 \\
1962 \\
1952 \\
\end{array}$ & $\begin{array}{l}40,296 \\
37,547 \\
34,953\end{array}$ & $\begin{array}{l}4,114 \\
3,503 \\
2,899 \\
\end{array}$ & $\begin{array}{l}5,379 \\
4,880 \\
4,308 \\
\end{array}$ & $\begin{array}{l}6,064 \\
5,837 \\
5,481 \\
\end{array}$ & $\begin{array}{l}6,178 \\
5,748 \\
5,236\end{array}$ & $\begin{array}{l}5,509 \\
5,241 \\
4,937 \\
\end{array}$ & $\begin{array}{l}4,225 \\
3,952 \\
3,653 \\
\end{array}$ & $\begin{array}{l}3,115 \\
2,928 \\
2,834 \\
\end{array}$ & $\begin{array}{l}2,026 \\
1,939 \\
1,909 \\
\end{array}$ & $\begin{array}{l}2,999 \\
2,917 \\
3,066 \\
\end{array}$ & $\begin{array}{l}683 \\
598 \\
626\end{array}$ \\
\hline Southcentral & $\begin{array}{l}1970 \\
1962 \\
1952\end{array}$ & $\begin{array}{l}40,815 \\
40,708 \\
40,616\end{array}$ & $\begin{array}{l}4,655 \\
4,413 \\
3,999 \\
\end{array}$ & $\begin{array}{l}6,135 \\
5,836 \\
5,404 \\
\end{array}$ & $\begin{array}{l}6,68.5 \\
6,636 \\
6,420 \\
\end{array}$ & $\begin{array}{l}6,327 \\
6,277 \\
6,130 \\
\end{array}$ & $\begin{array}{l}5,477 \\
5,493 \\
5,509 \\
\end{array}$ & $\begin{array}{l}4,104 \\
4,048 \\
4,261\end{array}$ & $\begin{array}{l}2,648 \\
2,818 \\
3,089 \\
\end{array}$ & $\begin{array}{l}1,779 \\
1,929 \\
2,062 \\
\end{array}$ & $\begin{array}{l}2,583 \\
2,813 \\
3,206 \\
\end{array}$ & $\begin{array}{l}418 \\
440 \\
532\end{array}$ \\
\hline Total, South...... & $\begin{array}{l}1970 \\
1962 \\
1952 \\
\end{array}$ & $\begin{array}{l}81,112 \\
78,255 \\
75,569 \\
\end{array}$ & $\begin{array}{l}8,769 \\
7,916 \\
6,898 \\
\end{array}$ & $\begin{array}{r}11,515 \\
10,717 \\
9,712 \\
\end{array}$ & $\begin{array}{l}12,749 \\
12,474 \\
11,901 \\
\end{array}$ & $\begin{array}{l}12,505 \\
12,026 \\
11,366\end{array}$ & $\begin{array}{l}10,987 \\
10,734 \\
10,447 \\
\end{array}$ & $\begin{array}{l}8,330 \\
8,001 \\
7,915 \\
\end{array}$ & $\begin{array}{l}5,764 \\
5,746 \\
5,924 \\
\end{array}$ & $\begin{array}{l}3,805 \\
3,869 \\
3,972 \\
\end{array}$ & $\begin{array}{l}5,583 \\
5,731 \\
6,272 \\
\end{array}$ & $\begin{array}{l}1,102 \\
1,038 \\
1,158 \\
\end{array}$ \\
\hline PNW Douglas-fir. & $\begin{array}{l}1970 \\
1962 \\
1952\end{array}$ & $\begin{array}{r}10,981 \\
9,063 \\
6,908 \\
\end{array}$ & $\begin{array}{r}1,539 \\
1,270 \\
999\end{array}$ & $\begin{array}{l}1,549 \\
1,296 \\
1,026\end{array}$ & $\begin{array}{l}1,525 \\
1,294 \\
1,026\end{array}$ & $\begin{array}{r}1,405 \\
1,202 \\
938\end{array}$ & $\begin{array}{r}1,249 \\
1,059 \\
800\end{array}$ & $\begin{array}{l}976 \\
777 \\
526\end{array}$ & $\begin{array}{l}758 \\
604 \\
449\end{array}$ & $\begin{array}{l}547 \\
434 \\
314\end{array}$ & $\begin{array}{r}1,105 \\
894 \\
648\end{array}$ & $\begin{array}{l}328 \\
233 \\
182\end{array}$ \\
\hline PNW ponderosa pine.............. & $\begin{array}{l}1970 \\
1962 \\
1952 \\
\end{array}$ & $\begin{array}{l}209 \\
192 \\
174 \\
\end{array}$ & $\begin{array}{l}50 \\
44 \\
38\end{array}$ & $\begin{array}{l}41 \\
37 \\
36\end{array}$ & $\begin{array}{l}28 \\
26 \\
23\end{array}$ & $\begin{array}{l}28 \\
27 \\
23 \\
\end{array}$ & $\begin{array}{l}8 \\
8 \\
7 \\
\end{array}$ & $\begin{array}{l}3 \\
3 \\
3\end{array}$ & $\begin{array}{r}10 \\
9 \\
9 \\
\end{array}$ & $\begin{array}{l}8 \\
7 \\
7\end{array}$ & $\begin{array}{l}28 \\
26 \\
23\end{array}$ & $\begin{array}{l}5 \\
5 \\
5\end{array}$ \\
\hline 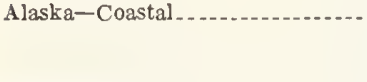 & $\begin{array}{l}1970 \\
1962 \\
1952\end{array}$ & $\begin{array}{l}298 \\
300 \\
298\end{array}$ & $\begin{array}{l}12 \\
17 \\
17\end{array}$ & $\begin{array}{l}20 \\
15 \\
15\end{array}$ & $\begin{array}{l}32 \\
15 \\
15\end{array}$ & $\begin{array}{l}34 \\
37 \\
36\end{array}$ & $\begin{array}{l}31 \\
34 \\
33\end{array}$ & $\begin{array}{l}33 \\
36 \\
36\end{array}$ & $\begin{array}{l}32 \\
34 \\
34\end{array}$ & $\begin{array}{l}31 \\
34 \\
33\end{array}$ & $\begin{array}{l}43 \\
46 \\
46\end{array}$ & $\begin{array}{l}26 \\
28 \\
28 \\
\end{array}$ \\
\hline California and Hawail. ........... & $\begin{array}{l}1970 \\
1962 \\
1952\end{array}$ & $\begin{array}{l}3,333 \\
3,194 \\
3,047\end{array}$ & $\begin{array}{l}202 \\
200 \\
192\end{array}$ & $\begin{array}{l}311 \\
314 \\
319\end{array}$ & $\begin{array}{l}315 \\
296 \\
249\end{array}$ & $\begin{array}{l}327 \\
301 \\
281\end{array}$ & $\begin{array}{l}351 \\
327 \\
300\end{array}$ & $\begin{array}{l}298 \\
277 \\
257\end{array}$ & $\begin{array}{l}281 \\
265 \\
241\end{array}$ & $\begin{array}{l}235 \\
217 \\
203\end{array}$ & $\begin{array}{l}598 \\
567 \\
536\end{array}$ & $\begin{array}{l}412 \\
427 \\
466\end{array}$ \\
\hline Total, Pacific Coast........ & $\begin{array}{l}1970 \\
1962 \\
1952 \\
\end{array}$ & $\begin{array}{l}14,822 \\
12,749 \\
10,427 \\
\end{array}$ & $\begin{array}{l}1,803 \\
1,532 \\
1,247 \\
\end{array}$ & $\begin{array}{l}1,922 \\
1,663 \\
1,397 \\
\end{array}$ & $\begin{array}{l}1,901 \\
1,632 \\
1,314 \\
\end{array}$ & $\begin{array}{l}1,794 \\
1,567 \\
1,278 \\
\end{array}$ & $\begin{array}{l}1,640 \\
1,428 \\
1,141 \\
\end{array}$ & $\begin{array}{r}1,310 \\
1,093 \\
822 \\
\end{array}$ & $\begin{array}{r}1,081 \\
913 \\
734 \\
\end{array}$ & $\begin{array}{l}821 \\
692 \\
557 \\
\end{array}$ & $\begin{array}{l}1,774 \\
1,533 \\
1,253 \\
\end{array}$ & $\begin{array}{l}771 \\
693 \\
681 \\
\end{array}$ \\
\hline Northern Rocky Mountain ${ }^{2}-\ldots .$. & $\begin{array}{l}1970 \\
1962 \\
1952 \\
\end{array}$ & $\begin{array}{l}721 \\
701 \\
634 \\
\end{array}$ & $\begin{array}{r}115 \\
105 \\
87 \\
\end{array}$ & $\begin{array}{r}118 \\
112 \\
95\end{array}$ & $\begin{array}{r}102 \\
100 \\
87\end{array}$ & $\begin{array}{l}92 \\
91 \\
80\end{array}$ & $\begin{array}{l}73 \\
68 \\
61\end{array}$ & $\begin{array}{l}53 \\
51 \\
46\end{array}$ & $\begin{array}{l}39 \\
40 \\
38\end{array}$ & $\begin{array}{l}31 \\
29 \\
28\end{array}$ & $\begin{array}{l}83 \\
87 \\
86\end{array}$ & $\begin{array}{l}11 \\
15 \\
23\end{array}$ \\
\hline Southern Rocky Mountain 2.... & $\begin{array}{l}1970 \\
1962 \\
1952\end{array}$ & $\begin{array}{l}3,785 \\
3,784 \\
3,325\end{array}$ & $\begin{array}{l}657 \\
444 \\
355\end{array}$ & $\begin{array}{l}942 \\
836 \\
705\end{array}$ & $\begin{array}{l}751 \\
839 \\
728\end{array}$ & $\begin{array}{l}575 \\
649 \\
579\end{array}$ & $\begin{array}{l}385 \\
440 \\
404\end{array}$ & $\begin{array}{l}223 \\
267 \\
250\end{array}$ & $\begin{array}{l}131 \\
155 \\
148\end{array}$ & $\begin{array}{l}63 \\
85 \\
84\end{array}$ & $\begin{array}{l}54 \\
66 \\
68\end{array}$ & $\begin{array}{l}0 \\
0 \\
0\end{array}$ \\
\hline Total, Rocky Mountain..... & $\begin{array}{l}1970 \\
1962 \\
1952 \\
\end{array}$ & $\begin{array}{l}4,507 \\
4,486 \\
3,960 \\
\end{array}$ & $\begin{array}{l}772 \\
550 \\
443 \\
\end{array}$ & $\begin{array}{r}1,060 \\
948 \\
800 \\
\end{array}$ & $\begin{array}{l}853 \\
939 \\
815 \\
\end{array}$ & $\begin{array}{l}668 \\
740 \\
659 \\
\end{array}$ & $\begin{array}{l}459 \\
508 \\
465 \\
\end{array}$ & $\begin{array}{l}277 \\
318 \\
296 \\
\end{array}$ & $\begin{array}{l}171 \\
196 \\
186 \\
\end{array}$ & $\begin{array}{r}95 \\
115 \\
112 \\
\end{array}$ & $\begin{array}{l}137 \\
153 \\
155\end{array}$ & $\begin{array}{l}11 \\
15 \\
23 \\
\end{array}$ \\
\hline Total, hardwoods..... & $\begin{array}{l}1970 \\
1962 \\
1952\end{array}$ & $\begin{array}{l}217,005 \\
196,669 \\
172,134\end{array}$ & $\begin{array}{l}30,646 \\
26,653 \\
21,324\end{array}$ & $\begin{array}{l}36,189 \\
31,888 \\
26,230\end{array}$ & $\begin{array}{l}35,828 \\
32,573 \\
28,080\end{array}$ & $\begin{array}{l}31,050 \\
28,048 \\
23,968\end{array}$ & $\begin{array}{l}25,778 \\
23,576 \\
20,925\end{array}$ & $\begin{array}{l}19,149 \\
17,427 \\
15,838\end{array}$ & $\begin{array}{l}13,277 \\
12,388 \\
11,745\end{array}$ & $\begin{array}{l}8,615 \\
8,227 \\
7,908\end{array}$ & $\begin{array}{l}13,575 \\
13,194 \\
13,366\end{array}$ & $\begin{array}{l}2,894 \\
2,692 \\
2,746\end{array}$ \\
\hline
\end{tabular}

1 Data may not add to totals because of truncating. Zeros indicate no data $\quad 2$ See footnote 2 , table 3.

or negligible amounts. 
T.ABE 12.- - Vet volume of sawtimber on commercial timberland in the Cinited States, by diameter class, softwoods and hardwoods, and timber supply region, as of December 31, 1952 and 1962, and January 1, 1970 ${ }^{1}$

[Million board feet, International $1 / 4-$-inch $\log$ rule]

SOFTWOOD SAWTIMBER

\begin{tabular}{|c|c|c|c|c|c|c|c|c|c|c|}
\hline \multirow{2}{*}{ Timber supply region } & \multirow{2}{*}{ Year } & \multirow{2}{*}{ Total } & \multicolumn{8}{|c|}{ Diameter class (inches) } \\
\hline & & & 9.0 to 11.0 & 11.0 to 13.0 & 13.0 to 15.0 & 15.0 to 17.0 & 17.0 to 19.0 & 19.0 to 21.0 & 21.0 to 29.0 & $29.0+$ \\
\hline Northeast. & $\begin{array}{l}19 \% 0 \\
1962 \\
1952\end{array}$ & $\begin{array}{l}49,846 \\
44,757 \\
40,584\end{array}$ & $\begin{array}{l}15,809 \\
13,419 \\
10,676\end{array}$ & $\begin{array}{r}11,799 \\
10,303 \\
9,154\end{array}$ & $\begin{array}{l}8,107 \\
7,399 \\
6,897\end{array}$ & $\begin{array}{l}5,532 \\
5,102 \\
4,856\end{array}$ & $\begin{array}{l}3,356 \\
3,155 \\
3,036\end{array}$ & $\begin{array}{l}2,131 \\
2,160 \\
2,352\end{array}$ & $\begin{array}{l}2,763 \\
2,835 \\
3,204\end{array}$ & $\begin{array}{l}346 \\
383 \\
409\end{array}$ \\
\hline Northcentral.. & $\begin{array}{l}1970 \\
1962 \\
1952 \\
\end{array}$ & $\begin{array}{l}30,215 \\
24,445 \\
18,355\end{array}$ & $\begin{array}{l}8,656 \\
7,178 \\
5,3.6\end{array}$ & $\begin{array}{l}6,373 \\
5,254 \\
4,127\end{array}$ & $\begin{array}{l}4,636 \\
3,698 \\
2,829\end{array}$ & $\begin{array}{l}3,521 \\
2,758 \\
1,804\end{array}$ & $\begin{array}{l}2,469 \\
1,920 \\
1,343\end{array}$ & $\begin{array}{r}1,742 \\
1,306 \\
977\end{array}$ & $\begin{array}{l}2,453 \\
2,023 \\
1,686\end{array}$ & $\begin{array}{l}362 \\
305 \\
210\end{array}$ \\
\hline Total, North. & $\begin{array}{l}1970 \\
1962 \\
1952 \\
\end{array}$ & $\begin{array}{l}80,061 \\
69,202 \\
58,939\end{array}$ & $\begin{array}{l}24,465 \\
20,597 \\
16,052 \\
\end{array}$ & $\begin{array}{l}18,172 \\
15,557 \\
13.281\end{array}$ & $\begin{array}{r}12,744 \\
11,097 \\
9,726\end{array}$ & $\begin{array}{l}9,053 \\
7,860 \\
6,660\end{array}$ & $\begin{array}{l}5,826 \\
5,075 \\
4,379 \\
\end{array}$ & $\begin{array}{l}3,873 \\
3,467 \\
3,329\end{array}$ & $\begin{array}{l}5,217 \\
4,858 \\
4,890 \\
\end{array}$ & $\begin{array}{l}708 \\
688 \\
619 \\
\end{array}$ \\
\hline Southesst... & $\begin{array}{l}1970 \\
1962 \\
1952 \\
\end{array}$ & $\begin{array}{r}114,712 \\
101,042 \\
92,326\end{array}$ & $\begin{array}{l}27,112 \\
24,844 \\
23,335\end{array}$ & $\begin{array}{l}28,622 \\
26,169 \\
24,488\end{array}$ & $\begin{array}{l}22,997 \\
19,994 \\
17,726\end{array}$ & $\begin{array}{l}15,447 \\
13,012 \\
11,218\end{array}$ & $\begin{array}{l}9,474 \\
7,776 \\
6,583\end{array}$ & $\begin{array}{l}5,068 \\
4,169 \\
3,634\end{array}$ & $\begin{array}{l}5,298 \\
4,486 \\
4,717\end{array}$ & $\begin{array}{l}691 \\
591 \\
624\end{array}$ \\
\hline Southcentral.. & $\begin{array}{l}1970 \\
1962 \\
1952\end{array}$ & $\begin{array}{r}161,163 \\
129,355 \\
93,245\end{array}$ & $\begin{array}{l}26,976 \\
22,911 \\
17,997\end{array}$ & $\begin{array}{l}33,932 \\
27,903 \\
21,140\end{array}$ & $\begin{array}{l}32,692 \\
25,607 \\
18,585\end{array}$ & $\begin{array}{l}25,981 \\
20,819 \\
14,443\end{array}$ & $\begin{array}{r}17,334 \\
13,959 \\
9,563 \\
\end{array}$ & $\begin{array}{r}11,309 \\
8,592 \\
5,278\end{array}$ & $\begin{array}{r}11,828 \\
8,772 \\
5,498\end{array}$ & $\begin{array}{r}1,108 \\
789 \\
738\end{array}$ \\
\hline Total, South. & $\begin{array}{l}1970 \\
1962 \\
1952 \\
\end{array}$ & $\begin{array}{l}275,875 \\
230,397 \\
185,571\end{array}$ & $\begin{array}{l}54,088 \\
47,755 \\
41,332\end{array}$ & $\begin{array}{l}62,554 \\
54,072 \\
45,628 \\
\end{array}$ & $\begin{array}{l}55,690 \\
45,601 \\
36,311 \\
\end{array}$ & $\begin{array}{l}41,429 \\
33,831 \\
25,661 \\
\end{array}$ & $\begin{array}{l}26,808 \\
21,735 \\
16,146 \\
\end{array}$ & $\begin{array}{r}16,378 \\
12,761 \\
8,912 \\
\end{array}$ & $\begin{array}{l}17,127 \\
13,259 \\
10,216 \\
\end{array}$ & $\begin{array}{l}1,799 \\
1,380 \\
1,362\end{array}$ \\
\hline PNW Douglas-fir... & $\begin{array}{l}1970 \\
1962 \\
1952\end{array}$ & $\begin{array}{l}562,341 \\
607,707 \\
658,954\end{array}$ & $\begin{array}{l}0 \\
0 \\
0\end{array}$ & $\begin{array}{l}24,156 \\
22,676 \\
20,913\end{array}$ & $\begin{array}{l}29,193 \\
27,391 \\
23,500\end{array}$ & $\begin{array}{l}32,652 \\
31,320 \\
29,816\end{array}$ & $\begin{array}{l}34,052 \\
32,981 \\
30,407\end{array}$ & $\begin{array}{l}33,825 \\
33,822 \\
33,279\end{array}$ & $\begin{array}{l}127,948 \\
131,732 \\
134,996\end{array}$ & $\begin{array}{l}280,515 \\
327,785 \\
386,043\end{array}$ \\
\hline PYW ponderosa pine... & $\begin{array}{l}1970 \\
1962 \\
1952\end{array}$ & $\begin{array}{l}182,132 \\
188,019 \\
191,159\end{array}$ & $\begin{array}{l}0 \\
0 \\
0 \\
\end{array}$ & $\begin{array}{l}16,729 \\
14,800 \\
12,312 \\
\end{array}$ & $\begin{array}{l}17,116 \\
15,373 \\
12,970\end{array}$ & $\begin{array}{l}17,178 \\
15,897 \\
14,195\end{array}$ & $\begin{array}{l}16,832 \\
16,088 \\
14,565\end{array}$ & $\begin{array}{l}15,494 \\
15,047 \\
14,310\end{array}$ & $\begin{array}{l}52,235 \\
51,156 \\
53,900\end{array}$ & $\begin{array}{l}46,548 \\
59,658 \\
68,907\end{array}$ \\
\hline Alaska.... & $\begin{array}{l}1970 \\
1962 \\
1952\end{array}$ & $\begin{array}{l}178,101 \\
1 \times 2,224 \\
183,928\end{array}$ & $\begin{array}{l}0 \\
0 \\
0\end{array}$ & $\begin{array}{l}5,65 \\
9,654 \\
9,748\end{array}$ & $\begin{array}{r}8,227 \\
10,386 \\
10,483\end{array}$ & $\begin{array}{l}10,326 \\
10,751 \\
10,851\end{array}$ & $\begin{array}{l}12,488 \\
10,386 \\
10,483\end{array}$ & $\begin{array}{l}12,875 \\
18,404 \\
18,576\end{array}$ & $\begin{array}{l}52,225 \\
43,369 \\
43,7 ; 5\end{array}$ & $\begin{array}{l}76,301 \\
79,267 \\
80,009\end{array}$ \\
\hline California and Hawaii. & $\begin{array}{l}1970 \\
1962 \\
1952 \\
\end{array}$ & $\begin{array}{l}271,671 \\
296,633 \\
331,161\end{array}$ & $\begin{array}{l}0 \\
0 \\
0\end{array}$ & $\begin{array}{l}6,409 \\
5,828 \\
5,105\end{array}$ & $\begin{array}{l}9,363 \\
8,660 \\
7,795\end{array}$ & $\begin{array}{r}11,063 \\
10,359 \\
9,423\end{array}$ & $\begin{array}{l}11,706 \\
11,149 \\
10,416\end{array}$ & $\begin{array}{l}12,733 \\
12,328 \\
11,750\end{array}$ & $\begin{array}{l}57,715 \\
58,784 \\
59,674\end{array}$ & $\begin{array}{l}162,679 \\
189,521 \\
226,994\end{array}$ \\
\hline Total, Pacific Coast... & $\begin{array}{l}1970 \\
1962 \\
1952 \\
\end{array}$ & $\begin{array}{l}1,194,245 \\
1,274,583 \\
1,365,202\end{array}$ & $\begin{array}{l}0 \\
0 \\
0\end{array}$ & $\begin{array}{l}52,951 \\
52,962 \\
48,079\end{array}$ & $\begin{array}{l}63,900 \\
61,811 \\
54.749\end{array}$ & $\begin{array}{l}71,219 \\
68,327 \\
64,286\end{array}$ & $\begin{array}{l}75,074 \\
70,605 \\
65,8 \pi 2\end{array}$ & $\begin{array}{l}74,928 \\
79,601 \\
77,916\end{array}$ & $\begin{array}{l}290,123 \\
285,041 \\
292,345\end{array}$ & $\begin{array}{l}566,044 \\
656,232 \\
761,953 \\
\end{array}$ \\
\hline Northern Rocky Mountain ${ }^{2}$... & $\begin{array}{l}1970 \\
1962 \\
1952\end{array}$ & $\begin{array}{l}251,387 \\
267,307 \\
256,570\end{array}$ & $\begin{array}{l}39,607 \\
37,420 \\
32,297\end{array}$ & $\begin{array}{l}36,753 \\
36,692 \\
32,256\end{array}$ & $\begin{array}{l}32,550 \\
34,885 \\
31,341\end{array}$ & $\begin{array}{l}28,140 \\
31,480 \\
28,737\end{array}$ & $\begin{array}{l}23,561 \\
27,075 \\
25,354\end{array}$ & $\begin{array}{l}19,485 \\
22,745 \\
21,671\end{array}$ & $\begin{array}{l}48,481 \\
55,381 \\
55,704\end{array}$ & $\begin{array}{l}22,805 \\
21,629 \\
29,210\end{array}$ \\
\hline Southern Rocky Mountain ${ }^{2} \ldots$ & $\begin{array}{l}1970 \\
1962 \\
1952\end{array}$ & $\begin{array}{l}103,719 \\
114,037 \\
112,603\end{array}$ & $\begin{array}{l}12,521 \\
13,245 \\
11,361\end{array}$ & $\begin{array}{l}12,157 \\
12,056 \\
10,602\end{array}$ & $\begin{array}{l}12,555 \\
13,141 \\
11,918\end{array}$ & $\begin{array}{l}12,794 \\
13,635 \\
12,708\end{array}$ & $\begin{array}{l}11,807 \\
12,681 \\
12,161\end{array}$ & $\begin{array}{r}9,974 \\
11,228 \\
11,142\end{array}$ & $\begin{array}{l}24,541 \\
28,075 \\
29,757\end{array}$ & $\begin{array}{r}7,366 \\
9,976 \\
12,954\end{array}$ \\
\hline Total, Rocky Mountain.. & $\begin{array}{l}1970 \\
1962 \\
1952 \\
\end{array}$ & $\begin{array}{l}355,106 \\
381,344 \\
369,173 \\
\end{array}$ & $\begin{array}{l}52,129 \\
50,665 \\
43,658\end{array}$ & $\begin{array}{l}48,911 \\
48,748 \\
42, \times 58\end{array}$ & $\begin{array}{l}45,106 \\
48,026 \\
43.259 \\
\end{array}$ & $\begin{array}{l}40,934 \\
45,115 \\
41,445\end{array}$ & $\begin{array}{l}35,369 \\
39,756 \\
37,515\end{array}$ & $\begin{array}{l}29,460 \\
33,973 \\
32,813 \\
\end{array}$ & $\begin{array}{l}73,023 \\
83,456 \\
85,461 \\
\end{array}$ & $\begin{array}{l}30,172 \\
31,605 \\
42,164\end{array}$ \\
\hline Total, softwoods. & $\begin{array}{l}1970 \\
1962 \\
1952\end{array}$ & $\begin{array}{l}1,905,289 \\
1,955,527 \\
1,998,856\end{array}$ & $\begin{array}{l}130,682 \\
119,017 \\
101,042\end{array}$ & $\begin{array}{l}182,589 \\
171,341 \\
149,847\end{array}$ & $\begin{array}{l}177,440 \\
166, \approx 36 \\
144,046\end{array}$ & $\begin{array}{l}162,636 \\
155,134 \\
138,053\end{array}$ & $\begin{array}{l}143,083 \\
137,172 \\
123,913\end{array}$ & $\begin{array}{l}124,640 \\
129,803 \\
122,970\end{array}$ & $\begin{array}{l}3 \times 5,490 \\
386,615 \\
392,913\end{array}$ & $\begin{array}{l}598,725 \\
689,906 \\
806,099\end{array}$ \\
\hline
\end{tabular}

HARDWOOD SAWTIMBER

\begin{tabular}{|c|c|c|c|c|c|c|c|c|c|c|}
\hline 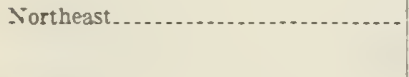 & $\begin{array}{l}1970 \\
1962 \\
1952\end{array}$ & $\begin{array}{r}110,305 \\
98,004 \\
84,022\end{array}$ & $\begin{array}{l}0 \\
0 \\
0\end{array}$ & $\begin{array}{l}29,194 \\
24,972 \\
19,480\end{array}$ & $\begin{array}{l}25,236 \\
21,905 \\
17,700\end{array}$ & $\begin{array}{l}18,892 \\
16,686 \\
14,413\end{array}$ & $\begin{array}{l}13,415 \\
12,120 \\
10,744\end{array}$ & $\begin{array}{l}8,605 \\
7,980 \\
7,390\end{array}$ & $\begin{array}{l}12,841 \\
12,400 \\
12,404\end{array}$ & $\begin{array}{l}2,118 \\
1,941 \\
1,861\end{array}$ \\
\hline Northcentral.......... & $\begin{array}{l}1970 \\
1962 \\
1952\end{array}$ & $\begin{array}{l}141,501 \\
123,480 \\
103,342\end{array}$ & $\begin{array}{l}0 \\
0 \\
0\end{array}$ & $\begin{array}{l}37,262 \\
31,899 \\
24,059\end{array}$ & $\begin{array}{l}31,486 \\
26,880 \\
21,559\end{array}$ & $\begin{array}{l}24,181 \\
20,678 \\
16,983\end{array}$ & $\begin{array}{l}16,855 \\
14,613 \\
12,776\end{array}$ & $\begin{array}{r}10,636 \\
9,541 \\
8,808\end{array}$ & $\begin{array}{l}17,773 \\
16,739 \\
10 \hat{,}, 101\end{array}$ & $\begin{array}{l}3,303 \\
3,127 \\
3,053\end{array}$ \\
\hline Total, North & $\begin{array}{l}1970 \\
1962 \\
1952\end{array}$ & $\begin{array}{l}251,806 \\
221,484 \\
187,364\end{array}$ & $\begin{array}{l}0 \\
0 \\
0\end{array}$ & $\begin{array}{l}66,456 \\
56,871 \\
43,539\end{array}$ & $\begin{array}{l}56,723 \\
48,785 \\
39,259\end{array}$ & $\begin{array}{l}43,076 \\
37,364 \\
31,426\end{array}$ & $\begin{array}{l}30,271 \\
26,733 \\
23,520\end{array}$ & $\begin{array}{l}19,242 \\
17,521 \\
16,198\end{array}$ & $\begin{array}{l}30,614 \\
29,139 \\
28,505\end{array}$ & $\begin{array}{l}5,421 \\
5,068 \\
4,914\end{array}$ \\
\hline
\end{tabular}

See footnotes at end of table. 
TABLE 12.- Net volume of sawtimber on commercial timberland in the United States, by diameter class, softwoods and hardwoods, and timber supply region, as of December 31, 1952 and 1962, and January 1, 1970 1-Continued

[Million board feet, International 1/4-inch log rule]

HARDWOOD SAWTIMBER-Continued

\begin{tabular}{|c|c|c|c|c|c|c|c|c|c|c|}
\hline \multirow[b]{2}{*}{ Timber supply region } & \multirow[b]{2}{*}{ Year } & \multirow{2}{*}{ Total } & \multicolumn{8}{|c|}{ Diameter class (inches) } \\
\hline & & & 9.0 to 11.0 & 11.0 to 13.0 & 13.0 to 15.0 & 15.0 to 17.0 & 17.0 to 19.0 & 19.0 to 21.0 & 21.0 to 29.0 & $29.0+$ \\
\hline Southeast................ & $\begin{array}{l}1970 \\
1962 \\
1952\end{array}$ & $\begin{array}{r}102,303 \\
96,843 \\
92,879\end{array}$ & $\begin{array}{l}0 \\
0 \\
0\end{array}$ & $\begin{array}{l}21,417 \\
19,934 \\
18,168\end{array}$ & $\begin{array}{l}22,236 \\
21,172 \\
19,943\end{array}$ & $\begin{array}{l}18,414 \\
17,262 \\
15,957\end{array}$ & $\begin{array}{l}14,024 \\
13,215 \\
12,784\end{array}$ & $\begin{array}{l}9,295 \\
8,932 \\
8,809 \\
\end{array}$ & $\begin{array}{l}13,808 \\
13,588 \\
14,335\end{array}$ & $\begin{array}{l}3,106 \\
2,739 \\
2,882 \\
\end{array}$ \\
\hline Southcentral $\ldots$ & $\begin{array}{l}1970 \\
1962 \\
1952\end{array}$ & $\begin{array}{l}105,671 \\
107,687 \\
112,617 \\
\end{array}$ & $\begin{array}{l}0 \\
0 \\
0 \\
\end{array}$ & $\begin{array}{l}24,409 \\
24,127 \\
23,531\end{array}$ & $\begin{array}{l}24,211 \\
24,169 \\
24,214\end{array}$ & $\begin{array}{l}19,433 \\
19,074 \\
20,063\end{array}$ & $\begin{array}{l}13,013 \\
13,771 \\
15,078\end{array}$ & $\begin{array}{r}8,974 \\
9,686 \\
10,353\end{array}$ & $\begin{array}{l}13,392 \\
14,518 \\
16,540\end{array}$ & $\begin{array}{l}2,236 \\
2,339 \\
2,834\end{array}$ \\
\hline Total, South..................... & $\begin{array}{l}1970 \\
1962 \\
1952 \\
\end{array}$ & $\begin{array}{l}207,974 \\
204,530 \\
205,496 \\
\end{array}$ & $\begin{array}{l}0 \\
0 \\
0\end{array}$ & $\begin{array}{l}45,827 \\
44,061 \\
41,699 \\
\end{array}$ & $\begin{array}{l}46,447 \\
45,341 \\
44,157 \\
\end{array}$ & $\begin{array}{l}37,848 \\
36,336 \\
36,020 \\
\end{array}$ & $\begin{array}{l}27,037 \\
26,986 \\
27,862 \\
\end{array}$ & $\begin{array}{l}18,270 \\
18,618 \\
19,162 \\
\end{array}$ & $\begin{array}{l}27,200 \\
28,107 \\
30,876 \\
\end{array}$ & $\begin{array}{l}5,343 \\
5,078 \\
5,717 \\
\end{array}$ \\
\hline PNW Douglas-fir & $\begin{array}{l}1970 \\
1962 \\
1952\end{array}$ & $\begin{array}{l}37,873 \\
31,037 \\
23,318\end{array}$ & $\begin{array}{l}0 \\
0 \\
0\end{array}$ & $\begin{array}{l}6,414 \\
5,490 \\
4,317 \\
\end{array}$ & $\begin{array}{l}6,419 \\
5,469 \\
4,171\end{array}$ & $\begin{array}{l}5,574 \\
4,477 \\
3,112\end{array}$ & $\begin{array}{l}4,750 \\
3,823 \\
2,881\end{array}$ & $\begin{array}{l}3,636 \\
2,923 \\
2,141\end{array}$ & $\begin{array}{l}8,222 \\
6,274 \\
4,645\end{array}$ & $\begin{array}{l}2,858 \\
2,581 \\
2,051 \\
\end{array}$ \\
\hline PNW ponderosa pine & $\begin{array}{l}1970 \\
1962 \\
1952 \\
\end{array}$ & $\begin{array}{l}512 \\
446 \\
424 \\
\end{array}$ & $\begin{array}{l}0 \\
0 \\
0\end{array}$ & $\begin{array}{l}122 \\
107 \\
101\end{array}$ & $\begin{array}{l}41 \\
36 \\
36\end{array}$ & $\begin{array}{l}17 \\
16 \\
15\end{array}$ & $\begin{array}{l}51 \\
44 \\
43\end{array}$ & $\begin{array}{l}46 \\
38 \\
37\end{array}$ & $\begin{array}{l}192 \\
163 \\
152\end{array}$ & $\begin{array}{l}43 \\
42 \\
40 \\
\end{array}$ \\
\hline Alaska & $\begin{array}{l}1970 \\
1962 \\
1952\end{array}$ & $\begin{array}{l}1,273 \\
1,279 \\
1,268\end{array}$ & $\begin{array}{l}0 \\
0 \\
0\end{array}$ & $\begin{array}{l}164 \\
165 \\
163\end{array}$ & $\begin{array}{l}171 \\
172 \\
171\end{array}$ & $\begin{array}{l}164 \\
165 \\
163\end{array}$ & $\begin{array}{l}173 \\
174 \\
172\end{array}$ & $\begin{array}{l}156 \\
157 \\
156\end{array}$ & $\begin{array}{l}305 \\
307 \\
304\end{array}$ & $\begin{array}{l}137 \\
138 \\
137 \\
\end{array}$ \\
\hline California and Hawail................. & $\begin{array}{l}1970 \\
1962 \\
1952\end{array}$ & $\begin{array}{l}6,735 \\
6,447 \\
6,297\end{array}$ & $\begin{array}{l}0 \\
0 \\
0\end{array}$ & $\begin{array}{l}627 \\
575 \\
533\end{array}$ & $\begin{array}{l}795 \\
739 \\
679\end{array}$ & $\begin{array}{l}766 \\
709 \\
660\end{array}$ & $\begin{array}{l}765 \\
719 \\
667 \\
\end{array}$ & $\begin{array}{l}706 \\
640 \\
606 \\
\end{array}$ & $\begin{array}{l}1,765 \\
1,677 \\
1,608 \\
\end{array}$ & $\begin{array}{l}1,310 \\
1,386 \\
1,542 \\
\end{array}$ \\
\hline Total, Pacific Coast.............. & $\begin{array}{l}1970 \\
1962 \\
1952\end{array}$ & $\begin{array}{l}46,394 \\
39,209 \\
31,307\end{array}$ & $\begin{array}{l}0 \\
0 \\
0 \\
\end{array}$ & $\begin{array}{l}7,327 \\
6,337 \\
5,114 \\
\end{array}$ & $\begin{array}{l}7,427 \\
6,417 \\
5,057 \\
\end{array}$ & $\begin{array}{l}6,521 \\
5,367 \\
3,950 \\
\end{array}$ & $\begin{array}{l}5,739 \\
4,760 \\
3,763 \\
\end{array}$ & $\begin{array}{l}4,544 \\
3,759 \\
2,940 \\
\end{array}$ & $\begin{array}{r}10,484 \\
8,421 \\
6,709\end{array}$ & $\begin{array}{l}4,349 \\
4,147 \\
3,770 \\
\end{array}$ \\
\hline Northern Rocky Mountain 2......... & $\begin{array}{l}1970 \\
1962 \\
1952\end{array}$ & $\begin{array}{l}2,105 \\
2,095 \\
2,003 \\
\end{array}$ & $\begin{array}{l}0 \\
0 \\
0\end{array}$ & $\begin{array}{l}485 \\
473 \\
415 \\
\end{array}$ & $\begin{array}{l}411 \\
381 \\
343 \\
\end{array}$ & $\begin{array}{l}295 \\
283 \\
255\end{array}$ & $\begin{array}{l}209 \\
215 \\
204\end{array}$ & $\begin{array}{l}169 \\
162 \\
154\end{array}$ & $\begin{array}{l}458 \\
478 \\
475\end{array}$ & $\begin{array}{r}75 \\
103 \\
157 \\
\end{array}$ \\
\hline Southern Rocky Mountain 2........ & $\begin{array}{l}1970 \\
1962 \\
1952\end{array}$ & $\begin{array}{l}7,196 \\
7,485 \\
6,901 \\
\end{array}$ & $\begin{array}{l}0 \\
0 \\
0\end{array}$ & $\begin{array}{l}2,787 \\
2,882 \\
2,563\end{array}$ & $\begin{array}{l}1,924 \\
1,964 \\
1,804\end{array}$ & $\begin{array}{l}1,163 \\
1,207 \\
1,129\end{array}$ & $\begin{array}{l}703 \\
713 \\
683\end{array}$ & $\begin{array}{l}335 \\
403 \\
399 \\
\end{array}$ & $\begin{array}{l}281 \\
315 \\
322 \\
\end{array}$ & $\begin{array}{l}0 \\
1 \\
1\end{array}$ \\
\hline Total, Rocky Mountain & $\begin{array}{l}1970 \\
1962 \\
1952 \\
\end{array}$ & $\begin{array}{l}9,301 \\
9,580 \\
8,904\end{array}$ & $\begin{array}{l}0 \\
0 \\
0\end{array}$ & $\begin{array}{l}3,272 \\
3,355 \\
2,978 \\
\end{array}$ & $\begin{array}{l}2,336 \\
2,345 \\
2,147 \\
\end{array}$ & $\begin{array}{l}1,459 \\
1,490 \\
1,381\end{array}$ & $\begin{array}{l}912 \\
928 \\
887 \\
\end{array}$ & $\begin{array}{l}505 \\
565 \\
553\end{array}$ & $\begin{array}{l}740 \\
793 \\
797 \\
\end{array}$ & $\begin{array}{r}76 \\
104 \\
158 \\
\end{array}$ \\
\hline Total, hardwoods. . . & $\begin{array}{l}1970 \\
1962 \\
1952\end{array}$ & $\begin{array}{l}515,477 \\
474,804 \\
433,072\end{array}$ & $\begin{array}{l}0 \\
0 \\
0\end{array}$ & $\begin{array}{r}122,883 \\
110,624 \\
93,331\end{array}$ & $\begin{array}{r}112,934 \\
102,889 \\
90,621\end{array}$ & $\begin{array}{l}88,905 \\
80,558 \\
72,782\end{array}$ & $\begin{array}{l}63,961 \\
59,407 \\
56,034\end{array}$ & $\begin{array}{l}42,561 \\
40,464 \\
38,854\end{array}$ & $\begin{array}{l}69,040 \\
66,460 \\
66,888\end{array}$ & $\begin{array}{l}15,190 \\
14,399 \\
14,560\end{array}$ \\
\hline
\end{tabular}

1 Data may not add to totals because of truncating. Zeros indicate no data or negligible amounts.

${ }^{2}$ See footnote 2 , table 3.

TABLE 13.-Net volume of growing stock on commercial timberland in the East by species, diameter class, and timber supply region, January 1, $1970^{1}$

[Million cubic feet]

\begin{tabular}{|c|c|c|c|c|c|c|c|c|c|c|c|c|}
\hline \multirow[b]{2}{*}{$\begin{array}{l}\text { Timber supply region and } \\
\text { diameter class (inches) }\end{array}$} & \multirow[b]{2}{*}{$\begin{array}{c}\text { Total } \\
\text { all } \\
\text { species }\end{array}$} & \multicolumn{11}{|c|}{ Softwoods } \\
\hline & & $\begin{array}{c}\text { Total } \\
\text { soft- } \\
\text { woods }\end{array}$ & $\begin{array}{l}\text { Longleaf } \\
\text { and } \\
\text { slash } \\
\text { pines }\end{array}$ & $\begin{array}{c}\text { Shortleaf } \\
\text { and } \\
\text { loblolly } \\
\text { pines }\end{array}$ & $\begin{array}{l}\text { Other } \\
\text { yellow } \\
\text { pines }\end{array}$ & $\begin{array}{c}\text { Eastern } \\
\text { white } \\
\text { and red } \\
\text { pines }\end{array}$ & $\begin{array}{l}\text { Jack } \\
\text { pine }\end{array}$ & $\begin{array}{l}\text { Spruce } \\
\text { and } \\
\text { balsam } \\
\text { fir }\end{array}$ & $\begin{array}{c}\text { Eastern } \\
\text { hemlock }\end{array}$ & Cypress & $\begin{array}{c}\text { Other } \\
\text { eastern } \\
\text { so't- } \\
\text { woods }\end{array}$ & $\begin{array}{l}\text { Pon- } \\
\text { derosa } \\
\text { and } \\
\text { Jeffrey } \\
\text { pine }\end{array}$ \\
\hline $\begin{array}{l}\text { Northeast: } \\
5.0 \text { to } 7.0 \\
7.0 \text { to } 9.0 \\
9.0 \text { to } 11.0 \\
11.0 \text { to } 13.0 \\
13.0 \text { to } 15.0 \\
15.0 \text { to } 17.0 \\
17.0 \text { to } 19.0 \\
19.0 \text { to } 21.0 \\
21.0 \text { to } 29.0 \\
29.0 \text { t }\end{array}$ & $\begin{array}{r}16,873 \\
17,728 \\
15,602 \\
11,932 \\
8,847 \\
6,117 \\
3,998 \\
2,456 \\
3,457 \\
530\end{array}$ & $\begin{array}{r}6,936 \\
6,559 \\
4,720 \\
3,235 \\
2,111 \\
1,361 \\
793 \\
480 \\
611 \\
74 \\
\end{array}$ & $\begin{array}{l}0 \\
0 \\
0 \\
0 \\
0 \\
0 \\
0 \\
0 \\
0 \\
0\end{array}$ & $\begin{array}{r}62 \\
109 \\
127 \\
102 \\
64 \\
48 \\
23 \\
10 \\
14 \\
0\end{array}$ & $\begin{array}{r}199 \\
268 \\
235 \\
193 \\
97 \\
69 \\
16 \\
4 \\
6 \\
0\end{array}$ & $\begin{array}{r}842 \\
976 \\
837 \\
732 \\
686 \\
480 \\
303 \\
258 \\
395 \\
64\end{array}$ & $\begin{array}{l}0 \\
0 \\
0 \\
0 \\
0 \\
0 \\
0 \\
0 \\
0 \\
0\end{array}$ & $\begin{array}{r}4,573 \\
3,859 \\
2,431 \\
1,334 \\
671 \\
344 \\
176 \\
75 \\
49 \\
0\end{array}$ & $\begin{array}{r}854 \\
856 \\
755 \\
643 \\
476 \\
357 \\
244 \\
122 \\
133 \\
7\end{array}$ & $\begin{array}{l}0 \\
0 \\
0 \\
0 \\
0 \\
0 \\
0 \\
0 \\
0 \\
0\end{array}$ & $\begin{array}{r}403 \\
489 \\
333 \\
229 \\
114 \\
61 \\
29 \\
10 \\
11 \\
2\end{array}$ & $\begin{array}{l}0 \\
0 \\
0 \\
0 \\
0 \\
0 \\
0 \\
0 \\
0 \\
0\end{array}$ \\
\hline Total & 87,544 & 26,884 & 0 & 562 & 1,092 & 5,576 & 0 & 13,517 & 4,451 & 0 & 1,684 & 0 \\
\hline
\end{tabular}

See footnote at end of table. 
TABLE 13.- - iet volume of growing stock on commercial timberland in the East by species, diameter class, and timber supply region, January $1,1970^{1}-$ Continued

[Million cubic feet]

\begin{tabular}{|c|c|c|c|c|c|c|c|c|c|c|c|c|}
\hline \multirow[b]{2}{*}{$\begin{array}{l}\text { Timber supply region and } \\
\text { diameter class (inches) }\end{array}$} & \multirow[b]{2}{*}{$\begin{array}{l}\text { Total } \\
\text { all } \\
\text { species }\end{array}$} & \multicolumn{11}{|c|}{ Softwoods } \\
\hline & & $\begin{array}{c}\text { Total } \\
\text { soft- } \\
\text { woods }\end{array}$ & $\begin{array}{l}\text { Longleaf } \\
\text { and } \\
\text { slash } \\
\text { pines }\end{array}$ & $\begin{array}{l}\text { Shortleai } \\
\text { and } \\
\text { loblolly } \\
\text { pines }\end{array}$ & $\begin{array}{l}\text { Other } \\
\text { yellow } \\
\text { pines }\end{array}$ & $\begin{array}{c}\text { Eastern } \\
\text { white } \\
\text { and red } \\
\text { pines }\end{array}$ & $\begin{array}{l}\text { Jack } \\
\text { pine }\end{array}$ & $\begin{array}{l}\text { Spruce } \\
\text { and } \\
\text { balsam } \\
\text { fir }\end{array}$ & $\begin{array}{l}\text { Eastern } \\
\text { hemlock }\end{array}$ & Cypress & $\begin{array}{l}\text { Other } \\
\text { eastern } \\
\text { soft- } \\
\text { woods }\end{array}$ & $\begin{array}{l}\text { Pon- } \\
\text { derosa } \\
\text { and } \\
\text { Jeffrey } \\
\text { pine }\end{array}$ \\
\hline 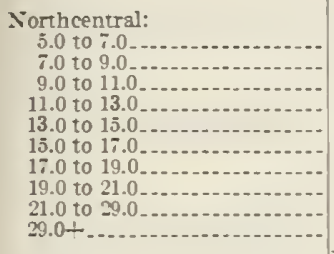 & $\begin{array}{r}12,655 \\
13,530 \\
11,361 \\
8,706 \\
6,828 \\
5,108 \\
3,475 \\
2,217 \\
3,610 \\
609\end{array}$ & $\begin{array}{r}3,321 \\
3,008 \\
1,919 \\
1,320 \\
873 \\
632 \\
420 \\
300 \\
376 \\
55\end{array}$ & $\begin{array}{l}0 \\
0 \\
0 \\
0 \\
0 \\
0 \\
0 \\
0 \\
0 \\
0\end{array}$ & $\begin{array}{r}96 \\
135 \\
150 \\
111 \\
70 \\
31 \\
13 \\
3 \\
2 \\
0 \\
\end{array}$ & $\begin{array}{r}59 \\
82 \\
86 \\
62 \\
41 \\
20 \\
8 \\
2 \\
1 \\
0\end{array}$ & $\begin{array}{r}229 \\
236 \\
236 \\
298 \\
285 \\
241 \\
211 \\
159 \\
188 \\
36\end{array}$ & $\begin{array}{r}548 \\
563 \\
347 \\
191 \\
69 \\
25 \\
4 \\
0 \\
0 \\
0 \\
\end{array}$ & $\begin{array}{r}1,568 \\
1,195 \\
538 \\
252 \\
109 \\
83 \\
31 \\
22 \\
4 \\
0\end{array}$ & $\begin{array}{r}56 \\
97 \\
133 \\
157 \\
147 \\
135 \\
101 \\
80 \\
134 \\
10 \\
\end{array}$ & $\begin{array}{r}0 \\
0 \\
0 \\
1 \\
1 \\
7 \\
2 \\
2 \\
11 \\
6\end{array}$ & $\begin{array}{r}750 \\
678 \\
410 \\
223 \\
131 \\
71 \\
40 \\
22 \\
31 \\
1 \\
\end{array}$ & $\begin{array}{r}10 \\
19 \\
25 \\
23 \\
17 \\
13 \\
7 \\
6 \\
3 \\
0\end{array}$ \\
\hline Total .. & 68,133 & 12,229 & 0 & 615 & 363 & 2,125 & 1,751 & 3,795 & 1,054 & 32 & 2,362 & 127 \\
\hline 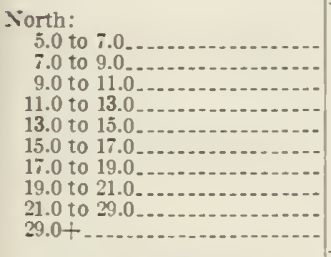 & $\begin{array}{r}29,358 \\
31,258 \\
26,963 \\
20,639 \\
15,676 \\
11,225 \\
7,474 \\
4,674 \\
7,068 \\
1,139\end{array}$ & $\begin{array}{r}10,257 \\
9,567 \\
6,640 \\
4,556 \\
2,984 \\
1,994 \\
1,213 \\
780 \\
988 . \\
130\end{array}$ & $\begin{array}{l}0 \\
0 \\
0 \\
0 \\
0 \\
0 \\
0 \\
0 \\
0 \\
0\end{array}$ & $\begin{array}{r}159 \\
244 \\
277 \\
214 \\
134 \\
79 \\
36 \\
14 \\
16 \\
0\end{array}$ & $\begin{array}{r}259 \\
350 \\
321 \\
255 \\
139 \\
89 \\
25 \\
6 \\
7 \\
0\end{array}$ & $\begin{array}{r}1,071 \\
1,212 \\
1,074 \\
1,030 \\
971 \\
725 \\
515 \\
417 \\
583 \\
100\end{array}$ & $\begin{array}{r}548 \\
563 \\
347 \\
191 \\
69 \\
25 \\
4 \\
1 \\
0 \\
0 \\
\end{array}$ & $\begin{array}{r}6,142 \\
5,054 \\
2,960 \\
1,586 \\
781 \\
428 \\
207 \\
98 \\
54 \\
0\end{array}$ & $\begin{array}{r}911 \\
953 \\
888 \\
801 \\
624 \\
492 \\
345 \\
202 \\
267 \\
18 \\
\end{array}$ & $\begin{array}{r}0 \\
0 \\
0 \\
1 \\
1 \\
7 \\
2 \\
2 \\
11 \\
6\end{array}$ & $\begin{array}{r}1,154 \\
1,168 \\
744 \\
452 \\
245 \\
133 \\
69 \\
32 \\
43 \\
4\end{array}$ & $\begin{array}{r}10 \\
19 \\
25 \\
23 \\
17 \\
13 \\
7 \\
6 \\
3 \\
0\end{array}$ \\
\hline Total, North. & $155,67 i$ & 39,114 & 0 & 1,177 & 1,455 & 7,702 & 1,751 & 17,313 & 5,506 & 32 & 4,047 & 127 \\
\hline 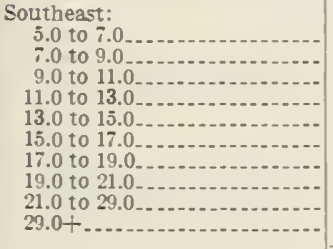 & $\begin{array}{r}9,019 \\
12,196 \\
13,487 \\
12,799 \\
10,393 \\
7,363 \\
4,985 \\
3,033 \\
4,023 \\
832\end{array}$ & $\begin{array}{r}4,905 \\
6,817 \\
7,422 \\
6,621 \\
4,853 \\
3,138 \\
1,869 \\
1,007 \\
1,023 \\
149\end{array}$ & $\begin{array}{r}1,382 \\
2,004 \\
2,248 \\
1,831 \\
1,140 \\
584 \\
245 \\
103 \\
63 \\
1\end{array}$ & $\begin{array}{r}2,266 \\
3,149 \\
3,537 \\
3,333 \\
2,699 \\
1,928 \\
1,197 \\
671 \\
640 \\
47\end{array}$ & $\begin{array}{r}784 \\
1,014 \\
944 \\
725 \\
455 \\
255 \\
151 \\
57 \\
38 \\
0\end{array}$ & $\begin{array}{r}37 \\
53 \\
57 \\
77 \\
70 \\
48 \\
37 \\
36 \\
67 \\
9\end{array}$ & $\begin{array}{l}0 \\
0 \\
0 \\
0 \\
0 \\
0 \\
0 \\
0 \\
0 \\
0\end{array}$ & $\begin{array}{l}0 \\
1 \\
1 \\
1 \\
0 \\
0 \\
0 \\
0 \\
0 \\
0\end{array}$ & $\begin{array}{l}12 \\
15 \\
19 \\
27 \\
20 \\
25 \\
22 \\
15 \\
35 \\
23\end{array}$ & $\begin{array}{r}351 \\
529 \\
560 \\
587 \\
473 \\
285 \\
207 \\
118 \\
174 \\
68\end{array}$ & $\begin{array}{r}68 \\
48 \\
53 \\
36 \\
23 \\
9 \\
7 \\
3 \\
3 \\
0 \\
\end{array}$ & $\begin{array}{l}0 \\
0 \\
0 \\
0 \\
0 \\
0 \\
0 \\
0 \\
0 \\
0\end{array}$ \\
\hline Total ....... & 78,134 & 37,837 & 9,606 & $19, \pm 72$ & 4,427 & 495 & 0 & 8 & 218 & 3,355 & 254 & 0 \\
\hline 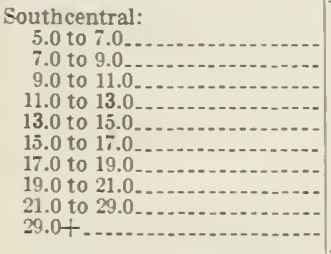 & $\begin{array}{r}8,579 \\
11,925 \\
13,362 \\
13,141 \\
11,459 \\
8,603 \\
5,578 \\
3,648 \\
4,486 \\
596\end{array}$ & $\begin{array}{r}3,924 \\
5,789 \\
6,677 \\
6,814 \\
5,982 \\
4,498 \\
2,929 \\
1,869 \\
1,903 \\
178\end{array}$ & $\begin{array}{r}3 \pi \\
675 \\
827 \\
940 \\
679 \\
420 \\
204 \\
71 \\
52 \\
0\end{array}$ & $\begin{array}{r}3,203 \\
4,670 \\
5,403 \\
5,410 \\
4,811 \\
3,722 \\
2,438 \\
1,599 \\
1,580 \\
80\end{array}$ & $\begin{array}{r}202 \\
241 \\
229 \\
220 \\
161 \\
102 \\
68 \\
41 \\
40 \\
5 \\
\end{array}$ & $\begin{array}{r}5 \\
13 \\
20 \\
19 \\
22 \\
19 \\
18 \\
9 \\
19 \\
3\end{array}$ & $\begin{array}{l}0 \\
0 \\
0 \\
0 \\
0 \\
0 \\
0 \\
0 \\
0 \\
0\end{array}$ & $\begin{array}{l}0 \\
0 \\
0 \\
0 \\
0 \\
0 \\
0 \\
0 \\
0 \\
0\end{array}$ & $\begin{array}{l}2 \\
7 \\
7 \\
7 \\
8 \\
9 \\
2 \\
4 \\
4 \\
0\end{array}$ & $\begin{array}{r}45 \\
114 \\
157 \\
194 \\
287 \\
218 \\
193 \\
141 \\
206 \\
87\end{array}$ & $\begin{array}{r}87 \\
67 \\
32 \\
21 \\
10 \\
5 \\
4 \\
1 \\
0 \\
0\end{array}$ & $\begin{array}{l}0 \\
0 \\
0 \\
0 \\
0 \\
0 \\
0 \\
0 \\
0 \\
0\end{array}$ \\
\hline Total & 81,383 & 40,567 & 4,249 & 32,918 & 1,314 & 151 & 0 & 0 & 55 & 1,646 & 231 & $\underline{0}$ \\
\hline 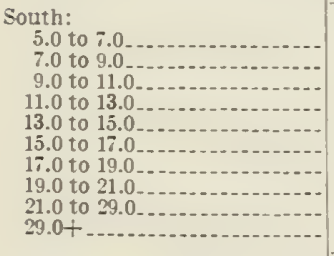 & $\begin{array}{r}17,598 \\
24,122 \\
26,850 \\
25,941 \\
21,852 \\
15,966 \\
10,563 \\
6,682 \\
8,509 \\
1,429\end{array}$ & $\begin{array}{r}8,829 \\
12,606 \\
14,100 \\
13,435 \\
10,865 \\
7,636 \\
4,799 \\
2,876 \\
2,926 \\
327\end{array}$ & $\begin{array}{r}1,760 \\
2,679 \\
3,076 \\
2,771 \\
1,819 \\
1,005 \\
450 \\
175 \\
116 \\
1\end{array}$ & $\begin{array}{r}5,470 \\
7,819 \\
8,940 \\
8,744 \\
7,510 \\
5,650 \\
3,635 \\
2,270 \\
2,220 \\
128\end{array}$ & $\begin{array}{r}987 \\
1,255 \\
1,173 \\
945 \\
617 \\
357 \\
219 \\
98 \\
79 \\
6\end{array}$ & $\begin{array}{l}43 \\
66 \\
77 \\
97 \\
92 \\
67 \\
55 \\
45 \\
86 \\
12\end{array}$ & $\begin{array}{l}0 \\
0 \\
0 \\
0 \\
0 \\
0 \\
0 \\
0 \\
0 \\
0\end{array}$ & $\begin{array}{l}1 \\
1 \\
1 \\
1 \\
1 \\
0 \\
0 \\
1 \\
0 \\
0\end{array}$ & $\begin{array}{l}15 \\
23 \\
26 \\
34 \\
29 \\
34 \\
25 \\
20 \\
39 \\
23\end{array}$ & $\begin{array}{l}396 \\
643 \\
717 \\
781 \\
761 \\
503 \\
400 \\
260 \\
381 \\
155\end{array}$ & $\begin{array}{r}155 \\
115 \\
86 \\
58 \\
34 \\
15 \\
12 \\
4 \\
3 \\
0\end{array}$ & $\begin{array}{l}0 \\
0 \\
j \\
0 \\
0 \\
0 \\
0 \\
0 \\
0 \\
0\end{array}$ \\
\hline Total, South............. & 159,517 & 78,404 & 13,855 & 52,391 & $5,7 \pm 1$ & 646 & 0 & 8 & 273 & 5,002 & 485 & 0 \\
\hline $\begin{array}{l}\text { Summary of the East: } \\
5.0 \text { to } 7.0 \\
7.0 \text { to } 9.0 \\
9.0 \text { to } 11.0 \\
11.0 \text { to } 13.0 \\
13.0 \text { to } 15.0 \\
15.0 \text { to } 17.0 \\
17.0 \text { to } 19.0 \\
19.0 \text { to } 21.0 \\
21.0 \text { to } 29.0 \\
29.0+\end{array}$ & $\begin{array}{r}47,157 \\
55,380 \\
53,813 \\
46,580 \\
37,529 \\
27,192 \\
18,038 \\
11,356 \\
15,578 \\
2,569 \\
\end{array}$ & $\begin{array}{r}19,087 \\
22,174 \\
20,740 \\
17,992 \\
13,850 \\
9,630 \\
6,013 \\
3,657 \\
3,915 \\
457\end{array}$ & $\begin{array}{r}1,760 \\
2,679 \\
3,076 \\
2,771 \\
1,819 \\
1,005 \\
450 \\
175 \\
116 \\
1 \\
\end{array}$ & $\begin{array}{r}5,629 \\
8,064 \\
9,218 \\
8,958 \\
7,645 \\
5,730 \\
3,671 \\
2,284 \\
2,236 \\
128\end{array}$ & $\begin{array}{r}1,247 \\
1,606 \\
1,495 \\
1,201 \\
756 \\
447 \\
244 \\
105 \\
87 \\
6\end{array}$ & $\begin{array}{r}1,114 \\
1,279 \\
1,152 \\
1,128 \\
1,063 \\
792 \\
570 \\
463 \\
669 \\
113\end{array}$ & $\begin{array}{r}548 \\
563 \\
347 \\
191 \\
69 \\
25 \\
4 \\
0 \\
0 \\
0\end{array}$ & $\begin{array}{r}6,142 \\
5,056 \\
2,962 \\
1,588 \\
782 \\
428 \\
207 \\
98 \\
54 \\
0\end{array}$ & \begin{tabular}{r|}
926 \\
977 \\
915 \\
835 \\
653 \\
527 \\
371 \\
223 \\
307 \\
42 \\
\end{tabular} & $\begin{array}{l}396 \\
643 \\
717 \\
782 \\
762 \\
511 \\
403 \\
262 \\
392 \\
161 \\
\end{array}$ & $\begin{array}{r}1,309 \\
1,284 \\
830 \\
510 \\
.79 \\
148 \\
81 \\
36 \\
46 \\
4 \\
\end{array}$ & $\begin{array}{r}10 \\
19 \\
25 \\
23 \\
17 \\
13 \\
7 \\
6 \\
3 \\
0\end{array}$ \\
\hline Total... & 315,194 & 117,519 & 13,855 & 53,569 & 7,197 & 8,348 & 1,751 & 17,321 & 5,779 & 5,034 & 4,533 & 127 \\
\hline
\end{tabular}




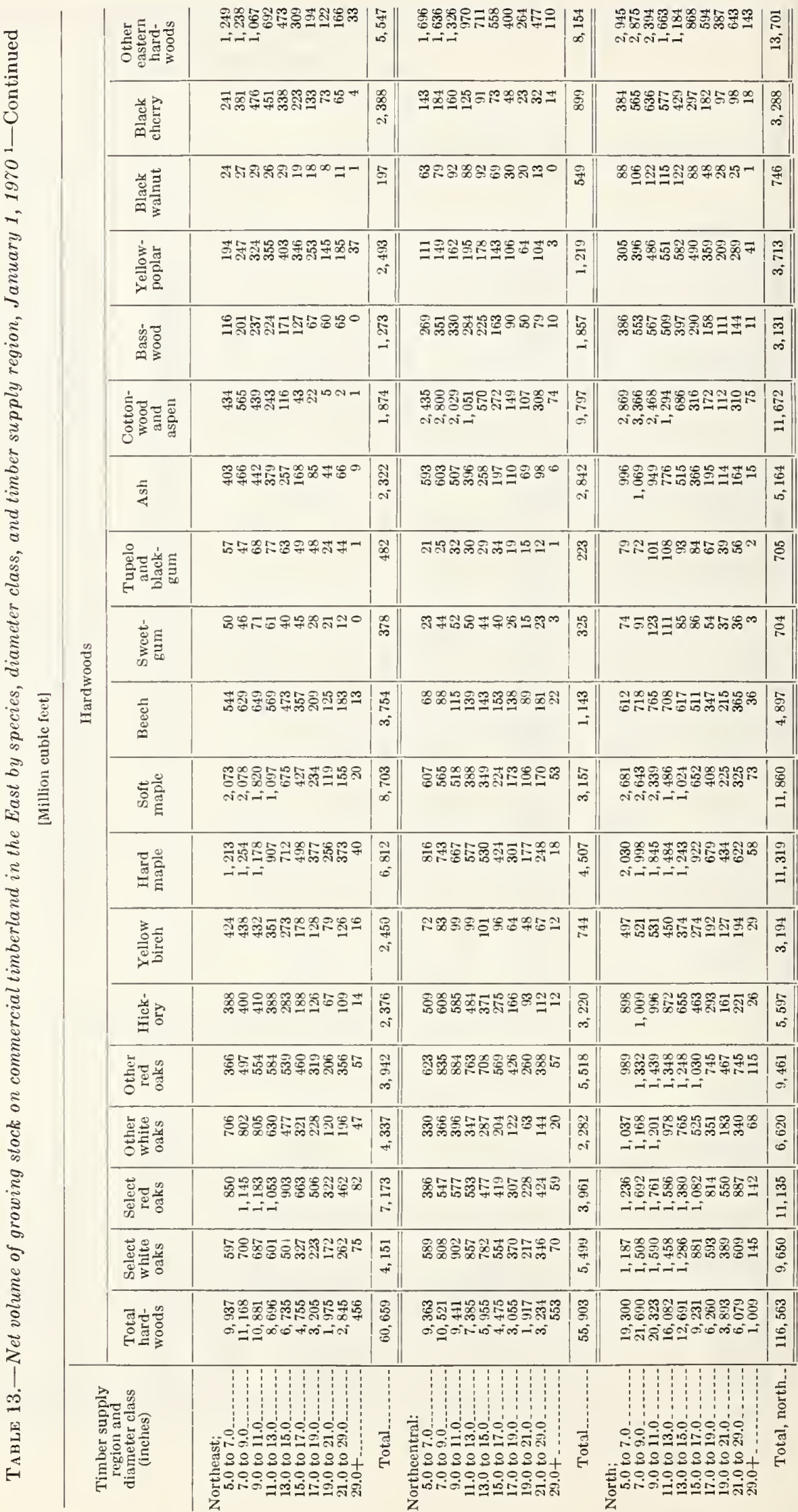




\begin{tabular}{|c|c|c|c|c|c|c|c|}
\hline 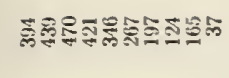 & 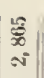 & 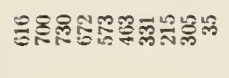 & 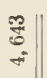 & 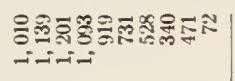 & 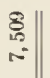 & 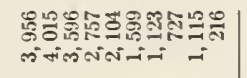 & 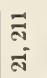 \\
\hline สิลิบก $x+N \cap 1-0$ & $\bar{\infty}$ & 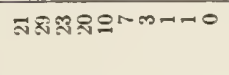 & $\cong$ & 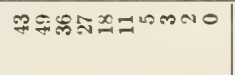 & $\stackrel{\infty}{\Xi}$ & 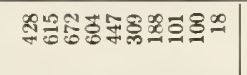 & 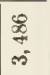 \\
\hline$\Omega=\Xi \pm シ ン 0 \rho 0 n-$ & 5 & ๓สลสฺのー- & $\Xi$ & 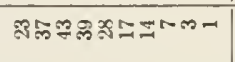 & $\stackrel{\varrho}{*}$ & 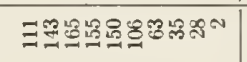 & $\%$ \\
\hline 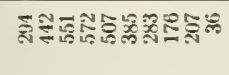 & $\frac{5}{2}$ & 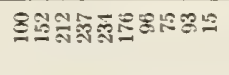 & 需 & 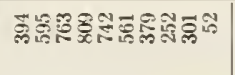 & $\begin{array}{l}\text { 总 } \\
+\infty \\
+\infty\end{array}$ & 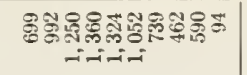 & $\begin{array}{l}0 \\
6 \\
c \\
\infty \\
\infty\end{array}$ \\
\hline 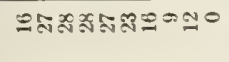 & $\stackrel{D}{D}$ & 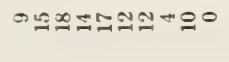 & \pm & 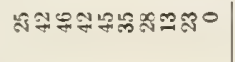 & 芦 & 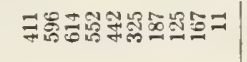 & 第 \\
\hline$m \backsim x \sim n g 0+=0$ & $\approx$ & 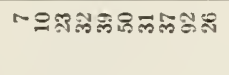 & 率 & 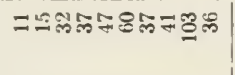 & $\overrightarrow{\mathrm{J}}$ & 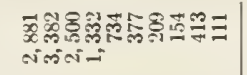 & 焉 \\
\hline 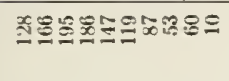 & $\stackrel{3}{3}$ & 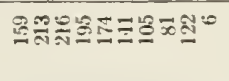 & $\stackrel{F}{F}$ & 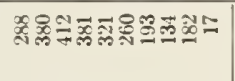 & 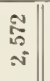 & 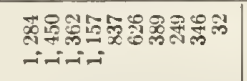 & 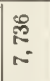 \\
\hline 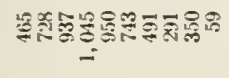 & 管 & 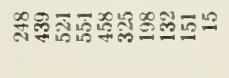 & $\begin{array}{c}\frac{9}{8} \\
\text { i }\end{array}$ & 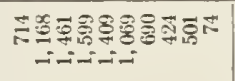 & $\stackrel{m}{2}$ & 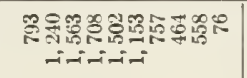 & $\begin{array}{l}\infty \\
\infty \\
\infty \\
\infty\end{array}$ \\
\hline 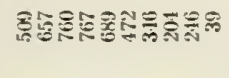 & 愛 & 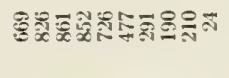 & 禺 & 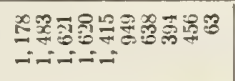 & 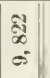 & 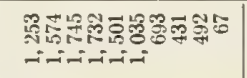 & 点 \\
\hline 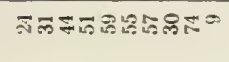 & क्षे & 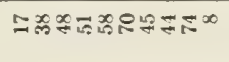 & 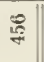 & 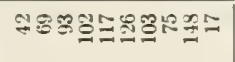 & 妥 & 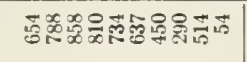 & 里 \\
\hline 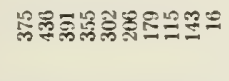 & 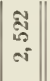 & 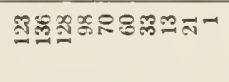 & $\begin{array}{l}\infty \\
\mathbb{8}\end{array}$ & 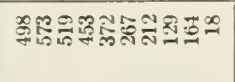 & 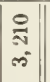 & 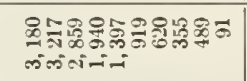 & \begin{tabular}{|l}
8 \\
8 \\
-3 \\
2
\end{tabular} \\
\hline 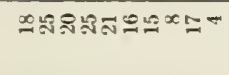 & $\Xi$ & 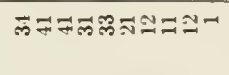 & $\stackrel{ }{ }$ & 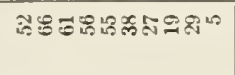 & $\cong$ & 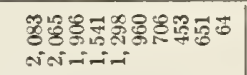 & 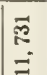 \\
\hline$r+\cos n \operatorname{coshcos} 0$ & \& & M-1-1-000NO & $\infty$ & non & 范 & 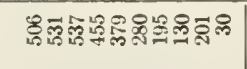 & 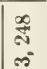 \\
\hline 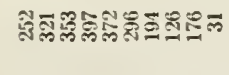 & 苨 & 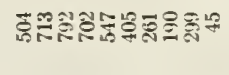 & 夏 & 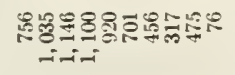 & $\left|\begin{array}{c}0 \\
0 \\
0 \\
0\end{array}\right|$ & 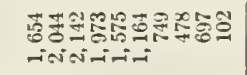 & 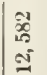 \\
\hline 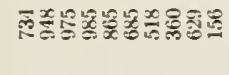 & 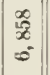 & 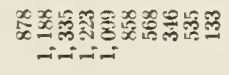 & 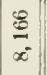 & 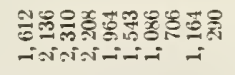 & $\left|\begin{array}{|c|}3 \\
0 \\
0 \\
2\end{array}\right|$ & 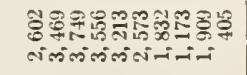 & 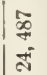 \\
\hline 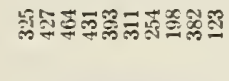 & $\begin{array}{c}m \\
m \\
m \\
m\end{array}$ & 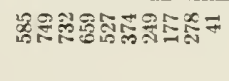 & 趈 & 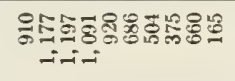 & $\begin{array}{l}x \\
: \\
:=\end{array}$ & 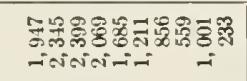 & 总 \\
\hline 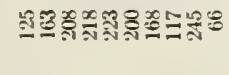 & 胥 & 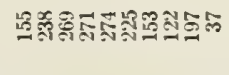 & : & 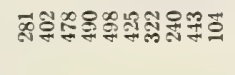 & $\mid \begin{array}{l}a \\
0 \\
0 \\
n\end{array}$ & 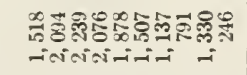 & $\begin{array}{l}8 \\
\infty \\
\infty \\
=\end{array}$ \\
\hline 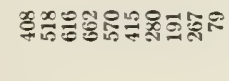 & $\begin{array}{l}9 \\
\stackrel{9}{0} \\
\circ\end{array}$ & 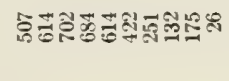 & $\vec{m}$ & 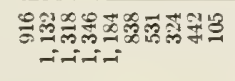 & $\mid \begin{array}{l}\Xi \\
\infty\end{array}$ & 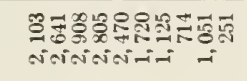 & 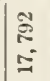 \\
\hline 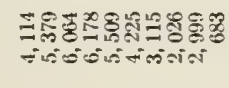 & 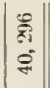 & 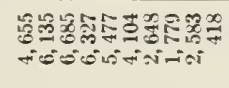 & 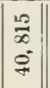 & 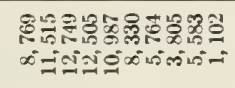 & $\begin{array}{l}\because \\
\infty \\
-\infty\end{array}$ & 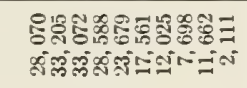 & $\begin{array}{l}8 \\
8 \\
8 \\
9 \\
9\end{array}$ \\
\hline 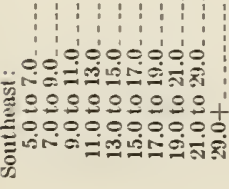 & $\frac{}{\mathrm{\Xi}}$ & 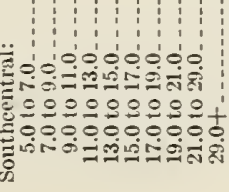 & 离 & 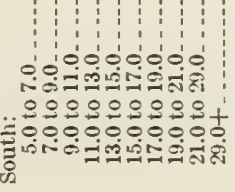 & 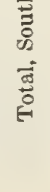 & 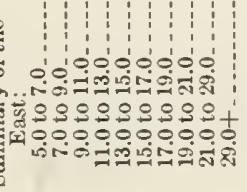 & : \\
\hline
\end{tabular}




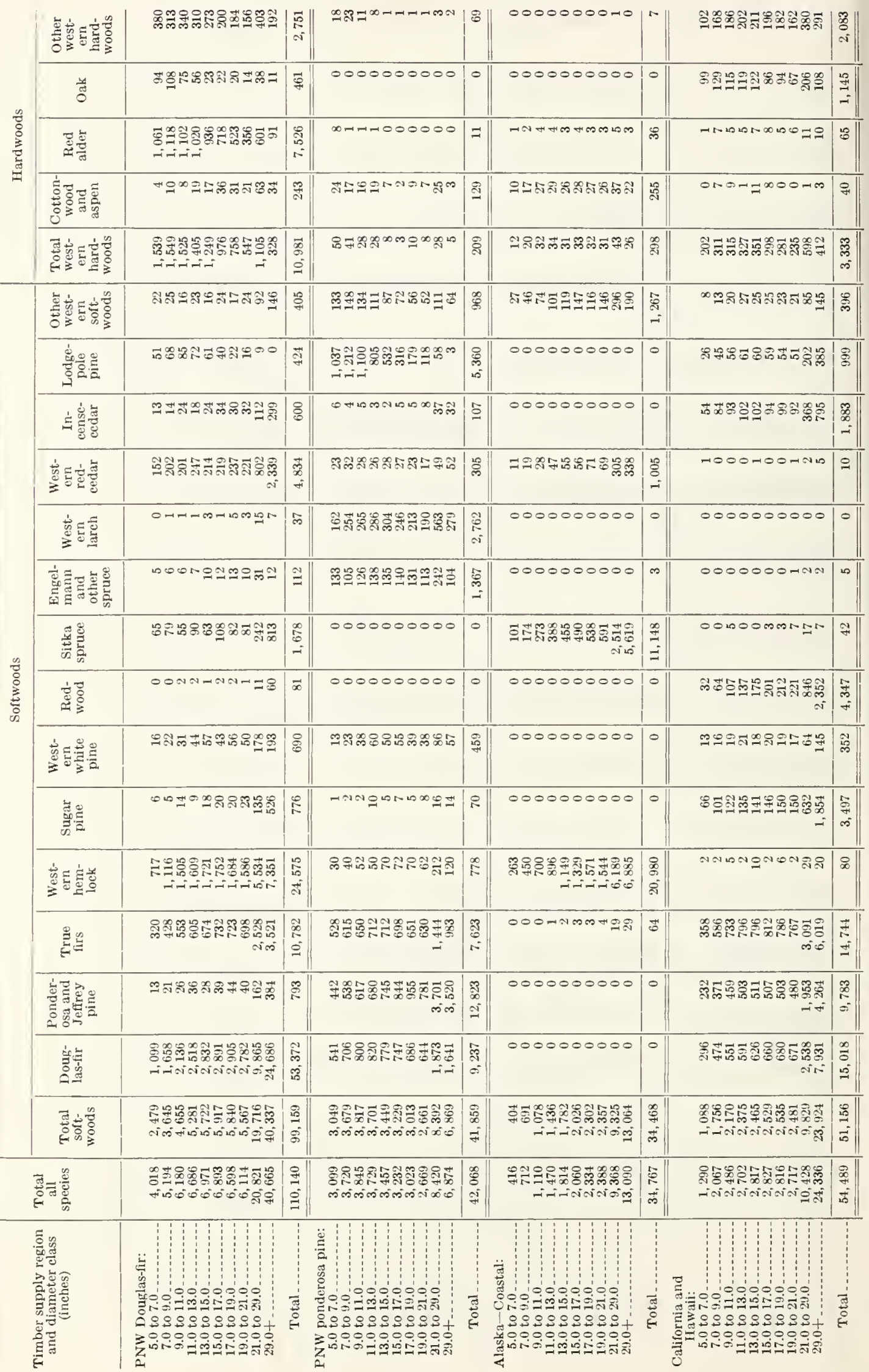




\begin{tabular}{|c|c|c|c|c|c|c|c|c|c|}
\hline 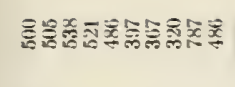 & $\equiv$ & $=58=0+N m-$ & 2 & 00000000 & N & \#สลシの & $\overrightarrow{\underline{2}}$ & 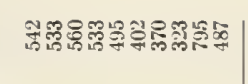 & 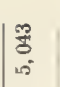 \\
\hline 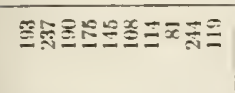 & $\stackrel{0}{-1}$ & 0000000000 & $=$ & 0000000000 & 0 & 0000000000 & 0 & 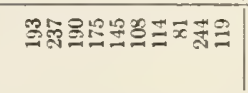 & 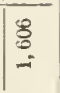 \\
\hline 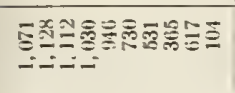 & 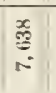 & $=000000000$ & 0 & 0000000000 & 0 & 0000000000 & 0 & 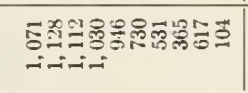 & 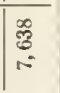 \\
\hline 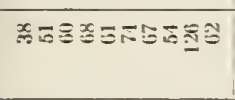 & 5 & $\bar{R} 8 \bar{x} \bar{x}: x 5$ & 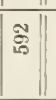 & 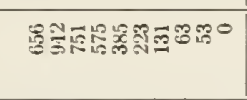 & $\left|\begin{array}{l|l}0 \\
x \\
x \\
n \\
\infty\end{array}\right|$ & 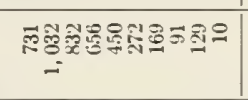 & 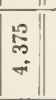 & 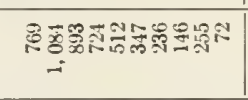 & $\mid \begin{array}{l}\text { 9a } \\
\text { के } \\
\text { is }\end{array}$ \\
\hline 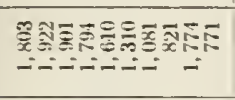 & 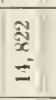 & 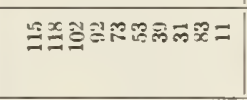 & $\overrightarrow{\mathrm{N}}$ & 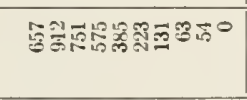 & $\begin{array}{l}\infty \\
\infty \\
\infty\end{array}$ & 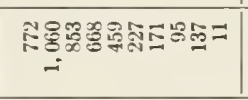 & 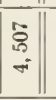 & 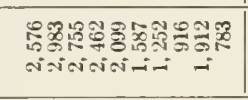 & 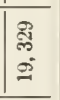 \\
\hline 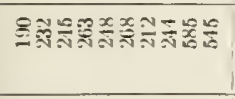 & 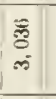 & 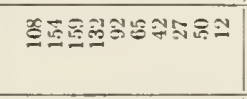 & 要 & 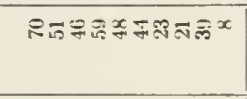 & $\cong$ & 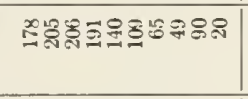 & $\mid \begin{array}{c}\infty \\
3 \\
\vdots \\
-1 \\
\end{array}$ & 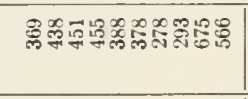 & 蔗 \\
\hline 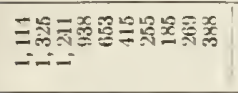 & $\begin{array}{l}\infty \\
0 \\
0 \\
=\end{array}$ & 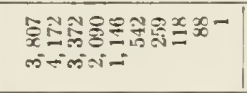 & 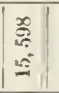 & 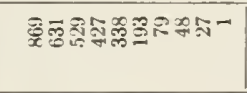 & $\left|\frac{\infty}{\infty}\right|$ & 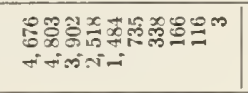 & 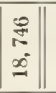 & 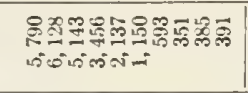 & 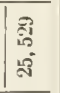 \\
\hline 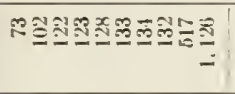 & $\begin{array}{l}0 \\
\vdots \\
-1\end{array}$ & 0000000000 & 0 & 0000000000 & - & 0000000000 & - & 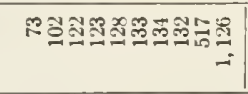 & 营 \\
\hline 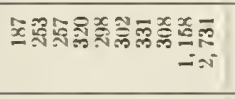 & $\stackrel{\bar{\sigma}}{=}$ & 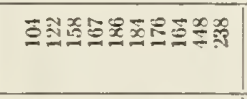 & $\overrightarrow{\overrightarrow{5}}$ & 0000000000 & 0 & 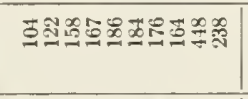 & 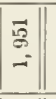 & 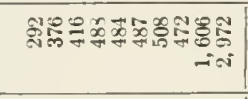 & $\frac{8}{\infty}$ \\
\hline 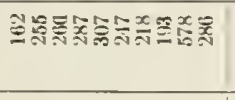 & 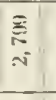 & 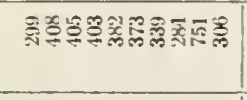 & \begin{tabular}{|l|}
$\mid \overrightarrow{\hat{a}}$ \\
$\vec{m}$
\end{tabular} & 0000000000 & 0 & 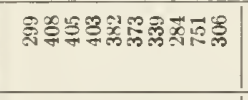 & 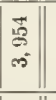 & 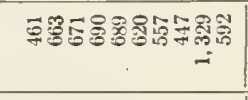 & $\begin{array}{l}\text { 昌 } \\
0 \\
0 \\
0\end{array}$ \\
\hline 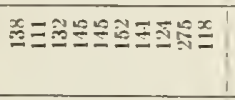 & $\stackrel{-}{-2}$ & 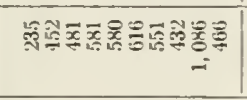 & $\mid$\begin{tabular}{c|}
$\vec{x}$ \\
$\vdots$ \\
5 \\
5
\end{tabular} & 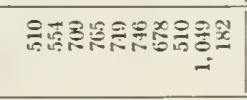 & \begin{tabular}{|l|} 
\\
5 \\
5 \\
\end{tabular} & 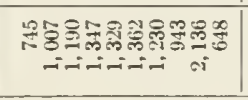 & $\begin{array}{l}\text { 임 } \\
\vdots \\
=\end{array}$ & 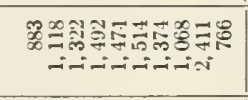 & $\mid$\begin{tabular}{l}
$\infty$ \\
\hdashline \\
\hdashline \\
\hdashline \\
\hdashline
\end{tabular} \\
\hline 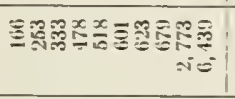 & $\begin{array}{l}x \\
x \\
\underline{x} \\
\text { N } \\
\end{array}$ & 0000000000 & 0 & 0000000000 & 0 & 0000000000 & 0 & 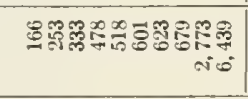 & \begin{tabular}{l}
$\infty$ \\
$\infty$ \\
$\infty$ \\
\hdashline \\
\hdashline
\end{tabular} \\
\hline 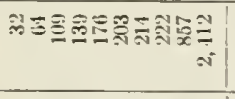 & 齐 & 0000000000 & 0 & 0000000000 & 0 & 0000000000 & 0 & 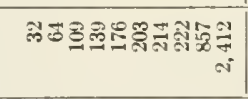 & 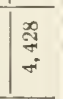 \\
\hline 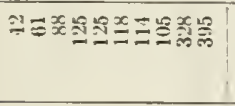 & - & 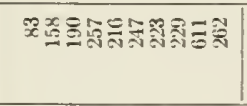 & $\left|\begin{array}{c}3 \\
\vdots \\
-4\end{array}\right|$ & 0000000000 & $\approx$ & 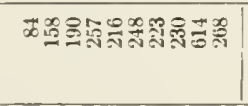 & \begin{tabular}{|c|}
$\vec{s}$ \\
\multirow{2}{*}{$\mid$}
\end{tabular} & 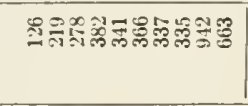 & 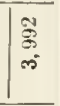 \\
\hline 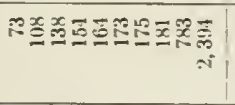 & $\stackrel{m}{m}$ & 0000000000 & 0 & 0000000000 & - & 0000000000 & - & 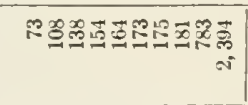 & 蒂 \\
\hline 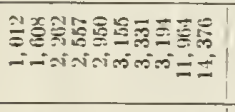 & $\stackrel{0}{=}$ & 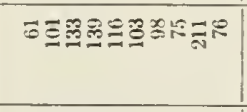 & 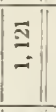 & $00000000 \mathrm{NA}$ & + & 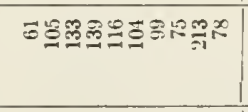 & $\underset{0}{0}$ & 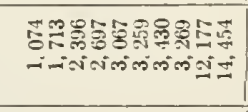 & 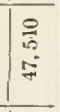 \\
\hline 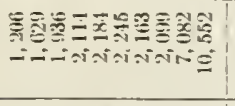 & 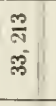 & 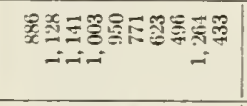 & 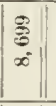 & 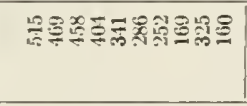 & $\left|\begin{array}{c}\infty \\
7 \\
\infty\end{array}\right|$ & 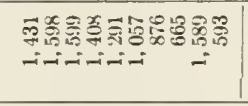 & @i: & 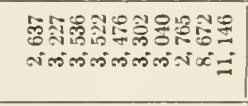 & 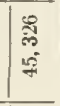 \\
\hline $\begin{array}{l}0 \\
0\end{array}$ & 逽 & 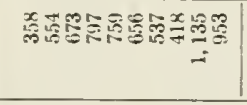 & $\mid \begin{array}{l}0 \\
0 \\
0 \\
0\end{array}$ & 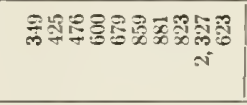 & $\left|\begin{array}{l}\mathrm{O} \\
\mathrm{a} \\
x^{\circ}\end{array}\right|$ & 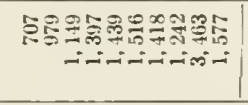 & $\left|\begin{array}{l}0 \\
3 \\
x \\
= \\
=\end{array}\right|$ & 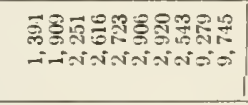 & 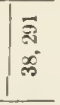 \\
\hline 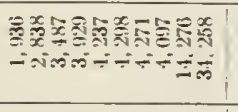 & s. & 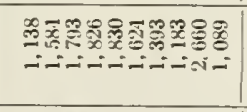 & $\mid \begin{array}{l}\vec{\Xi} \\
\vdots \\
\end{array}$ & 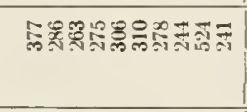 & $\left|\frac{s}{m}\right|$ & 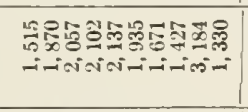 & 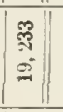 & 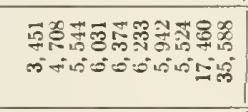 & $\begin{array}{l}8 \\
8 \\
5 \\
5\end{array}$ \\
\hline 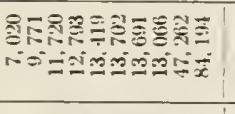 & ma & 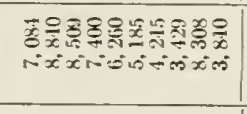 & $\frac{8}{8}$ & 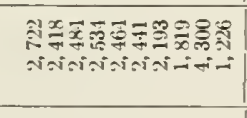 & $\mid$\begin{tabular}{l|}
2 \\
0 \\
3 \\
3
\end{tabular} & 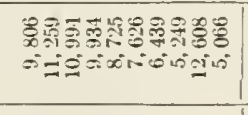 & $\begin{array}{l}\approx \\
\infty \\
\infty\end{array}$ & 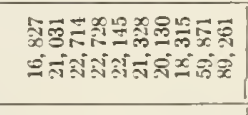 & 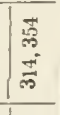 \\
\hline 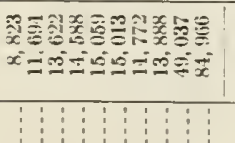 & 筞 & 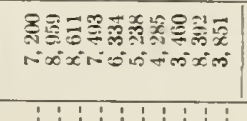 & 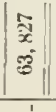 & 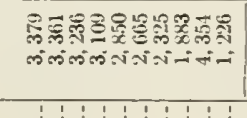 & $\left|\begin{array}{l}\overrightarrow{\mathrm{s}} \\
x \\
\text { wे }\end{array}\right|$ & 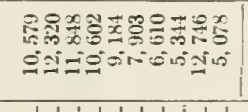 & 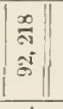 & 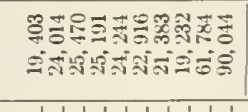 & 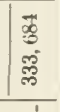 \\
\hline 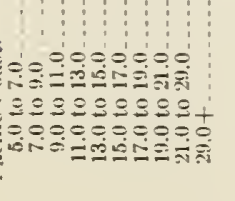 & 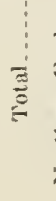 & 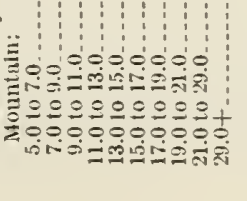 & $\stackrel{\frac{1}{E}}{\stackrel{E}{E}}$ & 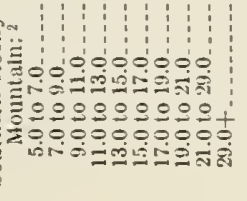 & : & 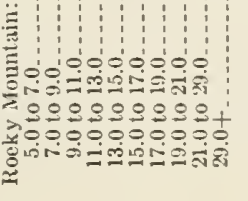 & : & 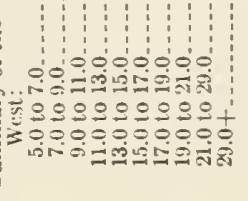 & है \\
\hline
\end{tabular}


TABLE 15.-Net volume of sawtimber on commercial timberland in the East by species, diameter class, and timber supply region January 1, $1970^{1}$

[Million board feet, International $1 / 4$-inch $\log$ rule]

\begin{tabular}{|c|c|c|c|c|c|c|c|c|c|c|c|c|}
\hline \multirow[b]{2}{*}{$\begin{array}{l}\text { Timber supply region and } \\
\text { diameter class (inches) }\end{array}$} & \multirow[b]{2}{*}{$\begin{array}{l}\text { Total } \\
\text { all } \\
\text { species }\end{array}$} & \multicolumn{11}{|c|}{ Softwoods } \\
\hline & & $\begin{array}{l}\text { Total } \\
\text { soft- } \\
\text { woods }\end{array}$ & $\begin{array}{c}\text { Longleaf } \\
\text { and } \\
\text { slash } \\
\text { pines }\end{array}$ & $\begin{array}{c}\text { Shortleaf } \\
\text { and } \\
\text { loblolly } \\
\text { pines }\end{array}$ & $\begin{array}{l}\text { Other } \\
\text { yellow } \\
\text { pines }\end{array}$ & $\begin{array}{c}\text { Eastern } \\
\text { white } \\
\text { and red } \\
\text { pines }\end{array}$ & $\begin{array}{l}\text { Jack } \\
\text { pine }\end{array}$ & $\begin{array}{l}\text { Spruce } \\
\text { and } \\
\text { balsam } \\
\text { fir }\end{array}$ & $\begin{array}{l}\text { Eastern } \\
\text { hemlock }\end{array}$ & Cypress & $\begin{array}{l}\text { Other } \\
\text { eastern } \\
\text { soft- } \\
\text { woods }\end{array}$ & $\begin{array}{l}\text { Ponder- } \\
\text { osa and } \\
\text { Jeffrey } \\
\text { pine }\end{array}$ \\
\hline $\begin{array}{l}\text { Northeast: } \\
9.0 \text { to } 11.0 \\
11.0 \text { to } 13.0 \\
13.0 \text { to } 15.0 \\
15.0 \text { to } 17.0 \\
17.0 \text { to } 19.0 \\
19.0 \text { to } 21.0 \\
21.0 \text { to } 29.0 \\
29.0+\end{array}$ & $\begin{array}{r}15,809 \\
40,994 \\
33,344 \\
24,424 \\
16,772 \\
10,737 \\
15,604 \\
2,464\end{array}$ & $\begin{array}{r}15,809 \\
11,799 \\
8,107 \\
5,532 \\
3,356 \\
2,131 \\
2,763 \\
346\end{array}$ & $\begin{array}{l}0 \\
0 \\
0 \\
0 \\
0 \\
0 \\
0 \\
0 \\
\end{array}$ & $\begin{array}{r}399 \\
340 \\
233 \\
184 \\
97 \\
46 \\
61 \\
0 \\
\end{array}$ & $\begin{array}{r}802 \\
678 \\
383 \\
276 \\
73 \\
16 \\
36 \\
0 \\
\end{array}$ & $\begin{array}{r}2,788 \\
2,675 \\
2,669 \\
1,985 \\
1,330 \\
1,164 \\
1,801 \\
\quad 296 \\
\end{array}$ & $\begin{array}{l}0 \\
0 \\
0 \\
0 \\
0 \\
0 \\
0 \\
0\end{array}$ & $\begin{array}{r}8,349 \\
5,011 \\
2,610 \\
1,424 \\
727 \\
328 \\
219 \\
0\end{array}$ & $\begin{array}{r}2,391 \\
2,272 \\
1,773 \\
1,428 \\
1,010 \\
530 \\
590 \\
37\end{array}$ & $\begin{array}{l}0 \\
0 \\
0 \\
0 \\
0 \\
0 \\
0 \\
0 \\
\end{array}$ & $\begin{array}{r}1,079 \\
820 \\
436 \\
232 \\
117 \\
45 \\
54 \\
12\end{array}$ & $\begin{array}{l}0 \\
0 \\
0 \\
0 \\
0 \\
0 \\
0 \\
0\end{array}$ \\
\hline Total ... & 160,151 & 49,846 & 0 & 1,362 & 2,267 & 14,711 & 0 & 18,670 & 10,035 & 0 & 2,799 & 0 \\
\hline $\begin{array}{l}\text { Northcentral: } \\
9.0 \text { to } 11.0 \ldots \\
11.0 \text { to } 13.0 \ldots \\
13.0 \text { to } 15.0 \ldots \\
15.0 \text { to } 17.0 \ldots \\
17.0 \text { to } 19.0 \ldots \\
19.0 \text { to } 21.0 \\
21.0 \text { to } 29.0 \ldots \\
29.0+\end{array}$ & $\begin{array}{r}8,656 \\
43,635 \\
36,123 \\
27,705 \\
19,325 \\
12,378 \\
20,226 \\
3,665 \\
\end{array}$ & $\begin{array}{r}8,656 \\
6,373 \\
4,636 \\
3,521 \\
2,469 \\
1,742 \\
2,453 \\
362 \\
\end{array}$ & $\begin{array}{l}0 \\
0 \\
0 \\
0 \\
0 \\
0 \\
0 \\
0\end{array}$ & $\begin{array}{r}593 \\
525 \\
405 \\
180 \\
64 \\
17 \\
12 \\
2 \\
\end{array}$ & $\begin{array}{r}419 \\
327 \\
229 \\
112 \\
48 \\
12 \\
5 \\
0 \\
\end{array}$ & $\begin{array}{r}1,293 \\
1,618 \\
1,676 \\
1,442 \\
1,273 \\
904 \\
1,225 \\
229\end{array}$ & $\begin{array}{r}1,451 \\
876 \\
343 \\
153 \\
19 \\
3 \\
0 \\
0 \\
\end{array}$ & $\begin{array}{r}2,367 \\
1,121 \\
515 \\
408 \\
193 \\
139 \\
25 \\
0\end{array}$ & $\begin{array}{r}675 \\
820 \\
787 \\
762 \\
587 \\
482 \\
870 \\
74\end{array}$ & $\begin{array}{r}1 \\
8 \\
9 \\
38 \\
15 \\
16 \\
83 \\
42 \\
\end{array}$ & $\begin{array}{r}1,748 \\
953 \\
570 \\
337 \\
214 \\
119 \\
201 \\
13 \\
\end{array}$ & $\begin{array}{r}106 \\
122 \\
99 \\
84 \\
52 \\
45 \\
28 \\
0 \\
\end{array}$ \\
\hline Total ... & 171.716 & 30,215 & 0 & 1,800 & 1,155 & 9,662 & 2,847 & 4,772 & 5,061 & 216 & 4,159 & 539 \\
\hline $\begin{array}{l}\text { North: } \\
9.0 \text { to } 11.0 \ldots \\
11.0 \text { to } 13.0-\ldots \\
13.0 \text { to } 15.0- \\
15.0 \text { to } 17.0 \ldots \\
17.0 \text { to } 19.0 \ldots \\
19.0 \text { to } 21.0 \ldots \\
21.0 \text { to } 29.0 \ldots \\
29.0+\end{array}$ & $\begin{array}{r}24,465 \\
84,629 \\
69,467 \\
52,130 \\
36,097 \\
23,115 \\
35,831 \\
6,129 \\
\end{array}$ & $\begin{array}{r}24,465 \\
18,172 \\
12,744 \\
9,053 \\
5,826 \\
3,873 \\
5,217 \\
708 \\
\end{array}$ & $\begin{array}{l}0 \\
0 \\
0 \\
0 \\
0 \\
0 \\
0 \\
0\end{array}$ & $\begin{array}{r}992 \\
865 \\
638 \\
365 \\
161 \\
64 \\
73 \\
2\end{array}$ & $\begin{array}{r}1,221 \\
1,005 \\
613 \\
388 \\
122 \\
28 \\
42 \\
0\end{array}$ & $\begin{array}{r}4,081 \\
4,293 \\
4,345 \\
3,428 \\
2,603 \\
2,069 \\
3,026 \\
525\end{array}$ & $\begin{array}{r}1,451 \\
876 \\
343 \\
153 \\
19 \\
3 \\
0 \\
0\end{array}$ & $\begin{array}{r}10,716 \\
6,133 \\
3,125 \\
1,833 \\
920 \\
467 \\
245 \\
0 \\
\end{array}$ & $\begin{array}{r}3,067 \\
3,092 \\
2,561 \\
2,191 \\
1,598 \\
1,012 \\
1,461 \\
112 \\
\end{array}$ & $\begin{array}{r}1 \\
8 \\
9 \\
38 \\
15 \\
16 \\
83 \\
42 \\
\end{array}$ & $\begin{array}{r}2,827 \\
1,774 \\
1,007 \\
570 \\
331 \\
165 \\
256 \\
26 \\
\end{array}$ & $\begin{array}{r}106 \\
122 \\
99 \\
84 \\
52 \\
45 \\
28 \\
0\end{array}$ \\
\hline Total $\ldots$ & 331,868 & 80,061 & 0 & 3,163 & 3,422 & 24,374 & 2,847 & 23,442 & 15,096 & 216 & 6,959 & 539 \\
\hline $\begin{array}{l}\text { Southeast: } \\
9.0 \text { to } 11.0 \ldots \\
11.0 \text { to } 13.0 \ldots \\
13.0 \text { to } 15.0 \ldots \\
15.0 \text { to } 17.0 \ldots \\
17.0 \text { to } 19.0 \ldots \\
19.0 \text { to } 21.0 \ldots \\
21.0 \text { to } 29.0 \ldots \\
29.0+\end{array}$ & $\begin{array}{r}27,112 \\
50,040 \\
45,234 \\
33,861 \\
23,498 \\
14,364 \\
19,107 \\
3,797\end{array}$ & $\begin{array}{r}27,112 \\
28,622 \\
22,997 \\
15,447 \\
9,474 \\
5,068 \\
5,298 \\
691\end{array}$ & $\begin{array}{r}8,972 \\
8,302 \\
5,555 \\
2,875 \\
1,256 \\
512 \\
340 \\
5\end{array}$ & $\begin{array}{r}12,401 \\
14,303 \\
12,687 \\
9,557 \\
6,116 \\
3,400 \\
3,322 \\
233\end{array}$ & $\begin{array}{r}3,297 \\
2,949 \\
2,023 \\
1,190 \\
712 \\
271 \\
191 \\
1\end{array}$ & $\begin{array}{r}214 \\
336 \\
327 \\
236 \\
187 \\
179 \\
350 \\
43\end{array}$ & $\begin{array}{l}0 \\
0 \\
0 \\
0 \\
0 \\
0 \\
0 \\
0\end{array}$ & $\begin{array}{r}10 \\
11 \\
7 \\
2 \\
3 \\
6 \\
2 \\
0\end{array}$ & $\begin{array}{r}67 \\
115 \\
97 \\
122 \\
113 \\
79 \\
172 \\
100 \\
\end{array}$ & $\begin{array}{r}\mathbf{1}, 934 \\
2,444 \\
2,197 \\
\mathbf{1}, 415 \\
1,048 \\
607 \\
902 \\
305\end{array}$ & $\begin{array}{r}214 \\
157 \\
102 \\
47 \\
35 \\
12 \\
17 \\
0 \\
\end{array}$ & $\begin{array}{l}0 \\
0 \\
0 \\
0 \\
0 \\
0 \\
0 \\
0\end{array}$ \\
\hline Total & 217,015 & 114,712 & 27,821 & 62,022 & 10,638 & 1,877 & 0 & 44 & 868 & 10,854 & $\overrightarrow{586}$ & 0 \\
\hline 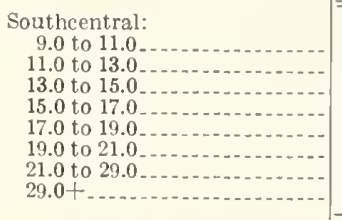 & $\begin{array}{r}26,976 \\
58,341 \\
56,903 \\
45,415 \\
30,348 \\
20,283 \\
25,220 \\
3,344 \\
\end{array}$ & $\begin{array}{r}26,976 \\
33,932 \\
32,692 \\
25,981 \\
17,334 \\
11,309 \\
11,828 \\
1,108 \\
\end{array}$ & $\begin{array}{r}3,545 \\
4,765 \\
3,734 \\
2,420 \\
1,201 \\
436 \\
325 \\
0\end{array}$ & $\begin{array}{r}21,758 \\
27,019 \\
26,383 \\
21,569 \\
\mathbf{1 4 , 4 9 2} \\
9,711 \\
9,873 \\
508\end{array}$ & $\begin{array}{r}882 \\
1,050 \\
854 \\
569 \\
371 \\
237 \\
241 \\
39\end{array}$ & $\begin{array}{r}71 \\
89 \\
106 \\
98 \\
89 \\
50 \\
98 \\
19\end{array}$ & $\begin{array}{l}0 \\
0 \\
0 \\
0 \\
0 \\
0 \\
0 \\
0\end{array}$ & $\begin{array}{l}0 \\
0 \\
0 \\
0 \\
0 \\
0 \\
0 \\
0\end{array}$ & $\begin{array}{r}27 \\
30 \\
43 \\
44 \\
14 \\
25 \\
22 \\
4\end{array}$ & $\begin{array}{r}594 \\
890 \\
1,519 \\
1,252 \\
1,137 \\
841 \\
1,269 \\
536\end{array}$ & $\begin{array}{r}96 \\
87 \\
50 \\
27 \\
28 \\
6 \\
0 \\
0\end{array}$ & $\begin{array}{l}0 \\
0 \\
0 \\
0 \\
0 \\
0 \\
0 \\
0\end{array}$ \\
\hline Total & 266,834 & 161,163 & 16,428 & 131,316 & 4,246 & 622 & 0 & 0 & 211 & 8,040 & 297 & 0 \\
\hline $\begin{array}{l}\text { South: } \\
9.0 \text { to } 11.0 \ldots \\
11.0 \text { to } 13.0 \ldots \\
13.0 \text { to } 15.0 \ldots \\
15.0 \text { to } 17.0 \ldots \\
17.0 \text { to } 19.0 \ldots \\
19.0 \text { to } 21.0 \ldots \\
21.0 \text { to } 29.0 \ldots \\
29.0 \text {. }\end{array}$ & $\begin{array}{r}54,088 \\
108,381 \\
102,137 \\
79,277 \\
53,846 \\
34,648 \\
44,327 \\
7,142 \\
\end{array}$ & $\begin{array}{r}54,088 \\
62,554 \\
55,690 \\
41,429 \\
26,808 \\
16,378 \\
17,127 \\
1,799\end{array}$ & $\begin{array}{r}12,517 \\
13,067 \\
9,290 \\
5,296 \\
2,457 \\
948 \\
665 \\
5\end{array}$ & $\begin{array}{r}34,160 \\
41,322 \\
39,070 \\
31,126 \\
20,609 \\
13,112 \\
13,195 \\
742\end{array}$ & $\begin{array}{r}4,180 \\
4,000 \\
2,877 \\
1,759 \\
1,083 \\
508 \\
432 \\
41\end{array}$ & $\begin{array}{r}286 \\
426 \\
434 \\
334 \\
277 \\
229 \\
449 \\
62\end{array}$ & $\begin{array}{l}0 \\
0 \\
0 \\
0 \\
0 \\
0 \\
0 \\
0\end{array}$ & $\begin{array}{r}10 \\
11 \\
7 \\
2 \\
3 \\
6 \\
2 \\
0\end{array}$ & $\begin{array}{r}94 \\
146 \\
140 \\
166 \\
128 \\
104 \\
194 \\
105\end{array}$ & $\begin{array}{l}2,529 \\
3,334 \\
3,716 \\
2,667 \\
2,185 \\
1,448 \\
2,171 \\
842\end{array}$ & $\begin{array}{r}310 \\
244 \\
153 \\
75 \\
64 \\
19 \\
17 \\
0\end{array}$ & $\begin{array}{l}0 \\
0 \\
0 \\
0 \\
0 \\
0 \\
0 \\
0\end{array}$ \\
\hline Total _. . & 483,850 & 275,875 & 44,249 & 193,338 & 14,884 & 2,499 & 0 & 44 & 1,080 & 18,895 & 883 & 0 \\
\hline $\begin{array}{l}\text { Summary of the East: } \\
9.0 \text { to } 11.0 \\
11.0 \text { to } 13.0 \\
13.0 \text { to } 15.0 \\
15.0 \text { to } 17.0 \\
17.0 \text { to } 19.0 \\
19.0 \text { to } 21.0 \\
21.0 \text { to } 29.0 \\
29.0+\end{array}$ & $\begin{array}{r}78,553 \\
193,011 \\
171,605 \\
131,407 \\
89,944 \\
57,763 \\
80,159 \\
13,272 \\
\end{array}$ & $\begin{array}{r}78,553 \\
80,727 \\
68,434 \\
50,482 \\
32,635 \\
20,251 \\
22,344 \\
2,507 \\
\end{array}$ & $\begin{array}{r}12,517 \\
13,067 \\
9,290 \\
5,296 \\
2,457 \\
948 \\
665 \\
5\end{array}$ & $\begin{array}{r}35,152 \\
42,188 \\
39,709 \\
31,491 \\
20,711 \\
13,176 \\
13,268 \\
741 \\
\end{array}$ & $\begin{array}{r}\mathbf{5}, 401 \\
5,006 \\
3,491 \\
2,148 \\
1,206 \\
537 \\
474 \\
41\end{array}$ & $\begin{array}{r}4,367 \\
4,719 \\
4,779 \\
3,763 \\
2,880 \\
2,298 \\
3,475 \\
588\end{array}$ & $\begin{array}{r}1,451 \\
876 \\
343 \\
153 \\
19 \\
3 \\
0 \\
0\end{array}$ & $\begin{array}{r}10,726 \\
6,144 \\
3,132 \\
1,836 \\
923 \\
474 \\
247 \\
0\end{array}$ & $\begin{array}{r}3.162 \\
3,238 \\
2,701 \\
2,357 \\
1,726 \\
1,117 \\
1,655 \\
217\end{array}$ & $\begin{array}{l}2,530 \\
3,343 \\
3,725 \\
2,705 \\
2,201 \\
1,465 \\
2,254 \\
884\end{array}$ & $\begin{array}{r}3,138 \\
2,019 \\
1,160 \\
645 \\
395 \\
184 \\
273 \\
26\end{array}$ & $\begin{array}{r}106 \\
122 \\
99 \\
84 \\
52 \\
45 \\
28 \\
0\end{array}$ \\
\hline Total ... & 815,718 & 355,937 & 44,249 & 196,502 & 18,307 & 26,873 & 2,847 & 23,486 & 16,177 & 19,111 & 7,842 & 539 \\
\hline
\end{tabular}


APPENDIX I. FOREST STATISTICS, 1970

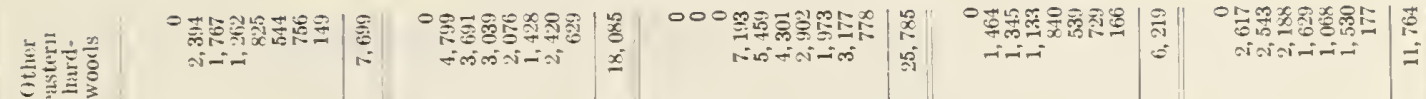

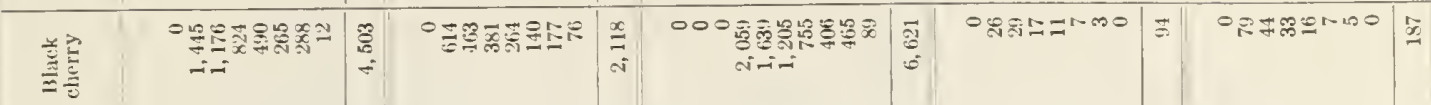

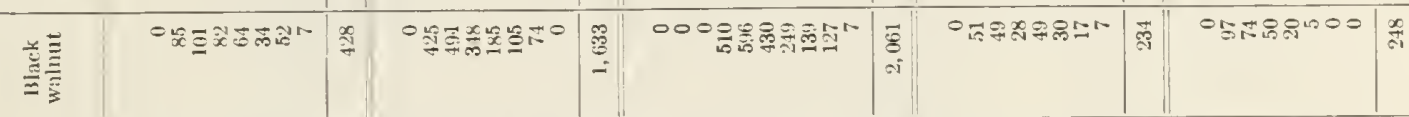

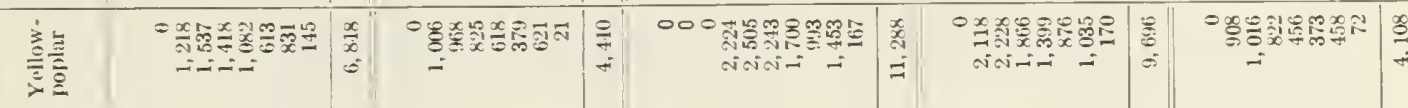

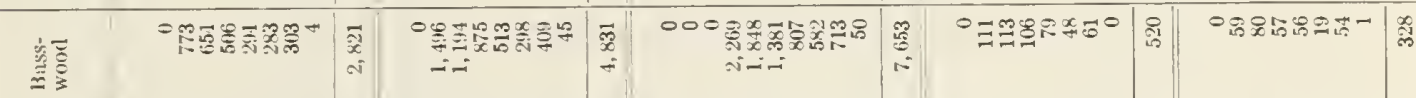

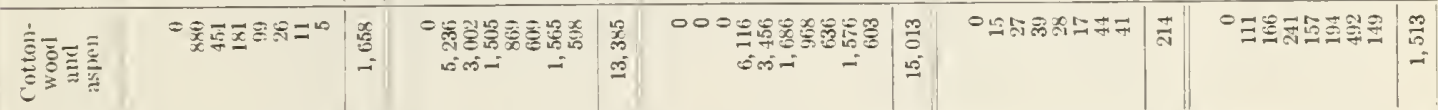

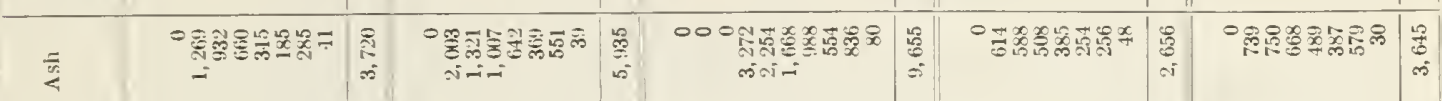

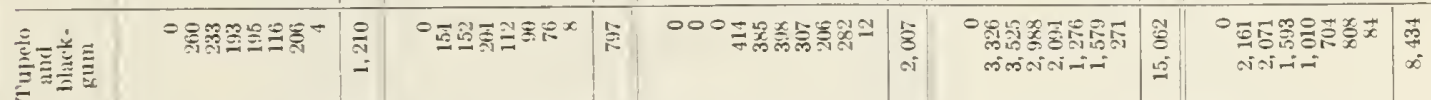

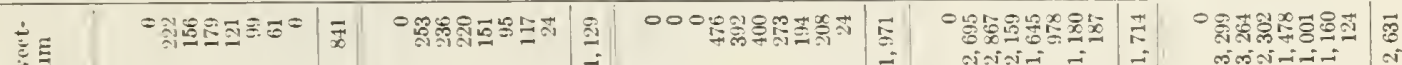
r. 1

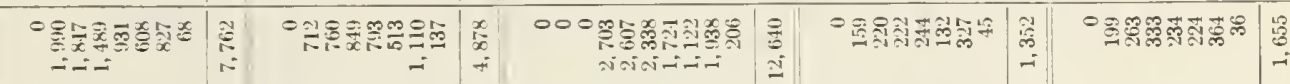

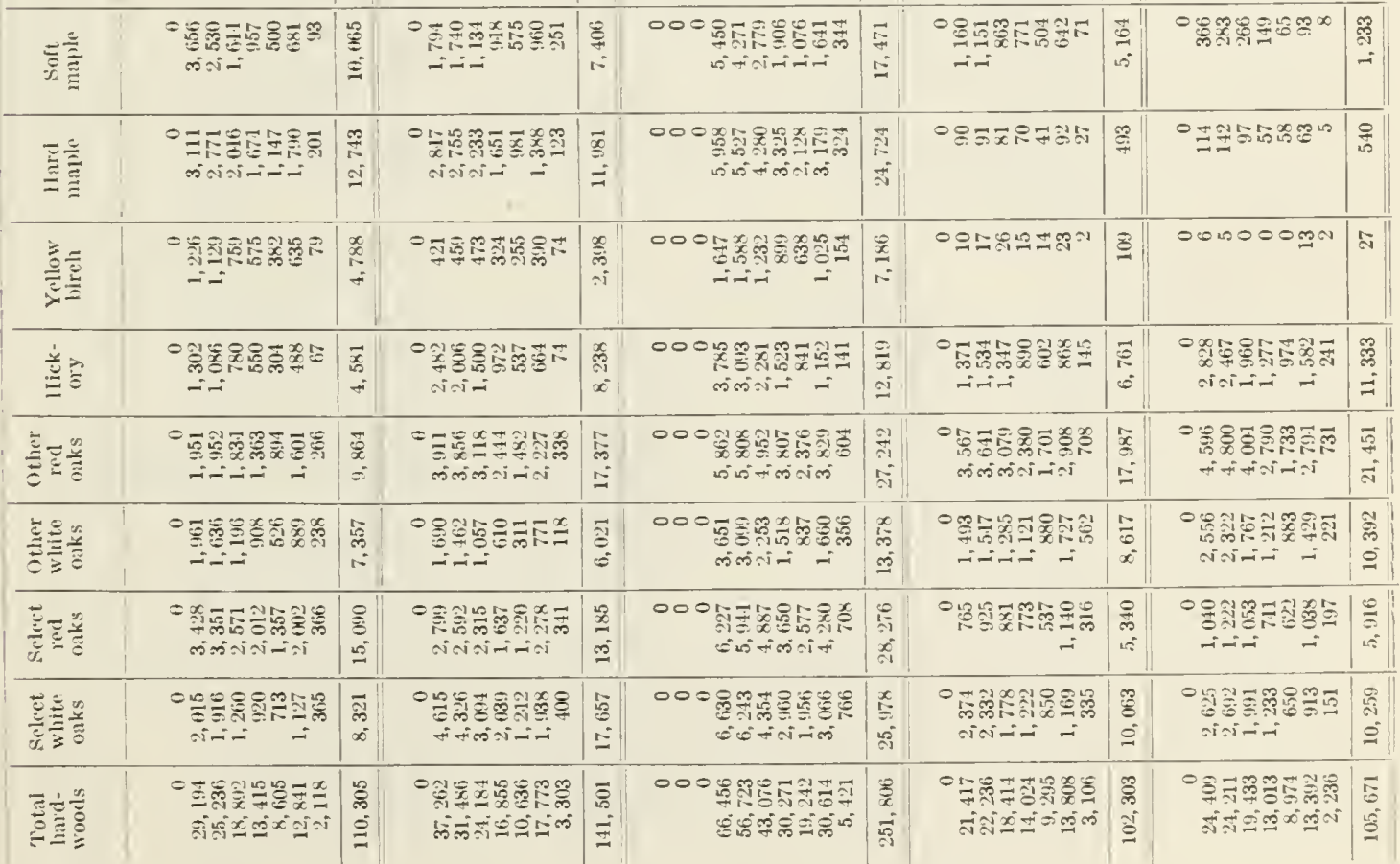




\begin{tabular}{|c|c|c|c|c|}
\hline 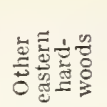 & 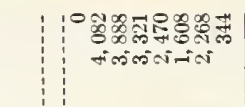 & $\mid \begin{array}{l}\overrightarrow{0} \\
\stackrel{0}{\Xi} \\
=\end{array}$ & 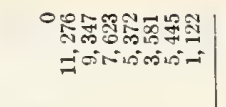 & 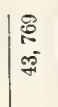 \\
\hline 总总 & 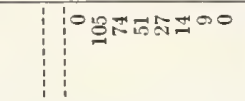 & $|\vec{a}|$ & 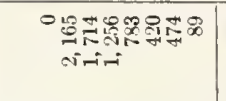 & 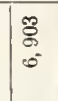 \\
\hline 总崖 & 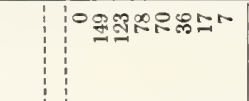 & 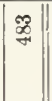 & 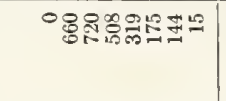 & 苦 \\
\hline 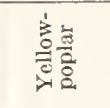 & 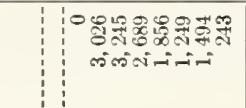 & 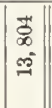 & 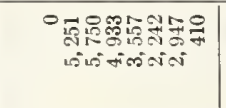 & 要 \\
\hline 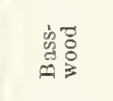 & 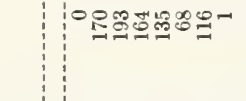 & $\left|\begin{array}{l}9 \\
\infty \\
\infty\end{array}\right|$ & 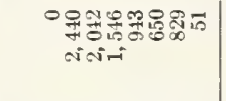 & $\mid \begin{array}{l}\text { yे } \\
6 \\
0 \\
\infty \\
\infty\end{array}$ \\
\hline & 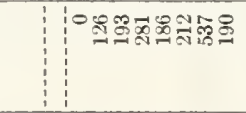 & 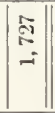 & 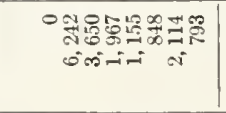 & $\mid \begin{array}{l}E \\
0 \\
0\end{array}$ \\
\hline$\frac{5}{4}$ & 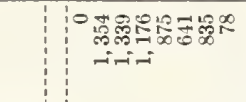 & $\left|\begin{array}{l}\vec{b} \\
0 \\
0\end{array}\right|$ & 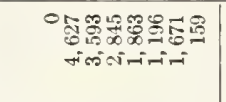 & $\begin{array}{l}5 \\
5 \\
: 5 \\
: 5\end{array}$ \\
\hline & 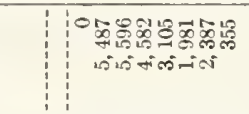 & 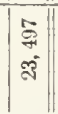 & 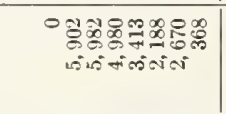 & $\begin{array}{l}8 \\
8 \\
20 \\
25\end{array}$ \\
\hline & 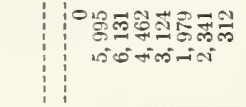 & 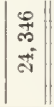 & 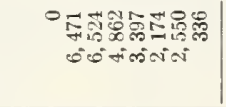 & $\mid \begin{array}{l}\infty \\
m \\
0 \\
0 \\
0\end{array}$ \\
\hline 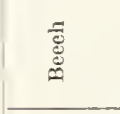 & 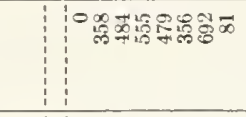 & $\left|\begin{array}{l}\hat{0} \\
\tilde{c} \\
\infty\end{array}\right|$ & 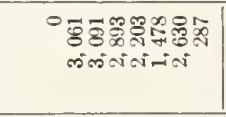 & $\mid \begin{array}{l}\infty \\
0 \\
0 \\
0 \\
0\end{array}$ \\
\hline & 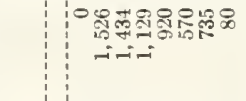 & $\mid \begin{array}{l}\infty \\
\text { 总 } \\
0 \\
\end{array}$ & 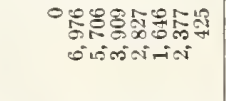 & 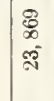 \\
\hline & 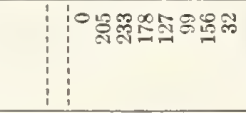 & $\left|\begin{array}{c}\tilde{m} \\
\dddot{m} \\
-i\end{array}\right|$ & 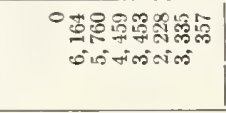 & 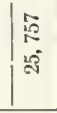 \\
\hline & 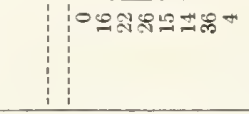 & 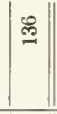 & 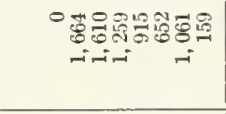 & 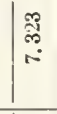 \\
\hline & 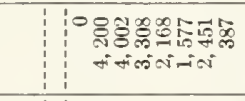 & $\left|\begin{array}{l}0 \\
8 \\
0 \\
0\end{array}\right|$ & 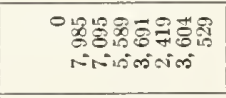 & $\mid \begin{array}{l}5 \\
5 \\
0 \\
0\end{array}$ \\
\hline 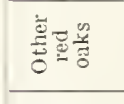 & 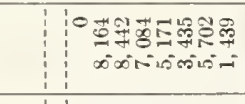 & 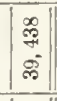 & 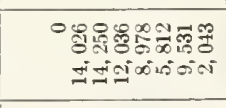 & $\mid \begin{array}{l}8 \\
8 \\
8 \\
8\end{array}$ \\
\hline 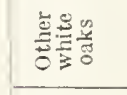 & 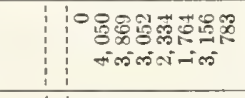 & $\left|\begin{array}{l}0 \\
0 \\
0 \\
0\end{array}\right|$ & 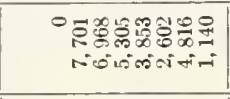 & 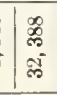 \\
\hline 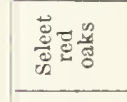 & 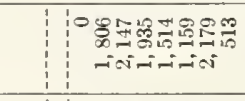 & $\mid \begin{array}{l}\hat{1} \\
\mathbf{a} \\
= \\
=\end{array}$ & 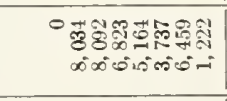 & $\mid \begin{array}{l}\overrightarrow{0} \\
0 \\
0 \\
0\end{array}$ \\
\hline 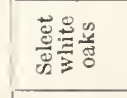 & 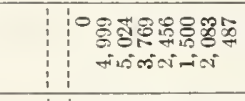 & 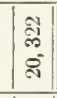 & 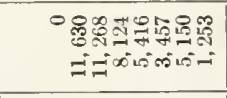 & 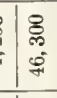 \\
\hline 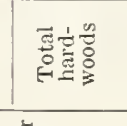 & 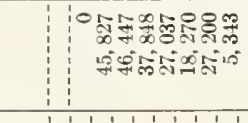 & $\mid \begin{array}{l}\overrightarrow{5} \\
5 \\
5 \\
\vdots \\
\vdots\end{array}$ & 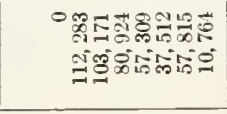 & $\begin{array}{l}\overrightarrow{0} \\
0 \\
0.9 \\
a+a\end{array}$ \\
\hline 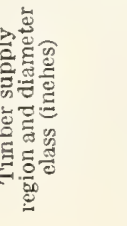 & 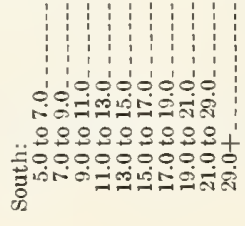 & 造 & $\begin{array}{l} \\
0 \\
0\end{array}$ & 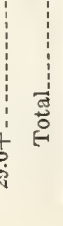 \\
\hline
\end{tabular}




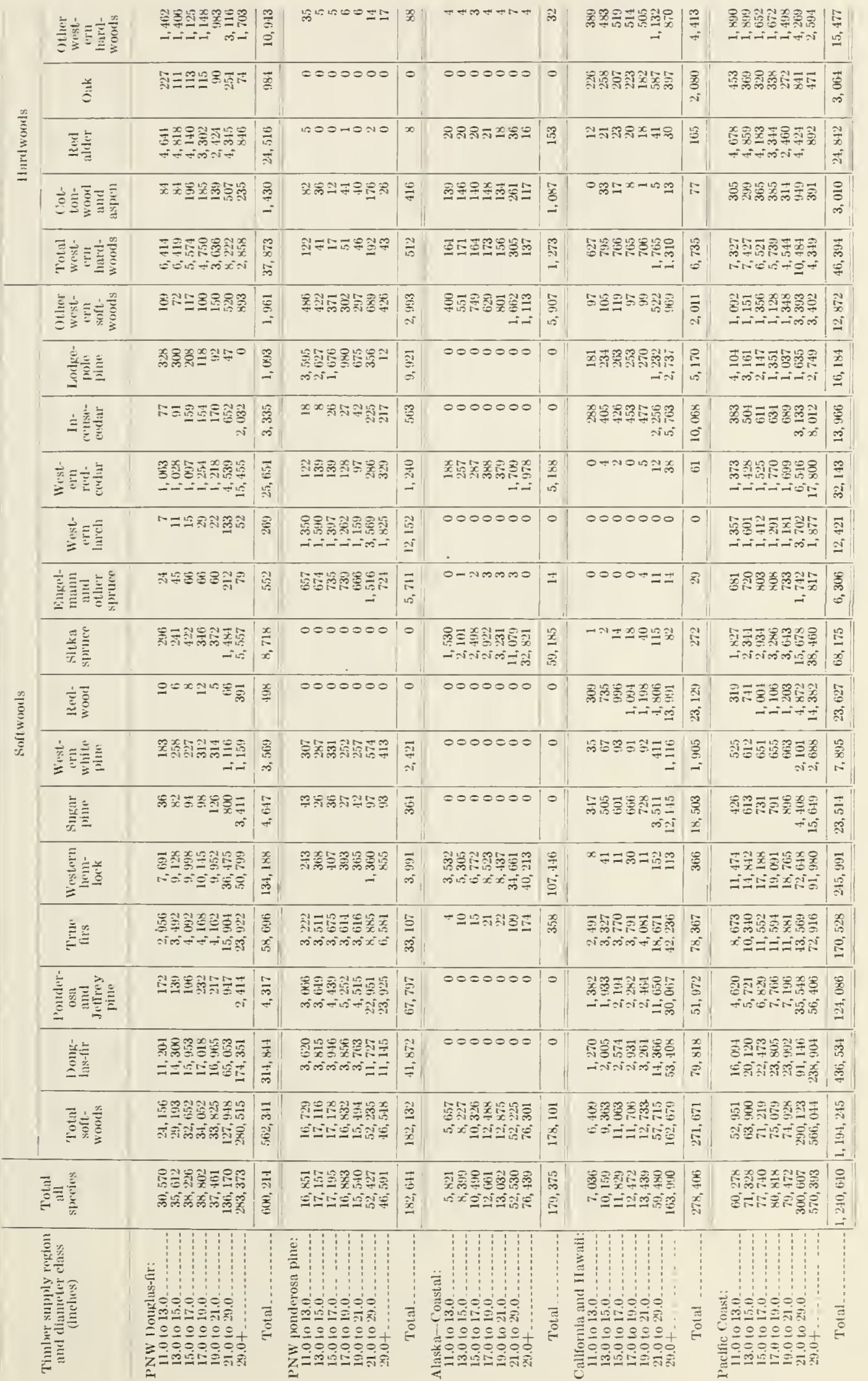


TABLE 17.- Net tolume of growing stock on commercial timberland in the East, by species and section, region, and State January 1, 1970 !

[Million cubic fcet]

\begin{tabular}{|c|c|c|c|c|c|c|c|c|c|c|c|c|}
\hline \multirow[b]{2}{*}{ Section, region, and State } & \multirow[b]{2}{*}{$\begin{array}{l}\text { Total } \\
\text { all } \\
\text { species }\end{array}$} & \multicolumn{11}{|c|}{ Softwoods } \\
\hline & & $\begin{array}{c}\text { Total } \\
\text { soft- } \\
\text { woods }\end{array}$ & $\begin{array}{l}\text { Longleaf } \\
\text { and } \\
\text { slash } \\
\text { pines }\end{array}$ & $\begin{array}{l}\text { Shortleaf } \\
\text { and } \\
\text { loblolly } \\
\text { pines }\end{array}$ & $\begin{array}{l}\text { Other } \\
\text { yellow } \\
\text { pines }\end{array}$ & $\begin{array}{l}\text { Eastern } \\
\text { white } \\
\text { and red } \\
\text { pines }\end{array}$ & $\begin{array}{l}\text { Jack } \\
\text { pine }\end{array}$ & $\begin{array}{l}\text { Spruce } \\
\text { and } \\
\text { balsam } \\
\text { fir }\end{array}$ & $\begin{array}{l}\text { Eastern } \\
\text { hemlock }\end{array}$ & Cypress & $\begin{array}{l}\text { Other } \\
\text { eastern } \\
\text { soft- } \\
\text { woods }\end{array}$ & $\begin{array}{l}\text { Ponder- } \\
\text { osa and } \\
\text { Jeftrey } \\
\text { pine }\end{array}$ \\
\hline 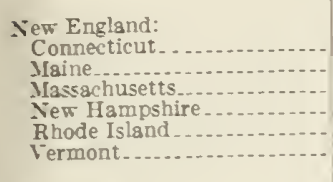 & $\begin{array}{r}1.898 \\
21,253 \\
2,717 \\
5,147 \\
267 \\
3,925 \\
\end{array}$ & $\begin{array}{r}228 \\
14,763 \\
770 \\
2,902 \\
20 \\
1,508 \\
\end{array}$ & $\begin{array}{l}0 \\
0 \\
0 \\
0 \\
0 \\
0\end{array}$ & $\begin{array}{l}0 \\
0 \\
0 \\
0 \\
0 \\
0 \\
\end{array}$ & $\begin{array}{r}3 \\
0 \\
6 i \\
0 \\
0 \\
0\end{array}$ & $\begin{array}{r}57 \\
1,517 \\
395 \\
1,267 \\
15 \\
314 \\
\end{array}$ & $\begin{array}{l}0 \\
0 \\
0 \\
0 \\
0 \\
0 \\
\end{array}$ & $\begin{array}{r}0 \\
10,756 \\
41 \\
1,159 \\
0 \\
796 \\
\end{array}$ & $\begin{array}{r}135 \\
1,151 \\
258 \\
\$ 60 \\
0 \\
337 \\
\end{array}$ & $\begin{array}{l}0 \\
0 \\
0 \\
0 \\
0 \\
0 \\
\end{array}$ & $\begin{array}{r}34 \\
1,339 \\
6 \\
15 \\
5 \\
61 \\
\end{array}$ & $\begin{array}{l}0 \\
0 \\
0 \\
0 \\
0 \\
0 \\
\end{array}$ \\
\hline Total. . & 35.210 & 20,191 & 0 & o & 70 & 3.565 & 0 & 12,755 & $2,3+1$ & 0 & 1,460 & 0 \\
\hline 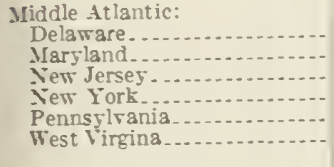 & $\begin{array}{r}65 \pi \\
3.074 \\
1,729 \\
12.517 \\
20.271 \\
14,056 \\
\end{array}$ & $\begin{array}{r}229 \\
531 \\
355 \\
3,291 \\
1,600 \\
657 \\
\end{array}$ & $\begin{array}{l}0 \\
0 \\
0 \\
0 \\
0 \\
0 \\
\end{array}$ & $\begin{array}{r}175 \\
308 \\
6 \\
0 \\
0 \\
73 \\
\end{array}$ & $\begin{array}{r}54 \\
192 \\
300 \\
21 \\
184 \\
272 \\
\end{array}$ & $\begin{array}{r}0 \\
0 \\
23 \\
1,321 \\
584 \\
85 \\
\end{array}$ & $\begin{array}{l}0 \\
0 \\
0 \\
0 \\
0 \\
0 \\
\end{array}$ & $\begin{array}{r}0 \\
0 \\
0 \\
673 \\
11 \\
78 \\
\end{array}$ & $\begin{array}{r}0 \\
20 \\
28 \\
1,121 \\
796 \\
145 \\
\end{array}$ & $\begin{array}{l}0 \\
0 \\
0 \\
0 \\
0 \\
0 \\
\end{array}$ & $\begin{array}{r}0 \\
11 \\
28 \\
155 \\
26 \\
5\end{array}$ & $\begin{array}{l}0 \\
0 \\
0 \\
0 \\
0 \\
0 \\
-\end{array}$ \\
\hline Total. & 52,334 & 6,693 & 0 & 562 & 1.023 & 2.013 & 0 & 762 & 2.110 & 0 & 225 & 0 \\
\hline 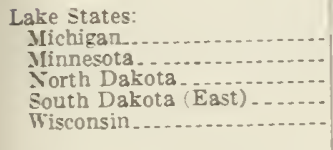 & $\begin{array}{r}16,558 \\
11,727 \\
276 \\
102 \\
11,411 \\
\end{array}$ & $\begin{array}{r}4.313 \\
3.896 \\
0 \\
19 \\
2.663 \\
\end{array}$ & $\begin{array}{l}0 \\
0 \\
0 \\
0 \\
0 \\
\end{array}$ & $\begin{array}{l}0 \\
0 \\
0 \\
0 \\
0 \\
\end{array}$ & $\begin{array}{l}0 \\
0 \\
0 \\
0 \\
0 \\
\end{array}$ & $\begin{array}{r}724 \\
665 \\
0 \\
0 \\
693 \\
\end{array}$ & $\begin{array}{r}412 \\
8800 \\
0 \\
0 \\
452\end{array}$ & $\begin{array}{r}1,399 \\
1,735 \\
0 \\
0 \\
662 \\
\end{array}$ & $\begin{array}{r}642 \\
0 \\
0 \\
0 \\
360 \\
\end{array}$ & $\begin{array}{l}0 \\
0 \\
0 \\
0 \\
0 \\
\end{array}$ & $\begin{array}{r}1,136 \\
610 \\
0 \\
0 \\
491 \\
\end{array}$ & $\begin{array}{r}0 \\
0 \\
0 \\
19 \\
0 \\
\end{array}$ \\
\hline Total ... & $40 \quad 074$ & 10,891 & 0 & 0 & 0 & 2.057 & 1.750 & 3. 796 & 1.002 & 0 & 2,237 & $\stackrel{19}{\longrightarrow}$ \\
\hline 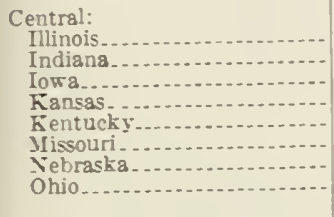 & $\begin{array}{r}2,328 \\
3,607 \\
1,807 \\
534 \\
8,547 \\
6,496 \\
505 \\
4,233 \\
\end{array}$ & $\begin{array}{r}19 \\
70 \\
4 \\
0 \\
622 \\
385 \\
115 \\
124 \\
\end{array}$ & $\begin{array}{l}0 \\
0 \\
0 \\
0 \\
0 \\
0 \\
0 \\
0 \\
\end{array}$ & $\begin{array}{r}16 \\
13 \\
0 \\
0 \\
234 \\
353 \\
0 \\
0\end{array}$ & $\begin{array}{r}0 \\
26 \\
0 \\
0 \\
258 \\
0 \\
0 \\
80\end{array}$ & $\begin{array}{r}0 \\
0 \\
0 \\
0 \\
10 \\
0 \\
0 \\
28\end{array}$ & $\begin{array}{r}0 \\
0 \\
0 \\
0 \\
0 \\
0 \\
1 \\
0 \\
\end{array}$ & $\begin{array}{l}0 \\
0 \\
0 \\
0 \\
0 \\
0 \\
0 \\
0 \\
\end{array}$ & $\begin{array}{r}0 \\
0 \\
0 \\
0 \\
45 \\
0 \\
0 \\
0 \\
8\end{array}$ & $\begin{array}{r}2 \\
11 \\
0 \\
0 \\
8 \\
11 \\
0 \\
0 \\
\end{array}$ & $\begin{array}{r}2 \\
20 \\
4 \\
0 \\
66 \\
21 \\
4 \\
8 \\
\end{array}$ & $\begin{array}{r}0 \\
0 \\
0 \\
0 \\
0 \\
0 \\
109 \\
0\end{array}$ \\
\hline Total. ......... & 28,058 & 1.339 & 0 & 616 & 364 & 35 & 1 & 0 & 53 & 32 & 125 & 109 \\
\hline Total, North_... & $15.5,6.6$ & 39.114 & 0 & 1,178 & $1,45 \pi$ & 7.703 & 1,751 & 17.313 & 5,506 & 32 & $4,04 \pi$ & 128 \\
\hline $\begin{array}{l}\text { South Atlantic: } \\
\text { Vorth Carolina ... } \\
\text { South Carolina... } \\
\text { Virginia........... }\end{array}$ & $\begin{array}{l}19,680 \\
12,700 \\
15,171 \\
\end{array}$ & $\begin{array}{l}8,509 \\
6,369 \\
4,216 \\
\end{array}$ & $\begin{array}{r}358 \\
903 \\
0 \\
\end{array}$ & $\begin{array}{l}5,834 \\
4,336 \\
2,520 \\
\end{array}$ & $\begin{array}{r}1,565 \\
5 \times 3 \\
1,349 \\
\end{array}$ & $\begin{array}{r}254 \\
19 \\
157 \\
\end{array}$ & $\begin{array}{l}0 \\
0 \\
0 \\
\end{array}$ & $\begin{array}{l}8 \\
0 \\
1 \\
\end{array}$ & $\begin{array}{r}114 \\
4 \\
92 \\
\end{array}$ & $\begin{array}{r}296 \\
478 \\
48 \\
\end{array}$ & $\begin{array}{l}80 \\
47 \\
45 \\
\end{array}$ & $\begin{array}{l}0 \\
0 \\
0 \\
\end{array}$ \\
\hline Total......... & 47.551 & 19.094 & 1,261 & 12.690 & 3,497 & 430 & 0 & 9 & 210 & 822 & 175 & 0 \\
\hline $\begin{array}{l}\text { East Gulf: } \\
\text { Florida } \\
\text { Georgia........ }\end{array}$ & $\begin{array}{l}10,888 \\
19,695 \\
\end{array}$ & $\begin{array}{r}6,904 \\
11,839 \\
\end{array}$ & $\begin{array}{r}4.039 \\
4.305 \\
\end{array}$ & $\begin{array}{r}511 \\
6.272 \\
\end{array}$ & $\begin{array}{l}435 \\
495\end{array}$ & $\begin{array}{r}0 \\
65\end{array}$ & $\begin{array}{l}0 \\
0 \\
\end{array}$ & $\begin{array}{l}0 \\
0\end{array}$ & $\begin{array}{r}0 \\
10\end{array}$ & $\begin{array}{r}1,545 \\
687 \\
\end{array}$ & $\begin{array}{r}74 \\
5 \\
\end{array}$ & $\begin{array}{l}0 \\
0 \\
\end{array}$ \\
\hline Total ..... & 30.583 & $18,7+3$ & 8.314 & 6,783 & 930 & 65 & 0 & 0 & 10 & 2,532 & 79 & 0 \\
\hline $\begin{array}{l}\text { Central Gulf: } \\
\text { Alabama...... } \\
\text { Jlississippi.... } \\
\text { Tennessee }\end{array}$ & $\begin{array}{l}16,010 \\
13,8,8 \\
10,396 \\
\end{array}$ & $\begin{array}{l}9,232 \\
7,189 \\
1,800 \\
\end{array}$ & $\begin{array}{r}2,029 \\
1,281 \\
0 \\
\end{array}$ & $\begin{array}{r}6,634 \\
5,578 \\
819 \\
\end{array}$ & $\begin{array}{l}421 \\
1+5 \\
6 \pm 2 \\
\end{array}$ & $\begin{array}{r}0 \\
0 \\
151 \\
\end{array}$ & $\begin{array}{l}0 \\
0 \\
0 \\
\end{array}$ & $\begin{array}{l}0 \\
0 \\
0 \\
\end{array}$ & $\begin{array}{r}0 \\
0 \\
55 \\
\end{array}$ & $\begin{array}{r}114 \\
161 \\
29 \\
\end{array}$ & $\begin{array}{r}35 \\
24 \\
104 \\
\end{array}$ & $\begin{array}{l}0 \\
0 \\
0 \\
\end{array}$ \\
\hline Total. .... & 40,281 & 18,221 & 3,310 & 13.031 & 1,208 & 151 & 0 & 0 & 55 & 304 & 163 & 0 \\
\hline $\begin{array}{l}\text { West Gulf: } \\
\text { Arkansas. } \\
\text { Louisiana } \\
\text { Oklahoma. } \\
\text { Texas....................... }\end{array}$ & $\begin{array}{r}15,366 \\
13,602 \\
1,648 \\
10,483\end{array}$ & $\begin{array}{r}6,539 \\
7,596 \\
850 \\
-, 361 \\
\end{array}$ & $\begin{array}{r}0 \\
674 \\
0 \\
266 \\
\end{array}$ & $\begin{array}{r}6,303 \\
5,725 \\
845 \\
7,016 \\
\end{array}$ & $\begin{array}{r}0 \\
10 \overline{7} \\
0 \\
0 \\
\end{array}$ & $\begin{array}{l}0 \\
0 \\
0 \\
0 \\
\end{array}$ & $\begin{array}{l}0 \\
0 \\
0 \\
0 \\
\end{array}$ & $\begin{array}{l}0 \\
0 \\
0 \\
0 \\
\end{array}$ & $\begin{array}{l}0 \\
0 \\
0 \\
0 \\
\end{array}$ & $\begin{array}{r}187 \\
1,088 \\
1 \\
67 \\
\end{array}$ & $\begin{array}{r}49 \\
2 \\
5 \\
13 \\
\end{array}$ & $\begin{array}{l}0 \\
0 \\
0 \\
0 \\
\end{array}$ \\
\hline Total..... & 41,099 & 22,346 & 940 & 19,889 & 107 & 0 & 0 & 0 & 0 & 1,343 & 69 & 0 \\
\hline Total, South. & 159,517 & 78,404 & 13.855 & 52,393 & 5,742 & 646 & 0 & 9 & 275 & 5,001 & 496 & 0 \\
\hline $\begin{array}{l}\text { Total, Eastern Cnited } \\
\text { States. }\end{array}$ & 315,193 & 117,518 & 13,855 & $53,5 \pi 1$ & 7,199 & 8.349 & 1,751 & 17,322 & 5,781 & 5,033 & 4,533 & 128 \\
\hline
\end{tabular}

See footnote at end of table. 


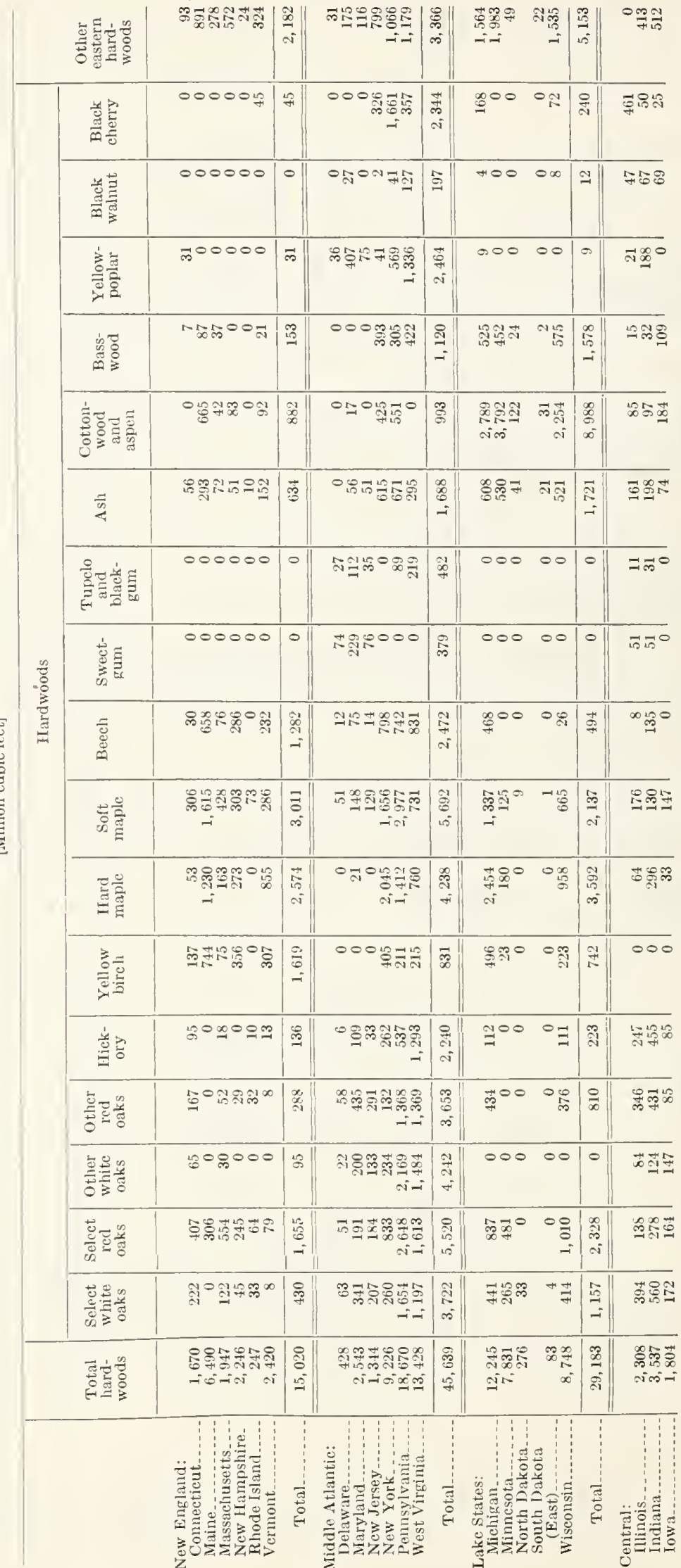




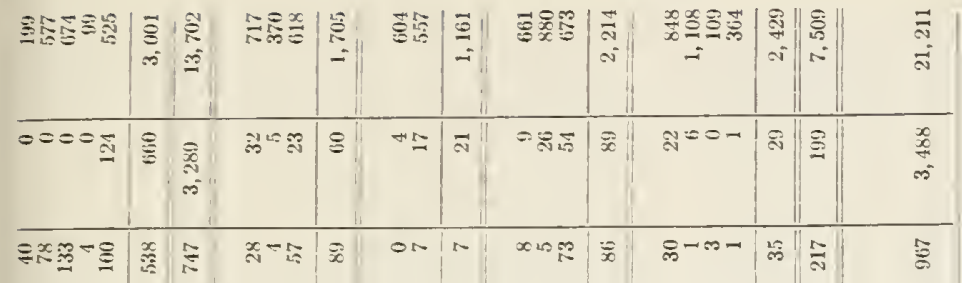

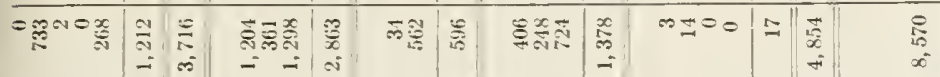

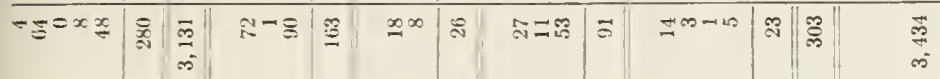

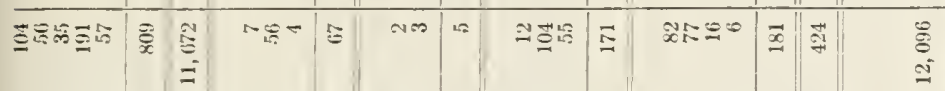

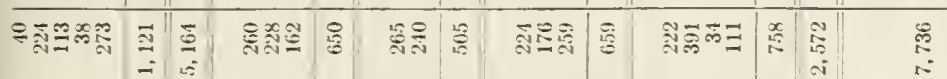

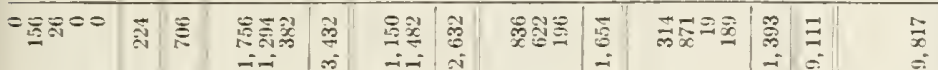

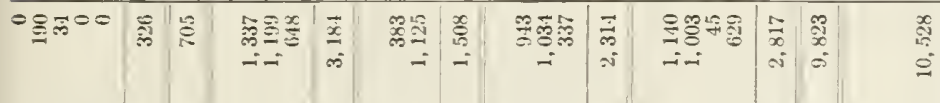
-

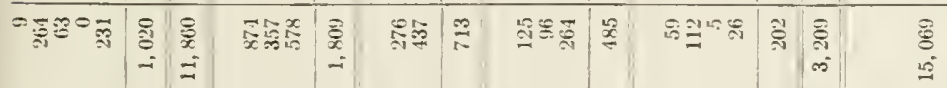

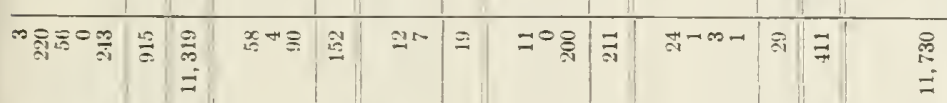

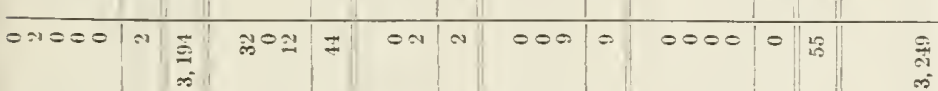

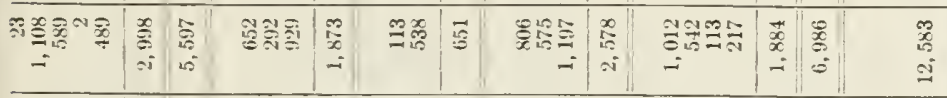

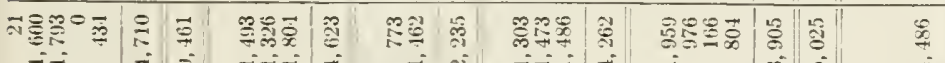

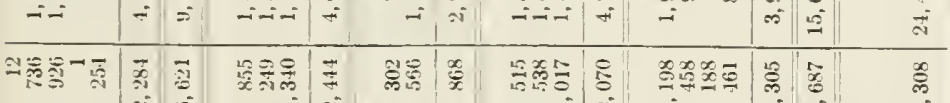

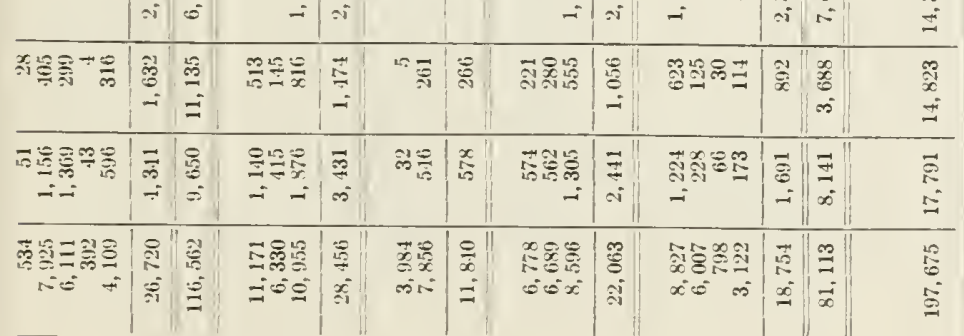

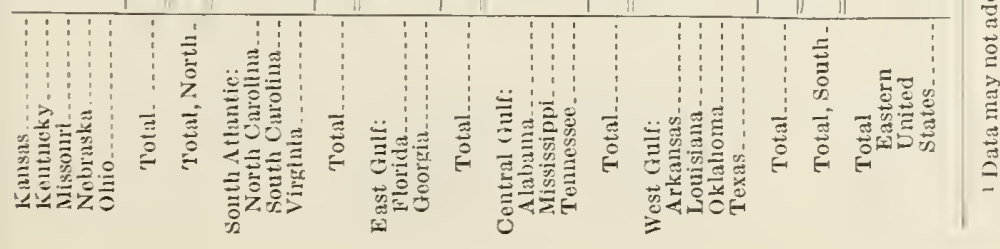




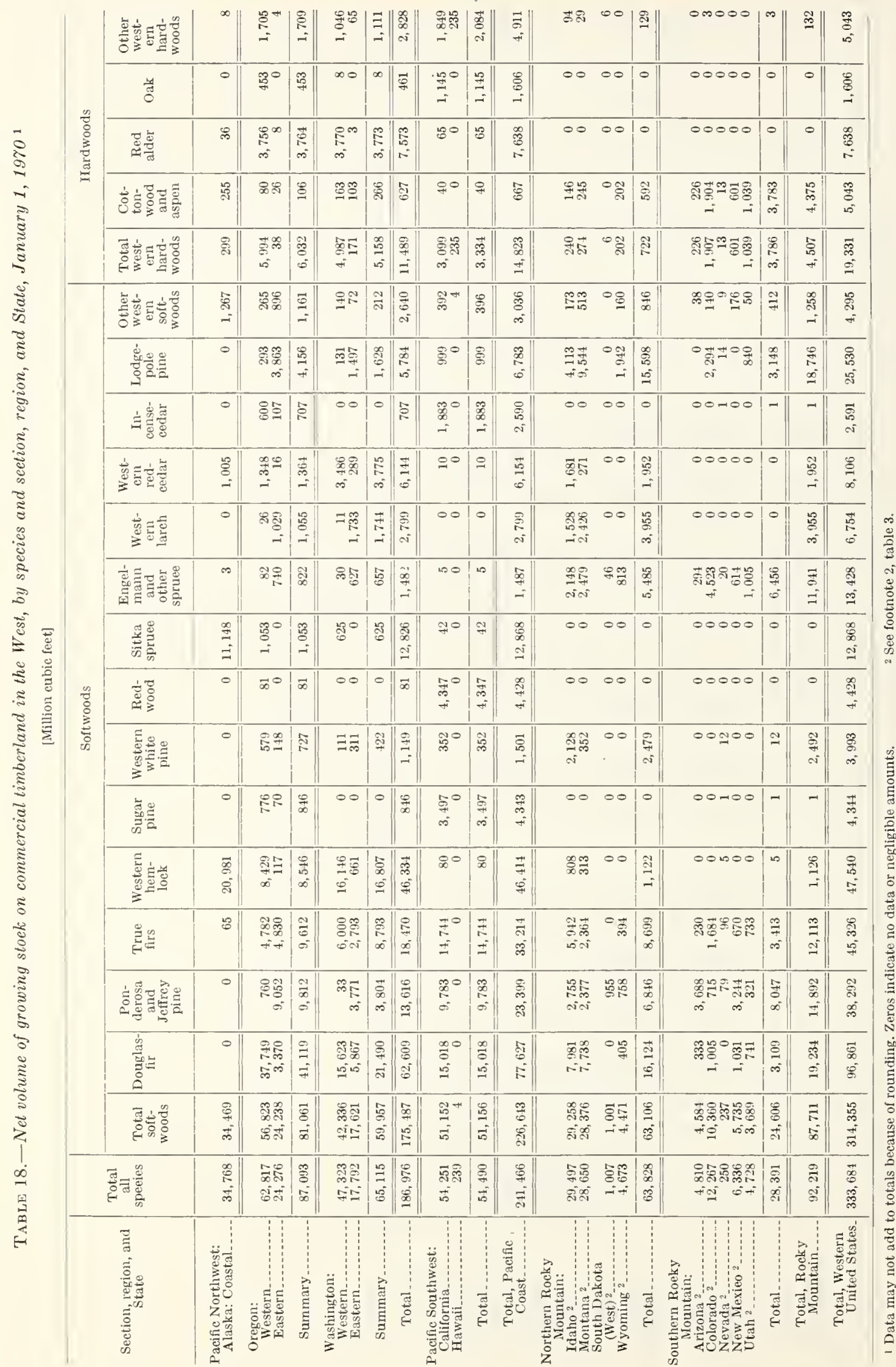


TABLE 19.-. Vet volume of sautimber on commercial timberland in the East by species and section, region, and State, as of January 1, $1970^{2}$

[Million board feet, International $1 / 4$-inch log rule]

\begin{tabular}{|c|c|c|c|c|c|c|c|c|c|c|c|c|}
\hline \multirow[b]{2}{*}{ Section, region, and State } & \multirow[b]{2}{*}{$\begin{array}{l}\text { Total } \\
\text { all } \\
\text { species }\end{array}$} & \multicolumn{11}{|c|}{ Softwoods } \\
\hline & & $\begin{array}{c}\text { Total } \\
\text { softwoods }\end{array}$ & $\begin{array}{l}\text { Longleaf } \\
\text { and } \\
\text { slash } \\
\text { pines }\end{array}$ & $\begin{array}{l}\text { Shortleaf } \\
\text { and } \\
\text { loblolly } \\
\text { pines }\end{array}$ & $\begin{array}{l}\text { Other } \\
\text { yellow } \\
\text { pines }\end{array}$ & $\begin{array}{l}\text { Eastern } \\
\text { white } \\
\text { and red } \\
\text { pines }\end{array}$ & $\begin{array}{l}\text { Jack } \\
\text { pine }\end{array}$ & $\begin{array}{l}\text { Spruce } \\
\text { and } \\
\text { balsam } \\
\text { fir }\end{array}$ & $\begin{array}{l}\text { Eastern } \\
\text { hemlock }\end{array}$ & Cypress & $\begin{array}{c}\text { Other } \\
\text { eastern } \\
\text { softwoods }\end{array}$ & $\begin{array}{l}\text { Ponderosa } \\
\text { and } \\
\text { Jeffrey } \\
\text { pine }\end{array}$ \\
\hline 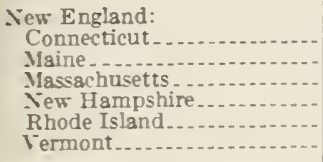 & $\begin{array}{r}2,611 \\
34,520 \\
3,125 \\
10,010 \\
193 \\
6,7.65\end{array}$ & $\begin{array}{r}346 \\
23,456 \\
1,324 \\
6,862 \\
25 \\
2,800\end{array}$ & $\begin{array}{l}0 \\
0 \\
0 \\
0 \\
0 \\
0 \\
\end{array}$ & $\begin{array}{l}0 \\
0 \\
0 \\
0 \\
0 \\
0\end{array}$ & $\begin{array}{r}6 \\
0 \\
48 \\
0 \\
0 \\
0\end{array}$ & $\begin{array}{r}95 \\
4,568 \\
832 \\
3,701 \\
23 \\
693\end{array}$ & $\begin{array}{l}0 \\
0 \\
0 \\
0 \\
0 \\
0 \\
0\end{array}$ & $\begin{array}{r}0 \\
13.838 \\
30 \\
2,064 \\
0 \\
1,337\end{array}$ & $\begin{array}{r}238 \\
2,666 \\
411 \\
1,078 \\
0 \\
720\end{array}$ & $\begin{array}{l}0 \\
0 \\
0 \\
0 \\
0 \\
0 \\
0\end{array}$ & $\begin{array}{r}7 \\
2,383 \\
3 \\
18 \\
3 \\
50\end{array}$ & $\begin{array}{l}0 \\
0 \\
0 \\
0 \\
0 \\
0\end{array}$ \\
\hline Total ... & 57,270 & 34,813 & 0 & 0 & 54 & 9.912 & 0 & 17,269 & 5,113 & 0 & 2,464 & 0 \\
\hline $\begin{array}{l}\text { Middle Atlantic: } \\
\text { Delaware......... } \\
\text { Maryland....... } \\
\text { Jew Jersey..... } \\
\text { New York } \\
\text { Pennsylrania..... } \\
\text { West Virginia.... }\end{array}$ & $\begin{array}{r}1,361 \\
6,962 \\
14,266 \\
24,980 \\
29,616 \\
35,686 \\
\end{array}$ & $\begin{array}{r}460 \\
1,281 \\
-749 \\
-, 274 \\
3,434 \\
1.836 \\
\end{array}$ & $\begin{array}{l}0 \\
0 \\
0 \\
0 \\
0 \\
0 \\
\end{array}$ & $\begin{array}{r}418 \\
798 \\
10 \\
0 \\
0 \\
138 \\
\end{array}$ & $\begin{array}{r}42 \\
432 \\
561 \\
41 \\
357 \\
7.8 \\
\end{array}$ & $\begin{array}{r}0 \\
0 \\
26 \\
3,116 \\
1,400 \\
257 \\
\end{array}$ & $\begin{array}{l}0 \\
0 \\
0 \\
0 \\
0 \\
0 \\
\end{array}$ & $\begin{array}{r}0 \\
0 \\
0 \\
1.178 \\
9 \\
213 \\
\end{array}$ & $\begin{array}{r}0 \\
21 \\
99 \\
2,711 \\
1,651 \\
441 \\
\end{array}$ & $\begin{array}{l}0 \\
0 \\
0 \\
0 \\
0 \\
0\end{array}$ & $\begin{array}{r}0 \\
30 \\
53 \\
227 \\
17 \\
8 \\
\end{array}$ & $\begin{array}{l}0 \\
0 \\
0 \\
0 \\
0 \\
0\end{array}$ \\
\hline Total .... & 102.851 & 15,034 & 0 & 1,364 & 2,211 & 4.799 & 0 & 1,400 & 4,923 & 0 & 335 & 0 \\
\hline $\begin{array}{l}\text { Lake States: } \\
\text { Michigan } \\
\text { Ifinnesota } \\
\text { Jorth Dakota } \\
\text { South Dakota (East). } \\
\text { Wisconsin................... }\end{array}$ & $\begin{array}{r}35.087 \\
20.067 \\
564 \\
339 \\
22.296\end{array}$ & $\begin{array}{r}11,026 \\
8,041 \\
0 \\
58 \\
6,963\end{array}$ & $\begin{array}{l}0 \\
0 \\
0 \\
0 \\
0 \\
\end{array}$ & $\begin{array}{l}0 \\
0 \\
0 \\
0 \\
0\end{array}$ & $\begin{array}{l}0 \\
0 \\
0 \\
0 \\
0 \\
\end{array}$ & $\begin{array}{r}3.351 \\
3,254 \\
0 \\
0 \\
2,967\end{array}$ & $\begin{array}{r}372 \\
1,863 \\
0 \\
0 \\
611 \\
\end{array}$ & $\begin{array}{r}1,891 \\
2,104 \\
0 \\
0 \\
777 \\
\end{array}$ & $\begin{array}{r}3,189 \\
0 \\
0 \\
0 \\
1,688\end{array}$ & $\begin{array}{l}0 \\
0 \\
0 \\
0 \\
0 \\
\end{array}$ & $\begin{array}{r}2,221 \\
820 \\
0 \\
0 \\
920 \\
\end{array}$ & $\begin{array}{r}0 \\
0 \\
0 \\
58 \\
0\end{array}$ \\
\hline Total ... & 81,353 & 26,088 & 0 & 0 & 0 & 9.572 & 2.816 & 4,772 & \pm 877 & 0 & 3,961 & 58 \\
\hline $\begin{array}{l}\text { Central: } \\
\text { Illinois } \\
\text { Indiana } \\
\text { Iowa } \\
\text { Kansas } \\
\text { Kentucky } \\
\text { Missouri } \\
\text { Mebrasks } \\
\text { Ohio }\end{array}$ & $\begin{array}{r}7,834 \\
11,209 \\
6,597 \\
1,903 \\
30,200 \\
16,050 \\
1,992 \\
11,579\end{array}$ & $\begin{array}{r}25 \\
181 \\
10 \\
1 \\
1,968 \\
1,072 \\
489 \\
378 \\
\end{array}$ & $\begin{array}{l}0 \\
0 \\
0 \\
0 \\
0 \\
0 \\
0 \\
0\end{array}$ & $\begin{array}{r}10 \\
12 \\
0 \\
0 \\
782 \\
996 \\
0 \\
0\end{array}$ & $\begin{array}{r}0 \\
64 \\
0 \\
0 \\
822 \\
0 \\
0 \\
270\end{array}$ & $\begin{array}{r}0 \\
0 \\
0 \\
0 \\
35 \\
0 \\
0 \\
56\end{array}$ & $\begin{array}{l}0 \\
0 \\
0 \\
0 \\
0 \\
0 \\
1 \\
0\end{array}$ & $\begin{array}{l}0 \\
0 \\
0 \\
0 \\
0 \\
0 \\
0 \\
0 \\
0\end{array}$ & $\begin{array}{r}0 \\
0 \\
0 \\
0 \\
154 \\
0 \\
0 \\
30 \\
\end{array}$ & $\begin{array}{r}13 \\
74 \\
0 \\
0 \\
61 \\
68 \\
0 \\
0\end{array}$ & $\begin{array}{r}1 \\
34 \\
10 \\
1 \\
115 \\
8 \\
7 \\
22 \\
\end{array}$ & $\begin{array}{r}0 \\
0 \\
0 \\
0 \\
0 \\
0 \\
482 \\
0\end{array}$ \\
\hline Total ....... & 90,364 & \pm 127 & 0 & 1,800 & 1,156 & 91 & 1 & 0 & 184 & 216 & 198 & 482 \\
\hline Total, North.-. & 331,868 & 80.062 & 0 & 3,164 & 3,421 & 24,374 & 2,847 & 23,441 & 15.097 & 216 & 6,958 & 540 \\
\hline $\begin{array}{l}\text { South Atlantic: } \\
\text { North Carolina... } \\
\text { South Carolina..- } \\
\text { Virginia.......... }\end{array}$ & $\begin{array}{l}58,128 \\
36, \pm 34 \\
39,227 \\
\end{array}$ & $\begin{array}{l}28,612 \\
20,352 \\
11,855 \\
\end{array}$ & $\begin{array}{r}987 \\
2,800 \\
0\end{array}$ & $\begin{array}{r}20,630 \\
13.989 \\
8.066\end{array}$ & $\begin{array}{l}3,992 \\
1,717 \\
2,614\end{array}$ & $\begin{array}{r}971 \\
68 \\
549 \\
\end{array}$ & $\begin{array}{l}0 \\
0 \\
0 \\
\end{array}$ & $\begin{array}{r}42 \\
0 \\
2 \\
\end{array}$ & $\begin{array}{r}442 \\
13 \\
380 \\
\end{array}$ & $\begin{array}{r}1,322 \\
1,732 \\
209\end{array}$ & $\begin{array}{r}226 \\
62 \\
65 \\
\end{array}$ & $\begin{array}{l}0 \\
0 \\
0\end{array}$ \\
\hline Total... & 133,789 & 60,879 & 3,787 & 42,685 & 8,323 & 1.588 & 0 & 41 & 835 & 3.263 & 353 & 0 \\
\hline $\begin{array}{l}\text { East Gulf: } \\
\text { Florida } \\
\text { Georgia }\end{array}$ & $\begin{array}{l}30,464 \\
52,762\end{array}$ & $\begin{array}{l}19.966 \\
33,868 \\
\end{array}$ & $\begin{array}{l}11,245 \\
12,788 \\
\end{array}$ & $\begin{array}{r}1,983 \\
17,354 \\
\end{array}$ & $\begin{array}{l}1,055 \\
1,260\end{array}$ & $\begin{array}{r}0 \\
290 \\
\end{array}$ & $\begin{array}{l}0 \\
0\end{array}$ & $\begin{array}{l}0 \\
0\end{array}$ & $\begin{array}{r}0 \\
34 \\
\end{array}$ & $\begin{array}{l}5,454 \\
2,138\end{array}$ & $\begin{array}{r}228 \\
5\end{array}$ & $\begin{array}{l}0 \\
0\end{array}$ \\
\hline Total... & 83.226 & 53.834 & 24,033 & $19.33 i$ & 2,315 & 290 & 0 & 0 & 34 & 7,592 & 233 & 0 \\
\hline $\begin{array}{l}\text { Central Gulf: } \\
\text { Alabama } \\
\text { Mississippi } \\
\text { Tennessee.............. }\end{array}$ & $\begin{array}{l}52,769 \\
44,732 \\
26,340\end{array}$ & $\begin{array}{r}34,874 \\
28,079 \\
4,699 \\
\end{array}$ & $\begin{array}{r}7,914 \\
4,825 \\
0\end{array}$ & $\begin{array}{r}24,975 \\
21,689 \\
1,972 \\
\end{array}$ & $\begin{array}{r}1,376 \\
679 \\
1,668 \\
\end{array}$ & $\begin{array}{r}0 \\
0 \\
622 \\
\end{array}$ & $\begin{array}{l}0 \\
0 \\
0\end{array}$ & $\begin{array}{l}0 \\
0 \\
0 \\
\end{array}$ & $\begin{array}{r}0 \\
0 \\
212 \\
\end{array}$ & $\begin{array}{l}550 \\
840 \\
130 \\
\end{array}$ & $\begin{array}{l}58 \\
47 \\
95 \\
\end{array}$ & $\begin{array}{l}0 \\
0 \\
0\end{array}$ \\
\hline Total.... & 123,841 & $6 \overline{7}, 652$ & 12.739 & $=\stackrel{48,636}{=}$ & 3,723 & 622 & 0 & 0 & 212 & 1,520 & 200 & 0 \\
\hline 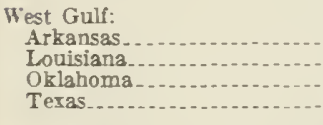 & $\begin{array}{r}46,386 \\
53,997 \\
4,490 \\
38,121 \\
\end{array}$ & $\begin{array}{r}25,252 \\
35,012 \\
2,799 \\
30,459 \\
\end{array}$ & $\begin{array}{r}0 \\
2,639 \\
0 \\
1,050\end{array}$ & $\begin{array}{r}24,258 \\
26,575 \\
2,777 \\
29,070 \\
\end{array}$ & $\begin{array}{r}0 \\
524 \\
0 \\
0 \\
\end{array}$ & $\begin{array}{l}0 \\
0 \\
0 \\
0 \\
\end{array}$ & $\begin{array}{l}0 \\
0 \\
0 \\
0 \\
\end{array}$ & $\begin{array}{l}0 \\
0 \\
0 \\
0 \\
\end{array}$ & $\begin{array}{l}0 \\
0 \\
0 \\
0 \\
\end{array}$ & $\begin{array}{r}940 \\
5,268 \\
3 \\
310 \\
\end{array}$ & $\begin{array}{r}53 \\
6 \\
9 \\
29 \\
\end{array}$ & $\begin{array}{l}0 \\
0 \\
0 \\
0\end{array}$ \\
\hline Total & 142,994 & 93.512 & 3.689 & 82,680 & 524 & 0 & 0 & 0 & 0 & 6,521 & 97 & 0 \\
\hline Total, South & 483,850 & $275,87 i$ & 44.248 & 193,338 & $14,88.5$ & 2,500 & 0 & 44 & 1.081 & 18.896 & 883 & 0 \\
\hline $\begin{array}{l}\text { Total, Eastern United } \\
\text { States........... }\end{array}$ & 815,718 & 355,939 & 44,248 & 196,502 & 18,306 & 26,874 & 2,847 & 23,485 & 16,173 & 19,112 & 7,841 & 540 \\
\hline
\end{tabular}




\begin{tabular}{|c|c|c|c|c|c|c|c|c|c|c|}
\hline & & 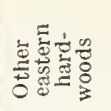 & 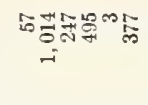 & 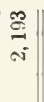 & 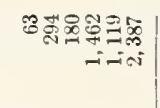 & $\left|\begin{array}{|c|c|}0 \\
0 \\
0 \\
0\end{array}\right|$ & 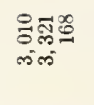 & 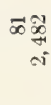 & - & क्ष \\
\hline 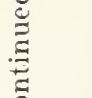 & & 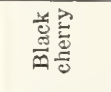 & 000008 & 电 & 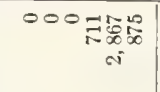 & 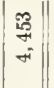 & స్ㅇㅇ & $o R$ & 必 & 器里: \\
\hline I & & 晜节 & 000000 & 10 & $\rho_{80}^{\circ}$ & $\left|\begin{array}{c}\infty \\
\multirow{3}{*}{}\end{array}\right|$ & 900 & - & $\mathscr{\infty}$ & 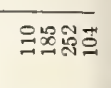 \\
\hline$\ddot{z}$ & & 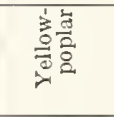 & S్d 00000 & $\stackrel{\Xi}{\Xi}$ & 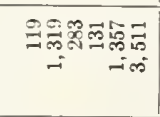 & $\left|\begin{array}{c}8 \\
0 \\
0 \\
0\end{array}\right|$ & mంo & 00 & 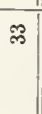 & 我足 \\
\hline $\begin{array}{l}5 \\
5 \\
5\end{array}$ & & & 웠 & 윰 & 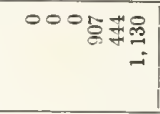 & $\left|\begin{array}{c}\vec{b} \\
0 \\
-i\end{array}\right|$ & $\begin{array}{l}\vec{\infty}=\vec{\sigma}^{\infty} \\
= \\
=\end{array}$ & $\stackrel{-1}{\stackrel{0}{0}}$ & 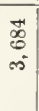 & 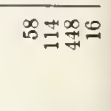 \\
\hline 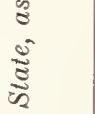 & & 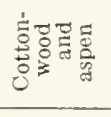 & ○ $\vec{g}^{\infty}$ & 趈 & 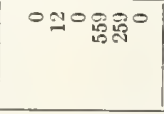 & $\ddot{\infty}$ & 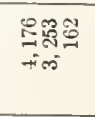 & 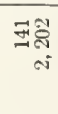 & 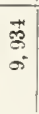 & 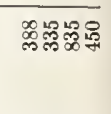 \\
\hline हु & & $\frac{5}{4}$ & 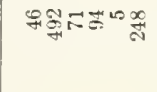 & 总 & 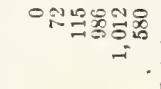 & $\mid \begin{array}{l}0 \\
8 \\
0 \\
0\end{array}$ & 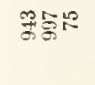 & Fi & $\mid \begin{array}{l}\infty \\
0 \\
\vdots \\
\vdots\end{array}$ & 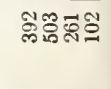 \\
\hline 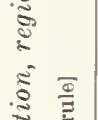 & & 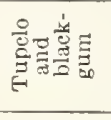 & 000000 & 10 & ৪: & 量 & 000 & 00 & 10 & $\infty \nexists^{\circ}$ \\
\hline 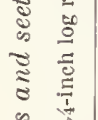 & 号 & 离 & 000000 & 0 & ప్రార్య쥬 & 齐 & 000 & 00 & o & 5 \\
\hline 芯 & 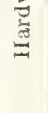 & 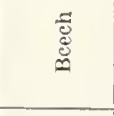 & "g乃 & $\begin{array}{c}\infty \\
\frac{1}{35} \\
\frac{5}{5}\end{array}$ & 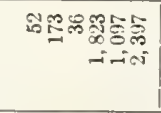 & $\left|\begin{array}{c}\infty \\
0 \\
15 \\
20 \\
10\end{array}\right|$ & 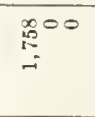 & ${ }_{\infty}^{\infty}$ & $\mid \begin{array}{l}\frac{2}{\infty} \\
-1 \\
=\end{array}$ & F害 \\
\hline 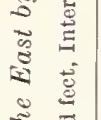 & & 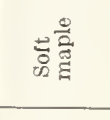 & 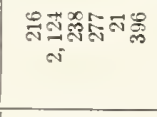 & $\left|\begin{array}{c}\vec{a} \\
\hat{i} \\
n^{2}\end{array}\right|$ & 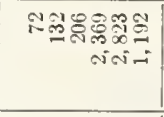 & $\left|\begin{array}{l}\overrightarrow{0} \\
\vdots \\
0 \\
0\end{array}\right|$ & 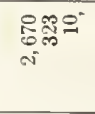 & $m$ & $\begin{array}{l}\overrightarrow{5} \\
\dot{\omega}\end{array}$ & 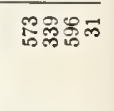 \\
\hline 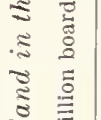 & & 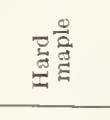 & 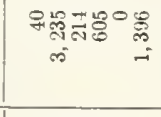 & $\left|\begin{array}{c}0 \\
+ \\
25\end{array}\right|$ & 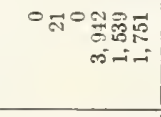 & $\left|\begin{array}{l}n \\
\vdots \\
n \\
n\end{array}\right|$ & 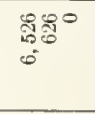 & 胥 & $\left|\begin{array}{l}\mid \\
\multirow{1}{*}{} \\
0 \\
0 \\
0\end{array}\right|$ & 踏吕 \\
\hline 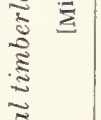 & & 施: & 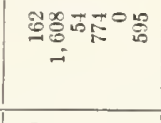 & $\mid \frac{\mathscr{m}}{\rightarrow}$ & 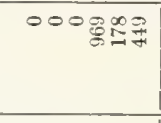 & $\mid \begin{array}{l}0 \\
\mathscr{2} \\
0 \\
0 \\
-1\end{array}$ & $\underset{7}{\vec{F} 00}$ & 욯 & $\begin{array}{c}\text { के } \\
\text { के } \\
\text { जे }\end{array}$ & 00 \\
\hline 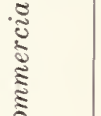 & & 密客 & $\underset{\mathrm{O}}{0.0000}$ & : & 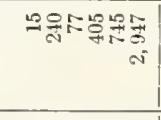 & 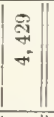 & סु & $\theta g$ & 임 & 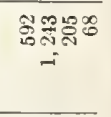 \\
\hline $\begin{array}{l}8 \\
\Xi \\
0\end{array}$ & & 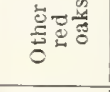 & 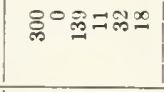 & 䆚 & 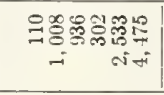 & 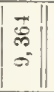 & $5^{\circ}$ & ○蛹 & $\begin{array}{l}\mathscr{Q} \\
\vdots \\
-1\end{array}$ & 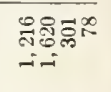 \\
\hline & & 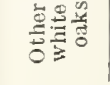 & 708000 & 5 & 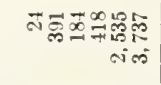 & $\left|\begin{array}{c}0 \\
0 \\
0 \\
\sim \\
-1\end{array}\right|$ & 000 & 00 & $\circ$ & 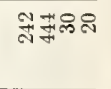 \\
\hline 8 & & 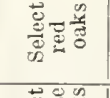 & 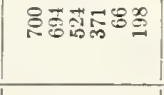 & 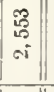 & 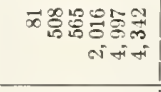 & 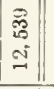 & 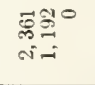 & 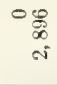 & $\begin{array}{l}\frac{9}{7} \\
\frac{1}{6}\end{array}$ & 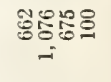 \\
\hline ב⿱艹 & & 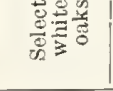 & 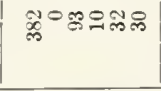 & 预 & 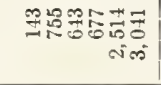 & $\mid \begin{array}{l}8 \\
\stackrel{2}{N} \\
i\end{array}$ & 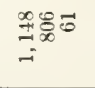 & ro & $\underset{\vec{n}}{\vec{m}}$ & 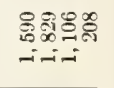 \\
\hline & & 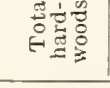 & 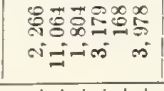 & | & 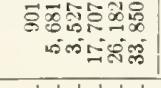 & \begin{tabular}{|l|}
$\frac{\infty}{\infty}$ \\
$\infty$ \\
$\infty$ \\
$\infty$
\end{tabular} \mid & 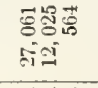 & 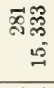 & $\begin{array}{l}\text { 芯 } \\
\text { : } \\
\text { i⿱ }\end{array}$ & 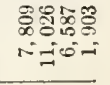 \\
\hline & & & 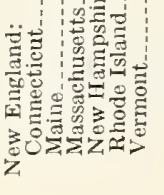 & हैं & 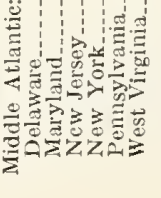 & 要 & 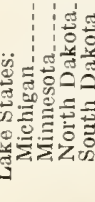 & . & 苞 & 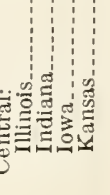 \\
\hline
\end{tabular}




\begin{tabular}{|c|c|c|c|c|c|c|c|c|c|c|c|c|}
\hline 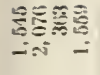 & - & \begin{tabular}{l}
$\bar{x}$ \\
\multirow{3}{*}{} \\
\multirow{3}{*}{}
\end{tabular} & 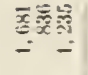 & 峁 & 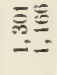 & $\stackrel{5}{\stackrel{5}{*}}$ & 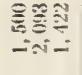 & $\begin{array}{l}0 \\
\\
0\end{array}$ & 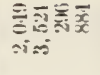 & $\begin{array}{l}\frac{5}{6} \\
-0\end{array}$ & 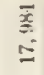 & 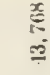 \\
\hline e=c & 禫 & $\overline{=}$ & $x \sim$ & ? & $==$ & N & 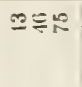 & $\overline{\underline{x}}$ & ஸேニ & $: 8$ & $\bar{x}$ & 8 \\
\hline$\frac{x}{\Delta} \triangleq \unrhd$ & 产 & 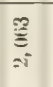 & $\overline{\bar{x}}=\bar{y}$ & $\frac{x}{i N}$ & $=$ & $=$ & 头玨 & $\hat{\underline{x}}$ & $\tilde{\sigma}=\Xi 0$ & $\Xi$ & $\frac{2}{x}$ & 产 \\
\hline $\begin{array}{l}n=\frac{x}{E} \\
\therefore=-1\end{array}$ & $\stackrel{x}{\stackrel{x}{=}}$ & 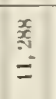 & 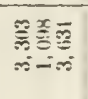 & $\frac{\hat{w}}{\vec{x}}$ & 要言 & $\bar{E}$ & $\underline{\underline{x}}$ & $\stackrel{0}{\div}$ & $s_{\infty}==$ & $\dddot{*}$ & $\begin{array}{l}\overline{\overline{\bar{x}}} \\
\underline{z}^{2}\end{array}$ & 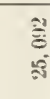 \\
\hline 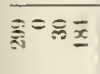 & $\equiv$ & $\bar{\Xi}$ & 焉一宏 & $\bar{\varphi}$ & $E \equiv$ & $\equiv$ & 的巨 & 突 & $\xi \infty \times 0$ & 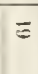 & $\frac{x}{x}$ & \\
\hline
\end{tabular}

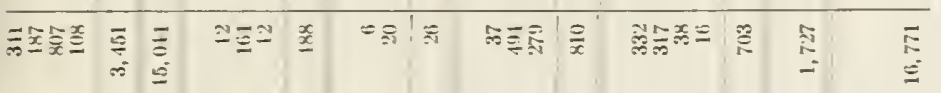

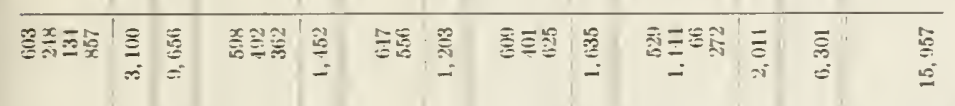

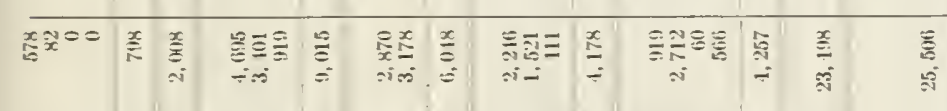

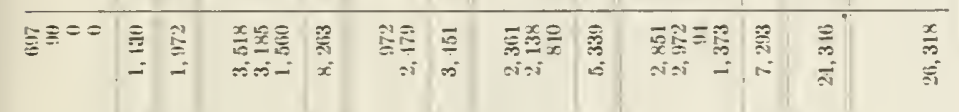

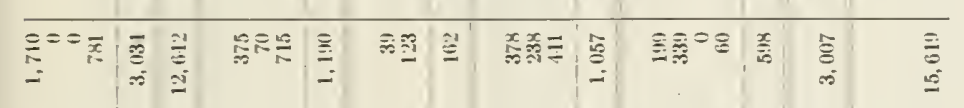

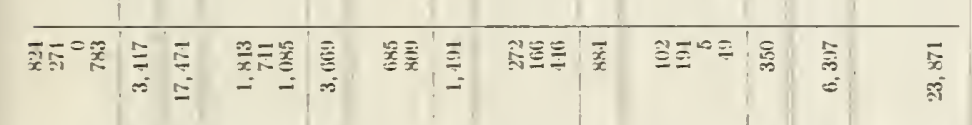

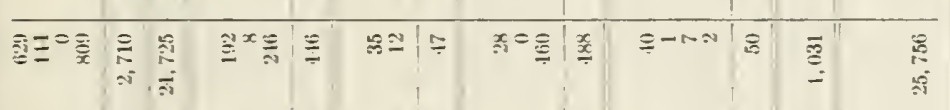

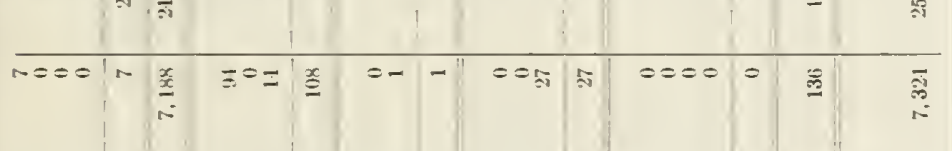

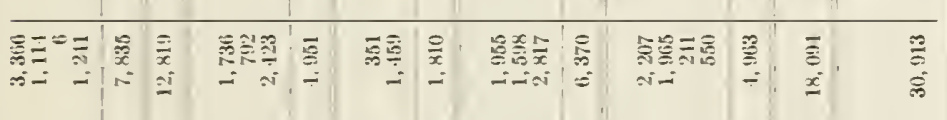

\begin{tabular}{|c|c|c|c|c|c|c|c|c|c|c|c|c|}
\hline 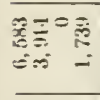 & 音 & $\overline{5}$ & 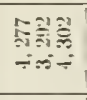 & $\begin{array}{l}\bar{x} \\
= \\
=\end{array}$ & 吝 & 告 & 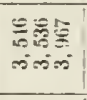 & $=$ & 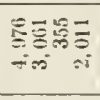 & 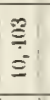 & 产 & 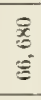 \\
\hline $\begin{array}{l}\frac{x}{x}=-\frac{a}{x} \\
0 ;=-\end{array}$ & $\begin{array}{l}1 \\
= \\
=\end{array}$ & 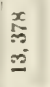 & 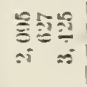 & 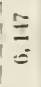 & 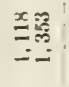 & $\underset{3}{5}$ & 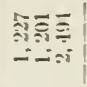 & $\stackrel{1}{-}$ & 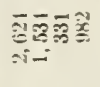 & $\bar{c}$ & $\begin{array}{l}\bar{\Xi} \\
\vdots\end{array}$ & 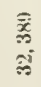 \\
\hline 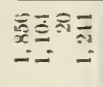 & 象 & $\begin{array}{l}x \\
5 \\
x \\
x \\
y\end{array}$ & 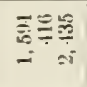 & $\stackrel{\Xi}{=}$ & $=\frac{x}{x}$ & 言 & 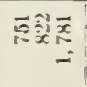 & $\begin{array}{l}\overrightarrow{0} \\
\infty\end{array}$ & 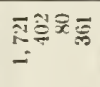 & $\mid \begin{array}{l}\overrightarrow{\hat{a}} \\
\text { s. } \\
\end{array}$ & = & : \\
\hline 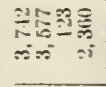 & 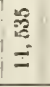 & 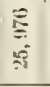 & 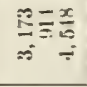 & 范 & 三焉 & i & 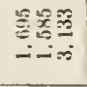 & $\stackrel{\pi}{=}$ & 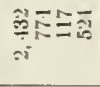 & $\begin{array}{l}\frac{5}{x} \\
x^{5}\end{array}$ & $\overrightarrow{0}$ & 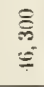 \\
\hline 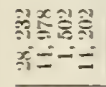 & 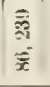 & 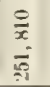 & 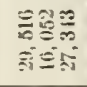 & $\begin{array}{l}\bar{\Xi} \\
\hat{i}\end{array}$ & 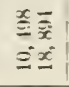 & 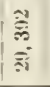 & 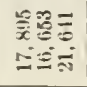 & | & 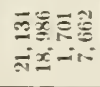 & $\stackrel{\mathscr{Z}}{=}$ & 突 & $\begin{array}{l}\text { 妾 } \\
\overline{\bar{b}}\end{array}$ \\
\hline
\end{tabular}

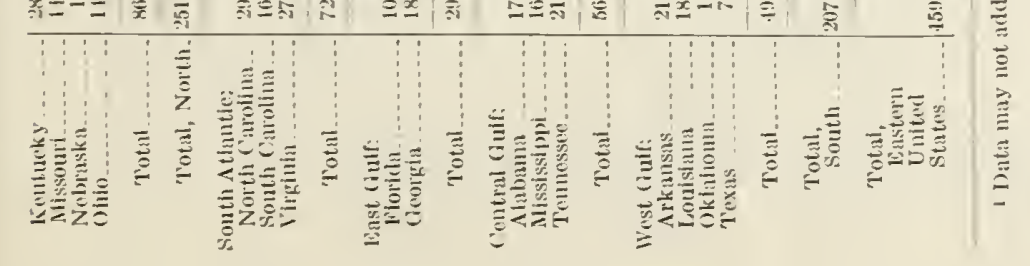


THE OUTLOOK FOR TIMBER IN THE UNITED STATES

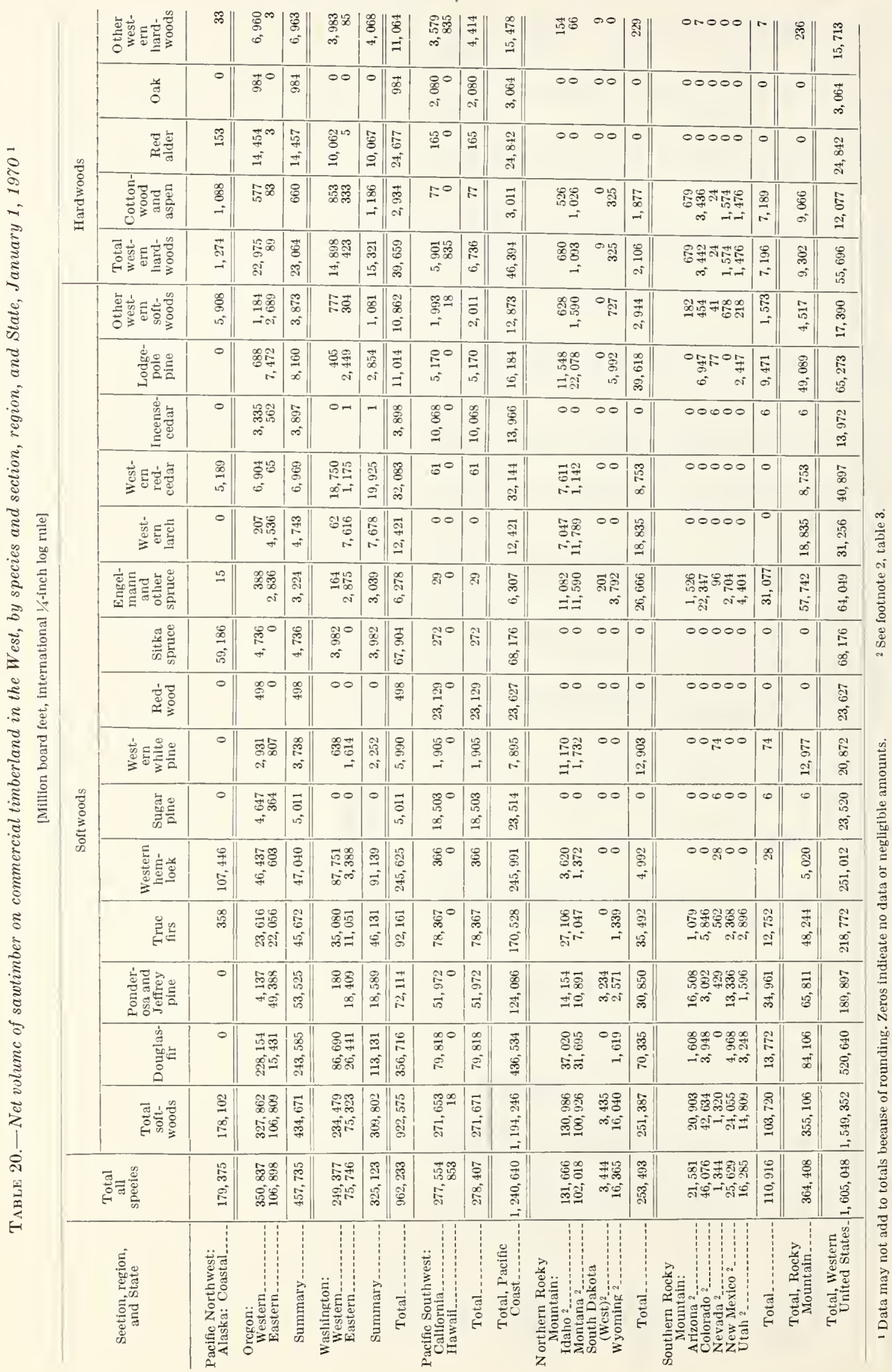




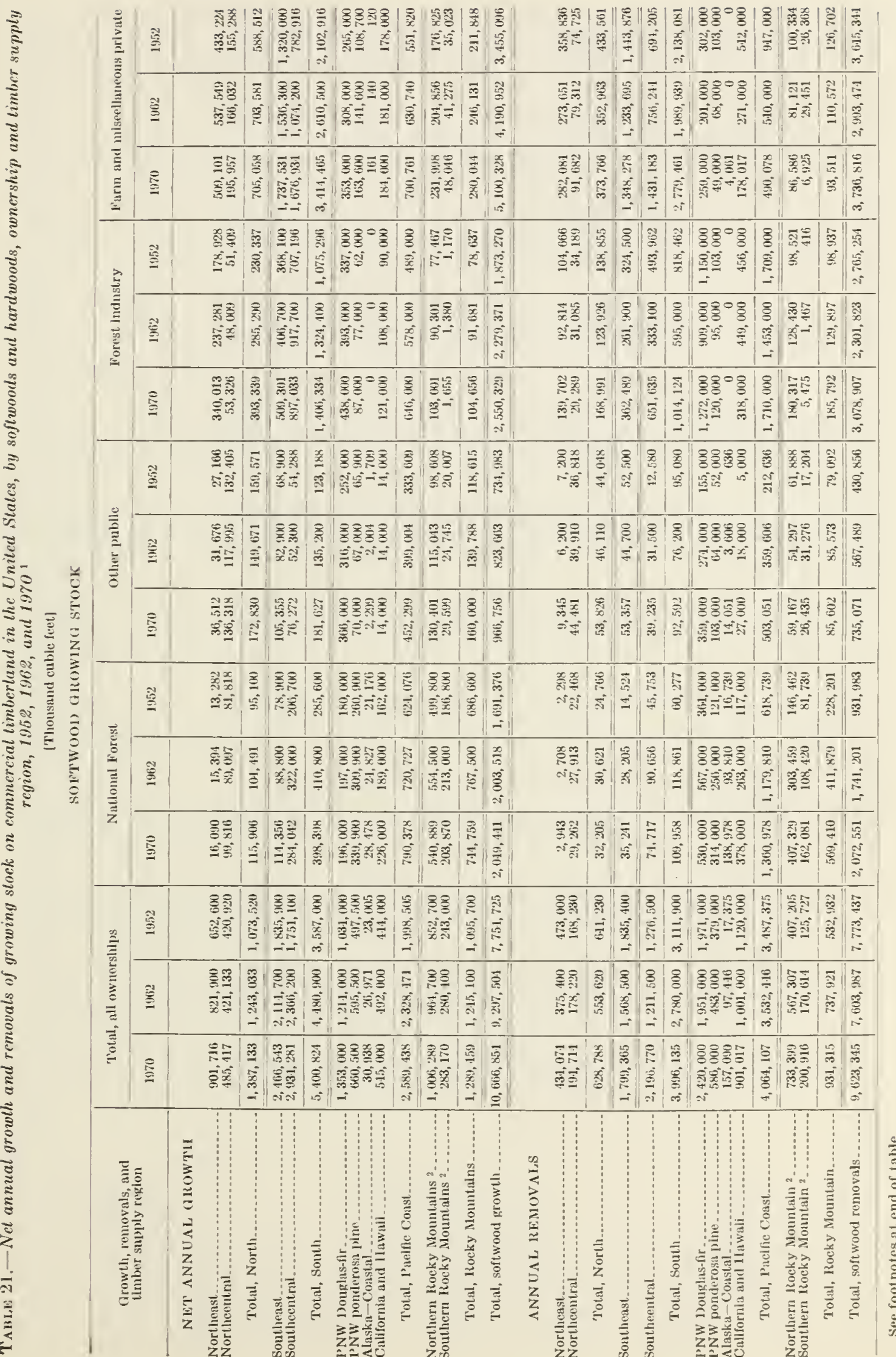




\begin{tabular}{|c|c|c|c|c|c|c|c|c|c|c|c|c|c|c|c|c|c|c|c|c|c|}
\hline & 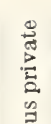 & 总 & 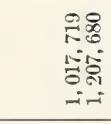 & 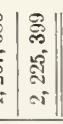 & 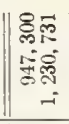 & 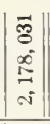 & 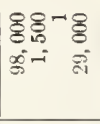 & 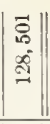 & 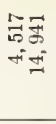 & 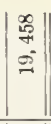 & & & 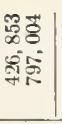 & 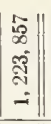 & 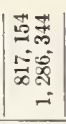 & 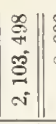 & 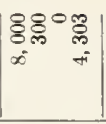 & $\mid$ & $\mid \begin{array}{l}\infty \\
\infty\end{array}$ & 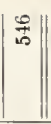 & 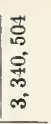 \\
\hline & 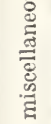 & 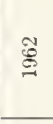 & 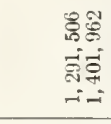 & 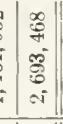 & 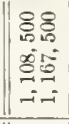 & 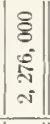 & 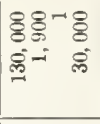 & \begin{tabular}{|l|}
$\vec{E}$ \\
$\overrightarrow{0}$ \\
$\vec{\omega}$
\end{tabular} & 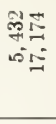 & 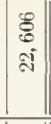 & 量 & & 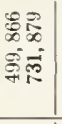 & 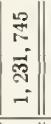 & 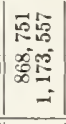 & 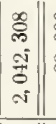 & 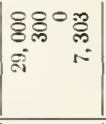 & $\mid$ & $\bar{\infty} \frac{2}{10}$ & : & 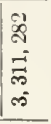 \\
\hline & 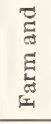 & 尽 & 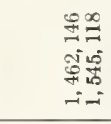 & 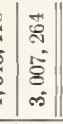 & 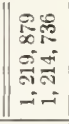 & 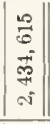 & 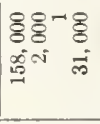 & $\mid$\begin{tabular}{l|}
$\vec{\delta}$ \\
$\bar{\Xi}$
\end{tabular} & 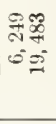 & 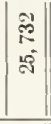 & 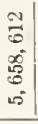 & & 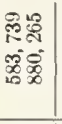 & 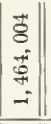 & 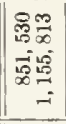 & 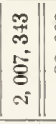 & 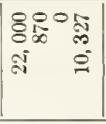 & 点 & $=\square$ & 怘 & $\begin{array}{l}0 \\
\infty 1 \\
\infty \\
5 \\
0 \\
0 \\
\infty\end{array}$ \\
\hline & & 窎 & 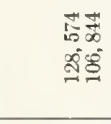 & 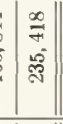 & 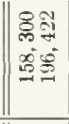 & 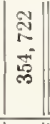 & 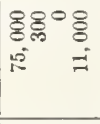 & 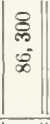 & 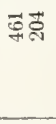 & \& & 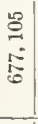 & & 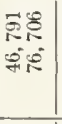 & $\mid$ & 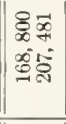 & $\left|\begin{array}{|c||}\vec{a} \\
0 \\
0 \\
0 \\
0\end{array}\right|$ & 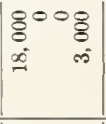 & 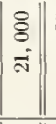 & $\vec{B}=$ & 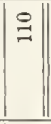 & 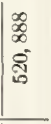 \\
\hline & 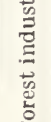 & 임 & 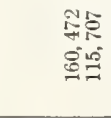 & 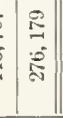 & 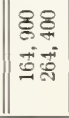 & 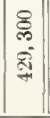 & 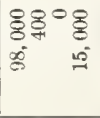 & 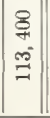 & $\overrightarrow{8}$ & $\vec{\infty} \mid \vec{\infty}$ & 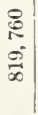 & & 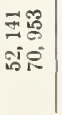 & 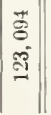 & 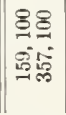 & 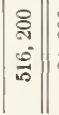 & 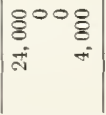 & $\mid$ & $\underline{m}=$ & 垔 & $\begin{array}{l}\text { F } \\
0 \\
0 \\
8\end{array}$ \\
\hline & & 总 & 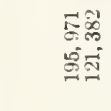 & 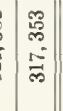 & 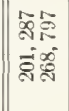 & \begin{tabular}{|l||}
$\overrightarrow{0}$ \\
$\stackrel{8}{8}$ \\
$\stackrel{8}{*}$
\end{tabular} & 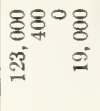 & 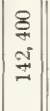 & 冓莣 & - & 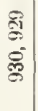 & & 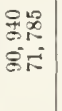 & $\mid$\begin{tabular}{|c|}
0 \\
$i$ \\
$i$ \\
0 \\
0 \\
0
\end{tabular} & 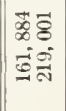 & $\left|\begin{array}{l|}\infty \\
\infty \\
\infty \\
0 \\
\infty \\
\infty \\
\infty\end{array}\right|$ & $\left|\begin{array}{ccc}80 & 0 & 8 \\
5 & 0 \\
7 & 1\end{array}\right|$ & 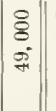 & 90 & 8 & 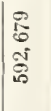 \\
\hline & & 总 & 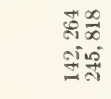 & 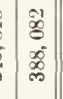 & 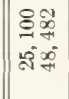 & 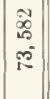 & 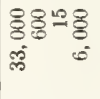 & \begin{tabular}{|l||}
0 \\
0 \\
0 \\
0.0 \\
$m$
\end{tabular} & 融宸 & $\mid$ & 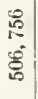 & & $\begin{array}{l}85 \\
8 x \\
35= \\
35\end{array}$ & 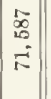 & 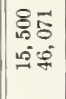 & $\left|\begin{array}{|c|}\frac{1}{6} \\
6 \\
6 \\
0\end{array}\right|$ & {$\left[\begin{array}{lll}800 & 0 \\
0 & 0 \\
15 & =\end{array}\right.$} & $\begin{array}{c}1 \\
0 \\
0 \\
0\end{array}$ & "ే⿱ & 今人े & 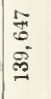 \\
\hline 븡 & 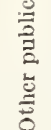 & 駡 & 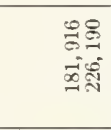 & $\frac{8}{\stackrel{8}{8}}$ & | & $\mid \begin{array}{c}8 \\
0 \\
-1 \\
0\end{array}$ & 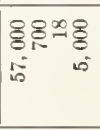 & 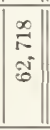 & $\begin{array}{l}\text { 莺尽 } \\
\text { जim }\end{array}$ & $\mid$ & 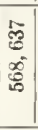 & & 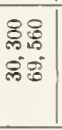 & 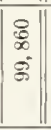 & $\begin{array}{l}88 \\
78 \\
9 \\
9 \\
9\end{array}$ & $\mid \begin{array}{c}8 \\
8 \\
0 \\
0 \\
0\end{array}$ & 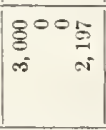 & $\left|\begin{array}{|c||}5 \\
9 \\
15\end{array}\right|$ & 需 & $\underset{\sim}{\not}$ & $\begin{array}{l}0 \\
0 \\
0 \\
6 \\
0 \\
0\end{array}$ \\
\hline 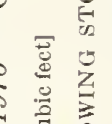 & & 量 & 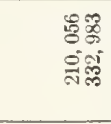 & 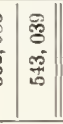 & 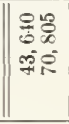 & $\begin{array}{l}2 \\
= \\
\pm \\
\Xi\end{array}$ & 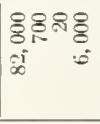 & \begin{tabular}{|c||}
$\mathcal{B}$ \\
$i$ \\
$\infty$ \\
$\infty$ \\
$\infty$
\end{tabular} & 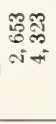 & $\mid \begin{array}{l}0 \\
8 \\
0 \\
0\end{array}$ & 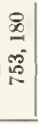 & & 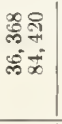 & $\mid$\begin{tabular}{|c||}
$\infty$ \\
0 \\
0 \\
0 \\
\\
\end{tabular} & 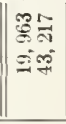 & $\left|\begin{array}{|}\mathscr{D} \\
\underset{\mathfrak{B}}{\mathfrak{B}} \\
\mid\end{array}\right|$ & 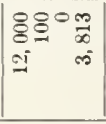 & 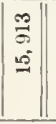 & 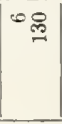 & $\stackrel{\mathscr{D}}{.}$ & 홍 \\
\hline 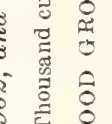 & & 客 & 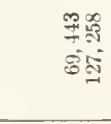 & 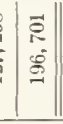 & 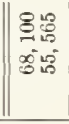 & 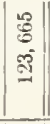 & 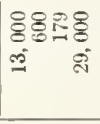 & 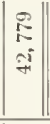 & 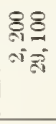 & $\mid \begin{array}{l}\text { \& } \\
-\bar{m} \\
-\bar{m}\end{array}$ & 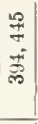 & & 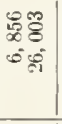 & 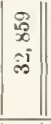 & 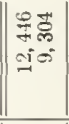 & 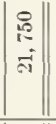 & 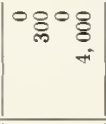 & 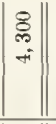 & 혹: & 量 & $\mid \begin{array}{l}\infty \\
0 \\
0 \\
0 \\
8 \\
8 \\
8\end{array}$ \\
\hline 吾 & 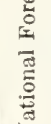 & 웜 & 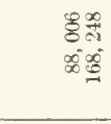 & 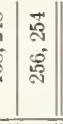 & 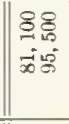 & 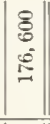 & 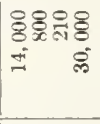 & 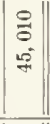 & 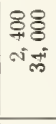 & $\begin{array}{l}8 \\
\vdots \\
1 \\
-\infty\end{array}$ & $\begin{array}{l}\text { 䓫 } \\
\vec{H} \\
\vec{b}\end{array}$ & & 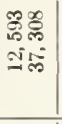 & 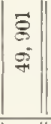 & 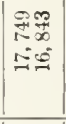 & 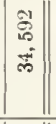 & 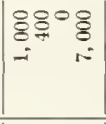 & $\mid$\begin{tabular}{|c|}
8 \\
+ \\
$\infty$ \\
$\infty$
\end{tabular} & 站总 & $\mid$\begin{tabular}{l|}
3 \\
0 \\
0 \\
$\sim$ \\
$\sim$
\end{tabular} & $\mid \begin{array}{l}0 \\
0 \\
0 \\
8 \\
8\end{array}$ \\
\hline & & $\stackrel{8}{9}$ & 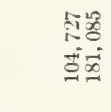 & $\mid \begin{array}{l}a \\
\infty \\
0 \\
0 \\
0 \\
-1\end{array}$ & 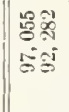 & $\mid$ & 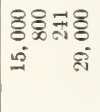 & 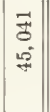 & 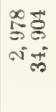 & 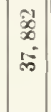 & 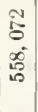 & & 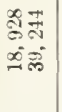 & 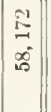 & 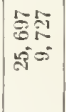 & 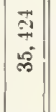 & 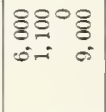 & $\left|\begin{array}{c}8 \\
- \\
9 \\
9\end{array}\right|$ & $\begin{array}{r}\text { 7क्षे } \\
\text { जi }\end{array}$ & $\begin{array}{l}\vec{a} \\
\vec{a} \\
\vec{v}\end{array}$ & 学 \\
\hline & $\stackrel{\infty}{\rightleftarrows}$ & 鸹 & 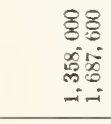 & $\begin{array}{l}8 \\
0 \\
0 \\
0 \\
0 \\
0 \\
\infty \\
\infty\end{array}$ & 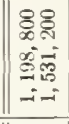 & 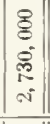 & 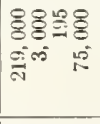 & 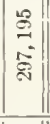 & 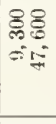 & 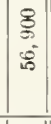 & 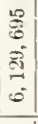 & & 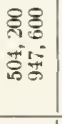 & 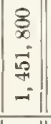 & 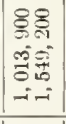 & $\left|\begin{array}{c}8 \\
8 \\
0 \\
8 \\
0 \\
0 \\
0\end{array}\right|$ & 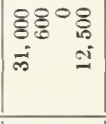 & $\left|\begin{array}{l}\S \\
\exists \\
\forall\end{array}\right|$ & 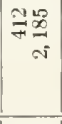 & $\begin{array}{l}\text { 勇 } \\
\text { oi }\end{array}$ & $\mid$ \\
\hline & 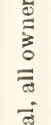 & 임 & 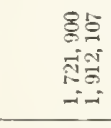 & 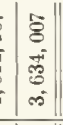 & 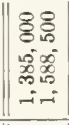 & 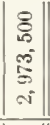 & 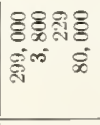 & 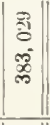 & 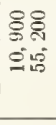 & $\left|\begin{array}{l|}8 \\
0 \\
8 \\
8\end{array}\right|$ & 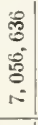 & & 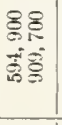 & $\left|\begin{array}{c}8 \\
8 \\
0 \\
\vec{b} \\
-1\end{array}\right|$ & 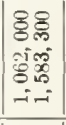 & $\left|\begin{array}{c|}0 \\
0 \\
0 \\
0 \\
0 \\
0 \\
01\end{array}\right|$ & 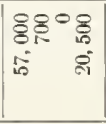 & $\mid$\begin{tabular}{|c||}
8 \\
0 \\
0 \\
0 \\
10
\end{tabular} & 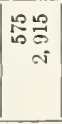 & $\mid$\begin{tabular}{c|}
8 \\
$⿱ 亠 䒑$ \\
$m$ \\
$m$
\end{tabular} & 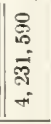 \\
\hline & تें & $\stackrel{尺}{9}$ & 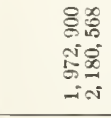 & 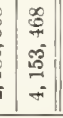 & 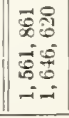 & 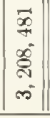 & 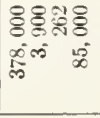 & 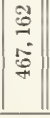 & 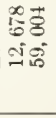 & 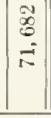 & $\begin{array}{l}0 \\
0 \\
0 \\
0 \\
0\end{array}$ & & 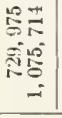 & \begin{tabular}{|c||}
0 \\
0 \\
0 \\
0 \\
0 \\
0 \\
-1
\end{tabular} & 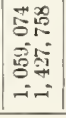 & 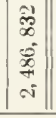 & 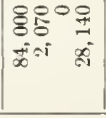 & 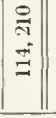 & $\begin{array}{r}x \rightarrow \overrightarrow{8} \\
\text { si } \\
\text { si }\end{array}$ & 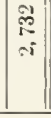 & 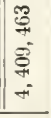 \\
\hline & & & 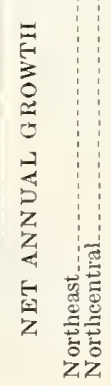 & 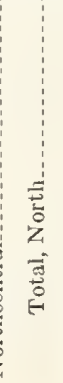 & 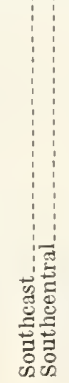 & 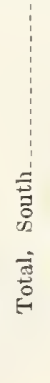 & 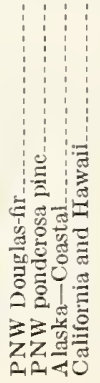 & 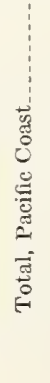 & 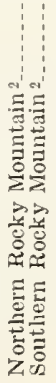 & 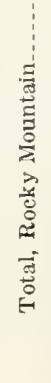 & 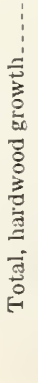 & 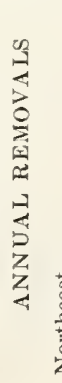 & 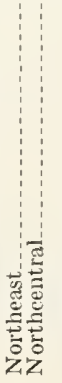 & 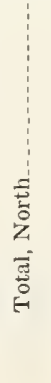 & 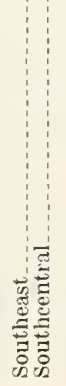 & 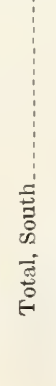 & 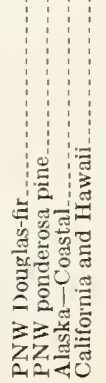 & 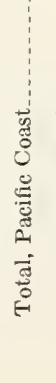 & 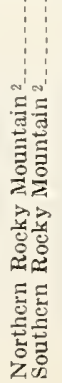 & 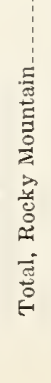 & 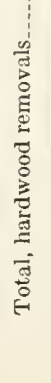 \\
\hline
\end{tabular}




\begin{tabular}{|c|c|c|c|c|c|c|c|c|c|c|c|c|c|c|c|c|c|c|c|c|c|}
\hline 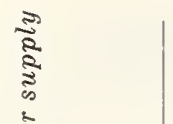 & 总 & 乌్ & 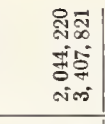 & 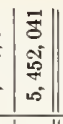 & 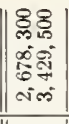 & \begin{tabular}{l|l||}
8 & \\
0 \\
0 \\
0 \\
0 \\
0
\end{tabular} & 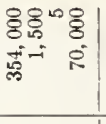 & | & 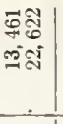 & $\left|\begin{array}{l}\tilde{y} \\
0 \\
0 \\
0 \\
0\end{array}\right|$ & 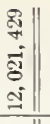 & & $\mid$ & 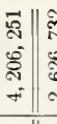 & 等 & 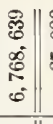 & 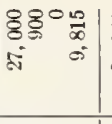 & 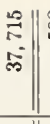 & 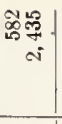 & $\begin{array}{l}\hat{\vec{b}} \\
\dot{\circ}^{\circ}\end{array}$ & 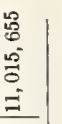 \\
\hline 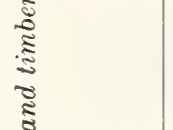 & 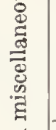 & ळ్ & 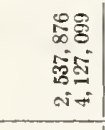 & 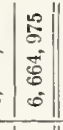 & 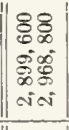 & 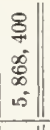 & 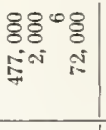 & 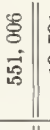 & 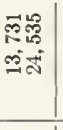 & $\mid$ & 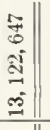 & & 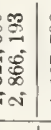 & 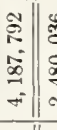 & 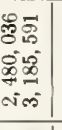 & 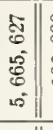 & 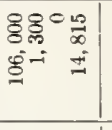 & 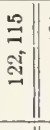 & 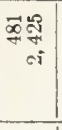 & $\begin{array}{l}\mathscr{0} \\
\vdots \\
\text { i. }\end{array}$ & $\begin{array}{l}\frac{f}{8} \\
\infty \\
\infty \\
\infty \\
\infty\end{array}$ \\
\hline & 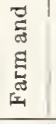 & $\stackrel{\circ}{\stackrel{9}{9}}$ & 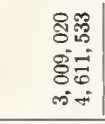 & $\left|\begin{array}{c|}\mid \\
0 \\
0 \\
0 \\
0 \\
0 \\
0 \\
1\end{array}\right|$ & 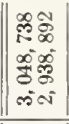 & $\left|\begin{array}{c}0 \\
: \\
0 \\
\dot{0} \\
0 \\
10\end{array}\right|$ & 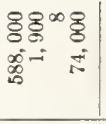 & 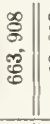 & 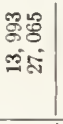 & $\begin{array}{l}\infty \\
\dot{0} \\
\vec{F}\end{array}$ & 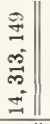 & & 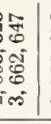 & 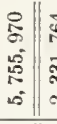 & 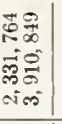 & 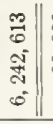 & 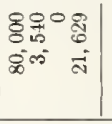 & 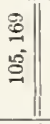 & '8: & 亦 & 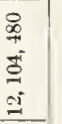 \\
\hline & & 畺 & 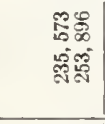 & 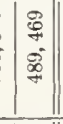 & 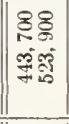 & $\left|\begin{array}{|c||}8 \\
0 \\
0 \\
8 \\
8\end{array}\right|$ & 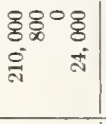 & $\begin{array}{l}8 \\
8 \\
0 \\
\tilde{\Xi} \\
\tilde{\Xi}\end{array}$ & 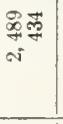 & $\left|\begin{array}{l}\approx \\
0 \\
o \\
i\end{array}\right|$ & 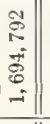 & & : & 罢 & 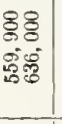 & 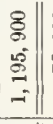 & 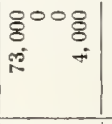 & \begin{tabular}{l||}
$\$$ \\
5 \\
1
\end{tabular} & 9 & $\stackrel{\infty}{\circ}$ & 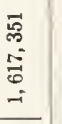 \\
\hline & 苞 & 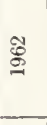 & 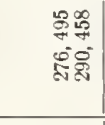 & 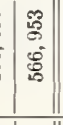 & 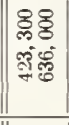 & 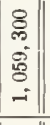 & 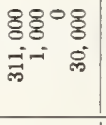 & 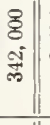 & 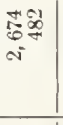 & 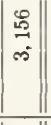 & 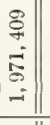 & & 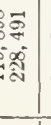 & 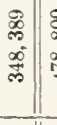 & 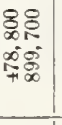 & $\begin{array}{c}0 \\
0 \\
0 \\
\infty \\
0 \\
0 \\
-1 \| \\
-1 \|\end{array}$ & $\left|\begin{array}{lll}8 & 0 & 0 \\
0 & 0 & 0 \\
\infty & 1 & 1\end{array}\right|$ & 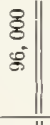 & ళ్రిల్ & $\tilde{\otimes}$ & 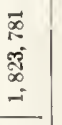 \\
\hline & & 呑 & 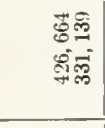 & $\begin{array}{l}8 \\
0 \\
5 \\
5 \\
5 \\
5\end{array}$ & 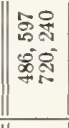 & 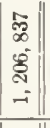 & 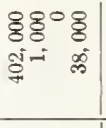 & \begin{tabular}{l||}
8 \\
$\vdots$ \\
$=$ \\
\end{tabular} & 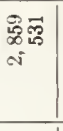 & 离 & 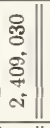 & & 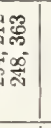 & 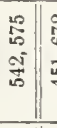 & 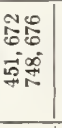 & 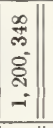 & 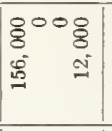 & 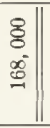 & 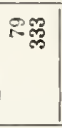 & $\underset{\exists}{\mp}$ & 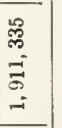 \\
\hline 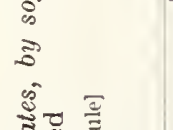 & & 总 & 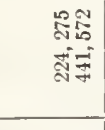 & 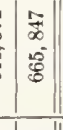 & 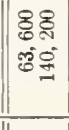 & $\mid$ & 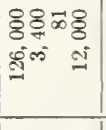 & 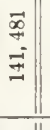 & $\begin{array}{l}\text { 路苛 } \\
\text { ris }\end{array}$ & \begin{tabular}{|l||}
$\overrightarrow{5}$ \\
$\overrightarrow{5}$ \\
$\overrightarrow{0}$
\end{tabular} & $\left|\begin{array}{c|}\multirow{2}{*}{} \\
-i \\
\dot{\delta} \\
-1\end{array}\right|$ & & $\begin{array}{l}35 \\
55 \\
58 \\
58\end{array}$ & 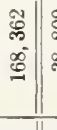 & 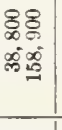 & 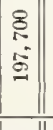 & 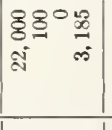 & 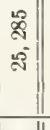 & 甭节 & $\mid$ & 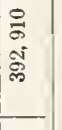 \\
\hline r & 递 & 罵 & 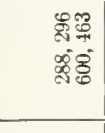 & 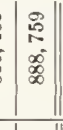 & 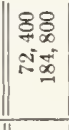 & $\mid$\begin{tabular}{|c||}
8 \\
0 \\
0 \\
0 \\
0
\end{tabular} & 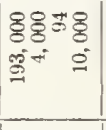 & $\begin{array}{l}\text { है } \\
\text { sें| }\end{array}$ & 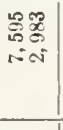 & $\mid$ & 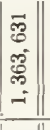 & & | & 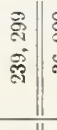 & 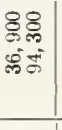 & 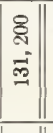 & 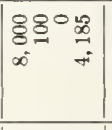 & 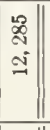 & 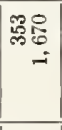 & है: & 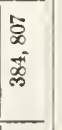 \\
\hline 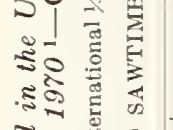 & & 量 & 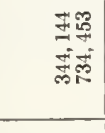 & 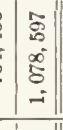 & 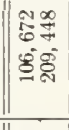 & 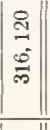 & 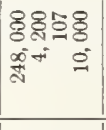 & 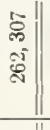 & 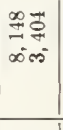 & 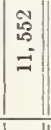 & $\left|\begin{array}{c}0 \\
6 \\
0 \\
0 \\
0 \\
-1\end{array}\right|$ & & 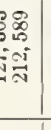 & 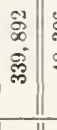 & 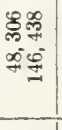 & $\mid$ & 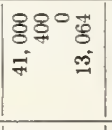 & $\mid$\begin{tabular}{|}
$\overrightarrow{0}$ \\
$\overrightarrow{0}$ \\
$\overrightarrow{0}$
\end{tabular} & ஜొত్ర & 范 & 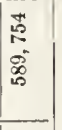 \\
\hline 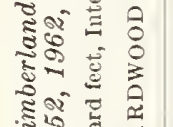 & $\overrightarrow{\mathrm{g}}$ & 雷 & 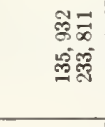 & 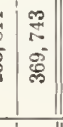 & 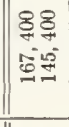 & 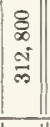 & 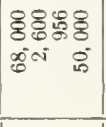 & 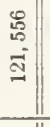 & 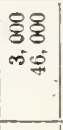 & 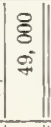 & 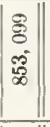 & & 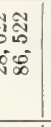 & 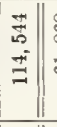 & 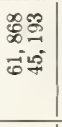 & $\mid$\begin{tabular}{l|}
$\overrightarrow{8}$ \\
0 \\
0 \\
0
\end{tabular} & 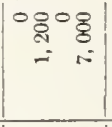 & $\mid$ & 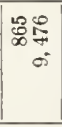 & $\begin{array}{l}\vec{F} \\
0 \\
0 \\
0 \\
0\end{array}$ & $\mid$ \\
\hline 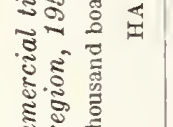 & 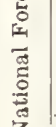 & 吅 & 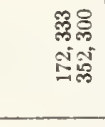 & 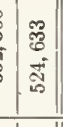 & 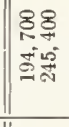 & $\mid \begin{array}{l}8 \\
0 \\
0 \\
0 \\
0\end{array}$ & 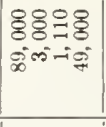 & 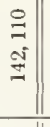 & 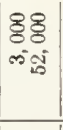 & $\begin{array}{c}8 \\
8 \\
4 \\
4 \\
4\end{array}$ & $\mid \begin{array}{l}9 \\
\infty \\
0 \\
0 \\
0 \\
0 \\
-1\end{array}$ & & 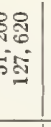 & 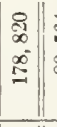 & 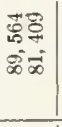 & $\mid$\begin{tabular}{|c||}
0 \\
6 \\
0 \\
0 \\
0
\end{tabular} & 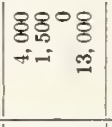 & \begin{tabular}{|l||}
0 \\
$b$ \\
0 \\
0 \\
-1
\end{tabular} & 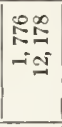 & 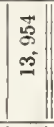 & 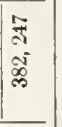 \\
\hline 5 & z & 呑 & 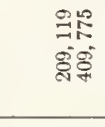 & 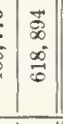 & 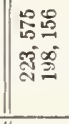 & 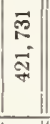 & 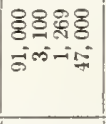 & 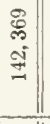 & 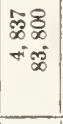 & 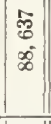 & $\mid$\begin{tabular}{c|}
$\vec{B}$ \\
$\vec{B}$ \\
$\overrightarrow{-}$ \\
- \\
$-i$
\end{tabular} & & 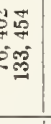 & 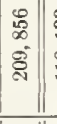 & 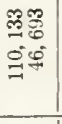 & $\left|\begin{array}{c}0 \\
01 \\
\infty \\
0 \\
0 \\
-3 \\
-1\end{array}\right|$ & 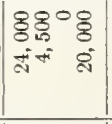 & 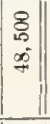 & 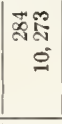 & 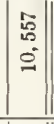 & $\mid$ \\
\hline & 参 & 菏 & 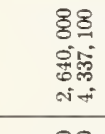 & $\left|\begin{array}{c}8 \\
8 \\
0 \\
5 \\
5 \\
0\end{array}\right|$ & 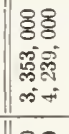 & \begin{tabular}{|c|} 
\\
8 \\
0 \\
0 \\
0 \\
0 \\
\end{tabular} & 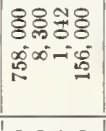 & | & 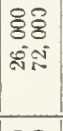 & $\mid \begin{array}{c}\$ \\
\$ \\
\infty \\
\infty\end{array}$ & 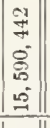 & & 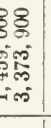 & 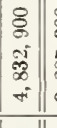 & 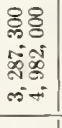 & 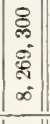 & 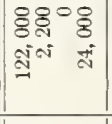 & 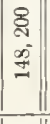 & 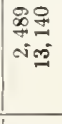 & \begin{tabular}{l|}
8 \\
0 \\
0 \\
2 \\
-2
\end{tabular} & 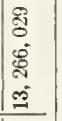 \\
\hline & 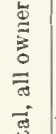 & $\Phi$ & 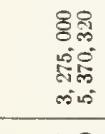 & 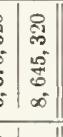 & 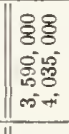 & 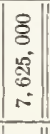 & 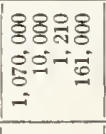 & 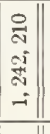 & 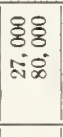 & $\mid \begin{array}{l}8 \\
8 \\
0 \\
0\end{array}$ & \begin{tabular}{|l|}
0 \\
0 \\
0 \\
0 \\
0 \\
0 \\
-1 \\
\end{tabular} & & 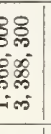 & 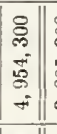 & 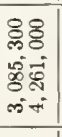 & 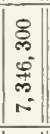 & 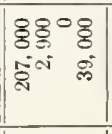 & 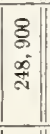 & 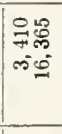 & 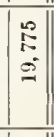 & 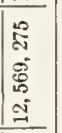 \\
\hline & 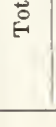 & 옹 & 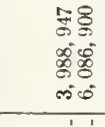 & 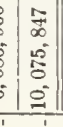 & 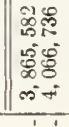 & 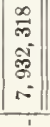 & 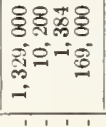 & 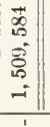 & 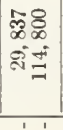 & 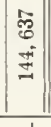 & 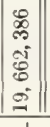 & & 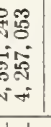 & $\begin{array}{l}0 \\
8 \\
0 \\
\infty \\
\infty \\
0 \\
0 \\
0\end{array}$ & 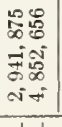 & 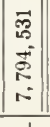 & 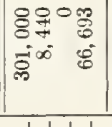 & $\mid$\begin{tabular}{c|}
2 \\
9 \\
0 \\
0 \\
0 \\
0
\end{tabular} & $\begin{array}{l}\text { 㔬悉 } \\
= \\
=\end{array}$ & 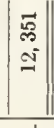 & 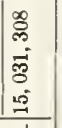 \\
\hline & & 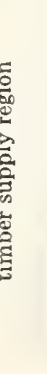 & 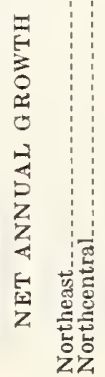 & 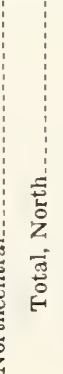 & 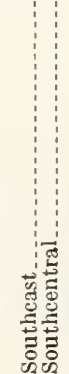 & 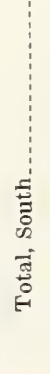 & 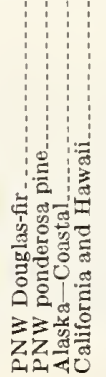 & 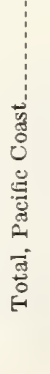 & 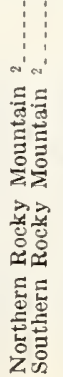 & 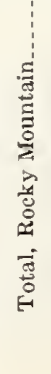 & 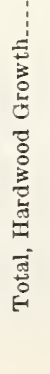 & 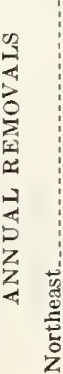 & 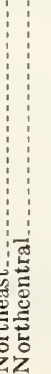 & 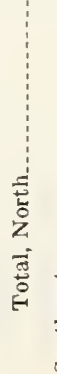 & 苑 & 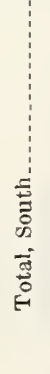 & 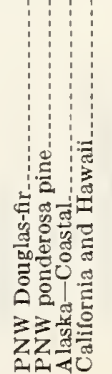 & 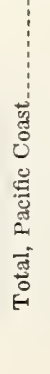 & 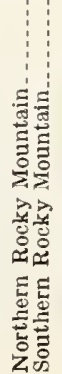 & 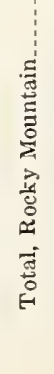 & 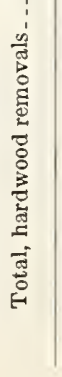 \\
\hline
\end{tabular}




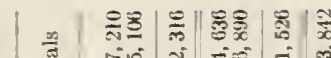

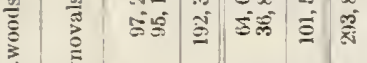

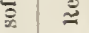

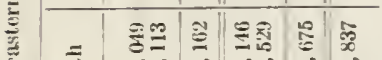

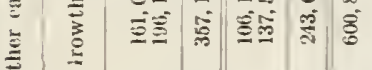

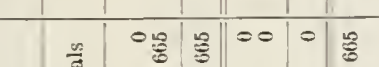

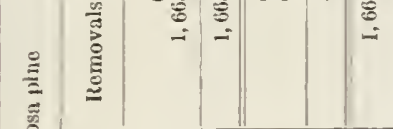

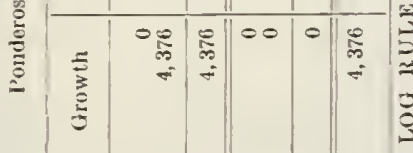

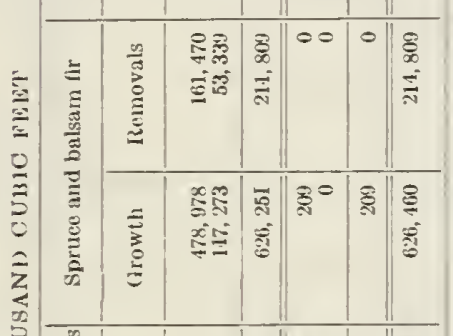

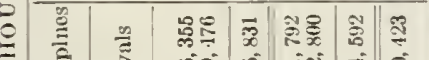

एक

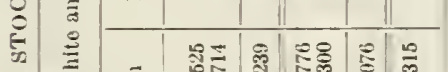

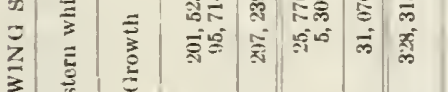

紊

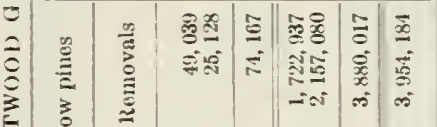

空

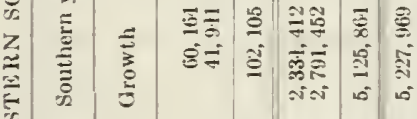

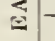

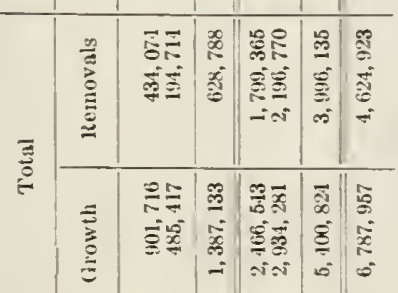

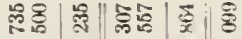

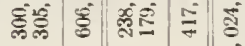

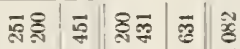

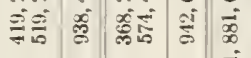

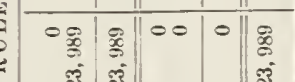

สं
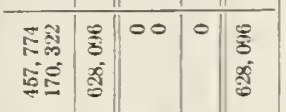

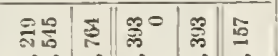

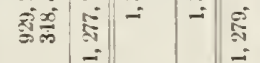

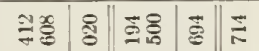
xูํำ

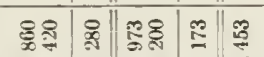

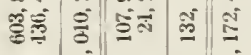

我苛|

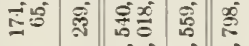
要

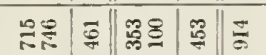
छE $\frac{m}{m}$ 认ิ

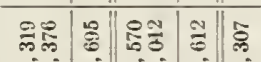

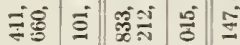
紊 웅옹|융 콜

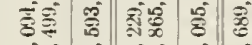
कน ल $x=$ का
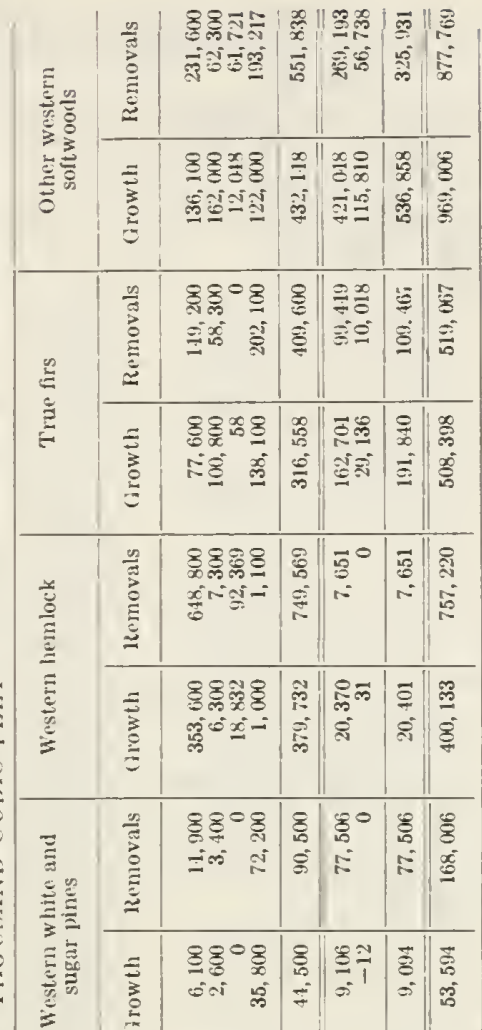

$1 \frac{1}{5}$

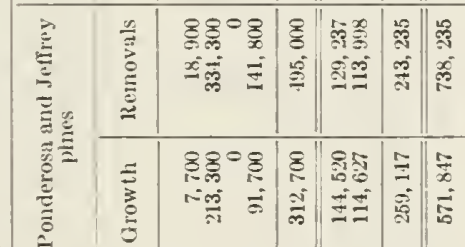



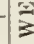

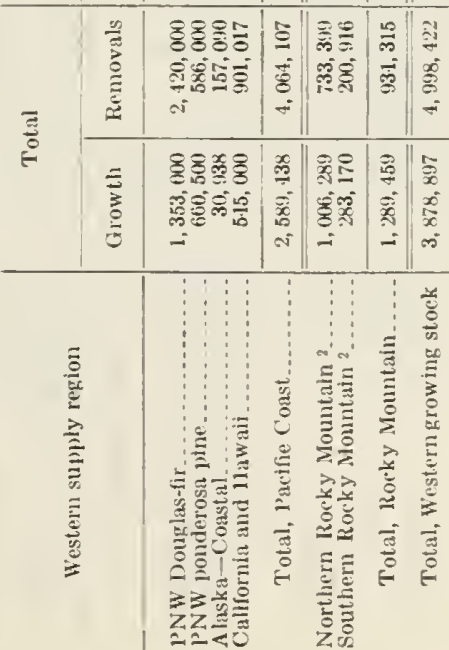

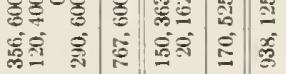

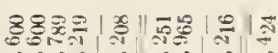

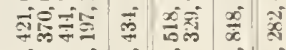

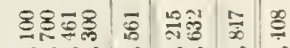

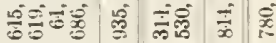

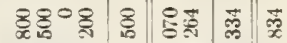

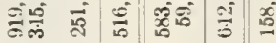

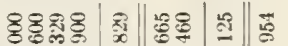

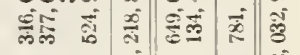

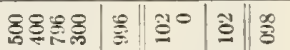

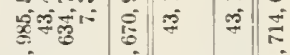

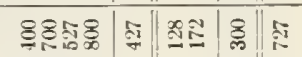
รูํำำ

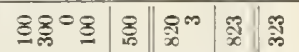
หำ

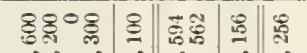

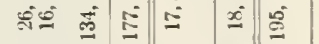

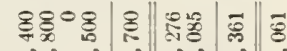

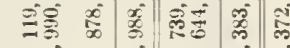

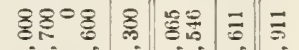

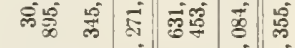
产

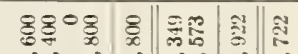

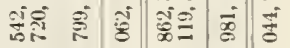
$x^{-}= \pm$-

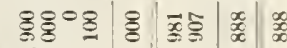

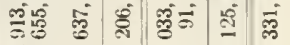

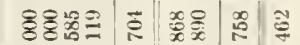

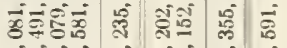

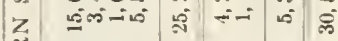

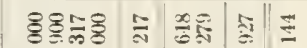
มูํํำ कर
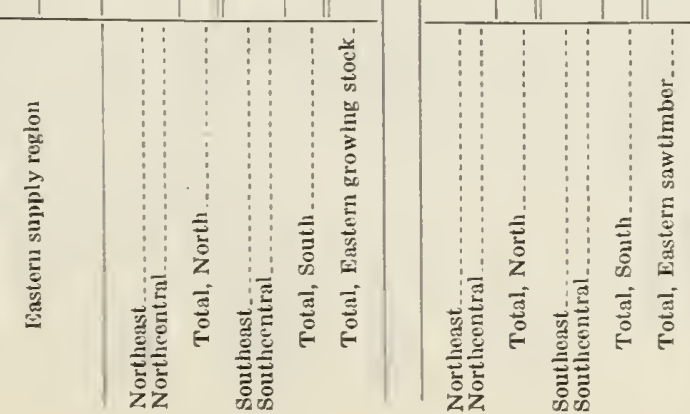


\begin{tabular}{|c|c|c|c|c|c|c|c|c|c|c|c|}
\hline & $\begin{array}{l}\text { no } \\
\vdots \\
0\end{array}$ & 蛞 & 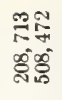 & 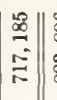 & 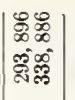 & 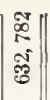 & 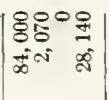 & $\left|\begin{array}{l}\stackrel{8}{a} \\
\multirow{3}{*}{}\end{array}\right|$ & 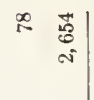 & $\begin{array}{l}\text { co } \\
\text { ô } \\
\text { i }\end{array}$ & 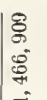 \\
\hline & 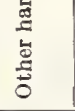 & 苞 & 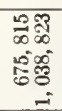 & 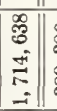 & 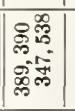 & 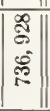 & 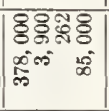 & 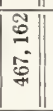 & 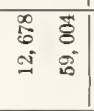 & $\begin{array}{l}0 \\
0 \\
: \\
i\end{array}$ & $\mid$ \\
\hline & 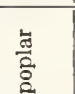 & 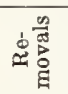 & 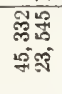 & 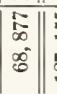 & 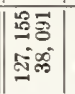 & 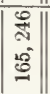 & 0000 & 0 & 0 & o & 莡 \\
\hline & 产 & 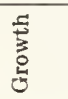 & 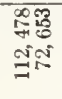 & 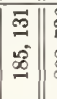 & 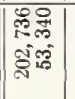 & 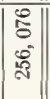 & 0000 & 0 & 00 & 0 & $\begin{array}{l}\text { 拿 } \\
\text { E }\end{array}$ \\
\hline & 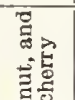 & 䍃 & 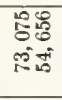 & $\left|\begin{array}{c|}\vec{p} \\
0 \\
\mathbf{s}\end{array}\right|$ & 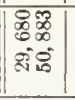 & 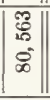 & 0000 & 10 & 00 & 0 & 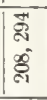 \\
\hline & 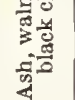 & 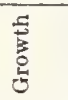 & 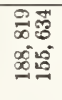 & 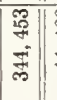 & 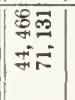 & 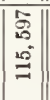 & 0000 & 0 & 00 & 0 & 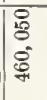 \\
\hline & 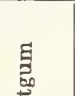 & 密 & $\frac{357}{605}$ & 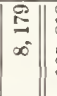 & 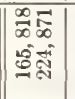 & 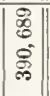 & 0000 & 10 & 00 & 0 & 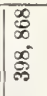 \\
\hline & 总 & 吾 & 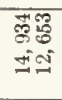 & 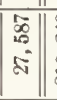 & 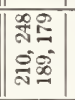 & 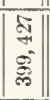 & 0000 & 10 & 00 & 0 & $\mid \begin{array}{l}\pi \\
0 \\
j \\
j\end{array}$ \\
\hline 息 & 总 & 竞 & 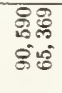 & 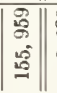 & 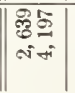 & $\mid$\begin{tabular}{|c|}
$\mid \begin{array}{c}0 \\
0 \\
0 \\
0\end{array}$ \\
0
\end{tabular} & 0000 & 0 & 00 & 0 & 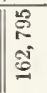 \\
\hline $\begin{array}{l}9 \\
0 \\
0 \\
0\end{array}$ & 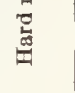 & 章 & 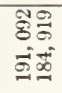 & $\left|\begin{array}{l|}\bar{\vdots} \\
0 \\
0 \\
0 \\
0\end{array}\right|$ & 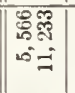 & 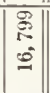 & 0000 & 10 & 00 & 0 & 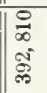 \\
\hline $\begin{array}{l}8 \\
0 \\
0 \\
z\end{array}$ & हू & 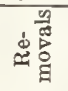 & $\begin{array}{l}\text { 욱여 } \\
\text { if = }\end{array}$ & 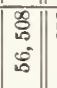 & | & 敢 & $\mid 0000$ & 10 & $\circ 0$ & $\circ$ & 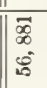 \\
\hline $\begin{array}{l}4 \\
0 \\
0 \\
0 \\
0\end{array}$ & 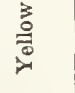 & 㝴 & 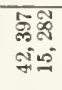 & 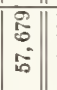 & 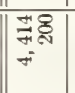 & $\mid \begin{array}{l}\vec{T} \\
0 \\
+\end{array}$ & 0000 & 10 & 00 & 0 & 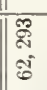 \\
\hline 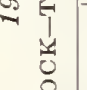 & 究 & 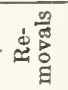 & 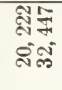 & \begin{tabular}{|c||}
8 \\
0 \\
0 \\
0
\end{tabular} & 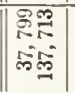 & 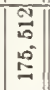 & 10000 & 0 & 0.0 & 0 & \begin{tabular}{|l}
$\overrightarrow{\mathbf{D}}$ \\
$\vec{s}$ \\
\multirow{2}{*}{} \\
\multirow{2}{*}{}
\end{tabular} \\
\hline $\begin{array}{l}5 \\
0 \\
z \\
z\end{array}$ & 总 & 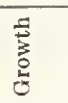 & 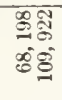 & 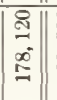 & 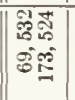 & 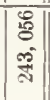 & 0000 & 10 & $\circ \circ$ & 0 & | \\
\hline 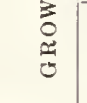 & 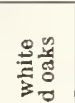 & 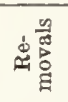 & 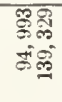 & 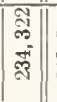 & 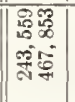 & 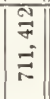 & 0000 & 10 & $\circ 0$ & 0 & 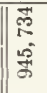 \\
\hline & 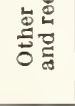 & 起 & 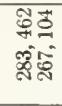 & 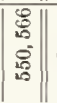 & 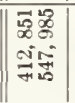 & 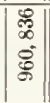 & 0000 & 10 & 00 & 0 & 管 \\
\hline & 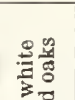 & 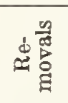 & 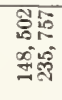 & 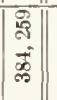 & 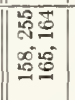 & 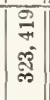 & 10000 & 10 & 00 & 0 & $\begin{array}{l}\infty \\
0 \\
0 \\
8 \\
0\end{array}$ \\
\hline & 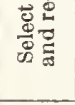 & 㝴 & 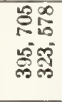 & 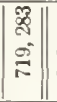 & 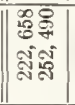 & 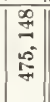 & 0000 & 10 & 00 & & | \\
\hline & $\bar{\Xi}$ & 造尊 & 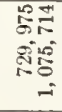 & $\left|\begin{array}{|c|}0 \\
0 \\
0 \\
0 \\
0 \\
\infty \\
-1\end{array}\right|$ & 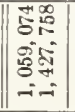 & $\left|\begin{array}{c}0 \\
0 \\
0 \\
0 \\
0 \\
0 \\
0 \\
0\end{array}\right|$ & 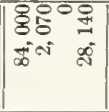 & 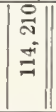 & 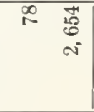 & $\begin{array}{l}\text { वृ } \\
\text { ơ } \\
\text { and }\end{array}$ & 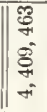 \\
\hline & $\stackrel{\circ}{*}$ & 营 & 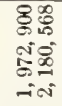 & 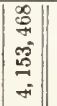 & 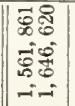 & 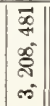 & 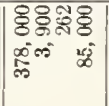 & 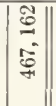 & 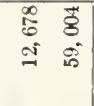 & 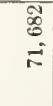 & 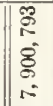 \\
\hline
\end{tabular}

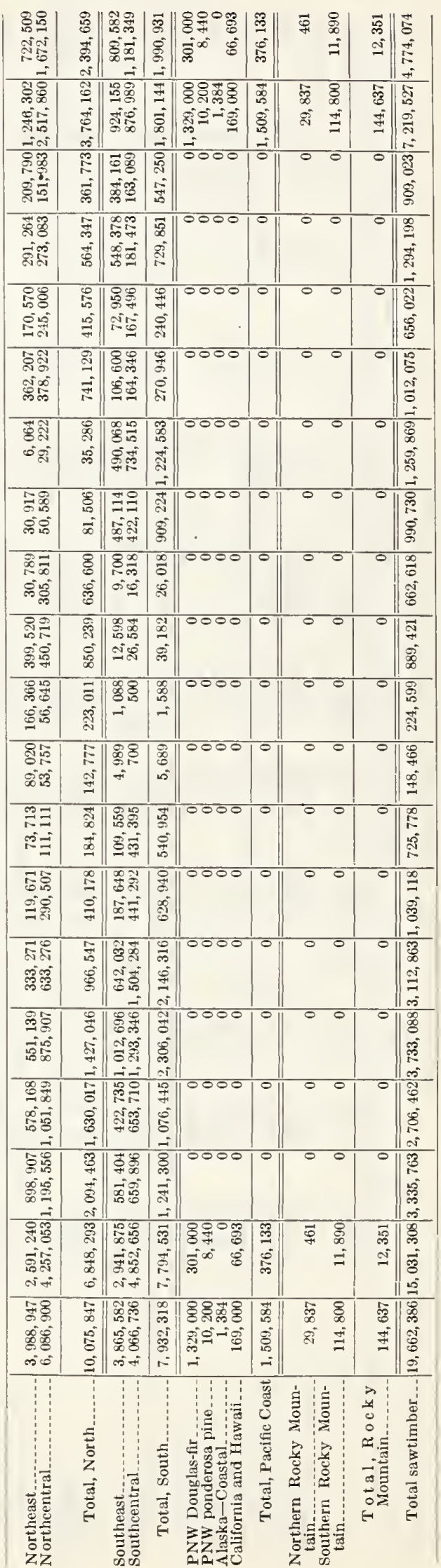


TABLE 25.-. Yet annual growth and removals of growing stock on commercial timberland in the United States, by softwoods and hardwoods and section, region, and State, $1970^{1}$

[Thousand cubic feet]

\begin{tabular}{|c|c|c|c|c|c|c|}
\hline \multirow{2}{*}{ Section, region, and State } & \multicolumn{2}{|c|}{ All species } & \multicolumn{2}{|c|}{ Softwoods } & \multicolumn{2}{|c|}{ Hardwoods } \\
\hline & Growth & Removals & Growth & Removals & Growth & Removals \\
\hline $\begin{array}{l}\text { New England: } \\
\text { Connecticut } \\
\text { Maine } \\
\text { Ifassachusetts } \\
\text { New Hampshire } \\
\text { Rhode Island......... } \\
\text { Vermont.... }\end{array}$ & $\begin{array}{r}45,362 \\
710,800 \\
80,999 \\
138,136 \\
9,758 \\
92,850\end{array}$ & $\begin{array}{r}8,553 \\
408,700 \\
31,329 \\
60,490 \\
2,376 \\
50,995\end{array}$ & $\begin{array}{r}6,110 \\
550,000 \\
22,585 \\
85,818 \\
889 \\
45,416\end{array}$ & $\begin{array}{r}1,310 \\
275,200 \\
14,709 \\
24,635 \\
493 \\
22,043\end{array}$ & $\begin{array}{r}39,252 \\
160,800 \\
58,414 \\
52,318 \\
8,869 \\
47,434\end{array}$ & $\begin{array}{r}7,243 \\
133,500 \\
16,620 \\
35,855 \\
1,883 \\
28,952\end{array}$ \\
\hline Total... & $1,077,905$ & 562,443 & 710,818 & 338,390 & 367,087 & 224,053 \\
\hline $\begin{array}{l}\text { Middle Atlantic: } \\
\text { Delaware } \\
\text { Maryland } \\
\text { New Jersey } \\
\text { New York } \\
\text { Pennsylrania- } \\
\text { West Virginia. }\end{array}$ & $\begin{array}{r}\mathbf{3 0}, 959 \\
106,499 \\
56,911 \\
285,857 \\
762,820 \\
\mathbf{5 5 3}, 665\end{array}$ & $\begin{array}{r}11,858 \\
75,572 \\
12,301 \\
114,904 \\
231,755 \\
155,216\end{array}$ & $\begin{array}{r}8,076 \\
16,576 \\
16,082 \\
80,247 \\
44,375 \\
25,542\end{array}$ & $\begin{array}{r}8,337 \\
30,774 \\
5,501 \\
21,983 \\
16,413 \\
12,646\end{array}$ & $\begin{array}{r}22,883 \\
89,923 \\
40,829 \\
205,610 \\
718,445 \\
528,123\end{array}$ & $\begin{array}{r}3,521 \\
44,798 \\
6,800 \\
92,921 \\
215,312 \\
142,570\end{array}$ \\
\hline Total.. & $1,796,711$ & 601,606 & 190,898 & 95,684 & $1,605,813$ & 505,922 \\
\hline $\begin{array}{l}\text { Lake States: } \\
\text { Michigan } \\
\text { Minnesota- } \\
\text { North Dakota } \\
\text { South Dakota (East) } \\
\text { Wisconsin }\end{array}$ & $\begin{array}{r}605,111 \\
455,635 \\
4,973 \\
4,158 \\
503,637\end{array}$ & $\begin{array}{r}213,078 \\
155,198 \\
3,136 \\
1,859 \\
308,983\end{array}$ & $\begin{array}{r}176,878 \\
114,881 \\
0 \\
928 \\
133,039 \\
\end{array}$ & $\begin{array}{r}54,770 \\
70,227 \\
0 \\
409 \\
39,185 \\
\end{array}$ & $\begin{array}{r}428,233 \\
340,754 \\
4,973 \\
3,230 \\
370,598 \\
\end{array}$ & $\begin{array}{r}158,308 \\
84,971 \\
3,136 \\
1,450 \\
269,798\end{array}$ \\
\hline Total ... & $1,573,514$ & 682,254 & 425,726 & 164,591 & $1,147,788$ & 517,663 \\
\hline $\begin{array}{l}\text { Central: } \\
\text { IIlinois } \\
\text { Indiana } \\
\text { Iowa } \\
\text { Kansas } \\
\text { Kentucky } \\
\text { Missouri } \\
\text { Iebraska } \\
\text { Ohio }\end{array}$ & $\begin{array}{r}92,502 \\
106,525 \\
81,181 \\
16,002 \\
319,214 \\
302,683 \\
16,718 \\
157,645\end{array}$ & $\begin{array}{r}91,096 \\
65,692 \\
50,405 \\
7,616 \\
141,254 \\
108,835 \\
10,156 \\
113,120\end{array}$ & $\begin{array}{r}1,388 \\
3,886 \\
230 \\
23 \\
21,222 \\
24,096 \\
3,831 \\
5,015\end{array}$ & $\begin{array}{r}1,009 \\
484 \\
318 \\
20 \\
11,067 \\
14,086 \\
1,256 \\
1,883 \\
\end{array}$ & $\begin{array}{r}91,114 \\
10,639 \\
80,951 \\
15,979 \\
297,992 \\
278,587 \\
12,887 \\
152,631\end{array}$ & $\begin{array}{r}90,087 \\
65,208 \\
50,087 \\
7,596 \\
130,187 \\
94,799 \\
8,900 \\
111,237\end{array}$ \\
\hline Total... & $1,092,471$ & 588,174 & 59,691 & 30,123 & $1,032,780$ & 558,051 \\
\hline Total, North.- & $5,540,601$ & $2,434,477$ & $1,387,133$ & 628,788 & $4,153,468$ & $1,805,689$ \\
\hline $\begin{array}{l}\text { South A tlantic: } \\
\text { North Carolina. } \\
\text { South Carolina } \\
\text { Virginis }\end{array}$ & $\begin{array}{l}885,140 \\
691,354 \\
563,478\end{array}$ & $\begin{array}{l}690,716 \\
448,977 \\
442,907\end{array}$ & $\begin{array}{l}449,010 \\
410,372 \\
168,518\end{array}$ & $\begin{array}{l}376,816 \\
298,758 \\
165,956\end{array}$ & $\begin{array}{l}436,130 \\
250,982 \\
394,960\end{array}$ & $\begin{array}{l}313,900 \\
150,219 \\
276,951 \\
\end{array}$ \\
\hline Total... & $2,139,972$ & $1,582,600$ & $1,057,900$ & 841,530 & $1,082,072$ & 741,070 \\
\hline $\begin{array}{l}\text { East Gulf: } \\
\text { Florida } \\
\text { Georgia }\end{array}$ & $\begin{array}{r}531,800 \\
1,356,632\end{array}$ & $\begin{array}{l}347,900 \\
927,939\end{array}$ & $\begin{array}{l}415,500 \\
993,143\end{array}$ & $\begin{array}{l}278,300 \\
679,535\end{array}$ & $\begin{array}{l}116,300 \\
363,489\end{array}$ & $\begin{array}{r}69,600 \\
248,404\end{array}$ \\
\hline Total.... & $1,888,432$ & $1,275,839$ & $1,408,643$ & 957,835 & 479,789 & 318,004 \\
\hline $\begin{array}{l}\text { Central Gulf: } \\
\text { Alabami } \\
\text { Mississippi-...... } \\
\text { Tennessee }\end{array}$ & $\begin{array}{l}947,149 \\
966,261 \\
509,100\end{array}$ & $\begin{array}{l}807,183 \\
745,962 \\
216,400\end{array}$ & $\begin{array}{l}718,691 \\
591,665 \\
102,900\end{array}$ & $\begin{array}{r}521,487 \\
461,870 \\
33,200\end{array}$ & $\begin{array}{l}228,458 \\
374,596 \\
406,200\end{array}$ & $\begin{array}{l}285,696 \\
284,092 \\
183,200\end{array}$ \\
\hline Total.... & $2,422,510$ & $1,769,545$ & $1,413,256$ & $1,016,557$ & $1,009,254$ & 752,988 \\
\hline 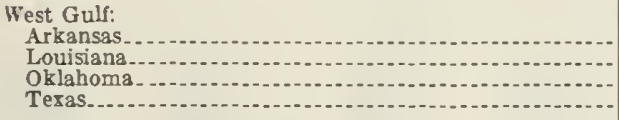 & $\begin{array}{r}778,511 \\
743,842 \\
70,066 \\
565,972\end{array}$ & $\begin{array}{r}620,108 \\
721,637 \\
52,076 \\
461,162\end{array}$ & $\begin{array}{r}402,972 \\
604,804 \\
48,421 \\
464,828\end{array}$ & $\begin{array}{r}299,414 \\
522,901 \\
22,532 \\
335,366\end{array}$ & $\begin{array}{r}375,539 \\
139,038 \\
21,645 \\
101,144\end{array}$ & $\begin{array}{r}320,694 \\
198,736 \\
29,544 \\
125,796\end{array}$ \\
\hline Total & $2,158,391$ & $1,854,983$ & $1,521,025$ & $1,180,213$ & 637,366 & 674,770 \\
\hline Total, South.- & $8,609,305$ & $6,482,967$ & $5,400,824$ & $3,996,135$ & $3,208,481$ & $2,486,832$ \\
\hline $\begin{array}{l}\text { Pacific Northwest: } \\
\text { Alaska: Coastal. }\end{array}$ & 31,200 & 157,090 & 30,938 & 157,090 & 262 & 0 \\
\hline $\begin{array}{l}\text { Oregon: } \\
\text { Western.-1 } \\
\text { Eastern-o }\end{array}$ & $\begin{array}{l}786,000 \\
365,000\end{array}$ & $\begin{array}{r}1,204,000 \\
352,000\end{array}$ & $\begin{array}{l}633,000 \\
364,500\end{array}$ & $\begin{array}{r}1,183,000 \\
352,000\end{array}$ & $\begin{array}{r}153,000 \\
500\end{array}$ & $\begin{array}{r}21,000 \\
0\end{array}$ \\
\hline Summary... & $1,151,000$ & $1,556,000$ & 997,500 & $1,535,000$ & 153,500 & 21,000 \\
\hline
\end{tabular}

See footnotes at end of table. 
TABLE 25.- Net annual growth and removals of growing stock on commercial timberland in the United States, by softwoods and hardwoods and section, region, and State, $1970^{1}$-Continued

[Thousand cubic feet]

\begin{tabular}{|c|c|c|c|c|c|c|}
\hline \multirow{2}{*}{ Section, region, and State } & \multicolumn{2}{|c|}{ All species } & \multicolumn{2}{|c|}{ Softwoods } & \multicolumn{2}{|c|}{ Hardwoods } \\
\hline & Growth & Removals & Growth & Removals & Growth & Removals \\
\hline \multicolumn{7}{|l|}{$\begin{array}{l}\text { Pacific Northwest-Continued } \\
\text { Washington: }\end{array}$} \\
\hline Western & 945,000 & $1,300,000$ & 720,000 & $1,237,000$ & 225,000 & 63,000 \\
\hline Eastern_-_- & 299,400 & 236,070 & 296,000 & 234,000 & 3,400 & 2,070 \\
\hline Summary & $1,244,400$ & $1,536,070$ & $1,016,000$ & $1,471,000$ & 228,400 & 65,070 \\
\hline Total _ - & $2,426,600$ & $3,249,160$ & $2,044,438$ & $3,163,090$ & 382,162 & 86,070 \\
\hline $\begin{array}{l}\text { Paclfic Southwest: } \\
\text { California }\end{array}$ & & & & & & \\
\hline California... & $\begin{array}{r}630,000 \\
20\end{array}$ & $\begin{array}{r}927,000 \\
2,157\end{array}$ & $\begin{array}{r}545,000 \\
20\end{array}$ & $\begin{array}{r}901,000 \\
17\end{array}$ & $\begin{array}{r}85,000 \\
20\end{array}$ & $\begin{array}{r}26,000 \\
2,140\end{array}$ \\
\hline Total ....... & 630,000 & 929,157 & 545,000 & 901,017 & 85,000 & 28,140 \\
\hline Total, Pacific Coast. - & $3,056,600$ & $4,178,317$ & $2,589,438$ & $4,064,107$ & 467,162 & 114,210 \\
\hline Northern Rocky Mountain: & 509063 & & & & & \\
\hline Montana & $\begin{array}{l}502,903 \\
443,141\end{array}$ & $\begin{array}{l}357,256 \\
324,411\end{array}$ & $\begin{array}{l}496,981 \\
439,644\end{array}$ & $\begin{array}{l}357,210 \\
324,379\end{array}$ & $\begin{array}{l}5,982 \\
3,497\end{array}$ & $\begin{array}{l}46 \\
32\end{array}$ \\
\hline South Dakota (West) ${ }^{3}$ & 27,110 & 15,655 & 26,910 & 15,655 & 200 & 0 \\
\hline Wyoming ${ }^{3} \ldots \ldots$ & 45,753 & 36,155 & 42,754 & 36,155 & 2,999 & 0 \\
\hline Total & $1,018,967$ & 733,477 & $1,006,289$ & 733,399 & 12,678 & 78 \\
\hline Southern Rocky Mountain: & & & & & & \\
\hline Colorado 3 & $\begin{array}{r}71,275 \\
157,338\end{array}$ & $\begin{array}{l}87,741 \\
58,993\end{array}$ & $\begin{array}{r}66,239 \\
123,393\end{array}$ & $\begin{array}{l}87,557 \\
57,489\end{array}$ & $\begin{array}{r}5,036 \\
33,945\end{array}$ & $\begin{array}{r}184 \\
1,504\end{array}$ \\
\hline Nevada ${ }^{3}-\ldots \ldots \ldots$ & 2,293 & & 2,052 & & 241 & 0 \\
\hline New Mexico ${ }^{3}$ & 75,061 & 44,086 & 65,888 & 43,600 & 9,173 & 486 \\
\hline Utah ${ }^{3} \ldots \ldots+2 \ldots$ & 36,207 & 12,740 & 25,598 & 12,260 & 10,609 & 480 \\
\hline Total.... & 342,174 & 203,570 & 283,170 & 200,916 & 59,004 & 2,654 \\
\hline Total, Rocky Mountain & $1,361,141$ & 937,047 & $1,289,459$ & 934,315 & 71,682 & 2,732 \\
\hline Total, all regions... & $18,567,647$ & $14,032,808$ & $10,666,854$ & $9,623,345$ & $7,900,793$ & $4,409,463$ \\
\hline
\end{tabular}

1 Zeros indlcate no data or negligible amounts.

${ }^{3}$ See footnote 2 , table 3 .

2 Growth estimate for Hawali is not available.

TABLE 26.-Net annual growth and removals of sawtimber on commercial timberland in the United States, by softwoods and hardwoods and section, region, and State, $1970^{1}$

[Thousand board feet]

Section, region, and state

\begin{tabular}{|c|c|c|c|c|c|}
\hline \multicolumn{2}{|c|}{ All species } & \multicolumn{2}{|c|}{ Softwoods } & \multicolumn{2}{|c|}{ Hardwoods } \\
\hline Growth & Removals & Growth & Removals & Growth & Removals \\
\hline $\begin{array}{r}81,519 \\
1,622,000 \\
111,740 \\
304,892 \\
7,686 \\
162,727\end{array}$ & $\begin{array}{r}28,293 \\
1,299,000 \\
128,219 \\
219,676 \\
6,400 \\
162,972\end{array}$ & $\begin{array}{r}12,611 \\
1,224,000 \\
47,192 \\
230,885 \\
1,395 \\
94,828\end{array}$ & $\begin{array}{r}3,687 \\
878,000 \\
59,859 \\
98,995 \\
1,209 \\
69,648\end{array}$ & $\begin{array}{r}68,908 \\
398,000 \\
64,548 \\
74,007 \\
6,291 \\
67,899\end{array}$ & $\begin{array}{r}24,606 \\
421,000 \\
68,360 \\
120,681 \\
5,191 \\
93,324\end{array}$ \\
\hline $2,290,564$ & $1,844,560$ & $1,610,911$ & $1,111,398$ & 679,653 & 733,162 \\
\hline $\begin{array}{r}62,641 \\
268,053 \\
141,337 \\
702,595 \\
1,274,604 \\
1,343,198\end{array}$ & $\begin{array}{r}32,984 \\
320,585 \\
37,059 \\
415,915 \\
718,630 \\
662,826\end{array}$ & $\begin{array}{r}20,456 \\
43,019 \\
37,168 \\
213,213 \\
96,087 \\
73,191\end{array}$ & $\begin{array}{r}21,503 \\
126,837 \\
11,569 \\
66,391 \\
52,619 \\
51,002\end{array}$ & $\begin{array}{r}42,185 \\
225,034 \\
104,169 \\
489,382 \\
1,178,517 \\
1,270,007\end{array}$ & $\begin{array}{r}11,481 \\
193,748 \\
25,490 \\
349,524 \\
666,011 \\
611,824\end{array}$ \\
\hline $3,792,428$ & $2,187,999$ & 483,134 & 329,921 & $3,309,294$ & $1,858,078$ \\
\hline $\begin{array}{r}1,588,533 \\
1,057,665 \\
18,390 \\
15,719 \\
1,348,068\end{array}$ & $\begin{array}{r}867,017 \\
485,168 \\
6,785 \\
4,623 \\
795,824\end{array}$ & $\begin{array}{r}545,975 \\
353,554 \\
0 \\
3,459 \\
380,547\end{array}$ & $\begin{array}{r}206,816 \\
242,855 \\
0 \\
770 \\
127,470\end{array}$ & $\begin{array}{r}1,042,558 \\
704,111 \\
18,390 \\
12,260 \\
967,521\end{array}$ & $\begin{array}{r}660,201 \\
242,313 \\
6,785 \\
3,853 \\
668,354\end{array}$ \\
\hline $4,028,375$ & $2,159,417$ & $1,283,535$ & 577,911 & $2,744,840$ & $1,581,506$ \\
\hline $\begin{array}{l}288,587 \\
238,416 \\
338,274\end{array}$ & $\begin{array}{l}396,942 \\
350,851 \\
162,530\end{array}$ & $\begin{array}{r}1,800 \\
8,176 \\
805\end{array}$ & $\begin{array}{r}1,983 \\
1,030 \\
864\end{array}$ & $\begin{array}{l}286,787 \\
280,240 \\
337,469\end{array}$ & $\begin{array}{l}394,959 \\
349,821 \\
161,666\end{array}$ \\
\hline
\end{tabular}

See footnotes at end of table. 
TABLE 26.-Net annual growth and removals of sawtimber on commercial timberland in the United States, by softwoods and hardwoods and section, region, and State, $1970^{1}$-Continued

[Thousand board feet]

\begin{tabular}{|c|c|c|c|c|c|c|}
\hline \multirow{2}{*}{ Section, region, and State } & \multicolumn{2}{|c|}{ All species } & \multicolumn{2}{|c|}{ Softwoods } & \multicolumn{2}{|c|}{ Hard woods } \\
\hline & Growth & Removals & Growth & Removals & Growth & Removals \\
\hline $\begin{array}{l}\text { Central-Continued } \\
\text { Kansas } \\
\text { Kentucky } \\
\text { Missouri } \\
\text { Visbraska. } \\
\text { Ohio }\end{array}$ & $\begin{array}{r}48,199 \\
1,198,381 \\
832,103 \\
80,491 \\
483,974\end{array}$ & $\begin{array}{r}35,691 \\
728,089 \\
460,450 \\
51,630 \\
571,829\end{array}$ & $\begin{array}{r}0 \\
75,768 \\
91,249 \\
21,214 \\
17,353\end{array}$ & $\begin{array}{r}0 \\
39,846 \\
30,168 \\
3,085 \\
5,489\end{array}$ & $\begin{array}{r}48,199 \\
1,122,613 \\
740,854 \\
59,277 \\
466,621\end{array}$ & $\begin{array}{r}35,691 \\
688,243 \\
430,282 \\
48,545 \\
566,340\end{array}$ \\
\hline Total ... & $3,558,425$ & $2,758,012$ & 216,365 & 82,465 & $3,342,060$ & $2,675,547$ \\
\hline Total, North. & $13,669,792$ & $8,949,988$ & $3,593,945$ & $2,101,695$ & $10,075,847$ & $6,848,293$ \\
\hline $\begin{array}{l}\text { South Atlantic: } \\
\text { North Carolina } \\
\text { South Carolina } \\
\text { Virginia. }\end{array}$ & $\begin{array}{l}2,718,217 \\
2,126,688 \\
1,511,156\end{array}$ & $\begin{array}{l}2,028,851 \\
1,513,088 \\
1,187,050\end{array}$ & $\begin{array}{r}1,668,692 \\
1,486,581 \\
542,584\end{array}$ & $\begin{array}{r}1,208,834 \\
999,446 \\
486,952\end{array}$ & $\begin{array}{r}1,049,525 \\
640,107 \\
968,572\end{array}$ & $\begin{array}{l}820,017 \\
513,642 \\
700,098\end{array}$ \\
\hline Total_.. & $6,356,061$ & $4,728,989$ & $3,697,857$ & $2,695,232$ & $2,658,204$ & $2,033,757$ \\
\hline $\begin{array}{l}\text { East Gulf: } \\
\text { Florida- } \\
\text { Georgia }\end{array}$ & $\begin{array}{l}1,687,500 \\
4,051,940\end{array}$ & $\begin{array}{l}1,153,700 \\
2,892,756\end{array}$ & $\begin{array}{l}1,322,500 \\
3,209,562\end{array}$ & $\begin{array}{r}934,000 \\
2,204,338\end{array}$ & $\begin{array}{l}365,000 \\
842,378\end{array}$ & $\begin{array}{l}219,700 \\
688,418\end{array}$ \\
\hline Total.... & $5,739,440$ & $4,046,456$ & $4,532,062$ & $3,138,338$ & $1,207,378$ & 908,118 \\
\hline 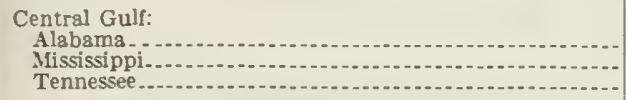 & $\begin{array}{l}3,073,164 \\
3,228,384 \\
1,428,200\end{array}$ & $\begin{array}{r}2,900,450 \\
2,756,830 \\
819,600\end{array}$ & $\begin{array}{r}2,547,610 \\
2,346,722 \\
309,000\end{array}$ & $\begin{array}{r}2,028,440 \\
1,825,233 \\
124,000\end{array}$ & $\begin{array}{r}525,554 \\
881,662 \\
1,119,200\end{array}$ & $\begin{array}{l}872,010 \\
931,597 \\
695,600\end{array}$ \\
\hline Total _. & $7,729,748$ & $6,476,880$ & $5,203,332$ & $3,977,673$ & $2,526,416$ & $2,499,207$ \\
\hline $\begin{array}{l}\text { West Gulf: } \\
\text { Arkansas } \\
\text { Louisiana } \\
\text { Oklahoma- } \\
\text { Texas. }\end{array}$ & $\begin{array}{r}2,603,740 \\
3,153,495 \\
191,965 \\
2,253,519\end{array}$ & $\begin{array}{r}2,537,270 \\
3,024,281 \\
188,834 \\
1,837,433\end{array}$ & $\begin{array}{r}1,713,949 \\
2,737,600 \\
156,684 \\
2,354,166\end{array}$ & $\begin{array}{r}1,375,816 \\
2,350,655 \\
101,840 \\
1,406,058\end{array}$ & $\begin{array}{r}889,791 \\
415,895 \\
35,281 \\
199,353\end{array}$ & $\begin{array}{r}1,161,454 \\
673,626 \\
86,994 \\
431,375\end{array}$ \\
\hline Total ... & $8,202,719$ & $7,587,818$ & $6,662,399$ & $5,234,369$ & $1,540,320$ & $2,353,449$ \\
\hline Total, South... & $28,027,968$ & $22,840,143$ & $20,095,650$ & $15,045,612$ & $7,932,318$ & $7,794,531$ \\
\hline $\begin{array}{l}\text { Pacific Northwest: } \\
\text { Alaska: Coastal.. }\end{array}$ & 164,701 & $1,079,585$ & 163,317 & $1,079,585$ & 1,384 & 0 \\
\hline $\begin{array}{l}\text { Oregon: } \\
\text { Western........... } \\
\text { Eastern......... }\end{array}$ & $\begin{array}{l}3,628,000 \\
1,367,000\end{array}$ & $\begin{array}{l}7,678,000 \\
2,098,000\end{array}$ & $\begin{array}{l}3,035,000 \\
1,365,900\end{array}$ & $\begin{array}{l}7,591,000 \\
2,098,000\end{array}$ & $\begin{array}{r}593,000 \\
1,100\end{array}$ & $\begin{array}{r}87,000 \\
0 \\
\end{array}$ \\
\hline Summary & $4,995,000$ & $9,776,000$ & $4,400,900$ & $9,689,000$ & 594,100 & 87,000 \\
\hline 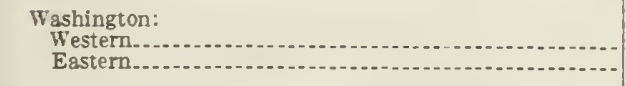 & $\begin{array}{l}4,326,000 \\
1,233,100\end{array}$ & $\begin{array}{l}7,707,000 \\
1,401,440\end{array}$ & $\begin{array}{l}3,590,000 \\
1,224,000\end{array}$ & $\begin{array}{l}7,493,000 \\
1,393,000\end{array}$ & $\begin{array}{r}736,000 \\
9,100\end{array}$ & $\begin{array}{r}214,000 \\
8,440 \\
\end{array}$ \\
\hline Summary & $5,559,100$ & $9,108,440$ & $4,814,000$ & $8,886,000$ & 745,100 & 222,440 \\
\hline Total & $10,718,801$ & $19,964,025$ & $9,378,217$ & $19,654,585$ & $1,340,584$ & 309,440 \\
\hline $\begin{array}{l}\text { Pacific Southwest: } \\
\text { California.......... } \\
\text { Hawaii ............ }\end{array}$ & $\begin{array}{r}2,422,000 \\
20\end{array}$ & $\begin{array}{r}5,637,000 \\
10,812\end{array}$ & $\begin{array}{r}2,253,000 \\
20\end{array}$ & $\begin{array}{r}5,581,000 \\
119\end{array}$ & $\begin{array}{r}169,000 \\
20\end{array}$ & $\begin{array}{l}56,000 \\
10,693\end{array}$ \\
\hline Total........ & $2,422,000$ & $5,647,812$ & $2,253,000$ & $5,581,119$ & 169,000 & 66,693 \\
\hline Total, Pacific Coast.... & $13,140,801$ & $25,611,837$ & $11,631,217$ & $25,235,704$ & $1,509,584$ & 376,133 \\
\hline $\begin{array}{l}\text { Northern Rocky Mountain: } \\
\text { Idaho }{ }^{3} \\
\text { Montana } \\
\text { South Dakota (West) } \\
\text { Wyoming }{ }^{3} \text {. }\end{array}$ & $\begin{array}{r}2,005,146 \\
1,486,242 \\
98,815 \\
164,282\end{array}$ & $\begin{array}{r}2,105,695 \\
1,814,856 \\
87,091 \\
195,687\end{array}$ & $\begin{array}{r}1,992,087 \\
1,473,401 \\
98,815 \\
160,345\end{array}$ & $\begin{array}{r}2,105,424 \\
1,814,666 \\
87,091 \\
195,687\end{array}$ & $\begin{array}{r}13,059 \\
12,841 \\
0 \\
3,937\end{array}$ & $\begin{array}{r}271 \\
190 \\
0 \\
0\end{array}$ \\
\hline Total & $3,754,485$ & $4,203,329$ & $3,724,648$ & $4,202,868$ & 29,837 & 461 \\
\hline 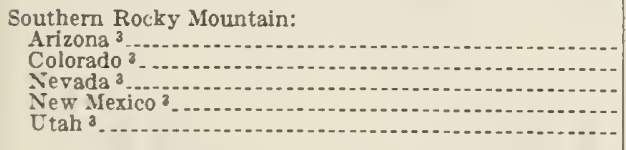 & $\begin{array}{r}306,295 \\
671,734 \\
10,412 \\
252,516 \\
85,122\end{array}$ & $\begin{array}{r}491,706 \\
341,219 \\
63 \\
262,103 \\
69,689\end{array}$ & $\begin{array}{r}289,445 \\
609,698 \\
10,102 \\
226,625 \\
75,409\end{array}$ & $\begin{array}{r}491,131 \\
332,813 \\
63 \\
259,314 \\
69,569\end{array}$ & $\begin{array}{r}16,850 \\
62,036 \\
310 \\
25,891 \\
9,713\end{array}$ & $\begin{array}{r}575 \\
8,406 \\
0 \\
2,789 \\
120\end{array}$ \\
\hline Total... & $1,326,079$ & $1,164,780$ & $1,211,279$ & $1,152,890$ & 114,800 & 11,890 \\
\hline Total, Rocky Mountain & $5,080,564$ & $5,368,109$ & $4,935,927$ & $5,355,758$ & 144,637 & 12,351 \\
\hline Total, all regions... & $59,919,125$ & $62,770,077$ & $40,256,739$ & $47,738,769$ & $19,662,386$ & $15,031,308$ \\
\hline
\end{tabular}




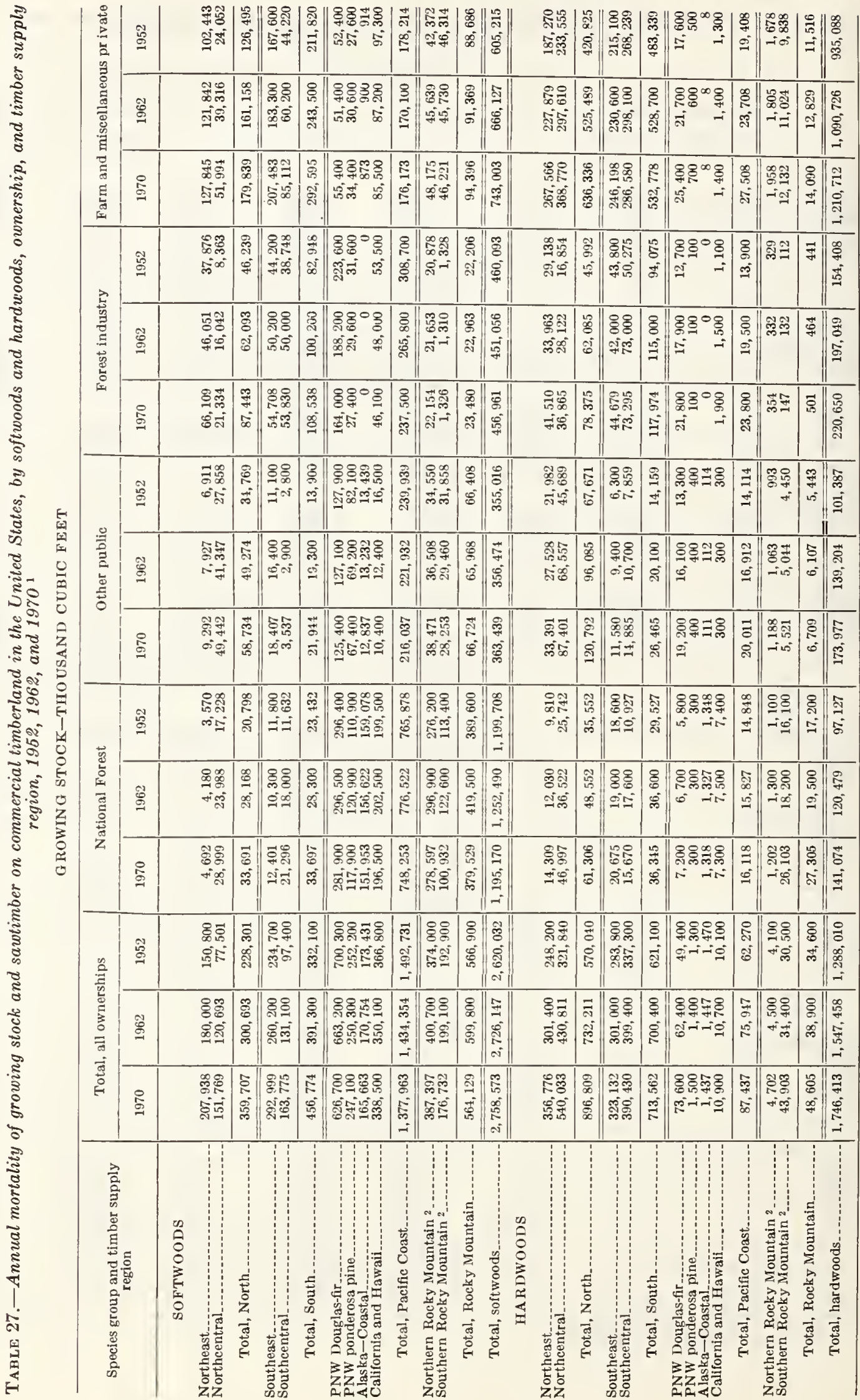




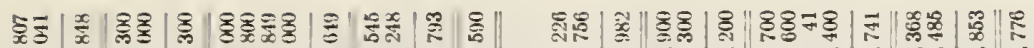

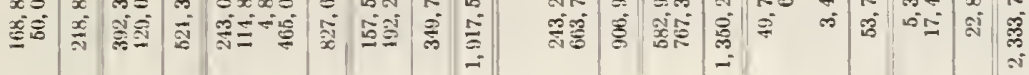

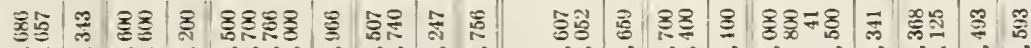

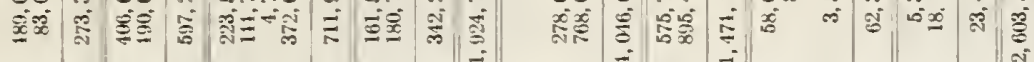

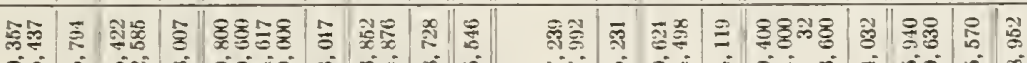

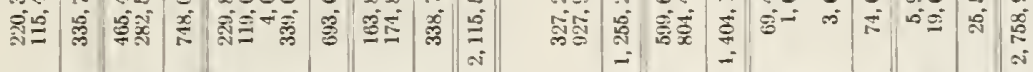

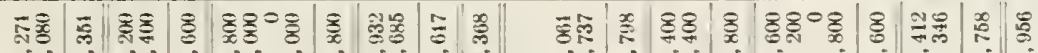

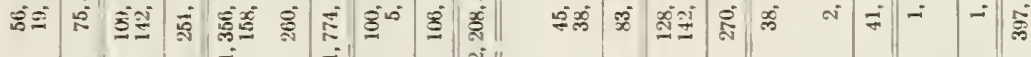

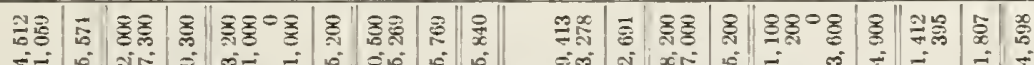

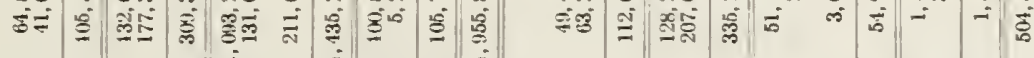

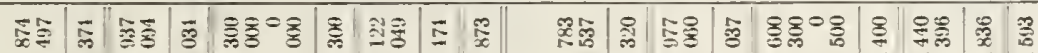

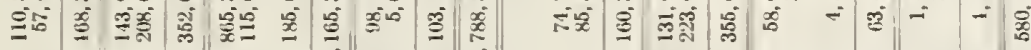

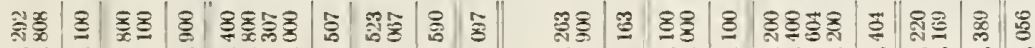

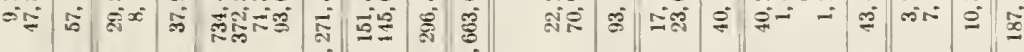

成吉|

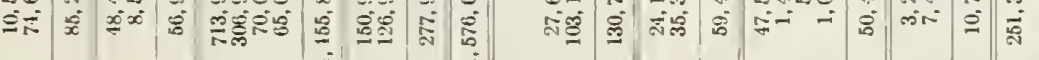

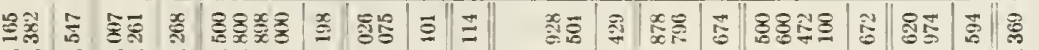
ป气

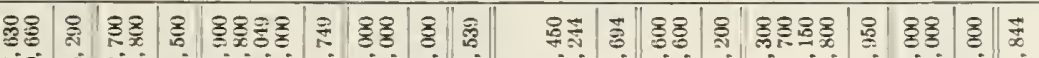

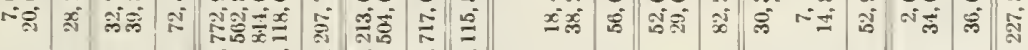

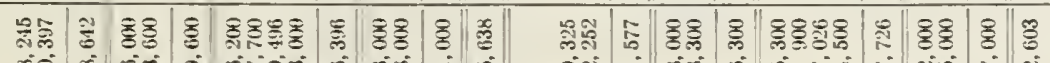

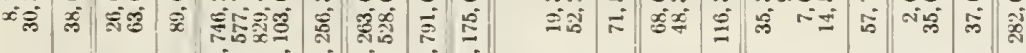

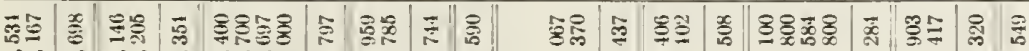

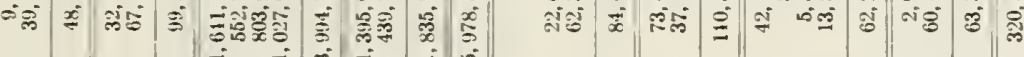

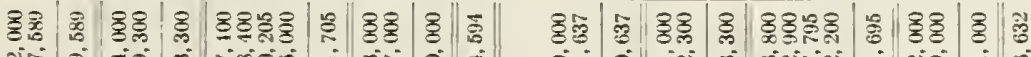

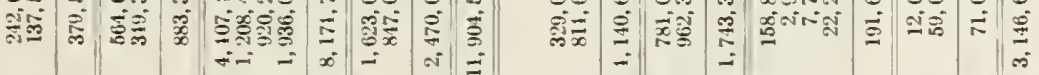

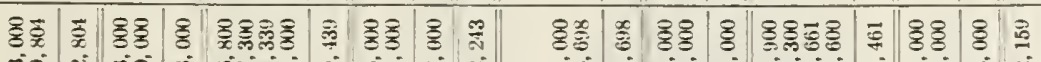
ภำ

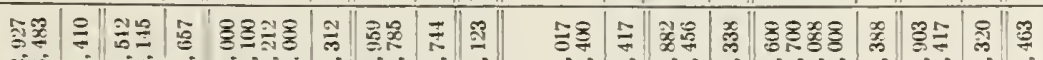

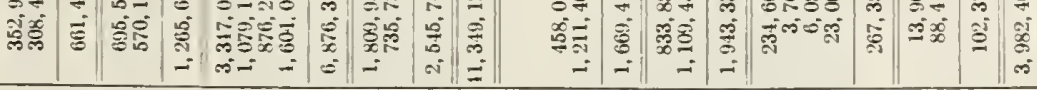

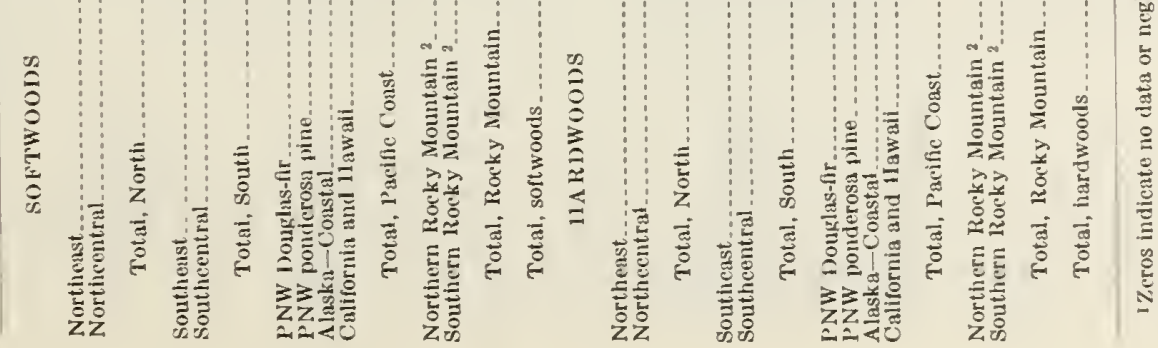


$\stackrel{8}{\S}$

$\stackrel{\infty}{3}$

$\stackrel{2}{\frac{1}{2}}$

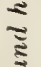

密

突

छ

$\overrightarrow{3}$

(ู)

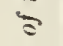

育

3

(ำ

ปัँ

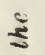

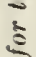

(2)

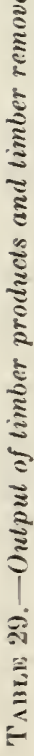

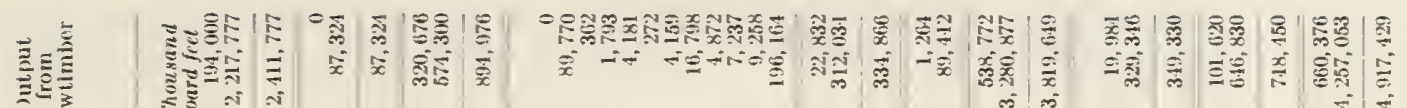

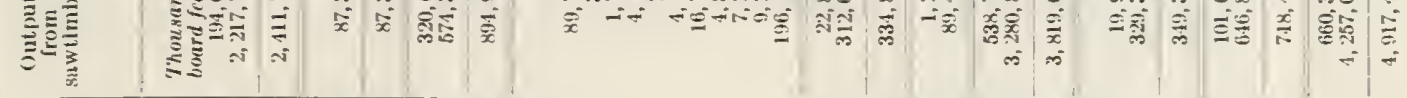

|

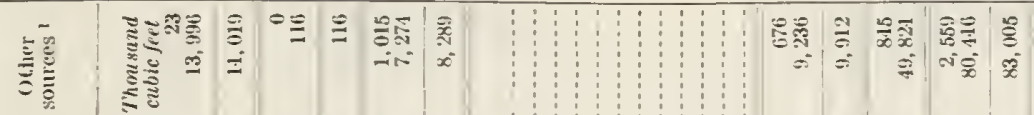

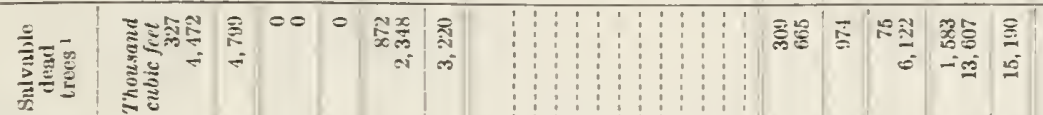

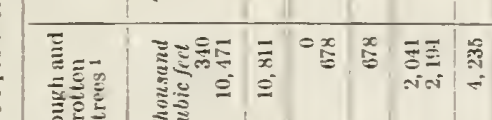

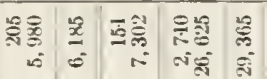

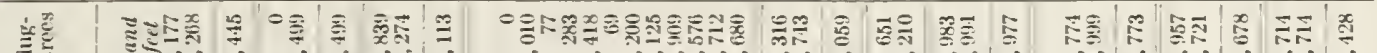

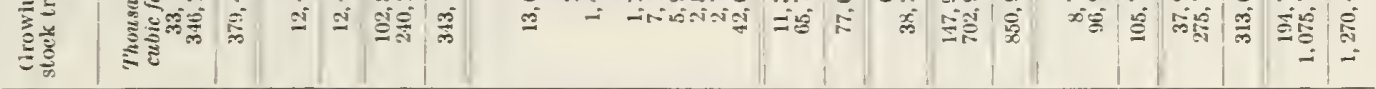

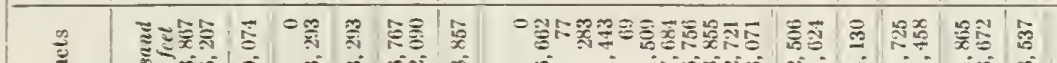

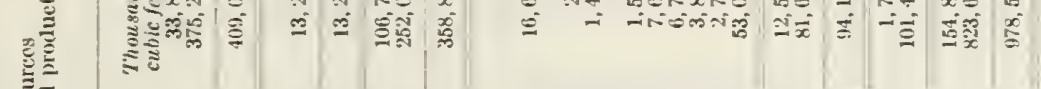

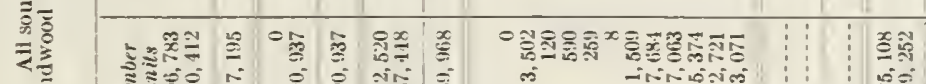

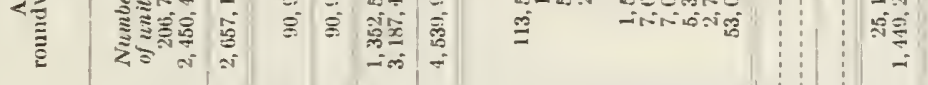

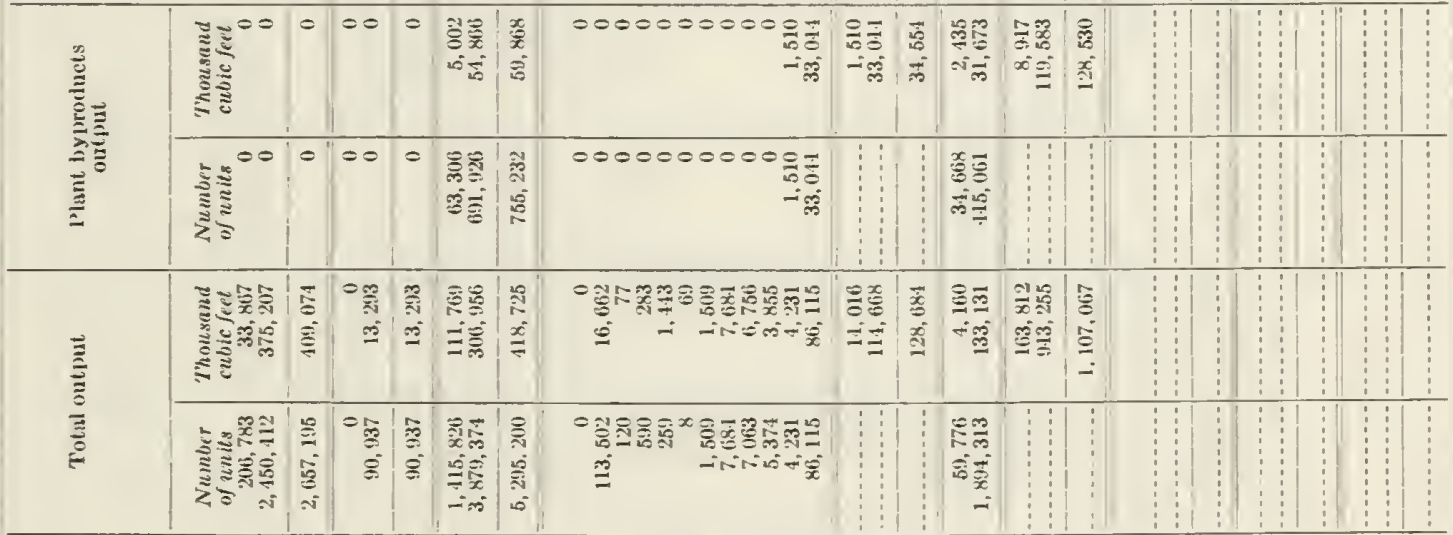

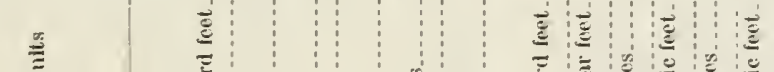

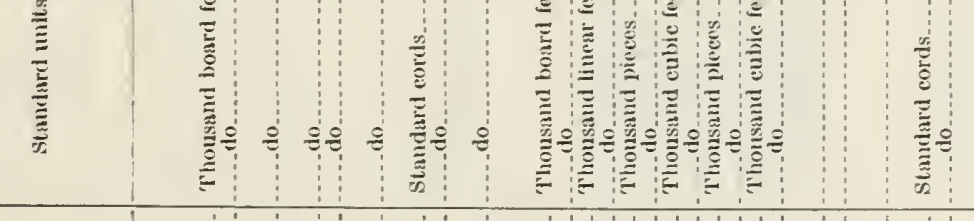

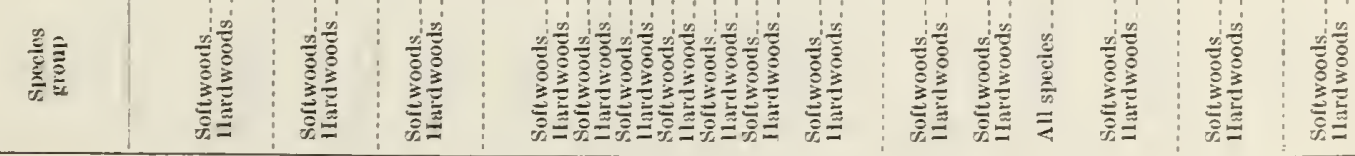

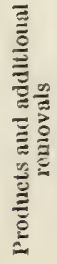

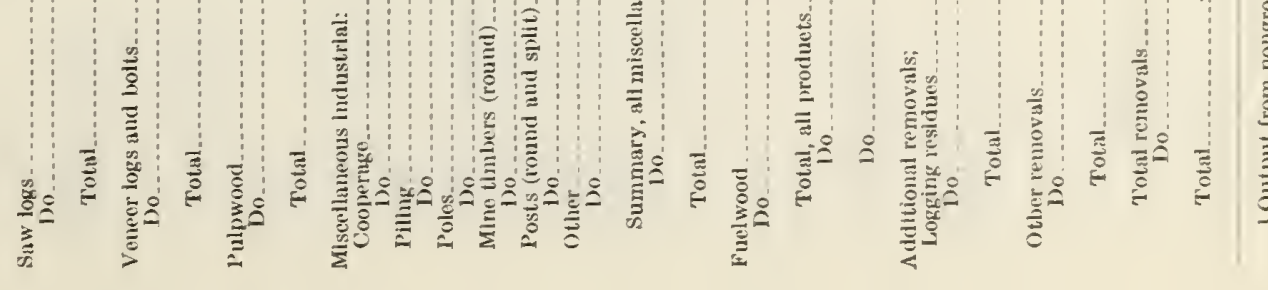

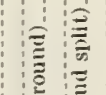




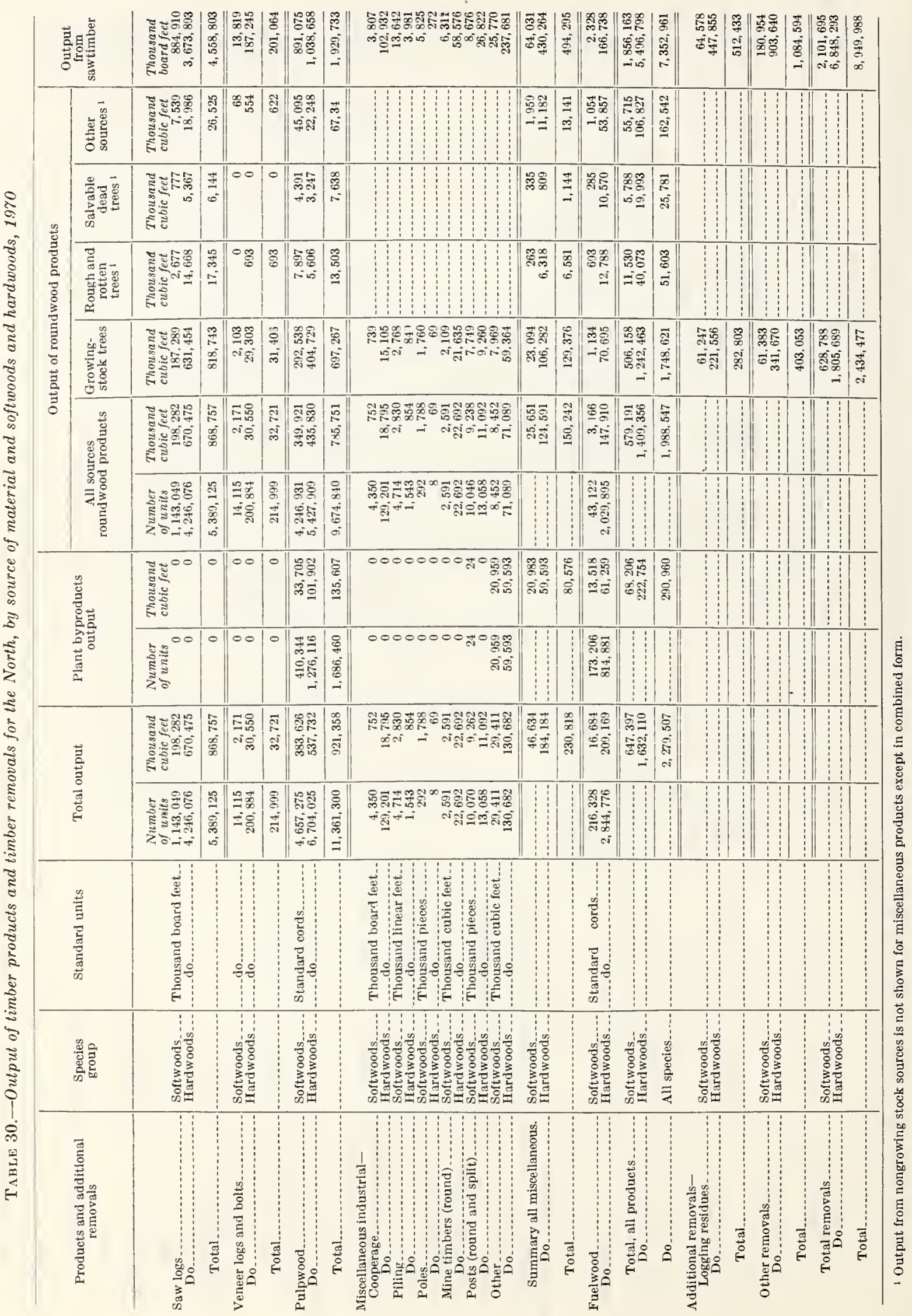




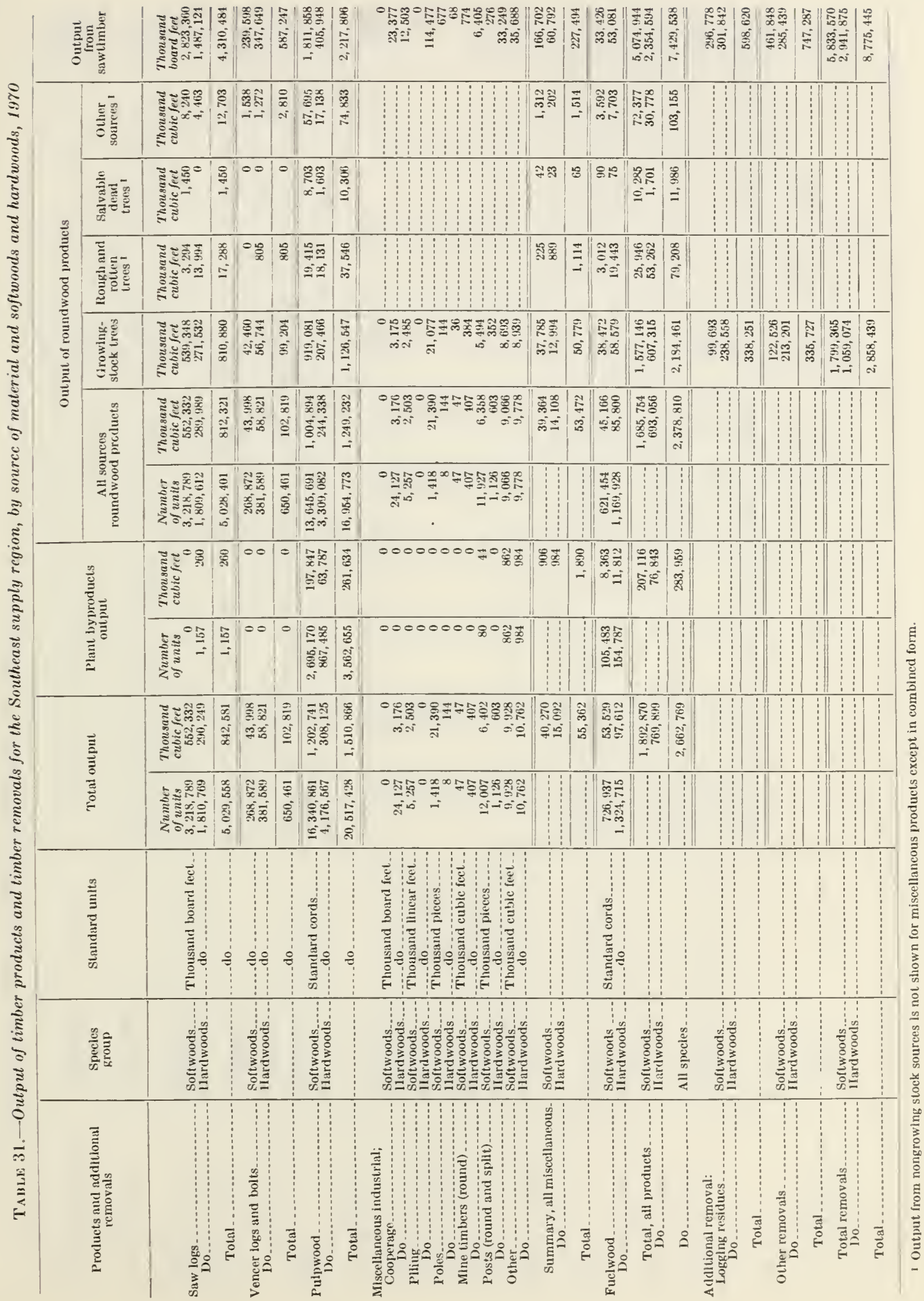




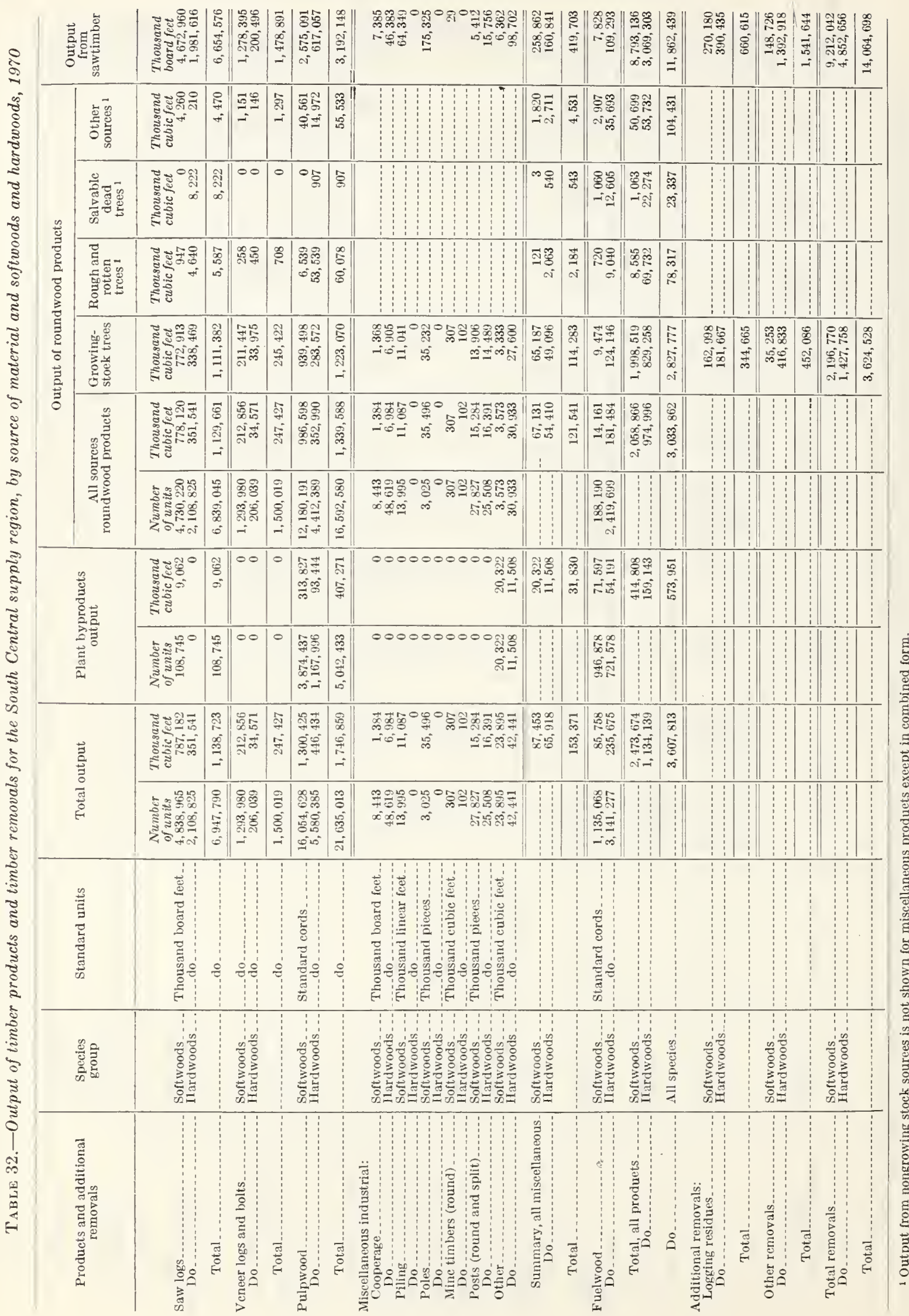




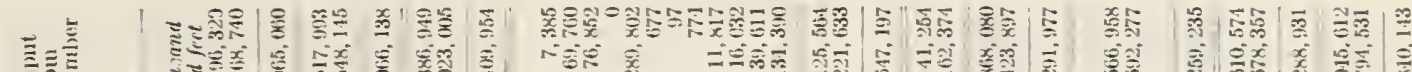

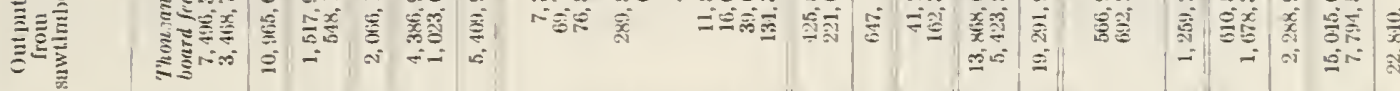

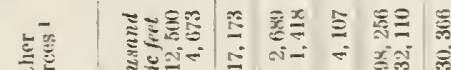

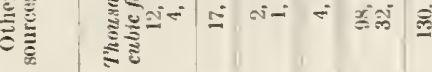

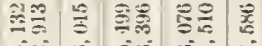

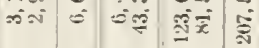

\begin{tabular}{|c|c|c|c|c|c|c|c|c|c|c|c|c|c|c|c|c|c|c|}
\hline 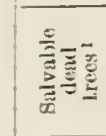 & 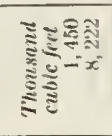 & : & $=0$ & $=$ & $\begin{array}{l}\sum_{i=0} \\
x \rightarrow=0\end{array}$ & $\begin{array}{l}\stackrel{0}{=} \\
= \\
=\end{array}$ & & 果 & है & 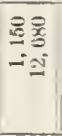 & 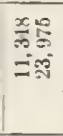 & 紟 & & & & & & \\
\hline 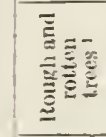 & 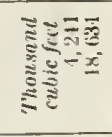 & 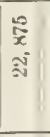 & - & $=$ & 政是 & S & & 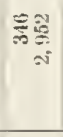 & $\begin{array}{l}x \\
\text { 羙 } \\
\text { in }\end{array}$ & 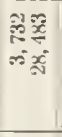 & 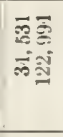 & 常 & & & & & & \\
\hline 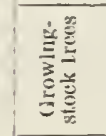 & 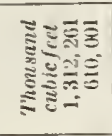 & 喊 & 象 & 密 & 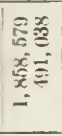 & 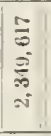 & 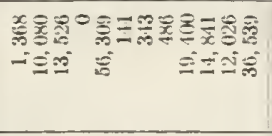 & 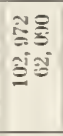 & 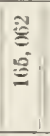 & 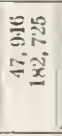 & 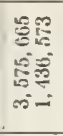 & 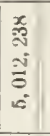 & 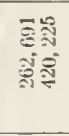 & 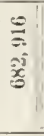 & 福 & $\begin{array}{l}\frac{m}{x} \\
\frac{x}{x} \\
\frac{n}{x}\end{array}$ & 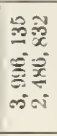 & 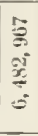 \\
\hline \multirow{2}{*}{ 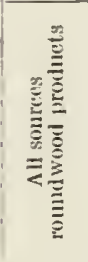 } & 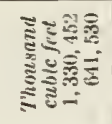 & 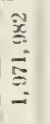 & 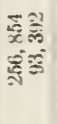 & 竞 & 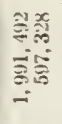 & 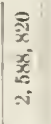 & 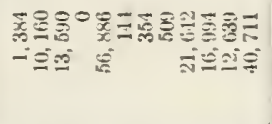 & $\begin{array}{l}5 x \\
50 \\
5 x\end{array}$ & $\begin{array}{l}\frac{m}{5} \\
\frac{1}{2} \\
\frac{5}{2}\end{array}$ & 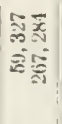 & 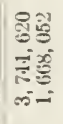 & 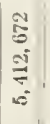 & & & & & & \\
\hline & 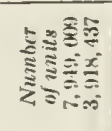 & 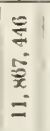 & 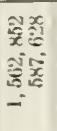 & 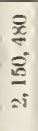 & 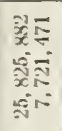 & 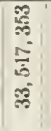 & 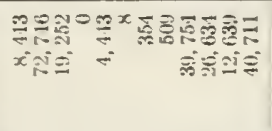 & $\vdots$ & & 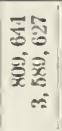 & & 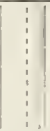 & & & & & & \\
\hline \multirow{2}{*}{ 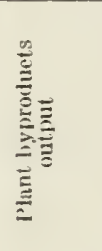 } & 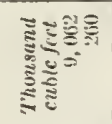 & $\stackrel{1}{=}$ & $=0$ & $=$ & 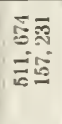 & 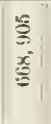 & 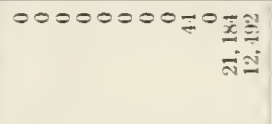 & 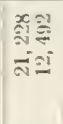 & 胥 & 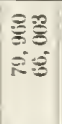 & 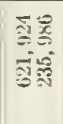 & 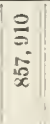 & & & & & & \\
\hline & 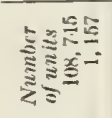 & 产 & $=0$ & $=$ & 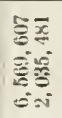 & $\mid$ & 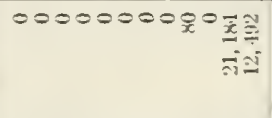 & & & 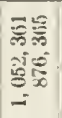 & & & & & & & & \\
\hline
\end{tabular}

$\Xi$

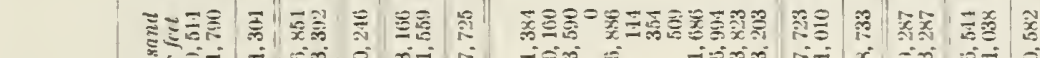

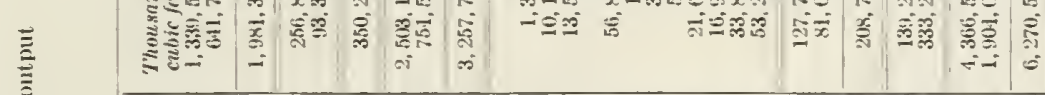

言

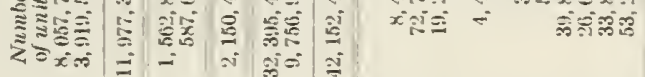

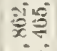

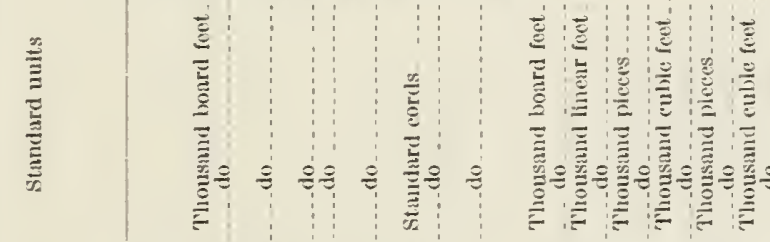

垔

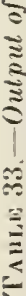

$\stackrel{2}{E}$

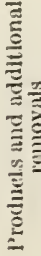

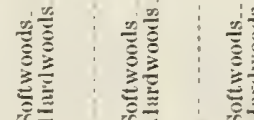

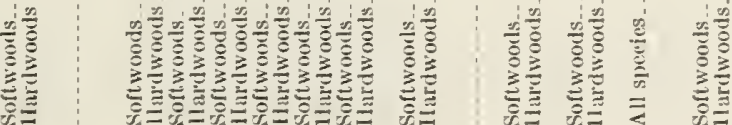

递

次

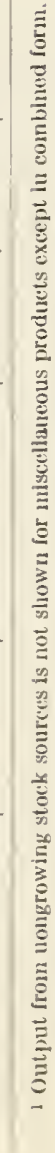




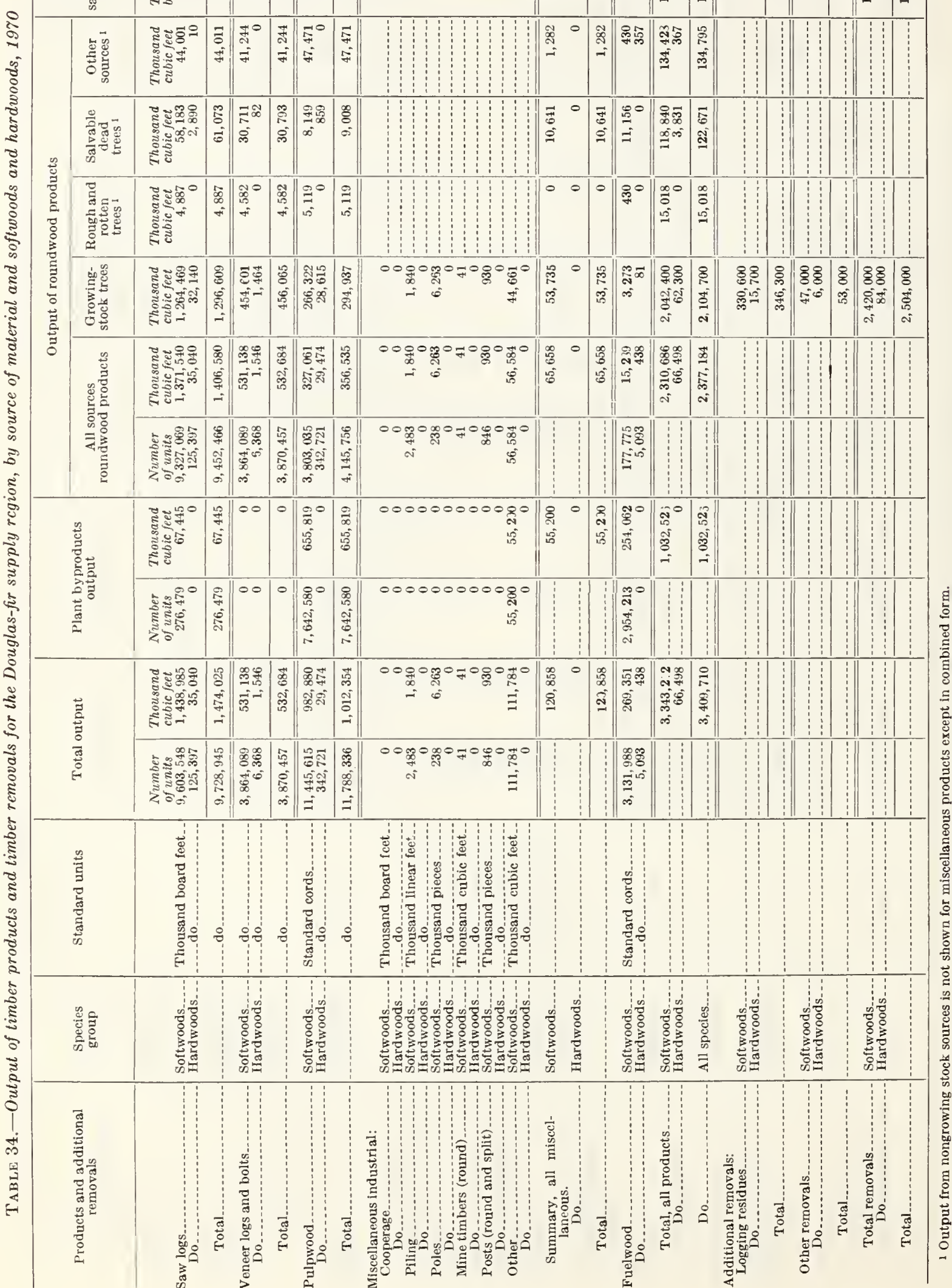




\begin{tabular}{|c|c|c|c|c|c|c|c|c|c|c|c|c|c|c|c|c|c|c|}
\hline 亥部产 & 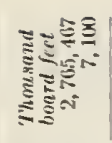 & 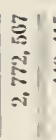 & 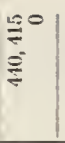 & & 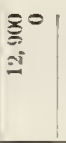 & 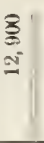 & 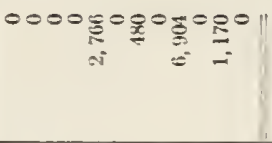 & $\begin{array}{l}\text { 禺 } \\
=\end{array}$ & 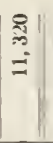 & $\mid$ & 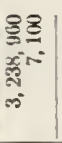 & 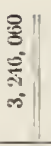 & 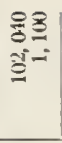 & $\frac{P}{2 ! 1}$ & 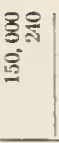 & 焉 & 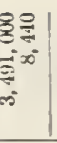 & 家 \\
\hline 讋总 & 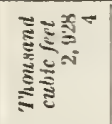 & $\begin{array}{l}\text { 尊 } \\
\text { - }\end{array}$ & 80 & : & 00 & $=$ & & $\hat{z}^{\circ}$ & 愛 & $\infty$ & $\begin{array}{c}\overbrace{}^{-} \\
\overbrace{}^{-}\end{array}$ & 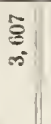 & & & & & & \\
\hline 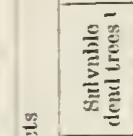 & 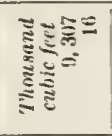 & $=$ & $5^{\circ}$ & 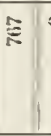 & $=0$ & $=$ & & $\vec{N}^{\circ}$ & $\overline{\mathrm{N}}$ & 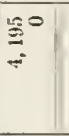 & $\begin{array}{l}8=0 \\
5\end{array}$ & 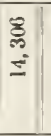 & & & & & & \\
\hline 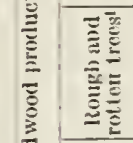 & 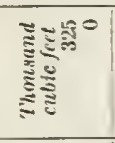 & 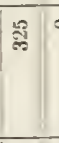 & $=0$ & 0 & eo & 0 & & No & N & $\begin{array}{l}x=1 \\
x=0 \\
=-1\end{array}$ & 然 & $=$ & & & & & & \\
\hline 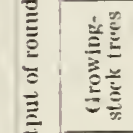 & 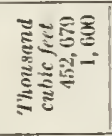 & 䨠 & $\begin{array}{l}\varrho \\
\vdots \\
x^{-}\end{array}$ & $\frac{5}{0}$ & $\begin{array}{l}\vec{r}_{x}= \\
\text { sive }\end{array}$ & $\begin{array}{l}\underset{x}{x} \\
s\end{array}$ & 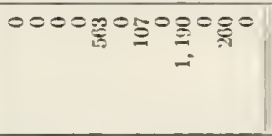 & $\frac{20}{i}$ & ลิ & $=$ & 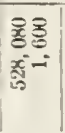 & 要 & 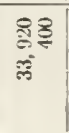 & 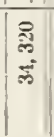 & $\begin{array}{l}8 \% \\
\frac{8}{5}\end{array}$ & $\mid \begin{array}{l}0 \\
0 \\
0 \\
-1\end{array}$ & 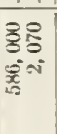 & $\mid \begin{array}{l}8 \\
8 \\
x \\
x \\
x \\
6\end{array}$ \\
\hline 童 & 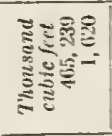 & 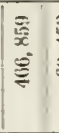 & 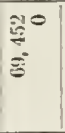 & $\frac{i}{\dot{\Xi}}$ & $\begin{array}{l}\sqrt{x}=0 \\
\text { vi }\end{array}$ & $\begin{array}{l}\vec{x} \\
\text { oi }\end{array}$ & 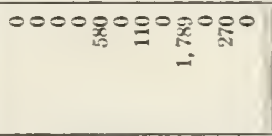 & $\underbrace{\circ}_{i}$ & 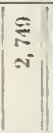 & 管 & 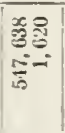 & 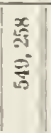 & & & & & & \\
\hline 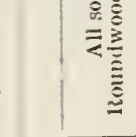 & 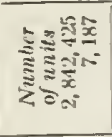 & 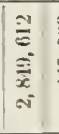 & $\begin{array}{l}x= \\
x=0 \\
x=2\end{array}$ & $\mid$ & 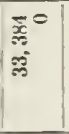 & 赢 & 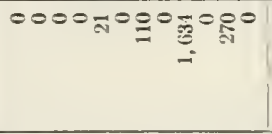 & & & $\begin{array}{l}0^{\circ} \\
50\end{array}$ & & & & & & & & \\
\hline 总 & 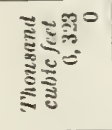 & 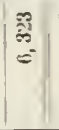 & 00 & $=$ & 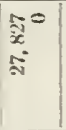 & 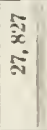 & 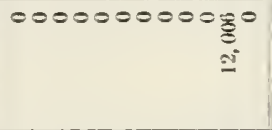 & $\begin{array}{l}8^{\circ} \\
2^{\circ}\end{array}$ & $\mid \begin{array}{ll}0 \\
\frac{\pi}{2}\end{array}$ & 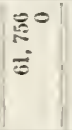 & 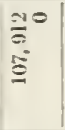 & 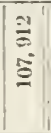 & & & & & & \\
\hline 氦 & 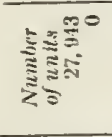 & 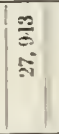 & 00 & $=$ & 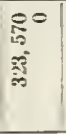 & 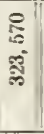 & $\begin{array}{r}00000000000_{0}^{\circ} \\
I^{1}\end{array}$ & 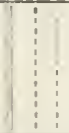 & & $\begin{array}{l}\frac{x}{3} \\
\frac{x}{2}\end{array}$ & & : & & & & & & \\
\hline 訔 & 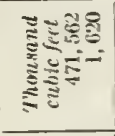 & $\mid \begin{array}{l}3 \\
\frac{1}{x} \\
\frac{2}{2}\end{array}$ & $\begin{array}{l}\text { 춘 } \\
\text { sं }\end{array}$ & $\frac{3}{3}$ & 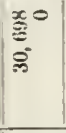 & 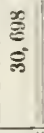 & 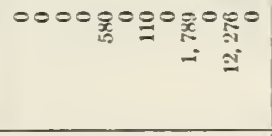 & 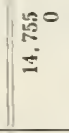 & 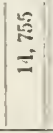 & $\begin{array}{l}x_{5}^{\circ} \\
3^{\circ}\end{array}$ & 施商 & 兽 & & & & & & \\
\hline E & 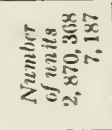 & 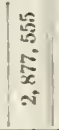 & 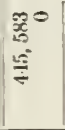 & $\mid$ & 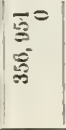 & 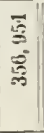 & 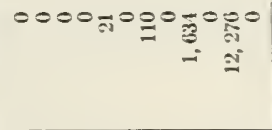 & & & 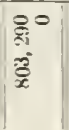 & & & & & & & & \\
\hline 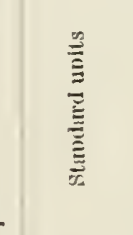 & 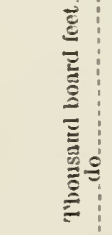 & $\stackrel{0}{\square}$ & 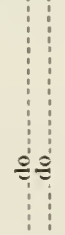 & $\stackrel{\Xi}{\Xi}$ & $\begin{array}{cc} \\
\vdots \\
0\end{array}$ & ğ & 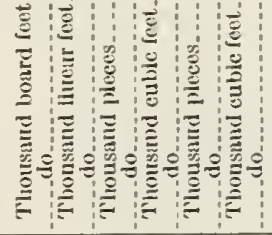 & & & : & & & & & & & & \\
\hline
\end{tabular}




\begin{tabular}{|c|c|c|c|c|c|c|c|c|c|c|c|c|c|c|c|c|c|c|c|}
\hline \multicolumn{2}{|c|}{ 范总总 } & 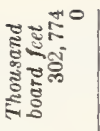 & 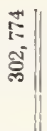 & 00 & & 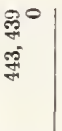 & 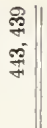 & ( & ( & & 00 & $\mid$ & $\mid$ & $\begin{array}{l}\vec{\infty}^{\circ} \\
\vec{\infty}^{-0} \\
\vec{R}^{-1}\end{array}$ & $\begin{array}{l}\bar{\alpha} \\
0 \\
\bar{R}^{2}\end{array}$ & 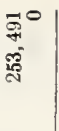 & 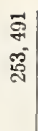 & $\begin{array}{l}l^{\circ} \\
6 \\
0 \\
8 \\
8 \\
-1\end{array}$ & - \\
\hline \multirow{6}{*}{ 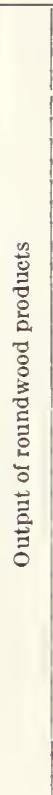 } & 总总 & 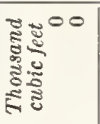 & $\circ$ & 00 & 0 & 00 & 0 & & 00 & $\circ \|$ & $00 \|$ & 100 & $\circ$ & & & & & & \\
\hline & 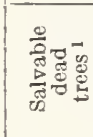 & 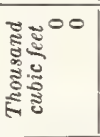 & $\circ$ & 00 & $\circ$ & $\begin{array}{l}\mathbb{N}^{\circ} \\
=\end{array}$ & $\begin{array}{l}\text { 岕 } \\
- \\
-\end{array}$ & & $\infty$ & $\circ \|$ & 00 & $\begin{array}{l}\mathfrak{A}^{\circ} \\
- \\
-\end{array}$ & : & & & & & & \\
\hline & 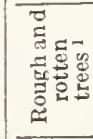 & 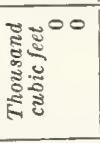 & 0 & 00 & $\circ$ & 00 & 0 & & 00 & $\circ$ & $\infty$ & 00 & 0 & & & & & & \\
\hline & 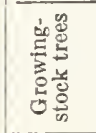 & 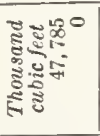 & $\begin{array}{l}2 \\
2 \\
2 \\
5 \\
5\end{array}$ & 00 & 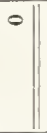 & $\begin{array}{l}20 \\
g \\
8 \\
8 \\
8\end{array}$ & 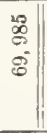 & 000000000000 & 00 & $\circ$ & 00 & $\mid \begin{array}{l}R^{\circ} \\
\vdots \\
\vdots \\
\approx\end{array}$ & \begin{tabular}{|l|}
8 \\
\multirow{2}{*}{} \\
$=$ \\
$=$
\end{tabular} & 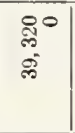 & 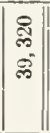 & 100 & 0 & $\begin{array}{l}8^{\circ} \\
0 \\
5 \\
5 \\
-1\end{array}$ & 8 \\
\hline & \multirow{2}{*}{ 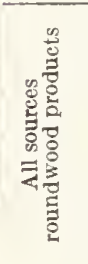 } & 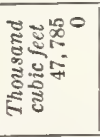 & $\begin{array}{l}0 \\
0 \\
0 \\
-5\end{array}$ & 00 & $\circ$ & 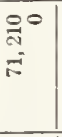 & 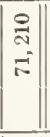 & 000000000000 & $\infty$ & $=$ & $\infty$ & $\mid \begin{array}{l}\mathrm{w}_{0}^{\circ} \\
\mathrm{d} \\
0 \\
=\end{array}$ & $\begin{array}{l}\text {. } \\
\text { के } \\
\infty \\
=\end{array}$ & & & & & & \\
\hline & & 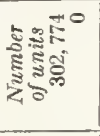 & 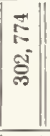 & 00 & $\circ$ & $\begin{array}{l}\text { స్ } \\
\text { వ్ర }\end{array}$ & 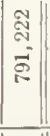 & 00000000 & & & 00 & & $\begin{array}{c:c}\vdots \\
\vdots \\
\vdots \\
\vdots\end{array}$ & & & & & & \\
\hline & \multirow{2}{*}{ 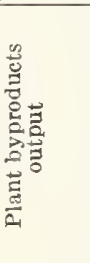 } & 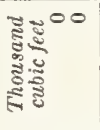 & 0 & 100 & $\circ$ & $\begin{array}{l}\mathscr{D}_{0}^{\circ} \\
\mathscr{c}^{\circ}\end{array}$ & $\left|\begin{array}{l|} \\
8 \\
\infty \\
\infty\end{array}\right|$ & 000000000000 & $|\infty|_{1}-1+2$ & $\circ \|$ & 00 & $\left|\begin{array}{l}\infty \\
0 \\
\infty \\
\infty\end{array}\right|$ & $\left|\begin{array}{c|}\mathbf{s} \\
0 \\
\infty \\
\infty\end{array}\right|$ & & & & & & \\
\hline & & है: & 0 & 00 & $\circ$ & 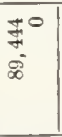 & $\left|\begin{array}{l}5 \\
7 \\
\infty \\
\infty\end{array}\right|$ & 000000000000 & & : & 00 & & 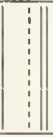 & & & & & & \\
\hline & \multirow{2}{*}{ 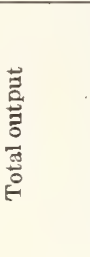 } & 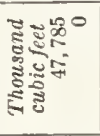 & 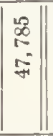 & 00 & $\circ$ & $\begin{array}{l}\mathscr{D}_{0}^{\circ} \\
\hat{i}^{\circ}\end{array}$ & 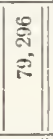 & 000000000000 & $\infty$ & 0 & $00 \mid$ & $\mid$\begin{tabular}{l|}
$\vec{o}^{\circ}$ \\
$\mathrm{a}$ \\
$\mathrm{a}$
\end{tabular} & $\mid$\begin{tabular}{|c|}
$\vec{g}$ \\
$\overrightarrow{\mathrm{g}}$ \\
$\mathrm{G}$
\end{tabular} & & & & & & \\
\hline & & 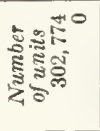 & 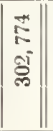 & 00 & 0 & $\begin{array}{l}\mathscr{E}_{0}^{\circ} \\
0^{\circ} \\
8 \\
0\end{array}$ & $\left|\begin{array}{l}0 \\
0 \\
0 \\
0 \\
\infty \\
\infty\end{array}\right|$ & 000000000000 & & 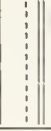 & $\mid 00$ & & & & & & & & \\
\hline & 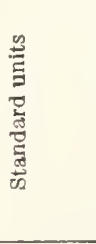 & 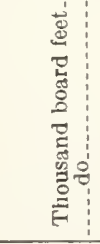 & 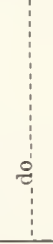 & 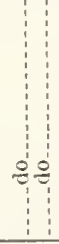 & '̊ & 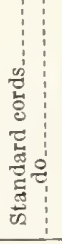 & ְִ & 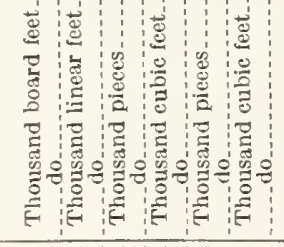 & & & \begin{tabular}{l|l} 
& \\
& \\
0 & \\
0 \\
0
\end{tabular} & & & & & & & & \\
\hline & 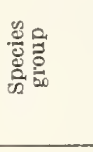 & 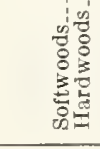 & & 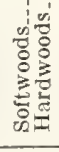 & & 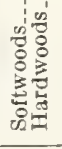 & & 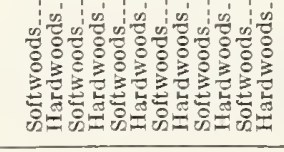 & 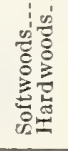 & & 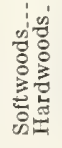 & 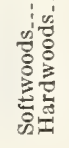 & 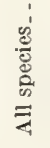 & 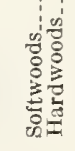 & & 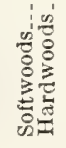 & & 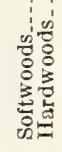 & \\
\hline & 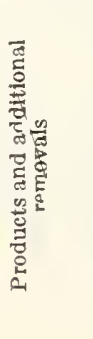 & 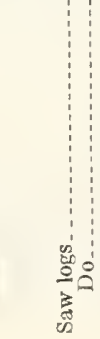 & 这 & 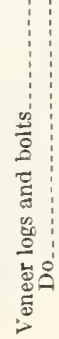 & & $\begin{array}{l}1 \\
0 \\
0 \\
0 \\
0\end{array}$ & 京 & 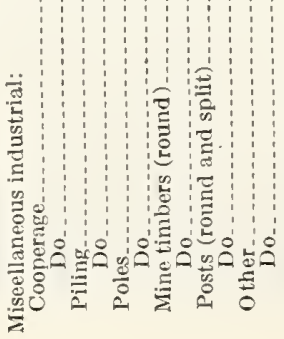 & 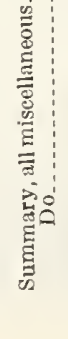 & & 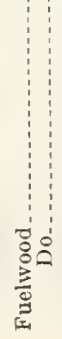 & 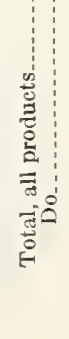 & $\stackrel{8}{\circ}$ & 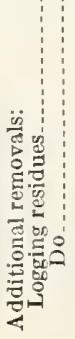 & & 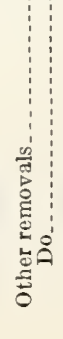 & हึ & 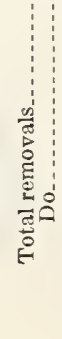 & 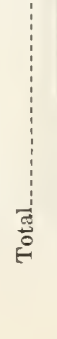 \\
\hline
\end{tabular}




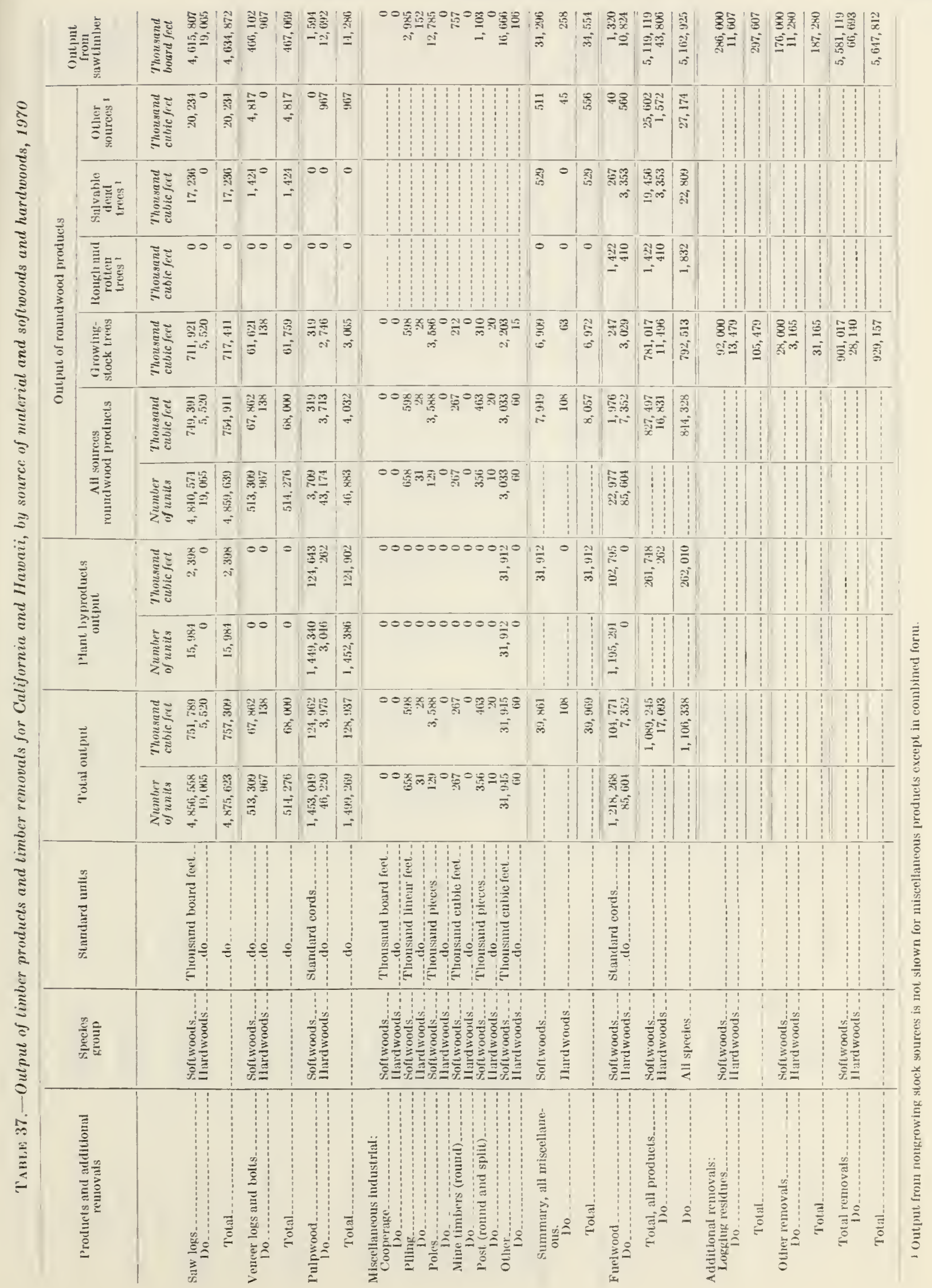









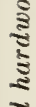

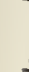

西

(2)

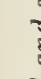

.

(3)

(3)

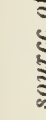

3

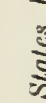

ะี

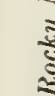

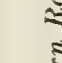

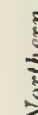

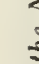

s

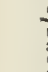

.

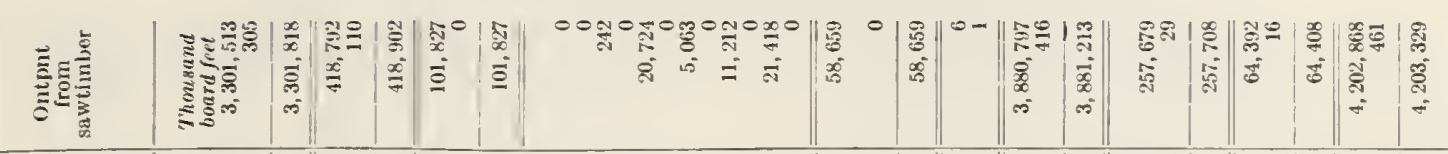

\begin{tabular}{|c|c|c|c|c|c|c|c|c|c|c|c|c|c|c|c|c|c|c|c|}
\hline & 总密 & 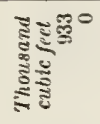 & 号 & $\mathscr{\infty}^{-}$ & $\infty$ & 50 & $\overline{5}$ & & $\notin 0$ & 19 & $\vec{m}^{*}$ & $\begin{array}{l}8 \infty \\
= \\
=\end{array}$ & 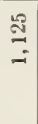 & & & & & & \\
\hline & 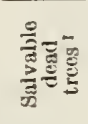 & 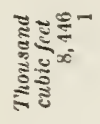 & $\stackrel{\sum}{x}$ & : & $\stackrel{\square}{:-1}$ & $\begin{array}{l}﹎{0}^{0} \\
-=\end{array}$ & $\stackrel{\frac{T}{\sigma}}{\sigma}$ & & & $\stackrel{9}{7}$ & ఫ్ & 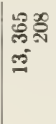 & 疍 & & & & & & \\
\hline & 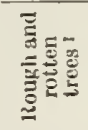 & 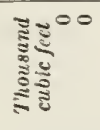 & 0 & loo & $\circ$ & $\overrightarrow{\mathrm{d}}^{\circ}=$ & : & & 잉 & . & $\notin 0$ & $9^{\circ}$ & $\frac{9}{1}$ & & & & & & \\
\hline & 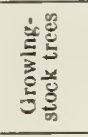 & 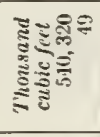 & 勇 & 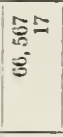 & $\begin{array}{c}\vec{x} \\
\substack{x \\
s} \\
s\end{array}$ & $\begin{array}{l}\frac{x^{0}}{x^{2}} \\
\stackrel{\infty}{a}\end{array}$ & $\begin{array}{c}\bar{x} \\
\underset{x}{\infty}\end{array}$ & 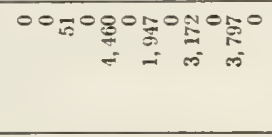 & & 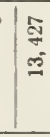 & $=-$ & 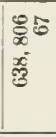 & 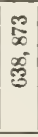 & $\begin{array}{l}\overrightarrow{\mathrm{g}}= \\
\vec{\infty}\end{array}$ & 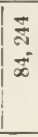 & 俤- & 怘 & 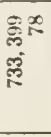 & 点 \\
\hline & \multirow{2}{*}{ 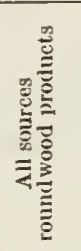 } & 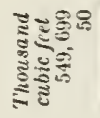 & 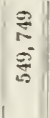 & $\begin{array}{l}1 \infty \\
0 \\
0 \\
0 \\
0\end{array}$ & $\mid$ & 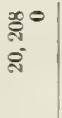 & 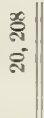 & 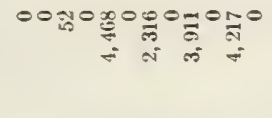 & & 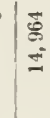 & 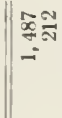 & 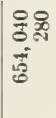 & 幽 & & & & & & \\
\hline & & 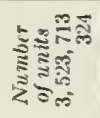 & ! & 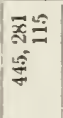 & 品 & 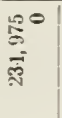 & 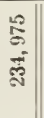 & 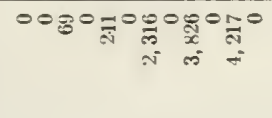 & & & 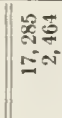 & & & & & & & & \\
\hline & \multirow{2}{*}{ 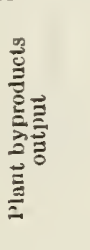 } & 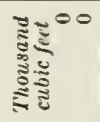 & 10 & 00 & 0 & 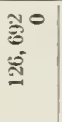 & 害 & $\begin{array}{r}000000000000 \\
= \\
.\end{array}$ & & $\stackrel{?}{=}$ & 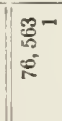 & 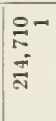 & $\begin{array}{l}\bar{\Xi} \\
\frac{\pi}{\pi}\end{array}$ & & & & & & \\
\hline & & 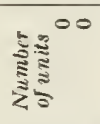 & $\theta$ & $\theta \theta$ & $\theta$ & 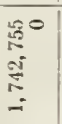 & 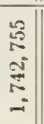 & 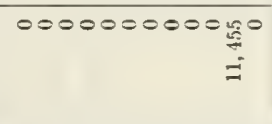 & & & 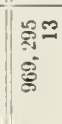 & & & & & & & & \\
\hline & \multirow{2}{*}{ 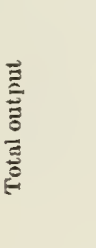 } & 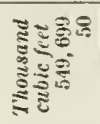 & 余 & 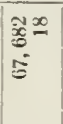 & : & 然是 & 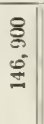 & 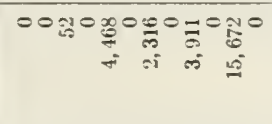 & & 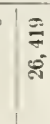 & 总: & 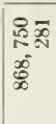 & $\begin{array}{l}\overline{8} \\
\overline{8}\end{array}$ & & & & & & \\
\hline & & 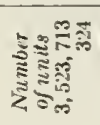 & $\mid$ & 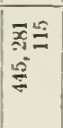 & 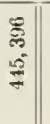 & 邑 & 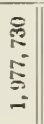 & 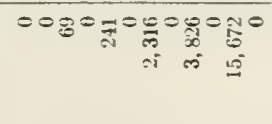 & & & 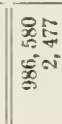 & & & & & & & & \\
\hline
\end{tabular}

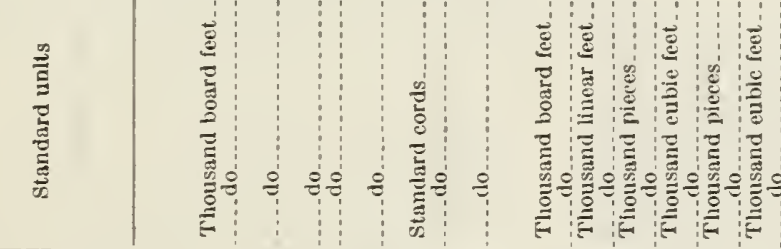

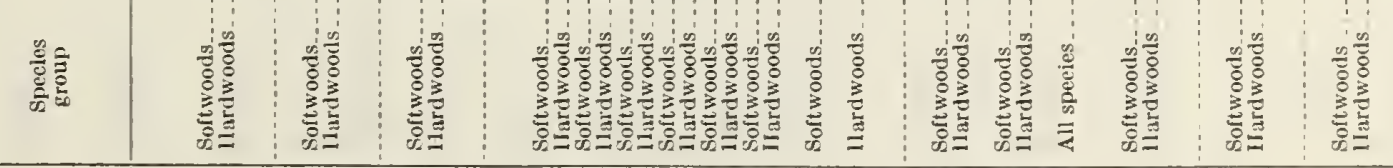

氖

을 


\begin{tabular}{|c|c|c|c|c|c|c|c|c|c|c|c|c|c|c|c|c|c|c|c|}
\hline & & 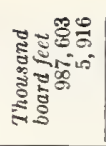 & 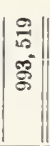 & $\mid \begin{array}{l}0^{\circ} \\
\tilde{m}^{\circ}\end{array}$ & 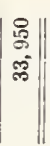 & 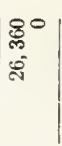 & 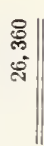 & 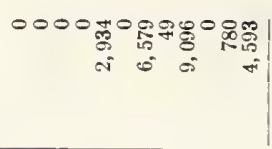 & 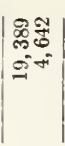 & $\left|\begin{array}{|c|}\overrightarrow{\mathscr{g}} \\
\overrightarrow{\mathrm{n}}\end{array}\right|$ & & 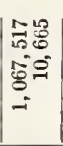 & 然 & 每器 & 营 & 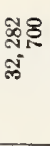 & 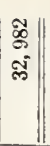 & 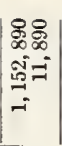 & 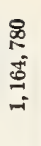 \\
\hline & 点象 & 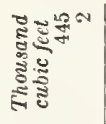 & F & శ్లా & ฉి| & 00 & 0 & & $\nabla^{\infty}$ & is & 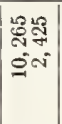 & 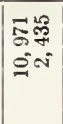 & 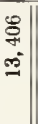 & & & & & & \\
\hline & 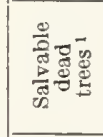 & 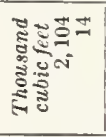 & $\begin{array}{l}\infty \\
= \\
\sim\end{array}$ & $9^{\circ}$ & $\stackrel{9}{9}$ & 00 & 0 & & : & 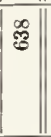 & 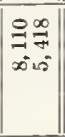 & 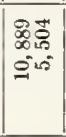 & 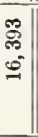 & & & & & & \\
\hline 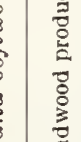 & 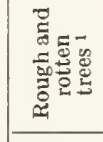 & 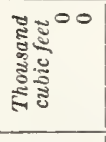 & $0 \mid$ & 100 & $\circ$ & 00 & 0 & & $\bullet_{\infty}$ & 18 & 100 & $\varphi_{\infty}$ & 8 & & & & & & \\
\hline 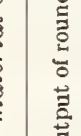 & 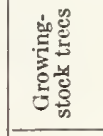 & 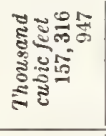 & 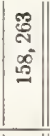 & $\begin{array}{l}\mathscr{E}^{\circ} \\
n^{\circ}\end{array}$ & $\begin{array}{c}\mathscr{A} \\
\text { and } \\
\text { in }\end{array}$ & $\mid \begin{array}{l}150 \\
0 \\
\infty \\
\infty \\
\infty\end{array}$ & $\left|\begin{array}{l}1 \\
0 \\
0 \\
\infty \\
\infty\end{array}\right|$ & 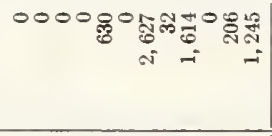 & 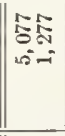 & 营 & 䒼。 & 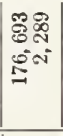 & $\begin{array}{l}\stackrel{\infty}{\infty} \\
\stackrel{\infty}{\infty} \\
\stackrel{\infty}{=}\end{array}$ & 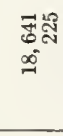 & 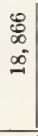 & 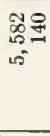 & 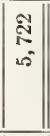 & 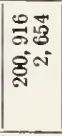 & \\
\hline$\tilde{\sigma}$ & 焉 & 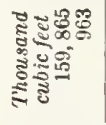 & $\left|\begin{array}{c}\infty \\
\alpha \\
\infty \\
0 \\
0 \\
-1\end{array}\right|$ & $\begin{array}{l}\infty \\
\text { 禹 } \\
\text { in }\end{array}$ & 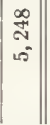 & $\mid \begin{array}{l}150 \\
\infty \\
\infty \\
\infty \infty^{\circ}\end{array}$ & $\begin{array}{l}1 \\
0 \\
\infty \\
\infty \\
\infty\end{array}$ & 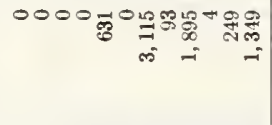 & 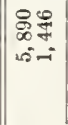 & 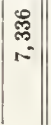 & 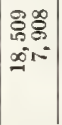 & 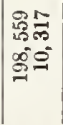 & $\begin{array}{l}0 \\
\infty \\
\infty \\
\overbrace{}^{\circ}\end{array}$ & & & & & & \\
\hline & 行 & 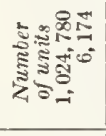 & 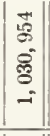 & $\begin{array}{l}m_{0}^{\circ} \\
i^{\circ}\end{array}$ & 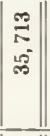 & $\begin{array}{l}\mathrm{c}_{0}^{\circ} \\
\overbrace{}^{\circ} \\
9\end{array}$ & 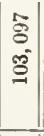 & 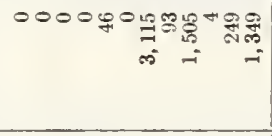 & 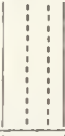 & 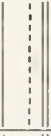 & 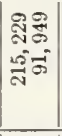 & & & & & & & & \\
\hline & 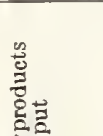 & 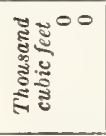 & $0 \mid$ & 100 & 0 & \begin{tabular}{|l}
$\operatorname{y}^{2}$ \\
$\min ^{2}$
\end{tabular} & 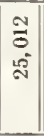 & $0000000000 \frac{\bar{\sigma}}{\text { के }}$ & 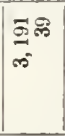 & 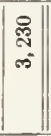 & 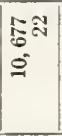 & $\mid \begin{array}{l}\infty \\
\infty \\
\infty \\
\infty \\
\infty \\
\infty\end{array}$ & $\begin{array}{c}\text { Fे } \\
\text { के } \\
\infty \\
\infty\end{array}$ & & & & & & \\
\hline & $\begin{array}{l}\overrightarrow{3} \\
\overrightarrow{\vec{m}} \\
\frac{\mathrm{m}}{2}\end{array}$ & 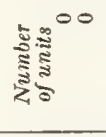 & 0 & 100 & 10 & $\mid$ & 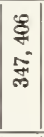 & 0000000000 志屜 & 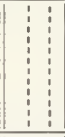 & & 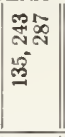 & & & & & & & & \\
\hline & $\begin{array}{l}\vec{z} \\
\vec{z}\end{array}$ & 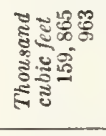 & 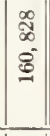 & $\begin{array}{l}\infty \\
\mathcal{Z}^{\circ} \\
\text { is }\end{array}$ & $\begin{array}{c}\stackrel{\infty}{\mathcal{T}} \\
15\end{array}$ & 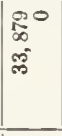 & $\begin{array}{l}\mathbb{5} \\
\infty \\
\infty \\
\infty \\
\infty\end{array}$ & 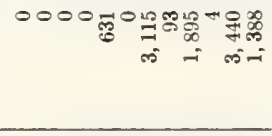 & 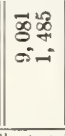 & 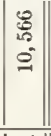 & 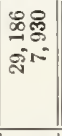 & 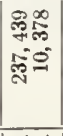 & 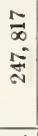 & & & & & & \\
\hline & 要 & 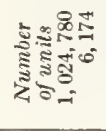 & 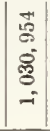 & $\begin{array}{l}m^{\circ} \\
n^{\circ}\end{array}$ & $\left|\begin{array}{c|}m \\
i \\
2 \\
m\end{array}\right|$ & 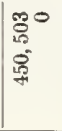 & 密 & 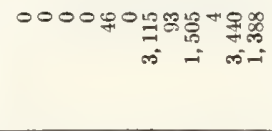 & & & 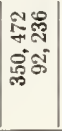 & & & & & & & & \\
\hline
\end{tabular}

(⿸丆口

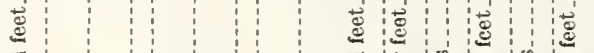

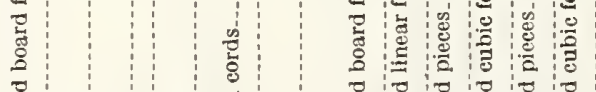

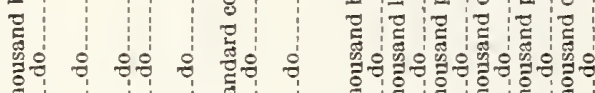

ह $\quad$ का

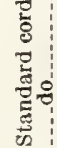

난

है

के

$\frac{\sqrt[3]{3}}{3}$

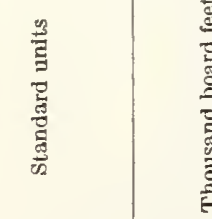

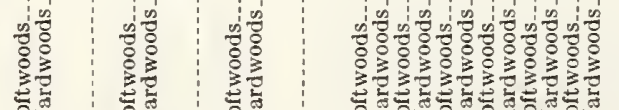

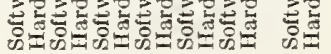

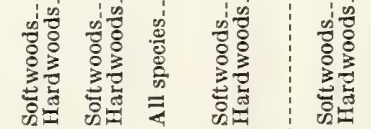

要这

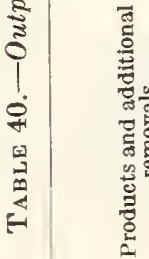

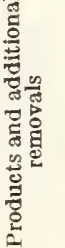

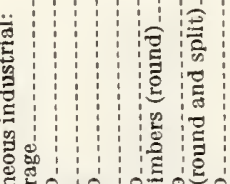

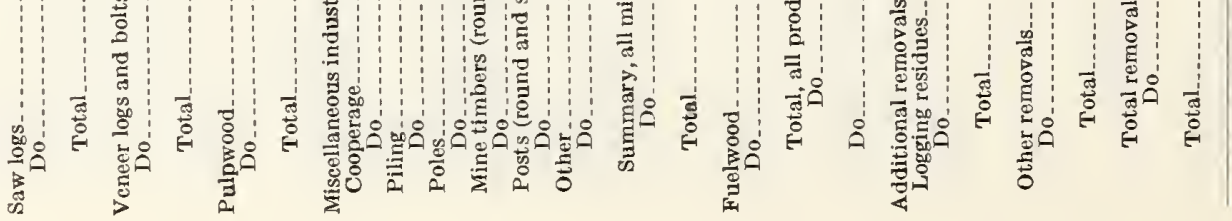

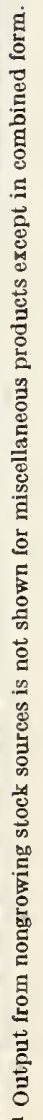




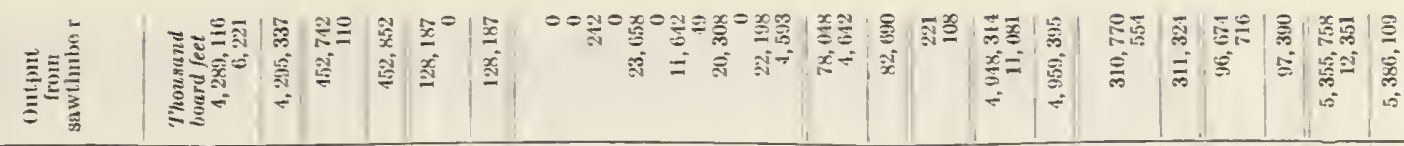

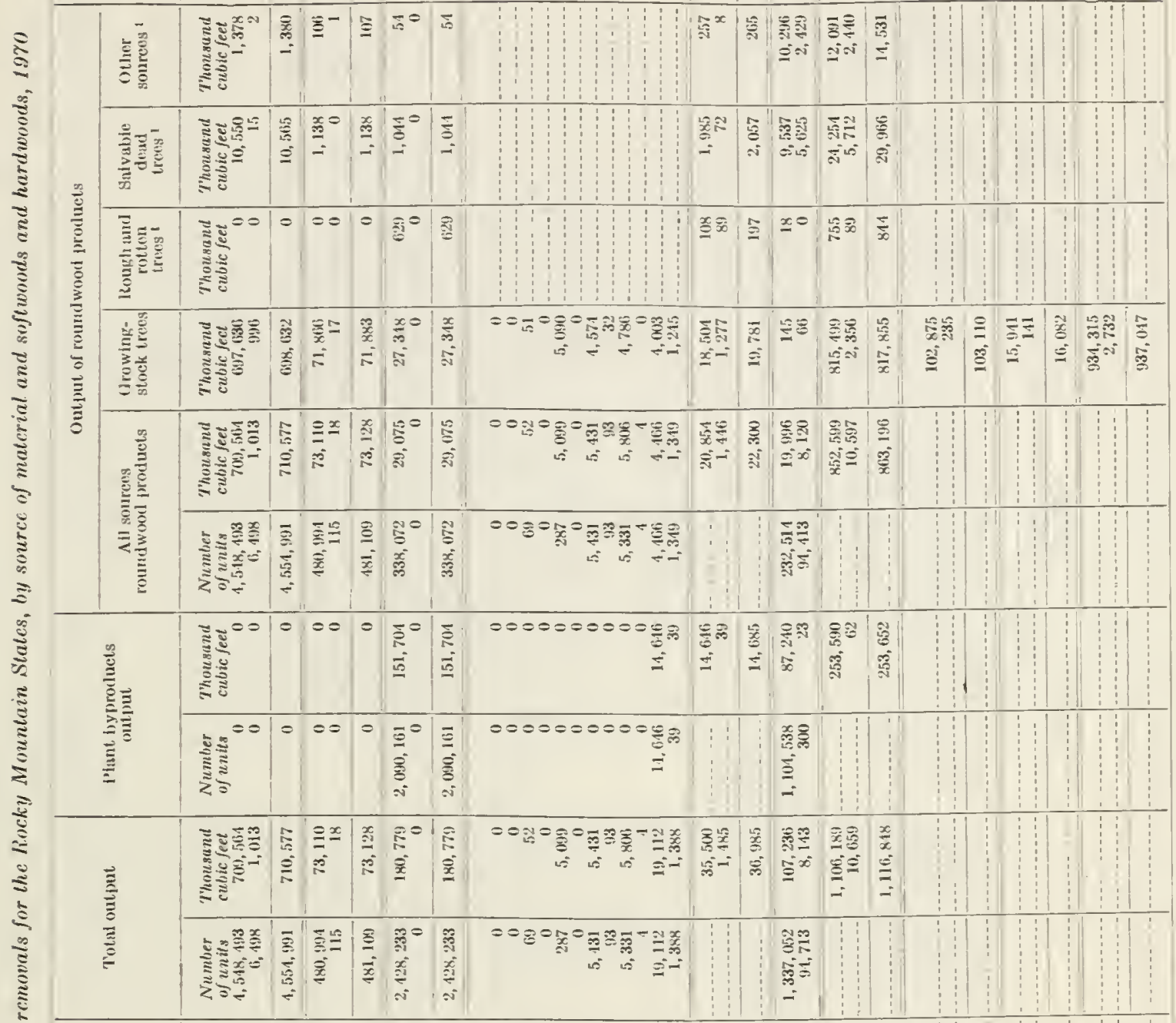

总

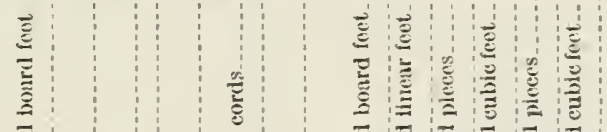

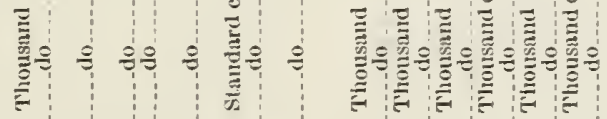

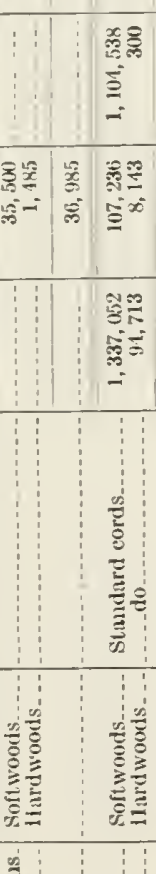

胥

है

紊

:

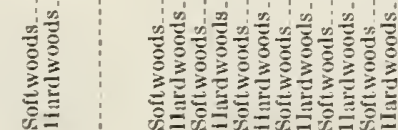

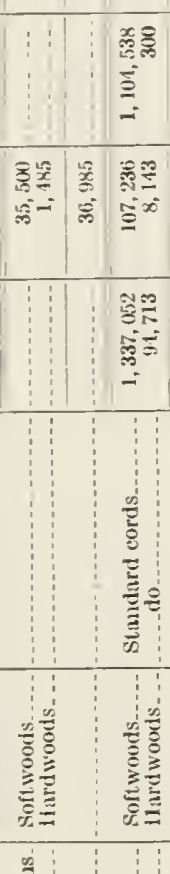

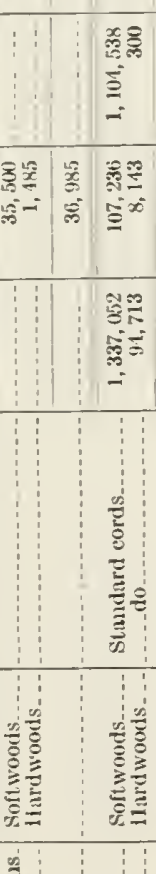

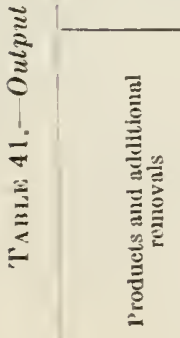

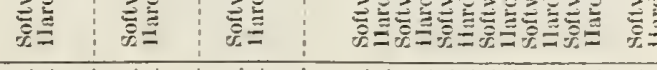

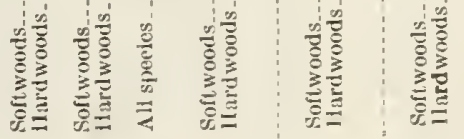

蓄

(ิ)

(a)

产 


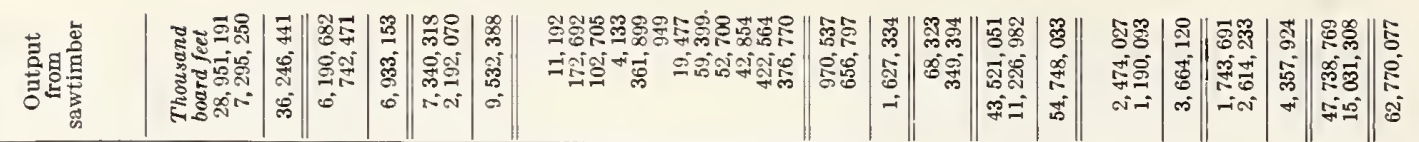

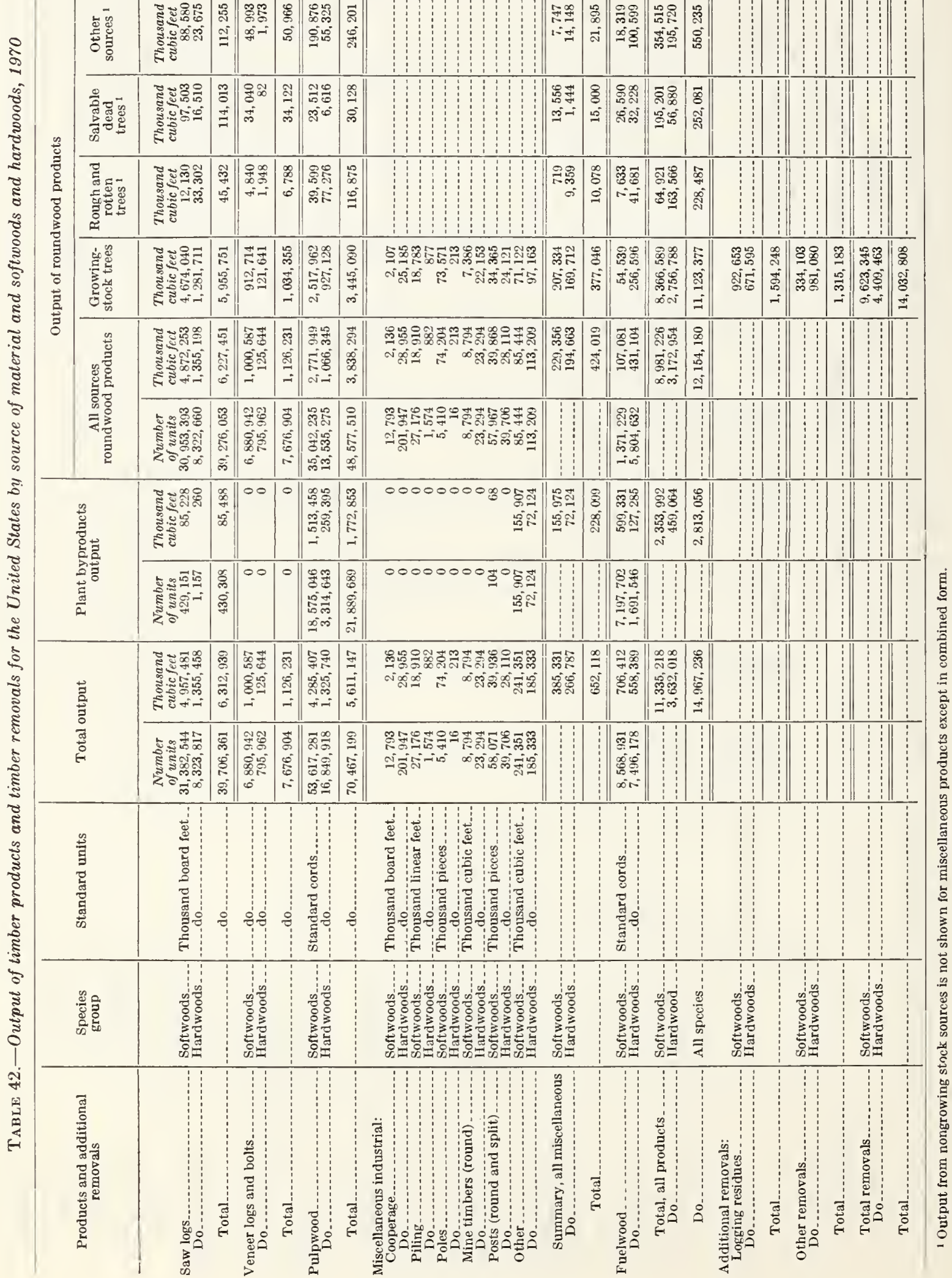


TABLE 43.-Volume of unused residues at primary manufacturing plants in the United States, by timber supply region, industrial source, type of material, softwoods and hardwoods, $1970^{1}$

[Thousand cubic feet]

\begin{tabular}{|c|c|c|c|c|c|c|c|c|c|c|c|c|}
\hline \multirow{2}{*}{$\begin{array}{l}\text { Species group and timber } \\
\text { supply region }\end{array}$} & \multicolumn{3}{|c|}{ All industries } & \multicolumn{3}{|c|}{ Lumber industry } & \multicolumn{3}{|c|}{ Veneer and plywood industry } & \multicolumn{3}{|c|}{ Other primary industries } \\
\hline & Total & Coarse & Fine & Total & Coarse & Fine & Total & Coarse & Fine & Total & Coarse & Fine \\
\hline \multicolumn{13}{|l|}{ SOFTWOODS } \\
\hline 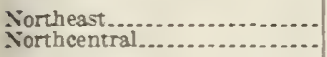 & $\begin{array}{r}23,608 \\
6,94 ?\end{array}$ & $\begin{array}{r}11,483 \\
4,153\end{array}$ & $\begin{array}{r}12,125 \\
2,789\end{array}$ & $\begin{array}{r}22,504 \\
6,942\end{array}$ & $\begin{array}{r}11,121 \\
4,153\end{array}$ & $\begin{array}{r}11,383 \\
2,789\end{array}$ & $\begin{array}{l}0 \\
0\end{array}$ & $\begin{array}{l}0 \\
0\end{array}$ & $\begin{array}{l}0 \\
0\end{array}$ & 1,104 & $\begin{array}{r}362 \\
0\end{array}$ & $\begin{array}{r}742 \\
0\end{array}$ \\
\hline Total, North.. & 30,550 & 15,636 & 14,914 & 29,446 & 15,274 & 14,172 & 0 & 0 & 0 & 1,104 & 362 & 742 \\
\hline $\begin{array}{l}\text { Southeast... } \\
\text { Southcentral......... }\end{array}$ & $\begin{array}{l}89,427 \\
85,998\end{array}$ & $\begin{array}{l}19,586 \\
31,665\end{array}$ & $\begin{array}{l}69,841 \\
5-1,333\end{array}$ & $\begin{array}{l}87,177 \\
74,643\end{array}$ & $\begin{array}{l}18,315 \\
28,375\end{array}$ & $\begin{array}{l}68,862 \\
46,268\end{array}$ & $\begin{array}{l}1,379 \\
2,071\end{array}$ & $\begin{array}{l}787 \\
213\end{array}$ & $\begin{array}{r}592 \\
1,858\end{array}$ & 9,281 & 3,077 & $\begin{array}{r}387 \\
6,207\end{array}$ \\
\hline Total, Sonth.... & 175,425 & 51,251 & 124,174 & 161,820 & 46,690 & 115,130 & 3,450 & 1,000 & 2,450 & 10,155 & 3,561 & 6,594 \\
\hline $\begin{array}{l}\text { PNW Douglas-fir } \\
\text { P } \\
\text { Alaska-Coastal ponderosa pine. } \\
\text { California and Hawail }\end{array}$ & $\begin{array}{r}131,096 \\
45,711 \\
8,371 \\
152,080\end{array}$ & $\begin{array}{r}57,414 \\
21,829 \\
6,605 \\
68,782\end{array}$ & $\begin{array}{r}73,682 \\
23,882 \\
1,766 \\
83,298\end{array}$ & $\begin{array}{r}81,575 \\
43,244 \\
8,371 \\
145,810\end{array}$ & $\begin{array}{r}26,415 \\
19,605 \\
6,605 \\
62,542\end{array}$ & $\begin{array}{r}55,160 \\
23,639 \\
1,766 \\
83,298\end{array}$ & $\begin{array}{r}25,535 \\
2,410 \\
0 \\
6,033\end{array}$ & $\begin{array}{r}22,812 \\
2,211 \\
0 \\
6,033\end{array}$ & $\begin{array}{r}2,723 \\
229 \\
0 \\
0\end{array}$ & $\begin{array}{r}23,986 \\
27 \\
0 \\
207\end{array}$ & $\begin{array}{r}8,187 \\
13 \\
0 \\
207\end{array}$ & $\begin{array}{r}15,799 \\
14 \\
0 \\
0\end{array}$ \\
\hline Total, Pacific Cosst..... & 337,258 & 154,630 & 182,628 & $2 \pi 9,030$ & 115,167 & 163,863 & 34,008 & 31,056 & 2,952 & 24,220 & 8,407 & 15,813 \\
\hline $\begin{array}{l}\text { Northern Rocky Mountain... } \\
\text { Southern Rocky Mountain... }\end{array}$ & $\begin{array}{l}92,985 \\
45,631\end{array}$ & $\begin{array}{l}33,117 \\
15,104\end{array}$ & $\begin{array}{l}59,868 \\
30,527\end{array}$ & $\begin{array}{l}92,666 \\
45,447\end{array}$ & $\begin{array}{l}32,798 \\
14,920\end{array}$ & $\begin{array}{l}59,868 \\
30,527\end{array}$ & $\begin{array}{l}319 \\
184\end{array}$ & $\begin{array}{l}319 \\
184\end{array}$ & $\begin{array}{l}0 \\
0\end{array}$ & $\begin{array}{l}0 \\
0\end{array}$ & $\begin{array}{l}0 \\
0\end{array}$ & $\begin{array}{l}0 \\
0\end{array}$ \\
\hline Total, Rocky Mountain_ & 138,616 & 48,221 & 90,395 & 138,113 & 47,718 & 90,395 & 503 & 503 & 0 & 0 & 0 & 0 \\
\hline Total, softwoods & $6 \$ 1,849$ & 269,738 & 412,111 & 608,409 & 224,819 & 383,560 & 37,961 & 32,559 & 5,402 & 35,479 & 12,330 & 23,149 \\
\hline HARDWOODS & & & & & & & & & & & & \\
\hline 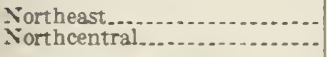 & $\begin{array}{l}71,485 \\
70,034\end{array}$ & $\begin{array}{l}41,206 \\
30,619\end{array}$ & $\begin{array}{l}30,279 \\
39,417\end{array}$ & $\begin{array}{l}68,114 \\
63,922\end{array}$ & $\begin{array}{l}39,878 \\
28,839\end{array}$ & $\begin{array}{l}28,236 \\
35,083\end{array}$ & $\begin{array}{l}436 \\
747\end{array}$ & $\begin{array}{r}94 \\
175\end{array}$ & $\begin{array}{l}342 \\
572\end{array}$ & $\begin{array}{l}2,935 \\
5,365\end{array}$ & $\begin{array}{l}1,234 \\
1,605\end{array}$ & $\begin{array}{l}1,701 \\
3,760\end{array}$ \\
\hline Total, North............. & 141,519 & 71,825 & 69,694 & 132,036 & 68,717 & 63,319 & 1,183 & 269 & 914 & 8,300 & 2,839 & 5,461 \\
\hline $\begin{array}{l}\text { Southeast } \\
\text { South central }\end{array}$ & $\begin{array}{l}77,791 \\
89,772\end{array}$ & $\begin{array}{l}23,779 \\
35,896\end{array}$ & $\begin{array}{l}54,012 \\
53,876\end{array}$ & $\begin{array}{l}71,637 \\
75,750\end{array}$ & $\begin{array}{l}20,040 \\
29,996\end{array}$ & $\begin{array}{l}51,597 \\
45,754\end{array}$ & $\begin{array}{l}3,265 \\
2,415\end{array}$ & $\begin{array}{l}2,591 \\
2,089\end{array}$ & $\begin{array}{l}674 \\
326\end{array}$ & $\begin{array}{r}2,889 \\
11,607\end{array}$ & $\begin{array}{l}1,148 \\
3,811\end{array}$ & $\begin{array}{l}1,741 \\
7,796\end{array}$ \\
\hline Total, South............ & $16 \pi, 563$ & 59,675 & $10 \%, 888$ & 147,387 & 50,036 & 97,351 & 5,680 & 4,680 & 1,000 & 14,496 & 4,959 & 9,537 \\
\hline $\begin{array}{l}\text { PNT Douglas-fir } \\
\text { PNW ponderosa pine........ } \\
\text { Alaska-Coastal } \\
\text { Californis and Hawaii........ }\end{array}$ & $\begin{array}{r}1,637 \\
0 \\
0 \\
0\end{array}$ & $\begin{array}{r}582 \\
0 \\
0 \\
0\end{array}$ & $\begin{array}{r}1,055 \\
0 \\
0 \\
0\end{array}$ & $\begin{array}{r}1,561 \\
0 \\
0 \\
0\end{array}$ & $\begin{array}{r}512 \\
0 \\
0 \\
0\end{array}$ & $\begin{array}{r}1,049 \\
0 \\
0 \\
0\end{array}$ & $\begin{array}{r}76 \\
0 \\
0 \\
0\end{array}$ & $\begin{array}{r}70 \\
0 \\
0 \\
0\end{array}$ & $\begin{array}{l}6 \\
0 \\
0 \\
0\end{array}$ & $\begin{array}{l}0 \\
0 \\
0 \\
0\end{array}$ & $\begin{array}{l}0 \\
0 \\
0 \\
0\end{array}$ & $\begin{array}{l}0 \\
0 \\
0 \\
0\end{array}$ \\
\hline Total, Pacific Coast...... & 1,637 & 582 & 1,055 & 1,561 & 512 & 1,049 & 76 & 70 & 6 & 0 & 0 & 0 \\
\hline $\begin{array}{l}\text { Northern Rocky Mountain... } \\
\text { Southern Rocky Mountain... }\end{array}$ & $\begin{array}{r}10 \\
435\end{array}$ & $\begin{array}{r}5 \\
230\end{array}$ & $\begin{array}{r}5 \\
205\end{array}$ & $\begin{array}{r}10 \\
435\end{array}$ & $\begin{array}{r}5 \\
230\end{array}$ & $\begin{array}{r}5 \\
205\end{array}$ & $\begin{array}{l}0 \\
0\end{array}$ & $\begin{array}{l}0 \\
0\end{array}$ & $\begin{array}{l}0 \\
0\end{array}$ & $\begin{array}{l}0 \\
0\end{array}$ & $\begin{array}{l}0 \\
0\end{array}$ & $\begin{array}{l}0 \\
0\end{array}$ \\
\hline Total, Rocky Mountain. & 445 & 235 & 210 & 445 & 235 & 210 & 0 & 0 & 0 & 0 & 0 & 0 \\
\hline Total, hardwoods. . & 311,164 & 132,317 & 178,847 & 281,429 & 119,500 & 161,929 & 6,939 & 5,019 & 1,920 & 22,796 & 7,798 & 14,998 \\
\hline
\end{tabular}

${ }^{1}$ Zeros indicate no data or negligible amounts.

TABLE 44.-Roundwood products, logging residues, and other removals from growing stcck and sawtimber, by section, region, State and species group, 1970

\begin{tabular}{|c|c|c|c|c|c|c|c|c|}
\hline \multirow{2}{*}{ Section, region, and State } & \multirow{2}{*}{ Species } & \multicolumn{3}{|c|}{ Roundwood products } & \multicolumn{2}{|c|}{ Logging residues } & \multicolumn{2}{|c|}{ Other removals } \\
\hline & & $\begin{array}{l}\text { All } \\
\text { Sources }\end{array}$ & $\begin{array}{l}\text { Growing } \\
\text { stock }\end{array}$ & $\begin{array}{l}\text { Saw- } \\
\text { timber }\end{array}$ & $\begin{array}{l}\text { Growing } \\
\text { stock }\end{array}$ & $\begin{array}{l}\text { Saw- } \\
\text { timber }\end{array}$ & $\begin{array}{l}\text { Growing } \\
\text { stock }\end{array}$ & $\begin{array}{l}\text { Saw- } \\
\text { timber }\end{array}$ \\
\hline 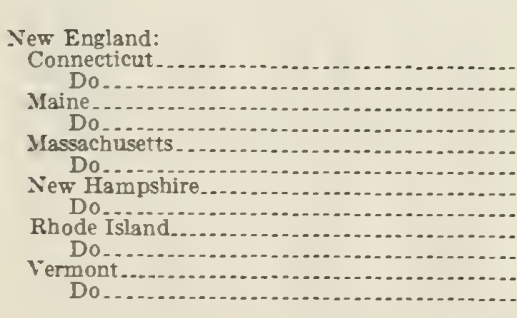 & 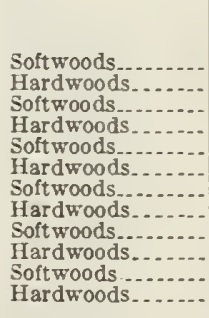 & $\begin{array}{r}\text { Thousand } \\
\text { cubic feet } \\
1,049 \\
6,386 \\
281,135 \\
123,511 \\
12,256 \\
13,530 \\
21,418 \\
29,773 \\
490 \\
1,603 \\
17,143 \\
25,035\end{array}$ & $\begin{array}{r}\text { Thousand } \\
\text { cubic feet } \\
951 \\
5,028 \\
231,703 \\
108,469 \\
10,862 \\
12,103 \\
20,474 \\
27,915 \\
429 \\
1,238 \\
15,908 \\
21,485\end{array}$ & $\begin{array}{r}\text { Thousand } \\
\text { board feet } \\
2,715 \\
17,671 \\
826,811 \\
377,581 \\
45,745 \\
53,301 \\
86,945 \\
96,118 \\
1,057 \\
3,924 \\
52,260 \\
76,368\end{array}$ & $\begin{array}{r}\text { Thousand } \\
\text { cubic feet } \\
59 \\
633 \\
36,183 \\
19,618 \\
1,766 \\
2,371 \\
1,198 \\
3,302 \\
16 \\
63 \\
1,818 \\
4,778\end{array}$ & $\begin{array}{r}\text { Thousand } \\
\text { board feet } \\
139 \\
1,563 \\
26,539 \\
28,875 \\
3,452 \\
5,669 \\
135 \\
11,165 \\
40 \\
158 \\
2,773 \\
7,975\end{array}$ & $\begin{array}{r}\text { Thousand } \\
\text { cubic feet } \\
300 \\
1,582 \\
7,309 \\
5,413 \\
2,571 \\
2,146 \\
2,963 \\
4,638 \\
48 \\
582 \\
4,317 \\
2,659\end{array}$ & $\begin{array}{r}\text { Thousand } \\
\text { board feet } \\
833 \\
5,372 \\
24,650 \\
14,544 \\
10,662 \\
9,390 \\
11,915 \\
13,398 \\
112 \\
1,109 \\
14,615 \\
8,981\end{array}$ \\
\hline Total ... & $\begin{array}{l}\text { Softwoods } \\
\text { Hardwoods....... }\end{array}$ & $\begin{array}{l}336,491 \\
199,838\end{array}$ & $\begin{array}{l}280,327 \\
176,238\end{array}$ & $\begin{array}{r}1,015,533 \\
624,963\end{array}$ & $\begin{array}{l}40,555 \\
30,76 \tilde{5}\end{array}$ & $\begin{array}{l}33,078 \\
55,405\end{array}$ & $\begin{array}{l}17,508 \\
17,050\end{array}$ & $\begin{array}{l}62,787 \\
52,794\end{array}$ \\
\hline
\end{tabular}


TABLE 44.-Roundwood products, logging residues, and other removals from growing stock and sawtimber, by section, region, State and species group, 1970-Continued

\begin{tabular}{|c|c|c|c|c|c|c|c|c|}
\hline \multirow[b]{2}{*}{ Section, region, and State } & \multirow[b]{2}{*}{ Species } & \multicolumn{3}{|c|}{ Roundwood products } & \multicolumn{2}{|c|}{ Logging residues } & \multicolumn{2}{|c|}{ Other removals } \\
\hline & & $\begin{array}{l}\text { All } \\
\text { Sourecs }\end{array}$ & $\begin{array}{l}\text { Growing } \\
\text { stock }\end{array}$ & $\begin{array}{l}\text { Saw- } \\
\text { timber }\end{array}$ & $\begin{array}{l}\text { Growing } \\
\text { stock }\end{array}$ & $\begin{array}{l}\text { Saw- } \\
\text { timber }\end{array}$ & $\begin{array}{l}\text { Growing } \\
\text { stock }\end{array}$ & $\begin{array}{l}\text { Saw- } \\
\text { timber }\end{array}$ \\
\hline 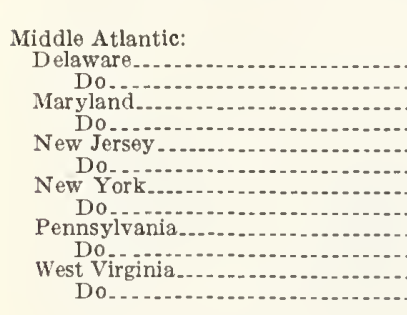 & 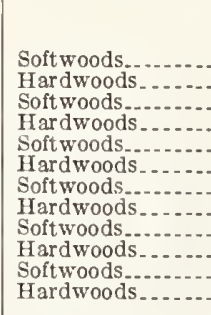 & $\begin{array}{r}\text { Thousand } \\
\text { cubic feet } \\
8,844 \\
2,964 \\
27,449 \\
31,986 \\
6,866 \\
7,608 \\
19,482 \\
80,194 \\
13,002 \\
145,332 \\
12,192 \\
117,762 \\
\end{array}$ & $\begin{array}{r}\text { Thousand } \\
\text { cubic feet } \\
7,004 \\
2,474 \\
25,056 \\
29,757 \\
4,550 \\
5,537 \\
18,000 \\
69,493 \\
12,070 \\
140,768 \\
11,168 \\
115,202 \\
\end{array}$ & $\begin{array}{r}\text { Thousand } \\
\text { board feet } \\
19,604 \\
8,936 \\
119,263 \\
142,739 \\
10,109 \\
22,158 \\
61,818 \\
305,054 \\
43,434 \\
542,632 \\
47,630 \\
569,439 \\
\end{array}$ & $\begin{array}{r}\text { Thousand } \\
\text { cubic feet } \\
387 \\
585 \\
5,631 \\
9,149 \\
316 \\
593 \\
3,696 \\
15,976 \\
16,261 \\
46,887 \\
627 \\
20,602 \\
\end{array}$ & $\begin{array}{r}\text { Thousand } \\
\text { board feet } \\
33 \\
677 \\
7,144 \\
23,760 \\
37 \\
689 \\
3,605 \\
11,957 \\
599 \\
16,842 \\
98 \\
9,179 \\
\end{array}$ & $\begin{array}{r}\text { Thousand } \\
\text { cubic fect } \\
946 \\
462 \\
87 \\
5,892 \\
635 \\
670 \\
287 \\
7,452 \\
3,112 \\
27,657 \\
851 \\
6,766 \\
\end{array}$ & $\begin{array}{r}\text { Thousand } \\
\text { board feet } \\
1,866 \\
1,868 \\
430 \\
27,249 \\
1,423 \\
2,643 \\
968 \\
32,513 \\
8,586 \\
106,537 \\
3,274 \\
33,206 \\
\end{array}$ \\
\hline Total & $\begin{array}{l}\text { Softwoods } \\
\text { Hardwoods...... }\end{array}$ & $\begin{array}{r}87,835 \\
385,846 \\
\end{array}$ & $\begin{array}{r}77,848 \\
363,231\end{array}$ & $\begin{array}{r}301,858 \\
1,590,958\end{array}$ & $\begin{array}{l}11,918 \\
93,792\end{array}$ & $\begin{array}{l}11,516 \\
63,104\end{array}$ & $\begin{array}{r}5,918 \\
48,899\end{array}$ & $\begin{array}{r}16,547 \\
204,016\end{array}$ \\
\hline $\begin{array}{l}\text { Lake States: } \\
\text { Michigan } \\
\text { Do } \\
\text { Minnesota } \\
\text { Do } \\
\text { North Dakota. } \\
\text { Do } 0.1 \\
\text { South Dakota (East) } \\
\text { Do } \\
\text { Wisconsin } \\
\text { Do }\end{array}$ & 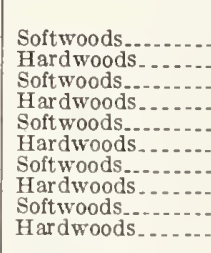 & $\begin{array}{r}47,832 \\
142,867 \\
52,487 \\
82,982 \\
136 \\
1,147 \\
308 \\
1,050 \\
37,463 \\
166,128 \\
\end{array}$ & $\begin{array}{r}45,598 \\
129,096 \\
50,417 \\
73,761 \\
0 \\
687 \\
151 \\
523 \\
36 \\
148,455 \\
148,436 \\
\end{array}$ & $\begin{array}{r}175,058 \\
585,354 \\
184,045 \\
222,830 \\
3,027 \\
327 \\
320 \\
1,571 \\
120,259 \\
53,2,824 \\
\end{array}$ & $\begin{array}{r}4,309 \\
11,579 \\
2,027 \\
6,085 \\
0 \\
36 \\
1 \\
34 \\
1,591 \\
15,405 \\
\end{array}$ & $\begin{array}{r}14,393 \\
31,280 \\
2,418 \\
6,820 \\
0 \\
138 \\
0 \\
139 \\
2,110 \\
24,255 \\
\end{array}$ & $\begin{array}{r}4,863 \\
17,633 \\
17,783 \\
5,125 \\
0 \\
2,413 \\
257 \\
893 \\
1,439 \\
105,957\end{array}$ & $\begin{array}{r}17,365 \\
43,567 \\
56,392 \\
12,663 \\
3,620 \\
4,60 \\
450 \\
2,143 \\
5,101 \\
108,275\end{array}$ \\
\hline Total & $\begin{array}{l}\text { Softwoods } \\
\text { Hardwoods..... }\end{array}$ & $\begin{array}{l}138,226 \\
394,174\end{array}$ & $\begin{array}{l}132,321 \\
352,503\end{array}$ & $\begin{array}{r}479,682 \\
1,348,606\end{array}$ & $\begin{array}{r}7,928 \\
33,139\end{array}$ & $\begin{array}{l}18,921 \\
62,632\end{array}$ & $\begin{array}{r}24,342 \\
132,021 \\
\end{array}$ & $\begin{array}{r}79,308 \\
170,268 \\
\end{array}$ \\
\hline 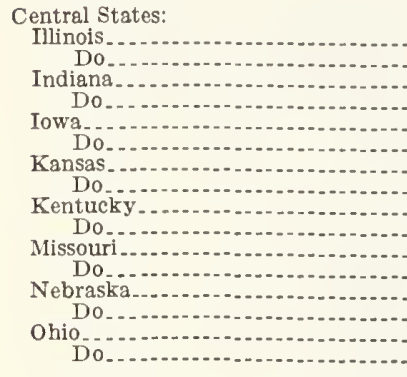 & 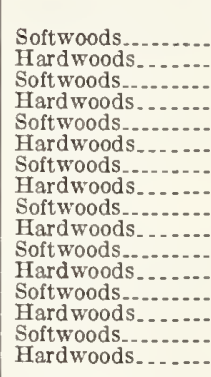 & $\begin{array}{r}185 \\
42,879 \\
131 \\
52,146 \\
49 \\
14,723 \\
13 \\
7,899 \\
9,724 \\
107,040 \\
4,117 \\
103,552 \\
671 \\
7,442 \\
1,811 \\
93,817\end{array}$ & $\begin{array}{r}149 \\
35,430 \\
126 \\
49,308 \\
46 \\
11,265 \\
10 \\
6,183 \\
9,309 \\
95,629 \\
3,793 \\
63,054 \\
633 \\
6,455 \\
1,596 \\
83,167\end{array}$ & $\begin{array}{r}746 \\
206,292 \\
523 \\
280,258 \\
212 \\
60,138 \\
0 \\
30,709 \\
35,278 \\
516,802 \\
15,679 \\
350,720 \\
1,770 \\
41,587 \\
4,882 \\
445,765 \\
\end{array}$ & $\begin{array}{r}15 \\
5,425 \\
8 \\
11,237 \\
3 \\
1,533 \\
0 \\
579 \\
524 \\
59,189 \\
182 \\
4,428 \\
24 \\
796 \\
90 \\
20,673\end{array}$ & $\begin{array}{r}17 \\
14,281 \\
11 \\
54,028 \\
7 \\
3,716 \\
0 \\
2,661 \\
716 \\
86,579 \\
223 \\
21,373 \\
32 \\
3,213 \\
57 \\
80,863\end{array}$ & $\begin{array}{r}845 \\
49,232 \\
350 \\
4,663 \\
2699 \\
37,289 \\
10 \\
834 \\
1,34 \\
15,369 \\
10,111 \\
27,267 \\
599 \\
1,699 \\
197 \\
7,397 \\
\end{array}$ & $\begin{array}{r}1,220 \\
174,386 \\
496 \\
15,535 \\
645 \\
97,812 \\
0 \\
2,321 \\
3,852 \\
84,862 \\
14,266 \\
58,189 \\
1,283 \\
3,745 \\
550 \\
39,712 \\
\end{array}$ \\
\hline Total....... & $\begin{array}{l}\text { Softwoods....... } \\
\text { Hardwoods...... }\end{array}$ & $\begin{array}{r}16,701 \\
429,498\end{array}$ & $\begin{array}{r}15,662 \\
350,491\end{array}$ & $\begin{array}{r}59,090 \\
1,932,271\end{array}$ & $\begin{array}{r}846 \\
63,860\end{array}$ & $\begin{array}{r}1,063 \\
266,714 \\
\end{array}$ & $\begin{array}{r}13,615 \\
143,700 \\
\end{array}$ & $\begin{array}{r}22,312 \\
476,562 \\
\end{array}$ \\
\hline Total, North... & $\begin{array}{l}\text { Softwoods...... } \\
\text { Hardwoods.... }\end{array}$ & $\begin{array}{r}579,253 \\
1,409,356 \\
\end{array}$ & $\begin{array}{r}506,158 \\
1,242,463 \\
\end{array}$ & $\begin{array}{l}1,856,163 \\
5,496,798 \\
\end{array}$ & $\begin{array}{r}61,247 \\
221,556 \\
\end{array}$ & $\begin{array}{r}64,578 \\
447,855 \\
\end{array}$ & $\begin{array}{r}61,383 \\
341,670 \\
\end{array}$ & $\begin{array}{r}180,954 \\
903,640 \\
\end{array}$ \\
\hline 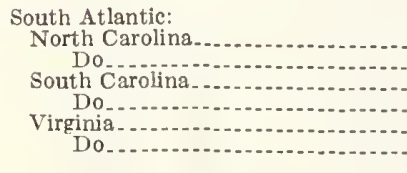 & $\begin{array}{l}\text { Softwoods-...... } \\
\text { Hardwoods.... } \\
\text { Softwoods.-.... } \\
\text { Hardwoods.... } \\
\text { Softwoods } \\
\text { Hardwoods..... }\end{array}$ & $\begin{array}{l}347,137 \\
199,267 \\
283,931 \\
121,448 \\
158,038 \\
194,748 \\
\end{array}$ & $\begin{array}{l}321,822 \\
174,615 \\
268,228 \\
104,829 \\
148,620 \\
173,578 \\
\end{array}$ & $\begin{array}{r}1,117,058 \\
652,768 \\
927,246 \\
395,346 \\
441,296 \\
614,168 \\
\end{array}$ & $\begin{array}{l}23,689 \\
92,958 \\
17,030 \\
20,522 \\
6,497 \\
67,762 \\
\end{array}$ & $\begin{array}{r}33,565 \\
99,247 \\
30,824 \\
81,632 \\
8,995 \\
27,806 \\
\end{array}$ & $\begin{array}{l}31,305 \\
46,327 \\
13,500 \\
18,868 \\
10,839 \\
35,611 \\
\end{array}$ & $\begin{array}{l}58,211 \\
68,002 \\
41,376 \\
36,664 \\
36,661 \\
58,124 \\
\end{array}$ \\
\hline Total..... & $\begin{array}{l}\text { Softwoods...... } \\
\text { Hardwoods... }\end{array}$ & $\begin{array}{l}789,106 \\
515,463 \\
\end{array}$ & $\begin{array}{l}738,670 \\
453,022 \\
\end{array}$ & $\begin{array}{l}2,485,600 \\
1,662,282 \\
\end{array}$ & $\begin{array}{r}47,216 \\
187,242 \\
\end{array}$ & $\begin{array}{r}73,384 \\
208,685 \\
\end{array}$ & $\begin{array}{r}55,644 \\
100,806 \\
\end{array}$ & $\begin{array}{l}136,248 \\
162,790 \\
\end{array}$ \\
\hline $\begin{array}{l}\text { East Gulf: } \\
\text { Florida: } \\
\text { Do............... } \\
\text { Georgia } \\
\text { Do.............. }\end{array}$ & $\begin{array}{l}\text { Softwoods--.- } \\
\text { Hardwoods.- } \\
\text { Softwoods.- } \\
\text { Hard woods.- }\end{array}$ & $\begin{array}{r}246,870 \\
38,363 \\
649,778 \\
139,230 \\
\end{array}$ & $\begin{array}{r}228,397 \\
31,492 \\
610,079 \\
122,801 \\
\end{array}$ & $\begin{array}{r}778,843 \\
133,902 \\
1,810,501 \\
558,410 \\
\end{array}$ & $\begin{array}{l}13,736 \\
10,474 \\
38,741 \\
40,842\end{array}$ & $\begin{array}{r}31,941 \\
23,197 \\
191,453 \\
69,960\end{array}$ & $\begin{array}{l}36,167 \\
27,634 \\
30,715 \\
84,761 \\
\end{array}$ & $\begin{array}{r}123,216 \\
62,601 \\
202,384 \\
60,048 \\
\end{array}$ \\
\hline Total_...... & $\begin{array}{l}\text { Softwoods.-. } \\
\text { Hardwoods.- }\end{array}$ & $\begin{array}{l}896,648 \\
177,593 \\
\end{array}$ & $\begin{array}{l}838,476 \\
154,293 \\
\end{array}$ & $\begin{array}{r}2,589,344 \\
692,312 \\
\end{array}$ & $\begin{array}{r}52,477 \\
51,316 \\
\end{array}$ & $\begin{array}{r}223,394 \\
93,157 \\
\end{array}$ & $\begin{array}{r}66,882 \\
112,395 \\
\end{array}$ & $\begin{array}{l}325,600 \\
122,649 \\
\end{array}$ \\
\hline 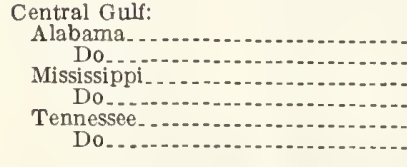 & 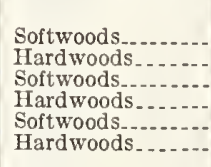 & $\begin{array}{r}506,445 \\
238,384 \\
443,086 \\
207,805 \\
28,745 \\
132,598\end{array}$ & $\begin{array}{r}488,287 \\
197,160 \\
428,354 \\
175,523 \\
27,744 \\
118,645\end{array}$ & $\begin{array}{r}1,971,548 \\
632,696 \\
1,767,682 \\
602,320 \\
112,413 \\
556,092\end{array}$ & $\begin{array}{r}31,600 \\
31,425 \\
33,516 \\
35,679 \\
1,958 \\
35,965\end{array}$ & $\begin{array}{r}50,942 \\
64,692 \\
57,551 \\
79,120 \\
3,293 \\
77,803 \\
\end{array}$ & $\begin{array}{r}1,600 \\
57,111 \\
72,890 \\
3,498 \\
28,990 \\
\end{array}$ & $\begin{array}{r}5,950 \\
174,622 \\
0 \\
250,157 \\
8,294 \\
61,705 \\
\end{array}$ \\
\hline Total_..... & $\begin{array}{l}\text { Softwoods...... } \\
\text { Hardwoods... }\end{array}$ & $\begin{array}{l}978,276 \\
578,787\end{array}$ & $\begin{array}{l}944,385 \\
491,328 \\
\end{array}$ & $\begin{array}{l}3,851,643 \\
1,791,108\end{array}$ & $\begin{array}{r}67,074 \\
103,069 \\
\end{array}$ & $\begin{array}{l}111,786 \\
221,615 \\
\end{array}$ & $\begin{array}{r}5,098 \\
158,591 \\
\end{array}$ & $\begin{array}{r}14,244 \\
486,484 \\
\end{array}$ \\
\hline
\end{tabular}


TABLE 44.-Roundwood products, logging residues, and other removals from growing stock and sawtimber, by section, region, State and species group, 1970-Continued

\begin{tabular}{|c|c|c|c|c|c|c|c|c|}
\hline \multirow[b]{2}{*}{ Section, region, and State } & \multirow[b]{2}{*}{ Species } & \multicolumn{3}{|c|}{ Roundwood products } & \multicolumn{2}{|c|}{ Logging residues } & \multicolumn{2}{|c|}{ Other removals } \\
\hline & & $\begin{array}{l}\text { All } \\
\text { sources }\end{array}$ & $\begin{array}{l}\text { Growing } \\
\text { stock }\end{array}$ & $\begin{array}{l}\text { Saw- } \\
\text { timber }\end{array}$ & $\begin{array}{l}\text { Growing } \\
\text { stock }\end{array}$ & $\begin{array}{l}\text { Saw- } \\
\text { timber }\end{array}$ & $\begin{array}{l}\text { Growing } \\
\text { stock }\end{array}$ & $\begin{array}{l}\text { Saw- } \\
\text { timber }\end{array}$ \\
\hline $\begin{array}{l}\text { West Gulf: } \\
\text { Arkansas. } \\
\text { Do } \\
\text { Louisiana. } \\
\text { Do } \\
\text { Oklahoma } \\
\text { Do } \\
\text { Texas } \\
\text { Do }\end{array}$ & $\begin{array}{l}\text { Softwoods } \\
\text { Hardwoods...... } \\
\text { Softwcods } \\
\text { Hardwoods } \\
\text { Softwoods } \\
\text { Hardwoods.... } \\
\text { Softwoods.... } \\
\text { Hardwoods. }\end{array}$ & $\begin{array}{r}\text { Thousand } \\
\text { cubic feet } \\
276,126 \\
184,781 \\
467,186 \\
135,167 \\
20,678 \\
18,126 \\
316,600 \\
58,135\end{array}$ & $\begin{array}{r}\text { Thousand } \\
\text { cubic feet } \\
270,068 \\
162,214 \\
455,883 \\
112,837 \\
20,202 \\
15,172 \\
307,981 \\
47,707 \\
\end{array}$ & $\begin{array}{r}\text { Thousand } \\
\text { board feet } \\
1,313,452 \\
655,181 \\
2,161,220 \\
395,420 \\
97,223 \\
47,995 \\
1,369,588 \\
179,599 \\
\end{array}$ & $\begin{array}{r}\text { Thousand } \\
\text { cubic feet } \\
25,955 \\
43,116 \\
40,385 \\
24,533 \\
2,199 \\
1,932 \\
27,385 \\
9,017 \\
\end{array}$ & $\begin{array}{r}\text { Thousand } \\
\text { board fett } \\
46,811 \\
95,880 \\
71,116 \\
54,427 \\
3,997 \\
3,801 \\
36,470 \\
14,712 \\
\end{array}$ & $\begin{array}{r}\text { Tho sand } \\
\text { cubic fect } \\
3,391 \\
115,364 \\
26,633 \\
61,366 \\
131 \\
12,440 \\
0 \\
69,072\end{array}$ & $\begin{array}{r}\text { Thousand } \\
\text { board feet } \\
15,553 \\
410,393 \\
118,309 \\
223,779 \\
620 \\
35,198 \\
0 \\
237,064\end{array}$ \\
\hline Total & $\begin{array}{l}\text { Softwoods........ } \\
\text { Hardwoods....... }\end{array}$ & $\begin{array}{r}1,080,590 \\
396,209 \\
\end{array}$ & $\begin{array}{r}1,054,134 \\
337,930 \\
\end{array}$ & $\begin{array}{l}4,941,493 \\
1,278,195 \\
\end{array}$ & $\begin{array}{l}95,924 \\
78,598 \\
\end{array}$ & $\begin{array}{l}158,394 \\
168,820 \\
\end{array}$ & $\begin{array}{r}30,155 \\
258,242 \\
\end{array}$ & $\begin{array}{l}134,482 \\
906,434 \\
\end{array}$ \\
\hline Total, South.. & $\begin{array}{l}\text { Soltwoods........ } \\
\text { Hardwoods. . . . . }\end{array}$ & $\begin{array}{l}3,744,620 \\
1,668,052 \\
\end{array}$ & $\begin{array}{l}3,575,665 \\
1,436,573 \\
\end{array}$ & $\begin{array}{r}13,868,080 \\
5,423,897 \\
\end{array}$ & $\begin{array}{l}262,691 \\
420,225 \\
\end{array}$ & $\begin{array}{l}566,958 \\
692,277 \\
\end{array}$ & $\begin{array}{l}157,779 \\
630,034 \\
\end{array}$ & $\begin{array}{r}610,574 \\
1,678,357 \\
\end{array}$ \\
\hline $\begin{array}{l}\text { Pacific Northwest: } \\
\text { Alaska: Coastsl. - }\end{array}$ & $\begin{array}{l}\text { Softwoods........ } \\
\text { Hardwoods. . . }\end{array}$ & $\begin{array}{r}118,995 \\
0 \\
\end{array}$ & $\begin{array}{r}117,770 \\
0 \\
\end{array}$ & $\begin{array}{r}746,213 \\
0 \\
\end{array}$ & $\begin{array}{r}39,320 \\
0\end{array}$ & $\begin{array}{r}79,881 \\
0 \\
\end{array}$ & 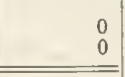 & $\begin{array}{r}253,491 \\
0 \\
\end{array}$ \\
\hline 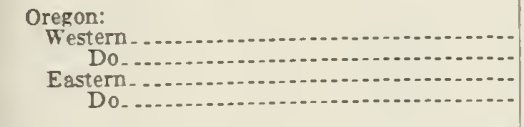 & $\begin{array}{l}\text { Soft woods } \\
\text { Hardwoods } \\
\text { Soft woods } \\
\text { Hardwoods....... }\end{array}$ & $\begin{array}{r}1,166,746 \\
18,032 \\
344,263 \\
0 \\
\end{array}$ & $\begin{array}{r}1,006,000 \\
16,800 \\
330,850 \\
0 \\
\end{array}$ & $\begin{array}{r}7,006,300 \\
75,600 \\
2,035,060 \\
0 \\
\end{array}$ & $\begin{array}{r}172,000 \\
4,200 \\
21,120 \\
0\end{array}$ & $\begin{array}{r}551,700 \\
11,400 \\
62,940 \\
0 \\
\end{array}$ & $\begin{array}{r}5,000 \\
0 \\
0 \\
0\end{array}$ & $\begin{array}{r}33,000 \\
0 \\
0 \\
0\end{array}$ \\
\hline Summary & $\begin{array}{l}\text { Soft woods......... } \\
\text { Hard woods. }\end{array}$ & $\begin{array}{r}1,511,009 \\
18,032 \\
\end{array}$ & $\begin{array}{r}1,336,880 \\
16,800 \\
\end{array}$ & $\begin{array}{r}9,041,360 \\
75,600 \\
\end{array}$ & $\begin{array}{r}193,120 \\
4,200 \\
\end{array}$ & $\begin{array}{r}614,640 \\
11,400 \\
\end{array}$ & $\begin{array}{r}5,000 \\
0 \\
\end{array}$ & $\begin{array}{r}33,000 \\
0 \\
\end{array}$ \\
\hline $\begin{array}{l}\text { Washington: } \\
\text { Western } \\
\text { Do } \\
\text { Eastern } \\
\text { Do... }\end{array}$ & $\begin{array}{l}\text { Soft woods } \\
\text { Hard woods } \\
\text { Softwoods } \\
\text { Hardwoods }\end{array}$ & $\begin{array}{r}1,143,940 \\
48,466 \\
203,375 \\
1,620 \\
\end{array}$ & $\begin{array}{r}1,036,400 \\
45,500 \\
197,200 \\
1,600 \\
\end{array}$ & $\begin{array}{r}6,737,902 \\
168,700 \\
1,203,900 \\
7,100 \\
\end{array}$ & $\begin{array}{r}158,600 \\
11,500 \\
12,800 \\
400 \\
\end{array}$ & $\begin{array}{r}512,100 \\
25,300 \\
39,100 \\
1,100\end{array}$ & $\begin{array}{r}42,000 \\
6,000 \\
21,000 \\
70\end{array}$ & $\begin{array}{r}242,998 \\
20,000 \\
150,000 \\
240\end{array}$ \\
\hline Summary & $\begin{array}{l}\text { Softwoods } \\
\text { Hardwoods.......... }\end{array}$ & $\begin{array}{r}1,347,315 \\
50,086 \\
\end{array}$ & $\begin{array}{r}1,233,600 \\
47,100 \\
\end{array}$ & $\begin{array}{r}7,941,802 \\
175,800 \\
\end{array}$ & $\begin{array}{r}171,400 \\
11,900\end{array}$ & $\begin{array}{r}551,200 \\
26,400 \\
\end{array}$ & $\begin{array}{r}66,000 \\
6,070 \\
\end{array}$ & $\begin{array}{r}392,998 \\
20,240 \\
\end{array}$ \\
\hline Total Do.............. & 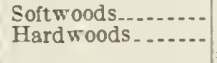 & $\begin{array}{r}2,977,319 \\
68,118\end{array}$ & $\begin{array}{r}2,688,250 \\
63,900 \\
\end{array}$ & $\begin{array}{r}17,729,375 \\
251,400 \\
\end{array}$ & $\begin{array}{r}403,840 \\
16,100 \\
\end{array}$ & $\begin{array}{r}1,245,721 \\
37,800\end{array}$ & $\begin{array}{r}71,000 \\
6,070 \\
\end{array}$ & $\begin{array}{r}679,489 \\
20,240 \\
\end{array}$ \\
\hline $\begin{array}{l}\text { Pacific Southwest: } \\
\text { California } \\
\text { Do } \\
\text { Hawail } \\
\text { Do }\end{array}$ & $\begin{array}{l}\text { Softwoods } \\
\text { Hardwoods } \\
\text { Softwoods } \\
\text { Hardwoods }\end{array}$ & $\begin{array}{r}827,480 \\
16,243 \\
17 \\
588 \\
\end{array}$ & $\begin{array}{r}781,000 \\
10,956 \\
17 \\
540\end{array}$ & $\begin{array}{r}5,119,000 \\
41,113 \\
119 \\
2,693 \\
\end{array}$ & $\begin{array}{r}92,000 \\
13,479 \\
0 \\
0\end{array}$ & $\begin{array}{r}286,000 \\
11,607 \\
0 \\
0\end{array}$ & $\begin{array}{r}28,000 \\
1,565 \\
0 \\
1,600\end{array}$ & $\begin{array}{r}176,000 \\
3,280 \\
0 \\
8,000 \\
\end{array}$ \\
\hline Total Do & $\begin{array}{l}\text { Softwoods......... } \\
\text { Hardwoods. }\end{array}$ & $\begin{array}{r}827,497 \\
16,831 \\
\end{array}$ & $\begin{array}{r}781,017 \\
11,496\end{array}$ & $\begin{array}{r}5,119,119 \\
43,806 \\
\end{array}$ & $\begin{array}{l}92,000 \\
13,479\end{array}$ & $\begin{array}{r}286,000 \\
11,607 \\
\end{array}$ & $\begin{array}{r}28,000 \\
3,165 \\
\end{array}$ & $\begin{array}{r}176,000 \\
11,280 \\
\end{array}$ \\
\hline Total, Pacific Coast & 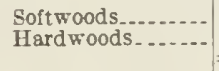 & $\begin{array}{r}3,804,816 \\
81,949 \\
\end{array}$ & $\begin{array}{r}3,469,267 \\
75,396 \\
\end{array}$ & $\begin{array}{r}22,848,494 \\
295,206 \\
\end{array}$ & $\begin{array}{r}495,840 \\
29,579 \\
\end{array}$ & $\begin{array}{r}1,531,721 \\
49,407 \\
\end{array}$ & $\begin{array}{r}99,000 \\
9,235 \\
\end{array}$ & $\begin{array}{r}855,489 \\
31,520 \\
\end{array}$ \\
\hline $\begin{array}{l}\text { Northern Rocky Mountain: } \\
\text { Idaho } \\
\text { Do Montana. } \\
\text { Do } \\
\text { South Dakota (West) } \\
\quad \text { Do } \\
\text { Wyoming } \\
\text { Do }\end{array}$ & $\begin{array}{l}\text { Softwoods } \\
\text { Hardwoods } \\
\text { Softwoods.... } \\
\text { Hardwoods } \\
\text { Softwoods..... } \\
\text { Hardwoods } \\
\text { Softwoods.... } \\
\text { Hardwoods. }\end{array}$ & $\begin{array}{r}325,698 \\
253 \\
279,533 \\
27 \\
15,124 \\
0 \\
33,685 \\
0\end{array}$ & $\begin{array}{r}316,395 \\
41 \\
275,279 \\
26 \\
14,888 \\
0 \\
32,244 \\
0\end{array}$ & $\begin{array}{r}1,965,218 \\
252 \\
1,647,355 \\
164 \\
85,245 \\
0 \\
182,979 \\
0\end{array}$ & $\begin{array}{r}37,175 \\
5 \\
44,009 \\
5 \\
581 \\
0 \\
2,469 \\
0 \\
\end{array}$ & $\begin{array}{r}117,283 \\
15 \\
135,801 \\
14 \\
733 \\
0 \\
3,862 \\
0\end{array}$ & $\begin{array}{r}3,640 \\
0 \\
5,091 \\
1 \\
186 \\
0 \\
1,442 \\
0\end{array}$ & $\begin{array}{r}22,923 \\
4 \\
31,510 \\
12 \\
1,113 \\
0 \\
8,846 \\
0\end{array}$ \\
\hline Total Do & $\begin{array}{l}\text { Softwoods } \\
\text { Hardwoods.......... }\end{array}$ & $\begin{array}{r}651,040 \\
280 \\
\end{array}$ & $\begin{array}{r}638,806 \\
67 \\
\end{array}$ & $\begin{array}{r}3,880,797 \\
416 \\
\end{array}$ & $\begin{array}{r}84,234 \\
10 \\
\end{array}$ & $\begin{array}{r}257,679 \\
29 \\
\end{array}$ & $\begin{array}{r}10,359 \\
1\end{array}$ & $\begin{array}{r}64,392 \\
16 \\
\end{array}$ \\
\hline $\begin{array}{l}\text { Southern Rocky Mountain: } \\
\text { Arizona. } \\
\text { Do } \\
\text { Colorado Do } \\
\text { Sevada. } \\
\text { Do } \\
\text { Tew Mexico Do } \\
\text { Dtah } \\
\text { Do }\end{array}$ & 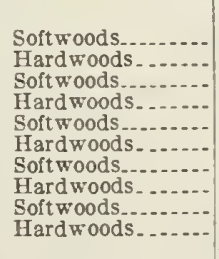 & $\begin{array}{r}86,985 \\
7,194 \\
52,257 \\
1,885 \\
572 \\
0 \\
46,790 \\
802 \\
11,955 \\
436\end{array}$ & $\begin{array}{r}78,463 \\
170 \\
48,629 \\
1,264 \\
0 \\
0 \\
38,556 \\
430 \\
11,045 \\
425\end{array}$ & $\begin{array}{r}466,278 \\
546 \\
294,377 \\
7,417 \\
0 \\
0 \\
241,701 \\
2,591 \\
65,161 \\
111\end{array}$ & $\begin{array}{r}8,537 \\
14 \\
4,623 \\
130 \\
0 \\
0 \\
4,689 \\
50 \\
792 \\
31\end{array}$ & $\begin{array}{r}23,372 \\
22 \\
12,562 \\
336 \\
0 \\
0 \\
15,380 \\
164 \\
1,777 \\
3\end{array}$ & $\begin{array}{r}557 \\
0 \\
4,237 \\
110 \\
10 \\
0 \\
355 \\
6 \\
423 \\
24\end{array}$ & $\begin{array}{r}1,481 \\
7 \\
25,874 \\
653 \\
63 \\
0 \\
2,233 \\
34 \\
2,631 \\
6\end{array}$ \\
\hline Total Do & $\begin{array}{l}\text { Softwoods } \\
\text { Hardwoods .......... }\end{array}$ & $\begin{array}{r}198,559 \\
10,317 \\
\end{array}$ & $\begin{array}{r}176,693 \\
2,289 \\
\end{array}$ & $\begin{array}{r}1,067,517 \\
10,665 \\
\end{array}$ & $\begin{array}{r}18,641 \\
225\end{array}$ & $\begin{array}{r}53,091 \\
525\end{array}$ & $\begin{array}{r}5,582 \\
140 \\
\end{array}$ & $\begin{array}{r}32,282 \\
700 \\
\end{array}$ \\
\hline Total, Rocky Mountain & $\begin{array}{l}\text { Softwoods......... } \\
\text { Hardwoods....... }\end{array}$ & $\begin{array}{r}852,599 \\
10,597 \\
\end{array}$ & $\begin{array}{r}815,499 \\
2,356 \\
\end{array}$ & $\begin{array}{r}4,948,314 \\
11,081 \\
\end{array}$ & $\begin{array}{r}102,875 \\
235 \\
\end{array}$ & $\begin{array}{r}310,770 \\
554 \\
\end{array}$ & $\begin{array}{r}15,941 \\
141\end{array}$ & $\begin{array}{r}96,674 \\
716 \\
\end{array}$ \\
\hline Total, all regions & 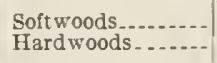 & $\begin{array}{l}8,981,288 \\
3,172,954\end{array}$ & $\begin{array}{l}8,366,589 \\
2,756,788\end{array}$ & $\begin{array}{l}43,521,051 \\
11,226,982\end{array}$ & $\begin{array}{l}922,653 \\
671,595\end{array}$ & $\begin{array}{l}2,474,027 \\
1,190,093\end{array}$ & $\begin{array}{l}334,103 \\
981,030\end{array}$ & $\begin{array}{l}1,743,691 \\
2,614,233\end{array}$ \\
\hline
\end{tabular}


TABLE 45 - Area of commercial timberland by ownership, forest type, stand size, and site, 1970 $1-N o r t h$

[Thousand acres]

NATIONAL FOREST

\begin{tabular}{|c|c|c|c|c|c|c|c|c|c|c|c|c|}
\hline Stand $\operatorname{siz} \theta$ and site & $\begin{array}{l}\text { White- } \\
\text { red-jack } \\
\text { pine }\end{array}$ & $\begin{array}{l}\text { Spruce- } \\
\text { fir }\end{array}$ & $\begin{array}{c}\text { Longleaf- } \\
\text { slash } \\
\text { nine }\end{array}$ & $\begin{array}{l}\text { Loblolly- } \\
\text { shortleaf } \\
\text { pine }\end{array}$ & $\begin{array}{l}\text { Oak- } \\
\text { pine }\end{array}$ & $\begin{array}{c}\text { Oak- } \\
\text { hickory }\end{array}$ & $\begin{array}{l}\text { Oak-gum- } \\
\text { cypress }\end{array}$ & $\begin{array}{l}\text { Elm-ash- } \\
\text { cotton- } \\
\text { wood }\end{array}$ & $\begin{array}{l}\text { Maple- } \\
\text { beech- } \\
\text { birch }\end{array}$ & $\begin{array}{l}\text { Aspen- } \\
\text { birch }\end{array}$ & $\begin{array}{c}\text { Non- } \\
\text { stocked }\end{array}$ & Total \\
\hline $\begin{array}{l}\text { Sawtimber: } \\
120+ \\
85 \text { to } 120 \\
50 \text { to } 85 \\
20 \text { to } 50\end{array}$ & $\begin{array}{r}7 \\
5 \\
177 \\
50\end{array}$ & $\begin{array}{r}17 \\
46 \\
122 \\
70 \\
\end{array}$ & $\begin{array}{l}0 \\
0 \\
0 \\
0\end{array}$ & $\begin{array}{r}19 \\
12 \\
76 \\
1\end{array}$ & $\begin{array}{r}7 \\
15 \\
104 \\
2\end{array}$ & $\begin{array}{r}26 \\
85 \\
626 \\
220\end{array}$ & $\begin{array}{l}0 \\
1 \\
1 \\
0\end{array}$ & $\begin{array}{r}0 \\
4 \\
47 \\
9\end{array}$ & $\begin{array}{r}70 \\
199 \\
744 \\
135\end{array}$ & $\begin{array}{r}0 \\
5 \\
142 \\
32\end{array}$ & $\begin{array}{l}0 \\
0 \\
0 \\
0 \\
\end{array}$ & $\begin{array}{r}147 \\
375 \\
2,042 \\
522 \\
\end{array}$ \\
\hline Total. . & 241 & 256 & 0 & 109 & 129 & 957 & 2 & 60 & 1,150 & 180 & 0 & 3,087 \\
\hline $\begin{array}{l}\text { Poletimber: } \\
120+ \\
85 \text { to } 120 \\
50 \text { to } 85 \\
20 \text { to } 50 .\end{array}$ & $\begin{array}{r}1 \\
13 \\
407 \\
113\end{array}$ & $\begin{array}{r}0 \\
27 \\
444 \\
314 \\
\end{array}$ & $\begin{array}{l}0 \\
0 \\
0 \\
0\end{array}$ & $\begin{array}{r}1 \\
6 \\
71 \\
5\end{array}$ & $\begin{array}{r}1 \\
2 \\
100 \\
2\end{array}$ & $\begin{array}{r}14 \\
36 \\
428 \\
487\end{array}$ & $\begin{array}{l}0 \\
0 \\
0 \\
0 \\
\end{array}$ & $\begin{array}{r}0 \\
4 \\
61 \\
30 \\
\end{array}$ & $\begin{array}{r}33 \\
188 \\
678 \\
108\end{array}$ & $\begin{array}{r}1 \\
26 \\
1,076 \\
265 \\
\end{array}$ & $\begin{array}{l}0 \\
0 \\
0 \\
0\end{array}$ & $\begin{array}{r}52 \\
304 \\
3,267 \\
1,327\end{array}$ \\
\hline Total & 534 & 786 & 0 & 83 & 105 & 966 & 0 & 96 & 1,009 & $1,-369$ & 0 & 4,951 \\
\hline $\begin{array}{l}\text { Seedlings and saplings: } \\
120+120 \\
85 \text { to } 120 \\
50 \text { to } 85 \\
20 \text { to } 50\end{array}$ & $\begin{array}{r}4 \\
11 \\
389 \\
77\end{array}$ & $\begin{array}{r}13 \\
15 \\
206 \\
154\end{array}$ & $\begin{array}{l}0 \\
0 \\
0 \\
0 \\
\end{array}$ & $\begin{array}{r}0 \\
2 \\
86 \\
47 \\
\end{array}$ & $\begin{array}{r}0 \\
0 \\
28 \\
22 \\
\end{array}$ & $\begin{array}{r}0 \\
2 \\
92 \\
168 \\
\end{array}$ & $\begin{array}{l}0 \\
0 \\
0 \\
0 \\
\end{array}$ & $\begin{array}{r}0 \\
2 \\
13 \\
14\end{array}$ & $\begin{array}{r}7 \\
42 \\
225 \\
64\end{array}$ & $\begin{array}{r}0 \\
11 \\
303 \\
59\end{array}$ & $\begin{array}{r}0 \\
5 \\
235 \\
110\end{array}$ & $\begin{array}{r}25 \\
93 \\
1,580 \\
719\end{array}$ \\
\hline Total & 483 & 388 & 0 & 136 & 51 & 263 & 0 & 30 & 340 & 374 & 351 & 2,418 \\
\hline $\begin{array}{l}\text { All size classes: } \\
120+ \\
85 \text { to } 120- \\
50 \text { to } 85 \\
20 \text { to } 50\end{array}$ & $\begin{array}{r}13 \\
30 \\
973 \\
241\end{array}$ & $\begin{array}{r}30 \\
88 \\
772 \\
539 \\
\end{array}$ & $\begin{array}{l}0 \\
0 \\
0 \\
0 \\
\end{array}$ & $\begin{array}{r}20 \\
20 \\
234 \\
54 \\
\end{array}$ & $\begin{array}{r}8 \\
17 \\
233 \\
27\end{array}$ & $\begin{array}{r}40 \\
124 \\
1,146 \\
875\end{array}$ & $\begin{array}{l}0 \\
1 \\
1 \\
0\end{array}$ & $\begin{array}{r}1 \\
11 \\
122 \\
53\end{array}$ & $\begin{array}{r}111 \\
431 \\
1,648 \\
308\end{array}$ & $\begin{array}{r}1 \\
43 \\
1,522 \\
356\end{array}$ & $\begin{array}{r}0 \\
5 \\
235 \\
110\end{array}$ & $\begin{array}{r}225 \\
773 \\
6,890 \\
2,568 \\
\end{array}$ \\
\hline Total.......... & 1,259 & 1,431 & 0 & 329 & 286 & 2,187 & 2 & 187 & 2,499 & 1,923 & 351 & 10,458 \\
\hline
\end{tabular}

OTHER PUBLIC

\begin{tabular}{|c|c|c|c|c|c|c|c|c|c|c|c|c|}
\hline $\begin{array}{l}\text { Sawtimber: } \\
120+ \\
85 \text { to } 120 \ldots \\
50 \text { to } 85 \\
20 \text { to } 50\end{array}$ & $\begin{array}{r}44 \\
72 \\
168 \\
125 \\
\end{array}$ & $\begin{array}{r}23 \\
42 \\
79 \\
195\end{array}$ & $\begin{array}{l}0 \\
0 \\
0 \\
0\end{array}$ & $\begin{array}{r}0 \\
23 \\
19 \\
1\end{array}$ & $\begin{array}{r}9 \\
30 \\
39 \\
15\end{array}$ & $\begin{array}{l}152 \\
255 \\
708 \\
300\end{array}$ & $\begin{array}{r}1 \\
4 \\
24 \\
1\end{array}$ & $\begin{array}{r}9 \\
47 \\
268 \\
262 \\
\end{array}$ & $\begin{array}{r}41 \\
110 \\
465 \\
474 \\
\end{array}$ & $\begin{array}{r}2 \\
37 \\
190 \\
111\end{array}$ & $\begin{array}{l}0 \\
0 \\
0 \\
0\end{array}$ & $\begin{array}{r}284 \\
624 \\
1,964 \\
1,486 \\
\end{array}$ \\
\hline Total.. & 411 & 341 & 0 & 43 & 94 & 1,417 & 30 & 587 & 1,093 & 341 & 0 & 4,360 \\
\hline $\begin{array}{l}\text { Poletimber: } \\
120+ \\
85 \text { to } 120 \\
50 \text { to } 85 \\
20 \text { to } 50\end{array}$ & $\begin{array}{r}62 \\
76 \\
198 \\
448\end{array}$ & $\begin{array}{r}86 \\
208 \\
690 \\
960\end{array}$ & $\begin{array}{l}0 \\
0 \\
0 \\
0\end{array}$ & $\begin{array}{r}2 \\
43 \\
38 \\
3\end{array}$ & $\begin{array}{r}5 \\
14 \\
71 \\
24\end{array}$ & $\begin{array}{r}65 \\
297 \\
779 \\
531 \\
\end{array}$ & $\begin{array}{r}0 \\
2 \\
16 \\
1\end{array}$ & $\begin{array}{r}20 \\
69 \\
305 \\
503\end{array}$ & $\begin{array}{r}33 \\
144 \\
489 \\
657\end{array}$ & $\begin{array}{r}7 \\
267 \\
1,496 \\
1,290\end{array}$ & $\begin{array}{l}0 \\
0 \\
0 \\
0\end{array}$ & $\begin{array}{r}281 \\
1,121 \\
4,084 \\
4,423\end{array}$ \\
\hline Total $\ldots$ & 785 & 1,945 & 0 & 87 & 114 & 1,673 & 20 & 898 & 1,325 & 3,060 & 0 & 9,911 \\
\hline $\begin{array}{l}\text { Seedlings and saplings: } \\
120+ \\
85 \text { to } 120 \\
50 \text { to } 85 \\
20 \text { to } 50\end{array}$ & $\begin{array}{r}23 \\
54 \\
170 \\
284 \\
\end{array}$ & $\begin{array}{r}39 \\
91 \\
552 \\
875\end{array}$ & $\begin{array}{l}0 \\
0 \\
0 \\
0\end{array}$ & $\begin{array}{r}0 \\
34 \\
25 \\
1\end{array}$ & $\begin{array}{r}2 \\
9 \\
33 \\
14 \\
\end{array}$ & $\begin{array}{r}55 \\
90 \\
283 \\
270\end{array}$ & $\begin{array}{r}0 \\
2 \\
12 \\
0\end{array}$ & $\begin{array}{r}6 \\
24 \\
207 \\
304\end{array}$ & $\begin{array}{r}10 \\
37 \\
173 \\
292 \\
\end{array}$ & $\begin{array}{r}1 \\
81 \\
769 \\
838 \\
\end{array}$ & $\begin{array}{r}14 \\
69 \\
587 \\
839 \\
\end{array}$ & $\begin{array}{r}153 \\
493 \\
2,814 \\
3,721 \\
\end{array}$ \\
\hline Total & 532 & 1,558 & 0 & 60 & 58 & 699 & 14 & 542 & 514 & 1,691 & 1,510 & 7,182 \\
\hline $\begin{array}{l}\text { All size classes: } \\
120+120 \\
85 \text { to } 120- \\
50 \text { to } 850 \\
20 \text { to } 50\end{array}$ & $\begin{array}{l}130 \\
202 \\
537 \\
858\end{array}$ & $\begin{array}{r}149 \\
342 \\
1,321 \\
2,032\end{array}$ & $\begin{array}{l}0 \\
0 \\
0 \\
0\end{array}$ & $\begin{array}{r}2 \\
100 \\
82 \\
5\end{array}$ & $\begin{array}{r}16 \\
53 \\
144 \\
54 \\
\end{array}$ & $\begin{array}{r}273 \\
643 \\
1,771 \\
1,101 \\
\end{array}$ & $\begin{array}{r}1 \\
8 \\
52 \\
3\end{array}$ & $\begin{array}{r}35 \\
140 \\
781 \\
1,070 \\
\end{array}$ & $\begin{array}{r}86 \\
292 \\
1,128 \\
1,424 \\
\end{array}$ & $\begin{array}{r}10 \\
386 \\
2,456 \\
2,239 \\
\end{array}$ & $\begin{array}{r}14 \\
69 \\
587 \\
839\end{array}$ & $\begin{array}{r}719 \\
2,239 \\
8,863 \\
9,630 \\
\end{array}$ \\
\hline Total & 1,729 & $3, \delta 46$ & 0 & 190 & 268 & 3,790 & 65 & 2,028 & 2,932 & 5,092 & 1,510 & 21,453 \\
\hline
\end{tabular}

FOREST INDUSTRY

\begin{tabular}{|c|c|c|c|c|c|c|c|c|c|c|c|c|}
\hline \multirow{2}{*}{$\begin{array}{l}\text { Sawtimber: } \\
120+1 \text { to } 120 \\
50 \text { to } 85 \\
20 \text { to } 50 \\
\quad \text { Total }\end{array}$} & $\begin{array}{l}158 \\
150 \\
262 \\
237\end{array}$ & $\begin{array}{l}357 \\
566 \\
607 \\
426\end{array}$ & $\begin{array}{l}0 \\
0 \\
0 \\
0\end{array}$ & $\begin{array}{r}6 \\
32 \\
11 \\
4\end{array}$ & $\begin{array}{l}27 \\
22 \\
26 \\
44\end{array}$ & $\begin{array}{r}91 \\
248 \\
241 \\
234\end{array}$ & $\begin{array}{r}2 \\
11 \\
7 \\
2\end{array}$ & $\begin{array}{l}166 \\
158 \\
415 \\
296 \\
\end{array}$ & $\begin{array}{r}169 \\
202 \\
567 \\
1,215\end{array}$ & $\begin{array}{r}48 \\
127 \\
208 \\
72\end{array}$ & $\begin{array}{l}0 \\
0 \\
0 \\
0\end{array}$ & $\begin{array}{l}1,029 \\
1,518 \\
2,348 \\
2,534\end{array}$ \\
\hline & 809 & 1,958 & 0 & 54 & 120 & 816 & 22 & 1,037 & 2,154 & 456 & 0 & 7,431 \\
\hline $\begin{array}{l}\text { Poletimber: } \\
120+ \\
85 \text { to } 120 \\
50 \text { to } 85 \\
20 \text { to } 50\end{array}$ & $\begin{array}{r}53 \\
206 \\
260 \\
120\end{array}$ & $\begin{array}{l}156 \\
719 \\
503 \\
385\end{array}$ & $\begin{array}{l}0 \\
0 \\
0 \\
0\end{array}$ & $\begin{array}{r}3 \\
20 \\
10 \\
3\end{array}$ & $\begin{array}{l}17 \\
26 \\
31 \\
24\end{array}$ & $\begin{array}{r}55 \\
190 \\
171 \\
163\end{array}$ & $\begin{array}{l}2 \\
5 \\
3 \\
2\end{array}$ & $\begin{array}{r}88 \\
284 \\
220 \\
230\end{array}$ & $\begin{array}{r}76 \\
240 \\
369 \\
488\end{array}$ & $\begin{array}{r}44 \\
211 \\
442 \\
322\end{array}$ & $\begin{array}{l}0 \\
0 \\
0 \\
0\end{array}$ & $\begin{array}{r}497 \\
1,905 \\
2,012 \\
1,740\end{array}$ \\
\hline Total & 640 & 1,764 & 0 & 37 & 99 & 580 & 13 & 824 & 1,174 & 1,020 & 0 & 6,155 \\
\hline
\end{tabular}

See footnote at end of table. 
TABLE 45-Area of commercial timberland by ownership, forest type, stand size, and site, 1970 1-North-Continued

[Thousand acres]

FOREST INDDSTRY-Continued

\begin{tabular}{|c|c|c|c|c|c|c|c|c|c|c|c|c|}
\hline Stand size and site & $\begin{array}{l}\text { White } \\
\text { red-jack } \\
\text { pine }\end{array}$ & $\begin{array}{l}\text { Spruce- } \\
\text { fir }\end{array}$ & $\begin{array}{l}\text { Longleaf- } \\
\text { slash } \\
\text { pine }\end{array}$ & $\begin{array}{l}\text { Loblolly- } \\
\text { shortleaf } \\
\text { pine }\end{array}$ & $\begin{array}{l}\text { Oak- } \\
\text { pine }\end{array}$ & $\begin{array}{c}\text { Oak- } \\
\text { hickory }\end{array}$ & $\begin{array}{l}\text { Oak-gum- } \\
\text { cypress }\end{array}$ & $\begin{array}{l}\text { Elm-ash- } \\
\text { cotton- } \\
\text { wood }\end{array}$ & $\begin{array}{l}\text { Maple- } \\
\text { beech- } \\
\text { birch }\end{array}$ & $\begin{array}{l}\text { Aspen- } \\
\text { birch }\end{array}$ & $\begin{array}{l}\text { Non- } \\
\text { stocked }\end{array}$ & Total \\
\hline $\begin{array}{l}\text { Seedlings and saplings: } \\
120+\ldots \ldots \\
\$ 5 \text { to } 120=\ldots \\
50 \text { to } 85 . \ldots \\
20 \text { to } 50 . . .\end{array}$ & $\begin{array}{r}22 \\
97 \\
162 \\
88\end{array}$ & $\begin{array}{l}122 \\
339 \\
343 \\
410\end{array}$ & $\begin{array}{l}0 \\
0 \\
0 \\
0\end{array}$ & $\begin{array}{r}3 \\
12 \\
6 \\
2\end{array}$ & $\begin{array}{l}0 \\
26 \\
14 \\
17\end{array}$ & $\begin{array}{r}15 \\
81 \\
83 \\
159\end{array}$ & $\begin{array}{l}0 \\
6 \\
3 \\
3\end{array}$ & $\begin{array}{r}36 \\
133 \\
219 \\
140 \\
\end{array}$ & $\begin{array}{r}31 \\
120 \\
175 \\
382\end{array}$ & $\begin{array}{r}38 \\
63 \\
290 \\
190\end{array}$ & $\begin{array}{r}1 \\
6 \\
35 \\
90\end{array}$ & $\begin{array}{r}269 \\
888 \\
1,333 \\
1,485\end{array}$ \\
\hline Total.... & 370 & 1,215 & 0 & 23 & 57 & 339 & 13 & 530 & 709 & 583 & 133 & 3,976 \\
\hline $\begin{array}{l}\text { All size classes: } \\
120+130 . \\
85 \text { to } 120 . \\
50 \text { to } 85 . \\
20 \text { to } 50 .\end{array}$ & $\begin{array}{l}234 \\
454 \\
685 \\
447\end{array}$ & $\begin{array}{r}636 \\
1,625 \\
1,454 \\
1,222 \\
\end{array}$ & $\begin{array}{l}0 \\
0 \\
0 \\
0\end{array}$ & $\begin{array}{r}12 \\
65 \\
25 \\
9\end{array}$ & $\begin{array}{l}45 \\
74 \\
72 \\
85\end{array}$ & $\begin{array}{l}162 \\
520 \\
496 \\
557\end{array}$ & $\begin{array}{r}4 \\
23 \\
14 \\
7\end{array}$ & $\begin{array}{l}291 \\
577 \\
855 \\
663\end{array}$ & $\begin{array}{r}276 \\
563 \\
1,112 \\
2,086 \\
\end{array}$ & $\begin{array}{l}131 \\
402 \\
940 \\
585\end{array}$ & $\begin{array}{r}1 \\
6 \\
35 \\
90\end{array}$ & $\begin{array}{l}1,796 \\
4,311 \\
5,694 \\
5,760\end{array}$ \\
\hline Total & 1,820 & 4,938 & 0 & 115 & 277 & 1,735 & 50 & 2,391 & 4,038 & 2,060 & 133 & 17,563 \\
\hline
\end{tabular}

FARM AND MISCELLANEOUS PRIVATE

\begin{tabular}{|c|c|c|c|c|c|c|c|c|c|c|c|c|}
\hline $\begin{array}{l}\text { Sawtimber: } \\
120+120 . \\
85 \text { to } 120 \ldots \text { to } 85 \ldots \\
20 \text { to } 50 \ldots \ldots\end{array}$ & $\begin{array}{r}343 \\
734 \\
1,112 \\
663\end{array}$ & $\begin{array}{l}294 \\
558 \\
665 \\
493 \\
\end{array}$ & $\begin{array}{l}0 \\
0 \\
0 \\
0\end{array}$ & $\begin{array}{r}30 \\
685 \\
383 \\
69\end{array}$ & $\begin{array}{l}112 \\
542 \\
312 \\
265\end{array}$ & $\begin{array}{r}710 \\
6,611 \\
7,555 \\
5,051 \\
\end{array}$ & $\begin{array}{r}10 \\
225 \\
247 \\
146 \\
\end{array}$ & $\begin{array}{r}247 \\
1,239 \\
3,147 \\
2,243 \\
\end{array}$ & $\begin{array}{r}578 \\
1,759 \\
3,505 \\
2,516 \\
\end{array}$ & $\begin{array}{r}30 \\
292 \\
494 \\
186\end{array}$ & $\begin{array}{l}0 \\
0 \\
0 \\
0\end{array}$ & $\begin{array}{r}2,359 \\
12,649 \\
17,426 \\
11,635 \\
\end{array}$ \\
\hline Total & 2,854 & 2,014 & 0 & 1,168 & 1,233 & 19,929 & 630 & 6,877 & 8,360 & 1,004 & 0 & 44,071 \\
\hline $\begin{array}{l}\text { Poletimber: } \\
120+ \\
85 \text { to } 120 \ldots \\
50 \text { to } 85 \\
20 \text { to } 50 \ldots \ldots\end{array}$ & $\begin{array}{l}211 \\
413 \\
952 \\
535 \\
\end{array}$ & $\begin{array}{r}345 \\
525 \\
916 \\
1,229 \\
\end{array}$ & $\begin{array}{l}0 \\
0 \\
0 \\
0\end{array}$ & $\begin{array}{r}18 \\
490 \\
278 \\
50 \\
\end{array}$ & $\begin{array}{r}62 \\
269 \\
396 \\
242 \\
\end{array}$ & $\begin{array}{r}679 \\
4,126 \\
5,674 \\
4,701 \\
\end{array}$ & $\begin{array}{r}4 \\
116 \\
118 \\
60 \\
\end{array}$ & $\begin{array}{r}326 \\
997 \\
1,889 \\
1,815 \\
\end{array}$ & $\begin{array}{r}394 \\
1,416 \\
2,213 \\
2,654 \\
\end{array}$ & $\begin{array}{r}148 \\
908 \\
2,342 \\
1,610 \\
\end{array}$ & $\begin{array}{l}0 \\
0 \\
0 \\
0\end{array}$ & $\begin{array}{r}2,190 \\
9,265 \\
14,780 \\
12,902 \\
\end{array}$ \\
\hline Total & 2,113 & 3,016 & 0 & 837 & 971 & 15,182 & 299 & 5,029 & 6,678 & 5,009 & 0 & 39,137 \\
\hline $\begin{array}{l}\text { Seedlings and saplings: } \\
120+ \\
85 \text { to } 120 \\
50 \text { to } 85 \ldots \ldots \\
20 \text { to } 50\end{array}$ & $\begin{array}{l}176 \\
536 \\
716 \\
705 \\
\end{array}$ & $\begin{array}{r}482 \\
900 \\
1,041 \\
1,230\end{array}$ & $\begin{array}{l}0 \\
0 \\
0 \\
0\end{array}$ & $\begin{array}{r}24 \\
436 \\
274 \\
45\end{array}$ & $\begin{array}{r}79 \\
430 \\
254 \\
284 \\
\end{array}$ & $\begin{array}{r}742 \\
3,388 \\
4,325 \\
4,255\end{array}$ & $\begin{array}{r}1 \\
142 \\
124 \\
46\end{array}$ & $\begin{array}{r}250 \\
967 \\
1,913 \\
2,325 \\
\end{array}$ & $\begin{array}{r}432 \\
1,312 \\
1,978 \\
2,424 \\
\end{array}$ & $\begin{array}{r}160 \\
1,297 \\
2,447 \\
1,489 \\
\end{array}$ & $\begin{array}{r}130 \\
697 \\
2,288 \\
4,460 \\
\end{array}$ & $\begin{array}{r}2,480 \\
10,107 \\
15,363 \\
17,265 \\
\end{array}$ \\
\hline Total & 2,134 & 3,653 & 0 & 780 & 1,048 & 12,711 & 314 & 5,457 & 6,148 & 5,393 & 7,576 & 45,217 \\
\hline $\begin{array}{l}\text { All size classes: } \\
120+ \\
85 \text { to } 120 \\
50 \text { to } 85 \\
20 \text { to } 50\end{array}$ & $\begin{array}{r}731 \\
1,684 \\
2,781 \\
1,905\end{array}$ & $\begin{array}{l}1,121 \\
1,984 \\
2,625 \\
2,952\end{array}$ & $\begin{array}{l}0 \\
0 \\
0 \\
0 \\
\end{array}$ & $\begin{array}{r}73 \\
1,612 \\
935 \\
165 \\
\end{array}$ & $\begin{array}{r}255 \\
1,242 \\
963 \\
792 \\
\end{array}$ & $\begin{array}{r}2,133 \\
14,126 \\
17,554 \\
14,008\end{array}$ & $\begin{array}{r}16 \\
484 \\
489 \\
253\end{array}$ & $\begin{array}{r}824 \\
3,204 \\
6,950 \\
6,384 \\
\end{array}$ & $\begin{array}{l}1,405 \\
4,488 \\
7,697 \\
7,594\end{array}$ & $\begin{array}{r}338 \\
2,498 \\
5,284 \\
3,286\end{array}$ & $\begin{array}{r}130 \\
697 \\
2,288 \\
4,460 \\
\end{array}$ & $\begin{array}{r}7,029 \\
32,022 \\
47,570 \\
41,803\end{array}$ \\
\hline Total & 7,101 & 8,683 & 0 & 2,787 & 3,253 & 47,823 & 1,244 & 17,364 & 21,186 & 11,407 & 7,576 & 128,426 \\
\hline
\end{tabular}

ALL OWNERSHIPS

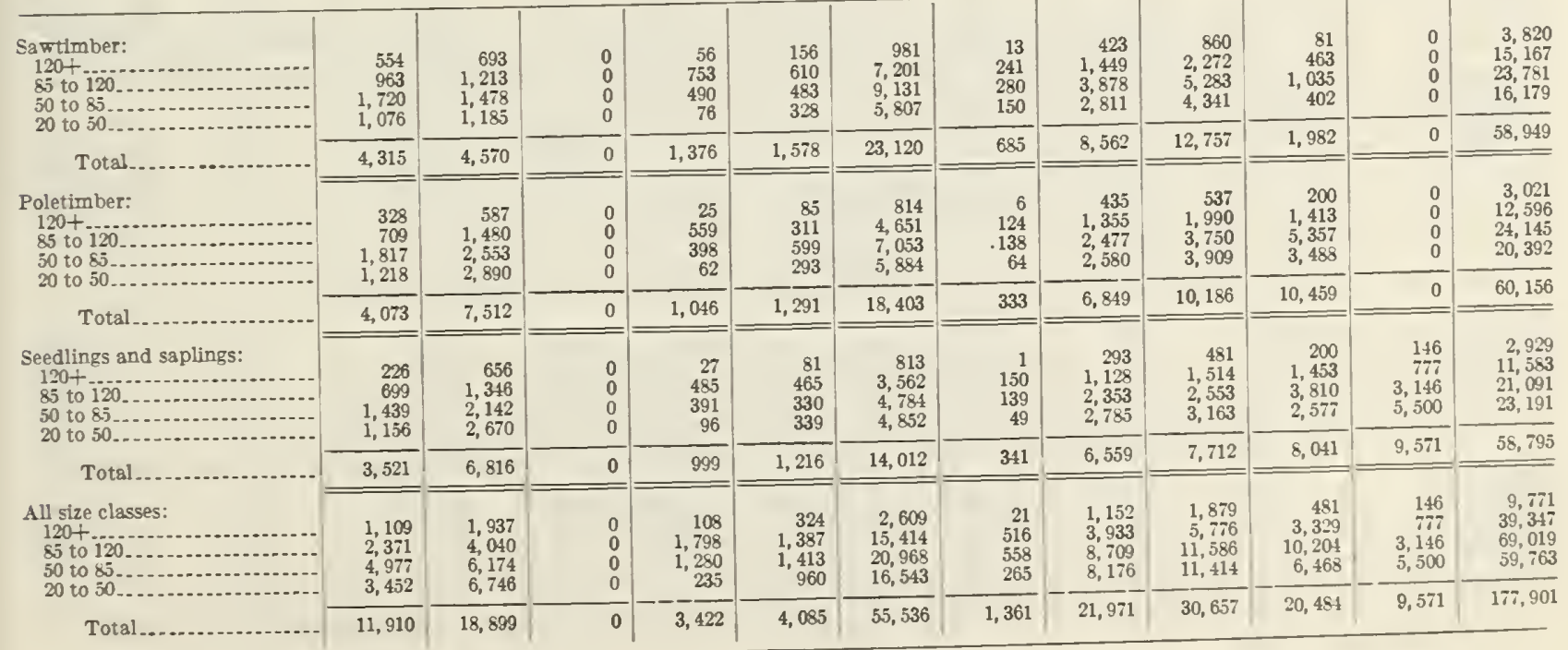


TABLE 46. - Area of commercial timberland by ownership, forest type, stand size, and site, 1970 1-South

[Thousand acres]

NATIONAL FOREST

\begin{tabular}{|c|c|c|c|c|c|c|c|c|c|c|c|c|}
\hline Stand size and site & $\begin{array}{l}\text { White- } \\
\text { red-jack } \\
\text { pine }\end{array}$ & $\begin{array}{l}\text { Spruce- } \\
\text { fir }\end{array}$ & $\begin{array}{c}\text { Longleaf- } \\
\text { slash } \\
\text { pine }\end{array}$ & $\begin{array}{l}\text { Loblolly- } \\
\text { shortleaf } \\
\text { pine }\end{array}$ & $\begin{array}{l}\text { Oak- } \\
\text { pine }\end{array}$ & $\begin{array}{c}\text { Oak- } \\
\text { hickory }\end{array}$ & $\begin{array}{c}\text { Oak-gum- } \\
\text { cypress }\end{array}$ & $\begin{array}{l}\text { Elm-ash- } \\
\text { cotton- } \\
\text { wood }\end{array}$ & $\begin{array}{l}\text { Maple- } \\
\text { beech- } \\
\text { birch }\end{array}$ & $\begin{array}{l}\text { Aspen- } \\
\text { birch }\end{array}$ & $\begin{array}{l}\text { Non- } \\
\text { stocked }\end{array}$ & Tota] \\
\hline 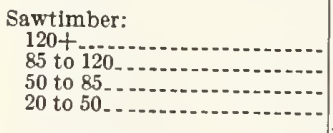 & $\begin{array}{r}18 \\
7 \\
30 \\
5 \\
\end{array}$ & $\begin{array}{l}0 \\
0 \\
2 \\
1\end{array}$ & $\begin{array}{r}24 \\
144 \\
262 \\
88 \\
\end{array}$ & $\begin{array}{l}259 \\
736 \\
781 \\
194 \\
\end{array}$ & $\begin{array}{r}67 \\
224 \\
440 \\
185 \\
\end{array}$ & $\begin{array}{r}54 \\
309 \\
908 \\
481 \\
\end{array}$ & $\begin{array}{l}46 \\
84 \\
87 \\
69 \\
\end{array}$ & $\begin{array}{r}0 \\
8 \\
12 \\
0\end{array}$ & $\begin{array}{r}1 \\
15 \\
44 \\
15\end{array}$ & $\begin{array}{l}0 \\
0 \\
0 \\
0 \\
\end{array}$ & $\begin{array}{l}0 \\
0 \\
0 \\
0 \\
\end{array}$ & $\begin{array}{r}47 \\
1,53 \\
2,57 \\
1,04 \\
\end{array}$ \\
\hline Total _. - & 61 & 4 & 519 & 1,971 & 917 & 1,754 & 287 & 21 & 76 & 0 & 0 & 5,614 \\
\hline $\begin{array}{l}\text { Poletimber: } \\
120+ \\
85 \text { to } 120 \\
50 \text { to } 85 \\
20 \text { to } 50\end{array}$ & $\begin{array}{l}1 \\
0 \\
0 \\
0\end{array}$ & $\begin{array}{l}0 \\
0 \\
0 \\
0\end{array}$ & $\begin{array}{r}0 \\
44 \\
108 \\
55 \\
\end{array}$ & $\begin{array}{r}32 \\
124 \\
386 \\
158 \\
\end{array}$ & $\begin{array}{r}16 \\
59 \\
266 \\
92\end{array}$ & $\begin{array}{r}16 \\
79 \\
746 \\
498\end{array}$ & $\begin{array}{l}11 \\
11 \\
30 \\
15\end{array}$ & $\begin{array}{l}0 \\
0 \\
2 \\
0\end{array}$ & $\begin{array}{r}0 \\
3 \\
11 \\
10\end{array}$ & $\begin{array}{l}0 \\
0 \\
0 \\
0 \\
\end{array}$ & $\begin{array}{l}0 \\
0 \\
0 \\
0 \\
\end{array}$ & $\begin{array}{r}77 \\
323 \\
1,552 \\
831\end{array}$ \\
\hline Total & 1 & 0 & 209 & 701 & 434 & 1,339 & 69 & 2 & 25 & 0 & 0 & 2,784 \\
\hline $\begin{array}{l}\text { Seedlings and saplings: } \\
120+ \\
85 \text { to } 120 \\
50 \text { to } 85 \\
20 \text { to } 50\end{array}$ & $\begin{array}{l}0 \\
1 \\
0 \\
1 \\
\end{array}$ & $\begin{array}{l}0 \\
0 \\
0 \\
0\end{array}$ & $\begin{array}{r}0 \\
54 \\
128 \\
46\end{array}$ & $\begin{array}{r}8 \\
109 \\
226 \\
159\end{array}$ & $\begin{array}{r}2 \\
97 \\
230 \\
168\end{array}$ & $\begin{array}{r}0 \\
85 \\
429 \\
436 \\
\end{array}$ & $\begin{array}{r}7 \\
15 \\
42 \\
14 \\
\end{array}$ & $\begin{array}{l}0 \\
0 \\
0 \\
0 \\
\end{array}$ & $\begin{array}{l}0 \\
0 \\
5 \\
4 \\
\end{array}$ & $\begin{array}{l}0 \\
0 \\
0 \\
0\end{array}$ & $\begin{array}{r}0 \\
0 \\
41 \\
48\end{array}$ & $\begin{array}{r}18 \\
363 \\
1,104 \\
878 \\
\end{array}$ \\
\hline Total & 2 & 0 & 229 & 503 & 498 & 951 & 79 & 0 & 9 & 0 & 89 & 2,365 \\
\hline $\begin{array}{l}\text { All size classes: } \\
120+ \\
85 \text { to } 120 \ldots \\
50 \text { to } 85 \\
20 \text { to } 50\end{array}$ & $\begin{array}{r}19 \\
8 \\
30 \\
6\end{array}$ & $\begin{array}{l}0 \\
0 \\
2 \\
2\end{array}$ & $\begin{array}{r}24 \\
244 \\
499 \\
190\end{array}$ & $\begin{array}{r}300 \\
970 \\
1,393 \\
511\end{array}$ & $\begin{array}{r}85 \\
380 \\
937 \\
446 \\
\end{array}$ & $\begin{array}{r}70 \\
474 \\
2,083 \\
1,416 \\
\end{array}$ & $\begin{array}{r}66 \\
111 \\
160 \\
98 \\
\end{array}$ & $\begin{array}{r}0 \\
8 \\
15 \\
0\end{array}$ & $\begin{array}{r}1 \\
19 \\
61 \\
30\end{array}$ & $\begin{array}{l}0 \\
0 \\
0 \\
0\end{array}$ & $\begin{array}{r}0 \\
0 \\
41 \\
48 \\
\end{array}$ & $\begin{array}{r}568 \\
2,217 \\
5,228 \\
2,750\end{array}$ \\
\hline Total & 65 & 4 & 958 & 3,176 & 1,850 & 4,045 & 436 & 24 & 112 & 0 & 89 & 10,764 \\
\hline
\end{tabular}

OTHER PUBLIC

\begin{tabular}{|c|c|c|c|c|c|c|c|c|c|c|c|c|}
\hline \multirow[t]{2}{*}{$\begin{array}{l}\text { Sawtimber: } \\
120+ \\
85 \text { to } 120 \\
50 \text { to } 85 \\
20 \text { to } 50 \\
\text { Total }\end{array}$} & $\begin{array}{l}0 \\
0 \\
0 \\
0\end{array}$ & $\begin{array}{l}0 \\
0 \\
0 \\
0 \\
\end{array}$ & $\begin{array}{r}21 \\
115 \\
202 \\
113 \\
\end{array}$ & $\begin{array}{r}89 \\
220 \\
215 \\
76\end{array}$ & $\begin{array}{r}28 \\
103 \\
190 \\
101\end{array}$ & $\begin{array}{r}15 \\
122 \\
374 \\
89\end{array}$ & $\begin{array}{r}145 \\
259 \\
208 \\
89 \\
\end{array}$ & $\begin{array}{r}21 \\
9 \\
17 \\
5 \\
\end{array}$ & $\begin{array}{r}0 \\
0 \\
14 \\
0\end{array}$ & $\begin{array}{l}0 \\
0 \\
0 \\
0\end{array}$ & $\begin{array}{l}0 \\
0 \\
0 \\
0\end{array}$ & $\begin{array}{r}322 \\
830 \\
1,224 \\
474 \\
\end{array}$ \\
\hline & 0 & 0 & 452 & 601 & 424 & 602 & 702 & 53 & 14 & 0 & 0 & 2,851 \\
\hline $\begin{array}{l}\text { Poletimber: } \\
120+1 \\
85 \text { to } 120 \\
50 \text { to } 85 \\
20 \text { to } 50\end{array}$ & $\begin{array}{l}4 \\
0 \\
0 \\
0\end{array}$ & $\begin{array}{l}0 \\
0 \\
0 \\
0\end{array}$ & $\begin{array}{r}6 \\
41 \\
88 \\
57\end{array}$ & $\begin{array}{r}18 \\
117 \\
131 \\
89\end{array}$ & $\begin{array}{r}10 \\
42 \\
130 \\
64 \\
\end{array}$ & $\begin{array}{r}7 \\
56 \\
223 \\
168\end{array}$ & $\begin{array}{l}32 \\
40 \\
76 \\
43\end{array}$ & $\begin{array}{r}10 \\
6 \\
10 \\
4\end{array}$ & $\begin{array}{l}0 \\
0 \\
0 \\
0\end{array}$ & $\begin{array}{l}0 \\
0 \\
0 \\
0\end{array}$ & $\begin{array}{l}0 \\
0 \\
0 \\
0\end{array}$ & $\begin{array}{r}89 \\
304 \\
660 \\
427\end{array}$ \\
\hline Total $\ldots$ & 4 & 0 & 193 & 356 & 247 & 455 & 193 & 32 & 0 & 0 & 0 & 1,482 \\
\hline $\begin{array}{l}\text { Seedlings and saplings: } \\
120+ \\
85 \text { to } 120 \\
50 \text { to } 85 \\
20 \text { to } 50\end{array}$ & $\begin{array}{l}0 \\
0 \\
0 \\
0\end{array}$ & $\begin{array}{l}0 \\
0 \\
0 \\
0\end{array}$ & $\begin{array}{r}4 \\
41 \\
176 \\
99\end{array}$ & $\begin{array}{r}0 \\
88 \\
128 \\
81\end{array}$ & $\begin{array}{r}2 \\
64 \\
160 \\
93\end{array}$ & $\begin{array}{r}0 \\
48 \\
312 \\
276\end{array}$ & $\begin{array}{l}33 \\
81 \\
81 \\
23\end{array}$ & $\begin{array}{r}8 \\
0 \\
11 \\
6\end{array}$ & $\begin{array}{l}0 \\
0 \\
0 \\
0\end{array}$ & $\begin{array}{l}0 \\
0 \\
0 \\
0\end{array}$ & $\begin{array}{r}0 \\
11 \\
106 \\
236\end{array}$ & $\begin{array}{r}49 \\
335 \\
978 \\
818\end{array}$ \\
\hline Total $\ldots$ & 0 & 0 & 322 & 299 & 320 & 637 & 219 & 26 & 0 & 0 & 354 & 2,181 \\
\hline $\begin{array}{l}\text { All sizes classes: } \\
120+ \\
85 \text { to } 120 \\
50 \text { to } 85 \\
20 \text { to } 50 .\end{array}$ & $\begin{array}{l}4 \\
0 \\
0 \\
0\end{array}$ & $\begin{array}{l}0 \\
0 \\
0 \\
0\end{array}$ & $\begin{array}{r}32 \\
197 \\
468 \\
269\end{array}$ & $\begin{array}{l}108 \\
425 \\
475 \\
247\end{array}$ & $\begin{array}{r}40 \\
210 \\
481 \\
259\end{array}$ & $\begin{array}{r}22 \\
227 \\
911 \\
534\end{array}$ & $\begin{array}{l}211 \\
381 \\
366 \\
156\end{array}$ & $\begin{array}{l}41 \\
15 \\
39 \\
16\end{array}$ & $\begin{array}{r}0 \\
0 \\
14 \\
0\end{array}$ & $\begin{array}{l}0 \\
0 \\
0 \\
0\end{array}$ & $\begin{array}{r}0 \\
11 \\
106 \\
236\end{array}$ & $\begin{array}{r}461 \\
1,470 \\
2,863 \\
1,720 \\
\end{array}$ \\
\hline Total $\ldots$ & 4 & 0 & 968 & 1,257 & 991 & 1,695 & 1,115 & 112 & 14 & 0 & 354 & 6,514 \\
\hline
\end{tabular}

FOREST INDUSTRY

\begin{tabular}{|c|c|c|c|c|c|c|c|c|c|c|c|c|}
\hline \multirow[t]{2}{*}{$\begin{array}{l}\text { Sawtimber: } \\
120+ \\
85 \text { to } 120 \\
50 \text { to } 85 \\
20 \text { to } 50 \\
\text { Total }\end{array}$} & $\begin{array}{l}4 \\
0 \\
4 \\
3\end{array}$ & $\begin{array}{l}0 \\
0 \\
0 \\
0\end{array}$ & $\begin{array}{l}142 \\
688 \\
704 \\
229\end{array}$ & $\begin{array}{r}1,095 \\
2,784 \\
1,768 \\
290\end{array}$ & $\begin{array}{r}500 \\
1,096 \\
805 \\
113\end{array}$ & $\begin{array}{l}224 \\
629 \\
697 \\
203\end{array}$ & $\begin{array}{r}386 \\
1,644 \\
1,161 \\
231\end{array}$ & $\begin{array}{r}93 \\
79 \\
92 \\
9\end{array}$ & $\begin{array}{l}0 \\
4 \\
8 \\
0\end{array}$ & $\begin{array}{l}0 \\
0 \\
0 \\
0\end{array}$ & $\begin{array}{l}0 \\
0 \\
0 \\
0\end{array}$ & $\begin{array}{l}2,447 \\
6,926 \\
5,242 \\
1,080\end{array}$ \\
\hline & 12 & 0 & 1,764 & 5,938 & 2,515 & 1,756 & 3,422 & 274 & 12 & 0 & 0 & 15,697 \\
\hline $\begin{array}{l}\text { Poletimber: } \\
120+ \\
85 \text { to } 120 \\
50 \text { to } 85 \\
20 \text { to } 50\end{array}$ & $\begin{array}{l}0 \\
0 \\
0 \\
0\end{array}$ & $\begin{array}{l}0 \\
0 \\
0 \\
0\end{array}$ & $\begin{array}{r}65 \\
514 \\
653 \\
213\end{array}$ & $\begin{array}{r}99 \\
635 \\
1,038 \\
220\end{array}$ & $\begin{array}{l}101 \\
269 \\
587 \\
145\end{array}$ & $\begin{array}{r}70 \\
277 \\
766 \\
316\end{array}$ & $\begin{array}{r}88 \\
326 \\
478 \\
108\end{array}$ & $\begin{array}{r}11 \\
26 \\
21 \\
0\end{array}$ & $\begin{array}{l}4 \\
0 \\
4 \\
0\end{array}$ & $\begin{array}{l}0 \\
0 \\
0 \\
0\end{array}$ & $\begin{array}{l}0 \\
0 \\
0 \\
0\end{array}$ & $\begin{array}{r}440 \\
2,049 \\
3,549 \\
1,004\end{array}$ \\
\hline Total & 0 & 0 & 1,447 & 1,993 & 1,103 & 1,431 & 1,001 & 59 & 8 & 0 & 0 & 7,044 \\
\hline
\end{tabular}

See footnote at end of table. 
TABLE 46. - Area of commercial timberland by ownership, forest type, stand size, and site, 1970 1-South-Continued

[Thousand acres]

FOREST INDESTRY-Continued

\begin{tabular}{|c|c|c|c|c|c|c|c|c|c|c|c|c|}
\hline Stand size and site & $\begin{array}{l}\text { White- } \\
\text { red-jack } \\
\text { pine }\end{array}$ & $\begin{array}{l}\text { Spruce- } \\
\text { fir }\end{array}$ & $\begin{array}{l}\text { Long- } \\
\text { leaf-slash } \\
\text { pine }\end{array}$ & $\begin{array}{l}\text { Loblolly- } \\
\text { shortleaf } \\
\text { pine }\end{array}$ & $\begin{array}{l}\text { Oak- } \\
\text { pine }\end{array}$ & $\begin{array}{l}\text { Oak- } \\
\text { hickory }\end{array}$ & $\begin{array}{l}\text { Oak- } \\
\text { gum- } \\
\text { cypress }\end{array}$ & $\begin{array}{l}\text { Elm-ash- } \\
\text { cotton- } \\
\text { wood }\end{array}$ & $\begin{array}{l}\text { Maple- } \\
\text { beech- } \\
\text { birch }\end{array}$ & $\begin{array}{l}\text { Aspen- } \\
\text { birch }\end{array}$ & $\begin{array}{l}\text { Non- } \\
\text { stocked }\end{array}$ & Total \\
\hline $\begin{array}{l}\text { Seedlings and saplings: } \\
120 \text { to } 120 \\
85 \text { to } 120 \\
50 \text { to } 85 \\
20 \text { to } 50\end{array}$ & $\begin{array}{l}0 \\
4 \\
0 \\
0\end{array}$ & $\begin{array}{l}0 \\
0 \\
0 \\
0\end{array}$ & $\begin{array}{r}55 \\
678 \\
1,718 \\
450\end{array}$ & $\begin{array}{r}219 \\
933 \\
2,056 \\
591\end{array}$ & $\begin{array}{r}94 \\
529 \\
1,304 \\
359\end{array}$ & $\begin{array}{r}68 \\
328 \\
953 \\
470\end{array}$ & $\begin{array}{r}84 \\
264 \\
401 \\
164\end{array}$ & $\begin{array}{r}34 \\
9 \\
25 \\
3\end{array}$ & $\begin{array}{l}0 \\
0 \\
0 \\
0\end{array}$ & $\begin{array}{l}0 \\
0 \\
0 \\
0\end{array}$ & $\begin{array}{r}25 \\
73 \\
317 \\
362\end{array}$ & $\begin{array}{r}583 \\
2,821 \\
6,776 \\
2,403\end{array}$ \\
\hline Total....................... & 4 & 0 & 2,903 & 3,800 & 2,288 & 1,820 & 915 & 73 & 0 & 0 & 778 & 12,583 \\
\hline $\begin{array}{l}\text { All size classes: } \\
120+\ldots \text { to } 120 \\
85 \\
50 \text { to } 85 \\
20 \text { to } 50\end{array}$ & $\begin{array}{l}4 \\
4 \\
4 \\
3\end{array}$ & $\begin{array}{l}0 \\
0 \\
0 \\
0\end{array}$ & $\begin{array}{r}262 \\
1,851 \\
3,076 \\
894\end{array}$ & $\begin{array}{l}1,414 \\
4,333 \\
4,862 \\
1,101\end{array}$ & $\begin{array}{r}696 \\
1,896 \\
2,697 \\
617\end{array}$ & $\begin{array}{r}364 \\
1,235 \\
2,417 \\
991\end{array}$ & $\begin{array}{r}559 \\
2,234 \\
2,041 \\
503\end{array}$ & $\begin{array}{r}139 \\
115 \\
138 \\
13\end{array}$ & $\begin{array}{r}4 \\
4 \\
12 \\
0\end{array}$ & $\begin{array}{l}0 \\
0 \\
0 \\
0\end{array}$ & $\begin{array}{r}25 \\
73 \\
317 \\
362\end{array}$ & $\begin{array}{r}3,470 \\
11,798 \\
15,568 \\
4,488\end{array}$ \\
\hline Total. . . . . & 16 & 0 & 6,115 & 11,731 & 5,907 & 5,008 & 5,339 & 407 & 21 & 0 & 778 & 35,325 \\
\hline
\end{tabular}

FARM AND MISCELLANEOUS PRIVATE

\begin{tabular}{|c|c|c|c|c|c|c|c|c|c|c|c|c|}
\hline $\begin{array}{l}\text { Sawtimber: } \\
120+ \\
85 \text { to } 120 \\
50 \text { to } 85 \\
20 \text { to } 50.20\end{array}$ & $\begin{array}{r}43 \\
14 \\
34 \\
3\end{array}$ & $\begin{array}{l}0 \\
0 \\
4 \\
0\end{array}$ & $\begin{array}{r}290 \\
939 \\
1,434 \\
656\end{array}$ & $\begin{array}{r}1,940 \\
4,679 \\
4,418 \\
541 \\
\end{array}$ & $\begin{array}{r}1,155 \\
2,635 \\
3,029 \\
751\end{array}$ & $\begin{array}{r}777 \\
3,048 \\
6,684 \\
2,702\end{array}$ & $\begin{array}{r}974 \\
6,659 \\
3,937 \\
1,096\end{array}$ & $\begin{array}{r}291 \\
529 \\
312 \\
81\end{array}$ & $\begin{array}{r}8 \\
27 \\
125 \\
18\end{array}$ & $\begin{array}{l}0 \\
0 \\
0 \\
0\end{array}$ & $\begin{array}{l}0 \\
0 \\
0 \\
0\end{array}$ & $\begin{array}{r}5,482 \\
18,532 \\
19,981 \\
5,881\end{array}$ \\
\hline Total & 96 & 4 & 3,350 & 11,579 & 7,572 & 13,212 & 12,668 & 1,214 & 179 & 0 & 0 & 49,877 \\
\hline $\begin{array}{l}\text { Poletimber: } \\
120+\ldots \\
85 \text { to } 120 \\
50 \text { to } 85 \\
20 \text { to } 50 \text {. }\end{array}$ & $\begin{array}{r}15 \\
3 \\
0 \\
4\end{array}$ & $\begin{array}{l}0 \\
0 \\
4 \\
0\end{array}$ & $\begin{array}{r}94 \\
795 \\
1,086 \\
381\end{array}$ & $\begin{array}{r}534 \\
2,140 \\
3,913 \\
860\end{array}$ & $\begin{array}{r}282 \\
1,300 \\
2,631 \\
903\end{array}$ & $\begin{array}{r}394 \\
2,266 \\
7,322 \\
4,171\end{array}$ & $\begin{array}{r}303 \\
2,043 \\
2,159 \\
592\end{array}$ & $\begin{array}{r}106 \\
181 \\
167 \\
61\end{array}$ & $\begin{array}{r}3 \\
13 \\
92 \\
4\end{array}$ & $\begin{array}{l}0 \\
0 \\
0 \\
0\end{array}$ & $\begin{array}{l}0 \\
0 \\
0 \\
0\end{array}$ & $\begin{array}{r}1,734 \\
8,745 \\
17,381 \\
6,979\end{array}$ \\
\hline Total................ & 23 & 4 & 2,357 & 7,450 & 5,121 & 14,155 & 5,097 & 517 & 114 & 0 & 0 & 34,840 \\
\hline $\begin{array}{l}\text { Seedings and saplings: } \\
120 \text { t } \\
85 \text { to } 120 \ldots \\
50 \text { to } 85 \ldots \ldots \\
20 \text { to } 50 \ldots \ldots\end{array}$ & $\begin{array}{r}24 \\
9 \\
19 \\
0 \\
\end{array}$ & $\begin{array}{l}0 \\
0 \\
0 \\
0\end{array}$ & $\begin{array}{r}112 \\
1,481 \\
2,267 \\
700\end{array}$ & $\begin{array}{r}599 \\
3,698 \\
8,002 \\
1,914\end{array}$ & $\begin{array}{r}369 \\
1,739 \\
5,650 \\
1,739 \\
\end{array}$ & $\begin{array}{r}278 \\
2,027 \\
9,051 \\
6,850\end{array}$ & $\begin{array}{r}281 \\
1,375 \\
2,255 \\
699\end{array}$ & $\begin{array}{r}87 \\
185 \\
145 \\
62\end{array}$ & $\begin{array}{r}0 \\
0 \\
16 \\
24\end{array}$ & $\begin{array}{l}0 \\
0 \\
0 \\
0\end{array}$ & $\begin{array}{r}11 \\
169 \\
1,195 \\
2,173 \\
\end{array}$ & $\begin{array}{r}1,762 \\
10,688 \\
28,604 \\
14,164\end{array}$ \\
\hline Total & 52 & 0 & 4,564 & 14,214 & 9,499 & 18,207 & 4,610 & 480 & 40 & 0 & 3,549 & 55,219 \\
\hline $\begin{array}{l}\text { All size classes: } \\
120+ \\
85 \text { to } 120 \\
50 \text { to } 85 \\
20 \text { to } 50\end{array}$ & $\begin{array}{r}83 \\
26 \\
53 \\
7 \\
\end{array}$ & $\begin{array}{l}0 \\
0 \\
8 \\
0\end{array}$ & $\begin{array}{r}496 \\
3,219 \\
4,788 \\
1,768 \\
\end{array}$ & $\begin{array}{r}3,074 \\
10,518 \\
16,334 \\
3,315 \\
\end{array}$ & $\begin{array}{r}1,807 \\
5,675 \\
11,314 \\
3,391 \\
\end{array}$ & $\begin{array}{r}1,449 \\
7,341 \\
23,059 \\
13,724\end{array}$ & $\begin{array}{r}1,558 \\
10,077 \\
8,352 \\
2,388 \\
\end{array}$ & $\begin{array}{l}484 \\
896 \\
625 \\
205 \\
\end{array}$ & $\begin{array}{r}12 \\
40 \\
234 \\
47\end{array}$ & $\begin{array}{l}0 \\
0 \\
0 \\
0\end{array}$ & $\begin{array}{r}11 \\
169 \\
1,195 \\
2,173 \\
\end{array}$ & $\begin{array}{r}8,978 \\
37,966 \\
65,967 \\
27,025 \\
\end{array}$ \\
\hline Total & 171 & 8 & 10,272 & 33,243 & 22,192 & 45,575 & 22,377 & 2,212 & 334 & 0 & 3,549 & 139,938 \\
\hline
\end{tabular}

ALL OWNERSHIPS

\begin{tabular}{|c|c|c|c|c|c|c|c|c|c|c|c|c|}
\hline $\begin{array}{l}\text { Santimber: } \\
120 \text { t } \\
85 \text { to } 120 \\
50 \text { to } 85 \\
20 \text { to } 50\end{array}$ & $\begin{array}{l}66 \\
21 \\
69 \\
13\end{array}$ & $\begin{array}{l}0 \\
0 \\
7 \\
1\end{array}$ & $\begin{array}{r}478 \\
1,887 \\
2,603 \\
1,116\end{array}$ & $\begin{array}{l}3,385 \\
8,420 \\
7,183 \\
1,101\end{array}$ & $\begin{array}{l}1,751 \\
4,059 \\
4,465 \\
1,151\end{array}$ & $\begin{array}{l}1,071 \\
4,110 \\
8,665 \\
3,477\end{array}$ & $\begin{array}{l}1,553 \\
8,646 \\
5,395 \\
1,486\end{array}$ & $\begin{array}{r}407 \\
626 \\
435 \\
96\end{array}$ & $\begin{array}{r}9 \\
47 \\
193 \\
33\end{array}$ & $\begin{array}{l}0 \\
0 \\
0 \\
0\end{array}$ & $\begin{array}{l}0 \\
0 \\
0 \\
0\end{array}$ & $\begin{array}{r}8,724 \\
27,820 \\
29,018 \\
8,477\end{array}$ \\
\hline Total & 170 & 8 & 6,056 & 20,090 & 11,428 & 17,325 & 17,082 & 1,564 & 284 & 0 & 0 & 74,041 \\
\hline $\begin{array}{l}\text { Poletimber: } \\
120+ \\
85 \text { to } 120 \\
50 \text { to } 85 \\
20 \text { to } 50\end{array}$ & $\begin{array}{r}21 \\
3 \\
0 \\
4\end{array}$ & $\begin{array}{l}0 \\
0 \\
4 \\
0\end{array}$ & $\begin{array}{r}165 \\
1,396 \\
1,937 \\
708\end{array}$ & $\begin{array}{l}681 \\
3,017 \\
5,469 \\
1,329\end{array}$ & $\begin{array}{r}409 \\
1,672 \\
3,618 \\
1,205\end{array}$ & $\begin{array}{r}488 \\
2,680 \\
9,058 \\
5,154\end{array}$ & $\begin{array}{r}435 \\
2,421 \\
2,744 \\
759\end{array}$ & $\begin{array}{r}128 \\
214 \\
202 \\
66\end{array}$ & $\begin{array}{r}7 \\
17 \\
108 \\
15\end{array}$ & $\begin{array}{l}0 \\
0 \\
0 \\
0\end{array}$ & $\begin{array}{l}0 \\
0 \\
0 \\
0\end{array}$ & $\begin{array}{r}2,340 \\
11,423 \\
23,144 \\
9,242\end{array}$ \\
\hline Total & 28 & 4 & 4,207 & 10,501 & 6,906 & 17,381 & 6,361 & 611 & 148 & 0 & 0 & 46,151 \\
\hline $\begin{array}{l}\text { Seedlings and saplings: } \\
120+ \\
85 \text { to } 120 \\
50 \text { to } 85 \\
20 \text { to } 50\end{array}$ & $\begin{array}{r}24 \\
14 \\
19 \\
1\end{array}$ & $\begin{array}{l}0 \\
0 \\
0 \\
0\end{array}$ & $\begin{array}{r}172 \\
2,259 \\
4,292 \\
1,296\end{array}$ & $\begin{array}{r}827 \\
4,830 \\
10,413 \\
2,745\end{array}$ & $\begin{array}{r}469 \\
2,431 \\
7,346 \\
2,360\end{array}$ & $\begin{array}{r}346 \\
2,488 \\
10,747 \\
8,035\end{array}$ & $\begin{array}{r}407 \\
1,736 \\
2,780 \\
901\end{array}$ & $\begin{array}{r}130 \\
195 \\
182 \\
72\end{array}$ & $\begin{array}{r}0 \\
0 \\
21 \\
28\end{array}$ & $\begin{array}{l}0 \\
0 \\
0 \\
0\end{array}$ & $\begin{array}{r}36 \\
254 \\
1,660 \\
2,820\end{array}$ & $\begin{array}{r}2,413 \\
14,209 \\
37,463 \\
18,263\end{array}$ \\
\hline Total & 58 & 0 & 8,020 & 18,817 & 12,607 & 21,617 & 5,825 & 580 & 50 & 0 & 4,771 & 72,349 \\
\hline $\begin{array}{l}\text { All size classes: } \\
120 \text { t } \\
85 \text { to } 120 \\
50 \text { to } 85 \\
20 \text { to } 50 \ldots\end{array}$ & $\begin{array}{r}111 \\
39 \\
88 \\
18\end{array}$ & $\begin{array}{r}0 \\
0 \\
11 \\
2\end{array}$ & $\begin{array}{r}816 \\
5,543 \\
8,833 \\
3,122\end{array}$ & $\begin{array}{r}4,898 \\
16,268 \\
23,066 \\
5,176\end{array}$ & $\begin{array}{r}2,630 \\
8,163 \\
15,430 \\
4,718\end{array}$ & $\begin{array}{r}1,906 \\
9,279 \\
28,471 \\
16,667\end{array}$ & $\begin{array}{r}2,396 \\
12,804 \\
10,920 \\
3,146\end{array}$ & $\begin{array}{r}665 \\
1,035 \\
820 \\
235\end{array}$ & $\begin{array}{r}17 \\
64 \\
323 \\
77\end{array}$ & $\begin{array}{l}0 \\
0 \\
0 \\
0\end{array}$ & $\begin{array}{r}36 \\
254 \\
1,660 \\
2,820\end{array}$ & $\begin{array}{l}13,478 \\
53,452 \\
89,626 \\
35,984\end{array}$ \\
\hline Total......... & 257 & 13 & 18,314 & 49,409 & 30,942 & 56,324 & 29,268 & 2,756 & 482 & 0 & 4,771 & 192,542 \\
\hline
\end{tabular}

\footnotetext{
${ }^{1}$ Data may not add to totals because of truncating. Zeros indicate no data or negligible amounts.
} 
TABLE 47.-Area of commercial timberland by ownership, forest type, stand size, and site, $1970^{1}{ }^{1}$ Rocky Mountains ${ }^{2}$ [Thousand acres]

NATIONAL FOREST

\begin{tabular}{|c|c|c|c|c|c|c|c|c|c|c|c|}
\hline Stand size and site & $\begin{array}{l}\text { Douglas } \\
\text { fir }\end{array}$ & $\begin{array}{l}\text { Ponder- } \\
\text { osa pine }\end{array}$ & $\begin{array}{c}\text { Western } \\
\text { white } \\
\text { pine }\end{array}$ & $\begin{array}{c}\text { Fir- } \\
\text { spruce }\end{array}$ & $\begin{array}{l}\text { Hemlock- } \\
\text { Sitka } \\
\text { spruce }\end{array}$ & Larch & $\begin{array}{l}\text { Lodge- } \\
\text { pole } \\
\text { pine }\end{array}$ & Redwood & $\begin{array}{c}\text { Western } \\
\text { hard- } \\
\text { woods }\end{array}$ & $\begin{array}{c}\text { Non- } \\
\text { stocked }\end{array}$ & Total \\
\hline $\begin{array}{l}\text { Sawtimber: } \\
120+ \\
85 \text { to } 120 \\
50 \text { to } 85 \\
20 \text { to } 50\end{array}$ & $\begin{array}{r}651 \\
927 \\
1,532 \\
2,220\end{array}$ & $\begin{array}{r}158 \\
216 \\
1,238 \\
3,738\end{array}$ & $\begin{array}{r}225 \\
53 \\
19 \\
1\end{array}$ & $\begin{array}{r}464 \\
1,007 \\
1,699 \\
2,572\end{array}$ & $\begin{array}{l}95 \\
88 \\
69 \\
70\end{array}$ & $\begin{array}{r}336 \\
195 \\
149 \\
14\end{array}$ & $\begin{array}{r}256 \\
618 \\
796 \\
1,556\end{array}$ & $\begin{array}{l}0 \\
0 \\
0 \\
0\end{array}$ & $\begin{array}{r}18 \\
28 \\
163 \\
436\end{array}$ & $\begin{array}{l}0 \\
0 \\
0 \\
0\end{array}$ & $\begin{array}{r}2,206 \\
3,135 \\
5,668 \\
10,609\end{array}$ \\
\hline 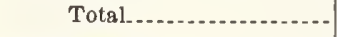 & 5,332 & 5,350 & 300 & 5,743 & 323 & 695 & 3,227 & 0 & 646 & 0 & 21,620 \\
\hline $\begin{array}{l}\text { Poletimber: } \\
120+ \\
85 \text { to } 120 \\
50 \text { to } 85 \\
20 \text { to } 50\end{array}$ & $\begin{array}{l}176 \\
293 \\
185 \\
256\end{array}$ & $\begin{array}{r}45 \\
13 \\
70 \\
600\end{array}$ & $\begin{array}{r}80 \\
15 \\
8 \\
0\end{array}$ & $\begin{array}{r}96 \\
165 \\
190 \\
401\end{array}$ & $\begin{array}{r}23 \\
26 \\
5 \\
6\end{array}$ & $\begin{array}{r}199 \\
97 \\
37 \\
1\end{array}$ & $\begin{array}{r}337 \\
856 \\
771 \\
1,387\end{array}$ & $\begin{array}{l}0 \\
0 \\
0 \\
0\end{array}$ & $\begin{array}{r}43 \\
130 \\
193 \\
745\end{array}$ & $\begin{array}{l}0 \\
0 \\
0 \\
0\end{array}$ & $\begin{array}{l}1,001 \\
1,599 \\
1,463 \\
3,399\end{array}$ \\
\hline Total & 911 & 729 & 104 & 854 & 62 & 335 & 3,353 & 0 & 1,112 & 0 & 7,462 \\
\hline $\begin{array}{l}\text { Seedlings and saplings: } \\
120+ \\
85 \text { to } 120 \ldots \\
50 \text { to } 85 \\
20 \text { to } 50 .\end{array}$ & $\begin{array}{l}106 \\
228 \\
131 \\
170\end{array}$ & $\begin{array}{r}7 \\
18 \\
63 \\
345\end{array}$ & $\begin{array}{r}43 \\
12 \\
4 \\
0\end{array}$ & $\begin{array}{l}101 \\
205 \\
154 \\
289\end{array}$ & $\begin{array}{l}10 \\
10 \\
11 \\
10\end{array}$ & $\begin{array}{r}108 \\
58 \\
9 \\
10\end{array}$ & $\begin{array}{l}145 \\
311 \\
189 \\
618\end{array}$ & $\begin{array}{l}0 \\
0 \\
0 \\
0\end{array}$ & $\begin{array}{r}0 \\
9 \\
64 \\
239\end{array}$ & $\begin{array}{r}218 \\
255 \\
325 \\
1,168\end{array}$ & $\begin{array}{r}741 \\
1,109 \\
953 \\
2,853\end{array}$ \\
\hline Totel & 636 & 434 & 61 & 751 & 41 & 186 & 1,264 & 0 & 314 & 1,967 & 5,657 \\
\hline $\begin{array}{l}\text { All size classes: } \\
120+ \\
85 \text { to } 120 \\
50 \text { to } 85 \\
20 \text { to } 50\end{array}$ & $\begin{array}{r}934 \\
1,449 \\
1,849 \\
2,647\end{array}$ & $\begin{array}{r}210 \\
247 \\
1,372 \\
4,683\end{array}$ & $\begin{array}{r}349 \\
81 \\
33 \\
1\end{array}$ & $\begin{array}{r}663 \\
1,378 \\
2,044 \\
3,263\end{array}$ & $\begin{array}{r}128 \\
125 \\
85 \\
87\end{array}$ & $\begin{array}{r}643 \\
351 \\
196 \\
25\end{array}$ & $\begin{array}{r}739 \\
1,785 \\
1,758 \\
3,562\end{array}$ & $\begin{array}{l}0 \\
0 \\
0 \\
0\end{array}$ & $\begin{array}{r}61 \\
168 \\
421 \\
1,421\end{array}$ & $\begin{array}{r}218 \\
255 \\
325 \\
1,168\end{array}$ & $\begin{array}{r}3,949 \\
5,844 \\
8,085 \\
16,861\end{array}$ \\
\hline Total & 6,880 & 6,513 & 466 & 7,349 & 426 & 1,217 & 7,845 & 0 & 2,073 & 1,967 & 34,740 \\
\hline
\end{tabular}

\begin{tabular}{|c|c|c|c|c|c|c|c|c|c|c|c|}
\hline $\begin{array}{l}\text { Sawtimber: } \\
120+ \\
85 \text { to } 120 \ldots \\
50 \text { to } 85 \\
20 \text { to } 50\end{array}$ & $\begin{array}{r}41 \\
155 \\
537 \\
572\end{array}$ & $\begin{array}{r}12 \\
187 \\
802 \\
1,722\end{array}$ & $\begin{array}{r}27 \\
30 \\
0 \\
0\end{array}$ & $\begin{array}{r}54 \\
162 \\
313 \\
203\end{array}$ & $\begin{array}{r}9 \\
64 \\
29 \\
10\end{array}$ & $\begin{array}{l}33 \\
21 \\
57 \\
18\end{array}$ & $\begin{array}{r}0 \\
8 \\
46 \\
174\end{array}$ & $\begin{array}{l}0 \\
0 \\
0 \\
0\end{array}$ & $\begin{array}{r}1 \\
8 \\
16 \\
155\end{array}$ & $\begin{array}{l}0 \\
0 \\
0 \\
0\end{array}$ & $\begin{array}{r}180 \\
638 \\
1,803 \\
2,855\end{array}$ \\
\hline Total.... & 1,306 & 2,725 & 58 & 733 & 113 & 131 & 228 & 0 & 182 & 0 & 5,478 \\
\hline $\begin{array}{l}\text { Poletimber: } \\
120+ \\
85 \text { to } 120 \\
50 \text { to } 85 \\
20 \text { to } 50\end{array}$ & $\begin{array}{r}0 \\
17 \\
20 \\
202\end{array}$ & $\begin{array}{r}0 \\
12 \\
12 \\
205\end{array}$ & $\begin{array}{l}0 \\
0 \\
0 \\
0\end{array}$ & $\begin{array}{r}0 \\
10 \\
11 \\
17\end{array}$ & $\begin{array}{l}0 \\
0 \\
7 \\
6\end{array}$ & $\begin{array}{r}0 \\
0 \\
14 \\
13\end{array}$ & $\begin{array}{r}0 \\
0 \\
55 \\
267\end{array}$ & $\begin{array}{l}0 \\
0 \\
0 \\
0\end{array}$ & $\begin{array}{r}0 \\
0 \\
7 \\
258\end{array}$ & $\begin{array}{l}0 \\
0 \\
0 \\
0\end{array}$ & $\begin{array}{r}0 \\
39 \\
128 \\
971\end{array}$ \\
\hline Total & 240 & 229 & 0 & 39 & 13 & 27 & 323 & 0 & 265 & 0 & 1,139 \\
\hline $\begin{array}{l}\text { Seedlings and saplings: } \\
120+ \\
85 \text { to } 120 \\
50 \text { to } 85 \\
20 \text { to } 50\end{array}$ & $\begin{array}{r}3 \\
28 \\
17 \\
44\end{array}$ & $\begin{array}{r}4 \\
0 \\
21 \\
67\end{array}$ & $\begin{array}{r}13 \\
0 \\
0 \\
0\end{array}$ & $\begin{array}{l}12 \\
13 \\
22 \\
19\end{array}$ & $\begin{array}{l}0 \\
6 \\
6 \\
0\end{array}$ & $\begin{array}{l}0 \\
0 \\
2 \\
0\end{array}$ & $\begin{array}{r}0 \\
0 \\
0 \\
88\end{array}$ & $\begin{array}{l}0 \\
0 \\
0 \\
0\end{array}$ & $\begin{array}{r}0 \\
0 \\
4 \\
46\end{array}$ & $\begin{array}{r}0 \\
0 \\
15 \\
123\end{array}$ & $\begin{array}{r}34 \\
48 \\
91 \\
389\end{array}$ \\
\hline Total... & 94 & 93 & 13 & 67 & 13 & 2 & 88 & 0 & 52 & 139 & 563 \\
\hline $\begin{array}{l}\text { All size classes: } \\
120+ \\
85 \text { to } 120 \ldots \\
50 \text { to } 85 \\
20 \text { to } 50\end{array}$ & $\begin{array}{r}45 \\
200 \\
575 \\
819\end{array}$ & $\begin{array}{r}16 \\
199 \\
836 \\
1,994\end{array}$ & $\begin{array}{r}40 \\
30 \\
0 \\
0\end{array}$ & $\begin{array}{r}67 \\
186 \\
347 \\
239\end{array}$ & $\begin{array}{r}9 \\
71 \\
43 \\
16\end{array}$ & $\begin{array}{l}33 \\
21 \\
74 \\
31\end{array}$ & $\begin{array}{r}0 \\
8 \\
101 \\
530\end{array}$ & $\begin{array}{l}0 \\
0 \\
0 \\
0\end{array}$ & $\begin{array}{r}2 \\
8 \\
29 \\
460\end{array}$ & $\begin{array}{r}0 \\
0 \\
15 \\
123\end{array}$ & $\begin{array}{r}214 \\
726 \\
2,024 \\
4,215\end{array}$ \\
\hline Total & 1,641 & 3,048 & 71 & 840 & 140 & 161 & 639 & 0 & 500 & 139 & 7,181 \\
\hline
\end{tabular}

FOREST INDUSTRY

\begin{tabular}{|c|c|c|c|c|c|c|c|c|c|c|c|}
\hline $\begin{array}{l}\text { Saw timber: } \\
120+ \\
85 \text { to } 120 \ldots \\
50 \text { to } 85 \\
20 \text { to } 50\end{array}$ & $\begin{array}{r}69 \\
57 \\
219 \\
144\end{array}$ & $\begin{array}{r}9 \\
71 \\
261 \\
244\end{array}$ & $\begin{array}{r}30 \\
16 \\
11 \\
0\end{array}$ & $\begin{array}{r}36 \\
103 \\
164 \\
18\end{array}$ & $\begin{array}{l}27 \\
31 \\
45 \\
30\end{array}$ & $\begin{array}{l}45 \\
36 \\
71 \\
22\end{array}$ & $\begin{array}{r}6 \\
1 \\
4 \\
14\end{array}$ & $\begin{array}{l}0 \\
0 \\
0 \\
0\end{array}$ & $\begin{array}{l}0 \\
8 \\
4 \\
3\end{array}$ & $\begin{array}{l}0 \\
0 \\
0 \\
0\end{array}$ & $\begin{array}{l}225 \\
325 \\
782 \\
478\end{array}$ \\
\hline Total & 491 & 586 & 58 & 322 & 134 & 175 & 26 & 0 & 17 & 0 & 1,812 \\
\hline $\begin{array}{l}\text { Poletimber: } \\
120+ \\
85 \text { to } 1200 \\
50 \text { to } 85 \\
20 \text { to } 50 .\end{array}$ & $\begin{array}{r}0 \\
1 \\
3 \\
51\end{array}$ & $\begin{array}{r}0 \\
1 \\
4 \\
34\end{array}$ & $\begin{array}{l}0 \\
4 \\
1 \\
0\end{array}$ & $\begin{array}{l}0 \\
1 \\
9 \\
2\end{array}$ & $\begin{array}{l}0 \\
0 \\
0 \\
0\end{array}$ & $\begin{array}{r}0 \\
0 \\
20 \\
0\end{array}$ & $\begin{array}{r}0 \\
0 \\
20 \\
79\end{array}$ & $\begin{array}{l}0 \\
0 \\
0 \\
0\end{array}$ & $\begin{array}{l}0 \\
0 \\
1 \\
7\end{array}$ & $\begin{array}{l}0 \\
0 \\
0 \\
0\end{array}$ & $\begin{array}{r}0 \\
8 \\
61 \\
175\end{array}$ \\
\hline Total & 55 & 40 & 6 & 13 & 0 & 20 & 99 & 0 & 9 & 0 & 245 \\
\hline
\end{tabular}


TABLE 47.-Area of commercial timberland by ownership, forest type, stand size, and sile, $19700^{2}$-Racky Hcuntains ${ }^{2}$-Con. [Thousand acres]

FOREST INDUSTRY-Continued

\begin{tabular}{|c|c|c|c|c|c|c|c|c|c|c|c|}
\hline Stand size and site & $\begin{array}{l}\text { Douglas- } \\
\text { fir }\end{array}$ & $\begin{array}{l}\text { Ponder- } \\
\text { osa pine }\end{array}$ & $\begin{array}{l}\text { Western } \\
\text { white } \\
\text { pine }\end{array}$ & $\begin{array}{c}\text { Fir- } \\
\text { spruce }\end{array}$ & $\begin{array}{l}\text { Hemlock- } \\
\text { Sitks } \\
\text { spruce }\end{array}$ & Larch & $\begin{array}{l}\text { Lodge- } \\
\text { pole } \\
\text { pine }\end{array}$ & Redwood & $\begin{array}{l}\text { Western } \\
\text { hard. } \\
\text { woods }\end{array}$ & $\begin{array}{l}\text { Non- } \\
\text { stocked }\end{array}$ & Total \\
\hline $\begin{array}{l}\text { Seedling and saplings: } \\
120+ \\
85 \text { to } 120 \\
50 \text { to } 85 \\
20 \text { to } 50\end{array}$ & $\begin{array}{r}1 \\
9 \\
19 \\
2\end{array}$ & $\begin{array}{r}2 \\
0 \\
4 \\
14\end{array}$ & $\begin{array}{l}0 \\
0 \\
0 \\
0\end{array}$ & $\begin{array}{r}10 \\
26 \\
16 \\
0\end{array}$ & $\begin{array}{l}0 \\
0 \\
7 \\
0\end{array}$ & $\begin{array}{l}0 \\
0 \\
3 \\
0\end{array}$ & $\begin{array}{r}0 \\
0 \\
0 \\
18\end{array}$ & $\begin{array}{l}0 \\
0 \\
0 \\
0\end{array}$ & $\begin{array}{l}0 \\
0 \\
1 \\
1\end{array}$ & $\begin{array}{r}0 \\
0 \\
24 \\
11\end{array}$ & $\begin{array}{l}14 \\
35 \\
77 \\
49\end{array}$ \\
\hline Total... & 32 & 21 & 0 & 54 & 7 & 3 & 18 & 0 & 2 & 35 & 176 \\
\hline 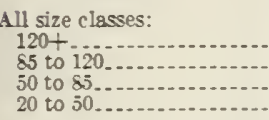 & $\begin{array}{r}70 \\
67 \\
242 \\
198\end{array}$ & $\begin{array}{r}11 \\
72 \\
270 \\
294\end{array}$ & $\begin{array}{r}30 \\
20 \\
12 \\
0\end{array}$ & $\begin{array}{r}47 \\
191 \\
190 \\
21\end{array}$ & $\begin{array}{l}27 \\
31 \\
52 \\
30\end{array}$ & $\begin{array}{l}45 \\
36 \\
95 \\
22\end{array}$ & $\begin{array}{r}6 \\
1 \\
24 \\
112\end{array}$ & $\begin{array}{l}0 \\
0 \\
0 \\
0\end{array}$ & $\begin{array}{r}0 \\
8 \\
7 \\
12\end{array}$ & $\begin{array}{r}0 \\
0 \\
24 \\
11\end{array}$ & $\begin{array}{l}239 \\
370 \\
920 \\
703\end{array}$ \\
\hline Total_.... & 579 & 618 & 64 & 390 & 142 & 199 & 144 & 0 & 28 & 35 & 2,233 \\
\hline
\end{tabular}

FARII AND MISCELLANEOUS PRIVATE

Sawtimber:

$120+$

85 to 12

20 to 50

Total

Poletimber:

$120+$

50 to 12

20 to 50

Total.

Seedling and saplings:

120

85 to 120

50 to 85

20 to $50-$

Total

All size classes:

$120+$

85 to 120

50 to 85

Total.

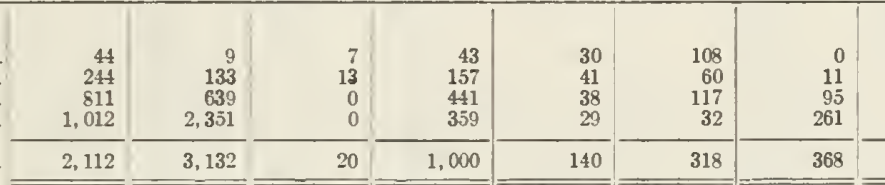

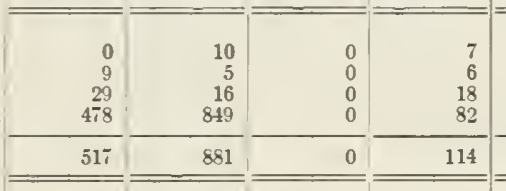

\begin{tabular}{r|r}
\hline \hline 1 & 25 \\
16 & 0 \\
80 & 37 \\
55 & 166 \\
\hline 154 & 229 \\
\hline \hline 45 & \\
\hline 271 & 45 \\
921 & 692 \\
1,546 & 3,366 \\
\hline 2,785 & 4,243 \\
\hline
\end{tabular}

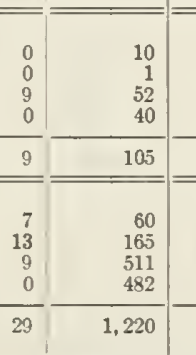

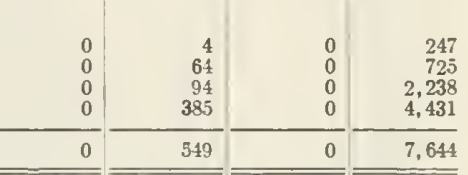

ALL OWNERSHIPS

\begin{tabular}{|c|c|c|c|c|c|c|c|c|c|c|c|}
\hline 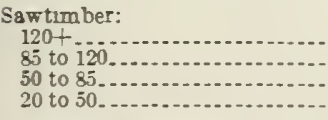 & $\begin{array}{r}807 \\
1,385 \\
3,101 \\
3,949\end{array}$ & $\begin{array}{r}189 \\
608 \\
2,941 \\
8,056\end{array}$ & $\begin{array}{r}291 \\
113 \\
31 \\
1\end{array}$ & $\begin{array}{r}598 \\
1,431 \\
2,617 \\
3,152\end{array}$ & $\begin{array}{l}162 \\
225 \\
182 \\
141\end{array}$ & $\begin{array}{r}524 \\
313 \\
396 \\
87\end{array}$ & $\begin{array}{r}262 \\
638 \\
943 \\
2,005\end{array}$ & $\begin{array}{l}0 \\
0 \\
0 \\
0\end{array}$ & $\begin{array}{r}24 \\
110 \\
280 \\
980\end{array}$ & $\begin{array}{l}0 \\
0 \\
0 \\
0\end{array}$ & $\begin{array}{r}2,860 \\
4,826 \\
10,493 \\
18,375\end{array}$ \\
\hline Total... & 9,243 & 11,795 & 437 & 7,799 & i12 & 1,321 & 3,850 & 0 & 1,395 & 0 & 36,555 \\
\hline $\begin{array}{l}\text { Poletimber: } \\
120 \text { t } \\
85 \text { to } 120 . \\
50 \text { to } 85 \\
20 \text { to } 50\end{array}$ & $\begin{array}{l}176 \\
321 \\
239 \\
988\end{array}$ & $\begin{array}{r}56 \\
31 \\
103 \\
1,689\end{array}$ & $\begin{array}{r}80 \\
20 \\
10 \\
0\end{array}$ & $\begin{array}{l}104 \\
183 \\
230 \\
505\end{array}$ & $\begin{array}{l}23 \\
34 \\
13 \\
18\end{array}$ & $\begin{array}{r}199 \\
107 \\
158 \\
14\end{array}$ & $\begin{array}{r}343 \\
869 \\
971 \\
2,365\end{array}$ & $\begin{array}{l}0 \\
0 \\
0 \\
0\end{array}$ & $\begin{array}{r}43 \\
130 \\
239 \\
1,858\end{array}$ & $\begin{array}{l}0 \\
0 \\
0 \\
0\end{array}$ & $\begin{array}{l}1,025 \\
1,698 \\
1,965 \\
7,439\end{array}$ \\
\hline Total_.. & 1,725 & 1,880 & 110 & 1,022 & 89 & 478 & 4,549 & 0 & 2,272 & 0 & 12,129 \\
\hline $\begin{array}{l}\text { Seedlings and saplings: } \\
120+5 \\
85 \text { to } 120 \\
50 \text { to } 85 \\
20 \text { to } 50\end{array}$ & $\begin{array}{l}112 \\
282 \\
248 \\
273\end{array}$ & $\begin{array}{r}39 \\
18 \\
127 \\
593\end{array}$ & $\begin{array}{r}56 \\
12 \\
13 \\
0\end{array}$ & $\begin{array}{l}135 \\
247 \\
245 \\
350\end{array}$ & $\begin{array}{l}28 \\
24 \\
24 \\
17\end{array}$ & $\begin{array}{r}108 \\
66 \\
46 \\
10\end{array}$ & $\begin{array}{l}145 \\
328 \\
189 \\
877\end{array}$ & $\begin{array}{l}0 \\
0 \\
0 \\
0\end{array}$ & $\begin{array}{r}5 \\
9 \\
87 \\
502\end{array}$ & $\begin{array}{r}227 \\
275 \\
453 \\
1,715\end{array}$ & $\begin{array}{r}859 \\
1,265 \\
1,436 \\
4,338\end{array}$ \\
\hline Total & 916 & 778 & 83 & 978 & 94 & 232 & 1,540 & 0 & 604 & 2,671 & 7,900 \\
\hline $\begin{array}{l}\text { All size classes: } \\
120+\text { t } \\
85 \text { to } 120 \\
50 \text { to } 85 \\
20 \text { to } 30\end{array}$ & $\begin{array}{l}1,096 \\
1,989 \\
3,589 \\
5,211\end{array}$ & $\begin{array}{r}284 \\
6.58 \\
3,171 \\
10,339\end{array}$ & $\begin{array}{r}428 \\
146 \\
55 \\
1\end{array}$ & $\begin{array}{r}837 \\
1,861 \\
3,093 \\
4,007\end{array}$ & $\begin{array}{l}214 \\
284 \\
221 \\
177\end{array}$ & $\begin{array}{l}832 \\
487 \\
600 \\
111\end{array}$ & $\begin{array}{r}751 \\
1,836 \\
2,104 \\
5,248\end{array}$ & $\begin{array}{l}0 \\
0 \\
0 \\
0\end{array}$ & $\begin{array}{r}73 \\
250 \\
606 \\
3,341\end{array}$ & $\begin{array}{r}227 \\
275 \\
453 \\
1,715\end{array}$ & $\begin{array}{r}4,746 \\
7,789 \\
13,895 \\
30,153\end{array}$ \\
\hline Total... & 11,885 & 14,454 & 631 & 9,800 & 896 & 2,032 & 9,940 & 0 & 4,272 & 2,671 & 56,585 \\
\hline
\end{tabular}

1 Data may not add to totals because of truncating. Zeros indicate no data or negligible amounts.

2 See footnote 2 , table 3 . 
TABLE 48.-Area of commercial timberland by ownership, forest type, stand size, and site, 1970 1-Pacific Coast [Thousand acres]

NATIONAL FOREST

\begin{tabular}{|c|c|c|c|c|c|c|c|c|c|c|c|}
\hline Stand size and site & $\begin{array}{l}\text { Douglas- } \\
\text { fir }\end{array}$ & $\begin{array}{l}\text { Ponder- } \\
\text { osa pine }\end{array}$ & $\begin{array}{c}\text { Western } \\
\text { white } \\
\text { pine }\end{array}$ & $\begin{array}{l}\text { Fir- } \\
\text { spruce }\end{array}$ & $\begin{array}{l}\text { Hemlock- } \\
\text { Sitka } \\
\text { spruce }\end{array}$ & Larch & $\begin{array}{l}\text { Lodge- } \\
\text { pole } \\
\text { pine }\end{array}$ & Redwood & $\begin{array}{c}\text { Western } \\
\text { hard- } \\
\text { woods }\end{array}$ & $\begin{array}{l}\text { Non- } \\
\text { stocked }\end{array}$ & Total \\
\hline $\begin{array}{l}\text { Sawtimber: } \\
120+120 \\
85 \text { to } 120 \\
50 \text { to } 85 \\
20 \text { to } 50\end{array}$ & $\begin{array}{r}1,644 \\
1,279 \\
2,711 \\
421\end{array}$ & $\begin{array}{r}578 \\
1,568 \\
3,155 \\
1,078\end{array}$ & $\begin{array}{c}20 \\
23 \\
24 \\
45\end{array}$ & $\begin{array}{r}1,140 \\
1,309 \\
1,940 \\
492\end{array}$ & $\begin{array}{r}1,827 \\
2,006 \\
960 \\
129\end{array}$ & $\begin{array}{r}39 \\
52 \\
115 \\
33\end{array}$ & $\begin{array}{r}9 \\
199 \\
361 \\
41\end{array}$ & $\begin{array}{l}1 \\
1 \\
2 \\
0\end{array}$ & $\begin{array}{r}233 \\
286 \\
293 \\
33\end{array}$ & $\begin{array}{l}0 \\
0 \\
0 \\
0\end{array}$ & $\begin{array}{l}5,492 \\
6,724 \\
9,562 \\
2,273\end{array}$ \\
\hline Total...................... & 6,055 & 6,379 & 112 & 4,881 & 4,924 & 239 & 610 & 4 & 846 & 0 & 24,052 \\
\hline 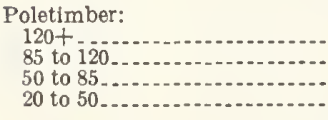 & $\begin{array}{r}142 \\
111 \\
330 \\
78\end{array}$ & $\begin{array}{r}21 \\
123 \\
362 \\
149\end{array}$ & $\begin{array}{l}1 \\
1 \\
0 \\
0\end{array}$ & $\begin{array}{r}109 \\
114 \\
239 \\
67\end{array}$ & $\begin{array}{r}98 \\
82 \\
52 \\
4\end{array}$ & $\begin{array}{l}19 \\
29 \\
35 \\
10\end{array}$ & $\begin{array}{r}18 \\
483 \\
575 \\
52\end{array}$ & $\begin{array}{l}0 \\
0 \\
0 \\
0\end{array}$ & $\begin{array}{r}40 \\
34 \\
67 \\
4\end{array}$ & $\begin{array}{l}0 \\
0 \\
0 \\
0\end{array}$ & $\begin{array}{r}450 \\
979 \\
1,660 \\
365\end{array}$ \\
\hline Total & 661 & 655 & 2 & 531 & 238 & 93 & 1,128 & 0 & 146 & 0 & 3,456 \\
\hline $\begin{array}{l}\text { Seedlings and saplings: } \\
120+ \\
85 \text { to } 120 \\
50 \text { to } 85 \\
20 \text { to } 50\end{array}$ & $\begin{array}{r}192 \\
123 \\
201 \\
43\end{array}$ & $\begin{array}{r}31 \\
124 \\
266 \\
86\end{array}$ & $\begin{array}{r}6 \\
55 \\
5 \\
2\end{array}$ & $\begin{array}{r}84 \\
103 \\
129 \\
38\end{array}$ & $\begin{array}{r}181 \\
134 \\
56 \\
13\end{array}$ & $\begin{array}{l}33 \\
44 \\
45 \\
19\end{array}$ & $\begin{array}{r}11 \\
106 \\
156 \\
21\end{array}$ & $\begin{array}{l}0 \\
0 \\
0 \\
0\end{array}$ & $\begin{array}{l}55 \\
53 \\
54 \\
18\end{array}$ & $\begin{array}{l}158 \\
253 \\
381 \\
120\end{array}$ & $\begin{array}{r}752 \\
997 \\
1,294 \\
362\end{array}$ \\
\hline Total..... & 559 & 507 & 68 & 356 & 386 & 141 & 294 & 0 & 181 & 914 & 3,407 \\
\hline $\begin{array}{l}\text { All size classes: } \\
120+10 \\
85 \text { to } 120 \\
50 \text { to } 85 \\
20 \text { to } 50 .\end{array}$ & $\begin{array}{r}1,978 \\
1,513 \\
3,242 \\
542\end{array}$ & $\begin{array}{r}630 \\
1,815 \\
3,783 \\
1,313\end{array}$ & $\begin{array}{l}27 \\
79 \\
29 \\
47\end{array}$ & $\begin{array}{r}1,334 \\
1,527 \\
2,309 \\
598\end{array}$ & $\begin{array}{r}2,107 \\
2,224 \\
1,069 \\
147\end{array}$ & $\begin{array}{r}91 \\
125 \\
195 \\
62\end{array}$ & $\begin{array}{r}38 \\
788 \\
1,092 \\
114\end{array}$ & $\begin{array}{l}1 \\
1 \\
2 \\
0\end{array}$ & $\begin{array}{r}329 \\
375 \\
414 \\
55\end{array}$ & $\begin{array}{l}158 \\
253 \\
381 \\
120\end{array}$ & $\begin{array}{r}6,695 \\
8,701 \\
12,518 \\
3,001\end{array}$ \\
\hline Total_.......... & 7,275 & 7,541 & 182 & 5,769 & 5,549 & 473 & 2,032 & 4 & 1,175 & 914 & 30,915 \\
\hline
\end{tabular}

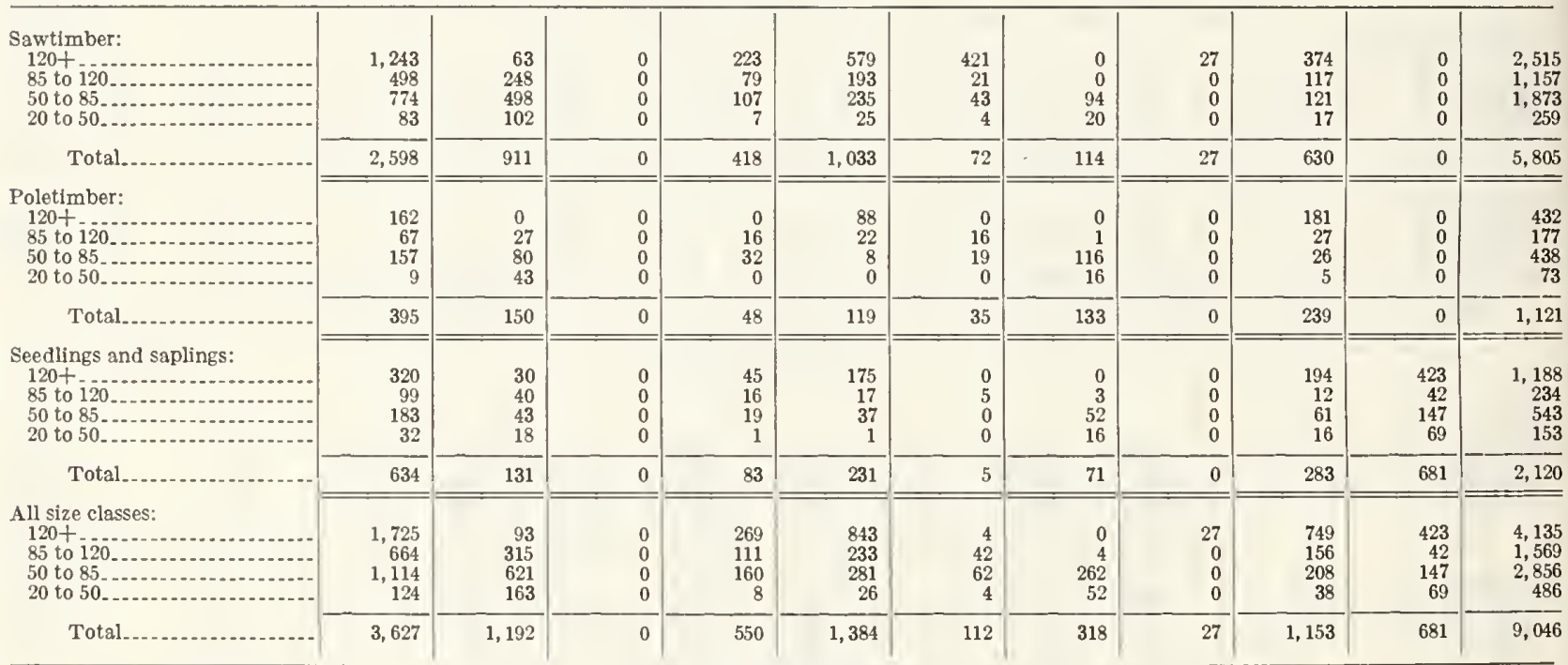

FOREST INDUSTRY

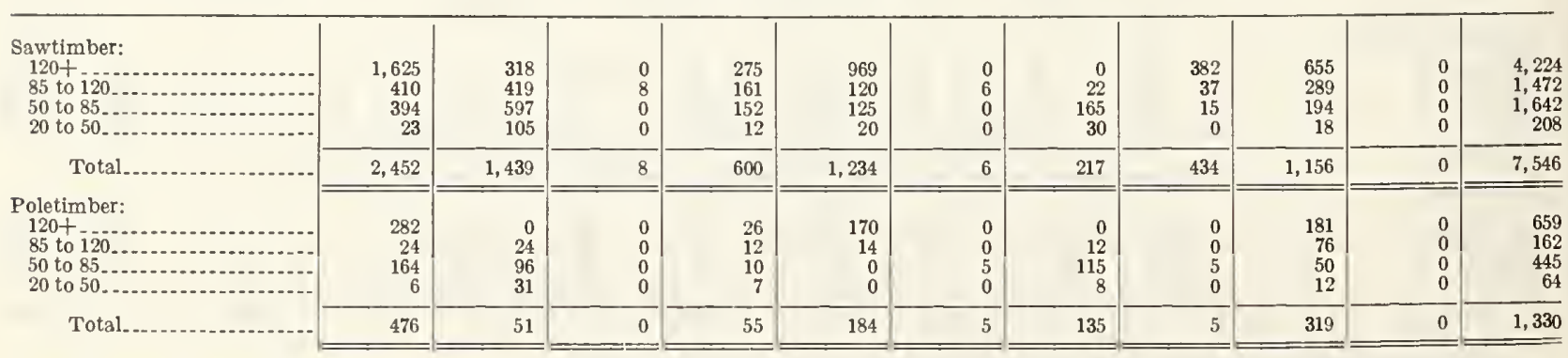

See footnote at end of table. 


\section{APPENDIX II}

\section{Glossary of Terms}

Acceptable tree. Growing-stock tree of commercial species that meets specified standards of size and quality, but not qualifying as desirable tree.

Allowable harvest. The volume of timber that would be cut on commercial timberland during a given period under specified management plans aimed at sustained production of timber products.

Coarse residue. Plant residue that is suitable for chipping, such as slabs, edgings, and veneer cores.

Commercial timberland. Forest land producing or capable of producing crops of industrial wood and not withdrawn from timber utilization. (Note: Areas qualifying as commercial timberland have the capability of producing in excess of 20 cubic feet per acre per year of industrial wood in natural stands. Currently inaccessible and inoperable areas are included, except when the areas involved are small and unlikely to become suitable for production of industrial wood in the foreseeable future.)

Cord. A pile of stacked wood containing 128 cubic feet within its outside surfaces. The standard dimensions are 4 by 4 by 8 feet.

Cropland. Land under cultivation within the past 24 months, including cropland harvested, crop failures, cultivated summer fallow, idle cropland used only for pasture, orchards, and land in soil improving crops, but excluding land cultivated in developing improved pasture.

Deferred forest land. National Forest land that meets productivity standards for commercial timberland, but under study for possible inclusion in the Wilderness System.

Desirable tree. Growing-stock tree (a) having no serious defects in quality limiting present or prospective use for timber products, (b) of relatively high vigor, and (c) containing no pathogens that may result in death or serious deterioration before rotation age. (Note: This is the type of tree forest managers try to grow; that is, the tree favored in cultural operations. In over-rotation-age stands, desirable trees are low-risk trees.)

Diameter classes. A classification of trees based on diameter outside bark, measured at breast height (4-1/2 feet above the ground). (Note: D.b.h. is the common abbreviation for diameter at breast height. Two-inch diameter classes are commonly used in Forest Survey, with the even inch the approximate midpoint for a class. For example, the 6-inch class includes trees 5.0 through 6.9 inches d.b.h., inclusive.)

Farm. A place of 10 or more acres from which the sale of agricultural products totaled $\$ 50$ or more annually, or a place of less than 10 acres from which the sale of agricultural products totaled $\$ 250$ or more during the previous year.

Farm and miscellaneous lands. Privately owned lands other than in forest industry ownership.

Fine residues. Residues not suitable for chipping, such as sawdust, shavings, and veneer clippings.

Forest land. Land at least 10 percent occupied by forest trees of any size, or formerly having had such tree cover, and not currently developed for nonforest use. (Note: The minimum area for classification of forest land is 1 acre. Roadside, streamside, and shelterbelt strips of timber must have a crown width at least 120 feet wide to qualify as forest land. Unimproved roads and trails, streams, or other bodies of water or clearings in forest areas are classed as forest if less than 120 feet in width.) Also see definitions for land area, commercial timberland, noncommercial forest land, productive-reserved forest land, stocking, and unproductive forest land.

Forest site productivity class. A classification of forest land in terms of potential cubic-foot volume growth per acre at culmination of mean annual increment in fully stocked natural stands.

Forest type. A classification of forest land based upon the species forming a plurality of live-tree stocking. Type is determined on the basis of species plurality of all live trees that contribute to stocking.

Growing-stock trees. Live trees of commercial species qualifying as desirable or acceptable trees. Excludes rough, rotten, and dead trees.

Growing-stock volume. Net volume in cubic feet of growing-stock trees 5.0 inches d.b.h. and over from a 1-foot stump to a minimum 4.0-inch top diameter outside bark of the central stem or to the point where the central stem breaks into limbs.

Growth impact. Mortality plus growth loss.

Growth loss. Timber loss due to (a) delay in restocking or deficiencies in stocking resulting from damage by insects, disease, animals, fire, or adverse weather, and (b) the reduction in growth due to changes in timber type, defoliation, reduction of tree vigor, increase in cull percent, or deterioration of site due to destructive agents.

Hardwoods. Dicotyledonous trees, usually broad-leaved and deciduous.

Indian lands. Tribal lands held in fee by the Federal Government, but administered for Indian tribal groups, and Indian trust allotments.

Industrial wood. All roundwood products, except fuelwood.

Ingrowth. The number or net volume of trees that grow large enough during a specified year to qualify as saplings, poletimber, or sawtimber.

Land area.

a. Bureau of the Census. The area of dry land and land temporarily or partly covered by water, such as marshes, swamps and river flood plains (omitting tidal flats below mean high tide); streams, sloughs, estuaries and canals less than $1 / 8$ of a statute mile in width; and lakes, reservoirs and ponds less than 40 acres in area.

b. Forest Survey. Same as the Bureau of the Census except minimum width of streams, etc. is 120 feet and minimum size of lakes, etc. is 1 acre.

Limbwood. That part of the tree above the stump which does not meet the requirement for saw logs and upperstem portions, including all live, sound branches to a minimum of 4 inches outside bark. 
Log scale. A measure of the board-foot content of roundwood. Local scale may include Scribner, Doyle or other rules. The international ${ }^{1 / 1}$-inch $\log$ rule is used as standard in the Forest Survey.

Logging residues. Unused portions of trees cut or killed by logging.

Mortality. Number or sound-wood volume of live trees dying from natural causes during a specified period.

Multiple-use management. The management of land resources aimed at achieving optimum yields of products and services from a given area without impairing the productive capacity of the site.

National Forest lands. Federal lands which have been legally designated as National Forests or purchase units, and other lands under the administration of the Forest Service, including experimental areas and Bankhead-Jones Title III lands.

Net annual growth. The increase in volume of trees during a specified year. Components of net annual growth include the increment in net volume of trees at the beginning of the specified year surviving to its end, plus the net volume of trees reaching the minimum size class during the year, minus the volume of trees that died during the year, and minus the net volume of trees that became rough or rotten trees during the year.

Net volume in board feet. The gross board-foot volume of trees less deductions for rot or other defect affecting use for lumber.

Net volume in cubic feet. Gross volume in cubic feet less deductions for rot.

Noncommercial forest land. (1) Unproductive forest land incapable of yielding crops of industrial wood, because of adverse site conditions and (2) productive forest land reserved for nontimber uses.

Noncommercial species. Tree species of typically small size, poor form, or inferior quality which normally do not develop into trees suitable for industrial wood products.

Nonforest land. Land that has never supported forests and lands formerly forested where use for timber management is precluded by development for other uses. (Note: Includes areas used for crops, improved pasture, residential areas, city parks, improved roads of any width and adjoining clearings, powerline clearings of any width, and 1 - to 40-acre areas of water classified by the Bureau of the Census as land. If intermingled in forest areas, unimproved roads and nonforest strips must be more than 120 feet wide, and clearings, etc., more than 1 acre in size, to qualify as nonforest land.)

Nonstocked areas. Commercial timberland less than 10 percent occupied with growing-stock trees.

Old-growth stands. Stands in which 50 percent or more of the area is occupied by old-growth timber.

Old-growth timber. Trees that are at least 100 years old.

Other removals. The net volume of growing-stock trees removed from the inventory by cultural operations such as timber-stand improvement, by land clearing and by changes in land use, and not utilized for timber products.

Pasture and rangeland. Land which is currently improved for grazing by cultivation, seeding or irrigation, and natural grasslands.

Plant byproducts. Wood products such as pulp chips obtained incidental to production of other manufactured products.

Plant residues. Waste materials from the manufacture of lumber, plywood and other wood products. Includes slabs, edgings, trimmings, miscuts, sawdust, shavings, veneer cores and clippings, and pulp screenings.

Poletimber stands. Stands at least 10 percent occupied with growing-stock trees of which half or more of this stocking is in poletimber and/or sawtimber trees, and with poletimber stocking exceeding that of sawtimber.

Prescribed burning. The application of fire to land under such conditions of weather, soil moisture, and other factors as presumably will accomplish specific silvicultural, wildlife, grazing, or fire-hazard-reduction purposes.
Primary wood-processing plants. Plants using round wood products such as saw logs, pulpwood bolts, veneer $\operatorname{logs}$, etc.

Productive-reserved forest land. Forest land sufficiently productive to qualify as commercial timberland, but withdrawn from timber utilization through statute or administrative designation.

Removals. Tolumes of timber removed from the growingstock inventory, including timber products, logging residues, and other removals such as land clearing.

Rotation. The period of years between establishment of a stand of timber and the time when it is considered ready for final harvest and regeneration.

Rotten tree. Live tree of commercial species that does not contain, now or prospectively, at least one 12 -foot saw log or two noncontiguous saw logs each 8 feet or longer, and/or does not meet regional specifications for freedom from defect primarily because of rot; that is, when more than 50 percent of the cull volume in a tree is rotten.

Rough tree. (1) Live tree of commercial species that does not contain, now or prospectively, at least one 12-foot saw log or two noncontiguous saw logs each 8 feet or longer, and/or does not meet regional specifications for freedom from defect primarily because of roughness or poor form, and (2) live tree of noncommercial species.

Roundwood products. Logs, bolts, or other round sections cut from trees for industrial or consumer use.

Roundwood equivalent. The volume of logs or other round products required to produce woodpulp, lumber, or other processed products.

Salvable dead trees. Standing or down dead trees that are considered merchantable by regional standards.

Sampling error. The probable error of an estimated total or average that arises from taking a sample rather than making a complete inventory or measurement.

Saplings. Live trees 1.0 inch to 5.0 inches in diameter at breast height.

Saw-log portion. That part of the bole of sawtimber trees between the stump and the saw-log top.

Saw logs. Logs meeting minimum regional standards of diameter, length, and defect. Logs must be at least 8 feet long, have a minimum diameter inside bark of 6 inches for sof twoods and 8 inches for hardwoods and maximum defect as specified by regional standards

Sawtimber stands. Stands at least 10 percent occupied with growing-stock trees, with half or more of total stocking in sawtimber or poletimber trees, and with sawtimber stocking at least equal to poletimber stocking.

Sawtimber trees. Live trees of commercial species containing at least one 12 -foot saw log or two noncontiguous 8-foot logs, and meeting regional specifications for freedom from defect. Softwood trees must be at least 9.0 inches in diameter breast height, except in California, Oregon, Washington, and coastal Alaska where the minimum diameter is 11.0 inches. Hardwood trees must be at least 11.0 inches in diameter in all States.

Secondary wood-processing plants. Plants using primary manufactured products such as lumber, woodpulp, veneer, or plywood.

Seedling and sapling stands. Stands at least 10 percent occupied with growing-stock trees of which more than half of the stocking is saplings and/or seedlings.

Seedlings. Live trees less than 1.0 inch in diameter at breast height that are expected to survive according to regional standards.

Site preparation. Removal or deadening of unwanted vegetation prior to planting trees, including prescribed burning, use of herbicides, and disking and other mechanical means of removing vegetative cover.

Softwoods. Coniferous trees, usually evergreen having needles or scalelike leaves.

Stand improvement. Measures such as thinning, release cutting, girdling, weeding, or poisoning of unwanted trees aimed at improving growing conditions. 
Stand-size class. A classification of forest land based on the size class of growing-stock trees on the area; that is, sawtimber, poletimber, or seedlings and saplings.

Stocking. The degree of occupancy of land by trees, measured by basal area and/or number of trees by size or age and spacing, compared to a stocking standard, i.e., the basal area and/or number of trees required to fully utilize the growth potential of the land.

Timber demand. The volume of timber that would be purchased at specified prices at a specified point in time under specified or implied assumptions relating to population, income, and other technological or institutional factors.

Timber supply (or timber harvest). Net volume of roundwood products available to forest industries from all sources at specified or implied price levels.

Tree size class. A classification of trees based on diameter at breast height, including sawtimber trees, poletimber trees, saplings and seedlings.

Trend level. Estimate based on a curve or regression equation constructed from observed values over time.

Unproductive forest land. Forest land incapable of producing 20 cubic feet per acre of industrial wood under natural conditions because of adverse site conditions such as sterile soils, dry climate, poor drainage, high elevation, steepness, or rockiness.

Unregulated forest land. Commercial timberland in National Forests not organized for timber production under sustained-yield principles, including experimental forests, recreation and administrative sites, and tracts of commercial timberland so remote from manufacturing centers that scheduling sustained periodic harvest is impractical.

Upper stems. That part of the bole of sawtimber trees above the saw-log top to a minimum top diameter of 4.0 inches outside bark or to the point where the central stem breaks into limbs.

Wilderness area. An area of undeveloped Federal land retaining its primeval character and influence, without permanent improvements or human habitation, which is protected and managed so as to preserve natural conditions.

Young-growth stands. Stands in which 50 percent or more of the stand is occupied by sawtimber trees less than 100 years old. 


\section{APPENDIX III \\ Timber Supply Tables}

Table

No.

1 Estimated costs and softwood harvest change with intensified forest management on farm and miscellaneous private lands, by rate of return grouping at 1970 prices.

2 Estimated costs and softwood harvest change with intensified forest management on National Forests, by rate of return grouping at 1970 prices.

3 Estimated costs and softwood harvest change with intensified forest management on farm and miscellaneous private lands, by rate of return and alternative prices.
Table

No.

4 Estimated costs and softwood harvest change with intensified forest management of National Forest lands, by rate of return and price alternatives.

5 Estimated costs and softwood harvest change on farm and miscellaneous private lands with continuing programs of intensification.

6 Estimated costs and softwood harvest change on $\mathrm{Na}$ tional Forest lands with continuing programs of intensification. 


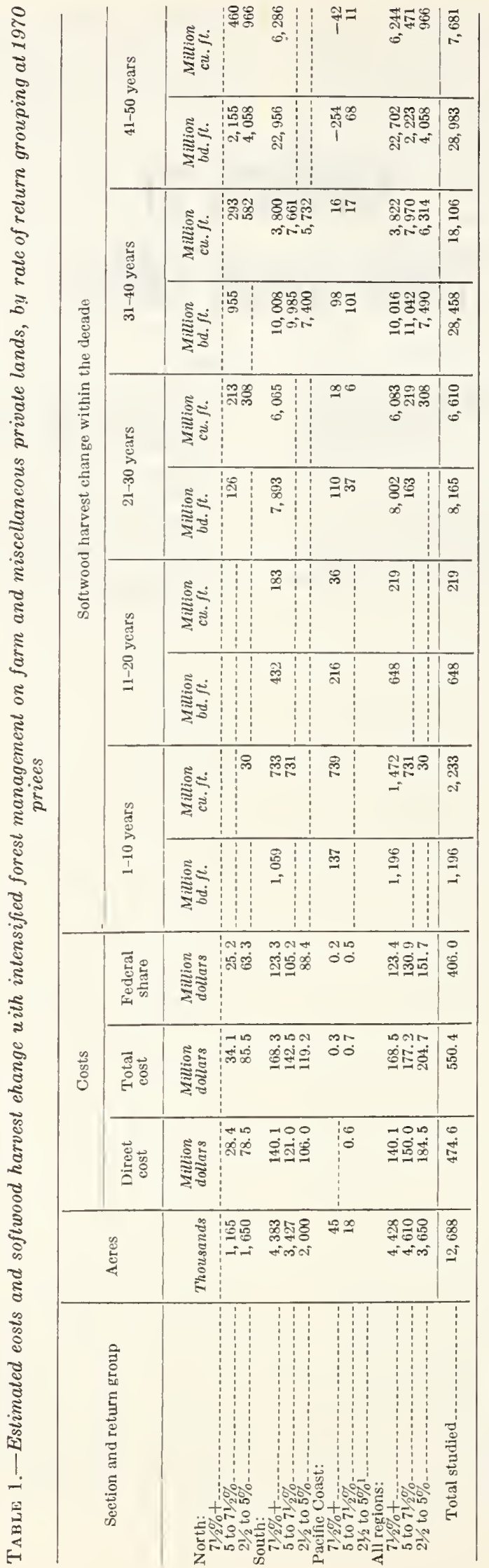


TABLE 2.-Estimated costs and softwood harvest change with intensified forest management on National Forests, by rate of return grouping at 1970 prices

\begin{tabular}{|c|c|c|c|c|c|c|c|c|c|c|c|c|c|}
\hline \multirow{2}{*}{ Section and return group } & \multirow{2}{*}{ Acres } & \multicolumn{2}{|c|}{ Costs } & \multicolumn{10}{|c|}{ Softwood harvest change within the decade 1} \\
\hline & & Direct & Total & \multicolumn{2}{|c|}{$1-10$ years } & \multicolumn{2}{|c|}{$11-20$ years } & \multicolumn{2}{|c|}{$21-30$ years } & \multicolumn{2}{|c|}{$31-40$ years } & \multicolumn{2}{|c|}{ 41-50 years } \\
\hline & Thousands & $\begin{array}{l}\text { Million } \\
\text { dollars }\end{array}$ & $\begin{array}{l}\text { Million } \\
\text { dollars }\end{array}$ & $\begin{array}{l}\text { Million } \\
b d . f t .\end{array}$ & $\begin{array}{c}\text { Million } \\
\text { cu. ft. }\end{array}$ & $\begin{array}{l}\text { Million } \\
\text { bd. } f t .\end{array}$ & $\begin{array}{l}\text { Million } \\
\text { cu.ft. }\end{array}$ & $\begin{array}{l}\text { Million } \\
b d . f t .\end{array}$ & $\begin{array}{l}\text { Million } \\
\text { cu. } t t .\end{array}$ & $\begin{array}{l}\text { Million } \\
\text { bd. } f t .\end{array}$ & $\begin{array}{l}\text { Million } \\
\text { cu. } f t .\end{array}$ & $\begin{array}{c}\text { Million } \\
\text { bd. ft. }\end{array}$ & $\begin{array}{l}\text { Million } \\
\text { cu. ft. }\end{array}$ \\
\hline $\begin{array}{l}\text { North: } \\
71 / 2 T_{0}+ \\
5 \text { to } 71 / 2 \% \\
21 / 2 \text { to } 5 \%\end{array}$ & $\begin{array}{l}304 \\
145 \\
127\end{array}$ & $\begin{array}{l}5.3 \\
6.8 \\
6.1\end{array}$ & $\begin{array}{l}10.8 \\
13.6 \\
12.0\end{array}$ & - & 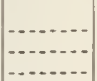 & \begin{tabular}{r}
130 \\
\hdashline-1 \\
\end{tabular} & $\begin{array}{c}104 \\
\end{array}$ & $\begin{array}{r}844 \\
22\end{array}$ & $\begin{array}{l}40 \\
79 \\
32\end{array}$ & $\begin{array}{r}1,747 \\
143\end{array}$ & $\begin{array}{r}53 \\
5 \\
42\end{array}$ & $\begin{array}{r}1,396 \\
611 \\
301\end{array}$ & $\begin{array}{r}-74 \\
32 \\
39\end{array}$ \\
\hline 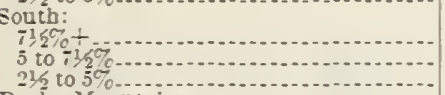 & $\begin{array}{l}223 \\
137 \\
410\end{array}$ & $\begin{array}{r}3.8 \\
7.9 \\
24.8\end{array}$ & $\begin{array}{r}7.9 \\
15.3 \\
47.7\end{array}$ & (n- & & \begin{tabular}{r}
93 \\
\hdashline \\
\end{tabular} & \begin{tabular}{c}
2 \\
$\ldots \ldots$ \\
\hdashline$\ldots$
\end{tabular} & $\begin{array}{r}491 \\
66 \\
\end{array}$ & $\begin{array}{r}153 \\
2 \\
-\end{array}$ & $\begin{array}{r}856 \\
334 \\
-\end{array}$ & $\begin{array}{r}5 \\
10.5 \\
233\end{array}$ & $\begin{array}{r}1,714 \\
634 \\
336\end{array}$ & $\begin{array}{r}9 \\
18 \\
61\end{array}$ \\
\hline $\begin{array}{l}\text { Rocky Mountains: } \\
5 \text { to } 71 / 2 \% \\
21 / 2 \text { to } 5 \% \\
0 \text { to } 21 / 2 \%\end{array}$ & $\begin{array}{l}241 \\
860 \\
804\end{array}$ & $\begin{array}{r}4.3 \\
23.0 \\
49.7\end{array}$ & $\begin{array}{r}8.5 \\
44.8 \\
98.3\end{array}$ & $\begin{array}{r}653 \\
1,740 \\
1,973\end{array}$ & & $\begin{array}{r}967 \\
2,833 \\
2,647\end{array}$ & ..... & $\begin{array}{l}1,023 \\
3,347 \\
2,663\end{array}$ & - & $\begin{array}{l}1,080 \\
3,860 \\
2,680\end{array}$ & & $\begin{array}{l}1,080 \\
3,860 \\
2,680\end{array}$ & . \\
\hline 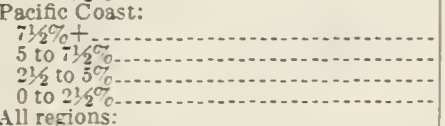 & $\begin{array}{l}276 \\
327 \\
427 \\
231\end{array}$ & $\begin{array}{r}5.1 \\
7.9 \\
20.9 \\
15.1\end{array}$ & $\begin{array}{l}10.5 \\
15.8 \\
41.3 \\
29.6\end{array}$ & $\begin{array}{r}728 \\
1,013 \\
1,613 \\
668\end{array}$ & 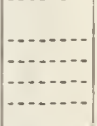 & $\begin{array}{r}970 \\
1,350 \\
2,150 \\
890\end{array}$ & 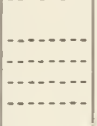 & $\begin{array}{r}970 \\
1,350 \\
2,150 \\
890\end{array}$ & 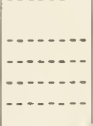 & $\begin{array}{r}970 \\
1,350 \\
2,150 \\
890\end{array}$ & 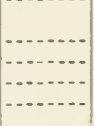 & $\begin{array}{r}970 \\
1,350 \\
2,150 \\
890\end{array}$ & (n-1 n \\
\hline $\begin{array}{l}71 / 2 \% \text { t } \\
5 \text { to } 71 / 2 \% \\
21 / 2 \text { to } 5 \% \\
0 \text { to } 216 \%\end{array}$ & $\begin{array}{r}803 \\
850 \\
1,824 \\
1,035\end{array}$ & $\begin{array}{l}14.2 \\
26.9 \\
74.8 \\
64.8\end{array}$ & $\begin{array}{r}29.2 \\
53.2 \\
145.8 \\
127.9\end{array}$ & $\begin{array}{r}728 \\
1,696 \\
3.353 \\
2,641\end{array}$ & & $\begin{array}{l}1,193 \\
2,317 \\
4,983 \\
3,537\end{array}$ & $\begin{array}{c}106 \\
\\
\end{array}$ & $\begin{array}{l}2,305 \\
2,461 \\
5,497 \\
3,553\end{array}$ & $\begin{array}{r}193 \\
81 \\
32\end{array}$ & $\begin{array}{l}3,573 \\
2,907 \\
6,010 \\
3,570\end{array}$ & $\begin{array}{r}58 \\
110 \\
275 \\
\end{array}$ & $\begin{array}{l}4,080 \\
3,675 \\
6,707 \\
3,570\end{array}$ & $\begin{array}{r}-65 \\
50 \\
100 \\
\end{array}$ \\
\hline Total studied. & 4,512 & 180.7 & 356.1 & 8,418 & & 12,030 & 106 & 13,816 & 306 & 16,060 & 443 & 18,032 & 85 \\
\hline
\end{tabular}

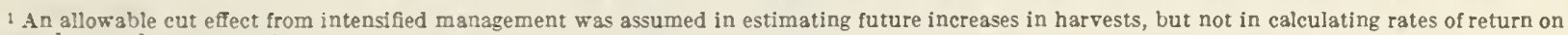
increased costs of management. 


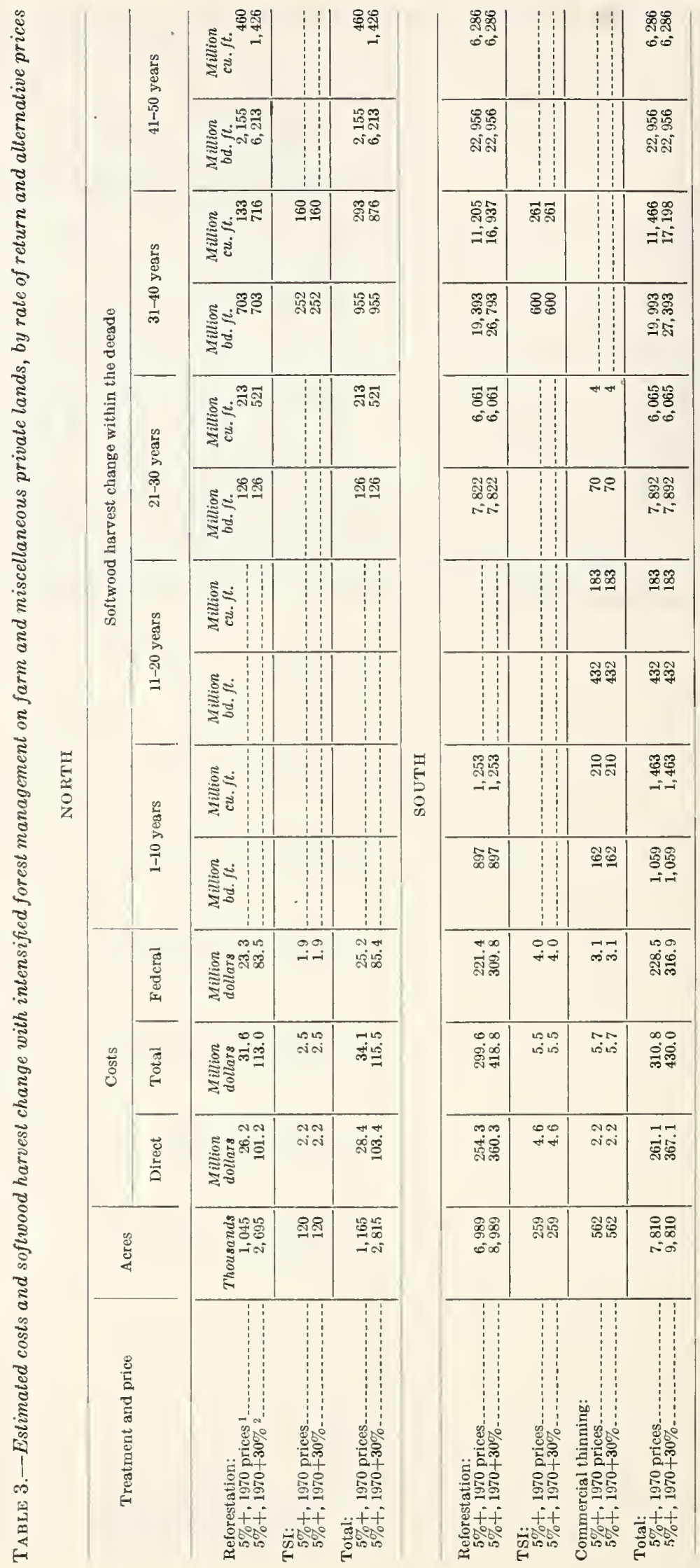


APPENDIX III. TIMBER SUPPXY TABLES

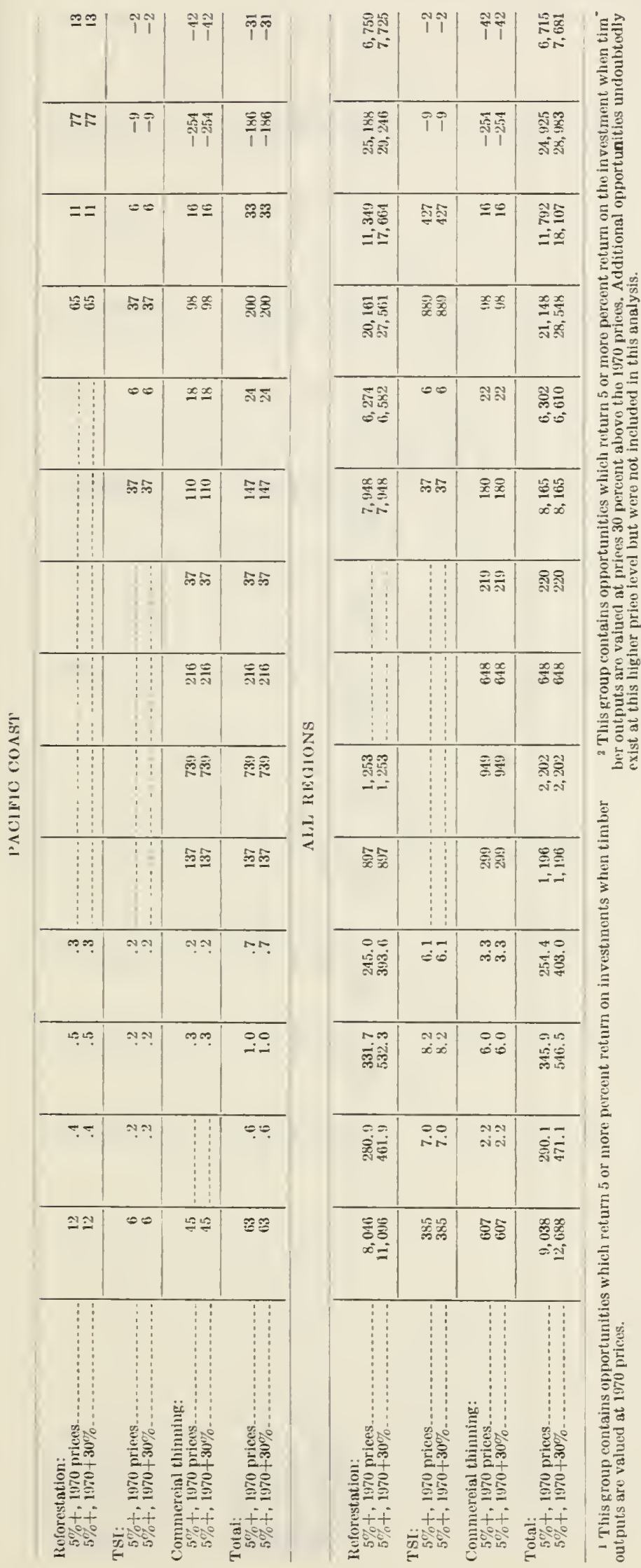




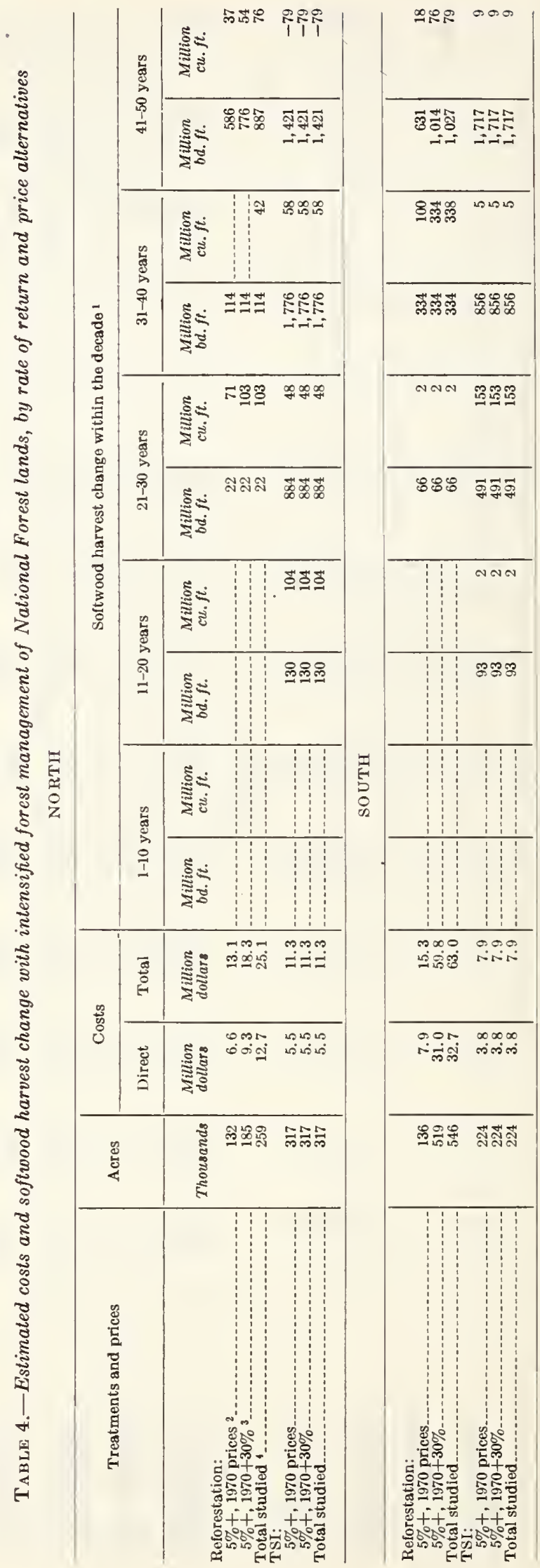




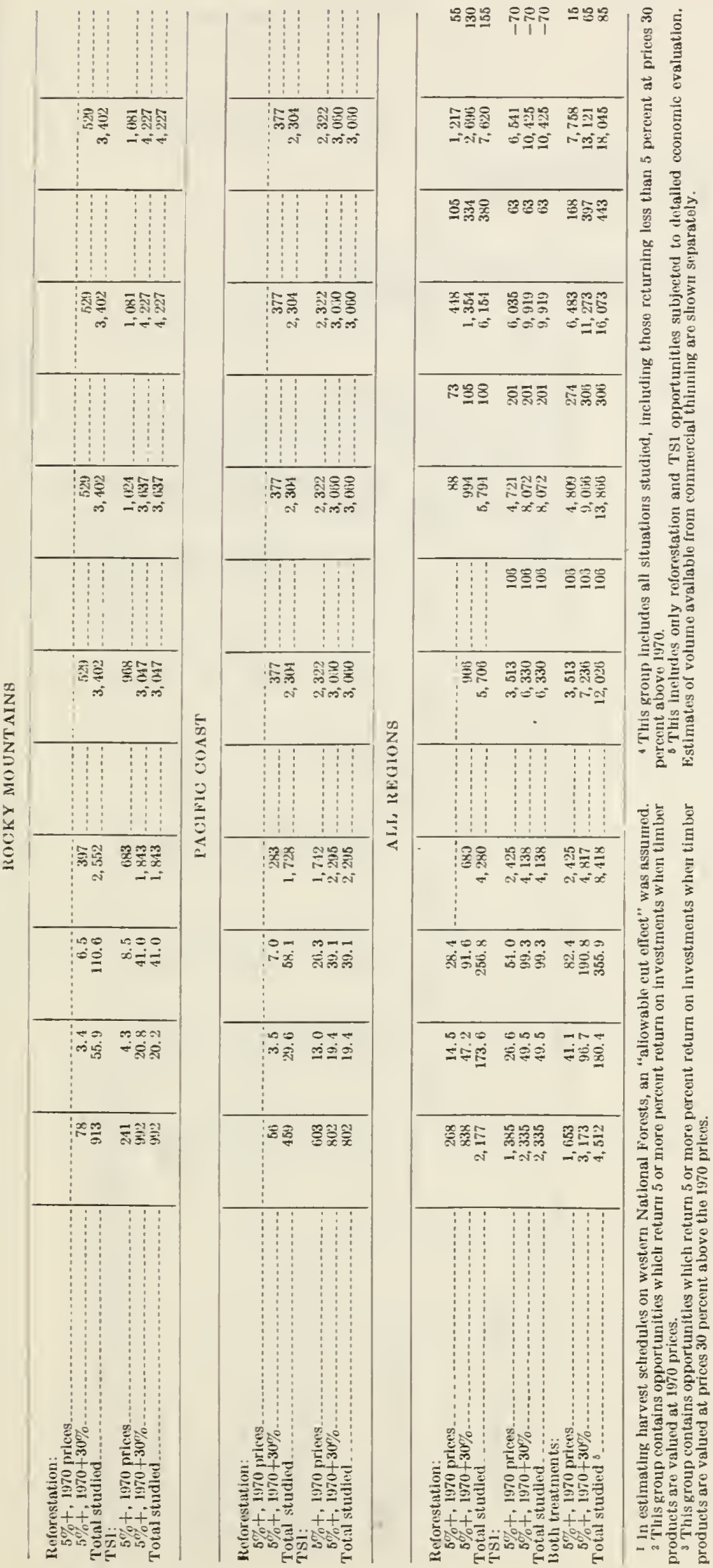



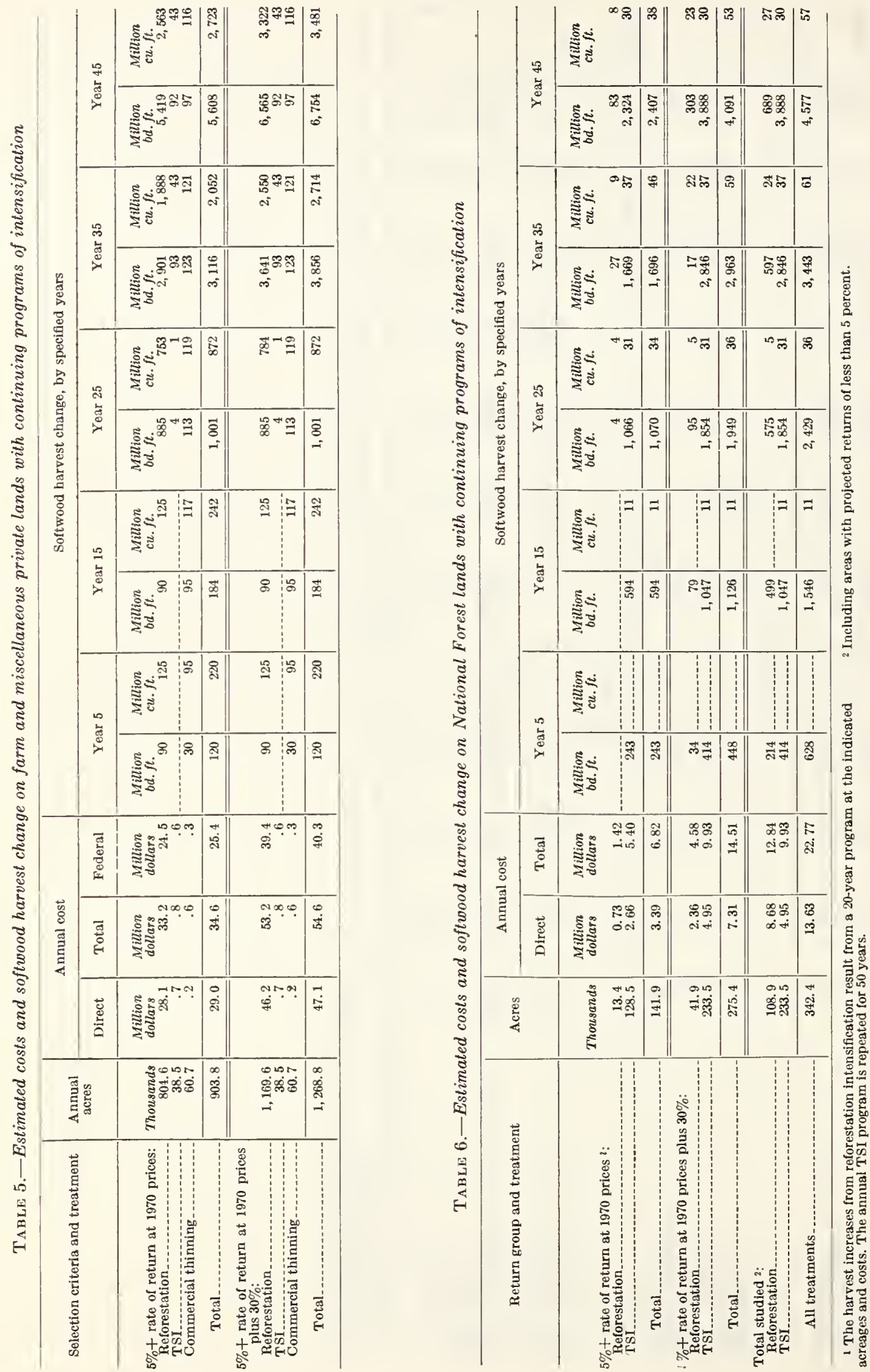


\section{APPENDIX IV \\ Timber Imports and Exports}

Table

No.

1 Imports of timber products, by softwoods and hardwoods and major product, 1950-72

2 Imports of lumber, by softwoods and hardwoods and country of origin, $1950-72$

3 Imports of pulp products, by product, 1950-72

4 Imports of hardwood plywood, by country of origin, $1950-72$

5 Imports of hardwood veneer, by country of origin, $1950-72$

\section{Table
No.}

6 Exports of timber products, by softwoods and hardwoods and major product, 1950-72

7 Exports of lumber, by softwoods and hardwoods and country of destination, 1950-72

8 Exports of pulp products, by product, 1950-72

9 Exports of logs, by major species, 1950-72

10 Exports of logs, by major region of destination, $1950-72$

11 Imports and exports of timber products, by product, 1940-72 


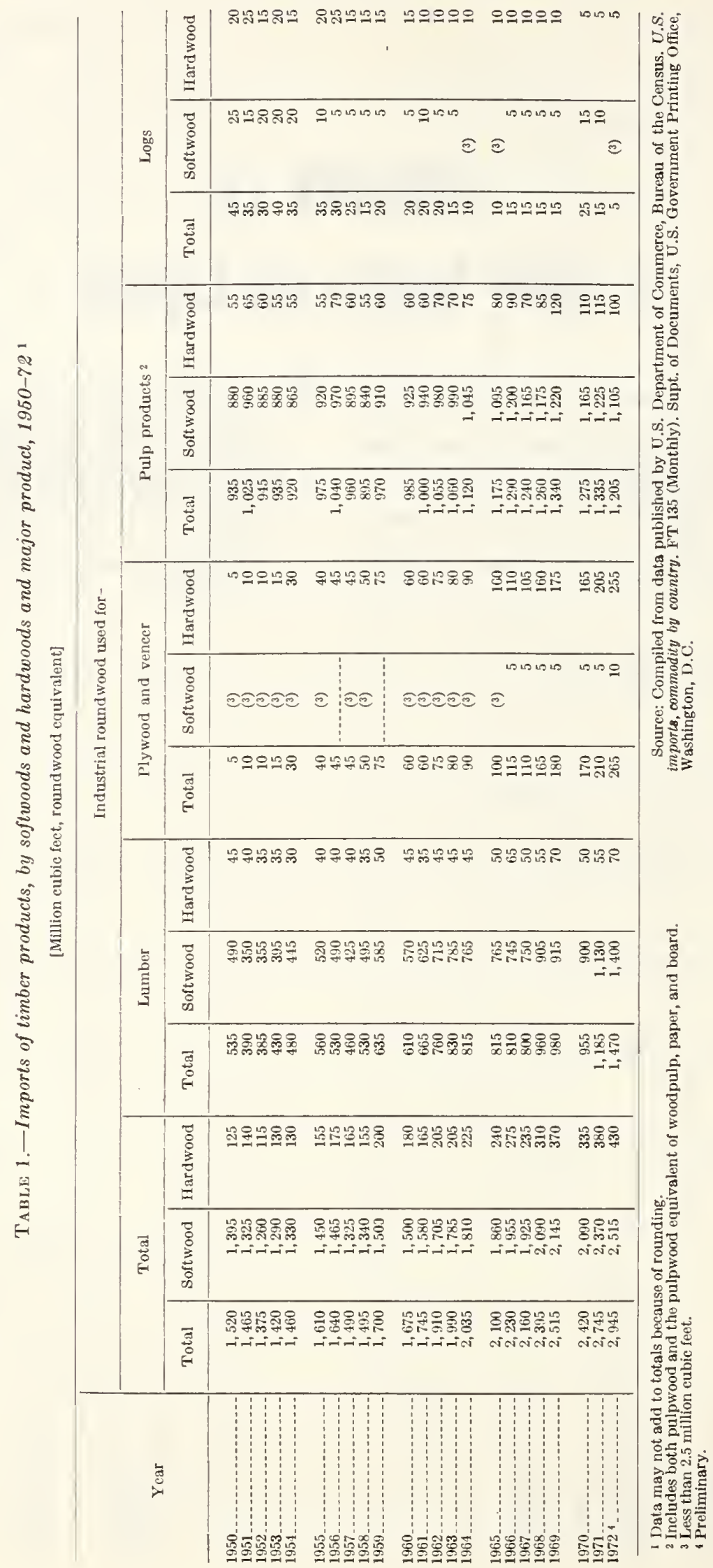


APPENDIX IV. TIMBER IMPORTS AND EXPORTS

TABLE 2.-Imports of lumber, by softwoods and hardwoods and country of origin, 1950-72 1

[Million board feet]

\begin{tabular}{|c|c|c|c|c|c|c|c|c|c|c|c|c|}
\hline \multirow{2}{*}{ Year } & \multicolumn{4}{|c|}{ All species 2} & \multicolumn{4}{|c|}{ Soltwoods } & \multicolumn{4}{|c|}{ Hardwosds } \\
\hline & Total & Canada & Mexico & Other & Total 3 & Canads ${ }^{3}$ & Merico & Other & Total & Canada & Mexico & Other \\
\hline $\begin{array}{l}1950 \\
1951 \\
1952 \\
1953 \\
1954 \ldots \ldots\end{array}$ & $\begin{array}{l}3,423.5 \\
2,511.6 \\
2,481.6 \\
2,759.4 \\
3,063.1\end{array}$ & $\begin{array}{l}3,102.2 \\
2,240.3 \\
2,257.7 \\
2,541.2 \\
2,844.1\end{array}$ & $\begin{array}{r}208.0 \\
135.5 \\
106.0 \\
83.8 \\
80.0\end{array}$ & $\begin{array}{l}113.3 \\
135.8 \\
117.9 \\
134.3 \\
139.0\end{array}$ & $\begin{array}{l}3,140.2 \\
2,250.0 \\
2,266.9 \\
2,526.8 \\
2,854.6\end{array}$ & $\begin{array}{l}2,899.5 \\
2,080.2 \\
2,139.9 \\
2,409.6 \\
2,747.7\end{array}$ & $\begin{array}{r}191.4 \\
119.0 \\
92.1 \\
73.0 \\
74.5\end{array}$ & $\begin{array}{l}49.3 \\
50.8 \\
35.0 \\
44.2 \\
32.4\end{array}$ & $\begin{array}{l}283.2 \\
261.6 \\
214.7 \\
232.6 \\
208.5\end{array}$ & $\begin{array}{r}202.7 \\
160.1 \\
117.9 \\
131.7 \\
96.4\end{array}$ & $\begin{array}{r}16.6 \\
16.5 \\
13.9 \\
10.9 \\
5.5\end{array}$ & $\begin{array}{r}64.0 \\
84.9 \\
82.9 \\
90.1 \\
106.6\end{array}$ \\
\hline $\begin{array}{l}1955 \ldots 5 \\
1956 \ldots 57 \\
1958 \\
1959\end{array}$ & $\begin{array}{l}3,593.0 \\
3,404.5 \\
2,958.0 \\
3,389.6 \\
4,063.6\end{array}$ & $\begin{array}{l}3,349.7 \\
3,168.3 \\
2,754.0 \\
3,17.8 \\
3,785.9\end{array}$ & $\begin{array}{l}75.3 \\
51.6 \\
53.0 \\
49.3 \\
53.1\end{array}$ & $\begin{array}{l}168.1 \\
184.6 \\
150.9 \\
162.5 \\
224.6\end{array}$ & $\begin{array}{l}3,326.8 \\
3,131.0 \\
2,711.9 \\
3,154.5 \\
3,741.5\end{array}$ & $\begin{array}{l}3,225.9 \\
3,060.7 \\
2,644.7 \\
3,088.0 \\
3,661.7\end{array}$ & $\begin{array}{l}69.7 \\
47.8 \\
48.2 \\
45.1 \\
49.7\end{array}$ & $\begin{array}{l}31.2 \\
22.5 \\
19.0 \\
21.4 \\
30.2\end{array}$ & $\begin{array}{l}266.3 \\
273.5 \\
246.1 \\
235.1 \\
322.0\end{array}$ & $\begin{array}{r}123.8 \\
107.6 \\
109.3 \\
89.7 \\
124.2\end{array}$ & $\begin{array}{l}5.6 \\
3.8 \\
4.8 \\
4.3 \\
3.4\end{array}$ & $\begin{array}{l}136.9 \\
162.1 \\
132.0 \\
141.1 \\
194.4\end{array}$ \\
\hline $1960 \ldots 61.1962$ & $\begin{array}{l}3,930.6 \\
4,257.9 \\
4,892.9 \\
5,335.4 \\
5,222.6\end{array}$ & $\begin{array}{l}3,693.9 \\
4,042.6 \\
4,637.7 \\
5,104.7 \\
5,004.1\end{array}$ & $\begin{array}{l}41.6 \\
48.5 \\
47.8 \\
28.6 \\
10.2\end{array}$ & $\begin{array}{l}195.1 \\
166.8 \\
207.4 \\
202.0 \\
208.4\end{array}$ & $\begin{array}{l}3,639.3 \\
4,013.4 \\
4,583.7 \\
5,032.0 \\
4,917.5\end{array}$ & $\begin{array}{l}3,576.1 \\
3,943.4 \\
4,507.1 \\
4,975.6 \\
4,872.0\end{array}$ & $\begin{array}{r}36.9 \\
43.7 \\
40.4 \\
21.4 \\
7.0\end{array}$ & $\begin{array}{l}26.4 \\
26.3 \\
36.2 \\
32.0 \\
38.5\end{array}$ & $\begin{array}{l}291.2 \\
244.5 \\
309.2 \\
303.3 \\
305.1\end{array}$ & $\begin{array}{r}117.8 \\
99.2 \\
130.6 \\
129.1 \\
132.0\end{array}$ & $\begin{array}{l}4.7 \\
4.8 \\
7.4 \\
4.3 \\
3.1\end{array}$ & $\begin{array}{l}168.7 \\
140.5 \\
171.2 \\
170.0 \\
169.9\end{array}$ \\
\hline 1965 & $\begin{array}{l}5,232.5 \\
5,200.1 \\
5,140.7 \\
6,154.2 \\
6,300.6\end{array}$ & $\begin{array}{l}5,016.6 \\
4,920.9 \\
4,902.5 \\
5,899.2 \\
5,963.4\end{array}$ & $\begin{array}{r}10.1 \\
5.2 \\
5.5 \\
4.0 \\
6.7\end{array}$ & $\begin{array}{l}205.8 \\
274.0 \\
232.7 \\
251.1 \\
330.6\end{array}$ & $\begin{array}{l}4,898.1 \\
4,-79.2 \\
4,798.1 \\
5,809.1 \\
5,854.0\end{array}$ & $\begin{array}{l}4,855.7 \\
4,730.4 \\
4,747.1 \\
5,750.0 \\
5,784.4\end{array}$ & $\begin{array}{l}8.1 \\
3.7 \\
3.1 \\
3.2 \\
5.8\end{array}$ & $\begin{array}{l}34.3 \\
45.2 \\
47.9 \\
55.9 \\
63.7\end{array}$ & $\begin{array}{l}334.3 \\
420.8 \\
342.7 \\
345.1 \\
446.6\end{array}$ & $\begin{array}{l}160.9 \\
190.5 \\
155.4 \\
149.2 \\
179.0\end{array}$ & $\begin{array}{l}2.0 \\
1.5 \\
2.5 \\
.8 \\
.8\end{array}$ & $\begin{array}{l}171.4 \\
228.8 \\
184.8 \\
195.1 \\
266.8\end{array}$ \\
\hline 1970 & $\begin{array}{l}6,114.3 \\
7,606.8 \\
9,430.1\end{array}$ & $\begin{array}{l}5,867.6 \\
7,331.9 \\
9,029.1\end{array}$ & $\begin{array}{r}7.5 \\
6.5 \\
20.8\end{array}$ & $\begin{array}{l}239.3 \\
268.4 \\
380.1\end{array}$ & $\begin{array}{l}5,777.7 \\
7,249.0 \\
8,984.8\end{array}$ & $\begin{array}{l}5,722.5 \\
7,189.4 \\
8,877.8\end{array}$ & $\begin{array}{r}5.5 \\
4.9 \\
18.9\end{array}$ & $\begin{array}{l}49.7 \\
54.7 \\
88.1\end{array}$ & $\begin{array}{l}336.7 \\
357.8 \\
445.2\end{array}$ & $\begin{array}{l}145.1 \\
142.5 \\
151.3\end{array}$ & $\begin{array}{l}2.0 \\
1.6 \\
1.9\end{array}$ & $\begin{array}{l}189.6 \\
213.7 \\
292.0\end{array}$ \\
\hline
\end{tabular}

1 Data may not add to totals because of rounding.

2 Excludes mixed species (not classified as softwoods or hardwoods) for the years $1950-59$.

Includes small volumes of hardwoods for the years 1960-72. 1 Preliminary.

Source: See source note, table 1.

TABLE 3.-Imports of pulp products, by product, 1950-72 1

[Million cords, round wood equivalent]

\begin{tabular}{|c|c|c|c|c|c|c|c|c|c|}
\hline Year & Total & Pulpwood 2 & Woodpulp & $\begin{array}{c}\text { Paper and } \\
\text { board }\end{array}$ & Year & Total & Pulpwood 2 & Woodpulp & $\begin{array}{l}\text { Paper and } \\
\text { board }\end{array}$ \\
\hline $\begin{array}{l}1950 \ldots \ldots \\
1951 \\
1952 \\
1953 \\
1954 \ldots \ldots \ldots\end{array}$ & $\begin{array}{l}12.0 \\
13.2 \\
12.1 \\
12.0 \\
11.8\end{array}$ & $\begin{array}{l}1.4 \\
2.5 \\
2.1 \\
1.6 \\
1.6\end{array}$ & $\begin{array}{l}4.3 \\
4.2 \\
3.5 \\
3.9 \\
3.7\end{array}$ & $\begin{array}{l}6.3 \\
6.5 \\
6.5 \\
6.6 \\
6.5\end{array}$ & $\begin{array}{l}1960 \\
1961 \\
1962 \\
1963 \\
1964 \ldots \ldots \ldots\end{array}$ & $\begin{array}{l}12.7 \\
12.9 \\
13.6 \\
13.7 \\
14.4\end{array}$ & $\begin{array}{l}1.3 \\
1.3 \\
1.4 \\
1.6 \\
1.5\end{array}$ & $\begin{array}{l}4.2 \\
4.3 \\
4.8 \\
4.8 \\
5.0\end{array}$ & $\begin{array}{l}7.2 \\
7.3 \\
7.3 \\
7.3 \\
8.0\end{array}$ \\
\hline $\begin{array}{l}1955 \\
1956 \\
1957 \\
1958 \\
1959\end{array}$ & $\begin{array}{l}12.6 \\
13.4 \\
12.3 \\
11.5 \\
12.5\end{array}$ & $\begin{array}{l}1.8 \\
1.9 \\
1.8 \\
1.4 \\
1.2\end{array}$ & $\begin{array}{l}3.9 \\
4.1 \\
3.7 \\
3.7 \\
4.3\end{array}$ & $\begin{array}{l}6.8 \\
7.4 \\
6.9 \\
6.5 \\
7.0\end{array}$ & $\begin{array}{l}1965 \\
1966 \\
1967 \\
1968 \\
1969 \\
1970 \\
1971 \\
1972\end{array}$ & $\begin{array}{l}15.1 \\
16.5 \\
15.9 \\
16.2 \\
17.2 \\
16.3 \\
17.1 \\
15.4\end{array}$ & $\begin{array}{l}1.3 \\
1.4 \\
1.6 \\
1.4 \\
1.0 \\
1.1 \\
1.2 \\
1.0\end{array}$ & $\begin{array}{l}5.3 \\
5.7 \\
5.4 \\
5.9 \\
6.8 \\
6.0 \\
5.4 \\
5.7\end{array}$ & $\begin{array}{r}8.5 \\
9.4 \\
8.9 \\
8.8 \\
9.3 \\
9.2 \\
10.5 \\
8.7\end{array}$ \\
\hline
\end{tabular}

1 Dats may not sdd to totals because of rounding.

Roundwood and chips.

Preliminary. 


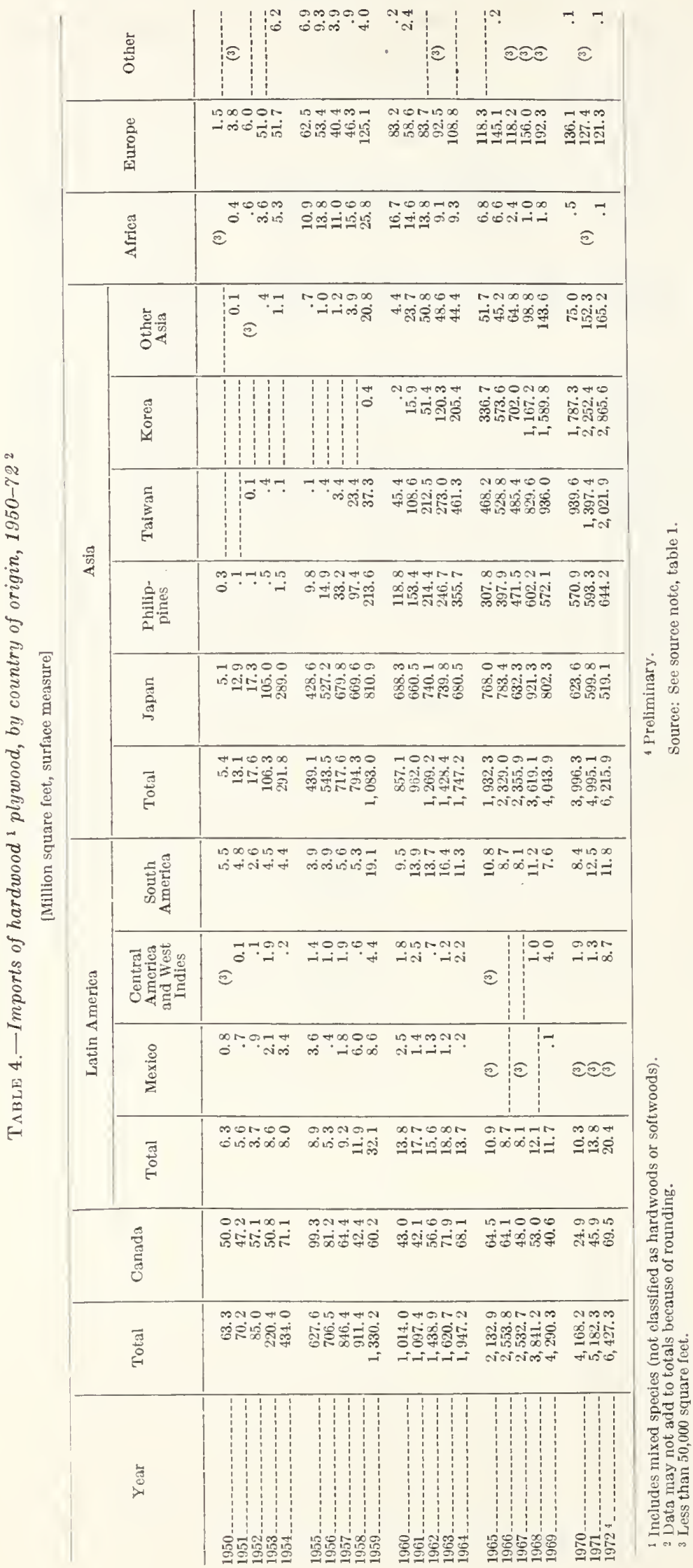


APPENDIX IV. TIMBER IMPORTS AND EXPORTS

TABLE 5.-Imports of hardwood ${ }^{1}$ veneer, by country of origin, 1950-72 2

[Million square feet, surface measure]

\begin{tabular}{|c|c|c|c|c|c|c|c|c|c|c|c|c|c|}
\hline \multirow[b]{2}{*}{ Year } & \multirow[b]{2}{*}{ Total } & \multirow[b]{2}{*}{ Canada } & \multicolumn{4}{|c|}{ Latin America } & \multicolumn{4}{|c|}{ Asia } & \multirow[b]{2}{*}{ Africa } & \multirow[b]{2}{*}{ Europe } & \multirow[b]{2}{*}{ Other } \\
\hline & & & Total & Mexico & $\begin{array}{l}\text { Central } \\
\text { America } \\
\text { and West } \\
\text { Indies }\end{array}$ & $\begin{array}{l}\text { South } \\
\text { America }\end{array}$ & Total & Japan & $\begin{array}{l}\text { Philip- } \\
\text { pines }\end{array}$ & $\begin{array}{c}\text { Other } \\
\text { Asia }\end{array}$ & & & \\
\hline $\begin{array}{l}1950 \\
1951 \\
1952 \\
1953\end{array}$ & $\begin{array}{l}361.9 \\
443.2 \\
428.0 \\
583.5 \\
534.2\end{array}$ & $\begin{array}{l}348.5 \\
396.5 \\
402.5 \\
511.6 \\
524.1\end{array}$ & $\begin{array}{l}2.3 \\
8.2 \\
6.0 \\
1.0 \\
2.5\end{array}$ & $\begin{array}{l}\text { (3) } \\
\left({ }^{3}\right) \\
2.3\end{array}$ & $\begin{array}{r}2.3 \\
7.7 \\
5.7 \\
1.0 \\
.4\end{array}$ & $\begin{array}{l}\text { (3) } \\
\text { (3) }^{(3)} \\
(3)\end{array}$ & $\begin{array}{r}0.6 \\
2.0 \\
.9 \\
21.3 \\
29.0\end{array}$ & $\begin{array}{r}0.5 \\
2.0 \\
.6 \\
.3 \\
.3\end{array}$ & $\begin{array}{r}0.1 \\
21.0 \\
28.6\end{array}$ & ${ }^{(3)} 0.1$ & $\begin{array}{r}3.4 \\
31.8 \\
15.7 \\
45.0 \\
24.2\end{array}$ & $\begin{array}{l}7.1 \\
4.6 \\
2.9 \\
4.4 \\
3.1\end{array}$ & $\begin{array}{r}0.1 \\
.1 \\
1.2\end{array}$ \\
\hline $\begin{array}{l}1955 \ldots \\
1956 \\
1955_{1} \\
1958 \\
1959\end{array}$ & $\begin{array}{r}765.4 \\
729.1 \\
502.8 \\
650.4 \\
1,061.0\end{array}$ & $\begin{array}{l}674.6 \\
621.0 \\
373.7 \\
455.6 \\
559.9\end{array}$ & $\begin{array}{r}6.9 \\
7.7 \\
9.3 \\
7.4 \\
21.1\end{array}$ & $\begin{array}{l}6.1 \\
7.3 \\
4.8 \\
1.3 \\
4.3\end{array}$ & $\begin{array}{r}.8 \\
.4 \\
4.4 \\
5.9 \\
6.5\end{array}$ & 10.3 & $\begin{array}{r}51.2 \\
56.2 \\
77.2 \\
153.4 \\
399.8\end{array}$ & $\begin{array}{r}.3 \\
3.3 \\
7.4 \\
82.2 \\
225.4\end{array}$ & $\begin{array}{r}49.7 \\
51.4 \\
69.5 \\
70.7 \\
174.1\end{array}$ & $\begin{array}{r}1.2 \\
1.5 \\
.3 \\
.5 \\
.3\end{array}$ & $\begin{array}{l}29.0 \\
37.8 \\
37.8 \\
29.5 \\
57.7\end{array}$ & $\begin{array}{r}2.8 \\
5.3 \\
4.7 \\
4.3 \\
25.5\end{array}$ & $\begin{array}{r}.9 \\
1.1 \\
.1 \\
.1\end{array}$ \\
\hline $\begin{array}{l}1960 \\
1961 \\
1962 \\
1963\end{array}$ & $\begin{array}{r}840.8 \\
894.8 \\
1,232.2 \\
1,397.9 \\
1,705.3\end{array}$ & $\begin{array}{l}472.3 \\
515.9 \\
635.4 \\
651.6 \\
781.3\end{array}$ & $\begin{array}{l}22.3 \\
27.6 \\
42.7 \\
63.1 \\
69.8\end{array}$ & $\begin{array}{l}5.2 \\
5.8 \\
3.5 \\
1.7 \\
.7\end{array}$ & $\begin{array}{r}5.9 \\
8.8 \\
16.9 \\
14.3 \\
21.8\end{array}$ & $\begin{array}{l}11.3 \\
13.0 \\
22.3 \\
47.2 \\
47.3\end{array}$ & $\begin{array}{l}225.2 \\
237.0 \\
338.4 \\
455.2 \\
664.4\end{array}$ & $\begin{array}{r}19.9 \\
8.6 \\
5.7 \\
4.0 \\
2.1\end{array}$ & $\begin{array}{l}205.0 \\
223.7 \\
295.6 \\
391.0 \\
557.2\end{array}$ & $\begin{array}{r}.3 \\
4.7 \\
37.1 \\
60.1 \\
105.2\end{array}$ & $\begin{array}{r}98.1 \\
96.0 \\
168.7 \\
146.9 \\
158.8\end{array}$ & $\begin{array}{l}22.8 \\
18.2 \\
44.0 \\
48.2 \\
33.8\end{array}$ & (3) $\begin{array}{r}.1 \\
.1 \\
.2\end{array}$ \\
\hline $\begin{array}{l}1965 \\
1966 \\
1967 \\
1965 \\
1969\end{array}$ & $\begin{array}{l}1,871.2 \\
1,813.6 \\
1,796.7 \\
2,178.7 \\
1,855.7\end{array}$ & $\begin{array}{l}852.0 \\
792.8 \\
755.8 \\
837.7 \\
713.9\end{array}$ & $\begin{array}{r}67.2 \\
96.4 \\
140.9 \\
200.4 \\
152.7\end{array}$ & $\begin{array}{r}.1 \\
.3 \\
.1 \\
1.5 \\
.6\end{array}$ & $\begin{array}{r}19.2 \\
21.2 \\
8.0 \\
16.8 \\
13.1\end{array}$ & $\begin{array}{r}47.8 \\
74.9 \\
132.8 \\
182.2 \\
139.0\end{array}$ & $\begin{array}{l}687.0 \\
714.1 \\
580.9 \\
837.7 \\
838.6\end{array}$ & $\begin{array}{l}4.8 \\
3.8 \\
3.8 \\
4.3 \\
5.3\end{array}$ & $\begin{array}{l}527.0 \\
522.7 \\
451.8 \\
609.8 \\
671.4\end{array}$ & $\begin{array}{l}155.2 \\
187.6 \\
125.3 \\
223.6 \\
161.9\end{array}$ & $\begin{array}{l}219.8 \\
209.7 \\
271.2 \\
276.5 \\
128.1\end{array}$ & $\begin{array}{l}44.3 \\
29.6 \\
27.7 \\
26.3 \\
22.2\end{array}$ & $\begin{array}{r}.9 \\
1.0 \\
.2 \\
.3\end{array}$ \\
\hline $\begin{array}{l}1970 \ldots \\
1971 \\
1972\end{array}$ & $\begin{array}{l}1,605.8 \\
2,035.2 \\
2,7=6.0\end{array}$ & $\begin{array}{r}672.4 \\
812.4 \\
1,051.8\end{array}$ & $\begin{array}{l}191.0 \\
216.0 \\
277.9\end{array}$ & (3) $^{.6}$ & $\begin{array}{r}5.0 \\
15.1 \\
2.8\end{array}$ & $\begin{array}{l}185.4 \\
200.5 \\
275.0\end{array}$ & $\begin{array}{r}569.2 \\
809.5 \\
1,226.5\end{array}$ & $\begin{array}{l}3.3 \\
4.5 \\
0.9\end{array}$ & $\begin{array}{l}460.0 \\
590.9 \\
822.5\end{array}$ & $\begin{array}{l}105.8 \\
214.0 \\
403.1\end{array}$ & $\begin{array}{l}147.0 \\
143.1 \\
153.9\end{array}$ & $\begin{array}{l}26.1 \\
24.0 \\
30.2\end{array}$ & 45.7 \\
\hline
\end{tabular}

1 Includes mixed species (not classified as hardwoods or softwoods) for the years $1950-59$.

2 Data may not add to totals because of rounding.
${ }^{3}$ Less than 50,000 square feet.

4 Preliminary.

Source: See source note, table 1. 
THE OUTLOOK FOR TIMBER IN THE UNITED STATES

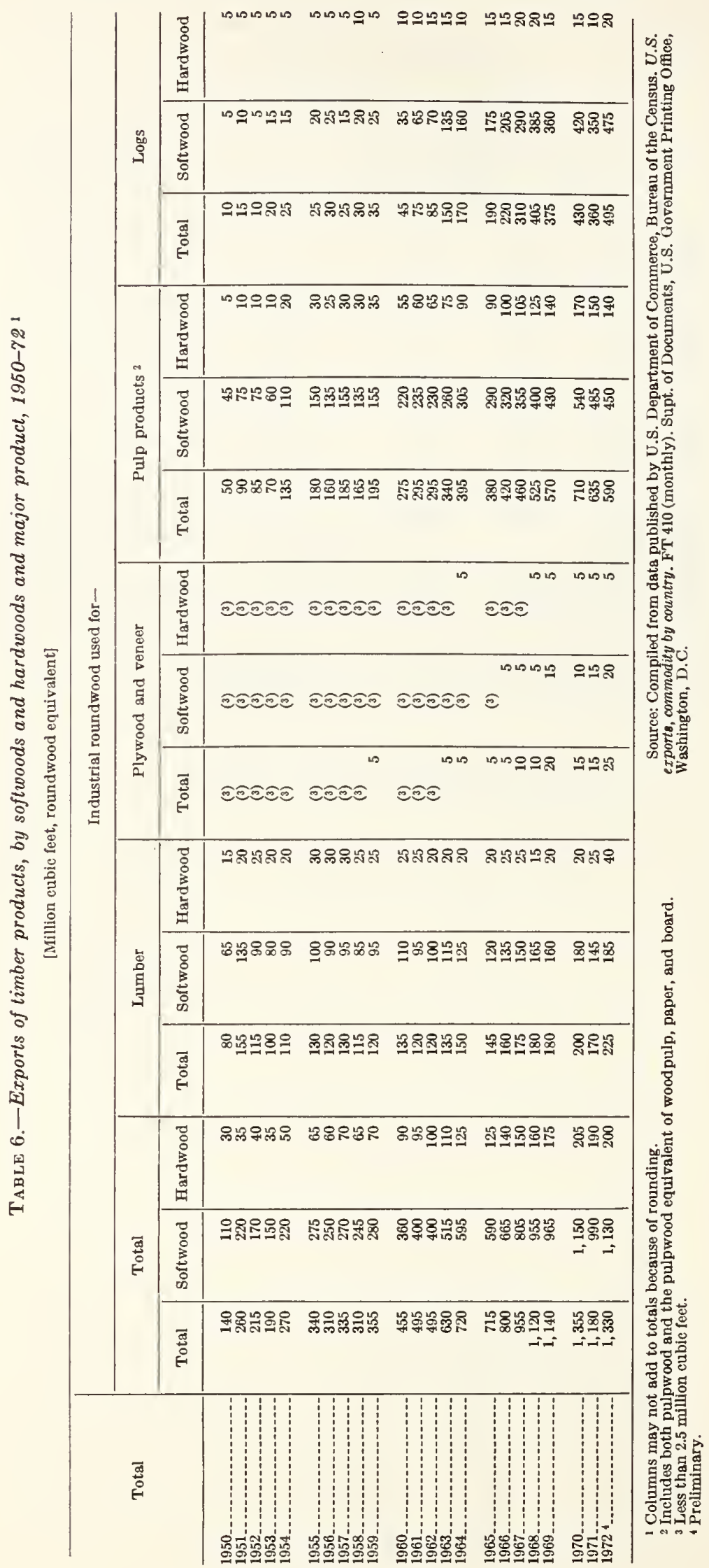


APPENDIX IV. TIMBER IMPORTS AND EXPORTS

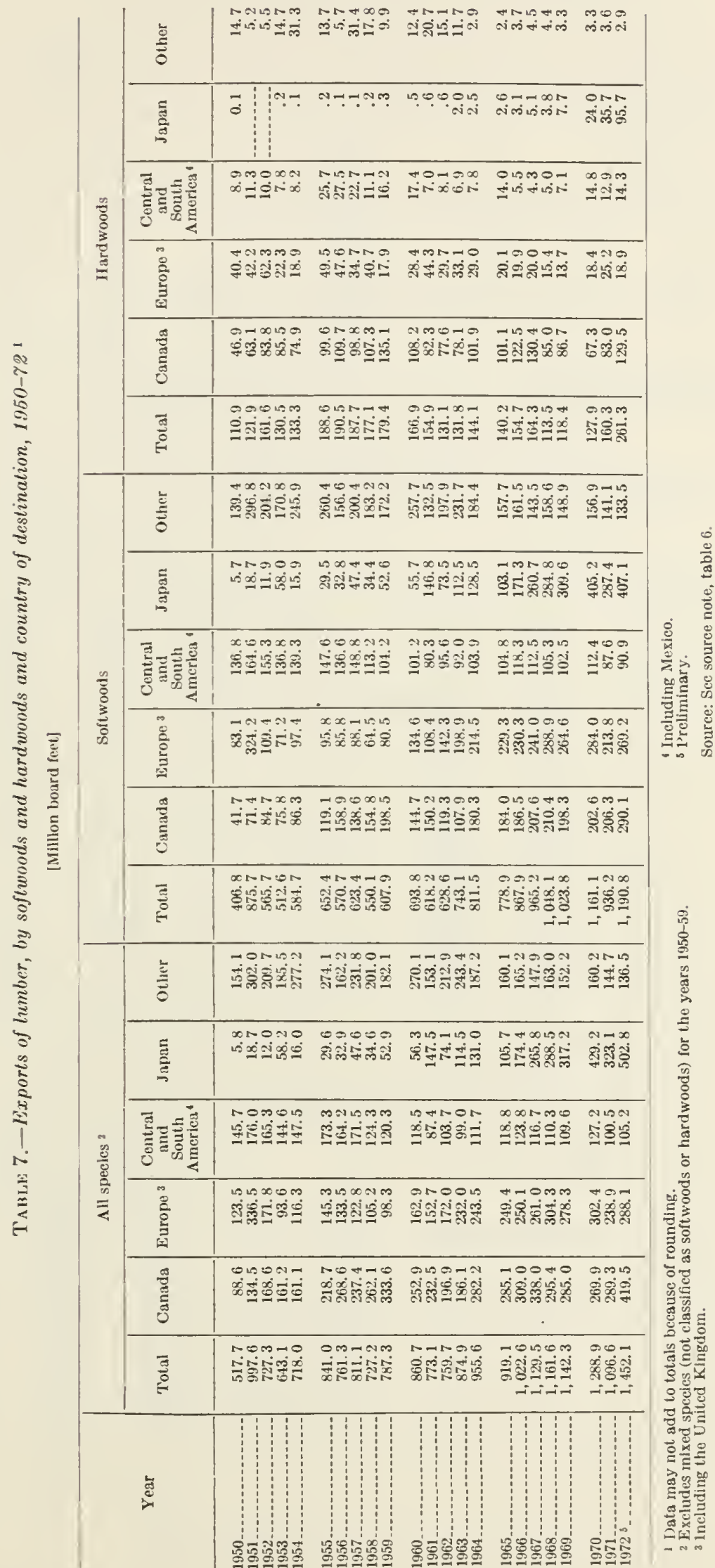


TABLE 8.-Exports of pulp products, by product, 1950-72 1

[Million cords, roundwood equivalent]

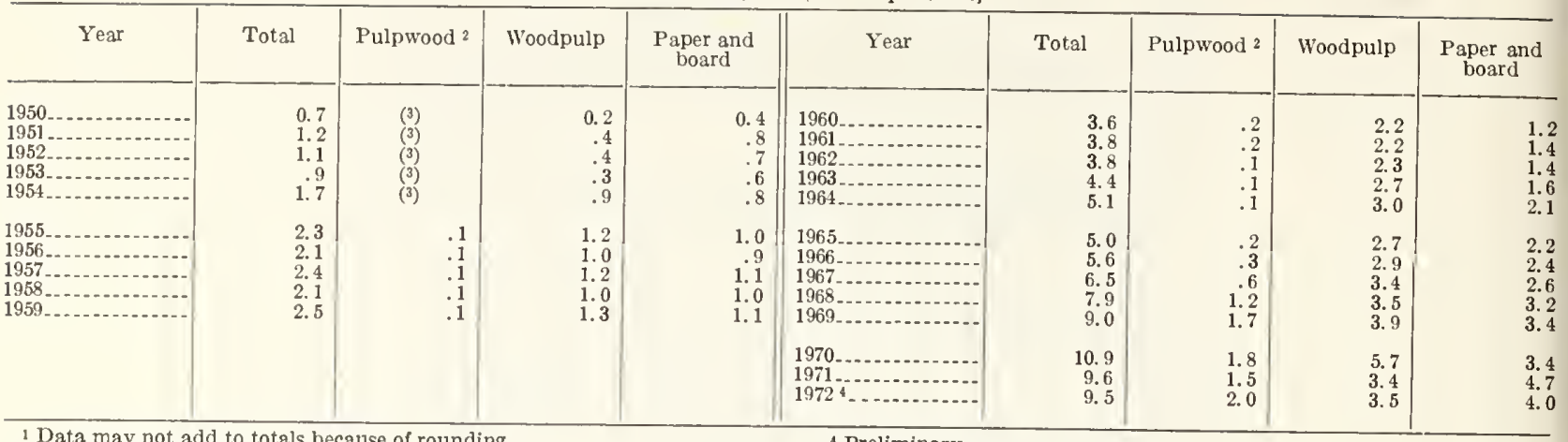

1. Data may not add to totals because of rounding.
2 Roundwood and chips.

3 Less than 50 thousand cords.

Source: See source note, table 6.

TABLE 9.-Exports of logs, by major species, 1950-72 1

[Million board feet, log scale]

\begin{tabular}{|c|c|c|c|c|c|c|c|c|}
\hline \multirow[b]{2}{*}{ Year } & \multirow[b]{2}{*}{ Total } & \multicolumn{4}{|c|}{ Softwoods } & \multicolumn{3}{|c|}{ Hardwoods } \\
\hline & & Total & Douglas-fir & $\begin{array}{l}\text { Port Orford } \\
\text { cedar }\end{array}$ & Other & Total & Walnut & Other \\
\hline $\begin{array}{l}1950 \\
1951 \\
1952 \\
1953 \\
1954\end{array}$ & $\begin{array}{r}48.2 \\
79.4 \\
63.7 \\
115.1 \\
139.5\end{array}$ & $\begin{array}{r}28.9 \\
57.9 \\
44.4 \\
86.0 \\
106.4\end{array}$ & $\begin{array}{r}1.0 \\
2.4 \\
4.2 \\
12.4 \\
12.8\end{array}$ & $\begin{array}{r}0.3 \\
.6 \\
1.9 \\
3.5 \\
13.8\end{array}$ & $\begin{array}{l}27.6 \\
54.9 \\
38.3 \\
70.0 \\
79.8\end{array}$ & $\begin{array}{l}19.3 \\
21.5 \\
19.2 \\
29.2 \\
33.1\end{array}$ & $\begin{array}{r}1.0 \\
1.0 \\
.3 \\
.5 \\
.6\end{array}$ & $\begin{array}{l}18.3 \\
20.5 \\
18.9 \\
28.6 \\
32.5\end{array}$ \\
\hline $\begin{array}{l}1955 \\
1956 \\
1957 \\
1958 \\
1959-201\end{array}$ & $\begin{array}{l}166.2 \\
187.7 \\
139.3 \\
169.8 \\
204.6\end{array}$ & $\begin{array}{l}144.2 \\
154.9 \\
107.3 \\
127.3 \\
167.6\end{array}$ & $\begin{array}{r}9.8 \\
15.8 \\
8.1 \\
12.4 \\
20.8\end{array}$ & $\begin{array}{l}10.7 \\
13.9 \\
22.8 \\
32.3 \\
39.2\end{array}$ & $\begin{array}{r}123.7 \\
125.2 \\
76.4 \\
82.7 \\
107.7\end{array}$ & $\begin{array}{l}22.0 \\
32.8 \\
32.0 \\
42.5 \\
37.0\end{array}$ & $\begin{array}{l}1.2 \\
1.1 \\
1.4 \\
2.3 \\
3.7\end{array}$ & $\begin{array}{l}20.8 \\
31.6 \\
30.6 \\
40.2 \\
33.2\end{array}$ \\
\hline $\begin{array}{l}1960 \\
1961 \\
1962 \\
1963\end{array}$ & $\begin{array}{r}266.3 \\
481.8 \\
522.2 \\
951.3 \\
1,086.3\end{array}$ & $\begin{array}{r}210.3 \\
432.2 \\
452.7 \\
879.6 \\
1,022.6\end{array}$ & $\begin{array}{l}27.5 \\
66.8 \\
48.1 \\
71.6 \\
94.6\end{array}$ & $\begin{array}{l}37.2 \\
61.2 \\
41.5 \\
63.9 \\
37.0\end{array}$ & $\begin{array}{l}145.6 \\
304.2 \\
363.1 \\
744.1 \\
891.0\end{array}$ & $\begin{array}{l}56.0 \\
49.5 \\
69.5 \\
71.8 \\
63.7\end{array}$ & $\begin{array}{r}10.2 \\
7.2 \\
10.3 \\
16.5 \\
11.1\end{array}$ & $\begin{array}{l}45.9 \\
42.4 \\
50.2 \\
55.3 \\
52.6\end{array}$ \\
\hline $\begin{array}{l}1965 \\
1966 \\
1968 \\
1969\end{array}$ & $\begin{array}{l}1,192.8 \\
1,393.1 \\
1,970.7 \\
2,568.1 \\
2,397.0\end{array}$ & $\begin{array}{l}1,111.4 \\
1,317.5 \\
1,873.6 \\
2,473.2 \\
2,316.8\end{array}$ & $\begin{array}{l}111.3 \\
130.5 \\
272.0 \\
396.5 \\
380.6\end{array}$ & $\begin{array}{l}39.1 \\
43.0 \\
34.6 \\
38.4 \\
40.7\end{array}$ & $\begin{array}{r}961.0 \\
1,144.0 \\
1,567.0 \\
2,038.3 \\
1,895.6\end{array}$ & $\begin{array}{l}81.4 \\
75.6 \\
97.1 \\
94.9 \\
80.2\end{array}$ & $\begin{array}{l}23.6 \\
12.8 \\
16.4 \\
21.9 \\
20.6\end{array}$ & $\begin{array}{l}57.9 \\
62.8 \\
80.7 \\
73.0 \\
59.5\end{array}$ \\
\hline $\begin{array}{l}1070 \\
1971 \\
19722^{2}\end{array}$ & $\begin{array}{l}2,753.0 \\
2,292.4 \\
3,143.3\end{array}$ & $\begin{array}{l}2,684.1 \\
2,233.4 \\
3,049.4\end{array}$ & $\begin{array}{l}487.7 \\
448.1 \\
662.2\end{array}$ & $\begin{array}{l}54.1 \\
40.2 \\
45.1\end{array}$ & $\begin{array}{l}2,142.3 \\
1,745.1 \\
2,942.4\end{array}$ & $\begin{array}{l}68.9 \\
59.0 \\
93.9\end{array}$ & $\begin{array}{l}17.4 \\
12.9 \\
15.2\end{array}$ & $\begin{array}{l}51.5 \\
46.2 \\
78.7\end{array}$ \\
\hline
\end{tabular}

1 Data may not add to totals because of rounding.

Source: See source note, table 6.

TABLE 10.-Exports of logs, by major region of destination, 1950-72 1

[Million board feet, log scale]

\begin{tabular}{|c|c|c|c|c|c|c|c|c|c|c|c|}
\hline Year & Total & Canada & $\begin{array}{l}\text { Western } \\
\text { Europe }\end{array}$ & Japan & Other & Year & Total & Canada & $\begin{array}{l}\text { Western } \\
\text { Europe }\end{array}$ & Japan & Other \\
\hline $\begin{array}{l}1950 \ldots \ldots \\
1951 \\
1952 \\
1953 \\
1954 \ldots \ldots \ldots\end{array}$ & $\begin{array}{r}48.2 \\
79.4 \\
63.7 \\
115.1 \\
139.5\end{array}$ & $\begin{array}{l}42.5 \\
71.8 \\
53.8 \\
69.2 \\
75.4\end{array}$ & $\begin{array}{l}3.6 \\
4.7 \\
3.0 \\
3.8 \\
4.8\end{array}$ & $\begin{array}{r}1.4 \\
6.5 \\
41.6 \\
54.5\end{array}$ & $\begin{array}{r}2.1 \\
1.6 \\
.4 \\
.6 \\
4.7\end{array}$ & $\begin{array}{l}1960 \\
1961 \\
1962 \\
1963 \\
1964 \ldots \ldots\end{array}$ & $\begin{array}{r}266.3 \\
481.8 \\
522.2 \\
951.3 \\
1,086.3\end{array}$ & $\begin{array}{r}150.7 \\
99.6 \\
167.3 \\
209.3 \\
288.5\end{array}$ & $\begin{array}{l}15.9 \\
16.3 \\
24.8 \\
32.2 \\
19.0\end{array}$ & $\begin{array}{r}98.6 \\
364.8 \\
329.0 \\
691.1 \\
755.4\end{array}$ & $\begin{array}{r}1.1 \\
1.1 \\
1.2 \\
18.8 \\
23.4\end{array}$ \\
\hline $\begin{array}{l}1955 \ldots \ldots \\
1956 \ldots \ldots \\
1957 \\
1958 \\
1959\end{array}$ & $\begin{array}{l}166.2 \\
187.7 \\
139.3 \\
169.8 \\
204.6\end{array}$ & $\begin{array}{r}138.4 \\
160.2 \\
97.1 \\
112.6 \\
126.6\end{array}$ & $\begin{array}{l}8.9 \\
5.7 \\
5.3 \\
7.7 \\
7.2\end{array}$ & $\begin{array}{l}18.0 \\
20.5 \\
36.0 \\
47.9 \\
70.1\end{array}$ & $\begin{array}{r}.8 \\
1.2 \\
1.0 \\
1.6 \\
.7\end{array}$ & $\begin{array}{l}1965 \ldots \\
1966 \\
1967 \\
1968 \\
1969 \\
1970 \ldots \ldots \\
1971 \\
19722^{2}\end{array}$ & $\begin{array}{l}1,192.8 \\
1,393.1 \\
1,970.7 \\
2,568.1 \\
2,397.0 \\
2,753.2 \\
2,292.4 \\
3,143.3\end{array}$ & $\begin{array}{l}352.9 \\
266.2 \\
335.8 \\
341.8 \\
324.6 \\
291.8 \\
343.6 \\
518.1\end{array}$ & $\begin{array}{l}29.4 \\
17.3 \\
20.8 \\
28.8 \\
29.9 \\
23.6 \\
20.8 \\
32.6\end{array}$ & $\begin{array}{r}804.4 \\
1,083.0 \\
1,583.6 \\
2,119.2 \\
2,007.8 \\
2,377.3 \\
1,847.1 \\
2,529.9\end{array}$ & $\begin{array}{r}6.2 \\
26.5 \\
30.6 \\
78.4 \\
34.8 \\
60.3 \\
80.9 \\
61.7\end{array}$ \\
\hline
\end{tabular}

1 Data may not add to totals because of rounding.

2 Preliminary.

Source: See source note, table 6. 


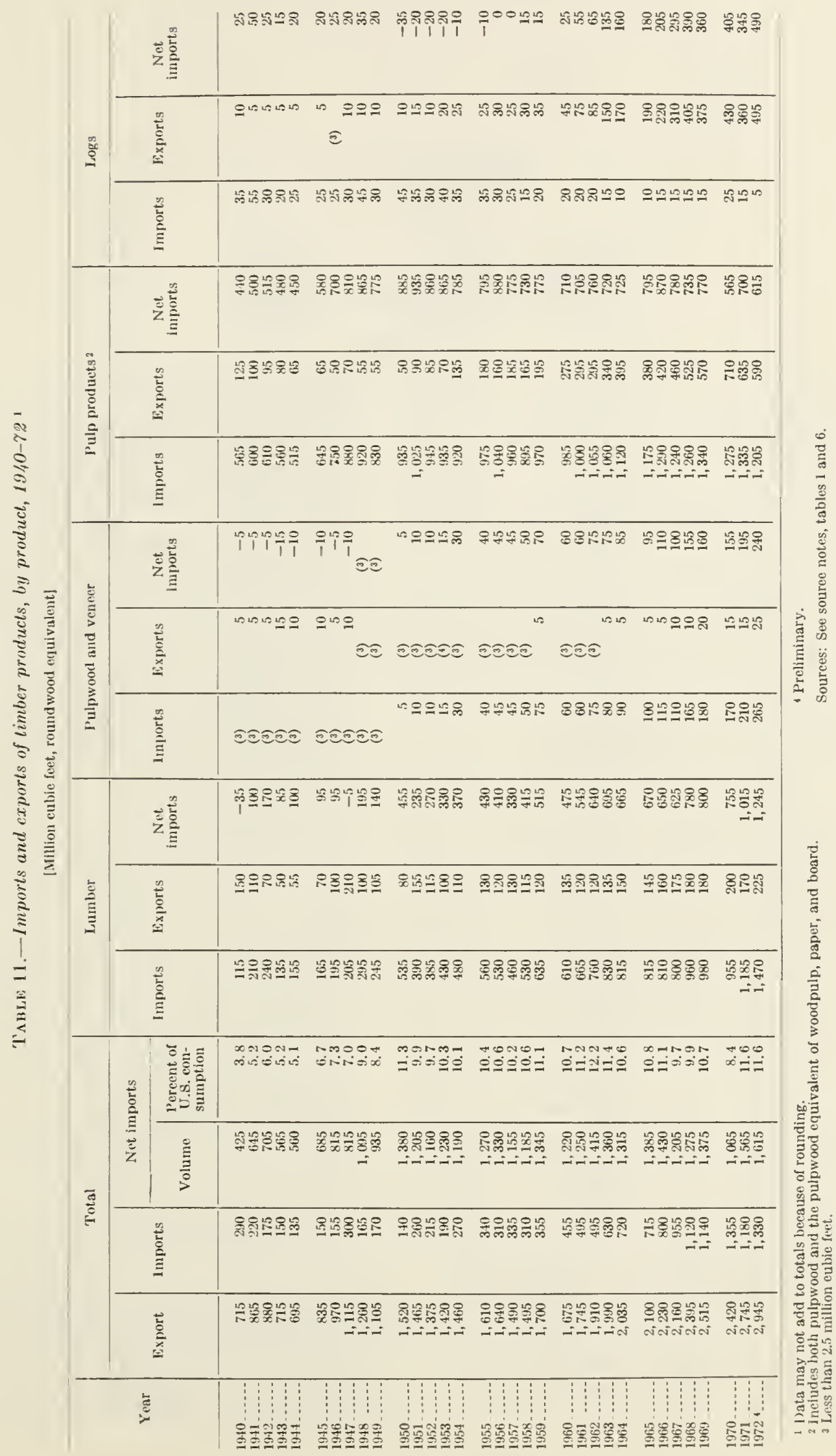




\section{APPENDIX V}

\section{Timber Demand Tables}

Table
No.

1 Measures of population and economic growth, 1920-72 _............

2 Average stumpage and lumber prices of Douglas-fir, southern pine, and ponderosa pine, 1910-1972

3 Relative wholesale price index of lumber, 1800-1972.

4 Wholesale price indexes of selected timber products and competing materials, 19261972

5 Panel products consumed per housing unit, by type of unit, 1970 , with projections (1970 relative prices) to 2000

6 Per capita expenditures for new non residential construction, by construction class, 1920-70, with projections to 2000.

7 Lumber used in new nonresidential construction, by construction class, 1962 and 1970 , with projections (1970 relative prices) to 2000.--

8 Plywood used in new nonresidential construction, by construction class, 1962 and 1970 , with projections (1970 relative prices) to $2000_{-}$

9 Building board used in new nonresidential construction, by construction class, 1962 and 1970 , with projections (1970 relative prices) to 2000

10 Per capita value of manufacturing shipments by product group, specified years 1948-70, with projections to 2000

11 Lumber use in manufacturing, by product group, specified years $1948-70$, with projections (1970 relative prices) to 2000

12 Veneer and plywood ( $3 / 8$-inch basis) use in manufacturing, by product group, specified years $1948-70$, with projections (1970 relative prices) to 2000

13 Hardboard (1/8-inch basis) use in manufacturing, by product group, specified years $1960-70$, with projections (1970 relative prices) to 2000

14 Particleboard ( $3 / 4$-inch basis) use in manufacturing, by product group, specified years $1960-70$, with projections (1970 relative prices) to 2000

15 Lumber consumption, exports, imports, and domestic production, 1920-72

16 Plywood consumption, exports, imports, and domestic production, 1950-72

17 Apparent consumption, exports, imports, and domestic production of paper and board, 1920-72

18 Apparent consumption, exports, imports, and domestic production of paper, 1920-72

19 Apparent consumption, exports, imports, and domestic production of paperboard, 1920-72.
Page

331

332

334

338

338

339

340

341

342

346

347

348

349

350

351
Table

No.

20 Apparent consumption, exports, imports, and domestic production of building board,

21 Paper and board exports from the United States, by grade and major region of destination, 1971

22 Paper and board imports into the United States, by grade and major region of origin, 1971

23 Fibrous materials consumed in the manufacture of paper and board, by type of material, specified years 1919-72

24 Apparent consumption, exports, imports, domestic production of woodpulp, 1920-72

25 Woodpulp exports from the United States, by type and major region of destination, 1971_.

26 Woodpulp imports into the United States, by type and major region of origin, 1971 . . .

27 Apparent consumption, exports, imports, and domestic production of pulpwood, 1920-72_-

28 Consumption of pulpwood in the manufacture of woodpulp, 1920-72.

29 Production, imports, exports, and apparent consumption of forest products, by major products, 1940-72

30 Roundwood production, imports, exports, and apparent consumption, by major product, 1950-72, with projections (medium level) under alternative price assumptions to $2000 \ldots$

31 Softwood roundwood production, imports, exports, and apparent consumption, by major product, 1950-72, with projections (medium level) under alternative price assumptions to 2000

32 Hardwood roundwood production, imports, exports, and apparent consumption, by major product, $1950-72$, with projections (medium level) under alternative price assumptions to 2000

33 Sawtimber production, imports, exports, and apparent consumption, by major product, 1950-72, with projections (medium level) under alternative price assumptions to 2000

34 Softwood sawtimber production, imports, exports, and apparent consumption, by major product, 1950-72, with projections (medium level) under alternative price assumptions to 2000

35 Hardwood sawtimber production, imports, exports, and apparent consumption, by major product, $1950-72$, with projections (medium level) under alternative price assumptions to 2000

36 Consumption of industrial raw materials in the U.S., by broad product groups, 1920-69...
Page 
APPENDLX V. TIMBER DEMAND TABLES

TABLE 1.-Measures of population and economic growth, 1920-72

\begin{tabular}{|c|c|c|c|c|c|c|}
\hline Year & Population & $\begin{array}{l}\text { Gross } \\
\text { national } \\
\text { product }\end{array}$ & $\begin{array}{c}\text { Per capita } \\
\text { gross } \\
\text { national } \\
\text { product }\end{array}$ & $\begin{array}{l}\text { Disposable } \\
\text { personal } \\
\text { income }\end{array}$ & $\begin{array}{l}\text { Per capita } \\
\text { disposable } \\
\text { personal } \\
\text { income }\end{array}$ & $\begin{array}{c}\text { Index of } \\
\text { manufacturing } \\
\text { production }\end{array}$ \\
\hline $\begin{array}{l}1920 \ldots-- \\
1921 \ldots-- \\
1922 \ldots \ldots \\
1923 \ldots-- \\
1924 \ldots \ldots\end{array}$ & $\begin{array}{l}\text { Millions } \\
106.5 \\
108.5 \\
110.1 \\
112.0 \\
114.1\end{array}$ & $\begin{array}{r}\text { Billions of } 1967 \text { dollars } \\
160.5 \\
145.4 \\
166.5 \\
186.8 \\
186.2\end{array}$ & $\begin{array}{r}1967 \text { dollars } \\
1,507 \\
1,340 \\
1,512 \\
1,668 \\
1,632\end{array}$ & $\mid \begin{array}{c}\text { Billions of } 1967 \text { dollars } \\
-1 \\
-1 .\end{array}$ & 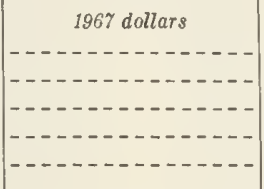 & $\begin{array}{r}1967=100 \\
16.2 \\
12.3 \\
16.2 \\
18.9 \\
17.7\end{array}$ \\
\hline $\begin{array}{l}1925--- \\
1926 \ldots-- \\
1927 \ldots-- \\
1925_{---} \\
1929 \ldots--\end{array}$ & $\begin{array}{l}115.8 \\
117.4 \\
119.0 \\
120.5 \\
121.8\end{array}$ & $\begin{array}{l}\text { 201. } 8 \\
212.8 \\
213.3 \\
216.7 \\
239.4\end{array}$ & $\begin{array}{r}1,743 \\
1,813 \\
1,792 \\
1,798 \\
1,966\end{array}$ & $\mid$ & $\mid$ & $\begin{array}{l}\text { 19. } 8 \\
20.9 \\
20.7 \\
21.8 \\
22.8\end{array}$ \\
\hline $\begin{array}{l}1930 \ldots \ldots \\
1931 \ldots \\
1932 \ldots-- \\
1933 \ldots-- \\
1934 \ldots--\end{array}$ & $\begin{array}{l}123.2 \\
124.1 \\
124.9 \\
125.7 \\
126.5\end{array}$ & $\begin{array}{l}\text { 215. } 8 \\
199.1 \\
169.6 \\
166.4 \\
181.4\end{array}$ & $\begin{array}{l}1,752 \\
1,604 \\
1,358 \\
1,324 \\
1,434\end{array}$ & $\begin{array}{l}159.0 \\
153.0 \\
131.7 \\
128.4 \\
137.7\end{array}$ & $\begin{array}{l}1,291 \\
1,233 \\
1,054 \\
1,021 \\
1,089\end{array}$ & $\begin{array}{l}18.7 \\
15.3 \\
11.8 \\
14.0 \\
15.3\end{array}$ \\
\hline $\begin{array}{l}1935 \ldots-- \\
1936 \_-- \\
1937 \ldots-- \\
1938 \ldots-- \\
1939 \ldots--\end{array}$ & $\begin{array}{l}127.4 \\
128.2 \\
129.0 \\
130.0 \\
131.0\end{array}$ & $\begin{array}{l}199.3 \\
226.9 \\
238.9 \\
226.8 \\
246.2\end{array}$ & $\begin{array}{l}1,564 \\
1,770 \\
1,852 \\
1,745 \\
1,879\end{array}$ & $\begin{array}{l}150.8 \\
169.8 \\
175.2 \\
164.3 \\
178.4\end{array}$ & $\begin{array}{l}1,184 \\
1,324 \\
1,358 \\
1,264 \\
1,362\end{array}$ & $\begin{array}{l}18.0 \\
21.5 \\
23.4 \\
18.0 \\
21.5\end{array}$ \\
\hline $\begin{array}{l}1940 \ldots--- \\
1941 \ldots-- \\
1942 \ldots-- \\
1943 \ldots \ldots \\
1944 \ldots--\end{array}$ & $\begin{array}{l}132.6 \\
133.9 \\
135.4 \\
137.3 \\
138.9\end{array}$ & $\begin{array}{l}267.1 \\
310.1 \\
350.2 \\
396.4 \\
424.8\end{array}$ & $\begin{array}{l}2,014 \\
2,316 \\
2,586 \\
2,887 \\
3,058\end{array}$ & $\begin{array}{l}\text { 190. } 3 \\
217.7 \\
244.1 \\
254.9 \\
265.0\end{array}$ & $\begin{array}{l}1,435 \\
1,626 \\
1,803 \\
1,857 \\
1,908\end{array}$ & $\begin{array}{l}25.4 \\
32.4 \\
37.8 \\
47.0 \\
50.9\end{array}$ \\
\hline $\begin{array}{l}1945 \ldots \ldots \\
1946 \ldots-- \\
1947 \ldots \ldots \\
1948 \ldots-- \\
1949 \ldots--\end{array}$ & $\begin{array}{l}140.5 \\
141.9 \\
144.7 \\
147.2 \\
149.8\end{array}$ & $\begin{array}{l}\text { 417. } 6 \\
367.6 \\
364.4 \\
380.6 \\
381.1\end{array}$ & $\begin{array}{l}2,972 \\
2,591 \\
2,518 \\
2,586 \\
2,544\end{array}$ & $\begin{array}{l}262.8 \\
259.7 \\
249.4 \\
262.9 \\
264.1\end{array}$ & $\begin{array}{l}1,870 \\
1,830 \\
1,724 \\
1,786 \\
1,763\end{array}$ & $\begin{array}{l}42.6 \\
35.3 \\
39.4 \\
40.9 \\
38.7\end{array}$ \\
\hline $\begin{array}{l}1950 \ldots \\
1951 \ldots \\
1952 \ldots- \\
1953 \ldots-- \\
1954 \ldots--\end{array}$ & $\begin{array}{l}152.3 \\
154.9 \\
157.6 \\
160.2 \\
163.0\end{array}$ & $\begin{array}{l}417.8 \\
450.8 \\
464.6 \\
485.4 \\
478.6\end{array}$ & $\begin{array}{l}2,743 \\
2,910 \\
2,948 \\
3,030 \\
2,936\end{array}$ & $\begin{array}{l}285.6 \\
292.5 \\
301.2 \\
315.1 \\
318.4\end{array}$ & $\begin{array}{l}1,875 \\
1,888 \\
1,911 \\
1,967 \\
1,953\end{array}$ & $\begin{array}{l}45.0 \\
48.6 \\
50.6 \\
55.1 \\
51.5\end{array}$ \\
\hline $\begin{array}{l}1955 \ldots-- \\
1956 \ldots-- \\
1957 \ldots-- \\
1958 \ldots-- \\
1959 \_--\end{array}$ & $\begin{array}{l}165.9 \\
168.9 \\
172.0 \\
174.9 \\
177.8\end{array}$ & $\begin{array}{l}515.0 \\
524.5 \\
532.0 \\
525.9 \\
559.6\end{array}$ & $\begin{array}{l}3,104 \\
3,105 \\
3,093 \\
3,007 \\
3,147\end{array}$ & $\begin{array}{l}339.5 \\
353.9 \\
361.3 \\
364.7 \\
381.0\end{array}$ & $\begin{array}{l}2,046 \\
2,095 \\
2,101 \\
2,085 \\
2,143\end{array}$ & $\begin{array}{l}58.2 \\
60.5 \\
61.2 \\
56.9 \\
64.1\end{array}$ \\
\hline $\begin{array}{l}1960 \ldots \ldots \\
1961 \ldots-- \\
1962 \ldots-- \\
1963 \ldots \ldots \\
1964 \ldots-\end{array}$ & $\begin{array}{l}180.7 \\
183.7 \\
186.5 \\
189.2 \\
191.9\end{array}$ & $\begin{array}{l}573.4 \\
584.6 \\
622.9 \\
647.9 \\
683.3\end{array}$ & $\begin{array}{l}3,173 \\
3,182 \\
3,340 \\
3,424 \\
3,561\end{array}$ & $\begin{array}{l}389.2 \\
401.2 \\
420.2 \\
436.2 \\
466.7\end{array}$ & $\begin{array}{l}2,154 \\
2,184 \\
2,253 \\
2,305 \\
2,432\end{array}$ & $\begin{array}{l}65.4 \\
65.6 \\
71.4 \\
75.8 \\
81.2\end{array}$ \\
\hline $\begin{array}{l}1965--- \\
1966 \_-- \\
1967--- \\
1968 \_-- \\
1969---\end{array}$ & $\begin{array}{l}194.3 \\
196.6 \\
198.7 \\
200.7 \\
202.7\end{array}$ & $\begin{array}{l}726.4 \\
773.8 \\
793.9 \\
830.8 \\
853.2\end{array}$ & $\begin{array}{l}3,739 \\
3,936 \\
3,995 \\
4,140 \\
4,209\end{array}$ & $\begin{array}{l}497.7 \\
525.0 \\
546.3 \\
570.8 \\
587.6\end{array}$ & $\begin{array}{l}2,562 \\
2,670 \\
2,749 \\
2,844 \\
2,899\end{array}$ & $\begin{array}{r}89.1 \\
98.3 \\
100.0 \\
105.7 \\
110.7\end{array}$ \\
\hline $\begin{array}{l}1970 \ldots \ldots \\
1971 \ldots \ldots \\
1972 \ldots \ldots\end{array}$ & $\begin{array}{l}204.9 \\
207.0 \\
208.8\end{array}$ & $\begin{array}{l}849.0 \\
872.1 \\
928.3\end{array}$ & $\begin{array}{l}4,143 \\
4,213 \\
4,446\end{array}$ & $\begin{array}{l}610.0 \\
634.6 \\
662.0\end{array}$ & $\begin{array}{l}2,977 \\
3,066 \\
3,170\end{array}$ & $\begin{array}{l}\text { 106. } 6 \\
\text { 106. } 8 \\
114.3\end{array}$ \\
\hline
\end{tabular}

NOTE: Conversion to 1967 dollars by U.S. Department of Agriculture, Forest Service.

Sources: Population, U.S. Department of Commerce, Bureau of the Census. 1920-59-Population estimates and projections. Curr. Pop. Reps. Ser. P-25, No. 442, 1970; 1960-72-Population estimates and projcctions, Curr. Pop. Reps. Ser. P-25, No. 499, 1973.

Gross national product and per capita gross national product, 1920-28-U.S. Congress, Joint Committee on the Economic Report. Potential economic growth of the United States during the ncxt decade. $83 \mathrm{~d}$ Cong., $2 \mathrm{~d}$ sess., 1954; 1929-72-Economic report of the Prcsident. 1973. Disposable personal income, 1929-72-Economic rcport of the Prcsident. 1972.

Per capita disposable income, 1929-72-Computed by the Forest Service.

Index of manufacturing production, 1929-72-Economic report of the Prcsidcnt. 1973. 
TABLE 2.-Average stumpage and lumber prices of Douglas-fir, southern pine, and ponderosa pine 1910-72

[Prices in constant 1967 dollars per thousand board feet, International 1/4-inch log rule for stumpage and mill tally for lumber]

\begin{tabular}{|c|c|c|c|c|c|c|c|c|c|c|c|c|c|}
\hline \multirow{2}{*}{ Year } & \multicolumn{2}{|c|}{ Douglas-fir } & \multicolumn{2}{|c|}{ Ponderosa pine } & \multicolumn{2}{|c|}{ Southern pine } & \multirow{2}{*}{ Year } & \multicolumn{2}{|c|}{ Douglas-fir } & \multicolumn{2}{|c|}{ Ponderosa pine } & \multicolumn{2}{|c|}{ Southern pine } \\
\hline & Stumpage & Lumber & Stumpage & Lumber & Stumpage & Lumber & & Stumpage & Lumber & Stumpage & Lumber & Stumpage & Lumber \\
\hline 1910 & 4. 42 & 35.98 & 8.15 & 39.17 & 3.44 & 36.53 & 1940-. & 4.15 & 48.09 & 4.47 & 59.93 & 9.27 & 52.68 \\
\hline 1911 & 5.03 & $\begin{array}{l}33.03 \\
31.75\end{array}$ & 6. 15 & $\begin{array}{l}40.71 \\
37.34\end{array}$ & 6. 99 & 41.45 & $1941 \ldots$ & 5.84 & 56.49 & 4.75 & 63.59 & 20.02 & 56.60 \\
\hline . & $\begin{array}{l}4.01 \\
3.45\end{array}$ & $\begin{array}{l}31.85 \\
23.89\end{array}$ & $\begin{array}{l}0.10 \\
5.03\end{array}$ & $\begin{array}{l}37.34 \\
32.22\end{array}$ & $\begin{array}{l}3.47 \\
3.94\end{array}$ & $\begin{array}{l}26.94 \\
264\end{array}$ & $1947 \ldots$ & 9.46 & 83.73 & 8,93 & 75,94 & 11.90 & 89.91 \\
\hline $1914 \ldots$ & 3.33 & 23.04 & 4.68 & 29.87 & 6.89 & 47. 22 & 1948 & 17.56 & 88.28 & 14.51 & 87.63 & 16.54 & 91.10 \\
\hline 1915 & 5.92 & 29.57 & 5.75 & 39.98 & 4.90 & 34.65 & $\begin{array}{l}1949 \ldots \\
1950 \ldots\end{array}$ & $\begin{array}{l}10.31 \\
14.66\end{array}$ & $\begin{array}{l}81.22 \\
96.32\end{array}$ & $\begin{array}{l}18.42 \\
18.42\end{array}$ & $\begin{array}{l}88.15 \\
96.57\end{array}$ & $\begin{array}{l}20.91 \\
27.26\end{array}$ & $\begin{array}{l}86.61 \\
93.44\end{array}$ \\
\hline 1916 & $\begin{array}{l}0.99 \\
1.99\end{array}$ & 24.44 & & 32.92 & 6.06 & 32. 49 & $1951 \ldots$ & 20.38 & 94.63 & 30.36 & 101.58 & 31.71 & $\begin{array}{l}9.44 \\
89.94\end{array}$ \\
\hline 1917 & 1.93 & 26.86 & 2.99 & 32.32 & 4. 69 & 31.35 & & & & & & & \\
\hline $\begin{array}{l}1918 \ldots \ldots \\
1919 \ldots\end{array}$ & $\begin{array}{l}1.95 \\
2.46\end{array}$ & $\begin{array}{l}27.78 \\
34.46\end{array}$ & $\begin{array}{l}\text { 3. } 29 \\
\text { 3. } 46\end{array}$ & $\begin{array}{l}30.88 \\
38.84\end{array}$ & $\begin{array}{l}3.71 \\
4.33\end{array}$ & $\begin{array}{l}36.08 \\
40.19\end{array}$ & $1952 \ldots$ & $\begin{array}{l}21.29 \\
16.90\end{array}$ & $\begin{array}{l}96.35 \\
89.92\end{array}$ & $\begin{array}{l}25.47 \\
24.41\end{array}$ & $\begin{array}{l}103.06 \\
105.40\end{array}$ & $\begin{array}{l}36.30 \\
32.70\end{array}$ & $\begin{array}{l}93.44 \\
93.91\end{array}$ \\
\hline & & & & 38.84 & & & 1954 & 13.53 & 91.39 & $\begin{array}{l}25.41 \\
25.58\end{array}$ & 99.70 & 28.33 & $\begin{array}{l}9.91 \\
89.54\end{array}$ \\
\hline $1920 \ldots$ & 1.65 & $\begin{array}{l}43.43 \\
35.84\end{array}$ & 3.83 & 48.63 & 4. 61 & 45. 06 & $1955 \ldots$ & 24.05 & 99.57 & 24.47 & 103.30 & 30.43 & 92.85 \\
\hline 1922 & $\begin{array}{l}2.60 \\
3.67\end{array}$ & $\begin{array}{l}\begin{array}{l}3.84 \\
41.98\end{array} \\
\text { (a) }\end{array}$ & $\begin{array}{l}\text {. } 24 \\
6.61\end{array}$ & $\begin{array}{l}53.55 \\
55.66\end{array}$ & $\begin{array}{l}0.14 \\
4.69\end{array}$ & $\begin{array}{l}37.45 \\
47.45\end{array}$ & _1956 & 30.40 & 96.02 & 24.70 & 107.16 & 34.46 & 93.09 \\
\hline 1923 & 3.52 & 51.97 & 6.18 & 63.72 & 4.83 & 57.42 & $1957 \ldots$ & 20.53 & 83.94 & 21.36 & 95.05 & 28.20 & 86.98 \\
\hline 1924. & 3.18 & 43.71 & 5.70 & 54.89 & 5.79 & 52.55 & 1958 & 16.84 & 81.22 & 16.62 & 90.26 & 27.45 & 84.48 \\
\hline 1925. & 2.88 & 39.25 & 5.56 & 51.93 & 5.01 & 49.60 & $1960 \ldots$ & $\begin{array}{l}28.68 \\
24.65\end{array}$ & $\begin{array}{l}92.42 \\
84.40\end{array}$ & $\begin{array}{l}17.89 \\
16.57\end{array}$ & $\begin{array}{l}98.01 \\
92.80\end{array}$ & $\begin{array}{l}31.01 \\
30.36\end{array}$ & $\begin{array}{l}87.14 \\
85.68\end{array}$ \\
\hline 1926 & 3.11 & 39.05 & 5.90 & 51.56 & 5.82 & 51. 38 & 1961 & 21.35 & 81.22 & 10.54 & 85.66 & 23.68 & 82.33 \\
\hline $1927-$ & $\begin{array}{l}3.71 \\
4.24\end{array}$ & 39.46 & 5.68 & 52.83 & 5.93 & 48.22 & 1962 & & & & & & \\
\hline 1929 & $\begin{array}{l}4.24 \\
4.02\end{array}$ & $\begin{array}{l}30.08 \\
40.83\end{array}$ & 6.04 & 53.91 & $\begin{array}{l}.0 .02 \\
5.95\end{array}$ & 52.26 & 1963 & $\begin{array}{l}18.89 \\
21.58\end{array}$ & $\begin{array}{l}85.87 \\
86.87\end{array}$ & $\begin{array}{l}13.78 \\
13.76\end{array}$ & $\begin{array}{l}8.30 \\
89.02\end{array}$ & $\begin{array}{l}22.91 \\
22.18\end{array}$ & $\begin{array}{l}82.00 \\
81.98\end{array}$ \\
\hline 1930 & 5.41 & 37.93 & 6.65 & 52.76 & 6.00 & 47,24 & $\begin{array}{l}1964 \ldots \\
1965\end{array}$ & $\begin{array}{l}29.41 \\
32.24\end{array}$ & $\begin{array}{l}88.15 \\
85.76\end{array}$ & $\begin{array}{l}16.52 \\
16.88\end{array}$ & $\begin{array}{l}89.65 \\
87.91\end{array}$ & $\begin{array}{l}24.52 \\
27.41\end{array}$ & $\begin{array}{l}81.90 \\
81.74\end{array}$ \\
\hline & 5. 64 & 32.04 & & 54 & 7.55 & 45.18 & $1966 \ldots$ & 36.62 & 86.98 & 16. 34 & 88.17 & 32.30 & $\begin{array}{l}86.92 \\
86.92\end{array}$ \\
\hline 19 & 3.70 & 31.6 & & 50. & 6.97 & 39.70 & & & & & & & \\
\hline 1933. & 2.58 & & & 54.5 & 6.6 & 52.6 & $1967 \ldots$ & 30.49 & 89.73 & 18.28 & 87.04 & 31.99 & 86.60 \\
\hline 1934 & 2.84 & 41.77 & 5.33 & 53.08 & 6.27 & 56.00 & 1968 & 43.63 & 105.17 & 24.25 & 99.29 & 34.38 & 96.02 \\
\hline 1935. & 3. 01 & 38.69 & 4.79 & 49.42 & 9.11 & 44.18 & 1970 & $\begin{array}{l}56.43 \\
27.72\end{array}$ & $\begin{array}{r}110.99 \\
88.44\end{array}$ & $\begin{array}{l}54.89 \\
23.90\end{array}$ & $\begin{array}{r}120.98 \\
98.59\end{array}$ & $\begin{array}{l}40.55 \\
33.46\end{array}$ & $\begin{array}{r}102.29 \\
89.81\end{array}$ \\
\hline & 3. 69 & 42.42 & 4.3 & 52.40 & 10.23 & 49.83 & $1971 \ldots$ & 31.51 & 108.40 & 27.71 & 112.65 & 38. 32 & 101.73 \\
\hline 1937 & 2. 63 & 44.22 & 4. 07 & 55.14 & $9.9 \overline{5}$ & 49.86 & & & & & & & \\
\hline 1938 & 4.51 & 42.66 & 5.08 & 54.83 & 15. 05 & 46. 91 & $1972 \ldots$ & 43.99 & 121.74 & 45.47 & 127.63 & 46.06 & 110.15 \\
\hline 193 & 4. 04 & 45.03 & 4.97 & 57. 20 & 12.18 & 49. 53 & & & & & & & \\
\hline
\end{tabular}

Source: Row, Clark. Probabilities of flnancial returns from southern pine timber growing. Ph.D. dissertation. Tulane Univ., New Orleans. 1973. Data presented are based on information from the following sources: Douglas-fir stumpage, 1910-31 National Forest timber sales, all species Washington and Oregon; 1932-41, all species western Washington and western Oregon; 1947-56, National Forest and Bureau of I and Management sales, Douglas-fir only in western Washington and western Oregon; 1957-72 National Forest sales, Douglas-fir only in western Washington and western Oregon.

Southern pine stumpage, 1910-34 prices of privately owned second-growth southern pine timber; 1935-49 National Forest timber sales, all species; 1950-72 National Forest sales, pine only.

Ponderosa pine stumpage, 1910-72 National timber sales, California.

Lumber prices, Forest Service estimates based on data published by the Bureau of Labor Statistics, the western Wood Products Association, and unpublished information collected by the Forest Service's Division of Timber Management.

Note: All U.S. Forest Service National Forest prices in this table are the bid prices (including $\mathrm{KV}$ payments) for timber sold on a Scribner Decimal $\mathrm{C}$ log rule basis and adjusted, using a mathematical model developed by the author, to International 1/1-inch log rule units comparable to sawtimber removals. Prices exclude timber sold by land exchanges and from land utilization project lands. 
APPENDIX V. TIMBER DEMAND TABLES

TABLE 3.-Relative wholesale price index of lumber, 1800-1972 ${ }^{1}$

$[1967=100]$

\begin{tabular}{|c|c|c|c|c|c|c|c|c|c|c|c|}
\hline Year & $\begin{array}{c}\text { All } \\
\text { lumber }\end{array}$ & Year & $\begin{array}{c}\text { All } \\
\text { lumber }\end{array}$ & Year & $\begin{array}{c}\text { All } \\
\text { lumber }\end{array}$ & Year & $\begin{array}{c}\text { All } \\
\text { lumber }\end{array}$ & Year & $\begin{array}{c}\text { All } \\
\text { lumber }\end{array}$ & Year & $\stackrel{\text { All }}{\text { lumber }}$ \\
\hline $\begin{array}{l}1800 \ldots \ldots . \\
1801 \\
1802 \ldots \ldots . \\
1803 \ldots \ldots \\
1804 \ldots \ldots\end{array}$ & $\begin{array}{l}6.4 \\
6.6 \\
8.0 \\
6.8 \\
6.8\end{array}$ & $\begin{array}{l}1830 \ldots \ldots \\
1831 \ldots \ldots . \\
1532 \ldots \ldots \\
1533 \ldots \ldots \\
1534 \ldots \ldots\end{array}$ & $\begin{array}{l}11.2 \\
11.2 \\
11.1 \\
11.6 \\
12.8\end{array}$ & $\begin{array}{l}1860 \ldots \ldots \\
1861 \ldots \ldots \\
1862 \ldots \\
1863 \ldots \\
1864 \ldots\end{array}$ & $\begin{array}{l}20.5 \\
19.9 \\
18.2 \\
17.4 \\
17.4\end{array}$ & $\begin{array}{l}1890 \ldots \ldots \\
1891 \ldots \ldots \\
1892 \ldots . . \\
1893 \ldots \\
1894 \ldots\end{array}$ & $\begin{array}{l}30.2 \\
29.7 \\
30.9 \\
30.5 \\
33.7\end{array}$ & $\begin{array}{l}1920 \ldots \\
1921 \\
1922 \\
1923 \\
1924 \ldots\end{array}$ & $\begin{array}{l}53.8 \\
46.0 \\
51.6 \\
56.0 \\
51.0\end{array}$ & $\begin{array}{l}1950 \ldots \\
1951 \ldots \\
1952 \ldots \\
1953 \ldots \\
1954 \ldots\end{array}$ & $\begin{array}{l}105.9 \\
102.8 \\
103.0 \\
103.5 \\
101.6\end{array}$ \\
\hline $\begin{array}{l}1805 \ldots . . . \\
1806 \ldots . . . \\
1807 . \ldots . \\
1808 \ldots \ldots \\
1809 \ldots \ldots \\
\end{array}$ & $\begin{array}{l}7.0 \\
7.1 \\
7.6 \\
7.4 \\
7.0\end{array}$ & $\begin{array}{l}1835 \ldots \ldots \\
1836 \ldots \ldots \\
1837 \ldots \ldots \\
1838 \ldots \ldots \\
1839 \ldots \ldots\end{array}$ & $\begin{array}{l}11.3 \\
10.3 \\
14.7 \\
15.4 \\
11.6\end{array}$ & $\begin{array}{l}1865 \ldots \\
1866 \ldots \ldots \\
1867 \ldots \ldots \\
1868 \ldots \\
1869 \ldots\end{array}$ & $\begin{array}{l}16.2 \\
20.3 \\
21.6 \\
22.3 \\
21.8\end{array}$ & $\begin{array}{l}1895 \ldots \ldots \\
1896 \ldots \ldots \\
1897 \ldots \ldots \\
1898 \ldots \\
1899 \ldots \ldots\end{array}$ & $\begin{array}{l}31.5 \\
33.2 \\
32.2 \\
32.5 \\
33.3\end{array}$ & $\begin{array}{l}1925=- \\
1926=. \\
1927=- \\
1928=- \\
1929 .\end{array}$ & $\begin{array}{l}49.1 \\
48.7 \\
47.7 \\
45.4 \\
48.0\end{array}$ & $\begin{array}{l}1955-\ldots \\
1956-- \\
1957- \\
1958- \\
1959-\end{array}$ & $\begin{array}{r}107.5 \\
106.4 \\
97.4 \\
94.5 \\
101.7\end{array}$ \\
\hline $\begin{array}{l}1810 \ldots \ldots . \\
1811 \ldots \ldots . \\
1812 \ldots \ldots \\
1813 \ldots \ldots \\
1814 \ldots \ldots\end{array}$ & $\begin{array}{l}6.5 \\
6.5 \\
6.1 \\
5.5 \\
4.7\end{array}$ & $\begin{array}{l}1840 \ldots \ldots \\
1841 \ldots \ldots . \\
1842 \ldots \ldots \ldots \\
1843 \ldots \ldots \\
1844 \ldots \ldots\end{array}$ & $\begin{array}{l}16.1 \\
16.7 \\
16.5 \\
16.2 \\
17.0\end{array}$ & $\begin{array}{l}1870 \ldots \ldots \\
1871 \ldots \ldots \\
1872 \ldots \ldots \\
1873 \ldots \ldots \\
1874 \ldots\end{array}$ & $\begin{array}{l}22.3 \\
23.6 \\
24.0 \\
24.4 \\
24.1\end{array}$ & $\begin{array}{l}1900 \ldots \\
1901 . . \\
1902-. \\
1903 . . \\
1904 . .\end{array}$ & $\begin{array}{l}34.4 \\
35.0 \\
34.3 \\
36.3 \\
33.9\end{array}$ & $\begin{array}{l}1930 \ldots \\
1931 \ldots \\
1932 \ldots \\
1933 \ldots \\
1934 \ldots\end{array}$ & $\begin{array}{l}48.2 \\
46.6 \\
43.9 \\
52.3 \\
54.9\end{array}$ & $\begin{array}{l}1960 \ldots \\
1961 \ldots \\
1962-. \\
1963 \ldots \\
1964 \ldots\end{array}$ & $\begin{array}{l}97.0 \\
92.4 \\
93.8 \\
96.5 \\
98.0\end{array}$ \\
\hline $\begin{array}{l}1815 \ldots \ldots \\
1816 \ldots \ldots \\
1817 \ldots \ldots . . \\
1818 \ldots \ldots \\
1819 \ldots \ldots\end{array}$ & $\begin{array}{l}8.2 \\
9.1 \\
\text { 8. } 0 \\
7.5 \\
8.6\end{array}$ & $\begin{array}{l}1845 \ldots \ldots . \\
1846 \\
1547 \ldots \ldots \\
1845 \ldots \ldots \\
1849 \ldots \ldots\end{array}$ & $\begin{array}{l}18.8 \\
17.7 \\
17.1 \\
17.9 \\
18.1\end{array}$ & $\begin{array}{l}1875 \ldots \ldots \\
1876 \ldots \ldots \\
1877 \ldots \ldots \\
1878 \ldots \ldots \\
1879 \ldots \ldots\end{array}$ & $\begin{array}{l}23.0 \\
23.6 \\
23.8 \\
23.8 \\
25.5\end{array}$ & $\begin{array}{l}1905 \ldots \\
1906 \ldots \\
1907 \ldots \ldots \\
1908 \ldots . . \\
1909 \ldots\end{array}$ & $\begin{array}{l}36.0 \\
42.6 \\
40.6 \\
38.9 \\
36.2\end{array}$ & $\begin{array}{l}1935 \ldots \\
1936 \ldots . . \\
1937 \ldots \\
1938 \ldots \\
1939 \ldots\end{array}$ & $\begin{array}{l}49.8 \\
52.4 \\
56.4 \\
54.1 \\
58.9\end{array}$ & $\begin{array}{l}1965 \ldots \\
1966 \ldots \\
1967 \ldots \\
1968 \ldots \\
1969 \ldots\end{array}$ & $\begin{array}{r}97.3 \\
100.3 \\
100.0 \\
114.5 \\
123.5\end{array}$ \\
\hline $\begin{array}{l}1820 \ldots \ldots \\
1821 \ldots \ldots \ldots \\
1822 \ldots \ldots \ldots \\
1823 \ldots \ldots \\
1524 \ldots \ldots\end{array}$ & $\begin{array}{l}9.6 \\
9.5 \\
9.0 \\
9.7 \\
9.8\end{array}$ & $\begin{array}{l}1850 \ldots \ldots \\
1851 \ldots \ldots \\
1852 \ldots \ldots \\
1853 \ldots \ldots \\
1854 \ldots \ldots\end{array}$ & $\begin{array}{l}19.0 \\
18.3 \\
20.1 \\
19.4 \\
19.0\end{array}$ & $\begin{array}{l}1880 \ldots \ldots \\
1881 \ldots \ldots \\
1882 \ldots \ldots \\
1583 \ldots \ldots \\
1884 \ldots\end{array}$ & $\begin{array}{l}24.8 \\
26.6 \\
27.0 \\
26.8 \\
28.7\end{array}$ & $\begin{array}{l}1910 \ldots \ldots \\
1911 \ldots . . \\
1912 \ldots \ldots \\
1913 \ldots \ldots \\
1914 \ldots . .\end{array}$ & $\begin{array}{l}34.4 \\
36.9 \\
37.3 \\
38.9 \\
37.0\end{array}$ & $\begin{array}{l}1940 \ldots \ldots \\
1941 \ldots \ldots \\
1942 \ldots \ldots \\
1943 \ldots \ldots \\
1944 \ldots\end{array}$ & $\begin{array}{l}63.7 \\
68.4 \\
65.6 \\
66.6 \\
71.7\end{array}$ & $\begin{array}{l}1970 \ldots \\
1971 \ldots \\
1972 \ldots\end{array}$ & $\begin{array}{l}103.0 \\
119.0 \\
133.8\end{array}$ \\
\hline $\begin{array}{l}1825 \ldots . . . \\
1826 \\
1827 \\
1828 \ldots . . . . . . . . \\
1829\end{array}$ & $\begin{array}{l}10.2 \\
10.9 \\
11.0 \\
11.5 \\
11.4\end{array}$ & $\begin{array}{l}1855 \ldots \ldots \\
1856 \ldots \ldots \\
1857 \\
1858 \ldots \ldots \\
1859 \ldots \ldots\end{array}$ & $\begin{array}{l}20.0 \\
20.5 \\
21.1 \\
21.0 \\
20.5\end{array}$ & $\begin{array}{l}188.5 \ldots \\
1886 \\
1887 \\
188 . \\
1889 \ldots \\
188 .\end{array}$ & $\begin{array}{l}29 . \\
30.3 \\
30.4 \\
29.6 \\
29.6\end{array}$ & $\begin{array}{l}1915 \ldots \\
1916 \ldots \\
1917 \ldots . . \\
1918 \ldots \\
1919 \ldots\end{array}$ & $\begin{array}{l}35.3 \\
32.4 \\
30.9 \\
32.1 \\
41.1\end{array}$ & $\begin{array}{l}1945 \ldots \ldots \\
1946 \ldots \ldots \\
1947 \\
1948 \ldots \\
1949 \ldots\end{array}$ & $\begin{array}{l}71.3 \\
71.8 \\
93.3 \\
97.9 \\
94.3\end{array}$ & & \\
\hline
\end{tabular}

1 Derived by dividing the actual price index by the all commodities price index.

Sources: 1800-1911-Cornell University Agricultural Experiment Station.
Wholesale prices for 213 years, 1720 to 1932. Miemoir 142, 1932, Part I, table 49 pp. 107-119.

1915-1972-U.S. Department of Labor, Bureau of Labor Statistics. Wholesale prices and price indexes. Monthly. 
TABLE 4.-Wholesale price indexes of selected timber products and competing materials, 1926-1972

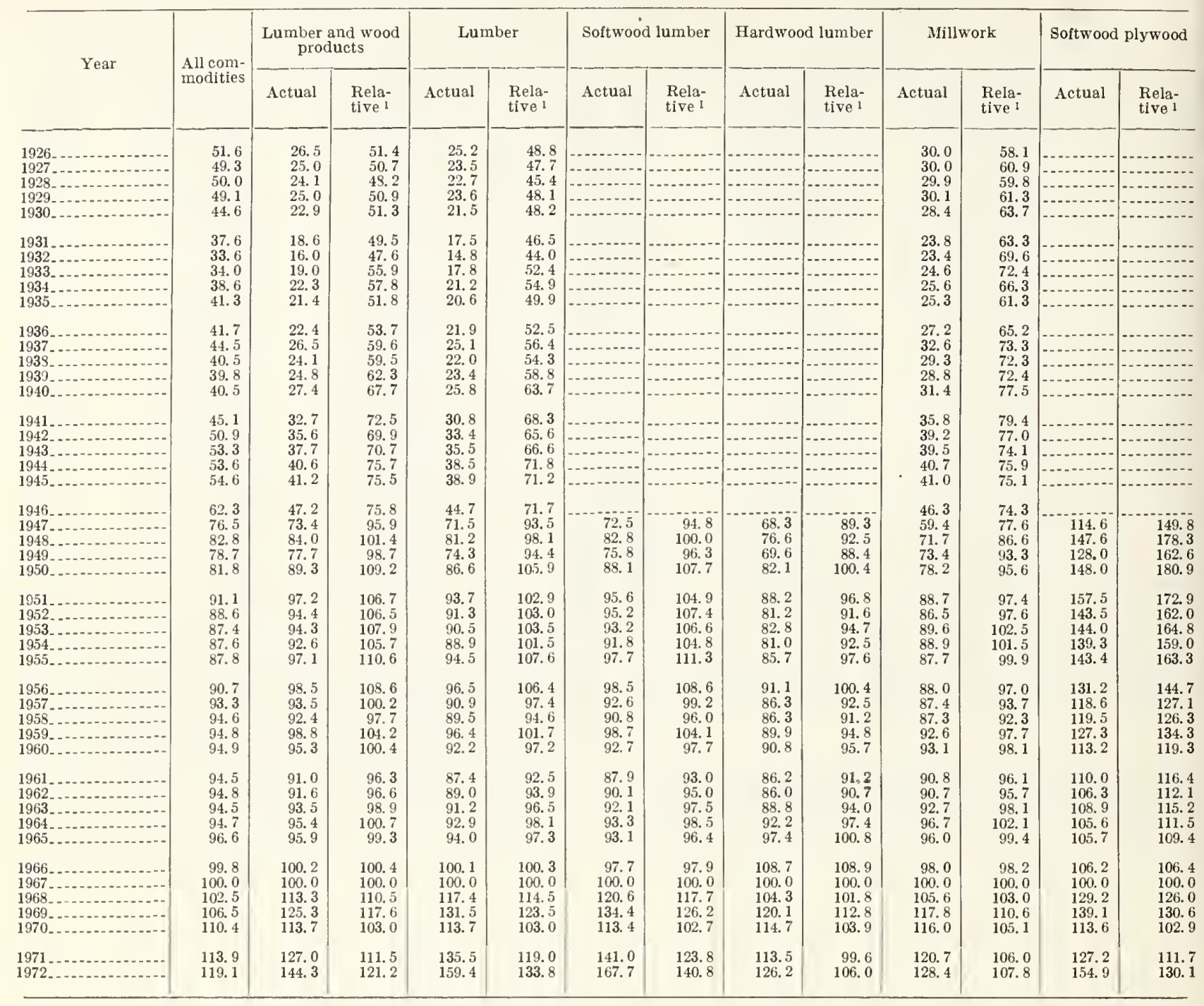

See footnotes at end of table. 
TABLE 4.-Wholesale price indexes of selected timber products and competing materials, 1926-1972-Continued

[1967 $=100]$

\begin{tabular}{|c|c|c|c|c|c|c|c|c|c|c|c|c|c|c|}
\hline \multirow{2}{*}{ Year } & \multicolumn{2}{|c|}{$\begin{array}{l}\text { Metals and metal } \\
\text { products }\end{array}$} & \multicolumn{2}{|c|}{ Structural shapes } & \multicolumn{2}{|c|}{$\begin{array}{l}\text { Metal doors, sash } \\
\text { and trim }\end{array}$} & \multicolumn{2}{|c|}{$\begin{array}{l}\text { Aluminum siding } \\
\text { noninsulated }\end{array}$} & \multicolumn{2}{|c|}{$\begin{array}{l}\text { Galvanized car- } \\
\text { bon steel sheets }\end{array}$} & \multicolumn{2}{|c|}{ Flat glass } & \multicolumn{2}{|c|}{ Concrete products } \\
\hline & Actual & $\begin{array}{l}\text { Rela- } \\
\text { tive I }\end{array}$ & Actual & $\begin{array}{l}\text { Rela- } \\
\text { tive 1 }\end{array}$ & Actual & $\begin{array}{l}\text { Rela- } \\
\text { tive } 1\end{array}$ & Actual & $\begin{array}{l}\text { Rela- } \\
\text { tive 1 }\end{array}$ & Actual & $\begin{array}{l}\text { Rela- } \\
\text { tive } 1\end{array}$ & Actual & $\begin{array}{l}\text { Rela- } \\
\text { tive } 1\end{array}$ & Actual & $\begin{array}{l}\text { Rela- } \\
\text { tive } 1\end{array}$ \\
\hline $\begin{array}{l}1926 \ldots \ldots \\
1927 \ldots \ldots \\
1928 \ldots \ldots \\
1929 \ldots \ldots \\
1930 \ldots \ldots\end{array}$ & $\begin{array}{l}41.4 \\
38.8 \\
38.8 \\
40.2 \\
36.2\end{array}$ & $\begin{array}{l}80.2 \\
78.7 \\
77.6 \\
81.9 \\
81.2\end{array}$ & $\mid$\begin{tabular}{|c|}
$\ldots \ldots$ \\
\end{tabular} & $\left|\begin{array}{l} \\
-2\end{array}\right|$ & $\mid$\begin{tabular}{|c|}
$-\ldots \ldots$ \\
$-\ldots$
\end{tabular} & (1. & $\left.\mid \begin{array}{|c|} \\
-\end{array}\right)$ & $\left|\begin{array}{|l|l|} & 0 \\
\end{array}\right|$ & (2. & 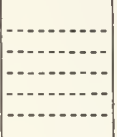 & 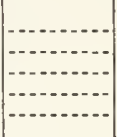 & 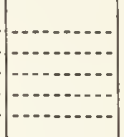 & $\begin{array}{l}70.5 \\
70.5 \\
70.5 \\
69.4 \\
70.4\end{array}$ & $\begin{array}{l}136.6 \\
143.0 \\
141.0 \\
141.3 \\
157.8\end{array}$ \\
\hline $\begin{array}{l}1931 \ldots \ldots \\
1932 \ldots \ldots \\
1933 \ldots \ldots \\
1934 \ldots \ldots \\
1935 \ldots \ldots\end{array}$ & $\begin{array}{l}32.6 \\
29.9 \\
30.7 \\
33.9 \\
33.8\end{array}$ & $\begin{array}{l}86.7 \\
89.0 \\
90.3 \\
87.8 \\
81.8\end{array}$ & 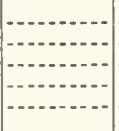 & 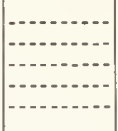 & $\mid$\begin{tabular}{l}
-1 \\
\hdashline-1.2
\end{tabular} & 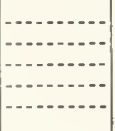 & $\left|\begin{array}{|c|} \\
\hdashline-1\end{array}\right|$ & 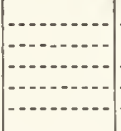 & 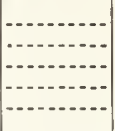 & 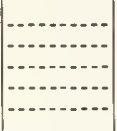 & 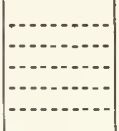 & 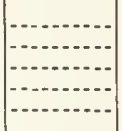 & $\begin{array}{l}66.3 \\
61.2 \\
62.1 \\
62.1 \\
56.7\end{array}$ & $\begin{array}{l}176.3 \\
182.1 \\
182.6 \\
160.9 \\
137.3\end{array}$ \\
\hline \begin{tabular}{|l|}
$1936 \ldots \ldots$ \\
$1937 \ldots \ldots$ \\
$1938 \ldots \ldots$ \\
$1939 \ldots \ldots$ \\
$1940 \ldots \ldots$
\end{tabular} & $\begin{array}{l}34.5 \\
39.4 \\
38.0 \\
37.6 \\
37.8\end{array}$ & $\begin{array}{l}82.7 \\
88.5 \\
93.8 \\
94.5 \\
93.3\end{array}$ & 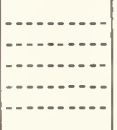 & $\begin{array}{l}-. \\
- \\
-- \\
-- \\
--\end{array}$ & $\left|\begin{array}{|c|}\ldots \ldots \\
\hdashline\end{array}\right|$ & 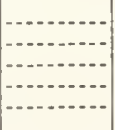 & \begin{tabular}{|l|} 
\\
$\cdots$ \\
$\cdots$
\end{tabular} & . & $\mid$ & & 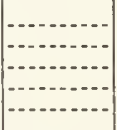 & $\mid \begin{array}{l}-- \\
-- \\
-- \\
--\end{array}$ & $\begin{array}{l}60.3 \\
60.6 \\
55.6 \\
55.4 \\
49.3\end{array}$ & $\begin{array}{l}144.6 \\
136.2 \\
137.3 \\
139.2 \\
121.7\end{array}$ \\
\hline $\begin{array}{l}1941 \ldots \ldots \\
1942 \ldots \ldots \\
1943 \ldots \ldots \\
1944 \ldots \ldots \\
1945 \ldots \ldots\end{array}$ & $\begin{array}{l}38.5 \\
39.1 \\
40.0 \\
40.0 \\
39.6\end{array}$ & $\begin{array}{l}85.4 \\
76.8 \\
75.0 \\
74.6 \\
72.5\end{array}$ & 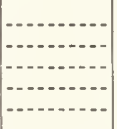 & $\begin{array}{l}-- \\
- \\
- \\
- \\
-\end{array}$ & (n..... & $\mid$\begin{tabular}{|c|}
$\ldots \ldots$ \\
\hdashline
\end{tabular} & $\left|\begin{array}{|l|} \\
-2 \ldots\end{array}\right|$ & $\mid$\begin{tabular}{l}
-- \\
\hdashline- \\
\hdashline- \\
\hdashline-
\end{tabular} & 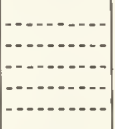 & $\left|\begin{array}{|c|}\mid \\
\hdashline \ldots \ldots .\end{array}\right|$ & & 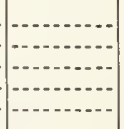 & $\begin{array}{l}57.3 \\
59.2 \\
59.2 \\
59.2 \\
59.2\end{array}$ & $\begin{array}{l}127.1 \\
116.3 \\
111.1 \\
110.4 \\
108.4\end{array}$ \\
\hline $\begin{array}{l}1946 \ldots \ldots \\
1947 \ldots \ldots \\
1948 \ldots \ldots \\
1949 \ldots \ldots \\
1950 \ldots \ldots\end{array}$ & $\begin{array}{l}44.3 \\
54.9 \\
62.5 \\
63.0 \\
66.3\end{array}$ & $\begin{array}{l}71.1 \\
71.8 \\
75.5 \\
80.1 \\
81.1\end{array}$ & $\begin{array}{l}39.5 \\
48.1 \\
52.8 \\
56.6\end{array}$ & $\begin{array}{l}51.6 \\
58.1 \\
67.1 \\
69.2\end{array}$ & $\begin{array}{l}71.9 \\
75.1 \\
76.7 \\
82.0\end{array}$ & $\begin{array}{r}94.0 \\
90.7 \\
97.5 \\
100.2\end{array}$ & 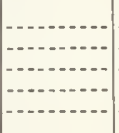 & 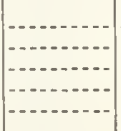 & $\begin{array}{l}51.6 \\
58.4 \\
61.0 \\
67.9\end{array}$ & $\begin{array}{l}67.5 \\
70.5 \\
77.5 \\
83.0\end{array}$ & $\begin{array}{l}66.8 \\
70.4 \\
73.9 \\
75.6\end{array}$ & $\begin{array}{l}87.3 \\
85.0 \\
93.9 \\
92.4\end{array}$ & $\begin{array}{l}62.7 \\
71.3 \\
74.7 \\
96.4 \\
78.2\end{array}$ & $\begin{array}{r}100.6 \\
93.2 \\
90.2 \\
97.1 \\
95.6\end{array}$ \\
\hline $\begin{array}{l}1951 \ldots \ldots \\
1952 \ldots \ldots \\
1953 \ldots \ldots \\
1954 \ldots \ldots \\
1955 \ldots \ldots\end{array}$ & $\begin{array}{l}73.8 \\
73.9 \\
76.3 \\
76.9 \\
82.1\end{array}$ & $\begin{array}{l}81.0 \\
83.4 \\
87.3 \\
87.8 \\
93.5\end{array}$ & $\begin{array}{l}60.0 \\
61.3 \\
64.7 \\
67.3 \\
71.0\end{array}$ & $\begin{array}{l}65.9 \\
69.2 \\
74.0 \\
76.8 \\
80.9\end{array}$ & $\begin{array}{r}90.1 \\
87.8 \\
91.4 \\
96.5 \\
103.9\end{array}$ & $\begin{array}{r}98.9 \\
99.1 \\
104.6 \\
110.2 \\
118.3\end{array}$ & 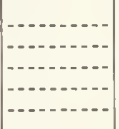 & 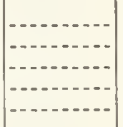 & $\begin{array}{l}75.2 \\
75.1 \\
73.3 \\
74.7 \\
79.0\end{array}$ & $\begin{array}{l}82.5 \\
84.8 \\
83.9 \\
85.3 \\
90.0\end{array}$ & $\begin{array}{l}80.3 \\
80.5 \\
85.0 \\
87.6 \\
90.1\end{array}$ & $\begin{array}{r}88.1 \\
90.9 \\
97.3 \\
100.0 \\
102.6\end{array}$ & $\begin{array}{l}83.3 \\
83.4 \\
85.5 \\
87.1 \\
88.0\end{array}$ & $\begin{array}{r}91.4 \\
94.1 \\
97.8 \\
99.4 \\
100.2\end{array}$ \\
\hline $\begin{array}{l}1956 \ldots \ldots \\
1957 \ldots \ldots \\
1958 \ldots \ldots \\
1959 \ldots \ldots \\
1960 \ldots \ldots\end{array}$ & $\begin{array}{l}89.2 \\
91.0 \\
90.4 \\
92.3 \\
92.4\end{array}$ & $\begin{array}{l}98.3 \\
97.5 \\
95.6 \\
97.4 \\
97.4\end{array}$ & $\begin{array}{l}76.2 \\
87.7 \\
91.4 \\
93.4 \\
93.4\end{array}$ & $\begin{array}{l}84.0 \\
94.0 \\
96.6 \\
98.5 \\
98.4\end{array}$ & $\begin{array}{r}108.5 \\
104.8 \\
105.7 \\
100.7 \\
98.9\end{array}$ & $\begin{array}{l}119.6 \\
112.3 \\
111.7 \\
106.2 \\
104.2\end{array}$ & 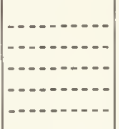 & 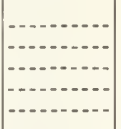 & $\begin{array}{l}84.5 \\
86.9 \\
89.2 \\
91.8 \\
93.0\end{array}$ & $\begin{array}{l}93.2 \\
93.1 \\
94.3 \\
96.8 \\
98.0\end{array}$ & $\begin{array}{l}93.9 \\
95.5 \\
95.3 \\
95.2 \\
93.3\end{array}$ & $\begin{array}{r}103.5 \\
102.4 \\
100.7 \\
100.4 \\
98.3\end{array}$ & $\begin{array}{l}91.1 \\
93.6 \\
94.9 \\
96.1 \\
97.2\end{array}$ & $\begin{array}{l}100.4 \\
100.3 \\
100.3 \\
101.4 \\
102.4\end{array}$ \\
\hline $\begin{array}{l}1961 \ldots \ldots \\
1962 \ldots \ldots \\
1963 \ldots \ldots \\
1964 \ldots \\
1965 \ldots\end{array}$ & $\begin{array}{l}91.9 \\
91.2 \\
91.3 \\
93.8 \\
96.4\end{array}$ & $\begin{array}{l}97.2 \\
96.2 \\
96.6 \\
99.0 \\
99.8\end{array}$ & $\begin{array}{l}93.4 \\
93.4 \\
94.1 \\
96.2 \\
96.2\end{array}$ & $\begin{array}{r}98.8 \\
98.5 \\
99.5 \\
101.6 \\
99.6\end{array}$ & $\begin{array}{l}98.4 \\
97.9 \\
95.5 \\
96.0 \\
95.4\end{array}$ & $\begin{array}{r}104.1 \\
103.3 \\
101.1 \\
101.4 \\
98.8\end{array}$ & $\begin{array}{r}108.7 \\
102.2 \\
98.9 \\
100.1 \\
98.2\end{array}$ & $\begin{array}{l}115.0 \\
107.8 \\
104.7 \\
105.7 \\
101.7\end{array}$ & $\begin{array}{r}93.0 \\
93.0 \\
95.6 \\
96.8 \\
100.0\end{array}$ & $\begin{array}{r}98.4 \\
98.1 \\
101.2 \\
102.2 \\
103.5\end{array}$ & $\begin{array}{l}92.3 \\
92.5 \\
93.7 \\
97.6 \\
96.2\end{array}$ & $\begin{array}{r}97.7 \\
97.6 \\
99.2 \\
103.1 \\
99.6\end{array}$ & $\begin{array}{l}97.2 \\
97.3 \\
96.5 \\
95.7 \\
96.3\end{array}$ & $\begin{array}{r}102.9 \\
102.6 \\
102.1 \\
101.1 \\
99.7\end{array}$ \\
\hline $\begin{array}{l}1966 \ldots \ldots \\
1967 \ldots \ldots \\
1968 \ldots \ldots \\
1969 \ldots \ldots \\
1970 \ldots \ldots\end{array}$ & $\begin{array}{r}98.8 \\
100.0 \\
102.6 \\
108.5 \\
116.7\end{array}$ & $\begin{array}{r}99.0 \\
100.0 \\
100.1 \\
101.9 \\
105.7\end{array}$ & $\begin{array}{r}99.9 \\
100.0 \\
101.8 \\
108.1 \\
115.3\end{array}$ & $\begin{array}{r}100.1 \\
100.0 \\
99.3 \\
101.5 \\
104.4\end{array}$ & $\begin{array}{r}95.9 \\
100.0 \\
103.9 \\
108.4 \\
112.9\end{array}$ & $\begin{array}{r}96.1 \\
100.0 \\
101.4 \\
101.8 \\
102.3\end{array}$ & $\begin{array}{l}102.4 \\
100.0 \\
100.3 \\
100.9 \\
104.6\end{array}$ & $\begin{array}{r}102.6 \\
100.0 \\
97.9 \\
94.7 \\
94.7\end{array}$ & $\begin{array}{l}100.0 \\
100.0 \\
102.7 \\
105.7 \\
109.7\end{array}$ & $\begin{array}{r}100.2 \\
100.0 \\
100.2 \\
99.2 \\
99.4\end{array}$ & $\begin{array}{r}96.0 \\
100.0 \\
104.4 \\
109.2 \\
115.5\end{array}$ & $\begin{array}{r}96.2 \\
100.0 \\
101.9 \\
102.5 \\
104.6\end{array}$ & $\begin{array}{r}97.7 \\
100.0 \\
102.6 \\
106.5 \\
112.2\end{array}$ & $\begin{array}{r}97.9 \\
100.0 \\
100.1 \\
100.0 \\
101.6\end{array}$ \\
\hline $1971 \ldots . .$. & $\begin{array}{l}119.0 \\
123.5\end{array}$ & $\begin{array}{l}104.5 \\
103.7\end{array}$ & $\begin{array}{l}126.8 \\
134.6\end{array}$ & $\begin{array}{l}111.3 \\
113.0\end{array}$ & $\begin{array}{l}118.0 \\
120.5\end{array}$ & $\begin{array}{l}103.6 \\
101.2\end{array}$ & $\begin{array}{l}105.2 \\
105.8\end{array}$ & $\begin{array}{l}92.4 \\
88.8\end{array}$ & $\begin{array}{l}114.9 \\
122.1\end{array}$ & $\begin{array}{l}100.9 \\
102.5\end{array}$ & $\begin{array}{l}123.9 \\
122.4\end{array}$ & $\begin{array}{l}108.8 \\
102.8\end{array}$ & $\begin{array}{l}120.6 \\
125.6\end{array}$ & $\begin{array}{l}105.9 \\
105.5\end{array}$ \\
\hline
\end{tabular}

1 Relative wholesale price indexes obtained by dividing the actual price index by the all commodity wholesale price index.

Source: U.S. Department of Labor, Bureau of Labor Statistics, Wholesale prices and price indexes. Monthly. 
APPENDIX V. TLIBER DEMAND TABLES

TABLE 4.- Wholesale price indexes of selected timber products and competing materials, 1926-1972-Continued

$[1967=100]$

\begin{tabular}{|c|c|c|c|c|c|c|c|c|c|c|c|c|c|c|}
\hline \multirow{2}{*}{ Tear } & \multicolumn{2}{|c|}{ Building brick } & \multicolumn{2}{|c|}{ Clay tile } & \multicolumn{2}{|c|}{$\begin{array}{l}\text { Prepared asphalt } \\
\text { roofing }\end{array}$} & \multicolumn{2}{|c|}{ Paper } & \multicolumn{2}{|c|}{ Gypsum products } & \multicolumn{2}{|c|}{$\begin{array}{l}\text { Asbestos cement } \\
\text { shingles, siding } \\
\text { shingles }\end{array}$} & \multicolumn{2}{|c|}{$\begin{array}{l}\text { Hard surface } \\
\text { floor coverings }\end{array}$} \\
\hline & Actual & Relative 1 & Actual & Relatire 1 & Actual & Relative 1 & Actual & Relative b & Actual & Relative 1 & Actual & Relative ${ }^{1}$ & Actual & Relative 1 \\
\hline $\begin{array}{l}1926 \ldots \\
1927 \ldots \\
1925 \ldots \\
1929 \ldots \\
1930 \ldots\end{array}$ & $\begin{array}{l}\ldots \ldots \\
\ldots \ldots \\
\ldots \ldots \\
\ldots\end{array}$ & 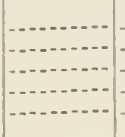 & , & 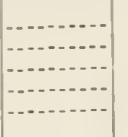 & $\begin{array}{l}83.5 \\
78.8 \\
70.6 \\
62.2 \\
63.7\end{array}$ & $\begin{array}{l}161.8 \\
159.8 \\
141.2 \\
126.7 \\
142.8\end{array}$ & $\begin{array}{l}45.0 \\
41.1 \\
40.7 \\
40.0 \\
39.9\end{array}$ & $\begin{array}{l}87.2 \\
83.4 \\
81.4 \\
81.5 \\
89.5\end{array}$ & $\mid$\begin{tabular}{|c|}
$\mid \ldots \ldots$ \\
\hdashline
\end{tabular} & $\left|\begin{array}{|c|} \\
\end{array}\right|$ & 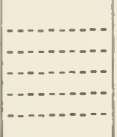 & - & 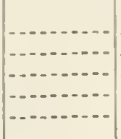 & 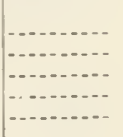 \\
\hline $\begin{array}{l}1931 \ldots \\
1932 \ldots \\
1933 \ldots \\
1931 \ldots \\
1935 \ldots\end{array}$ & 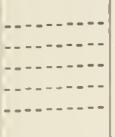 & $\left|\begin{array}{|c|}\ldots \ldots \\
\hdashline\end{array}\right|$ & $\mid \begin{array}{c} \\
\end{array}$ & 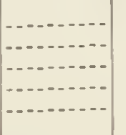 & $\begin{array}{l}66.0 \\
60.4 \\
61.9 \\
66.7 \\
69.9\end{array}$ & $\begin{array}{l}175.5 \\
179.8 \\
132.1 \\
172.8 \\
169.2\end{array}$ & $\begin{array}{l}38.6 \\
36.2 \\
34.5 \\
36.0 \\
36.2\end{array}$ & $\begin{array}{r}102.7 \\
107.7 \\
101.5 \\
93.3 \\
87.7\end{array}$ & 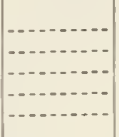 & 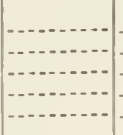 & \begin{tabular}{|c|}
$\ldots \ldots$ \\
\end{tabular} & 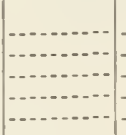 & 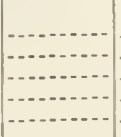 & 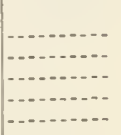 \\
\hline $\begin{array}{l}1936 \ldots . . . \\
1937 \ldots \ldots \\
1933 \ldots \ldots \\
1933 \ldots \ldots \\
1910 \ldots \ldots\end{array}$ & 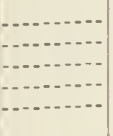 & $\begin{array}{l}\ldots . \\
\cdots \\
\cdots \\
\cdots- \\
\cdots\end{array}$ & $\mid \begin{array}{l}0 \\
\end{array}$ & $\left.\mid \begin{array}{l} \\
\hdashline\end{array}\right]$ & $\begin{array}{l}68.9 \\
75.3 \\
60.9 \\
63.0 \\
68.7\end{array}$ & $\begin{array}{l}165.2 \\
169.2 \\
150.4 \\
158.3 \\
169.6\end{array}$ & $\begin{array}{l}36.4 \\
33.6 \\
39.4 \\
38.5 \\
40.3\end{array}$ & $\begin{array}{l}87.3 \\
86.7 \\
97.3 \\
96.7 \\
99.5\end{array}$ & ( & 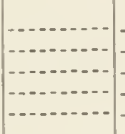 & 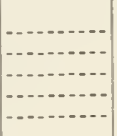 & 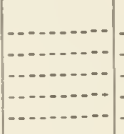 & 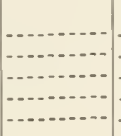 & | \\
\hline $\begin{array}{l}1941 \ldots \ldots \\
1942 \ldots \ldots \\
1943 \ldots \ldots \\
1944 \ldots \ldots \\
1945 \ldots \ldots\end{array}$ & 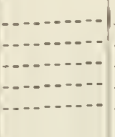 & 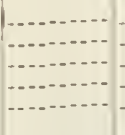 & ( & 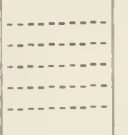 & $\begin{array}{l}70.9 \\
69.1 \\
69.0 \\
69.7 \\
71.0\end{array}$ & $\begin{array}{l}157.2 \\
135.8 \\
129.5 \\
130.3 \\
130.0\end{array}$ & $\begin{array}{l}42.3 \\
43.4 \\
44.5 \\
45.5 \\
45.9\end{array}$ & $\begin{array}{l}93.8 \\
85.3 \\
83.5 \\
81.9 \\
81.1\end{array}$ & $\left.\mid \begin{array}{|c|} \\
\hdashline \\
\end{array}\right]$ & $\left|\begin{array}{|c|} \\
\end{array}\right|$ & & & & $\left|\begin{array}{l}\mid \\
\ldots\end{array}\right|$ \\
\hline $\begin{array}{l}1946 \ldots . . . \\
1947 \ldots \ldots \\
1945 \ldots \ldots \\
1949 \ldots \ldots \\
1950 \ldots \ldots\end{array}$ & $\begin{array}{l}53.9 \\
66.1 \\
69.0 \\
71.5\end{array}$ & $\begin{array}{l}79.5 \\
87.7 \\
87.4\end{array}$ & $\begin{array}{l}69.2 \\
74.2 \\
76.6\end{array}$ & $\begin{array}{l}90.5 \\
\$ 7.2 \\
94.2 \\
93.6\end{array}$ & $\begin{array}{l}74.3 \\
84.7 \\
92.8 \\
92.6 \\
91.2\end{array}$ & $\begin{array}{l}119.3 \\
110.7 \\
112.1 \\
117.7 \\
111.5\end{array}$ & $\begin{array}{l}50.2 \\
59.5 \\
65.5 \\
66.3 \\
67.9\end{array}$ & $\begin{array}{l}80.6 \\
77.8 \\
79.1 \\
84.2 \\
83.0\end{array}$ & $\begin{array}{l}70.3 \\
76.8 \\
76.1 \\
77.8\end{array}$ & $\begin{array}{l}91.9 \\
92.8 \\
96.7 \\
95.1\end{array}$ & $\begin{array}{l}47.2 \\
53.6 \\
55.7 \\
58.2\end{array}$ & $\begin{array}{l}61.7 \\
64.7 \\
70.8 \\
71.1\end{array}$ & $\begin{array}{l}81.3 \\
82.5 \\
79.9 \\
78.1\end{array}$ & $\begin{array}{r}106.3 \\
99.6 \\
101.5 \\
95.5\end{array}$ \\
\hline $\begin{array}{l}1951 \ldots \ldots \\
1952 \ldots \ldots \\
1953 \ldots \ldots \\
1954 \ldots \ldots \\
1955 \ldots \ldots\end{array}$ & $\begin{array}{l}76.2 \\
75.9 \\
77.1 \\
78.1 \\
81.0\end{array}$ & $\begin{array}{r}83.6 \\
85.7 \\
85.2 \\
89.2 \\
92.3\end{array}$ & $\begin{array}{l}82.5 \\
82.6 \\
83.8 \\
85.6 \\
85.2\end{array}$ & $\begin{array}{r}90.6 \\
93.2 \\
95.9 \\
97.7 \\
100.5\end{array}$ & $\begin{array}{l}94.4 \\
92.6 \\
96.6 \\
93.7 \\
95.5\end{array}$ & $\begin{array}{l}103.6 \\
104.5 \\
110.5 \\
107.0 \\
108.8\end{array}$ & $\begin{array}{l}76.0 \\
79.1 \\
80.1 \\
80.8 \\
82.8\end{array}$ & $\begin{array}{l}83.4 \\
89.3 \\
91.6 \\
92.2 \\
94.3\end{array}$ & $\begin{array}{l}87.4 \\
87.5 \\
90.1 \\
90.9 \\
90.9\end{array}$ & $\begin{array}{r}95.9 \\
98.8 \\
103.1 \\
103.8 \\
103.5\end{array}$ & $\begin{array}{l}60.8 \\
61.7 \\
65.3 \\
68.2 \\
71.6\end{array}$ & $\begin{array}{l}66.7 \\
69.6 \\
74.7 \\
77.9 \\
81.5\end{array}$ & $\begin{array}{l}83.4 \\
86.9 \\
89.4 \\
91.8 \\
93.9\end{array}$ & $\begin{array}{r}91.5 \\
98.1 \\
102.3 \\
104.8 \\
106.9\end{array}$ \\
\hline $\begin{array}{l}1956 \ldots . . . \\
1957 \ldots \ldots \\
1955 \ldots \ldots \\
1959 \ldots \ldots \\
1960 \ldots \ldots\end{array}$ & $\begin{array}{l}55.9 \\
81.0 \\
87.7 \\
89.9 \\
91.3\end{array}$ & $\begin{array}{l}94.7 \\
93.2 \\
92.7 \\
94.8 \\
96.2\end{array}$ & $\begin{array}{l}91.4 \\
91.6 \\
92.4 \\
93.9 \\
95.7\end{array}$ & $\begin{array}{r}100.8 \\
98.2 \\
97.7 \\
93.1 \\
100.8\end{array}$ & $\begin{array}{r}100.5 \\
110.1 \\
101.6 \\
104.9 \\
96.6\end{array}$ & $\begin{array}{l}110.8 \\
118.0 \\
107.4 \\
110 . \frac{4}{7} \\
101.8\end{array}$ & $\begin{array}{l}87.6 \\
90.5 \\
90.7 \\
91.5 \\
92.7\end{array}$ & $\begin{array}{l}96.6 \\
97.0 \\
95.9 \\
96.5 \\
97.7\end{array}$ & $\begin{array}{l}94.6 \\
94.6 \\
98.2 \\
99.0 \\
99.1\end{array}$ & $\begin{array}{l}104.3 \\
101.4 \\
103.8 \\
104.4 \\
104.4\end{array}$ & $\begin{array}{l}77.2 \\
81.3 \\
84.6 \\
87.4 \\
91.6\end{array}$ & $\begin{array}{l}85.1 \\
87.1 \\
89.4 \\
92.2 \\
96.5\end{array}$ & $\begin{array}{l}98.9 \\
99.6 \\
98.3 \\
98.2 \\
99.9\end{array}$ & $\begin{array}{l}109.0 \\
106.8 \\
103.9 \\
103.6 \\
105.3\end{array}$ \\
\hline $\begin{array}{l}1961 \ldots \ldots \\
1962 \ldots \ldots \\
1963 \ldots \ldots \\
1961 \ldots \ldots \\
1965 \ldots\end{array}$ & $\begin{array}{l}91.5 \\
92.5 \\
93.6 \\
94.4 \\
95.6\end{array}$ & $\begin{array}{l}96.8 \\
97.6 \\
99.0 \\
99.7 \\
99.0\end{array}$ & $\begin{array}{l}96.4 \\
96.9 \\
96.9 \\
96.4 \\
96.7\end{array}$ & $\begin{array}{l}102.0 \\
102.2 \\
102.5 \\
101.8 \\
100.1\end{array}$ & $\begin{array}{r}104.0 \\
100.0 \\
94.9 \\
93.7 \\
98.0\end{array}$ & $\begin{array}{r}110.1 \\
105.5 \\
100.4 \\
98.9 \\
101.4\end{array}$ & $\begin{array}{l}92.9 \\
93.3 \\
93.1 \\
94.2 \\
94.6\end{array}$ & $\begin{array}{l}98.3 \\
98.4 \\
98.5 \\
99.5 \\
97.9\end{array}$ & $\begin{array}{l}101.0 \\
102.1 \\
102.5 \\
10.3 \\
101.2\end{array}$ & $\begin{array}{l}106.9 \\
107.7 \\
108.5 \\
111.2 \\
104.8\end{array}$ & $\begin{array}{l}93.7 \\
93.8 \\
93.8 \\
93.8 \\
9.7\end{array}$ & $\begin{array}{l}99.2 \\
98.9 \\
99.3 \\
99.0 \\
99.1\end{array}$ & $\begin{array}{r}101.2 \\
97.8 \\
99.0 \\
100.9 \\
101.7\end{array}$ & $\begin{array}{l}107.1 \\
103.2 \\
104.8 \\
106.5 \\
105.3\end{array}$ \\
\hline $\begin{array}{l}1966 \ldots \ldots \\
1967 \ldots \ldots \\
1959 \ldots \ldots \\
1959 \ldots \ldots \\
1970 \ldots \ldots\end{array}$ & $\begin{array}{r}99.3 \\
100.0 \\
103.4 \\
107.8 \\
112.2\end{array}$ & $\begin{array}{r}95.5 \\
100.0 \\
100.9 \\
101.2 \\
101.6\end{array}$ & $\begin{array}{r}97.9 \\
100.0 \\
102.5 \\
105.9 \\
108.7\end{array}$ & $\begin{array}{r}98.1 \\
100.0 \\
100.0 \\
99.4 \\
99.5\end{array}$ & $\begin{array}{l}102.6 \\
100.0 \\
104.0 \\
105.8 \\
101.8\end{array}$ & $\begin{array}{r}102.8 \\
100.0 \\
101.5 \\
99.3 \\
92.2\end{array}$ & $\begin{array}{r}97.5 \\
100.0 \\
102.0 \\
105.5 \\
111.0\end{array}$ & $\begin{array}{r}97.7 \\
100.0 \\
99.5 \\
99.1 \\
100.5\end{array}$ & $\begin{array}{r}99.6 \\
100.0 \\
102.6 \\
103.5 \\
100.0\end{array}$ & $\begin{array}{r}99.8 \\
100.0 \\
100.1 \\
97.2 \\
90.6\end{array}$ & $\begin{array}{r}97.3 \\
100.0 \\
103.2 \\
105.2 \\
116.4\end{array}$ & $\begin{array}{r}97.5 \\
100.0 \\
100.7 \\
101.6 \\
105.4\end{array}$ & $\begin{array}{l}100.9 \\
100.0 \\
104.2 \\
100.9 \\
101.0\end{array}$ & $\begin{array}{r}101.1 \\
100.0 \\
101.7 \\
94.7 \\
91.5\end{array}$ \\
\hline $\begin{array}{l}1971 \ldots \ldots \\
1972 \ldots \ldots\end{array}$ & $\begin{array}{l}117.4 \\
122.1\end{array}$ & $\begin{array}{l}103.1 \\
102.5\end{array}$ & $\begin{array}{l}112.4 \\
114.5\end{array}$ & $\begin{array}{l}98.7 \\
96.1\end{array}$ & $\begin{array}{l}126.5 \\
133.4\end{array}$ & $\begin{array}{l}111.1 \\
112.0\end{array}$ & $\begin{array}{l}114.1 \\
116.3\end{array}$ & $\begin{array}{r}100.2 \\
97.7\end{array}$ & $\begin{array}{l}106.8 \\
114.7\end{array}$ & $\begin{array}{l}93.8 \\
96.3\end{array}$ & $\begin{array}{l}120.7 \\
122.8\end{array}$ & $\begin{array}{l}106.0 \\
103.1\end{array}$ & $\begin{array}{l}104.2 \\
104.5\end{array}$ & $\begin{array}{l}91.5 \\
87.7\end{array}$ \\
\hline
\end{tabular}


TABLE 5.-Panel products consumed per housing unit, by type of unit, 1970, with projections (1970 relative prices) to 2000

\begin{tabular}{|c|c|c|c|c|c|c|c|c|c|}
\hline \multirow[t]{2}{*}{ Year } & \multicolumn{3}{|c|}{ Hardboard (1/8-Inch basis) } & \multicolumn{3}{|c|}{ Insulation board (1/2-Inch basis) } & \multicolumn{3}{|c|}{ Particleboard (3/4-inch basis) } \\
\hline & $\begin{array}{l}\text { One- and two- } \\
\text { family }\end{array}$ & Multifamily & Mobile homes & $\begin{array}{l}\text { One-and two- } \\
\text { family }\end{array}$ & Multifamily & Mobile homes & $\begin{array}{c}\text { One-and two- } \\
\text { family }\end{array}$ & Multifamily & Moblle homes \\
\hline $1970 \ldots . .$. & $\begin{array}{l}\text { Square feet } \\
\qquad 1,000\end{array}$ & $\begin{array}{l}\text { Square feet } \\
40\end{array}$ & $\begin{array}{l}\text { Square feet } \\
170\end{array}$ & $\begin{array}{r}\text { Square feet } \\
935\end{array}$ & $\begin{array}{l}\text { Square feet } \\
40\end{array}$ & $\begin{array}{l}\text { Square feet } \\
\qquad 10\end{array}$ & $\begin{array}{l}\text { Square feet } \\
250\end{array}$ & ${ }_{5}^{\text {Square feet }}$ & $\begin{array}{l}\text { Square feet } \\
560\end{array}$ \\
\hline
\end{tabular}

Projections

\begin{tabular}{|c|c|c|c|c|c|c|c|c|c|}
\hline $\begin{array}{l}1980 \ldots \\
1990 \ldots . . . \\
2000 \ldots . . .\end{array}$ & $\begin{array}{l}1,500 \\
1,740 \\
1,920\end{array}$ & $\begin{array}{l}45 \\
50 \\
60\end{array}$ & $\begin{array}{l}200 \\
240 \\
290\end{array}$ & $\begin{array}{l}855 \\
775 \\
720\end{array}$ & $\begin{array}{l}35 \\
30 \\
20\end{array}$ & $\begin{array}{l}600 \\
550 \\
520\end{array}$ & $\begin{array}{l}420 \\
590 \\
740\end{array}$ & $\begin{array}{r}70 \\
85 \\
100\end{array}$ & $\begin{array}{l}650 \\
715 \\
790\end{array}$ \\
\hline
\end{tabular}

TABLE 6.-Per capita expenditures for new nonresidential construction ${ }^{1}$ by construction class, 1920-70, with projections to 2000

\begin{tabular}{|c|c|c|c|c|c|c|c|c|c|c|c|c|}
\hline \multirow{3}{*}{ Year } & \multirow{2}{*}{\multicolumn{2}{|c|}{ All classes }} & \multicolumn{4}{|c|}{ Bulldings } & \multirow{2}{*}{\multicolumn{2}{|c|}{$\begin{array}{l}\text { Utilities, water and } \\
\text { sewer systems " }\end{array}$}} & \multirow{2}{*}{\multicolumn{2}{|c|}{ Higbways }} & \multirow{2}{*}{\multicolumn{2}{|c|}{ All other 3}} \\
\hline & & & \multicolumn{2}{|c|}{ Commercial 2} & \multicolumn{2}{|c|}{ Other ${ }^{3}$} & & & & & & \\
\hline & $\begin{array}{l}\text { Expend1- } \\
\text { tures }\end{array}$ & $\begin{array}{l}\text { Annual } \\
\text { rate of } \\
\text { change }\end{array}$ & $\begin{array}{l}\text { Expendi- } \\
\text { tures }\end{array}$ & $\begin{array}{l}\text { Annual } \\
\text { rate of } \\
\text { change }\end{array}$ & $\begin{array}{l}\text { Expendi- } \\
\text { tures }\end{array}$ & $\begin{array}{l}\text { Annual } \\
\text { rate of } \\
\text { change }\end{array}$ & $\begin{array}{l}\text { Expendi- } \\
\text { tures }\end{array}$ & $\begin{array}{l}\text { Annual } \\
\text { rate of } \\
\text { change }\end{array}$ & $\begin{array}{l}\text { Expend1- } \\
\text { tures }\end{array}$ & $\begin{array}{l}\text { Annual } \\
\text { rate of } \\
\text { change }\end{array}$ & $\begin{array}{c}\text { Expendi- } \\
\text { tures }\end{array}$ & $\begin{array}{l}\text { Annual } \\
\text { rate of } \\
\text { change }\end{array}$ \\
\hline 1920 . & $\begin{array}{c}1967 \\
\text { dollars } \\
109\end{array}$ & Percent & $\begin{array}{c}1967 \\
\text { dollars } \\
19\end{array}$ & Percent & $\underbrace{1967}_{48}$ & Percent & $\begin{array}{c}1967 \\
\text { dollars } \\
21\end{array}$ & Percent & $\begin{array}{l}\stackrel{1967}{\text { dollars }}_{9} \\
9\end{array}$ & Percent & $\begin{array}{c}1967 \\
\text { dollars } \\
13\end{array}$ & Percent \\
\hline $1925 \ldots$ & $\begin{array}{l}175 \\
191\end{array}$ & 9.9 & 32 & 11.0 & $\begin{array}{l}69 \\
69\end{array}$ & 7.5 & 37 & 12.0 & 17 & 13.6 & $\begin{array}{l}13 \\
20\end{array}$ & . \\
\hline $1935 \ldots$ & $\begin{array}{r}191 \\
91\end{array}$ & $\begin{array}{r}1.8 \\
-13.8\end{array}$ & $\begin{array}{r}28 \\
8\end{array}$ & $\begin{array}{r}-2.6 \\
-22.2\end{array}$ & $\begin{array}{l}69 \\
25\end{array}$ & $\begin{array}{r}.0 \\
-18.4\end{array}$ & $\begin{array}{l}40 \\
13\end{array}$ & $\begin{array}{r}1.6 \\
-20.1\end{array}$ & 28 & 10.5 & 26 & 5.4 \\
\hline $1940 \ldots$ & 135 & 8. 2 & 11 & 6.6 & 41 & 10.4 & 24 & 13.1 & 25 & $\begin{array}{r}-10.6 \\
9.3\end{array}$ & $\begin{array}{l}30 \\
35\end{array}$ & $\begin{array}{l}2.9 \\
3.1\end{array}$ \\
\hline $1945 \ldots \ldots$. & $\begin{array}{r}82 \\
157\end{array}$ & $\begin{array}{r}-9.5 \\
13.9\end{array}$ & $\begin{array}{r}5 \\
17\end{array}$ & $\begin{array}{r}-14.6 \\
27.7\end{array}$ & $\begin{array}{l}36 \\
58\end{array}$ & -2.6 & 14 & -10.2 & 5 & -27.5 & & -8.9 \\
\hline 1955 & 202 & 5.2 & 29 & 11.3 & 78 & $\begin{array}{r}10.0 \\
6.1\end{array}$ & $\begin{array}{l}41 \\
39\end{array}$ & $\begin{array}{r}24.0 \\
-1.0\end{array}$ & 21 & 33. 2 & 21 & -.9 \\
\hline $1960 \ldots$ & $\begin{array}{l}210 \\
253\end{array}$ & $\begin{array}{r}.8 \\
3.8\end{array}$ & $\begin{array}{l}29 \\
35\end{array}$ & $\begin{array}{r}.0 \\
3.8\end{array}$ & 79 & .3 & 38 & -.5 & 37 & $\begin{array}{l}8.1 \\
3.6\end{array}$ & $\begin{array}{l}25 \\
27\end{array}$ & $\begin{array}{l}3.6 \\
1.6\end{array}$ \\
\hline 1966 & & & & & & 5.7 & 44 & 3.0 & 43 & 3.1 & 27 & .0 \\
\hline $1966 \ldots . .$. & $\begin{array}{l}264 \\
258\end{array}$ & $\begin{array}{r}4.3 \\
-.4\end{array}$ & $\begin{array}{l}34 \\
32\end{array}$ & $\begin{array}{l}-2.9 \\
-5.9\end{array}$ & $\begin{array}{l}112 \\
107\end{array}$ & $\begin{array}{r}7.7 \\
-4.5\end{array}$ & $\begin{array}{l}47 \\
48\end{array}$ & 6.8 & 44 & 2.3 & & .0 \\
\hline 1968 . . . . & 262 & -.4 & 36 & 12.5 & 100 & -7.0 & $\begin{array}{l}48 \\
55\end{array}$ & $\begin{array}{r}2.1 \\
14.6\end{array}$ & $\begin{array}{l}43 \\
44\end{array}$ & $\begin{array}{r}-2.3 \\
2.3\end{array}$ & 27 & .0 \\
\hline $\begin{array}{l}1969 \ldots \ldots \\
1970 \ldots\end{array}$ & $\begin{array}{l}258 \\
242\end{array}$ & $\begin{array}{l}-1.5 \\
-6.2\end{array}$ & $\begin{array}{l}40 \\
38\end{array}$ & $\begin{array}{r}11.1 \\
-5.0\end{array}$ & $\begin{array}{r}100 \\
88\end{array}$ & $\begin{array}{r}0.0 \\
-11.1\end{array}$ & 52 & -5.5 & $\begin{array}{l}44 \\
40\end{array}$ & -9.1 & $\begin{array}{l}27 \\
26\end{array}$ & $\begin{array}{r}.0 \\
-3.7\end{array}$ \\
\hline & & & & & & & 54 & 3.8 & 38 & -5.0 & 24 & -7.7 \\
\hline
\end{tabular}

Low projections

\begin{tabular}{|c|c|c|c|c|c|c|c|c|c|c|c|c|}
\hline $\begin{array}{l}1980 \ldots \ldots \\
1990 \ldots \ldots \\
2000 \ldots \ldots\end{array}$ & $\begin{array}{l}327 \\
396 \\
487\end{array}$ & $\begin{array}{r}2.0 \\
2.0 \\
2.1\end{array}$ & $\begin{array}{l}50 \\
62 \\
78\end{array}$ & $\begin{array}{r}2.0 \\
2.2 \\
2.3\end{array}$ & $\begin{array}{l}133 \\
163 \\
201\end{array}$ & $\begin{array}{r}2.2 \\
2.1 \\
2.1\end{array}$ & $\begin{array}{r}62 \\
79 \\
106\end{array}$ & $\begin{array}{r}2.4 \\
2.5 \\
3.0\end{array}$ & $\begin{array}{l}51 \\
56 \\
61\end{array}$ & $\begin{array}{r}1.5 \\
.9 \\
.9\end{array}$ & $\begin{array}{l}31 \\
36 \\
41\end{array}$ & $\begin{array}{l}61 . \\
1 . \\
1 .\end{array}$ \\
\hline
\end{tabular}

Medium projections

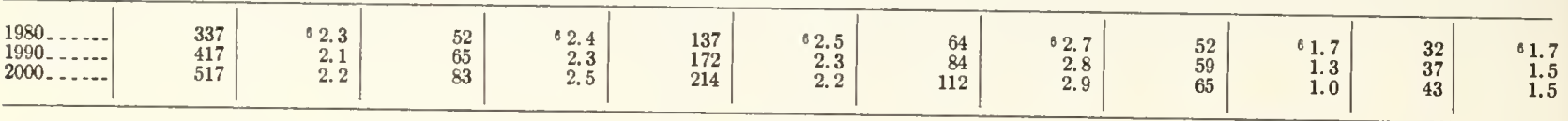

High projections

\begin{tabular}{|c|c|c|c|c|c|c|c|c|c|c|c|c|}
\hline $\begin{array}{l}1980 \ldots \ldots \\
1990 \ldots \ldots . . . \\
2000 \ldots \ldots\end{array}$ & $\begin{array}{l}344 \\
431 \\
542\end{array}$ & $\begin{array}{r}8.5 \\
2.3 \\
2.3\end{array}$ & $\begin{array}{l}53 \\
68 \\
87\end{array}$ & $\begin{array}{r}2.6 \\
2.5 \\
2.5\end{array}$ & $\begin{array}{l}140 \\
178 \\
224\end{array}$ & $\begin{array}{l}2.7 \\
2.4 \\
2.3\end{array}$ & $\begin{array}{r}65 \\
86 \\
118\end{array}$ & $\begin{array}{r}8.9 \\
2.8 \\
3.2\end{array}$ & $\begin{array}{l}53 \\
61 \\
68\end{array}$ & $\begin{array}{r}1.9 \\
1.4 \\
1.1\end{array}$ & $\begin{array}{l}33 \\
38 \\
45\end{array}$ & $\begin{array}{r}2.0 \\
1.4 \\
1.7\end{array}$ \\
\hline
\end{tabular}

1 Excludes expenditures for farm construction.

2 Includes private commercial buildings such as offices, stores, warehouses, and restaurants.

3 Includes public and private nonhousekeeping, industrial, educational religious, hospital and institutional, and similar miscellaneous buildings. 4 Includes telephone and telegraph, other public utilities, sewer systems, and water supply facilities.

${ }^{5}$ Includes military facilities, conservation and development, railroad construction except tract construction, and all other public and private construction not included in other categories.
- Rates of increase calculated from the following 1970 trend values: all classes $\$ 268$; commercial buildings, $\$ 41$; noncommercial, $\$ 107$; utilities, water and sewer systems, $\$ 49$; highways, $\$ 44$; and all other, $\$ 27$.

Note: Annual rates of increase are calculated for 5-year periods from 1920 through 1965, for 1-year periods 1965 through 1970, and for 10-year periods 1970 through 2000.

Note: Data may not add to totals because of rounding.

Sources: Calculated from information sbown in text tables 114 and 125. 
TABLE 7.-Lumber used in neu nonresidential construction, ${ }^{1}$ by canstruction class, 1962 and 1970 , uith projections (1970 relative prices) to 2000

\begin{tabular}{|c|c|c|c|c|c|c|c|c|c|c|c|c|}
\hline \multirow{3}{*}{ Year } & \multirow{2}{*}{\multicolumn{2}{|c|}{ All classes }} & \multicolumn{4}{|c|}{ Buildings } & \multirow{2}{*}{\multicolumn{2}{|c|}{$\begin{array}{l}\text { Utilities, water and } \\
\text { sewer systems } 1\end{array}$}} & \multirow{2}{*}{\multicolumn{2}{|c|}{ Highways }} & \multirow{2}{*}{\multicolumn{2}{|c|}{ All other 3}} \\
\hline & & & \multicolumn{2}{|c|}{ Commercial } & \multicolumn{2}{|c|}{ Noncommerclal 3} & & & & & & \\
\hline & Total & $\begin{array}{l}\text { Use per } 1,000 \\
\text { dollars of } \\
\text { expenditure } 5\end{array}$ & Total & $\begin{array}{l}\text { Use per } 1,000 \\
\text { dcllars of } \\
\text { expenditure }\end{array}$ & Total & $\begin{array}{l}\text { Use per } 1,000 \\
\text { dollars of } \\
\text { expenditure }\end{array}$ & Total & $\begin{array}{c}\text { Use per } 1,000 \\
\text { dollars of } \\
\text { expenditure }\end{array}$ & Total & $\begin{array}{l}\text { Use per } 1,000 \\
\text { dollars of } \\
\text { expenditure }\end{array}$ & Total & $\begin{array}{l}\text { Use per } 1,000 \\
\text { dollars of } \\
\text { expenditure }\end{array}$ \\
\hline $1962 \ldots$ & $\begin{array}{l}\text { Million } \\
\text { board } \\
\text { feet } \\
3,0 \pm 0 \\
2,610\end{array}$ & $\begin{array}{ll}\text { Board } & \\
\text { feet } & \\
& 75 \\
& 53\end{array}$ & $\begin{array}{l}\text { Million } \\
\text { board } \\
\text { feet } \\
350 \\
380\end{array}$ & $\begin{array}{l}\text { Board } \\
\text { feet }\end{array}$ & $\begin{array}{c}\text { Million } \\
\text { board } \\
\text { feet } \\
1,570 \\
970\end{array}$ & $\begin{array}{l}\text { Board } \\
\text { feet } \\
\\
\\
\\
\\
\\
\\
54\end{array}$ & $\begin{array}{l}\text { Million } \\
\text { board } \\
\text { feet } \\
480 \\
660\end{array}$ & $\begin{array}{l}\text { Board } \\
\text { feet }\end{array}$ & $\begin{array}{c}\text { Million } \\
\text { board } \\
\text { feet } \\
350 \\
270\end{array}$ & $\begin{array}{l}\text { Board } \\
\text { feet }\end{array}$ & $\begin{array}{c}\text { Million } \\
\text { board } \\
\text { feet } \\
290 \\
330\end{array}$ & $\begin{array}{l}\text { Board } \\
\text { feet }\end{array}$ \\
\hline
\end{tabular}

Low projections

\begin{tabular}{|c|c|c|c|c|c|c|c|c|c|c|c|c|}
\hline $\begin{array}{l}1960 \ldots \\
1990 \ldots . \\
2000 \ldots .\end{array}$ & $\begin{array}{l}2,920 \\
3,360 \\
3,850\end{array}$ & $\begin{array}{l}39 \\
34 \\
30\end{array}$ & $\begin{array}{l}410 \\
480 \\
540\end{array}$ & $\begin{array}{l}36 \\
31 \\
26\end{array}$ & $\begin{array}{l}1,170 \\
1,340 \\
1,550\end{array}$ & $\begin{array}{l}39 \\
33 \\
29\end{array}$ & $\begin{array}{r}700 \\
850 \\
1,040\end{array}$ & $\begin{array}{l}50 \\
43 \\
37\end{array}$ & $\begin{array}{l}260 \\
280 \\
310\end{array}$ & $\begin{array}{l}23 \\
20 \\
19\end{array}$ & $\begin{array}{l}380 \\
410 \\
440\end{array}$ & $\begin{array}{l}54 \\
47 \\
41\end{array}$ \\
\hline
\end{tabular}

Medium projections

\begin{tabular}{|c|c|c|c|c|c|c|c|c|c|c|c|c|}
\hline $\begin{array}{l}1950 \ldots . . . \\
1990 \ldots . . \\
2000 \ldots . . .\end{array}$ & $\begin{array}{l}3,030 \\
3,630 \\
4,360\end{array}$ & $\begin{array}{l}39 \\
34 \\
30\end{array}$ & $\begin{array}{l}420 \\
520 \\
600\end{array}$ & $\begin{array}{l}36 \\
31 \\
26\end{array}$ & $\begin{array}{l}1,220 \\
1,150 \\
1,740\end{array}$ & $\begin{array}{l}39 \\
33 \\
29\end{array}$ & $\begin{array}{r}730 \\
920 \\
1,170\end{array}$ & $\begin{array}{l}50 \\
43 \\
37\end{array}$ & $\begin{array}{l}270 \\
300 \\
350\end{array}$ & $\begin{array}{l}23 \\
20 \\
19\end{array}$ & $\begin{array}{l}390 \\
440 \\
500\end{array}$ & $\begin{array}{l}54 \\
47 \\
41\end{array}$ \\
\hline
\end{tabular}

High projections

\begin{tabular}{|c|c|c|c|c|c|c|c|c|c|c|c|c|}
\hline $\begin{array}{l}1980 \ldots \\
1990 \ldots \\
2000 \ldots\end{array}$ & $\begin{array}{l}3,150 \\
3,920 \\
4,890\end{array}$ & $\begin{array}{l}39 \\
34 \\
30\end{array}$ & $\begin{array}{l}440 \\
560 \\
680\end{array}$ & $\begin{array}{l}36 \\
31 \\
26\end{array}$ & $\begin{array}{l}1,270 \\
1,560 \\
1,950\end{array}$ & $\begin{array}{l}39 \\
33 \\
29\end{array}$ & $\begin{array}{r}750 \\
990 \\
1,310\end{array}$ & $\begin{array}{l}50 \\
43 \\
37\end{array}$ & $\begin{array}{l}280 \\
330 \\
390\end{array}$ & $\begin{array}{l}23 \\
20 \\
19\end{array}$ & $\begin{array}{l}410 \\
480 \\
560\end{array}$ & $\begin{array}{l}54 \\
47 \\
41\end{array}$ \\
\hline
\end{tabular}

1 Excludes farm construction.

Includes prirate commercial buildings such as offices, stores, warehouses, and restaurants.

${ }^{3}$ Includes public and private nonhousekeeping, industrial, educational, religious, hospital and institutional, and similar miscellaneous buildings. 1 Includes telephone and telegraph, other public utilities, sewer systems, and water supply facilities.

${ }_{5}^{5}$ Includes military facilities, conservation and development, railroad construction except track construction, and all other public and private construction not included in other categories.
61967 dollars. Use per 1,000 dollars of construction expenditure for 1962 and 1970 computed by Forest Service. (See table 125 for construction expenditures.)

Sources: Lumber, 1962 and 1970, estimates based on Forest Service Surveys except highways, which were adapted from data provided by U.S. Department of Transportation, Bureau of Public Roads.

Projections: U.S. Department of Agriculture, Forest Service. 

$T_{A B L E}$ 8.-Plywood used in new nonresidential construction 1 by construction class, 1962 and 1970, with projections (1970
relative prices) to 2000

[36-inch basis]

\begin{tabular}{|c|c|c|c|c|c|c|c|c|c|c|c|c|}
\hline \multirow{3}{*}{ Year } & \multirow{2}{*}{\multicolumn{2}{|c|}{ All classes }} & \multicolumn{4}{|c|}{ Bulldings } & \multirow{2}{*}{\multicolumn{2}{|c|}{$\begin{array}{l}\text { Utilities, water and } \\
\text { sewer systems }\end{array}$}} & \multirow{2}{*}{\multicolumn{2}{|c|}{ Highways }} & \multirow{2}{*}{\multicolumn{2}{|c|}{ All other s }} \\
\hline & & & \multicolumn{2}{|c|}{ Commercial 2} & \multicolumn{2}{|c|}{ Noncommercial 3} & & & & & & \\
\hline & Total & $\begin{array}{l}\text { Use per } 1,000 \\
\text { dollars of } \\
\text { expenditure }\end{array}$ & Total & $\begin{array}{l}\text { Use per } 1,000 \\
\text { dollars of } \\
\text { expenditure }\end{array}$ & Total & $\begin{array}{l}\text { Use per } 1,000 \\
\text { dollars of } \\
\text { expenditure }\end{array}$ & Total & $\begin{array}{l}\text { Use per } 1,000 \\
\text { dollars of } \\
\text { expenditure }\end{array}$ & Total & $\begin{array}{l}\text { Use per } 1,000 \\
\text { dollars of } \\
\text { expenditure }\end{array}$ & Total & $\begin{array}{l}\text { Use per } 1,000 \\
\text { dollars of } \\
\text { expenditure }\end{array}$ \\
\hline $\begin{array}{l}962 \ldots \\
970 \ldots\end{array}$ & 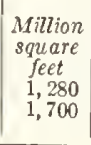 & $\begin{array}{l}\text { Square } \\
\text { feet } \\
\\
\\
32 \\
\\
34\end{array}$ & $\begin{array}{c}\text { Million } \\
\text { square } \\
\text { feet } \\
220 \\
170\end{array}$ & $\begin{array}{c}\text { Square } \\
\text { feet }\end{array}$ & $\begin{array}{c}\text { Million } \\
\text { square } \\
\text { feet } \\
570 \\
900\end{array}$ & $\begin{array}{l}\text { Square } \\
\text { feet } \\
\\
\qquad \begin{array}{l}37 \\
50\end{array}\end{array}$ & $\begin{array}{c}\text { Million } \\
\text { square } \\
\text { feet } \\
130 \\
180\end{array}$ & $\begin{array}{l}\text { Square } \\
\text { feet } \\
\\
\\
19 \\
16\end{array}$ & $\begin{array}{c}\text { Million } \\
\text { square } \\
\text { feet } \\
280 \\
360\end{array}$ & $\begin{array}{l}\text { Square } \\
\text { feet } \\
\\
\\
37 \\
46\end{array}$ & $\begin{array}{c}\text { Million } \\
\text { square } \\
\text { feet } \\
80 \\
90\end{array}$ & $\begin{array}{l}\text { Square } \\
\text { feet } \\
\\
\\
11 \\
19\end{array}$ \\
\hline
\end{tabular}

Low projections

\begin{tabular}{|c|c|c|c|c|c|c|c|c|c|c|c|c|}
\hline $\begin{array}{l}1980 \ldots \ldots \\
1990 \ldots \ldots \\
2000 \ldots \ldots\end{array}$ & $\begin{array}{l}2,580 \\
3,260 \\
4,050\end{array}$ & $\begin{array}{l}35 \\
33 \\
31\end{array}$ & $\begin{array}{l}190 \\
230 \\
290\end{array}$ & $\begin{array}{l}17 \\
15 \\
14\end{array}$ & $\begin{array}{l}1,660 \\
2,190 \\
2,780\end{array}$ & $\begin{array}{l}55 \\
54 \\
52\end{array}$ & $\begin{array}{l}220 \\
280 \\
340\end{array}$ & $\begin{array}{l}16 \\
14 \\
12\end{array}$ & $\begin{array}{l}380 \\
390 \\
410\end{array}$ & $\begin{array}{l}33 \\
28 \\
25\end{array}$ & $\begin{array}{l}130 \\
170 \\
230\end{array}$ & $\begin{array}{l}19 \\
20 \\
21\end{array}$ \\
\hline
\end{tabular}

Medium projections

\begin{tabular}{|c|c|c|c|c|c|c|c|c|c|c|c|c|}
\hline $\begin{array}{l}1980 \ldots \\
1990 \\
2000\end{array}$ & $\begin{array}{l}2,680 \\
3,530 \\
4,550\end{array}$ & $\begin{array}{l}35 \\
33 \\
31\end{array}$ & $\begin{array}{l}200 \\
250 \\
340\end{array}$ & $\begin{array}{l}17 \\
15 \\
14\end{array}$ & $\begin{array}{l}1,720 \\
2,370 \\
3,120\end{array}$ & $\begin{array}{l}55 \\
54 \\
52\end{array}$ & $\begin{array}{l}230 \\
300 \\
380\end{array}$ & $\begin{array}{l}16 \\
14 \\
12\end{array}$ & $\begin{array}{l}390 \\
420 \\
460\end{array}$ & $\begin{array}{l}33 \\
28 \\
25\end{array}$ & $\begin{array}{l}140 \\
190 \\
250\end{array}$ & $\begin{array}{l}19 \\
20 \\
21\end{array}$ \\
\hline
\end{tabular}

High projections

\begin{tabular}{|c|c|c|c|c|c|c|c|c|c|c|c|c|}
\hline $\begin{array}{l}1980 \ldots \\
1990 \ldots \\
2000 \ldots\end{array}$ & $\begin{array}{l}2,800 \\
3,800 \\
5,100\end{array}$ & $\begin{array}{l}35 \\
33 \\
31\end{array}$ & $\begin{array}{l}210 \\
270 \\
370\end{array}$ & $\begin{array}{l}17 \\
15 \\
14\end{array}$ & $\begin{array}{l}1,790 \\
2,550 \\
3,500\end{array}$ & $\begin{array}{l}55 \\
54 \\
52\end{array}$ & $\begin{array}{l}240 \\
320 \\
420\end{array}$ & $\begin{array}{l}16 \\
14 \\
12\end{array}$ & $\begin{array}{l}410 \\
460 \\
520\end{array}$ & $\begin{array}{l}33 \\
28 \\
25\end{array}$ & $\begin{array}{l}150 \\
200 \\
290\end{array}$ & $\begin{array}{l}19 \\
20 \\
21\end{array}$ \\
\hline
\end{tabular}

1 Excludes farm construction. 2 Includes private commercial buildings such as offices, stores, warehouses,
and restaurants.

Includes public and private nonhousekeeping, industrial, educational, religious, hospital and institutional, and similar miscellaneous buildings. Includes telephone and telegraph, other public utilities, sewer systems, and water supply facilities.

5 Includes military facilities, conservation and development, railroad construction except track construction, and all other public and private
construction not included in other categories.
1967 dollars. Use per 1,000 dollars of construction expenditure for 1962 and 1970 computed by Forest Scrvice. (See table 125 for construction ex-

Sources: Plywood use, 1962 and 1970, estimates based on Forest Service Surveys except highways, which were adapted from data provided by U.S. Department of Transportation, Bureau of Public Roads.

Projections: U.S. Department of Agriculture, Forest Service. 
TABLE 9.-Building board' used in new nonresidential construction ${ }^{2}$ by construction class, 1962 and 1970 , with projections (1970 relative prices) to 2000

[1/2-inch basis]

\begin{tabular}{|c|c|c|c|c|c|c|c|c|c|c|c|c|}
\hline \multirow{3}{*}{ Year } & \multirow{2}{*}{\multicolumn{2}{|c|}{ All classes }} & \multicolumn{4}{|c|}{ Buildings } & \multirow{2}{*}{\multicolumn{2}{|c|}{$\begin{array}{l}\text { Utilities, water and } \\
\text { sewer systems }{ }^{6}\end{array}$}} & \multirow{2}{*}{\multicolumn{2}{|c|}{ Highways }} & \multirow{2}{*}{\multicolumn{2}{|c|}{ All other ${ }^{\circ}$}} \\
\hline & & & \multicolumn{2}{|c|}{ Commercial 3} & \multicolumn{2}{|c|}{ Noncommerclal } & & & & & & \\
\hline & Total & $\begin{array}{l}\text { Use per } 1,000 \\
\text { dollars of } \\
\text { expenditures }\end{array}$ & Total & $\begin{array}{l}\text { Use per } 1,000 \\
\text { dollars of } \\
\text { expenditures }\end{array}$ & Total & $\begin{array}{l}\text { Use per } 1,000 \\
\text { dollars of } \\
\text { expenditures } 7\end{array}$ & Total & $\begin{array}{c}\text { Use per } 1,000 \\
\text { dollars of } \\
\text { expenditures } 7\end{array}$ & Total & $\begin{array}{c}\text { Use per } 1,000 \\
\text { dollars of } \\
\text { expenditures }\end{array}$ & Total & $\begin{array}{l}\text { Use per } 1,000 \\
\text { dollars of } \\
\text { expenditures ? }\end{array}$ \\
\hline $1962 \ldots . .$. & $\begin{array}{c}\text { Million } \\
\text { square } \\
\text { feet } \\
430 \\
720\end{array}$ & $\begin{array}{r}\text { Square feet } \\
11 \\
14\end{array}$ & $\begin{array}{c}\text { Million } \\
\text { square } \\
\text { feet } \\
90 \\
155\end{array}$ & $\begin{array}{r}\text { Square feet } \\
15 \\
20\end{array}$ & $\begin{array}{c}\text { Million } \\
\text { square } \\
\text { feet } \\
300 \\
500\end{array}$ & $\begin{array}{r}\text { Square feet } \\
20 \\
28\end{array}$ & $\begin{array}{l}\text { Million } \\
\text { square } \\
\text { feet } \\
5 \\
20\end{array}$ & $\begin{array}{r}\text { Square feet } \\
0.7 \\
1.8\end{array}$ & $\begin{array}{c}\text { Million } \\
\text { square } \\
\text { feet } \\
10 \\
15\end{array}$ & $\begin{array}{r}\text { Square feet } \\
1.3 \\
1.9\end{array}$ & $\begin{array}{l}\text { Million } \\
\text { square } \\
\text { feet } \\
25 \\
30\end{array}$ & $\begin{array}{r}\text { Square feet } \\
5.1 \\
6.3\end{array}$ \\
\hline
\end{tabular}

Low projections

\begin{tabular}{|c|c|c|c|c|c|c|c|c|c|c|c|c|}
\hline $\begin{array}{l}1950 \ldots \ldots \\
1990 \ldots \ldots \\
2000 \ldots . . .\end{array}$ & $\begin{array}{l}1,030 \\
1,280 \\
1,420\end{array}$ & $\begin{array}{l}14 \\
13 \\
11\end{array}$ & $\begin{array}{l}200 \\
250 \\
280\end{array}$ & $\begin{array}{l}18 \\
16 \\
14\end{array}$ & $\begin{array}{r}730 \\
920 \\
1,020\end{array}$ & $\begin{array}{l}24 \\
23 \\
19\end{array}$ & $\begin{array}{l}20 \\
20 \\
20\end{array}$ & $\begin{array}{r}1.4 \\
1.0 \\
.7\end{array}$ & $\begin{array}{l}20 \\
20 \\
20\end{array}$ & $\begin{array}{l}1.8 \\
1.4 \\
1.2\end{array}$ & $\begin{array}{l}60 \\
70 \\
80\end{array}$ & $\begin{array}{l}8.6 \\
8.0 \\
7.4\end{array}$ \\
\hline
\end{tabular}

Medium projections

\begin{tabular}{|c|c|c|c|c|c|c|c|c|c|c|c|c|}
\hline $\begin{array}{l}1950 \ldots \ldots \\
1990 \ldots \ldots \\
2000 \ldots . . .\end{array}$ & $\begin{array}{l}1,080 \\
1,380 \\
1,600\end{array}$ & $\begin{array}{l}14 \\
13 \\
11\end{array}$ & $\begin{array}{l}210 \\
270 \\
320\end{array}$ & $\begin{array}{l}18 \\
16 \\
14\end{array}$ & $\begin{array}{r}770 \\
1,000 \\
1,150\end{array}$ & $\begin{array}{l}24 \\
23 \\
19\end{array}$ & $\begin{array}{l}20 \\
20 \\
20\end{array}$ & $\begin{array}{r}1.4 \\
1.0 \\
.7\end{array}$ & $\begin{array}{l}20 \\
20 \\
20\end{array}$ & $\begin{array}{l}1.8 \\
1.4 \\
1.2\end{array}$ & $\begin{array}{l}60 \\
70 \\
80\end{array}$ & $\begin{array}{l}8.6 \\
8.0 \\
7.4\end{array}$ \\
\hline
\end{tabular}

High projections

\begin{tabular}{|c|c|c|c|c|c|c|c|c|c|c|c|c|}
\hline $\begin{array}{l}1950 \ldots \ldots \\
1990 \ldots \ldots \\
2000 \ldots \ldots\end{array}$ & $\begin{array}{l}1,120 \\
1,490 \\
1,790\end{array}$ & $\begin{array}{l}14 \\
13 \\
11\end{array}$ & $\begin{array}{l}220 \\
290 \\
360\end{array}$ & $\begin{array}{l}18 \\
16 \\
14\end{array}$ & $\begin{array}{r}790 \\
1,080 \\
1,290\end{array}$ & $\begin{array}{l}24 \\
23 \\
19\end{array}$ & $\begin{array}{l}20 \\
20 \\
20\end{array}$ & $\begin{array}{r}1.4 \\
1.0 \\
.7\end{array}$ & $\begin{array}{l}20 \\
20 \\
20\end{array}$ & $\begin{array}{l}1.8 \\
1.4 \\
1.2\end{array}$ & $\begin{array}{l}60 \\
70 \\
80\end{array}$ & $\begin{array}{l}8.6 \\
8.0 \\
7.4\end{array}$ \\
\hline
\end{tabular}

1 Includes hardboard, particleboard, and insulation board.

2 Excludes farm construction.

3 Includes private commercial buildings such as offices, stores, warehouses, and restaurants.

$i$ Inclutes public and private nonhousekeeping, industrial, educational, ligious, hospitals and institutional, and similar miscellaneous buildings.

s Inclutes telephone and telegraph, other public utilities, sewer systems, 5 Inclu les telephone and

and water supply iscilities. construction, except trick construction, and all other public and private construction not included in other categories.
71067 dollars. Use per 1,000 dollars of construction expenditures for 1962 and 1970 computed by Forest Service. (See table 125 for construction expenditures.)

Note: Data may not add to totals because of rounding.

Sources: Building board use 1962 and 1970 estimates based on Forest Service surveys, except highways, which were adapted from data provided by U.S. Department of Transportation, Bureau of Public Roads.

Projections: U.S. Department of Agriculture, Forest Service. 
TABLE 10.-Per capita value of manufacturing shipments, specified years 1948-70, by product group, with projections to 2000

\begin{tabular}{|c|c|c|c|c|c|c|c|c|c|c|c|c|}
\hline \multirow{2}{*}{ Year } & \multicolumn{2}{|c|}{ All products } & \multicolumn{2}{|c|}{ Household furniture } & \multicolumn{2}{|c|}{$\begin{array}{l}\text { Commercial and in- } \\
\text { stitutional furniture }\end{array}$} & \multicolumn{2}{|c|}{ Consumer goods 1} & \multicolumn{2}{|c|}{$\begin{array}{l}\text { Commercial and in- } \\
\text { dustrial equipment }\end{array}$} & \multicolumn{2}{|c|}{ Other products 3} \\
\hline & Value & $\begin{array}{l}\text { Annual } \\
\text { rate of } \\
\text { increase }\end{array}$ & Value & $\begin{array}{l}\text { Annual } \\
\text { rate of } \\
\text { increase }\end{array}$ & Value & $\begin{array}{l}\text { Annual } \\
\text { rate of } \\
\text { increase }\end{array}$ & Value & $\begin{array}{l}\text { Annual } \\
\text { rate of } \\
\text { increase }\end{array}$ & Value & $\begin{array}{l}\text { Annual } \\
\text { rate of } \\
\text { increase }\end{array}$ & Value & $\begin{array}{l}\text { Annual } \\
\text { rate of } \\
\text { increase }\end{array}$ \\
\hline $\begin{array}{l}1948 \ldots \ldots \ldots \\
1950 \ldots \ldots \ldots \\
1955 \ldots \ldots \ldots \\
1960 \ldots \ldots \ldots \\
1965 \ldots \ldots \ldots\end{array}$ & $\begin{array}{c}1967 \\
\text { dollars } \\
1,657 \\
1,741 \\
2,126 \\
2,107 \\
2,560\end{array}$ & $\begin{array}{r}\text { Percent } \\
1.6 \\
4.1 \\
-.2 \\
3.9\end{array}$ & $\begin{array}{l}1967 \\
\text { dollats } \\
16.43 \\
17.90 \\
21.37 \\
20.89 \\
24.95\end{array}$ & $\begin{array}{r}\text { Percent } \\
4.4 \\
3.6 \\
-.5 \\
3.6\end{array}$ & $\begin{array}{r}1967 \\
\text { dollars } \\
4.04 \\
5.00 \\
6.84 \\
7.97 \\
10.10\end{array}$ & $\begin{array}{r}\text { Percent } \\
11.2 \\
6.5 \\
3.1 \\
4.8\end{array}$ & $\begin{array}{c}1967 \\
\text { dollars } \\
16.58 \\
18.61 \\
17.96 \\
20.27 \\
23.87\end{array}$ & $\begin{array}{r}\text { Percent } \\
5.9 \\
-.7 \\
2.4 \\
3.3\end{array}$ & $\begin{array}{c}1967 \\
\text { dollars } \\
172.95 \\
183.96 \\
236.22 \\
264.83 \\
362.38\end{array}$ & $\begin{array}{r}\text { Percent } \\
3.1 \\
5.1 \\
2.4 \\
6.5\end{array}$ & $\begin{array}{c}1967 \\
\text { dollars } \\
1,447 \\
1,516 \\
1,845 \\
1,794 \\
2,139\end{array}$ & $\begin{array}{r}\text { Percent } \\
2.4 \\
4.0 \\
-.6 \\
3.6\end{array}$ \\
\hline $\begin{array}{l}1966 \ldots \ldots \\
1967 \ldots \ldots \\
1968 \ldots \ldots \\
1969 \ldots \ldots \\
1970 \ldots \ldots\end{array}$ & $\begin{array}{l}2,682 \\
2,738 \\
2,868 \\
2,960 \\
2,880\end{array}$ & $\begin{array}{l}4.8 \\
3.8 \\
3.1 \\
3.2 \\
2.7\end{array}$ & $\begin{array}{l}25.60 \\
25.61 \\
27.60 \\
27.93 \\
25.83\end{array}$ & $\begin{array}{r}2.6 \\
7.8 \\
-7.2 \\
-7.5\end{array}$ & $\begin{array}{l}11.21 \\
11.67 \\
11.57 \\
12.61 \\
11.59\end{array}$ & $\begin{array}{r}11.0 \\
4.1 \\
.9 \\
9.0 \\
-8.1\end{array}$ & $\begin{array}{l}24.92 \\
25.05 \\
25.78 \\
28.10 \\
26.52\end{array}$ & $\begin{array}{r}4.4 \\
.5 \\
2.9 \\
9.0 \\
-5.6\end{array}$ & $\begin{array}{l}406.01 \\
422.15 \\
427.32 \\
441.54 \\
413.88\end{array}$ & $\begin{array}{r}12.0 \\
4.0 \\
1.2 \\
3.3 \\
-6.3\end{array}$ & $\begin{array}{l}2,214 \\
2,254 \\
2,375 \\
2,450 \\
2,402\end{array}$ & $\begin{array}{r}3.5 \\
1.8 \\
5.4 \\
3.2 \\
-2.0\end{array}$ \\
\hline $1948-70 \ldots$ & 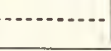 & 2.5 & & 2.1 & & 4.9 & & 2.2 & & 4.1 & & 2.3 \\
\hline
\end{tabular}

Low projections

\begin{tabular}{|c|c|c|c|c|c|c|c|c|c|c|c|c|}
\hline $\begin{array}{l}1980 \ldots \ldots \\
1990 \ldots \ldots \\
2000 \ldots \ldots\end{array}$ & $\begin{array}{l}3,789 \\
4,829 \\
6,246\end{array}$ & $\begin{array}{r}2.5 \\
2.5 \\
2.6\end{array}$ & $\begin{array}{l}36.77 \\
45.92 \\
57.53\end{array}$ & $\begin{array}{r}2.5 \\
2.2 \\
2.2\end{array}$ & $\begin{array}{l}17.50 \\
23.60 \\
31.64\end{array}$ & $\begin{array}{r}3.1 \\
3.0 \\
3.0\end{array}$ & $\begin{array}{l}35.33 \\
44.98 \\
58.02\end{array}$ & $\begin{array}{r}2.8 \\
2.4 \\
2.6\end{array}$ & $\begin{array}{r}675.85 \\
974.94 \\
1.413 .02\end{array}$ & $\begin{array}{r}4.9 \\
3.7 \\
3.3\end{array}$ & $\begin{array}{l}3,024 \\
3,740 \\
4,686\end{array}$ & $\begin{array}{r}2.2 \\
2.2 \\
2.3\end{array}$ \\
\hline
\end{tabular}

\begin{tabular}{|c|c|c|c|c|c|c|c|c|c|c|c|c|}
\hline $\begin{array}{l}1980 \ldots \ldots \\
1990 \ldots \ldots \ldots \\
2000 \ldots \ldots \ldots\end{array}$ & $\begin{array}{l}3,978 \\
5,268 \\
6,989\end{array}$ & $\begin{array}{l}3.1 \\
2.8 \\
2.9\end{array}$ & $\begin{array}{l}37.88 \\
48.24 \\
61.16\end{array}$ & $\begin{array}{r}2.8 \\
2.5 \\
2.4\end{array}$ & $\begin{array}{l}18.42 \\
25.46 \\
35.35\end{array}$ & $\begin{array}{r}3.7 \\
3.3 \\
3.3\end{array}$ & $\begin{array}{l}36.39 \\
47.25 \\
61.67\end{array}$ & $\begin{array}{r}3.0 \\
2.6 \\
2.7\end{array}$ & $\begin{array}{r}709.25 \\
1,062.86 \\
1,586.12\end{array}$ & $\begin{array}{r}4.4 \\
4.1 \\
4.1\end{array}$ & $\begin{array}{l}3,176 \\
4,084 \\
5,245\end{array}$ & $\begin{array}{r}2.7 \\
2.6 \\
2.5\end{array}$ \\
\hline
\end{tabular}

High projections

\begin{tabular}{|c|c|c|c|c|c|c|c|c|c|c|c|c|}
\hline $\begin{array}{l}1980 \ldots . . . . . \\
1990 \ldots . . . \\
2000 \ldots . . .\end{array}$ & $\begin{array}{l}4,147 \\
5,685 \\
7,836\end{array}$ & $\begin{array}{r}3.5 \\
3.2 \\
3.3\end{array}$ & $\begin{array}{l}39.19 \\
50.60 \\
64.90\end{array}$ & $\begin{array}{r}13.1 \\
2.6 \\
2.5\end{array}$ & $\begin{array}{l}19.30 \\
27.94 \\
40.23\end{array}$ & $\begin{array}{r}14.2 \\
3.8 \\
3.7\end{array}$ & $\begin{array}{l}37.17 \\
48.92 \\
64.61\end{array}$ & $\begin{array}{r}3.3 \\
2.8 \\
2.8\end{array}$ & $\begin{array}{r}744.67 \\
1,163.14 \\
1,806.35\end{array}$ & $\begin{array}{r}4.9 \\
4.6 \\
4.5\end{array}$ & $\begin{array}{l}3,307 \\
4,394 \\
5,859\end{array}$ & $\begin{array}{r}3.1 \\
2.9 \\
2.9\end{array}$ \\
\hline
\end{tabular}

1 Includes sporting goods, musical instruments, boat building and repair, toys and games, luggage and trunks, handles, morticlans' goods, shoe and

boot findings, and wood matches.
2 Includes commercial refrigeration, signs and displays, patterns and jigs,

products, \$2963.38; household furniture, \$28.81; commercial and institutional truck bodies and trailers, general machinery, agricultural implements, electrical equipment, and textile machinery supplies.

3 All manufactured products except those listed above and products such as pallets, prefabricated wooden buildings and structural members, containers, mobile homes, millwork, flooring and other similar goods included in the construction and shipping sections of this study.

4 Rates of increase calculated from the following 1970 trend values: all furniture, $\$ 12.84$; consumer goods, $\$ 26.86$; commercial and industrial equipment, $\$ 459.96$; other products, $\$ 2435.06$

Note: Conversion to 1967 dollars by U.S. Department of Agriculture Forest Service. Annual rates of increase are calculated for 5-year periods from 1950 through 1965 , for 1 -year periods 1965 through 1970, and for 10-year periods 1970 through 2000 .

Note: Data may not add to totals because of rounding.

Source: Calculated from information shown in text tables 114 and 129. 
APPENDIX V. TIMBER DEMAND TABLES

TABLE 11.-Lumber use in manufacturing, by product group, specified years 1948-70, with projections (1970 relative prices) to 2000

\begin{tabular}{|c|c|c|c|c|c|c|c|c|c|c|c|c|}
\hline \multirow{2}{*}{ Year } & \multicolumn{2}{|c|}{ All products } & \multicolumn{2}{|c|}{ Household furniture } & \multicolumn{2}{|c|}{$\begin{array}{l}\text { Commercial and insti- } \\
\text { tutional furniture }\end{array}$} & \multicolumn{2}{|c|}{ Consumer goods 1} & \multicolumn{2}{|c|}{$\begin{array}{l}\text { Commercial and indus. } \\
\text { trial equipment }{ }^{2}\end{array}$} & \multicolumn{2}{|c|}{ Other products ${ }^{3}$} \\
\hline & Total & $\begin{array}{l}\text { Per dollar } \\
\text { of ship- } \\
\text { ments }\end{array}$ & Total & $\begin{array}{l}\text { Per dollar } \\
\text { of ship- } \\
\text { ments } 1\end{array}$ & Total & $\begin{array}{l}\text { Per dollar } \\
\text { of ship- } \\
\text { ments } 1\end{array}$ & Total & $\begin{array}{l}\text { Per dollar } \\
\text { of ship- } \\
\text { ments } 1\end{array}$ & Total & $\begin{array}{l}\text { Per dollar } \\
\text { of ship- } \\
\text { ments }\end{array}$ & Total & $\begin{array}{l}\text { Per dollar } \\
\text { of ship- } \\
\text { ments }\end{array}$ \\
\hline $\begin{array}{l}1948 \ldots . . . \\
1960 \ldots . . . \\
1965 \ldots . . \\
1970 \ldots . . .\end{array}$ & $\begin{array}{c}\text { Million } \\
\text { board feet } \\
3,924 \\
3,864 \\
4,609 \\
4,670\end{array}$ & $\begin{array}{r}\text { Board feet } \\
0.016 \\
.010 \\
.009 \\
.005\end{array}$ & $\begin{array}{c}\text { Million } \\
\text { board feet } \\
1,970 \\
2,116 \\
2,987 \\
2,961\end{array}$ & $\begin{array}{r}\text { Board feet } \\
0.814 \\
.560 \\
.612 \\
.558\end{array}$ & $\begin{array}{r}\text { Million } \\
\text { board feet } \\
321 \\
289 \\
280 \\
271\end{array}$ & $\begin{array}{r}\text { Board feet } \\
0.540 \\
.201 \\
.142 \\
.114\end{array}$ & $\begin{array}{r}\text { Million } \\
\text { board feet } \\
723 \\
643 \\
518 \\
621\end{array}$ & $\begin{array}{r}\text { Board feet } \\
0.296 \\
.176 \\
.111 \\
.114\end{array}$ & $\begin{array}{r}\text { Million } \\
\text { board feet } \\
518 \\
414 \\
619 \\
620\end{array}$ & $\begin{array}{r}\text { Board feet } \\
0.020 \\
.009 \\
.009 \\
.007\end{array}$ & $\begin{array}{r}\text { Million } \\
\text { board feet } \\
392 \\
403 \\
20.5 \\
197\end{array}$ & $\begin{array}{r}\text { Board feet } \\
0.0018 \\
.0001 \\
.0005 \\
.0004\end{array}$ \\
\hline
\end{tabular}

Low projections

\begin{tabular}{|c|c|c|c|c|c|c|c|c|c|c|c|c|}
\hline $\begin{array}{l}1980 \ldots . . . \\
1990 \ldots . . \\
2000 \ldots . .\end{array}$ & $\begin{array}{l}5,480 \\
6,290 \\
7,140\end{array}$ & $\begin{array}{r}0.006 \\
.005 \\
.004\end{array}$ & $\begin{array}{l}3,450 \\
3,830 \\
4,250\end{array}$ & $\begin{array}{r}0.415 \\
.336 \\
.278\end{array}$ & $\begin{array}{l}330 \\
380 \\
440\end{array}$ & $\begin{array}{r}0.084 \\
.064 \\
.052\end{array}$ & $\begin{array}{r}740 \\
880 \\
1,030\end{array}$ & $\begin{array}{r}0.092 \\
.079 \\
.067\end{array}$ & $\begin{array}{r}760 \\
970 \\
1,130\end{array}$ & $\begin{array}{r}0.005 \\
.004 \\
.003\end{array}$ & $\begin{array}{l}200 \\
230 \\
290\end{array}$ & $\begin{array}{l}0.0003 \\
.0002 \\
.0002\end{array}$ \\
\hline
\end{tabular}

Medium projections

\begin{tabular}{|c|c|c|c|c|c|c|c|c|c|c|c|c|}
\hline $\begin{array}{l}1980 \ldots . . . \\
1990 \ldots . . \\
2000 \ldots . . .\end{array}$ & $\begin{array}{l}5,720 \\
6,850 \\
8,130\end{array}$ & $\begin{array}{r}0.006 \\
.005 \\
.004\end{array}$ & $\begin{array}{l}3,580 \\
4,130 \\
4,780\end{array}$ & $\begin{array}{r}0.415 \\
.336 \\
.278\end{array}$ & $\begin{array}{l}350 \\
420 \\
510\end{array}$ & $\begin{array}{r}0.084 \\
.064 \\
.052\end{array}$ & $\begin{array}{r}760 \\
950 \\
1,160\end{array}$ & $\begin{array}{r}0.092 \\
.079 \\
.067\end{array}$ & $\begin{array}{r}810 \\
1,090 \\
1,310\end{array}$ & $\begin{array}{r}0.005 \\
.004 \\
.003\end{array}$ & $\begin{array}{l}220 \\
260 \\
340\end{array}$ & $\begin{array}{r}0.0003 \\
.0002 \\
.0002\end{array}$ \\
\hline
\end{tabular}

High projections

\begin{tabular}{|c|c|c|c|c|c|c|c|c|c|c|c|c|}
\hline $\begin{array}{l}1950 \ldots \\
1990 \ldots . . . \\
2000 \ldots .\end{array}$ & $\begin{array}{l}6,040 \\
7,560 \\
9,360\end{array}$ & $\begin{array}{r}0.006 \\
.005 \\
.004\end{array}$ & $\begin{array}{l}3,780 \\
4,520 \\
5,390\end{array}$ & $\begin{array}{r}0.415 \\
.336 \\
.278\end{array}$ & $\begin{array}{l}380 \\
480 \\
630\end{array}$ & $\begin{array}{r}0.084 \\
.064 \\
.052\end{array}$ & $\begin{array}{r}790 \\
1,030 \\
1,300\end{array}$ & $\begin{array}{r}0.092 \\
.079 \\
.067\end{array}$ & $\begin{array}{r}860 \\
1,240 \\
1,630\end{array}$ & $\begin{array}{r}0.005 \\
.004 \\
.003\end{array}$ & $\begin{array}{l}230 \\
290 \\
410\end{array}$ & $\begin{array}{r}0.0003 \\
.0002 \\
.0002\end{array}$ \\
\hline
\end{tabular}

1 Includes sporting goods, musical instruments, boat building and repair, toys and games, luggage and trunks, handles, morticians' goods, shoe and boot firdings, and wood matches.

${ }^{2}$ Includes commercial refrigeration, signs and displays, patterns and jigs, truck bodies and trailers, general machinery. agricultural implements, electrical equipment, and testile machinery supplies.

\& All manufactured products except those listed above and products such as pallets, prefabricated wooden buildings, and structural members, containers, mobile homes, millwork, flooring and other similar goods included in the construction and shipping sections of this study.

1967 dollars. Use per dollar of shipments in the 1948-70 period computed by Forest Service. (See table 129 for value of shipments.)
Note: Data may not add to totals because of rounding.

Sources: Lumber use, U.S. Department of Agriculture, Forest Service. 1948-Wood use 1 in manufocture, 1948. Forest Resource Rep, 1951;1960-Wood used in manufacturing industries, 1960 . Statist. Bull. 353, 1965; 1965-Wood used in manufacturing industries, 1965 . Statist. Bull, 440, 1969.1970-Estimates used in ma nufacturing industries, 1965 . Statist. Bull. 440, 1969; 1970-Estimates
based on preliminary value of shipments (table 129) and trends in timber products use per dollar of shipments.

Projections: U.S. Department of Agriculture, Forest Service. 
TABLE 12.-Veneer and plywood (3/8-inch basis) use in manufacturing, by product group, specified years 1948-70, with projections (1970 relative prices) to 2000

\begin{tabular}{|c|c|c|c|c|c|c|c|c|c|c|c|c|}
\hline \multirow{2}{*}{ Year } & \multicolumn{2}{|c|}{ All products } & \multicolumn{2}{|c|}{ Household furniture } & \multicolumn{2}{|c|}{$\begin{array}{c}\text { Commercial and } \\
\text { institutional furniture }\end{array}$} & \multicolumn{2}{|c|}{ Consumer goods 1} & \multicolumn{2}{|c|}{$\begin{array}{c}\text { Commercial and } \\
\text { industrial equipment } 2\end{array}$} & \multicolumn{2}{|c|}{ Other products } \\
\hline & Total & $\begin{array}{l}\text { Per dollar } \\
\text { of ship- } \\
\text { ments } 4\end{array}$ & Total & $\begin{array}{l}\text { Per dollar } \\
\text { of ship- } \\
\text { ments }\end{array}$ & Total & $\begin{array}{l}\text { Per dollar } \\
\text { of ship- } \\
\text { ments }\end{array}$ & Total & $\begin{array}{l}\text { Per dollar } \\
\text { of ship- } \\
\text { ments }\end{array}$ & Total & $\begin{array}{l}\text { Per dollar } \\
\text { of ship- } \\
\text { ments }\end{array}$ & Total & $\begin{array}{l}\text { Per dol- } \\
\text { lar of } \\
\text { ship- } \\
\text { ments }\end{array}$ \\
\hline $\begin{array}{l}1948 \ldots . . \\
1960 \ldots \\
1965 \ldots \\
1970 \ldots\end{array}$ & $\begin{array}{l}\text { Million } \\
\text { square } \\
\text { feet } \\
1,126 \\
1,822 \\
1,562 \\
1,656\end{array}$ & $\begin{array}{c}\text { Square } \\
\text { feet } \\
0.005 \\
.005 \\
.003 \\
.003\end{array}$ & $\begin{array}{l}\text { Million } \\
\text { square } \\
\text { feet } \\
592 \\
877 \\
789 \\
838\end{array}$ & $\begin{array}{c}\text { Square } \\
\text { fect } \\
0.245 \\
.232 \\
.163 \\
.158\end{array}$ & $\begin{array}{l}\text { Million } \\
\text { square } \\
\text { feet } \\
274 \\
342 \\
230 \\
227\end{array}$ & $\begin{array}{c}\text { Square } \\
\text { feet } \\
0.461 \\
.238 \\
.117 \\
.095\end{array}$ & $\begin{array}{l}\text { Million } \\
\text { square } \\
\text { feet } \\
57 \\
246 \\
273 \\
303\end{array}$ & $\begin{array}{c}\text { Square } \\
\text { feet } \\
0.023 \\
.067 \\
.059 \\
.056\end{array}$ & $\begin{array}{l}\text { Million } \\
\text { square } \\
\text { feet } \\
73 \\
75 \\
170 \\
179\end{array}$ & $\begin{array}{l}\text { Square } \\
\text { feet } \\
0.003 \\
.002 \\
.002 \\
.002\end{array}$ & $\begin{array}{l}\text { Million } \\
\text { square } \\
\text { feet } \\
130 \\
282 \\
100 \\
109\end{array}$ & $\begin{array}{l}\text { Square } \\
\text { feet } \\
0.0006 \\
.0009 \\
.0002 \\
.0002\end{array}$ \\
\hline
\end{tabular}

Low projections

\begin{tabular}{|c|c|c|c|c|c|c|c|c|c|c|c|c|}
\hline $\begin{array}{l}1980 \ldots \ldots \\
1990 \ldots \ldots \\
2000 \ldots \ldots\end{array}$ & $\begin{array}{l}2,290 \\
2,950 \\
3,760\end{array}$ & $\begin{array}{r}0.003 \\
.002 \\
.002\end{array}$ & $\begin{array}{l}1,160 \\
1,460 \\
1,780\end{array}$ & $\begin{array}{r}0.140 \\
.128 \\
.116\end{array}$ & $\begin{array}{l}280 \\
330 \\
380\end{array}$ & $\begin{array}{r}0.070 \\
.056 \\
.044\end{array}$ & $\begin{array}{l}380 \\
470 \\
600\end{array}$ & $\begin{array}{r}0.047 \\
.042 \\
.039\end{array}$ & $\begin{array}{l}320 \\
510 \\
750\end{array}$ & $\begin{array}{r}0.002 \\
.002 \\
.002\end{array}$ & $\begin{array}{l}150 \\
180 \\
250\end{array}$ & $\begin{array}{r}0.0002 \\
.0002 \\
.0002\end{array}$ \\
\hline
\end{tabular}

Medium projections

\begin{tabular}{|c|c|c|c|c|c|c|c|c|c|c|c|c|}
\hline $\begin{array}{l}1980 \ldots \ldots \\
1990 \ldots \ldots \\
2000 \ldots \ldots\end{array}$ & $\begin{array}{l}2,400 \\
3,220 \\
4,300\end{array}$ & $\begin{array}{r}0.003 \\
.002 \\
.002\end{array}$ & $\begin{array}{l}1,210 \\
1,570 \\
1,990\end{array}$ & $\begin{array}{r}0.140 \\
.128 \\
.116\end{array}$ & $\begin{array}{l}300 \\
360 \\
440\end{array}$ & $\begin{array}{r}0.070 \\
.056 \\
.044\end{array}$ & $\begin{array}{l}390 \\
510 \\
680\end{array}$ & $\begin{array}{r}0.047 \\
.042 \\
.039\end{array}$ & $\begin{array}{l}340 \\
570 \\
890\end{array}$ & $\begin{array}{r}0.002 \\
.002 \\
.002\end{array}$ & $\begin{array}{l}160 \\
210 \\
300\end{array}$ & $\begin{array}{r}0.0002 \\
.0002 \\
.0002\end{array}$ \\
\hline
\end{tabular}

High projections

\begin{tabular}{|c|c|c|c|c|c|c|c|c|c|c|c|c|}
\hline $\begin{array}{l}1980 \ldots \ldots \\
1990 \ldots \ldots \\
2000 \ldots \ldots\end{array}$ & $\begin{array}{l}2,530 \\
3,570 \\
5,010\end{array}$ & $\begin{array}{r}0.003 \\
.002 \\
.002\end{array}$ & $\begin{array}{l}1,270 \\
1,720 \\
2,270\end{array}$ & $\begin{array}{r}0.140 \\
.128 \\
.116\end{array}$ & $\begin{array}{l}320 \\
420 \\
540\end{array}$ & $\begin{array}{r}0.070 \\
.056 \\
.044\end{array}$ & $\begin{array}{l}410 \\
550 \\
760\end{array}$ & $\begin{array}{r}0.047 \\
.042 \\
.039\end{array}$ & $\begin{array}{r}360 \\
650 \\
1,090\end{array}$ & $\begin{array}{r}0.002 \\
.002 \\
.002\end{array}$ & $\begin{array}{l}170 \\
230 \\
350\end{array}$ & $\begin{array}{r}0.0002 \\
.0002 \\
.0002\end{array}$ \\
\hline
\end{tabular}

'Includes sporting goods, musical instruments, boat building and repair, toys and games, luggage and trunks, handles, morticians' goods, shoe and boot findings, and wood matches.

2 Includes commercial refrigeration, signs and displays, patterns and jigs, truck bodies and trailers, general machinery, agricultural implements, clectrical equipment, and textile machinery supplies.

3 All manufactured products except those listed above and products such as pallets, prefabricated wooden buildings and structural members, containers, mobile homes, millwork, flooring and other similar goods included in the contruction and shipplng sections of this study.

$\$ 1937$ dollars. Use per dollar of shipments in the 1948-70 period computed by Forest Service. (See table 129 for value of shipments.)

Sources: Veneer and plywood use, U.S. Department of Agriculture, Forest Service. 1948-Wood used in manufacture, 1948. Forest Resource Rep.2, 1951; 1960-Wood used in manufacturing industries, 1960. Statist. Bull. 353, 1965; 1965-Wood used in manufacturing industries, 1965. Statis. Bull. 440, 1969: 1970-Estimates based on preliminary value of shipments (table 129) and trends in timber products use per dollar of shipments.

Projections: U.S. Department of Agriculture, Forest Service. 
TABLE 13.-Hardboard (1/s-inch basis) use in manufacturing, by product group, specified years 1960-70, with projections (1970 relative prices) to 2000

\begin{tabular}{|c|c|c|c|c|c|c|c|c|c|c|c|c|}
\hline \multirow{2}{*}{ Year } & \multicolumn{2}{|c|}{ All products } & \multicolumn{2}{|c|}{ Household furniture } & \multicolumn{2}{|c|}{$\begin{array}{l}\text { Commercial and } \\
\text { institutional fumiture }\end{array}$} & \multicolumn{2}{|c|}{ Consumer goods 1} & \multicolumn{2}{|c|}{$\begin{array}{l}\text { Commercial and } \\
\text { industrial equipment } 2\end{array}$} & \multicolumn{2}{|c|}{ Other products } \\
\hline & Total & $\begin{array}{l}\text { Per dollar } \\
\text { of ship: } \\
\text { ments }\end{array}$ & Total & $\begin{array}{l}\text { Per dollar } \\
\text { of ship- } \\
\text { ments }\end{array}$ & Total & $\begin{array}{c}\text { Per dollar } \\
\text { of ship- } \\
\text { ments }\end{array}$ & Total & $\begin{array}{l}\text { Per dollar } \\
\text { of ship- } \\
\text { ments }\end{array}$ & Total & $\begin{array}{l}\text { Per dollar } \\
\text { of ship- } \\
\text { ments }\end{array}$ & Total & $\begin{array}{l}\text { Per dol- } \\
\text { lar of } \\
\text { ship- } \\
\text { ments }\end{array}$ \\
\hline $\begin{array}{l}1960 \ldots \ldots \\
1965 \ldots \ldots \\
1970 \ldots \ldots\end{array}$ & $\begin{array}{l}\text { Minlion } \\
\text { Equare } \\
\text { feet } \\
760 \\
1,135 \\
1,361\end{array}$ & $\begin{array}{l}\text { Square } \\
\text { feet } \\
0.0020 \\
.0023 \\
.0023\end{array}$ & $\begin{array}{l}\text { Million } \\
\text { square } \\
\text { feet } \\
231 \\
526 \\
663\end{array}$ & $\begin{array}{l}\text { Square } \\
\text { feet } \\
0.061 \\
.105 \\
.125\end{array}$ & $\begin{array}{l}\text { Million } \\
\text { square } \\
\text { feet } \\
145 \\
133 \\
127\end{array}$ & $\begin{array}{l}\text { Square } \\
\text { feet } \\
0.101 \\
.070 \\
.053\end{array}$ & $\begin{array}{l}\text { Mullion } \\
\text { square } \\
\text { feet } \\
\\
30 \\
43 \\
48\end{array}$ & $\begin{array}{l}\text { Square } \\
\text { feet } \\
0.012 \\
.009 \\
.009\end{array}$ & $\begin{array}{l}\text { Million } \\
\text { square } \\
\text { feet } \\
\\
58 \\
41 \\
49\end{array}$ & $\begin{array}{l}\text { Square } \\
\text { feet } \\
0.0022 \\
.0006 \\
.0006\end{array}$ & $\begin{array}{l}\text { Million } \\
\text { square } \\
\text { feet } \\
296 \\
387 \\
474\end{array}$ & $\begin{array}{l}\text { Square } \\
\text { feet } \\
0.0009 \\
.0009 \\
.0009\end{array}$ \\
\hline
\end{tabular}

Low projections

\begin{tabular}{|c|c|c|c|c|c|c|c|c|c|c|c|c|}
\hline $\begin{array}{l}19 \$ 0 \ldots \ldots \\
1990 \ldots \ldots \\
2000 \ldots \ldots\end{array}$ & $\begin{array}{l}2,140 \\
3,050 \\
4,230\end{array}$ & $\begin{array}{r}0.0025 \\
.0025 \\
.0025\end{array}$ & $\begin{array}{l}1,140 \\
1,650 \\
2,260\end{array}$ & $\begin{array}{r}0.135 \\
.145 \\
.148\end{array}$ & $\begin{array}{l}150 \\
200 \\
240\end{array}$ & $\begin{array}{r}0.038 \\
.037 \\
.028\end{array}$ & $\begin{array}{r}80 \\
110 \\
150\end{array}$ & $\begin{array}{l}0.009 \\
.009 \\
.010\end{array}$ & $\begin{array}{r}90 \\
140 \\
230\end{array}$ & $\begin{array}{r}0.0006 \\
.0006 \\
.0006\end{array}$ & $\begin{array}{r}680 \\
950 \\
1,350\end{array}$ & $\begin{array}{r}0.0010 \\
.0010 \\
.0011\end{array}$ \\
\hline
\end{tabular}

Medium projections

\begin{tabular}{|c|c|c|c|c|c|c|c|c|c|c|c|c|}
\hline $\begin{array}{l}1950 \ldots . . . \\
1990 \ldots \\
2000 \ldots \ldots\end{array}$ & $\begin{array}{l}2,240 \\
3,350 \\
4,550\end{array}$ & $\begin{array}{r}0.0025 \\
.0025 \\
.0025\end{array}$ & $\begin{array}{l}1,190 \\
1,750 \\
2,510\end{array}$ & $\begin{array}{r}0.135 \\
.145 \\
.148\end{array}$ & $\begin{array}{l}160 \\
220 \\
250\end{array}$ & $\begin{array}{r}0.035 \\
.037 \\
.028\end{array}$ & $\begin{array}{r}80 \\
110 \\
170\end{array}$ & $\begin{array}{r}0.009 \\
.009 \\
.010\end{array}$ & $\begin{array}{l}100 \\
160 \\
270\end{array}$ & $\begin{array}{r}0.0006 \\
.0006 \\
.0006\end{array}$ & $\begin{array}{r}710 \\
1,080 \\
1,590\end{array}$ & $\begin{array}{r}0.0010 \\
.0010 \\
.0011\end{array}$ \\
\hline
\end{tabular}

High projections

\begin{tabular}{|c|c|c|c|c|c|c|c|c|c|c|c|c|}
\hline $\begin{array}{l}1950 \ldots . . . . \\
1990 \ldots . . . \\
2000 \ldots \ldots\end{array}$ & $\begin{array}{l}2,370 \\
3,720 \\
5,650\end{array}$ & $\begin{array}{r}0.0025 \\
.0025 \\
.0025\end{array}$ & $\begin{array}{l}1,250 \\
1,950 \\
2,390\end{array}$ & $\begin{array}{l}0.138 \\
.145 \\
.148\end{array}$ & $\begin{array}{l}170 \\
250 \\
340\end{array}$ & $\begin{array}{r}0.038 \\
.037 \\
.028\end{array}$ & $\begin{array}{r}80 \\
130 \\
190\end{array}$ & $\begin{array}{l}0.009 \\
.009 \\
.010\end{array}$ & $\begin{array}{l}110 \\
190 \\
320\end{array}$ & $\begin{array}{r}0.0006 \\
.0006 \\
.0006\end{array}$ & $\begin{array}{r}760 \\
1,200 \\
1,910\end{array}$ & $\begin{array}{r}0.0010 \\
.0010 \\
.0011\end{array}$ \\
\hline
\end{tabular}

1 Includes sporting goods, musical instruments, boat building and repair. toys and games, luggage and trunks, handles, morticians' goods, shoe and boot findings, and wood matches.

2 Includes commercial refrigeration, signs and displays, patterns and jigs, truck bodies and trailers, general machinery, agricultural implements, elec trical equipment, and textile machinery supplies.

3 All manufactured products except those listed above and products such as pallets, prefabricated wooden buildings and structural members, containers, mobile homes, millwork, flooring and other similar goods included in the construction and shipping sections of this study.
$\$ 1967$ dollars. Use per dollar of shipments in the 1960-70 period computed by Forest Service. (See table 129 for value of shipments.)

Sources: Wood used, C.S. Department of Agriculture, Forest Serrice. $1948-$ Wood used in manufacture 1918. Forest Resource Rep.2, 1951:1960-Wood used in manufacturing industries 1960 . Statist. Bull. 353,$1965 ; 1965-$ Wood used in manufacturing industries, 1965. Statist. Bull. 410, 1969; 1970-Estimates based on preliminary value of shipments (table 129) and trends in timber products use per dollar of shipments.

Projections: C'.S. Department of Agriculture, Forest Service. 
TABLE 14.-Particleboard (3/4-inch basis) use in manufacturing, by product group, specified years 1960-70, with projections (1970 relative prices) to 2000

\begin{tabular}{|c|c|c|c|c|c|c|c|c|c|c|c|c|}
\hline \multirow{2}{*}{ Year } & \multicolumn{2}{|c|}{ All products } & \multicolumn{2}{|c|}{ Household furniture } & \multicolumn{2}{|c|}{$\begin{array}{c}\text { Commerclal and } \\
\text { institutional furniture }\end{array}$} & \multicolumn{2}{|c|}{ - Consumer goods 1} & \multicolumn{2}{|c|}{$\begin{array}{c}\text { Commercial and } \\
\text { industrial equipment } 2\end{array}$} & \multicolumn{2}{|c|}{ Other products ${ }^{3}$} \\
\hline & Total & $\begin{array}{l}\text { Per dollar } \\
\text { of ship- } \\
\text { ments } 1\end{array}$ & Total & $\begin{array}{c}\text { Per dollar } \\
\text { of ship- } \\
\text { ments }\end{array}$ & Total & $\begin{array}{l}\text { Per dollar } \\
\text { of ship- } \\
\text { ments } 4\end{array}$ & Total & $\begin{array}{l}\text { Per dollar } \\
\text { of ship- } \\
\text { ments } 4\end{array}$ & Total & $\begin{array}{l}\text { Per dollar } \\
\text { of ship- } \\
\text { ments }\end{array}$ & Total & $\begin{array}{l}\text { Per dol- } \\
\text { lar of } \\
\text { ship- } \\
\text { ments }\end{array}$ \\
\hline $\begin{array}{l}1960 \ldots \ldots \\
1965 \ldots \ldots \\
1970 \ldots \ldots\end{array}$ & $\begin{array}{l}\text { Million } \\
\text { square } \\
\text { feet } \\
106 \\
476 \\
669\end{array}$ & $\begin{array}{c}\text { Square } \\
\text { feet } \\
0.0003 \\
.0010 \\
.0011\end{array}$ & $\begin{array}{l}\text { Million } \\
\text { square } \\
\text { feet } \\
58 \\
312 \\
427\end{array}$ & $\begin{array}{c}\text { Square } \\
\text { feet } \\
0.0153 \\
.0642 \\
.0800\end{array}$ & $\begin{array}{l}\text { Million } \\
\text { square } \\
\text { feet } \\
34 \\
119 \\
179\end{array}$ & $\begin{array}{l}\text { Square } \\
\text { feet } \\
0.0236 \\
.0605 \\
.0750\end{array}$ & $\begin{array}{l}\text { Million } \\
\text { square } \\
\text { feet } \\
5 \\
10 \\
14\end{array}$ & $\begin{array}{l}\text { Square } \\
\text { feet } \\
0.0014 \\
.0022 \\
.0026\end{array}$ & $\begin{array}{r}\text { Million } \\
\text { square } \\
\text { feet } \\
7 \\
16 \\
19\end{array}$ & $\begin{array}{c}\text { Square } \\
\text { feet } \\
0.0001 \\
.0002 \\
.0002\end{array}$ & $\begin{array}{l}\text { Million } \\
\text { square } \\
\text { feet } \\
2 \\
19 \\
30\end{array}$ & $\begin{array}{c}\text { Square } \\
\text { feet } \\
(8) \\
0.0001 \\
.0001\end{array}$ \\
\hline
\end{tabular}

Low projections

\begin{tabular}{|c|c|c|c|c|c|c|c|c|c|c|c|c|}
\hline $\begin{array}{l}1980 \ldots . . . \\
1990 \ldots \ldots \\
2000 \ldots . . .\end{array}$ & $\begin{array}{l}1,330 \\
2,100 \\
3,090\end{array}$ & $\begin{array}{r}0.0016 \\
.0018 \\
.0019\end{array}$ & $\begin{array}{r}830 \\
1,280 \\
1,840\end{array}$ & $\begin{array}{r}0.1000 \\
.1125 \\
.1200\end{array}$ & $\begin{array}{r}400 \\
660 \\
1,010\end{array}$ & $\begin{array}{r}0.1000 \\
.1123 \\
.1200\end{array}$ & $\begin{array}{l}20 \\
30 \\
50\end{array}$ & $\begin{array}{r}0.0028 \\
.0029 \\
.0030\end{array}$ & $\begin{array}{l}30 \\
50 \\
70\end{array}$ & $\begin{array}{r}0.0002 \\
.0002 \\
.0002\end{array}$ & $\begin{array}{r}50 \\
80 \\
120\end{array}$ & $\begin{array}{r}0.0001 \\
.0001 \\
.0001\end{array}$ \\
\hline
\end{tabular}

Medlum projectlons

\begin{tabular}{|c|c|c|c|c|c|c|c|c|c|c|c|c|}
\hline $\begin{array}{l}1980 \ldots \ldots \\
1990 \ldots \ldots \\
2000 \ldots \ldots\end{array}$ & $\begin{array}{l}1,400 \\
2,300 \\
3,540\end{array}$ & $\begin{array}{r}0.0015 \\
.0017 \\
.0018\end{array}$ & $\begin{array}{r}870 \\
1,380 \\
2,060\end{array}$ & $\begin{array}{r}0.1000 \\
.1125 \\
.1200\end{array}$ & $\begin{array}{r}420 \\
730 \\
1,190\end{array}$ & $\begin{array}{r}0.1000 \\
.1123 \\
.1200\end{array}$ & $\begin{array}{l}20 \\
40 \\
50\end{array}$ & $\begin{array}{r}0.0028 \\
.0029 \\
.0030\end{array}$ & $\begin{array}{l}30 \\
50 \\
90\end{array}$ & $\begin{array}{r}0.0002 \\
.0002 \\
.0002\end{array}$ & $\begin{array}{r}60 \\
100 \\
150\end{array}$ & $\begin{array}{r}0.0001 \\
.0001 \\
.0001\end{array}$ \\
\hline
\end{tabular}

High projections

\begin{tabular}{|c|c|c|c|c|c|c|c|c|c|c|c|c|}
\hline $\begin{array}{l}1980 \ldots . . . \\
1990 \ldots \\
2000 \ldots .\end{array}$ & $\begin{array}{l}1,480 \\
2,560 \\
4,140\end{array}$ & $\begin{array}{r}0.0015 \\
.0017 \\
.0018\end{array}$ & $\begin{array}{r}910 \\
1,510 \\
2,340\end{array}$ & $\begin{array}{r}0.1000 \\
.1125 \\
.1200\end{array}$ & $\begin{array}{r}450 \\
840 \\
1,450\end{array}$ & $\begin{array}{r}0.1000 \\
.1123 \\
.1200\end{array}$ & $\begin{array}{l}20 \\
40 \\
60\end{array}$ & $\begin{array}{r}0.0028 \\
.0029 \\
.0030\end{array}$ & $\begin{array}{r}40 \\
60 \\
110\end{array}$ & $\begin{array}{r}0.0002 \\
.0002 \\
.0002\end{array}$ & $\begin{array}{r}60 \\
110 \\
180\end{array}$ & $\begin{array}{r}0.0001 \\
.0001 \\
.0001\end{array}$ \\
\hline
\end{tabular}

1 Includes sporting goods, musical instruments, boat building and repair, toys and games, luggage and trunks, handles, morticians'goods, shoe and boot toys and games, luggage and tru

2 Includes commercial refrigeration, signs and displays, patterns and jigs,

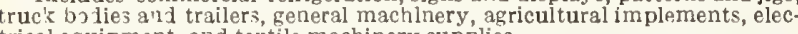
trical equipment, and textile machinery supplies.

3 All manufactured products except those listed above and products such as pallets, prefabricated wooden buildings and structural members, containers, mobile homes, millwork, flooring and other similar goods included in the construction and shipping sections of this study.

1967 dollars. Use per dollar of shipments in the 1948-70 period computed by Forest Service. (See table 129 for value of shipments.)

s Negligible.
Note: Dats may not add to totals because of rounding.

Sources: Wood use, U.S. Department of Agriculture, Forest Service 1948-Wood used in manufacture, 1948. Forest Resource Rep. 2, 1951; 1960Wood used in manufacturing industries, 1966. Statist. Bull. 353, 1965; 1965Wood used in monufacturing industries, 1965 . Statist. Bull. 440, 1969 ; 1970-Estimates based on preliminary value of shipments (table 129) and trends in tlmber products use p 3 r dollar of shipments.

trends in tlmber products use p 3 r dollar of shipments.
Per dollar value of shipments computed by Forest Servlce based on total value of shipments, table 129.

Projections: U.S. Department of Agriculture, Forest Service. 
APPENDIX V. TIMBER DEMAND TABLES

TABLE 15.-Lumber consumption, exports, imports, and domestic productiun, 1920-72

\begin{tabular}{|c|c|c|c|c|c|c|c|c|c|c|c|c|c|}
\hline \multirow{2}{*}{ Year } & \multicolumn{4}{|c|}{ Domestic consumption } & \multicolumn{3}{|c|}{ Exports } & \multicolumn{3}{|c|}{ Imports } & \multicolumn{3}{|c|}{ Domestic production } \\
\hline & Total & $\begin{array}{c}\text { Per } \\
\text { capita }\end{array}$ & $\begin{array}{l}\text { Soft- } \\
\text { woods } 1\end{array}$ & $\begin{array}{l}\text { Hard- } \\
\text { woods }\end{array}$ & Total & $\begin{array}{l}\text { Soft- } \\
\text { woods I }\end{array}$ & $\begin{array}{l}\text { Hard- } \\
\text { woods }\end{array}$ & Total & $\begin{array}{l}\text { Soft- } \\
\text { woods } 1\end{array}$ & $\begin{array}{l}\text { Hard- } \\
\text { woods }\end{array}$ & Total & $\begin{array}{l}\text { Soft- } \\
\text { woods }\end{array}$ & $\begin{array}{l}\text { Hard- } \\
\text { woods }\end{array}$ \\
\hline $\begin{array}{l}1920 \\
1921 \\
1922 \\
1923 \\
1924 \ldots \ldots \ldots\end{array}$ & 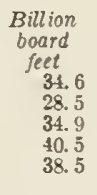 & $\begin{array}{l}\text { Board } \\
\text { feet } \\
325 \\
263 \\
317 \\
362 \\
337\end{array}$ & $\begin{array}{c}\begin{array}{c}\text { Billion } \\
\text { board } \\
\text { feet }\end{array} \\
27.4 \\
23.0 \\
28.8 \\
32.9 \\
30.8\end{array}$ & $\begin{array}{l}\begin{array}{c}\text { Billion } \\
\text { board } \\
\text { feet } \\
7.2 \\
5.5 \\
6.1 \\
7.6 \\
7.7\end{array}\end{array}$ & 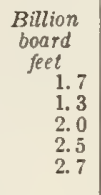 & $\begin{array}{l}\text { Billion } \\
\text { board } \\
\text { feet } \\
1.5 \\
1.2 \\
1.7 \\
2.2 \\
2.4\end{array}$ & $\begin{array}{r}\text { Billion } \\
\text { board } \\
\text { feet } \\
0.2 \\
.1 \\
.3 \\
.3 \\
.3\end{array}$ & $\begin{array}{l}\begin{array}{c}\text { Billion } \\
\text { board } \\
\text { feet }\end{array} \\
1.4 \\
.8 \\
1.6 \\
2.0 \\
1.7\end{array}$ & $\begin{array}{r}\begin{array}{c}\text { Billion } \\
\text { board } \\
\text { feet }\end{array} \\
1.3 \\
.8 \\
1.5 \\
1.9 \\
1.7\end{array}$ & $\begin{array}{r}\text { Billion } \\
\text { board } \\
\text { feet } \\
(2) \\
{ }^{(2)} \\
{ }^{(2)} \\
0.1 \\
.1\end{array}$ & 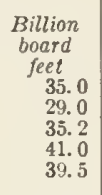 & 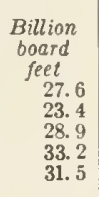 & $\begin{array}{l}\begin{array}{c}\text { Billion } \\
\text { board } \\
\text { feet }\end{array} \\
7.4 \\
5.6 \\
6.3 \\
7.8 \\
8.0\end{array}$ \\
\hline $\begin{array}{l}1925 \ldots \ldots \\
1926 \ldots 27 \\
1927 \\
1925 \\
1929 \ldots \ldots \ldots \ldots\end{array}$ & $\begin{array}{l}40.2 \\
38.8 \\
35.9 \\
35.0 \\
37.1\end{array}$ & $\begin{array}{l}347 \\
330 \\
302 \\
290 \\
305\end{array}$ & $\begin{array}{l}32.8 \\
31.4 \\
29.0 \\
28.5 \\
29.5\end{array}$ & $\begin{array}{l}7.5 \\
7.4 \\
7.0 \\
6.5 \\
7.6\end{array}$ & \begin{tabular}{l|}
2.6 \\
2.8 \\
3.1 \\
3.2 \\
3.2
\end{tabular} & $\begin{array}{l}2.2 \\
2.5 \\
2.6 \\
2.8 \\
2.7\end{array}$ & $\begin{array}{r}.4 \\
.4 \\
.4 \\
.5 \\
.5\end{array}$ & $\begin{array}{l}1.8 \\
1.9 \\
1.7 \\
1.5 \\
1.5\end{array}$ & $\begin{array}{l}1.7 \\
1.8 \\
1.6 \\
1.4 \\
1.4\end{array}$ & $\begin{array}{l}.1 \\
.1 \\
.1 \\
.1 \\
.1\end{array}$ & $\begin{array}{l}41.0 \\
39.8 \\
37.3 \\
36.8 \\
38.7\end{array}$ & $\begin{array}{l}33.3 \\
32.1 \\
30.0 \\
29.9 \\
30.8\end{array}$ & $\begin{array}{l}7.7 \\
7.7 \\
7.3 \\
6.9 \\
7.9\end{array}$ \\
\hline $\begin{array}{l}1930 \ldots \ldots \\
1931 \\
1932 \\
1933 \\
1934 \ldots \ldots \ldots \ldots\end{array}$ & $\begin{array}{l}28.2 \\
19.0 \\
12.7 \\
16.2 \\
17.8\end{array}$ & $\begin{array}{l}229 \\
153 \\
102 \\
130 \\
141\end{array}$ & $\begin{array}{l}22.5 \\
15.2 \\
10.3 \\
13.1 \\
13.8\end{array}$ & $\begin{array}{l}5.8 \\
3.8 \\
2.5 \\
3.1 \\
3.9\end{array}$ & $\begin{array}{l}2.4 \\
1.7 \\
1.2 \\
1.3 \\
1.3\end{array}$ & $\begin{array}{r}1.9 \\
1.4 \\
.9 \\
1.0 \\
1.1\end{array}$ & $\begin{array}{l}.4 \\
.3 \\
.2 \\
.3 \\
.3\end{array}$ & $\begin{array}{r}1.2 \\
.7 \\
.4 \\
.4 \\
.3\end{array}$ & $\begin{array}{r}1.2 \\
.7 \\
.4 \\
.3 \\
.3\end{array}$ & $\begin{array}{l}(2) \\
(2) \\
(2) \\
(2) \\
(2)\end{array}$ & $\begin{array}{l}29.4 \\
20.0 \\
13.5 \\
17.2 \\
18.8\end{array}$ & $\begin{array}{l}23.2 \\
15.9 \\
10.8 \\
13.8 \\
14.6\end{array}$ & $\begin{array}{l}6.1 \\
4.1 \\
2.7 \\
3.4 \\
4.2\end{array}$ \\
\hline $\begin{array}{l}1935 \ldots \ldots \\
1936 \\
1937 \\
1938 \\
1939\end{array}$ & $\begin{array}{l}22.1 \\
27.0 \\
28.2 \\
24.4 \\
28.4\end{array}$ & $\begin{array}{l}173 \\
211 \\
219 \\
188 \\
217\end{array}$ & $\begin{array}{l}17.6 \\
21.6 \\
22.6 \\
19.7 \\
23.1\end{array}$ & $\begin{array}{l}4.5 \\
5.4 \\
5.6 \\
4.7 \\
5.3\end{array}$ & $\begin{array}{l}1.3 \\
1.3 \\
1.4 \\
1.0 \\
1.1\end{array}$ & $\begin{array}{r}1.0 \\
.9 \\
1.1 \\
.7 \\
.8\end{array}$ & $\begin{array}{l}.3 \\
.3 \\
.4 \\
.3 \\
.3\end{array}$ & $\begin{array}{l}.4 \\
.7 \\
.7 \\
.5 \\
.7\end{array}$ & $\begin{array}{l}.4 \\
.6 \\
.6 \\
.5 \\
.6\end{array}$ & $\begin{array}{l}.1 \\
1 \\
1 \\
1 \\
.1\end{array}$ & $\begin{array}{l}22.9 \\
27.6 \\
29.0 \\
24.8 \\
28.8\end{array}$ & $\begin{array}{l}18.2 \\
22.0 \\
23.1 \\
20.0 \\
23.3\end{array}$ & $\begin{array}{l}4.7 \\
5.6 \\
5.9 \\
4.9 \\
5.5\end{array}$ \\
\hline $\begin{array}{l}1940 \ldots \ldots \ldots \\
1941 \\
1942 \\
1943 \\
1944 \ldots \ldots \ldots\end{array}$ & $\begin{array}{l}31.0 \\
37.2 \\
37.4 \\
34.8 \\
33.6\end{array}$ & $\begin{array}{l}234 \\
278 \\
276 \\
254 \\
242\end{array}$ & $\begin{array}{l}25.4 \\
30.5 \\
30.6 \\
27.4 \\
25.7\end{array}$ & $\begin{array}{l}5.5 \\
6.7 \\
6.8 \\
7.4 \\
7.8\end{array}$ & $\begin{array}{r}1.0 \\
.7 \\
.5 \\
.3 \\
.4\end{array}$ & $\begin{array}{l}.8 \\
.5 \\
.4 \\
.2 \\
.3\end{array}$ & $\begin{array}{l}.2 \\
.1 \\
.1 \\
.1 \\
.1\end{array}$ & $\begin{array}{r}.7 \\
1.4 \\
1.5 \\
.9 \\
1.0\end{array}$ & $\begin{array}{r}.6 \\
1.2 \\
1.4 \\
.7 \\
.8\end{array}$ & $\begin{array}{l}.1 \\
.2 \\
.1 \\
.1 \\
.1\end{array}$ & $\begin{array}{l}31.2 \\
36.5 \\
36.3 \\
34.3 \\
32.9\end{array}$ & $\begin{array}{l}25.6 \\
29.9 \\
29.5 \\
26.9 \\
25.2\end{array}$ & $\begin{array}{l}5.5 \\
6.7 \\
6.8 \\
7.4 \\
7.8\end{array}$ \\
\hline $\begin{array}{l}1945 \ldots 10 \\
1946 \ldots \ldots+1 \\
1947 \\
1948 \\
1949\end{array}$ & $\begin{array}{l}28.8 \\
34.7 \\
35.4 \\
38.2 \\
33.1\end{array}$ & $\begin{array}{l}205 \\
244 \\
244 \\
260 \\
221\end{array}$ & $\begin{array}{l}21.7 \\
26.3 \\
27.9 \\
30.7 \\
27.4\end{array}$ & $\begin{array}{l}7.0 \\
8.4 \\
7.5 \\
7.5 \\
5.7\end{array}$ & $\begin{array}{r}.4 \\
.6 \\
1.4 \\
.6 \\
.7\end{array}$ & $\begin{array}{r}.3 \\
.6 \\
1.2 \\
.6 \\
.5\end{array}$ & $\begin{array}{l}.1 \\
.1 \\
.2 \\
.1 \\
.1\end{array}$ & $\begin{array}{l}1.1 \\
1.2 \\
1.3 \\
1.9 \\
1.6\end{array}$ & $\begin{array}{l}.9 \\
1.0 \\
1.1 \\
1.7 \\
1.4\end{array}$ & $\begin{array}{l}.2 \\
.2 \\
.2 \\
.2 \\
.1\end{array}$ & $\begin{array}{l}28.1 \\
34.1 \\
35.4 \\
37.0 \\
32.2\end{array}$ & $\begin{array}{l}21.1 \\
25.9 \\
27.9 \\
29.6 \\
26.5\end{array}$ & $\begin{array}{l}7.0 \\
8.3 \\
7.5 \\
7.4 \\
5.7\end{array}$ \\
\hline $\begin{array}{l}1950 \\
1951 \\
1952 \\
1953 \\
1954 \ldots \ldots\end{array}$ & $\begin{array}{l}40.9 \\
38.7 \\
39.2 \\
38.9 \\
38.7\end{array}$ & $\begin{array}{l}269 \\
250 \\
249 \\
243 \\
237\end{array}$ & $\begin{array}{l}33.4 \\
30.9 \\
31.9 \\
31.6 \\
31.5\end{array}$ & $\begin{array}{l}7.5 \\
7.8 \\
7.3 \\
7.3 \\
7.1\end{array}$ & $\begin{array}{r}.5 \\
1.0 \\
.7 \\
.6 \\
.7\end{array}$ & $\begin{array}{l}.4 \\
.9 \\
.6 \\
.5 \\
.6\end{array}$ & $\begin{array}{l}.1 \\
.1 \\
.2 \\
.1 \\
.1\end{array}$ & $\begin{array}{l}3.4 \\
2.5 \\
2.5 \\
2.8 \\
3.1\end{array}$ & $\begin{array}{l}3.1 \\
2.3 \\
2.3 \\
2.5 \\
2.9\end{array}$ & $\begin{array}{l}.3 \\
.3 \\
.2 \\
.2 \\
.2\end{array}$ & $\begin{array}{l}38.0 \\
37.2 \\
37.5 \\
36.7 \\
36.4\end{array}$ & $\begin{array}{l}30.6 \\
29.5 \\
30.2 \\
29.6 \\
29.3\end{array}$ & $\begin{array}{l}7.4 \\
7.7 \\
7.2 \\
7.2 \\
7.1\end{array}$ \\
\hline $\begin{array}{l}1955 \ldots \ldots \\
1956 \ldots \ldots \\
1957 \\
1958 \\
1959\end{array}$ & $\begin{array}{l}40.1 \\
40.9 \\
35.0 \\
36.1 \\
40.5\end{array}$ & $\begin{array}{l}242 \\
242 \\
204 \\
206 \\
228\end{array}$ & $\begin{array}{l}32.5 \\
32.8 \\
29.2 \\
30.0 \\
33.7\end{array}$ & $\begin{array}{l}7.6 \\
8.1 \\
5.8 \\
6.1 \\
6.8\end{array}$ & $\begin{array}{l}.8 \\
.8 \\
.8 \\
.7 \\
.8\end{array}$ & $\begin{array}{l}.7 \\
.6 \\
.6 \\
.6 \\
.6\end{array}$ & $\begin{array}{l}.2 \\
.2 \\
.2 \\
.2 \\
.2\end{array}$ & $\begin{array}{l}3.6 \\
3.4 \\
3.0 \\
3.4 \\
4.1\end{array}$ & $\begin{array}{l}3.3 \\
3.2 \\
2.7 \\
3.2 \\
3.8\end{array}$ & $\begin{array}{l}.3 \\
.3 \\
.2 \\
.2 \\
.3\end{array}$ & $\begin{array}{l}37.4 \\
38.2 \\
32.9 \\
33.4 \\
37.2\end{array}$ & $\begin{array}{l}29.8 \\
30.2 \\
27.1 \\
27.4 \\
30.5\end{array}$ & $\begin{array}{l}7.6 \\
8.0 \\
5.8 \\
6.0 \\
6.7\end{array}$ \\
\hline $\begin{array}{l}1960 \ldots 1 \\
1961 \\
1962 \\
1963 \\
1964 \ldots \ldots \ldots \ldots\end{array}$ & $\begin{array}{l}36.0 \\
35.5 \\
37.3 \\
39.2 \\
40.8\end{array}$ & $\begin{array}{l}199 \\
193 \\
200 \\
207 \\
213\end{array}$ & $\begin{array}{l}29.6 \\
29.5 \\
30.8 \\
31.8 \\
33.4\end{array}$ & $\begin{array}{l}6.4 \\
6.0 \\
6.5 \\
7.3 \\
7.4\end{array}$ & $\begin{array}{r}.9 \\
.8 \\
.8 \\
.9 \\
1.0\end{array}$ & $\begin{array}{l}.7 \\
.6 \\
.6 \\
.7 \\
.8\end{array}$ & $\begin{array}{l}.2 \\
.2 \\
.1 \\
.1 \\
.1\end{array}$ & $\begin{array}{l}3.9 \\
4.3 \\
4.9 \\
5.3 \\
5.2\end{array}$ & $\begin{array}{l}3.6 \\
4.0 \\
4.6 \\
5.0 \\
4.9\end{array}$ & $\begin{array}{l}.3 \\
.2 \\
.3 \\
.3 \\
.3\end{array}$ & $\begin{array}{l}32.9 \\
32.0 \\
33.2 \\
34.7 \\
36.6\end{array}$ & $\begin{array}{l}26.7 \\
26.1 \\
26.8 \\
27.6 \\
29.3\end{array}$ & $\begin{array}{l}6.3 \\
6.0 \\
6.4 \\
7.2 \\
7.3\end{array}$ \\
\hline $\begin{array}{l}1965 \\
1966 \\
1967 \\
1968 \\
1969\end{array}$ & $\begin{array}{l}41.1 \\
40.8 \\
38.8 \\
41.5 \\
41.0\end{array}$ & $\begin{array}{l}212 \\
207 \\
195 \\
207 \\
202\end{array}$ & $\begin{array}{l}33.4 \\
32.8 \\
31.1 \\
34.0 \\
33.2\end{array}$ & $\begin{array}{l}7.7 \\
8.0 \\
7.6 \\
7.4 \\
7.8\end{array}$ & $\begin{array}{l}.9 \\
1.0 \\
1.1 \\
1.2 \\
1.1\end{array}$ & $\begin{array}{r}.8 \\
.9 \\
1.0 \\
1.0 \\
1.0\end{array}$ & $\begin{array}{l}.1 \\
.2 \\
.2 \\
.1 \\
.1\end{array}$ & $\begin{array}{l}5.2 \\
5.2 \\
5.1 \\
6.2 \\
6.3\end{array}$ & $\begin{array}{l}4.9 \\
4.8 \\
4.8 \\
5.8 \\
5.9\end{array}$ & $\begin{array}{l}.3 \\
.4 \\
.3 \\
.3 \\
.4\end{array}$ & $\begin{array}{l}36.8 \\
36.6 \\
34.7 \\
36.5 \\
35.8\end{array}$ & $\begin{array}{l}29.3 \\
28.8 \\
27.3 \\
29.3 \\
28.3\end{array}$ & $\begin{array}{l}7.5 \\
7.7 \\
7.4 \\
7.2 \\
7.5\end{array}$ \\
\hline 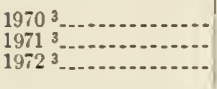 & $\begin{array}{l}39.5 \\
43.5 \\
47.4\end{array}$ & $\begin{array}{l}192 \\
208 \\
227\end{array}$ & $\begin{array}{l}32.1 \\
36.3 \\
40.0\end{array}$ & $\begin{array}{l}7.3 \\
7.1 \\
7.4\end{array}$ & $\begin{array}{l}1.3 \\
1.1 \\
1.5\end{array}$ & $\begin{array}{r}1.2 \\
.9 \\
1.2\end{array}$ & $\begin{array}{l}.1 \\
.2 \\
.3\end{array}$ & $\begin{array}{l}6.1 \\
7.6 \\
9.4\end{array}$ & $\begin{array}{l}5.8 \\
7.2 \\
9.0\end{array}$ & $\begin{array}{l}.3 \\
.4 \\
.4\end{array}$ & $\begin{array}{l}34.7 \\
37.0 \\
39.4\end{array}$ & $\begin{array}{l}27.5 \\
30.0 \\
32.2\end{array}$ & $\begin{array}{l}7.1 \\
6.9 \\
7.2\end{array}$ \\
\hline
\end{tabular}

1 Includes small volumes of mixed species (not classified as softwoods or hardwoods).

2 Less than 50 million board feet.

3 Preliminary, Forest Service estimates.

Note: Data may not add to totals because of rounding.
Sources: U.S. Department of Commerce, Bureau of the Census. Production-Lumber production and mill stocks. Curr. Ind. Reps. Ser. MA-24T (annual); Exports-U.S. expcrts-schedule B commodity and country. FT 410 (monthly); Imports-U.S. imports-general and consumption, schedule $A$ commodity and country. FT 135 (monthly). 
TABLE 16.-Plywood consumption, exports, imports, and domestic production, 1950-72

$[3 / 8$-inch basis]

\begin{tabular}{|c|c|c|c|c|c|c|c|c|c|c|c|c|c|}
\hline \multirow{2}{*}{ Year } & \multicolumn{4}{|c|}{ Domestic consumption } & \multicolumn{3}{|c|}{ Exports } & \multicolumn{3}{|c|}{ Imports } & \multicolumn{3}{|c|}{ Domestic production } \\
\hline & Total & $\begin{array}{c}\text { Per } \\
\text { capita }\end{array}$ & $\begin{array}{l}\text { Soft- } \\
\text { woods }\end{array}$ & $\begin{array}{l}\text { Hard- } \\
\text { woods }\end{array}$ & Total & $\begin{array}{l}\text { Soft- } \\
\text { woods }\end{array}$ & $\begin{array}{c}\text { Hard- } \\
\text { woods } 2\end{array}$ & Total & $\begin{array}{c}\text { Soft- } \\
\text { woods }\end{array}$ & $\begin{array}{l}\text { Hard- } \\
\text { woods }\end{array}$ & Total & $\begin{array}{c}\text { Soft- } \\
\text { woods }\end{array}$ & $\begin{array}{l}\text { Hard- } \\
\text { woods }\end{array}$ \\
\hline 1950 & $\begin{array}{l}\text { Million } \\
\text { square } \\
\text { feet }\end{array}$ & $\begin{array}{c}\text { Square } \\
\text { feet }\end{array}$ & $\begin{array}{c}\text { Million } \\
\text { square } \\
\text { feet } \\
2,672\end{array}$ & $\begin{array}{l}\text { Million } \\
\text { square } \\
\text { feet }\end{array}$ & $\begin{array}{l}\text { Million } \\
\text { square } \\
\text { feet }\end{array}$ & $\begin{array}{l}\text { Million } \\
\text { square } \\
\text { feet }\end{array}$ & $\begin{array}{l}\text { Million } \\
\text { square } \\
\text { feet } \\
(3)\end{array}$ & $\begin{array}{l}\text { Million } \\
\text { square } \\
\text { feet } \\
{ }_{45}\end{array}$ & $\begin{array}{l}\text { Million } \\
\text { square } \\
\text { feet } \\
(3)\end{array}$ & $\begin{array}{l}\text { Million } \\
\text { square } \\
\text { feet }_{45}\end{array}$ & $\begin{array}{l}\text { Million } \\
\text { square } \\
\text { feet }\end{array}$ & $\begin{array}{l}\text { Million } \\
\text { square } \\
\text { feet } \\
2,676\end{array}$ & $\begin{array}{l}\text { Million } \\
\text { square } \\
\text { feet }\end{array}$ \\
\hline $1951-$ & 4,241 & 27 & 2,995 & 1,245 & 4 & 4 & 1 & 53 & 4 & 49 & 4,192 & 2,995 & 1,197 \\
\hline $1952 \ldots$ & 4,450 & 28 & 3,166 & 1,284 & 13 & 13 & & 60 & & 60 & 4,403 & 3,178 & 1.224 \\
\hline $1953 \ldots$ & $\begin{array}{l}5,222 \\
5,405\end{array}$ & $\begin{array}{l}33 \\
33\end{array}$ & $\begin{array}{l}3,839 \\
3,983\end{array}$ & $\begin{array}{l}1,383 \\
1,422\end{array}$ & $\begin{array}{r}10 \\
7\end{array}$ & $\begin{array}{r}10 \\
7\end{array}$ & $\begin{array}{l}1 \\
1\end{array}$ & $\begin{array}{l}156 \\
306\end{array}$ & $\begin{array}{l}(3) \\
(3)\end{array}$ & $\begin{array}{l}155 \\
306\end{array}$ & $\begin{array}{l}5,076 \\
5,106\end{array}$ & $\begin{array}{l}3,848 \\
3,089\end{array}$ & $\begin{array}{l}i, 228 \\
1,116\end{array}$ \\
\hline $1955 \ldots$ & & 43 & 5,276 & 1,795 & 10 & 8 & 2 & 443 & (a) & 442 & 6. 639 & 5. 28.4 & \\
\hline & 262 & 43 & 5,418 & 1,8 & 16 & 15 & 1 & 498 & & 498 & $\begin{array}{l}6,7 \\
6,7\end{array}$ & 5,4 & $\begin{array}{l}1,347 \\
1,345\end{array}$ \\
\hline 1957 & 7,412 & 43 & 5,639 & 1,773 & 15 & 15 & 1 & 597 & (3) & 597 & 6,830 & 5,653 & 1,177 \\
\hline$\ldots . .$. & 8,267 & 47 & 6,475 & 1,792 & 14 & 12 & 2 & 643 & (3) & 643 & 7,638 & 6,487 & 1,151 \\
\hline $1959 \ldots$ & 9,945 & 56 & 7,664 & 2,281 & 75 & 72 & 3 & 938 & & 938 & 9,082 & 7,736 & 1,346 \\
\hline 1960 . & 9,571 & 53 & 7,757 & 1,814 & 15 & 13 & 2 & 725 & 11 & 715 & 8,861 & 7,759 & 1,102 \\
\hline 1961 . & 10,523 & 57 & 8,495 & 2,02 & 17 & 14 & 3 & 739 & 13 & 727 & 9,801 & 8,496 & 1,305 \\
\hline 1962 & 11,716 & 63 & 9,311 & 2,40 & 19 & 17 & 2 & 903 & 13 & 891 & 10,831 & 9,315 & 1,516 \\
\hline & 12,984 & 69 & 10,367 & 2,617 & 19 & 18 & 1 & 945 & 10 & 935 & 12,058 & 10,375 & 1,683 \\
\hline $1964 \ldots$ & 14,380 & 75 & 11,431 & 2,949 & 31 & 28 & 2 & 1,045 & 5 & 1,040 & 13,366 & 11,455 & 1,912 \\
\hline $1965 \ldots$ & 15,492 & 80 & 12,402 & 3,090 & 37 & 30 & 6 & 1,052 & 5 & 1,047 & 14,477 & 12,428 & 2,049 \\
\hline 1966 & 16,126 & 82 & 12,804 & 3,321 & 56 & 48 & $\begin{array}{l}8 \\
8\end{array}$ & 1,257 & 3 & 1,254 & 14,925 & 12,849 & 2,076 \\
\hline 1967 - & $\begin{array}{l}15,909 \\
18,213\end{array}$ & $\begin{array}{l}80 \\
91\end{array}$ & $\begin{array}{l}12,758 \\
14\end{array}$ & $\begin{array}{l}3,152 \\
3,889\end{array}$ & 93 & 85 & 8 & 1,247 & 3 & 1,244 & 14,756 & 12,840 & 1,916 \\
\hline . & $\begin{array}{l}18,213 \\
17,314\end{array}$ & $\begin{array}{l}91 \\
85\end{array}$ & $\begin{array}{l}14,332 \\
13,354\end{array}$ & $\begin{array}{l}3,882 \\
3,960\end{array}$ & $\begin{array}{r}78 \\
215\end{array}$ & $\begin{array}{r}64 \\
199\end{array}$ & $\begin{array}{l}14 \\
16\end{array}$ & $\begin{array}{l}1,896 \\
2,121\end{array}$ & 10 & $\begin{array}{l}1,886 \\
2,107\end{array}$ & 16,395 & $\begin{array}{l}14,385 \\
53\end{array}$ & $\begin{array}{l}2,009 \\
1,869\end{array}$ \\
\hline 1970 & & & 年 & & 172 & 114 & & & & & & 10, , voo & 1,008 \\
\hline $\begin{array}{l}1970 \\
1971\end{array}$ & $\begin{array}{l}16,822 \\
20,722\end{array}$ & 100 & $\begin{array}{l}14,050 \\
16,262\end{array}$ & $\begin{array}{l}3,63 t \\
4,4 m\end{array}$ & 114 & $\begin{array}{r}117 \\
99\end{array}$ & 15 & 2,548 & $\frac{2}{3}$ & $\begin{array}{l}2,047 \\
2,545\end{array}$ & $\begin{array}{l}15,945 \\
18,288\end{array}$ & $\begin{array}{l}14,149 \\
16,858\end{array}$ & $\begin{array}{l}1,796 \\
1,930\end{array}$ \\
\hline 19724 & 23,455 & 112 & 18,089 & 5,3 & 247 & 220 & 26 & 3,162 & 6 & 3,156 & 20,540 & 18,303 & 2,237 \\
\hline
\end{tabular}

1 Includes production from both domestic and imported vi eer.

2 Includes mired species (not classified as hardwoods or soft oods).

3 Less than 500,000 square feet.

4 Preliminary, Forest Service estimates.

Note: Data may not add to totals because of rounding.

Sources: U.S. Department of Commerce, Bureau of the Census. Produc-

tion-Softwood plywood. Curr. Ind. Reps. Ser. MA24H (annual); Hardwood plywood. Curr. Ind. Reps. Ser. MA24F (annual); Exports-U.S. exports- schedule $B$ commodity and country. FT 410 (monthly); Imports-U.S. imports-general and consumption, schcdule A commodity and country. FT 135 (monthly). 
APPENDIX V. TIMBER DEMAND TABLES

TABLE 17.-Apparent ccnsumption, exports, imports, and domestic production of paper and board, 1920-72 1

\begin{tabular}{|c|c|c|c|c|c|c|c|c|c|c|c|}
\hline \multirow{2}{*}{ Year } & \multicolumn{2}{|c|}{$\begin{array}{c}\text { Apparent } \\
\text { consumption }\end{array}$} & \multirow{2}{*}{ Exports } & \multirow{2}{*}{ Imports } & \multirow{2}{*}{$\begin{array}{l}\text { Domestic } \\
\text { production }\end{array}$} & \multirow{2}{*}{ Year } & \multicolumn{2}{|c|}{$\begin{array}{c}\text { Apparent } \\
\text { consumption }\end{array}$} & \multirow{2}{*}{ Exports } & \multirow{2}{*}{ Imports } & \multirow{2}{*}{$\begin{array}{l}\text { Domestic } \\
\text { production }\end{array}$} \\
\hline & Total & $\begin{array}{l}\text { Per } \\
\text { capita }\end{array}$ & & & & & Total & $\begin{array}{l}\text { Per } \\
\text { capita }\end{array}$ & & & \\
\hline $\begin{array}{l}1920 \ldots \ldots \ldots \\
1921 \ldots \ldots \ldots \\
1922 \\
1923 \ldots \ldots \ldots \\
1921 \ldots \ldots\end{array}$ & $\begin{array}{c}\text { Thousend } \\
\text { tans } \\
7,744 \\
6,061 \\
7,575 \\
9,205 \\
9,298\end{array}$ & $\begin{array}{r}\text { Pounds } \\
145 \\
112 \\
143 \\
164 \\
163\end{array}$ & $\begin{array}{l}\text { Thousand } \\
\text { tons } \\
219 \\
91 \\
90 \\
86 \\
91\end{array}$ & $\begin{array}{r}\text { Thousand } \\
\text { tons } \\
778 \\
819 \\
1,099 \\
1,423 \\
1,459\end{array}$ & 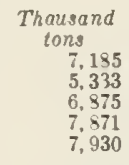 & $\begin{array}{l}1915 \ldots \\
1915 \ldots \\
1917 \ldots \ldots \\
1919 \ldots \ldots \\
1919 \ldots \ldots\end{array}$ & $\begin{array}{c}\text { Thousand } \\
\text { tons } \\
19,827 \\
22,550 \\
24,775 \\
26,070 \\
24,781\end{array}$ & $\begin{array}{r}\text { Paunds } \\
253 \\
319 \\
311 \\
356 \\
332\end{array}$ & $\begin{array}{r}\text { Thousand } \\
\text { tons } \\
396 \\
305 \\
352 \\
295 \\
295\end{array}$ & $\begin{array}{r}\text { Thousand } \\
\text { tons } \\
2,751 \\
3,622 \\
4,116 \\
4,575 \\
4,746\end{array}$ & $\begin{array}{l}\text { Thousand } \\
\text { tons } \\
17,371 \\
19,278 \\
21,114 \\
21,897 \\
20,315\end{array}$ \\
\hline $\begin{array}{l}1925 \ldots \ldots \\
1926 \ldots \ldots \\
1927 \\
1928 \ldots \ldots \\
1929 \ldots \ldots\end{array}$ & $\begin{array}{l}10,437 \\
11,607 \\
11,951 \\
12,459 \\
13,421\end{array}$ & $\begin{array}{l}180 \\
198 \\
201 \\
207 \\
220\end{array}$ & $\begin{array}{r}92 \\
117 \\
113 \\
136 \\
179\end{array}$ & $\begin{array}{l}1,528 \\
1,930 \\
2,055 \\
2,222 \\
2,485\end{array}$ & $\begin{array}{r}9,002 \\
9,791 \\
10,002 \\
10,103 \\
11,110\end{array}$ & $\begin{array}{l}1950 \\
1951 \\
1952 \\
1953 \\
1951\end{array}$ & $\begin{array}{l}29,109 \\
30,530 \\
25,971 \\
31,520 \\
31,516\end{array}$ & $\begin{array}{l}392 \\
394 \\
369 \\
391 \\
397\end{array}$ & $\begin{array}{l}297 \\
529 \\
199 \\
353 \\
591\end{array}$ & $\begin{array}{l}4,999 \\
5,139 \\
5,173 \\
5,215 \\
5,182\end{array}$ & $\begin{array}{l}24,375 \\
26,047 \\
24,418 \\
26,605 \\
26,876\end{array}$ \\
\hline $\begin{array}{l}1930 \ldots \ldots \\
1931 \ldots \ldots \ldots \\
1932 \ldots \ldots \\
1933 \ldots \ldots \ldots \\
1934 \ldots \ldots \ldots\end{array}$ & $\begin{array}{r}12,310 \\
11,400 \\
9,803 \\
10,569 \\
11,201\end{array}$ & $\begin{array}{l}201 \\
154 \\
157 \\
173 \\
177\end{array}$ & $\begin{array}{r}160 \\
121 \\
85 \\
98 \\
127\end{array}$ & $\begin{array}{l}2,326 \\
2,105 \\
1,527 \\
1,825 \\
2,250\end{array}$ & $\begin{array}{r}10,169 \\
9,332 \\
7,993 \\
9,190 \\
9,187\end{array}$ & $\begin{array}{l}1955 \ldots \\
1955 \ldots \ldots \\
1957 \\
1955 \ldots \ldots \\
1959 \ldots \ldots\end{array}$ & $\begin{array}{l}34,979 \\
36,396 \\
35,290 \\
35,248 \\
38,793\end{array}$ & $\begin{array}{l}422 \\
431 \\
410 \\
403 \\
436\end{array}$ & $\begin{array}{l}736 \\
669 \\
751 \\
728 \\
793\end{array}$ & $\begin{array}{l}5,463 \\
5,814 \\
5,433 \\
5,120 \\
5,579\end{array}$ & $\begin{array}{l}30,178 \\
31,441 \\
30,666 \\
30,823 \\
31,036\end{array}$ \\
\hline $\begin{array}{l}1935 \\
1936 \\
1937 \\
1935 \ldots \ldots \ldots \\
1939 \ldots \ldots \\
\end{array}$ & $\begin{array}{l}12,820 \\
11,652 \\
15,653 \\
13,951 \\
15,982\end{array}$ & $\begin{array}{l}301 \\
229 \\
243 \\
215 \\
244\end{array}$ & $\begin{array}{l}139 \\
137 \\
177 \\
156 \\
193\end{array}$ & $\begin{array}{l}2,438 \\
2,832 \\
3,401 \\
2,336 \\
2,653\end{array}$ & $\begin{array}{l}10,479 \\
11,976 \\
12,337 \\
11,381 \\
13,510\end{array}$ & $\begin{array}{l}1950 \ldots \ldots \\
1961 \ldots \ldots \\
1952 \ldots \ldots \\
1953 \ldots \ldots \\
1951 \ldots \ldots\end{array}$ & $\begin{array}{l}39,295 \\
40,461 \\
42.345 \\
43,913 \\
46,518\end{array}$ & $\begin{array}{l}435 \\
440 \\
451 \\
464 \\
485\end{array}$ & $\begin{array}{r}897 \\
1,012 \\
1,001 \\
1,149 \\
1,493\end{array}$ & $\begin{array}{l}5,715 \\
5,751 \\
5,821 \\
5,762 \\
6,351\end{array}$ & $\begin{array}{l}34,441 \\
35,698 \\
37,543 \\
39,231 \\
41,703\end{array}$ \\
\hline $\begin{array}{l}1940 \ldots \ldots \ldots \\
1941 \ldots \ldots \ldots \\
1942 \ldots \ldots \ldots \\
1943 \ldots \ldots \ldots \\
1944 \ldots \ldots\end{array}$ & $\begin{array}{l}16,700 \\
20,356 \\
19,731 \\
19,611 \\
19,510\end{array}$ & $\begin{array}{l}254 \\
306 \\
293 \\
237 \\
252\end{array}$ & $\begin{array}{l}490 \\
399 \\
264 \\
255 \\
254\end{array}$ & $\begin{array}{l}2,812 \\
3,055 \\
3,036 \\
2,717 \\
2,574\end{array}$ & $\begin{array}{l}14,451 \\
17,762 \\
17,051 \\
17,036 \\
17,183\end{array}$ & $\begin{array}{l}1965 \\
1956 \\
1967 \\
1955 \\
1969\end{array}$ & $\begin{array}{l}49,244 \\
52,640 \\
52,075 \\
55,798 \\
59,001\end{array}$ & $\begin{array}{l}507 \\
536 \\
524 \\
555 \\
552\end{array}$ & $\begin{array}{l}1,610 \\
1,813 \\
1,956 \\
2,467 \\
2,603\end{array}$ & $\begin{array}{l}6,770 \\
7,481 \\
7,071 \\
7,007 \\
7,419\end{array}$ & $\begin{array}{l}44,091 \\
47,113 \\
46,926 \\
51,245 \\
51,187\end{array}$ \\
\hline & & & & & & 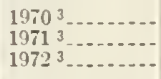 & $\begin{array}{l}58,050 \\
59,672 \\
61,322\end{array}$ & $\begin{array}{l}567 \\
577 \\
616\end{array}$ & $\begin{array}{l}2,698 \\
2,996 \\
2,999\end{array}$ & $\begin{array}{l}7,238 \\
7,581 \\
7,994\end{array}$ & $\begin{array}{l}53,516 \\
55,092 \\
59,313\end{array}$ \\
\hline
\end{tabular}

1 Data may not add to totals because of rounding.

2 Includes changes in newsprint stccks beginning in 1929.

3 Preliminary.

ed. and 1972 sup.), and Manthly statistical summary. New York; U.S. Department of Commerce, Bureau of the Census. Pulp, paper and baard. Cur. Indus. Reps. Ser. M26A. (annual); U.S. Department of Commerce, Bureau of Domestic Commerce. Pulp, paper and board. Quart. Indus. Rep.; and U.S. Department of Agriculture, Forest Service. 
TABLE 18.-Apparent consumption, exports, imports, and domestic production of paper, 1920-721

\begin{tabular}{|c|c|c|c|c|c|c|c|c|c|c|c|}
\hline \multirow{2}{*}{ Year } & \multicolumn{2}{|c|}{$\begin{array}{c}\text { Apparent } \\
\text { consumption } 2\end{array}$} & \multirow{2}{*}{ Exports } & \multirow{2}{*}{ Imports } & \multirow{2}{*}{$\begin{array}{c}\text { Domestic } \\
\text { production }\end{array}$} & \multirow{2}{*}{ Year } & \multicolumn{2}{|c|}{$\begin{array}{c}\text { Apparent } \\
\text { consumption } 2\end{array}$} & \multirow{2}{*}{ Exports } & \multirow{2}{*}{ Imports } & \multirow{2}{*}{$\begin{array}{c}\text { Domestic } \\
\text { production }\end{array}$} \\
\hline & Total & $\begin{array}{l}\text { Per } \\
\text { capita }\end{array}$ & & & & & Total & $\begin{array}{l}\text { Per } \\
\text { capita }\end{array}$ & & & \\
\hline $\begin{array}{l}1920 \ldots \ldots \\
1921 \\
1922 \\
1924\end{array}$ & $\begin{array}{r}\text { Thousand } \\
\text { tons } \\
5,448 \\
4,327 \\
5,717 \\
6,397 \\
6,435\end{array}$ & $\begin{array}{r}\text { Pounds } \\
102 \\
80 \\
104 \\
114 \\
113\end{array}$ & $\begin{array}{r}\text { Thousand } \\
\text { tons } \\
158 \\
66 \\
67 \\
52 \\
50\end{array}$ & $\begin{array}{r}\text { Thousand } \\
\text { tons } \\
735 \\
799 \\
1,066 \\
1,372 \\
1,404\end{array}$ & $\begin{array}{r}\text { Thousand } \\
\text { tons } \\
4,872 \\
3,594 \\
4,719 \\
5,078 \\
5,080\end{array}$ & $\begin{array}{l}1945 \\
1946 \\
1947 \\
1948 \\
1949\end{array}$ & $\begin{array}{c}\text { Thousand } \\
\text { tons } \\
11,004 \\
13,091 \\
14,445 \\
15,350 \\
14,859\end{array}$ & $\begin{array}{r}\text { Pounds } \\
157 \\
185 \\
200 \\
209 \\
199\end{array}$ & $\begin{array}{r}\text { Thousand } \\
\text { tons } \\
255 \\
217 \\
214 \\
161 \\
181\end{array}$ & $\begin{array}{r}\text { Thousand } \\
\text { tons } \\
2,700 \\
3,680 \\
4,057 \\
4,500 \\
4,676\end{array}$ & $\begin{array}{r}\text { Thousand } \\
\text { ions } \\
8,457 \\
9,773 \\
10,705 \\
11,119 \\
10,350\end{array}$ \\
\hline $\begin{array}{l}1925 \ldots \ldots \\
1926 \ldots \ldots \\
1927 \\
1928 \ldots \ldots \ldots \\
1929 \ldots \ldots \ldots\end{array}$ & $\begin{array}{l}7,131 \\
7,956 \\
8,188 \\
8,455 \\
9,101\end{array}$ & $\begin{array}{l}123 \\
136 \\
138 \\
140 \\
149\end{array}$ & $\begin{array}{l}60 \\
63 \\
57 \\
70 \\
93\end{array}$ & $\begin{array}{l}1,476 \\
1,875 \\
2,016 \\
2,184 \\
2,445\end{array}$ & $\begin{array}{l}5,715 \\
6,144 \\
6,228 \\
6,342 \\
6,776\end{array}$ & $\begin{array}{l}1950 \\
1951 \\
1952 \\
1953 \\
1954\end{array}$ & $\begin{array}{l}16,833 \\
17,630 \\
16,839 \\
17,724 \\
17,873\end{array}$ & $\begin{array}{l}221 \\
228 \\
214 \\
221 \\
219\end{array}$ & $\begin{array}{l}175 \\
277 \\
326 \\
189 \\
326\end{array}$ & $\begin{array}{l}4,913 \\
5,025 \\
5,090 \\
5,091 \\
5,073\end{array}$ & $\begin{array}{l}12,064 \\
13,010 \\
12,197 \\
12,739 \\
13,077\end{array}$ \\
\hline $\begin{array}{l}1930 \ldots \ldots \\
1931 \\
1932 \\
1933 \ldots \ldots \ldots \\
1934 \ldots \ldots \ldots\end{array}$ & $\begin{array}{l}8,416 \\
7,671 \\
6,587 \\
6,893 \\
7,219\end{array}$ & $\begin{array}{l}137 \\
124 \\
106 \\
110 \\
114\end{array}$ & $\begin{array}{l}76 \\
55 \\
41 \\
49 \\
75\end{array}$ & $\begin{array}{l}2,297 \\
2,085 \\
1,809 \\
1,810 \\
2,229\end{array}$ & $\begin{array}{l}6,191 \\
5,604 \\
4,755 \\
5,182 \\
5,173\end{array}$ & $\begin{array}{l}1955 \ldots \\
1956 \\
1957 \\
1958 \ldots \ldots \\
1959 \ldots \ldots\end{array}$ & $\begin{array}{l}19,422 \\
20,537 \\
19,757 \\
19,560 \\
21,540\end{array}$ & $\begin{array}{l}234 \\
243 \\
230 \\
224 \\
242\end{array}$ & $\begin{array}{l}414 \\
340 \\
387 \\
346 \\
329\end{array}$ & $\begin{array}{l}5,259 \\
5,688 \\
5,308 \\
4,986 \\
5,392\end{array}$ & $\begin{array}{l}14,503 \\
15,419 \\
14,909 \\
14,887 \\
16,506\end{array}$ \\
\hline $\begin{array}{l}1935 \\
1936 \\
1937 \\
1938 \\
1939\end{array}$ & $\begin{array}{r}8,234 \\
9,308 \\
9,969 \\
8,970 \\
10,029\end{array}$ & $\begin{array}{l}129 \\
145 \\
155 \\
138 \\
153\end{array}$ & $\begin{array}{l}77 \\
71 \\
94 \\
71 \\
97\end{array}$ & $\begin{array}{l}2,413 \\
2,799 \\
3,363 \\
2,309 \\
2,654\end{array}$ & $\begin{array}{l}5,855 \\
6,598 \\
7,109 \\
6,340 \\
7,484\end{array}$ & $\begin{array}{l}1960 \ldots \\
1961 \\
1962 \ldots \ldots \\
1963 \ldots \\
1964 \ldots \ldots\end{array}$ & $\begin{array}{l}22,055 \\
22,474 \\
23,231 \\
23,976 \\
25,330\end{array}$ & $\begin{array}{r}244 \\
245 \\
249 \\
.253 \\
264\end{array}$ & $\begin{array}{l}361 \\
405 \\
349 \\
382 \\
432\end{array}$ & $\begin{array}{l}5,574 \\
5,605 \\
5,632 \\
5,537 \\
6,117\end{array}$ & $\begin{array}{l}16,809 \\
17,224 \\
17,966 \\
18,752 \\
19,685\end{array}$ \\
\hline $\begin{array}{l}1940 \ldots \ldots \\
1941 \\
1942 \\
1943 \\
1944\end{array}$ & $\begin{array}{l}10,606 \\
12,081 \\
11,790 \\
11,043 \\
10,599\end{array}$ & $\begin{array}{l}161 \\
181 \\
175 \\
162 \\
153\end{array}$ & $\begin{array}{l}264 \\
264 \\
161 \\
182 \\
180\end{array}$ & $\begin{array}{l}2,791 \\
3,019 \\
2,961 \\
2,663 \\
2,522\end{array}$ & $\begin{array}{l}8,105 \\
9,362 \\
9,115 \\
8,415 \\
8,220\end{array}$ & $\begin{array}{l}1965 \\
1966 \\
1967 \\
1968 \\
1969\end{array}$ & $\begin{array}{l}26,793 \\
28,719 \\
28,836 \\
30,171 \\
31,794\end{array}$ & $\begin{array}{l}276 \\
292 \\
290 \\
301 \\
314\end{array}$ & $\begin{array}{l}499 \\
527 \\
517 \\
540 \\
531\end{array}$ & $\begin{array}{l}6,508 \\
7,238 \\
6,861 \\
6,727 \\
7,127\end{array}$ & $\begin{array}{l}20,761 \\
22,148 \\
22,447 \\
23,971 \\
25,198\end{array}$ \\
\hline & & & & & & 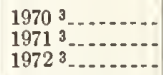 & $\begin{array}{l}31,692 \\
32,404 \\
34,076\end{array}$ & $\begin{array}{l}309 \\
313 \\
326\end{array}$ & $\begin{array}{l}548 \\
563 \\
574\end{array}$ & $\begin{array}{l}7,027 \\
7,306 \\
7,577\end{array}$ & $\begin{array}{l}25,219 \\
25,669 \\
27,087\end{array}$ \\
\hline
\end{tabular}

Data may not add to totals because of rounding

2 Includes changes in newsprint stocks beginning in 1929.
3 Preliminary.

Sources: See source note table 17, Append. V. 
APPENDIX V. TIMBER DEMAND TABLES

TABLE 19.-A pparent consumption, exports, imports, and domestic production cf paperboard, ${ }^{1} 1920-72{ }^{2}$

\begin{tabular}{|c|c|c|c|c|c|c|c|c|c|c|c|}
\hline \multirow{2}{*}{ Year } & \multicolumn{2}{|c|}{$\begin{array}{l}\text { Apparent } \\
\text { consumption }\end{array}$} & \multirow{2}{*}{ Exports } & \multirow{2}{*}{ Imports } & \multirow{2}{*}{$\begin{array}{l}\text { Domestic } \\
\text { production }\end{array}$} & \multirow{2}{*}{ Year } & \multicolumn{2}{|c|}{$\begin{array}{c}\text { Apparent } \\
\text { consumption }\end{array}$} & \multirow{2}{*}{ Exports } & \multirow{2}{*}{ Imports } & \multirow{2}{*}{$\begin{array}{l}\text { Domestic } \\
\text { production }\end{array}$} \\
\hline & Total & $\begin{array}{c}\text { Per } \\
\text { capita }\end{array}$ & & & & & Total & $\begin{array}{c}\text { Per } \\
\text { capita }\end{array}$ & & & \\
\hline $\begin{array}{l}1920 \ldots \ldots \ldots \\
1921 \\
1922 \ldots \ldots . \\
1923 \ldots \ldots . \\
1924\end{array}$ & 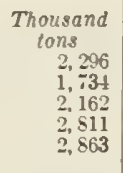 & $\begin{array}{r}\text { Pounds } \\
43 \\
32 \\
39 \\
50 \\
50\end{array}$ & $\begin{array}{c}\text { Thousand } \\
\text { tons } \\
61 \\
26 \\
28 \\
34 \\
41\end{array}$ & $\begin{array}{l}\text { Thousand } \\
\text { tons } \\
43 \\
20 \\
31 \\
52 \\
54\end{array}$ & 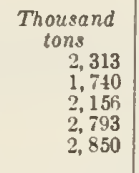 & $\begin{array}{l}1945 \ldots \ldots \\
1946 \\
1947 \ldots \ldots \ldots \\
1948 \\
1949 \ldots \ldots \ldots\end{array}$ & $\begin{array}{c}\text { Thousand } \\
\text { tons } \\
7,933 \\
8,481 \\
9,265 \\
9,455 \\
9,085\end{array}$ & $\begin{array}{r}\text { Pounds } \\
113 \\
120 \\
128 \\
128 \\
121\end{array}$ & $\begin{array}{l}\text { Thousand } \\
\text { tons } \\
96 \\
61 \\
97 \\
98 \\
89\end{array}$ & $\begin{array}{l}\text { Thousand } \\
\text { tons } \\
22 \\
14 \\
26 \\
45 \\
48\end{array}$ & $\begin{array}{r}\text { Thousand } \\
\text { lons } \\
8,008 \\
8,529 \\
9,337 \\
9,508 \\
9,127\end{array}$ \\
\hline $\begin{array}{l}1925 \ldots \ldots \\
1926 \ldots \ldots \ldots \\
1927 \ldots \ldots \ldots \\
1928 \\
1929 \ldots \ldots \ldots\end{array}$ & $\begin{array}{l}3,224 \\
3.549 \\
3,655 \\
3,953 \\
4,183\end{array}$ & $\begin{array}{l}56 \\
60 \\
62 \\
66 \\
69\end{array}$ & $\begin{array}{l}27 \\
51 \\
36 \\
39 \\
50\end{array}$ & $\begin{array}{l}15 \\
20 \\
18 \\
11 \\
11\end{array}$ & $\begin{array}{l}3,236 \\
3,550 \\
3.702 \\
3,981 \\
4,222\end{array}$ & $\begin{array}{l}1950 \\
1951 \\
1952 \\
1953 \ldots \ldots \\
1951 \ldots \ldots\end{array}$ & $\begin{array}{l}11,046 \\
11,626 \\
10,820 \\
12,417 \\
12,149\end{array}$ & $\begin{array}{l}145 \\
150 \\
137 \\
155 \\
149\end{array}$ & $\begin{array}{r}99 \\
226 \\
149 \\
172 \\
241\end{array}$ & $\begin{array}{l}55 \\
81 \\
57 \\
98 \\
64\end{array}$ & $\begin{array}{l}11,090 \\
11,771 \\
10,912 \\
12,491 \\
12,327\end{array}$ \\
\hline $\begin{array}{l}1930 \ldots \ldots \\
1931 \ldots \ldots \\
1932 \\
1933 \ldots \ldots \\
1934 \ldots \ldots \ldots\end{array}$ & $\begin{array}{l}3,816 \\
3,622 \\
3.151 \\
3,930 \\
3,923\end{array}$ & $\begin{array}{l}62 \\
58 \\
50 \\
63 \\
62\end{array}$ & $\begin{array}{l}47 \\
47 \\
31 \\
32 \\
34\end{array}$ & $\begin{array}{r}8 \\
3 \\
1 \\
12 \\
11\end{array}$ & $\begin{array}{l}3,855 \\
3,666 \\
3,181 \\
3,950 \\
3,946\end{array}$ & $\begin{array}{l}1955 \ldots \ldots \\
1956 \ldots \ldots \\
1957 \ldots \ldots \\
1958 \ldots \ldots \\
1959 \ldots \ldots\end{array}$ & $\begin{array}{l}13,891 \\
14,151 \\
13,914 \\
13,963 \\
15,236\end{array}$ & $\begin{array}{l}167 \\
168 \\
162 \\
160 \\
171\end{array}$ & $\begin{array}{l}296 \\
300 \\
338 \\
362 \\
443\end{array}$ & $\begin{array}{r}141 \\
71 \\
52 \\
54 \\
55\end{array}$ & $\begin{array}{l}14,015 \\
14,381 \\
14,200 \\
14,271 \\
15,624\end{array}$ \\
\hline $\begin{array}{l}1935 \ldots \ldots \\
1936 \ldots \ldots \\
1937 \ldots \ldots \\
1938 \ldots \ldots \\
1939 \ldots \ldots \ldots\end{array}$ & $\begin{array}{l}4,521 \\
5,257 \\
5,586 \\
4,873 \\
5,850\end{array}$ & $\begin{array}{l}71 \\
82 \\
87 \\
75 \\
89\end{array}$ & $\begin{array}{l}39 \\
39 \\
52 \\
61 \\
73\end{array}$ & $\begin{array}{l}16 \\
16 \\
19 \\
12 \\
12\end{array}$ & $\begin{array}{l}4,514 \\
5,280 \\
5,618 \\
4,922 \\
5,911\end{array}$ & $\begin{array}{l}1960 \ldots \ldots \\
1961 \ldots \ldots \\
1962 \ldots \ldots \\
1963 \ldots \ldots \\
1964 \ldots \ldots\end{array}$ & $\begin{array}{l}15,371 \\
16,054 \\
17,048 \\
17,682 \\
18,739\end{array}$ & $\begin{array}{l}170 \\
175 \\
183 \\
187 \\
195\end{array}$ & $\begin{array}{r}515 \\
615 \\
630 \\
740 \\
1,034\end{array}$ & $\begin{array}{l}35 \\
39 \\
46 \\
42 \\
20\end{array}$ & $\begin{array}{l}15,851 \\
16,629 \\
17,632 \\
18,380 \\
19,753\end{array}$ \\
\hline $\begin{array}{l}1940 \ldots \ldots \\
1941 \\
1942 \ldots \ldots \ldots \\
1943 \\
1944 \ldots \ldots \ldots\end{array}$ & $\begin{array}{l}6,001 \\
7,679 \\
7,059 \\
7,695 \\
8,006\end{array}$ & $\begin{array}{r}91 \\
115 \\
104 \\
112 \\
115\end{array}$ & $\begin{array}{r}209 \\
106 \\
84 \\
63 \\
61\end{array}$ & $\begin{array}{l}10 \\
13 \\
50 \\
24 \\
21\end{array}$ & $\begin{array}{r}6,200 \\
7,771 \\
7,093 \\
7,734 \\
8,045\end{array}$ & $\begin{array}{l}1965 \ldots 6 \\
1966 \ldots \ldots \\
1967 \ldots \ldots \\
1968 \ldots \\
1969 \ldots \ldots \\
1970^{3} \ldots \ldots \ldots \\
19711^{3} \ldots \ldots \ldots \\
19722^{3} \ldots \ldots \ldots\end{array}$ & $\begin{array}{l}19,885 \\
21,526 \\
20,833 \\
22,795 \\
24,210 \\
23,530 \\
23,900 \\
26,410\end{array}$ & $\begin{array}{l}205 \\
219 \\
210 \\
227 \\
239 \\
\\
230 \\
231 \\
253\end{array}$ & $\begin{array}{l}1,112 \\
1,252 \\
1,418 \\
1,892 \\
2,026 \\
2,105 \\
2,381 \\
2,364\end{array}$ & $\begin{array}{l}18 \\
56 \\
22 \\
28 \\
20 \\
\\
19 \\
23 \\
13\end{array}$ & $\begin{array}{l}20,979 \\
22,722 \\
22,229 \\
24,659 \\
26,217 \\
\\
25,616 \\
36,258 \\
28,761\end{array}$ \\
\hline
\end{tabular}

1 Includes wet machine board. Also includes small quantities of building ard for the years 1920-21.

${ }^{2}$ Data may not add to totals because of rounding.
3 Preliminary.

Sources: See note table 17, Append. V. 


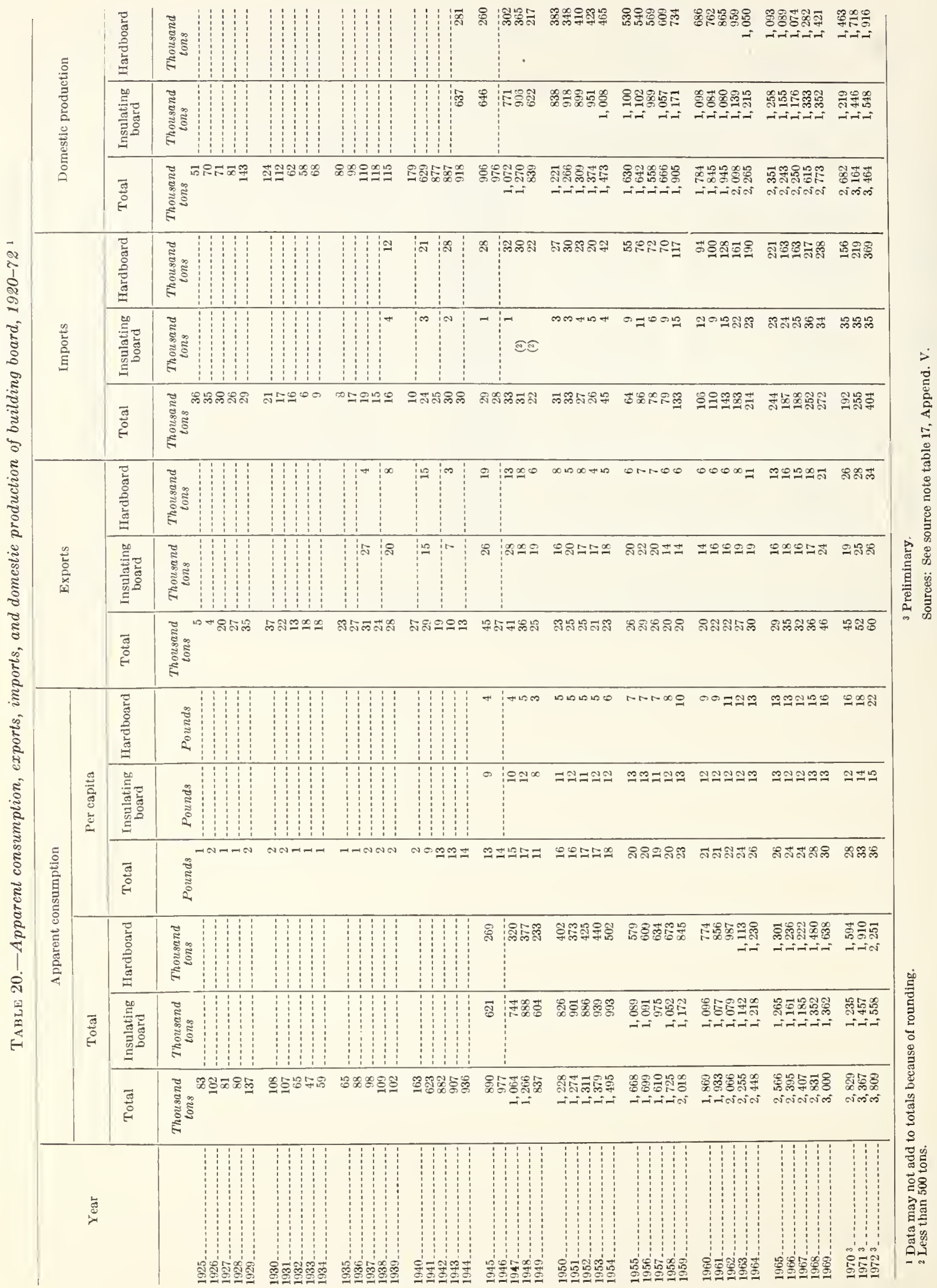


TABLE 21.-Paper and board exports from the United States, by grade and major region of destination, $1971{ }^{1}$

[Thousand tons]

\begin{tabular}{|c|c|c|c|c|c|c|c|c|c|c|}
\hline \multirow{2}{*}{ Region } & \multirow{2}{*}{$\begin{array}{l}\text { Total } \\
\text { paper } \\
\text { and } \\
\text { board }\end{array}$} & \multicolumn{6}{|c|}{ Paper } & \multicolumn{3}{|c|}{ Board } \\
\hline & & Total & $\begin{array}{l}\text { News- } \\
\text { print }\end{array}$ & $\begin{array}{l}\text { Book } \\
\text { paper }\end{array}$ & $\begin{array}{l}\text { Fine } \\
\text { paper }\end{array}$ & $\begin{array}{c}\text { Coarse } \\
\text { and in- } \\
\text { dustrial } \\
\text { paper }\end{array}$ & $\begin{array}{l}\text { Other } \\
\text { paper }\end{array}$ & Total & $\begin{array}{l}\text { Building } \\
\text { board }\end{array}$ & $\begin{array}{l}\text { Other } \\
\text { board }\end{array}$ \\
\hline $\begin{array}{l}\text { Canada } \\
\text { Latin A merica } \\
\text { Western Europe } \\
\text { Eastern Europe } \\
\text { Africa } \\
\text { Fear and Jiddie East } \\
\text { Far East } \\
\text { Ocesnis. } \\
\text { Other countries. }\end{array}$ & $\begin{array}{r}307 \\
701 \\
1,323 \\
24 \\
153 \\
117 \\
303 \\
60 \\
8\end{array}$ & $\begin{array}{r}121 \\
167 \\
90 \\
\text { (2) } \\
25 \\
11 \\
127 \\
16 \\
5\end{array}$ & $\frac{i 3}{i}$ & $\begin{array}{r}26 \\
29 \\
31 \\
- \\
3 \\
1 \\
4 \\
3 \\
1\end{array}$ & $\begin{array}{r}36 \\
13 \\
21 \\
3 \\
1 \\
24 \\
4 \\
1\end{array}$ & $\begin{array}{r}48 \\
41 \\
28 \\
18 \\
9 \\
17 \\
5 \\
2\end{array}$ & $\begin{array}{rr} & 10 \\
& 11 \\
& 2 \\
\text { (2) } & \\
\text { (2) } & 1 \\
& 1 \\
& 2 \\
1\end{array}$ & $\begin{array}{r}186 \\
533 \\
1,233 \\
24 \\
128 \\
106 \\
176 \\
44 \\
3\end{array}$ & $\begin{array}{rr} & 33 \\
& 3 \\
& 11 \\
(2) & \\
& 2 \\
& 1 \\
& 1 \\
(2) & \\
& 1\end{array}$ & $\begin{array}{r}153 \\
530 \\
1,222 \\
24 \\
126 \\
106 \\
175 \\
44 \\
2\end{array}$ \\
\hline Total .......... & 2,996 & 563 & 166 & 97 & 102 & 169 & 29 & 2,434 & 52 & 2,381 \\
\hline
\end{tabular}

1 Data may not add to totals because of rounding.

Less than 500 tons.

Source: U.S. Department of Commerce, Bureau of the Census. U.S. exports. FT 410. 1971 (annual).

TABLE 22.-Paper and board imports into the United States, by grade and major region of origin, 19711

[Thousand tons]

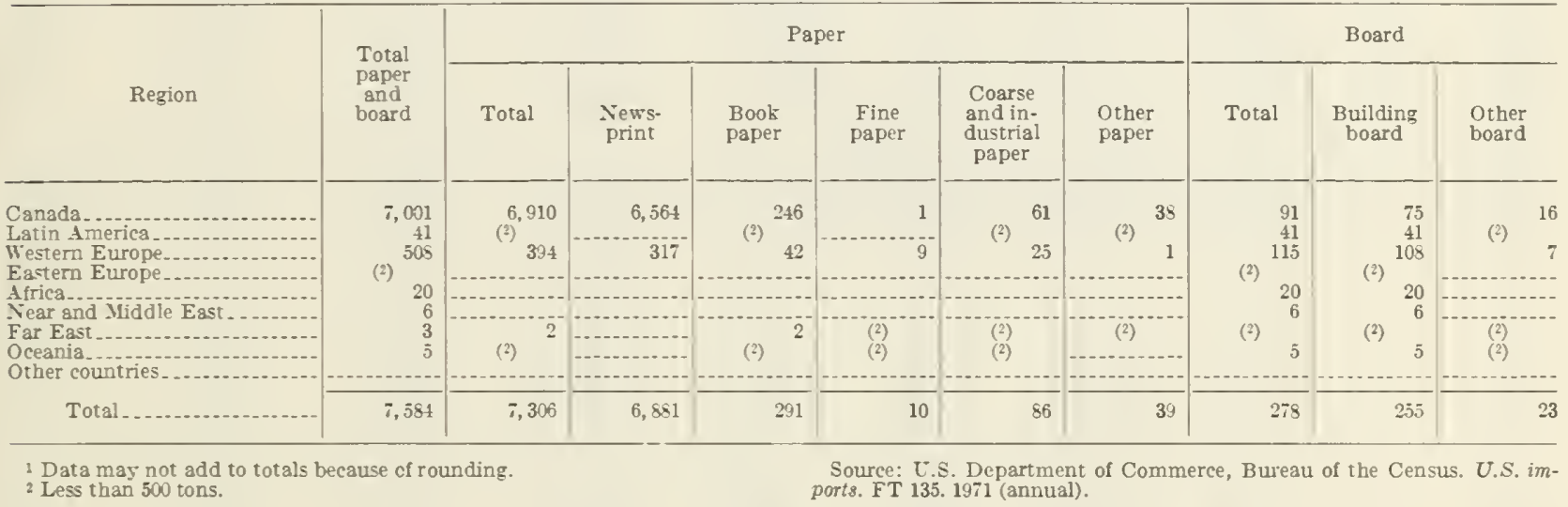


TABLE 23.-Fibrous materials consumed in the manufacture of paper and board, by type of material, specified years 1919-72 1

\begin{tabular}{|c|c|c|c|c|c|c|c|c|}
\hline \multirow{2}{*}{ Year } & \multicolumn{4}{|c|}{ Consumption of fibrous materials } & \multicolumn{4}{|c|}{$\begin{array}{l}\text { Consumption of fibrous materials per ton of } \\
\text { paper and board produced }\end{array}$} \\
\hline & Total & $\begin{array}{l}\text { Wood- } \\
\text { pulp }\end{array}$ & $\begin{array}{l}\text { Waste- } \\
\text { paper }\end{array}$ & Other & Total & $\begin{array}{l}\text { Wood- } \\
\text { pulp }\end{array}$ & $\begin{array}{l}\text { Waste- } \\
\text { paper }\end{array}$ & Other \\
\hline $\begin{array}{l}1919 \ldots \\
1929 \\
1935 \\
1939\end{array}$ & $\begin{array}{l}\text { Thousand } \\
\text { tons } \\
6,622 \\
11,575 \\
10,999 \\
14,177\end{array}$ & $\begin{array}{l}\text { Thousand } \\
\text { tons } \\
4,020 \\
6,289 \\
6,442 \\
8,650\end{array}$ & $\begin{array}{l}\text { Thousand } \\
\text { tons } \\
1,854 \\
3,842 \\
3,587 \\
4,366\end{array}$ & $\begin{array}{r}\text { Thousand } \\
\text { tons } \\
748 \\
1,443 \\
969 \\
1,161\end{array}$ & $\begin{array}{l}\text { Tons } \\
\text { 1. } 110 \\
\text { 1. } 039 \\
\text { 1. } 050 \\
\text { 1. } 049\end{array}$ & $\begin{array}{r}\text { Tons } \\
0.674 \\
.565 \\
.615 \\
.640\end{array}$ & $\begin{array}{r}\text { Tons } \\
0.311 \\
.345 \\
.342 \\
.323\end{array}$ & $\begin{array}{r}\text { Tons } \\
0.125 \\
.129 \\
.092 \\
.086\end{array}$ \\
\hline $\begin{array}{l}1940 \ldots \ldots \\
1941 \ldots-\ldots \\
1942 \\
1943 \\
1944 \ldots \ldots\end{array}$ & $\begin{array}{l}15,493 \\
18,856 \\
17,858 \\
18,199 \\
18,747\end{array}$ & $\begin{array}{r}9,782 \\
11,364 \\
11,038 \\
10,635 \\
10,502\end{array}$ & $\begin{array}{l}4,668 \\
6,075 \\
5,495 \\
6,368 \\
6,859\end{array}$ & $\begin{array}{l}1,044 \\
1,418 \\
1,325 \\
1,196 \\
1,385\end{array}$ & $\begin{array}{l}\text { 1. } 070 \\
\text { 1. } 062 \\
\text { 1. } 045 \\
\text { 1. } 068 \\
\text { 1. } 091\end{array}$ & $\begin{array}{l}.675 \\
.640 \\
.646 \\
.624 \\
.611\end{array}$ & $\begin{array}{l}.322 \\
.342 \\
.322 \\
.374 \\
.399\end{array}$ & $\begin{array}{l}.072 \\
.080 \\
.078 \\
.070 \\
.081\end{array}$ \\
\hline $\begin{array}{l}1945 \ldots \\
1946 \\
1947 \\
1948 \\
1949\end{array}$ & $\begin{array}{l}18,969 \\
20,752 \\
22,788 \\
23,411 \\
21,451\end{array}$ & $\begin{array}{l}10,825 \\
12,092 \\
13,253 \\
14,375 \\
13,636\end{array}$ & $\begin{array}{l}6,800 \\
7,278 \\
8,009 \\
7,585 \\
6,600\end{array}$ & $\begin{array}{l}1,344 \\
1,382 \\
1,526 \\
1,452 \\
1,215\end{array}$ & $\begin{array}{l}\text { 1. } 092 \\
\text { 1. } 077 \\
\text { 1. } 079 \\
\text { 1. } 069 \\
\text { 1. } 056\end{array}$ & $\begin{array}{l}.623 \\
.627 \\
.628 \\
.657 \\
.671\end{array}$ & $\begin{array}{l}.391 \\
.378 \\
.379 \\
.346 \\
.325\end{array}$ & $\begin{array}{l}.077 \\
.072 \\
.072 \\
.066 \\
.060\end{array}$ \\
\hline $\begin{array}{l}1950 \ldots \\
1951 \\
1952 \ldots \\
1953 \ldots \ldots \\
1954 \ldots \ldots\end{array}$ & $\begin{array}{l}25,904 \\
28,265 \\
26,378 \\
28,469 \\
28,045\end{array}$ & $\begin{array}{l}16,509 \\
17,737 \\
17,286 \\
18,684 \\
18,989\end{array}$ & $\begin{array}{l}7,956 \\
9,071 \\
7,881 \\
8,531 \\
7,857\end{array}$ & $\begin{array}{l}1,439 \\
1,457 \\
1,211 \\
1,255 \\
1,200\end{array}$ & $\begin{array}{l}\text { 1. } 062 \\
\text { 1. } 085 \\
\text { 1. } 080 \\
\text { 1. } 072 \\
\text { 1. } 044\end{array}$ & $\begin{array}{l}.677 \\
.681 \\
.708 \\
.703 \\
.707\end{array}$ & $\begin{array}{l}.326 \\
.348 \\
.323 \\
.321 \\
.292\end{array}$ & $\begin{array}{l}.059 \\
.056 \\
.050 \\
.047 \\
.045\end{array}$ \\
\hline $\begin{array}{l}1955 \ldots \\
1956 \\
1957 \\
1958 \\
1959\end{array}$ & $\begin{array}{l}31,835 \\
33,386 \\
32,058 \\
32,157 \\
35,549\end{array}$ & $\begin{array}{l}21,454 \\
22,998 \\
22,459 \\
22,483 \\
25,155\end{array}$ & $\begin{array}{l}9,041 \\
8,836 \\
8,493 \\
8,671 \\
9,414\end{array}$ & $\begin{array}{r}1,340 \\
1,551 \\
1,105 \\
1,003 \\
979\end{array}$ & $\begin{array}{l}\text { 1. } 056 \\
\text { 1. } 052 \\
\text { 1. } 045 \\
\text { 1. } 043 \\
\text { 1. } 045\end{array}$ & $\begin{array}{l}.711 \\
.730 \\
.732 \\
.729 \\
.740\end{array}$ & $\begin{array}{l}.300 \\
.282 \\
.277 \\
.281 \\
.277\end{array}$ & $\begin{array}{l}.045 \\
.040 \\
.036 \\
.033 \\
.028\end{array}$ \\
\hline $\begin{array}{l}1960 \ldots \\
1961 \\
1962 \\
1963 \\
1964 \ldots\end{array}$ & $\begin{array}{l}35,703 \\
36,595 \\
38,636 \\
41,117 \\
42,860\end{array}$ & $\begin{array}{l}25,700 \\
26,683 \\
28,598 \\
30,220 \\
32,088\end{array}$ & $\begin{array}{l}9,032 \\
9,018 \\
9,075 \\
9,613 \\
9,843\end{array}$ & $\begin{array}{r}971 \\
894 \\
963 \\
1,285 \\
929\end{array}$ & $\begin{array}{l}\text { 1. } 036 \\
\text { 1. } 025 \\
\text { 1. } 029 \\
\text { 1. } 048 \\
\text { 1. } 019\end{array}$ & $\begin{array}{l}.746 \\
.747 \\
.762 \\
.770 \\
.768\end{array}$ & $\begin{array}{l}.262 \\
.253 \\
.242 \\
.245 \\
.228\end{array}$ & $\begin{array}{l}.028 \\
.025 \\
.025 \\
.033 \\
.023\end{array}$ \\
\hline 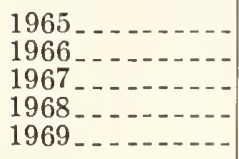 & $\begin{array}{l}45,116 \\
48,466 \\
47,718 \\
52,429 \\
55,517\end{array}$ & $\begin{array}{l}34,006 \\
36,922 \\
36,994 \\
41,303 \\
43,700\end{array}$ & $\begin{array}{r}10,231 \\
10,564 \\
9,888 \\
10,222 \\
10,939\end{array}$ & $\begin{array}{l}879 \\
980 \\
836 \\
905 \\
878\end{array}$ & $\begin{array}{l}\text { 1. } 024 \\
\text { 1. } 029 \\
\text { 1. } 017 \\
\text { 1. } 023 \\
\text { 1. } 024\end{array}$ & $\begin{array}{l}.772 \\
.784 \\
.788 \\
.806 \\
.806\end{array}$ & $\begin{array}{l}.232 \\
.224 \\
.211 \\
.199 \\
.202\end{array}$ & $\begin{array}{l}.020 \\
.021 \\
.018 \\
.018 \\
.016\end{array}$ \\
\hline 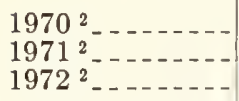 & $\begin{array}{l}54,614 \\
56,041 \\
58,801\end{array}$ & $\begin{array}{l}43,192 \\
44,183 \\
46,622\end{array}$ & $\begin{array}{l}10,594 \\
10,997 \\
11,269\end{array}$ & $\begin{array}{l}828 \\
861 \\
910\end{array}$ & $\begin{array}{r}1.021 \\
1.017 \\
.991\end{array}$ & $\begin{array}{l}.807 \\
.802 \\
.786\end{array}$ & $\begin{array}{l}.198 \\
.200 \\
.190\end{array}$ & $\begin{array}{l}.015 \\
.016 \\
.015\end{array}$ \\
\hline
\end{tabular}

1 Data may not add to totals because of rounding. 2 Preliminary.

Sources: American Paper Institute. Wood pulp statistics. New York, 1972 (annual); U.S. Department of Commerce,
Bureau of the Census. Pulp, paper and board. Cur. Indus: Reps. Ser. M26A (annual); and U.S. Department of Agriculture, Forest Service. 
APPENDIX $V$. TIMBER DEMAND TABLES

TABLE 24.-Apparent consumption, exports, imports, and domestic production of woodpulp, 1920-72 1

\begin{tabular}{|c|c|c|c|c|c|c|c|c|c|c|c|}
\hline \multirow{2}{*}{ Year } & \multicolumn{2}{|c|}{ Apparent consumption } & \multirow{2}{*}{ Exports } & \multirow{2}{*}{ Imports } & \multirow{2}{*}{$\begin{array}{l}\text { Domestic } \\
\text { production }\end{array}$} & \multirow{2}{*}{ Year } & \multicolumn{2}{|c|}{ Apparent consumption } & \multirow{2}{*}{ Exports } & \multirow{2}{*}{ Imports } & \multirow{2}{*}{$\begin{array}{l}\text { Domestic } \\
\text { production }\end{array}$} \\
\hline & Total & Per capita & & & & & Total & Per capita & & & \\
\hline $\begin{array}{l}1920 \\
1921 \\
1922 \\
1923 \\
1924\end{array}$ & $\begin{array}{c}\text { Thousand } \\
\text { tons } \\
4,696 \\
3,544 \\
4,756 \\
5,149 \\
5,214\end{array}$ & $\begin{array}{r}\text { Pounds } \\
88 \\
65 \\
86 \\
92 \\
91\end{array}$ & $\begin{array}{r}\text { Thousand } \\
\text { tons } \\
32 \\
28 \\
25 \\
23 \\
32\end{array}$ & $\begin{array}{r}\text { Thousand } \\
\text { tons } \\
906 \\
697 \\
1,259 \\
1,383 \\
1,523\end{array}$ & $\begin{array}{l}\text { Thousand } \\
\text { tons } \\
3,822 \\
2,876 \\
3,522 \\
3,789 \\
3,723\end{array}$ & $\begin{array}{l}1945 \\
1946 \\
1947 \\
1948 \\
1949\end{array}$ & $\begin{array}{r}\text { Thousand } \\
\text { tons } \\
11,786 \\
12,373 \\
11,138 \\
14,955 \\
13,848\end{array}$ & $\begin{array}{r}\text { Pounds } \\
168 \\
175 \\
196 \\
204 \\
186\end{array}$ & $\begin{array}{r}\text { Thousand } \\
\text { tons } \\
135 \\
39 \\
130 \\
94 \\
122\end{array}$ & $\begin{array}{r}\text { Thousand } \\
\text { tons } \\
1,754 \\
1,805 \\
2,322 \\
2,176 \\
1,763\end{array}$ & $\begin{array}{r}\text { Thousand } \\
\text { tons } \\
10,167 \\
10,607 \\
11,946 \\
12,872 \\
12,207\end{array}$ \\
\hline $\begin{array}{l}1925 \ldots 26 \\
1926 \\
1927 \\
1928 \\
1929\end{array}$ & $\begin{array}{l}5,558 \\
6,092 \\
5,957 \\
6,232 \\
6,690\end{array}$ & $\begin{array}{r}97 \\
104 \\
100 \\
103 \\
110\end{array}$ & $\begin{array}{l}38 \\
34 \\
32 \\
33 \\
54\end{array}$ & $\begin{array}{l}1,664 \\
1,731 \\
1,676 \\
1,755 \\
1,881\end{array}$ & $\begin{array}{l}3,962 \\
4,395 \\
4,313 \\
4,511 \\
4,863\end{array}$ & $\begin{array}{l}1950 \\
1951 \\
1952 \\
1953 \\
1954\end{array}$ & $\begin{array}{l}17,138 \\
18,683 \\
18,198 \\
19,533 \\
19,865\end{array}$ & $\begin{array}{l}225 \\
241 \\
231 \\
244 \\
244\end{array}$ & $\begin{array}{r}96 \\
202 \\
212 \\
162 \\
442\end{array}$ & $\begin{array}{l}2,385 \\
2,361 \\
1,937 \\
2,158 \\
2,051\end{array}$ & $\begin{array}{l}14,849 \\
16,524 \\
16,473 \\
17,537 \\
18,256\end{array}$ \\
\hline $\begin{array}{l}1930 \ldots \ldots \\
1931 \\
1932 \\
1933\end{array}$ & $\begin{array}{l}6,412 \\
5,952 \\
5,194 \\
6,139 \\
6,099\end{array}$ & $\begin{array}{r}104 \\
96 \\
83 \\
98 \\
97\end{array}$ & $\begin{array}{r}48 \\
53 \\
48 \\
79 \\
143\end{array}$ & $\begin{array}{l}1,830 \\
1,596 \\
1,432 \\
1,942 \\
1,806\end{array}$ & $\begin{array}{l}4,630 \\
4,409 \\
3,760 \\
4,276 \\
4,436\end{array}$ & $\begin{array}{l}1955 \\
1956 \\
1957 \\
1958 \\
1959\end{array}$ & $\begin{array}{l}22,323 \\
23,938 \\
23,278 \\
23,38.5 \\
26,162\end{array}$ & $\begin{array}{l}269 \\
283 \\
271 \\
267 \\
294\end{array}$ & $\begin{array}{l}631 \\
525 \\
622 \\
515 \\
653\end{array}$ & $\begin{array}{l}2,214 \\
2,332 \\
2,101 \\
2,105 \\
2,431\end{array}$ & $\begin{array}{l}20,740 \\
22,131 \\
21,800 \\
21,796 \\
24,383\end{array}$ \\
\hline $\begin{array}{l}1935 \\
1936 \\
1937 \\
1935 \\
1939 \ldots \ldots\end{array}$ & $\begin{array}{l}6,687 \\
7,779 \\
3,645 \\
7,503 \\
8,880\end{array}$ & $\begin{array}{l}105 \\
121 \\
134 \\
116 \\
136\end{array}$ & $\begin{array}{l}172 \\
193 \\
323 \\
140 \\
140\end{array}$ & $\begin{array}{l}1,933 \\
2,278 \\
2,395 \\
1,710 \\
2,026\end{array}$ & $\begin{array}{l}4,926 \\
5,695 \\
6,573 \\
5,934 \\
6,993\end{array}$ & $\begin{array}{l}1960 \\
1961 \\
1962 \\
1963 \\
1964\end{array}$ & $\begin{array}{l}26,563 \\
27,812 \\
29,511 \\
31,474 \\
33,777\end{array}$ & $\begin{array}{l}294 \\
303 \\
316 \\
332 \\
352\end{array}$ & $\begin{array}{l}1,142 \\
1,178 \\
1,186 \\
1,422 \\
1,580\end{array}$ & $\begin{array}{l}2,389 \\
2,467 \\
2,789 \\
2,775 \\
2,942\end{array}$ & $\begin{array}{l}25,316 \\
26,522 \\
27,908 \\
30,121 \\
32,415\end{array}$ \\
\hline $\begin{array}{l}1940 \ldots \ldots \ldots \\
1941 \\
1942 \\
1943 \\
1944\end{array}$ & $\begin{array}{r}9,703 \\
11,205 \\
11,642 \\
10,685 \\
10,962\end{array}$ & $\begin{array}{l}147 \\
168 \\
173 \\
156 \\
158\end{array}$ & $\begin{array}{l}481 \\
329 \\
378 \\
301 \\
218\end{array}$ & $\begin{array}{l}1,225 \\
1,158 \\
1,237 \\
1,306 \\
1,072\end{array}$ & $\begin{array}{r}8,960 \\
10,375 \\
10,783 \\
9,690 \\
10,108\end{array}$ & $\begin{array}{l}1965 \\
1966 \\
1967 \\
1968\end{array}$ & $\begin{array}{l}35,721 \\
38,388 \\
38,126 \\
42,522 \\
44,751\end{array}$ & $\begin{array}{l}368 \\
391 \\
384 \\
424 \\
442\end{array}$ & $\begin{array}{l}1,402 \\
1,572 \\
1,721 \\
1,902 \\
2,103\end{array}$ & $\begin{array}{l}3,130 \\
3,357 \\
3,170 \\
3,532 \\
4,040\end{array}$ & $\begin{array}{l}33,993 \\
36,603 \\
36,677 \\
40,892 \\
42,813\end{array}$ \\
\hline & & & & & & $\begin{array}{l}1970^{2} \ldots \ldots \ldots \\
1971^{2} \ldots \ldots \\
1972^{2} \ldots \ldots\end{array}$ & $\begin{array}{l}44,085 \\
45,273 \\
47,817\end{array}$ & $\begin{array}{l}426 \\
437 \\
458\end{array}$ & $\begin{array}{l}3,095 \\
2,175 \\
2,253\end{array}$ & $\begin{array}{l}3,518 \\
3,515 \\
3,728\end{array}$ & $\begin{array}{l}43,662 \\
43,933 \\
46,342\end{array}$ \\
\hline
\end{tabular}

1 Data may not add to totals hecause of rounding.

2 Preliminary.

Note: Total woodpulp production data prior to 1940 contains woodpulp not shown separately by type.

Sources: American Paper Institute. Wood pulp statistics. New York, 1972* (annual); U.S. Department of Commerce, Bureau of the Census. Pulp, paper and board. Cur. Indus. Reps. Ser. M26A. (annual); U.S. Department of Commerce. Pulp, paper and board, Quart. Indus. Rep.; and U.S. Department of Agriculture, Forest Service. 
TABLE 25.-Woodpulp exports from the United States, by type and major region of destination, $1971^{1}$

[Thousand tons]

\begin{tabular}{|c|c|c|c|c|c|}
\hline Region & Total & $\begin{array}{l}\text { Dissolving } \\
\text { and special } \\
\text { alpha }\end{array}$ & Sulfite & Sulfate & All other \\
\hline $\begin{array}{l}\text { Canada } \\
\text { Latin America } \\
\text { Western Europe. } \\
\text { Eastern Europe. } \\
\text { Africa } \\
\text { Near and Middle East. } \\
\text { Far East_. } \\
\text { Oceania } \\
\text { Other }\end{array}$ & $\begin{array}{r}72 \\
277 \\
1,079 \\
82 \\
46 \\
24 \\
533 \\
60 \\
1\end{array}$ & $\begin{array}{rr} & 17 \\
& 106 \\
& 345 \\
& 70 \\
\left({ }^{2}\right) & \\
& 5 \\
& 241 \\
\left(^{2}\right) & 6\end{array}$ & $\begin{array}{r}6 \\
\\
27 \\
\quad 74 \\
(2) \quad \\
\\
\\
\\
\\
5 \\
79 \\
20\end{array}$ & $\begin{array}{r}49 \\
144 \\
659 \\
12 \\
45 \\
14 \\
206 \\
\\
\text { (2) } \quad 35\end{array}$ & 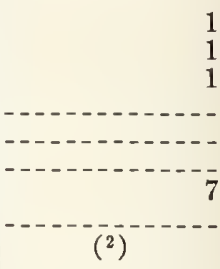 \\
\hline Total & 2,175 & 790 & 213 & 1,164 & 9 \\
\hline
\end{tabular}

1 Data may not add to totals because of rounding.

${ }^{2}$ Less than 500 tons.
Source: U.S. Department of Commerce, Bureau of the Census. U.S. Exports. FT 410. 1971 (annual).

TABLE 26.-Woodpulp imports into the United States, by type and major region of origin, $1971^{1}$ [Thousand tons]

\begin{tabular}{|c|c|c|c|c|c|c|c|}
\hline Region & Total & $\begin{array}{c}\text { Dissolving } \\
\text { and special } \\
\text { alpha }\end{array}$ & Sulfite & Sulfate & Soda & $\begin{array}{l}\text { Ground- } \\
\text { wood }\end{array}$ & $\begin{array}{c}\text { All } \\
\text { other }\end{array}$ \\
\hline Canada $\ldots \ldots \ldots$ & 3,385 & 250 & 401 & 2,533 & $(2)$ & 179 & 22 \\
\hline Latin America & 3 & - - - - - - - - - - & 2 & 1 & - - - & - & \\
\hline Western Europe & 62 & & 5 & & - - - & $(2)$ & $\overline{4}$ \\
\hline Eastern Europe & & --- & & $---1--$. & & ---1 & \\
\hline Africa $\ldots$ & 65 & 64 & - $-\ldots-1$ & - - n - n & - - - - n & $(2)$ & 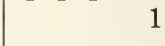 \\
\hline $\begin{array}{l}\text { Near and Middle East } \\
\text { Far East }\end{array}$ & $-\cdots-\cdots$ & (-1-2- & $---1--1$ & - - - - - - - - & $---1--1$ & -------1 & - - - - - - - - \\
\hline Oceania................. & 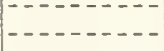 & 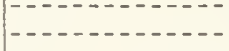 & 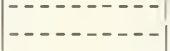 & 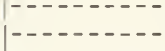 & 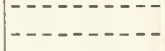 & 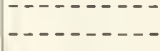 & 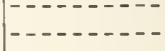 \\
\hline Total_........ & 3,515 & 315 & 408 & 2,584 & $(2)$ & 179 & 28 \\
\hline
\end{tabular}

1 Data may not add to totals because of rounding.

2 Less than 500 tons.
Source: U.S. Department of Commerce, Bureau of the Census. U.S. Imports. FT 135. 1971 (annual). 


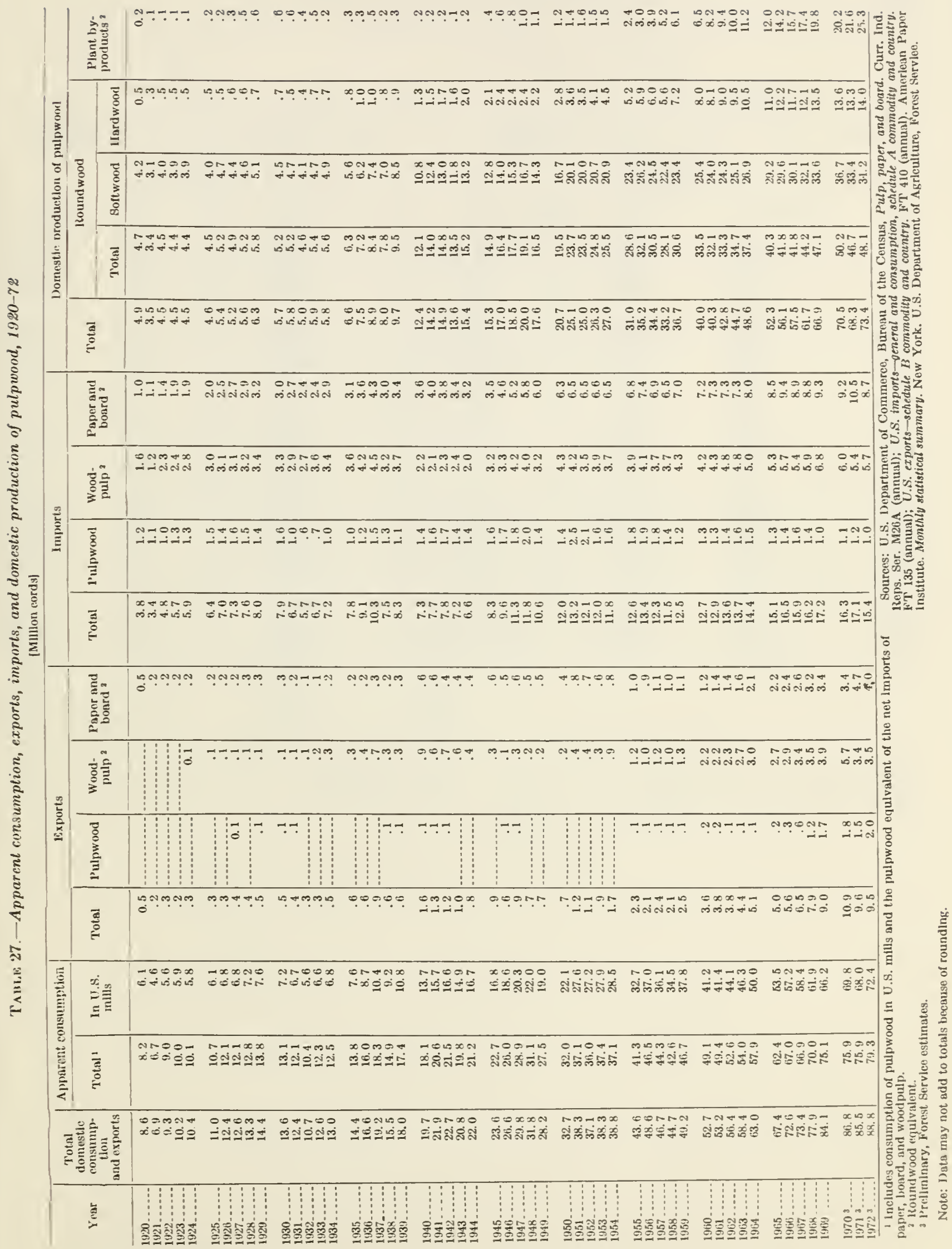


TABLE 28.-Consumption of pulpwood in the manufacture of woodpulp, 1920-72

\begin{tabular}{|c|c|c|c|c|c|c|c|}
\hline \multirow{3}{*}{ Year } & \multicolumn{3}{|c|}{ Total } & \multirow{3}{*}{ Year } & \multicolumn{3}{|c|}{ Total } \\
\hline & \multicolumn{2}{|c|}{ Pulpwood consumption } & \multirow{2}{*}{$\begin{array}{l}\text { Woodpulp } \\
\text { production }\end{array}$} & & \multicolumn{2}{|c|}{ Pulpwood consumption } & \multirow{2}{*}{$\begin{array}{l}\text { Woodpulp } \\
\text { production }\end{array}$} \\
\hline & Total & $\begin{array}{l}\text { Per ton of pulp } \\
\text { produced }\end{array}$ & & & Total & $\begin{array}{l}\text { Per ton of pulp } \\
\text { produced }\end{array}$ & \\
\hline $\begin{array}{l}1920 \ldots \ldots \\
1921 \ldots \ldots- \\
1922 \ldots \ldots- \\
1923 \ldots \ldots- \\
1924 \ldots \ldots\end{array}$ & $\begin{array}{r}\text { Thousand cords } \\
6,114 \\
4,557 \\
5,549 \\
5,873 \\
5,768\end{array}$ & $\begin{aligned} & \text { Cords } \\
& 1.60 \\
& 1.58 \\
& 1.58 \\
& 1.55 \\
& \text { 1. } 55\end{aligned}$ & $\begin{array}{l}\text { Thousand tons } \\
3,822 \\
2,876 \\
3,522 \\
3,789 \\
3,723\end{array}$ & $\begin{array}{l}1945 \ldots \ldots \\
1946 \ldots \ldots \\
1947 \ldots \ldots \\
1948 \ldots \ldots \\
1949 \ldots \ldots\end{array}$ & $\begin{array}{r}\text { Thousand cords } \\
16,776 \\
18,641 \\
20,293 \\
22,009 \\
19,029\end{array}$ & 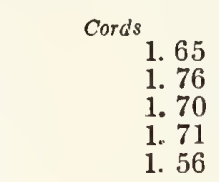 & $\begin{array}{r}\text { Thousand tons } \\
10,167 \\
10,607 \\
11,946 \\
12,872 \\
12,207\end{array}$ \\
\hline $\begin{array}{l}1925 \ldots-\ldots \\
1926 \ldots-- \\
1927-\ldots- \\
1928 \ldots \ldots \\
1929 \ldots \ldots-\end{array}$ & $\begin{array}{l}6,094 \\
6,766 \\
6,751 \\
7,160 \\
7,645\end{array}$ & $\begin{array}{l}1.54 \\
1.54 \\
1.57 \\
\text { 1. } 59 \\
1.57\end{array}$ & $\begin{array}{l}3,962 \\
4,395 \\
4,313 \\
4,511 \\
4,863\end{array}$ & $\begin{array}{l}1950 \ldots \ldots \\
1951 \ldots \ldots- \\
1952 \ldots \ldots \\
1953 \ldots \ldots- \\
1954 \ldots \ldots\end{array}$ & $\begin{array}{l}22,101 \\
27,625 \\
27,153 \\
27,863 \\
28,534\end{array}$ & $\begin{array}{l}\text { 1. } 49 \\
\text { 1. } 67 \\
\text { 1. } 65 \\
\text { 1. } 59 \\
1.56\end{array}$ & $\begin{array}{l}14,849 \\
16,524 \\
16,473 \\
17,537 \\
18,256\end{array}$ \\
\hline $\begin{array}{l}1930 \ldots-- \\
1931 \ldots-- \\
1932 \ldots-- \\
1933 \ldots-- \\
1934 \ldots-\ldots\end{array}$ & $\begin{array}{l}7,195 \\
6,723 \\
5,633 \\
6,582 \\
6,797\end{array}$ & $\begin{array}{l}1.55 \\
1.52 \\
1.50 \\
1.54 \\
1.53\end{array}$ & $\begin{array}{l}4,630 \\
4,409 \\
3,760 \\
4,276 \\
4,436\end{array}$ & $\begin{array}{l}1955 \ldots \ldots \\
1956 \ldots \\
1957 \ldots \\
1958 \ldots \\
1959 \ldots\end{array}$ & $\begin{array}{l}32,652 \\
36,958 \\
36,087 \\
34,509 \\
37,772\end{array}$ & $\begin{array}{l}1.57 \\
1.67 \\
1.66 \\
1.58 \\
1.55\end{array}$ & $\begin{array}{l}20,740 \\
22,131 \\
21,800 \\
21,796 \\
24,383\end{array}$ \\
\hline $\begin{array}{l}1935 \ldots--- \\
1936 \ldots--- \\
1937-\ldots-- \\
1938 \ldots--- \\
1939 \ldots---\end{array}$ & $\begin{array}{r}7,628 \\
8,716 \\
10,394 \\
9,194 \\
10,816\end{array}$ & $\begin{array}{l}1.55 \\
1.53 \\
1.58 \\
1.55 \\
1.55\end{array}$ & $\begin{array}{l}4,926 \\
5,695 \\
6,573 \\
5,934 \\
6,993\end{array}$ & $\begin{array}{l}1960 \ldots \\
1961 \ldots \\
1962 \ldots \\
1963 \ldots \\
1964 \ldots\end{array}$ & $\begin{array}{l}41,170 \\
41,434 \\
44,064 \\
46,251 \\
49,991\end{array}$ & $\begin{array}{l}1.63 \\
1.56 \\
1.58 \\
1.54 \\
1.54\end{array}$ & $\begin{array}{l}25,316 \\
26,523 \\
27,908 \\
30,121 \\
32,415\end{array}$ \\
\hline $\begin{array}{l}1940 \ldots \ldots \\
1941 \ldots \ldots \\
1942 \\
1943 \ldots \ldots \\
1944 \ldots\end{array}$ & $\begin{array}{l}13,743 \\
15,736 \\
16,567 \\
14,935 \\
16,700\end{array}$ & $\begin{array}{l}1.53 \\
1.52 \\
1.54 \\
1.54 \\
1.65\end{array}$ & $\begin{array}{r}8,960 \\
10,375 \\
10,783 \\
9,680 \\
10,108\end{array}$ & $\begin{array}{l}1965 \ldots \\
1966 \ldots \\
1967 \ldots \\
1968 \\
1969 \ldots \\
1970 \\
1971 \\
1972\end{array}$ & $\begin{array}{l}53,468 \\
57,174 \\
58,419 \\
61,903 \\
66,225 \\
69,760 \\
68,040 \\
72,425\end{array}$ & $\begin{array}{l}1.57 \\
1.56 \\
1.59 \\
1.51 \\
1.55 \\
1.60 \\
1.55 \\
1.56\end{array}$ & $\begin{array}{l}33,993 \\
36,603 \\
36,677 \\
40,892 \\
42,813 \\
43,662 \\
43,933 \\
46,342\end{array}$ \\
\hline
\end{tabular}

1 Preliminary.

Sources: American Paper Institute, Inc. Wood pulp statistics. 1972 (annual); U.S. Department of Commerce,
Bureau of the Census. Pulp, paper and board. Cur. Indus. Reps. Ser. M26A. 
TABLE 29.-Production, imports, exports, and apparent domestic consumption of forest products, by major products, $1940-721$

[Mrillon tons, air dry weight]

\begin{tabular}{|c|c|c|c|c|c|c|c|c|c|c|}
\hline \multirow{3}{*}{ Fear } & \multicolumn{2}{|c|}{ All products } & \multicolumn{8}{|c|}{ Products from industrial roundwood } \\
\hline & \multirow{2}{*}{$\begin{array}{l}\text { Domestic } \\
\text { production }\end{array}$} & \multirow{2}{*}{$\begin{array}{l}\text { Apparent } \\
\text { consumption }\end{array}$} & \multicolumn{4}{|c|}{ Total } & \multicolumn{4}{|c|}{ Lumber } \\
\hline & & & $\begin{array}{l}\text { Domestic } \\
\text { production }\end{array}$ & Imports & Exports & $\begin{array}{c}\text { Apparent } \\
\text { consumption }\end{array}$ & $\begin{array}{l}\text { Domestic } \\
\text { production }\end{array}$ & Imports & Exports & $\begin{array}{c}\text { Apparent } \\
\text { consumption }\end{array}$ \\
\hline $\begin{array}{l}1940 \ldots \ldots \ldots \\
1941 \\
1942 \\
1943 \\
1944 \ldots \ldots \ldots \\
\end{array}$ & $\begin{array}{l}139.1 \\
142.1 \\
127.5 \\
121.5 \\
123.3\end{array}$ & \begin{tabular}{l|}
140.9 \\
145.2 \\
131.1 \\
124.4 \\
126.0
\end{tabular} & $\begin{array}{l}63.6 \\
72.4 \\
71.9 \\
67.5 \\
66.7\end{array}$ & $\begin{array}{l}3.9 \\
4.6 \\
4.8 \\
3.9 \\
3.7\end{array}$ & $\begin{array}{l}2.1 \\
1.6 \\
1.2 \\
1.1 \\
1.0\end{array}$ & $\begin{array}{l}65.4 \\
75.5 \\
75.5 \\
70.4 \\
69.4\end{array}$ & $\begin{array}{l}34.4 \\
40.9 \\
40.5 \\
38.9 \\
38.0\end{array}$ & $\begin{array}{r}0.8 \\
1.5 \\
1.6 \\
.9 \\
1.1\end{array}$ & $\begin{array}{r}1.0 \\
.7 \\
.4 \\
.3 \\
.4\end{array}$ & $\begin{array}{l}34.2 \\
41.7 \\
41.7 \\
39.5 \\
38.7\end{array}$ \\
\hline $\begin{array}{l}1945 \ldots \ldots \ldots \\
1946 \ldots \ldots \\
1944 \ldots \ldots \ldots \\
1948 \ldots \ldots \ldots \\
1949 \ldots \ldots \ldots\end{array}$ & $\begin{array}{l}117.9 \\
120.2 \\
123.9 \\
124.4 \\
113.9\end{array}$ & $\begin{array}{l}121.4 \\
124.5 \\
128.2 \\
130.5 \\
124.2\end{array}$ & $\begin{array}{l}60.2 \\
65.3 \\
71.8 \\
72.7 \\
64.2\end{array}$ & $\begin{array}{l}4.6 \\
5.5 \\
6.4 \\
7.2 \\
6.6\end{array}$ & \begin{tabular}{l|}
1.1 \\
1.1 \\
2.0 \\
1.2 \\
1.3
\end{tabular} & $\begin{array}{l}63.7 \\
72.6 \\
76.1 \\
78.8 \\
69.5\end{array}$ & $\begin{array}{l}32.7 \\
39.4 \\
40.1 \\
41.6 \\
35.7\end{array}$ & $\begin{array}{l}1.2 \\
1.4 \\
1.4 \\
2.0 \\
1.7\end{array}$ & $\begin{array}{r}.5 \\
.7 \\
1.3 \\
.6 \\
.8\end{array}$ & $\begin{array}{l}33.4 \\
40.1 \\
40.2 \\
43.0 \\
36.6\end{array}$ \\
\hline $\begin{array}{l}1950 \ldots \ldots \\
1951 \ldots \ldots \\
1952 \\
1953 \ldots \ldots \\
1954 \ldots \ldots \ldots\end{array}$ & $\begin{array}{l}118.4 \\
118.3 \\
113.2 \\
112.0 \\
110.2\end{array}$ & $\begin{array}{l}126.7 \\
124.9 \\
119.9 \\
119.4 \\
117.3\end{array}$ & $\begin{array}{l}74.3 \\
75.0 \\
74.3 \\
74.7 \\
74.5\end{array}$ & $\begin{array}{l}9.5 \\
8.6 \\
8.3 \\
8.9 \\
9.2\end{array}$ & $\begin{array}{l}1.1 \\
1.9 \\
1.6 \\
1.5 \\
2.1\end{array}$ & $\begin{array}{l}82.6 \\
81.6 \\
81.0 \\
82.1 \\
81.6\end{array}$ & $\begin{array}{l}42.6 \\
42.0 \\
42.0 \\
41.3 \\
40.7\end{array}$ & \begin{tabular}{l|}
3.6 \\
2.7 \\
2.6 \\
2.9 \\
3.2
\end{tabular} & $\begin{array}{r}.6 \\
1.1 \\
.8 \\
.7 \\
.8\end{array}$ & $\begin{array}{l}45.6 \\
43.6 \\
43.8 \\
43.5 \\
43.1\end{array}$ \\
\hline $\begin{array}{l}1955 \ldots \ldots \ldots \\
1956 \ldots \ldots \ldots \\
1957 \ldots \ldots \ldots \\
1958 \ldots \ldots \ldots \\
1959 \ldots \ldots \ldots\end{array}$ & $\begin{array}{l}111.9 \\
112.6 \\
103.2 \\
102.7 \\
103.0\end{array}$ & $\begin{array}{l}119.6 \\
120.7 \\
110.2 \\
110.0 \\
116.7\end{array}$ & $\begin{array}{l}78.0 \\
80.4 \\
72.7 \\
73.9 \\
80.9\end{array}$ & $\begin{array}{r}10.2 \\
10.6 \\
9.7 \\
9.9 \\
11.6\end{array}$ & $\begin{array}{l}2.6 \\
2.6 \\
2.6 \\
2.6 \\
2.9\end{array}$ & $\begin{array}{l}85.7 \\
88.5 \\
79.7 \\
81.2 \\
89.6\end{array}$ & $\begin{array}{l}41.3 \\
42.6 \\
35.8 \\
36.6 \\
40.7\end{array}$ & $\begin{array}{l}3.8 \\
3.6 \\
3.1 \\
3.5 \\
4.3\end{array}$ & $\begin{array}{l}.9 \\
.9 \\
.9 \\
.8 \\
.9\end{array}$ & $\begin{array}{l}44.2 \\
45.3 \\
38.0 \\
39.3 \\
44.1\end{array}$ \\
\hline $\begin{array}{l}1960 \ldots \ldots \\
1961 \\
1962 \\
1963 \ldots\end{array}$ & $\begin{array}{l}102.0 \\
101.2 \\
102.7 \\
108.1 \\
112.8\end{array}$ & $\begin{array}{l}109.6 \\
108.6 \\
111.3 \\
115.6 \\
120.1\end{array}$ & $\begin{array}{l}76.6 \\
77.5 \\
80.7 \\
87.5 \\
93.6\end{array}$ & $\begin{array}{l}11.4 \\
11.8 \\
13.1 \\
13.5 \\
14.2\end{array}$ & $\begin{array}{l}3.8 \\
4.4 \\
4.5 \\
6.0 \\
6.9\end{array}$ & $\begin{array}{r}81.2 \\
81.9 \\
89.3 \\
95.0 \\
100.9\end{array}$ & $\begin{array}{l}35.9 \\
34.8 \\
36.2 \\
38.1 \\
40.1\end{array}$ & $\begin{array}{l}4.1 \\
4.4 \\
5.1 \\
5.5 \\
5.4\end{array}$ & $\begin{array}{r}.9 \\
.9 \\
.8 \\
.9 \\
1.0\end{array}$ & $\begin{array}{l}39.1 \\
38^{\circ} \cdot 3 \\
40^{.} .5 \\
42^{\circ} .7 \\
44^{*} .5\end{array}$ \\
\hline $\begin{array}{l}1965 \ldots \ldots \\
1966 \ldots \ldots \\
1967 \\
1968 \ldots \ldots\end{array}$ & $\begin{array}{l}114.9 \\
117.3 \\
114.6 \\
121.1 \\
120.0\end{array}$ & $\begin{array}{l}122.4 \\
124.7 \\
118.9 \\
124.3 \\
123.8\end{array}$ & $\begin{array}{r}97.0 \\
100.8 \\
99.4 \\
107.4 \\
107.9\end{array}$ & $\begin{array}{l}14.7 \\
15.8 \\
15.1 \\
17.1 \\
18.3\end{array}$ & $\begin{array}{r}7.3 \\
8.4 \\
10.9 \\
13.9 \\
14.4\end{array}$ & $\begin{array}{l}104.5 \\
108.2 \\
103.7 \\
110.6 \\
111.7\end{array}$ & $\begin{array}{l}40.5 \\
40.5 \\
38.4 \\
39.8 \\
39.5\end{array}$ & $\begin{array}{l}5.5 \\
5.5 \\
5.4 \\
6.4 \\
6.6\end{array}$ & $\begin{array}{l}1.0 \\
1.1 \\
1.2 \\
1.2 \\
1.2\end{array}$ & $\begin{array}{r}45.0 \\
44.9 \\
42.9 \\
45.6 \\
44.0 \\
.9\end{array}$ \\
\hline $\begin{array}{l}1970^{2}, \ldots \ldots \\
19711^{2} \ldots \ldots \ldots \\
19722^{2} \ldots \ldots \ldots\end{array}$ & $\begin{array}{l}118.6 \\
121.6 \\
130.9\end{array}$ & $\begin{array}{l}119.1 \\
126.8 \\
134.2\end{array}$ & $\begin{array}{l}108.1 \\
111.8 \\
121.6\end{array}$ & $\begin{array}{l}17.4 \\
19.5 \\
21.4\end{array}$ & $\begin{array}{l}16.9 \\
14.3 \\
18.1\end{array}$ & $\begin{array}{l}108.6 \\
117.0 \\
124.9\end{array}$ & $\begin{array}{l}37.8 \\
39.4 \\
42.5\end{array}$ & $\begin{array}{l}6.3 \\
7.8 \\
9.7\end{array}$ & $\begin{array}{l}1.3 \\
1.2 \\
1.6\end{array}$ & $\begin{array}{r}43 \\
46.0 \\
50.7 \\
.6\end{array}$ \\
\hline
\end{tabular}

See footnotes at end of table. 
TABLE 29.-Production, imports, exports, and apparent domestic consumption of forest products, by major products, 1y40-72 1 -Continued

[Million tons, alr dry weight]

\begin{tabular}{|c|c|c|c|c|c|c|c|c|c|c|c|c|c|c|c|}
\hline \multirow{3}{*}{ Years } & \multicolumn{14}{|c|}{ Products from industrial round wood-Continued } & \multirow{3}{*}{$\begin{array}{c}\text { Fuelwood-- } \\
\text { apparent } \\
\text { consump- } \\
\text { tioul }\end{array}$} \\
\hline & \multicolumn{4}{|c|}{ Plywood and veneer } & \multicolumn{4}{|c|}{ Panel products ${ }^{3}$} & \multicolumn{4}{|c|}{ Woodpulp 4} & \multirow{2}{*}{$\begin{array}{c}\text { Miscella- } \\
\text { neous prod- } \\
\text { ucts }{ }^{8}- \\
\text { apparent } \\
\text { consump- } \\
\text { tion }\end{array}$} & \multirow{2}{*}{$\underset{\text { exports }}{\text { Log }}$} & \\
\hline & $\begin{array}{l}\text { Domes- } \\
\text { tic pro- } \\
\text { duction }\end{array}$ & Imports & Exports & $\mid \begin{array}{c}\text { A pparent } \\
\text { consump- } \\
\text { tion } 5\end{array}$ & $\begin{array}{l}\text { Domes- } \\
\text { tic pro- } \\
\text { duction }\end{array}$ & Imports & Exports & $\begin{array}{l}\text { Apparent } \\
\text { consump- } \\
\text { tion }\end{array}$ & $\begin{array}{l}\text { Domes- } \\
\text { tic pro- } \\
\text { duction }\end{array}$ & $\lim _{\text {ports }}{ }^{\circ}$ & $\begin{array}{c}\text { Ex- } \\
\text { ports ? }\end{array}$ & $\begin{array}{c}\text { Apparent } \\
\text { consump- } \\
\text { tion }\end{array}$ & & & \\
\hline $\begin{array}{l}1940 \ldots . . \\
1941 \ldots \ldots \\
1942 \ldots . . \\
1943 \ldots \\
1944 \ldots . . .\end{array}$ & $\begin{array}{l}1.8 \\
1.7 \\
1.7 \\
1.5 \\
1.5\end{array}$ & $\begin{array}{l}(*) \\
(*) \\
(*) \\
(*) \\
(*)\end{array}$ & $\begin{array}{l}\left({ }^{*}\right) \\
\left(^{*}\right) \\
0.1 \\
.1 \\
.1\end{array}$ & $\begin{array}{l}1.8 \\
1.7 \\
1.6 \\
1.4 \\
1.4\end{array}$ & $\begin{array}{r}0.2 \\
.6 \\
.9 \\
.9 \\
.9\end{array}$ & $\begin{array}{l}(*) \\
(*) \\
(*) \\
(*)\end{array}$ & $\begin{array}{l}(*) \\
(*) \\
(*) \\
(*) \\
(*)\end{array}$ & $\begin{array}{r}0.2 \\
.6 \\
.9 \\
.9 \\
.9\end{array}$ & $\begin{array}{l}8.8 \\
9.7 \\
9.9 \\
8.8 \\
9.2\end{array}$ & $\begin{array}{l}\text { 3.1 } \\
3.1 \\
3.2 \\
3.0 \\
2.6\end{array}$ & $\begin{array}{r}0.9 \\
.7 \\
.6 \\
.5 \\
.4\end{array}$ & $\begin{array}{l}11.0 \\
12.1 \\
12.5 \\
11.3 \\
11.4\end{array}$ & \begin{tabular}{l|l}
18.2 \\
19.4 \\
18.8 \\
17.3 \\
17.0
\end{tabular} & $\begin{array}{r}0.2 \\
.1 \\
.1 \\
.1 \\
.1\end{array}$ & $\begin{array}{l}75.5 \\
69.7 \\
55.6 \\
54.0 \\
56.6\end{array}$ \\
\hline $\begin{array}{l}1945 \ldots \ldots \\
1946 \ldots . . . \\
1947 \ldots \ldots \\
1948 \ldots . . \\
1949 \ldots . .\end{array}$ & $\begin{array}{l}1.3 \\
1.5 \\
1.8 \\
1.9 \\
2.0\end{array}$ & $\begin{array}{l}(*) \\
(*) \\
(*) \\
(*) \\
(*)\end{array}$ & $\begin{array}{l}.1 \\
: 1 \\
\left(^{*}\right)^{1}\end{array}$ & $\begin{array}{l}1.2 \\
1.4 \\
1.7 \\
1.9 \\
2.0\end{array}$ & $\begin{array}{r}.9 \\
1.0 \\
1.1 \\
1.3 \\
.9\end{array}$ & $\begin{array}{l}(*) \\
(*) \\
(*) \\
(*) \\
(*)\end{array}$ & $\begin{array}{l}(*) \\
(*) \\
(*) \\
(*) \\
(*)\end{array}$ & $\begin{array}{r}.9 \\
1.0 \\
1.1 \\
1.3 \\
.9\end{array}$ & $\begin{array}{r}9.3 \\
9.6 \\
10.9 \\
11.7 \\
11.4\end{array}$ & $\begin{array}{l}3.4 \\
4.0 \\
4.9 \\
5.2 \\
4.9\end{array}$ & $\begin{array}{l}.4 \\
.3 \\
.4 \\
.3 \\
.3\end{array}$ & $\begin{array}{l}12.3 \\
13.3 \\
15.4 \\
16.6 \\
16.0\end{array}$ & $\begin{array}{l}15.9 \\
16.8 \\
17.7 \\
16.0 \\
14.0\end{array}$ & $\begin{array}{l}\left(^{*}\right)^{1} \\
.2 \\
.2 \\
.2\end{array}$ & $\begin{array}{l}57.7 \\
51.9 \\
52.1 \\
51.7 \\
54.7\end{array}$ \\
\hline $\begin{array}{l}1950 \ldots \ldots \\
1951 \ldots \ldots \\
1952 \ldots \ldots \\
1953 \ldots \ldots \\
1954 \ldots . .\end{array}$ & $\begin{array}{l}2.1 \\
2.3 \\
2.4 \\
2.7 \\
2.7\end{array}$ & $\begin{array}{l}.1 \\
.1 \\
.1 \\
.2 \\
.3\end{array}$ & $\begin{array}{l}(*) \\
(*) \\
(*) \\
(*) \\
(*)\end{array}$ & $\begin{array}{l}2.2 \\
2.4 \\
2.5 \\
2.9 \\
3.0\end{array}$ & $\begin{array}{l}1.3 \\
1.3 \\
1.4 \\
1.4 \\
1.6\end{array}$ & $\begin{array}{l}(*) \\
(*) \\
(*) \\
(*) \\
(*)\end{array}$ & $\begin{array}{l}(*) \\
(*) \\
(*) \\
(*)\end{array}$ & $\begin{array}{l}1.3 \\
1.3 \\
1.4 \\
1.4 \\
1.6\end{array}$ & $\begin{array}{l}13.6 \\
15.3 \\
15.2 \\
16.2 \\
16.8\end{array}$ & $\begin{array}{l}5.7 \\
5.8 \\
5.6 \\
5.8 \\
5.7\end{array}$ & $\begin{array}{l}.3 \\
.6 \\
.6 \\
.4 \\
.9\end{array}$ & $\begin{array}{l}19.0 \\
20.5 \\
20.2 \\
21.6 \\
21.6\end{array}$ & $\begin{array}{l}14.5 \\
13.8 \\
13.1 \\
12.7 \\
12.3\end{array}$ & $\begin{array}{l}.2 \\
.3 \\
.2 \\
.4 \\
.4\end{array}$ & $\begin{array}{l}44.1 \\
43.3 \\
38.9 \\
37.3 \\
35.7\end{array}$ \\
\hline $\begin{array}{l}1955 \ldots \ldots \\
1956 \ldots \ldots \\
1957 \ldots \ldots \\
1958 \ldots \ldots \\
1959 \ldots \ldots\end{array}$ & $\begin{array}{l}3.5 \\
3.6 \\
3.6 \\
4.1 \\
4.8\end{array}$ & $\begin{array}{l}.4 \\
.4 \\
.4 \\
.5 \\
.7\end{array}$ & $\begin{array}{l}(*) \\
(*) \\
(*) \\
(*) \\
(*)\end{array}$ & $\begin{array}{l}3.9 \\
4.0 \\
4.0 \\
4.6 \\
5.5\end{array}$ & $\begin{array}{l}1.7 \\
1.8 \\
1.8 \\
2.0 \\
2.4\end{array}$ & $\begin{array}{r}0.1 \\
.1 \\
.1 \\
.1 \\
.1\end{array}$ & $\begin{array}{l}\left(^{*}\right) \\
(*) \\
(*) \\
(*) \\
(*)\end{array}$ & $\begin{array}{l}1.8 \\
1.9 \\
1.9 \\
2.1 \\
2.5\end{array}$ & $\begin{array}{l}19.1 \\
20.5 \\
20.2 \\
20.1 \\
22.5\end{array}$ & $\begin{array}{l}6.0 \\
6.5 \\
6.0 \\
5.8 \\
6.4\end{array}$ & $\begin{array}{l}1.2 \\
1.1 \\
1.3 \\
1.2 \\
1.4\end{array}$ & $\begin{array}{l}23.9 \\
25.9 \\
24.9 \\
24.7 \\
27.5\end{array}$ & $\begin{array}{l}11.9 \\
11.4 \\
10.9 \\
10.5 \\
10.0\end{array}$ & $\begin{array}{l}.5 \\
.5 \\
.4 \\
.6 \\
.5\end{array}$ & $\begin{array}{l}33.9 \\
32.2 \\
30.5 \\
28.8 \\
27.1\end{array}$ \\
\hline $\begin{array}{l}1960 \ldots \\
1961 \ldots \\
1962 \ldots \\
1963 \ldots \\
1964 \ldots \\
\end{array}$ & $\begin{array}{l}4.6 \\
5.2 \\
5.7 \\
6.3 \\
7.0\end{array}$ & $\begin{array}{l}.6 \\
.6 \\
.7 \\
.8 \\
.9\end{array}$ & $\begin{array}{l}(*) \\
(*) \\
(*) \\
(*) \\
(*)\end{array}$ & $\begin{array}{l}5.2 \\
5.8 \\
6.4 \\
7.1 \\
7.9\end{array}$ & $\begin{array}{l}2.2 \\
2.3 \\
2.6 \\
2.8 \\
3.2\end{array}$ & $\begin{array}{l}.1 \\
.1 \\
.1 \\
.2 \\
.2\end{array}$ & $\begin{array}{l}(*) \\
(*) \\
(*) \\
(*) \\
(*)\end{array}$ & $\begin{array}{l}2.3 \\
2.4 \\
2.7 \\
3.0 \\
3.4\end{array}$ & $\begin{array}{l}23.5 \\
24.7 \\
26.0 \\
28.0 \\
30.2\end{array}$ & $\begin{array}{l}6.5 \\
6.7 \\
7.1 \\
7.0 \\
7.6\end{array}$ & $\begin{array}{l}2.0 \\
2.2 \\
2.1 \\
2.4 \\
2.8\end{array}$ & $\begin{array}{l}28.0 \\
29.2 \\
31.0 \\
32.6 \\
35.0\end{array}$ & $\begin{array}{r}9.6 \\
9.2 \\
8.7 \\
9.6 \\
10.1\end{array}$ & $\begin{array}{l}.8 \\
1.3 \\
1.5 \\
2.7 \\
3.0\end{array}$ & $\begin{array}{l}25.4 \\
23.7 \\
22.0 \\
20.6 \\
19.2\end{array}$ \\
\hline $\begin{array}{l}1965 \ldots \\
1966 \ldots \\
1967 \ldots \\
1968 \ldots \\
1969 \ldots \\
\end{array}$ & $\begin{array}{l}7.5 \\
7.8 \\
7.7 \\
8.6 \\
8.0\end{array}$ & $\begin{array}{l}.9 \\
1.1 \\
1.0 \\
1.5 \\
1.7\end{array}$ & $\begin{array}{l}(*) \\
.1 \\
.1 \\
.1 \\
.2\end{array}$ & $\begin{array}{r}8.4 \\
8.8 \\
8.6 \\
10.0 \\
9.5\end{array}$ & $\begin{array}{l}3.5 \\
3.7 \\
3.8 \\
4.6 \\
5.3\end{array}$ & $\begin{array}{l}.3 \\
.2 \\
.2 \\
.3 \\
.3\end{array}$ & $\begin{array}{l}(*) \\
(*) \\
(*) \\
\left({ }^{*}\right) \\
0.1\end{array}$ & $\begin{array}{l}3.8 \\
3.9 \\
4.0 \\
4.9 \\
5.5\end{array}$ & $\begin{array}{l}31.6 \\
34.4 \\
34.4 \\
38.3 \\
40.0\end{array}$ & $\begin{array}{l}8.1 \\
9.0 \\
8.6 \\
8.9 \\
9.7\end{array}$ & $\begin{array}{l}2.9 \\
3.3 \\
4.1 \\
5.5 \\
6.4\end{array}$ & $\begin{array}{l}36.8 \\
40.1 \\
38.9 \\
41.7 \\
43.3\end{array}$ & $\begin{array}{r}10.5 \\
10.5 \\
9.6 \\
9.0 \\
8.5\end{array}$ & $\begin{array}{l}3.4 \\
3.9 \\
5.5 \\
7.1 \\
6.6\end{array}$ & $\begin{array}{l}17.9 \\
16.5 \\
15.2 \\
13.7 \\
12.1\end{array}$ \\
\hline $\begin{array}{l}19702^{2}-\ldots \\
19712^{2} \ldots \\
19722^{2}=\end{array}$ & $\begin{array}{r}8.3 \\
9.6 \\
10.7\end{array}$ & $\begin{array}{l}1.6 \\
2.0 \\
2.4\end{array}$ & $\begin{array}{l}.1 \\
.2 \\
.2\end{array}$ & $\begin{array}{r}9.8 \\
11.4 \\
12.9\end{array}$ & $\begin{array}{l}5.4 \\
6.7 \\
7.9\end{array}$ & $\begin{array}{l}.2 \\
.3 \\
.5\end{array}$ & $\begin{array}{l}.1 \\
.1 \\
.1\end{array}$ & $\begin{array}{l}5.5 \\
6.9 \\
8.3\end{array}$ & $\begin{array}{l}40.9 \\
40.8 \\
42.9\end{array}$ & $\begin{array}{l}9.2 \\
9.4 \\
8.8\end{array}$ & $\begin{array}{l}7.7 \\
6.6 \\
7.5\end{array}$ & $\begin{array}{l}42.4 \\
43.6 \\
44.2\end{array}$ & $\begin{array}{l}7.9 \\
8.4 \\
8.9\end{array}$ & $\begin{array}{l}7.7 \\
6.3 \\
8.7\end{array}$ & $\begin{array}{r}10.5 \\
9.8 \\
9.3\end{array}$ \\
\hline
\end{tabular}

- Less than 50,000 tons.

1 Data may not add to totals because of rounding

2 Preliminary.

3 Includes hardboard, insulating board, and particleboard.

4 Excludes woodpulp used in hardboard and insulating board.

- Excludes veneer produced and consumed in industries other than the plywood industry.

Includes both woodpulp and the woodpulp equivalent of paper and board except hardboard and insulating board.
? Includes pulpwood, woodpulp, and the woodpulp equivalent of pape and board except hardboard and insulating board.

8 Includes cooperage logs, poles and piling, fence posts, hewn ties, round mine timbers, box bolts, excelsior bolts, chemical wood, shingle bolts, and miscellaneous items.

Sources: Based on data published by the U.S. Departments of Commerce and Agriculture. 
(3)

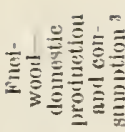

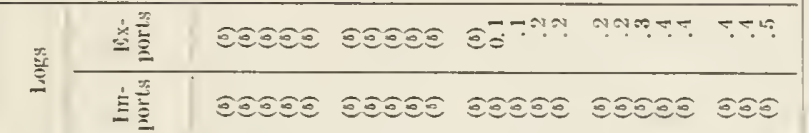

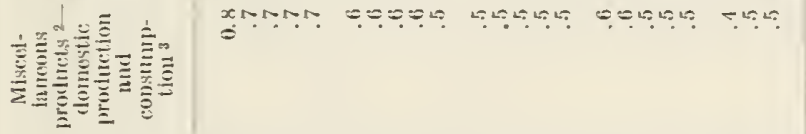

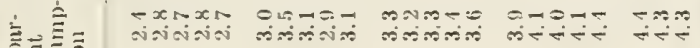

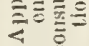

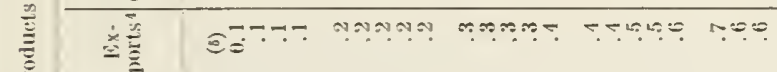

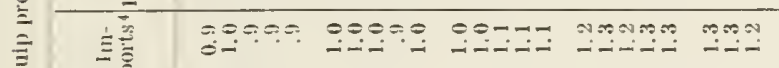
$\equiv$

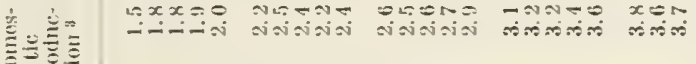

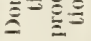

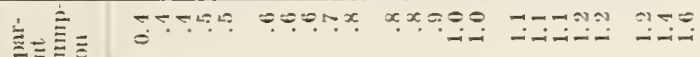
运新

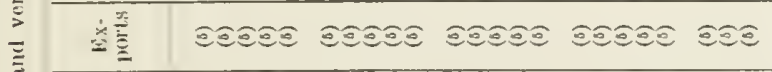

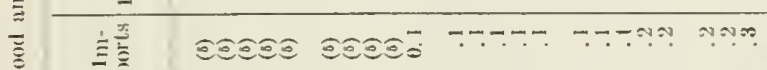
$\geqq$

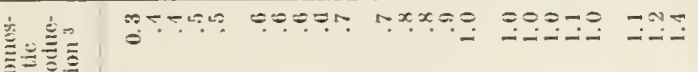

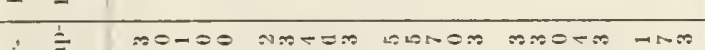

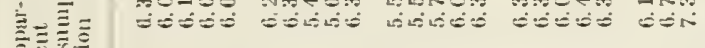

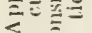

m

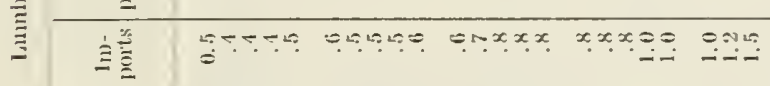

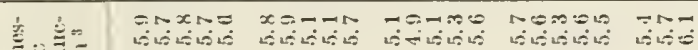

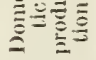

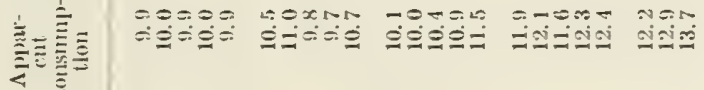

Fل

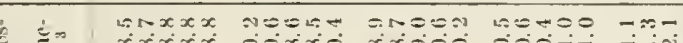

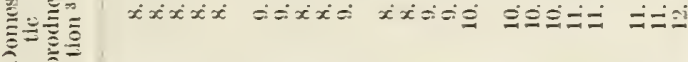

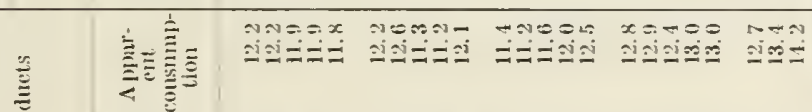

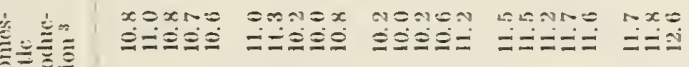

(1)

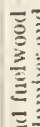

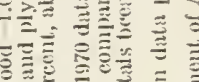

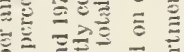

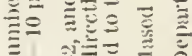

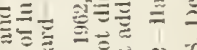

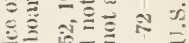
m, on

$\circ$ ‡Nis

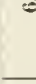

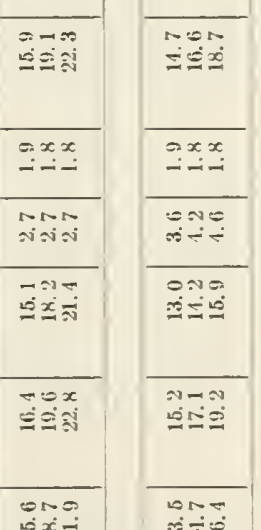
ำำสำ $\cong=$

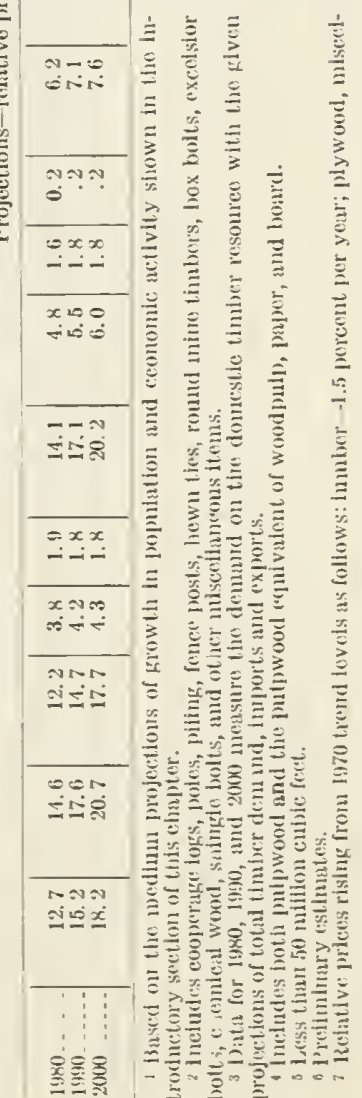

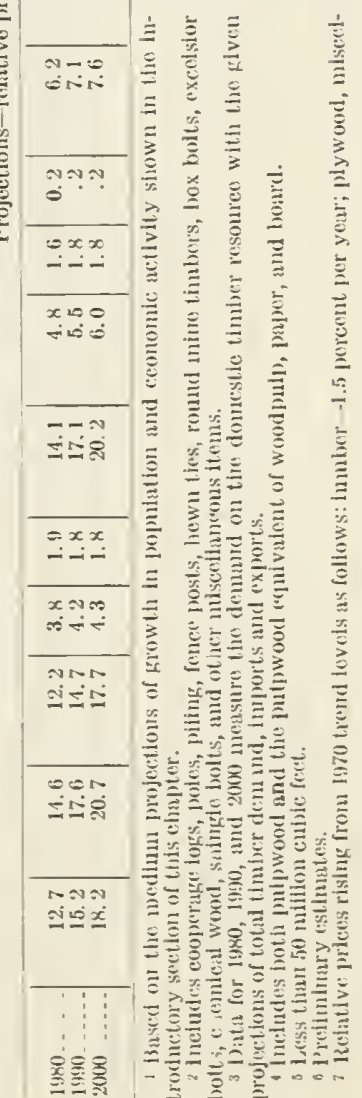



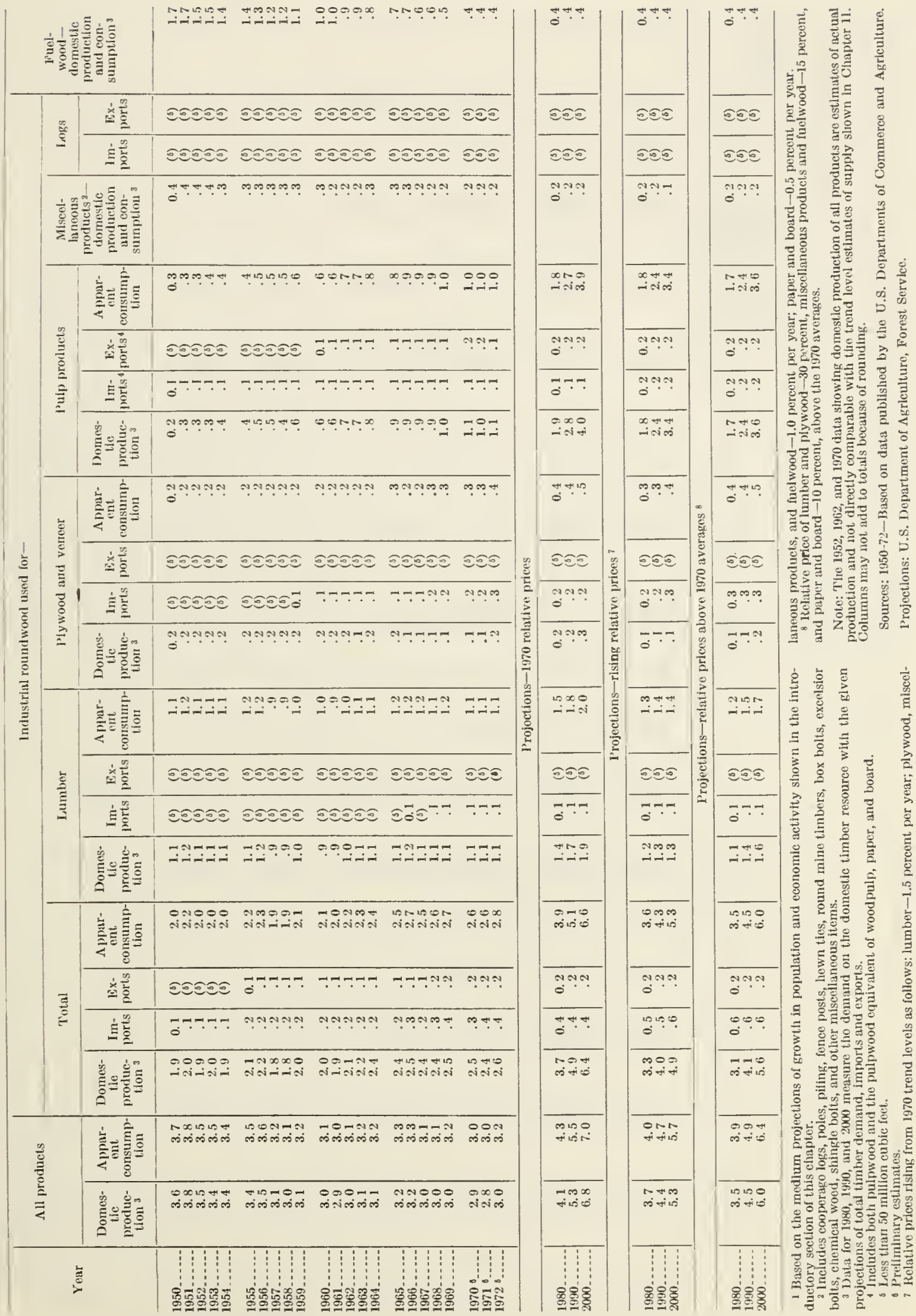


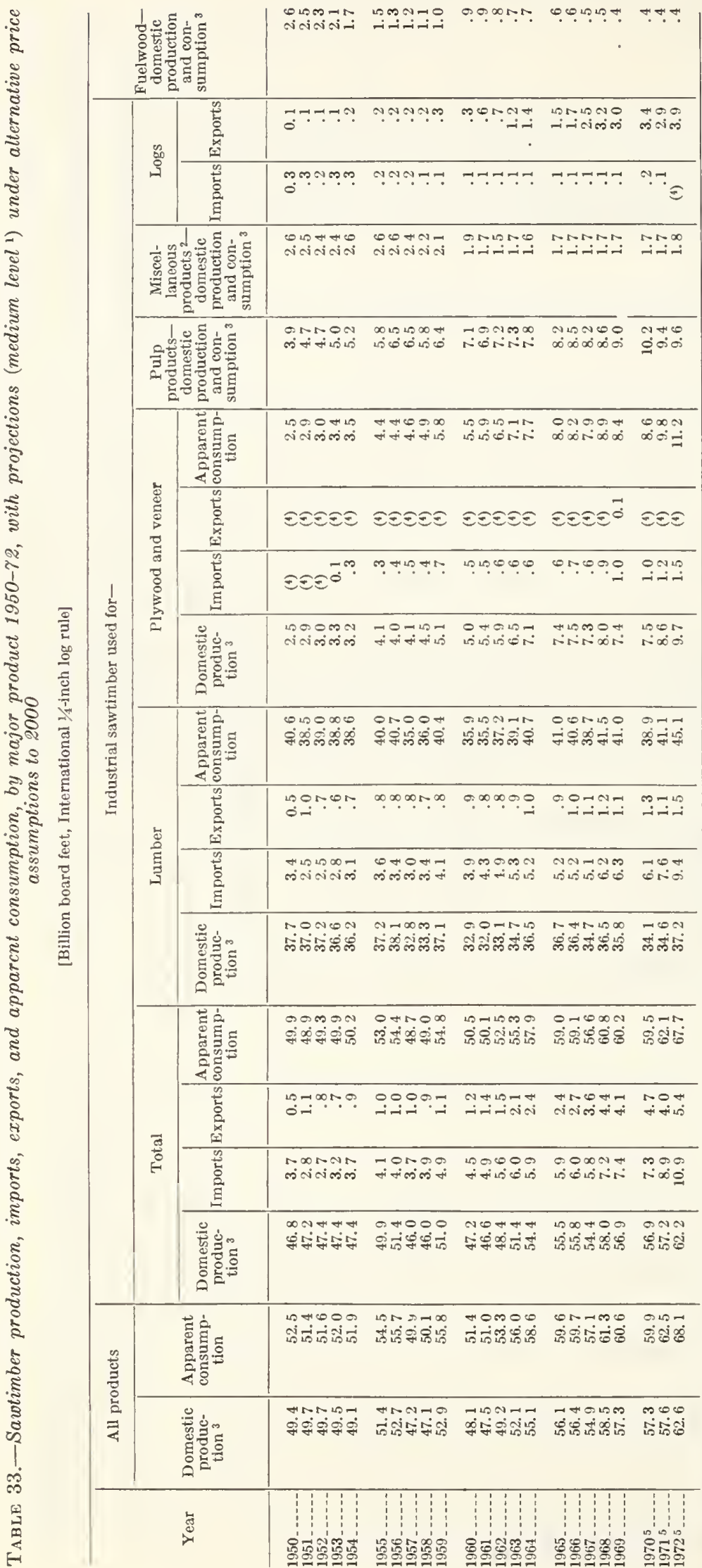

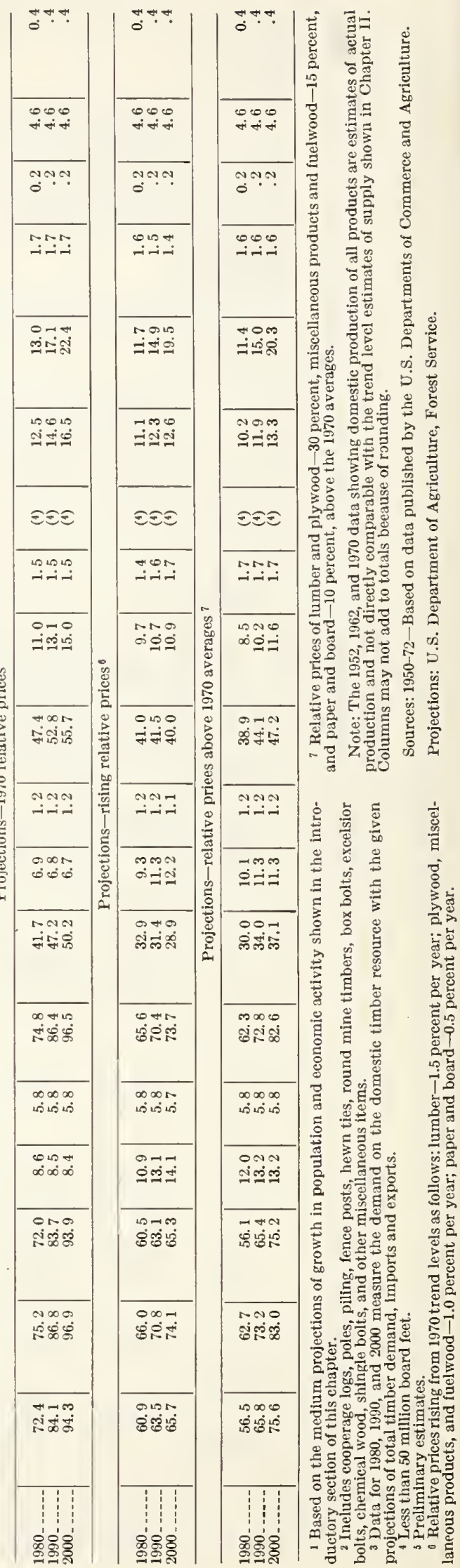




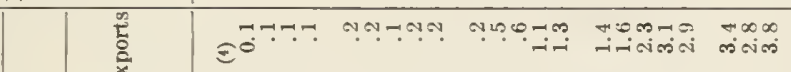

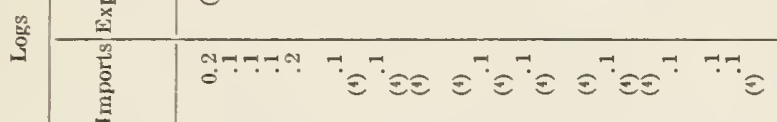

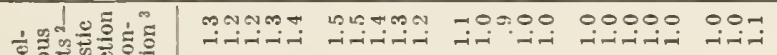

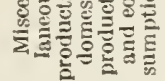

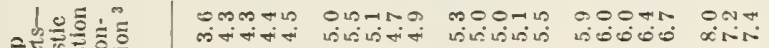

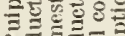

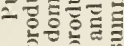
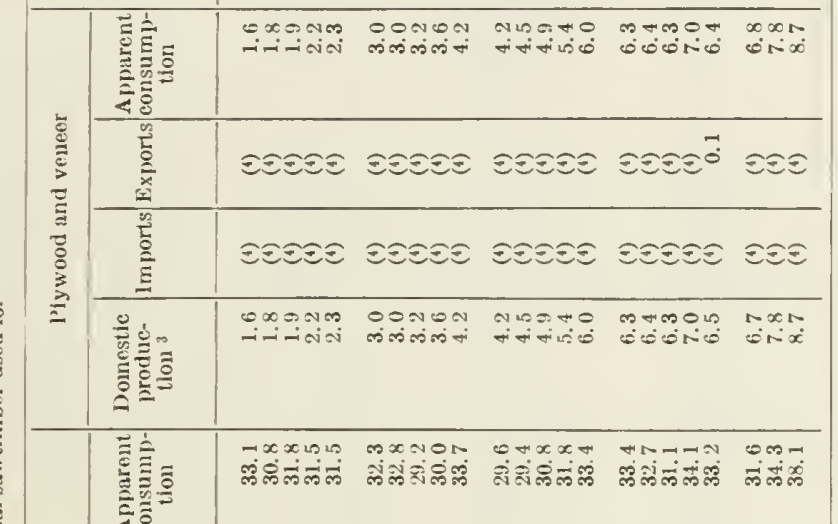

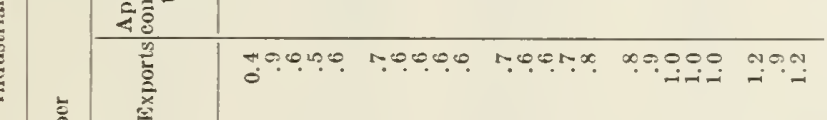

ڤั)

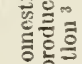
递

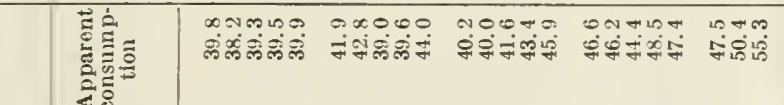

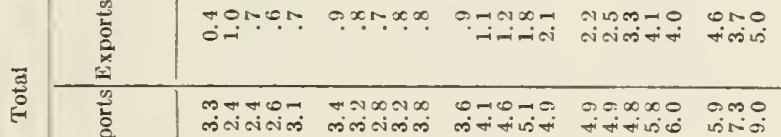

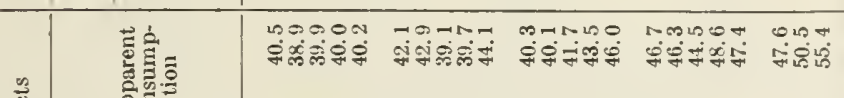

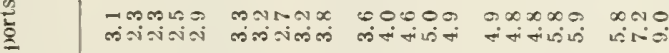

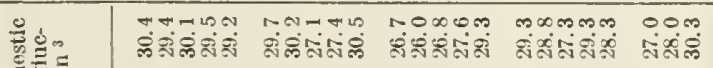
(1)

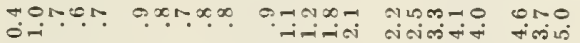

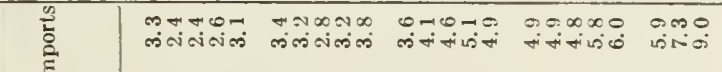

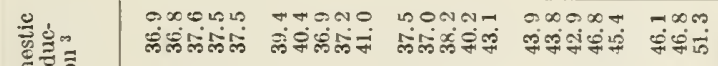

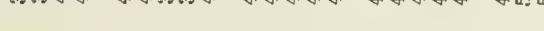

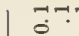

.

$-$

000

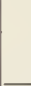

No:

ono

๑ே‡

ઈモ气

ono

தี⿻

递

in No

๓่ ฟ่ำ

푸련

यक तथ

iो

๓ंळ

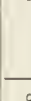

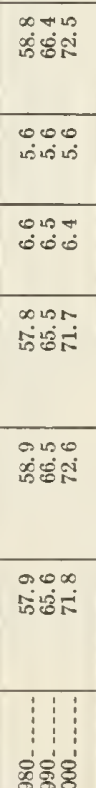
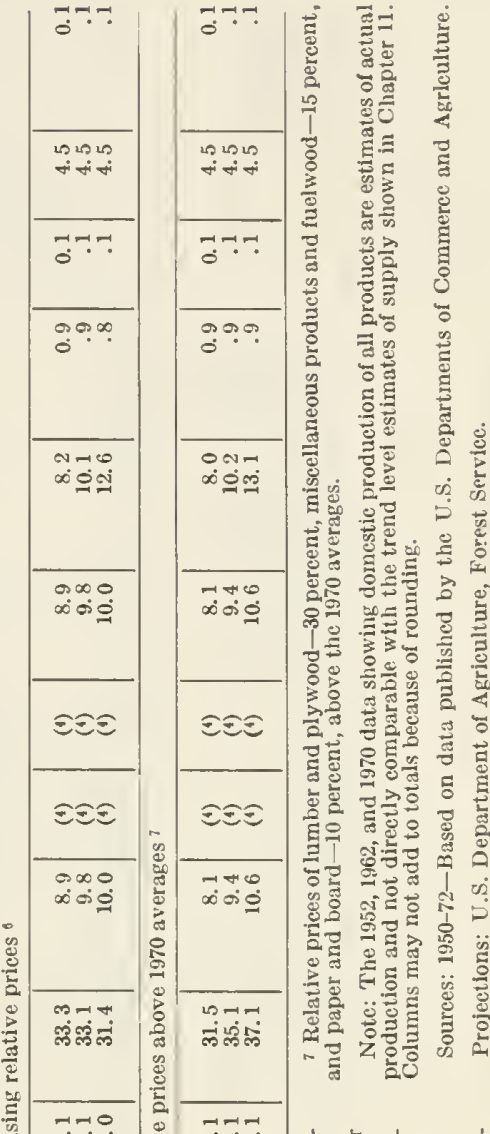

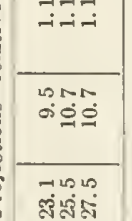

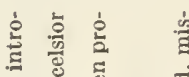

宊

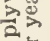

它焉

क्ष

릉

\begin{tabular}{|c|c|}
\hline 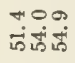 & 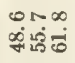 \\
\hline 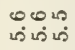 & $\begin{array}{l}000 \\
\sin ^{\circ}\end{array}$ \\
\hline $\begin{array}{l}\infty \infty \\
\infty \\
\infty\end{array} \stackrel{=}{=1}$ & 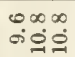 \\
\hline 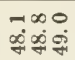 & 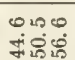 \\
\hline
\end{tabular}

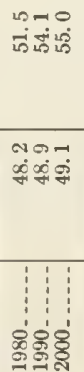

$\rightarrow \infty$

कुष

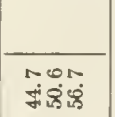

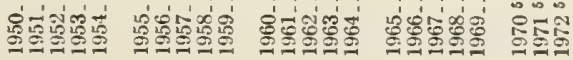



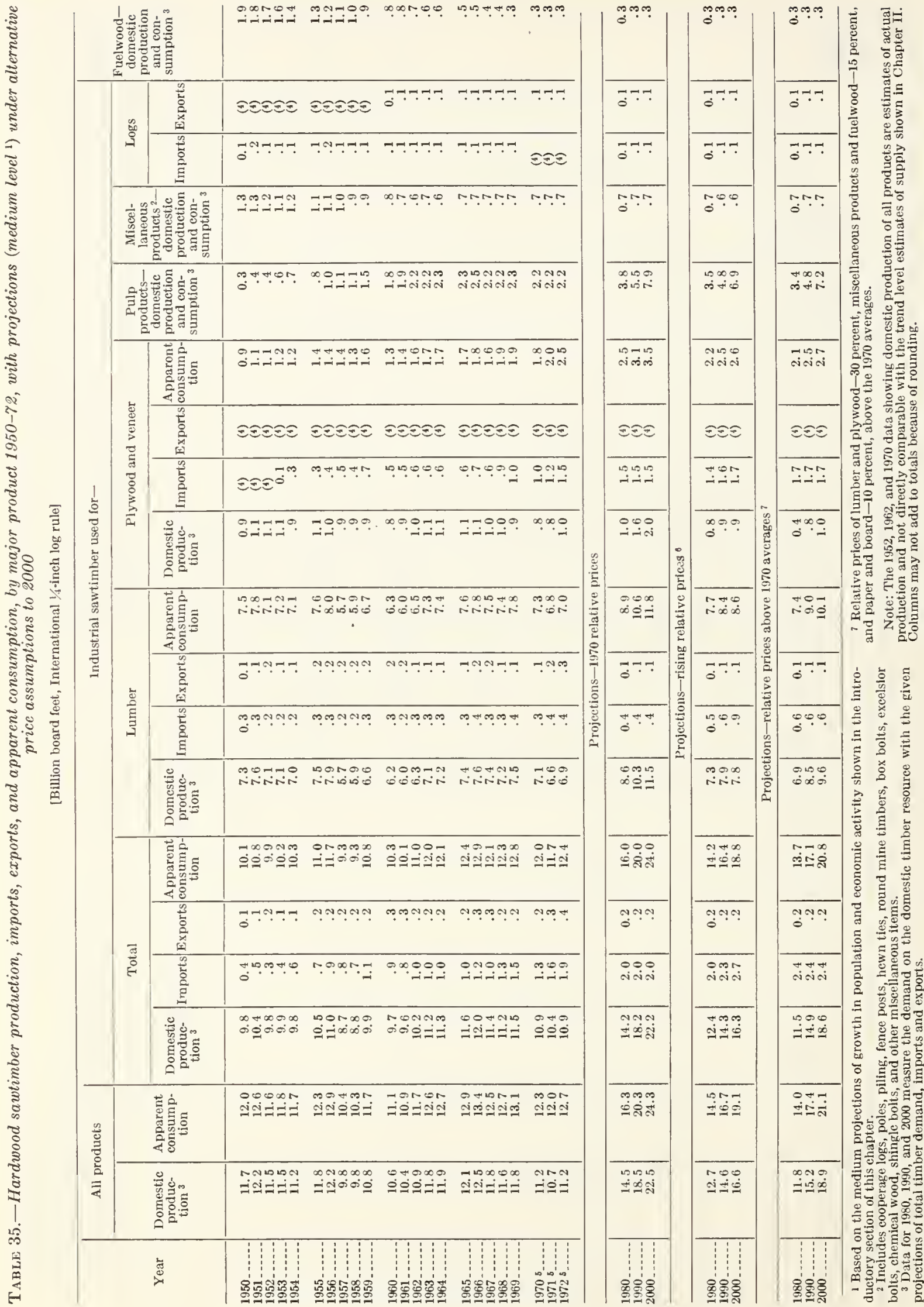

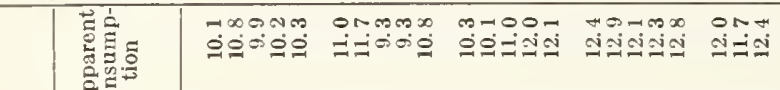

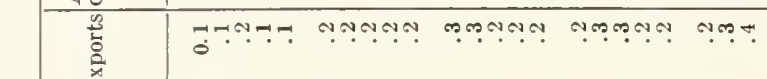

항 尊

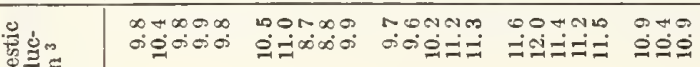

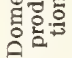


APPENDIX V. TLIBER DEMAND TABLES

TABLE 36.-Consumption of industrial raw materials in the United States, by broad product groups, 1920-69

[Millions of 1967 dollars]

\begin{tabular}{|c|c|c|c|c|c|c|c|c|}
\hline \multirow{2}{*}{ Year } & \multicolumn{2}{|c|}{ All industrial raw materials } & \multicolumn{2}{|c|}{$\begin{array}{l}\text { Agriculture and fishery nonfoods } \\
\text { and wildlife products }\end{array}$} & \multicolumn{2}{|c|}{ Industrial timber products 2} & \multicolumn{2}{|c|}{ Minerals except fuels ${ }^{3}$} \\
\hline & Dollars & $\begin{array}{l}\text { Percent of all } \\
\text { raw materials }\end{array}$ & Dollars & $\begin{array}{l}\text { Percent of all } \\
\text { industrial } \\
\text { materials }\end{array}$ & Dollars & $\begin{array}{l}\text { Percent of all } \\
\text { industrial } \\
\text { materials }\end{array}$ & Dollars & $\begin{array}{l}\text { Percent of all } \\
\text { industrial } \\
\text { materials }\end{array}$ \\
\hline 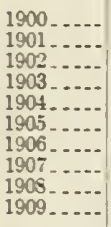 & $\begin{array}{l}4,463 \\
4,452 \\
4,995 \\
4,896 \\
5,239 \\
5,520 \\
6,113 \\
5,891 \\
5,555 \\
6,139\end{array}$ & $\begin{array}{l}25.7 \\
25.5 \\
26.7 \\
25.3 \\
25.7 \\
26.6 \\
25.0 \\
27.2 \\
25.8 \\
27.4\end{array}$ & $\begin{array}{l}1,317 \\
1,198 \\
1,407 \\
1,311 \\
1,677 \\
1,629 \\
1,892 \\
1,634 \\
1,737 \\
1,798\end{array}$ & $\begin{array}{l}29.5 \\
26.7 \\
28.2 \\
26.8 \\
32.0 \\
29.5 \\
31.0 \\
27.7 \\
31.3 \\
29.3\end{array}$ & $\begin{array}{l}2,030 \\
2,107 \\
2,210 \\
2,274 \\
2,353 \\
2,415 \\
2,573 \\
2,652 \\
2,462 \\
2,604\end{array}$ & $\begin{array}{l}45.5 \\
47.0 \\
44.2 \\
46.4 \\
44.9 \\
43.8 \\
42.0 \\
44.9 \\
44.3 \\
42.4\end{array}$ & $\begin{array}{l}1,116 \\
1,177 \\
1,378 \\
1,311 \\
1,209 \\
1,476 \\
1,648 \\
1,605 \\
1,356 \\
1,737\end{array}$ & $\begin{array}{l}25.0 \\
26.3 \\
27.6 \\
26.8 \\
23.1 \\
26.7 \\
27.0 \\
27.4 \\
24.4 \\
28.3\end{array}$ \\
\hline 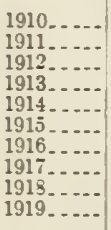 & $\begin{array}{l}6,256 \\
6,278 \\
6,185 \\
6,454 \\
6,777 \\
5,985 \\
6,906 \\
7,023 \\
7,052 \\
6,412\end{array}$ & $\begin{array}{l}27.1 \\
26.8 \\
25.7 \\
26.9 \\
27.5 \\
25.4 \\
25.3 \\
27.1 \\
27.1 \\
25.3\end{array}$ & $\begin{array}{l}1,850 \\
2,090 \\
1,769 \\
2,033 \\
2,767 \\
1,834 \\
2,112 \\
2,564 \\
2,779 \\
2,267\end{array}$ & $\begin{array}{l}29.6 \\
33.3 \\
28.6 \\
31.5 \\
40.8 \\
30.7 \\
30.6 \\
36.5 \\
39.4 \\
35.4\end{array}$ & $\begin{array}{l}2,601 \\
2,503 \\
2,608 \\
2,548 \\
2,438 \\
2,312 \\
2,485 \\
2,306 \\
2,110 \\
2,207\end{array}$ & $\begin{array}{l}41.5 \\
39.9 \\
42.2 \\
39.5 \\
36.0 \\
38.6 \\
36.0 \\
32.8 \\
29.9 \\
34.4\end{array}$ & $\begin{array}{l}1,805 \\
1,685 \\
1,808 \\
1,873 \\
1,572 \\
1,839 \\
2,309 \\
2,153 \\
2,163 \\
1,938\end{array}$ & $\begin{array}{l}28.9 \\
26.8 \\
29.2 \\
29.0 \\
23.2 \\
30.7 \\
33.4 \\
30.7 \\
30.7 \\
30.2\end{array}$ \\
\hline $\begin{array}{l}1920 \ldots \ldots \\
1921=\ldots \\
1922-\ldots \\
1923 \ldots \\
1924-\ldots \\
1925-\ldots \\
1926 \\
1927 \\
1928 \\
1929\end{array}$ & $\begin{array}{l}7,015 \\
4,634 \\
6,273 \\
7,432 \\
7,231 \\
7,913 \\
8,036 \\
8,017 \\
7,958 \\
8,637\end{array}$ & $\begin{array}{l}26.3 \\
20.3 \\
23.8 \\
25.5 \\
25.1 \\
26.7 \\
26.3 \\
26.5 \\
26.1 \\
27.0\end{array}$ & $\begin{array}{l}2,628 \\
1,400 \\
2,042 \\
2,394 \\
2,495 \\
2,811 \\
2,813 \\
3,034 \\
2,952 \\
3,197\end{array}$ & $\begin{array}{l}37.5 \\
30.2 \\
32.6 \\
32.3 \\
34.5 \\
35.6 \\
35.4 \\
37.9 \\
37.1 \\
37.0\end{array}$ & $\begin{array}{l}2,274 \\
1,914 \\
2,253 \\
2,538 \\
2,412 \\
2,487 \\
2,459 \\
2,342 \\
2,279 \\
2,411\end{array}$ & $\begin{array}{l}32.4 \\
41.3 \\
3.9 \\
34.1 \\
33.4 \\
31.4 \\
30.6 \\
29.2 \\
28.6 \\
27.9\end{array}$ & $\begin{array}{l}2,113 \\
1,320 \\
1,978 \\
2,500 \\
2,324 \\
2,815 \\
2,734 \\
2,641 \\
2,727 \\
3,029\end{array}$ & $\begin{array}{l}30.1 \\
28.5 \\
31.5 \\
33.6 \\
32.1 \\
33.0 \\
34.0 \\
32.9 \\
34.3 \\
35.1\end{array}$ \\
\hline $\begin{array}{l}1930 \ldots \ldots \\
1931 \\
1932 \\
1933 \\
1934 \\
1935 \\
1936 \\
1937 \\
1938 \\
1939\end{array}$ & $\begin{array}{l}6,989 \\
5,870 \\
4,359 \\
5,322 \\
5,421 \\
6,103 \\
7,590 \\
7,981 \\
6,359 \\
7,820\end{array}$ & $\begin{array}{l}23.4 \\
20.6 \\
16.7 \\
19.2 \\
18.9 \\
21.2 \\
24.0 \\
24.8 \\
21.1 \\
23.7\end{array}$ & $\begin{array}{l}2,744 \\
2,675 \\
2,358 \\
2,783 \\
2,781 \\
2,909 \\
3,372 \\
3,359 \\
2,838 \\
3,353\end{array}$ & $\begin{array}{l}39.2 \\
45.6 \\
53.7 \\
52.3 \\
51.3 \\
47.7 \\
44.4 \\
42.1 \\
44.6 \\
42.9\end{array}$ & $\begin{array}{l}1,928 \\
1,408 \\
1,060 \\
1,262 \\
1,342 \\
1,576 \\
1,876 \\
2,012 \\
1,756 \\
1,982\end{array}$ & $\begin{array}{l}27.6 \\
24.0 \\
24.2 \\
23.7 \\
24.8 \\
25.8 \\
24.7 \\
25.2 \\
27.6 \\
25.3\end{array}$ & $\begin{array}{l}2,317 \\
1,787 \\
971 \\
1,277 \\
1,298 \\
1,618 \\
2,342 \\
2,610 \\
1,765 \\
2,485\end{array}$ & $\begin{array}{l}33.2 \\
30.4 \\
22.1 \\
24.0 \\
23.9 \\
26.5 \\
30.9 \\
32.7 \\
27.8 \\
31.8\end{array}$ \\
\hline $\begin{array}{l}1940 \ldots \ldots \\
1941 \\
1942 \\
1943 \ldots \\
1944 \\
1945 \\
1946 \\
1947 \\
1948 \\
1949\end{array}$ & $\begin{array}{r}8,655 \\
11,194 \\
11,136 \\
10,801 \\
10,489 \\
10,136 \\
10,650 \\
10,786 \\
11,346 \\
10,376\end{array}$ & $\begin{array}{l}24.8 \\
29.0 \\
28.3 \\
26.7 \\
24.8 \\
24.2 \\
25.4 \\
25.1 \\
26.3 \\
24.8\end{array}$ & $\begin{array}{l}3,580 \\
4,356 \\
4,197 \\
4,207 \\
4,143 \\
4,063 \\
4,389 \\
4,078 \\
4,150 \\
3,635\end{array}$ & $\begin{array}{l}41.4 \\
38.9 \\
37.7 \\
38.9 \\
39.5 \\
40.1 \\
41.2 \\
37.8 \\
36.6 \\
35.0\end{array}$ & $\begin{array}{l}2,140 \\
2,498 \\
2,528 \\
2,322 \\
2,289 \\
2,086 \\
2,428 \\
2,536 \\
2,705 \\
2,378\end{array}$ & $\begin{array}{l}24.7 \\
22.3 \\
22.7 \\
21.5 \\
21.8 \\
20.6 \\
22.8 \\
23.5 \\
23.8 \\
22.9\end{array}$ & $\begin{array}{l}2,935 \\
4,340 \\
4,411 \\
4,272 \\
4,057 \\
3,987 \\
3,833 \\
4,172 \\
4,491 \\
4,363\end{array}$ & $\begin{array}{l}33.9 \\
38.8 \\
39.6 \\
39.6 \\
38.7 \\
39.3 \\
36.0 \\
38.7 \\
39.6 \\
42.1\end{array}$ \\
\hline 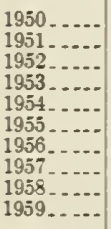 & $\begin{array}{l}12,476 \\
12,394 \\
12,27 \\
12,745 \\
12,129 \\
13,249 \\
13,640 \\
13,089 \\
12,793 \\
14,031\end{array}$ & $\begin{array}{l}27.4 \\
26.7 \\
36.3 \\
26.5 \\
25.5 \\
26.2 \\
26.1 \\
25.4 \\
25.0 \\
26.1\end{array}$ & $\begin{array}{l}4,367 \\
4,184 \\
3,952 \\
3,948 \\
3,673 \\
3,925 \\
4,017 \\
3,750 \\
3,644 \\
3,983\end{array}$ & $\begin{array}{l}35.0 \\
33.8 \\
32.2 \\
31.0 \\
30.3 \\
29.6 \\
29.4 \\
28.7 \\
28.5 \\
28.4\end{array}$ & $\begin{array}{l}2,811 \\
2,820 \\
2,807 \\
2,822 \\
2,804 \\
2,952 \\
3,064 \\
2,727 \\
2,724 \\
3,004\end{array}$ & $\begin{array}{l}22.5 \\
22.8 \\
22.9 \\
22.1 \\
23.1 \\
22.3 \\
22.5 \\
20.8 \\
21.3 \\
21.4\end{array}$ & $\begin{array}{l}5,298 \\
5,390 \\
5,518 \\
5,975 \\
5,652 \\
6,372 \\
6,559 \\
6,612 \\
6,425 \\
7,044\end{array}$ & $\begin{array}{l}42.5 \\
43.4 \\
44.9 \\
46.9 \\
46.6 \\
48.1 \\
48.1 \\
50.5 \\
50.2 \\
50.2\end{array}$ \\
\hline $\begin{array}{l}1960 \ldots \\
1961 \\
1962 \\
1963 \\
1964 \\
1965 \\
1966 \\
1967 \\
1968 \\
1969\end{array}$ & $\begin{array}{l}13,476 \\
13,560 \\
14,600 \\
14,652 \\
15,539 \\
16,404 \\
17,096 \\
16,450 \\
17,158 \\
17,145\end{array}$ & $\begin{array}{l}25.1 \\
24.9 \\
25.8 \\
25.3 \\
26.0 \\
26.7 \\
26.9 \\
25.5 \\
25.6 \\
25.0\end{array}$ & $\begin{array}{l}3,814 \\
3,842 \\
4,132 \\
3,952 \\
4,068 \\
4,221 \\
4,357 \\
4,093 \\
4,193 \\
4,031\end{array}$ & $\begin{array}{l}28.3 \\
28.3 \\
28.3 \\
27.0 \\
26.2 \\
25.7 \\
25.5 \\
24.9 \\
24.4 \\
23.5\end{array}$ & $\begin{array}{l}2,831 \\
2,805 \\
2,949 \\
3,082 \\
3,254 \\
3,362 \\
3,386 \\
3,217 \\
3,400 \\
3,401\end{array}$ & $\begin{array}{l}21.0 \\
20.7 \\
20.2 \\
21.0 \\
20.9 \\
20.5 \\
19.8 \\
19.5 \\
19.8 \\
19.8\end{array}$ & $\begin{array}{l}6,831 \\
6,913 \\
7,519 \\
7,618 \\
8,217 \\
8,821 \\
9,353 \\
9,140 \\
9,565 \\
9,713\end{array}$ & $\begin{array}{l}50.7 \\
51.0 \\
51.5 \\
52.0 \\
52.9 \\
53.8 \\
54.7 \\
55.6 \\
55.8 \\
56.7\end{array}$ \\
\hline
\end{tabular}

1 Cotton and other fibers, oils, hides, rubber, furs, and other similar products.

2 Saw logs; reneer logs; pulpwood; turpentine; rosin; and miscellaneous products, such as pries, piling, and ports. Excludes fuel wood.
prow

Dimension stone, crushed and broken stone, sand and gravel, fire clay, common clay and shale, gypsum, metal ores, chemical and fertilizer minerals, abrasives, and other similar construction materials. Also, includes some minerals fuels that are user for nonfuel uses.

Source: T-.S. Department of Commerce, Bureau of the Census and U.S. Department of the Interior, Bureau of the Mines. Raic materials in the United States economy 190n-1969. Working Paper 35, 1972. 


\section{INDEX}

Alaska, 9, 10, 77, 79, 90, 91, 128

Allowable cut, 36, 45, 73, 74, 90, 99, 103, 104 121, 218, 221

Base projections of supply

area assumptions, $36,43,44$

assumed improvements in utilization, 123, 124

management assumptions, 36-43, 215

North, 61-71

Pacific Coast, 77-88

removal assumptions, 36, 44-46, 215

Rocky Mountains, 69-78

South, 52-64

summary for United States, 46-53, 215-219

Building board

exports, 186,187

imports, $186,187,193$

production, 186,187

Building board use and projected demand

alternative growth assumptions, 186, 189, 190

alternative price assumptions, 186,187

demand on U.S. mills, 186,187

miscellaneous uses, $177-179,186$

new housing, 150, 157-160, 186

new nonresidential construction, 161, 162, 165-167, 186

per capita, $186,187,190$

summary of all uses, $186,187,189-191$

upkeep and improvements, 160, 161, 177, 178, 186

Canada

exports, 127, 129-131, 134-137, 139, 181, 193, 198, 200, 204,209

forest resources, $\mathbf{1 3 4 - 1 3 7}$

potential timber supplies, 133-137, 139, 181, 193, 198

production of forest products, $134-136,181$

utilization trends, 134-137

Commercial timber land

a rea, $8,10-15,43,44,53,54,61,64,70,71,77,78$

area projections, $43,44,54,61,64,70,71,78$

classification, 100

forest types, $12,13,112$

North, 8, 10-15, 43, 61, 64, 112, 113

ownership, 11, 12, 54, 64, 70,71, 78, 107

Pacific Coast $9-15,43,77,78$

productivity, 13, 14, 62, 94, 108, 112, 120

Rocky Mountains, 9-12, 14, 15, 43, 70, 71

site quality, 13, 14, 107

South, 8, 10, 11, 13-15, 43, 53, 54, 107, 108

stand size classes, 14, 15, 94, 107, 112

stocking, 14, 15, 94, 108, 112, 113

taxation, 43

trends, 10-13, 43, 44, 53, 54, 61, 64, 70, 71, 77, 78

United States, 8, 10, 11, 14, 15, 43, 44

Construction expenditures

nonresidential, 161-167

upkeep and improvements, 160, 161

Containers

hardboard use, 174,178

lumber use, $174,177,178$

timber products use per dollar of shipments, 177,178

value of shipments, 177,178

veneer and plywood use, 174, 177, 178, 183

Cooperage, 21-23, 201, 203

Crossties, 166, 168, 219
Cultural measures, 110, 218, 219, 221

intermediate cut, 107, 108, 110, 111, 221

prescribed burning, 37, 38, 96, 101, 108, 110, 221

thinning, 41, 95, 96, 98-101, 104, 105, 108, 111, 113, $115,117,121,122,218,219,221$

Cut (see Removals)

Demand for timber products

manufactured products, $166,168,169,172-175,179$, $181,183,186$

miscellaneous uses, 177-179, 181, 183, 186, 201, 203

new housing, 150-160, 179, 181, 183, 186

new nonresidential construction, 161-167, 179, 181, 183,186

railroad construction, 166,168

residential upkeep and improvements, 160, 161, 179, $181,183,186$

shipping, 174, 177, 179, 181, 183, 186

summary of all uses 181-184, 186, 187

Demand-price relationships

lumber, 149, 150, 180-182

paper and board, 149, 150, 188, 191-194

plywood, 149, 150, 183-185

Demand projections

basic assumptions, $\mathbf{1 4 3 - 1 5 0}$

effect of price increases, 149, 150, 180-188, 191-194, $198,200-202,206-212,215-219$

hardwood, 180-185, 199-201, 207-212, 217-219

manufactured products, $173-175,181$

miscellaneous uses, $178,179,201,203$

new housing, 150, 153-160

new nonresidential construction, 161, 165-167

pulpwood, 199-202

railroad construction, 166,168

roundwood, $46,49,50,52,206-212,215-219$

sawtimber, 208-212, 215-219

shipping, 177,179

softwood, 180-185, 199-201, 207-212, 215, 216

upkeep and improvements, 160,161

Demand-supply relationships

hardwood, 217-219

roundwood, $215-218$

sawtimber, 215-219

softwood, 215-218

Destructive agents

fire control, 36-38, 42, 95-99, 106, 121, 221

impacts on growth, 17-19, 108, 221

insect and disease control, 38, 39, 42, 95, 97-99, 106, $108,109,121,221$

Disposable personal income, $144,145,151,154,166,168-$ $171,188,191$

Dwellings (see Residential construction)

Economic projections of supply, 36, 87-92, 215-218

Environmental impacts

bark residues, 34

Europe, 130

Japan, 131

logging residues, 24,48

on intensified management, $19,45,91,94,98,99,218$, 220,221

on reforestation, 40,45

on supply, $36,43-45,58,70,79,90,91,94,96,218,220$

paper and board consumption, 188,191

waste paper consumption, 196, 221 
Exports

building board, 186,187

Canada, 127, 193, 204

Europe, 127-131, 193, 197

hardwood, 128, 140,182, 184, 204, 210, 211, 217

Japan, 127-129, 131, 132, 193, 197, 199, 204

Latin America, $127,193,197$

logs, 127-129, 131, 139-141, 204, 208

lumber, $127,128,131,140,141,181,182$

paper and board, $127,128,131,139-141,192,193,199$, 202

plywood and veneer, $127,128,140,141,183,184$

projections, $140,141,182,184,187,192,193,197-200$, $202,204,208-211,216,217$

pulpwood, 30, 127, 128, 131, 139-141, 188, 198-202, 208, 210

sawtimber, 208, 209, 211, 216, 217

softwood, 127, 128, 131, 140, 182, 184, 204, 208, 210, 211, 216

total roundwood equivalent, 127, 141, 208-210, 216, 217

trends, 126-129, 139, 182, 184, 187, 192, 197, 199, 200, $202,204,208-211,216,217$

value, 127,128

volume, $127,128,140,141,182,184,187,192,193,197$, $199,200,202,204,208-211,216,217$

woodpulp, 127, 128, 131, 140,141, 196-199, 202

Farm and miscellaneous private lands

area, $11,44,54,61,64,71,78,79,107,109,111$

area projections, $44,64,71,78$

classification, 97

intensified management, $94,96-106,108-112,123$

inventories, $29,32,64,69,71,78,84,86-88$

North, $11,61,64,67-69,71,112$

Pacific Coast, $11,78,79,81-84,123$

reforestation, $39,40,104-106,108,111$

Rocky Mountains, 11, 71, 74-76, 78

roundwood, $57,67,82-84$

South, $11,54,57-60,64,97,106-112$

supply projections, $51-53,57-60,67-69,74-76,82,83$, 112

trends, $11,44,54,64,76-79$

United States, 11, 44

Fence posts, 21-23, 201, 203

Fertilization, 17, 41, 95, 96, 98, 101, 106, 107, 110, 121, $122,218,222$

Fire protection, 42, 95-99, 106, 121, 221

area burned, 37,38

area protected, 37,38

expenditures, $36-38$

hazard reduction, 37,38

mortality, 19. 38,108

ownership, 37

trends, 36-38

Forest industry lands

area, $11,44,54,64,71,78,79,107$

area projections, $44,64,71,78$

intensified management, $95,98,99,106,109,110,123$, 218

inventories, $29,32,64,69,71,78,86-88$

North, 11, 64, 67-69, 71

Pacific Coast, $11,78,79,82,83,123$

reforestation, $39,40,98,99,110$

Rocky Mountains, 11, 71, 75, 76, 78

South, 11, 54, 57-60, 64, 98, 107, 109, 110

supply projections, $51-53,57-60,67-69,75,76,82,83$

trends, $11,44,54,64,76,78,79$

United States, 11, 44

Forest management

intensified, 92, 94-125, 216, 218-222

management classes, $100,107,109,111-113,115,116$, 120,121

1970 level defined, 36-43

Forest types

Alaska, 10
Forest types-Continued

area, 12,13

distribution, $12,13,112$

Douglas-fir and ponderosa pine, 13

eastern hardwoods, $12,13,112$

eastern softwoods, 12, 13

growth, 60

southern pines, 13

species breakdown, 12,13

trends, 13

western hardwoods, 12,13

western softwoods, $12,13,120-123$

Forestry assistance, 41, 97, 98, 101, 110, 111, 125, 220

Forestry research

expenditures, 41,42

logging, 42, 124, 125

processing, $42,124,125,196,205$

role in intensified management, $42,96,120,222$

utilization improvement, $42,48,96,124,125,196,205$, 206

Fuelwood

consumption, 203, 204, 206, 207, 209, 218, 219

plant byproducts, 21-23, 30, 33, 34, 203, 204

production, $21-24$

roundwood, 21-24, 203, 204, 206, 207, 209, 218, 219

trends, 21, 30, 203, 204, 206, 207, 209, 218, 219

Furniture

hardboard use, $166,168,169,172,173,186$

lumber use, $166,168,169,172-174,207$

particleboard use, $166,168,169,172,173,186$

plywood and veneer use, $166,168,169,172-174,183$, 208

value of shipments, $168-170,172$

Gross national product, 161-164, 166, 169, 191, 192, 196, 201

disposable personal income, $144,145,151,154,166$, $168-171,188,191$

manufacturing activity, 144, 146

projections, 144,145

rates of growth, $144,145,212$

trends, $144,145,212$

Growing stock

growth, $16,17,25,26,46-48,59,61-63,70,76,77,79$ 84-86

growth projections, $46,70,72,76,77,79,84,85$

growth-removal relationships, $25,26,46-49,59,61,62$, 84,85

inventories, $27-32,46,52,55,64,65,71,72,77-79,86$, 87

logging residues, $21-25,46,49,55,57,65,79,123,124$ mortality, $17-19,46,49,76,77,79,84-86$

removals $19-26,45-49,54-56,58,59,61-63,65,67$, $72,74,79$

Growth

growing stock, $16,17,25,26,46-48,59,61-63,70,76$. $77,79,84-86$

impact of destructive agents, 17-19, 108, 221

net growth, $15-18,25-27,45-48,55,56,59-62,65-68$, $70,72-74,76,77,79,80,84-86$

North, 15-17, 25, 26, 61-63, 65-68, 70, 113

ownership, $17,27,59,62,63,66-68,70,77,84-86$

Pacific Coast, $15-17,25-27,79,80,84-86$

per acre, $15-17,27,59,60,66,84,85$

potential, $17,46,47,63,218,222$

rates, 59-61, 63

Rocky Mountains, 15-17, 25, 26, 72, 73, 76, 77

sawtimber, $16,17,25,26,47,56,59,61,62,66,76$ 77,80

South, $15-17,25,26,55,56,59-63$

trends, $15-17,25,26,46-48,55,56,59,65,66,71-74$, $77,79,80,84-86$

United States, 15-17, 25-27, 46-48 
Growth projections

growing stock, $46,70,72,76,77,79,84,85$

North, 70, 113

ownership, 70, 77, 84-86

Pacific Coast, $79,80,84-86$

Rocky Mountains, 72, 73, 76, 77

sawtimber, $47,73,76,77,80$

South, $\mathbf{5 5}, \mathbf{5 6}$

United States, 46, 47

Growth-removal relationships

growing stock, 25, 26, 46-49, 59, 61, 62, 84, 85

North, 25, 26, 61-63

ownership, 27, 62, 63

Pacific Coast, 25-27, 84-86

Rocky Mountains, 25, 26

sa wtimber, $25,26,47,59,61,62$

South, 25, 26, 54, 58-60

trends, 25, 26, 46-49, 59

United States, 25-27, 46-49

Hardboard (see Building board)

Housing (see Residential construction)

Imports

building board, 186, 187, 193

Canada, 127, 135-137, 139, 193, 198, 200, 204, 209

hardwood, 127, 128, 137-141, 182, 184, 204, 210, 211, 217,219

logs, 127-129, 137, 140, 141, 204

lumber, 126-129,137-141, 181, 182, 209-211

miscellaneous, 127,128

net imports, $128,129,139,141,201,210,211,220$

paper and board, 126-129, 137, 139-141, 192, 193, 199, 201,202

plywood and veneer, 126-129, 137, 138, 140, 141, 184, 210,211

projections, $137,139-141,182,184,187,192,193,197-$ $199,202,204,209-211,216,217$

pulpwood, 127, 128, 137, 139-141, 199-202, 209, 210

sawtimber, $210,211,216,217$

softwood, 127, 128, 137, 138, 140, 141, 182, 184, 204, $209-211,216$

total roundwood equivalent, $126,128,129,137,139,141$, $201,209,210,216$

trends, 126-129, 137, 139, 181-184, 187, 192, 197, 198, $202,204,209-211,216,217$

tropical woods, 137-139, 184, 204, 219

value, 126,129

volume, 126-129, 137, 139-141, 197-199, 201, 202

woodpulp, 126-129, 137, 139-141, 197-199, 201, 202

Improved utilization

assumptions in base projections of supply, 48, 123, 124

construction, $124,125,165,221$

impact on demand, 146, 198, 204-206, 217, 221

impact on potential supply, 57, 91, 92, 110, 123-125, $200,201,218,221,222$

logging, 42, 48, 96, 124, 125, 221, 222

processing, 42, 124, 125, 174, 200, 205, 206, 218, 221 , 222

research, 42, 48, 96, 124, 125, 196, 205, 206

residential construction, $124,125,159,221$

residues, 48, 57, 123-125, 200, 201, 205, 206, 221

timber sale practices, 124

Industrial raw materials

consumption, 212,213

projected demand, 213

relative importance of timber, 212,213

Industry lands (see Forest industry lands)

Insect and disease control, 42, 95, 97-99, 106, 221

expenditures, 38,39

North, 39

ownership, 38

Pacific Coast, 121

South, 39, 108, 109

trends, 38
Insulating board (see Building board)

Intensified management

costs, $101,103,104,111,113,117-122,218-222$

extended program, 105,106

management classes, $100,107,109,111-113,115,116$, 120,121

North, 97, 112-120

opportunities, $94-125,218,219,221,222$

ownership, 96-98, 108, 109, 123

Pacific Coast, 95, 98, 99, 105, 120-123

potential increases in supply, 92, 94-125, 216, 218, 219

research, 42, 96, 120, 222

return on investment, 102-105, 111, 114-119, 121-123

Rocky Mountains, 105

South, 95, 97, 98, 105-112

ten-year program, 99-105

yields, 101-106, 108, 110-112, 114, 116-123, 216

Inventories

diameter class, 28-31, 86, 87

Douglas-fir, 27, 30, 31

growing stock, 27-32, 46, 52, 55, 64, 65, 71, 72, 77-79, 86,87

North, 28, 29, 32, 65, 66, 69, 71, 113

ownership, $29,32,64,69,71,78,86-88$

Pacific Coast, 27-29, 32, 79, 80, 86-88

projections, $46,47,52,56,61,65,66,69,71-73,77-$ $80,86-88,113$

quality, 27-29

Rocky Mountains, 29, 32, 72, 73, 77, 78

sawtimber, $27-30,32,47,52,56,66,73,77,78,80$, $86-88$

South, $28,29,32,55,56,61,64$

southern pines, 28,30

species groups, $27-32,46,47,52,56,64-66,71-73,79$, $80,86-88$

trends, $29,30,32,46,47,52,55,56,61,64-66,71-73$, $77-80,86-88$

United States, 27-32, 46, 47

Logging residues

environmental impacts, 24,48

growing stock, 21-25, 46, 49, 55, 57, 65, 79, 123, 124

nongrowing stock, 21,123

North, 25, 65

Pacific Coast, 21, 25, 79, 80

Rocky Mountains, 25, 73

South, 21, 25, 55-57

species, 21-23, 25, 46, 47, 49, 55, 56, 65, 73, 79, 80

trends, $21,46-49,55-57,65,73,79,80$

Logs

exports, 127-129, 131, 139-141, 204, 208

imports, 127-129, 137, 140, 141, 204

Lumber

exports, $127,128,131,140,141,181,182$

imports, 126-129, 137-141, 181, 182, 209-211

production, 88,182

Lumber use and projected demand

alternative growth assumptions, 179-181

alternative price assumptions, 180-182

containers, $174,177,178$

demand on U.S. mills, 182

manufactured products, 166, 168, 169, 172-175, 179, 181,207

miscellaneous uses, $177-179,181$

new housing, $150,157-160,179,181$

new nonresidential construction, 161, 162, 165-167, 179,181

pallets, $174,176,177,179,207,208$

per capita, $179,181,182$

railroad construction, 166,168

shipping, 174, 177, 179, 181

summary of all uses, 179-182

upkeep and improvements, 160, 161, 179, 181 
Manufactured products

furniture, 166, 168-170, 172-174, 186, 207, 208

hardboard use, $166,168,169,172-175,186$

lumber use, $166,168,169,172-175,179,181,207$

particleboard use, $166,168,169,172-175,186$

plywood and veneer use, 166, 168, 169, 172-175, 183, 208

timber products demand projections, 173-175, 181

timber products use per dollar of shipments, 172-174

value of shipments, $168-172$

Manufacturing activity

index of production, 144, 146, 174, 176

projections, 144,146

rates of growth, 144,146

Mine timbers, 21-23, 201, 203

Miscellaneous industrial roundwood products consumption, 21-24, 201, 203, 206, 207, 209

from plant byproducts, $21-23,33,34,203$

Miscellaneous uses of timber products, 177-179, 181, 183, $186,201,203$

Mortality

effect on growth and supply, 17-19, 38, 46, 47, 49, 55, $56,65,66,72,73,76,79,80,84-86,108,218,221$

growing stock, $17-19,46,49,76,77,79,84-86$

projections, $46,47,49,55,56,65,66,72,73,76,77$, 79,80

salvage, $19,49,90,91,99,104,123,124,218,221$

sawtimber, $17-19,47,49,66,73,76,77,80,84-86,221$

species groups, $18,19,46,47,49,55,56,65,66,72,73$, $79,80,86$

National Forest lands

area, $11,12,43,44,54,64,71,78,107$

area projections, $43,44,64,71,78$

intensified management, 94-99, 101, 103-106, 109, 110

inventories, $29,32,64,69,71,78,86-88$

North, 11, 64, 67-71

Pacific Coast, $11,78,81-88$

reforestation, $39,40,101,104-106$

Rocky Mountains, $11,12,71,73-78$

South, 11, 54, 57-64, 107, 109, 110

supply projections, $45,51-53,57-60,67-69,74,76,81-$ $83,90,91$

trends, $12,44,54,64,71,78$

United States, 11, 44

Noncommercial forest lands

Alaska, 9, 10

area, 8,9

deferred, $9,10,12,70$

North, 9

Pacific Coast, 9

reserved, $9,10,43,70$

Rocky Mountains, $9,10,70,74$

South, 9, 10

trends, 10,11

United States, 8-10

Nonresidential construction

building board use, 161, 162, 165-167, 186

expenditures, 161-167

lumber use, $161,162,165-167,179,181$

plywood and veneer use, 161, 162, 165-167, 183

projected timber products demand, 165-167, 181, 183, 186

timber products use per dollar of expenditures, 162, 165-167

upkeep and improvements, 177,178

Nontimber uses

forest area projections, $43-45,54$

timber land, 8-11, 14, 43, 44, 97, 218

impact on supply, $36,45,53,59,65,70,78,79,94$, 96-98, 218

removals, $19,24,25,45,56,110$

Ownership

and intensified management, 96-98, 108, 109, 123

commercial timber land, 11, 12, 54, 64, 70, 71, 78, 107
Ownership-Continued

growth, $17,27,59,62,63,66-68,70,77,84-86$

inventories, $29,32,64,69,71,78,86-88$

removals, $19,27,45,51,52,58,61-63$

supply, 51-53, 57, 59, 60, 65, 67-69, 75, 81-83, 90-92

Pallets

hardboard use, $174,176,177$

lumber use, $174,176,177,179,207,208$

plywood and veneer use, 174, 176, 177

production, 174,176

projected demand for timber products, 176,177

Paper and board

consumption of fibrous materials, 194-202

exports, 127, 128, 131, 139-141, 192, 193, 199, 202

imports, 126-129,137, 139-141, 192, 193, 199, 201, 202 production, 192-194

Paper and board use and projected demand

alternative growth assumptions, 189, 190, 192

alternative price assumptions, 192-194

demand on U.S. mills, 192-194

factors affecting consumption, 188, 191

per capita, 188, 190-192

world demands, 193, 198

Particleboard

production, 187

summary of all uses, 186,187

use in manufactured products, $166,168,169,172-175$, 186

use in residential construction, 150, 157-160

use of plant byproducts, $30,34,124,203,205$

use of plant residues, $31-34,124,186,200,205$

Piling, 21-23, 201, 203

Plant byproducts

fuelwood, 21-23, 30, 33, 34, 203, 204

miscellaneous industrial products, 21-23, 30, 33, 34, 203

particleboard, 30, 34, 124, 200, 203, 205

production, $22,23,33,34$

pulpwood, 21-23, 30,31, 33, 34, 199, 200, 202, 205

trends in use, 30, 31, 123, 124, 199, 202, 205, 206

Plant residues

bark, 34

environmental impacts, 34

Pacific Coast, 31,200

primary processing, 31-33, 200, 205

production, $31-33$

pulpwood, $31-34,124,200,205,206,219,221$

Rocky Mountains, 31

secondary processing, 33,34

South, 31

species, 31,33

Planting (see Reforestation)

Plywood and veneer

exports, 127, 128, 140,141, 183, 184

imports, $126-129,137,138,140,141,184,210,211$

production, $21,88,184$

softwood, $21,88,183,184$

South, 21

Plywood and veneer use and projected demand

alternative growth assumptions, 183, 185

alternative price assumptions, 183-186

demand on U.S. mills, 184, 186

manufactured products, $166,168,169,172-175,183$, 208

miscellaneous uses, $177-179,183$

new housing, $150,157-160,183$

new nonresidential construction, $161,162,165-167,183$

per capita, 183, 184

railroad construction, 166

shipping, 174, 176-179

summary of all uses, 182-186

upkeep and improvements, 160, 161. 183

Poles, 21-23, 201, 203 
Population

assumptions, 143-145

effect on housing demand, 150-152

fertility rates, 143,144

immigration, 144

projections, 143,144

trends, 143-145

Prices

assumptions for demand projections, 147-150

effects of increases on timber demands, $149,150,180$

188, 191-194, 198, 200-202, 206-212, 215-219

impact on supply, 87-92, 97, 121-124, 215-220

lumber, 88, 148-150, 180-182

paper and board, 88, 148-150, 192-194, 202

plywood and veneer, $88,148-150,184-186$

pulp and paper, $88,148,200-202$

sawlogs, 114

stumpage, $87,102,113,148,149,217$

timber, 87

timber products, $87,88,147-150$

woodpulp, 198, 202

Productivity

commercial timber lands, $13,14,62,94,108,112,120$

labor, 145

Public forest lands

area, $11,12,43,44,54,64,71,78,79,107$

area projections, $43,44,64,71,78$

intensified management, 123

inventories, $29,32,64,69,71,78,86-88$

North, 11, 12, 62-64, 69, 71

Pacific Coast, $11,12,77,87,123$

reforestation, 39,40

Rocky Mountains, $11,71,74,78$

South, 11, 54, 57, 59-61, 64, 107, 109, 110

supply projections, $45,51-53,57-60,67-69,74,76$, $81-83,91$

United States, 11, 44

Pulpwood use and projected demand

alternative growth assumptions, 199-201

alternative price assumptions, 200-202, 206, 207, 209

consumption, 188, 198-202, 206, 207, 209

domestic demand, 198-202

domestic production, $21-24,88,188,198-202$

exports, $30,127,128,131,139-141,188,198-202,208$, 210

hardwood, 21-24, 198-202, 206-209

imports, 127. 128, 137, 139-141, 199-202, 209, 210

logging residues, $24,124,200,201,219,221$

North, 24

Pacific Coast, 24, 200

plant byproducts, 21-23, 30, 31, 33, 34, 199, 200, 202, 205

plant residues, $31-34,124,200,205,206,219,221$

Rocky Moupntains, 24

roundwood, 21-23, 199-202, 206-210, 212

sawtimber, 21-23, 201, 209

softwood, 21-24, 199-202, 207-209, 212

South, 21, 24

trends, 21, 199, 200, 202, 206, 207, 209

United States, 21-24, 198-202, 206, 207, 209

use per ton of pulp, 198, 200

Railroad construction

crossties, 166,168

lumber use, 166

plywood and veneer use, 166

Reforestation

area planted, 39,40

area seeded, 40

costs, $40,41,101,105,110,120,121$

genetic improvement, $42,59,94,96,106,107,109,110$, $121,122,221$

natural regeneration, $39,40,45,94,96,98,108,110$, 111,117

North, $39,40,120$

ownership, 39,40
Reforestation-Continued

Pacific Coast, $39,40,121,122$

płanting, 39-41, 94, 95, 97, 99, 101, 108, 110, 111, $120-122,221$

Rocky Mountains, 40

South, 39, 40, 94, 109-111

trends, 39,40

Removals

assumptions for projections, 44-48, 54, 58, 74

growing stock, $19-26,45-49,54-56,58,59,61-63,65$, $67,72,74,79$

logging residues, $19,21-24,46-49,55-58,65-67,72-$ $74,79-81$

nongrowing stock, 20-23, 46, 56, 74, 80, 81, 91

nontimber uses, $19,24,25,45,56,110$

North, 20-26, 50, 51, 61-63, 65-67, 113

ownership, $19,27,45,51,52,58,61-63$

Pacific Coast, $19-27,50,51,77-87$

per acre, 27,58

projections, $46-51,61,65,66,72,73,81$

pulpwood, 19, 21-24, 48

Rocky Mountains, 20-26, 50, 51, 71, 73, 74

roundwood, $19-26,46-52,55,56,58,61,66,67,72,79$ 81

sawlogs, 19-24, 48, 55, 56, 58

sawtimber, $19-23,25,26,45,47,48,51,54,55,58,59$, $61,62,66,73,80$

South, 19-26, 50, 51, 54-59, 61

species groups, $19-26,46,47,49-52,54-58,61-63,65-$ 67. $72,73,79-81$

trends, $20,21,25,26,46-51,54,55,58,59,61,66$, $71,73,79-81$

United States, 19-27, 46-52

veneer logs, $19,21-24$

Residential construction

building board use, 150, 157-160, 186

characteristics of dwellings, 157-159

conversions, 153,157

demand for new housing, 150-153, 155-157

household formation, 150-153

housing inventory, 152-155

lumber use, $150,157-160,179,181$

mobile homes, $150,153-158$

multifamily dwellings, $150,152,156-159$

one- and two-family dwellings, $150,152,156-159$

plywood and veneer use, $150,157-160,183$

projected timber products demand, 159-161, 181, 183 , 186

replacements, $150-154,157$

size of dwellings, 157,158

timber products use per unit, 150, 157-159

upkeep and improvements, 160, 161

vacancies, $153-155$

Road development, 42, 43, 45, 78, 99, 124, 221

Roundwood use and projected demand

alternative growth assumptions, 206-208, 211

alternative price assumptions, 206-212

consumption, 201, 203, 204, 206-211

domestic production, $20-25,46,50,199-202,210,211$, 216,217

exports, 127, 128, 141. 204, 208-211, 216, 217

fuelwood, 21, 24,203,204,206,207,209,218, 219

imports, 126-129, 137, 139, 141, 204, 209-211, 216, 217, 220

miscellaneous industrial products, 206, 207, 209

nongrowing stock, $20,22,23,45,46,49,56$

North, 20, 24, 25, 50, 65-67

Pacific Coast, $19,20,24,25,50,77-87$

projected demand from U.S. forests, 46, 49, 50, 52, 206$212,215-219$

pulpwood, 21-23, 199-202, 206-210, 212

removals, $19-26,46-52,55,56,58,61,66,67,72,79-81$

Rocky Mountains, 20, 24, 25, 50, 72-74

sawlogs, 20-24, 58, 206-209, 211

sawtimber, 208-212, 215-217

South, $19,20,24,25,50,52,55-59$ 
Roundwood use and projected demand-Continued species groups, 19-25, 46, 50, 55-59, 65-67, 72, 73, 79, $80,207-212,215-217$

trends, 206-211, 216, 217

United States, 19-25, 46-52, 206-212, 215-219

veneer logs, 21-24, 206, 207, 209

Salvage, $19,49,90,91,95,99,104,109,123,124,218$, 221

Sawlogs

consunption, 206-209, 211

domestic production, 20-24, 211

North, 20-24

Pacific Coast, 20-24

removals, $19-24,48,55,56,58$

Rochy" Mountains, 20-24

South, 20-24

species groups, 20-24, 207-209, 211

trends, 20, 21, 208, 209,211

Sawtimber use and projected demand

alternative growth assumptions, 208

alternative price assumptions, 208, 209, 211, 215-219

consumption, 208, 209, 211, 216, 217

increasing softwood supply, 216-218

projected demand, 208, 209, 211, 215-219

projected demand from U.S. forests, 211, 215-219

removals, $19-26,45,47,50,51,54-56,66,80$

Shipping

containers, $174,177,178,183,188,191$

dunnage and blocking, 174,177

hardboard use, 174,179

lumber use, $174,177,179,181$

pallets, $174,176,179,207,208$

plywood and veneer use, 174, 176-179

projected timber products demand, $177,179,181$

Site quality (see Productivity)

Stand conversion, 95, 101, 107, 108, 110, 111, 113, 114, $121,122,221$

Stand improvement (see Timber stand improvement)

Stand size classes

commercial timber land, 14, 15, 94, 107

distribution, $14,15,60$

inventories, $28-31,86,87$

North, 14, 15, 63, 112

Pacific Coast, 14,15

Rocky Mountains, 14, 15, 75

South, 14, 15, 60, 107

Stocking, 14, 15, 49, 62, 94, 100, 107-113, 115, 120, 121

Substitution for wood products construction, 124, 146, 158, 159, 183, 186, 203, 220 containers, $146,177,188,191$

economic impact, 220,221

furniture, $124,146,172,173,186,220$

impact on environment, 106, 220, 221

new housing, $158,159,183,186,220$

nonresidential construction, $165,183,186$

woodpulp, 124,196

Supply

allowable cut, $36,45,73,74,90,99,103,104,121,218$, 221

increase through improved utilization, 57, 91, 92, 110, $123-125,200,201,218,221,222$

increase through intensified management, 92, 94-125, $216,218,219,221,222$

North, 50, 51, 61-69, 113

ownership, 51-53, 57, 59, 60, 65, 67-69, 75, 81-83, $90-92$

Pacific Coast, 50, 51, 77-87, 120-123

Rocky . Mountains, 50. 51, 69-77

roundwood, $36,45-47,49-52,56,57,59,64,65,67,69$, $72-75,81-83,92,112,215-219$

sawtimber, $45-51,60,68,74,76,80,83,89-92,99$, $107,112,215-219$

South, 50-61, 107, 112

species groups, 46, 47, 50-52, 59, 60, 65, 67, 69, 72, $75,76,79-83,107,215-219$
Supply-Continued

trends, 46, 47, 50-52, 59, 65, 79, 80, 83

United States, 45-53, 215-219

Supply-price relationships

intensified management, 97, 104, 114, 115, 117-124

lumber, 88

paper and board, 88

plywood, 88

sof twood, sawtimber, 88-92, 215-218

stumpage, $87,104,114,117,217$

timber products, $87-89,215-219,220$

Supply projections

assumptions, $36,43-50,123,124$

base projections, $36,44-87,215-219$

economic projections, $36,87-92,215-218$

1970 level of management, $36-92,112,113,215-219$

North, 50, 51, 65, 67-69, 113

ownership, 51, 52, 57, 59, 60, 67-69, 75, 81-83, 92

Pacific Coast, 50, 51, 77-87

procedure, 36,44

Rocky Mountains, 50, 51, 69-77

roundwood, $36,45-52,57,59,65,67,69,72,75,79$, $81-83,92,112,215-219$

sawtimber, $47,49,50,51,57,60,68,76,83,89-92,107$, $112,215-219$

species group, 46, 47, 50-52, 57, 59, 60,65, 67-69, 72, $75,79-83,107,215-219$

softwood sawtimber, $47,50,51,57,60,68,76,83$, $89-92,107,112,215-218$

South, 50-61, 107, 112

United States, 46-53, 92, 215-219

Technological improvement

forest management, $19,41,42$

impact on demand, $42,146,168,172,173,203-206,217-$ $219,221,222$

impact on supply, 96, 123-125, 198, 200, 201, 217-219, 221,222

nonresidential construction, $124,125,165$

pulp production, $121,198,200,201$

residential construction, $124,125,158,159$

timber utilization, $31,42,48,57,96,123-125,200,201$, 204-206, 217-219, 221, 222

Thinning (see Cultural measures)

Timber demand (see Demand)

Timber demand projections (see Demand projections)

Timber growth-removal relationships (see Growth-removal relationships)

Timber inventories (see Inventories)

Timber removals (see Removals)

Timber supply (see Supply)

Timber supply projections (see Supply projections)

Timber stand improvement, 95-98, 104-106, 111-120, 221

area treated, 41

costs, $41,101,113,117-119$

North, 41, 113, 114, 117-119

ownership, 41

Pacific Coast, $41,121,122$

Rocky Mountains, 41, 221

South, 41, 111

trends, 41

Upkeep and improvements

building board use, $160,161,186$

lumber use, $160,161,179,181$

nonresidential structures, 177,178

plywood and veneer use, $160,161,183$

projected timber products demand, $160,161,181,183$, 186

residential expenditures, 160,161

timber products use per dollar of expenditures, 160 , 161

Veneer logs

consumption, 206, 207, 209

domestic production, 21-24

North, 24

Pacific Coast, 24

quality, 21 
Veneer logs-Continued removals, $19,21-24$

Rocky Mountains, 24

South, 21, 24

species groups, 21-24, 207, 209

trends, 21, 206, 207, 209

Waste paper, 125, 194-196, 206, 219, 221

Woodpulp

consumption, $194-198$

demand on U.S. mills, 195-198

exports, $127,128,131,140,141,196-199,202$

imports, 126-129, 137, 139-141, 197-199, 201, 202 production, 197, 198

projected demand for nonpaper products, 196, 197

projected demand for paper and board, 195, 196
World timber resources and demands

Canada, 134-137, 139, 193

- Europe, 129-131, 133, 134, 193

forest lands, 132-134, 137, 138

Japan, 129-134, 193, 200, 204

other areas, 130, 132-134

projections, $131,132,135,136,193$

romdwood production, 130, 131, 133-136, 13心, 139)

supplies, 130-135, 137-139, 193, 198

timber demands, 129-132, 136, 139, 193, 198

timber inventory, 133, 135

Tropical forests, $137-139$

Tropical plantations, 138,139

USSR, 130, 132-134, 138, 139, 193 
